
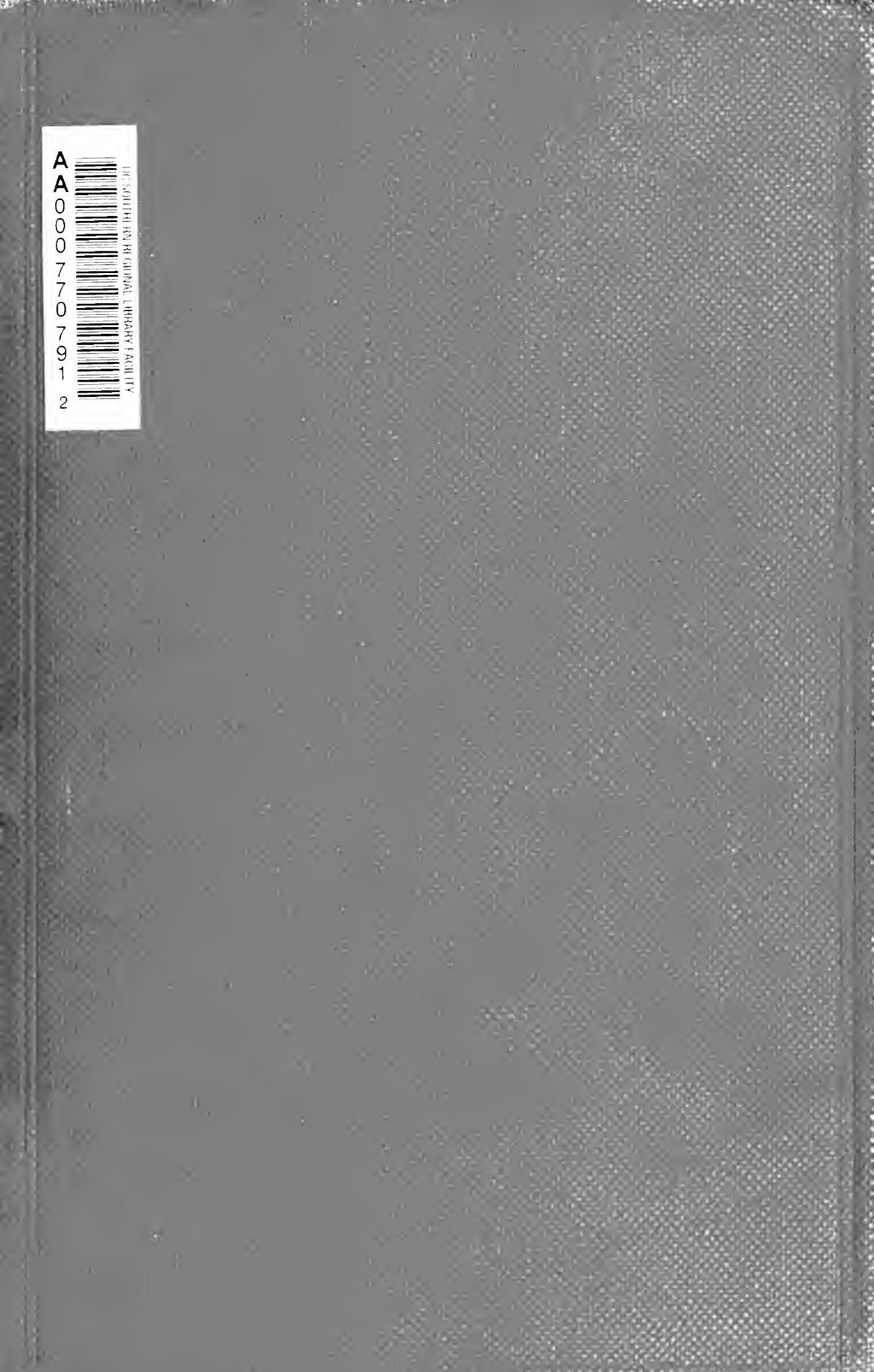


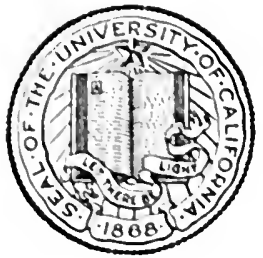

THE LIBRARY

OF

THE UNIVERSITY

OF CALIFORNIA

LOS ANGELES

SCHOOL OF LAW

往

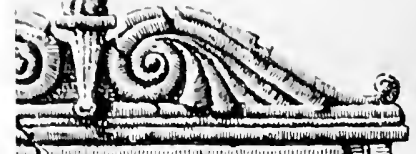

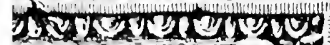
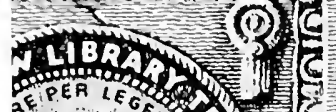

a $\left.-\mathrm{S}_{3} \mathrm{C}\right)$

IIIIIIIIIIII]

Infinin|min|

IIIIIIIIitit

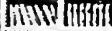
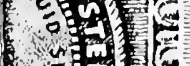

- wa

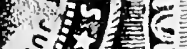

(1)

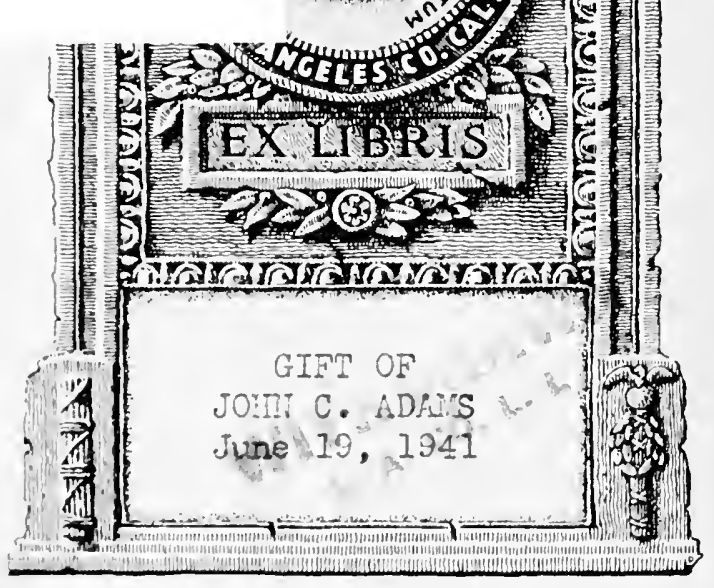




\section{算}

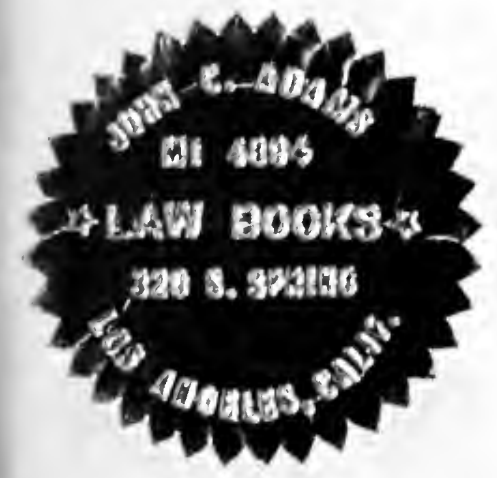


,

$$
\bullet
$$




\section{Digitized by the Internet Archive in 2008 with funding from Microsoft Corporation}




\title{
THE LAW
}

\section{OF \\ NEGOTIABLE INSTRUMENTS}

\section{STATUTES, CASES AND AUTHORITIES}

\author{
EDITED BY \\ ERNEST W. HUFFCUT \\ PROFESSOR OF LAW IN CORNELL UNIVERSITY COLLEGE OF LAW
}

SECOND EDITION REVISED AND ENLARGED

$B Y$

\section{FREDERICK D. COLSON}

OF THE NEW YORK BAR

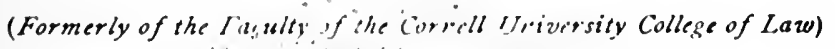

\author{
NEW YORK \\ BAKER, VOORHIS \& COMPANY
}




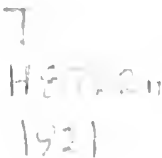

COPYRIGHT, 1898

By ERNEST W. HuFFCUT

COPYRIGHT, IOIO

By Lillian L. Huffcut 


\section{PREFACE TO FIRST EDITION.}

THE enactment of the Negotiable Instruments Law in several American States and its probable enactment in others, renders necessary a familiarity with that Code on the part of all law students. Founded as it is upon the Digest of Judge Chalmers, afterward enacted into the English Bills of Exchange Act, it presents the best statement available of the results of English and American judicial decisions. Even before its adoption by the legislatures in Great Britain and the United States, Judge Chalmers' Digest had been edited for use in law schools, and had met with much favor for purposes of study and instruction.

A Digest or Code is, however, but a set of abstract rules. The student needs to see the rules in operation upon concrete facts in order to appreciate their force and effect. It is the purpose of this book to set over against each important rule a case or a selection of cases from which the rule might be deduced did no Code exist and in which the rule, as embodied in the Code, may be studied in its application to concrete facts. In this way it is hoped to give vitality and interest to what are otherwise mere abstract propositions of law. As to the relation of the cases to the Code, the reader is referred to Judge Chalmers' remarks, found on page 119 [5] of this work, and to the opinion of Lord Herschell on page 127 [126], and of Lord Russell of Killowen on page 4.42 [396].

Under the sections of the statute will be found references to the "Cases and Authorities" which make up Part II [I] of this work. Conversely there is set opposite the title to each case the section number of the statute which is applicable to it. Under this arrangement the student has constantly before him the enactment of the legislatures and the derisions of the courts.

In Article I, dealing mainly with matters of historical interest, the editor has made free use of the Introduction to Chalmers' Digest and of the first two chapters of Mr. Scrutton's Elements of Mercantile Law. Elsewhere in the book, two or three chapters of Byles' Treatise on Bills of Exchange have been reprinted, where a selection of cases would have occupied space out of proportion. 
to the importance of the subject. The topies of "Guaranty," "Nonnegotiable Notes," and some others of minor interest, have been added to those included within the Negotiable Instruments Law.

In the preparation of the book the editor has derived the greatest assistance from the well-known works of Sir John Byles, Mr. Daniel, and Irofessor Ames, and from the artiele on Bills of Exehange in the second edition of the Amcrican and English Encyelopedia of Law.

The book is intended primarily for students. It constitutes, however, a somewhat complete annotation of the Negotiable Instruments Law, and as such may prove of value to practitioners. On many points, editorial notes have been added, in order to give greater completeness to the subject treated, and to indicate any conflict of authority that may have preceded the enactment of the statute.

CoRnell University,

E. W. H.

February, 1898. 


\section{PREFACE TO THE SECOND EDITION.}

AT the date of the preface to the first edition of this work only four states had passed the Negotiable Instruments Law and there had been no cases decided under it. Since that time this act has been adopted in thirty-eight states and territories. The main purpose of this edition is to bring the first edition down to date by incorporating into it such cases decided under this enactment as seem desirable in order to present the case law on negotiable instruments as it exists to-day. The effort, of course, has been to select those cases where it is held that the Negotiable Instruments Act has changed the pre-existing law or at least has resolved a conflict existing among the earlier authorities. So far, however, as the cases in the first edition, no matter how old, are satisfactory illustrations of the provisions of the statute, they have not, in general, been displaced simply in order to get more recent cases or even cases citing the Negotiable Instruments Law. A few cases not decided under the statute have been added where the treatment in the first edition of the subjects involved seemed inadequate.

Practically all of Mr. Huffcut's notes have been retained. These are followed by the letter " $\mathrm{H}$," while the notes added by the present editor are followed by the letter "C."

Permission was very kindly given by Mr. McKeehan and the American Law Register to reprint the extracts from the article on "The Anes-Brewster Controversy," and by Professor Williston and the Harvard Law Review Association to reprint the article entitled "An Ambiguity in the Negotiable Instruments Law." It is regretted that the limitations of space forbade the reprinting of more of Mr. MeKeehan's article, for it remains to-day, in the opinion of the editor, the best exposition and general survey of most of the troublesome parts of the Negotiable Instruments Law. The list of states and territories which have enacted this statute was compiled largely, with the kind permission of the draftsman of the act (J. J. Crawford, Esq.), from the list given in the third edition of his work on the Negotiable Instruments Law.

Albany, New York,

F. D. C.

September, 1910. 



\title{
TABLE OF CONTENTS.
}

\author{
PART I. \\ Cases and Authorities.
}

\section{ARTICLE I.}

\section{General Provisions.}

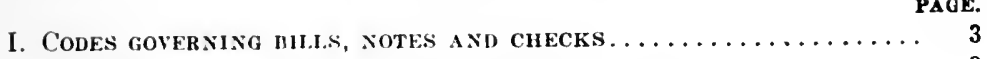

1. The English Bills of Exchange Act.............. 3

2. The American Negotiable Instruments Law............ 9

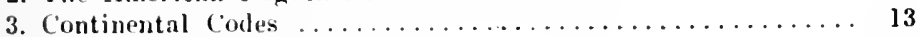

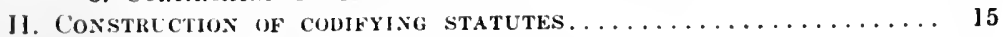

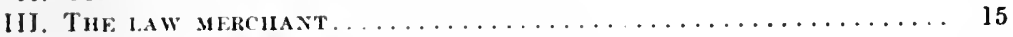

1. The Law Mrehant and jts history . . . . . . . . . . . . 15

2. History of negrotiable instruments................ 24

(a) Bills, notes and checks................... 24

(b) Other negotiable paper................... 31

\section{AR'IIICLE II.}

\section{Form and Interpretation.}

\section{(i) Form Required.}

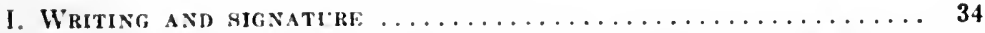

II. CXCONHITIONAI, l'ROMISt: OR ORDER TO PAY A SUM CERTAIN IN MONEY, 37

1. A note must contain a promise................. 37

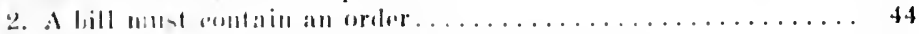

3. The promigu or urder must be unconditional ............ 46

(a) conditional promises or orlers not negutiable....... 46

(b) An order or promise to pay out of a particular fund is comlitimnal ...................... 49

(c) In indisation of a particular fund does not render promicr ponditional .................. 50

(d) Nor a stutroment of transaction which gives rise to

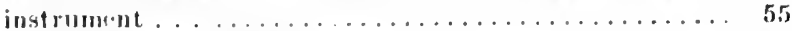

4. The sum to fre paid must tw erertain................ til

(a) What amounte to erertuinty generally............ ol

(b) lingugement to fuy interest: contingeney........... ti.

(c) Engagenunt to pay by instalments: contingency..... 67

(d) Engngenont that in dofault whole shall lo dus....... 72

(e) Eingagrement to pay exchange................ 74

(f) Pingingrument to paty coste of colloction or attorney's fees, 78

6. Must he payahlw in money ................... 81

(a) Juyinent must he in money............... 81

(b) What ofutitutes rurrent money............. 82 


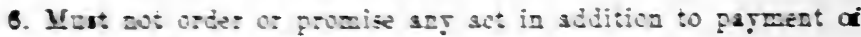
mozer .......................... 90

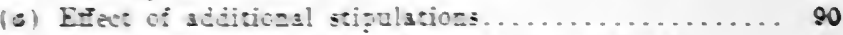

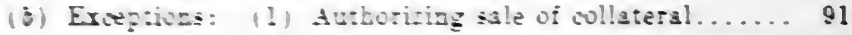

- Atubuiring conjessiog of judgruent, 93

3 Wairiz: exemptions . .......... 94

14 Election to requite something in lieu of woger . . . . . . . . . . . . .

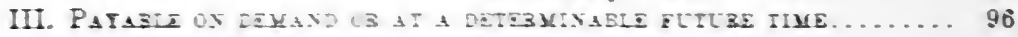

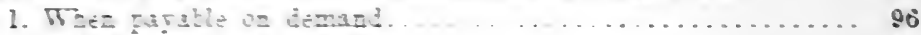

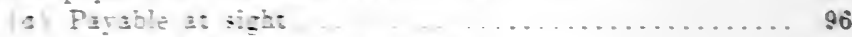

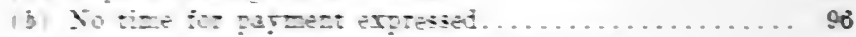

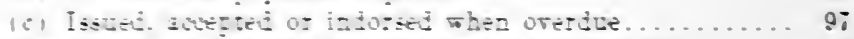

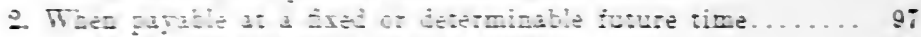

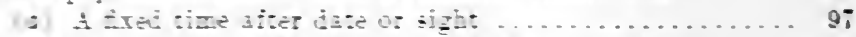

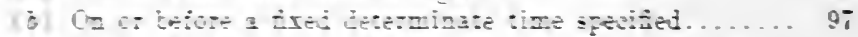

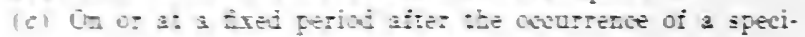

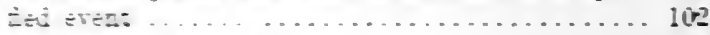

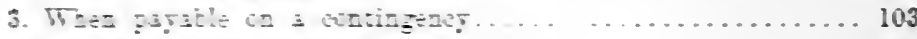

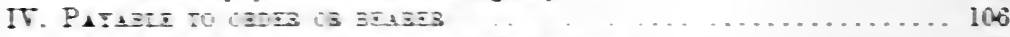

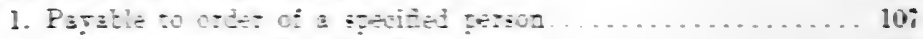

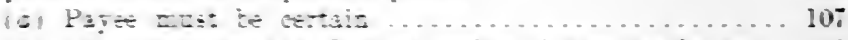

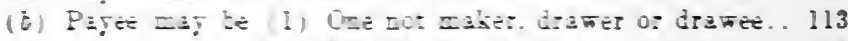

2) Drame: or ma'ser.......... 113

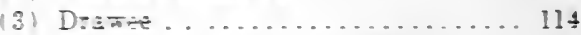

14) Tho oz zore partes joint!...... 115

(5) Ore or mure oi sereral pajtees... 11 s

(6) The bolder ot sn ofwe for the time koisg................. 121

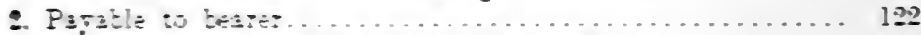

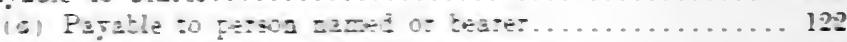

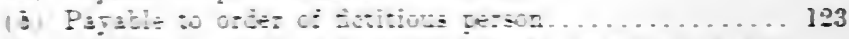

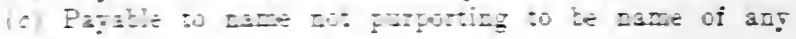

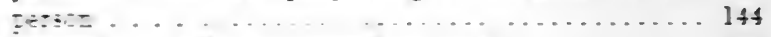

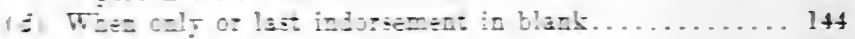

r. Dis

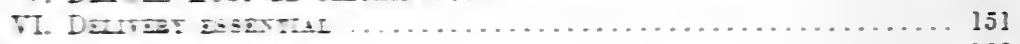

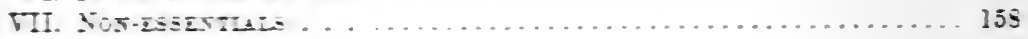

(ii) Irotergetstion.

TTII. DAIz . . . . . . . . . . . . . . . . . . . . . . 161

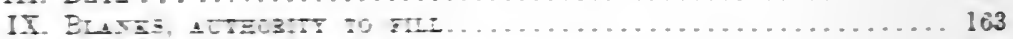

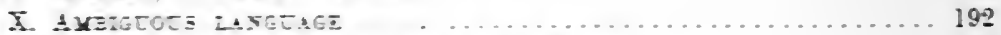

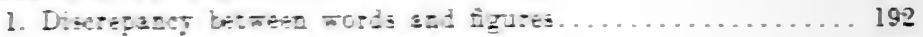

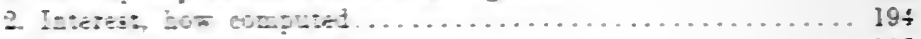

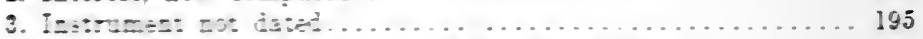

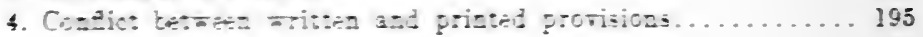

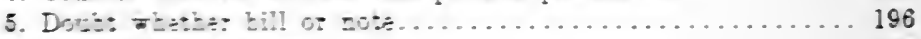

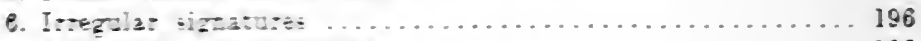

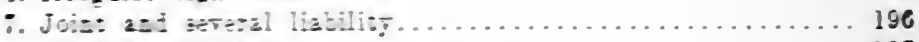

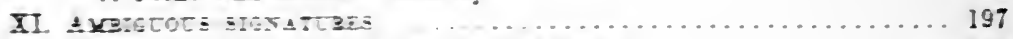

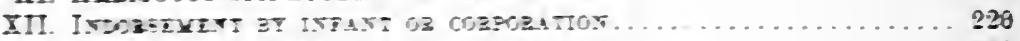

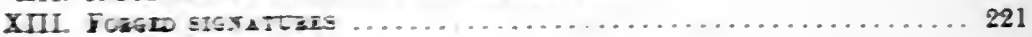




\section{ARTICLE III.}

\section{Cosidiepation of Negutiable Irstetyests.}

II. What cosstittetes cossideratios................... 239

III. HOLDEB FOR TALTE. . . . . . . . . . . . . . . . . . . 249

IV. EFFECT OF KANT OF COISIDERATION .................. 253

V. LIABILITY OF ACCOMYODATIOY PABTI................... 254

\section{APTICLE IS.}

\section{Negotiatios.}

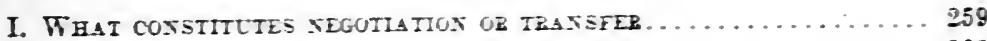

1. Iranifer br delivert....................... $\mathbf{q} 60$

2. Transfer tr indorsement and delitery................ 201

(a) Transfer br indorsing assignment.............. 261

(b) Transier bt indorsing guaranty............... 263

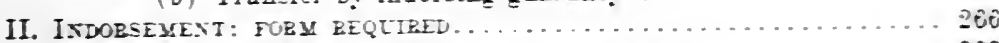

1. Must be written on instrument or allonge........... 200

2. Must be of entire instrument.................... get

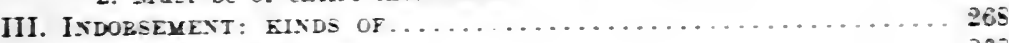

1. Special indorsement ........................

2. Blank indorsement ............................ 86

3. Restrictire indorsement .....................

4. Qualified indorsement ...................... \$\$4

5. Conditions! indorsement ........................

IT. INDORSEMEST: METHODS ASD EFIECT . . . . . . . . . . . . . SS

1. Indorsement of instrumen: parable to bearer ........... Des

2. Indorement where parable to two or more frersons......... $29 s$

3. Indorsement where parable io castier, etc........... 299

4. Indorsement where name missuelled. etc............. 301

5. Presumption as to time of indorsment............. 3ư?

6. Presumption a to place of indorsement.............. 30 ?

7. Continuation of negotiatle chatactet.............. 300

8. Striking out indorsment....................... 306

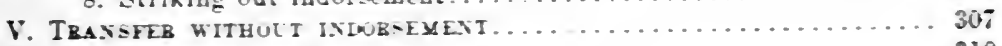

V1. RE-TRAXSELE TO PEIOE PARTY..................... 310

APTICLE V:

Rigits OF HOLDER.

I. TO STE AXD RECETVE PAYMENT . . . . . . . . . . . . . 314

11. HOLDER IN DTF. COTPEE A. . . . . . . . . . . . . 319

1. Requisites to constitute holder in due course ........... 319

(a) Instrument must be complete and regular........ 319

(b) Instrument musi not be oresdue............. 330

(c) Mu-t be taken in goond faith and for value.........33\%

(d) Must te taken without notice of infirmits or defect... 340

(e) Notice tefore full smount paid.........................

2. Holder deriving title from holder in due course......... 360

3. Right of holder in due courve to recover full amount....... 361

4. Burden of prow $\ldots \ldots \ldots \ldots . \ldots . \ldots . \ldots 5$

III. Drtexces to xdotiagle ixstrt verts............... 370 


\section{AR'TICLE VI.}

\section{Liabulty of Pahties.}

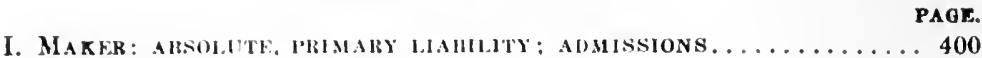

1. Presentment for pilyment nnnecessary............400

2. Liability on lost of destroyed instrmment............. 400

3. Admission of existence and eapaleity of payee......... 401

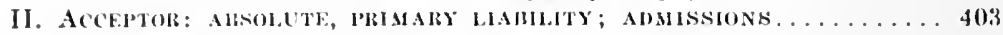

1. Presentment for payment umecessary.............403

2. Admissions as to drawer aud payee...............403

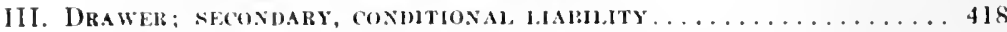

I. Conditions: presentment, notice, protest........... 418

2. Alluissions as to payee................... 418

IV. Seller: warkanties......................... 419

1. Instrument genuine and what it purports to be.........4 419

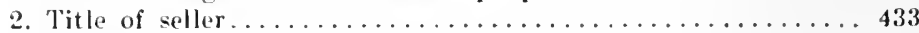

3. Capacity of prior parties................... 434

4. Knowledge of invalidity or valuelessness...........435

5. Indorser: instrument valid and subsisting.......... 437

6. Liability of agent as seller.................. 44I

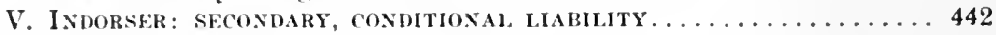

1. Indorser's contract as seller................. 442

2. Indorser's contract as assurer of payment........... 442

3. Irregular indorser ...................... 446

4. Order of indorsers' liability .................. 459

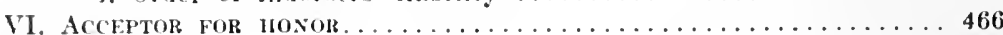

VII. Guarantor ............................ 466

I. (a) Does guaranty-indorsement by holder transfer title?. . 466

(b) May a guaranty be written above a blank indorsement? 466

2. Is a transferee a holder in due course?........... 467

3. What is the contraet of the guarantor?........... 467

4. Is the guaranty transferable? . . . . . . . . . . . 471

(a) Is it negotiable?......................... 471

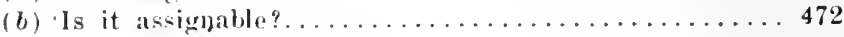

5. Defences available to guarantor............... 474

\section{AR'T'TCLE VII.}

\section{Dutles of Ilolder: Presentment for Payment.}

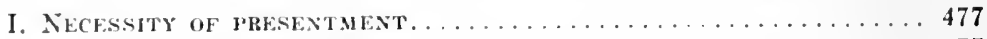

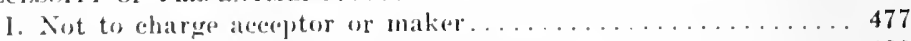

2. I'resentment necessary to charge drawer or indorser......480

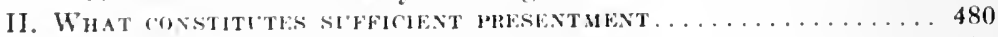

1. Iy holder or authorized representative.............480

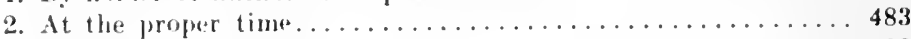

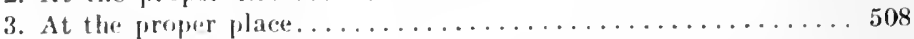

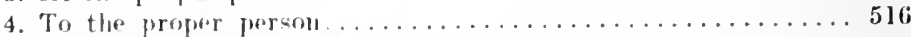

5. By exhibiting the instrument............... 518

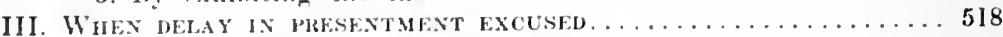

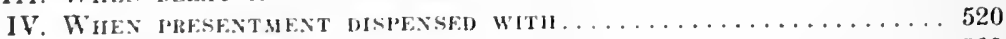

1. When no right to require or expect it ............. 520

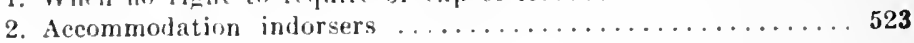


3. When impossible $\ldots \ldots \ldots \ldots \ldots \ldots \ldots \ldots \ldots \ldots \ldots \ldots \ldots \ldots \ldots$

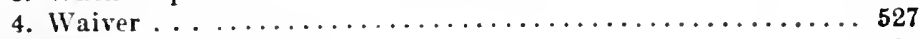

V. Payment in due coubse...................... 529

\section{AR'IICLE VIII.}

Duties of Holder: Notice of Dishonor.

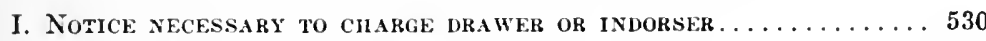

II. What constitutes sufficiest notice $\ldots \ldots \ldots \ldots \ldots \ldots \ldots \ldots \ldots 53$

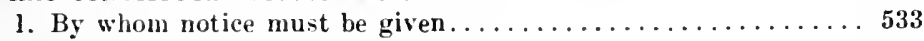

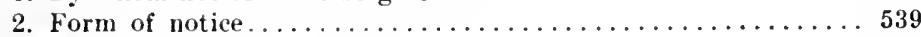

3. Mode of notice......................... 542

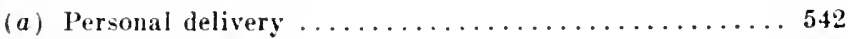

(b) Mail delivery ...................... 543

4. To whom notice may be given............... 546

5. Time within which notice must be given........... 548

(a) Where parties reside in the same place......... 548

(b) Where parties reside in different places.......... 554

(c) Successive notices ................... 561

6. Place at which notice must be given $\ldots \ldots \ldots \ldots \ldots \ldots 565$

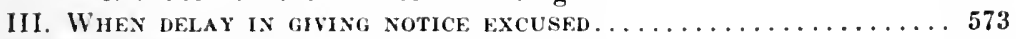

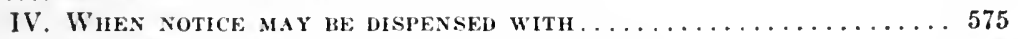

1. When notice need not be given to drawer........... 575

2. When notice need not be given to indorser.......... 577

3. When notice to drawer or indorser dispensed with.......580

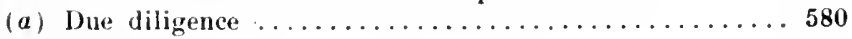

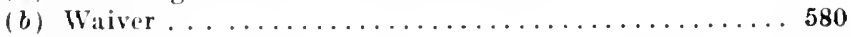

(c) Notice of non-payment where acceptance refused.....586

(d) Etfect of omission to give notice of non-acceptance... 587

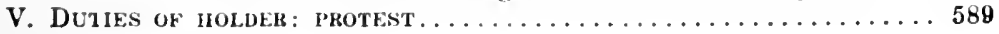

\section{ART'ICLE IX.}

\section{Discharge of Negotiable Instruments.}

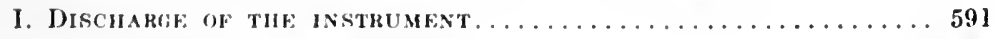

1. Payment and re-tranefer ................. 591

2. Cancellation or renunciation ................ 599

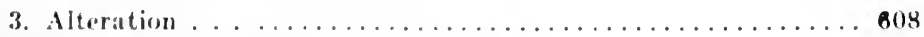

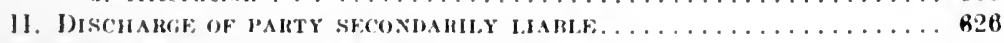

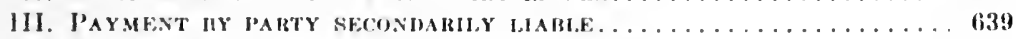

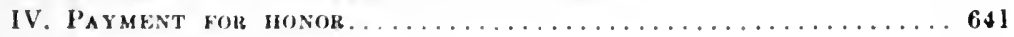

\section{$\triangle$ R'TICIL X.}

\section{BHis of FxchangF: Form and Interpretation.}

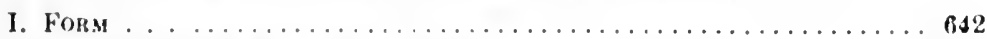

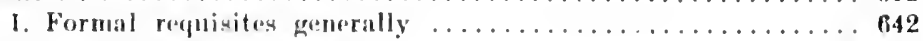

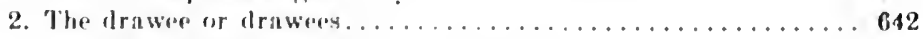

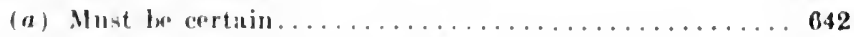

(b) Vay be joint, lut not alternative or suceessive...... 642

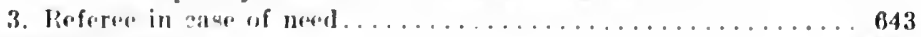

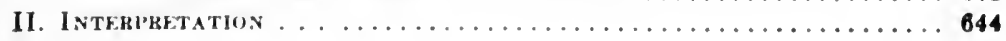


PAOX.

1. Bill not an assignment of funds................644

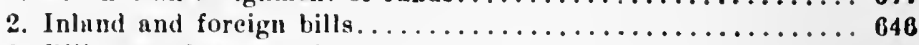

3. Bill treated as promissory note.................. 647

\section{AR'TICLE XI. \\ Acceptance of Bhils of Exchanae.}

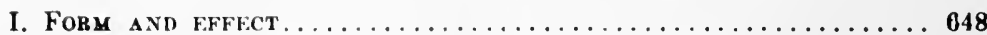

1. Acceptance must be in writing and signed by drawee....... 648

(a) Writing and signature .................648

(b) Only the drawee can accept..............649

(c) Delivery necessary .................6. 650

2. Acceptance by separate instrument..............651

3. Promise to accept must be in writing.............654

4. Acceptance by refusal to return the bill.............6. 658

5. Acceptance of incomplete or dishonored bill..........666

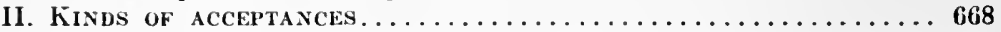

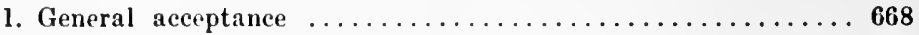

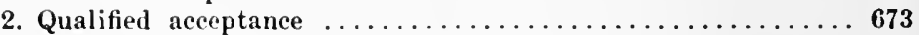

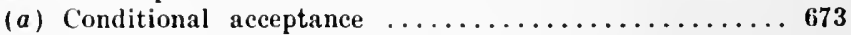

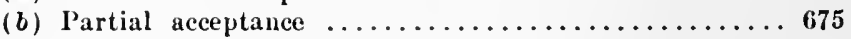

(c) Local acceptance .......................675

(d) Acceptance qualified as to time.............676

(e) Acceptance by one or more drawees, but not by all.... 676

3. Effect of qualified acceptance.................677

(a) Holder may refuse qualified acceptance...........677

(b) Qualified acceptance discharges non-assenting antecedent

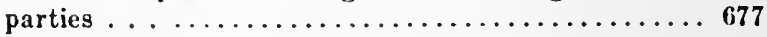

\section{ARTICLE XII.}

\section{Presentment of Bills of Exchinge for Acceptance.}

I. In wiat Cases presentment for acceptance necessary . . . . 679

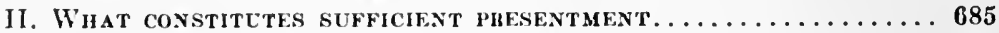

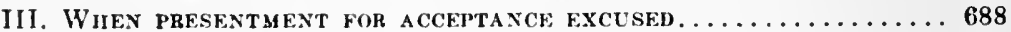

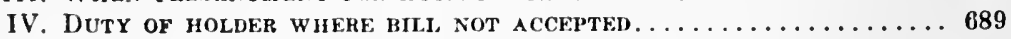

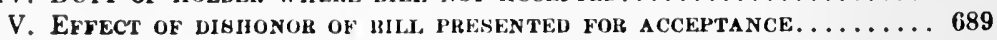

\section{ARTICLE XIII. \\ Protest of Bilis of Exchange.}

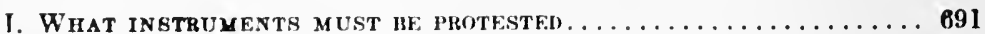

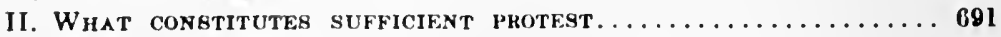

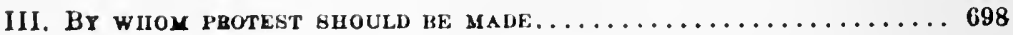

AR'TICLE XIV.

ACCEPTAKEE YOR HONOB........................... 701

ARTICLE XV. 
ARTICLE XVI.

PAOE.

Brus In a str. $\ldots \ldots \ldots \ldots \ldots \ldots \ldots \ldots \ldots \ldots \ldots \ldots \ldots \ldots \ldots \ldots \ldots \ldots$

\section{ARTICLE XVII.}

Promissory Notes and Checks.

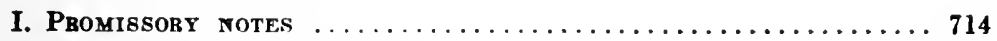

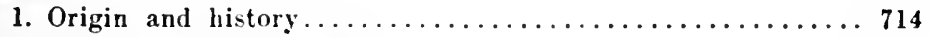

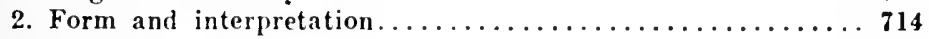

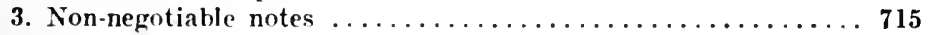

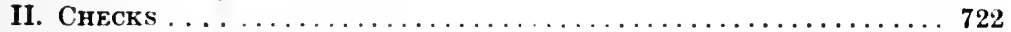

1. Check distinguished from bill of exchange........... 722

2. Presentment of check....................... 725

(a) Effect of delay upon drawer's liability........... 725

(b) Effect of delay upon indorser's liability.......... 734

3. Certification of check ......................... 743

(a) Effect upon drawer's liability............... 743

(b) Effect upon indorser's liability .............. 748

4. A check not an assignment of funds................ 752

5. Forged or raised checks: reciprocal obligations of bank and depositor ............................. 758

6. Liability of drawee to drawer for wrongful dishonor....... 772

\section{PART II.}

List of the states and territorifs which have enacted the NFootia-

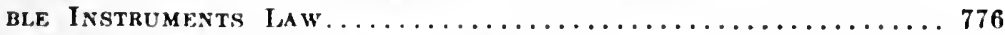

Tue New York Negotiabe Instruments Law............... 779

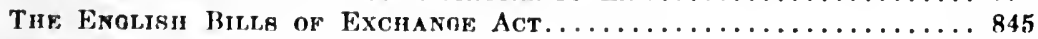

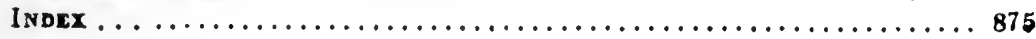





\section{TABLE OF CASES REPORTED.}

Where $n$ is prefixed to the page number, the case is digested in a note.

Adams v. King............

Adams v Wright............

Adrian v. MeCaskill.........

Agawam Nat. Bank v. Downing. Almich v. Downey........... American Express Co. v. Pinckney. . . . . . . . . . . . American Nat. Bank v. Junk Bros. . . .............

American Nat. Bank v. Sprague. Anderton v. Shoup......... Anon (12 Mod. 447) ........ Armstrong v. National Bank.. Arnd v. Sjoblom........... Arpin v. Owens............. Atlantic Nat. Bank v. Davis... Aungst v. Creque.........n. Aymar v. Beers .........n.

Bank of Commerce v. Chambers Bank of England v. Vagliano Bros. . ..............

Bank of Feneval v. Howlett... Bank of IJouston $v$. Day...... Bank of Michigan v. Fly.... Bank of Orleans $v$. Whittemore. Bank of the Repmblic v. Millard. Bank of Rochester v. Firay.... Barnes v. Vaughan......... Bartlett v. Robinson........ Beauregard v. Knowlton...... Belden v. IIann.......... Biesenthall v. Williams....n. Birket v. Flward.......... Bissell v. Dickerson......... Bitzer v. Wagar.......... Blake v. Hamilton Dime Sav. ings Bank ..........

Blake v. Mc.Millen..........

Blenn v. Lyfort...........

Bochm v. Garcian..........

Bolles v. Stearns............

Borough of Montvale v. People's

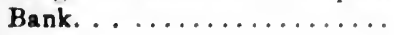

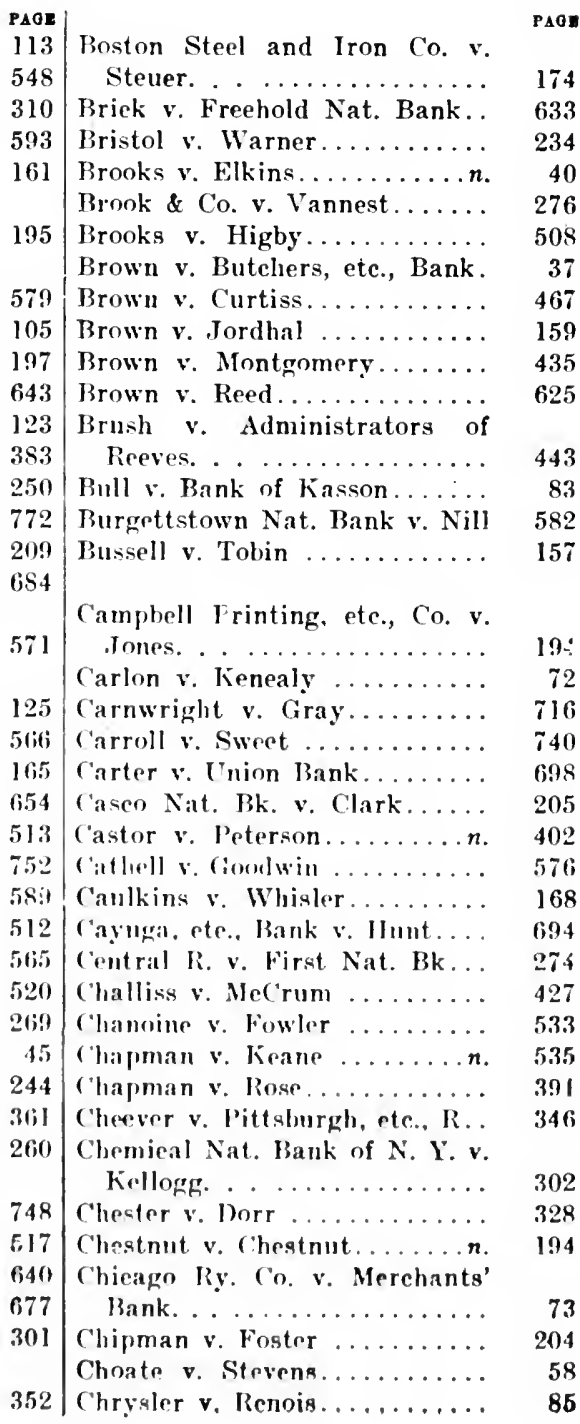


Citizenn' Nat. Bk. v. Piollet..n. Clark v. Pease...............

Clarke v. Patrick ...........

Cock v. Fellows ............

Collins v. Drisenll ..........

Columbian Banking Company v. Bowen. . ................

Commereial Nilt. Bank v. Zint. merman. . . . ...........

Commonwealth v. Butterick....

Continental life Ins. Co. v. Barher. ..................

Cooke v. Horn .............

Cooper v. Dedrick ...........

Coulter v. Richmond.........

Critten v. Chemical Nat. Bank.

Cromwell v. llewitt ..........

Crouch v. Credit Foncier.......

Currier v. Lockwood..........

Curtis v. Sprague ...........

Cushman v. Hayues .......n.

Dabney $r$ Stidger ..........

Daniels $v$. Hammond.......n.

Dart v. Sherwood...........

Davies v. Wilkinson.........

Davis v. Garr.............

Davis Sewing Machine Co. v.

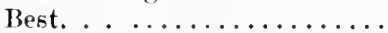

De la Torre $\vee$ Barclay........

Dennistoun v. Stewart ........

De Witt v. Perkins...........

Deyo $\mathbf{v}$. Thompson..........

Dilley v. Van Wie.........

Dodge v. Emerson ...........

Dresser v. Missouri, etc., Co...

Dunavan v. Flynn...........

Dunn v. O'Keefe............

Dwight v. Pease ...........

Edelman v. Rams...........

Eldred v. Malloy.............

Elgin City Banking Co. v. Zelch.

Eng. \& Scot. Amer. Mort. etc. Co. v. Globe Loan \& Trust Co.

Erwin v. Downs ............

Evans v. Freeman ..........

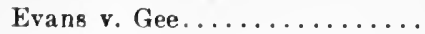

Emerson v. Gere.............

Fall River Union Bank v. Willard. . . ................

Farnsworth v. Allen..........

Fields v. Fields...........n,
PAOA
First Nat. Bank, etc. v. Buttery First Nat. Bunk v. Furneman. . First Nat. Bank v. Forsyth.... First Nat. Bank v. Lightner...n. lirst Nat Bank v. Miller..n. 79, First Nat. Bank v. Slette...... lirst Nat. lauk of Atchison v. Commercial Savings Bank... First Nat. Bank of Detroit v. Currie. . . ............ First Nat. Bank of Farmersville v. Greenville Nat. Bank....n. First Nat. Bank of Lishon v. Bank of Wyndmere ........ First Nat. Bank of Richmond v. Richmond Elec. Co......n. Flanders v. Snare ......... Floyd Accptances, The......

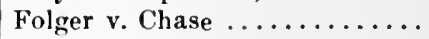
Ford v. Brown............. Fox v. Citizens' Bank......... Frazier v. Massey ........... Freeman v. Exchange Bank.... Freeman's Nat. Bk. v. Savery..n. Funk v. Babbitt ...............

Gardner v. Beacon Trust Co...

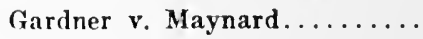

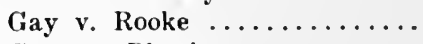
Geary v. Physic ............ Genrige Alexander \& Co. v. Hazelrigg. . . . . . ....... George v. Bacon............ German-American Bank, etc., v. Milliman. . ............ Germania Nat. Bk. v. Mariner..

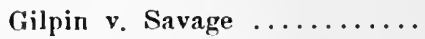
Gordon v. Anderson........... Gordon v. Lansing State Bank.

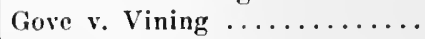
Gowan v. Jackson ........... Grange v. Reigh ........... Greene v. McAuley .......... Greenway v. Wm. D. Orthwein Grain Co. ...............

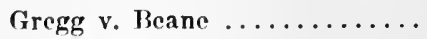
Grey v. Cooper ............ Grocers' Bank v. Penfield...... Guerrant v. Guerrant ......n. Haddock, Blanchard \& Co. $\nabla$. Haddock. . . ............. Hall v. Toby ............... PAOI 98 565 335 54 558 81 651 748 
Hamilton v. Vought.........

Hammett v. Brown...........

Hannum v. Richardson.......

Harrisburg Trust Co. v. Shufeldt. . ..............

Harrison v. Nicollet Nat. Bank.

Harrison v. Ruscoe.........n.

Hart v. Smith..............

Haslach v. Wolf..........n.

Hastings $v$. Thompson.........

Hatcher v. Stalworth.........

Havana Cent. R. Co. v. Knickerbocker Trust Co.........n.

Hays v. Hathorn .............

Head v. Hornblower.........

Herrick v. Bennett..........

Herring v. Woodhull.........

Hibbs v. Brown...........

Hickok v. Bunting..........

Hillsdale College v. Thomas....

Hobbs v. Straine. . . . . . . . . .

Hodges v. Shuler............

Hoffman v. Bank............

Hogue v. Williamson..........

Holbrook v. Payne...........

Hook v. Pratt..............

Hopps \& Co. v. Savage.......

Horn v. Newton City Bank....

Horowitz v. Willowitz........

Horstatter v. Wilson.......n.

Hoyt v. Lynch..............

Hughes v. Kiddell. . . . . . . . . .

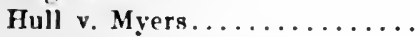

Hunter v. Wilson............

Huntington v. Shute.......n.

Hussey v. Winslow............

Hyne v. Dewdney ...........

Jackson v. Hudson............

James v. Wade.............

Jarvis v. St. Croix Mfg. Co....

Jarvis v. Wilkins.........n.

Jefferson Bank v. ChapmanWhite-Lyons. . . ..........

Jenkins v. Mackenzie........

Jennings v. Roherts........n.

Jerman v. Fdwarls...........

Johnson v. Barrow ...........

Johnson v. Buffalo Center State

Bank. . . . ..............

Johnson v. Conklin..........

Johnson v. Haight...........

Johnson v. Mitchell...........

Jones v. Gordon.............

NRGOT. INBTRUMRNTH - 2

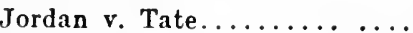
Joseph v. Catron.............

Joslyn v. Eastman............

Josselyn v. Lacier..........n.

Keenan v. Blue............

Keiden v. Winegar...........

Kelley v. Hemmingway........

Kimball v. Costa..........n.

Kimball v. Huntington.......n.

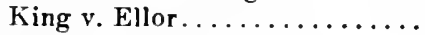

King v. Hurley.............

Kinyon $v$. Wohlford..........

Laird v. State................

Lancaster v. Baltzell..........

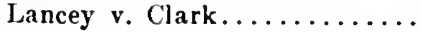

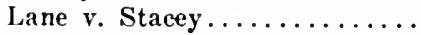

Larkin v. Hardenbrook........

Leask $v$. Dew .............

Leavitt v. Putnam...........

Le Due v. First Nat. Bank of Kasson.

Lent v. Hodgman............

Leonard v. Mason............

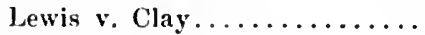

Light v. Kingsbury...........

Lindenberger v. Beall.........

Linn v. Horton . . . . . . . . .

Little v. Slackford............

Lloyd's Bank, Ltd. v. Cooke...

Lomax v. Picot.............

Long v. Stephenson............

Lyndonville National Bank v. Fleteher. . . . . . . . . . . .

Lysaght v. Bryant............

MacBoth v. North and South

Wales Bank ...............

McCormick v. Shea..........

McGregory v. MeGiregory......

McIntosh v. Jytle..........

McMann v. Walker...........

MeNeely Co. v. Bank of North America.

Madden $v$ Gaston...........

Madison Square Bank v. Pierce.

Yarket and Fulton N. I3. v. Sar-

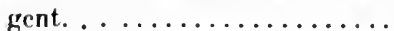

Markey v. Corey............

Marling v. Jones............

Marshall v. Sonneman........ Masaachusette Nat. Bk. v. Snow. Matteson v. Moulton.........
Pae:

106

629

50

142

201

103

194

45

539

152

82

221

597

466

599

601

272

320

63

81

384

97

554

561

45

185

367

442

605

534

131

628

400

107

401

76.9

191

594

170 
Maynard v. Mier............

Megowan v. Peterann........n.

Mehlberg v. l'isher..........

Merrill v. Hurley...........

Merritt $r$ Benton..........

Mever $v$ Richards...........

Meyer \& Co. v. Decroix, Verley

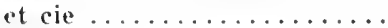

Miller v. Austin............

Mills $v$. Rauk of $\mathrm{I}$. S.......

Minot v. liuss.............

Mont gomery v. Elliott........

Moore v. Cushing...........

Moore v. First Nat. Bauk....n.

Moreland's Adm'rs v, Citizens

Nat. Bank ...........

Morris v. Birminglam Nat. Bk.

Morris ('o. Brick Co. v. Austin..

Morris \&. IIusson............

Moskowitz v. Meutseh.........

Munger v. Shanuon.......n.

Musselman $v$ Oakes.........

Nat. Bank of Commonwealth $v$. Law. . . . . ..........

National Bank of Michigan $v$. Green.................

National Bank of Rolla v. First Nat. Bank of Salem......n.

National Exchange Bank v. Lester. . . . . . . . . . .

National Exehange Bank $v$. Lubrano. ............

Newark, etc., Mfg. Co. v. Bishop

Nixon v. Jalmer...........

Foll $v$. Smith.............

Northern State Bank of Grand Fork v. Bellamy ........n.

Noxon v. Smith...........

O'Bannon, J. WV. v. Curran.... Ohio life Ins. etc., Co. v. MeCague.

Oothout v. Ballard.........

Oppenheim v. Simon Reigel Cigar r'o.

Osborn v. Hawley...........

Osgood v. Artt............

Page v. Cook.............

Page $v$. Morrel.............

Palmer v. Ward.........n.

Pardee v. Fish............

Parker v. Kellogg.
Palker v. Jymeil.

Parker $y$. Reddick. ........

P'arsons v. Iackson..........

P'arsons v. Utiea Cement Co...

l'earce v. I,auertit...........

Petit v. Benson. ............

Peto v. Reyuolda........n. Phillips v. Mereantile Nat. Bk.

l'irr v. Hoinriehshoffen.......

l'lato v. Rivynolds...........

Jlover Savings Bank v. Moodie.

l'ow.r v. finnie...........

l'utnam v. Crymes..........

l'utnan v. Schuyler........

Railroad Co. v. National Bank..

Ranger v. Cary............

Ransom v. Mack...........

Reamer v. Bell...........

Rediman v. Adams........n.

hendall v. Harriman.......n.

lieg. v. Ilarper............

Rice v. Sitearns...........

Richardson v. Carpenter....n.

Richarison v. Ellett.........

Ricler v. Taintor.............

Riker v. Sprague Mfg. Co......

Robertson v. Kensington.....n.

Robinson v. Ames..........

Rockfield v. First Nat. Bank of

Springfielı. .......... 447

Rockville Bauk v. Holt....... 629

Ruff v. Webb............. 45

Sackett v. Palmer.......... 105

Salley v. Terrill........... 153

Saloman v. Pfeister \& Vogel Leather Co. ............. 541

Saunders v. McCarthy....... 207

Sehlesinger v. Lehmaier....... 378

Schmittler v. Simon........ $\quad 50$

Sclimit\% v. Hawkeye, etc., Co.. 4]

Schofield v. Bayard......... 704

Scott v. ralkin........... 270

Sharpe v. Drew............ 685

Shaw v. ('amp............. 102

Shaw v. McNeill. . . . . . . . . 584

Shaw v. Smith............ 111

Sheldon v. Benham........ 543

Shipman v. Bank........n. 135

Siegel v. ('hicago Trust, ete., Pank. ............... 
Simpson v. Turney..........

Slade v. Mutrie............

Snith v. Allen...........

Smith v. Baver..........

Smith v. Crane...........

Smith v. Kendall.........

Smith v. Prosser..........

Smith v. Poillon...........

Souhegan Nat. Bank v. Boardman. . ............

Spear v. Pratt...........

Sprague v. Fletcher.......n.

Stacy v. Kemp............

Stafford v. Yates...........

Stagg v. Elliott...........

Stainback v. Bank of Virginia..

Stapleton v. Louisville Banking Co. ................

State Bank v. Solomon......

State Bank of Chicago v. First Nat. Bank of Omaha...... Start v. Tupper........... Stevens v. Androscoggin Water Power Co.

Stewart $v$. Hen...

Stinson $v$.

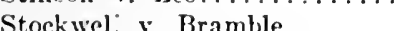

Stoddard v. Burton ..........

Stoddard v. Kimball........

Sullivan v. Rudisill..........

Sussex Bank v. Baldwin.....

Taylor v. Dobhins..........

Taylor v. Snyder.........n.

Times Square Auto. Co. v.

Rutherford Nat. Bank.....

Toby v. Maurian ..........

Tombeckber IBank v. Jumell...

Traders Nat. Bank v. Jones...

Troy City Bank v. Jauman,...

True v. Fuller............

Trust ('o, v. National Bank....

Trust Co. of Amer. v. llamilton

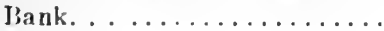

Union National Bank v. Marr's Adm'r. . . . . . . . . . . .

United States v. Amer. Fxch. Nat. Bank.
PAQE

563

600

Valley Nat. Bk. v. Croweil.... Van Buskirk v. State Bank of Rocky Ford .............. Vander Ploeg v. Van Zuuk....

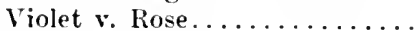

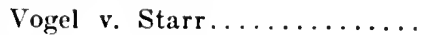

Walker v. Bank............

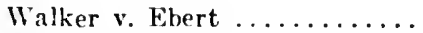
Wallace v. Agry............

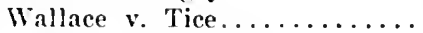
Walsh v. Blatchley........... Walton v. Williams..........

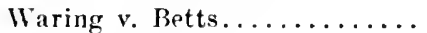

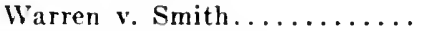
Watrous v. Hallbrook......... Watson v. Evans............ Wellington v. Jackson........ Wells v. Brigham........... West Branch State Bank v. Haines. . ........... Western Wheeled Scraper Co. v. MeMillen.............. 199 Wettlaufer v. Baxter......... 145 Wheeler v. Webster......... 150 White v. Cushing.......... 46 Whitwell v. Johnson......... 554 Willard v. Crook.......... 221 Williams v. Tishomingo Sav. Inst. . . . . . . . . . . Williamshurgh Trust Co. v. Tum Sudem ........... Wilson $v$ Hendee.......... Wilson v. leek..........n. Wintermute $v$. Post........ Winthrop v. Pepooll........ Misner $v$. Trust Nat. Bank.... Witte v. Williams.......... Witty v. Micliemn, ete. Ins. ("o. Wolstenholmu v. Smith....... Worden Groeer Co. v. Blanding. Werdon v. Doulge.......... Worth v. Cast............. Worthington $v$, Cowles........

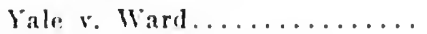





\section{PART I.}

CASES AND AUTHORITIES 


\section{EXPLANATORY NOTE}

The section numbers opposite the titles of cases and elsewhere refer to the sections of the New York Negotiahle Instruments Law. Where ares it other juriselietions ite the Nogotiable Instruments Law, the corresponding sections of the New lork Act are given in the footnotes, except where the context renders this cross-reference unnecessary. 


\title{
CASES AND AUTHORITIES
}

\author{
ON \\ NEGOTIABLE INSTRUMENTS.
}

\section{ARTICLE I. \\ General Provisions.}

\section{Codes governing bills, notes and checks.}

1. The Exglish Bills of Exchange Act.

a Digest of the Law of Bills of Exchange, Promissory Notes and Cheques. BY M. D. Chalmers, 1 M. A., of the Inyer Temple, BabbistER at Law. Lowion, 1878.

[From the Introduction to the First Edition.]

As far as form goes, the present Digest is modeled on the Indian Codes. * * $*$ It is almost needless to point out, that the similarity between the Indian Codes and a Digest like the present is merely resemblance in form. There all analogy ends. In a code the subject in hand is treated completely and finally. A corle states methodically the law as the legislature is of opinion that it onght to be. This Digest is an attempt to state methodically the law as it is. In a code, propositions and illustrations are alike authoritative. In this Digest, the illustrations taken from decided cases are alone authoritative. The gomeral propositions are only entitled to weight in so far as they are complete and legitimate inductions from decided cases which are unquestioned law. A general proposition, supported by reference to cases, merely amounts to a verifiable hypothesis as to what the law is. In the theory of English law, there exists in nubitus a complete set of principles applicable to every ronecivable state of facts that can arise. Theoretically the judges do not make law. They only interpret it. They are merely the conduetors by which the principle is brought down from the clouds and made available to 
men. Practically, however, their functions are frequently and of necessity legislative. If a wide subject be investigated systematically, four states of the law will be fomnd to exist. First, the law on $\mathbf{8}$ given point nay be reasonably certain. All authority, or the great weight of authority, may he in faror of a given proposition. Secondly, a proposition on a given point ean only be stated as probably holding good. For instance, it may rest merely on unchallenged obiter dicta, or there may be a decision in favor of it, and weighty obiter dicta opposed to it. Thirdly, the law on a given point may be uncertain. Decisions may be in direct conflict, or again there may be a decision in point which has never been directly questioned, but the ratio decidendi of which seens entirely opposed to the principle of later cases. Fourthly, there may be an entire absence of authority on a given question. Such being the state of the materials available for forming a Digest, it is clear that if the subject is to be treated methodically, many propositions can only be stated tentatively. Many of the articles, therefore, are qualified with a (probably) or a (perhaps), and the reason of the qualification is then stated in a note.

On doubtful points frequent reference is made to American cases and Continental Codes and writers. In mercantile matters when the law is uncertain or authority wanting, there is an increasing tendency to refer to foreign codes and laws in order to see how other nations have solved the difficulty. This is especially the case as regards negotiable instruments, the most cosmopolitan of all contracts. Mr. Justice Story, in his judgment in Swift v. Tyson (16 Peters, 1), gives forcible expression to the principle. He says, "The law respecting negotiable instruments may be truly declared, in the language of Cicero, adopted by Lord Mansfield in Luke v. Lyde (2 Burr. 887), to be in a great measure, not the law of a single country only, but of the commercial world. Non erit lex alia Roma, alia Athenis, alia nunc, alia post hac, sed et apud omnes gentes et omni tempore una eademque lex obtinebit."

An American decision, it is needless to say, is not a binding authority in this country, but, if well reasoned, it is always considered with respect by our courts. Many of the American judgments are very valuable as expounding and testing the principles of English decisions. An English case there, like an American case here, is only an authority in so far as it appears to be a correct deduction from the greneral principles of the common law and the law merchant which prevail in both countries alike.

When the subject matter of an article of this Digest is dealt with by the French "Code de Commerce," or the "German General Exchange Law, 1849," their respective provisions are compared. 


\section{[From the Introduction to the Third Edition.]}

Soon after the publication of the Second Edition of this Digest the law relating to bills, notes, and cheques was codified by the Bills of Exchange Act, 188:. For the most part the propositions of the Act were taken word for word from the propositions of the Digest. In the introduction to the Second Edition it was pointed out that the general propositions of the Digest could only be considered as law, in so far as they were correct and logical inductions from the decided cases which were cited as illustrations. Now the position is reversed. The cases decided before the Act are only law in so far as they can be shown to be correct and logical deductions from the general propositions of the Act. The illustrations, therefore, must always be tested by the language of the Act itself.

In the notes to the Act I have carefully pointed out the few provisions which were deliberately intended to alter the law. When a proposition in the Act appears to be of wide scope, I have added illustrations taken from decided cases. When a proposition appears to be of narrow scope, I have merely given a reference to the cases which were before me when drafting it. It may be said that the Act should be left to speak for itself. I am well aware that there is no necessary connection between the intention of the drafteman and the intention of the Legislature as deduced by the Courts from the terms of a statute. Still, in the present case, there will be a strong disposition on the part of the Courts to construe the Act as declaratory; and it may be useful to the profession to be referred from the abstract propositions of the Act to the concrete facts which gave rise to them. As Mr. Justice Holmes, in his admirable work on the Common Law, observes (p. 27), "However much we may codify the law into a series of seemingly self-sulficient propositions, those propositions will be but a phase in a continuons growth. To molerstand their scope fully, to know how they will be dealt with by judges trained in the past which the law embodies, we must onrselves know something of that past. The history of what the law has heen is necessary to the knowledge of what the law is."

The Bills of Exchange Act, 188\%, was the first enactment codifying any branch of the Common Law which found its way into the Statute Book. It has now been followed by the Partnership Act, 1890, which was originally drafted by Sir Frederick Pollock. ${ }^{2}$ But as a Code is

2 For an accomnt of this Act, see the Introduction to the 5 th edition of Pollock on Partnership. 
still somewhat of a novelty in the Fuglish law, it may be of interest to refer to the conditions under which the experiment was suecessfully arried out, and to consider how lan it can ol ought to be repeated as regards other portions of the law. Of late years several attempts at coditication have been made but from various eauses they have mostly proved mosuccestul. 'The success of the Bills of Exehange Bill depended on the wise lines laid down by Lord IIerschell. He insisted that the Bill should be introduced in a form which did nothing more than codify the existing law, and that all amendments should be left to Parliament. A Bill which merely improves the form, without altering the substance, of the law creates no opposition, and gives very little room for controversy. Of course codifieation pure and simple is an impossibility. The draftsman comes across doubtful points of law which he must decide one way or the other. Again, roluminous though our ease law is, there are oceasional gaps which a codifying bill nust bridge over if it aims at anything like completeness. Still in drafting the Bills of Exchange Bill ny aim was to reproduce as exactly as possible the existing law, whether it seemed good, bad, or indifferent in its effects. The idea of codifying the law of negotiable instruments was first suggested to me by Sir FitzJames Stephen's Digest of the Law of Evidence, and Șir F. Pollock's Digest of the Law of Partnership. Bills, notes, and cheques seemed to form a well isolated subject, and I therefore set to work to prepare a digest of the law relating to them. I found that the law was contained in some 2,500 eases, and 17 statutory enactments. I read through the whole of the decisions, beginning with the first reported case in 1603. But the cases on the subjeet were comparatively few and unimportant until the time of Lord Mansfield. The general principles of the law were then settled, and subsequent decisions, though very numerous, have been for the most part illustrations of, or deduetions from, the general propositions then laid down. On some points there was a curious dearth of authority. As regards such points I had recourse to American decisions, and to inquiry as to the usages among bankers and merchants. As the result, a good many propositions in the Digest, even on points of frequent oceurrence, had to be stated with a (probably) or a (perhaps). Some two years after the publication of iny Digest, I read a paper on the question of codifying the law of negotiable instruments before the Institute of Bankers. Mr. John Hollams, the well known commercial lawyer, who was present, pointed out the advantages of a c'ode to the mereantile community; and, mainly I think on his advice, I received instructions from the Institute of Bankers and the Associated Chambers of Commerce to prepare a bill on the subject. The draft of the bill was first submitted to a 
sub-committee of the Council of the Institute of Bankers, who carefully tested such portions of it as dealt with matters of usage uncovered by authority. ${ }^{3}$ The bill was then introduced by Sir John Lubbock, the President of the Institute. After it had been read a second time in the Commons, it was referred to a strong Select Committee of merchants, bankers, and lawyers, with Sir Farrer Herschell as chairman. ${ }^{4}$ As the Scotch law of negotiable instruments differed in certain particulars from English law, the bill was originally drafted to apply to England and Ireland only. The first work of the Select Committee was to take the evidence of Sheriff Dove-Wilson of Aberdeen, a well-known authority on Scotch Commercial Law. He pointed out the particulars in which the bill, if applied to Scotland, would alter the law there. With three exceptions the points of difference were insignificant. The Committee thereupon resolved to apply the bill to Scotland, and Sheriff Dove-Wilson undertook the drafting of the necessary amendments. Eventually the Scotch rules were in three cases preserved as to Scotland, while on the other points the Scotch rule was either adopted for England, or the English rule applied to Scotland. A few amendments in the law were made when the Committee was unanimous in their favor, but very wisely no amendments were pressed on which there was a difference of opinion. Sir Farrer Hersehell reported the bill to the House, and it was read a third time and sent up to the Lords without alteration. In the House of Lords it was again referred to a Select Committee with Lord Bramwell for Chairman. A few amendments were there inserted, mainly at Lord Bramwell's suggestion. These were agreed to by the Commons, and the bill passed without opposition.

The Act has now (1891) heen in operation for more than eight years, so that some estimate can be formed as to its results. Merchants and Bankers say that it is a great eonvenience to them to have the whole of the general principles of the law of bills, notes, and cheques contained in a single $A$ ct of 100 seetions. As regards particular cases which arise, it is seldom neeessary to go beyond the Act itself. It must also be an advantage to foreigners who have English bill transactions to have an anthoritative statement of the English law

3 Mr. Billinghurst, of the London and Westmingter Bank, and Mr. Slater, of the Inndon and County liank, undertook the brunt of the work.

4 The committee included Sir Farrer Ilerschell, Q. C.; Sir John Lubbock; Mr. Asher, Q. C.; Mr. Cohen, Q. C.; Mr. Reid, Q. C.; Mr. Whitley, Mr. T. C. Baring, Mr. R. B. Martin, Mr Orr-Fwing, Mr. Jackson, and Sir Charles Mill.

- The committee included the Lord ('hancellor (Selborne), Lord Bramwell, Lord Fitzgerald, Lord Balfour of Burleigls, and Lord Wolverton. 
on the subject in an accessible form. If I could do the work over again, I certainly could do it better and should profit by past experience. But as it is, the Aet, as yet, has given rise to very little litigation. I am sure that further codifying measures can be got through Parliament, if those in elarge of them will not attempt too much, but will be content to follow the lines laid down by Lord Herschell. Let a codifying bill in the first instance simply reproduce the existing law, however defeetive. If the defects are patent and glaring, it will be easy to get them amended. If an amendment be opposed, it can be dropped without sacrificing the bill. The form of the law at any rate is improved, and its substance can always be amended by subsequent legislation. If a bill when introduced proposes to effect changes in the law, every clause is looked at askance, and it is sure to encounter opposition.

Assuming then the possibility of further codification, the question arises whether its extension is expedient. All the continental nations have codified their laws, and none of them show any signs of repenting it. On the contrary, most of them are now engaged in remodeling and amplifying their existing codes. In India a good deal of codification has been carried out, and public and professional opinion seems almost unanimous in its favor. The Bills of Exchange Act, 1882, has been adopted by New Zealand, Victoria, New South Wales, South Australia, Queensland, Tasmania, and with slight modifications by Canada. ${ }^{6}$

\section{[From the Preface of the Seventh Edition.]}

The Bills of Exchange (Crossed Cheques) Act, 1906, has for the first time amended the Act of 1882. It interprets section 82 of the principal Act, and overrides Gordon v. London and Midland Bank (1903), A. C. 242, H. L., in so far as that case turned on the construction of that section. 'The Bill was drafted by me in 1903, under instructions from Lord Halsbury, but it failed to pass the House of Commons till 1906.

- It has now been adopted by forty of the English colonies and dependencies. See Art. by E. Dove-Wilson, on Codification of Commercial Law, in 8 Jurid. Rev. (1896), 329. - II.

[In the 7th edition (1909) of Chalmers' Digest of the Law of Bills of Exchange, etc., the author gives on pages 401-402 a list of forty-three British colonies which have enacted laws relating to bills, notes, and checks, giving also the citation to these laws. He remarks, however, that "The above laws pre not necessarily framor on the same lines as the Imperia! Act." - C.] 


\section{The American Negotiable Instrunents Law.}

LAwS OF NEW York, 1890, Chapter 205.

$\S 1$. Within thirty days after the passage of this act, the governor shall appoint, by and with the consent of the senate, three commissioners, who are hereby constituted a board of commissioners by the name and style of " (ommissioners for the Promotion of Uniformity of Legislation in the Lnited States." It shall be the duty of said board to examine the subjects of marriage and divorce, insolvency, the form of notarial certificates and other subjects; to ascertain the best means to effect an assimilation and uniformity in the laws of the States, and especially to consider whether it would be wise and practicable for the State of New York to invite the other States of the Union to send representatives to a convention to draft uniform laws to be submitted for the approval and adoption of the several States, and to devise and recommend such other course of action as shall best accomplish the purpose of this act. ${ }^{7}$

The Negotiable Instruments Law. (A Review of the Ames-Brewgter Costroversy.) By Charles l. Mcheehan, of the philadelpili bar. Tile americin Law Register, Yol. 41, N. S., Nos. 8, 9, 10, Algest, Septemiber, October, 1902.

\section{[l'ages $438-142$.}

At the Annual Conference of the Commissioners on Tniform State Laws, held in Detroit in 1895, a resolution was passed requesting the Committee on Commercial Law to procure, as soon as practicable, a draft of a bill relatine to eommercial paper based upon the English Bills of Exchange Aet and upon such sources of information as the Committee might deem proper to enusult. The matter was referred to a suh-eommittere ennsisting of .lurge Lyman D. Brewster, of Connectient: Henry ' '. Willeox, of New York, and Frank Bergen, of New Jersey, whe semured Mr. Inlun .J. ('rawford, of the New York bar, a well-known expert on the law of bills and notes, to draft the proposed bill.

The English art hart followel the enntinental endes as to form, i. $c$. it dealt primarily with bills of exchange, and then applied these provisions, on far as they were applicable, to promisory notes, adding provisione which were peculiar to the latter elass of instruments. Deeming this form to be unsuited to Amerienn enditions - the use

Similar arts have bern passed in many of the Aluerican States, and com. missionera appointed, $-\mathrm{H}$. 
of hills of exchange being propolionately less extensive here than in

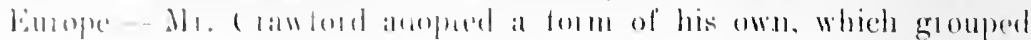

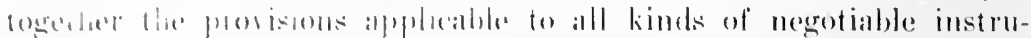

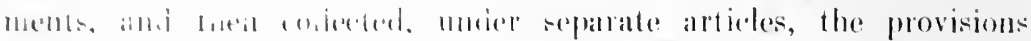

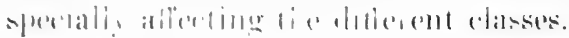

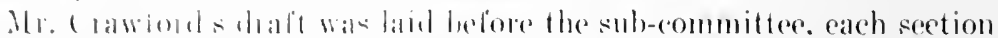

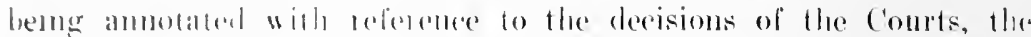
comments of tor-houk whites, and the statute laws of the several states. This doatt (slighly ameloled by the sub-comnittee) and the drafteman's nores were pinful along with the English bill for com. parison, and aphis were sont to ald member of the conference, to many pominne lawyers and law professors, and to several English juelges and lawress, with an invitation for suggestions and criticisms. The draft was then submited to the comference at Saratoga in 1896. 'The twenty-seven ('ommissioners who were in altendanee - representing fourtern ditferent states - went nver it section by section, and made some amendments to it, "most of which," says Mr. ('rawford. "were to incorporate into the original draft." s The draft as thus amended was adofucel by the conterence, and in such form has been submitted to the various state Legislatures.

The most impostant contribution that has been marle to the act is the Ames-Brewster contooversy. In the Fomrteenth Harvard Law Review, Professor James Barl Ames, Dean of the Harvard Law Faculty, for some years lecturer on Bills and Notes in the Harvard Law School. and the author of the learling case book on the subject. published an article criticising some twenty-three sections of the new act, and expressing the opinion that notwithstanding the act's many merits. "its arloption by fifteen states must be regarded as a misfortune, and its enaetment in alditional states, withont considerahte amendment, shombl he an impossilility." Professor Anes' eritieisms were answered by Judge Ixman I). Brewster, President of the National Conference on Lniform sitate Laws, and a member of the subcommittee which drafted the ald. The discussion consists of two articles in the Marrard law Lieviow. ly l'rofessor Ames, ${ }^{9}$ and two artieles by Judge Prewster, one publisbed in the Yale Law Journal and one in the Harvard law Reviow: ${ }^{1}$ In a pamphlet recently pullished by the Harvard Law Review Publishing Association, containing the text of the act, together with these artioles, there are added. a

8 ('rawford's An. X. J. I. Prefore.

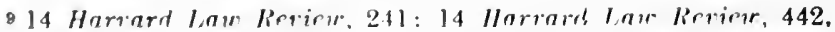

110 Yale Law Journal, 84; 15 Ilarnard Lau lirricu, 26. 
supplementary note by Professor Ames criticising two additional sections of the act - a reply thereto by Judge Brewster, and a letter containing comments on some points of the discussion by Mr. Arthur Cohen, Q. C., a member of the committee which framed the English act, who was recommended by Judge Chalmers as one of the three best authorities in England on the law of bills and notes.

As Judge Brewster remarks, "No keener weapon than that wielded by the accomplished Dean of the Harvard Law School could be turned against the Negotiable Instruments Law." Professor Ames knows more about the law of bills and notes from the student's standpoint than any one else in this country. Whatever one's conclusions may be as to the soundness of his criticisms, there is little doubt that few, if any, of the vulnerable points in the act have escaped his notice, and that the sections he criticises are those most likely to come up for construction. A familiarity with his criticisms and with Judge Brewster's replies cannot but aid both the bench and bar in giving some sections of the act their proper meaning. This consideration, together with the difficulty of understanding the discussion in its present form, where the criticism of each section, the answer, replication and rejoinder are spread out through four separate articles, has prompted me to write a review of the controversy.

Two general observations may be made, which should be borne in

2 The articles contained in the pampllet referred to, together with Mr. McKechan's "Review of the Ames-Brewster Controversy," are reprinted in Professor J. D. Brannan's work on the Negotiable Instruments Law, published by the Harvard Law Review Association in 1908.

See also "The Negotiable Instruments Law, a Reply to the Criticisms of James Barr Ames," by John Lawrence Farrell, of the New York har, in The Brief of Phi Delta Phi, Vol. Ill., No. 2, First Quarter, 1901; and "The Negotiable Instruments Law: Its IIistory and Practical Operation," by Amasa M. Faton, in The Michigan Jaw Revirw, Vol. IJ., No. 4, January, 1904.

See the article by Profesenr Julian W. Mack in 1 Ill. Law Rev. 592 (April, 1907), entitled "Some anggestions on the proposal to enat the "Uniform Negotiabl. Instruments Law" in Illinois," arlvocating rertain elanges from the Act as drafted by the Commissioners on Uniformity of Jaws. This article should be rearl in connection with the articles on the "Ames-Brewster Controversy" Ineause as Profesonr Mack says (p. (605), "Many of the changes advocated in the foregoing suggestions are taken from Profesonr Ames' artieles. The reasons in alpport of them will he fouml therein and in Mr. Meliehan's pamphlet." Moat of theare propesed rhanges were ndopted ly the Illimoia legislature in rnaeting the Law in that atate. Ser the very instruetive article written by Professor I. M. Cirecley shortly after the passige of the Illinois act in 2 III. Jaw liev. 145 (Oetoler, 1907 ), rxplaining the new act and pointing out the changes it effected in the prior law, and Professor Mack's comments on this article in 2 lll. Law liev. 205. - C. 
mind throughont the entire discussion. In the first place, no one can judge the new net fairly who does not realize that the Commissioners were attempting to codify the law. ${ }^{3}$ 'Their aim was not to reform the law of negotiable paper. It was to state accurately and concisely the existing law. Of course, here and there it was necessary to choose between two or more conflicting views. Very frequently a section changes the law in a small minority of states which had departed from the almost uniform eurrent of authority. Occasionally, though very rarely and only when there seemed to be no room for a difference of opinion, the law was deliberately changed. But the main, and almost the sole purpose of the framers of the Negotiable Instruments Law was to reproduce, as exactly as possible, that which the great weight of authority had declared to be the law.

Second, in interpreting some sections of the act, the language used must be given not a hyper-literal meaning, but a reasonable legal meaning, derived, to some extent, from a knowledge of the cases on which the sections are based. It would be a great achievement for a code to state the law, in every instance, in language capable of meaning only one thing, even to a man entirely withont legal training and unacquainted with what the law was before the code. But it will be a long time before such a code is framed. Of course, in the great majority of instances the Negotiable Instruments Law does this. But it is not a serious reflection on the act that in some instances a familiarity with the cases on which the language of the act is based, is - if not necessary - at least very helptul in deciding what the language means. Indeed, Judge Brewster said to the American Bar Association, in discussing the new act in 1898, "Care has been taken to preserve, as far as possible, the use of words which have had repeated construction by the courts, and have become recognized terms in the law merchant."

With these observations we may proceed to consider the discussion of particular sections. ${ }^{4}$

3 The discussion between Professor Ames and Judge Brewster makes no attempt to take up the broad question as to the propriety and utility of codification. For a most learned and able argument against codification, the reader mar he referred to a book by R. F. Clarke, Esq., of the New York bar. entitled "The Srience of Law, and Law Making." The arguments in favor of at loast a partial codification of such a branch of the law as that relating to commercial paper are concisely stated by Judge Brewster in a paper read before the American Bar Association in 1898 on "Uniform State Laws," which is reprinted in the report of the Ninth Conference of the Commissioners for Promoting Uniformity of Incialation in the United States.

4 A few extracts from Mr. Mckephan's article, discussing certain sections of the Negotiable Instruments Law, will be found hereinafter printed. - C. 


\section{Continental Codes.}

\section{Chalmers' Digest of the Law of Bills of Exchange, etc.}

\section{[From the Introduction to the Third Edition.]}

The French Code ${ }^{5}$ is of particular interest. Although enacted more than eighty years ago, no substantial alteration has been made in it by subsequent legislation. For many years it was the model of nearly all the Continental Code's. For instance, the Belgian Code de Commerce of 1872 enacted for Belgium the provisions of the French Code regarding bills and notes, with a few slight modifications borrowed from Germany, and the addition of three or four articles which embodied the result of French judicial decisions on the construction of the Code. Of late years, however, there has been a tendency to arlopt the somewhat wider provisions of the German Exchange Iaw. Until 1883 the Italian Commereial Code was elosely modeled on the Freneh, but the new Italian Code which came into force in $\mathbf{1 8 8 3}$ has departed from the French model as regards bills and notes, and has substantially adopted the provisions of the German Exchange Law. Again. the Portuguese Code of 1833 was mainly founded on the French Code. But the Code of 1858 in many respects departs from the French model, and has in the main followed the German Exchange Iaw, though a few provisions seemed to be borrowed from the English Act. I helieve the Hungarian Code of 1875, the Scandinavian laws of 1880, the Swiss law of 1881, and the Spanish Code of 1885 have also leparted from the French idea and followed the German lead. French law is worthy of attention in another respect. In the absence of English anthority, our Courts have, in some instances, conseinusly taken it as their guile. (See per Parke, B., in Foster v. Dauber, 6 Exch. 85.) 'The "Code de Commerce," to a great extent, embodies and enacts the opinions of Pothier, whose anthority, says Best, C. J. (in Co.x v. Troy, 5 B. \& Ald. 481), " is as ligh as can be had next to the decision of a Court of Justice in this country." On doubtful points not dealt with by the Code, reference is occasinnly made to Pothicr. and also to the exhaustive treatise of II. Nouguier (Des Lettres de Change et des Effets de Commerce, 4th 1875), which gives the latest results of French law.

The German General Exchange Law of 18.19 (slightly modified, $1869)$, is important in 1 wo respects. First, it is the most elaborate and carefully workeil out of the foreign codes, and it appears to be the model to which the other continental states (with the exception of France) are now assimilating their laws. Secondly, it is an interna-

s Code de Commerce, 1807. This is availabie in translation in a work by $\mathbf{L}$. Goiraud on the French Corle of Commerce, Jondon, 1880. Articles 110-189 deal with bills and notes. Clucks are dealt with in separate Acts (1865 \& 1874). - H. 
tional and not merely a national Code. All the German States, including Anstria, have adophed it, and the terms of its adoption are these: Each state is at liberty to supplement it by additional laws of its own, but such laws are not in any way to contradict or override it. M. Nonguier. in the work above referred to, gives in French the text of the Wodnange lan. and also the various supplementary laws passed by the dillerent states."

It would probathly he rery antrantageous to the commercial world if this principle of an Intermational Code could be further extended. The difliculties of earying it out do not seem insuperable, though, donbtless. they would he great. 'The provisions of such a Code would have to be settled by agreement, and then each State would mact it for its own territory. In the case of England it would probably be necessary to confine its operation to foreign bills, that is to say, to bills drawn or payable abroad. Our law, as regards foreign bills, does not widely diverge from the law of other commereial countries, and it diverges eliefly by allowing greater latitude than is adopted in practice.

Occasional reference is also made to the Indian Code (Act XXVI, of 1881 , as amended by Act II of 1885) which in sulistance reproduces. the English law as it stood in 1881. In a work like the present, it is thought it would be waste of space to earry references to foreign laws or authorities any further, but it may be worth while to mention where they can be found.

Borchardt (Vollständige Sammlung der geltenden Wechsel-und Handels Gesetze aller Länder, 18\%1), collects the statutory enactments of all countries relating to Bills of Exchange. Part I gives a German translation. Part II the original text. More than forty countries have codified their law on this sulject; in fact, some English colonies and the United States seem to be the only civilized nations which have not done so. Sinee Borchardt's work was published, however, several continental states have re-cast their laws relating to negotiable instruments. A new Commercial Code has been enacted for the Netherlands, and an official translation of the part relating to negotiable instruments bas been published in England. [Sire Commercial, No. 30. of 1880 , c. 2609.] M. Nolnguier, in a supplementary rhapter to his work on Bills (Des Lettres de Change, 1855), compares the laws of the rhief commereial nations with the French Code. The Comité le législation Etrangère, under the direction of the French Ministry of Justice, are preparing cheap French translations of the various foreign laws relating to commercial matters. Several volumes have already been published with excel-

\footnotetext{
B See Art. by E. Schuster on the German Civil Code, 12 Law Q. R. (1896), $17,-\mathrm{H}$.
} 
lent introductions and notes. Having regard to our own insular isolation, I fear it will be long before any English government department undertakes similar useful work. M. Massé's "Droit Commercial et des Gens" is a valuable work on the conflict of laws, especially as regards bills.

\section{Construction of codifying statutes.}

\section{BANK OF ENGLAND $v$. VAGLIANO BROTHERS.}

[Reported herein at $p .125$.

\section{The law merchant.}

I. Tite Law Merchant and its History.

The Elements of Mercantile law. By Thomas Edward Scrutton. LoNDON, 1891.

\section{[From Chapter I.]}

IBooks recommended.- The best, and almost the only satisfactory sketch of the history of the Law Merchant with which I am acquainted, is the introduction prefixed by Master Macdonell to the tenth edition of Snith's Mercantile Law. See also the Prefaces to Chalmers on Bills of Exchange, and Lowndes on Marine Insurance; and Scrutton on the Influence of the Roman Law on the Law of England, chapters xiii, xiv.]

\section{I.}

The fact that so wide a meaning is given $* * *$ to the term "Common Law," may properly call your attention to the different meanings that the term "Common Law," itself has. In the first place "Common Law" is used in distinetion to "Piquity." The Common Law alone was administored hy the King's Courts in this country, and suitors who complainerd of the rules of the law addressed petitions to the King, as the fountain of justice, asking for "Equity." The King, if he had time or inclination, realt with these petitions himself; but when, as generally happened, he had not time or inelination, he referred them to his Chancellor, and the Chancellor dealt out "Equity" to petitioners injured by the stringent rules of the Common Law. "The Equity administered at first was variable; as Selden said, it "varied with the length of the Chancellor's foot," but hy degrees Fquity itself came to settle down to rigid rules, until with the sane case you might know heforehand that you would be successful on the Common Law side of Westminster Hall and unsuc- 
cessful on the Equity side. At last under the Judicature Act ${ }^{\text {? }}$ the rules of Eynity prevaited orer the rules of Common Law, and the distinction becance atholished exeept in as far as certain subjects were assigned to the Cond of Chancery, and that certain subjects were assigned to the Queen's Bench Division.

I seend meaning of the term "Common Law" is when it is used in opposition to "Statute Law." In that sense Common Law is the unwritten law of the kingdom which exists in gremio legis, in the hosom of the judges, which they bring forth from that mysterious rucess when new points have to he dealt with: while the Statute Law is the uritten law of the kingdom as it has been laid down by the Legislature in Arts of Parliament.

Another sense in which the term "Common Law" is used is when it is distinguished from the "Civil law," and in that rense the Common Law is the law of England; the Civil Law is the law of those countries who have founded their system upon the Roman Law. For instance, if you go north of the Border to Scotland, you find a sistem administered differing from the Law of Erigland, and founded upon the Civil Law. If you cross the $A$ tlantic to the United States you find the States in the North, such as Massachnsetts, administering a system founded on Common Law; and if you so to Lounsiana, in the South, you find a system founded on the old Roman Law, and known as a Civil Law system.

\section{II.}

There was yet another distinction which leads me to the subject of this course of lectures. If you read the law reports of the seven- teenth rentuly you will be struck with one very remarkalse fact; eithor linglishmen of that day dicl not engage in commerce, or they appear not to have been litigious people in commercial matters, each of which alternatives appears improbable. But it is a curious fact that one finds in the reports of that century, two hundred years ago, hardly any commereial cases. If one looks up the Law of Bills of Exchange, "the cases on the subject are enmparatively few and unimportant till the time of Lord Mansfield." 8 If you curn to Policies of Insurance, and to the work of Mr. Justice Park on the subject published at the beginning of this century, you find him saying: "I am sure I rather go beyond bounds if I assert that in all our reports from the reign of Qincen Elizaheth to the year 1756 when Lord Mansfield became Chief .Justice of the King's Bench, there are sixty cases upon matters of insurance." If you come

736 and 37 Vic. c. 6.6. \$ 5, s8. 11 .

8 ('halmers. Hills, Pref. p. 36.

O Park, I. Pref, 43. 
to Charter Parties and Bills of Lading, which have always been productive of litigation, you find Sir John Davies in the seventeenth century saying that "until he understood the difference between the I.aw of Merchants and the Common Law of England, he did not a little marvel what should be the cause that in the books of the Common Law of England there should be found so few cases concerning morchants and ships, but now the reason was apparent, for that the Common Law did leare these cases to be ruled by another l.sw, the Law Merchant, which is a branch of the Law of Nations." 1

The reason why there were hardly any cases dealing with commercial matters in the Reports of the Common Law Courts is that such cases were dealt with ly special Courts and under a special law. That law was an old established law and largely based on mercantile custonis. Gerard llalvmes, who wrote the first work on the Merchant 1.aw in England, called his book, published in 1622. "Consuetudo rel Lex Mercatorio," or the Ancient Law Merchant; and he said in his prefier: "I have entituled the book according to the ancient name of Lex Mercatorin and not Jus Mercatormm, becanse it is a customary law approwel hy the authority of all kingdoms and comnonweales, and not a law established by the sovereignty of any prince." And Blackstone, in the middle of the last century, says: "The atfairs of commerce are regulated by a law of their own caller the Law Merchant or Lex Mercutoria, which all nations agree in and take notice of, and it is particularly held to be a part of the law of England which decides the causes of merchants by the general rules which oltain in all commercial comntries, and that often even in matters relating to domestic trade, as for instanee, in the drawing. the acreptance, and the transfer of Bills of Exchange." 2 Later thin Blackstone, Jord Mansfeld lays down that "Mereantile Law is not the law of a particular country, hut the law of all nations:" 3 while so rerently as 1883 you find lord Blacklom saying in the Ilouse of loorts that "the gremeral I.aw Yorelant for many rears has in all comutries ansed Bills of Wxolanger to be negotiable: there are in some a ase differences and peenliarities which hy the municipal law of rach esmontry are grafted on it, hut the general rules of the Law Merchant are the same in all conntries."

III.

Now if we follow the growth of this Law Mrerchant or Moreantile Iaw, which was two hmmlred years igo so distinct from the Com-

1 \%ouch, Iuriadiention of the Admiralty (1686) , P. 89.

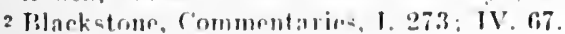

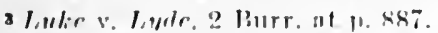

- H'Lan v. Clydesdale litunk, ! Ap. C., at p. 105.

NKGOT. INBTRUM RNTS - 2 
mon Law, we find it in lingland going through three stages of development." 'The tirst stage may be fixed as ending at the appointment of Colse as Lord Chief Justice in the year 1606, and before that time you will find the Law Merehant as a special law administered by special Courts for a speeial class of people.

In the first place as to the special Courts. The greater part of the foreign trate of England, and indeed of the whole of Emope at that time, was conducted in the great fairs, held at fixed places and fixed times in each yoar, to which merchants of all countries came; fairs very similar to those which meet every year at the present time at Novgorod in Russia, and at other places in the East. In England, also, there were then the great fairs of Winehester and Stourbridge, and the fairs of Besançon and lyons in France, and in each of those fairs a court sat to administer speedy justice by the Law Merchant. to the merchants who congregated in the fairs, and in case of doubt and diffieulty to have that law declared on the basis of mereantile customs by the merchants who were present. You will find this Court mentioned in the old English law books as the Court Pepoudrous, so called because justice was administered "while the dust fell from the feet," so quick were the Courts supposed to be. "This Court is incident to every fair and market beense that for contrats and injuries done concerning the fair or market there shall be as speedy justice done for advancement of trade and traffic as the dust can fall from the feet, the proceeding there being de hora in horam." 6 Indeed, so far back as Bracton in the thirteenth century, it had been recognised that there were certain classes of people "who onght to have swift justice, snch as merchants, to whom justice is given in the Court Pepoudrous." 7 The records of these Courts are few, for obvionsly in Courts for rapid business law reporters were rather at a discount. As a consequence, "there is no part of the history of English law more obscure than that connected with the maxim that the Law Merchant is part of the law of the land." 8 Wre are, however, fortunate enough to have one or two records of the Courts of the Fairs. The Selden Society has succeeder in unearthing the Abbott's roll of the fair of St. Ives held in 1275 and $1291,^{9}$ containing a series of eases which show how the merchants administered the Law Merehant in the Courts of the fair, and why such eases did not eome into the King's Court. For instance:- "Thomas, of Wells, complains of Arlam Garsop that

- Macdonell, Preface to Smith's Mercantile Law, p. 82.

"Coke, Inst. IV. 272. ["Pypowder" courts appurtenant to fairs were authorized in Now York in 1692. - 1 Col. Laws (ed. 1894), p. 298. - H.]

7 Bracton, f. 334.

- Blackburn on Sale 1st Ed. p. 207.

- Selden Society, Vol. II. pp. 130 et seq. 
he unjustly detains and deforces from him a coffer which the said Adam sold to him on Wednesday next after Mid Lent last past for sixpence, whereof he paid to the said Adam twopence and a drink in advance" - (it appears to have been a very good mercantile custom, still existing, to "wet a bargain," and the drink was a matter to which great importance was attached by the merchants present); " and on the Octave of Easter came and would have paid the rest, but the said Adam would not receive it nor answer for the said coffer, but detained it unconditionally to his damage and dishonour, $2 s$., and he produces suit. The said Adam is present and does not defend. Therefore let him make satisfaction to the said Thomas and be in mercy for the unjust detainer; fine $6 d$.; pledge his overcoat." The next defendant was not so fortunate so as to have an overcoat. "Reginald Picard of Stamford came and confessed by his own mouth that he sold to Peter Redhood of London a ring of brass for $5 \mathrm{r} / 2 d$. saying that the said ring was of the purest gold, and that he and a one-eyed man found it on the last Sunday in the churchyard of St. Ives, near the cross." (One fancies onc has heard that tale about the brass ring before.) "Therefore it is considered that the said Reginald do make satisfaction to the said Peter for the $5 \mathrm{l} / 2 d$. and be in mercy for the trespass: he is poor; pledge his body." The next case introduces the Law Merchant. "Nicolas Legge complains of Nicolas of Mildenhall for that unjustly he imperles him from having, according to the usage of merchants, part in a certain ox which Nicolas of Mildenhall bought in his presence in the village of St. Ives on Monday last past to his damage $2 s$. , whereas he was ready to pay half the price, which price was as. fid. And Nicolas of Mildenhall defends, and says that the Law Merchant does well allow that every merchant may participate in a bargain in the butcher's trade if he claim a part thereof at the time of the sale: but to prove that the said Nicolas Legge was not present at the time of the purchase nor claimed a part therenf he is ready to make law." Then they went to the proof. The enstom of the Law Merehant relied on admitted any merchant standing by to elaim a share in any hargain on paying a share of the price. The defence is, "You were not there, so yoll cannot claim." The next and last case is one which puzzled the Court, and therefore I nmit the details, but it is recited in the Abbott's roll: "And the ease is respited till it shall be more thoroughly discussed hy the merchants. And the merchants of the various commonalities and others heing convoked in full Court it is considered"- and then they go on to discuss it. There your see the Merchants' Court at work, griving quick justien in all mereantile disputes, and in eases of doulot calling upon the merehants present to deelare what the Law Merchant is. Sn nuch for the fairs.

In most seaport towns also you will find a similar Court dealing 
with enses arising out of ships. In the Domesday Book of Ipswich ${ }^{1}$ it is stisted, "The pleas between strange folk that men call "pypoudrous ' should be pleaded from day to day. The pleas in lime of fair between stranger and passer shond be pleaded from hour to hour, as well in the foremoon as in the afternoon, and that is to wit of plaints hegun in the same time of fair, and the pleas given to the law marine for strange mariners passing, and for them that abide not but their tide, should be pleaded from tide to tide." Any ship (a)ming into the port of Ipswich with a dispute about its Charter Party or bill of Iading may get summary justice at once from this Court at Ipswich between tide and tide. Stress may be laid on the fact that the Courts sat in the afternoon, hecause at that time the King's Courts only sat from eight in the morning till eleven and then adjourned for the rest of the day. "For in the afternoons these Courts are not holden. But the suitors then resort to the perusing of their writings, and elsowhere romsulting with the sergeantsat-law and other their comnsellors," " so that the time taken up in consultation by the Conrts in London was taken up by the Courts at Ipswich in dealing summarily with cases, and letting the strange mariners go who were only waiting for their tide.

There were special Courts by statute, of which a number of "grave and discreet mercliants" were necessary members, in order that the Mercantile Law founded on the custom of merchants might be duly applied to the case before them." The law which these Courts administered was what was called by merchints the Law Merchant and Law of the Sea, and it was common to nearly every European country. Much of it was to be found in a series of codes of Sea Iaws, such as the Laws of Oleron and Wisbury, and the Consolato del Mare, embodying the customs and practices of merchants of different countries, and it was not the Common Law of England. Further, it was only for a particular class. You had to show yourself to be a merchant before you got into the Mercantile Court; and until about two hundred years ago it was still necessary to show yourself to be a merchant in the Common Law Courts before yon could get the benefit of the Law Merchant."

IV.

Now the second stage of development of the Law Merchant may be dated from Lord Coke's taking office in 1606, and lasts until the

1 Black Book of Admiralty, Rolls Series, II. 23.

2 Sir J. Fortescue.

3 E. g. the Court established by 43 Eliz. c. 12, of which eight "grave and discreet merchants" were to be members, who were to letermine all insurance cases in a brief and summary course, without formalities of pleadings or proceedings.

1 Vide post, pp. 29, 30. [Hercin at p. 27. - H.] 
time when Lord Mansfield became Chief Justice in 1756, and during that time the peculiarity of its development is this: That the special Courts die out, and the Law Merchant is administered by the King's Courts of Common Law, but it is administered as a custom and not as law, and at first the custom only applies if the plaintiff or defendant is proved to be a merchant. In every action on a Bill of Exchange it was necessary formally to plead "secundum usum et consuetudinem Mereatorum"- according to the use and eustom of merchants;" and it was sometimes pleaded that the plaintiff was not a merchant but a gentleman. ${ }^{6}$ And as the Law Merchant was considered as custom, it was the habit to leave the custom and the facts to the jury without any directions in point of law, with a result that cases were rarely reported as laying down any particular rule, because it was almost impossible to separate the custom from the facts: as a result little was done towards building up any system of Mercantile Law in England.

V.

The construction of that svstem began with the accession of Lord Mansfield to the Chief Insticeship of the King's Bench in 1756 , and the result of his arministration of the law in the Court for thirty years was to build up a system of law as part of the Common Law, embodying and giving form to the existing eustoms of merchants. When he retired after his thirty vears of office, Mr. Justice Buller paid a great tribute to the service that he had done. In giving judgment in Lirkbarrow v. Mason, ${ }^{7}$ he said: "Thus the matter stond till within these thirty years. Since that time the Commercial Law of this country has taken a very different turn from what it did before. Lord Hardwicke himself was proceding with great cantion, not establishing any greneral principle, but decreeing on all the circumstances put together. Before that period we find in C'onrts of Law all the evidence in mercantile cases was thrown fogether; they were left generally to the jury, and they produced no established principle. From that time we all know the groat study has been to find some certain general principle, not only to rule the particular case nuder consideration, but to serve as a guide for the future. Most of us have heard those principles stated, reasoned upon, enlarged, and explaimed till we have been lost in adniration at the strength and streteh of the humau understanding, and 1 shomld be sorry to find myolf under the necessity of differing from Iord Mansfield, who may truly be said to

shalmers, Bills, Pref. 44.

- Cf. Sarsficld v. Witherby (1692), Carthew, 82.

72 T. R. 73. 
he the founder of the Commercial law of this country." Lord Manstield, with a Scotch training, was not too favourable to the C'ommon Law of England, and he derived many of the principles of Mercantile Law, that he laid down, from the writings of foreign jurists, as embodying the custom of nerchants all over Europe. For instance, in his mreat judgment in luke v. Lyde, ${ }^{8}$ which raised a question of the frejerht due for goods lost at sea, he eited the Roman Pandects, the Consolato del Mare, laws of Wisbury and Oleron, two English and two forejgn mereantile writers, and the Freneh Ordonnances, and deduced from them the principle which has since been part of the law of England." While he oltained his legal principles from those somrees. he took his eustoms of trade and his facts from Ilereantile special . Iuries, whom he very earefully directed on the law; and Iord Campbell, in his life of lood Mansfield, has left an account of Lord Mansfield's procedure. He says:" "Lord Mansficld reared a body of speeial jurymen at Guildhall, who were generally returned on all commereial eases to be tried there. He was on terms of the most familiar intereourse with them, not only conversing freely with them in Court, but inviting them to dine with him. From them he learned the usages of trade, and in return he took great pains in explaining to them the principles of jurisprudence by which they were to be guided. Several of these gentlemen survived when I began to attend Guildhall as a student, and were designated and honoured as ' Lord Mansfield's jurymen.' One in particular I remember, Mr: Edward Vaux, who always wore a cocked hat, and had almost as much authority as the Lord Chief Justice himself."

Since the time of Lord Mansfield other judges have carried on the work that he began, notably Abbott, Lord Chicf Justice, afterwards Lord Tenterden, the author of "Abbott on Shipping," Mr. Justice Lawrence, and the late Mr. Justice Willes; and as the result of their labours the English Law is now provided with a fairly complete code of mercantile rules, and is conseruently inclined to disregard the practice of other comntries. In Iord Mansficld's time it would have been a strong argument to urge that all other countries had adopted a particular rule; at the present time English Courts are not alarmed by the fact that the law they administer differs from the law of other countries. In a recent case before the Court of Appeal, Lord Esher says:" "It was urged that even if the

82 Burr. 883.

9 Cf. the judgment of Willes, J., in Dakin v. Oxley, I5 C. B. N. S. 646, for similar authoritirs.

1 Camprell's Lives of the Kord Chief .Justices, 11. 407, note.

2 Siendsen v. Hallace, 13 Q. B. D. 73, ef. per Willes, J. in Lloyd v. Guibert, L. R. 1 Q. B. 119,123 . 
proposition is stated in terms larger than have hitherto been recognised in English Law, yet it ought now to be adopted in order to bring the principle of English Law on the subject into consonance with the laws of all other countries. But to this I cannot agree. It is useless to inquire whether the law is, as stated, the same in all European countries. For if it is, yet no English Court has any mission to adapt the Law of England to the laws of other countries; it has authority only to declare what the Law of England is." Lord Mansfield would have found out what the Law of England in mercantile matters was by considering what was the law of other countries, if there was no English decision laying down any clear rule. The Courts of the present day in the wealth of English commercial law, feel entitled to disregard the law of other countries.

\section{VI.}

Further than this, the Law Merchant, which was originally hased upon the usage of merchants, can now be extended by new usages which have sprung up, may be constantly added to by proof of fresh usages of the mereantile world. That is very clearly and strongly laid down in the case of Goodwin v. Robarts. ${ }^{3}$ It was a case involving the question whether a particular form of debenture scrip was negotiable, and it was alleged that by the custom of merchants it had been so for the last twenty vears. It was answered to that, relying upon the judgment of Mr. Justice Blackburn, that no addition could he made to the Law Merchant by so recent a usage as twenty years, but that it must be shown to be part of the ancient Law Merchant; but Chief Justice Cockburn, in delivering the judgment of the Court of Exchefuer Chamber in Goodwin v. Robarts, said: "Having given the fullest consideration to this ardument, we are of opinion that it cannot prevail. It is founded on the view that the Law Merchant is fixed and sterentyperl, and incapable of heing enlarged so as to meet the wants and requirements of trade in the varying circumstances of rommere. It is true that Iaw Merchant is sometimes spoken of as a fixed borly of law forming part of the law, and, as it were, coesal with it. but as a matter of legal history this view is altogether incorrect. * * * The Law Morelant is of comparatively reeent origin: it is neither more or less than flue nsagres of merriants and tradrors in the different departments of trade ratified by thre derisions of the ('ourts of law, which, upon such usages heing proven leforo them, have adopted them as soltled law with a view to the interests of tranlo and public conventenese, the Court proceding herein on the well-known principle of law that, with

3 I. R. 10 lix. 346, 352.

- Crouch v. Credit Foncier, I. R. 8 Q. B. 386. 
respect to transactions in the diflerent departments of trade, Courts of Law, in griving elleet to the contracts and dealings of the parties, will assume that the latter have dealt with one another on the footing of any custom or usage prevaling in that particular department." 'Tluus it is that Courts of I.aw continually take notice of customs of trate. only to the word "customs" they give a much wider meaning than it bears in the Common Law. A well-known lawer said rather cynically once that he had heard a good many customs foumd by juries, hut he had never heard one proved yet; and it is so that the evidence on which a mereantile jury, who know a great deal more abont the matter than the lawyers or witnesses, very often will find that a custom exists, is such as would not suflice to establish any custom under the strict rules of the Common Law.

For aceording to the Common Iaw a custom must have six attributes. In the first place it must date from time immemorial, which has been conveniently fixed by the Common Law as when our Isord Richard returned from Palestine, in 1189. Now, obviously, when our Lord Richard returned from Palestine, the amount of mercantile eustom existing in England was of the very slightest description, and if one is to trace all one's mercantile customs back to his return from Palestine, or if a custom is liable to be defeated by proof of a later origin, very few mereantile customs can possibly be proved. The custom must be continuous from that date in the second place. In the third place it must be universally acquiesced in. In the fourth place it must be reasonable. In the fifth place it must be certain; and in the last place it must be binding. Now in proving a mereantile eustom you can dispense with our Lord Richard at once; it is sufficient for you to prove that the custom is certain, so that people know what it is; that it is reasonable; that it is fairly universal (of course it is not quite universal, because somebody is disputing it in the action in question) ; that it has existed for some time (five years may suffice); and that merchants in the trade consider it hinding; and on those lines the law is continually being added to by the finding of customs by special juries.

2. History of Negotiahe Instruments.

(a) Bills, notes and chechs.

Scrutton. Elements of Mercantile Law, 1891.

[From Chapter II.]

IFor authorities, see the Preface to Mr. Chalmers' work on Bills of Exchange; the notes to Miller v. Race in 1 Smith's Leading Cases, 
9th ed. p. 491; and the judgment of Cockburn, C. J., in Goodwin v. Robarts, L. R. 10 Ex. 346.]

Many of the rules of Mercantile Law, the Law Merchant, are directed to evade inconvenient rules of the Common Law.

Another rule of the Common Law which is found inconvenient by merchants is the old rule that a "chose in action" is not transferable. A "chose in action" is a right to recover a thing, as distinguished from the thing itself. A bill of lading, as distinguished from the goods it represents, is such a "chose in action." If you [X.] had a right to recover property from $A$., and wanted to assirn that right to B., so that B. could recover such property from A., you could not do it by the old common law. Equity would have recognised that you had transferred the right to B., but even then B. must bring his action in the name of $\mathrm{X}$., who had given him the right; he could not sue in his own name. And further, when the "cliose in action" was transferred. such a transfer passer no better title than the transferor had. Now the Law Merchant dealt with many "choses in action," and it wonld have heen very inconvenient, for instance, that the man who took a hill of exchange should not be able to sue on it in his own name, but should have to sue in the name of the man whose name was mentioned as payee in the hill of exchange. It would have been slightly inconvenient that the indorsee of a hill of exchange should have to inquire into the title of all previous indorsers, to see that there was no defect in any of their titles. As a result the Law Merchant establishes certain instruments or "choses in action," which were transferable by delivery or indorsement, so that the holder could sue in his own name, and which passed a good title to a transferce who took them in good faith, notwithstanding that the transferor or his predecessors had no title. These documents had thus two distinguishing features: They could be sued on by the holder in his own name; and they were not affected by previous lack of title; and instruments of this class are called Negotiable Instruments." To illustrate the general doetrine I have been explaining to you, a hill of exchange is by the custom of merchants transferahle either by delivery, if it is to bearer. or by indorsement, if it is to ordor, and the indorse or person who takes it can sue in his own name, and is not affected ly the fact of previous want of title in an indorser if he was not a party to that defect.

The indorement of a hill of lading by the custom of merchants passes such property in the goods represented by it as it was intended

S See the leading cage of Miller v. Race, 1 Smith J. (. 9th ed. 491, and per Bowen, L. J., in Picker v. London and County Bank, 18 Q. B. D. 519. 
to pass: ${ }^{\circ}$ but it needed a statute, the Bills of Lading Act, ${ }^{7}$ to get a further efleret anct allow a holder of a bill of lading to sue in his own name on the contrat comtained in the bill of lading. 'Thus the bill of lading ohtained a similar position to that of a negotiable instrmment hy the double etfect of the enstom of merchants and of the statute. A policy of insurance does not by assignment pass gronds insmred moler it, althomgh the assignee may by statute sne in his own nilne. and therefore it is not a complete negotiable instrument. For to malie a megrotiable instrument you must have two marks: that the holder grets a title, though his transferor had no title. and that the holder ean sue in his own name-each of these marks meeting one of the rules of the Common Law already referred to.

The law of negotiable instruments is, with some few exceptions depending on statutes, antirely built upon the eustom of merchants, and the history of that law as applied to partienlar classes of instruments you will fund best stated in the judgment of Lord Chief Justice Cockburn in Gooduin v. Robarts. ${ }^{8}$ which I recommend to your careful realing. The earliest form of negotiable instrument was the bill of exchange. ${ }^{9}$ Originally bills of exchange were used solely for the purpose of foreign trade. It was an instrument by which an English merchant contrived to avoid sending money out of the country or bringing money into the country by giving an order on his foreign debtor to pay a third person, or by accepting an order to pay a third person fiom his foreign creditor.' It was purely a trade transaction for the purpose of avoiding sending money out of the country, and the French Law has adhered to that idea of a bill of exchange to this day. and treats it merely as a trade transaction. The English Law has treated it as an instrument of credit. Bills of cichange seem to have been introduced into Fngland by the Venetians or Florentines, and there were hills of exchinge for foreign trade known to England as early as the reign of Richard II. 'The first reported case in the English Courts is in the year 1603,2 and the Courts, in developing what was originally simply a bill in a transaction of foreign trade, have followed the eustom of merchants. Chief . Instice Treby, in the case of Bromwich v. Lloyd, ${ }^{3}$ explained the stages by which a bill of exchange was developed. "Bills of Exchange," he said, "at first extended only to merchant strangers

6 Tide post. p. 153.

718 \& 19 Vic. c. 111.

8 I. R. $10 \mathrm{Fx} .34 \mathrm{f}$.

9 Definer in Pills of Exchange Act, 1882, $\$ 3$, and post, pp. 40, 41.

1 See C'hnlmers, Bills. Pref. p. 46.

2 Martin v. Bourr, ('ro. Jac. 6.

3 (1698) 2 Jutwyche's Reports, p. 1585. 
trafficking with English merchants; and afterwards to inland bills between merchants trafficking the one with the other in England; and afterwards to all traders, and then to all persons whether traders or not; and there was then no need to allege any custom of merchants." So beginning with the necessity to allege an English merchant and a foreign merchant, you dispense with the foreign merchant and allege two English merchants trading; then you dispense with the particular transaction of trade; then you drop the trader, or the allegation that there is any merchant at all, and simply produce the bill. But in a case in $1613^{4}$ there was a plea that an acceptor of a bill of exchange was not a merchant, and it was held a good answer. A bill of exchange could not he made at that time hy people who were not merchants. In 1692 , however, the Courts had got a little further. ${ }^{5}$ There was a plea then that the acceptor of a bill of exchange was a gentleman and not a merchant, and the Court of Queen's Bench, following the earlier case. held that a goorl defense; but the Court of Appeal, the Exchequer Chamber, reversed the decision, "having consideration to the inconvenience that might ensue and the suspicion which might increase among foreign merchants," and they laid down very sensibly that if "gentlemen" took upon themselves to accept bills they ought to pay them. The custom of merchants has gone on developing bills of exchange until the law with regard to them is now all but settled; they pass by indorsement or delivery the right to the indorsee to sue in his own name: they pass title to a bona fide holder for value thongh the indorser's title is bad; and it is not necessary to allege any consideration for the bill, for consideration is presumed until the contrary is prover. The only trace of the former history of hills of exchange is the difference between inland and foreign bills of exchange, which is, in the words of Lord Holt, "All the differenee between foreign and inland bills is that foreign bills must be protested before a notary before the drawer can be charged: but inland bills need no protest," " notice of dishonor heing sufficient.

The next document which obtained the features of negotiability was a promissory note. In a bill of exehange there are, after aceeptance, two penple who offer sesurity to the holder. the drawer and the acceptor : in a promissory note there is at first only the single security, that of the person who promises in the note to pay. 'The first case in which promissory notes were recognizerd by the C'ourts as negotiable instruments was the rase of Shelden v. I/enlley. ${ }^{7}$ in 1680 , where the Court hold a promissory note to he a negotiable instrument, expressly

- Oaste v. Taylor, I riro. Jac. 306.

B Rarsfield v. Wilherby, rarthew, 82.

- Buller v. Cripps, o Mod. 20.

I 2 Showers, p. 160. 
saying that " it was the custom of merchants that made that good." 'That decision for some years afterwards was followed in other cases till llolt became Chicf Justice. lood Ilolt set his face against the custom of merchants aml against promissory notes as negotiable instruments. In the "ase of Clark v. Martin's the reporter says: " But Holt, C. I., was with all his strength against this action, (on a promissory note), and said that this note could not be a bill of exchange: that the maintaining of these actions upon such notes were inmovations upon the rules of Common Law, and that it amounted to setting up a new sort of specialty unknown to the Common Law, and invented in lombard street. which attempted in these matters of bills of exchange to give laws to Westminster Hall; that the contimuing to declare upon these notes upon the custom of merchants proceeded from ohstinacy and opinionativeness, since he had always expressed his opinion against them." It appears that Iombard street and the merchants therein thought that the "obstinacy and opinionativeness" was upon the side of Lord Holt, for they continued to use these doeuments and to sue upon them; and in the next year, in another case of Buller v. Crispe, ${ }^{3}$ Lord Holt again expressed his opinion in strong terms, and said that these notes were not in the nature of bills of exehange, but were only an invention of the groldsmiths in Lombard Street, who had a mind to make a law to bind all that did deal with them. "At another day IIolt, C. J., declared that he had desired to speak with two of the most famous merchants in Jondon, to be informed of the mighty ill-consequences that it was pretended would ensue by obstrueting this form, and they had told him that it was very frequent with them to make such notes, and that they looked upon them as bills of exchange, and that they had been used for a matter of thirty years: that not only notes but bonds for money were transferred frequently, and endorsed as bills of exchange," and the reporter winds up significantly, "the Court at last took the vacation to consider of it." larliament stepped in and saved them from considering it any further, for by an act of the year $1704^{1}$ it was expressly provided that promissory notes should be deemed as negotiable as bills of exchange. 'The preamble of the Act began: "Whereas it hath been held that promissory notes are not indorsable over, within the custom of merehants, therefore to encourage trade and commerce be it enacted." $S_{0}$ in this case also the custom of merchants introduced an innovation into the law of Westminster Hall, although it needed the sanction of Parliament to induce Westrninster Hall to recognize it.

\footnotetext{
8 (1702) 2 Lord Raymond, 758.

\&6 Morlern Reports, p. 29.

$13 \& 4$ Anne, c. 9.
} 
The next step in the history was that bankers and goldsmiths who held money on deposit began to issue promissory notes payable on demand, that is to say they began to issue Bank Notes. To these again the custom of merchants very speedily gave negotiability, and in the leading case of Miller $v$. Race, ${ }^{2}$ Lord Mansfield decided that bank notes also wre negotiable instruments, holding that it was necessary for the purposes of commeree that their eurrency should be established and secured. And hy the custom of merchants, bank notes have acquired a superior position to promissory notes. They are payable to any holder who may present them without the necessity of his indorsing them. There is a legend that the Bank of England always required persons presenting their hank notes to indorse them, and that on one occasion when the clerk of the bank hehind the counter spoke in rather a cavalier manner to a gentleman who came in, telling hin that he could not be paid unless he wrote his name on the back. the gentleman with the note walked out and promptly sued the Bank of England for dishonoring their promissory note, and of course sued them successfully, with the result of altering the custom at the Bank. Bank of England notes are now legal curreney and tender. and in the case of country banks their notes may be, under certain circumstances. treated as currency and payment.

The next step was when the banks, besides issuing their promissory notes payable on demand, or bank notes, accepted and honored bills of exchange drawn on them by their customers, payable on demand; that is to say when the system of Cheques came into existence, for a cheque is a bill of exchange drawn on a bank by its customer, payable on demand. ${ }^{3}$ 'To cheques, also, the practice of merchants has affixed certain incidents, as for instance the practice of crossing cheques, which originated partly in the usages of commerce and partly in the Clearing Honse; and has now been definitely recognized by $A$ ct of Parliament. Banks, hy the custom of merchants, are also bound to honor cheques if they have funds of the customer in their hands: though a drawee, even thougl he had funds in his hand, would not he bound to acept a bill of exchange.

So far. the law of negotiahle instruments, (bills of exchange, promissory notes, rherpues, bank notes). has been coditiol hy Parliament in the Bills of Exchange Act, 1882: "an Aet to corlify the law relating to bills of exchange, cheques, and promissory notes," and on all matter treaterl on by that Aret the law Merehant is now to be found in its clauses, and not in the cases and customs on which those clauses were founded.

21 Smith's Ifading ('agea, 9th ed. p. 490.

a Bills of Exchange Act (1882), $\$ 73$.

445 \& 46 Vic. c. 61 . 
Chalmers' Digest of Bills of Exchange, etc.

\section{[From the Introluction to the Third Edition.]}

The results of this formation of the law by custom are instructive. A reference to Marius treatise on Bills of Exchange, written about 16i0, or Beawes' lex Mereatoria, written about 1720, will slow that the law. of perlaps rather the practice, as to bills of exchange, was even then pretty well defined. Comparing the usage of that time with the law as it now stands, it will he seen that it has been modified in some important respects. Comparing English law with French, it will be seen that, for the most part. where they differ, French law is in strict aceorlance with the rules laid down by Beawes. The fact is, that when Beawes wrote, the law or practice of both nations on this subject was uniform. The French law, however, was embodied in a Code by the "Ordomnance de 1673," which is amplified but substantially adopted by the Code de Commerce of 1818. Its development was thus arrested, and it remains in substance what it was 200 years ago. English law has been leveloped piecemeal by judicial decision founded on custom. The result has been to work out a theory of bills widely different from the original. The English theory may be called the Banking or Currency theory, as opposed to the French or Mercantile theory. A bill of exchange in its origin was an instrument by which a trade debt, due in one place, was transferred in another. It merely avoided the necessity of transmitting cash from place to place. This theory the French law steadily keeps in view. In England bills have developed into a perfectly flexible paper eurrency. In France a bill represents a trade transaction; in England it is merely an instrument of credit. ${ }^{5}$ English law gives full play to the system of accommodation paper; French law endeavors to stamp it out.

A comparison of some of the main points of divergence between English and French law will show how the two theories are worked out. In England it is no longer necessary to express on a bill that value has been given, for the law raises a presumption to that effect. In France the nature of the value must be expressed, and a false statement of value avoids the bill in the hands of all parties with notice. In England a bill may now be drawn and payable in the same place (formerly it was otherwise, see the definition of bill in Comyns' Digest). ${ }^{6}$ In France the place where a bill is drawn must

shis passage was written in 1878 . when the first edition was published. The theory it advances is independently confirmed by the excellent introduction to the Portuguese Commercial Code in the French edition, published by the Comité de Législation Ftrangère. See p. xxix.

- A bill of exchange is when a man takes money in one country or city upon exchange, and draws a bill whereby he directs another person in another country or city to pay so much to $A$, or order for value received of $B$, and subscribes it." 
be so far distant from the place where it is payable, that there may be a possible rate of exchange between the two. A false statement of places, so as to evade this rule, avoids the bill in the hands of a holder with notice. As French lawyers put it, a bill of exchange necessarily presupposes a contract of exchange. ${ }^{7}$ In England, since $\mathbf{1 7 6 5}$, a bill may be drawn payable to bearer, though formerly it was otherwise." In France it must be payable to order; if it were not so, it is clear that the rule requiring the consideration to be expressed would be an absurdity. In England a bill originally payable to order becomes payable to bearer when indorsed in blank. In France an indorsement in blank merely operates as a procuration. An indorsement, to operate as a negotiation, must be an indorsement to order, and must state the consideration; in short, it must conform to the conditions of an original draft. In England, if a bill be refused acceptance, a right of action at once accrues to the holder. This is a logical consequence of the curreney theory. In France no cause of action arises unless the bill is again dishonored at maturity; the holder, in the meantime, is only entitled to demand security from the drawer and indorsers. In Fingland a sharp distinction is drawn between current and overdue bills. In France no such distinetion is drawn. In England no protest is required in the case of an inland bill, notice of dishonor alone being sufficient. In France every dishonored bill must be protested. Grave doubts may exist as to whether the English or the French system is the soundest and most beneficial to the mercantile community, but this is a problem which it is beyond the province of a lawyer to attempt to solve.

\section{(b) Other negotiable paper.}

Scrutton, Flemexts of Mercanthe Law. 1891.

[From Chapter II.]

There are, however, other nogotiable instruments hesidrs those which have heen dealt with by the A ct of 1882 , and to such instruments the rules of the ('ommon law and the customs of the Law Merchant are still applieahle. Fresh usages may be introduced, or new documents may be proved hy the usage of merehants to have the two marks of negotiability already stated." The usage that is proved must, however, be a usage of English merchants. In the case of Picker v. The London and County Bank,' an attempt was made to

This rule is said to be now obsolote; lut the Code remains unaltered.

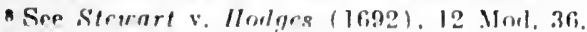

- Ante, p. 26. [Herrin PP. 25-26. - H.]

118 Q. B. D. P. 515. 
treat certain Prussian bonds as negotiable instruments in England; but the only evidence that was oflered was that those bonds were negotiable by the custom of l'russian merehants, and the court manimonsly rejected the evidenee as insullicient. As it was pointedly put. the falet that in Africal cowries are negotiable instruments toes not therefore bind the English Couts to accept cowries as negotiable instruments in lingland, and the same principle has always been applind in any attempt to prove the negotialsility of instruments in lingland: the biage proved must be a usage-of Funtish merehants. It is not necessary that that usage should be from time immenorial, Mr. Justice Blackburn did, indeed, iq one case = lay down that such a usage. existing as part of the ancient Jaw Merchant was necessary: lout in the later case, Gooduin v. Robarls, ${ }^{3}$ both the Court of Appeal and the Ilouse of Jords beld that to be ton narrow a limitation, deciding that the Law Merchant might he added to by proof of reent nsage. and thus that new negotiable instruments might be from time to time created. We find in the laports a series of illustrations of these prineiples of law in the varions documents that have leen from time to time proved ne unt proved to he negotiable instruments. For instance, in the rase of (ilynn v. Buker, East India bonds were hedel not to be megotialide in the absence of any evidence that they costonarily passed hy dolivery; but the decision in the Courts was immediately remedied hy Parliament, who passed an Aet givine to bist India bonds the chatacter of negotiability." In Diron v. Borill, a docmment "alled an "iron warant," running "I will deliver one hundred tons of iron when required after Sept. 18th to the party lodging this document with me," was held hy the House of Lome not to be a negotiable instrmacut, and not therefore to pass by delivery, there being no evidenere before the Court of any mercantile nsage affecting such documents: it is, howerer. very probable that if the puestion of iron warants came before the Court at the present day. they conld he ahmondantly proved to be negotiable.

To eome to morr recent sases. in The fine lets sociely v. The Inion Banli? it was hede that Post Oflien orders crosesed for eollection by a hank were not nogotiahlo instruments: and in Croush v.

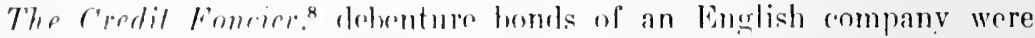

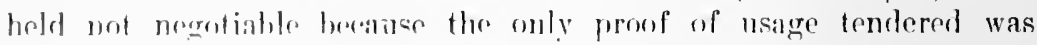

2 renurh v. Crelit Fomrirr. J. R. 8 Q. 3. 374, followed on this by Manisty, J., in 20 Q. I?. 1). at $\mathrm{P} .239$.

3 J.. R. 10 Ex. at P. 355: 1 App. C. at p. 494.

413 East, 509 .

5.51 Ciso. III. C. 64.

B.3. Maeriliern's Pirports, p. 1.

717 O. B. D. 705.

8 L. R. 8 Q. I3. D. 374. 
one originating in the last twenty years. On the other hand, in Ciorgier v. Mieville, ${ }^{9}$ certain foreign bonds were held to be negotial.le instruments on proof that bonds of that description were sold in ti:e English market, and passed from hand to hand daily like Fxchequer bills. And that case was followed in Goodwin v. Robarts, ${ }^{1}$ in which certain scrip, which on the payment of all instalments due was to be exchanged for bonds, was held a negotiable instrument on procf of usage of the English Stock Exchange. ${ }^{2}$ There is one other case I wish to mention to you as an illustration of the Common Law maxim I have already reminded you of, that a man eannot give what he has not got. and therefore if he has not got a title cannot give it. The recent case of Barton v. The London and North Western Railway $^{3}$ is at the present time exciting very great apprehension in commereial circles. MIr. Barton held certain shares in the L. \& N. W. Railway which passed to his executors, and one of the executors by forging the signature of the other executor sold those shares some twelve or thirteen years ago. The purchaser took the transfer with the forged signature to the L. \& N. W. Railway Company, who registered it, and for the twelve or thirteen years the purchaser has been registered for those shares and has received the dividends. The executrix whose signature was forged - for a lady was coneerned did not find out the absence of these shares for the thirteen years, but on finding it out and on proof of the forgery, the L. \& N. W. Company were ordered to replace her name on the register, and the unfortunate purehasers have had to give up their shares, and to pay back the dividends which they have received during the thirteen years. A man cannot give what he has not got.

The people who purported to pass these shares had not got them to give. At present agritation. if nne may use such a word. is taking place on every English Stock Exchange for an Act which will protect the people whose transfers have been registered by Railway Companies against the rules of the Common Law."

3 13. \& C. 45.

I I. R. $10 \mathrm{l}$.x.

2 For recent cases in which the qulestion of negotiability was raised sce Lord

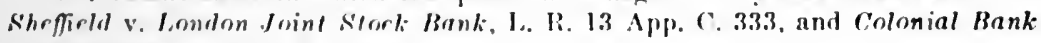
v. Hillinms. 15 App. ('. H. 267.

3 L. R. 21 Q. B. D. 77.

- Sre also on the subjert of negotiahle instruments, other than hilla, notes and check. Chalmere' Dills of Fxclunge Act (5th edl.). pp. 312-327: 2 Ames' ('aspu on Bills and Noter. pr. 748.784; 2 Daniel on Neg. Inst., pp. 496-595, 730. 785. - II.

N ROOT. INBTHUMRNTE - 3 


\section{ARTICLE II.}

\section{Form and Intrimitietation.}

(i) Form Required.

\section{Writing and signature.}

GEARY $v$. PHYSIC.

5 Bariewall, \& Creswell (K, B.) 234. - 1826.

Assumpsit by the plaintiff as indorsee against the defendant as maker of a promissory note for the sum of $30 l$. payable two months after date to the order of one Folder, and indorsed by him, Folder, to one Kemp, who subsequently indorsed the note to the plaintiff. At the trial hefore Abhott, C. J., at the London sittings after Hilary term, 1825, it appeared that the indorsement ly Kemp to the plaintiff was in pencil, and it was thereupon objected that the plaintiff conld not recover: an indorsement in pencil not being such an indorsement as the law and custom of merchants recognizes to be sufficient to pass the interest in a bill of exehange, and promissory notes being by the statute 3 and 4 Ann, e. $9, \S 1$, assignable or indorsable in the same manner as unpaid bills of exchange are acending to the custom of merchants. The Lord Chief Justice thought it sufficient, and directed the jury to find a verdict for the plaintiff, reserving liberty to the defendant's counsel to move to enter a nonsuit, if the court should be of opinion that the indorsement of the promissory note in peneil was not a good and valid indorsement.

Аввотт, C. J. - There is no anthority for saying that where the law requires a contract to be in writing, that writing must be in ink. The passage cited from lord Coke shows that a deed must be written on paper or parchment, but it does not show that it must be written in ink. That being so. I am of opinion that an indorsement on a bill of exchange may he by writing in peneil. There is not any great danger that our decision will induce individuals to adopt such a mode of writing in preference to that in general use. The imperfectinn of this mode of writing, its heing so subject to obliteration, and the impossilility of proving it when it is obliterated, will prevent it being generally adopted. There being no authority to show that a contract which the law requires to be in writing shonld be written in any particular mode, or with any specific material, and the law of merchants requiring only that an indorsement of hills of exchange should be in writing," without specifying the manner with

s See custom stated in lutuyche, 878. 
which the writing is to be made, I am of opinion that the indorsement in this case was a sufficient indorsement in writing within the meaning of the law of merchants, and that the property in the bill passed by it to the plaintiff.

BAYLEY, J. - I think that a writing in pencil is a writing within the meaning of that term at common law, and that it is a writing within the custom of merchants. I cannot see any reason why, when the law requires a contract to be in writing, that contract shall be void if it be written in pencil. If the character of the handwriting were thereby wholly destroyed, so as to be ineapable of proof, there might be something in the objection; but it is not thereby destroyed, for, when the writing is in pencil, proof of the character of the handwriting may still he given. I think, therefore, that this is a valid writing at common law, and also that it is an indorsement according to the usage and custom of merchants: for that usage only requires that the indorsement should be in writing. and not that that writing should be made with any specific materials.

Holroyd, J., concurred.

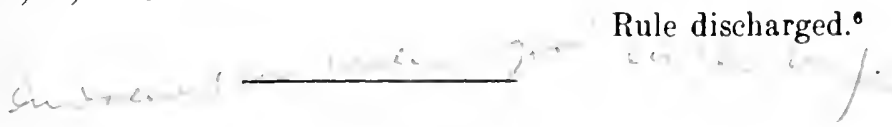

REG. $r$. HARPER.

L. R. 7 Queen's Bexcu Division, 78, - 1881 .

[Court for Crown Cases Reserved.]

INDictMENT for forging an indorsement to a bill of exchange. John Watson \& Son drew a bill on Harper, but did not sign it. Harper accepted it, forged the indorsement of John Hunt, and returned it.

- Accord: Brown v. Butchers, ete., Bank, 6 llill (N. Y.) 443, post, p. 37;

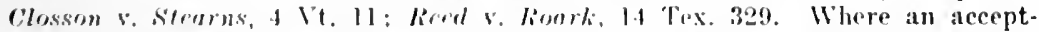
ance of a bill is requiresl by statute to be in writing (Neg. Inst. L., § 220), a telegraphic acceptance sitisfirs the statute. Garrettson v. North Atchison Bank, 39 Fed. Rep. 163; 47 Fed. Rep. 867; 51 Fed. Rep. 168.

A negotiable instrument may be drawn in any langruage. Re Marseilles Co., J. R. 30 ('). 1). 598 . - H.

[Signature to a cheek by a bank depositor by her mark in lead pencil is valid. "Citation of anthority is not neessary to show that it is immaterial with what kind of an instrument a -ignature is made." L.Alu, .J., in Drefahl v. Security Sto. Bk. 132 lowa 563, 573.

It was held in Flanders v. Snore. 37 Pa. Super. ('t. 28, that there is nothing in the Negotiable Instruments Iaw to prevent the use of a rubber stamp in the indorsement of negotiable paper. "Of eourse, we are not to be understood as saying that an indorsement made ly the nue of a mbher stamp, any more than one made in manuseript, proves itself. In rither case the maker or acceptor. when called upon to pay by one elaiming to he the lawful holder by virtue of such indorsement, may demand proper proof of the genuineness and authenticity of the indorsement." Hr.AD, J., p. 31. - C.] 
Watson and Son indorsed it and placed it in bank for collection. They did not at any time sign it as drawers. The following is a copy of the bill:

£2: 10s. $4 d$

KilMaßNOCK, 2 Nov. 1880.

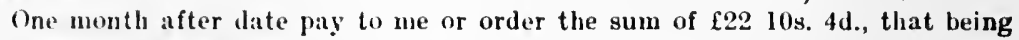
for value received in machinery.

'To Mr. J. Haki'kk, lite.

[Across the face]: Accepted payable at the Union Bank of London. Jour HARI'E.

[Indorsed]: JoHN IIUNT. JoHn Watson \& Son.

Harper was convicted and sentenced, but exceution of the sentence was suspended till the decision of the case by the Court for Crown Cases Rescrved.

Lord Coleridge, C. J.- The conviction cannot be sustained. The instrument was not a bill of exchange; it was an inchoate bifl of exchange. 'The point requires no authority, though it has the authority of the cases of McCall v. Taylor (34 L. J. C. P. 365); Stoessiger v. South Eastern Ry. Co. (3 E. \& B. 549); Peto v. Reynolds (23 L. J. Ex. 98; 9 Ex. 410; 11 Ex. 418) ; and Rex v. Pateman (Russ \& Ry. 455$)$.

Stepilen, J. - Though I entirely agree with the opinion expressed by my Lord, I cannot help observing that the act of the prisoner has all the effect of a forgery punishable under the statute as a felony; the prisoner could, however, have been indicted, and ought to have been indicted, for forgery at common law.

Grove, Hawkins and Lopes, JJ., concurred.

Conviction quashed.?

$\$ 20$

\section{TAYLOR $v$. DOBBINS.}

l Strange (K. B.) $399 .-1720$.

In case upon a promissory note the declaration ran, that the defendant made a note, et manu sua propria scripsit. Exception was taken, that since the statute he should have said that the defendant signed the note, but the Court held it well cnough, because laid to be wrote with his own hand, and there needs no sulsscription in that case, for it is sufficient his name is in any part of it. I. J. S. promise to pay, is as good as I promise to pay, subscribed $J . S$.

7 Accord: Tevis v. Young, l Metc. (Ky.) 197; IIeman v. Francisco, 12 Mo. App. 560. - H.

a Vide Eliot v. Couper, I Strange, 609. [Accord: Quin v. Sterne, 26 Ga. 223. The courts make a clear distinetion between the statutory requirement that an instrument shall be "signed" and the requirement that it shall be "subscribed." - James v. Patten, 6 N. Y. 9. - H.] 
6 HILL (N. Y.) 443. - 184.

On error from the Superior Court of the city of New York, where the Butchers and Drovers' Bank sued Brown as the indorser of a bill of exchange, and recovered judgment. The indorsement wis made with a lead pencil, and in figures, thus, "1. 2. 8." no ninne being written. Evidence was given strongly tending to show that the figures were in Brown's handwriting, and that he meant they should bind him as indorser; though it also appeared he could write. The court below charged the jury that, if they believed the figures upon the bill were made by Brown, as a substitute for his proper name, intending thereby to bind himself as indorser, he was liable. Exception. The jury found a verdict for the plaintiffs below, on which judgment was rendered, and Brown thereupon brought error.

By the Court, Neison, Ch. J. - It has been expressly decided that an indorsement written in pencil is sufficient: (Geary v. Physic, 5 Barn. \& Cress. 234) ; and also that it may be made by a mark. (George v. Surrey, 1 Mood. \& Malk. 516). In a recent ease in the K. B. it was held that a mark was a good signing within the statute of frauds; and the court refused to allow an inquiry into the fact whether the party could write, saying that would make no difference. (Baker v. Dening, 8 Adol. \& Ellis, 94 ; and see Harrison v. Harrison, 8 Ves. 186 ; Addy v. Grix, id. 504.)

These cases fully sustain the ruling of the court below. They show, I think, that a person may become bound by any mark or designation he thinks proper to adopt, provided it be used as a sulstitute for his name, and he-intend to bind himself. ${ }^{9}$

Judgment affirmed.

\section{Unconditional promise or order to pay a sum certain in money.}

\section{A Note Must Contain a Promise.}

GAY $v$. ROOKE.

151 Massachesets', $115 .-1890$.

Contract on the following instrument, declared on as a promissory note:

MARI,BOBO', St.PT. 23, 1881. dolls. 5-100 for value received.

I. O. U., E. A. Gry, the sum of seventeen Jonr R. Rookr.

Writ dated September 19, 1887. At the trial in the Superior Court, without a jury, before Dewry, J., the only issue was whether the

- See Rogers v. Coit, 6 Hill, 322, 3. 
plaintiff was entitled to interest from the date of the instrument, or from that of the writ, the service of which was the only demand made by the plaintill.

The plaintitl asked the judge to rule, as a matter of law, that he was entitled to interest from the date of the instrument. The judge declined so to rule, and ruled that interest could be recovered from the date of the writ only, and found for the plaintill for $\$ 17.05$ only; and the plaintitf alleged rxceptions.

Drvess, J. - In order to constitute a grood promissory note there should be an express promise on the face of the instrument to pay. the money. A mere promise implied by law, founded on an acknowledged indebtedness, will not be sufficient. (Story, Prom. Notes, \$ 14; Brown v. Gilman, 13 Mass. 158.) While such promise nend not be expressed in any particular form of words, the language llsol must he such that the written undertaking to pay may fairly be cieduced therefrom. (Commonwealth Ins. Co. v. Whitney, 1 Met. 21.) In this view the instrmment sued on camnot be considered a promissory note. It is an acknowledgment of a debt only, and, although from such an acknowledgment a promise to pay may be legally implied, it is an implication from the existence of the debt, and not from any promissory language. Something more than this is necessary to establish a written promise to pay money. It was therefore held in Gray v. Bowden (23 Pick. 28:), that a memorandum on the back of a promissory note, in these words, "I acknowledge the within note to be just and due," signed by the maker and attested by a witness, was not a promissory note signed in the presence of an attesting witness within the meaning of the statute of limitations. In England an T. O. U., there being no promise to pay embraced therein, is treater as a due bill only. The cases, which arose principally under the Stamp Act, are very numerous, and they have held that such a paper did not require a stamp, as it was only evidence of a debt. (1 Danl. Neg. Inst. 3d ed. § 36: 1 Raudolph Com. Paper, § 88; Fesenmayer v. Adcock, 16 M. \& W. 449: Melanotte v. Teasdale, 13 M. \& W. 216; Smith v. Smith, 1 F. \& F. 539; Gould v. Coombs, 1 C. B. 543; Fisher v. Leslie, 1 Esp. 425 ; Israel v. Israel, 1 Camp. 499 ; Childers v. Boulnois, Dowl. \& Ry. N. P. 8: Beeching v. Westbrook, 8 M. \& W. 411.)

While in a few States it has been held otherwise, the law as generally understoor in this country is, that, in the absence of any statute, a mere acknowledgment of a debt is not a promissory note, and such is, we think, the law of this Commonwealth. (Gray v. Bowden, 23 Pick. 282; Commonwealth Ins. Co. v. Whitrey, 1 Met. 21 ; Daggett v. Daggett, 124 Mass. 149; 1 lmy v. Winslow, 126 Mass. 342 ; Carson v. Lucas, 13 B. Mon. (Ky.) 213; Garland v. Scott, 15 La. Ann. 143 ; Currier v. Lockwood, 40 Conn. 349 ; Brenzer v. Wight- 
man, 7 Watts \& Serg. 26t; Bishup v. Oberle, 6 Mo. App. 583.) Some States have by statute extended the law of bills and promissory notes to all instruments in writing whereby any person acknowlenges any sum of money to be due to any other person. (1 Randolph, Com. Paper, § 88; Rev. Sts. Ill. 1884, c. 98, \$3; Gen Sts. Col. 1883, c. 9, § 3 ; Rev. Sts. Ind. 1851, § 5501; Code. Iowa. 1873, \$2085; Rev. Code Miss. 1880, \$\$ 1123,11 ?.)

We have no occasion to comment upon those instruments in which words have heen used or superadded from which an intention to accompany the acknowledgment with a promise to pay has been gathered. or where the form of the instrument fairly led to that conclusion. (Daggett v. Daggett, 124 Mass. 149; Almy v. Winslow, 126 Mass. 342.) No such words exist in the instrument sued, nor is it in form anything but an acknowledgment. The words "for value received" recite indeed the consideration, but they add nothing which can be interpreted as a promise to pay. It is therefore unnecessary to consider whether if the paper were a pronissory note, interest should be calculated from its date. Upon this point we express no opinion.' If it is to le treated as an acknowledgment of debt only, as we think it nust be, the plaintiff is not entitled to interest except from the date of the writ. Even if it was the duty of the defendant to liave paid the debt on demand, yet if no demand was made, if no time was stipulated for its payment, if there was no contract or usage requiring the payment of interest, and if the defendant was not a wrongdoer in acquiring or lletaining the money, interest should he computed only from the demand made by the service of the writ. (Dodge v. Perlins, 9 Pick. 36is; IImmt v. Nevers, 15 Pick. 500.) "In general," says ('hief Justice Shaw, "when there is a loan withont any stipulation to pay interest, and where one has the money of another, having been guilty of no wrong in obtaining it, and no fault in rotaining it, interest is not chargeable." (II ubbard v. Charlestoun liailroad, 11 Ilot 124; Callon v. Bragg, 15 East., 22.?; Shaw v. Picton, 4 B. \& ('. 715: Moses v. Macferlan, 2 Burr. 1005; Waller v. Constable, 1 Bos. \& l'. 306.)

Exceptions overruled.

It serems that in the ense of a negetiable instrument payable on dromand, no intrest lwing reservel, inferost will run only from lle date of demand. seoril

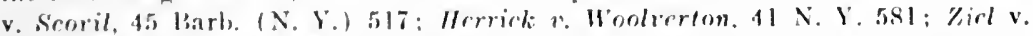
lokes, 12 (alif. 47!. Sut, hringing an action conatitutes drmand. l'ierer v. Fothergill, 2 ling. N. C. 167; Bank v. Javidson, 70 N. Car. 118. See $\$ 130$, post, and cases. - H. 


\section{SMITH $v$ ALILEN.}

5 DaY (CONN.) 337. - 1812.

SмIтн, J. - This was a writ of error, brought hy the defendants in the eourt below, to reverse a judgment rendered against them in that court.

The deelaration was in common form, in assumpsit, counting upon a promissory note, and demanding $\$ 100$ damages. To this, there was a denurrer and joinder in denurrer. The writing counted upon, and recited in the declaration, was of the following tenor, viz.

Due John Allen ninety-four dollars, 91 cents, on demand.

Joseri L. SMITH. Seth P. BeErs.

Litchfield, A A ugust 30, 1808.

The court below adjudged the declaration to be sufficient and rendered judgment for the plaintiff, to recover 111 dollars, 99 cents, damages. * * * *

On this subject, in my view, it is very clear, that where a writing contains nothing more than a bare acknowledgnent of a debt, it does not, in legal construction, import an express promise to pay. It would not appear, from such a writing, that the parties intended the debt should be paid. Their meaning might be, in such ease, merely to settle their accounts, in writing, with a view to further dealings.

But where a writing imports not only the acknowledgment of a debt, but an agreement to pay it, this amounts to an express contract.

From the writing in question, it is perfectly manifest that the debt acknowledged to be due was to be paid on demand, as fully, as if the words "to he paid" or "which we promise to pay," had been inserted next before the words "on demand."

I think, therefore, that the declaration is suffieient; and that the cause ought to be remanded for further proceedings.

The other judges severally concurred in this opinion. Judgment reversed, and the cause remanded. ${ }^{2}$

2 "Due A. B. \$325 pavable on demand," Kimball v. Huntington, 10 Wend. (N. Y.) 675 ; “I. O. U. $£ 20$ to be paid on the $22 d$ instant," Brooks v. Elkins, 2 Meeson \& Welsby, 74, accord. "Borrowed this day of A. B. $£ 100$ for one or two months; elieck, elo0, on the Naval Bank," IIyne v. Dewdney, 21 Law Journal, Q. B. 278 , contra. If the due bill have words of negotiation as "or order " or "or bearer," it is generally held to be a promissory note. Russell v. Whipple, 2 Cow. (N. Y.) 536; Sackett v. Speneer, 29 Barb. (N. Y.) 180. - H. 
$\S 20$ Hegeman $v$. Moon, 131 New York, 462. - 1892. “ One yesr after my death $I$ hereby direet my executors to pay to A. B., etc., being the balance due him for cash advaneed, etc." Peckiam, J. "The acknowledgment of the indebtedness, and that it is due, implies a promise to pay it on demand. It is a promissory note within the statute. $* * *$ The direction is, however, in the nature of a promise and expresses a time of payment, and, therefore, excludes the presumption that it is payable immediately, which would otherwise arise from the use of the word due."

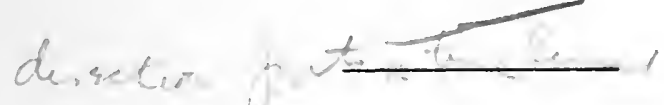

$\S 20$ Schmitz v. Hawkeye Gold Mining Co., 8 S. Dak. 544, 67 N. W. R. 618. - 1896. "Tjme Cheek, No. 189. \$98.65. General Managers' Office, Hawkeye Gold Mining Company. Pluma, So. Dak., June 10th, 1893. Due W. C. Robinson the sum of ninety-eight dollars and sixty-five cents $(\$ 98.65)$, payable at this office, on the 20th day of June, 1893, to him or order. David Hunter, General Manager, by L. A. Fell. WT. C. Robinson." [Indorsed] “W. C. Robinson." Fulder, .T. -_.As the writing before us is negotiable in form, and the signer, in legal effect, promises to pay a specified sum of money, we conclude that the instrument is a promissory note, and that appellant's [Rohinson's] liability was only that of an indorser. The words "payable to W. C. Robinson or order,' unconditionally, at a specticed time nd place, a certain amount of money, import a promise: and the instrument contains every essential element of a promissory note. $* * *$ There was no allegation in the complaint nor pronf at the trial by which to charge appellant, as an indorser or otherwise."

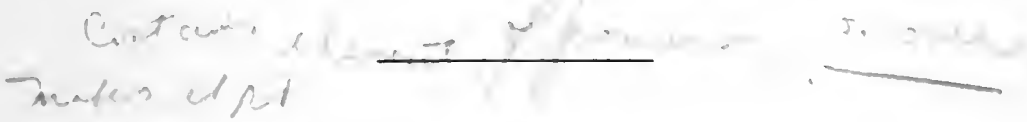

§20 Hussey v. Winsiow, 59 Maine, 170. - 1870. "Nohlehoro, Oct. 4, 1869. Nathaniel O. Winslow, Cr. By labor 163/4 days (a) \$t per day. \$fir.00. Ciood to hearer. Willian Vannah." DANronTu, J. - "It would sem that the only pmssible ennstruetion which can he given to this instrument is, substantially, this: In consideration of $163 / 4$ days' laluer, performed hy Nathaniel O. Winshow, at $\$ 4$ per day, amounting to $\$ 67.00$, I promise to pay him, or bearer, that sum on demand. Signed. William Vannah. Ilere we have every element of a urgotialule promissory note: a maker, a payre, a promise or engagement to pay a cretain sum of money at a specified time, atsontutely and unconditionally, and the word bearer to make it negotiable." 


\section{CURRIER $r$. LOCKWOOD.}

40 convericut, $349 .-1873$.

Assumpsit upon a writen instrument, which the plaintiffs claimed was a promissory note, notn-negotiable, and was not barred until seventeren yeats from its dite. The trial court held it not a promissory note and that it was barred by the statute of limitations.

SErnolk. ('. I. - The thrst question in this case is whether the writing smed 1 pun is a promissory note within the meaning of those words in the statute of limitations. The statute is as follows: "No action shall be hrought on any bond or writing obligatory, contract unler seal. or promissory note not negotiahle, but within seventeen years next after an action shall acerue." The instrument sued upon is as follows:

Bndifont, Jan. 22no, 1863, \$17.14. Due Currier and Barker seventeen dollars and fourteen cents, value received.

Frederick Lockwood.

Promissory notes not negotiahle are by the statute above recited put upon the fonting of sprecialtios in regard to the period of limitation, and for most other purposes such notes have been regarded as specialties in Connecticut. 'The instrument, however, to which this distinction has been attached is the simple express promise to pay money in the sterentyued form familiar to all. The writing given in evidence in this rase is a due bill and nothing more. Such acknowled ments of delut are common and pass under the name of due lills. They are informal nemoranta, sometimes here as in Fngland in the form "1. O. I." They are not the promissory notes which are clased with sperialties in the statute of limitations. The law implies indece a promise to pay from such acknowledgments, but the promise is simply implied and not express. It is well said hr. Smith. . ., in Smill, v. All,n (5 Day. 33i), "Where a writing contains nothine more than a hare aknowledgment of a debt, it does not in lecral construction import an express promise to pay; but where a writing imuerts not ouly the acknowledement of a deht but an agreement to pay it, this amounts to an express contract."

In that rase the words "on demand" were held to import and to he an exprese promise to pay. That rase adopts the correct principle, namely, that to enstitute a promissory note there must be an express as contra-distinguished from an implied promise. The words "on demand" arr here wanting. "Thr words "value received," which are in the writing signed by the defondant, cannot he regarded as equivalent to the words "on drmand." The ease of Smith v. Allen went to the extreme limit in holding the writing there given to be a promiscory note, and we do not foel at liberty to go further in that direction than the court then went. 
The writing then not being a promissory note, the plaintiff's action is barred by the six years clause of the statute, unless revived by a new promise to pay.

A new trial is not advised. ${ }^{3}$

Park and Carpenter, JJ., concur. Foster aud Phelps, JJ., dissent.

\section{MILLER $v$. AUSTIN.}

13 Howard (U. S.) $218 .-1851$.

Actiox by indorsee against indorser, alleging due presentment, demand, notice and protest. Judgment for plaintiff. Defendant brings writ of error.

Mr. Justice Catrox delivered the opinion of the court.

The only question this case presents that we deem worthy of notice is. whether the paper sued on is a negotiable instrument: it is as follows:

No. 959. Mississippt Priox PaNk.

Jacksos. (Miss.) Feb. 8, Is40. I hereby certify, that Hugh Short has deposited in this bank, payable twelve montlis from lst May, 1839, with 5 per cent. interest till due, fifteen hundred dollars, for the use of llenry Miller, and payable only to his order upon the return of this certificate. $\$ 1.500$.

Wilima P. Grayson, Cashier.

The suit was by the last indorsce against his immediate indorser, and brought in Ohio. Thle stitute of that State declares all promissory notes, drawn for a certain sum. payalle to any person or order, or to any pereon or his assigne, reorotialile he indorsement.

The established doctrine is. that a fromies to deliver. or to be accountable for, so mulel monere is a gend hill or note. Here the sum is certain, and the promise dieret. Exery reason exists why

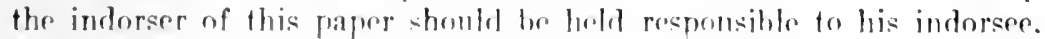
that ran prevail in rases where the paper indoresed is in the ordinary form of a promissory notr: and as such note. the State courts gen-

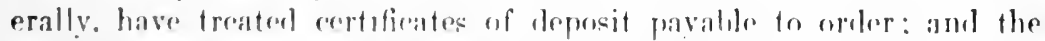
principles adopted hy the State courts in ermine to this romelusion. are fully sustainerl by thro writers of trations on hills and notes. Being of opinion that the cirrolit cente properly held the paper indoresd, negentialite, it is arderest that the junlgument be affirmed."

3ontra: Jarquin v. Warren, 10 lll. 15!); Mrally v. rhandler, 3I Mo. 28.

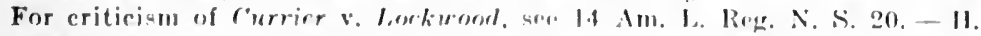

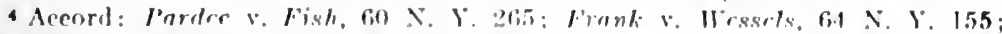

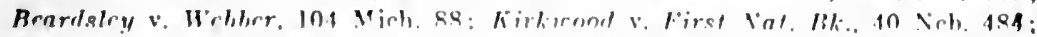
Klauber v. Biggerstaff. 47 Wis. 551. The rertifieate of deposst is to to dia- 


\title{
2. A Bifle Must Contain an Order.
}

$\S 20$

\author{
HOY'T' '. IIYNCH.
}

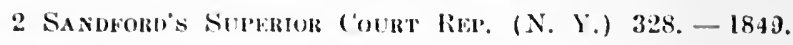

Assumpsit on an order drawn upon the defendant, with the enmmon counts. At thre trial, it appeired that smith and Woglom, builders, erected certinin buildings for the defendant in Williamsburgh, in 18tr. The plaintitl plitimed to have tinned the roofs and put up the gutters for those huildings, and his bill for the work, rendered to S. \& $1 \mathrm{H}$., anomited to $\$ 300$. sS. They gave an order on the defendant, written at the foot of the tritl, as hereafter set forth. The order was presented by one Harris to the defendant, who said he could not pay it until he went and salw how the buildings progressed. The plaintiff then proved by Inarris, that two or three days afterwards the defendant met the latter at the buildings, and there promised to pay the order an soon as the sashes were put in, and those were put in carly in .January, 1818.

The bill and order were read in evidence in these words, viz:-

Mesers. SMitul AND Wogiom,

NEW lork, l6th Dec., 1847.

To C. H. Hor', Dr.

To tin roof. 86 ft. $x 371 / 2 \mathrm{ft} .3225 \mathrm{ft}$. (a) $71 / 2 \mathrm{e} \ldots \ldots \ldots \ldots \$ 241.87$

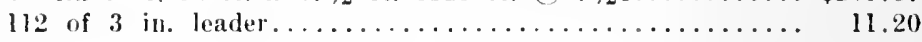

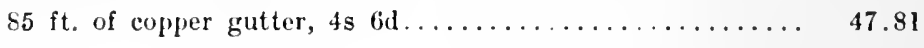

$\$ 300.88$

Williamsburgit, Dee. I6, 1847.

Mr. J. LYNCH

Pleace pay the above bill, loring the amnunt for tinning your houses on South Sixth street, and eharge the same to our acenint.

And mueh oblige yours,

SмIти \& WogLom.

tinguibled from the "deposit slip." which is merely" a reecipt or memorandum, entaining no promiae, and requiring no return. First Nat. Bk. v. Clark, 13.4 N. Y. 3fis, 372 .

For orders on savings banks, se White v. Cushing, 88 Me. 339, post, p. $46 .-1 \mathrm{I}$.

I" Doublese a errtifiente of deposit may be iscued in the form of a negotiable inctrument. (Fronk v. Wessels, ti4 N. Y. 155.) But from our examination of the whbect there sems to be no uniform nsige in commercial eireles or with monotary institutions as to their forms. Some are plainly negotiable, some erpually plainly are not negotiable, while between the two extremea are many of the lehatahe elass." CUIJ.eN, C. J., in Zander v. $N$. Y. Security \& Trust Co., 178 N. Y. 208, 210.

For certificates of deposit held to be negotiable under the Negotiable Instru. ments Law, sep Forrest v. Safrty Banling \& Trust Co.. 174 Fed. 345; Kava. nogh v. Bank of Amerira, 239 III. 404: Dickey v. Adler, 127 Southwestern (Kansas City Ct. App., Mo.) 593. - C.] 
By the Court. OAKLEY, CH. J.- - [After disposing of another matter.] There was another question argued, which must arise on a new trial, and it is right that we should express our riews upon it at this time. It is said that the order upon which the suit is founded, is a bill of exchange, and that there is no written acceptance of the same.

On consideration, we have come to the conclusion that this is a bill of exchange. It is an order in writing, drawn by one party on another, requesting the latter to pay a certain sum of money to a third party, at all events; depending upon no contingency, and payable out of no particular fund. It comes within the reason of the statute requiring a written acceptance to charge the drawee. It is true this order is not negotiable, but that is not necessary to make it a bill of exchange. ${ }^{5}$

\section{New trial granted.}

$\S 20$ Tile King $v$. Elion, 1 Leach, Crown Law, 323. - 1784. "Messrs. Songer, - Please to send $£ 10$ by the bearer, as I an so ill I cannot wait on you. Elizabeth Wery." Ellor was indicted for forging a bill of exchange. Tire CourT. - "This appears to be a mere letter, rather requesting the loan of money than ordering the payment of it. The terms of it do not import anything compulsory on the part of the drawee to pay it."

$\S 20$ Ruff $v$. Webb, 1 Espinasse, 129. - 1\%94. “Mr. Nelson will much oblige Mr. Nebb hy paying J. Ruff, or order, twenty guineas on his account." "Tond KExyos said, that he was of opinion, that the paper offered in evidence was a bill of exchange; that it was an order by one person to another, to pay money to the plaintiff or his order, which was in point of form a bill of exchange."

$\S 20$ Little $v$. Slack Fond, Moody \& Malkin, 171. - 1828. “Mr. Little: - Please to let the bearer have seven pounds, and place to my account, and you will oblige, your humble servant, R. Slackford." Lonn Trexterden, C. J. - "The paper does not purport to be a demand made hy a party having a right to eall on the other to pay. The fair meaning is, "you will oblige me by doing it."."

5 See Urhlberg v. Tisher, 24 Wia. 607, post. - H.

s "Thomas Williams, Faq. - I'lease let the Learer have \$50. I will arrange it with you this noon. Yours, most obedient. S. R. Biesenthall," was held to be a bill of exchange. Bicsenthall v. Williams, l Duvall (Ky.) 329, 1864. 


\section{The Promise oli Olider Must be Unconditional.}

(a) C'onditional promises or orders are not negotiable.

\section{WHITE v. CUSHING.}

SS MaINe, 339. - 1896 .

Assimpsit on an order. The trial court muled that the order was negotiable and the action could he maintained in the name of White by a simple indorsement by Lawler. Defendant excepted.

Fostek, J. - The plaintiff sues as indorsee of an order signed by the defendant of the following tenor:

$\$ 120$.

DOVEr, Oct. 27, 1893.

Piscataques Savings Bank.

Pay James Lawler, or order, one hundred and twenty dollars, and charge to my account on book No. -

J. N. Cusinnf.

Witness

The bank book of the depositor must accompany this order.

The order was indorsed in blank on the back by James Lawler and Samuel Lewis, and the plaintiff claimed to recover against the defendant as upon a negotiable instrument. The real question presented is whether-the instrument declared on is negotiable, so that an action may be maintained upon it in the name of the indorsee.

To constitute a negotiah]e draft or order, it must be a written order from one party to another for the payment of a certain sum of money, and that absolutely, and without any contingeney that would embarass its circulation, to a third party or his order or bearer.

It has often been held that a hill or note is not negotiable if marle payable out of a particular fund. But there is a distinction between such instruments made payahle ont of a particular fund, and those that are simply chargeable to a particular aceount. In the latter case, the payment is not made to depend upon the adequacy of that fund. the only purpose being to inform the drawee as to his means of reimbursement, and the negotiability of the instrument is not affected by it.

The oljection that is raised to the negotiability of this instrument is, not that it is made payable out of a particular fund, but that it is subject to such a contingeney as necessarily embarrasses its circula-

Words of civility do not prevent the instrument from bcing an order. Theatlry v. strobr. 12 eat. 92 .

By the law merchant a bill of exchange need not be payable to order or bearer, or have the words value received, or be payable at a day certain or at any particular place. Thus: "To Hoxie \& Rich: Please pay to ('bas. Mehlberg the sum of $\$ 69.20$, and eharge to me. ('has. 'Tisher," is a hill of exchange by the law merchant. Mehlberg v. Tisher, 24 Wis. 607 , post. See $\S 25$, post. - H.

7 Sce note in $125 \mathrm{Am}$. St. Rep. at p. 192, - C. 
tion and imposes a restraint upon its negotiability, by means of these words contained upon the face of the order: "The bank book of the depositor must accompany this order." Although these words are upon the face of the order helow the signature of the drawer, they were there at the time of its inception, became a substantive part of it and qualified its terms as if they had been inserted in the body of the instrument. (Littlefield $\mathrm{v}$. Coombs, $\mathrm{\gamma} 1$ Ifaine. 110: Cushing v. Field, r0 Maine, 50, 54: Johnson v. Heagan, 23 Maine. 329; Barnard v. Cushing. \& Metealf. 230: Heywood v. Perrin, 10 Pick. 228 ; Benedict v. Couden, 49 N. Y. 396 ; Costelo v. Crowell, 127 Mass. 293, and cases there cited.)

Was the order negotiable? The answer to that depends upon the effect of the words "The bank brok of the depositor must accompany this order." If not negotiable, the plaintiff as indorsee cannot maintain an action upon it. (Noyes v. Gilman, 65 Maine, 589.) If their effect is such as constitutes a contingency in relation to the payment of the order. dependent upon the production of the-drawer's bank book by the holder or indorsee of the order, then they must be regarded as such an embarassment to the negatiation-of-the order, and such restriction upon its circulation for commercial purposes as to render it non-negntiable.

Without these words the order is payable absolutely, and there is no apparent uncertainty affecting its negotiability. With them, the order is payable only upon contingency. or condition, and that is upon the production of the drawer's hank bonk. This is rendered imperative from the language employed, and the bank upon which the order is drawn, would have the right to insist upon such production of the book in compliance with the terms of the order: and the case shows that it has refused payment mprit-presentation of the order for the reason that it was not accompanied by the bank book. It cannot, therefore. be regarded as pavable absoluinly and without any contingeney that would embarrass its circulation. The drawer has it in his power to defeat its pavment by wibluolding the bank book. Certainly the bank book of the depositor is within his own eontrol rather than that of the indorsee of this order.

It was the necessity of rertainty and precioion in mercantile atrairs and the inconvenirenoes which would result if commereial palper was incumbered with comditions and contingencies, that led to the establishment of an inflexible rule that to be negotiable they must be payable absolutely and without any conditions or contingoncies to embarrass their circulation. (.1merican Lir. Banli v. Blanchard. o Allen, 333.) Tn thit case the words. "subject to the poliey" hoing inclurled in a promissory notr, were beld to render the proinise eonditional and not ahenlute. and so the note was hold not to be negotiahle. (Noyes v. Gilman, 65 Maine, 589, 591; Hubbard v. Mosoly, 11 Grav, 170.) 
$A$ ease in every essential like the one we are considering was before the Supreme Court of Pennsylvania in 1891. A fac simile of the order is given in the opinion. No two cases could be nearer alike. There, as here, the order was drawn on a savings bank. The suit was hy the indorsee against the drawer as in this case. There, as here, the nader entained a statement upon its face, but below the sienature of the drawer, that the " Deposit book must be at hank hefore money ean he paid." In diseussing the question of its negotiability eases are cited from the courts of Maine, Vermont, Massachusetts and New York, as well as from Pennsylvania. In the conrse of the opinion the court says:

"It sufliciently appears from the memoranda on its face that it was drawn on a specially deposited fund held by the bank subject to certain rules and regulations, in force between it and the depositor, requiring certain things to be done before payment could be required, viz. : previous notice of depositor's intention to draw upon the fund, return of the notice ticket with the order to pay, and the presentation of the deposit book at the bank, so that payment might be entered therein. * * * It is, in substance, merely an order on the dollar savings bank to pay J. W. Quinn, or order, nine hundred dollars in nine weeks from date, or February 1, 1888, provided he or his transferee present to the bank, with the order, the notice ticket, and also produce at and hefore the time of payment the drawer's deposit book. As already remarked, these are undoubtedly prerequisites which restrain or qualify the generality of the order to pay as contained in the body of the instrument. They are also prerequisites with which it may he difficult, if not sometimes impossible, for the payee, transferee, or holder of such an order to comply.' (Iron City Nat. Bank v. McCord, 139 Pa. St. 52, 23 Am. State Rep. 166.)

The order in question was drawn upon a savings bank, and it is common knowledge that all such banks in this State have a by-law which all depositors are required to subseribe to, that "no money shall be paid to any person without the production of the original book that such payment may be entreed therein."

This court in the case of Sullivan v. Lewiston Inst. for Savings ( 56 Maine, 50\%), has considered the purpose and necessity of these salutary regulations. We should be slow to countenance any departure from this rule needed for the protection of depositors in our savings banks now numbering more than 160,000 , and where deposits aggregate nearly $\$ 60,000,000$.

Inasmuch as this order is not negntiable and no suit can be maintained upon it by the plaintiff as indorsee, it hecomes unnecessary to consider the other exceptions.

Exceptions sustained. 
(b) An order or promise to pay out of a particular fund is conditional. ${ }^{\text {s }}$

4 Denio (N. Y.) 159. - 1847.

Assumpsit. On the trial the plaintiff gave in evidence an agreement, signed by the defendants, bearing date Octoher 12, 1839, by which, for value received, they jointly and severally promised to pay to the plaintiff, by his name or order, $\$ 250$, with interest, parable one-half in two years and the other half in three years from the day of said agreement, "out of the net proceeds, after paying the cost and expenses of ore to be raised and sold from the bed on the lot this day conveyed br Edward Madden to Edwin Dodge, which bed is to be opened and the ore disposed of as soon as conreniently may be."

On reading the agreement the plaintiff rested, and the defendants moved for a nonsuit, as the plaintiff had not shown that the defendants had received enough from the ore to pay the note, nor had they shown any default or negligence on their part. 'The judge held that the plaintiff could not recover without proving that the defendants had received funds from the ore to enable them to pay, or had neglected to work the ore bel, and directed a nonsuit.

The plaintiff excepted.

By the Court, Beardsisy, J. - The nonsuit was proper. A promissory note must he payable absolutely, and not upon any contingency as to time or event. (3 Kent, 5th ed. p. 74; Smith on Mere. Law, 113,$116 ;$ Story on Prom. Notes, $\$ \$ 1,22$ to $26 ; I d$. on Bills of Exch. \$\$ 46, 47; Chit. on Bills, 10th Amer. od., p. 132 to 139.)

This was not such an engagement, for although the promise was to make payments at certain specified times, the payments were to be made "out of the not proceeds" "of ore to be raised and sold" from a certant ore-bed. Here was a contingoncy; the fund might turn out to be inaderpate, in which asse there wonld be no ohligation to pay at any time. It is not a promise to paly "alsolutely and at all events," as a promissory note always is.

Now trial denicd. ${ }^{\circ}$

8. See note in $125 \mathrm{Am}$. St. Repr. at page 196.- ('.

"Please pay A. B., or order, \$500, for valur reenved.

out of the procepds of the claim ngainst the lealogly Eastate. now in your hands to enllect, when the same shall have lwen collectorl hy you," is not n negotiable instrument, as the money is payable ont of a particular fund. Richerelson v. Carpenter, 4f, N. Y. fifio.

"You will plesase pray to A. B. the amount of a mote for $\$ 2.000$. dated December 31st, 1868, and draluct the same from my share of the profits of 
(c) An indication of a particular fund does nol remder promise condiliennt.-

101 New Yokk, 554. - 1886 .

Ryger, Ch. J. - The plaintifl clained to recover as the holder of a draft drawn-upon and aceepted by the defendant, reading as follows:

New Yовк, Pebruary 26, 1877.

Mr. Aoum Simox, exeentor, will please pay to Johanues Schmittler or hus orter, on the first day of July, which will be in the year 3879 . the sum of $\$ 900$, with seven per cent. interest, to be paid besides this amount yearly, July month, and charge the amomt against me and of my mother's estate.

WILIIAM d. SCHAREN.

[Written upon the face]: Accept, ADAm SIMon, exceutor; [and indorsed]: Pay to the order of Mary Schmittler, the amount of note.

\section{JoliANNES SCHMITTLER.}

Tpon the trial, after proving the execution of the draft, its acceptance and transfer, and offering to prove the payment of a consideration by the plaintiff to the payee, which was objected to by defendant, and exchded hy the court, the plaintiff rested. The defendant thereupon moved to nonsuit upon the ground that the obligation was not binding upon the defendant personally, but he was liable thereon, if at all, in his representative character alone, and that it was payable out of a specific fund, and a recovery thereon could not be had without proving the existence and extent of such fund. The court thereupon nonsuited the plaintiff, to which decision she excepted. 'The General 'Term having affirmed the determination of the trial court, the plaintiff took this appeal.

We think the court below erred as to both of the grounds upon which their judgment proceeded. That the defendant was liable upon the draft, if liable at all, in his individual eapacity alone, seems under the anthorities to admit of no doult. ${ }^{2} * * *$

our partnershif busines in malting," is not a lill of exchange, for it is payable out of all uncertain fund, from profits. Hunger v. Shannon, 6I N. Y. 251.

Jossely. v. LACjer, 10 Mod. R. 294, 316. - 1715. Evans drew a bill upon Jossclyn, refuiring him to pay lacier seven pounds every month out of the growing ubeistence of Evans, and place it to his aceount. Josselyn accepted it, and afterward refused to pay. PARker, C. J. - "We are all of opinion that it is not a bill within the custom of merehants; it eoncerns neither trade nor eredit; it is to bre paid out of the growing subsistenee of the drawer; if the party die or his subistenee be taken away, it is not to be paid." Aceord: Jenney v. Herle. 2 Ld. liaym. 1361: Mcliee v. Larramore, 50 Mo. 425; Jaekman v. Bowker, 4 llet. (Mass.) 235. - H.

1 Soe note in $125 \mathrm{Am}$. St. Rep. at page $196-\mathrm{C}$.

2 On a subserpuent apreal after a new trial, the court thoughi thir majalt might be qualified by parol evidence. s. c. 1 i4 N. Y. 177. See Neg. Inst. $\S 74 .-\mathrm{H}$. 
Being of the opinion,. therefore, that the defendant is liable upon the draft in question in his individual capacity alone, the question still remains as to the extent of such liability. $* * *$ The court below held that the draft in question was payable only from a particular fund, and was, therefore, non-negotiable, and enforceable only to the extent of the fund referred to.

Considering the question as we are compelled to do from the language of the instrument alone, we are unable to agree to the interpretation thus put upon it. It is not clained that there is any distinction between the instrument in question and an ordinary bill of exchange except that made by the clause referring to the mother's estate. Unless that elause deprives the paper of its eommercial character. the rights and liabilities of the parties thereto must be governed by the rules pertaining to negotiable securities, which would render the defendant liable for the amount named in the draft, upon the theory that his acceptance was an admission by him of assets applicable to its payment.

The distinction between a fund from which a draft or order is directed 10 be paid, and one referred to as the means of reimbursement fo is drawee, is a material one and cannot be disregarded in the mistriction of such instruments. Thus it is said: "When a reference is illade to a special fund merely as a direction to the drawer low to reimburse himself, and the payment is not made to depend 11 mo the adequacy of the fund, it will not vitiate the bill." (Edu. on lills and Notes, $\S 158$; see also Parsons on Merc. Law, 87; ('hilly on Bills, 158.) Dwight, Com., in Munger v. Shannon (61 N. Y. 25.5$)$, says: "A bill is an order drawn by one person on another to paly a third a eertain sum of money absolutely and at all events. Uniler this definition the order cannot be paid out of a partieular fund, but must be drawn on the general eredit of the drawer. thongh it is no oljection, when so drawn, that a particular fund is epecified from which the drawee may reimburse himself." Judge lanpallo in Brill v. Tultle (81 N. Y. 457), says: "If a draft be drawn erencrally upon the drawee, to be paid hy him in the first instance. on the credit of the drawer and without regard to the sourero from which the money used for its payment is obtained, the designation by the drawer of a particular fund, out of which the drawere is to subsecuently roimhurso himself for such payment, or a mrticular nereont to which it is on be charged, will not ennvert the draft into an ascignment of the fund, and the payee of the draft can have no action thereon against the drawee unless he duly accepts." In that ease the drawee rofused to accept and the action was sought to be maintained upon the theory of an equitable assignment. It was held under the preuliar circumstances of the case, and the form of the instrument, that it dis transfer the fund. 
It is thus seen that the mere mention of a fund in a draft,-does not necessarily deprive it of the character of commercial paper, but it must further appear, in order to lave that effect, that it contains rither an express or implied direction to pay it therefrom, and not otherwise.

The question, therefore. to be letermined here is, whether the fund in question is referred to an the medsure of linhility or the means of reimbursement. While the point is not free from doubt, we think a reasonable construction of the llaft farors the conclusion that it is mentioned only as the source of reimbursement. No express language in it can be pointed out as repuiring its paynent from the fund mentioned, and none from which that requirement can be implied, except such as exists in all drafts where a fund is referred to. Its language is to "charge the amonnt against me and of my mother's estate" and contains no provision for delay until the amount is realized from the estate, or for payment pro tanto in case the estate should prove insufficient to pay the whole amount. 'There is no language importing a transfer of the fund to the payee, and nothing from which such an intention can be inferred. 'The draft contains an absolute direction to pay a fixed sum, at a specified date, with interest. It imports a present indebtedness of a sum named, from the drawee to the payee, and an absolute direction to pay that sum at a fixed date, suliject to no contingency either as to time or amount. In express language he directs the amount when paid to be charged against hin individually, and adds the words, plainly implying. as we think, that the fund for the acceptor's reimbursement would be found in an amount eventually, or immediately parable to the drawer from his mother's estate.

We think, also, that the insertion of words expressly making the paper negotiable, was quite signifieant and indicated an intention on the part of all parties, that it would be transferable, and partake of the character of commercial paper. Any contingency inferable from the language of the draft, making the amount payable thereon indefinite and uncertain, would tend largely to depreciate its value for such purpose, and defeat the intention with which it was apparently marls.

If the language of the paper conld he consillered at all ambiguous, it was the diuty of the defendant to limit his liability by apt words of acceptance when it was presented to him, hut as it is, he has unqualifiedy promised to pay a fixed and definite sum at a specified time, and we think, should he held to the contract which other parties were authorized by his acceptance to infer he intended to make.

The case of Tassey v. Church (4 Watts \& Sergeant, 346), seems quite in point. The instrument there read: 
$\$ 555.48$.

Alleghany, Ist July, 1840.

Please pay Church, McVay \& Gordon $\$ 555.48$ and eharge the estate of Thomas C. Patterson. ADAM Flemmix, Trustee.

To JoH N TASSEY, Administrator.

[Indorsed]: Accepted. JoH TASSEY, Administrator.

Fleming was the trustee of Mrs. Patterson, who was the heir at law of Thomas C. Patterson; Tassey was the administrator of Patterson's estate. It was held that the promise of the acceptor was unconditional and bound him absolutely. In r'hilds r. Monins (6 Eng. C. L. 228), the defendants, as executors of the estate of Thomas Taylor, promised to pay $£ 200$ on demand with interest, signing as executors. It was held that they became personally liable, and that the plea of plene administravit was no defense. It was further held that the promise to pay interest made the debt that of the administrators personally. In Kelly v. Brooklyn ( 4 Hill, 263), the action was upon an order drawn by the mayor upon the treasurer of the defendant in the following words: "Pay Alexander Lyon or order $\$ 1,500$ for award No. $千$, and charge to Bedford Road Assessment." It was held that it was a bill of exchange and not payable from a particular fund. For further illustration of the point under discussion we would refer to IIollister v. Hophins (13 Hun, 210); Redman v. Adams (51 Me. 429); Luff v. Pope (5 Hill, 413). The case of Tooker r. Arnoux ( 76 N. Y. 39\%), is referred to by the respondent as sustaining the views of the court below; but we are of the opinion that it cannot be so regarded. The order there dirceted the drawee to pay a certain sum out "of the money to be realized from the sale" of ecrtain houses. This order was accepted, and it was held that a sale of the houses was a condition precedent to any liability on the part of the acceptor. This was the plain language of the contract.

In all the cases examined by us where an order has heen held to oprate as an equitable assignment of a fund, there were either special phrases contained in the instrument, indieating an intent to have it so operate, or ambignoms langrage used, which, construed in the light of surrounding eiremetsuces, justified the inference of a limitation of liability. (Porlier r. S'yraruse, 31 N. Y. 3\%6; Alger v. Seoll, 51 il. 14: Munger v. Shannon, 61 id. 251 ; Erichs v. De Mill, \%. id. 3\%); Ririll v. Fullle, supra.) Here, however, there is no such language, and this contract is to pay a fixed imount al a speeified Tiater alsolutely and nno

We are, therefore, of the opinion that the instrument in question is a bill of exchange and rendered the parties executing it liable absolutely for the amount stated therein. 


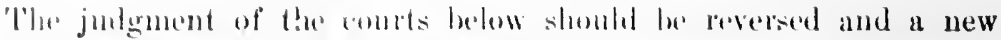
trial orderid, with eosts to abide the event.

All conent.

\section{Judgment reversed. ${ }^{3}$}

3 "Please pay to order of G. F. and 6 . W. Tilden forty dollars, and charge same agalust whatever amount may le due me for my share of lish ealught

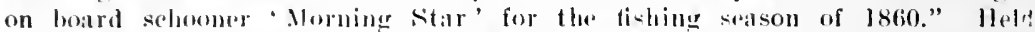

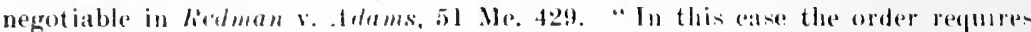

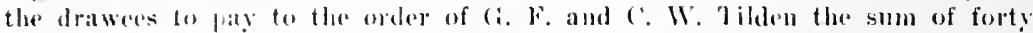
dollars, absolutaly and without eontingeney. A muas of mimbursement is indieated to the drawere in the work appended, "and charge the same against whatever amount may be due me for my share of tish, ote. but the payment of the order is not made to depend upon his having any share of fish, nor is the "all limited to the proeereds thereof." lisnoows, J., on p. 433.

A bill reading. pily to thr order of $A, \$ 1,500$, "on account of contract between you and the Snyder Planing-mill company" signed by the company, held to be negotiable. "Soction 10 (N. Y. \$ 22) of our negotiable instruments law, which is meroly drelaratory of the common law upon the subject, reads as follows: . . The controversy is thus narrowed lown to whether the words 'on account of contract betiveen you and the Snyder Nill company' amount to a dipection to pay out of a particular fund, or, on the other hand, are to be considered as simply indicating the fund from which the drawee, Lightner, might roimburse himself. . . . The weight of authority and reason supports the proposition that the words amount to no more than an indication of the fund from which the drawee is to reim. burse himself. The words used are substantially the sime as though the orders read 'and charge to account of eontract with Snyder Jlaning-mill Company' or 'credit to aceount of eontract, etc." Porter, J., in First National Bank v. Lightner, 74 Kan. 736, 742. Spe this ease with notes in 8 L. N. S. 231. 118 Am. St. Rep. 353, and 11 Am. and Eng. Ann. Cas. 596. See al $=0$ note in 7 col. Law Rev. 216.

In Hibbs v. Browen, $190 \mathrm{~N}$. Y. 167, the action was to replevy stolen coupons originally attached to a hond issued hy the Adums Express Company, an unincorporated joint stock ascociation. and appedant's right to recover turned on the question whether said hond and compons were negotiable. The bond was issued by the Express fomplany in its association name and was seeured by a trust indenture eonvering and pledging for its payment a large amount of securities and property. Among other clauses was one provicling that "no person or future shareholdor. ollicer, manager or trustce of the Express Company shall be personally liable as partmer or otherwise in respect to this bond or the (o)pons pertaining thereto, hat the sume shall be payable solely out of the acects asuigned and trameferred to the said Trust Company or out of other anetes of the Expresse ( ompany."

Appellant claimed that this clanse rendered the bond non-negotiable as it prevented the bomel from being colleceted from the individual property of the mombers of the ascociation and therefore made the remainine property from which it comlil be colleeted a particular fund. He pointed out the ditlerence betwern a joint sock association and a corporation, contondine that the individnal liability of the members of the former is as escontial a characterjatie as it is in the case of a partnerslip. and that, therefore. it eould not be eliminaterl without materially affecting the entrect of the association.

Huscock. J.. helf that "s mamy of the attributes and elaracteristies of a corporation have been impressed upon the modern joint stock association that 
(d) Statement of transaction which gives rise to instrument does not render promise conditional.

\section{$\S 22$ SIEGEL $v$. CHICAGO TRUST \& SAVINGS BANK.}

131 It.linois, 569. -1890.

Mr. Chiff Justice Srope delivered the opinion of the Court.

This was an action of assumpsit, by appellee, against appellants, upon the following instrument:

$\$ 300$.

('HCago, March 5, 1887 .

On July 1, 1887, we promise to pay D. Dalziel, or order, the sum of three hundred dollars, for the privilege of one framed advertising sign, size $-\mathrm{x}-$ inches, one end of each of one hundred and tifty-nine street cars of the North Chicago City Railway Co, for a term of three months, from May J5, 1887.

Siegri, ('OOPER ANI C'o.

- which was indorsed by Dalziel, the payee, to appellee, for value on the day of its exeention.

The first question presented is, is this instrument negotiable? and this case has been answered affirmatively by the Circuit and Appellate Courts. The Appellate court having affirmed the judgment in faror of the plaintiff, the case is brought here by appeal, upon certifieate of importance granted by that court.

It appears, that before the time when the privilege of advertising was to commence Dalziel forfeited any right he may have aequired to nse the ears in the manner indicaterl, and the privilege speeified never was furnished appocllants; and it is insisted that the instrument is a simple contract, only, and that therefore the same defense, - failure $0^{\circ}$ consideration, - is availahle against the indorsee of the paper for value, and before due, as might be interposed against such paper in the hands of the payee. It is also insisted, that the instrument shows, on its fare, that payment depended upon a condition precedent to be performed by the payee. and therefore the intorser tork it with notice, and ly the failure of

in my opinion. for the purpuses of the question now before ns, we are amply

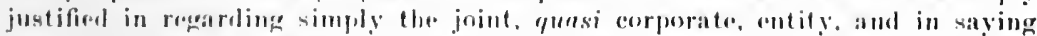

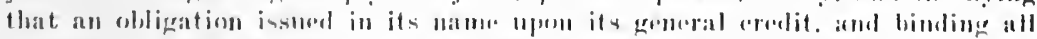

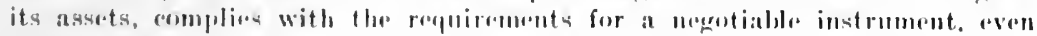

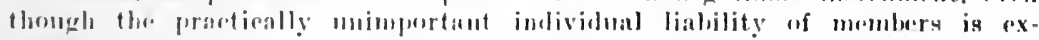
elude.d." P. 177.

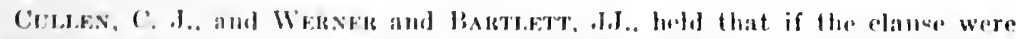

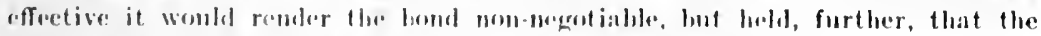
elanse was verid, and that the bund was therefore unegotiable.

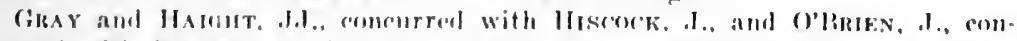
curred with Hrsork. .l. in apinion. Hhus making the views in these opinions the holding of the majority of the court.

Sere note on "Negrotialility of foint stock asuociation bouds pxompting

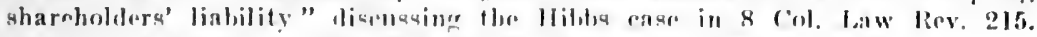

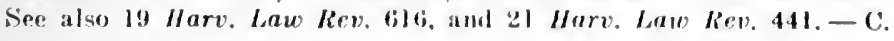


the payee to perform the condition, no right of recovery exists in the indorsee. It is not contended that the indorsee had any other notice than that contained in the instrument itself, and it is apparent that at the time of its indorsement, which was the day of its execution, no right to the consideration had acerned to the makers. It is a promise to pay a certain sum of money at a day certain, for a consideration thereafter to he rendered, and depends for its validity upon the implied promise of the payee to furnish the consideration at the time and in the mamer stipulated, - that is, it is a promise to pay a sum certain on a particular day, in consideration of the promise of the payee to do and perform on his part. A promise is a valuable consideration for a promise.

But the question remains, whether the statement or the recital of the consideration on the face of the instrument impairs its negotiability, and, in this instance, amounts to a condition precedent. The mere fact that the consideration for which a note is given is recited in it, although it may appear thereby that it was given for or in consideration of an executory contract or promise on the part of the payee, will not destroy its negotiabitity, unless it appears, through the recital, that it qualifies the promise to pay, and renders it conditional or uncertain, either as to the time of payment or the sum to be paid. (Daniel on Neg. Inst. secs. 790-797; Davis v. McCready, 17 N. Y. 320; State Nat. Bank v. Casson, 39 La. Ann. 865; Goodloe v. Taylor, 13 N. C. 458 ; Stevens v. Blunt, Y Mass. 240.)

In State Nat. Bank v. Casson (supra), it is said: "Plaintiff received the note before maturity, and before the failnre of the consideration. Even if it were known to him that the consideration was future and contingent, and that there might be offsets against it, this would not make him liable to the equities between the defendant and the payee. It cannot affect the negotiability of a note that its consideration is to be hereafter realized, or that, from contingency, it may never be enjoyed."

The most that can be said of a recital in the instrument itself, of the consideration upon which it rests, is, that the indorsee, taking it before maturity, is chargeable with notice of the recital. Such recital, however, is not sufficient, of itself, to advise him that there was, or would necessarily be, a fallire of consideration, but if, at the time of the indorsement, the consideration has in fact failed, the recital might be sufficient to put him upon inquiry, and, in connection with other facts, anount to notice. (Menneberry v. Morse, 56 Ill. 394.) The case at bar does not, lowever, fall within the rule just stated, for the assignment was made the same day the note was made, and by the terms of the recital it was apparent the payee was required to do no act till the 15 th of May following, - an interval of seventy days. 
There is a distinction, clearly recognized in the authorities, between an instrument payable at a particular day, and one payable thon the mppening of some event; and the rule is, that where the parties insert a specific date of payment, the instrument is then payable at all events, - and this, although, in the same instrument, an uncertain and different time of payment may be mentioned, as, that it shall be payable upon a particular day, or upon the completion of a house, or the performance of other contracts, and the like. (McCarty v. Howell, 24 Ill. 341, and authorities supra.) But the doctrine of this and kindred cases, where there are both a certain day of payment and one more or less contingent, need not be here invoked, for the time of payment in the instrument under consideration is not made to depend upon the happening or not happening of any event, but is specific and certain, and must occur by the efflux of time, alone.

If, therefore, it be conceded, as it must, that a condition inserted in a promissory note, postponing the day of payment until the happening of some uncertain or contingent event, will destroy its negotiability and render the instrument a mere agreement, yet under the authorities, if by the instrument the maker promises to pay a sum certain at a day certain to a certain person or his order, such instrument must be regarded as negotiable, although it also contains a recitat of the consideration upon which it is based, and although it further appear that such consideration, if executory, may not have been performed. Here, the mnney was payable, absolutely, on the first day of July, 188\%, - a time when the contract for the advertising could not have been completed. If the instrument had remained the property of the payee, and upon its maturity and performance to that time, suit hat heen hronght, it is clear that no plea of partial failure of ensideration conth have heen sustained, for the reason that the entire term had not then expired. No analysis of the instrument itself is necessary. The most eareful examination of it will fail to disclose a condition precedent to the payment of the money at the time stipulater. Nor is there anything in the recital of the consideration to put the indorse upon inquiry at the time the indorsement was marle. Indecel, it is clear that at that time no inquiry would have led to notice that Inalziel would fail to comply with his contract on the 15th of May thereafter, when the term was to commence. All that the recitals would give notice of was, that the note was given in consideration of an agreement on the part of the payee that the privilege of advertisement named slionld be enjoyed by the makers for three monthe, from May 15, 188\%. Giving to the language employed its broidest possible meaning, it eannot be eonstrued as noties to the indersen of the future breach of the contract hy Dalziel. "'he presumption of law would be, that the 
contract would be carried out in good faith, and the consideration performed as stipmlated. The makers had jut their promissory note in the hands of Dalziel upon an express eonsideration which they were thereafter to recoive, and for the performanee of which they had soen fit to rely upon the motertaking of Dalziel, and we are aware of no rule by which they ean hold this indorsee for value, hefore due and before the time of performance was to begin, ehargeable with notice that the promise upon which the makers relied would not be kept and performed. (Wade on Notice, \$94a; Loomis v. Muury, 15 N. Y. 312; Daivis v. MrCready, supra.) * * *

The judgment of the Appellate Conrt will be affirmed.

116 MICHIGAN, 28. -1898.

Hooker, J. - The defendants have appealed from a judgment upon three written instruments, substantially alike, of one of which the following is a copy: “\$115.00. Detroit, July 25, 18!33. For value reecived. Warch 16.1895 , after date, I promise to pay to the order of Low's Art Tile Soda-Fountain Co., one hundred and fifteen dollars, with interest 6 per cent. The consideration of this and other notes is the soda-dranght apparatus describer in contract of same date as this and other notes, which soda-draught apparatus the undersigned has received of said Iow's Art Tile Soda-Fountain ('n. Nevertheless it is understond and agreed by and between the m!n!crsigned and the said Iow's Art 'Tile Soda-Fountain Co. that the titlo to the above-mentioned property does not pass to the undersigmenl. and that, until all said notes are paid, the title to the aforesaid sla:ll remain in the said Low's Art Tile Soda-Fountain Co., who shall have the right, in case of nonpayment at maturity of either of said notes. without process of law, to enter and retain immediate possession of sair property, wherever it may he, and remove the same. Payable at the Preston National Bank."

Each hears, as an indorsement, the name of the payee. The defendants say that they were improperly admitted in evidence, for the reason that they are not promissory notes, and. if the indorsements are to be treated as an assignment of the ehose in action. it should have been allegerl in-the derlaration: and, further, that there was

4 Accord: Chase v. Behrman. 10 Daly (N. Y.) 344. ('ontra: Jarvis v. Wilkins. 7 M. \& W. 410 , where the instrument read: "I undertake to pay A. B. the sum of $\{64 \mathrm{~s}$., for a suit of, ordered by Daniel Page." Fletcher v. Thompson. 55 N. H. 308. - H. 
no evidence that the plaintiff was the owner of the notes sued upon. Both briefs indicate that the question consiclered nost important, if not decisive of the case, is that of the negotiability of the notes. The instruments - to the end of the fifth line ${ }^{5}$ - are in form promissory notes. If there were nothing more, they would be as perfect and complete promissory notes as it is possible to make. The writing proceeds to state the consideration for said notes, which, though not essential, was harmless. (Wright v. Irwin, 33 Mich. 32.) 'This is followed by the statement that the parties agree that the title to the property for which the notes were given shall remain in the payee, who, in case of nonpayment at maturity of either of said notes, "may enter and retain immediate possession of the property, without process of law, wherever it may be, and remove the same." If it can he said that this writing shows a sale of the soda fountain, as contradistinguished from a contract to sell, the provisions as to title amount-to no more than a chattel nortgage. Mr. Justice HarLaN said in the case of Chicago Ry. Equipment Co. v. Merchanls' Bank, $136 \mathrm{U}$. S. $280,10 \mathrm{Sup}$. Ct. 1002 : "The fact that, by agreement, the title is to remain in the vendor of personal property until the notes for the purchase price are paid, does not necessarily import that the transaction was a conditional sale." In that case the court was able to find from the evidence that the parties intended to effect a sale, and that the title roserved was morely the title of a mortgagee. The distinguisher jurist added that "each ease must depend upon its special cireumstances." which proposition is mplasized by the ease of Harleness v. Russell, 118 T. S. 663. 7 Sup. Ct. 51, where the facts were held to show a ronditional, and not an ahsolute. sale. If we can place this construction on this transaction.- i. e. that it was a sale,- there is no difficulty in sustaining the negotiability of this note, under our own dereisions. See Brooke v. Struthers $(110$ Mich. 562: Wilson v. ('amploell, id. 580.)

The record shows that the soda fountain was furnished under a written contract, and that these notes were given some days later after delivery, in accordance with its terms. If we were to ronsider the provisions of this contract, we should not hesitale to say that this was a sale with a rescruation of title by way of sceurity. As said in Browle r. Slrulhers (110 Michigan, 5fiz), there are ases which hold that a contemporaneous writing may be examined to determine the nogotiability, or non-nogotiability of a note. Sere cases cited. While, prorhas this contract is not striefly a contemporanrous writing, it was one of the surrommling rimomstances morlor which the notes were made. But wr find it unnecessary to pass upon that question, as we think the same is implied by the notes. These being

DThough the words: "With interest 6 per cent." 
negotiable notes, a declaration upon the common counts was sufficient under our well-settled rule.

Ho find no error in the record, and the judgment is affirmed.

'The other justices concurred. ${ }^{6}$

\section{WORDEN GROCER CO. v. BLANDING.}

\section{Nortunestern Reporter (Mich.) 212. - 1910.}

Action on the following note:

$\$ 150$.

Coral, Mich., April 2, 1903.

Sixty days after date. for value received, we promise to pay to the order of Fred Soules, one hundred and fifty dollars, at the bank of O'Donald \& Scott at Howard City, Michigan, with interest at 7 per cent. per annum until paid. This note is given subjot-to the approval of Fred Soules, Coral, Michigan, for a stock of groceries invoiced at $\$ 933.00$ this day reccived of Fred Soules; the title to the said stock of groceries to remain in said Sonles until this note is fully paid.

W. A. Blanding.

JAMES BLANDING.

There appeared on the hack of the note the indorsement "Fred Soules, Coral. Mich."

Judgment for defendants, and plaintiff brings error.

Buair. J. - * * *

First. 'The principal question in this case is whether the note in question is negotiable on its face. Counsel for plaintiff contend

6 See this case reported with note in 43 L. R. A. 277.

"The real purpose of this clanse (namely, $\$ 22$, subd. 2), as we learn from Mr. Crawford (Crawf. An. Neg. Jnst. 1., p. 12), who drafted the act, and from .Judge Brewster (10 Yale Law Jour., p. 87), is to eover the case of a note which enntains a statement that it is given for a chattel, which is to be the property of the owner until the note is paid. Such notes are usually regarded as negotiable (citing the Choatc case and Chicago Co. v. Merch. Bli., 136 U. S. 268: Howard v. S'impkins, 69 Ga. 773; Heard v. Dubuque Bk., 8 Neb. 10; Mntt v. Havana Bk.. 22 Hun, 354: Nat. Bk. of Royersford v. Davis, fi Montg. ('o. 99; Kimball v. Mellon. 80 Wis. 133). Several states, however, have taken the opposite view, lolding that such notes are non-negotiable leiting Sloon v. II crarthy. 134 Mass. 245; South Bend Co. v. Paddock, 37 Kan. 510: Third Nat. Bk. v. Armstrong. 25 Minn. 530: Decring v. Thorn, 29 Minn. 120). and it was to bring the latter states into accord with the more general viow and unify the law on this point that this clause was inserted." MeKeehan. 41 Am. Law Rigg., N. S., p. 443.

See further in Mr. McKechan's article for a statement of the doubts which have been raised as to whether this subdivision of the law will accomolish the above result. In this ennection note the following ease of Worden Grocer Co. v. Blanding. See also Kimpton v. S'tudebaker Bros. Co., 14 Idaho, 552, where a titlo rotaining note was held non-negotiable under $\$ \S 20$ and 24 of the Negotiable Instruments Law. The effect, however, of $\$ 22$, subd. 2, was not discussed. Sep the authorities pro and con in the notes to this case in $\mathbf{1 2 5}$ Am. St. Rep. 194, and in 14 A. \& E. Ann. Cas, 1129, - C. 
that it is, under the alleged general rule that a reservation of title does not destroy the negotiability of a note; citing $4 \mathrm{Am}$. \& Eng. Ency. of Law, p. 12\%, and authorities cited in footnote 4. Reliance is also had upon the case of Choate v. Stevens (116 Mich. 28); as approved in Van Den Borch v. Bowman (138 Mich. 624). We are unable to agree to the plaintiff"s contention that this case is ruled by Choate r. Stevens. So far as this record discloses, the note in question contains the entire contract of the parties, and it is obvious from a consideration of its terms that it presents the ordinary case of a conditional sale in which the title never passed to the defendants, and not a completed sale with a reservation of title in defendants by way of sceurity only. (Bunday v. Columbus Machine Co. 143 Mich. 10). On the other hand, the case of Choate v. Stevens was held to present a case of a completed sale with reservation of title by way of security only, and the judgment of the court proceeded upon that basis. We are of the opinion that this case falls within the rule of Wright v. Traver (73 Mich. 493). In that case the court said: "The instrument before us has more the appearance of a contract of sale, with the title reserved in the property to the seller until paid for, than it has of a promissory note." And it was held that the condition contained in the note that, "if not paid when due, the property for which it is given shall be the property" of the payee, destroyed its character as a promissory note, and reduced it to a mere contract.

The precise question involved here was before the Supreme $\mathrm{Ju}_{\mathrm{u}}$ dicial Court of Massachusetts, and it was held that an instrument otherwise a promissory note was converted into a mere contract by the condition, "Said horse to be and remain the entire and absolute property of the said Sloan until paid for in full by me." Sloan v. McCarly (134 Mass. 245). We are of the opinion, therefore, that the court did not err in treating the instrument in question as nonnegrotiable.

[On other grounds, however, the judgment was reversed and a new trial granted].

4. Tul Sum to re Paid Mrist be Certain.

(a) What amounts to certainty generally. ${ }^{7}$

$\$ 20$

DODGE $v$. FMERSON.

34 MaIxf, 96. - 1852.

Assumpsit, by the indorsee against the makers of a note payahle to the Protertion Insurance Company or nrier, for "\$271.25, with

7 See note in $125 \mathrm{Am}$. St. Rep. at p. 203.- C. 
Euch additional premium as may arise on poliey No. 50, issned at the Calatis anceney."

Alpleros, J.- No principle of law is more fully established by authority and the miversal concurrence of the commercial world, than that to make a 1 ritten promise a valid promissory note, it must he for a fiscl and certain, and not for a rariable aumount. In France it is sodefermined by the provisions of the code Napeleon. It is the reconized mereantile law of continental Enrope In kingland and in this country, it has received the sanction of repeated and well-eonsidered arljudications. (Story on Promissory Notes, § 20.) Hithont this essential requisite, a written promise, though in terms payahle to order, is to be regarded as a simple contract and not negotiable.

The defendants in this case have promised to pay two several sums: one certain and definite, the other uneertain and contingent. 'The defendants' liability being for both these sums, is obviously for an unasertained and indefinite amount.

It is insisted in argument. that the plaintiff may abandon all elaim for the additional premium, which is uncertain, and proceed only for the cortain sum expressed in the contract. Undoulitedly lie may take judgunent for any sum less than the amount due, and in that mode ahanton a portion of his legal claims, but that still leaves the contract in its original state, and ran in no way affeet its legal construction. He could not erase the clause rebating to the adrlitional premium, without thereby making such an alteration in the instrument declared on, as would discharge the defendants.

In Smith r. Nightingale ("S Stark. R. 355 ), the promise was to pay the payee sixty-five pombls and all other sums that may be due him. and it was claimed for the plaintiff. to whom the interest in the enntract had passed hy indorsoment, that he might dismegard the latter clause and reover on the rertain sum set forth in his rontract as indorsee. lut the Court decided ntherwise. (Dovis v. Millinson, 10) Arol. \& Fl. 9.

The infuiry is made hy the comnsel for the plaintiff, whether the clanse providing for the payment of an additional sum, intendued after the promise to pay the smm fixed and eertain, controls that sum so as to make it in any erent meertain. The amount due to the laintiff is uncertain. Whother the contraet is to be regarded as a promise to pay one smm, which shall he the ageregate composed of a certain and of an uncertain smm, the amount of which is to be ascertained at some subsequent time, or as a promise to pay two sums, one fixed and the ofler morertain, is perfectly immaterial. In either case there is no precise and ascertained amount due hy the contract, and it enumot he resarded as a promissory mote. If it was not in its origin $\therefore$ annot be mate one by any abandonment, 
which the plaintiff may deem it advisable to make, of any portion of the sum due him. 'I'le contract declared on not being in its character negotiable, the action cannot be maintined by the present plaintiff.

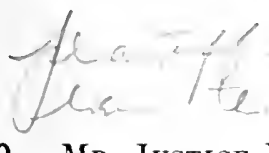

Plaintiff nonsuit. ${ }^{8}$

\section{$\$ 20$ Mr. Jistice Bradeey in PARSONS v. JACKSON.}

\section{Uxited States, 434, 438, 440. - 1878.}

Eacu hond, on its face, certifies "that the Vicksburg. Shreveport, and Texas Railroad Company is indebted to John Ray, or hearer, for value receive, in the sum of either $£ 225$ sterling or $\$ 1.000$ lawful money of the United States of America, to wit. E25 sterling if the principal and interest are payable in London, and $\$ 1.000$ lawful money of the United States of America, if the principal and interest are payable in New York or New Orleans," etc. This is the ol,ligatory part of the instrument, and is necessarily indeterminate in its character without some further designation of the place at which it is to he pairl. Each bond. further, on its face declares that "the president of said company is autborized to fix. by his indorsement, the place of payment of the prineipal and interest in enformity with the terms of this obligation." And on the back of the bonds is indorsed a printed blank in the following words, to wit, "I hereby agree that the within bond and the interest conpons thereto attached shall he parable in _." * * *

The uncertainty of the amount payahle. in the absenee of the required inclorsement, is of itsolf a defeet which deprives these instruments of the rharacter of uegotiahility. As they stand. ther amount to a promise to pay so many ponnds. or so many dollars, - withont saying which. One of the first rubes in regard to negotialle paper

" "\$350, and also such additional promimm as may locome due on said

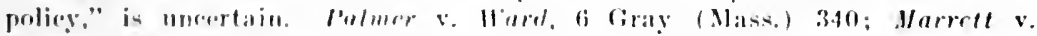

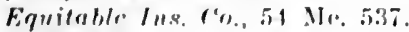

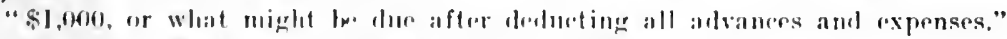

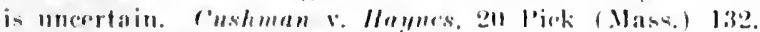

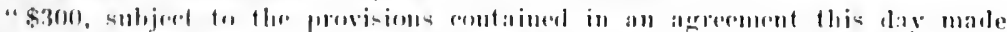

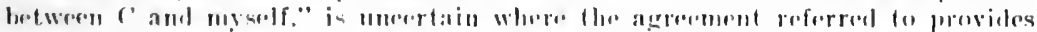

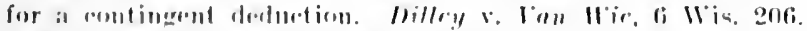

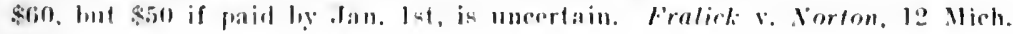
130.

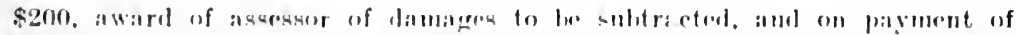

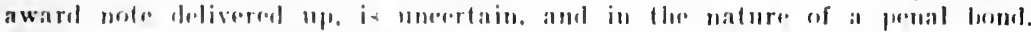
Ellott v. Eibrets. 74 Iow: $5 ! 17$.

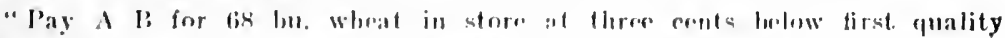

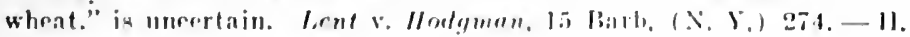


is that the amount to be paid must be certain, and not be made to depend on a contingeney. (1 Daniel, Neg. Inst., 53.) And althourh it is held that id crrlum est quod certum reddi potest, - a maxim which would have griven the bonds negotiability in this instance, hatd the reguisite indorsement been made, - yet, without such indorsement. the uncertainty remains, and operates as an intrinsic defect in the security itself. trinsic

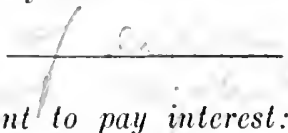

(b) Engagement to pay interest: contingency.

PARKER $v$. PLYMELL.

23 KANSAS, 402. - 1880.

JILGMENT for defendants and plaintiff appeals.

Brewer, J. - This was an action on two notes, and for a foreelosure of the mortgage given as security for them. The plaintiff was a bona fide holder for value, before-maturity. No actual notice of any defenses was shown. The notes were negotiable, unless and save as affected by the following matters. The promise was to pay interest at twelve per cent., after maturity; and after this promise were these words: "If this note is not paid at maturity, the same shall bear twelve per cent. interest from date." As a fact, there was usury in the inception of the notes. As a conclusion of law, the court held, that by reason of the words above quoted, the purchaser took the notes, charged with notice of the usury; and this presents the sole question for our consideration -

Clearly, these words do not destroy the negotiability of the paper.

They do not leave uncertain either the fact, the time, or the amount of payment. Indeed, up to and including the maturity of the notes, they are entirnly withont force. They become operative only after the notes are dishonored and have ceased to be negotiable, and then there is no uncertainty in the manner or extent of their operation. They ereate, as it were, a penalty for non-payment at maturity, and the penalty the amount of which is definite, certain and fixid. * * *

The judement will be reversed, and the case remanded with instructions to ronder jurlgment for the full amount of principal and interest due upon the face of the papers.

All the justices concurring. ${ }^{1}-$

3 See note in $125 \mathrm{Am}$. St. Rep. at p. 204. - C.

1 Aceord: C'rump v. Brrdan, 97 Mich. 297; Hope v. Barker, 112 Mo. 338. An option on the part of the dehtor to pay interest in paper money at 7 3-10 per cent. or in gold at 6 per cent. does not destroy negotiability. Dinsmore $v$, Duncan, 57 N. Y. 573.- H. 
MERRILL $v$. HURLEY.

6 South DAkотA, 592. - 1895.

Question was as to the negotiability of a note reading in part as follows: "we promise to pay * * * six hundred dollars, with interest thereon at the rate of seven per centum per annum, payable semi-annually. * * * If any part of the principal is not paid at maturity, it shall bear interest at the rate of twelve per cent. per annum, payahle annually; and, if any interest remains unpaid twenty days after date, the principal shall become due and collectible at onee without notice, at the option of the holder."

Fulder. J.- * * * Upon the authority of Hegler v. Comstock (1 S. D. 138), the respondents' enunsel contend that the foregoing is not a negotiable instrument. $* * *$ The provision in the note in the case of Hegler v. Comstock, considered by this court and found to be sufficient to destroy its negotiability, is as follows: "With interest from date until paid at the rate of ten per cent. per annum ; eight per cent. if paid when due." While, in the opinion of the writer a promissory note, otherwise unobjectionable, meets the requirements, and stands the test of negotiability, when there is no date at which the exact amount then due cannot be ascertaned by inspection and computation, this conrt has placed itself in line with a class of authorities which require such a degree of certainty that the exact amount to become due and payable at any future time is elearly ascertainable at the date of the note, uniufluenced by any conditions not certain of fulfillment: and the rule thus established must control cases subserjuently arising. where the facts are substantially the same. But, in our opinimn, the note in suit is clearly distinguishable from the note in thre case of Hegeler v. Comstock, supra. That note is inloerently morertain as to the rate of interest that will he paid for the use of the money. There is nothing from which the payee or purchaser can determine with cretainty the amount which he will realize upon his loan or investment, or the rate of interest that the note is Irawing. until by reason of its dishonor it has lost every element and incident of negntiability. The same eannot be said concerning the notre lefore us. If the maker of this note fails to perform his contract, he heromes absolutely liable to pay 12 per eent interest after a default exists: but the rate of interest before dislonor is monomditionally fixed at F-per cent., and no act or omission of either party can change the stipulated rate of interest, which is, in clfect 7 per cent. from date till dure and 12 per cent. therenfter. amd. as therr sems to be no condition not certain of fulfillment. We churacterize and regard the note as a negotiable iustrument. H, was said in Towne v. Rice (122 Mass. 67), that "an instrumbut which in its terms and form is a nego- 
tiable promissory note loes not lose that character because it also reites that an additional rate of interest will be paid after due."

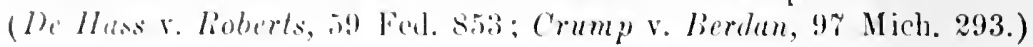

In onr opinion, there is no provision in the note in suit which, under the statute or medeantile law, destroys its negotiability.

Aстіок by indorsee against maker. Court charged that "the instrument ofiered in evidence is not a promissory note, but is subjeet to all equities existing letween the defendant and D. M. Osborne \& Co., whether it was assigned hefore or after maturity." Defendant has a rerdict. and plaintiff appeals from an order refusing a new trial.

BerRY, J.:$\$ 100$.

GoOD Thunder, July 24, 1882...

For value received on or before the first day of January, 1884, 1, or we, or either of us, promise to pay to the order of D. M. Osborne and Co. the sum of one humdred clollars, at the oflice of Gebland and Moore, in Mankato, with interest at ten per cent. pro ammm from date until paid; seven, if paid when due.

IV. J. B. Crane.

A negotiable promissory note must be certain as to amount. (Jones r Radalz, 20 Miun. 240.) It is so certain when the sum to become alsolutely payable upon it at any given time is ascertainable upon its face. (1 lmomiel, Neg. Inst., S53; Toune v. Rire, 122 Mass. 67: Jones r. Rutiatz, supra.)

'The defendants' position is that the foregoing instrument is rendered unertain as to amount be the interest clause. and therefore is not a negotiahle promissory note. As to the legal effect of such a clause the authorities disagre. Some bold that the coutrel resores the higher rate of interest. with a provision for its abutement. upon a condition to he performed. and that, therefore, the difference between the two rates is not a penalty, hut the somtract is to be coforeel according to it literal terms. The ases lolding this view rest upon Nicholls v. Waynarl (3 Atk. 519). (Sce Walmesley v. Booth, Barn. Ch. 4r8, ts 1; Jomafous v. Riglost. 3 Burr. 13io: Wraller v. Long, 6 Munf. (Va.) i1.) Other autlonritirs hold that the clanse is the same in effect as if it lad resered the lower rate of interest, with a provision that if the indeliterlnes is not pail at maturity. interest shall run at a higher

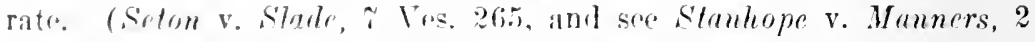
Edrn. 197: Brockwoy v. C'tarl:, fi Ohio, 45: Longworth v. Asliven. 15 Ohio St.. 3r0: Broun v. Batliham, 1 P. Wms. 65.) If this be the 
true construction of the clause, it is generally agreed that the difference between the two rates is to be treated as a penalty. (Talcott v. Marston, .3 Minn. 238, (339) ; Newell v. Houlton, 22 Minn. 19; and cases last cited.)

In our opinion the view taken by the authorities last mentioned as to the legal effect of the interest clause under consideration, is the more sensible, and most in accordance with what would seem to be the real object of the parties to the contract. What the payee really wants is his money at the due date of the contract, and to secure this he holds an increase of the rate of interest over the debtor's head. In other words the increase is a penalty for the debtor's delinquency. Treating the increase as a penalty, it follows, under the decisions of the court before cited, that the note in suit will in law draw the same rate of interest before as after maturity, - that is to say, $r$ per cent., - and that, therefore (whatever might be the case if the interest clause were upheld according to its literal terms), the sum absolutely payable upon the instrument at any given time is thus made certain, as the principal, and $r$ per cent. interest. $* * *$

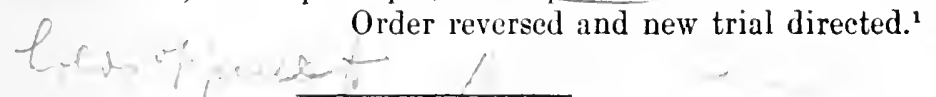

(c) Engagement to pay by stated instalments; contingent instalments. ${ }^{2}$

COOKE $v$. HORN.

29 LAW TIMES, N. S. (Q. B.) 369. -1873.

Trus was an action upon a promissory note, tried before Honyman, J., at the York Summer Assizes. A verdict of 175l. 5s. 10d. was found for the plaintiff, leave heing reserved to the defendant to move to enter a verdict for him, on the ground that the note was not good.

The form of the note was as follows:$£ 170$.

25 th A pril, 1872.

We promise to pay to Mesars. M. H. Cooke and ('o. 170l, with intereat thereon at the rate of 51 , pere cent. per annmu, as follows: the lirst payment, to wit, dol., or more, to be malde on the lat Fols. 1873, and 5 . on the tirst day of each monlh following until thie note and intreres shall be fully satistied. And in ease default shall be made in payment of any of the silid instalments, the full amount then remaining dure in respreet of the saticl note and interest ahall be forthwith payablo.

In Comn. Wut. Lifo Ins. Con. v. Wrsterhoff, 58 Noh. 379, it was held that a provision in a note that in default of the payment of the semi-anumal interest instalmont the whole dribl will benr interest at a higher rate than it would by its terms oflerwise benr, is in the nature of a penalty and will not be inforcerl. Followed in kendall v. Sirlby, 66 Neb. 60. - C.

2 See note in $125 \mathrm{Am}$. St. Rep. at p. 204. - C. 
The note was signed by the defendant and one John Horn, since deceased.

Brackune, J. - I do not think there should be any rule in this case. The objection to the note is, that if the first paymont were more than fol., which the note provides it might be, the subsequent instalments and the final time of payment would be indefinite. 'The amount of the notr. however, is certain, and any variation in the time will depend only upon the defendant. No ease has heen cited which is an anthority against this note: and by analogy with other objections, this one. as it seems to me, ought not to prevail. I do not see why a stipulation which enalles the maker of a note to reduce his liability for interest, should prevent the instrument containing it from being a promissory note.

Quain and Archibald, JJ., concurred.

Rule refused.

\section{$\S 21$ RIKER $v$. SPRAGUE MANUFACTURING CO.}

\section{Rhode Island, 402. - 1884.}

TIllinghast, J. - This case and the following one ${ }^{3}$ are actions, this case against the maker and indorsers, and the following one against the indorsers only, of a large number of promissory notes, set out and declared on by the plaintiff's as negotiable, and are tried together, by agreement of parties, upon the defendant's petition for a new trial, in each case on the ground of certain alleged misrulings by the court at the jury trials, and also that the verdict was against the evidence in each rase. The questions raised by the exceptions to the rulings of the court in this case, in so far as they were relied on at the trial, are first, whether the notes declared on are negotiable; and second, whether there was a waver by the indorsers of demand and notice, which excused the plaintifis from proofs thereof at the trial to the jury.

The notes are all in the following form, which is a copy of one of the notes in suit:

E. No.

$\$ 1,000$

Providexce, November 1st, 1873.

Three years from January 1 st, 1874, for value received, the A. \& W. Sprague Manufacturing Company promise to pay to the order of A. \& W. Sprague One Thousand Dollars, with interest from January 1. 1874, payable semi-annually, at the rate of seven and three-tenths per cent. per annum, till said principal sum is paid, whether at or after maturity; and all instalments of interest in arrear shall bear interest at the rate aforesaid till paid. but reserving the

a Post, p. 105. - H. 
right to pay this note before maturity in instalments of not less than five (5) per cent. of the principal thereof, at any time the semi-annual interest becomes payable. Principal and interest payable at their place of business in said Providence.

Amasa Spragce, Treasurer.

Countersigned,

Z. Chafee, Trustee.

[Indorsed]

A. \& W. Sprague.

The defendants contend that said notes are not negotiable for two reasons. namely: first, because the time of payment is uncertain; and second, hecanse the amourt to te paid is also uncertain.

If either of these grounds is established, the notes must be held not negotiable, and this action, as against the indorsers at least, cannot be maintained; for it is elementary law that amongst the essential requisites of a negotiable promissory note are certainty as to the amount to be paid, and certainty as to the time when the payment is to be made.

First, then, are the notes certain as to the amount? They are each for a definite, fixed, and certain sum, and the payment of this sum is not subject to any uncertainty or contingeney. But the defendants urge that by reason of the reserved right on the part of the maker expressed in the body of the note, to pay the same before maturity, in instalments of not less than five per cent. of the prineipal thereof, at any time the semi-annual interest becomes payable. the amount of the note is rendered uncertain. We fail to sre how the amount to be paid Thecomes any less certain by reason of this reservation. Suppose part payment to be made at one of the stated periods provided therefor: that is a payment on the principal of the note. and simply reduces said principal by so much as is pairl, leaving the note as definite as to amount as it was before; so that although the amount actually due upon the principal of one of these notes at a given time in its existence might be thifferent from the amomit due at some ofher time, yet it would always be a fixed and certain amount, and the total sum payable would not be changed. The object of the law, therefore, in requiring ecrtainty as to amount as well as to time of payment, which is to give to negotiable paper as far as possible the quality of a circulating medium, like money, and practically to make it represent money, is fully met in a note in this form.

The cases in which it las been held that there was not that cortainty as to amount to be paid which the law requires in negotiable paper are those, in the main, where the principal of the notr could not be determined by anything which aupeared therein: as where a promise was madeto pay a certain sum. "and all fines areording to rule" ( 1 yrry $\mathbf{v}$. Fearnsides, 4 M. \& W. Ifig); or a certain sum, and also "all other sums which may be duc" (S'mith v. Nightingale, 2 Stark. 375); or 
a certain sum with interest, and also to pay "the demands of the sick elub at, etce, in part of intrest" (Bolton v. Mugdale, 4 B. \& Ad.

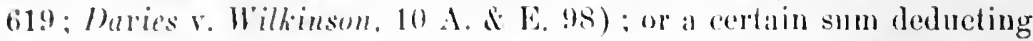
what interest or money A. may owe the maker (Barlow v. Broadhurst,

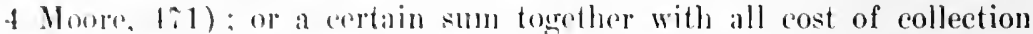
ineluding attorney's fers (Jomes r. Redetz, :2 Minn. 240; Maryland Fertilizing and Mamufuc. Co. v. Newman. 60 Md. 584; Johnston v. Speer, 9: l'a. St. 29x.) 'These, and many others of like character, illustrate and make plain what is meant hy the term "uncertain as to amount," as applied to promissory notes, and what degree of certainty is essential to render a note negotiable.

That no such uncertainty exists, however, in the notes declared on in the case at bar, is clarly nanifest upon the most easual inspection thereof; and we conelude that, so far as certainty in anount is concerned. they unquestionably come within the rule which the adjudged cases make.

Sccond, then, are they certain as to time of payment? 4 And upon this point lot us first ascertain what degree of certainty is meant by this expression. We think the rule of law is clearly this, namely: "that if the time of payment named in the note must certainly come, although the precise day may not be specified therein, it is sufficiently certain as to time." In other words, it must not depend upon any contingency: as to "when A. shall marry," (Pearson v. Garrett, 4 Mod. 242; or when a certain ship shall arrive (Coolidge v. Ruggles, 15 Mass. 387: Grant v. Woorl, 12 Gray, $220:$ Palmer v. Pratt, 2 Bing. 185): or when a certain suit is determined (Sholton v. Bruce, 9 Yerg. 24: see, also, Woodluury, Williams and English v. Roberts, 59 Jowa. 348.) And here the maxim, Id certum est quod rertum reddi potest, is applicable. although perhaps it is not as to the amount.

So in Cota v. Buck: (7 Met. 588), it was held, Shaw, C. ... delivering the opinion of the court, that a note in the following form, namely: "For value received I promise to pay .J. P., or bearer, s.50.50. it heing for property 1 purchased of him in value at this datr. as heing payable as sonn as can be realized of the above amount for the sail property I have this day purchased of said P., which is to loe paid in the course of the season now conning." was a negotiable promissory note, on the gromnd that it was payable at all events within a linited time, namely, "the coming season," and that whether that meant "harvest time or the end of the year, it must come by the mere lapse of time and that must be the ultimate limit of the time of payment."

So, also, in Curtis v. Horn (58 N. H. 504), a note payable " on or before the first day of May next," was held to be negotiable. In

4 See Neg. In-t. I.., \& 23. - II. 
delivering the opinion of the court in that case, Justice Bingham said: "It is now the common law, that where the payment is made to depend upon an event that is certain to come, and uncertain only in regard to the time when it will take place, the note or bill is negotiable. In Mattison v. Marks (31 Mich. 421), it was held that a promise to pay "on or before" a day named stated the time for payment with sufficient certainty. In that case Cooley, J., said: "The legal rights of the holder are clear and certain; the note is due at a time fixed, and is not due before. True, the inaker may pay sooner if he shall choose, but this option, if exercised, would be a payment in advance of the legal liability to pay, and nothing more. Note tike this are common in commercial transactions, and we are not aware that their negotiable quality is ever questioned in business dealings." (See, also, Edwards on Bills and Notes, 142; Story on Promissory Notes, §27; Whealley v. Williams, M. \& W. 533; Ernst v. Stechman, ${ }_{4} 4$ Pa. St. 13 ; Daniel on Neg. Inst., $\$ \S 43,48$.)

Indeed, the cases have gone so far in this direction as to hold that a note payable within a limited time after the death of a person named is sufficiently certain as to time. (Cooke v. Colehan, 2 Strange, 1217; C'olehan v. Cooke, Willes, 393.) So, also, it has been repeatedly held that notes payable in instalments at fixed dates are negotiable. (Van Bushirk v. Day, 32 Ill. 260; Carlon v. Kencaly, 12 M. \& W. 139.)

The cases of Way v. Smith (111 Mass. 523), and Stults v. Silva (119 Mass. 137), cited by the detendants, seem to support their position in the case at bar: but we prefer the reasoning of the court in Cota v. Buck, ante, to that given in the subsequent case of Hubbard v. Mosely (11 Gray, 1\%0), upon which these cases seem to rest.

The case of C'arlos v. Fancourt (5 Term Rep. 482), eited by the defendants, was one in which the noto was made pavable out of a fund that should arise from the sale of certain property, and was therefore held not negotialile because not payable at all events. It is in harmony with nearly all of the more modern decisions upon that point, and doubtless states the law correctly. (Story on Prom. Notes, $\$ 25$.) But we do not understand it to be seriously claimed in the case at bar, nor do we think it conld be successfully claimed, that the notes are necessarily payable out of any particular fund or property; or, in other words, that the payment thereof is based upon any contingency whatever.

The notes in suit are marle payable three years froms January 1 , 1874, with the reserwed right on the part of the maker to pay the same before maturity, in part or in whole, at any time whon the semi-annual interest becomes payahle. Thry are payahle al all events within a limited time, and payment canmot be enforeed until the expiration of that time: but the maker reserves an option within that limit of which he may avail himself if he sees lit. But even this 
option eannot be exercised except at certain periods which are definitely expressed in the notes.

We think that a note is negotiable if one certain time of payment is tixed, although the option of another time of payment be given.

As the notes in suit come clearly within both the letter and spirit of the rule which we have stated, we decide that they are negotiable promissory notes.

[Omitting portion on waver of demand and notice.]

It therefore follows that the notes were properly adinitted in evidence against the indorsers; and, there being no other defense than that concerning the negotiability of the notes, which we have already disposed of, that it was the plain duty of the court to direct a verdict for the plaintifls. The petition for a new trial must, therefore, be denied, and judgment entered on the verdiet.

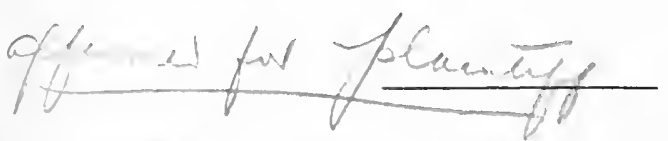

Petition dismissed.

(d) Engagement that on default the whole sum shall become due.

CARLON $v$. KENEALY.

12 Meeson \& Welspy (Exch.) 139. - 1843.

Assumpsit by the indorsee against the maker of a promissory note. The declaration stated, that the defendant on, etc.-, made his promissory note in writing, and delivered the same to ' $\mathrm{T}$. G., and thereby promised to pay the said 'T. C., or order, $52 l .10 s$, by two equal instalments, on the 1st of May, 1843, and the 1st of November, 1843, and that the whole amount, $5 \% 1$. $10 \mathrm{~s}$, should become immerliately payable on default being made in payment of the first instalment. The declaration then averred, that $T$. C. endorsed the note to the plaintiff; that the defendant made default in payment of the first instalment, and that he had not paid the amount of the note.

Special demurrer, on the ground that, the second instalment on the said promissory note being made payable by way of condition and penalty immediately on default in pavinent of the first instalment, the note was not made according to the custom of merchants with regard to inland hills of exchange, and consequently the title thereto, and the right of action thereon, could not pass by endorsement. Joinder in demurrer.

Lond Abinger, C. B. - Suppose the case of a note payable ten

$\$ \$ 50$, to be paid in such instalments and at such times as the directors of said company may, from time to time assess or require, is a promissory note. White v. Smith, 77 IIl. 351; Goshen Turnpike Co. v. Hurtin, 9 Johns. (N. Y.) 217. But see McClelland v. Norfolk Southern R. Co.. 110 N. Y. 469, 475-6.-H. 
days after sight - there the subsequent parties do not know when they are to be called upon. I think there is no ground for saying the defendant is not liable.

PARKe, B. - Now, to hold that actions could not be maintained upon such notes as this, would be to impugn all the established practice. Almost every note payable by instalments has such a condition. It is not a contingency - it depends on the aet of the maker himself ; and on his default, it becomes a promissory note for the whole amount. The point was in effect determined in Oridge v. Sherborne (11 M. \& W. 374$)$.

Gurney, B., and Rolfe, B., coneurred.

Judgment for the plaintiff.

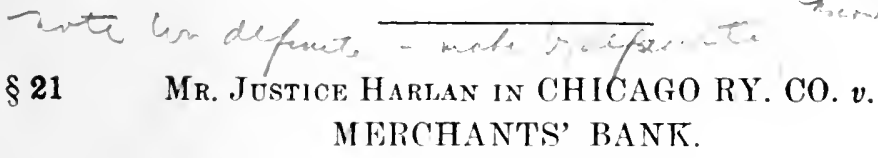

136 Unitej States, 268, 285-6. - 1889.

UPON like grounds it has been held that the negotiability of the note is not affected by its being made payable on or before a named date, or in instalments of a particnlar amount. In Achley School Dist. v. Hall (113 U. S. 135, 140), it was held that municipal bonds, issued under a statute providing that they should be payable at the pleasure of the district at any time hefore due, were negotiable; for, the court said: "By their terms, they were payable at a time which must certainly arrive; the lolder could not exact payment before the day fixed in the bonds; the debtor incurred no legal liability for non-payment mutil that day passed." In Mattison v. Marks (31 Mich. 421), which was the case of a note payable "on or before" a day named, it was sairl: "True, the maker may pay sooner if he shall choose, but this option, if exereised, would be a payment in advanec of the legal liability to pay, and nothing more. Notes like this are cormmon in commereial transartions, and we are not aware that their negotiable quality is ever questioner in husinese dealings." (Carlon v. Kenealy. 12 M. \& W. 139: Colehan v. Willes, W'illes, 393: Jordan v. Tate, 19 Ohin St. 586: r'urtis v. Home, 58 N. H. 50.t: Howard v. Simbins, fo rionrgia. 340: Protertion Ins. Co. v. Bill, 31 Conn. 534, 538: Goodloe v. Thylor. 3 Hawks, 458: Riler v. Sprague Mfg. Co., 14 R. I. 40?.) In the last named case it was said that if the time of payment namol in the note must certainly come, although the precise rlate may not loe specified, it is suflieiently certain as to time. It was, conserpuntly, held that a reservation in a note of the

- See Clark v. Skecn, 61 Kan. 526. - C. 
right to pay it before maturity in instalments of not less than five fer ent. of the principal al any time the semi-annual interest becomes payable, did not impirir its negotiability; the court observing that a note is negrotiathe if one cortitin tine of payment is fixed, although the option of another time of payment be griven. In view of these athorities, as well as upon principle, we adjudge that the negotiability of the notes in suit was not atlected by the provision that "pon the failure of the maker to pay any one of the notes of the series to which those in suit belonged, the rest should become due and payable to the holder.

\section{(e) Engagement to pay exchange?}

\section{HASTINGS $v$. THOMPSON.}

\section{Minnesota, 184. - 1893.}

Action by indorsee against maker to reenver on promissory notes. Defendant answered setting up a crood clefense, unless they were negotiable and in the hands of a bona fide indorsee for valne. Plaintiff demurred, and the sole question presented was, whether the insertion in the notes of the words, "with current exchange on New Fork City," rendered the notes non-negotiable and open to the defense. It was admitted that the plaintitl was a bona fide holder for-value before maturity. The trial comrt overruled the demurrer and plaintiff appeats.

Mitchell, J.- The only point raised on this appeal is whether the instruments sued on are promissory notes. for, if they are, they are unquestionably negotiable under the law merchant. They are promises to pay specified sums of moncy in St. Paul, "with current exchange on New York City;" and the only question is whether this provision as to rxchange renders the sums repuired to discharge them uncertain, within the meaning of the fanciliar rule that one of the essential qualities of a promissory note is that the amount to be paid must be fixed and certain and not contiugent. In the definitions of a promissory note or hill of exchange it is generally, if not always, stated that the amount necessary to rlischarge it must be ascertainable from the face of the paper itsolf. without having to refer to any extrinsir evidence. Construng this definition literally, it must be arlmitted that the instruments in ruestion ro not strictly fall within it. for, of course, extrinsic evidence must be resorted to in order to ascertain the rate of exchange at a griven time between two places.

Jpon examination of the reports and text-books it is surprising 
how little direct authority of any value is to be found as to the effect of the addition of sucli a provision to an instrument for the payment of money. Daniel, Randolph, and Tiedeman state in general that such aprovision does not affect the commercial or negotiable character of the paper, but none of them discuss it at any length, and all of them treat of the question as if it only went to the negotiability of the instruments, whereas the real question lies back of that, and is whether they are promissory notes or bills of exchange at all. (Tied. Com. Paper, §2Sa; Rand. Com. Paper, \$200; Daniel, Neg. Inst., $\S 54$.$) We have found no English case directly in point, and none$ bearing on the question, except Pollard v. Harries (3 Bos. \& P. 335), where such an instrument was declared on as a promissory note.

If the question was authoritatively settled in the leading commercial states of the Union or in the federal courts, we would be inclined, for the sake of uniformity, to follow their decisions: hit we have been unable to find that the Supreme Court of the United States, or of either Massachusetts. New York, or Pennsylvania, has ever passed upon the question. The only eases, state, feileral, or colonial, which we have found which may be considered as having passed on the question, are the following, which may be classified thus: That such instruments are not promissory notes: (Lowe v. Bliss, 24 Ill. 168; Read v. McNulty, 12 lich. Law, 445; Carroll Co. Sav. Bank v. Strother, 28 S. C. 504, 6 S. E. Rep. 313; Palmer v. Fahnestork, 9 Up. Can. C. P. 172 ; Saxton r. Stevenson, 23 Up. Can. C. P. 503 ; Philadelphia Bank v. Newtirk, 2 Miles, 442: New Windsor Bank v. Bynum, 84 N. C. 24; Russell v. Russell, 1 MacAr. 263; Fitzharris v. Leggall. 10 Mo. App. 527; Hughitl v. Johnsom, 28 Fed. Rep. 865; Windsor Sav. Bank v. McMahon, 38 Ferl. liep. 283). That such instrmments are promissory notes: (Smith v. Kendall, 9 Mich. 242; Johnson v. Frisbie, 15 Mich. 28fi; Leggett v. Jones, 10 Wis. 35; Morgan v. Edwards, 53 Wis. 599, (11 N. W. Rop. 21); Bradley v. Lill, 4 Bliss, 473). In very few of these mases is the furestion discussed at any length, or considered on principle. Some of them were decided by courts of inferior juristirtion. and in others the remarlis of the court were obiter. Many of those which hold that such instrmments are not promissory notes rest, withont disenssion, upon a strict literal eonstruetion of the rule that the surn to be paicl must appear from the face of the paper withont resort to extrinsic evirlence. Ahout the only cases where the question is discissuel at any longth upon principle or authority are Simith v. Lendall. Brolley v. Lill, Morgan v. Eidwards, and Windsor Sav.-Bante- Hr.Hahem, supra.

In view of this state of the derisions, while in mere numlers the decided weight of autherity may he in favor of the contention of the defendant, we feel at liberty to deride the puestion in the way we deem most in aceordance with principle and husiness usages, and 
in accordance with the rule which, in view of such usages, the leading courts of the comntry are most likely to finally settle down upon. The fellowing are, in brief the eonsiderations which have led us to the conclusion that such instruments ought to be held to be promissory notes under the law merchant:

1. The reason and purpose of the rule that the sum to be paid must be certuin is that the parties to the instrument may know the amount necessiry to discharge if, without investigating facts not within the general knowledge of everyone, and which may he subject to more or less uneertainty or more or less under the influence or control of one or other of the parties to the instrument. The provision for the payment of the current rate of exchange between the place of parment and some other place is not within the reason of this rule, or subject to the evils or inconveniences which it was designed to prevent. While the rate of exchange is not always the same, and while it is technically true that resort must be had to extrinsic evidence to ascertain what it is, yet the current rate of exchange between two places at a particular date is a inatter of common commereial knowledge, or at least casily ascertanable by ani one, so that the parties can always, without difficulty, ascertain the exact amount necesary to discharge the paper. It seems to us that within the spirit of the rule requiring precision in the amount to be paid a provision for the payment of the current rate of exchange in addition to the principal amount named does not introduce such an element of uncertainty as deprives the instrument of the essential qualities of a promissory note. A provision for the payment of exchange is very different from one for the payment of reasonable attorners' fees in rase of suit, as in Jones v. Radatz (27 Minn. 240, $6 \mathrm{~N}$. W. Rep. 800). The lattor introduces an element of uncertainty very different hoth in kind and degree from that introduced by the former. Not only is the amount of the attorneys' fees incapable of either easy or definite ascertainment, but the amount of it is more or less under the eontrol of the bolder of the instrument. Moreover. such a provision has never been eonsidererl in business eircles as properly aneillary or ineidental to commereial paper, or any part of its legitimate "luggage."

2 . The law merchant, inchuding the law of negotiable paper, is founded upon, and is the ereature of, commereial usage and custom. Custom and usage have really made the law, and courts, in their decis ions, mercly declare it. The law of negotiable paper is not only founded on commercial usage, but is designed to be in aid of trade and commerce. Its rules should, therefore, be construed with reference to and in harmony with general business usages. and, as far as possible, with the common understanding in commercial circles. 'This was the very purpose of the statute of Anne placing promissory notes on the 
same footing as bills of exchange, and thus setting at rest a question upon which there had been some difference of opinion in the courts. Now, we think we are safe in saying, and justified in taking notice of the fact, that if hankers or other business men aceustomed to dealing in commereial paper were asked whether such an instrument is a promissory note, and whether they would deal with it as negotiable paper. the answers would, in almost every instance, be unhesitatingly in the aflirmative. We have no donht but that this is the way in

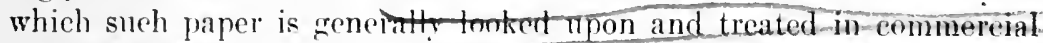
and other business circles: and, if so, the courts should, as far as possible-make their decisions to conform to this general custom and understanding. We recognize the importance of simplicity and certainty in the terms and conditions of commereial paper; and appreciate the objections to permitting it to be loaded down with unnecessary "luggage," but we cannot see, under all the circunstances, and especially in view of what we believe to be the eommercial usage, that any practical evil will result from permitting the atdition of such a provision for the payment of eurrent exchange on the principal amount. Nor are we disposed, as a rule, to extend the quality of negotiable paper to contracts for the payment of moncy beyond the strict limits of the already established rules of law; but to exclude from that eategory paper like that under consideration would be to exclude the very elias of paper which ought to be held negotiable, if any promissory notes ought to be so lield.- paper given and taken in commercial transactions, properly so ealled; for rarely, if ever, would a provision for exchange he incorporated in any other.

$$
\gamma(2, \infty)
$$
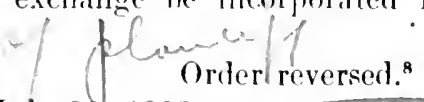

Application for re-aremuent denied .July 20.1893.

A See other cases. pro and con, eited in Maslach v. Wolf, 60i Neb. 600, and in the note to this cane in 1 A. \& li. Ann. ('is. 385.

"The whole matter turus upou the puretion whollor such a stipulation renders the amount unertain, so as to destrog one of the essential elements of negotiability. While it is true that in a sonse an uncertain rement is imported into the instrument by the agremont to pay exchange, the dilliculty is mote specions than real. linsinese is atoried on more or less in subordinit-

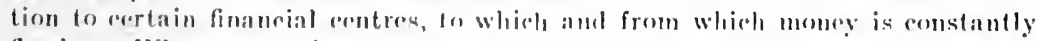
flowing. When a noto is made payaho in lineoln with Chieago exehange, the

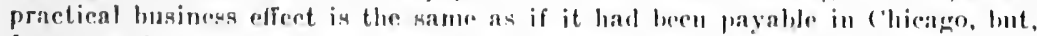
for convenienes, the partice harl nereed that it might he paid at lineoln, with the cost of transmixuion. . . . lomking in this way, the exehange becomes a mere ineident, not alfeeting the amount of tle dewt itself, and analogous to such malters as attorneye fers and eosts of ecolleetion, which do not affect negotiability." l'ound, $\dot{C}$., in Ilaslach v. Wolf, 6t; Neb. 600, 601. - C. 


\section{(f) Engagement to pay costs of collection or attorney's fees.'}

\section{\$21 STAPLETON $\because$ LOUISVILLE BANKING CO.}

95 Grokgia, s02. -1895.

Sumoss, C. J.- 'The controlling question in this ease is, whether a promissory note is rendered non-negotiable by a stipulation to pay "all costs and ten per ecent. on anount for eounsel fees, if placed in the hands of an attorney for suit." 'There is no prior decision of the eourt upon the question, and the decisions of other courts as to the effect of such stipulations are conflicting. We think the better riew, and the one supported by the weight of authority, is that such a stipulation does not impair the negotiable character of the paper. Our colle defines a promissory note to be "a written promise made by one or more to pay to another, or order, or bearer, at a specified time, a specific amount of money, or other articles of value." (\$ 2774.) It is defined by Story to be "a written promise by one person to pay to another person therein named, or order, a fixed sum of money, at all events and at a specified time, or at a time which must certainly arrive." (Story, Prom. Notes, p. 2). The note in question conforms to all these reguirements. It is certain as to the payee, as to the time of payment, and as to the amount. The stipulation as to costs and attorney's fees is not a part of the main engagement, but relates to the remedy in case of failure to comply with the contract, and is intended to compensate for the expense resulting from its breach. It does not become effective unless there is a failure to pay at the time specified; and it cannot then affect its negotiability, for negotiability in the full commercial sense reases at maturity. As has been well said by Mr. Daniel in his work on Neg. Imstrmments (vol. $1, \S 62 a$, 4the erl.), "it seems pararloxical to hold that instruments evidently framed as bills and notes are not negotiable during their currency, because when they cease to be eurrent they contain a stipulation to defray the expenses of collection." So far from tending to check the circulation of the paper. such a provision ards to its value and thus renders it more availahle for enmmereial purposes. In siupport of these views, see the following anthorities: $(1$ Daniel, Neg. Inst., 4th ed. \& 62 rt seq.: 1 Rondolph, Com. Paper, s\$ 205, 206; Parsons, Bills and Notes, 146, 14\%: Tiedeman, ('om. Pap., § 2sb; 2 Am. \& Eng. Enr. of Law, 324: Montgomery v. Crossthwait, 90 Ala. 553; Farmers' Not. Bank v. Sulton Mfg. Co.. 6 U. S. Appeals, 312, 331; Shenandoah Not. Bank v. Marsh. 89 Iowa, 273; Second Nat. Bank v. Auglin, 6 Wash. 403; Dorsey v. Wolff, 142 Ill. 589, affirming 38 Ill. App. 305: S'toneman v. Pyle, 35 Ind. 103; Proctor v. Balduin, 82 Ind. 3\%̃; Gaar v. Louisville Banking

${ }^{8}$ See note in $125 \mathrm{Am}$. St. Rep. at p. 207. - C. 
Co., 11 Bush (Ky.), 180; Seton v. Scovill, 18 Kans. 433; Nickerson v. Sheldon, 33 Ill. 3r3; Dietrich v. Bayhi, 23 La. Ann. 767; Trader v. Chidester, 41 Ark. 242 ; Farmers' Nat. Bank v. Rasmussen, 1 Dak. 60 ; Heard v. Dubuque Bank, 8 Neb. 10 ; Howenstein v. Barnes, 5 Dillon, 482; Bank of Commerce v. Fuqua, 11 Montana, 285. See also Towne v Rice, 122 Mass. 67; Arnold v. Rock River Valley R. Co., 5 Duer, 207; Adams v. Addington, 16 Fed. Rep. 89 ; Hughitt v. Johnson, 28 Fed. Rep. 865.'

It was complained that the court erred in directing the jury to find in favor of the plaintiff the amount of attorney's fees stipulated in the note, in addition to the principal and interest, the objection being that there was no evidence to show that the note had ever been placed in an attorney's hands for collection. We think the fact that the plaintiff was represented in this action by an attorney was sufficient, without further evidence, to authorize the court to so instruct the jury. (See No. Atchison Bank v. Gay, 114 Mo. 203.)

\section{Judgment affirmed.}

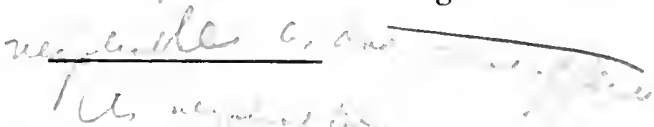

\section{MAYNARD $v$. MIER.}

85 Indiana, 317. - 1882.

Woods, C. J. - Appeal from a judgment on a promissory note, a copy of which was filed with the complaint. It contains a promise in the ordinary form, to pay a sum named. "with interest at the

1 Contra: First Nat. Bk. v. Babcock, 94 Cal. 96; Maryland Fertilizing Co. v. Newman, 60 Md. 584: Altman v. Rittershofer, lis Mieh. 287; Jones v. Radatz. 27 Minn 240; .ICloy v. Girern, 83 Mo. 626; Ifeorah First Nat. Bk. v. Laughlin, 4 X. Dak. 391; Weods v. North, 84 P'i. St. 407; Stilluater First Nat. Bk. v. Larsen, 60 IVis. 206. - II.

[See note in 4 A. \& E. Ann. Cas. 26.3, entitlod "Necrotiability of note containing stipulation for attorury's fees and costs of collection." giving a large number of anthorities pro aurl con.

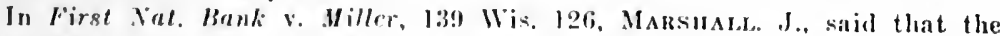
Nrgotiable Inatruments law "was eonidrerately draigned to supersedr the. judicial rulc in Jorgan v. Erluards, 53 Wis. 599: First Nat. Bl. v. Larsen, 60 Wis. 206: I'eterson v. Stoughton Sit. Bk. 78 Wis. 113; W. W. Kimball Co. v. Iellen, 80 Wis. 133 , and similar cass. . . When the Negotiable Instru. ments Jaw was enactrol a conflict of judicial authority on the subject in hand and others existed. In some stafes a clause similar to that luere was held to render the amount payable on thr instrument unertain and to destroy its negotiability. In many other states the obligation as to costs of collection was beld to he contingent upous colloction after lishonor. to appertain to the remedy for a breach of the primary contract. not to the debt itself, and, therefore, not to render the anomet uncritain, militating against negotiability. To superaede the confliet hy a ganeral rule the provision of the Negotiable Instruments atatute quoted was incorporated therein." I'. 127.- C.] 
rite of ten per cent., after maturity, and ten per cent. attorney's fers."

It is raimed that the court erred in overruling the defendants' demurrer to the complaint. "The entire argument on the point is in these words: "The complaint is not sufficient in this, it is not definite and certain, and the copy of the note shows that the agreement (is) to pay ten por rent. attorney's foes, which we insist is void. and that. Herefore. the mote is nsurious as to that amount, and shomld be hohd volil. and the judgment reversed."

If the stipulation for attormeys fees were conceded to be void the valielity of the note would not be otherwise aflected, and consequently the demurrer was properly overuled.

Judgment affirmed, with costs. ${ }^{2}$

2 There are three views as to the validity of the stipulation as to attorney's fees: (1) The stipulation is vilid. Bowic v. Hall, 69 Md. 433; Dorsey v. Wolff, 142 IIl. 5s9. (2) The stipulation is roid. Bullock: v. Taylor, 39 Mich. 137: Kixey v. l'carre, 89 Va. 1]3; Sccurity Co.v. Hycr, 36 Neb. 507 ; Witherspoon v. If usselman, 14 Bush (Ky.). 214. (3) The stipulation to pay such fees as the court adjudges reasmable, is valiu, but a stipulation for a specific sum is void. levens v. Briggs. 2] Ore. 333. Most courts hold? that the amount stipulated is not conchusice but there must he pronf of the actual value of the services. First Nat. Bank v. Larson, 60 Wis. 206; Goss v, Bowen, 104 Ind. 207.

There are four distinet loldings as to the result upon the negotiability of a bill or note of the insertion of a stipulation as to payment of attorney's fees: (1) The stipulation is valid and enforeeable, and does not affect the negotiability of the instrument. Dorsey v. Wolff, 142 1ll. 589. (2) The stipulation is valirl anr enforceable, but it lestroys the negotiability of the instrument. Jones v. Lialatz, 27 Minm. 240 ; Johnston Harrester Co. v. Clark, 30 Minn. 308; First Mat. Fk. ․ Larsan, fo Wis. 206. (3) The stipulation is void, and as it may therefore he disregarded, it does not affeet the negotiability of the instrument. Gilmore v. llirst, 56 kans. (i2t; Chamller v. kennedy, 8 S. Dak. 56. (4) The stipulation is void, but nevertheless it destroys the negotiability of the instrument. Bullock v. Taylor, 39 Mich. 137; Nltman v. Rittershofer, 68 Mich. 287; Tinsley v. Hostims, 111 N. C. 340; Now Windsor First Nat. Bk, v. Bymum, 84 N. ( .24 . It is liflicult to support this view upon principle. - H.

[A note contained a provision to pay "ten per centum attorney's fees in ca-e of eullection hy suit." IJold, the note was negotiable but the provision unenforcenble as heing a penalty. Ficlds v. Firlds, 105 Va. 714, eiting Rixey v. I'earre Bros. and Co., 89 Va. 113.

In Elmore v. Rugely. $107 \mathrm{~S}$. W. (Tex. Ct. Civ. App.) 151, it was held that such a provision is a contract of indemnity and not for liquidated damages, so that the maker is ruly liahle to the holder for the amount of attorney's fees actually contracterl for, or, in the absence of a special contraet for fees, for the reasonable value of the services rendered.

In a note to the Firlds ease in 7 Col. Law Rev. 67, it is said: "The two grounds for holding the stipulation invalid are usury and penalty. . . . The X. Y. Negrotialile In-truments Law. while declaring that such a note is negotiable, $\S 21$, is silent as to the validity of such a stipulation." - C.] 


\section{Must Be Payable in Money; But Particular Kind May be DESIGNATED.}

(a) Payment must be in money.

\section{§ 20 FIRST NATHONAL BANK OF BROOKLYN $v$. SLETTE.}

67 Minsesota, 425. - 1897.

Actios on an instrument set out in the opinion. Verdiet for plaintiff. From an order denying a new trial, defendants appeal.-

Start. ('. I. - This action is based upon an obligation, which is substantially in these worrls:

\section{$\$ 1.673$.}

HaLstad, Mixi., July 26, 1894.

For value received, we promise to pay to the order of the John Gool Cordage and Machine compally the sum of sixteen liundred and seventy-three dollars, a- follows: l'avalle by Now lork or Chicago exchange, \$560. Nov. 15th, 1894; \$56i0. Hec. I-t. 18!4: $\$ 56$ (io. Dec. 15th, 1894. Without interest, if paid as due; if not. then legal rate from date until paid.

The only question on this appeal is whether this is a negotiable instrument under the law merchant. It is alsolutely essential, in order to constitute a promissory note under the law merchant, that the promise lie to pay in money. If this intrument ean be construed as an absolute promiso to pay in money $\$ 1,673$, with exchange. it is negotiable: wtherwise, not. (Hastings v. Thompson, 54 Minn. 184, 55 N. W. 9ris.) 'l'he case of Brallry r. Lill (4 Biss. 4i3, Fed. Cas. No. 1.883), is the only one to which our attention has been called, where the langmage of the instrument was similar to the one under consideration. In the case referred to the note was made in Chicago, and was payalle at New York, "in "exchange; and it was held that the mote was negotiable, upon the ground that the promise was to pay the sum named in the note, "with" exchange, which was a mere incident to the debt. In the case at har the note is not payal,le at any particular place, and the promise is, not to pay a given mumber of lollars in money "with" - that is, plus — the current rate of excleange. hut it is to pay the sum named in the note

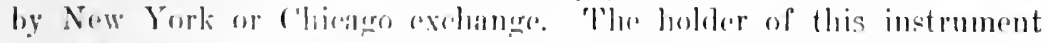

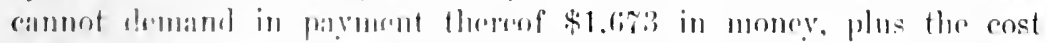
of exchange: for the inaker is not homend to dischares his mbligation exerpt be means of inland hills on New York or Chicago. Nor can the maker tender in payment \$1,6in? in money, with the cost of motiange: Tor his promise is to make payment by inland bills, which Te most puretiase in the narket. The instrument. then, is unt payabte th momer. nnd is. Pherefore. not a promissory note. within the law merehant. (Éreston v. Mydte. 13 Minn, 90 (Giil. 83): Jones v.

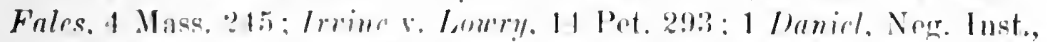
$\$ \S 55$, 56; Tich. Com. Pilper, s. 29; 1 liund. Com. Paper, § 90). 
In reaching this conclusion we hatre not been unmindful of the fact that, in commeredal usilge, bills of exchange are regarded as substitutes far money; but this tlsige cannot make them such.

Order reversed, and a new trial granted. ${ }^{3}$

(b) What constitufes current money.*

$$
\text { LAIRD } \because \text {. STA'TE. }
$$

61 Maryland, 309. - 1883.

Rominson, J., delivered the opinion of the Count

The plaintiff in error was indicted for forging and uttering a bill of exchange, which is set ont in the indictment as follows:

\section{Sianton, Va., September 4, 1882.}

Augusta National Bank, pay to .T. Edwin Laird or beacer, the sum of seventy-five lollars (\$75) current funds.

G. G. Goocir.

Correct, II. P'. 'TARss, Cashier.

[And endorscl] J. EDWIN LAIRD.

A demurrer was filed to the indictment, which was overruled, and the prisoner was tried before the conrt and found guilty.

Motions for new trial, and to quash the indictment were made, and both overruled, and the prisoner was sentenced to the penitentiary for five rears. The record connes before us on petition setting forth the points and questions, by the decision of which the plaintiff in error feels agrgrieved. * * *

In the next place it is argued, that the paper writing set forth in the indictment, is not a bill of exchange because it is payable "in current funds." Bills of exchange pass by delivery or indorsement, and it is essential that the instrument purporting to be one, should be payable in money. A direction to pay out of certain funds, or notes of a particular bank. or the currenry of a particular plare or state, have been held to destroy its negotiahility, because the medium of payment is fluctuating and uncertain. The many and conflieting decisions on this subject, will be fom collerted in 1 Daniel on Neg. Inst., sers. 61-3, and note. All the cases. however, agree, if the in-

3 "A $B$ has reposited in this bank $\$ 2.180$ in eks., payable to the order of him. self, on the return of this certificate properly indorsed." is not negotiable because it does not appear that the bauk promises to pay in money. - First National Bank of Farmersville v. Grernville National Bank. 84 Tex. 40. An order "to pay ronts as they beome lue" is not a bill of exebange because (1) it is payable out of a partieular fund, and (2) it is not payable in money on its face. "It is to pay rents, which may lo due in wheat, fowls, or services, as woll as money." - Iforton v. Inylor. 1 Hill (N. Y.), 583 (1841). - H.

4 Sre Nogr. In-t. I... \& 25. subsert. 5. - II.

[See note in $125 \mathrm{Am}$. St. Rep. at p. 197. - C.] 
strument be payable in current money, it is sufficient, because legal tender money will be presumed to be intended. The words "current funds," as used in the paper before us, mean nothing more or less than "current money," and so construed the instrument was

negotiable. * * $*$ legal budgment affirmed.

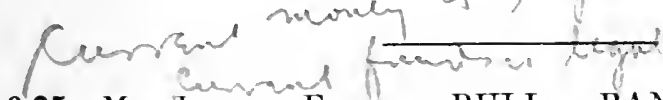

$\$ 25$ Mr. Jintice Field in BULL $v$. BANK OF KASSON.

123 Girted States, 105, 112. - 1887.

The certificate of division of opinion presents to us only one question, and yet, to answer that correctly, we must consider whether the negotiability of the instruments in suit was affected by the fact that they were payable "in current funds." Undoubtedly it is the law, that to be negotiable, a bill, promissory note or check, must he payable in money, or whatever is current as such by the law of the country where the instrument is drawn or payable. There are numerous cases where a designation of the parment of such instruments in notes of particular lanks or associations, or in paper not current as money, has been held to destroy their negotiability. (Irvine ․ Lowry, 14 Pet. 293: Miller v. Austen, 13 How. 218, ?28). But within a few years, commencing with the first issue in this eountry of notes declared to have the quality of legal tender, it has been a conmon practice of drawers of hills of exchange or checks, or makers of promissory notes, to indicate whether the same are to be paid in gold or silver, or in such notes: and the term "current funds" has been used to designate any of these, all being eurrent and declared, by positive anctment, to be legal tender. It was intended to cover whatever was receivalbe and enrent by law as money, whether in the form of notes or coin. Thus construed, we to not think the negrotiability of the paper in question was impaired hy the insertion of these words."

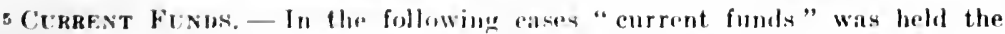

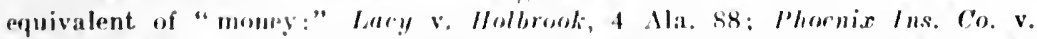
Allen, 11 Mich. 501; s. r., 13 Mirh, 1!11; While v. Rirhmond, 16 Oh. 6;

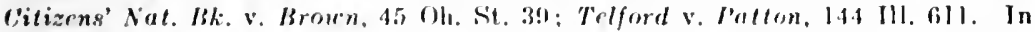

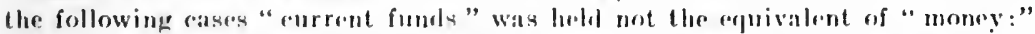
Lafayette Bank v, Ringrt, 51 Ind. 393; Johnson v. Lendersom, io N. Car. 227;

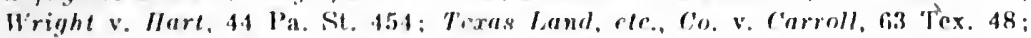
I'latt v. Sauk ('ro. Iank, 17 Wiis. 230.

CURrfacey. In the following eakes "eurreney" was hicld the rquivalent of

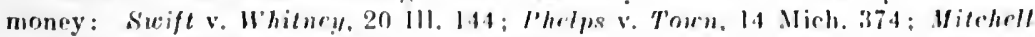

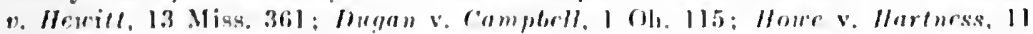
Oh. St. 449; Butler v, Jaine, g Minn. 394; Frank v. Wrssels, fit N. Y. 155 ("paper currency," when there is a legal tonder paper eurreney) : Klauber v. Biggerstaff, 47 Wix. $55 \mathrm{I}$; Wright v. Morgan ('Tex.), $37 \mathrm{~S}$. W. 627. In the fol. 
IT is further urged that the instrument in question is not commereial paper for the reason that it is male payable in eurrent bank notog-instead of money. The anthorities in this state, I think, are adverse to this position. In Keith v. Jones (9 Johns. 1\%0), the note upon which the action was bromght was declared to be payable in "York state bills or specie," and it was said that it "is the same thing as being made payable in lawlul current money of the state, for the bills mentioncd mean bank paper, which is here in conformity with common usage and common understanding regarded as eash." In Judah v. Ilarris (19 Johns. 141), a promissory note payahle "in bank notes current in the eity of New York," was held to be a negotiable note within the statute. It is said that these decisions were placed upon the ground that the court could take judicial notice that such bills are equivalent to specie. The same rule may well apply here, as "current bank notes" are notes or bills used in general circulation as money, and constituted the general currency of the country recognized by law at the time and place where payment was to be made and demanded. These notes which were in eirculation when the certificate was given and payment demanded, were almost entirely of one kind anthorized by the government as currency. 'They thus heing lawful money of the United States, the courts were bound to take judicial notice of that faet. The cases of Lieber v. Goodrich (5 Cow. 186), and Thompson v. Sloan (23 Wend. ri), are not in conflict with IIeath v. Jones and Judah v. Harris (supra). Although the doctrine of the latter was doubted in 3 Kent's C'ommrntaries, PP. $\% 5-\% 6$, and in some of the state courts it is held that a note payable in current funds is not negotiable, it is safe to follow the adjudications in this state as settling the law upon the suhject. Fron although a demand was necessary upon the bank

lowing casea "currency" was held not the equivalent of "money:" Mobile Bank v. Brom, 42 Ala. 108; Dillard v. Evans, 4 Ark, 175; Rindskoff v. Bar. rett, 11 Jowa, 172; /luse v. Ilamblin, 29 Iow: 501; Chambers v. Gcorge, 5 Litt. (Ky.) 335: (otherwise of "Kentucky eurreney", Lampton v. Iaggarl, 3 Monr. (Ky.) 14!) : Farwerll v. Krnnett, 7 Mo. 595; IIicklin v. Tucker, 2 Yerg. (Tenn.) 448: F'ord v. Witchell, 15 Wis. 334. - H.

["We aro aware that many courts have held that such a clause [payable: 'in current funds'] does not require payment in money, and destroys the negotiability of the inctrument. The eases so holding are either cases arising at a time when many forms of bank notes and bills were in use, varying in their values, or casms dreciled upon the authority of that class without regard to changer conditions. With regart to exioting conditions, we think the Supreme Court of the Inited States has drelared the law correctly in Bull v. Bank of Kasson." Invine, C., in Kirkwood v. First Nat. Bank, 40 Neb. 484, at p. $492 .-\mathrm{C}$. 
before an action could be brought against it on the instrument, thus distinguishing the case from that of a promissory note, where the maker may be sued without any-demand, I do not think that this fact takes amm the negrotiable character of the instrument under the decisions cited, and it must, therefore, be considered as possessing all the features of a negotiable promissory note.

43 New York, 209. - 1870.

Acrion by indorsee on a draft for 1,205 gold dollars. Judgment for plaintiff.

Allex, J.- [After disposing of another matter]. The bill in suit was drawn in Montreal on a business firm at Whitehall in this state, payable in New York in dollar's, the money of account of the state, and in gold dollars, a coin anthorized by Congress, and made a legal tender in the payment of deht. It was, therefore, negotiable as a bill of exchange. (1 R. S., 611, \& $1 ; 9$ U. S. Stat. at Large, 397.)

It is enough that it is for the payment of money and money only, in cash and not something that may difler in ralue from eash. (Leiber v. Goodrick, 5 Cow. 186.) It is agreed that bills payable in merchandise or anything but money are not good bills of exchange, but the cases are not agreed in all respects as to what shall be deemed money. In this state it is held that a promissory note, payable " in bank notes current in the city of New York" or "in New York state bills or specie," are negrotiable notes within the statutes (Keith v. Jomes, 9 Jolıns, 120; Judah v. Harris, 19. Johns. 144), while a note payable "in Canala money" is not a negotiable note. (T'hompson v. Sloan, 23 Went. $\because 1$.$) 'Thr first eases were decider upon the$ gromnd that the cont might take judicial notice that bank notes, enrrent in the city of New York, were customarily considered and

"Bask Notrs. The following were lield epuivalent to " money :" "The bank

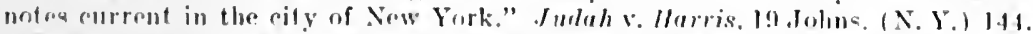
"rurrent lank notes." I'areler v. Fish. supra: Flrming v. Nall, l 'Tex. 24f.

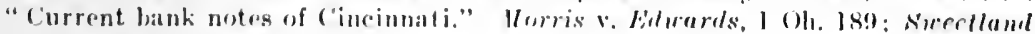
v. Crrigh, lis ()h, I18.

The following werr held not "quivalent to "monry". "Current hank paper." Camplell v. Wrister, I lift. (Ky.) 30. "Nofes recoivable in bank." Brerlin.

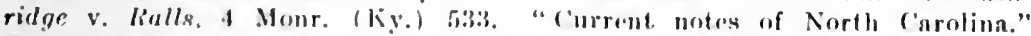

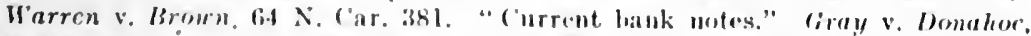

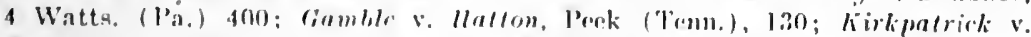

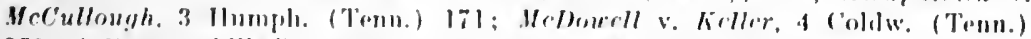
258. "Current lills." Collins v. Limeoln. $11 \mathrm{Vt}, 268$. - II.

[See note in 4 A. \& IE. Ann. ("as. at 1. bi3: on " negotiability of note payable in bank notes." - C.] 
treated as equivalent to money, which conld not be predicated of a note payable in Canada money. Coin current in Canada might not be current in this state, and foreign bills are not regirded as money.

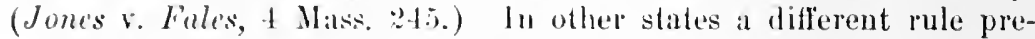
vails; and bills palyable in bank bills, cren of the state where payable, are held not negotiable. (McCormick v. Trotter, 10 Serg. \& R. 94.) In this action the hill is for 1,205 gold dollars, that is $\$ 1,205$ in gold coin, and, as is clamed, in coin of a particular denomination; lout it is nevertheless, payahle in a coin known and recognized as a part of the currency of the country, coined by authority of Congress and made receirable in all payments (9 Stat. at Large, 397). If the bill lad called for $\$ 1,205$ withont specifying the eoin or currency it would have been payable in any lawful curreney, and the acceptors might have discharced their obligations by tendering payment in "gold dollars." the tender would have been in money; but if " gold dollars" are but an article of merchandize, a commercial commodity. as clamed, a tender of these in satisfaction of an obligation for the payment of money woukd not be good, and a debtor could not by such tender relieve himself from his obligation. The laws have not been repealed which declare the money value of the gold and silver coin of the United States and make them a legal tender in the payment of debts. The bill has all the qualities of a negotiable bill of exchange; it is payable absolutely; and in money, and not out of a particular fund.

There are two descriptions of lawful money in use under acts of Congress (assuming the validity of the "legal tender" aets, so ealled, as applicable to any contract ealling for money), and it does not destroy the negotiability of commercial paper or change its eharacter, that it is in terms made payahle in any description of money that is recognized and known as money current in business, and which is made a legal tender in payment of dehts. (Butler v. Horwitz, 7 Wall. 258; Bronson v. Rodes, 7 Wall. 229.) Bills of exchange are favored as valuable instruments in commerce, and merchants must le permitted to make them payable in any money lawful and current in the place where payable; and if more than one description of money is recognized by the law of the place, to select that which is most convenient to the jarties, without changing the charaeter and lexal incidents of the instruments and destroying their negotiability.

But the rrferee has found, as a question of fact, that the contents of the said bill of exchange or draft were expressed in the money of account and currency of the province of Canada, and has awarded damages for non-payment upon that theory, that is, has given judgment for the value of the amount called for in Canada coin in Montreal on the day the bill matured. In this the referee erred. The contract, interpreted by the law of the place where payable, 
called for payment in money there current and the construction of the contract was one of law not of fict.

The error of the referee carried into the judgment in the assessment of the damages.

Upon this construction of the contract, and an allegation in the complaint, that the value in New York of a draft on Montreal for $\$ 1,205$ was at the time of the default in payment, $\$ 1,831.60$, not denied by the answer, the referee reported in favor-of the-plaintiff for that amount, with interest to the date of the report, and the plaintiff had judgment accordingly. The plaintiff was entitled to a judgment following the contract. and payable in coin for the amount to which the law entitled him upon the dishonor of the bill. That was the sum speeified in the bill, with interest thereon, at the rate allowed by law.

There is no warrant for an allowanee of damages for the non-payment of money beyond the interest. given by statute, neither can the courts compel a party, who has stipulated for the receipt of money in coin, to accept of an equivalent in depreciated curreney. So long as the inferior currency, which is excluded from the operation of the contract, and cannot be paid, or tendered in satisfaction, fluctuates in value, alsolute justice cimnot be done to the parties by adjudging payment in the depreciated currency of a debt due in coin, with an addition for the diflerence in value.

'The only way in which eflect can be given to the contract, is by a judgment in terms payable in the better currency to which the creditor is entitled, and an execution following the judgrment, and so long as the law recognizes the two currencies of diflerent values, judgments upon contracts for the payment in the better eurrency, must of necessity. he griven in this form, or the distinction between the two kinds of money as affecting the rights of parties, vanishes when the contract is mored in the judgument, and the rights of a creditor under a contract for payment in coin are of no value. This form of judgment is sanctionsel ly precerelent, and has the warrant of the Supreme Court of the Inited Sitates. (Rronson v. Rodes, 7 Wall.

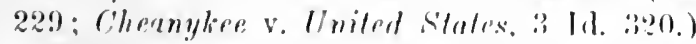

The jurlgment must be modified, and redured to the amount to which the plaintiff was entitled, payable in coin, with rosts of the contrt below, payable in correney, without costs to either party npon the appeal.

All the jubleres comenrring, judgment modified in accordance with the opinion of Allen, J.

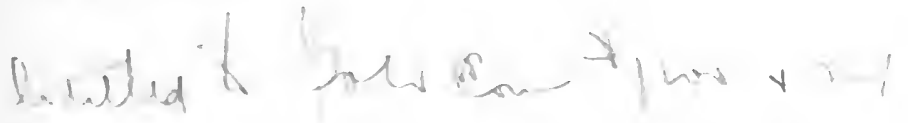


GaINes. Associati distel. - This is a question certified to us for determination by the court of ('ivil Appeals for the Third Supreme ducticial lostrict. The certiticate is as follows:

" Thr plaintiti, Hogne, brought suit against defendant, Williamson, upon a wriltul whligation, which reats als follows:

SiatitLo, January 25, 1888.

On or beiole May 1, Isss. I promise to pay $(\therefore$ C. Hogue, or order, one thousand Mexicall silver dollans.

$\$ 1,000, M x$.

Geo, S. Williamson.

The petition alleges that on May 1, 188s, Mexican dollars were each worth $8 . i$ cents in 'American' coin, and plaintiff' asks judgment for $\$ 850$. He states in his petition that the note is payable in Mexiean silver dolliars.

The defendant filed a general denial, and also averred in his answer. muder oath, that the note sued on was given for money which the plaintitl had won from defendant in a game of cards, and was therefore illegal and void.

Upon the trial in the court helow, the plaintiff put in evidence the written obligation sued on, and proved that on May 1, 1888, Mexican silver dollars were worth so rents each. The plaintiff then rested and the defondant introduced no testimony.

The conrt instructed the jury to return a verdict for defendant, which was done, and judgment entered accordingly.

If the instrument snet on was a promissory note, this is in error. (Neuton v. Newton, is l'exas, 511.)

With this explanation, the (onnt of Civil Appeals for the Third Suprene Judicial District centifies and sulmits to the Supreme Court, for decision as a part of the law of this case, as a new or novel question, the following proposition:

Was the burden of pronf on the plaintiff, after the introduction of the instrument sued on, to show non-porformance of its obligations by defendant? In other words, is the written obligation sued on a promisenry note, ohligating its maker to pay a certain sum of money; or is it an ordinary contract for the delivery of a certain commodity: and must the plaintiff, by atfirmative testimony, show a breach of the eontract?"

We are of the opinion that the instrument in question is a promissory note. It is such in form and substance, muless the fact that the sum payahle is expresend in Mexican silver dollars should make a difference. Speaking of the sum for which a bill of exchange must be drawn, Mr. (hitty says: "It may be the money of any country." (Chitty on Bills, 160). Judge Sitory savs: "list provided the note be for the payment of mome only, it is wholly immaterial in the currency or money of what country it may be payable. It may be payable 
in the money or currency of England, or France, or Spain, or Holland, or Italy, or any other country. It may be payable in coins, such as pounds sterling, livres, tomnosis, francs, florins, etc., for in all these and the like cases the sum of money to be paid is fixed by the par of exchange. or the known denomination of the currency with reference to the par." (Story on Prom. Notes. \$ 1\%.) The same rule is distinetly laid down in 1 Daniel on Neg. Inst.. \$ 58, and in Tiedeman on Com. Paper. $\$ 29 b$. In view of the opinion of these eminent text-writers, it is remarkable that we have foumd but two eases in which the question is discussed or decided.

In Black v. Ward (29 Mich. 191). it is held, that a note made in Michigan, payable in Canada in "Canada currency" is payable in money, and is therefore negotiable. But in Thompson v. S'loan (23 Wendell, 71 ), a note made in New York and payable there in "Canada currency" was held not negotiahle. The court, however, say; "This view of the ease is not incompatible with a bill or note payable in money of a foreign denomination, or any other denomination, being negotiable, for it can be paid in our own coin of equiralent value, to which it is always reduced by a recovery. A note payable in pounds, shillings, and pence, marle in any country, is but another mode of expressing the amount in dollars and cents, and is so understood judicially. The course therefore in an action on such instrument is to aver and prove the value of the sum expressed in our own tenderable coin."

This decision was made in 1840. and it is to be inferred that at that time the dollar was not a dennmination of the law fot moner of Canta. Meatso inter, that when the Michigan case arose, this had heen changed and the dennmination of C'anada money corresponded with that of the United States. ITpon this theory, it would seem that the cases may he reconciled. 'T'he language quoted from the opinion in Thompson v. Slome. supru, inclieates clearly. that if the money named in the notr laar lien the denomination of Canada money, the ruling would have lern different, untess, prochance, the word "curreney" would have affected the question. "The note we have under consideration is for Mexican silver dollars - coins recognired by the laws of the United States as money of the Repullie of Mexico. (U. S. Rev. Stats., \& 3rofi.)

We conclude that the mote suml upen in this ase was a negotiahle promissory note, and that when the plaintiff offered it in crillence, and proved the value of the Mexienn dollar at the time of its matnrity, he had made a prima farie case, and our npinion will be certified accordingly. ${ }^{7}$

7 A note payable in Now Brunswick in "U. S. mereney" is negotiable. "It is not necessary that the money payalile by a note should be current in the place of payment or where the bill is drawn; it may be in the money of any 
6. Mfost not Contain an Olider or Promise to do Any Aot in ADDition to l'AYMENT OF MONEY.

(a) Effect of additional stipulations.

DAVIES $v$. WIIKINSON.

10 Abolpius \& Ellis (Q. B.) 98. - 1839.

On the trial the plaintiff gave in eridence the following document:

"I agree to pay to Mr. Charles Davies, or his order, the sum of 6951 ., at four instalments. viz, the first instalment to be paid on Monday next, June 10th, 1833, being 200\%.; the seeond on the settling day at Doncaster after the St. Leger, being 150l.; the third on the settling day at Doneaster, after Epsom, 1834, being 150l.; and the fousth on the settling day at Doneaster, after the St. Leger, 1834, heing 100l.; the semainder, $95 l$., to go as a set-off for an order of Mr. Reynolds to Mr. Thompson, and the remainder of his debt owing from C. Davies to him. (Signed) JaMES WILKıNSON."

The defendant's counsel objected that the instrument was a promissory note. and should have been stamped aceordingly.

L.ORD DENMax. C. J. - The first oljection is, that this instrument was improperly received in evidence, being a promissory note not duly stamped. It is a note, up to a certain point but it ends, " $95 l$. to go as a set-off for an order of Mr. Reynolds to Mr. Thompson, and the remainder of his deht owing from C. Davies to him." I think that takes from it the character of a promissory note, and makes it an agreement, and that it was properly received. ${ }^{8}$

country whatever. . . . And may it not be assumed that 'United States eurreney' means the money of the Inited states. mul that the note is for the payment of three hundred and seventy-one lollars of the United States. [Citing statute rengnizing [nited States coinage.] This is a legislative recognition that the ragle of the Lnited States and the divisions thereof are coins; or, in other worls, the curreney of that eountry." - St. Stephen Branch Ry. Co. v. Black, 2 Hanney (N. B.), 139 (1870).-H.

["A note payable in pounds sterling or British sovereigns is payable in 'money' just is mueh and as eertainly as if it was payable in dollars. The case is different from a note payable in ' eurrency,' which may be 'money' only eomrontionally, but not legally. But where a notr is made payable in a par. tienlar denromination of foreign money, as pounds sterling, it is payable in money the same as if it was payable in a denomination of domestic money." DeAuY, 1). J., in King v. Hamilton, 12 Fed. liep. 478, 479. - C.]

8 An order limeting the drawee to pay $\$ 400$, and take up the drawer's note given to A $\mathrm{B}$, is not a bill. "The essential qualities of a bill or note are (1) that it he payabl. at all events; not dependent on any eontingeney, nor payable out of any partieular fund; and (2) that it he for the payment of money noly, and not for the jerformance of some other aet, or in the alternative." - Conol: v. S'alterler, fo Cow. (X. Y.) 108. Aceord: Killam v. Schoeps: 26 Kans. 310 ; Bunker v. Athearn, 35 Me, 364, - H. 


\section{$\S 24$}

LEONARD $v$. MASON.

1 WeNDEI.L (. Y.) $522 .-1928$.

Error from the Onondaga Common l'leas. A. Leonard sued Mason in a Justice's Court, on an order for the parment of money acepted by Mason. The plaintiff held a promissory note against one $\mathrm{N}$. Leonarl for $3.3+.4$, unterneath which was witten an order or bill of exchange, in these worls: "Levi Mason. Esq.. please pay the above note, and hold it against me in nur sottlement. .X. Lenard." The justice gave judgment for the defendiant, and the plantitl appealed to the Onondaga Common Pleas. On the trial in that court, the note, with the order written thereunder, were produced, and a presentment to, and a parol acepptance and promise to pay by, the drawee proved. The Common Pleas nonsuited the plaintiff, holding the promise of the defendant to be within the statute of frauds.

By the Court, Savagiv, Cr. J. - The only question is, whether the order which the defendant accepted is a good bill of exchange: if so, a parol acceptance is good. ${ }^{9}$ It is supposed that this case depends on the same principles as the case of Cooke v. Satterlee \& Satterlee (6 Cowen, 108). The rule there recognized is, that a bill of exchange must be for the parment of money, and nothing else. In that case, the drawees were required to pay a certain sum of money, and take up a note given by the drawer to a third person. Here it is to pay a note, which is referred to merely to ascertain the amount: and the retaining the note as a voucher is no more the h-t performance of another-the heside the payment of the money than the retaining the order itself for the same purpose.

The court erred. The judgment must he reversed, and a venire de novo is awarded to Onondaga Common Pleas.

(b) Exceptions: (1) Authorizing salo of collateral.

VALLFY NATIONAI, BANK $\%$ CROWELI,

148 Proxigunain Statf, 294. - 1892.

ACtrons on promissory notes.

The defense set up by the afficlavit was that there was no technieal liability as indorsers on the part of defendants, beanse of the nonnegotiability of the noles seret on. 'l'hese notes contained, in addition to the ordinary form of note, the chuse which is quoted in the opinion of the Supreme Court.

- But see Negotiable Instruments Law, § $220 .-H$. 
The court below. Sadler, P. J., of the Ninth judicial district, sperially presiding. made the rules alssolute in both eases, and defendints appealed.

Emors assigned were maling the rule absolute and entering judgment.

Pen Coliam, Mar. 28, 1892:

The only question in this ase was whether the note in controversy wis negrotiahle. It is in the usual form of negotiable paper, but it is contemeded that its negotialibity is destroyed by reason of the following provision contained therein:

"Having deposited herewith a like amount of Crowell Company mortgage bonds as collateral security, which we authorize the holder of this note, upon the non-periomance of this promise at maturity, to sell either at the broker's board, or at publie or private sale, without demanding payment of this mote or the Ifht lue thereon. and withont further notice, and apply proceeds, or as much thereof as may be necessary, to the payment of this mote and all neecssary clarges, holding us, as makess and indorsers, responsible for any defieiency."

We find nothing in this to destroy the negotiability of the note. While it has heen truly said that a promissory note is a courier without luggage, we find nothing in the language quoted beyond the statement that the note is accompanied with certain-eoltateral. The mere giving of collateral securify with a promissory note does not destroy its negotiability. (Arnold v. Rork River Valley Union. R. R. 5 Dier, 382; Towne v. Rice, 122 Mass. 6\%.) In Woods v. North (8+ Pa. 407); Johnston v. Speer (92 Pa. 227), the amount of the note was locld to be uncertain. In Bank v. Poillet (126 l'a. 195), the court refused to hold the indorser liable, because the time of payment was not fixed, and in Bank v. Mecord (139 Pa. 52), the payment was made dependent upon cortain conditions. In the case in hand, the amount of the note is not uncertain, nor is there any question about the time of payment. And the payment is not made dependent upon any condition-whatever.

The agreement, that if the collateral proves insufficient for the payment of the note, and all necessary expenses and charges, the makers will be responsible for any defieieney, neither increases nor decreases the responsibility of the makers. It merely requires them to do what the law would compel them to do without such an agreement.'

We are of the opinion that the affidavit of defense was insuffieient, and the jurlgment properly entered.

Judgment affirmed.

1 See especially, Arnold v. R. R., 5 Duer (N. Y.), 207. - H. 
(b) Exceptions: (?) Authorizing confession of judgment.

19 Оніо, $130 .-1850$.

Caldwell, J.- The action in the court below was assumpsit. The plaintiff declared as indorsee of a promissory note made by defendant fol \$\$.5.00. The declaration also contained the common counts. The case heing at issue, the plaintiff offered the note in evidenee, which was ruled out by the court, and the plaintiff nonsuited. The refusal by the court to permit the note to go in evidence is assigned for error. No argument is presented on either side, and the of exceptions only shows that the court decided that the note was not proper evidence in the eause.

On examination of the record, we do not see any objection to the note heing in evidence, and we think the enurt erred in ruling it out. The note has attached to it, and forming a part of the instrument. a power of attorney to eonfess a judgment, and we presume the court may have held that that fact would prevent its negotiability. And on that presumption, we would merely remark that the power of attorney, being addled to the note. does not in any way change the legal character of the note. excent that it gires a more summary proceeding for its collection. It is still a promissory note and being payable to oder is notidule by indorsement. The powe of attorney is not negotiable, and when the legal title to the note is transferred, the power of attorney heenmes invalid. and un power whalever can be exercised under it. for the henefit of the indorsee; and he holds the note as if no such power had ever heen attached to it.

'The judgment of the Court of Common l'leas will be reversed, and the cause remanded for further proceedingsin

2 Contra: Ouerton v. Ty/er. 3 Parr. (Pa.) 346. - II.

I"It is quite erertain that the note was not neentiahle. hesanse by the power of attorney which it contajued, julgment could lie entered upon it at any lime after its date, whether dur or not. Thus the time of pasurent depends upon the whim or caprier of the holder. and is almolutely morertain. This doprives

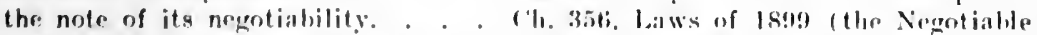
Instrument Law), provides that tlar becotiable rharacter of an inctrument is not affected ly a proviojon anthoriming a confesion of imlgument if the

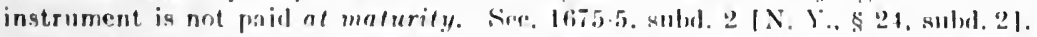
Upon familiar principlos of stafutory construction this provision makes a note like the prearnt non-negetiable." Wisstow, J., in Wisconsin Yeariy Meeting v. Babler, 115 Wis. 289, 292. - C.] 


\section{(b) Exceptions: (3) Wairing exemptions.}

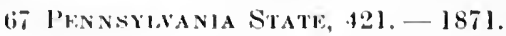

In an action on a note the court eharged that " the note offered in cvidence not heing necrotiable has been rejected, and eonsequently there is no evidence to sustain the action, and you will find for defendant." Judgment lor defendant and plaintill appeals.

liEsD, J. - The paper in this ease comes within all the definitions of the best text-writers of a promisory note, for it is a written promise by the defendant to pay E. W. Lowe or order one hundred and twenty-five dollars, six months after date, for value received with interest, absolutely and at all events. But it is urged that the words "waiving the right of appeal, and of all valuation, appraisements, stay and exemption laws," destroy its negotiahility. In what way? They do not contain any condition or contingency. but after the note falls due and is unpaid, and the maker is sued, facilitate the collection by waiving certain rights which he might exereise to delay or impede it. Instead of elogging its negotiability it adds to it, and gives additional value to the note.

Judgment reversed and new trial ordered.

(b) Exceptions:

(4) Election to require something in lieu of money.

\section{$\S 24$} HODGES $v$. SHULER.

22 New York. 114. - 1860.

Tre action was against the defendants as indorsers of the following instrument or note:

\section{Rutland and Burlington Railroad Company.}

No. 253.

Poston, April 1, 1850.

$\$ 1,000$
1850 .
rlington

In four years from date. for value received, the Rutland and Burlington or order. $\$ 1,000$, with interest thereon, payable semi-annually, as per interest warrants hereto attached. as the same shall become due; or upon the surrender of this note, togetlier with the interest warrants, not due, to the treasurer, at any time untileix months of its maturity: he shall issue to the holder thereof ten shares in the eapital stock in said eompany in exchange therefor, in which case interest shall be paid to the date to which a dividend of profits shall have been previously declared, the holder not being entitled to both interest and accruing profits during the same period. 
The court decided that the plaintiff was entitled to recover against the defendants, and gave judgment accordingly.

WrIGHT, J. - The single question is, whether the defendants can be held as indorsers. It is insisted that they cannot, for the reasons: 1st. That the instrument set out in the complaint, is neither in terms nor legal effect a negotiable promissory note, but a mere agreement; the indorsement in blank of the defendants, operating, if at all, only as a mere transfer, and not as an engagemnet to fulfill the contract of the railroad company in case of its default; and ?nd. That if it be a note, the notice of its dishonor was insufficient to charge the defendants as indorsers. $* * *$

The instrument on which the action was brought has all the essential qualities of a negotiable promissory note. It is for the unconditional payment of a certain sum of money, at a specified time, to the payee's order. It is not an agreement in the alternative, to pay in money or railroad stock. It was not optional with the makers to pay in money or stock, and thus fulfill their promise in either of two specified ways; in such case, the promise would have been in the alternative. The possibility seems to have been contemplated that the owner of the note might, before its maturity, surrender it in exchange for stock, thus canceling it and its money promise; but that promise was nevertheless absolute and unconditional, and was as lasting as the note itself. In no event could the holder require money and stock. It was only upon a surrender of the note that he was to receive stock; and the money payment did not mature until six months after the holder's right to exchange the note for stock had expired. We are of the opinion that the instrument wants none of the essential requisites of a negotiable promissory note. It was an absolute and unconditional engagement in pay money on a day fixed: and although an rection was given to the promisees, upon a surrender of tho instrument six months before its Inaturity, to exchange it for stock. this did not alter its character. or make the promise in the alternative. in the sense in which that word is used respecting promices to pay. The engagement of the railroad company was to pay the sum of $\$ 1.000$ in four years $f$ rom date, and its promise conld mily be fulfilled by the payment of the money, at the day named.

[Omitting the question of notice.]

I nm of the opinion that the action was well brought against the defendants as indorsers of a negetiahle promissory note, and that the notice of its dishomor was sufficient.

The judgment of the Supreme Court should he affirmed.

All the judges agreed that the instrument in suit was a promissory note; Denio and Werces, JJ., dissented on the ground that the 
notice of non-payment was insufficient in omitting the number upon the watrgin of the note."

\section{Payable on demand or at a determinable future time.}

\section{When Patable on Demand.}

(b) No lime for payment cipressed.

Assumpsit on a promissory note. The first count of the plaintifl's declaration stated, that the defendant, on May 25, 1809, at, ete., made his eertain promissory note in writing, subseribed, ete., and then and there delivered the same to the plaintiff. by which said note the defendant promised to pay to the plaintitr, or order, $\$ 112.53$; hy reason whereof. ete. 'There was a demurrer to this count of the declaration, which was submitted to the court withont argument.

Per Cintay. It is to be presumed that the plaintiff has stated the note in lis reclaration, according to the terms of it, and that is sufficient. The conclusion of the law is, that whe time of payment is specifed in a note. It is parable immedintely. The first comnt, then. shows a cause of action, and the plaintiff is entitled to judgment. Juderment for the plinintiff."

3. Ses $\$ \S 166-167$, post. - II.

4 "I prumise to paly to the order of W. $\$ 55$ at my atore for in gools on demand)," is a promissory note. Irosstaltr v. IIilson, 36 Barl. (N. Y.) 307. rontra. Dommett v. Gonduin, 32 Me. 44. - II.

"Py the law morehant there are some distinetions hetween inatruments payable on demand and those payable at sight: as. for example, in the matter of days of graee. See Daniel on Negotiable Instruments, \$\$ fit7-619. [1)emand] bills or notes were not entitled to rays of grace, hut there was a confliet of authority as to instruments pavable at sight. the weight of authority holding that they wereso entitled. - r.l This was also the offeet of former statutes in some of the states. Walsh v. Dart, 12 Wis. fish. The now statute aholishes all these distinctions." rrawforl's Nogntublr Instruments law. 3d ed., p. 18.

Days of graee are aholished by $\$ 145$ of the New York act. - C.

s Acenrd: Baron v. I'agr. 1 Conn. 4n4: Innes v. Brourn. ll Oh. St. 601; Messmore v. Horrison. 172 '’a. St. 300 : Bank v. I'rier. 52 Iowa, 570; Libby v. Mikelborg, 28 Minn. 38; Roberts v. Snow, 27 Neb. 425. - H. 
(c) Issued, accepted or indorsed when overdue.

LIGHT $v$. KINGSBURY.

50 llissovri, 331. - 1872.

Adans, Jedge. * * * But it is unnecessary to review any of the positions assmmed by commel in this case, as the petition on its face does not state facts sufficient to constitute a cause of action against the defendants as indorsers of this note. It is a negotiable note, indorsed after dluc. Such indorsement is equivalent to drawing a new hill at sight, and the same diligence in making demand and giving notice is required to charge the indorsers. (See Davis v. Francisco, 11 Tho. 5i2, opinion of ScotT, J.: also Moody et al v. Mack, 43 Mo. 210: Berry v. Robinson, 9 Johns. 121: Mchinney v. Crawford, s Serg. \& R. 351 ; Rugby v. Davidson, 2 Mills Const. $33 .^{7}$ )

The petition alleges that the indorsement was made about the 19th of April, and alleges a demand and refusal on the 3d of July following, and gives no excuse whatever for the delay. Even if this petition could be held good after verdict, there was nothing in the evidence to justify the delay in presenting the note for payment, and the indorsers were discharged by such delay. ${ }^{8}$

Judgment affirmed. The other judges concur.

\section{Wiren Payable at a Fixed or Determinable Futule Time.}

(a) A fixed time after date or sight. SIEGEL $v$. CHICAGO, ETC., CO.

[Reported herein at p. 190.]

(b) On or before a fixed or determinable time specified. JORDAN $r$ 'T'ATE.

19 Onо Statr. 586. - 1869.

Motios for leave to file a petition in cror to reverse a judgement of the District Conrt of Montgomery county, affirming the judgment of the Court of Common Plens.

7 "A negotiahlo instrument indorsed after muturity is regarded as equivalent to one payahlo on demand. Such a bill or notre thomgh overdue, continues to he negotinhle. and ia in the nature of a new bill payalise on demand. Daniel

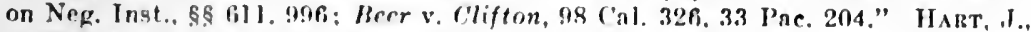
in Wills v. Booth, o Cal, App. 197, 201.

"As betwern indorsar and indorsere, such note is to be treated as a note on demand, dated at the time of the transfer, so far as demand and noties aro eoncerned." Rick. J., in Gondwin v. Datenport. 47 Me. 112. 116. - C.

- Accord: Bussenthrset v. Willy!, 45 Ohio St. 333 (deluy from July 30 to Nov. 21). Sce Neg. Inst. 1... \$ 131. - II. 
Br тиe Count: 'The neerotiahle chalracter of a promissory note is not aflected by the finet that it is made payable by its terms on or before a luture day therein named. 'Though the maker has a right to pay such note alt any time after its date, yet for all purposes of negotiation it is to be regarded as a note payable solely on the day therew named.

[Reported herein at p. 68.]

\section{§23 FIRST NATIONAL BANK OF POMEROY, IOWA, v. BUTTEPY.}

17 North Dakota, 326. - 1908.

Judgment for defendant, and plaintiff appeals.

Spalding. - This is an action on a promissory note. The note was sued on by the indorsee for value hefore maturity, and the court found that there was a failure of consideration, and that the contract was not a negotiable note, and entered judgment for the dismissal of the action. Only one question requircs consideration. If the instrument in question is a negotiable promissory note, the judgment should be reversed; otherwise, it should be affirmed:-

The note was made in this state, and is payable at Sionx City, Iowa. and the clause which the trial court held rendered it non-negotiable reads: "The makers and indorsers herein, severally waive presentment of payinent and notice of protest, and consent that the time of payment may be extended without notice." There is an apparent conflict of anthorities as to whether this or similar agreements render the note non-negotiable. The note is, by its terms, made payable on or before the 1st of October, 1903. Without the paragraph complained of, it would unquestionably be a negotiable instrument, and the indorsers wonld he released hy any extension of time of payment without their assent. We are of the opinion that this provision does not extend the time of payment indefinitely or render it uncertain. The time of payment is already fised.

It is strenuously argued that the use of the word "makers" in the waiver armits of an extension heing made at any time on the part of the holder, by a mere seeret mental process, unknown to any other

9 Accord: Mattison v. Marks, 31 Mich. 421. Contra: Stults v. Silva, 119 Mass. 137. - H. [Aecord: Leader v. Plante, 95 Me. 339. - C.] 
party. This may be true as a psychological fact. but we do not deem it so as a matter of practice in commerce and banking. To us it is clear that it has the same effect as though the note read "on the 1st day of October, 1903. or thereafter on demand." in which case there would be no question of its negotiability. Holders of notes do not by a secret mental process make in extension of the time of payment, but such extension. if made at all. is made by an agreemenf between the primeipal dedor and the liolder of the paper, either with or without the emsent of the indorsers. This provision seems to us to have heen inserted to protect the holder against any release of indorsers or others, by an extension without their assent. and the word "makers" is evidently included to prevent any nisunderstanding or misconstruction of the contract or failure to distinguish between makers, indorsers, sureties, and any other parties who might be or become liable thereon under certain contingencies as makers. ; Cyc. 614. This phrase does not express an agreement to extend time, but leaves the matter of extension optional with the holder, and not obligatory upon him, and the note on its face fixes the time when it becomes due. In this respect it must be distinguished from a provision to the effect that the time of payment shall he extended indefinitely, in which case the uncertainty of the time renders the instrument non-negotiable.

We feel that the reasoning in the National Baml of Commerce v. Kenney. 98 Tex. 293, $83 \mathrm{~S}$. W. 368, is not only satisfactory, but conclusive of this point The note involved in that case contained this provision: "The makers and indorsers hereof herehy severally waive protest. demand. and notice of protest and mon-pilyment in rase this note is not paid at macarity ald ascee to all extensions and partial

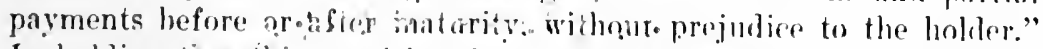
In holding toat this provision did not resdor the note non-negotiable, the Texas count says: "If. as is aroued. the efifere of the stipulation is to give the right to the maker, withont the consont of the holder, or to the holder withost the conernt, of the maker to appoint another date of payment. and therely exicud the tims? it may he that it wonld render the instrument nom-negotiahle. But we do not think it capahle of that construction. It does not sily that rither the holder or the maker may extend the note. 11 simply makrs a provision in ase the time of payment may be axtenderl. How extemded? It some to ne that the extension meant is that which takes place when the debtor and creditor make an aterrement upon a vilualule comsidelation for the payment of the deth on some day subserpent to that previonsly stipulated. The obvioms purpose of the stipulation taken as a whole was merely to reliese the linkder of the paper from the lumerdens made necessary by the rigid repuirements of the moreantile law in order to secure the continued liability of the indorsers and sureties on the paper. Therefore what was meant by the stipulation as to extension 
of time was simply that in case the holder and maker should agree upon an axtension the sureties and indorsers should not be diseharged. The holder and maker of a note may at any time agree upon an extension: therefore, the fact that they have that right does not affect the negotiability of the paiper. It is usually said that, in order to make an instriment negotialle under the law merchant, the time of payment must he certain. But a note payable on or before a certain date is negotiable. The maker of such a note has the right to pay before the date named. but the holder cannot demand payment before that date. So, in this ease. the time at which the maker may elect to pay is uncertain, but the time at which the holder may demand payment is certain. It follows that if the holder has the absolute right to demiand payment at a certain date, the note is negotiable. This is but an illustration of what we understand to be the general rule. There being nothing in the stipulation under consideration, which gave any one the right to demand of the holder of the note an extension of the time of payment, we think the time at which he could demand payment was fixed, and that, therefore, it was a negotiable note." * * *

[After discussing Jacobs v. Gibson, ry Mo. App. 244, Bank v. Commission Co., 93 Mo. App. 123, and Farmer v. Bank, 130 Yowa, 467, the court continues:]

We are, however, of the opinion that, under the plain terms of the negotiable instruments act of this state, this note is negotiable, without reference to other authority.

Section $6486 .{ }^{1}$ Rev. Codes 1905 , defines a negotiable promissory note as follows: "A negotiable promissory note within the meaning of this chapter is an unenditional promise in writing, made by one person to another, signed iy the maker, engaging to pay on demand, or at a fixed or a deturininable future time, a certain sum of money, to order or to bearer." Section $6309^{2}$ provides that an instrument is "payment on demand. * * * $*$. In which no time for payment is expressed." Section 642 ${ }^{3}$ proviles how such an instrument is "discharged against a person secondarily liable thereon." Paragraph 6 thereof provides that it is discharged by any agreement binding upon the holifer to extend time of payment, or to postpone the holder's right to enforce the instrument, unless made with the assent of the party secondarily liahle, or unless the right to recourse against such party is expressly reserved.

If, as is contended by the respondent in the case at bar, this instrument, taken as a whole, expresses no time for payment, then, under gection 6309 , it is an instrument payable on demand, and aceording to

1 N. Y., \& 320. - C.

2 N.Y., § 26. - C.

- N. Y., § 201. -C C. 
section 6486 the negotiability of a promissory note is not destroyed by its being made payable on demand. On the other hand, if it does express a time for payment, the 1st day of October, 1903, is a fixed and determinable future time as required by section 6486 , supra. This note was executed and dated within this state, and we are satisfied that the paragraph complained of as rendering it non-negotiable was drawn for the express purpose of protecting it within the terms of paragraph $6, \S 6422$, above quoted, and in accordance with other statutory provisions providing for waiver of presentment, notice of dishonor, and protest. Notes containing clauses similar to the one in question have been in almost universal use in this state for years, and the identical waiver complained of has been in common use, and the instruments containing them have been regarded and treated by the trade and bankers as negotiable.

For the reasons stated, the judgment of the District Court is reversed.

Pollock, District Judge, concuirs.

Fisk, J., disqualified; Hon. Chas. A. Pollock, judge of the Third Judicial District, sitting by request.

Morgan, C. J. (dissenting). I am unable to concur in the conclusion reached by my associates in this case. My reasons for reaching an opposite conclusion may be briefly stated.

The statute in express terms reguires that the time of payment must be definitely stated in the note or that it can be definitely determined therefrom when it becomes paralle, or it will be rendered nonnegotiable. From the face of the note, it seems to me conclusive that it does not show when the note may become due and payalle in view of the fact also stated therein that an extension may become operative and binding. It does not seem to me to be a sound conclusion to say that the note states a fixed day of payment when it also states that the day stated may not represent the date of payment if the stipulation as to an extension that follows is put into ellect. The note cannot be said to be a demand note, as by its very terms it is not such. It fixes day of payment, sulject to extensions. So far as having no fixed day of payment is concerned, the time is remlered as uncertain by reason of possible extensions as it would be if it provided for extensions indefinitely, and is therefore fairly within the principles of the Iowa cases cited in the opinion. In Bank v. Gunler, 6r Kan. 22\%, the note contained this stipulation: "The makers and indorsers hereby severally * * agree to all extensions * * * before or after maturity withont prejudice to the lolder," and in reference to the effect thereof upon the negotiability of the note. the rourt said: "In the note in question, payment is first fixed at 182 dayes after the datr, but as will be observed, a later provision makes thr time indefinite by stipulating that it may he changed and extended either hefore or after maturity. If the time is to remain fixed until maturity, when another time is to 
be tixed by the parties, or if payment is made to depend upon events which necessarily must ocemr, and the time of payment is nltimately certain, other consiblerations would arise; but here payment is not ultimately certain, for the time stated in the palper is subject to ehange at any time at the rolition of some of the parties to the action."

In Coffin r. Spencer (C. ('.) 39 Fed. ?6., the court said in reference to a similar stipulation: "Every smecessive taker of the paper is, of comrse, bound to take notice of the stipulation, and, instead of looking only to the face of the instrmuent for the lime of its maturity, as in case of commereial paper he must, ss put upon inquiry whether or not any agreement for a renewal or exfension of time has been made by his proposed assignor or by any previous holder."

In Oyler v. Miduray, $\%$ lnd. App. 645, the court said in speaking of a like stipulation: "The holder was not bound by the stipulation in either case to extend the time of payment. 'The material and controlling fact is thit the holder had the option, at any time before as well as after the time of payment stated in the note, to extend to the drawers and indorsers, or either of them, the time of payment."

The following authorities specifially hold that stipulations like the one contained in the note in suit render the note non-negotiable: 7 Cye. 600, and cases (ited; Damiel on Neg. Inst. (5th ed.) p. 49; Einton of Gilbert on Commercial Paper, p. 220: Smith v. Van Blarcom, 45 Mich. 3.1: Woodhmy v. Roberts, 59 Iowa, 348: Hodge v. Farmers' Bank of Frankfort, 7 Ind. App. 94: Oyler v. McMnray, 7 Ind. App. 645: Glidden v. Menry, 104 Ind. 278; Rosenthal v. Rambo, 28 Ind. App. 265: Idl., 165 Ind. 5st: Ermms v. Odem. 30 Ind. App. 207 ; Second National Bank: v. Wheeler, 55 Mich. 546; Lamb v. Story, 45 Mich. 4s8; Oyler v. Me.Murray, 7 Ind. App. 645; Citizens' Nat. Bank v. Jiollet, 126 Ра. 194.

On principle and anthority, the note should be held non-negotiable.

(c) On or at a fixed period after the occurrence of a specified event.

$$
\text { SHAW } v \text {. CAMP. }
$$

160 ILlinoIS, 425. - 1896.

Mr. TLStice Cartwrigite lelivered the opinion of the court:

Appelle filed a claim in the County Court of Piatt county, against the estate of Edward Swaney, deceased, and the claim was rejected. In the Circuit Conrt, on appeal, there was a trial by a jury and a verdict for the claimant for \$\$852.50, upon which judgment was entered. The judgment was affirmed by the Appellate Court and a certificate of importance granted, under which the case is brought

1 See note to this case rutitler "Effret on nogotiability of promissory note of provision fromitting extrn-ion of time," in $16 \mathrm{~L}$. N. S. 878 . See also note in 125 Am. St. Rep. 201. - C. 
to this court. On the trial the elaimant offered in evidence the instrument upon which his claim was founded, together with proof of the signature of the deceased. 'The instrument was as follows:

Benent, Ill., Dec. 27, 1890.

After my death date I promise to pay E. Hanson Camp, or order, the sum of $\$ 750$, without interest at per cent. per annum from date, value received.

Following the above there was a power of attorney, in the usual form, to confess judgment, and the signature of Edward Swaney. To the introduction of this instrument objection was made and overruled, and it is insisted that the ruling was wrong, for the reason that the instrument was not a promissory note. It is conceded that a promissory note may be made payable on the death of a certain person, or at a fixed time thereafter, or on demand after such death; but it is elaimed that this instrument was not payable at a time fixed, and that the words "after ny death date" should be construed to mean some uncertain time after that event. We do not regard the instrument as subject to the objection made. It did not beeome due until the death of the maker, which was an event certain to occur, but by its terms it became dne at once after the occurrence of that event. There is nothing in the langlage to indicate that the money was to be paid at some uncertin time after the maker's death. The objection was properly overruled. ${ }^{2}$

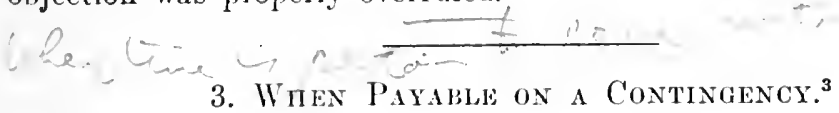

13 ILLINOIS, 604. - 1852.

Treat, C. J. This was an aetion brought by IIemmingway against Kelley before a justice of the prace, and taken by appeat to the Cirenit Conrt. On the trial in the later court, the plaintiff offered in evidence an instrument in these words:

('ASTLETon, April $27,1844$.

Due Ilenry I), Kelley fiftythree dollars, when he is twenty-one yeits old, with interest.

[On the back of which was this indorsemenl]

DAVID KELLEY.

linскти, .

Signed the within, payable to Moses Hemmingway.

HENRY KRLLY.

2 A bill or not. payable so many days after the death of a party is certain as

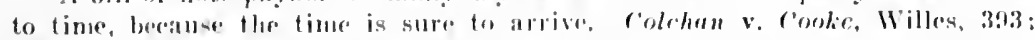
affirmed 2 Str. 1217; Bristol v. Worner. 19 (onm. 7, post: Comn v. Thorntorn, 46 Ala. 587; Price v. Jomes, 105 Iml. 513: C'armuright v. Gira!l, 127 N. Y. 92; Ilegrman v. Morm, 131 N. Y. 462; ante, 1. 41; Martin v. Stone, 67 N. H. 367. - I3.

3 See note in $125 \mathrm{Am}$. St. Rep. 202.- C. 
'T'he plaintiff proved that the payee became of age in August, 1849. The defendant objected to the introduction of the instrument because it was not negrotiable, bat the court admitted it in evidence and rendered judgment for the plaintitf.

()ur statute makes promissory notes assignable by indorsement in writing, so as alssolutely to vest the legal interest in the assignee. $\mathrm{W}$ as the instrument in question a promissory note? 'To eonstitute a promissory note, the money must be certainly payable, not dependent on any contingency, either as to event, or the fund out of which payment is to be made, or the parties by or to whom payment is to be made. If the terms of an instrument leave it uncertain whether the money will ever become payable, it cannot be considered as a promissory note. - (Chitty on Bills, 134.) Thus, a promise in writing to pay a sum of money when a particular person shall be married is not a promissory note, because it is not certain that he will ever be married. (Pearson v. Ganet, 4 Mod. 242; Beardesley v. Baldwin, 2 Strange, 1151.) So of a promise to pay when a particular ship shall return from sea, for it is not certain that she will ever return. (Palmer v. Pratt, 2 Bing. 185; Coolidge v. Ruggles, 15 Mass. 387.) In all such cases, the promise is to pay on a contingency that may never happen. But if the event on which the money is to become. payable must inevitably take place, it is a matter of no importance how long the payment may be suspended. A promise to pay a sum of money on the death of a partieular individual is a good promissory note, for the event on which the payment is made to depend will certainly transpire. (Colehan v. Cooke, Willes, 393 ; s. c. 2 Strange, 1217.)

In this case, the payment was to be made when the payee should attain his majority - an event that might or might not take place. The contingency might never happen, and therefore the money was not certainly and at all events payal,le. The instrument lacked one of the essential ingredients of a promissory note, and consequently was not negotiable under the statute. The fact that the payee lived till he was twenty-one years of age makes no difference. It was not is promissory note when made, and it could not become such by matter ex post facto. The plaintiff has not the legal title to the instrument. If it presents a cause of action against the maker, the suit must be bromght in the name of the payee. The case of Coss v. Nelson, (1 Burr, 226), is tearly distinguishable from the present. There, the note was marle payable to an infant when he should arrive at age, and the day when that was to be was speeified. The eourt held the instrument to be a good promissory note, but expressly on the ground that the money was at all events payable on the day named, whether the payee should live till that time, or die in the interim; and it was distinctly intimated, that the case would be very 
different had the day not been stated in the note. It was regarded as an absolute promise to pay on the dily specified, and no eflect was given to the words that the payee would then become of age.

The judgment must be reversed.

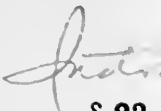

$\S 23$ SAckett $v$. PAlmer, 25 Barbour (N. Y.), 179. - $185 \%$. Action on a note parable "ninety days after the dissolution of the partnership between A. B. and C. D., and the settling of the books of said firm." Jounson, $J$. The instrument on which the action is brought is not a promissory note. It is payable ninety days after the happening of two events, one of which may never happen. 'The general rule is, that an instrument payable only in money, is not a promissory note, unless it is payable at all events, not depending on any contingency. Though if the event on which the instrument is to become payable must inevitably happen, it is no objection that it is uncertain when it will happen; nor is it of any importance how long the payment may be in suspense; it will still be regarded as a promissory note. (Chit on Bills [Sth Am. ed.], 155, 156.) It is not shown by the evidence how long the partnership was to continue by the agreement of the partners. It was certain, however, that there would at some time be a dissolution, by the death of one of the partners, if not otherwise. That event was sufficiently certain. But the settling of the books of the firm was an event which might never happen. It would not inevitably happen. It might, ant-probahly would, after a dissolution, in due course of law. But that is not enough; if it might not happen the instrument is not a promissory note.

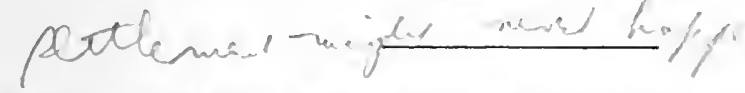

\$23 AMERICAN NATIONAL, BANK V. SPRAGUE.

I4 RUODE ISI,AND, $410 .-1884$.

Actios against indorsers an an instrument similar to the one in Riker v. Sprague Mfg. Co., (ante, p. 6s), except that it was indorsed as follows:

4A note reading " Ejon confirmation by the Congress of the United States of the certain land grant known as . . . I promise to puy," ete., held nonnegotiable sinee it was not ertainly and at all events payble; it not being certain that the grant would ever be confirmed by Congress, or through its instrumentalities. "It is no anawer. . . to show that the grant in question has, as a matter of fact, licen ronfirmed hy the rourt of private land claims. . . The qurstinn is. What were the conditions when the eontract was madr? Negotiability is to he julgerl by the front sight, not ly the back sight. The moral eertainty must he present at the time of its expeution and not be a matter of relation aecruing ly reason of subsequent events. If it be 
"Issued as collateral to A. ¿. W. Spragne Mfg. Co.'s draft accepted

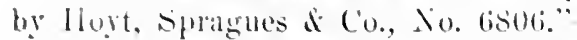

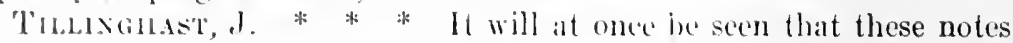
ditieg rery materially from dhese declared on in the former case, and alse that under the rube therom aldopted they are elearly not negotiable. 'They wore issued as collateral to certain drafts therein specifically

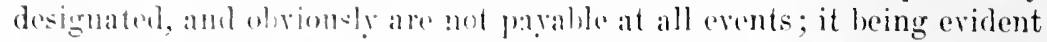
that the payment of the dralts would at once discharge both the maliers amb indresers of the notes, and renoler said notes mull and void. So also a partial parment on the dralts would at once reduce the amonut collectible on the notes pro tonto.

The undertaking of the defendants, therefore, was at most a contingent one. and the smm which might become due at the expiration of the notes was muertain.

Without considering the other points raised by the petition, we must, therefore, grant a new trial.

Petition granted. ${ }^{5}$

\section{Payable to order or to bearer.}

\section{Mest be Payable to Orimer ol Bearer to be Negotiable. ${ }^{6}$} $\S 20$ WETTTAITER $r$. BAXTER.

[Reported herrin at p. 1.j.]

not a bill or note ab initio, no subsepurnt event can make it so." Pope, .J., in Joseph v. Catron, 13 N. MI. 202, 2.23. See this ease reported with note in 1 J. X. S. 1120.

Siee aloo to the same effect Fldrel v. Malloy, 2 c'olo. :320. - C:

sIn rilizens" Vat. Bank v. Piollet, 126 l'a. St. 194, a note containing a

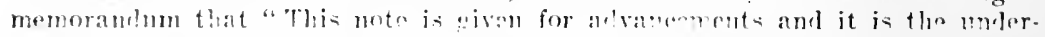
standing it will not le renowed at maturity" was held non-negotiable. "The statrment that it is riven for advaneements does not atleet the certainty of the note, and it eould ra-ily le regareled as a mere memorandum not clianging the contract and threrfore not material. Fint the remainder of the writing is an agrement that the mote will le renewerl at maturity. As the bank is the holder and discomnted the note when it was given, it. . . must be con. silloral a s lasing arreed to ronew the note at its maturity. This leeing so, the obligation of thr note is not an abiolute, meomditional contract to pay the monsy at maturity. It is a qualiforl ohligation to pay. with a eonrition that, instead of paying, the holder may give another note in its place which the bank would lw lomnd to acerpt inntral of money. This being so, the ease comes withn tho rulo that enmoreial pajor, to be nowotiahle, must be certain, uneonditional, and not contingent." GREes, .J., at P. 197.-C.

6 It is to be obervol that the Teg. Inst. Iaw applies only to instruments containing words of neorotiability. An instrument not eontaining words of negotiability may be a bill or notr. but it is not covered by this Act. The English Bills of Exchange Aet malies negotiable any bill or note which does not entain worls prohihiting transfer: but this changes the law. Chalmers, Bills of Exchange Act (5th ed.), 1. 25.- - H. 


\section{Payable to the Order of a Specified Person.}

\section{(?) Payee must be certain.}

\section{\$27 GORDON lis3 Vilenttiax, $143 .-1903$.}

JUDGMExt for plaintitf. and defendant brings error.

Moore, J. - This ease wis tried hy the Circuit judge without a jury. At the request of the defondant. he made a finding of facts, which is as follows:

"Monday morning, Decemsher 9. 1901, at ahout nine o'clock, there was presented at the bank of defendant at the city of Lansing for payment the following check. made upon the printed form of check supplied by defendant to its patrons, and signed ly plaintiff, viz.:

$$
\text { “. LAxisg, Miche. }
$$

" "LANSING STATE SAVINGS BANK OF LANSING.

" "Pay to the order of $\ldots \ldots \ldots \ldots \ldots \ldots \ldots \ldots$ nine hundred and seventy" dollars $(\$ 970.00)$.

\section{“'JNo. R. Gordon.'}

"The check was indorsed by Charles P. Downey, and was presented by an employee of Mr. Downey, and cash was paid at the time of presentation. The plaintiff had been a depositor at defendant's bank at periorls for three or four years, and at the opening of the bank on the morning of December ? 1901, his balance or credit upon the books of the bank was $\$ 3.40$. hut during the day $\$ 2,99 \% .50$ was added to plaintiff's credit. 'The day defendant cashed the check plaintiff was at the bank, and was informed that the cleeck for $\$ 9$;) had heen cashed by payment to Mr. Downey aml he then notifed defendant he would not accept the check as a voucher for the noney pilil. Derember 1t. 1901, plaintiff preparea and presented to defendinst his chece, payalile to himself, for $\$ 9 \%$ ), being the ammunt he dained to then hare on deposit in the bank. Filyment on this aleek was refused ly defendant upon the ground that plaintith had non funds in the hank."

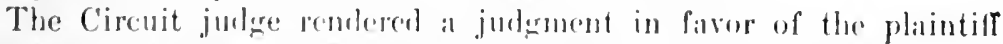
for $\$ 900$ and interest. The case is broment here be writ of error.

Two questions are disedesed ly connsel: First, the effect of not

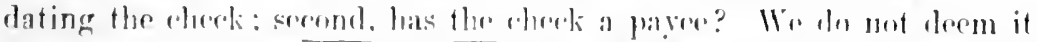

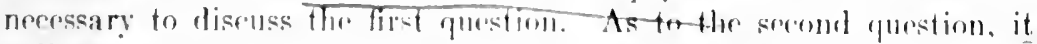

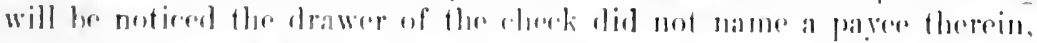
nor dist he leave a bank space where the name of a paree might he

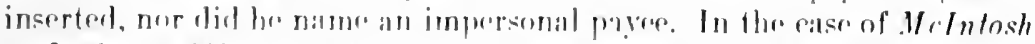

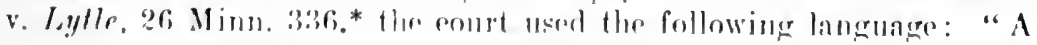

- In this rase thre instrument stmol on read ne follows: " 8200 .

S.r. PaIt. Mixs.. Ion. 22. 1879.

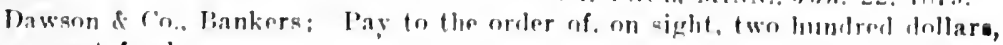
in current funds,

E. LYTLE." - C. 
check must name or indieate a payce. Checks drawn payable to an imprersonal payee, as to Bills layalibe or order, or to a number or order, are held to be paybible to bearer, on the ground that the use of the words "or order' indicate an intention that the paper shall be negotiable; and the mention of an impersonal payce, rendering an inclersement he the payee impossible, indicates an inlention that it shall be negotiahle without indorsement - that is, that it shall be parable to hearer. So, when a bill or note or check is made payable to a blank or order, and actually delivered to take effect as commereial paper, the person to whom delivered may insert his name in the hlank space as payee, and a boun fide holder may then recover on it. These eases differ essentially from the one at har. In the latter case the person to whom delivered is presumed, in favor of a bona fide holder. to have had anthority to insert a name as payce. In the former case the instrmment is, when it passes from the hands of the maker, complete, in just the form the parties intend. But in this case there is neither a blank space for the name of the payee, indicating authority to insert the payce's name, nor is the instrmment made payable to an impersonal payee, indicating a fully completed instrument. It is elaimed that the words 'on sight' are such impersonal payee. They were inserted, however. for another purpose - to fix the time of payment, and not to indicate the payec. It is clearly the ease of an inadvertent failure to enmplete the instrument intended by the parties. The drawer undoulstedly meant to draw a eheck, but, having left out the payee's name. without inserting in lien thereef words indicating the bearer as a payee, it is as fatally defective as it would he if the drawee's name were omitted."

See. also. Rush et al. v. Hnggard, fo Tex. 674: Prewitt v. Chapman, 6 Mla. S6: Brourn v. Gitmon of al., 13 Mass. 160 : Rich et at. v. Starburle. 51 Ind. 8r: Norton. Bills \& Notes (3r ed.) p. 59, and notes; Daniels, Neg. Inst. (4th ed.) § 102 .

The ease differs from the one at har in some respects, hut the important part of the decision is that a payee is necessary to make a enmplete instrument, and, even though the maker of the eheck may have intended to name a pavee. if he has not in fact done so the check is ineornplete. In the ease at har the failure to mame a payee was not an orersight, if wr may jurlge from what Mr. Gordon did, as will appear more in detail later.

Our attention has been alled to Crutchly v. Mann, 5 Taunton R. 529. In this case the bill of exchange was mate payable to the order of ......... The court found that under the facts slown the conclusion was irresistible that the name was filled in with the eonsent of the drawer. The same case was previonsly reported in 2 Maule \& Selw. 90, where. as the ease then stood, it appeared the hill of exchange had been sent out, the defendant leaving a blank for the name of the 
payee. One of the judges was of the opinion that the defendant, by leaving the blank, undertook to he answerable for it, when filled up in the shape of a bill of exchange: another judge. was of the opinion that it was as though the defendant had made the bill payable to bearer; while the third judge was of the opinion that the issuing of the bill in blank without the name of the payee was an authority to a bona fide holder to insert the name.

In the case of Harding v. The State, 54 Ind. 359, a promissory note was drawn leaving a blank space for the name of the payee, and it was held: "So the name of the payee may be left blank, and this will authorize any bona fide holder to insert his own name." In the case of Brummel et al. v. Enders et al., 18 Grat. 873, promissory notes, blank as to the names of the payees, had been put in the hands of an agent to be sold for the benefit of the makers. The agent sold them, at a greater discount than the legal rate of interest, to purchasers who did not know they were sold for the benefit of the makers. At the time of the sale the name of the purchasers was inserted, either by the purchasers or by the agent, in the blank left for the payee. When the notes were sued, the makers pleaded usury. The court, following the eases already eited, held that any bona fide holder of a bill or note which is blank as to the name of the payce may insert his own name, and thus aequire all the rights of the payee.

It will be observed that the case at bar differs from all of these eases. As before stated, not only dir Mr. Fordon fail to insert the name of a payee, or to leave a blank where the name of the payee might be inserted, but he dir more. He drew a line through the blank spare, making it impossible for any one else to insert therein a name, indicating very rlearly that he not only declined to name a payee, hut intended to make if impossible for any one else to do so. Had Mr. Gordon issued a check otherwise perfect, but with the hlank space for the amount of the eheek unfilled, and delivered it to a third person, it would be presumed the third pereon was erisen anthority to fill the blank spare. But had he, instead of leaving the space a blank, filled it hy drawing a line thromgly it. Womld any one say the third person might then insert a sum of money in that space? If not, upon what principle may the name of a payere be inserted when the space was filled in the same way, or upon what thery may it be presumed there was an impersonal payee when the maker has not made the check payable to cash, or some ofluer impersonal pilyer. In order to eonstrue the clieck as a completo instrument. We must rearl into it an intention not only unt expresesed by its language, but rentrary to the aet of the maker. The cherk. as it appears to-day, is without any payee. The record is sitent in relation to whom it was delivered, or whether the peran who presented it at the bank or the person whose indorsement it hears was a bona fide holder.

Judgment is affirmed. 
Montgomery, J., did not sit. Hooker, C. J., concurred with Monre, J.

CAlPETYR, I. I regret that 1 cannot eonenr in the opinion of my Brother Moore. I agree with him that the check in question is not governed by the authorities which hold that, where a blank is left for the insertion of the name of a payee, the instrument is to he treated as parable to bearer. I cannot anree, however, that the ease of $M$ I Intosh $\therefore$ Lytle, 26 Ihimn. 336, is controlling. That calse resembles this in many particulars. There is, however, a difference, which, in my judgment. renders the reasoning of that case inapplicable. 'The fact that the plaintifl in the case at hal used the ordinary blank, and drew a line throngh the space intended for the name of the payee, prevents our assuming, as did the court there - and its decision was based on this assumption - that it is "the case of an inadvertent failure to complete the instrument intended by the parties." The instrument under consideration is obviously complete, in just the form the naker intended.

In my judgment, the authorities which hold a check payable to the order of an impersonal payee to he valid and negotiable control this case. I quote from the case of Willets v. The Phoenix Bank, 2 Duer (N. Y.) at page 129: "One of the ehecks was payable to the order of 1658 , the other three to the order of bills payable; and, as the required order could not in either case possibly be given, the checks, unless transferable by delivery, were payable to no one, and were void upon their face. The law is well settled that a draft payable to the order of a fictitious person, inasmuch as a title cannot he given by an indorsement, is, in judgment of law, payable to hearer. Vere v. Lowis, 3 Term R. 183; Minet v. Gibson, 1\}. 481 ; Gibson v. Minet, 1 H. Black. 569, affirmed in the House of Lords. And it scems to us quite manifest that in principle these decisions embrace the present ease. At any rate, the bank, by certifying the checks as good, is estopped from denying that they were valid as drafts upon the funds of the maker, and, consequently, were payable to bearer. The giving of such a certificate, if otherwise ronstrued, would be a positive frand."

In Werhanirs' Bank v. Straiton, 3 Abb. Dee. (N. Y.) 269, a eheck payalule to bills payalie or order was held payable to bearer, the court saying: "By naming the persons to whose order the instrument is payable, the maker manifests his intention to limit its negotiability by imposing the condition of indorsement upon its first transfer. But no such condition is indicated by the decignation of a fictitious or impersonal payes. for indorsement. under such eircumstances, is manifestly impossible: and words of negotiahility, when used in connection with such designations, are eapahle of no reasonable interpretation, except as expressive of an intention that the bill shall he negotiable without indorsement-i. $\rho_{\text {., }}$ in the same manner as if it had been made payahle to bearer." 
We must decide that the check in the case at bar, like those in the cases cited, is either altogether void, or is transferable by delivery. I submit that we should iollow those eases, and decide that it is transferable by delivery. To quote the language of Lord Ellenborough, in Cruchley v. Clarance, 2 Maule \& Sclw. 90: "As the defendant has chosen to send the bill [eheck] into the world in this form, the world ought not to be deccived by his acts."

This view of the rase compels me to notice the fact that the check under consideration is not dated. According to the weight of authority, this omission does not invalidate it. See Zane on Banlis \& Banking, § 152; Daniels on Negotiable Instruments, § 15r7; Norton on Bills di Notes, p. 40 is. note.

I think the judgment of the court below should be reversed, and a judgment entered in this court for the defendant.

Grant, J., concurrd with Carpenter, J.'

$\S 27$

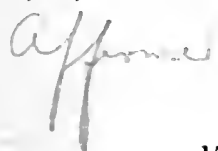

SHAI $v$. SMITH.

150 MASSACHUSETTS, 166. - 1889.

Costract by the arministrator de honis non of the estate of Frederick B. Bridgman, against the administrator of the estate of Eugene Bridgman, upon the following instrument:

$\$ 126.00$

Bezcilertown, July $19,1873$.

For value receiverl. I promise to pay F. B. Pridgman's estate. or order, one hundred and twenty-six dollars on demand, with interest annually.

Euglate Bridgman.

Witness, A. Brigiman.

Writ dated Marcl 1:3, 1.8s6. The answer set up, among other defenses, the statute of limitations.

The judge ruled that the instrument was not a witnessed promissory note, within the meaning of the statute, and was therefore barred by the statute of limitations, and foumd for the defendant; and the plaintiff alleged exceptions.

C. Aluse J. After providing that the ordinary limitation of actions of enntract shall he six years, it is enteted in the Pub. Sts. (c. $197, \S(i)$, that " none of the foregoing provisions shall apply to an artice brought upen a promissory note signed in the presenee of an attesting witness, if the action is brought by the original payer. or by his cxecutor or administrator" " and by $\S \dot{\gamma}$, such an action may be brought within twenty years. The defendint contends that the instrument surd on is not a promissory note, for want of a sufliciently definite payer, and he rites two dreisions which sustain him in this

7 It should is observed that the judgment below was aftirmed by an evenly divided court. - C. 
entention. (Lyon v. Marshall, 11 Barl). 241; Title v. Thomas, 30 Miss. 19:0)

But this would be too strict an application of the doctrine that the person to whom a note is payable must be clearly expressed. It is an equally crencral rule, that it is suffieient if there is in fact a payee, who is so drsignated that he (an he ascertained. (Story on Notes, § 36.) 'The illusfrations of the manner in which this rule has been applied are numerous. 'Thus. written promises have been held to be valid notes or hills of exchange. though made payahle to bearer, (Grant v. Janghem. 3 Burr. 1516): or to persons designated simply by their office. without naming them, e.g. the treasurer of the First Parish in 1t. or his successor in said oflice, (Buck v. Merrick, 8 Allen, 123); the trustees of a particular chureh, (Noxon v. Snith, 127 Mass. 485; Holmes v. Fuques. L. R. 1 Q. B. 376); the manager of the Provincial Bank of England. (Robertson v. Sheward, 1 Man. \& G. 511); the treasurer-general of the Royal treasury of Portugal, (Soares v. Glyn, 8 (. B. B. 1 ); the executors of the late W. B., (Hamilton v. Aston, 1 C. \& K. (659): the administrators of a particular estate, (Moody v. Threlliold, 13 Ga. 55; Adams v. King, 16 Ill. 169); the trustees acting under the will of the late Mr. W. B., (Megginson v. Harper, $2 \mathrm{Cr}$. $\$$ II. 32:). Also to the heirs of a particular person, even though that person was living at the time, (Bacon v. Fitch, 1 Root, 181; Lorkillood v. Jesup, 9 Conn. 22: : Cox v. Beltzhoover, 11 Miss. 142); to a business name adopted by the person in interest, (Bryant v. Eastman. $\{$ ('ush. 111: Brown v. Parlier, 7 Allen 33\%) : and to the steamboat Juda and owners. (Moore v. Auderson. 8 Ind. 18). So, a bill which was indorsed to a person who was already deceased was held valirl in the hands of his legal representatives. (Murray v. East India Co.. 5 P. \& Ald. 204.) More literally in point in the present case, and directly opposed to the two decisions relied on hy the defendant, are Pritior v. Bubillion. (4.5 Mich. 384), where a written promise payable to the order of .J. V. Mehling estate was held to be a good note. and Mrkimmey r. Harter, (7 Blackf. 385), which was substantially similar. See also Storm v. Stirling, (3 El. \& Bl. 832; s. c. sub. nom. ''omir v. Slirling, 6 El. \& Bl. 333); Yates v. Nash (8 C. B. N. S. $581)$ : where a promise to the officer for the time being of a society was he!l too indefinite, though the general rule as applied in other cases was recognized.

In the case lefore us, the promise was to pay to F. B. Bridgman's estate, or order. IIe was dear, and administrators had been appointed. There could be no doult that the promise was intended to be one of which the alministrators enuld avail themselves. They were in existence, and were ascertainable. If the administrators of his estate had been marle the payees. without naming them, there ean be no shadow of question that it would have been sufficient. It savors of too much 
refinement to hold that the instrument was not a valid promissory note for want of a suffieiently - definite payee.

This is the only question presented by the bill of exceptions.

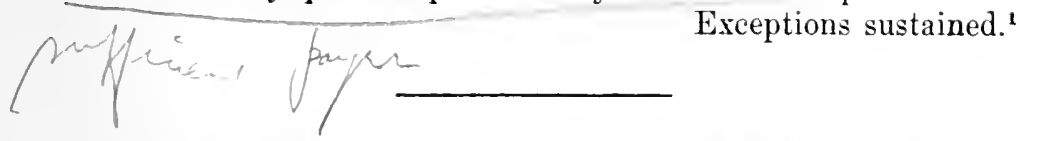

(b) Payee may be (1) one not maker, drawer or drawee.

[This is the normal case and calls for no special illustration.]

(b) Payee may be (2) the drawer or the maker.

\$27. Commonwealith $v$. Butterick, 100 Mass. 12.-1868. "Three months after date pay to the order of nyself eight hundred and fifty dollars, value received, and charge the same to the account of your oberlient servant. .J. S. Butterick. To J. S. Butterick, Sterling, Mass." [On the face]: "Payal,le at the Lancaster N. Bank, .T. S. Butterick." [Indorsed] : “J. S. Butterick." “J. M. Stevenson." Indictment for forging the name of J. M. Stevenson to a bill of exchange.

Foster, J. - "Upon principle, as well as by the authorities cited by the attorney-general, we entertain no roubt that an order for the payment of money, drawn by one in his own favor on himself, and by himself accepted and indorsed, may be treater as a bill of

1 A promissory note payable "to the order of the estate of A.." is payable to a fictitious payee where there is no such legal entity as the "Estate of A." and if negotiated by the maker is to be treated as a mote payahle to bearer. Lewisohn v. Kent \& S'tanley ('o., 87 Hun (N. Y.), 257. See Neg. Inst. L., $\$ 28$, subsec. 3. - H. ISier eriticism of this eace by Mr. Mckeehan (4) Am. Law Reg., N. S., p. 45l) and by Mr. ('rawford (Neg. Inst. Law, 3d ed., p. 21). - C.1

IIn Adams v. King, lo III. Ifig, a note parable "to the administrators of Abner ("hase. deeased." was held negotiahle on demurrer. "The geveral rule in relation to bills of exehanges and promissory notes refuires that the preson

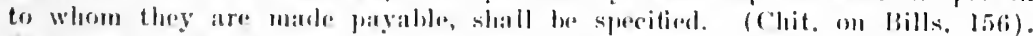
But this may be fone withoit inserling the name; for that is certain, which

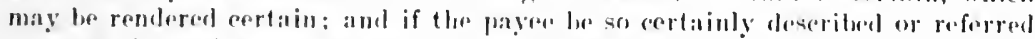

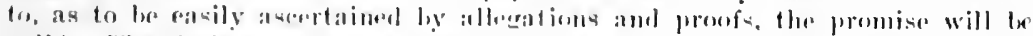

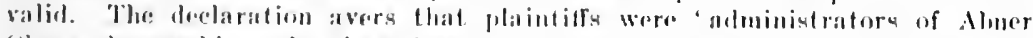
Chase, drecrased, at the time these promisses were madr: and that they were

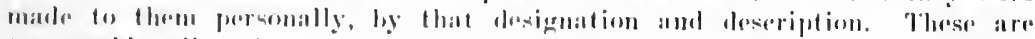

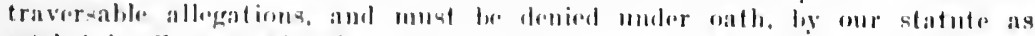

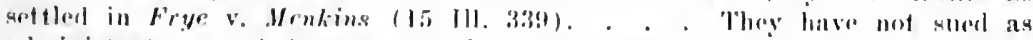
administrators. and it was therefore underssary to aior that tley were

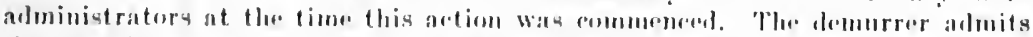
the promise to to to defomlante forsonally, by at description phraseologeg." Scates, J., at p. 170.- $\left(^{\circ} .1\right.$

A check drawn payable to a deeased person is void. $U$. S. v. f'irst Nat. BR., 82 Fid. I. $410 .-$ II. 
exchange, and so described in in indictment. Such instruments are well known in conneree; especially in the ease of nereantile firms which have branches in ditlerent rities, all composed of the same palrtners. Perhaps such a bill may also be dechared upon as a promissory note. But we arree with the court of Queen's Beneh in the latest linglish case on the question. Areviled in 185 , that "it is not mijust to presume that it was drawn in this form for the purpose of suing upon it cither as a promiseory note or a bill of exehange.' (lobyd v. Oliver, 18 (2. B. 1r1.) It is sullicient that the instrument was in the form of, and purpertul to be. a bill of exchange; and the defendant might be convicted of lorging this indorsement, if all the other names were also forged or were those of fietritious personages."

\section{(b) Payee may be (3) the drawee.}

WITTE $r$. WILLIAM.

8 South Carolina, 290. - 1876.

ACTION by indorsee agrainst drawer of a bill, drawn upon $J$. \& J. D. Kirkpatrick payable to the orter of the said J. \& J. D. Kirkpatrick and by them indorsed to plaintiff. 'The trial court held that the instrmment was not a hill of exchange and hence was open to a defense of fraud.

Moses, C. J., (after disposing of another matter). The presiding judge, without any exception to the report of the referee to the character of the instrument sued upon, holds that one of them is not a bill of exchange because drawn on J. \& J. D. Kirkpatriek, replesting the drawees to pay to their own order a certain sum of moner, while a lill of exchange presupposes a duty on them to pay io some other than themselves. 'The only anthority relied on in support of the position is found in Story on Rills, $s$ 35. With the accustomed doference that is due to so distinguisher a jurist as the late Mr. Justice Story, we are ohliged to say that the proposition is not sustainable on either principle or anthority. We are the more emboldened to say so breause, in the sane section, the learned writer thus expresses himself: "Nay, the drawer may at once become drawer, payee and drawee; as, for exanple, if he shonld draw a bill on himself, payable to his own order at a particular plawe, naming no drawee, and then should indorse it over, the indorsee might sue him as aceeptor of the bill or as maker of a promissory note, at his election." And in section 36 , he says, "the drawce and the payee may-be also one and the same person." But in Wildes 4 . Sarrge, (1 Story, 29), he lays down the rule in direct contradiction to his affimation cited by the pre- 
siding judge to sustain his own conclusion. We quote the very words of Justice Story: "The argument is that the bill is not a regular bill of exchange because it is drawn by Russell \& Co., payable to Wildes \& Co., who are the drawees of the bill. $* * *^{*}$ An instrument is not the less a bill of exchange because all the parties to it in the charaeter of drawer's, payees and drawees, are not different persons. $A$ bill drawn ly a person payable to his own order has always been deemed to be a bill of exchange in the commercial sense of the phrase, and it would not cease to be such a bill if it should be indorsed by the drawer payable to the drawee. Now, such a bill so indorsed differs in nothing smismtiatly from the present bill. In truth, where the bill is negotialile. and contains a drawer, a payee and a drawee, it is, in a commercial sense, a bill of exchange, although one or more of the varties shall fill a double character."

Mr. Chitty, in his work on Bills (page 25), says: "It is not, however, necessary that there should be three parties to a bill; there are sometimes only two: as where a person draws on another payable to his own order: and, indeed, a bill will be valid where there is only one party to it, for a man may draw on himself payable to his own order. In such rases, however, the instrument may be treated as, in legal operation, a promissory note, and declared on accordingly, but in practice it is menal to declare upon the instrument as if it were a lill not admitting the ilentity of drawer and drawee." The oljection thas taken the presing firnge to one of the bills eannot prevail, and, in conformity with our-views-herein expressed, the judgment must le set anifle-athl the case remanded to the Circuit Court for a ne': trial. It is so accordingly ordered.

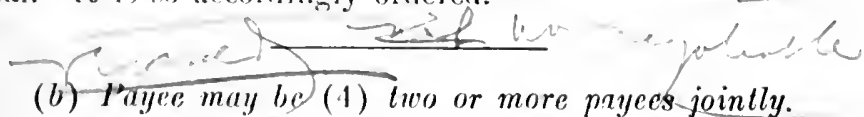

\section{$\S 27$}

(AORIOON $v$. ANDERSON.

8.3 lows, 224. - 1891 .

Ture plaintife, as assignere for value and lofore maturity of two promissory antes, exentoul by dofondants, payable "to Charlos R.

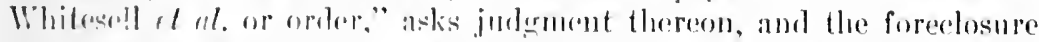

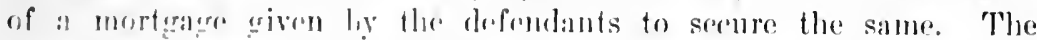

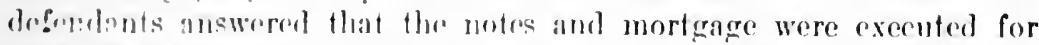
part of the rumehlase prifere of rertain real estate sold to them by Charles R., Emily. J. I., and Phobe .J., Whitesell, and for which

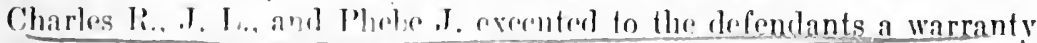
deed warrantiug the fitle to said property. The answer alleges a breach of the memants of warranty and damages in the sum of five honderel dollars. which the defondants ask as an offset against the notes. The plaintiff demurred to the answer on the ground that the

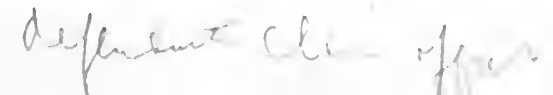


damages set up were chams agrainst the payee of the notes, and no defense arainst the notes, in his hands, The tritry-n-purehaser before nuaturity, and withont notice; and that the answer sets up no defense to said notes, as against the plantifl, he being an imocent holder for value before maturity. The demurrer was sustained, and the defendants electing to stand upon their answer, and refusing to plead over, a decree was entered for the plaintitf, from which the defendants appeal.

Gris, J. The discussion is addressed entirely to the question whether the promisory notes sued upon are negotiable. It will be observed that they are promises " to pay to Charles R. Whitesell et al. or order." The discussion is as to the construction to be given to the words " ct al.," and the effeet therenf. 'T'he words as here used evidently mean "and others." Therefore, the notes are payable to Charles R. Whitesell and others or order, without designating who the others are. To learn what qualities are essential to a negotiable promissory note, says Mr. Parsons, in his work on Notes and Bills, (page 30$)$. "we must bear in mind the purpose of the note, and of the law in relation to it. This is simply that the note may represent money, ant do all the work of money in business transactions. For this purpose the first requisite - that thing which includes all the rest - is certainty." Certainty, says the anthor, as to the person who shall receive the money, the person or persons who are to make the payment; the amount to be paid, and the time when payment is to be made. In Story" on Promissory Notes (\$35), it is said: "In instruments designed for circulation, it is of the highest importance to know to whom its obligations apply, and from whom a title can securely be derived." In Smith r. Marland, (59) Iowa, 645, 649), it is said: "The qualities essential to a negotiable promissory note are that it shall possess certainty as to the paror, the payee, the amount, the time of payment, and the place of payment." Such is the rule uniformly laid down in all the authorities and it loes not require further citations. This case must not be confounded with notes payable in the altermative, as "to A. or B.;" it is a promise to pay to Charles R. Whitesell and others jointly. Neither must it be confounder with notes payable to bearer, without maming any payee, nor with the cases in which it has been held that whoever legally owns such a note may recoser theroon. These notes being promises to pay Charles R. Whitesell and others jointly, Whitecell conld not alone transfer them so als to convey the interest of the other payees any more than if they har been named in the notes. A note made to several persons not partners can only be transferred by the joint action of all of them. (Ryhiner r. Fricliert, 92 III. 305): "and neither payee can. of course. indorse the names of the others without special authority:" (Randolph on Commercial Paper, \& 155.) 
The appellee contends that these notes are in accord with the provision of section 2085 of the Code. Turning to section 2082, we see that notes in writing, signed by the person promising "to pay to another person or his order or bearer, or to bearer only, any sum of money, are negotiable by indorsement or delivery." It will be observed that the promise must be to another person or his order or bearer, and does not dispense with the eertainty of which we have been speaking as to who that other person is. Seetion 2085 is as follows: "Instruments by which the maker promises to pay a sum of money in property or labor, or to pay or deliver property or labor, or acknowledges property or labor or money to be due to another, are negotiable instruments, with all the ineidents of negotiability, whenever it is manifest from their terms that such was the intent of the maker: but the use of the technical words 'order' or 'bearer' alone will not manifest such intent." Here, again. the promise must he to another, and there is nothing in the section to modify the rule requiring certainty as to who that other is. It is true, as contended, that negotiable instruments may be transferred by indorsement or delivery; but that does not aid us in determining whether these particular instruments are negotiable. It is said that charles R. Whitesen is the only payee named. That is true, but the notes show that he is not the only person to whom payment is to be made. If it be true, as alleged in the answer, that the other persons named, together with Charles R., are in fact pavees of the notes, then, surely, Charles $R$. is not the only payee, and could not alone transfor them Anthorities are cited in support of the elaim that, if any words are used which indirate that the maker intended that the notres shomld be nocotiable, the law will give offect to that intention, as against him. It is a sufficient answer to say that, in view of the law whirh requires certainty in negotiable instruments as to who the payee is, the fact that it is left uncertain rather indieates an intention that the insirument should not be negotiable.

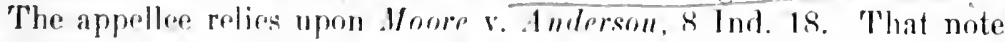
was payable to strambont Jula and owners, and the eourt hold that the word "owners." ats it urenrred in the note, sulficiently indirated a person, within the intent of the law. It is a familiar mole that, when a persen is designated as payen, and a punstion arises as to who of several persons bearing the same designation was meant, evidenee is

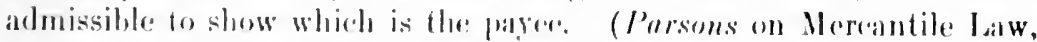
88.) Conder this mole it was admissible to show who was the owner of the steamboat, and leneer the designation was sufliciont. In Gromt v. Vaughan (3 Bulrows, 15lii), it is hold that a mote payalble "Io ship

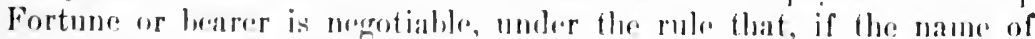
payee he not the name of a preron, as if if he the name of a ship, the

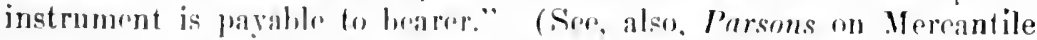

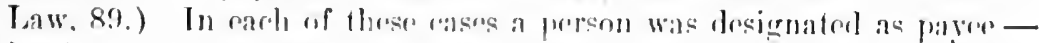
in the one as the owner of the steamboat Juda; and in the other as 
bearer. These notes are payahle to Cliarles R. Whitesell and others or order. "The others are mot designated hy name or otherwise, and, therefore, it is uncertain "as to the prersuns who shall receive the money," uncertain " to whom its ohligations apply, and from whom a title can securely" be derived."

We think the l)istrict ('ourt erred in sustaining the demurrer to the answer.

Reversed.

(b) P'ayee may be (5) one or some of several payees.

19 LlinoIs, $81 .-1857$.

Denurrak to declaration overruled, and judgment for plaintiff.

Catos, C. J. The declaration in this case was upon an instrument purporting to be a pronissory mote, payable to "Olive Fleteher or li. H. ()alkes," in an action bronght by Oakes. 'The declaration was demurred to, the demurrer overriled, and judgment rendered in favor of the plaintill below. This was erroneous. The instrument sued on was payalile in the altrinative to one or two persons, and for that reason is not a promissory note, and could not be sued on as sueh. It is indispensable to a promistory note that it not only must be for a sum certain, and payable at a certain time, and withont condition, lut it must also lor payable to a certain preson, either specified on the face of the note. of who may he cortainly identified by extrinsic proof, not ineonsistent with the face of the note, as assignee or bearer. Here the promise was to pay Fletcher or Oalkes, but which, is uncertain: which of them hat the right to receive the pay is not specified. and the legal right to the money is not vested in either. But this is a question of law too well settled lye the books to require discussion. and I will only refar to story on Prom. Notes (p. 40). The peculiarity of the note sined on was no donbt overlooked by the Cirenit Court.

The jullunant must be reversed.

Judgment reversed 2

2 "Mr. Crawford illustrates the meaning of this subdivision by the following "xample: 'A draft palyable to $A$, $B$, and $C$, or either of them or any two of thrm.' ('rawforl. p. 20. If this illustration correctly interprets the meaning of this suldivision - and $.11 \mathrm{r}$. ('rawford's comstruction is entitled to great consideration - the existing law has ben changed because the statute recognizes an instrument payalile to two payees in the alternative as negotiable whereas, under the law inerchant an instrument payalue to two persons in the alternative iq not negotialse. Musselman v. Oakes, 19 Ill. 81 ; Carpenter v.

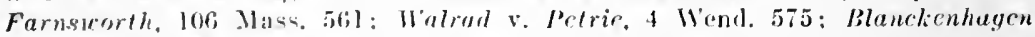
v. Blundell, $213 . \&$ Ald. 417. Put se Watson v. Evans, l Hurl. \& Colt. 663; Spaulding r. Erans, 2 Wrlean, 139, Fad. Cas. 13.216; Rerord v. Chisum, 25 Tex. 348." Bunker's Neg. Inst. Law, p. 48. - C. 


\section{§27 WATSON, SOUTHERN AND MAYER $v$. EVANS.}

\section{Herlstune \& Coltagan (Excif.) 662. - 1863.}

Declafation. That the defendant and William Patrick Evans and George Thomas Evans, on, etc., made their joint and several promissory note in the words, letters, and figures, following, and as follows, that is to say:-

$£ 100$.

Leamington, Dec. 2d, 1858.

On demand, we jointly and severally promise to pay Messrs. Joseph Watson, Thomas Southern, and Daniel Mayer, or to their order, or the major part of them, the sum of one hundred pounds, with lawful interest, for value received.

GeORge EvaNs.

William Patrick Evans.

George Thomas Evans.

That the said makers, by the said names following in the said note contained, that is to say, Joseph Watson, Thomas Southern, and Daniel Mayer, meant the plaintiffs; but the defendant and the said other makers did not, nor did either of them, pay the said note.

Demurrer, and joinder therein.-

Hayes Serjt. (C. E. Coleridge with him), in support of the demurrer. The document is void for uncertainty. Is the money to be paid to the three payees, or any two of them? Again, do the words "or the major part of them" refer to the parment or the indorsement, or to both? [РоLLock, C. B. - Is it not a promise to pay to the three persons or their order, or the order of the major part of them?] Suppose two of them said "pay to us; " and the other said "pay all three." If two alone sued, conld the maker plead in abatement the non-joinder of the third? Assuming that the promise is to pay all three provided they agree, if not to pay any two of them, suppose they all disagree, and each says, "Do not pay to the other." [ManTix, B. - Payment to one of several joint ereditors is a payent to all.] The general rule of law is qualified hy the express works of the contract. In buyley on Bills, (p. 34, 5th ed.), it is laid down that "uncertainty as to the person to whom the payment shall be made will prevent the document from heing a hill or notr: as making it payslole to $A$. or $13 . "$ "The anthority there cited is Blsmelenhengen v. Blundell. (2 B. \& Ald. 41\%). where Abbott, C. .J., and Holpovil, .J., agreed that such a document cannot he a promissory mote within the statute 3 and 4 Anne, e. 9, the promise being conditional. to pay $\Lambda$. only if the maker had not paid B. Jourers, B. - Here the three payers are suing, which dis-

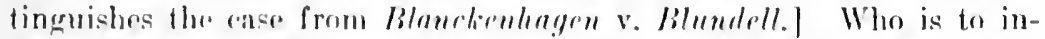
dorse the notes, the three or any two of thems? JMatron, B. - The words "or to their order, or the mijor part of them." mean the order of all three or of any two of them. "The worls "or the major part of them," must refer to the last antecedent ordor. WiLbs, B. - It is "I 
promise to pay to all three or their order, but I allow any two to sign for them all." If the indorsenent maly he made by the three, or any iwo of them, Blanckenhagen r. Blundell is an anthority that the doenment is not a promissory note within the statute 3 and 4 Anne, e. 9. [M.MTix, B. - There eannot be any doubt in this ease, as the three parees are suing. In the Anthor's life, prefixed to the 9 th edition of Noy's Maxims by Bythewood, p. viii., the following aneedote is related: "Three glaziers at a fair left their money with their hostess while they went to market: one of them returned, received the money and absconded: the other two sued the woman for delivering what she received from the three hefore they all came to demand it together. 'The cause was clearly against the woman, and julgment was ready to be pronounced when Mr. Noy, not being employed in the cause, desired the woman to give him a fee, as he could not plead in her behalf unless he was employed: and, having received it, he moved in arrest of judgment that he was retained by the defendant, and that the ease was this: the defendant had reeeived the money from the three together. and was not to dehiver it until the same three demanded it; that the money was ready to be paid whenever the three should demand it together. 'This motion altered the whole proceedings."]

Wellish appeared for the plaintiffs but was not ealled upon to argue.

Per Curiay. There must be judgment for the plaintiffs. Judgment for the plaintifis.

$\S 27$ Noxon v. Surti, 127 Mass. 485. - 1879. Soule, J. The instrument sued on is properly described as a promissory note. 'Though it purports to be payable to "the trustees of the Methodist Episcopal Church or their collector," the payee is not therefore uncertain, and the instrument does not come within the elass of cases in which instruments otherwise in the form of promissory notes are held not to be promissory notes because made payable in the alternative to either of two persons named. (Osgood v. Prarsons, 4 Gray, 455.) 'That rule applies to eases in which. so far as the instrument shows, the two persons named as alternative payees are strangers to each other. It does not apply when the instrument discloses the fact that one of the two persons named is named as agent for the other to receive the money. (Iolmes v. Jaques, I. R. 1 Q. B. 3\%6.) In the ease at bar, it is evirlent that "their collector" is merely a person anthorized by the payee to receive the money in its behalf. ${ }^{3}$

3 A note payable "to $M$. K. or heirs," is sufficiently definite as to the payee. Knight v. Jones. 21 Mich. 161. Put not one payable " to C. W. et al." Gordon v. Anderson, $83 \mathrm{Ia}$. 224 ; ante, p. 115. - $\mathrm{H}$. 
(b) Payee may be (6) the holder of an office for the time being.

6 NEW YORK, 124. - I851.

ACtion on promissory notes payable to "Joseph M. White, Charles A. Davis, and Louis McLane, trustees of the Apalachicola Land Company, or their successors in office, or order." Judgment for plaintiffs.

Gardiner, J. The first objection presented by the pleadings on the part of the defendants is, that the written instruments set forth in the declaration are payable to the trustees therein named or their successors in office, and that the uncertainty as to which of the two the payment is to be made invalidates them as promissory notes, though not as agreements.

I am unable to perceive any such contingency in the contracts. If the plaintiffs are to be considered as the representatives of a corporation, and the suit instituted for the benefit of their principal, the payment must be made to them, as trusees. If their term of office expired before the commencement of the suit, then, and in that event only, would a right of action enure to their suecessors. There never was a time, consequentt. Then the maker of the notes could discharge himself by a payment made at his election, to these plaintiffs, or their successors.

The term successors, implies nne who takes a place that another has left.

It might be as reasonably contended, that the payee was continrent. where a note was made payable to $A$. or his excentors, or administrators, etc.

It has been determined that an undertaking to pay C. or D., or his or their order, is not a promissory note, because payable to either of the payees, and that only on the contingency of its not being paid to the other. (S'lory on I'rom. Notes, $\S 3 \% ; 4$ Wend. 575; $2 \mathrm{~B} . \&$ Ald. 41\%) The distinction between those ases (even if the doctrine therelyy estabished is sound) and the present, is, that the enntingeney in them was applarent on the face of the instrument. Here there was no uncertainty in the contrat, when the notes were made, or became payable; the ambignity, if any, would arise from a change of trustees after the notre took effect as a pereecter entract.

Secondly. If the plaintiffs were not the representatives of a eorporation, as the drfendant insists, they rould sustain the action in their nwn name: the word "trustees," would le merely a designation of the persons, and the phrase "their suecessors," may be rejected as surplusage. It has beren decider that a note payahle to a trustee, or agent, or executor, will maintain a suit in the name of the person mentioned. (3) Harrington, 385: 3 Mass. R. 103; 2 Eng. [Ark.] R. 382. And see 9. John. 334: 8 Cowen, 31, and cases there 
cited. I think, therefore, that these contructs are promissory notes, and consequently metiable.

A majority of the court concurred in the foregoing opinion.

Foot, I., dissented, on the ground that the instruments declared upon were not promissory notes, there being a contingency as to the persons to whom payment was to be made.

Judgment affirmed.
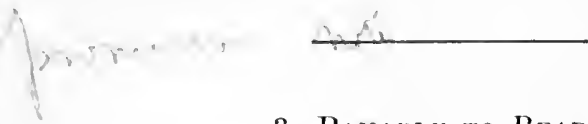

3. Payable to Bearkr.

(a) Payable to person named or bearer.

PUTNAM $v$. CRYMES.

1 McMullaN's law (S. C.) 9. -1840.

Tre plaintiff in this ease was not the original payee, but held the note by transfer to himself-by delivery. The note was made payable to Maneil Owens or holder; the plaintiff declared as holder, and defendants demurred on the ground that the holder could not sue without a written assignment. I regarded holder as synonymous with bearer and overruled the demurrer. Appeal by defendants on the grouml that the demurrer should have been smstained.

Curia, per Butuen, J. The word bearer is msually inserted in a negotiahle note, transferable by delivery. But without it, the maker of a note may make it transferable by delivery, either by cireumlocution, or using a word of precisely the same import. $\Lambda \mathrm{s}$ if a note were made payahle to $\mathrm{A}$. B. or to any one to whom he may deliver it; or to any one who might hold the same by delivery. In both cases the bearer would be sufficiently meant and designated, although the word was not used. If it was the intention of the maker to make it payable to any one who acquires possession by delivery, he has no right to complain when it is presented to him without a written transfer. Holder is a word of the same import as bearer, and both may acquire a title by lawful delivery, according to the terms of the contract. All the law requires is, that the paper must have negotiable words on its face, showing it to be the intention to give it a transferable quality by delivery otherwise the instrument must be transferresl by written indorsement, if payable to order; or sued on by the original payee, if thre are no negotiable words at all.

The decision below is affirmed t the whole court concurring.

4A bill or note payable "to hearer." or "to A. or bearer," is negotiable by delivery without indorsement. Piere v. Crafts, 12 Johns. (N. Y.) 90 ; Truesdell v. Thompson, 12 Met. (Mass.) 565. Sce Neg. Inst. L., § 60, post. - H 


\section{(b) Payable to order of fictitious person.}

46 Ohнo STate, 512. - 1889.

Action by plaintiff to recover $\$ 450$ due her on a deposit. She had drawn a check on defendant hank payable to "Williain Brown," who was represented to her by one Grimes to be an actuat person, and had delivered it to Grimes who procured it by fraul. Grimes indorsed on it the name "Millam Brown "and defendant, after prudent inquiry as to Grimes' identity, paid it. "William Brown" was a fictitious person. Judgment at Common Pleas for plaintilf; reversed at Cireuit. Plaintiff appeals from judgment of reversal:

Minsinal, C. J. This case is in its general features analogous to that of Dodge v. The National Exchange Bank, (20 Ohio St. 234), and should, we think, be ruled by it.

The fact that the chick was made payable to a person that had no existence does not alter the rights of the plaintiff as against the bank, for she supposed that Brown was-a-pent person, and intended that payment slonld be made to such person. The doctrine that treats-a cleoper tritt matc payable to a fictitious person as one made payahle to bearer, and so negntiahle without indorsement, applies only where it is so drawn with the knowledge of the parties. (Tatloch v. IIarris, ?3 T. R. 1\%t, 180: I'ere v. Lewis, Id. 182; Minet v. Gibson, ld. 481 : s. C., in the House of loords on error, Gibson v. Minet, 1 H. IBl. iri9: Collis v. E'mett, 1 H. Bl. 313 : Gibson v. IIunter, 2 H. Bl. 15\%.) The oloctrine that a hill payalule to a fictitious nerson or order, is equivalent to one payable to bearer, had its origin in these eases, which all grew out of hills drawn ly Levisay \& Co., bankrupts, payalle to a fictitious person or order. and were accepted by Cibson \& Co.; lut it will be noticed that the holding in each ease was upon the express ground, that the arecptor knew at the time of his acceptance that the hill was payalite to a fictitions person: and but for this fact the fictitions indorsment wombl have hen held to be a forgery - some of the jurleses expressing a doult whether it was not so, although its character was known to the aceptor. (3 T. R. 181.) These cases will he fomml reviewed in a note to Bemnett v. Farrcll (1 Camph. 130). It was held in this case that a bill made payable to a fictitious person or orter, is neither payable to the order of the trawer or bedrer, bit is comptetcty vold. But in an addendum to the case (at page lsoe of the report). Iord Ellenborough ohserves that this holding must be taken with this qualification: "unless it can be shown that the eiremetanes of the payee being a fictitious person was known to the arreptor." The rule with this qualification is staterl as the law in Piyles on Bills, 73. (Soe also, to the same effect, Forbes v. Lespy, 21 Ohin St. 483; 1 Rand. Com. Paper, 
\$ร 16:, 163, 164: 2 Parsons N. \& B. 591, and note a.) Mr. Daniel, in his work on New. Inst. (sere. 139), states the rule to be general, but, as shown hy Mr. Ramblph, the cases do not bear out the text. (1 Rand. Com. Paper, \$ 16.1 , note 4.) And upon prineiple we do not see how the law eould he held to be otherwise. For if the fictitious character of the payee is unknown to the drawer, whoever indorses the papere in that name with intent to defrand, perpetrates a forgery and the indorsement is void, a general intent to defraud being sufficient to constitute the oflense.

l'The court here disensses and distinguishes Lane v. Krekle, 22 Iowa. 399: Phillips v. Im T'hurn, 18 C. B. N. S. 694; Rogers v. Ware, 2 Neb. 29: Ort v. Fowler, 31 Kans. 4;8.]

If the drawer of a check, acting in good faith, makes it payable to a certain person or order, supposing there is such a person, when in fact there is none, no good reason can be perceived why the banker should be excused if he pay the eheck to a fraudulent holder upon any less precautions, than if it had-becn made-payable to a real person; in other words, why he should not be required to use the same precautions in the one case as in the other; that is, determine whether the indorsement is a genuine one or not. The fact that the payee is a non-existing person does not increase the liability of the bank to be deceived by the indorsement. The fact is that an ordinarily prudent banker would be less liable to be deceived into a mistaken parment by a fietitions indorsement such as this was, than hy a simple forcrery." The determination of the character of any indorsement involves the ascertainment of two things: (1) the identity of the indorser: and (2) the genuineness of his signature: and no careful banker would pay upon the faith of the genuineness of any name, until he bad fully satisfied himself hoth as to the identity of the person and the genuineness of his signature. Now, a careful hanker may be deceived as to the signature of a person with whose identity he may be familiar; but he is less liable to be deceived where both the signature and the person whose signature it purports to he, are unknown to him. In making the inquiry required in such case to warrant him in acting, he will either Icarn that there is no such person, or that no credible information can be obtained as to lis cxistence, which, with an ordinarily prudent banker, would be the same as actual knowlerlge that there is no smeh person, and he would withhold payment, as he would have the right to do in such case. But still, if he should be deceived as to the existence of the person, he would, nevertheless, require to be satisfied as to the genuineness of the signature. Of this. however, he conld not be through his skill in such matters and on which bankers ordinarily rely, for he would he

s Followed on this point by Jordan Marsh Co. v. National Shawmut Bank, 201 Mass. 397, 409. - C, 
without any standard of comparison, and he could have no knowledge of the handwriting of the supposed person, for there is no such person. So that, if lue acts at all, it must be upon the confidence lie may place in the hnowledge of some other person, and if he choose to act upon this, and mike, instead of withholding, payment, he acts at his peril and must sustain whaterer loss may ensue. It is a saying frequently repcated in "The Doctor and Student," that "he who loreth peril shall perish in it." In other words, where a person has a safe way and abandons it for one of uncertainty, he can blame no one but himself if he meets with misfortune.

Judgment of the, Cirenit Court reversed, and that of the Common Pleas affirmed. ${ }^{6}$

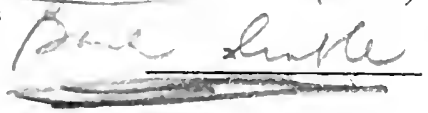

\section{$\S 28$ BANK OF ENGLAND $v$. TAGLIANO BROTHERS.}

\section{R. 1891, Appeal Cases (H. L.) 107.}

Plaintiffs carried on a large business in London as foreign bankers. Vucina, a bauker in Odessa, Russia, had had for twenty-nine years constint busines -relatious with plaintiffs and his bills on plaintiffs were each year numerous and in the aggrecate for very large amounts. On several oceasions Vucina had drawn them to the order of C. Petridi \& Co., a firm doing husiness in Constantinople.

Glyka was one of plaintiffs' clerks and harl charge of the correspondenee with persous residing in Russia. He forged the signature of Vucina to bills purporting to he drawn on the plaintiffs by Vucina to the order of C.-Petridi \& Co., aml resembling those which Vucina was in the habit of drawing on the plaintiffs, and placed among the plaintiffs' correspondence counterfeit letters of advice with respect to these bills recembling those orlinarily received from Vucina. By these means Gilyka procured the gemuine acepptaness of the plaintiffs to the bills which he had forged. Ho then forged on the hills indersements purporting to tie those of C. Petridi \& Co.. the payeres named therein, and was paid by the defondants across the combtor the amounts for whiclu the bijls were drawn

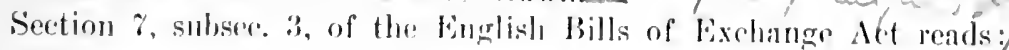

"Aecord: Shipman \&. Bank, 126 Y. Y. 31S. So dischusim of this case in

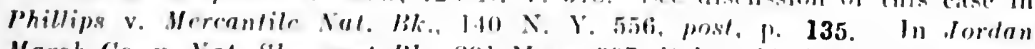
Marsh Co. v. Xat. Showmul BH., gol Mass. 397, it is sain that "The ease of Shipman v. Bank, $126 \mathrm{~N}$. Y. 318 , is almost irlentieal in its leading foatures with the cate lofore us, and the derision of it fully covers the conclusion which we have reaclierl." P. 110.

Ser also Boles v. Harding. 201 M:194. 103, anl Sienhoard Nat. Bk. v. Bk. of A merica, 193 S. Y. 26 , reported in 22 J. N. S. 499 with note. Extracts from this note will be found printed herein at $\mathrm{p}$. 141. - $\mathrm{C}$. 
"Where the payee is a fictitious or non-existing person the bill may be treated als pisyable to bearer." "

l'aintills now seck to recoser from the defomlants the amounts so paid, alleging that they were wronghully and withont their anthority dehited to their aceount.

(ase tried hefore Cunsibs, d., without a jury, who found for the plaintilfs. ?: Q. B. 1). 103. This judgment was affirmed by the Court of Appeal (23 Q. B. D. 243), and the defendants thereupon appealed to the llouse of Lords.

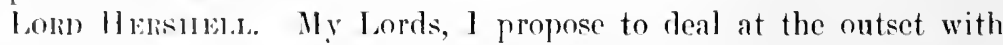
the guestion of the construction of the Bills of Exehange Act, which gave rise to a difference of opinion in the cont below. * * *

The conchsion at which the majority of the Court of Appeal arrived with reference to the construction of the sub-section of the Bills of Exchange Act with which your Lordships have to deal is thus stated: "The worl 'fictitious' must in each case be interpreted with due regard to the person agranst whom the bill is songht to be enfored. If the drawer is the person against whom the bill is to be treater as a bill pilyalle to bearer, the term 'fietitious' may le satisfied if it is fictitious as regards himself, or in other worls, fictitious to his knowledge. If the olligations of the acceptor are in question, and the acceptor is the person against whom the bill is to he so treated. "fictitions' must mean fictitions as regards the aceptor. and to his knowledge. Such an interpretation is based on gond sense and solnd commereial prineiple."

The conclusion thus expreseed was fonnded upon an examination of the state of the law at the time the Bills of Exchange $\Lambda$ ct was paseed. The prine authorities were suljected by the learned judges who coneurred in this conclusion to an claborate review, with the result that it was establiched to their satisfaction that a bill made payalle to a tictitious persom or his order was, as against the acceptor. in collect a bill payable to hearer, only when the aeceptor was aware of the ciremstance that the payere was a fictitious person, and further, that his liability in that case dependerl upon an applieation of the law of estoppel. It appeared to those learned julges that if the exception was to le further extended, it would rest npon mo principle, and that they might well pallse hefore holding that see. $\%$, sub-see. 3, of the stature was "infroderd not merely to codify the existing law, but to alter it and to introdue so remarkable and unintelligible a change."

My Irrids, with sinerere respect for the learned juderes who have taken this view. I rannot bring myself to think that this is the proper way to dral with such a statute as the Pills of Exchange Act, which was intended to lis a ende of the law relating to negotiable instrmments. I think the proper enures is in the first instanes to examine

7 Notice the diffrrent rearling of the Neg. Inst. Law, \& 28, subd. 3. - C. 
the language of the statute and to ask what is its natural meaning, uninfluenced by any considerations derived from the previous state of the law, and not to start with inquiring how the law previously stood, and then, assuming that it was probably intended to leave it unaltered, to see if the words of the enactment will bear an interpretation in conformity with this view.

If a statute, intended to embody in a code a particular branch of the law, is to be treated in this fashion, it appears to me that its utility will be ahnost entirely destroved, and that the very object with which it was enacted will be frustrated. 'The purpose of such a statute surely was that on any point specifically dealt with by it, the law should he ascertained by interpreting the language used instead of, as before, by roaming over a vast number of authorities in order to discover what the was, extracting it ty a minute eritical examination of the prior decisions, dependent upon a knowledge of the exact ellect even of an obsolete proceeding such as a demurrer to evilence. I an, of course, far from asserting that resort may never he had to the previous state of the law for the purpose of aiding in the construction of the provisions of the cole. If, for example, a provision he of doubtful inport, such resort would be perfectly legitimate. Or, again, if in a code of the law of negotiaf ble instruments words be found which have previously acquired a technical meaning, or been used in a sense other than their ordinary one, in relation to such instruments, the same interpretation might well be put upon them in the corle. I give these as examples merely; they, of course, do not exhanst the eaterory. What, lowever, I am venturing to insist upon is, that the first step taken slould be to interpret the language of the statute, and that an appeal to earlier decisions can only he justilind on some special gromomd.

One further remark I have to make before I proeecel to ensider the langulage of the statute. The Bills of Exehenge Aret was eertainly not intenderel to be merely a corle of the existing law. It is not open to gunestion blat it was intemderl to altere and did alter it in certain respects. And I do now think that it is to be presumed that any partionlar provision was interided to bo a statement of the existing law, rather than a substituterl malelment.

'Turning now to the words of the sult-section, I eonfess they appear to me to he free from ambignity. "Where the parese is a tietitions or non-existent person" means, surely, alecopling to ordi. ary canons of eonstruction, in erery case where this call, as a matter of fact, be predieated of the paree.

I can fond no warrant in the stafute itself for inserting any limitation or enditions. I am putting aldide for the present the guestion by whom a bill answering the deseription of the sub-section maty be

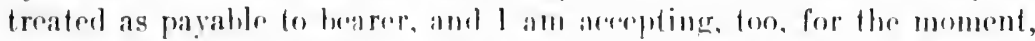
the meaning attributed by the majority of the court of Appeal to 
the word "fietitious," viz., a creation of the imagination, confining myself to the question in what ases a bill purporting on the face of it to be payable to order may be treated as payable to bearer. I fiml it impossible, withomt doing violence to the language of the statute. to grive any other answer than this:- In all cases in which the paree is a fictifious or non-existent person. The majority of the Court of Appeal read the section thus: Where the payee is a fictitions or non-existent person, the bill may, as against any party who hatl knowlerge of the fact, he treated as a bill payable to bearer. It seems to me that this is to add to the words of the statute and to insert a limitation which is not to he found in it or indicated by it. It is said that when the acceptor is the person against whom the bill is to he treated as payable to bearer, " fictitious' must mean fictitious as regards the acceptor, and to his knowledge." With all respect, I am unable to see why it must mean this. I confess I cannot altogetler follow the meaning of the words fictitious "as regards" the aceeptor. I have a difficulty in seeing low a payee, who is in fact a "fictitions" person in the sense in which that word is being used, (an be otherwise than fictitions as regards all the world - how such "payce can be "fictitious" as regarils one person and not another. The truth is the words, "as regards" the acceptor, are treated as equivalent to the words, "to the knowledge of" the acceptor. But I do not think these expressions are synonymous. It seems to me that to import into the statute after the words "fictitious persor" the worls "as regards" the acceptor or drawer, as the case may be, and then to interpret those words as meaning " to the knowledge of," only tends to obseure the fact that the condition that the payee must be fictitious to the knowledge of the person sought to be charged as upon a bill payable to bearer is being introduced into the enactment.

For the reasons I have given I find myself compelled to the conclusion. notwithstanding my respect for those who have expressed a contrary view, that in order to establish the right to treat a bill as payale to liearer it is enough to prove that the payee is in fact a fictitious person, and that it is not neressary if it be sought to charge the acceptor to prove in addition that he was cognizant of the fictitious character of the mavee.

Iy Lords, if the conclusion which I have indicated as being, in my opinion, the sound one, involved some absurdity or led to some manifestly unjust result, I might perhaps, cven at the risk of straining the language used, strive to put some other interpretation upon it. But I cannot sue that this is so, or that the interpretation I have adopterl does any violence to fond sense, or is otherwise than in accordance with soind rommercial principle. I will assume that as the law stood at the time the Bills of Exchange Act was passed, a bill drawn to the order of a fictitious payee could have been treated 
as a bill payable to bearer only as against a party who knew that the payee was fictitious. This decision even was arrived at little inore than a century ago, and was dissented from by distinguished judges, and it is obvious from the observations of Lord Ellenborough in I'rnnett $\mathbf{\nabla}$ Farnell (1 Camp. 130, 180, c.) that hy some eminent lawyers at least it was regarded rather as a departure from strict principle, which onght not to be further extended than as an embodiment of sound commercial principle.

But is it impossible to take any step beyond this without violating sound principle and working injustice? Let me draw attention for a moment to the relative position and rights of the drawer and aeceptor of a bill of exchange. A drawee who accepts a bill does so either because he has in his hands moneys of the drawer, or expects to have them before the bill falls due. or because he is willing to give the credit of his name to the drawer, and to make him an adramce by payment of his draft-It-is-immaterial to the acceptor to whom the drawer directs him to make payment; that is a matter for the choice of the drawer alone. The acceptor is only concerned to see that he makes the payment as directed, so as to be able to charge the arawer. It is in truth only with the drawer that the acceptor deals; it is at his instance that he aceepts; it is on bis behalf that he pays; and it is to him that he looks either for the funds to pay with, or for reimbursement if he holds no funds of the drawer at the time of payment.

In the ordinary case, where the payee designated in the bill is a real person intended by the drawer to receive payment, either by himself or hy some transferee, the acceptor can only charge the drawer, if he pays the person so designated, or some one deriving title through him. If payment be made to any other person. the drawer's liahility on the bill is not discharced by payment: he will or may remain liable to the real paree. or those claiming under him, and the acceptor having paid otherwise than arecording to the directions of the drawer cannot justify the use of his funds in making the payment, or claim to be reimbursed by him. But now suppose the drawer insorts as payee the name of a fictitious person, recquests the drawe to alcept a bill so drawn, indorses the payeces name, and puts the bill into circulation. II cortainly intended it to ohtain conrency and to be paid at

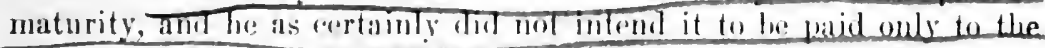
payce named, or some one doriving title flurongh lim. Nor, as it

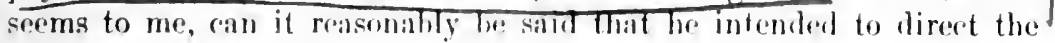
drawee to pay such person and sum persom only.

What then is the position of a lawful holder of a lill so diburu?

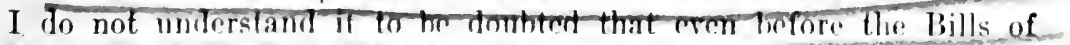
Exchange A.t silch a boder cont it enfore payment of the bill agilinst the drawer, for he not merely knew thit the parper designited was a fietitione person, hut was himcilf tler antline of the fiction. As against the drawer then such a bill conld be treated as payable to bearer. 
But if it eamnot be so treated as against the acceptor, the holder, who, it mily he, bought or diseomuted it on the faith of the acceptance, relying on the eredit of the anceptor, and mowilling to trust to that of the drawer alone, is deprived of that upon which he relied, and of the liabilits which he rexpaldol as his security for payment. The holder in sueli a ease sullers wrong. Would any injustice result if the bill conld, as agrainst the aceptor also, be treated as payable to bearer? 'The drawer must he taken to have intended the hill to be paid by the acteptor at maturity - hut to whom? Not to the fictitious payee, or some one claming through him. Why not then to the bearer, who can hold the drawer liable npon the bill, and treat it as payable to lim? And if it were the law that the acceptor was bound in such a ease to paly the bearer, who would suffer? Not the drawer, for payment would have been made to a person who could compel him to make parment, and he conld have no ground for complaint if the acceptor used his funds in thus discharging his liability on the bill, or in case he had not provided such funds if he were held liable to reimburse the acceptor. And how would the acceptor suffer in such a case? It was his object in accepting the bill to render himself liable to make palment to the person intended by the drawer to receive it, either ont of moneys provided by him, or looking to him for reimbursement. His position under such circumstances would be preeisely-what it would have heen if he had made payment to a real person designatel as payee, or to those claiming under him. And it might. I think, fairly be said that he was making the payment in accordance with the intention of the drawer.

It may be that the right of the holder to treat such a bill, as against an acceptor ignorant of the fictitions character of the payee, as a bill payille to bearer, could not be established merely by an appeal to the law of estoppel, and that such estoppel would exist only against the drawer who knew that the payee was a fictitious person. I will assume that this was the law prior to the recent statute. But why should not the Legislature have intervened with a positive enactment imposing this liability upon the aceeptor - an chactment which, it seems to me, would wrong no one, and would frevent a holder for value from suffuring wrong? Estoppel is not the only somed principle mpon which a liw can be based.-The law of troppet not thought to ifford sufficient protection to those dealing with the apparent owner of goods. The Legislature deemed it necessary to intorvene, and the Pretors Acts were passed, each of which added something to the protection of persons so dealing. Why, then. should it be thought improbable that the Iegislature should have created in the loller of a bill drawn payable to a fictitious person a new sight against the acceptor? If I am eorrect in thinking that this adrlerl right would olsviate and not entail injustice. that it would make the law more reasonable and bring it 
more into conformity with the course of commercial transactions, I can see no reason for doubting that the Legislature so intended, if this be the plain, natural meaning of the words they have used, or for endeavoring so to construe the language as to find in it no more than a statement of the previous law.

Even assuming, it is said, that where the payee is a "fictitious" person the bill may be treated as against the acceptor as a bill payable to bearer, the word "fictitious" is only applicable to a creature of the imagination, Faving no real existence, whilst in the present case " $\mathrm{C}$. Petridi and Company" was the name of a firm lraving a real existence, so that the payec here cannot be termed a fictitious person.

[After discussing this proposition at great length the court concludes:]

It seems to me, then, that where the name inserted as that of the payee is so inserted by way of pretence only, it mar, without impropriety, we suid that the payee is a feigned or pretended, or, in other words, a fictitious person. Stress was laid upon the fact that the words of the statute are "where the payee is a fictitions person," and not "where the payee is fictitious." There is not, to my mind, any substantial difference in the meaning of the two phrases; and I cannot think that the Legislature intended the rights and liabilities arising upon mercantile instruments to depend upon nice distinctions such as this.

* * * I have arriver at the conclusion that, whenever the name inserted as that of the payee is so inserted by way of pretence merely, without any intention that payment shall only be made in conformity therewith, the paree is a fictitious person within the meaning of the statute, whether the name be that of an existing person, or of one wh lais no existence, and that the bill may, in each ease, be treated Ty a lawful holder as payalle to bearer.

Iords Hal $f^{*}$ iny, Watson, Bramwell, Macnaghten, Morris, Field, and the Earl of Sellowrne, also delivered opinions.

Judgments of the Court of Appeal and of the Queen's Bench Division reversed and judgment entered for the defendants with costs here and below; cause remanded to the Queen's Bench Division.

\$28 MACBETH $v$ NOR'TH AND SOUTH WALES BANK.

One White, by falsely representing to the plaintiff that he had agreed to purchase from a wan named Kerr-gertain shares then held by Kerr in a company, and that he had arranged to resell the shares at a profit, 
induced the plaintiff to agree to assist him in financing the transaction. For this purpose the plaintiff drew a check on the Clydesdale Bank payahle to Kerr or order tor the amount of the purchase money, which was delivered to White in order that he might hand it to Kerr in payment for the shares. White forged Kerr's indorsement to the check, and paid it into his own account with the defendant bank, who credited him with the amount, and collected the money from the Clydesdale Bank. White had not agreed to buy any shares from Kerr and Kerr had at the time no shares in the eompany.

The plaintifl"s claim was for damages for the conversion of the check or alternately for money had and received to the plaintiff's use.

BraY, J., read the following judgment:

The plaintiff was told that Kerr was an engineer formerly living at Bootle, but then near Manchester. That was true. He was told that Kerr had agreed to sell the 5,000 shares to White. That was untrue, and he in fact held no shares. 'There had been no such transaction, but the plaintiff believed the statements made to him, and made the cheque payable to Kerr in order that he and no one else should get the money. Can Kerr, under these circumstances, be said to be a fictitious payee? I will first examine the authorities. In Vinden v. Inghes, [1905] 1 K. B. 895, the facts were, in my opinion, indistinguishable from the present case. Vinden had a real person in his mind when he drew the cheque, althongh in fact the payee was not his creditor, as he supposed, and had had no trausaction with him giving rise to such a deht. He had been deceiver by his elerk, but he intended the payee and no one else to receive the money. Warrington, $J$., held that the payee was not fietitious. He says: "It was not a mere pretense at the time he drew it. He had every reasen to believe, and he did helieve, that the cherpes were being drawn in the ordinary course of business for the purpose of the money being paid to the persons whose names appeared on the face of those cheques." That seems to me to exactly fit the present case. Under ordinary circumstanoes I should consider mvelf bound by this decision, but it was presed on me that Warrivriton, J., had misread the judgments in the Bank of England v. Vagliano. I think, therefore, $I$ ought to examine these jurfgments. What were the facts of that case? There was no real drawer: the bills had been drawn by Vagliano's elerk Glyka to make Tagliano think that they were real lills drawn in the ordinary course of business hy customers who were entitled to ask Vagliano to aecept them. In truth, the whole bills were fictitious, though Vagliano believed them to he real and accepted them. It was strongly urged that, inasmuch as it was the olligations of the acceptor which were in question, the payees could not he fictitious unless they were so to his knowledge, and the Court of Appeal so held; lut the ITonse 
of Lords held the contrary. I think the real ground of their decision is to be found in Lord Hersehell's judgment beginning near the bottom of p. 14\%. I have therefore to ask myself, is this the ordinary case where the payee designated in the hill " is a real person intenderl by the drawer to receive payment either by himself or by some transferee?" It seems to me that there can he but one answer to that question. Kerr was a real person intended by the plaintiff. the drawer, as I have found, to be the person who should receive payment. It is a fallacy to say that Kerr was fictitious because he had got no shires and had never agreed to sell any to White. The plaintiff believed he had, and intended him, and no one else, to receive the money. It seems to me that when there is a real drawer who has designated an existing person as the payee and intended that person should be the payee, it is impossible that that payee can be fictitious. I think the word "fictitious" implies that the name las been inserted by the person who has put it in for some dishonest purpose, without any intention that the cheque should be paid to that person only, and therefore it is that such a drawer is not permitted to say what he did not intend, viz., that the cherpe shall be paid to that person only, and the only way of effecting this is to say that it shall be payable to bearer. It matters not, in my apinion. how much the drawer of the cheque may have been deceived if he honestly intends that the cheque shall be paid to the pereon designated by him. T think Warrosetox, J., has not in any way misrearl the judguments in Banli of England $\mathrm{v}$. Vagliano. I think his decision and mine are really founded on the principles laid down in that case, and in the result therefore I an of opinion that the three contentions raised by Mr. Isalas fail, and that the plaintift is entitled to recover the whole 11,250$)$.

This jurgment was aflirmed by the Court of Appeal, [1908] $1 \mathrm{~K}$. B. 13, and an appeal was taken to the House of Lords.

\section{[1908] Appeal Cases, 137.}

Loki Lorebukx, L. C.

I arlopt the languagu of BraY, J.: "It sems to me that where there is a real drawer who has designated an existing person as the payee, and intends that that prerson should be the payce, it is impossible that the payce can he firtitions."

If the argument for the appollants wore to avil, namely, that the payee was a fictitions perann hecanse Whitr (who was himself no party to the cheque) did not intend the patyee to receive the proceeds of the cheque, most serious consecpuenres womld ensure. It would follow, ns it seems to me, that esery cherpue to order might be treatris as a dingue to bearer if the drawe ! a l h a dwerived, no matter by whom. into 
drawing it. 'To state surh a proposition is an rofute it. Yet nothing short of this combl estalilish the appellantse combention.

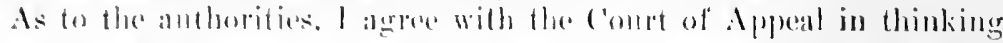
that neither lagliano $\mathrm{r}$. Banli of England nor ('lutlon v. Attenborongh.

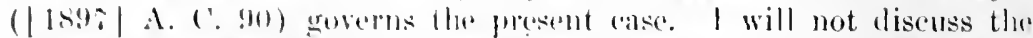
former of those anthorities heyond saying that it was not a case in which the drawer intembled the payee to receive the proceeds of the bill. And in the balter anthority the payce was a non-existent person whom no one either could ar did mean to be the recipient of the cheque.

That being so, I think this appeal should he dismissed with costs.

lord Robertson also delivered an opinion, and Lord Collins concurred.

Order of the Court of Appeal affimed, and appeal dismissed with costs. ${ }^{8}$

\section{PHILLIPS $r$. MERCANTILE NATIONAL BANK.}

\section{New York, 556. - 1894.}

ArTios by John E. Mhillips, as remiver of the National Bank of Simmtre. S. C., against the Mercantile National Bank of the eity of New York. From a julgment of the Guneral 'Term affirming a judgment at ('irenit dismissing the complanint, phintill apprals.

Gisu, I. 'The plaintitl' is the receives of the National Bank of Sumfrr. in South C'arolina. and thrumgh this action secks to recover a

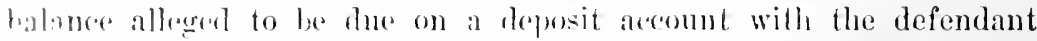
l...rk. The fuestion presented hy the record is whether certain twelve t a ks. drawn hy the ashier of the Sumter hank, which were paid ly throfofondant hink, comld properly be debited in areount to the Sumter lank. Piartlett. its rashier. had dr:awn thom upon the defendant for

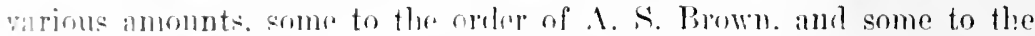

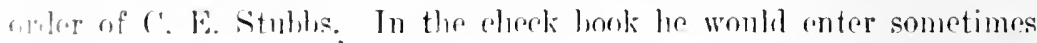
! a ral anomnt of thie rhecks, and sometimes an amount much lese than the dhecks artually worn drawn for. 'Tho names of these payees. wror thos of yersons who artually resided in sumber, and were dealers with the hank. but they know nothinge of these cherks, and bad no ronnection whatever with the transactions of the cashiop in issuing these

8 See Mr. Iohn D. Falermbridges's article entitled "Fictitions or non-existing payes:" in the ranala Lat Journal for April, 1907, J. 225, where the English

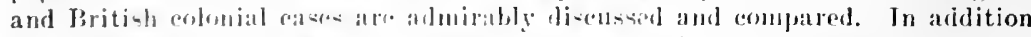

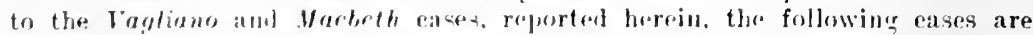

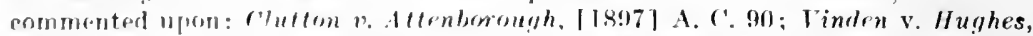

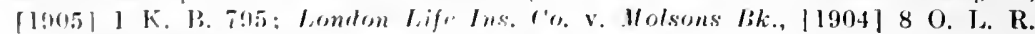

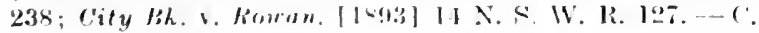


checks. Bartlett, after having drawn the checks, indorsed them in the name of the payee, making them payable to the order of some firm of stock brokers in New York, who collected them from the defendant. By subsequent manipulations of the books in his bank, Bartlett was able to prevent a discovery of his dishonest acts until after he had absconded, and the insolvency of the bank was disclosed. $* * *$

We think the judgments below were right. Whether indorsing the check in the name of the payee therein was a forgery in the legal sense or not is not the important question. In a general sense, of course, the cashier did forge the payee's name, but that fact did not affect the title or rights of the defendant. Coggill v. Bank, 1 N. Y. 113. In the ease cited, a bill was drawn upon the plaintiff to the order of one Truman Billings, and was discounted at a bank. The drawer had indorsed it with the name of the payee, Truman Billings, a person who in fact had no interest in the bill. It was held that the defendant in the case, who had accepted and paid the bill, held it by a good title. Brossox, J., said: "As the payee had no interest, and it was not intended that he should ever become a party to the transaction. he may be regarded, in relation to this matter, as a nonentity; and it is fully settled that, when a man draws and puts into circulation a bill which is payable to a fictitious person, the holder may declare and recover upon it as a bill payable to bearer. In legal effeet, though not in form, the bill is payable to hearer."

The case of shipman v. Bank, 126 N. Y. 318, which was recently before us, did not decide any question ineonsistently with what the courts below have decided.9 There it had been found that the eheeks were signed by the firm in the belief that the names of the payees represented real persons entitled to receive the amounts of the checks, and with the intention that they should be delivered to real pavees, and should not go into circulation otherwise than through a delivery to, and an indorsement by, the payees named. Bedell wis their elerk, whose employment did not comprehend the drawing or indorsing of

- In this ease plaintifr, wore depositors in dofundant bank. Tliey signed twenty-seven checks payalle to certilin peroons designatod by Bedell, a clerk in their amploy. and entruated these cherks to Borlell for delivery to the payen reapectively therein nanied, who were in good faith bolieved by the plaintiffs to he real porsons, entitled to receive the umounts of said checks, respectively. from them. The defendant paid the checks to a third person, upon an indorsement thereon of the payes named. forged ly Bedell, who converted the proceseds to his own 11 se. The names of the payees written in sixteen of the check were not the names of real lut fictitious persons. The remaining checks were made payalle to the order of ral persons, whose indorsementy wore in every ease forged by Bedoll. Judgment for plaintiffs, the eourt holding that the ehocks "eannof is treated as payable to bearer unless the maker knows the payee to bo fietitions uncl actually intends to make the paper payable to a fictitious person." I. 330.-C. 
checks or drafts: and in indorsing upon the ehecks the names of the payees he committed the crime of forgery, beanse he was withont anthority in that respect, and did so with the intention to deceive his employers, the makers, and to put their ehecks in cirenlation for his account. 'That was a case wholly other than was made out here. It was stated in the Shipman ease that the maker's intention is the controlling consideration which determines the character of the paper, and that the statutory rule which gives to paper drawn payable to the order of a fictitious person, and negotiated by the maker, the same validity as paper payable to bearer, applies only when such paper is put into circulation by the maker with knowledge that the name of the payee does not represent a real person. The prineiple of that decision is quite applicable to the ease at bar. Though Bartlett selected, for the execution of his dishonest purposes, the names of persons who were dealer's with his bank, it was, in legal effect, as though he had selected any names at random. The differenee is that, by the methods resorted to, he averted suspicion on the part of the directors or other officers of his bank. The names lie used were, for his purposes, fictitious, beeause he never intended that the paper should reach the persons whose names were upon it. ${ }^{1}$ The transaction was one solely for the fraudulent purpose of appropriating his bank's moneys by a trick which his position enabled him to perform. Concededly, if the names of the payees were of fietitious persons, the Sumter bank would have had no claim upon the defendant. How, then, can the transaction be said to assume a different aspect becanse the names adopted were of known persons? That the intention was to treat them as being of fictitious persons is manifest. As cashier, invested with the authority to draw cheeks upon the bank's accounts with its correspondents, instead of drawing them directly to the order of the parties who he intended should get the moners, he drew them to the order of persons who had no interest in them, and thereupon wrote their names under a direction to pay to the real parties, who were intended to be the reeipients of the funds drawn upon. If the checks had been drawn

1 In Snyler v. Corn Exchange Xat. Bank, 221 Pa. St. 599, the court says: "A fictitions person within the contemplation of the Act of 1901 is not merely a non-existing onw: for. if so, the word 'non-existing' would have been sufficient withont more. It is clear, then, that, when the Legislature declared that a check payable to a 'fictitious or non-existing person' is to be regarded as payable to lrarre, it meant a fietitions prison to be one who, thongh named as payee in a check. has no right to it, or the proceels of it, because the drawer of it so intended, and it therefore matters not whether the name of the payce used by him be that of one living or dead, or of one who never existed."

Ser this point discussed in Jorlan Marsh Co. v. Nat. Shawmut Ble, 201 Mass. at p. 410, where the eourt conchudes by saying that "The name so neel would be none the less fietitious that it was a real name of a person not intended to be designated." - C. 
directly to the order of the real parties, the defendant would undoubtedly have been protected in paying them. As it was, the payces were fictitions persons in the eje of the law, and the only real parties were the firms in New York, to whom the cashier sent them in such form as that they could draw the moneys upon them.

The fictitiousness of the maker's direction to pay does not depena upon the identification of the name of the payee with some existent person, but mpon the intention underlying the act of the maker in inscrting the name. Where, as in this case, the intent of the act was, by the use of the names of some known persons, to throw directors and officers off their guard, such a use of names was merely an instrumentality or a means which the eashier adopted, in the execution of his purpose to defraud the hank, in an apparently legitimate exereise of his anthority. The enshier, through his office and the power confided to him for exercise. was enabled to perpetrate a fraud upon his hank which a greater rigilance of its officers might have earlier discovered, if it might not have prevented. If his position and the confidence reposed in him were such as to enable him to escape detection for the while, then the consequences of his fraudulent acts should fall upon the bank whose direetors, by their misplaced confidenee and gift of powers, made them possible, and not upon others who, themselves acting innocently aml in good faitl, were warranted in believing the transaction to have been one coming within the cashier's powers.

It may be quite true that the cashier was not the agent of the bank to commit a forgery, or any other fraud of such a nature; but he was authorized to draw or check upon the bank's funds. If he ahused his authority, and rolwed his hank, it must suffer the loss. The distinetion between such a ease and the many other eases which the plaintiff's counsel eites from is in the fact that it was within the seope of this cashier's powers to bind the hank ly his cheeks. In transmitting them made out and indorsed as they were, the bank was so far enneluded by his acts as to be estopped from now denying their validity. For the reasons giren. the judement should he affirmed, with costs. All eonenr. except Bartlett, .J., not sitting. ${ }^{2}$

\section{$\S 28$} TRUST COMPANY OF AMERICA $r$. ILAMILTON BANK OF NEW VORK CI'T.

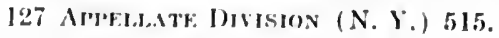

Motargindin. J. This is a controversy submitted to the enurt upon an agreed statement of facts under sertion 1289 of the Code

2 Followed in Suyder v. Corn Firchan!r Mat. Bk.. 221 Pa. 599, whure the court says that tlur Phillips ras is "singularly similat to the one now before u.." P. $607 . \rightarrow C^{\circ}$, 
of Civil Procedure. The eontroversy relates to four checks for $\$ 500$ each, drann mpen the plantitl, a trust company doing a banking business, and sigrted: " Estate of liate M. Wallace. Arthm B. Wallace, Almr." At the time the elicels me presented to the plaintill for parrusent, the estate of Kate M. Wallace was one of its depositors, having to its credit an amomt in cxeess of all the checks, which could be drawn out on ehecks signed by Arthur B. Wallace, administrator, when comtersigned by the United States Fidelity \& Guaranty Company. The Wallace estate had then heen practically settled, and the amount on deposit was realy for distribution among the next of kin of the decedent. The four checks in question were drawn withont the knowledge or authority of the administrator, his signature being forged, and in each there was inserted as payee the name of some one of the next of kin whose distributable share of the amount on deposit with the plaintiff was greater than the amount of the check or eheeks thus apparently payable to such person. The tirst check was dated September 25. 1905, and was presented on that day to the United States Fidelity \& Guaranty Company by a person mumed, without the knowledge of plaintiff or defendant. The United States Fidelity $\&$ Guaranty Company, relying upon the apparent genumeness of the check, comntersigned the same, and it was then, by some person unknown, presented to the plaintiff for acceptance and by it accepted, in writing. The name of the payee was then forged upon the back of the check as first indorser, and it was sulsequently deposited with the defendant, by one M. F. Kerby, one of its depositors, who was given eredit for the same. It then bore the following additional indorsements: "Harvey .J. Conkey. M. F. Kerly. A. Edward Fisher." Thereafter. the defendant, thromeh the New York Clearing House, presented the check to the plaintiff for payment, guaranteeing the indorsements, and it. rolying upon the gemineness of the check, with the guarantee of the defondant thereon, not linowing that the indorsement of the poyee was forgert, paid the same in gond faith. Substantially the same facts are true in regard to the seenud check, which was daterl in Sovember, 1905. The other two (hecks. dated in December, 190.5. and Jamary, 1906; were mot presented to plaintiff for aceeptance before parnent and wore deposited with rlefendant hy Harvey $J$. Conker. one of its depositors, to the ciolit of his aceount; otherwise. the same course was pursued with rearard to them. They were indorsed "Harvey. I. Conliey" below the forgere indorsement of the payee.

Tyon discovering the forgeries, the plaintiff at once notified the defendant, tendered lack the checelis, and demanded repayment. In the meantime brith lierly and Conkey land withdrawn the proceeds of the cherks, and the defondent, relying on plaintiff's aeceptance and paymont of thron, had paid out the same in good faith. The defendant has refuser to pay plaintiff the amount of the rhecks, or any of them, and the question presented is whether plaintiff is entitled thereto. 
The general rule is that payments made_under-a mistake-of fact may be rered, although negligently made; but it is also settled that, if the drawee of a bill of exchange to which the drawer's name has been forgcd accepts or pays the same, he ean neither repudiate the acceptance nor recorer the money paid, sinee he is bound to know- the drawer's signature. Price v. Neal, 3 Burrows, 1354; Bank of United States r. Bank of Georgia, 10 Wheat. (U. S.). 333 ; National Park Bank r. Ninth National Bank, 46 N. Y. 7\%; Goddard v. The Merchants Bank, $4 \mathrm{~N}$. Y. $14 \%$. It is also settled that, where the indorsement of the pavee of a bill of exchange has been forged. subsequent holders ohtain no title to it, and payments made to one who holds under such forged indorsements may be recovered. Corn Exchange Bank v. Nassau Bank, 91 N. Y. rt; Holt v. Ross, 54 N. Y. $472 ;$ Canal Bank v. Bank of Albany, 1 Hill, $28 \%$.

Therefore. if all the indorsements on the checks in question had been genuine, the plaintiff could not reeover; but if the maker's signatures had been genuine, and only the indorsements or any of them forged, it could recover. Having paid the ehecks, the plaintiff cannot now be heard to say that the maker's signatures are not genuine, or recover on the ground that the same were forged, and by reason of that fact it is suggested that the rights of the parties are precisely the same as though the drawer's signatures were genuine, and since the defendant never obtained good title to them, on aceount of the forged indorsements of the payees, the plaintiff is entitled to recover. There are authorities to support this contention. First Nat. Bank v. Northwestern Bank, 1,2. Ill. 296; Mcrall v. Croning, 3 Ia. Ann. 409. But it does not necessirily follow, hecalse the checks were not indorsed by the persons whose names appeared on them as parees, that the defendant, which received them in grond faith and paid value therefor, can he eompelled to repay their aunounts to the plaintiff.

A leading authority on the subject is Bank of Bugland v. Vagliano Bros., L. R. 1891 App. Cas. $10 \%$, which revered Tagliamo v. Bank of England, 23 Q. B. D. :43, and 2:3 (9. B. I. 103. This authority has

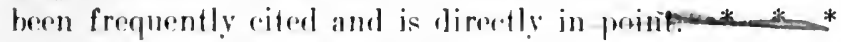

The eorrectness of the derision in lirst Notional Bank v. Northwestern Banli, suprn. may well be pluestioned. sine the decision of the lower comrt, which was pererserl hy the Itomse of Loris. in the Bank of England case, was aitre at longth and relied upon. Whether this be so or not, the decisions in our own state are entirely in harmony with the views expressed hy the Ilomse of lords. Thuse in Coggiil v. American E.rehange Bank, 1 X. Y. 113, 19 . Im. Dee. 310, a partner drew a hill of exchange in the name of the partnership, payahle to one Truman Billings and forerer therent the indorsement of the latter. The bill subsequently eame into the hands of the defendant hank, and the plaintiff, upren whom it was drawn. aecepted and paid it. It was held that the plaintift, on discusering the forgery, muld not re- 
cover the amount paid from the defendant, since the bill was in effect payable to hearer, and defendant land goonl title. Mr. Justice Bronson,

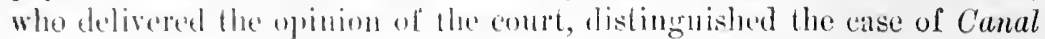
bank r. Bamle of Albemy. supma, and said:

"Is the payee hanl nu interest, and it was not intencled that he shombl erer berome a party to the dransaletion, he may be regarded, in relation to this matfer, as a nomentity ; and it is fully settled that when a man draws and puts into cireulation a bill which is payable to a fictitious person. Hhe holder may declare and recover upon it as a bill payahle to hearror. * * * In legal effect, though not in form, the bill is piyahle to bearer. * * * The plaintiff probably accepted and paid the hill under the mistaken assumption that the indorsement was gemine: but he was not mistaken about the main fact which he wis concerned to know, which was that the holder was the owner of the hill."

And in Phillips v. Mercantile National Bank, 140 N. Y. 556, the cashier of the National Bank of Sumter, S. C., drew checks in the name of the bank, inserting as payees the names of customers of the bank. whose indorsements he fored. The checks thus drawn were sent to rarious firms in New York and subsequently came into the hands of the clefendant, which receiver them in gool faith and eharged them to the account of the Sumter Bank. The receiver of the Sumter Bank thereaftor hrought an action to recover the amount of these checks, and it was hell that the same could not be maintained, since in legal effect the payees were fictitions and the checks payable to bearer, and for that reasou the defendant obtained good tille. * * *

Tnder the negotiable instruments law and the cases cited. I am of the opinion the checks in question, as between plaintiff and defendant, were payahlo to boarer. It loes not appear who forged the maker's signatures. but the suhseruent history of the dhecks does not leave it open to dombt that the person who did so knew that the parties whose names were lisel as payees would never lawe any interest in the instruments. Just as in the Bank of England and the Phillips cases. in orter to acomplish the frand more easily, the names inserted as payees were those of persons to whom chreks might naturally be made. Whether intorsing the names of the payees npon the checks was technically forecery or not it is unnecessary to consider. It has heen convenient to thus rlasulibe them. Despite these forged indorsements, then, the defenrlant acepuired good title, since in legal effect the checks were payable to burer. Flaintiff, havine paid them to a holder in due conrse, cannot recover upon the ground that the payees' signatures were forcerl.

Nor is this view at all in comflict, with, Shipman v. Bank of Stale of Now York, 126 X. Y. 318. * * * The comrt helel that the plaintiffs could recover from the bank the amount paid, distinguishing the Bank of Encland case. and the distinction is obvious. In the former 
case, the member of the firm who signed the checks in the firm name believed that in every instance the payee was a real person to whom alone the check was payable, while, in the latter case, the person who wrote the maker's signature was a forger who knew that, so far as the hills of exchange were concerned, the payee was fictitions. The court expressly recognized the rule that the maker's intention was eontrolling, saying:

"The maker's intention is the controlling consideration which determines the elaracter of such paper."

It is true that in many of the authorities eited the person guilty of the fraud was connected in some way with one of the parties, which may have affected the equities of the case, as was suggested in shipman v. Bank of State of New York, supra, eoncerning the decision in the Bank of England ease, while here, so far as appears, the guilty party was a stranger to both plaintiff and defendant, and they are equally innocent. But that eannot change the linw as to the fietitiousness of the payees, and, if it did. I am of the opinion that any equities in the present case are with the defendant. The risk of paying out money upon a forged signature of a depositor is one which a banker must assume, and, if the plaintiff had detected the forgeries when the ehecks were presented for payment, it would not have suffered any loss, and it is possible that the defendant would not.

I am of the opinion that the plaintiff has no legal claim against the defendant, and for that reason the latter is entitled to judgment upon the merits, with ensts. All eoncur. ${ }^{3}$

3 As the New lork Court of Appeals lias not in any of its decisions passed upon the preciso purstions imvolvel in this case, this deejsinn canut, of course, be regariled as settling the law in New York.

Sere a most instruntive article by professor I. M. Greeley in 3 Tll. Taw Rev. 331, entitlof "lietitions payere in forged cheoks or hills," eritieiming this ease and lamk v. lagliamo, and arguing that lirst Nat. Bank v. Northurstern

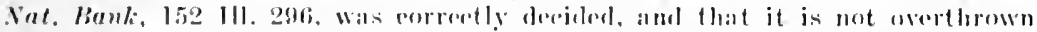

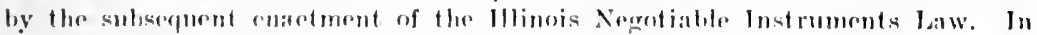

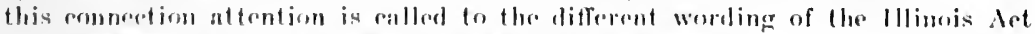
fit provides llat "the instrumest is paylub to bearer . . . when it is payable to the oroler of a jerson known by the drawer or maker to be fietitions or nom-existent, or of a living preson not intenderl to have any interest in it") which "sorms to 4 law writor . . . to justify a eonstruetion different froms that plaerel upon the buglisle and New York Arets." P. 33!.

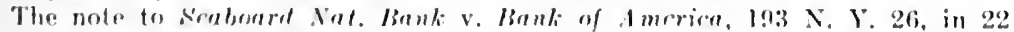

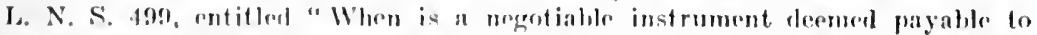
the order of a fectitions person within the rule which regards sucle an instru. ment as payble to hearer," disensses all the eases printerl herein on this subject, and deserves a most careforl reading. Attention is particularly called to the following rextruets:

"The courl, in kohn v. Walkins, 2f Kan, 69). . . makes a distinction bearing on the question now under eossieleration, as to the necessity of knowledge by the maker or elrawer of the lietitious charaeter of the payor. Jetween a case where an instrument purports to he payahlo to a ral persen, known at 


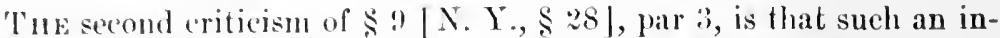
strument is, muder the act, payable to bearer without being indorsed, and that this, also, innores the tenor of the instrument. "Nor is there any judicial precedent or mercantile custom," says Professor Anes, " in support of the notion that a bill payable to a fictitions payee, but not indorsed in the name of such payee, is payable to bearer. In all the reported cases, instruments payable to a fictitious payee have been indorsed in the name of such payee before negotiation." "That is sub-

the time to exist, and present to the mind of the maker or drawer as the party to whose order it was to be paid, although, as a matter of fact, he had no connetion with the transaction, and a case where there was no such person in existence, although the maker or drawer supposed there was; holding that the llawer's belief that the preson named was the real payee will prevent the application of the rule as to fietitious payces in the former case, but not in the latter. As subsequently shown, substantially the same distinetion is made by the English cases, when the lagliano case is considered in connection with the subserpuent cases." P. 502.

"These cases [Shipman v. Bank, 126 N. Y. 318, and Armstrong v. Nat. Bank. autr. p. 1231 are . . elearly opposed to the distinction made in the hohn case and the later English calses." I'. 503.

"The opinions in these eases [Vinden v. IIughes (1905), I K. B. 795, and Jarbeth $v$. Bank. ante, p. 131$]$ leave, perhaps, some doubt as to whether the doctrine of the Iagliano case is restrieted to the very facts of that case; $i$. e, the case of acceptance of a bill where the drawer's signature as well as that of the payee is forged, or whether the doctrine of that case would still be applicable so as to characterize a bill as payable to a fictitions payce, as against an aceptor who had in mind an actually existing person as the payee, where the drawer knew of the fictitious character of the payee, that is, knew that the per-on namerl had no connection with the transaction.

"It will be noticed that Trust Company of America v. Hamilton Bank [aute, p. 137] . . . was very similar in its essential facts to the Vagliano ease. and the decision is in harmony with the doetrine of that case, even when confined to the lirst or narrower of the two hypotheses just stated.

"Asife from the aspect of the question just suggested, the English eases, when eronsidered together, sem to adopt practically the same position and distinction as the Kansas court. In other Words, the English doetrine appears to be that the belief of the party sought to be charged, that the payee was an actmatr existing person, to whom, or upon whose indorsement, he intended the instrument to be paid, will not prevent the application of the rule as to fictiliolls payere if there was in fact no real person in axistence whom he had particularly in mind as payee: but that the intention of the party sought to be eharged, at least if he is the drawer, that the instrument was to be paid to or upon the order of an actually existing person, known to him, and in his mind as the person to whom or upon whose order the instrument was to be pair, will refeat that rule." Pages 504. 505.

See also the article intitled "Fictitions payees under Negotiabie Instruments Aet" in 13 Law Notes, 23.

"In Keenan v. Blue, 240 III. 177, a promissory notr payable to D. L. Buck- 
stantially true." If such an instrument requires no indorsement, a departure has been made from what has been supposed to be the law - and Professor Ames and Judge Brewster agree that the new act dispenses with the necessity of an indorsement. Indeed, any other reading of it seems impossible, though whether an indorsement is necessary under the English act has never been decided, and seems fairly open."

Judge Brewster defends the change. He says: "Surely it is more logical to hold that a note which purports to be payable to a person

worth or order was indorsed by Buckworth '. . . to I. N. Porter or bearer,' signed 'D. L. Buckworth.' So indorsed the note was discounted by the plain. tiffs. . who sued the makers. It was held, . . Second, that the name 'I. N. Porter' was fictitious, and hence eould be disregarded, and the indorsement deemed to be to 'bearer.' The plaintiffs were therefore permitted to recover, thongh the note was not indorsed in the name of ' $I$. N. Porter.' One judge dissented on the ground that our statute requires an indorsement in the case of negotiable paper payable to a named person or bearer. Ill. R. S., ch. 98, $\$ 4$; Roosa v. Crist, 17 Ill. 450. Ile was of opinion that since the indorser did not know the name 'I. N. Porter' was fictitious, the name could not, as to him, be deened fietitious, and the indorsement treated as payable to bearer. . . The name 'I. N. Porter' was fictitions. 'This, however, was not known by the indorser. Buckworth, the name having been suggested by the plaintitls, when they arranged with certain note brokers to buy the note, in order to conceal their part in the transiction, the indorser simply writing the indorsement as directed hy the brokers. On these facts, it would seem that the name 'I. N. Porter' was simply another name for the plaintiffs, assumed for this transaction - not the name of a fictitious person. The decision of the court seems sonnd. thongh perbaps all of the reasons urged in support of it are not. I. M. G." \& III. Law liev. 354. - C.

4 In New York, however, it has heen held for many years that a bill or note payable to the order of a fictitions payes is payblo to hearer without being indorsed by the maker or payee. Ilets v. Johnson, 3 Ilill, 112; Central Bank of Brooklyn v. Lang, I Josworth, 203; Irving N. B. v. Alley, 79 N. Y. 356.

"It might be argued that the words "may be treated as payable to bearer" user in the linglish act mean that the bill may be so treated only when regular in all other respects, $i$. $e$, among other things, when property inilorsed. Judge Chalmers, the draughtsman of the lenglish act, says of this sib-section: "When a hill is payalole to the order of a fietitions persen, it is olvioms that a genuine indorsement can never he ohtained, and in aceordanee with the language of the old eases and text borkes. the aet puts it on the footing of a hill payable to bearer. But inasmench a a hill pilyalele to one person hut in the hands of another is patuntly irregular, it is elear that the hill shomld be indorsed, and perhaps a bona fide holder would le justified in indorsing it in the payee's name. It might have lese lecter if the act had provided that a bill payable to the order of a fietitione person might he treated as payable to the order of anyone who shomld indorwe it, or, in other words, as indorsable by the bearer." Chalmers' I3ills of Lxchange, stlı edition, page 22. From this, it would appear that the failure of the English art to require an indorsement was a mere oversight though the use of the worda "may : "treated" furnishes a method of corret. ing the omission. Juslge Irewster's rearliness to defend the ehange in the Ameriean act seems to indicate that the change was intentional. Except for this, one would suppose that it had beren an oversight. 
when there is no such person, and the maker knows it, must have been interded to the payahle to hearer, than to hold that somebody must assume the name of such fictitious nerson and make a false indorsement in order to give title to the mote." 'There is much common sense in that. But the tronble is that title to a note payable to order is derived through the indorsement on the hack of it. What "must have been intended "by a maker who mane's a fietitions payee it is extremely hard to say. Moreorer, hoth commercial practice and legal theory tend more and more to disregard everything except that which actmally appears on the instrument. When $\dot{\lambda}$. makes his note payable to "John White or order" all our notions about negotiable paper require that John White be written on the back of this note, even thongh no such person as John W'lite exists. It seems necessary for form's sake. T'o dispense with the neecsity for it gives a decided jolt to our ideals. Aside from this, however, it is difficult to see how any harm can result from the change. In the first place (and though this does not touch the theory of the criticism, it does tonch its practical worth) notes parahle to fictitious pavees and unindorsed, will be about as plentiful as comnterfeit dollars labelled "counterfeit." Fither the maker or the person to whom he delivers the instrument will indorse it in the name of the fietitious payce. Why? Beeause otherwise no one would discount it. It would be patently irregular on its face. An indorsement is necessary to give such a note amy commercial value.

(c) When the name of the payee does not purport to be the name of any person.

[Reported hercin at p. 10\%.]

(d) When the only or last indorsement is an indorsement in blank.

51 ('alfforita, 239. - 1876.

T11e defendant. Thomas Sprague, executed, and delivered his promissory note to the plaintiff. Dennis. Dennis indorsed the note in blank, and delivered it to F. Magruire. Subsequently, Maguire assigned the note to Dennis by indorsement. withont recourse. and redelivered the same to him. Afterwards, Dennis delivered the note to the plaintiff Churtis, withont receiving any value, but with an agreement that Curtis should bring suit and divide with him what he recovered. The plaintiff recovered judgment and the defendants appealer. 
By the Cuurt: * * *

2. 'There was no error in the refusal of the court below to nonsuit the plantifi on the motion of the defendants. When the note was delivered to Curtis, it had on the back the blank indorsement of Demıi.s. the payec: and " the first effect of an indorsement in blank, is to male the paper payable, not to the transferce as indorsce, but as hearer." ("? Pursons on Notes and Bills, 19.)

curtis. H:crefore, acguired the legal title to the note, with a corresponlime rignt of action, when it was delivered to him by the payee, indorsed in blank. We attribufe no importance to the fact that the-mate had before heen delivered by Demis with the hlank indorsement to Maguire, and that the latter had redelivered it to bennis, with a special assignment. The title would have heen as eflectually reinvested in Dennis ly mere delivery, without the assignment. as with it: and when Dennis afterwards delivered the note to Curtis, there was no merel that he shomld again indorse it in blank. in order (1) consey the legal title, as the blank indorsement already on it was ellectual for that purpose.

3. 'The loyal title and right of action heing wholly in curtis, the

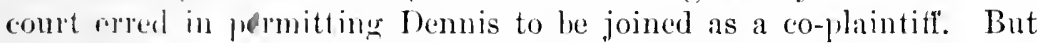
it was an cror which has wought no substantial injury to the defondants. Nerertlueless. in order to preserve a proper consistency in the record. we recon it better to remand the cause for further proceedingrs.

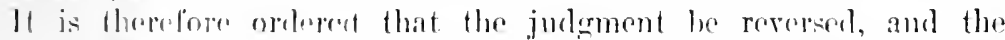
anse remanded, with an opeler to the eourt below to vacate the order

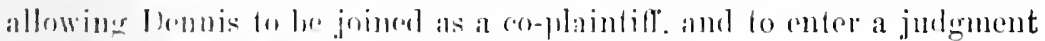
in the findings in favor of the plantill cortis.

$\S 28$

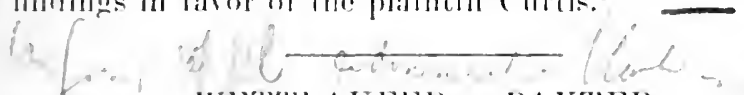

\section{WET'TAUTERA $v$. PANTER.

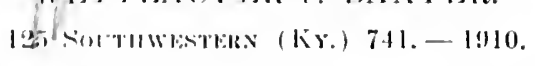

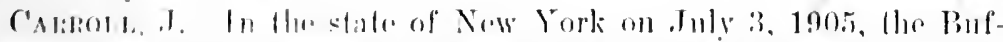

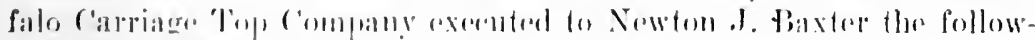

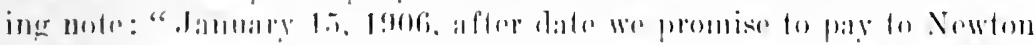

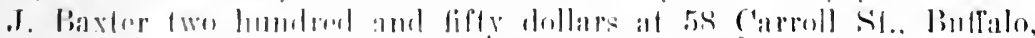

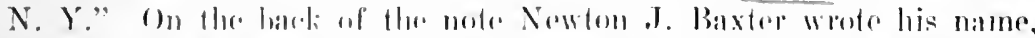

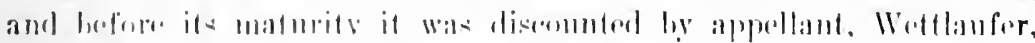

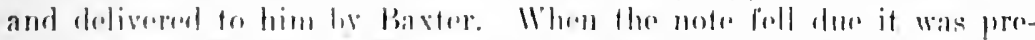

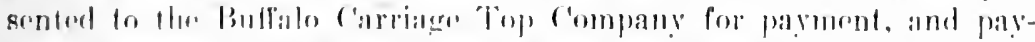
ment rofucol. 'Therempon the mote was protested hy a motary and notiore of its lishomor mailod on Baxter at his residenee. in Owona-

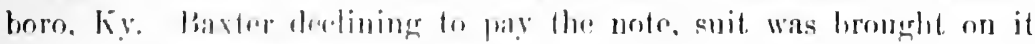

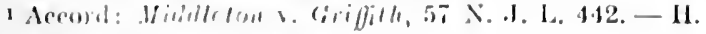

NEGOT, INATRUMENTA -10 
against him in the Daviess (irenit Court. A general demurrer was sustained to the petition, and, declining to plead further, the petition was dismissed.

The questions inrolred in the ease are: Was the note before its indorscment by Baxtel a negotiable instrument within the meaning of the negotiable instrument act? Or, if not, did Baxter, by signing his name on the hack of the note and selling and delivering it before maturity to 17 cttlaufer, convert it into a negotiable note and make all the parties to it subject to the negotiable instrument act the same as if it had been a negotiable note in the first instance?

The contention of eounsel for Baxter is that the note was not a negotiable instrument, and that Baxter by signing his name on the back of the note became merely an assignor. - * * *

On the other hand, the contention for Wettlanfer is that the liability of Baxter upon this note is to be determined by the negotiable instrument act, **** and that by the provisions of this act Baxter occupies the position of an indorser and not as assignor of the note. Or, in other words, that, although the note may not have been negotiable when first executed and delivered, Baxter by his indorsement converted it into a negotiable note. ***

[After quoting sections 1, 8, 9, 30, 34, and 184 of the Kentucky act, ${ }^{2}$ the court continues:]

For the purpose * * * of ascertaining what bills and notes it was intended should be negotiable within the meaning of this act, we may with propriety inguire what words were generally considered necessary to make a bill or note negotiable before this act went into effect, with a view of noting what change if any was made in this particular. In an article in 7 Cye., p. 606, hy a well-known writer on commereial paper, it is said: "the usual form of negotiable paper is a provision for payment to 'order' or 'hearer.' 'These or similar words are in general necessary to its negotiability, and are often required by statute, but a note which is non-negotiable for want of such words is still a valid note and may be declared on as such. Bills payable to learer were formerly held to be non-negotiable, as being without wrords of transfer; but they are now recognized as negotiable and transferable by delivery. Making the instrument payable 'to the order of' a person named is the same as to such person 'or order'; and in like manner to a person named 'or hearer' is the same in effect as 'to bearre.' Without words of negotiability purchasers take the bill or note subject to att defenses which were available between the original parties: and if it was originally non-negotiable, as against the original parties, it will not be rendered negotiable by subsequent transfer in negotiable form." The same rule is announced in $4 \mathrm{Am}$. \& Eng. Ency. of Iaw, 13.3; Story on Pills of Exchange, $\S 60$; Daniel on

2 N. Y., $\S \S 20,27,28,60,64$, and $320 .-\mathrm{C}$. 
Negotiable Instruments, $\S 105$; Bank v. Butler, 113 Tenn. 574, 83 S. W. 655 ; Westburg v. Chicago Lumber Co., 117 Wis. 589, 94 N. W. 572 .

It will thus be seen that it was uniformly held that, in order to make a note or a bill negotiable, the words " to order" or " to bearer," or equivalent words, must be used in the body of the note. It will be kept in mind, however, that the absence of these words do not affect the validity of a note or render it non-transferable or non-assignable. Their only effect is to make the instrument negotiable, and thereby cut off defenses that the maker or either of the parties to the paper might have and make against a holder in due conrse if the note was not negotiable. The negotiable instrument act does not apply to or affect the rights or liabilities of persons on paper that is not within its meaning negotiable. *** This note in our opinion, which was payable to Baxter alone, and did not contain the words "to order" or "bearer," was not a negotiable instrument. These words by sections 1 and $184^{3}$ are indispensable to make the paper a negotiable instrument within the meaning of the act.

But the argument is further made that as Baxter indorsed the note in blank - that is, signed his name on the back of it without any other words - he thereby converted the note into a negotiable instrument. It is true that section 9 of the aet provides that " the instrument is payable to bearer * * * when the only or last indorsement is an indorsement in blank;" but this does not mean that an indorsement in blank converts a note non-negotiable on its face and by its terms into a negotiable note. This construction would enable the person who last signed his name on the back of the note to change entirely the contract as entered into between the parties, and have the effect of making the maker, payee, and all prior indorsers liable upon a negotiahle instrument when they intended to and only became liable upon a note that was not negotialsle, and this, as ean readily be seen, would be a most important and matrial change in the obligation assumed by them when they signed the paper. 'To grive the act this enstruction would place it in the power of any indorser who chose to sign his name in hank to change hy this act the ent ire eharacter of the paper as well as the rights and liabilities of the parties to it. would make the character of the paper depend upen-the manner of the indorsement and not upon the terms expressed in the paper. Thus, if $A$. inclorsed it in blank to B., it-would he negotialble: hut. if $B$. indorsed it specifically to (.., it would he non-negotiable. Manifestly it was not intended that the mere indorsement of the noto by a remote or other indorser should have this effert. When a paper is started on its journey into the commercial world, it should retain to the and the character given to it in the beginning and written into its face. If it

3 N. Y., \$§ 20 and $320 .-C$. 
Was intemeled to be a mughtable instrmment, and was so written, it shombl continne to be ome. If it wa intended to be a non-negrotiable instrument and was so witten, it should so remain. 'Then every one who puts his nume on it, as well as exey one who diseounts or purMases it. will nowe only to rad it to know what it is and what his rights and liabilities ance.

In our opinion sortion ! wis merely intended lo deseribe or designate the conditions moler which a note necotiable on its face might become parahle to hearer, and was not intended to apply to a note not on its face or by its terms nogotiable. To illustrate, if this note was parable to " Nowton . I. Baxter or orler," then the paper upon its face rould he a negotiable instrument, although payble whly to Baxter or order, and the only elluet of the indorsement on the note by Baxter in blank would be to convert the note from a note payable to order into an instrument payalbe to bearer. But this indorsement would not in any mamer ehange the negotiability of the note, nor change the attitude of any of the prior parties on the note, or incense their liability or cut otf any defenses that they might have male, as it was at all times a negotiable instrument. 'Tlen, ton, "when the only or last indorsement is an indorsement in blank," the payee without notice of any defect in the tifle of the huldre may pay the same to him, as it will he presumed it came info his himts in dure cotres no indorsement being necessury. Athough the note under our construction of the Trgotiabte-mstrument Ict was not a negotiable instrument, yet Baxter lad the right to indorse it and transfer it by delivery, and pass whatever title he had to he transferee or assignee. But the assignee would then take the note, not subject to the provisions of the Negotiable Instrument Aet, but under the law applicable to non-negotiable paper. *** *

\section{$\nabla$. Drawee must be certain.}

The judgment is affirmed. ${ }^{4}$

Orinex, P. J. This snit was brought hy the hoirs of John S. Storrs against the estate of D. E. Watrous, on the following instrument of writing. viz.:

$\$ 271.62$

Montevallo, June $1,1858$.

Ten montlis after date pay to the order of John $S$. Storrs, two thousand seven hundred and seventy-one and 62.100 dollars, value received, and charge to account of

To

D. H. Watrous.

- Motile, Ala.

4 For furtlor di-cussin of $\$$. Instruments Law, pust, pp. .- C. 
The petition charged that for a valuable consideration from John S. Storr's to him theremuto moving, said Daniel E. Watrous executed and delivered to said Storrs the instrument of writing above set out, and that thereby said Watrous undertook, and bound himself, and became liable to pay said sum therein speeified.

To this petition the defendants filed a general and special demurrer, which were both overuled by the court, and judgment was rendered for the plaintiffs, and the defendants took their bills of exception to the ruling of the court, and brought the case here by appeal.

The only question now presented for decision is, does this instrument. independent of any allegations of ownership for a valuable consideration, or promise to pay, give the holder any cause of action.

This instrument is not a promissory note in its ordinary form, nor can it be treated as such, since there is 110 promise to pay in any event. The instrument is directed to no one, and thesefore cannot be considered a nraffer-fill of exchmec. Her it been accepted by any one, that acceptance woun hare constituted a promise to pay in the acceptor, and then the maker might have become liable as surety or guarantor: but as there is so drawee or acceptor, the maker cannot, without allegations aw proof of other facts setting forth and estatsTishing his liability, be held responsible. The instrument, with the exception of the want of a lrawee, is in the ordinary form of an accommodation bill or draft, on which the maker cannot be held liable until after an acceptance or non-alceptance. We think the instrument, as it is, is an imperfect hill or draft. for the payment of which no one is liable. With proper averments. slowing the objects and purpose of the parties, and that the maker intended to hind himself in the first instance to pay the same. he miglit possihly be held responsible without a drawee or acceptor, hut not otherwise.

We ean soe no material diflerenore betwen the writing here sued on and the one in Ball v. Allon (15 Mass. 133). in which the court says: "But the mere posession of a paper drawn in the form of an order, there lwing no drawere in existenes, we think eannot entitle the possessor to an artion in any form."

The same doetrine may be drawn from Peto v. Reynolds (a) Exch.

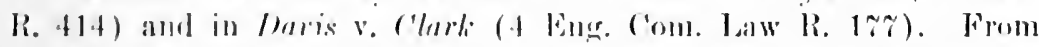
these untherities and the reason of law arowerning instruments of this

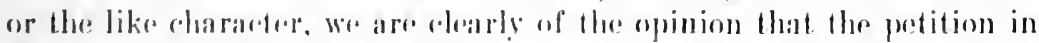
this ease did not sut out a gond ranse of action, and that the court

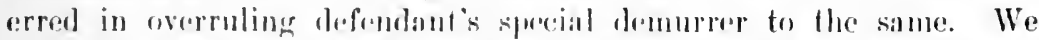
think the demorer should have leen sustained and the plaintiff permitted to ammend their pleadings. that, if desired, they might, by proper averments and proof, estaldish the liability of the maker or drawer in the first instance, without an aceptance or non-acceptance. 
The judgment of the Distriet Court is reversed and the cause reminded.

Reversed and remanded. ${ }^{5}$

\$20 Funk ". BabBitT, 156 IIl. 408. - 1895. "B. Apr. 23, 1891. Thirty days after date pay to the order of E. D. Babbitt $\$ 350$, for value received. Funk \& Lackey." Mr. Justice BAKER: "Said instruments were dechared on as promissory notes. It is urged that they are not notes. or eren promises to pay, and, not being directed to any one, do not constitute drafts or orders, and in fact amount to no more than bink pieces of paper. They are, undoubtedly, very irregular and informal instruments, but they are not void as written evidences of indeltedness. A person may draw a bill upon himself, payable to a third person, in which ease he is both drawer and drawee. Here the firm drew bills, but did not address them to any third person or persons, and it is therefore to be regarded that they were, in legal effect, addressed to themselves, as drawees, and the signatures of the firm to the several bills bound the firm both as drawers and aceptors. The instruments are inland bills of exchange, to which the firm sustains the triple relation of drawers, drawees, and acceptors, and as the declaration contains the consolidated common counts, the bills were admissible in evidence under them. Moreover, the drawers and drawees being the same, the bills are, in legal effect, promissory notes, and may be treated as such, or as bills, at the holder's option. (1 Daniel on Neg. Inst., $§ 128,129) . "$

$\S 20$ Whefler $v$. Webster, 1 E. D. Smith (N. Y. C. P.) 1 (1850). By the Court, Ingrailam, Finst J. "I am of the opinion that the omission of the name of the drawee at the foot of the bill will not vitiate it. The acceptance may be considered as supplying the defect, and as being an admission by the acceptor, that he is the person intended. At any rate, it does not lie with him to make such defense, after having admitted, by the acceptanee, that he was the person intended, and after having promised to pay the draft at maturity. He is estopped. Wh his own act, from such a defense."

SIn l'eto v. leynolds, (9 Exch. 410$)$, cited ahove, the bill was not addressed to any drawee, but across the face was written: "Accepted, Samuel Reynolds, Esq.. Shorn Jane, Bedminster, Bristol." One Rigliton (the drawer of the bill) wrote this acceptanee. Defendant denied Bigliton's anthority. There was evidenee that dofrondant had orally promised to pay the bill. iut whether absolutely or conditionally was not clear. Plaintiff had a verdict. The court held there must be a new trial because of the unsatisfactory state of the evidence. Three of the four judges expressed the opinion, however, that the instrument was not a bill of exchange for the want of a drawee, but might be treated as a promissory note if Peynolds, in fact, ratified the signature. - $\mathrm{H}$. 


\section{Delivery essential.}

\section{$\S 35$} HILLSDALE COLLEGE $v$. THOMAS.

40 Wisconsin, 661. - 1876.

Action on a promissory note signed by defendant's testator and payable to plaintiff.

The answer is to the effect that one Parmalee, an agent of the plaintiff, called upon the defendant's testator, and solicited him to purchase a scholarship in the plaintiff college, which he at first refused to do; that finally, at the request of Parmalee, he signed the note in suit, and left it with Parmalee, under an agreement that the latter should hold it for the testator until a certain time, to be returned to the testator in case he should not decide to purchase such scholarship, and in the meantime the note slould not be considered as delivered to the plaintiff; and that at the specifier time, the testator informed Parmalee that he had deeided not to purchase the scholarship, and demanded a return to him of the note, but Parmalee, professing to have sent the note by mistake to the plaintiff, did not comply with such demand. _-

On the trial, by proof and the defendant's admissions, plaintiff made a prima farie case. Defendant offered testimony tending to prove the averments of the answer, but an objection to its admission was sustained: and the jury, by direction of the court, returned a verdict for the plaintiff for the amomnt due on the note by its terms. From a judgment entered on such verdiet the defendant appealed.

Lyos, J. The ruling of the court rejecting all testimony under the answer is equivalent to an order sustaining a general demurrer thereto. It is an adjudication that the answer does not entain facts suffiejent to constitute a defense to the action. If it states a defonse, the ruling is erroneous and faltal to the jurlement. We have no dould whatever that the answer states a conplete lofense to the action, and that the testimony oflered to prove the allegrations thereof should have heen receiverl.

The note was not loft with lammaler, the anent of the plaintiff, as an esernw. On the contrary. Hhe defomdant's testator retained the ahsoluste control of the note. and the rienth to reesall it if he chose to do so. Such a depesit has nome of the resential features of a delivery in

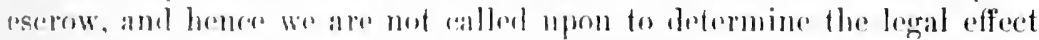

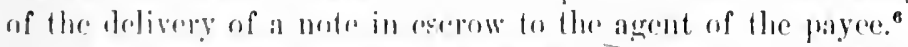

B While it is now generally enceled that a megotiable instrument may be

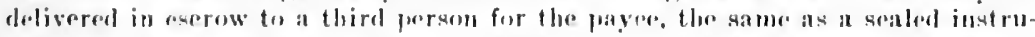
ment, it is a disputed question whetluer it may be so delivereal in aserow dierectly to the payere or his agent. The following asase hold that it may not:

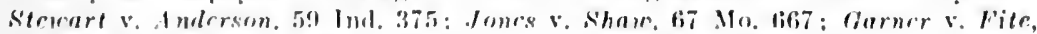

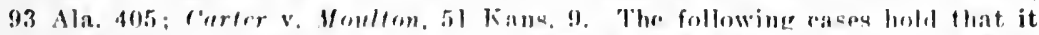
may: Burke v. Julancy, 153 U. S. 228 ; Bentom v. Martin, 52 N. Y. 570 ; Wat- 
There was no delivery of the instrument, and hence it never had an inception or legal existence as the note or obligation of the testator. It reminined mere waste paper, just as it wonld laave been had the testator kept it in his pocket instean of leaving it with Parmalece. The faret that Parmalee was the agent of the plaintill is of no importance. Were the plaintill a natural person, and had the testator left the note with such person moter the same circumstances, it would not he a delivery, and would conter no right of action. Had the paper been put in circulation, and weje the plaintill a bona fide holder thereof, for value, before dur, we would al might have to determine whether or not the testator had heen guilty of negligence in the premises. But we have no such question in this action. These views ale ahundantly sustained by the following cases: Waller v. Lbert, 29 Wis. 194: Kellogg v. Stoimer, Id. 626: Buller v. Corns, 37 Id. 61; Thomas v. Hatlins, 16 Id. 549 : ('hipman v. Tucker, 38 Id. 43 ; Roberts v. McGrath, Id. 52 ; Roberts y. Hood. Id. 60.

Judgment reversed and a new trial awarded. ${ }^{7}$

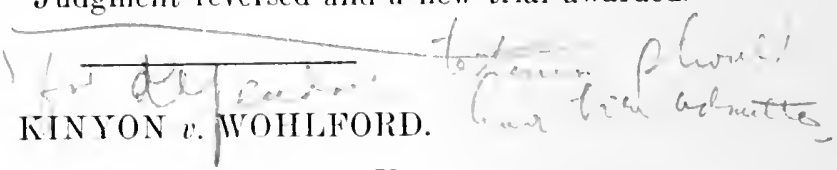

17 Miñesoti, $239 .-1871$.

Action on a promissory note, hrought in the District Court for Steele county, resulting in a verdict for the defendant. Plaintiff moved for a new trial, which was denied, and he appeals to this court from the order denying such new trial. A single point only is discussed in the appeal, which is fully stated in the opinion.

By the Court-Brakr, J. This is an action upon a promissory note parable by its terms to C. W. Stevens, or bearer, and signed by the defendant.

There was plenary evidence showing that the plaintiff is a bona fide holiler of the note, having purchased the same before maturity in good faith, withont notice, and for value.

'lie only defence urged here is that there was no delivery of the

kins v. Bowers, 119 Mass. 393; Brown v. Sit. Charles, G6 Nich. 71 ; Sucet v. Sterons, 7 R. 1. 375 . - II.

loor antloritires on the admissibitity of parol evidence to slow conditional delivery of bill or note sep the following: Beach v. Nevins, 162 fed. 129, 181. N. S. 2ss with notr: Graham v. lirmmol, 70 Ark. 140; St. I'aul's Lp. Ch. v.

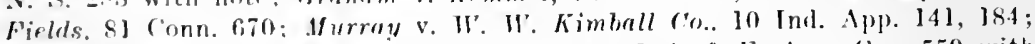
Gakland cem. Ass'n v. lalins. 12f Irwa, 121.3 A. \& E. Ann. (as. 559 with note; Mclight v. Parsons, 135 lowa, 390, 15 A. \& W. Ann. ('as. 605 with note: llurt v. Ford, 142 Mo. 2s3; famestoun lils. College v. Allen, 172 ×. Y. 201, $92 \mathrm{Am}$. St. Rep. 740 with notr. - r'.

7 Ses note on "Instruments put in circulation in violation of instructions or conditions" in 11 Am. St. Rep. 314-316. - C. 
note to any person by or on behalf- of the defendant; that for want of delivery it is not the note of defendant, and he is not liable thereon even to a bona fide holder. "A bona fide holder for value, without notice, is entitied to recover upon any negotiable instrument, which he has received before it has become due, notwithstanding any defect or infirmity in the title of the person from whom he derived it; as, for example, even though such person may have acquired it by frand, or even by theft, or by robbery." (Story on Prom. Notes, $\S 191 ; 2$ Gr. Ev., \$1 11; Swift v. T'yson, 16 Pet. 1 ; Goodman v. Symonds, 20 Howard 365; Raphael v. Bank of England, 17 C. B. 162; Wheeler v. Guild, 20 Pick. 545 ; Magee v. Badger, 34 N. Y. 249 ; Powers v. Ball, 27 Vt. 662; Catlin v. Ilamon, 1 Duer, 325; Gould v. Seger, 5 Duer, 268 ; Marston v. Allcn, \& Mees. \& W. 494; Sm. Lea. Cas. 597 et seq.; 1 Ross, Lead. Cases, 205 et seq.)

'The fact that there has been no delivery of the instrument by or for the maker, or by or for an indorser through whom the holder must claim, is a defect or infirmity of title within the meaning of the rule above cited, a rule which is said to be laid up among the fundamentals of the law. (Worcester C'o. Banl: v. Dorch. \& Melton Bli, 10 Cush. 488 ; Edvards on Pills and Notes, 1 ss; Gould v. Seger, supra: Ingham v. Primrose, 7 C. P. (N. S.) 82; Shippley v. Carroll, 45 Ill. 285 ; Clark v. Jolinson, 52 Ill.)

The order denying a new trial must be resersed. ${ }^{8}$

R For an excellent ease setting forth with great persuasiveness the contrary doetrine, sce salley v. Terrill, 9.5 Mr. 55\%. In this ease the detendant was cngiged in a lmbibering operation, and llurd was in his employ. Among his duties was that of kepping the tine of the men in the words, amil when one was discharged to draw an order on the defendant for the amount due. Blank orders were furnished Hurd ly the defendant for this purpose. As a matter of practice, Ilurd drew an order on the defendant, payable to the order of Harry Carter, for 975.25 , the same luing in full settlement for cooking. This order was never delivered to Carter, nor intended to be delisered. llumel left it on his tahle, with ofher papers, for a few moments, while le was ealled awny, and on his return he took all the piapers and everything, and burnt them up, and supposed the order wats thus burned. Carter in the meantime had alsotracted thr order. Later Ihurd, thinking of the oreler, asked farter, who had heen near when it was writen, if he hat seen it, and he said he had not. Carter negotiated the order to the plaintill for a valuable consideration witlout notice of the facts.

Judgenent was rendered for defoulint, the conrt saying: "In the cise

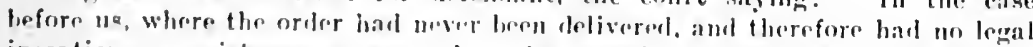
inception or exiatence na an order. the question is whether there is any liability upon it to an innowent imdorsee for value. $\lambda$ s is muil in Burson $v$. Huntingtem, 21 Mich. 415: "The Wrongful act of a thief or a tresplisser nay deprive the holeler of bis property in a note which has one beeme a note or property by delivery, and may trander the litle to an innocent purchaser for valuc. But a note in the hands of a maker hefore delivery is not property, nor the sulbject of owuership. as such. 11. is in law but a bank piece of paper. Can the theft or wrongful scizurc of this paper create a valid contract on the 
187 MAssachuskTs, 159. - 1905.

ACTun by the Massalchusette National Bank against one Snow. Vordict for defendant, and plaintifl brings exceptions.

Kxowlox. C. J. 'This is an action of contrat on three promissory notes, signed, " II. G. \& H. W. Stevens," payable to the order of the defendant, indorsed by him in blank, and discounted by the plaintitf- 'Tluey severally bear date December 9, 189\%, and the rights of the praties are accorlingly governed by St. 1898, p. 492, e. 533, sometimes called the "Negotiable Instruments Aet," which is now embodiel in Rev. Laws, e. $\pi 3, \$ \$ 18-212$, inchusive. In referring to different provisions of this statute, it may be convenient to cite the sections of the lievised Laws, rather than the original act.

The maker of the notes, H. W. Stevens, who did business under the name of H. G. \& H. IV. Stevens, has deceased; and the defendant introduced evidence tending to show that, after the defendant had indorsed the notes. they were taken from his possession by the maker, without his knowledge or consent. and discounted at the plaintiff bank. and that they were altered by the insertion of the words "seven

part of the maker against his will where none existed before? There is no principle of the law of contracts upon which this can be done, unless the facts of the case arr such that in justice and fairness, as between the maker and the innocent holder. the maker ought to he estopped to deny the making and Ielivery of the note.' . . . That there must be delivery of the paper, either actually or constructively, is elear. Until then it has no existence as a contraet. Bank v. Sitrang. 72 III. 559."

The conrt further held that the ease did not fall "within the principle that, when one of two innoesnt persons must suffer by the aet of a third, he who has enabled such third person to neeasion the loss must sustain it. . . . The oriler was drawn at the table of Hurd, and momentarily left there with other papers of his, to which no one had right of aecess, and from which it could only be abstracter by a eriminal aet. which he eould not reasonably anticipate."

Sice also the note in 19 I. N. S. 107, entitled "Rights of owner of negotiable paper payble to bearer, or indorsed in blank, as against bona fide purchaser from one unlawfully in possession therenf," wherr the authorities, pro and ent. on the question whether a delivery is necessary to the existenee of the instrument as an enforeible entract are exhaustively consilered (sce particularly, pages 109-111).

The erinflict of authority in the decisions represented by the Salley and the Kinyom rilses was rusolued in favor of the doctrine of the latter cases by sertion 35 of the Norgotiable Instruments Law. "The primary purpose of the Negntiable Instruments law was to make the law relating to commercial paper uniform tlirrughout the United States. Specifically, it was the purpose of the act to exclure non-delivery by the maker as a refense to a suit on a note complete in form and execution by a holder in due course." 8 Mich. Law Pev. 4l. "This ehange. like some others made by the act, is in the direction of facilitating the cireulation of commercial paper." Crawford's Neg. Inst. Law, 3d ed., p. 28,-C. 
per cent." after the words "with interest." The defense is founded on this evidence. The defendant's counsel stated that he made no contention that the bank had actual knowledge of any infirmity in the instruments, or defect in the title to them, or that it took them in bad faith. Nor was it contended by the defendant that in discounting the notes the bank acted otherwise than in the regular and usual course of business. But upon the defendant's testimony it might be found that the notes were given to him by the maker in payment of indebtedness: that, after he had indorsed them in blank, and put them in his desk for collection or discount, he was ealled out of his office, leaving the maker, Stevens, there; and that Stevens then took them without right, and three days later carried them to the plaintiff bank, and caused them to be discounted for his own benefit.

The plaintiff made many requests for rulings, which were refused, subject to its exception, among which were the following:

"Fifth. That, when an instrument is in the hands of a holder in due course, a valid delivery thereof by all parties prior to him, so as to make them liable to him, is conclusively presumed."

"Ninth. That a holder of a note is deemed prima farie to be a holder in due conrse.

"Nineteenth. 'That when an instrument has been materially altered, and is in the hands of a holder in due course, not a party to the alteration, he may cnforce payment thereof according to its original tenor."

The plaintiff also exeepted to the following instruetions given at the request of the defendant:

"Fourth. That if the jury find that the notes were taken from the defendant wrongfully, and that the same were never delivered hy the defendant to Stevens, the plaintiff gained no title to the notes by the negotiation of the same by Stevens, and the plaintiff cannot recover.

"Fifth. The burden is upon the plaintiff to show that the notes were delivered by the defendant to Stevens, or some other person authorizen to negotiate them at the plaintiff bank."

"Seventh. Or, in the alternative. if the jury find that the notes in question were altered by the addifion of the words 'seven pur cent.' thereto after the same were indorsed by the defendant, such an alteration is a material and wrongful one, destroying the validity of the notes, and upen the notes, or any one of them, thus altered, the plaintiff caunot recover."

The notes, heing indorsed in blank, were payable bo bearer, within the meaning of the stafute. Rev. Iaws, e. 73, s 26 (5)." When the notes were taken to the ptaintiff for discount. Stevens was the bearer Rev. Laws. C. 73. \$ 20\%.' 'The presentation of such notes for diseount

- N. Y., § 28, subd. 5. - C.

1 N. Y., §2. - C. 
mised a presumption of fact that the bearer was the owner of then. Pettee v. Proul. 3 Giry, 50:. ITpon the undisputed evidence, and upon the defondant a abuission that the plaintiff took them in good faith. and disomunted flum without linowledge of any infirmity in them or defect of title in stovens, the plantiff became a holder in lue course. within the definition of the statute. Rev. Laws, c. 73,

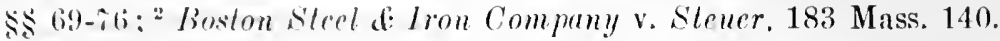

'The defendants contention that. after the notes had been delivered to the defendant and indorsed by him, they were stolen by Stevens, hrings us to the question whether, under the Negotiable Instruments Act, a holke in due course of a note payable to hearer, that has been stolen, (an acpuire a good title from the thicf. Even before the enactnent of the statute, while the decisions were not uniform, the weight of authority was in favor of an affirmative answer to the question. Whecler v. Guild, 20 Pick. 515, 550, 553; Worcesler, elc., Bank: v. Dorchester, ete., Bank, 10 Cush. 48s; Wyer v. Same, 11 Cush. 51, 53; Spooner v. Holmes, 102 Mass. 503 ; London Joint Stock Bank v. Simmons, (1S92) App. Cas. 201, and cases cited; Smith v. Bank, 1 Q. B. D. 31: Goodman v. Simonds, 20 Howarl 343-36.5; Murray v. Larilner, 2 Wall. 110: Iolchliss v. Nalional Shoe of Lenther Bank, 21 Wall. 35.4: Kimyon v. Wohlford, 1 \% Minn. 239 (Gil. 215) : Clarke v. Johnson, 54 Ill. 296; Seybel v. Nalional Currency Bank, $5+$ N. Y. 288; Erertson v. National Bank of Newport, 66 N. Y. 14; Kuhns v. Gettysburg National Bank, 68 Pa. 445.

The following specific language of the statute touching this question. as well as its provisions in other sections, was intended to establish the law in favor of holders in due course: "But where the instrument is in the lands of a holder in due course, a valid delivery thereof by all parties prior to him, so as to make them liable to him, is conciusively presumed." Rev. Iaws, c. $\% 3, \$ 3.3 .^{3}$ 'This conclusive presmmption exists as woll when the note is taken from a thief as in any other case. Of course, this rule does not apply to an instrument which is incomplete. But in reforence to a complete, negotiable promissory note, payalble to healer, it is a wholesome and salutary provision. See Gresser v. Sugurman, $3 \%$ Mise. (N. Y.) 799 . Upon the defendant's statement and the counsel's theory of the case, the rule is applicable. 'The note was not only complete in form and in execution, but, upon his testimony, it had leen delivered to him by the maker as a binding instrumont. and had afterwards been indorsed by him. Therefore the first senfence of Rev. Taws, c. 73, § 33, "Every contract on a negotiable instrument is incomplete and revocable until delivery of the instrument for the purpose of griving effect thereto," was inapplieable. The instrument had taken effect, and was subsequently

2 ฟ. Y., §§ $11-98 .-\mathrm{C}$.

s. Y., $335 .-\mathrm{C}$. 
negotiated by the bearer to the plaintiff as a holder in due course. That the bearer was also the maker was immaterial after the instrument had been so indorsed as to become payable to bearer. Upon the plaintiff"s theory of the facts, there was no theft, but an ordinary accommodation indorsenrent by the defendant for the benefit of the maker, and none of these questions arise. We are of opinion that the judge erred in giving the fourth and fifth instructions requested by the defendant, and in refusing other instructions requested by the plaintiff, founded upon a different view of the statute.

There was also error in the instructions given as to the alleged alteration of the notes. By Rev. Laws, c. $83 . \$ 141,{ }^{4}$ it is provided that "when an instrument has been materially altered, and is in the hands of a holder in due course, not a party to the alteration. he may enforce payment thereof acenrling to its original tenor." This language is direetly applicable to the present rase. Soe Scholfield v. Earl of Londesiorough, (1894) \& Q. B. 6660. (1895) 1 Q. B. 536, (1896) A. C. 514: Sicherartz v. Wilmer, 90 Md. 136-143.

We understand that the instructions wre given independently of any question of pleading, and we therefore do not deen it necessary to determine at this stage of the case whether the plaintiff should amend its declaration by inserting counts upon the notes as they were before the alleged alteration, if it wishes to recover upon them as notes bearing interest at only 6 per cent. See Mulual Loan .I ss'n v. Lesser, if App. Div. (N. Y.) 614. Nor do we enusider other questions which are not likely to arise upon a second trial.

\section{$\S 35$}
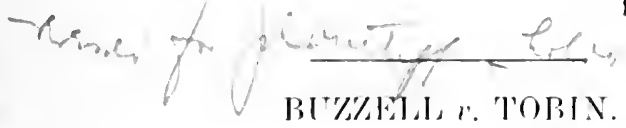

201 MASsACIISETTS. 1. - 1909.

Exceptions sustained.

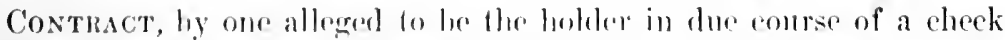

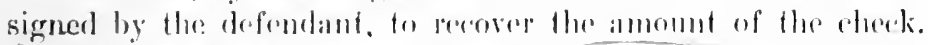

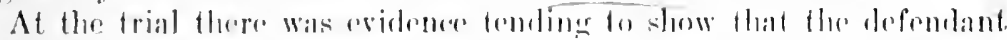

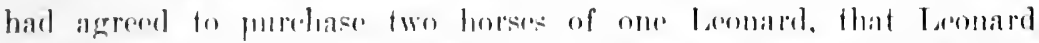

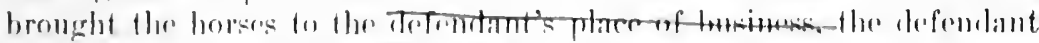

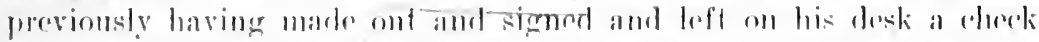

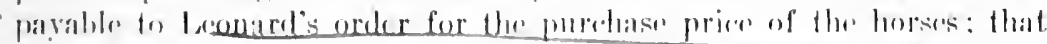

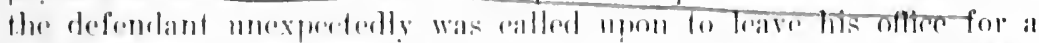

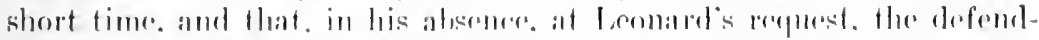

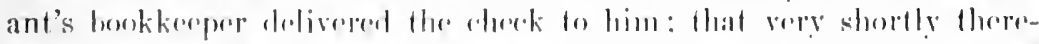

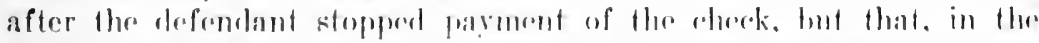

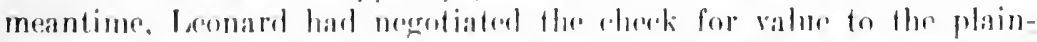

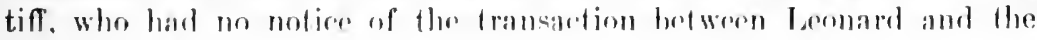

1 N. Y., § 205. - C. 
defendant. The defendant's evidenee tended to show that the bookkerper had no anthority to deliver the daek to Leonard, and that the reason why he stopped payment ou the check was that he discovered that the hotses were monsouml.

At the elose of the cvidene, the defondant requested the presiding jud are to mole that the plaintifl' could not reeover. 'The request was refused and the jury returned a verdict for the plaintiff. The defendant alleged exceptions. -

Bistly, i. If the ensideration of the cheek as between the defendant and the payee was the price of a pair of horses, which might have been found to have been unsound at the time of sale, yet the plaintiff as indorsee having taken it for value, and in good faith before it was orerdue. and without notice of any infirmity, or that payment hat been stopped at the bank, became a holder in due course, with all the rights appertaining to such il title. Rev. Laws, c. $73, \S 69 ;^{\circ}$ Whefler $:$ Guild, 20 Pick. 545, 552, 553, 32 Am. Dec. 231; Shawmut National Fank v. Manson, 168 Mass. 425; Massachusetts National Bank v. Snow, 187 Mass. 159. The defendant, while not expressly conceding this, rests his defense solely on the ground that, because his clerk had no express anthority to deliver the check to the payee, it was unlawfully put in circntation, and the contract being incomplete, no title passed to the plaintiff by its subsequent negotiation. Fearing v. Clark, 16 Gray, r4; Mill v. Hall, 191 Mass. 253, 265. But the check was in the hands of the plaintiff as a holder in due course, and as to him a valid delivery by the defendant was conchsively presumed, even if this defense wonld have been open as between the original parties. Rev. Laws, c. $73, \& 33 ;{ }^{6}$ Massachusetts National Bank v. Snow, 187 Mass. 159, 163. We are, therefore, not ealled upon to decide whether there was other evilence upon which, under suitable instructions, the jury could have found either actual or constructive delivery. It accordingly follows that the ruling requested could not properly have been given, and the case was rightly submitted to the jury.

VII. Non-essentials.

$\S 25$

MEITIRERG $r$. TISHER.

24 Wisconsin, 607. - 1869.

Actios on the following instrument:

To Hoxif, and Ricu: Jlease pay to Chas. Mehlberg the sum of $\$ 69.20$, and charge to me.

Chas. TISHER.

Townsup of Mancuester, Feb'y 23, 1881.

s. Y. Y.. \$91.-r:

B N. Y., \$35. - C : 
Dixos, C. J. The written instrument * * * was a bill of exchange. It is not essential to the validity of a bill of exchange that it should be made payable to order, or bearer, ${ }^{7}$ or have the words "value received," or be payable at a day certain, or at any particular place.

\section{$\S 25$}

\section{BROWN $v$. JORDHAL.}

32 Minnesota, 135. - 1884.

Plaintiff brought this action in the District Court for Freeborn county, as holder of the following instrument:

Township of Mansinester, Feb'y $23,1881$.

\$120. Six months after date, (or before, if made out of the sale of Drake's horse hay fork and hay earrier), I promise to pay James B. Drake, or bearer, one hundred and twenty dollars.

Negotiable and payable at the Freeborn County Bank, Albert Lea, Minn., with ten per eent. interest after maturity until paid.

Witness: J. WiLliamsox.

OLE J. JORDA HL [Seal].

[Seal].

At the trial, before Farmer, J., the plaintiff, having introduced evidence that he bought the note from Williamson for value, before maturity, in good faith and without notice of any defense to it, admitted that the note was obtained from defendant by Williamson by fraud, and that as between those parties the note was without consideration and fraudulent. 'The court thereupon directed a verdiet for defendant, a new trial was denied, and the plaintiff appealed.

Grifuldax, C. J. 'The defendant executed an instrument in the form of a negotiable promissory note, except that after and opposite the signature were brackets, and between them the word "seal" thus, "[seal]." Thr question in the case is, is this a negotiable promissory note, so as to be entitled to the peculiar privilenges and immunities acenrded to enmuercial paper? The rule that an instrument under seal, though otherwise in the form of a promiscory note, is not (eertainly when executed hy a natural person, however it may he when executed by a enrporation) a negotiable note. entitled to such privileges and immunities, is miversally recognizod. and is not disputed

F Nor to the validity of a promissory note that it should te payalide to order or bearer. Simith Y. Kimdall, 6 T. R. 12.1: Cummright v. Gary, 127 X. Y. 92; Wells v. Brigham, fi Cush. (Mass,) f, Coutra: Bristol v. Worner, lg Conn. 7. The matter as to promisury notes is one of eolutruction of statute, as such notes are the ereature of statute. Ser Neg. Inst. 1.., \$320. It must he remem. bered, however, that the Negotiabe Instruments Jaw applies only to negotiable paper. - II.

a "The omission of the words 'for value repeivel' dors not impair the note, affect its legal import or weaken the proumption that it was given for value." Mcleorl v. Hunter, 29 Mise. (N. Y.) $558,560 .-('$ 
in this state. But the appellant contends that merely placing upon an

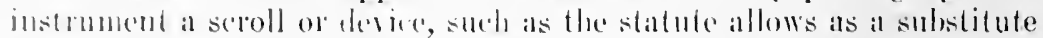
for a common-law seal, withont any reconnition of it ats al seal in the body of the instrument, does not malie it a sealed instrument. Undoubtedly, where there is a seroll or deviee upon an instrument, there must be somelling upon the instrument to show that the seroll $\alpha$ derice was intended for and used as a seal. 'The scroll or device does not necessarily, as does a common-law seal, estabisch its nwn character. Such words in the testimonium clause as " witness my hand and seal." or "sealed with my seal." would establish that the suroll or device was used as a seal. No such roference in the hody of the instrument was neecssary in the case of a common-law seal. (Goddarils

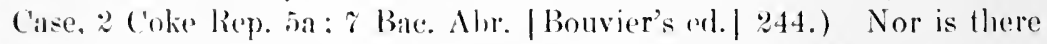
any reason to require it in the case of the statutory substitute, if the instrument anywhere shows dearly that the device was nsed as and intended for a seal. It would be diflienlt to conceive how the party could express that the device was intended for a seal more clearly than ly the word "seal," placed within and made a part of it. This was an instrument under seal.

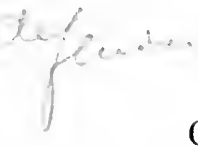

\section{CHRYSI.ER $\because$ RENOIS.}

Order affirmed. ${ }^{9}$

[Reported hercin at $p .85$.

HOGUE $v$. WIJIIAMSON.

[Reporter herein il [1. Ss.]

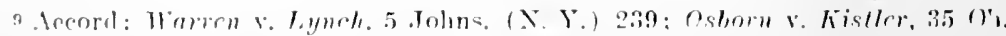

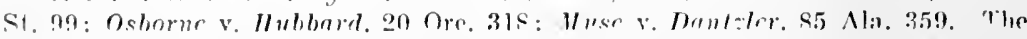
atatute (Nog. Inut. L.. \& 25, smbere. 4). changess the law upon this point.

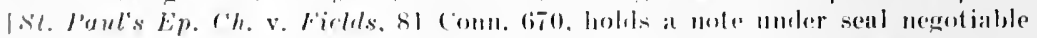

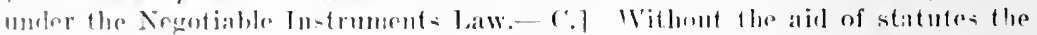
eomrte hasl Areider that the bill or note of a eorpuration did not lose its negetiable elatracter hersule of the presenes of the corpolate seal. Chase N. B. v. Faurol. 149 N. Y. 532: Mason v. Frirk, lo5 Pa. St. l62; Markay v. Saint

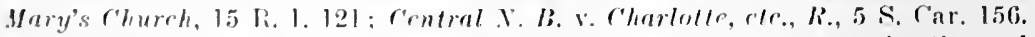
In orelor fo lewome a eninmon-law eperialty the instrument must recite the seal or otherwice indiente the intention of the maker to ereate a specialty. Wecks v. Esster, 433 N. Y. 374 ; cases supra. [lollowed in Matter of l'iric, 198 N. Y. 209. - C.] 
VIII. Date.

\section{(ii) Interpretation.}

\section{ALMICH $v$. DOWNEY.}

\section{Minnesota, 460. - 1891.}

Action on a promissory note for $\$ 500$, brought in the District Court for Le Sueur county. Trial before Edson, $J$, and verdict for defendants, who appeal from an order granting a new trial.

Vanderburgh, J. Plaintiff is the indorsee of the note/ in suit. The note was dated June 25,1886 , and was by its terms payable six months after date. It is alleged in the complaint to have been executed and delivered on the day of its date. It appears from the evidence, however, that the note was actually executed and delivered on the 25 th day of June, 1887, and that the date was written 1886, by mistake. 'There was evidence to go to the jury tending to show that it was indorsed to the plaintiff for value within six months from the actual date of its delivery, but not within six months or before its maturity, according to the face of the note. 'The court charged the jury, under plaintiff's exception, that if the note, when transferred to plaintiff, was due according to the date as actuilly expressed therein, and was given withont eonsideration, their verdict must be for the defendants. If a note is antedated or post-dated by the maker, it is a valid contract from the time of its delivery; and, since it is competent to express the agreement of the parties in that way, the courts will construe the instrument according to its terms; and if, when delivered, it is by its late overdue, it will then be treated as a dernand note. (1 Par.s., Notes and B., p. 49; 3 Rand., Com. Paper, $\$ 1034$.$) Hit where the note is intended to hear date as of the time$ of its delivery, that is the true date and if by mistake another date is writton on the fine of the note, the mistake may be corrected. exept is to in imocent indorser or purchiser who would be prejudiced th the correction, and the mistake may he shown hy parol. (2 Pars.e Notes and B.. 51t.) As it wearly appeared that the note was given in 1ssi, and the wrong year inserted in the datr by mistake, the note, hy intendment of law, was payable in six monthe from June

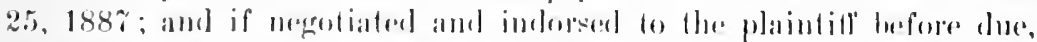
in gond fath and for value, the defonse of want of consideration is not availahle; and the mistake may in surb alse be shown as well by the indersere as the payere of the mote. (Drale v. Rogers, 32 Ne. 5et;

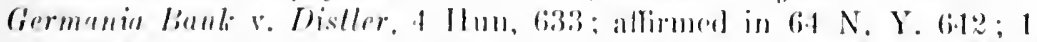
Daniol, Negr. Inst., s.8: 1 lidw., Bills and N., \& 1\%1.)

The mistake shomld strictly have bern allenerel in the complaint, but as the evidenee was rereiverd withoust ohjection, and the faret. was before the court as if properly plateded, and considered by the 
court in its charge, the objection to the pleading cannot be raised now. The pleading might have heen amended formally to conform to the pronts after the evidence was in.

For the reasons stated, it is apparent that the court erred in its charge on this branch of the case, and the order granting a new trial was proper, though based on other grounds.

Order affirmed.

69 Calrfornia, 550. - 1886.

Belcher, C. C. The controlling question in this ease relates to the statute of limitations. The action was commenced on the twentyfourth day of October, 1882, and was based on a promissory note dated May 1, 18i8, and payable one day after date, with interest. In the complaint it was alleged that the note was not in fact made or delivered to plaintiff until the fifteenth day of July, 1879; that during the year $18 i s$ the plaintiff loaned to the defendant sums of money, which amounted in the aggregate to the sum named in the note as principal, and which he verbally promised to repay, but made no written promise to do so; that on the fifteenth day of July, 1879, "the defendant, at his own instance, and without any request from plaintiff, caused said note to be prepared, and he signed and delivered the same to plaintiff without being thereto requested or required by the plaintiff; that said note was antedated as aforesaid, at defendant's own instance, for the reason that refendant wished to pay interest on said principal from the first day of May, A. D. 1878, and at the rate in said note specified." The defendant demurred to the complaint, upon the ground that the cause of action was barred by the statute of limitations. The conrt at first overruled the demurrer, but aiterwards reconsidered its ruling, and sustained it, and then entered judgment in favor of defendant.

In our opinion, the first ruling was right and the seeond wrong. "In general, it is not essential to a note that it shonld be dated; and if there be no date, it will he considered as dated at the time it was made. If it be dated, the date will be prima facie evilence of the time when the note was made, but not conclusive." (1 Pars., Notes \& Bills, 41.) A note may be antedated or postdated, and "where the purposes of justice reginire it, the real date may be inquired into, and effeet given to the instrument." (S'tory, Prom. Notes, $\S 48$; Paige-r. Carter, 64 ('al. 489.) And, whatever may be its date, a note takes effect only on delivery. Tntil it is delivered it is not made, in a legal sense, and by it no obligation is imposed on the maker. If the delivery be subsequent to the date, it lecomes a valid and binding note on the day of its delivery, and not before. "If it be made payable in so many days 
or weeks or months from the date, this period must begin from the date which the paper bears, without reference to the day of actual delivery; for it is perfectly competent for the parties to agree that the money should be payable when they please. and they express their agreement on this point by making it payable in so many days from a certain day. Thus, if a note payable in three months from date were delivered four months after date, it would be payable on demand." (1 Pars., Notes \& Bills, 49.)

Here, according to the averments of the complaint, which must be taken as true, the note was delivered on the fifteenth day of July, 1879. It was due at that time, and a canse of action at once acerued upon it. Until then there was no cause of action, because there was no note. But the statute of fimitations begins to run when the right of action acerues, and never before. This is a general rule, and applies to all actions.- Ender our statute one has four years in which to bring suit upon a promissory note after his right of action accrucs, and his action is never barred until that time has elapsed. As this action was commenced within four years after the plaintiff's cause of action accrued, it is clear the court erred in sustaining the demurrer. ${ }^{1}$

\section{Blanks: Authority to fill.}

3 Abeott's Appear. Decisions (N. Y.) 433. - IS66.

Irs and Orlando Page sued David and Danicl II. Norrel, composing the firm of Morrel \& Som, and Benjamin N. Nollis, in the Supreme

I Approved and followerl in Wrbber v. Wrbber, 146 Mieh. 31, where, lowever, it was atso hede that the notro being payable with interest, the interest ran from the date of the iustrmment and not from the time of its dolisery.

But in l'aul v. S'mith, 32 N. J. J. 13, it was held that where at the time a promiseory note was madr it was antedated a number of years by the agreement of the parties, the statute of limitations hegins to rou agaiust it from the tims it comes dur by its torms, and not from the tims it was made. The court said in part: "There can le no dembt that the true time when a note was madre may be shown if it was wronely daterl by fraul or mi-take. A note.

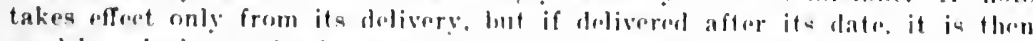

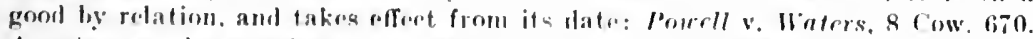
A note may be anterlated or prostatool, and in lorth cases it is valid if no statute exinte to the entrary: and where the purpouse of justiere require it, the real date mav l, inguliroil info, and effect given to the instrument: Story on P'romisaory Notes, \& 13. The note in question was rlue immoliately affer its delivery. It was not nutodnted by mistuke, or for any lunlawful jurpose. but to earry into offect the nhiject of the parties. To alter tles date, or to give

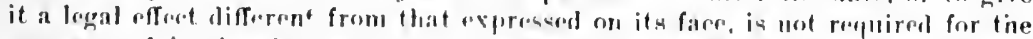
purposes of justice. lint would be to make a new bargain for the parties, and thus to do injustice." Ецмrs, J., at p. 14. - C. 
Comrt, on a promissory note, of which D. Morrel \& Son were makers, and Sollis tile indorser.

The note was made on Jmme 10, 18:5, for the sum of fifty dollars, piyablo thirty days after dite. It was dated June, but with a blank where the day of the month is usually statorl, thus: "June 185,?."

In this condition the note was indorsed hy the defendant Nellis for the aceommodation of the makers, and on the same day, the tenth, the makers trimsferred it for value to one Wiles. On the fifteenth of the month. Wiles trinsferred the note to the plaintiffs for value, and they, without the knowledge of any of the other parties thereto, and of conrse without their express consent, filled the blank in the date with the figure " $1, "$ so as to make the late "June 1, 1859."

The indorser having been charged, on non-payment thirty days after June 1, this action was brought; and the only question was, whether the note was valid against the defendants, notwithstanding the insertion of the figure in the date. The judge found the foregoing facts, and held that the note was valid, and gave judgment for the plaintiffs.

By the Court - J.unes C. Surti, .J. - The only question in this ease is. whether. as hetween these parties. the note is rendered invalid, in consequence of its having been antedated by the plaintiffs after the transfer to them. so that it had ten days less to mo than it would have had if it had heen dated as of the day when it was indorsed and negotiated to Wiles.

There can be no doubt that, if the same rlay of the month had been inserted by the makers when they negotiated the note to Wiles, without the knowledge of the indorser, the note would not thereby have been rendered invalid, as acainst the indorser: and so if the day had bern inserted hy Wiles, with the express direction or consent of the maker. In such case, the note, when indorsed, being perfeet in every respect but the date, and that having been left blank, the makers would have had an implied anthority from the indorser, to insort any lay of the month they might think proper. (Milchell v.

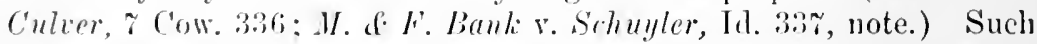
authorits results from the ormeral rule, that an indorement on a blank note. Without sum, or date, or time of parment, will hind the indorer, for any smm, payalile at any time, which the person, to whom the indrores trusts it, roorses to insert. The date of a note is no exception to this mol, althongh it $j$ not eszential to the validity of a note that the date ho expresend: for, where a note has no date, the time. if neossary, may he inquires into, and will be computed from the rlav it was issued. Put it is essential to the free and uninterrupted negrotiability of a note that it shomb lo dated, and, therefore, all the parties to a note intenrler for rirculation. are presumer to ennsent that a person, to whom such a note is intrusted for the purpose of 
rajing money, may fill up the blank with a date. (Ib.) And a blank, left for the day of the month, may be filled with any day in that month, there being no fraud, or express direction to the contrary.

Upon the same-principte, Wiles, to whom the note was delivered by the makers, had an inplied authority, from both makers and indorsers, to fill the blank with any day in the month.

But it is elaimed by the defendant's counsel, that the implied authority, above stated, is restricted to the first holder of a note, and that it was unlawfully exercised by the plaintiff, to whom the note was transferred in blank by Wiles.

That position cannot be maintained. It is immaterial, to the parties to the note, whether the blank in the date was filled by the first holder or his transferee. The latter acquired all the rights of the former in regard to the paper. Until the blank was filled, each successive holder took the note with authority to fill the blank, according to the implied intent of the parties. The reasoning of Justice Bockes upon this point, in the court below, is satisfactory and convineing. The case of Inglish v. Bruicmon (5 Ark. 3r\%), so far as it holds to the contrary, is not supported by authority.

The judgment should be affirmed.

All the judges coneurred, except Mnrgan, .T., who dissented. Judgment affirmed, with costs. ${ }^{2}$

122 South Westekn (Mo.--St. Louis CT. APP.) 756. - 1909.

$A$ CTion against accommodation indorsers on a promissory note delivered hy the defendant Meraskill to the plaintiff ahout December 1, 1905, and payahle four months after datr, lut not dated. Shortly after, plaintill"s eashier inserted the dato Deeember 30, 190\%. .Tudgment for defendants and plaintiff appeals.

Nortoni. J. * * * It is conceded throughont the rase that the date December 30th was inserted in the note by the cashier without any express anthority whatever from either the makers or the indorsers thereon: and, if the tratimony of dack Mrobaskill is to be helieved, it was inserted contrary to his instructions on dolivery of the unte to the hank. Meraskill fretified that he instrueted the cashier at the time of defivering the note to insert the date August 30.1905. Be this as it may, the plaintill bank does not rely upon any express anthority from any one to date the note December 30, 1905, but, on the contrary, relies upon the fact that the note was undated, and that

2 See note in 2 A. \& E. Ann. C'as. 331, entitled " Implied authority to fill in blanks so as to complete signed inatrument." - $C$. 
there was a hlank left therein for date at the time of its delivery and the implied authority which. in the ahsence of express instructions, is assured by the law to the holder of a note, to fill in such blanks as are necessary to either make the ohligation complete or render it an appropriate instrument as commereial paper.

The accommodation indoreses only defended the action, and the finding and judgment of the court were for them to the effect that in the absence of directions from $\mathrm{MlcCaskill}$ who delivered the note to the cashier of the hank, or an agreement of some kind to that effect, the asshier was without authority to postatate the note December 30, 1905: in other words. the instructions gn to the etlect that in the absence of a direction from or agreement with MeCaskill, who delivered the note to the hank, which might be regarded as express authority therefor, there is no authority implied by law authorizing the ashier to postdate the note December 30, 1905. The question, therefore, presented for decision-is the soundness of the proposition of law announced in these instructions.

Now. there is no doubt where a note is issued without a date and an inproper date is inserted therein by the payee and the note is thereafter negotiated to an innocent party or bona fide holder without notice that snch bona fide holder may enforce the same notwithstanding the improper date. This follows for the reason that one who signs such an instrument furnishes the means of fraud, and-is estopped to deny his Tiability thereen. Mitchell r. Culeer, 7 Cow. (N. Y.) 336; Frank v. Lilienfold, 33 rirat. (Va.) 378: Redlich v. Doll, 54 N. Y. 234: Joyce. Defenses to Commercial Paper, $\$$ 22 ; Daniels. Negotiable Instruments (5th ed.), \& 143; Androscoggin Bank v. Kimball, 10 Cush. (Mass.) 373.

It is no doubt true that a note issued bearing the month of its issue and the vear, with a blank for the day of the month, may be enforced by a subsequent holder, although the day of the month is filled in by him without express anthority therefor. Such was the case of Page v. Morrell, 3 Ah. Dec. (N. Y.) ¿33. In such a case it is obvious that the subsequent holder filling in the day of the month is not aware of the particular day on which the note was issued, for he knew nothing of its issue. The paper having come into his hands for value in tue course bearing date the month of June and the year in which it was issuerl. in the abener of any knowledge whatever as to the date of issue. anthority was implied to him to insert any date during the month mentioned. Howeper, that anthority is not in point here for the reacon that in that case the subserment bona fide holder of the note had no knowledge as to what was the true rate of the instrument; whereas. in the present controversy, the subsequent holder of the note (that is, the plaintiff bank). who it may be said purchased it from Da., the payee, in fact an accommodation party only, knew the day 
and date of its issue, and, indeed, with such knowledge oceupied the same position in respect of that matter as an original-payee who knows the true date of issue: that is, the plaintiff bank knew that it acquired the note about the 1st of December, and not December 30th, for such was the date of issue under the facts in this case. Having this knowledge as between it and these aceommodation indorsers, whom McCaskill represented when he delivered the note. it became the duty of the cashier of the bank to insert the date Angust 30, 1905, as instructed hy McCaskill, if his testimony is to be believed. On the contrary, if no instructions whatever were given, then it became the duty of the bank to insert the true date of issue identically as though it were an original payee. ***

After much eareful reading and reflection on the subject, we helieve as a general rule between the original parties to the instrument or subsequent holder with notice the original payce or such subsequent holder with notice has implied authority by rirtue of the blank contained in the note only to fill in the true date or such a date as was direeted or contemplated by the parties Daniels, Negotiable Instruments (5th ed). \& 143a, 144: ? Cyc. 163, 164: ? Am. \& Eng. Ene. Law (?d ed.). 255: Orerton v. Mathew's, 35 Ark. 146: Emmons v. Meeher. 55 Ind. 329. It is obrious that what has heen said is in aecord with the public poliey of this state as declared in the new negotiable instrument law approved April 10, 1905. See Laws of 1905 . And the note in suit is in all respects subject to that enactment. Section $6^{3}$ of the act referred to declares that the validity of a negotiable instrument is not alfected by the fart that it is not dated. Section $12^{1}$ declires that the instrument is not invalid for the reason only that it is anterater or postraterl. "provided this is not done for an illegal or fraudulent purpore. The person to whom an instrument so dated is delivered, acpuires the title thereto as of the date of deliverv." This section scems to contemplate instruments which are antediated or postdated by the parties in areordanee with a mutual angreement to that effect, as is frequently dome, and derlatres that they are not invalid because of surh fact. provided no illegal or framdulent purpose is introuled. Suretion $13^{2}$ of the act is as follows: [Qunting

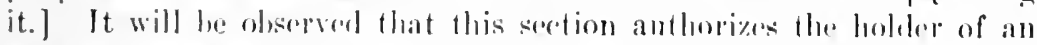
undated instrument to insert the trone date of issure therein and makes the instrument payalofe acenelingly. It provides, foo, that the insortion of a wroug date does not avolid the instrument in the hames of a

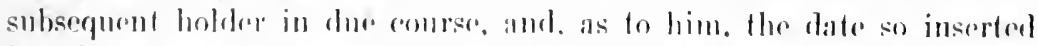

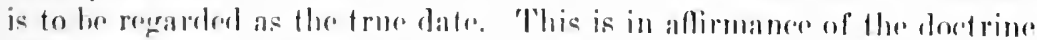
wheld ohtaine in the law merehant. and it implies, at loast. that the

\footnotetext{
3 N. Y. \& 25.-C.

IN. Y., \$31.-C.

2 N. Y. \$ 32, - C.
} 
insertion of a wrong date in an undated instrument by one having knowleder of the true date of issue wonld avoid the instrument. Such we understand to be the settled doctrine of the cases hereinbefore cited, expounding the prineiples of the law merehant; that is, that such amounts to an alteration. : Am. \& Eng. Ene. Law (2d ed.) 142. Now, for one to be a holder of commercial paper in clue course. the element of grood faith with respect to the same is essential. More v. Finger, 128 Cal. 313; Reese v. Bell, 138 Cal. xix. Therefore, the present plaintitf, having inserted an untrue date in the instrument when it was possessed of knowledge of the true date of issue, is not a subsequent holder in due course within the meaning of the statute.

Judgment affirmed. All concur.

29 Iows, 495. - 1870 .

Actios upon a promissory note; defense that the instrument is a forgery. The cause was submitted to the court without a jury. The court found the following facts: Defendant entered into a contract with one Smith to sell for him, as his agent, grain seeders. At Smith's request. defendant signed his name upon a blank piece of paper. which Sunith was to send to the manufacturers of the seeders, that they might know defendant's signature upon orders which he should make upon them for the machines. The signature was made for no other purpose.

The instrument in suit was printed over the signature of defendant. so ol,tained, without his knowledge and consent, and the stamp in the same mammer attached and canceled. The plaintiff purchased the note before maturity, for a valid consideration, and without knowledge of any matter. comnected with its execution. Upon these findings. the cont held, that the note is a forgery and void, and that plaintiff is not entitled to recover thereon. Plaintiff appeals.

Brck, J. - A holder of negotiable paper, acquired before distonor. is not protected against defenses that make void the instrument. He ran have no claim upon forged paper against the person whose name is falsely affixed thereto as the maker, and who is without fault as to the forgery and the taking of the paper by the holder. (1 Parsons, Bills and Notes, 75, and authorities cited.)

Is thr note sued rpon a forged instrument? "The making or alteration of any writing with fraudulent intent, whereby another may be prejudiced, is forcery." (State v. Wooderd, 20 Iowa, 542; Rev., \$ 4253.) In order to constitute the offense of forgery it is not necessary that the signature of the instrument be false. The instrument may be altered so that it is not the instrument signed by 
the maker, and, if this be fraudulently and falsely done, it is forgery. So if words be added to change its effeet, with like intent, it is a forgery. In the case before us the instrument was falsely and fraudulently made over the genuine signature of defendant, which was not obtained for the purpose of binding defendant by any-contract. It is erident that this differs, in no respect, from the cases mentioned, and that the note is a forgery and void. (See 2 Parsons, Bills and Notes, 554$.

The ease differs materially in its facts from the eases cited in support of plaintiff's right to recover. In those cases blanks were filled up contrary to the direction of the maker, or without his authority. But in all such eases the makers intended to execute an instrument that should be hinding upon them. Blanks were filled up contrary to the authority given hy the makers, or in some other way the instruments were made so that they did not correspond with the intention of the makers: but in all such cases there were makers and instruments, and through the frauls of those to whom the instruments were intrusted they were thus made to be of different effect than was designed by the makers. In these eases it is correctly held, that while the parties perpetrating the fraud in some cases may have been guilty of forgery, yet the maliers were bound upon the instruments, as against holders in good faith and for value. The reason is obvious. The maker ought rather to suffer, on accomnt of the frandulent act of one to whom he entrusts his paper, or who is made his agent in respect lof it, than an innorent party. The liw esteems him in fault in thus putting it in the power of another to perpetrate the fraud, and requires him to boar the loss consegunt upon his negrigenee. In the case mater constaeration no fartt call be imputed to the defendant. Ile did not intrust his sigmature to thre prssession of the forger for the-purpose of binding himself tiy a confract. Me couf ferred no power upon the party who enmmitted the crime to ne it for any sum purpose. ITe was not gnilty of neglienene in thes griving it, for it is not umusual, in nrober to identify signatures, and for wther purposes, for men thus

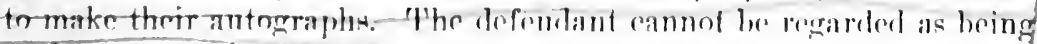
so far in fandt in the transaletion that he omght to be recpuired to beat the loss resulting form the arime.

In olle opininu the derision of the ('irenit court is in acenerd with the law, and is therefore

Aflirmml. ${ }^{3}$

a Ser Halker v. Ebert, 2! Wis. LM4, prost; Chapman v. Rose, 5t; N. Y. 137, post. - II. 
Wutruousb. J. - This was an antion on a promissory note for seven hundred and righty-five dollars. brought by the plaintill bank as indorsee of Earl B. Chate \& Compiny against the defendant as maker of the note.

The defendant seasonably tilcd his affidarit that the paper declared on hadd been materially altered since it was executed.

The facts were not controvered. The defendant had signed a prior note for the accommorlation of Chace $\&$ Company which was outstanding and overdue at the time of the signing of the note in question. At Chaces request he agreed to sign three other accommolation notes to take up the overdue note, each to be for one-third of the amonnt. But when the parties met for the purpose of executing this agreement, the amomnt of the overdue note was not definitely known to either of them. hut was molerstood to be between six hundred dollars and six lomedred and fifty dollars. Thereupon. at Chace's suggestion, the defendant signed three printed blank notes and delivered them to Chace, who agreed to dill them out with the requisite amount specified in each, when aseertained. and use them for the purpose of taking up the overlue note. T'he note in suit is one of the three notes thus signed. Butinsteat of making it for onethird of the overdue note according to his agreement, Chace framdulently wrote in "Sirson hundred and cightity-five dollars" and indorsed the note to the plaintill bank before maturity in the ordinary course of husiness, receiving therefor the full amount of the note less fifteen dollars and ninety-six cents discount thereon. It is not claimed, howcrer, that ('hace made any alteration in the printed terms of the blank thus delivered to him. He simply inserted in the blank spaces snch words and tigures as were necessary to constitute the instrument a complete promissory note. There is also positive testimony from the plaintiff's discount elerk that, at the time the mote was discounted. the lank had no knowledge of any equities existing between the drefondent and c'hare. hut tonk the note in the newal course of business. Upon this avidener the presifing justice dirented the jury to return a verliet for the plaintiff for the amount of the note in suit.

This instruction was correct. The conrt may nroperly instruct the jury to roturn a verlict for either narty when it is apparent that a contrary verdict rould not be sustained. (Heath v. Jaquith, 68 Mane, 433: J'well v. Gaqne, 82 Maine 431: Moore v. MeKenney, 83 Maine, 80.)

It is weell settled and fanilian law that. if one affixes his signature to a printed Bank for a promissory note and intrusts it to the custody 
of another for the purpose of having the blanks filled up and thus becoming a party to a negotiable instrument, he thereby confers the right, and such instrument carries on its face an implied authority to fill up the blanks and complete the contract at pleasure, as to names, terms :and anount, so far as consistent with its printed words. As to all purchasers for value without notice, the person to whom a blank note is thus intrusted must be deemed the agent of the signer, and the act of perfecting the instrument is decmed the act of the principal. In oral agreement between such principal and agent limiting the amount for which the note shall be perfected, cannot affect the rights of an indorsee who takes the note before maturity for value, in ignorance of such agreement, with a different amount written in it. (Bank of Pittsburgh v. Neal, 22 Howard, 97; Angle v. Ins. Co., 92 U. S. 330: Bank v. Stowell, 123 Mass. 196; Kellogg v. Curtis, 65 Maine, 59: Abbott v. Rose, 62 Maine, 194: Brectenridge v. Lewis, 84 Maine, 349 ; Bigelow's Bills and Notes, 5\%1. $)^{*} * *^{*}$ Exceptions overruled. ${ }^{5}$

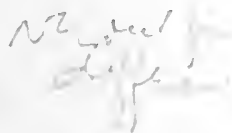

\section{SMITI $r$. PROSSER.}

\section{[1907] 2 King's liexch (Court of Appeal) 735.}

Tre defendant in South Africa, heing about to leave for England, gave to "felfer and another person a power of attorney to act for him in his absence. He further. in anticipation of the possibility of funds heing suddenly required during his abenee. signerl his name on two blank unstamper pieces of paper, which were lithographed forms of promissory notes, and handed them to 'Telfire with instructions that they should he retained in his ansterly until the alefonlant should, hy folegram or loltor from England. give instructions for their issue as promissory notes and as to the ammunts for whicle they should be

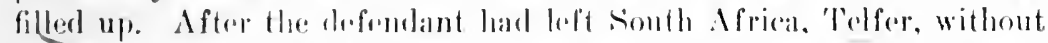
wating for instructions from llor dofondant (which wore in fact never

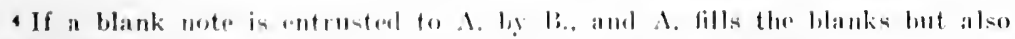
adds "with interest. ete.." at the end, llure beillg no blank space iudieatod for such purpose. li. is not liable. siner thie amounte to a material alteration

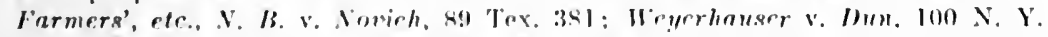
150. See Neg. Inst. L., \$ 20ti. post. So, also, the distinction must lo elearly drawn between ixaling an inatrument with blanks and isculing one in which

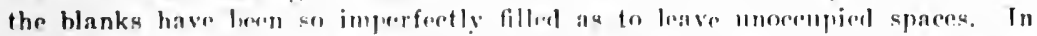
the latter case fo fill the upaciss would lo an ulteration and would destroy the instrument unlese the maker were lield to be astoped ly the negligent manner In which he sent the instrument into the world. See post, Art. IX. Dir. 1., 3. - $\mathrm{H}$.

s See note on "inctruments executed in llank and wrongfully filled up" in 11 Am. St. Rep. $316,-C$. 
given), and in frand of the defondant, filled in the blanks in the

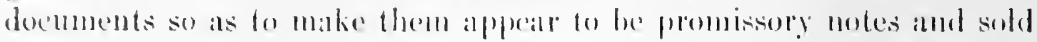
then to the plaintill, who took them honestly and in gool laith, and without notice of the frambl, and gave full value for them. For the purpose of suing upon them in Eingland, the notes were stamped as foreign litls.

The trial judge fombd that the notes had not heen properly negotiated to the plaintill, and that he was not entitled to recover. The plaintiff appoaled.

Fleteileh MOt'iton, I. J. * * *

The law stands thus. If a person signs a piece of paper and gives it to an agent with the intention that it shall in his hands form the hasis of a negotiable instrument, he is uot permitted to plead that he limited the power of his agent in a way not olvious on the face of the instrument. Notice of such limitation may be given in various ways by the instrument itselt. For instanee, if in the country where the negotiable instrument is made, a negotiable instrument can only be made on paper hearing an impressod arl ralorem stamp, the presence of a stamp on the picee of paper would be a notice of limitation of the agent's anthority as to the amount of the instrument.

But, in the absence of notice appearing on the face of the instrument, so soon as there is an intrution on the part of the signer that the piece of paper shall form the hasis of a nogotiable instrument, no limitation of the agent's authority can be allowed to affect third parties taking it withont notice. But in my opinion there was no such intention here, and the action fails for that reason. I think that the defendant deliveled the demments to 'Telfer (as representing his two attorneys) for safo eustody noly. No dould hoth parties contemplated that the flefendant might change his mind, and might dirert that the doomments. which phrsieally were in the possession of the agent might at some future time lie used as the basis of two promisenry antes. But that fact does not qualify the purpose for which the instruments were ensignorl to 'tolfor. 'They were handed to him as eustodian only, and it is imenaterial whether. when they were so banded. the defendant said that the time might rome when he might elesire to ehange their charactor, or whether he made no remark on the subject. Both parties knew that they wre delivered for safo rustorly only. The essential fact which is necessiry to cnable the phintill-to-establish his case is therefore alsent. 'Jhe defendant never issued the decmments with the intention that thry should lecome negotiable instrumests. We were presser with the atromont that, as pegards third partics, the question of the defendant's intention that 'Telfor should be the mere custodian of the locuments or that he slonld lave jower to issue them as notes loes not affect his liahility, hecause in rither view the possession of the documents nabler Telfer to put them in eirculation as promissory 
notes. Therefore Mr. Lush, quoting Lickbarrow v. Mason (5 T. R. (683) says that there is an estoppel on the defendant independent of any intention that they should become promissory notes. "In my opminion this argument goes much too far. If we are to measure the estoppel by the physical possilility of deception, s. 20 of the Bills of Exchange Act would contain something which would be absolutely irrelevant, and which yet is a condition of the section being applicable. That section commences with the words "Where a simple signature on a blank stamped paper is delivered by the signer in order that it may be converted into a bill:" in other words, the intention that it shall be converted info a bill is made a condition of the operation of the section. In my opinion section 20 is hased upon the doctrine of common law estoppel as it existed at the date of the act, and therefore the presence of the condition as to its operation shows that the Legislature realized that the intention that the document should be converted into a bill of exchange was essential in order to render the maker liable. In other work, hoth the common law and the statute realized the possibility of two rival dangers - on the one hand, a person who did nothing more than sign a blank stamped paper might find himself in the position of being the maker of a bill or note, on the other hand, a man might issue an incomplete bitl or note and place it in the hands of an agent with a limited authority to fill it up, and the agent might fill it mp without due regard to the limitations of his anthority and put it in circulation and therehy injure innocent persons. They therefore drew the line as reands the protection of third parties in the following very reasonalle and intelligible way: if the signer intended it to become a bill. it was for him to see that it was issued in aceordaner with his intentions, and if he did not do this, third parties wonld not he afferted; on the other hand. if he did not intend it to berome a bill, there would be no such duty incumbent upon him, and he wonld be in the same position as if he had merely signed it as an autograph. There wonld in that case be no animus emillendi. and te would therefore not be liable for the act of a bailee who turned the document into a negotiable instrument. 'The present case sharply raises the question of the line of demateation, and as I think that the signed forms wore in the possession of 'lelfer as enstorlian only, and not as the defendant's agent with an intention on the defendant's part that he should issue them as promissory notes, the defendant is not estopper from saying that he was not the maker of the notes sued upon. I agree that the appeal should be dismissed.

BUCKILY, J.. .J.

The reernt decision of this court in Ldoygd's Bank v. Cooke fpost. r. 1850 has no applipation to the present ease. There the person was entrusted with authority to fill up two promissory notes for a certain amount, and he filled them up for too large an amount. But the 
documents were landed to him for the purpose of issue as promissory notes. white here there has mevel been a negotiable instrument at all, and the authorities as to negotiahdre instruments have no application. 'The appeal must therefore be dismissed.

Vaughan Williams, L. J., also wrote an opinion.

Appeal dismissed. ${ }^{\circ}$

\section{$\S 33$}

\section{BOSTON STEEL AND IRON CO $r$ STEUER.}

183 MAssachusETtS, $140 .-1903$.

Contmict for $\$ 1,823.25$ for work tome and materials furnished for a building of the defendant numbered 811 on Beacon strect in Boston.

It the trial before Bishop, J., without a jury, the judge excluded certain evidence offered by the defendant and refused to make certain rulings requested by the defendant. He fomd for the plaintiff for \$2.043.86, and the defendant alleged exceptions.

Ionng, J. The only question in issue hetween the parties in this case was the right of the defendant to be credited with two smus, of $\$ 200$ and $\$ 400$ respectively, under the following circumstances: On December 31 , 1898 , the defendant's husband owed the plaintiff $\$ 1,\{81.30$, for ironwork furnished hy it to him in the construction of a house, No. 819 Beacon street. On being pressed for payment, the defendant's hushand, on Jammary 21 , 18:9!, delivered to the plaintiff the defendant's check for $\$ 200$ payble to the plantiff. It is stated in the bill of exceptions that on February 2, 1899. "he paid the plaintiff the further sum of $\$ 100$ in a check made by said Jemie D. Stever." But it appears from the amditor's report, which was before the court and is refored to in the hill of rxceptions, that the plantiff's manager's name was Newcomb, and that his story was that the rleck for $\$ 400$ "was bromely to him at his office on Devonshire street by $\mathrm{Mr}$. Stemer in respomse to further demands for money, and that it was made out in hlank and fillor up hy himsolf. Mr. Stonce being muwilling that it shomld be made for more than $\$ 200$. while Mr. Neweomb insisterl that it should he for the larerer amount, and so made it, with Mr. Simuer's consent, and applied it to his dolit." The defendant's story was "that she gave the check to Mr. Neweomb at her house."

In addition to the jon furnisled the defendant's husband for 819 Peacon strect, the defendant's hushand had ordered two iron columns and a hase plate from the plaintiff for another house. No. 811 Beacon street. whire the plaintiff supposed was Steuer's until he told the

SThis case is reported in 11 A. \& E. Ann. Cas. 191, with note entitled "Liability of maker of blank nexotiable instrument to bona fide holder where blanks are fraudulently filled in." - C. 
plaintiff's manager on March 10th that it belonged to his wife. These two columns and base plate were delivered on December 22, 1898, and at the rate charged in the hill of items were worth $\$ 150.35$. From December to Mareh there were negotiations between the defendant's husband and the plaintiff for a eontract by which all the ironwork for S11 Beacon street should be furnished by the plaintiff for a fixed sum, payments on aceount to be made as each floor was finished; and on or about March 1, 1899, the plaintifls' managor submitted to the defendant a written contract to this effect. On March 10th this was returned by the defendint's husband with the statement already referred to, that $\$ 11$ Beacon street belonged to his wife. and the contract should he made with her. No witten contract was ever made between the plaintifl and the defendant, but the plaintiff went forward and delivered the ironwork for two of the six stories of the house, part being dehvered hefore March 10 th and part after that date. The last was delivered on Mareh 1Sth, when the plaintiff stopped because it had not been paid for what it had done. Thereupon this action was brought to recover the reasonable value for the materials furnished and work done.

At the trial the defendant entended "that the amount of said payments should be credited to her in this action, on the gromnd that they were payments required by the plaintiff to be made in advanee on account of her said building numberer 811 Beacon strect, and that the checks were given to iıer saill hushand, as her agent, to make such payments," and "otfered evidence of her instrmetions to her hushand as to the use and applieation of said checks. not made in the presence of the plaintiff or anvone representing lim. and claimed that the same should be admittod in evidenore. The court declined to admit the same, and the defombant duly excepterd to the exrlusion." 'The other exceptions taken at the trial have heen waved, and the question raised hy this exception is the only matter now before ns. * * *

The jurlere before whom flor ase was tried without a jury found "that neither of said payments was recguired by the plaintiff to be made in alvanes on aceount of her sabd hoilding numbered 811 Beacon streel. and that neither of them was made acrobling to any agreament for payment fo lor made on accomt of said 811 beacon etreet, and that no foor in sail holldiner was emmpleted at the fime either of said payments was malr he said Permard Stener on aceount of his bublding numbered sls Buiden storel, and wore received by the plaintiff on areoment therofor."

This finding makes the revidumere axduded immaterial so far as the

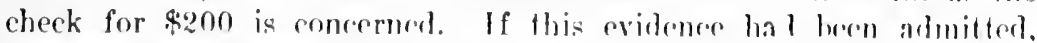
the defendant's ease on the $\$$ agon cherk would have hern this: $\Lambda$ check payahle to the plaintiff is handed hy the drawer to her husband, to be delivered by him to the plaintiff in payment of a deht to breome 
dur from the drawer of the rherk to the payee, and is fraudulently handed by the hushand to the payere of the check in payment of a debt due from him to the pavere, and is acerpted hy the payee in good faith in parment of that dehit. In such a case the payee of the check is a bome file purchaser of the check for value, without notice, and the briter comld not sot. up her himshand's frand in defense of the check, $11,11^{\circ}$ mintain an action for money had and received after payment of it on discovering the framet.

The fact that the plaintiti is the payee of a negotiable security does not prevent him from heroming a bona fide purchaser of it, with all the rights incident to a purchaser for value thereof without notice. 'lhat was decided in llatson v. Rassell (3 B. \& S. 34), and affirmed in the Excherpuer Chamber in the same case $(5$ B. \& S. 968). Tho the same ellect is Poirier v. Morris, 2 E. \& B. 89, and Netson v. Cowing, 6 Hill, 336, 339. Munoe r. Bordipr, S C. B. 862, and Armstrong v. American Bank, 133 U. S. 433, 453, seem to go on this ground. Fairbanks r. Snow, 145 Mass. 153, might have been deeided on this ground, but was disposed of on common-law principles.

That payment of the pre-existing dobt makes the plaintiff a purchaser for value in this commonwealth was settled law before the negotiable instruments act was enacted. Blanchard v. Slevens, 3 Cush. 162: Storldard v. Kimball, 6 Cush. 469: Goodwin v. Massachusetts Loan of Trust Co.. 152 Mass. 189. 199: National Revere Bank: v. Iorse, 163 Mass. 383; Holden v. Phoenix Rattan Co., 168 Mass. $5 \div 0$.

The checks in question in the case at har were given after the Nerrotiahle Instruments Act (St. 1898, c. 533; Rev. Laws, c. 73) went into effect, and are governed by its provisions. The plaintiff is a holder in due course of the $\$ 200$ chock, within Rev. Iaws, c. 73, $\$ 6.9 .^{\top}$ 'This sertion is taken from section 29 of the Bills of Fxchange Art of 1882. and Watson v. Pussell is eited in Chalmers, Bills of Exchange (ith ed.) 89, as an example of a person who is a holder in due comrse within that section. It was stated by Iold Russell in Lewis v. Clny, $6 \%$ L. J. Q. B. 2:4, that a payee of a promissory note camnot be a lokler in the comse within section 29 of the English Bill of Exchange Aet of 1882. In Hardman v. Wheeler, (1902) 1 K. B. 361,37\%, it was pointed ont that this statement of Lord Russell was ohiter, and it was also pointed out that in that case, as in Lewis r. rlay, it was not necessary to pass on that point. The case of Wratson v. Russell, 3 B. \& S. 34, ; B. \& S. 968 , does not seem to have been hrefore thr enurt in either of these ases: and in neither ease does the court seem to have taken into consideration the practice of a check being promerl, drawn by anotlıer, to be used in paying a debt due

IN. Y., \& 91. - C. 
from the person procuring the check to the person to whom the debtor has liad the check made payable. The practice is recognized in the case of foreign bills of exchange, and the per'son procuring the bill is known technically" as the "remitter" of it. See Munroe v. Bordier, 8 C. B. 862 , where it was held that the payee of a forcign bill, who took it from the remitter of it for value, was a bona fide purchaser for value; and this rule was applied in Watson v. Russell, 3 B. \& S. 34, in case of a check. In our opinion, a check received by the payee named in it, in payment of a debt due from the remitter of the check, is a holder in due course within section 69 of the Negotiable Instruments Act (St. 1898, c. 533; Rev. Laws, c. 73), even if we should follow the decision made in Herdman v. Wheeler, (1902) 1 K. B. 361, and hold that a payee never can be a holder in due course to whom the bill has been " negotiated," within the last clause of section $31^{8}$ of our act (Rev. Laws, c. 73 ) which is taken from section 20 of the English Bill of Exchange Act of 1882 (45\& 46 Vict. c. 61$)$. The rule that payment of a pre-existing debt is value was adopted in Rev. laws, c. $73,542 .{ }^{9}$

But so far as the check for $\$+00$ is concerned, we are of opinion that the evidence should have been almitted. If the defendant's story were found to be true, namely, that she handed the check to the plaintiff's manager at her house, this check would stand on the same footing as the other. But the story of the plaintifl's maniger was that the eheek was brought to him ly the defendant's husband, signed in blank by the defendant, and that it 'was fillod up by him for the sum of $\$ 400$, with the husband's consent. Ire assume, in faror of the plaintiff, that this is to he interpreterl to mean that the only blank in the check when it was hrouglit to the plaintifl's manager by the defendant's hushand was in the amount for which it was to be diawn. It has been held in England that sueh a piece of paper is not a check; that one who buys it huys an incomplete instrummt, and his rights depend upon the real anthority which the signer had in fact griven in

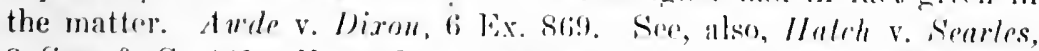

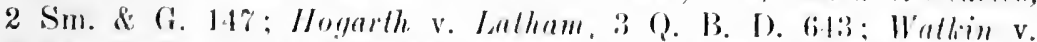

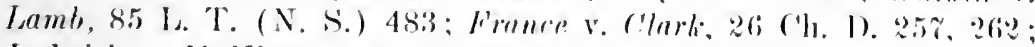
Ledwich v. Mckim, 53 N. Y. $30 \%$ Such an incomplote instrment

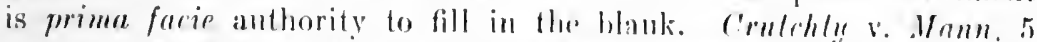

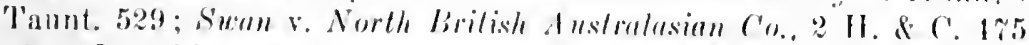
184. But this prima facie anthority, as we have said, may be met by evidence of what anthority was in fact given, as was dome in Audr. Dixon, 6 Ex. 869. If the hanks are fillod up before the instrument is negotiated, it does not tir in the makors month to sot up that it

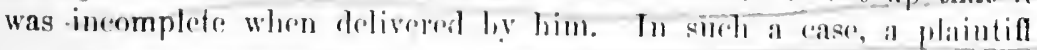

B N.Y., \&33.-C:

-N. Y., §51. - C. 
who huys for value without notice gets the rights of a boua fide purchaser for value of a negotiahle instrument; and the fact that there was no anthority for filling up the blanks as they were filled up, or for otherwise wrongfully dealing with the paper, is no defense. sichull: r. dslley. : bing. N. C. 5.14; Foster v. Machinnon, L. R. 4 (c. P. : 80.4, i1:.

In this eonmonwealth it was held, on the other hand, that a note with a hlank for the pryeres name was a promissory note, and not an ineomplete palure, which might be mate into a promissory note. lves

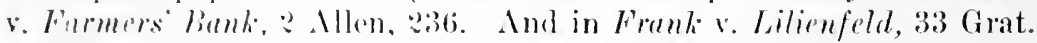
33 , it was helel that the purchaser in good faith of a note in printed form, indorsed by the defondant, where the dite, payee's name, and amount had heen left blank, had an alsohute right to fill in the amount advanced thereon and to fill up the other blanks. It also has been held here, as it has been held in Fngland, that such a blank, in the absence of other evidence. might loe filled in by a bona fide purchaser (see fudroseoggin Bank v. Kimball, 10 (nsh. :363), and that a bona fide purchaser of such a paper, which is filled berore it is negotiated, has the rights of a purchaser for value without notice. See Whitmore v. Niclierson, 125 Mass. 496,28 Am. Rep. 25\%; Binney v. Globe Nalional Bank, 150 Mass. $5 \%$.

It is not necessary to consider how a blank check wonld be dealt with in Massachusetts at common law, where the amount in place of the name or date is lacking. The Negotiable Instruments $\Lambda$ et (Rev. Laws, c. $73, \S 31^{1}$ ) adopted the English law on this point, and it follows that, if Neweml's story is to be believed, the blank cheek brought to him must be treated as an incomplete instrument, and not as a check.

The dofendant further contends that it was inadmissible to show the real anthority given to the hushand, in the alsence of the plaintiff, and cites in support of that contention Marley v. Mulual Benefit Ins. Co., 103 .Mass, 79, 93, and Byrme v. Mrassosoit Porking Co., 137 Mass. 313. These are cases whror the act done was within the ostensible scopr of the authority giren an agent, and for that reason the real authority could not hre invoked. The only act relied on as giving ostensible anthority to the husband in the case at har was putting him in possession of the liank rheck. There was no more ostensible anthority here than there was in I wde v. Dirom, 6 Ex. 869; Hogarth v. Latham, 3 (). B. D. 613, or Watlin v. Lamb, 85 I. 'T. (N. S.) 483. It was held lately ly this court, in Commerial Nolional Bank v. Bemis, $18 \%$ Mass. 95, is N. E. $1 \% 6$, that putting goods in the name of another in a warehouse. and issuing to the other a warehouse reeeipt therefor, did not wive that other ostensible authority to sell, 
but only held the other out as having possession of the goods represented by the receipt, and that his authority to transfer a title depended upon ti.e real authority given by the owner. Nlthough the possession of in incomplete check gives prima facie authority to fill it rip. if no mow imports ostensible authority than the possession of a warehouse receipt.

The plaintitl"s rights under the blank check for $\$ 400$, and to the money recerved for it, deremel npon the authority actually given by the defendant when she sioner it, and the evidence offered should have been almitted in respect of the credit claimed for the $\$+00$ paid under the blank check.

The entry must be:

Exceptions sustained.

135 JOWA, 350. - 1907.

Action on a promissory mote. I'laintiff appeals from judgment on a directed verdict in faror of defendants.

McClats, J. The facts, established practically whout dispute, are that the note for $\$ 2.000$, naming the plaintiff as payee, and the two defendants as joint makers with one Pothoven, on which this action is hrought, was signed by these two defendants hefore it was fully completed, being at the time their signatmes were affixed thereto a there names at the replenet nf totheven, who was a partmer of one of them in a mereantile business. on the reguesentation that he might

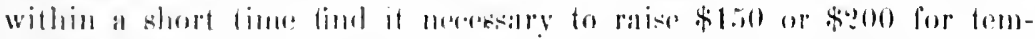

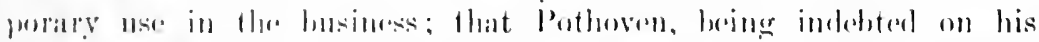

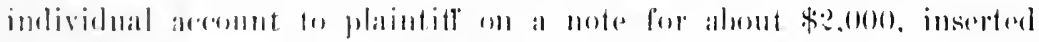

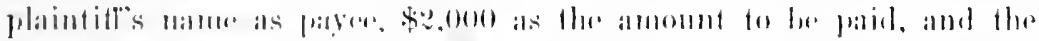
rate of interest, and delivered the instrument, filled ont he him with-

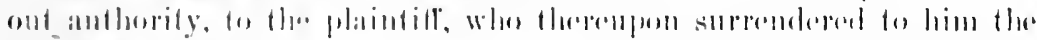

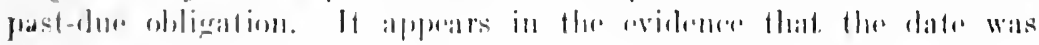

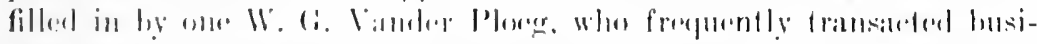

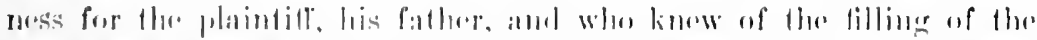

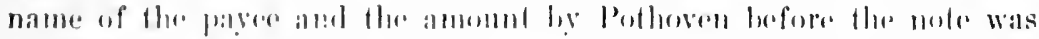
delivered to plaintilf: but the final delisery was marde diredly by Pothowen to plantilf, and there is a conflied in therevidenere as to whether the son hand any anthority to and for the plantilf in this particular transaction. or whether plantils had any linowlowlere that his son had so areded for lim. If it were material to (hatere the plaintitr with the knowledere which his son hasl as to the act of Pothoven in filling out the mote, the (puestion should have been submitted to the 
jury, and we shall therefore dispose of the case without taking into actount any knowledge of or participation in the act of Potasion in filling out the note, on the part of 11 . (G. Vinder Ploeg.

We have, then, the simple case of a note wrongfully filled out and delivered by one of the makers to the payce, without notice to lix payce that the instrument as clelivered is not filled out in accordasue witl the authority given by the other makers to the one who thus fill: it out and delivers it. With reference to the filling of blanks in an instrument after the aftixing of his signature by the maker sought to be charged, the Negotiable Instruments Act ( $\dot{A}$ cts 29th Gen. Assem. P. 81, (. 130: Code Supp. 1902, \$ :3060a) entains the following scetion: "See. 14," Blanks - when may be filled. Where the instrument is wanting in any material particular, the person in possession thereof has a prima facie authority to complete it by filling up the blanks therein. And a signature on a blank paper delivered by the person making the signature in order that the paper may be converted into a negotiable instrument operates as a prima facie authority to fill it up as such for any amount. In order, however, that any such instrument when completed may be enforced agrainst any person who became a party thereto-prior to its completion, it must be filled up strictly in accordance with the authority given and within a reasonable time. But if any such instrument, after completion, is negotiated to a holder in due course it is valid and effectual for all purposes in his hands, and he may enforee it as if it lat been filled up strictly in accordance with the authority given and within a reasonable time."

It is apparent from the last sentence of this section that, if plaintiff is to be regarded as "a holder in due course," then the instrument is effectual in his hands for all purposes as though it had been filled up strictly in accordance with the anthority given by defendants to Pothoren, i. e., defendants would not be allowed to contend as against a holder in due course that Pothoven did not have authority to fill the instrumerit out for $\$ 2.000$ : but, under the sentence immediatel! preceding the last, if plaintiff is not to be treated as a holder in due enurse. then, as defondiants became parties thereto prior to its enm. pletion, they are not liable to plaintiff, berause it was not filled up in accordance with the authority given. By section $191{ }^{3}$ the term "holder" is defined as meaning "the payee or indorsee of a bill or note who is in presession of it, or the licarer thereof," and by section 52 " a "holder in due course" is defined as one who has taken the instrument complete and regular upon its face, before maturity, without notice of previous dishonor, in goorl faith and for value, and without nofice that at the time it was negotiated to him there was

2 N. Y.. $\$ 33 .-\mathrm{C}$.

s N. Y., \&2. $-\mathrm{C}$.

4. Y., §91. - C. 
any infirmity or defect in the title of the person negotiating it. By section $59,{ }^{5}$ "every holder is deemed prima facie to be a holder in due course," and by seetion $57^{\circ}$ "a holder in due course holds the instrument free from any defect of title of prior parties and free from defenses available to prior partics among themselves, and may enforce payment of the instrument for the full amount thereof against all parties liable thereon."

It seems to us under these definitions and the applications thereof the plaintiff was a holder of the note, but not a loolder in due course. The latter term seems unquestionably to be used to indicate a person to whom after eompletion and delivery the instrument has heen negotiated. In the ordinary case the payee of the instrument is the person with whom the contract is made, and his rights are not in general dependent on any peculiarities in the law of negotiable instruments. 'The peculiarities of that law distinguishing-nesetiable-instruments from other contracts relate to a holder who has taken by negntiation, and not as an original party. This is the construction put on the same phrase used in the English Negotiable Instruments Act by Lord Russell, C. J., in Lewis. Clny. 67 L. J. Q. B. 22t, in which he says:

"A holder in due course is a person to whom after its completion by and as between the immediate partics the bill or note has been negotiated. In the present case, the plaintiff is named as payee, on the face of the promissory notes, and therefore is one of the immediate parties. The promissory notes held and sued on (ly the person named as payee therein) have in fact never been negotiated within the meaning of the act." In IIerdman v. Ithecler, 1 K. B. (1902) 361, this language of Lord Russell is said to be dirtum, and it evidently is so, for in the further course of the opinion he points ont that, without regard to the definition of that term which he gives. the result would be the same. But the court, in IIerdmen v. Whefler, lonlds that if the delivery of a note by one to whom it has been intmeted by the maker for the purpose of delivery after the filling in of the name of the payee, which has been left hlank af the time of the aflixing of the maker's signature. loes not ronstitute a nogotiation. then the payee whose name is thus filled in cannot be a holder in due eourse. In

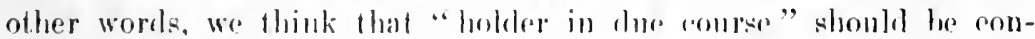
strued as applicalbe only to one who tikes the instrument by negotiation from another who is a holder. Certainly, in the case hefore ns, Pothoven was not a holder of a promisery note. for as the instrument was delivered to him it was not a note at all, lut ouly a bank form of a note with the makerse names aflixed. In cinerranl. v. Ciucreant 7 Va. Law Rogr. 6399, a case at nisi prins, it is held that the bolder filling a blank left in the instrument at the time of dolivery acts at

- N. Y.. \$ $\$ 9 .,-\mathrm{C}$

- N. Y., \$96. - C. 
his peril as to the anthority griven by the maker signing the instrument with the name of the payee left blank, and putting it in the hands of another for final delivery, and salys that, while this interpretation of the Negotiable lustruments A.t involves a ehange in the law as recognized in that state hefore the act was passed, sueh interpretation is required by the language of the act itself." In Boston Steel d. Irom Co. L Struer, 1s:3 Mass. 140, a rase decided under the Negotiable Instruments. Jet as adopted in that state, it is hede that one

: The following instructive note to the Gumrant ease appears in 7 Va. Law. Reg. at 1. 6.t?:

"Notr. - The point decided in this case is one of much importance to bankers and other dealers in commercial paper. The construction here placed upon the Negotiahle Instrmments law materially qualifies the familiar rule of the law merchant, that one who issues negotiable paper in an ineomplete condition gives the person to whom he intrusts it implied authority to fill the blanks and perfect thr instrument; and a transfer thereof to a bona fide hohler in due conrse will allectually hind the maker aceording to the terms of the completed instrument. ewen thougl, as betwern the original parties, there may have been a breach of trust in filling the blanks. See 1 Daniel on Neg. Inst. 142 ; Bank of Pitlstur! v. Neal, $22110 w .96$; Hank v. Lilienfeld, 33 Grati. 577.

"The point decided is that this rule is altrred to this extent, namely, that if a purchaser takes the piper lofore the blanks have been actually filled by the quasi agent, or by a sulsorquent holder, he is put on notice that the instrument was delivered in an incomplete state, and hence that there may have been some ayreement hetween the maker and the person to whom the instru. ment wa- intrusted. by whels the anthority of the latter was limited - and therefore it is his duty to inquire what these instructions are. Hence he takes the pilper at his peril.

"This construction seems inevitable from the language of section 14 of the Negrotiable Instruments Law [X. Y., $\$ 33]$, puoted in the opinion. The conclusion is strengthened hy the circumstaner that that purtion of section 14 here construed is a literal reproduction from seetion 20 of the English Bills of Exchange Aet, where it merely emboties the rule of the law merchant as expounded by the Englisle courts prior to the entacturent of the Bills of Exchange Act. Ser 1 Dimiel on Ney. Inst. (4th pll.), 147: Halch v. Scarles,

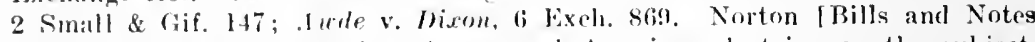
(3) (1.). 259]. after stating the general American doetrine on the subject, says: "such is the grancial rule, at least in the luited States, althongh in Fongland it is lohe that an unfilled blank charges the purehase with notice, and that he mu-t at his peril asertain the extent of the authority conferred.' Since the "natumant, by the English Act, of the rule that motice of an unfilled blank is notice of a poisible enguty, funting the purehaser on incuiry, was but declaratory of the alrealy rexi-ting rule of the law merchant, as imderstood in Englanil, it necescarily follows that in borrowing, in our Negotiable Instruments law, thr language of the English Aet, we alopted also the English interprestation of it.

"Judge Aiken's ruling seems reminently sound, and the hanking community shombl nake a carrul note of it. The decision in no wise affects the rights of a hrolder in dü conrse, who takes the papur after the blank have heen filled. without noties of the situation. How far such a holder wonld be affected by mere knowledge that blanks hasl been filled by a previons party to the instrument remains to be decided." - $\mathrm{C}$. 
who signs a check, leaving the name of the payee blank, and instructs another to fill in the proper amount necessary to satisfy the debt of such signer to the payce named, is not bound by the check in the hands of such payee, if it is used by the person thus intrusted with it for the payment of his own debt to the ereditor; the amount of such debt being correctly filled in by the creditor. In that case, the person to whom the check was intrusted exceeded his authority in using it for the payment of his own debt, instead of the deht of the signer of the check, and in this respect we think the case is analogous to the ane before us. There is language in the opinion with reference to another check which was fully completed as to name of payee and amount, but was also used by the person to whom it was intrusted in violation of his authority in the parment of his own debt, which is not in harmony with our conclusion that the payee to whom the instrument is first delivered cannot bo a holder in due course; but in this respect we are not inelined to follow the Massachusetts ease.

We do not mean to say that in no case can the person named as payee in a negotiable instrument be the holder thereof " in due course." If A., purchasing a draft to be transmitted to $B$. in payment of A.'s debt to B., causes the draft to he drawn payable to B., no doubt $A$. is the holder of such draft, and B. taking it for value becomes a holder in due course. 'This was true before the passage of the Negotiable Instruments Act. Armstrong $r$ A American Exchange Nat. Bank, 133 U. S. 433 ; Watson v. Riussell, 3 B. \& S. 34, affirmed in 5 B. \& S. 968. There is no reason to think the situation of the parties to such a transaction is different under the art. No doubt, the payee named in the promissory note might under similar circumstances he a holder in due course. This is the theory on which the court in Boston Sted de Irom Co. v. Steuce, supre, holds the payee named in the first of the cherets considered in that rase to be al holder in due rourse: but we are unable to understand how the rule is applicable under the farcts of the rase, for the dheek was not deliered by the drawer as a valid aud complete instrument to the person intrustorl with it, hut it was given into his hands only for delivery to the palyes in extinguishment of the drawer's debt to the payee. Intil thus dolisored fo the payee, it had no validity for ally purpose. licfore such delivery. the person intrusted with it was not is holdur. After surh dolisery, the payee was at holder, but not, as wo think, a holder in due ootured.

'The conctusion which we reach is perhaps ditferent from what it would have been had the Negotiabl. Instruments Aret not been passed. It las been regarded as werll-sedfled law that one who intrusts an incomplete instrument to anothere to bre completed by him and delisered is boumd to any one who relies in good faith on the enenuinomess of such instrunsent, although the preseon intrustod with completing and delivering the instrument has corended his anthority, and this rule 
luas been held applicable in favor of the payee as well as the transferee of such an instrument. Charilon I'low Co. v. Davidson, $16 \mathrm{Neb}$. 3\%., 20 N. W. :56; Androscogyin hamk v. Kimball, 10 Cush. 373; Johnson Ilarrester ('o. r. Mclean. if Wis. 258; Fullerlon v. Sturges, t Ohio St. 5:30; Dierels v. Loberls, 13 S. C. 338; Frank v. Lilienfeld, 33 Grat. ( Vil.) 3ir: Maris v. Lee, 26 Miss. 505, 59 Am. Dec. ?67; Russell v. Langslaffe, : Doug. (K. B.) 514; 1 Daniel, Negrotiable Inst. (5th ol.) Sุ 11:-14\%, \%69-769a; 1 Randolph, Commercial Paper (:d ed.) \$ 1si: ¿ Randolph, Commerrial Paper (2d ed.) \$ 986; 3 Rundolph. ('ommercial Paper (2d ed.) \$ 1875; Norton, Bills \& Notes (ad al.) 181: (lark d- Shyles. Ageney, \$ 60. Indeed, it secms to have heen thought immaterial whether or not the person to whom the instrument is made payable and delivered lad knowledge that it had been filled out so as to make it an effectual instrument, by one to whom it was intrusted by a maker who had signed it to be filled out and delivered, for it is said that the holker is entitled to assume that the person in whose liands it was placed for final execution had authority to do what he did do in making it an effectual instrument, and is not charged with knowledge of any limitations upon such authority. Jolinson v. Blasdale, 1 simedes di M. (Miss.) 17, 40 Am. Dec. S5; Joseph v. First Nalional Bank, 17 Kan. 256; II untington v. Branch Bank, 3 Ala. 186; 1 Daniel, Negotiable Inst. (5th ed.) \$ 843 ; Mechem, Agency, \$ 394. This principle is well illustrated by the rule, well settled in this state and elscwhere, that a surety who signs an instrument and intrusts it to the principal maker for delivery is bound, althougb the principal delivers it in violation of conditions or instructions imposed by the surety on the principal which were not known to the payec. Sanyers v. Campbell, 10y Iowa, 397, 56: Michlewait v. Noel.69 Towa, 344; Davis Sewing Machine Co. จ. Buckles, 89 Ill. 237; Smilh v. Moberly, 49 Ky. 266; Ward v. Harkett 30 Minn. 150; Craig v. Hobbs, 44 Ind. 363 ; Brandt, Suretyship (3d erl.) \$ $45 \%$.

But we must take the Negotiable Instruments Act as it is written, and, while the general purpose was to preserve the existing law so far as it was uniform, yet in many respects in which there was a conflict or doubt under the anthorities the language of the statute lays down rules which are not to be ignored simply berause in some respects a change in the law is effected. With reference to the language which we have been considering in this very case, taken substantially from section 20 of the English Bills of Fxchange Art, the court says, in IIerdman v. Wheeler, supra: "We have been very reluctant to come to the conclusion that the judgment in favor of the defendant in this case was right, because it appears dangerons even to cast any donlit upon a payee's right to recover when he has taken a bill or note complete and regular on the face of it, honestly and for value; but, after carefully considering the matter, we have come to the conclusion that 
we should be unfairly straining the words if we did not hold that 'negotiated,' in its proviso at the end of the twentieth section, meant transferred by one holder to another. It is to be observed that the Bills of Exchange Act, in section 2- [section 1.91 of our act] defines 'issue' as meaning 'the first delivery of a bill or note, complete in form, to a person who takes it as holder. * * * There is therefore a technical word defined and used in the act to mean that which [the person intrusted with the completion and delivery of the instrument] did here. and the appropriate words to have used in the proviso of section 20 , if it had been intended to include this ease, would have been, ' if such instrument after completion is issued or negotiated to a holder in due course.' Those are not the words, and, although we think that the present ease might possibly have been decided in the plaintiff's favor before the Bills of Exchange Act was passed, we think that we cannot consistently with the meaning of 'issue' and 'negotiate' in the act hold that the present case is covered by the words used in the proviso. That being so, it falls within the first part of the second subsection of section $20[i$. e., the sentence of our section preceding the last]; and, as the authority of the defendant was not strictly followed, he is not liable."

We see no escape from the conclusion that, under the statute, plaintiff, being not a holder in due course, but the person to whom the note was made payable, and to whom its delivery as an effective instrument was first made, took it subject to the defonse that Pothoven had no authority to fill in $\$ 2,000$ as the amount of the note and deliver it to plaintiff.

The judgment of the trial court is therefore affirmed. ${ }^{8}$

$\S 33$

LIÓYD'S BANK, LIMITED, r. COOKE.

[1907] I King's Bexcil (Court of APpeal) 794.

Actiox upon a joint and sereral pronissory note for 1,000 pounds by the plaintiffs as payees arainst the lefoudants as makers.

The defendant rookr had an areount with the plaintiffs' bank, and the note had heen given to the plaintiffs hy him as seeurity for an overdraft for 1,000 pounds. On applying to them for the overdraft, he had suggesterl that he conlal procure the firm of which he was a member and a relative namerl Sanhrook to join with him in signing

- This caso is reporterl in 13 L. N. S. 490. with note entitled " Right of an innocent payer to recever on a note signest in hank and interested to a thiril person whe excerels his authority in filling up the hanks lofore Jelivery to the payce."

See comment on this ease and on Lloydts Bank v. Cooke, post, p. 185, in 15 Case and Comment, 25 (.July, 1908). - C. 
a promissory note as security for the advance, and the plaintiffs ayreed to adranee the money on that serwity. I1 appeared that the defendant cooke had thereupon grone to defendant Sambrook, and, stating that he was applying for an alvame of ion poumels from the plaintifss' hank, asked Sambrook to join in giving promissory notes as security for it. On Sambrook's agreeing to deso, cooke produced two blank stamped pieces of pilper, to which he induced Sanbrook to put his signature, and whinh were then hambed over to Cooke, it heing arranged that he was to till ach of them up as a promissory note mayable to the plaintills for the amount of 250 pounds. It dicl not appear what had herome of onc of these piees of paper; but the other, which was the instrument upon which the action was brought, was filled up by ('ooke as a promissory note for 1,000 pounds, payable to the plaintifls, the stamp beimg sufficient to cover that amount, and was signed by him with his own and his firm's name. He then lianded it to the plaintiffs, who thereupon made the required advance. The defendant C'ooke did not lefend the action. It appeared that he had no authority to sign the note on behalf of the other members of his firm, and judgment was accordingly given for them; and, on the anthority of IIfrdman v. Itheeler, $([190 \% \mid 1$ K. B. 361), the trial judge gave judgment for the defendant siabrook.

This is an application by the plaintiffs for judgment or for a new trial.

Collins, M. R. This is a case of some importance and difficulty, more especially having regarel to the fact that, from one point of view, it might involve the guestion whether the considered judgment of the Divisional Court in Herdman v. Wheeler. [1902] 1 K. B. 361. upon the authority of which the learned judge at the trial acted, was rorrect. ***

The question appears to me to be purely one of estoppel at common law. It has heen contended that the common law doctrine of estopjel does not apply, and that, in the ease of a negotiable instrument, the rights of the parties must he ascertained solely by reference to the provisions of the statute relating to smch instruments, and that, upon the true construction of those provisions, the plaintiffs cannot maintain the action against the Jofendant Sambrook. * * *

That the doctrine of estoppel is applicable to circunstances such as existed in this case appears to me to be conclusively established by * * * the derision of the House of Iords in Rrocklesby v. Temperanes Permanent Puilding Society, [1895] A. C. 173. The headnote in that rase is as follows: "Where a principal intrusts an agent with securitirs, and instructs him to raise a certain sum upon them, and the agent borrows a larger sum upon the securities, and fraudulently appropriates the ritference (the lender aeting bona fide and in ignorance of the limitation), the principal cannot redeem the 
securities without paying the lender all he has lent, although the agent has obtained the loan by fraud and forgery, and although the lender did not know that the agent had anthority to borrow at all, and made no inquiry." That case scems to me to be a stronger one than the present; and, unless the doctrine of estoppel is exchuded here by reason of the fact that in this ease the document was, or was intended to become, a negotiable instrument, it appears to me to be conclusive of the present case.

So far from the fact that the document which was handed to the agent for the purpose of being used as a security, was a negotiable instrument, or was intender to become one, being a reason why the lender of money should be placed in a worse position for asserting a right on the ground of estoppel, it appears to me to be quite the contrary. I think that all the elements which form the foundation of the estoppel are more easily visible where the instrminent which is handed over to be used as a security for an advance is in the form of a negotiable instrument than where it is otherwise; for the intention that the security should be used as a means of raising money is more clearly indicated where the document is in its very nature one which is intended to be transferable from hand to hand as a security for money.

There is nothing, in my opinion, in the law as to negotiable instruments as containerl in the Bills of Exchange Act, 1S.S?, to prevent the transaction in the present rase from heing suliject to this rommon law doctrine of estoppel, heranse the document which was handed over for the purpose of procuring the advance was in the form of a negotiable instrument. $* * *$ conserpently I will pronouner no opinion on the question whether the plaintiffs were entitled to succeed as against the defendant Sanbook by virtue of the provisions of the Bills of Exrhange Art, 18s2. On these gromerls I think that the applieation of the plaintills for jurlement must be allowel. ${ }^{9}$

Fi.etchlak Mortitos, L. J. I am of the same opinion, ambl I agree with the reasons given by the Master of the liolls and ('owens-llardy.

- The view taken in this opinion that thr Bills of Fxchange Act. 1882, does

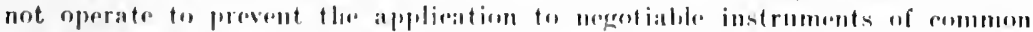

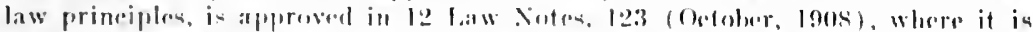
maintained that thro same doetrine should las aplied witle respect to the

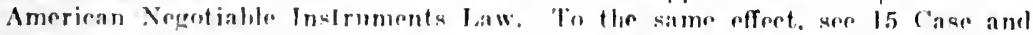
comment, 25. 26, 1.Iuly. 1908), whure it is said: "In expressly saving the rules of the law merchant in rases not provided for in the act. the American statute does not. like the linglish act, mention common-law rules: hut this arems immaterial for the reason that neitleer statute was intemlor to corlify rules of the common law lieyond the scope of the law merehant." Sire also Marling vitzgerald, I38 Wis. 93, where the court, in answer to the contrention of comner that a ertain apetion of the Segotiahle Instrunente Law controlled, said that "Those rules. . . give way to the supreme rule of rstoppel in pais." P. 100. - C. 
1. I.; but I wish to add a fow observations with reference to the argument hased unon section ?0 of the Bills of Exchange Act, 1882, which was pressed upon us hy the counsel for the defendant Sanbrook. In cases in which a blank stamped paper has been signed and delivered by the signer in order that it may be converted into a bill, subsection $\because$ of section $: 0$ provides that " in order that any such instrument when completed may be enforcuable against any person who beeame a party thereto prior to its completion, it must he filled up within a reasonable time, and striefly in accorlance with the anthority given." It was urged that this provision is an absolute limitation upon all claims based on such an instrument (whether by way. of estoppel or otherwise), and that the only way in which a person so claiming can escape from that linitation is by bringing himself within the proviso to the subsection, which provides that "if any such instrument after completion is negotiated to a holder in clue course it shall be valid and efiectual for all purposes in his hatuds, and he may enforce it as if it had been filled up within a reasonable time, and strietly in accordance with the authority given," and it was contended that the plaintiffs had failed to bring themselves within the words of this proviso becanse they were not "holders in due course."

In order to agree with this view, one would have to come to the conclusion that it was intended by the Bills of Exchange Act, 1882, to make an essential change in the law with regard to negotiable instruments by shutting out the payee of such an instrument, who had given full value without notice of anything wrong, from the advantages of the position of a bona fide holder for value.-Before the Bills of Exchange Act, 1882, if woull, in my opinion, have been impossible to contend that a payee of a promissory note who took it under circumstances such as existed here was not entitled to recover the full amount of the note from the maker of it. A long line of most emphatic judgments shows that, before the Act, a person who, like the defendant Sanbrook, chose to sign a bill or note in blank, and hand it to another person to he filled up, would, under circumstances such as exist in this case, be liable to the payee for the full amount for which the instrument was filled up, provided that it was not greater than the stamp would rover, so that an action such as this would then have been an undefended action. The contention of the counsel for the lefendant amounts, therefore, to saying that the Act has made this important (hange, namely, that it has taken away the right of a pavee to recover uniler such circumstances, leaving only the rights of an indorsee in this respect unchanged.

I cannot accept that vicw. I can see no indication in the Act of any intention to makr surch a radical change in the law, a change which does not commend itsolf to one's sense of justice, and which, if intended, would surely have heen made formally and explicitly, and not left to be gathered by mere implication. And, apart from the 
absence of any indication that such a serious change in the law is intended to be made, there are many things in the Act which lead me to the opposite conclusion. In the first place, I am satisfied that the term "hotder in due course," which is used in the Act, is intended to be the equivalent of the term "bona fide holder for value" which was used prior to the Act, and which would, in my opinion, have included a payer who had given full value for the bill or note in good faith. This appears from the judgment of Lord Selbourne in France v. Clark (26 Ch. D. 257 , at p. 262), in which he uses the expression "bona fide holder for value" in a sense which must include a payee who has given value in good faith. He says: "The person who has signed a negotiable instrument in hlank or with blank spaces is (on aceount of the negotiable character of that instrument) estopped by the law merchant from disputing any alteration made in the document after it has left his hands by filling up blanks (or otherwise in a way not $e x$ facie fraudulent) as against a bona fide holder for value without notice; but it has been repeatedly explained that this estoppel is in favor only of such a bona fide holder." Now, as I have said, the courts always held a payee entitled to the benefit of this estoppel if he took the instrument bona file and without notice, and therefore we have the authority of Lord Selborne in favor of the view that the term "bona fide holder for value" may include a payee; and, if the term "holder in due course" in the Bills of Exchange Act, 1882, is intended to be the equivalent of "bona fide-holder-for value," it must include such a payec.

But it will perhaps be said that one ought not primarily to he guided in the interpretation of such an Act ly considerations of what was the previous state of the law. The Art in its definition clanse defines in a statutory manner the meaning of the terms used in it, and, although there is a strongr presumption against any serious change in the general law heing intended, it is, after all, a question of the interpretation of the statute, and these definitions must be implicitly followed. This is true, hut the application of this principle only strengthens the view I have enunciated. When I look at the lefinition of "holder" in the Bills of Exchange Art, 1852, section \&. I fincl that, so far from its indicating any intention to create a difference of status between a holder who is a payer and a holder who is an indorsee, or to put a payee in any worse position in this respert than an indorsee, the contrary is the case. The Art takes sprecial care to place then on an equality, for it defines "holder" as meaning the "payce or indersee of a lill or note who is in pessession of it, or the bearer therenf." Therefore, unless the eontext rompels us to do otherwise, we must ronstrue the term "holder" as incholing a payer. I next find that in sertion 30. suberetion 2, of the Art it is provided that "every holder of a hill is prima farie deemed to be a holder in dne course," and that, if it is wished to dislorlere him from that posi- 
tion, it must be shown that there has heen frand or some other like ciremstance in connedion with the bill lefore it reached his lands, and even this only shifts the hurden of proof and makes it incumbent on him to prove that he grive value in grood laith.

These provisions specifically give to the prace the prima facie status of a "lobleder in due coure," and, if he ean show that value has in good faith been giren ly him for the bill, that prima facie status cannot be displaced.

It is suggested, however, that these eonchusions are negatived by the language of section $9 !)$, subsection 1, wheh states the conditions under which a person is a "holder in due course." I can find nothing in the language of that subsection which throws any doubt on the view that "holder in due course" would include a payee who has griven value in good faith, unless we are to construe the word "negotiated" as being merely equivalent to "indorsed." But, when the definition of "negotiation" given ly section 31 , subsection 1, is looked at, it appears clear that the Legislature intended to make it apply also to the original operation of transferring the bill to the payee. It lays down that " a bill is negotiated when it is transferred from one person to another in such manner as to constitute the transferee the holder of the bill." It carefully abstains from prescribing that the transferor nust be a "lodeler." All that is necessary to constitute "negotiation" of the bill is that it should have been transferred from one person to another in such a manner as to constitute the transferee the "lrolder of the bill," $i . e$ - - if we replace "holder" by its definition in the Act $=$ "the payee or indorsee who is in possession of the bill." A cheque, therefore, payable to a particular person, which is handed be the drawer to that person for value, would be "negotiated" within the meaning of the $\Lambda$ et.

These considerations lead me to the conclucion that the Act dic not intend to impair the position of a payee as contrasted with that of an indorsee, and that a payee who has given value in good faith is intended to rome within its provisions as a "holder in due course" just as much as an indorse. Finding, therefore, no indication in the Act of any intertion to interfere with the position of a payee of a negotiable instrument in this respert, I arrive with some confidence at the conclusion that, in the cirrumstances of a wase like the present, such a payee since the Act still oreripies the fasorable position which he would have har hefore the Act ly virtue of the law of estoppel as applied to a case where a promissory note has been signed in hlank by the maker and intrusted to another person to fill up.

A pplicalion allowed. ${ }^{\text {n }}$

in This case is reporter in $S A$. \& F. Ann. Cas. 182, with note entitled, "Liability of maker of blank negotiable instrument to bona fide holder where blanks are fraudulently filled in." - C. 
137 Appellate Division (N. Y.) 294. - 1910.

Action by Charlotte F. Madden against George H. Gaston, as executor of the last will and testament of Fliza Wilson, deceased. Appeal from a judgment entered on a dismissal of the complaint at the close of the plaintiff's evidence, in a suit on two checks, alleged to have been signed by the defendant's testatrix in blank and delivered to the plaintiff and thereafter by her filled out with the amounts of $\$ 5,000$ and $\$ 10,000$, respectively. The answer put in issue the making of the cheess, their delivery, the consideration, and due filling out of the blanks. 'l'he plaintifl proved the signature of the maker of the checks and oflered them in evidence; but they were excluded by the court upon the ground that there was no proof of the anthority given to fill up the blanks. The plaintiff then called the defendant, who testified that, on the day before the death of his testatrix, he had a conversation with the plaintiff, and then saw the elecks in question or similar papers.

Miller, J. The production of the checks by the plaintiff raised a presumption of a valid and intentional delivery of them to her by the maker. Section 35 of the Negotiable Instruments Law (chapter 38 of the Consolidated Laws). Such delivery operated as prima facie authority to fill up the hlanks for any amount. Section 33 of the Negotiable Instruments Law. The learned trial court was, therefore, wrong in bolding that it was ineumbent upon the plaintiff to prove her authority to fill up the blanks, as the statute imposes the burden upon the defendant to show the agreement, and that its terms have been violated, if that he claimed; and that was the rule at eommon law. Davidson v. Lamier, 4 Wall. 117. Siad section 33 also provides;

"In order, however, that any such instrmment, when rompleted, may be enforced against any porson who berame a party thereto prior to its completion, it must he lilled up strictly in acrordance with the authority given and within a reasonahle tince,"

It seems to me that there can le no presumption one way or the other as to the time within whirh the blanks were fillod up. Therefore, the burden was upon the plasintiff, who ascerted it, to prove that the blanks were filled up within a "reasonable time." It is allegred in

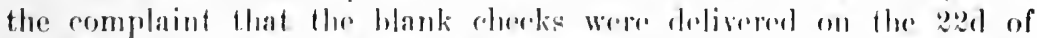
Octoher, 190\%. 'The maker died an the !ht of Jume, 1908. There is evidene which, perhapes, womld justify the informes that the defendant saw the rhecks on the sth of Iune in their present condition. Other than that, there is mothing fo show when the chereks were filled up, and restainly from (octoluer 22, $190 \%$, fo Jume 9. 1908, is, unexplained, more than a "reasonahle time." Inowrever, the plaintift could

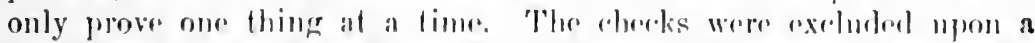
ground which the plaintiff could not obviate, and that ruling virtually 
ended the ease. Wherefore, the plaintiff should be permitted another oppurtumity to prove her aisis.

'Tle judirment slould be reversed, and a new trial granted, with costs to appellant to alide rent. All concur.

\title{
X. Ambiguous language.
}

\section{Discrepaney Between Words and Figures.}

\section{WITIY $r$. MC'HIGAN MU'UUAL LIFE INS. CO.}

\author{
123 INDIANA, 411. - 1889.
}

Berkshine, J. - This was an action brought by the appellee against the appellant on the following writing:

$\$ 1+7.70$.

INDIANAPOLIS, IND., Nov. 28, 1883.

Four months after date I promise to pay to the order of the Miehigan Mutual Life Ins. Co. _ dollars —-, and five per cent. attorney's fees thereon per annum from date until paid, value reeeived, witlout relief from valuation or appraisement laws of the State of Indiana. The indorsers jointly and severally waive presentment for payment, protest, and notice of protest, and non-payment of this note, and expressly agree, jointly and severally, that the holder may renew or extend the time of payment hereof from time to time, and receive interest in advance or otherwise from either of the makers or indorsers for any extension so made, without releasing them hereon.

Negotiable and parable at $-\longrightarrow$.

Mar. 28, 31, '84, Indiana.

J. B. WiTTY.

The appellee, in its complaint, did not ask for a reformation of the instrument, but relied on it as a promissory note complete in itself.

The appellant answered by the general denial only.

The cause was submitted to the court at Special Term, and a finding made for the appellee. The appellant filed a motion for a new trial, which the court overruled, and he excepted.

An appeal was taken to General T'erm, and upon the errors assigned the jurlgment at Special 'Term was affirmed, and from the judgment in Feneral 'T'erm this appeal is prosecuted.

There is but one question presented for our consideration. Is the written instrument, as it appears in the record, an enforceable obligation? We are of the opinion that it is, if not so otherwise, by virtue of $\$ 5501$, R. S. 1881, and is negotiable by indorsement.

It is signed by the appellant, and when taken as an entirety we think it contains a promise to pay $\$ 147.80$, together with five per cent. attorney's fees. - By the very terms of the instrument the appellant obligates himeelf to pay to the appellee "dollars," and it is expressly reciter that this promise rests upon a valuable consideration. No one can rear the writing without at once coming to the conclusion that the appellant intended to obligate himself to the appellee for the payment of some definite amount of money, and that the appellee understood that it was receiving such an obligation, 
Though there may be some formal imperfections in a written obligation or contract which parties have entered into, if it contains matter sufficient to enable the court to ascertain the terms and conditions of the obligation or contract to which the parties intended to bind themselves, it is sufficient In the language of Lord Campbell, in Warrington v. Early (? Ellis \& Bl., 763), "the effect of a written contract is to be collected from all within the four corners of the document," and no part of what appears there is to be excluded. We can imagine no good reason why the marginal figures upon the writing in question should be disregarded.

We know as a part of the commercial history of the country that the universal practice has been for a period so long that the memory of man runneth not to the contrary, to represent by superseription in figures upon all obligations for the payment of money the amount or sum which is written in the boly of the instrument. The superscription is always intended to represent the amount found in the body of the instrument, and not a different amount; if, therefore, an obligation is found where there is a promise to pay "dollars," but the number of dollars in the body of the instrument is blank, and the margin of the instrument is found to contain a superscription which states the number of dollars, why, in view of the usage or eustom which has so long prevailed, shouid the body of the instrument not he aided by the superscription? We think, in such a case, the figures found in the margin should be taken as the amount which the ohligor intended to obligate himself to pay, and the obligation enforeed accordingly. We do not think, in such a rase, that the courts would be justified in discegarding the evidunt intention of the partics as indicated by the superseription mon the paper. and in holding the instrument roid for morertainty, or on the wround that it is not a perfect writing. And especially are we of the opinion stated, in riew of the liheral statute which we have on the suliject of promissory notes and other written obligations and their negrotiation. (Sertion 5501, supra.)

In the ease under consideration the action is between the original parties to the instrument, and upon it in the form and condition in which it was execosted, and, therefore, we do not think it would be profitable to consider questions which might arise where the obligation is made payable at a hank, the hlank nomber of dollars afterwards filled in hy the payer and indorsed by him to an innocent holder for value hefore maturity.

We find no error in the recoril.

Judgment is affirmm, with rosts.'

I A note for the hundred dollaru. the figures being $\$ 300$. is gond for three hundred dollars, if the maker intemled it to be for three lumdred.

NBOOT, INATIUMENTB -13 
$\$ 36$ Mraks r. GraHAM, \& Blackf. (Ind.) 141.-1816. BlackFolid, I. - The circumstanee that the figures in the margin of the note arr "*3:31.15" and the words in the body are "three hundrod and thirty-three dollals and filteen rents," does not affect the validity of the noli. 'The works in the body must govern, and the note is therefore for $\$ 333.15$.

\section{?. INTERLST, How COMPUTED.}

\$ 36 Campreli. Plinteng Press, etc., Co. v. Jones, 79 Alabama, 475. - 1885. C'LOPTON, J. - The principle seems to be settled, that a promissory note payable at a future day, with interest, bears interest

v. Allen, I Gray (Mass.), 496. A hill payable in the United States for " 3,000 ," "three thousind __, omitting the dollar-mark and the word "dollars," is a valid bill for three thousand dollars. Williamson v. Smith, 1 Cold. ('Tenn.) 1. - H.

[Aceord: Kimball v. Costa, $76 \mathrm{Vt}$. 289. In this case the figures " $\$ 385$ " were in the margin, and the body of the note read: "lor value reeived, I hereby promise to pay F. E. Kimball or order the sum of F. E. Kimball dollars. $\$ 50$ payable August 9, 1902, and $\$ 50$ every two montlis thereafter until note is paid," etc. 'TYuer, J., said: "The writing of the name 'F. W. Kimball' after the words 'the sum of was elearly a elerical error, and the name in that place should be read out of the note. . . . The words, three hundred and eighty-five dollars, should be read into the body of the note. The defendant had no right to understand that $\$ 50$ or $\$ 100$ was all there was to be paid. The figures in the margin were notice to him of the amount for which the note was given." lieported in 1 A. \& E. Ann. Cas. 610, with note entitled, "Object and rffect of marginal figures in bills and notes."

Contra: Chestnut v. Chestrut, 104 Va. 539. In this case the figures "\$ $\$, 800$ " were in the margin, and the boly of the note contained a promise "to pay to the order of J. A. Chestnut___ dollars," ete. It was held error for the trial court to permit the plaintiff to put in evidence the note in its ineomplate form. Bronasis, J., sail: "The propricty of the court's ruling depends upon the question, whether or not the figures and words in the margin of a note fix the amount for which the note was intended to be given, where no amount has been inserted in the blank left for it in the body of the note. Tpon this furestion the decisions of the eourts are not in aecord. through the wright of authority, and the better reason, seems to be in favor uf the view that the snm named in the margin is generally the limit of the amount with which a bona fide holder may fill up the blank, but until so filled the instrmuent is incomplete, and no recovery ean be had upon it [eiting, among other authorities, Norwich Bank v. IIyde, 13 Conn. 281, a leading eace on the subject]. . . The reason for this rule of eonstruction is that one of the essential reguisites of a bill or note is that the amount for which it is made must be clrarly expressud in the instrmment, and as the marginal figures are not generally regarled as a part of it, but are intended as a convenient index, and as an aid to remove ambiguity or doubt in the instrument itself, they cannot supply the omission to insert the amount in the body of the instrument where a blank has leen left for that purpose." P. 54l. Reported with note in 2 I. N.S. $879 .-\mathrm{C}$. 
from date, it being considered as a part of the debt. (Dorman v. Dibden, R. \& M. 280 ; Richards v. Richards, 2 B. \& Ad. 447; Lerzenberg v. Cleveland, 19 La. An. 473.) *** Otherwise, the words, bearing legal rate of interest, would be without meaning and operation. Such is the legal effect after maturity, without express stipulation. In Kennedy v. Nash (1 Starkie, 52 ), Lord Ellenborough held, "that under the words, bearing interest, the plaintiff was entitled to recover interest from the date of the bill, sinee, without any such words, he would be entitled to interest from the time when the bill became due." The obligation of the note is to pay the principal, with interest. 'To limit the time when the interest begins to run, to maturity, is to presume that the parties contemplated the notes would not be paid when payahle, and therefore provided they should bear interest thereátter. In order to give some effect to all the terms of the notes, our conclusion is, that the interest runs from date. ${ }^{2}$

\section{Instrument Not Dated.}

§36 Richardson v. Ellettr, 10 Texas, 190.- 1853. Hempinili, CII. J.- Nor is the judgment excessive, as elarged by the plaintiff in error. It is true that the note, as copied in the petition, does not bear any date; lut the petition avers it to have been executed on the 8th day of January, 1850, a fact not controverted by the defendant. By its terms the instrument hears interest from its date, and it appears to have been accurately estimated."

\section{Conflict Between Writren and Printail Provisions.}

\$36 Amencan lixpless ('o. $\%$ Pinckney, 29 Ill. 392.- 1862. Action for negligence in collecting a draft. The question arises on the construction of a partly printed and partly written receipt by defendant. Brrsss, J.-The principle applicable in all such cases is, that a writing must be construed arerording to the vear intent of the parties, if that can be collectorl from the fare of the instrument. * * * linet there is another prineiple of law applicable. In a case whre the agreement is partly written and in part printed, the preference is always given to the written part. What is printed is intended to apply to large classes of contracts, and not to any one exchusively; the hlanks are left purposely, that the sperial statements or provisions should be inserted which belong to the particular contract,

2 Interest on notes payable on drmand runs only from thr time of lemand. Hunter v. Wool, 54 Ala. 71: Dodge v. Perkins, 9 liek. (Ma84.) 36s. - II.

see Byles on Bills (13tli ed.), [1. 79. Sre, as to date, $\$ \$ 25,30$, ante. - $\mathbf{K}$. 
and not to others, and thus to diseriminate this from others. So Lord Ellenborough leld, in the ease of liobertson and Thomasson v. French ( 4 East, 360$)$, when he said, that words superadded in writing are entitled, if there should be any reasonable doubt upon the sense and meaning of the whole, to have a greater effect attributed to them, than to the printed words, inasmuch as the written words are the immediate language and terms selected by the parties themselves for the expression of their meaning, and the printed words are a general formula adapted equally to their ease, and that of all other contracting parties, upon similar oecasions and subjects.

5. Doubt Whether BrhL or Note.

$\S 36$

FUNK $v$. BABBIT'T.

[Reported herein at $p .150.]^{4}$

$\S 36$

COMMONWEALTH $v$. BUTTFRICK.

[Reported herein at p. 113.]

6. Irregular Signature.

§36 GERMANIA NATIONAL BANK $v$. MARINER.

[Reported herein at p. 210.]

7. Jolnt ani Several Lanbility.

$\S 36$

DART $\because$. SHERWOOD.

7 Wiscoxsts, 523. - 1858.

THIs is an action of assumpsit brought by the appellee against the appeclants, as joint makers of a promissory note, which read as follows:

8400 .

Ripos, Wis., Nov. $4 t h, 1856$.

Thirty days after date, for value received, I promise to pay Putnam C. Dart, or order, four hundred dollars, with interest, at the rate of twelve per eent. per annum.

J. C. Sherwoon.

Wm. C. Silkrwoon,

Surety.

4 See also I'eto v. Reynolds, 9 Exeh. 410, note, ante, p. 150; and compare Watrous v. Holbrook, 39 Tex. 573, ante, p. 148. - H. 
On the trial the plaintiff offered the note in evidence, and the defendants made two objections to the reading of the same: * * * 2. That the note did not show a joint liability. The court allowed the note to be read, and the plaintiff rested his case. The defendants moved for a nonsuit on the ground that there was a mis-joinder of parties defendant. This motion was denied.

Judgment for plaintiff. Defendants appeal.

By the Court - Winton, C. J. - The judgment of the court below is correct and must be affirmed. The note declared upon is the joint and several note of the defendants; joint because it is signed by both; and several, because each defendant promised severally. (Story on Promissory Notes, $\$ 57$; Hunt v. Adams, 5 Mass. R. 358 ; same v. Same, 6 do. 519.) * * *

The judgment of the circuit court must, therefore, be affirmed.5

\section{$\mathrm{XI}$.Ambiguous signatures.}

$\S 37$

\section{ANDENTON $v$. SHOUP.}

17 OHo State, 125. - 1866.

Action against George W. Shoup on the following instrument:

DaYTon, August 11, 1S61.

Dayton Branch, State Bank of Ohio, pay to J. B., or bearer, two hundred thirty dollars.

$\$ 230$.

Sajuel Shoup, Agent.

Allegation that Samuel Shoup was defenciant's agent and acted as such in drawing the check; that plaintill is holder in due course; that the check was duly presented and was dishonored, ete.

Demurrer sustained and judgment for defendant. Plaintilf appeals.

DAY, C. J. - The averments in the petition will not warrant the claim in argument, that this is a case where a party limsolf uses a name other than his own in the transaction of his husiness. The most that can be claimed is, that the principal allowed the agent to sign his own nane as anent in the transaction of some of the business of the principal.

It is undoubledly well scttled that, where an ordinary simple contract is signed by an agent in his own name, with the addition of the word "agent" thereto, the prineipal may be made liable thereon, whether his narue apperars on the paper or unt. (Story on Aereney, $\$ 160 a$, and anthorities there (ited.) But, for commoreial reasons, a distinction is laken, in the anthorities, hetween eontracts of this class and negotiable paper. As to hills of exchange, it is sail that the agent

s Accord: Monsm v. Mruliuley. 40 ('oml. 552 ; Ely v. Clute, 19 IIun (N. Y.) 35; Wallace v. Jeuell, 21 Oh. Sit. 16ii, - 11. 
"must either sign the name of the principal to the bill, or it must appear on the face of the bill itself, in some way, that it was drawn for him, or the principal will not be bonnd." (Edw. on Bills, 80; Chitty on Bills, :27.)

The question as to the linhility of the prineipal, on paper executed by an agent in his own name, was well considered by the Supreme Court of Massachusetts, in the ases of the Eastern Railroad Company v. Benedict (5 (rayy, 561), and the Bank of America v. Hooper (Ib. 567$.

In the latter ease, it is said that " there will be found to be a leading distinction taken between eases of commerrial paper in the form of bills of exchange and negotiable promissory notes, and other simple contraets, holding that no one but a party to such negotiable paper ean be sued for the non-payment thereof." In support of this distinction the following anthorities are there eited: (Byles on Bills [5th ed.], 26 ; Emily v. Lye, 15 East, 7 ; Becham v. Drake, 9 M. \& W. 92; Pent v. Stanton, 10 Wend. 276; Stackpole v. Arnold, 11 Mass. 27; Bedford Com. Ins. Co. v. Covell, 8 Met. 412; Taber v. Cannon, Id. 456.)

The case of De Witt v. Walton (5 Seld. 571), decided by the New York Court of Appeals, is a strong ease to the same point. It was a suit brought on a negotiable promissory note, signed "David Hubbell Iloyt, agent for "The Churehman." IIoyt was an agent for a paper called "The Churehman," and was authorized to contract for the proprietor in that name, and the suit was against the proprietor, Hoyt's principal. It is said in the opinion, that "the good sense of many authorities upon this subject would seem to be, that, where a party is sought to be charged upon an express contract, it must at least appear upon the face of the instrument that the agent undertook to bind him as principal. Ilere the promise is not by the defendant or 'The C'hurchman,' nor by Iloyt for them or either of them, or in their behalf, but for himself. 'The formula used by him in the signature to the note in controversy has been determined, in this and other states, to rreate an obligation on the part of the agent personally, and not in hehalf of the principal. There is no great hardship in requiring that if a man undertakes to ollige another, by note, bill of rexchange, or other commercial instrument, he should manifest his purpose rlearly and intelligibly, or that his principal will not be bounel, whatever may he the result in referenee to himself."

It was further held in this ease, that the words alded to the name of the person signing the paper was merely descriptio persona.

The principle maintained in these eases, it is said by the author of the notes in Smith's Leading Cases (vol. 2, p. 433), "would seem to be well settled on both sides of the Atlantie."

These principles applied to the case before us are decisive of it. 
The name of the defendant is in no way indicated upon the face of the instrument upon which alone the action is based.

It follows, therefore, that the ruling of the court below was correct, and that the judgment rendered by it must be affirmed. ${ }^{\circ}$

\section{§35 WESTERN WHEELED SCRAPER CO. v. McMILLEN.}

71 Nebraska, $686 .-1904$.

ACtion on a note reading "we promise to pay" and signed: "Directors of 'Thedford Irrigation and Power Co. (Limited). J. M. McMillen, G. W. Miller, G. L. Matthews." Judgment for defendants and plaintiff brings error.

DuFrie, J. - * * *

The court, in its seventh instruction, told the jury: "You are further instructed that if you should believe from a preponderance of all the evidence in this case that the three notes set out in plaintiff's petition were made and executed by the Thedford Irrigation \& Power Company, Limited, and if said notes were signed by said defendants with the intention and understanding to bind the Thedford Irrigation \& Power Company, Limited, and not the signers of said notes as individuals, and if you should find from a preponderance of all the evidence that it was so understood by and between the agent of plaintiff and these defendants at the time said notes were executed and delivered, then your verdiet should be for the defendant, "No cause of action." "The jury returned a verdict for the defendants, and the plaintiff has brought the record to this court for review.

The petition in error, among other matters, alleges " that the court erred in permitting the defendants to introduce oral testimony tending to prove a different contract than that set out in the written contract, naincly, the notes sued upon," and in giving the instruction above quoted and other instructions, which it is unnecessary to discuss. The general rule undoubtedly is that, on areount of the qualities which the law annexes to negotiable instruments, none are bound except those who apprar on the face of the instrument as bound, and accordingly that extrinsic evidence cannot be admitted to charge parties whose names do not appear on the face of the instrument. * * It is undoubtedly true that the modern rases are more liberal than was formerly the case in allowing one who signs a negotiable instrument, designating limself as agent or trustee, to show by parol evidence that he was acting for another, who received all the

B Ser N. Y. Life Ins. Co. v. Martindale, 75 Kan. 142, reported in 21 L. N. 8. 1046. with exhaustive note entitled, "Liability of principal on negotiable paper executed by an agent." - C. 
benetits of the consideration for whith lhe note was given. Keidan v. IIneyur, 95 Mich. 430, 20 L. R. A. 705, is a case in point, and other cases referred to in the notes of the editor will furnish examples of the relaxation of the rule adopted by the courts at an earlier date upon this question. If this court land not put itself on record, we should be disposed to follow the modern decisions, but as early as 1856 , in Webster v. Wray. 19 Neb. 558, the comt, atter a full review of the authorities, held that " no party ean be elarged as principal upon a negotiable note or bill of exchange unless his name is thereon liselosed;" and it was further held in that case that parol evidence was not adnissible to show that one who appeared upon the face of the notes to be the maker was in fact acting as agent for another, or as the olficel of some corporation who had received the benefit of the consideration. This ease was followed by Andres v. Kridler, 47 Neb. 585 , where suit was brought upon a note made and signed substantially in the manner of those in suit, and it was held that, "where the pleadings disclose a cause of action against a defendant personally, superadded words, such as 'agent,' 'executor,' or 'director,' should be rejected as descriptio persona." We think this court is now fully committed to the doctrine that, in order to exempt an agent from liability upon an instrument exeeuted by him within the scope of his ageney, he must not only name his principal, but he must express by some form of words that the writing is the art of the principal, thougl done hy the hand of the agent. If he expresses this, the principal is bound, and the agent is not. But a mere description of the general relation or office which the person signing the paper holds to another person or to a corporation, without indicating that the particular signature is marle in the excention of the office and agency, is not sufficient to charge the principal or to exempt the agent from personal liability. There was evirlence which would fully support a finding that in executing these notes the defendants did not intend to bind themselves personally, and that the plaintiff's agent was not only fully aware of that fact, and understood that he was taking the notes of the corporation, but assisted and adrised as to the form in which the notes should be drawn in order to make them the obligation of the corporation. This being the ease, the lefemlants, upon a proper plea, would he entitled to have the notes reformed to express the real intention of the parties. Western Wheeled Sraper Company v. Stickleman et al., 122 Jowa, 396 , and anthorities there rited.

We reommend, therefore. that the case be reversed, and remanded to the District Comrt, with directions to allow the defendants to amend their answer, if they so elect: otherwice to enter jurlgment for the plaintiff for the amount due upon the notes.

KirkPatrick and Leteron, C'., meneur.

Pre Curiam. For the reasons stater in the foregoing opinion, the judgment is reversed, and remanded to the District Court, with direc- 
tions to allow the defendants to amend their answer, if they so elect; otherwise to enter judgment for the plaintifl lor the amount due upon the notes. ${ }^{7}$

\section{KEIDAN $r$. WINEGAR}

95 Michigax, 430. - 1893.

McGrath, J. Plaintiff had judgment upon the following promissory note: “\$336.96-100. Grand Rapids, Mich., Dec. 22, 1887. Ninety days after date, I promise to pay to the order of Geo. Keidan three hundred thirty-six and 96-100 dollars at the Old National Bank of Grand Rapids, Mich., value received, with interest at the rate of eight per cent. per annum until paid. W. S. Winegar, Agt." Defendant, with his plea, filed an affidavit setting forth " that the note, a copy of which is attaclied to the declaration in said cause, and served upon said deponent, with a copy of said declaration, is not the note of this deponent, defendant as aforesaid; and he denies the same and the execution thereof, and says that he, said defendant, is not indebted to

7 In Rendell $v$. Marriman, i5 Me. 497 , the note read "we promise to pay" and was signed

$\left.\begin{array}{l}\text { "Otis Harrimax } \\ \text { R. M. Trevett } \\ \text { L. Muditt } \\ \text { W. H. Cins }\end{array}\right\} \begin{gathered}\text { President } \\ \text { Directors of } \\ \text { Prospect and Stockton } \\ \text { Cheese Company." }\end{gathered}$

In an action by the payce against IIarriman et al., as individuals, the defendants offerel evidence to shew that the note, when delivered to the payee. was intended. to his knowledge, to be the obligation of the Cheese Company alone. Held that the evidener was inadmissible and that the defendants were liable as individuals. DANronTu, o., said: "It is trme, that in the cases cited, such evilenee was almithed and was perhaps admissible, under the well estab. lished rule of law, that when there is an ambiguty in the entract, when the language nsel is equally suserptible of two different enstruetions, evidener of the circumstances by which the parties were surrommed and under which the contract was made may lue giren, wot for the purpose of proving the inten. tion of the parties independent of the writing. hut that the intention may be more intelliently aserertained from its torms. But to make this evidenee admiasible some ambignity must first alpear: there must be language nsed such as may withent doing violence to its meaning. be explatimed ensistently with toe liability of either party, some langulage which as in simpsom $v$. Garland, i2 Mre 40 . tends, in the words of the statute. to show that the eon. tract was marle hy the agent in the name of the prinejpal. or in his own name for his principal.' Ju this cass no such ambiguity exiuts, no Huch language is used. The promise is that of the defondants alone without angthing to iudi. rate that it was for or in brhalf of anchloer. True, the defendants nflixed to their namea their offirial title, with the name of the eorporation in which they held oflier, lut nothing whatever to qualify their promise or in the slightest degree to show it other than their own. The statufe as woll as the decisions, with fow exeptions, as we have seen, reguires more than this to make the testimnny admissilite," r, $503,-\mathrm{C}$, 
said platutit upon said note, nor for any part thereof, nor is he indehferl to sald plantill in any sum whaterre, not in any manner whatever." Tpen the trial defembant oflered to show that in 1881 , before palutiff had any dealings with delentant, plantill was informed that hefendant was earrying on husiness as the agent of Maggie G. Wine. girr, and was not doing business for himself; fhat business relations Wore then ostablished hetween plaintill and said Maggie G. Winegar; that said husiness redations contimmed from the early part of $188 \mathrm{t}$ to and including the year lis\%, and embraced many transactions between plaintiff and Magere G. Winegar; that many instrmments were made hetween the parties, which were signed exactly as the note sued upon is signel, and that this form of execution had eome to be recognized and adopterl between the parties as binding Maggie $\mathrm{F}$. Winegar; that during that time no business was transacted by the defendant in his individual capacity, and all the business done was that of his principal, and known and understoor to be such by plaintiff; that the said note was given and accepted as the obligation of Maggie G. Winegar ; that the note was given for ducbills and gools furnished by plaintiff to Maggie G. Winegar on the hooks of plaintill: that the taking of these notes did not in the least cluange the charactur of the indebtedness; and that defendant never receives any benefit or consideration for said note. The court refused to admit the testimony, and directed a verdict for the plaintiff.

The elear weight of anthority is that the promise in the present case is prima facie the promise of William S. Winerar, and, as hetween one of the original parties and a third party, the addition of the word "agent" is not sufficient to put such thire party upon inquiry. The question here, however, is whether, as lutween the immediate parties to the instrument, parol evidence is admissible to show the real character of the transaction. - * * In Kean v. Davis, 47 Amer. Dee. 182, ('hief Justice Green says: "The ruestion is not, what is the true construction of the language of the contracting party, but, who is the contracting party? Whose language is it? And the evidence is not addueed to discharge the agent from a personal hiability which he has assumed, hut to prove that in fact he never infurres that liability: not to aid in the construction of the instrmment, but to prove whose instrument it is. Now, it is true that the construction of a written contract is a question of law, to be settler by the court upon the terms of the instrument. But whether the contract was in point of faut exeruted, when it was made, and by whom it was marle, are questions of fact, to be settled by a jury, and are provable in many instances by parol, even though the proof conflicts with the language of the instrument itself." * * * To the rule that extrincire evidenes eannot be received to contradict or vary the trrms of a valid instrument, there are many exceptions. As hetween the original parties, the consideration may be impeached; 
fraud or illegality in its inception may be shown. It may be shown that the note was delivered ronditionally, or for a speeified purpose, only; that it was made for accommodation, merely; if, by mistake, one party indorse's before another, such mistake may he shown to relieve him from his apparent liability; that a party who indorses lis name upon the back of a note may be maker or indorser, dependent. upon farol proof as to when he placed his signature; that, although the legal effect of successive indorsenents is to make the indorsers liable to each other in the order of time in which they signed their names, yet such legal effect may he rehutted by parol proof that all were accommodation indorsers, and, by agreement among themselves, cosureties; that the fact of a note being joint and several did not exclude proof that one of the signers was a surety, merely, and, where the ereditor knew the fact of suretyship, an extension of time, for a consideration, without the consent of such surety, released the surety.

* * *

As is so often said, it is the intent of the parties which is to be carried out by the courts. The rule that rejects words added to the signature is an arljitrary one. Its reason is not so much that the worls are not, or may not be, suggestire, but that they are but suggestive, and the instrument, as a whole, is not sufficiently complete to point to other parentage. The very suggestiveness of these added words has given rise to an irreconcilahle confusion in the authorities as to the legal effect of such an instrument. Extrinsic evidence, therefore, is admissible in such case, between the immediate parties, to explain a suggestion rontained on the face of the instrument, and to carry out the contract actually enterer into as suggested, but not fully shown, hy the note itself. 'The-presumption that persons dealing with negotiable instruments take them on the eredit of the parties whose names appear should unt he alsolute in favor of the immediate payee, from whom the encideration passerl, who must he deemed to have known all the farts and cirrumstances surrounding the inception of the note, and with such knowledge arerpeted a notre containine sum a suggestion. * * * We think that in the present rase defemlant was entitled to make the showing offored. Thuler the genoral issue, defendant was entitled to grive in evidence any matter of defonse going to the existenere of any promise having legal foree, as against. him. I shimn, Pl. \& Pr., \& 7 \%o.

'The judgment is resersed, and a new trial ordered. The other justices enconrend."

"This case is reportod in 20 I. R. A. 705, with exhaustive note entitled, "Arlmiqsibility of extrinsise evilener to show who is liable as the maker of a note."

Accord: Megowan v. Preterson, $173 \mathrm{~N} . \mathrm{V} .1$. In this ease the note read. "I promise te pay" and was signed " Charles G. Poterson, Trustce." Haiout, J., 


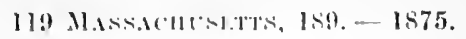

ConTRACT against tho dufomiants als drawers of three drafts indorsed in blank ly the patyes, of which the following is a copy:-

No. 176 .

$\$ 5,000$.

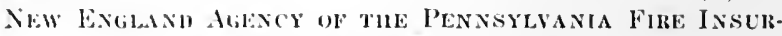

Fosmen \& cork, Gencrial deents for the

New England Sitale's.

15 beromshire Street. Boston. AXCl: COMPANY, PHIADELHIA.

Boston, August 18, 1873.

Pay to the order of Haley. Morse \& Company, five thousand dollars, being in full of all claims and demands ayalust sald comping for loss and lamage by fire on the thirtieth day of $\mathrm{May}, 1873$, to property insured under policy No. 824, of Boston. Mass., ageney.

Foster \& Cole.

To the Penusylvania Fire Insurance Company, Philadelphia.

Defendants were general anents of the Peunsylvania Fire Insurance Company of Philadelphia, and drew the drafts m question in pay-

after quoting section ig of the Negotiable Instruments Law, said: "Ile clid not. in the instrument itself, diselo-e the fact that he was trustee for the creditors of Jobmon \& Peterson. so that. under the provisions of this statute, he would hecome personally liable upon the note. unless he could show that at the timse of the delivery of the note to the plaintifls be disclosed the fact that the consicleration for which the note was given was for the benefit of the creilitors of Iohmson \& Peterson, and that he gave the note as the trustee for such creditors. It is contended on behalf of the plaintiffs that his representative character nust he disclosed mon the fare of the note. This may be so in so far as inueent pulchasers for value are concernel, but as to the payees named in the unte wa think a diffurent rule prevails. In the case of Bank v. Wallis, $150 \mathrm{~N}$. Y. 455 . the action was upon a promissory note signed hy Wallis, who ardecl to his signature 'President,' and by' Smith, who added to his signaturn 'Treasure'. 'They were in fact president and treasurer of the Wallis Iron Works, a corpuration, aud the unte was j-bued as an obligation for the corporation, and was disemnted ly the plaintiff lank. It was held that the plaintiff was entitlerl to seener upon the ground that the representative cliaractres of the defendants were not diselosed to the bank at the time that it discennted the paper. AxnRlis, C. J., in dolivering the opinion of the court, said with reforemere thereto: "It may le almiterl that if the bank, when it discomitel the paper. was informerl or knew that the note was issued by the esroration. ancl was intended to ereate only a corporate liability, it could not be enforesd against the lefendants as individuals, who, by mistake, liad executed it in such form as to make it on its face thrir own note, and not that of the corporation. Pist, aceording to the rules governing eommercial pajer, notling short of untiee. experes or implierl, brouglit home to the bank at the time of the discumnt. that the note was insurel as the note of the corporation, and was not intended to bind the lefoudant:, conld defeat its remedy against the parties actually liable thereon as promisors.' We lo not under. stand that thre statute to which we have alluded was designed to ehange the common-law rule in this regarl, which is to the effeet that, as between the original parties and those laving notice of the facts relied upon as constituting a defenor. the ron-idration aud the conditions under which the note was delịvered may be shown." Jages 4, 5. - C, 
ment of three policies issued by that company, The company refused to honor the drafts, and they were duly protested.

GraY, C. J. - Each of these drafts, upon its face, purports to be issued by the New England agency of the Pennsylvania Fire Insurance Company, and shows that Foster \& Cole are the general agents of that corporation for the New England States, as well as that the draft is drawn in payment of a claim against the corporation. It thus appears that Foster \& Cole, in drawing it, acted only as agents of the corporation, as clearly as if they had repeated words expressing their agency after their signature; and they cannot be held personally liable as drawers thereof. Carpenter v. Farnsworth, 106 Mass. 561, and cases cited.

Judgment for the defendants.

139 NEW YORK, 307. - 1893.

ACtion against defendants as makers of a promissory note. Judgment for plaintiff. The opinion states the facts.

GraY, J. - The action is upon a promissory note, in the following form, viz. :

Brooklyn, N. Y., August 2, 1890.

$\$ 7,500$. Three months after date, we promise to pay to the order of Clark \& Chaplin Icc Company, seventy-five hundred dollars at Mechanics' Bank: value received.

E. H. Close, Treas.

John Clark, Prest.

It was delivered in payment for ice sold by the payee company to the Ridgewood Ice Company, under a contract hetween those companies, and was discounted by the plaintiff for the payee, hefore its maturity. The appellants, Clark and Close, appearing as makers upon the note, the one describing himself as "Prest." and the other as "Treas.," were made individually defendants. 'They defended on the ground that they had made the note as officers of the lidgewood Ice Company, and did not hecome personally liable thereby for the debt represented.

Where a negotiable promissory note has been given for the payment of a debt contracted by a corporation, and the languige of the promise does not disclose the eorporate obligation, and the signatures to the paper are in the names of indlividuals, a holder, taking bona fide, and without notice of the circumstanes of its making, is entitled to hold the note as the personal undertaking of its signers, notwithstanding they affix to their names the title of an office. Such an affix 
will be regarded as descriptive of the persons and not of the character of the tiahility. Unless the promise purports to be by the corporation, it is that of the persons who subscribe to it; and the fact of adding to their names an abbreviation of some oflicial title has no legal signifieation as qualifying their obligation, and imposes no obligation upon the rorporation whose oflicers they may be. 'This must be regarded as the long and well-settled rule. (Byles on Bills, §§ 36, 37, 81 ; l'entz v. Stanton, 10 Wend. 271; T'aft v. Brewster, 9 John. 334; Hills v. Bannister, 8 Cow. 31; Moss v. Livingston, 4 N. Y. 208; Dellitt v. Walton, 9 Id. 571; Bottomley v. Fisher, 1 Hurlst. \& Colt. 211.) It is founded in the general principle that in a contract every material thing must be definitely expressed, and not left to conjecture. Unless the language ereates, or fairly implies, the undertaking of the corporation, if the purpose is equirocal, the obligation is that of its apparent makers.

It was said in Briggs v. Partridge (64 N. Y. 357, 363), that persons taking negotiable instruments are presumed to take them on the credit of the parties whose names appear upon them, and a person not a party cannot be charged, upon proof that the ostensible party signed, or indorsed, as his agent. It may be perfectly true, if there is proof that the holder of negotiable paper was aware, when he received it, of the facts and circumstances connected with its making, and knew that it was intended and delivered as a corporate obligation only, that the persons signing it in this manner could not be held individually liable. Such knowledge might be imputable from the language of the paper, in connection with other circumstances, as in the case of Mott v. IIicks (1 Cow. 513), where the note read, "the president and directors promise to pay," and was subseribed by the defendant as "president." The court held that that was sufficient to distinguish the case from Taft v. Brewster, supra, and made it evident that no personal engagement was entered into or intended. Much stress was placed in that case upon the proof that the plaintiff was intimately acquainted with the transaction out of which arose the giving of the corporate obligation.

In the case of Bank of Genesce v. Patchin Bank (19 N. Y. 312), referred to by the appellant's counsel, the action was against the defendant to hold it as the indorser of a bill of exchange, drawn to the order of "S. B. Stokes, Cas.," and indorsed in the same words. The plaintiff hank wrs advised, at the time of discounting the bill, by the president of the Patchin Bank, that Stokes was its eashier, and that he had heen directed to send it in for discount, and Stokes forwarded it in an official way to the plaintiff. It was held that the Patchin Bank was liable, herause the agency of the cashier in the matter was communicated to the knowledge of the plaintiff as well as apparent. 
Incidentally, it was said that the same strictness is not required in the execution of commercial paper as between banks, that is, in other respects, between individuals.

In the absence of competent evidence showing or charging knowledge in the holder of negotiable paper as to the character of the obligation, the established and safe rule must be regarded to be that it is the agreement of its ostensible maker and not of some other party, neither disclosed by the language, nor in the manner of execution. In this case the language is, "we promise to pay," and the signature by the defendants, Clark and Close, are perfectly consistent with an assumption by them of the company's debt.

The appearance upon the margin of the paper of the printed name "Ridgewood Ice Company" was not a fact carrying any presumption that the note was, or was intended to be, one by the company.

- It was competent for its officers to obligate themselves personally, for any reason satisfactory to themselves, and, apparently to the world, they did so by the language of the note; which the mere use of a blank form of note, having upon its margin the name of their company, was insufficient to negative.

[The court then decides that the fact that one Winslow was a director in the payce company, and also in the plaintiff lank, did not charge the latter with notice as to the origin of the paper.]

. Tndgment affirmed.'

\section{ENGLISH AND SCOTTISII AMERICAN MORTGAGE ANU INVESTMENT COMIANY $r$, GLOBE LOAN AND TRUST COMPANY.}

70 Nemisks, 435. -1903.

Aubert, C. 'This action was brought by the English \& Soottish American Mortgage \& Investment Company against the Globe Ioan \& Trust Company, Enmma O. Devries, as alministratrix of the estate of H. O. Devries, dereased, and W. Beach 'Taylor, on a promissory note, of which the following is a ropy:

$\$ 982.13$.

Оманм, Nin., March 1st, 1898.

GIOBE IOAN \& TRUST (OO., OWAIIA, NEBRASKA.

On or before two years after dilte, we fromise to pay to the Fingliah \& Sectish dmerican Mortgage \& I. Co.. or order. nine lundired and righty fwo and 13/100 Dollars, for value received: negotiable and payble at the oflier of the Globe Joan \& 'Trust company, Omaha, Nehraska, with intorest at the rate of six per cent. per annum from date until maturity.

Grone: Jos. \& Thust co.,

H. O. Deveifis, Presalt.

W. H. TAYIOR, SERY.

- See extract from Mrgowan v. Pricrsom, 179 N. Y. 1, in note on p. 203. - C, 
Only the last-named defendant is concerned in the litigation at this time. As a lofense to the note, he pleaderl that it was the note of the trust company alone. and that he signed as secretary in order to give it effect a- the obligation of smeth company, and for no other purpose. On the trial of the issues joined hetween the plaintiff and 'Taylor, the former otlered the note in crillence; and it was exeluded on the ground that it appeared on the face of the note that it was the oblifation of the trust 'ompany, and not the personal obligation of such defendant. Judgment was given for 'Taylor, and the plaintiff brings error.

'The sole question in this case is whether the note, on its face, shows a personal liability on the part of 'Taylor. If it does, the judgment of the Distriet ('ourt is wrong, and should be reversed.'

The plaintiff contends that the mere addition of the official title of an officer of a corporation to his signature on a note does not make it the note of the corporation, and that a note thus signed is the personal obligation of the officer thus signing it. Among the authorities cited in support of this contention are the following: Andres v. Kridler, 47 Neb. 585; Hays v. Crutcher, 54 Ind. 261 ; Scott v. Balier, 3 W. Ta. 285 ; Rendell ․ IIarriman, 75 Me. 497; Bank v. Clark, 139 N. Y. 307; Tucker Mfg. Co. v. Fairbanks, 98 Mass. 101. In none of the foregoing cases, however, is the name of the corporation itself attached to the note as maker; and those cases appear to rest on the familiar rule that, where an agent signs a negotiable instrument in his own name, without diselosing on the face of the instrument the name of his principal, he is personally liable thereon. But in the present case the name of the corporation is attached to the note, and is followed by that of Derries and Taylor, with the designation of their respective titles. In American Nationat Bank v. Omalia Coffin Mfg. Co., 95 N. W. 672, this court held that a note signed: "Omaha Coffin Mfg. Co. C. A. Claflin, Presdt. S. L. Andrews, Sec." - was the note of the corproration, and that the officers whose names were attached thereto were not liahle thereon. The doctrine announerl in that ase is supported by the following: Liobsher v. Kraus, 71 Wis. 387; Reeve v. First Nat. Dank, 54 N. J. Law, 208; Draper v. Steam II cating Co., 5 Allen, 3is; C'estle r. Fommlry ('o., 72 Ne. 167; Falk r. Moebs, 127 U. S. $59 \%$.

In the cases just cited but one signature followed that of the corporation, and in Ameriran Nationat Barli v. Omaha Coffin Mfg. Co., supra, the liability of the second offieer signing the instrument was not noesearily incolverl: and on that ground the plaintiff undertakes to distingruish between these rases and the case at har, and insists that while it may ho prosumed that Devries, in signing the note, intended merely to indirate by whom the corporate signature was affixed to the instrument, no such presumption is to be indulged as to Taylor, because the signature of Devries, to which is attached his official 
designation, following the name of the corporation, is sufficient of itself to indicate by whom the corporate signature was affixed. The plaintili"s argument on this point is agreeably plausible, but not conviscing. Viliale t..e liaw would have presumed a corporate obligation,

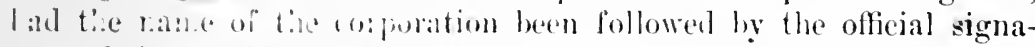

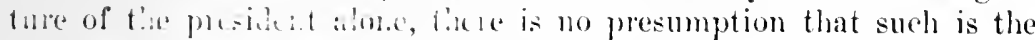
sule metlod of atte tiar line corporite signature. It is not unusual for corporations to resuig that instruments intended to bind them shall he exeruted $1:$ mo:ce t!:an one of their officers. And where, as in this instance, 1 (1) comporate mane is followed by the signatures of two of its offices, to which are attached the respective titles of such officers, the presumption which attends the signature of the first officer should he held to attend that of the second as well. This view is in harmony with molern methods and rommon usage. Instruments thus signed pass murrent as corporate ohligations only, and outside of a courtroom no one ever arts upon them in the helief that they bind, or were ever intended to hincl, the officers thus signing them, or any person other than the corporation itself.

We have not overlooked Heffner v. Brounell, 70 Iowa, 591, wherein the officers were held liable on a note signed precisely as the one in suit. But that case is contrary to the doctrine amounced by this court in American Natimal Bank v. Omaha Coffin Mfg. Co., supra, and, as we think, to the weight of modern authority.

It is recommended that the judgment of the District Court in favor of Taylor arainst the plaintiff be affirmed.

Barnes and filanville, C'(', concur.

Pron Crmo... For the reasons stated in the foregoing opinion, the jud rement of the District fourt in favor of Taylor against the plaintiff is alfirmed."."

10 See report of this rane in 6 A.\& F. Ann. ('as. 999, with exhanstive note

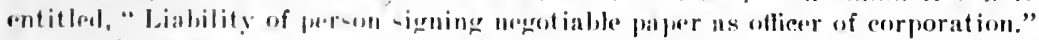

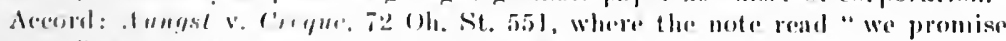
to pily" and Was signd "Thr Akron White Sand and Stone Co. I. K.

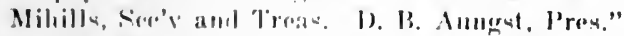

Helel that on ite face it was the note of the company nlone. and not the

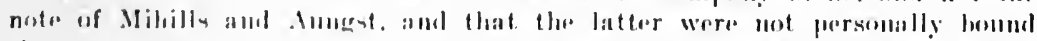

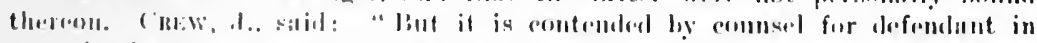

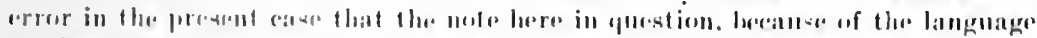

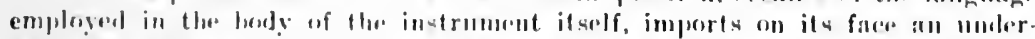
takinge on the part of all whose names are signed thereto that they will lo.

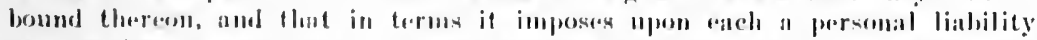
as $n$ maker of said note. (ounsel assume that the ner of the words "we promise to pay ' in the louly of the instrument, is comelnsive of the fare that this note is and wa intendorl to low the joint noto of the Akron White Sand \&

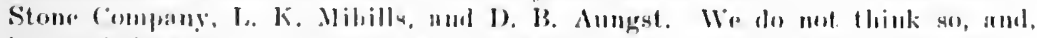

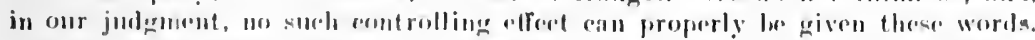

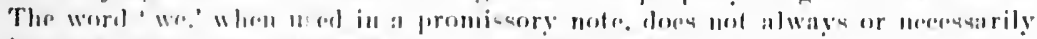
imply a plurality of mukers, nud it is often userl, as will appear from many

NEGOT. INBTRUMENTY - 14 


\section{$\S 39$}

\section{GERMANIA NA'TONAL,BANKF MILAUKEE v. MARINER.}

129 Wiscossix, 544. - 1906.

Wissiow, J. The plaintill sued the appellant and the Northmestern Straw Works as makers of the following promissory note:

Miluavkli, January 6, 1905.

Four montlis after date thr Northwestern Straw Works promise to pay to the order of $\%$. G. Bigelow $(\$ 20,000)$ Twenty Thomsambl Dollars at the First National Bank, Milwaukee. Value received.

'I'ue, Northwestern Straw Works,

E. R. Sthliman, Treas.

JollN W. MARINER.

The defendants answered jointly, alleging that the note was the note of the Northwestern Straw Works (a corporation) alone, and was signed by Mariner as secretary of the corporation and not in his individual capacity. The case was tried withont a jury, and the evidence showed without dispute that the plaintiff purchased the note from the payee in due course and for value lofore due; that it represented a loan made to the corporation defenclant alone; that the by-

of the cases cited in this opinion, to designate or describe a corporation aggregrte. It is said in Randolph on Commereial Paper, \$143, that “" We promise" seems the natural form of words for a corporation's promise, if the name itself is not used in the borly of the note.' . . . In Draper v. Massachusetts Steam lleating Co. and another, 5 Allen, 338 , the note in suit read, "We promise to pay', and the signing was similar to that in the case at bar, viz.: 'Mass. Steam Heating Co.- L. J. Fuller, 'Jreasurer.' Ho.k. J., in the opinion in that case, sayc: "The name of the company is signed to the note. This signature could not be made by the corporation itself, and must have been written by some oflier or agent. It was manifestly proper that some indication should be given by whom the signature was made, as evilenee of its genuineness; and Fuller added his own name, with the designation of his official elaracter. It would have heen better if the name of the primeipal had been inserted in the body of the contract as the eontracting party. or if the word "by" had preceded Fuller's name in the signature. But we think the omission to do this does not change the aplament chatraeter of the instrument, aud that the whole, taken together, shows it to he the signature of the Massachusetts Steam Heating company, and nut of Fuller." l'age 555.

After citing a larga number of eases the court wass: "In all of the above cases the noten wre lield to bo mambiguous, and to be the notes of the corporations alone." P. 55.

But to the other "xtreme, see Mathers \& Co. v. Mottress Co., 87 Iowa, 246, where the note real " wo promise to pay" and was signed, "Dubuque Mattress Co., John Kapp. Pt." Hall, that, upon the face of the note, Kapp was personally liable, and that even in an action hetween the immediate parties to the instrument oral testimony was inadmissible to show that he was at the time president of the company, and anthorized to sign notes for it, that the note was given for goorls sold to the company, and was intended to bind it alone, and that the payer knew that fort when he towk it.

See, also, Rendell v. Ilarriman, 75 Me. 497, in note on p. - - C. 
laws of the corporation required its notes to be signed by two officers, either the president or treasurer and the secretary; that Mr. Stillman was the treasurer of the corporation and Mr. Mariner the seeretary; that Mr. Mariner signed his name thereto simply for the purpose of making it the note of the corporation, and not intending to bind himself, but neglected to add the word "Secretary" to his name; that the plaintiff had no information as to the capacity in which Mariner signed the note, further than that afforderl by the note itself; and that the defendant corporation went into bankruptcy after the maturity of the note and made a composition with its ereditors under which there was paid to the plaintiff on the note $\$ 4,020$. 'There was no proof that the corporation had ever held out to the plaintiff or the public that Mr. Stillnan or any single officer had authority to execute notes for it. Upon these facts the court, upon notion, ordered the complaint amended so as to charge Mr. Mariner as indorser, found him liable as such, and entered judgment against him for the balance due upon the note, from which judgment Mariner appeals.

The question as to the liability of Mariner under the facts stated is certainly not free from difficulty. The general rule is well supported that when it elearly appears, either in the body of the note or by appropriate words added to the signatures themselves, that a corporation is the party making the promise, there is no individual liability on the part of the signers. 1 Randolph on ('on. Paper (2d ed.) 135. In an early case in this state, however (Demnison v. Austin, 15 Wis. 334), this principle was, in effect, modified, as it is modified in some other jurisdictions, by a proviso to the effect that, if the signers in fact had no authority to bind the corporation, they bind themselves indiridually. The Negotiable Instrument Law (chapter 356, p. 682, Laws of 1899 ) recognizes both the general principle and the proviso, in section $1675-200^{3}$ (page 691), in these words: "Where the instrument contains or a person adds to his signature words indicating that he signs for or on behalf of a principal, or in a representative capacity, he is not liable on the instrument, if he was duly authorized." 2 is it apperars withont dispute in the present ase that the signers of the note were anthorized to axorute it on bolalf of the corporation, the proviso need not be considered. In the present rase the hody of the note leerlares that the "Northwestern Straw Works" (presumably a corporation) is the promisor. It does not say "I" or "we" promise to pay, hut sprerifirally names a corporation as the promisor. Hence, so far as Mr. Stillman is conecrned, the note itsolf makes it clear that he signed only on behalf of the corporation. Parol evidence would not be admissible to show that he signed as a joint

1 N. Y. \& 39. - C

See the extract from Mr. Mekeehan's article on the Nogotiahlo Instrumente Law, post, pages —- C. 


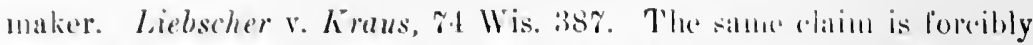
made as to the signature of the defendant Mariner, and it is not without autherity to support it. Shaver v. Ocean Mining Gompan!, ¿1 (al. 45.

We are not imlined, however, to rest the rase upon any doubtful proposition. Granting that the section loes not apply as to the signature of Mr. Mariner. We think it would he conceded that upon its face it is ambignous so far as Mr. Mariner is concemed. The instrument says that the "Northwestrru Straw Works" promises to pay. The signature of Mariner is the hare signature of an individual. 'This is certainly not usual, and should arrest the attention of any one dealing with it at once. People do not orlinarily sign contracts purporting on their face to be contracts of others. If they rlo, the fact itself suggests at once a doubt as to what they mean by it. In other words, the instrument hecomes, as to such signatures, ambiguous. The Negotiable lnstrument Law, before referred to, contains several provisions with reference to the construetion of negotiable instruments bearing the signatures of persons who have not marle their intentions clear, and these must be considered. Sublivision $6, \$ 1675-17,{ }^{3}$ p. 693, provides that, "where a signature is so placed on an instrument that it is not clear in what capacity the person making the same intended to sign, he is to be deemed an indorser." This provision, by its very terms, applies only to a case of doulit arising out of the location of the signature upon the instrument. Names are sometimes placed at the side, on the end, or across the face of the instrument, and thus a doubt arises as to whether the signer intended to be bound as a maker or an indorser, or perhaps as a guarantor, and to solve these doubts the section in question was evidently framed. It was to settle a doubt fairly arising from the ambignous location of the name, and applies to no other. In the present case there is no doubt of this nature. The signature of $\mathrm{Mr}$. Mariner is plaeed in the usual and proper, in faet the only proper, place for a maker. The doulst arising is not a doubt whether he intended to sirn as maker, indorser, or guarantor, for it is elear from the location of the name that he did not intend to sign as indorser or guarantor, but simply a doubt whether he intended to sign in an individual or in a representative capacity as maker. 'To say that, where it conclusively appears from the instrument that the signor intended to sign as a maker, the statute is intended to inake him an indorser, woul] be little slort of ridiculous. The statute was passed to meret a case where it is clonbtful from the instrument whether a man intended to lreome an indorser, not to make an indorser out of a person who, without doulit, intended to sign as maker, either individually or as lepresentative of another. We have no doubt, therefore, that this sertion has no application to the present case.

3 N. Y., § 36, subd. 6. - C. 
Sections $16 \% 7-3$ and $16 \% \%-4$, p. 712 , are also referred to as having sonte bearing on the question. Section $1679-3{ }^{4}$ provides that "a yerson placing his signature upon an instrument otherwise than as i.'alee, drawer or acceptor, is decmed to be an indorser, unless he 1haly indicates by appropriate words his intention to be bound in some other rapacity." Section 16 i -1 " provides that, "where a per-on not otherwise a party to in instrment places thereon his signainre in blank before dilivery, he is liable as an indoreer in accordance with the following mles." etr. As to the last-named section, it is manifest that it has mo applieation, heranse Mr. Mariner did not place his signature upon the note in hlink. 'The first-named section is equally inapplicable, becanse it is certain, from the instrument itself, that he placerl his signature thereon as maker, either individually or in a representative apacity: hence the contingency named in the section has not arisen. It seems entirely clear from the language of these two sections. and from the notes thereto, that they were intended to lay down in statutory form the propositions already deeided by this court in Cady 8 . shepard. 12 Wis. *639, and King v. Ritchie, 18 Wis. *554, and other cases following them. There are no other sections of the Negotiable Instrument Law which can be reasonably claimed to have any material bearing on the question now under consideration, and it must therefore he determined upon general principles of the common law.

It is elementary-that, in ease a written contract is ambiguous in its terms, parol proof of the facts and circunstances under which it was executed may be infroduced to aid in its construction. This rule applies to commercial paper, even in the hands of third persons, because, where the ambiguity is apprarent to a reasonahly prudent man on the face of the paper, he is neressarily put upon inquiry. Meachem on Ageney, \$ 443: I/ood v. Mallenbect. 7 Hun, 362: 10 Cyc. p. 1051; 4 Thompson on ('orporations, $\$ 5141$. The parol evidence in the present ease showed withont dispute that Mr. Mariner's signature was attached simply in his representative apacity and as agent of the corporation. There being a plain ambignity in this respect appearing on the face of the note, the avidence was properly reecerol, and the judgment against Mariner individually was erromeonsly rendered.

Judgment reversed, and artion remanded, with dirertions to dismiss the complaiut

- N. Y., \$113. - C.

* N. Y., \$ $114 .-$ C. 
16 Miximets, :2!3. - 1891.

Acroos against defendant as indorser npon the following promis sory note:

$\$ 1,000$.

Mineapolis, May $12,1884$.

Six months after date we promise to pay to the order of A. J. Boardman, treasurer. one thousand dollars, value received, with interest at eight per cent. after maturity.

Mrneapolis Evare and Machine Works.

By A. L. CвоскLи, Sec'y.

(Indorsed) A. J. Bo.AвDMax, Treasurer.

Defendant was treasurer of the Minneapolis Engine \& Machine Works, and clains to have made the indorsement in that capacity. Judgment for plaintiff.

Mitchell, J. (after stating the facts, and deciding that the trial court erred in not submitting to the jury a question as to the extension of the time of payment without the consent of the defendant). With a view to another trial it is necessary to consicler the questions involved in the first defense. These are (1) whether, on the face of the paper, this is the indorsement of the eorporation or of defendant individually; and (2) whether its character is conclusively determined by the terms of the instrument itself, or whether extrinsic evidence is admissible to show in what character - officially or individually - the defendant made the indorsement.

Where both the names of a eorporation and of an officer or agent of it appear upon a bill or note, it is often a perplexing question to determine whether it is in legal effect the contract of the corporation, or the individual contract of the officer or agent. It is very desirable that the rules of interpretation of commercial paper should be definite and certain; and if the courts of the highest authority on the subject had laid down any exact and definite rules of construetion for such cases, we would, for the sake of uniformity, he glad to adopt them. But, unfortunately, not only do different courts differ with each other, but we are not aware of any court whose deeisions furnish any definite rule or system of rules applicable to such eases. Each case seems to have been decided with reference to its own facts. If what the courts sometimes (all "corporate marks" greatly predominate on the face of the paper, they hold it to be the contract of the corporation, and that extrinsice evidence is inadmissable to show that it was the individual contract of the officer or agent. If these marks are less strong, they hold it prima farie the indivirlual contract of the officer or agent, but that extrinsic cridence is admissible to show that he executed it in his official rapacity in hehalf of the corporation; while in still other cases they hold that it is the personal contract of the party who signed it, that the terms "agent," "seeretary," and the like, are 
merely descriptive of the person, and that extrinsic evidence is not admissible to show the contrary. See Daniel, Neg. Inst. $\$ 398$, et seq. When others have thus failed we can hardly hope to succed. Perhaps the diffienlty is inherent in the nature of the subject.

This court has in a line of - tecisious-held that where a party signs a contract, affixing to his signature the term "agent," "trustee," or the Iike, it is prima facie lis individual contract, the term affixed being presumptively merely descriptive of his person, but that extrinsie evidence is admissible to show that the words were understood as determining the character in which he contracted. See Pratt $\mathbf{v}$ Beaupre, 13 Minn. 177; Bingham r.-Stewart, 13 Minn. 96, and 14 Minn. 153; Deering v. Thom, 29 Minn. 120; Rowell v. Oleson, 3\% Minn. 288; Peterson v. IIoman, 44 Minn. 166; Brunswick-Balke Co. v. Boutell, 45 Minn. 21. Only one of these, however, (Bingham v. Steuart), was a case of commercial paper where the name of a corporation appeared on its face, and in that case possibly the court did not give due weight to all the "corporate marks" upon it. Where there is nothing on the face of the instrument to indicate in what capacity a party executed it except his signature with the word "agent," "treasurer," or the like suffixed, there can be no doubt of the correctness of the proposition that it is at least prima facie his individual contract, and the suffix merely a description of his person. But bills, notes, acceptances, and indorsements are to some extent peeuliar - at least, the different relations of the parties, respectively, to the paper are circumstances which in themselves throw light upon, and in some cases control, its interpretation, regardless of the particular form of the signature. For example, if a draft were drawn on a corporation by name, and accepted by its duly authorized agent or officer in his individual name, adding his official designation, the acceptance wonld be deemed that of the corporation, for only the drawee ean accept a bill; while, on the other hand, if drawn on the drawee as an individual, he could not hy words of official description in his acceptance make it the acceptance of some one else. So if a note was made payable to a corporation by its corporate name, and is indorsed by its authorized official, it would be dremed the indorsement of the corporation; for it is only the payee who can be first indorser, and transfer the title to the paper. But this is not such a case. It does not appear on the face of this note what the defondant was treasurer of Fxtrinsic evidence lias to be resorted to at the very threshold of the rase to prove that fact.

C'ounsel for the defendant relies very largely upon the ease of Falk v. Moebs, 127 U. S. 597, which romes uearer sistaining his contention than any other case to which we have been referrol. Rut that ease differs from this in the very important particular that it appeared upen the face of the paper itself that the payee and iudorser was the secretary and treasurer of the corporation, and that as such he him. 
solf executed the note in its behalf. 'l'he ase was also decided largely upon the authority of Hildeock v. Buchanan, 105 U. S. 416, which is also clearly listinguishable from the present ase, for there the bill sued on purported on its face to be drawn at the oflice of the company, and directed the drawee to eharge the amount to the account of the compuny, of which the signers described themselves as president and seceretaly.

()ur conclusion is that there is nothing upon the face of the note sned on to take it out from under the rule lail down in the decisions of this court alrady refored to, that upon its face this is prima facie the indorsement of defendant individually, but that extrinsic evidence is admissible to show that he made the indorsement only in his official capacity as the indorsement of the corporation.

\section{Order reversed. ${ }^{\circ}$}

\section{$\S 39$}

\section{MckeEHAN, The Negotiable Instruants Law.}

[4l Am. LAw Reg., N. S., pp. 462-465.]

Professor Ames eriticises this section [N. Y., $\$ 39]$ as follows:

"Section 20 provides that a person who purports to sign an instrument in behalf of a named principal is not liable on the instrument, if he was duly anthorized by the prineipal. By necessary implication he is liable on the instrument if not duly authorized. ${ }^{7}$ This is a departure from the English act and from the almost uniform current of judicial decisions. This new rule involves a flat contradiction of the instrument, and the fiction works not justice, but injustice."

The section is copied from Article 95 of the German Exchange Law, and undoubtedly is a departure from the English act, under which the pretended agent is liable, not on the instrument, but for the damage resulting from the hreach of his implied warranty of authority to sign for the principal. Mr. Crawford's original draft embodied the

- There is a clear distinction hetween makers. Irawers, and acceptors, on the one hand, and indorsers on the otler. An iulorsement being necessary to transfer title a payee designated as "A. B. agent" may indorse in that form without becoming liable as indorcer. Huffeut on Ageney, $\$ 194 ;$ Babcock v. Beman, 1 F. D. Smith ( N. Y.) 593; I'ater v. Leris, 36i Ind. 288; First Nat. Bk. v. Hall, 44 N. Y. 395; Falk v. Moebs, 127 U. S. 597. See especially the statement in Collins v. Luckeye, etc., Co., $17 \mathrm{Oh}$. St. 215 . The rule is especially liberal in favor of cashiers who indorse instruments lrawn to their order, as, "pay to the order of A. B. eashier." Banl of Cienesee v. Iatchin Bank, 19 N. Y. 312; Folger v. C'hase, 18 P'ick. (Mass.) 63. Neg. Inst. L., § 72, post, which extends the liberal rule to a "cashier, or other fiscal officer of a bank or corporation."-- H. [See Johnson v. Buffalo Center St. Pk., I34 Iowa, 731, post. - C.]

7 "Mr. Crawford so interprets the section. Crawford's An. N. I. L. 26." 
English rule, ${ }^{8}$ but the commissioners changed it and adopted the German rule deliberately and after mature consideration. It is scarcely true that in doing so they departed from "the almost uniform current of judicial decisions." There is a strong conflict of authority on the point, some states holding the pretended agent liable on the instrument itself, while a somewhat larger number hold him_liable only for the damage resulting from the breach of his implied warranty of authority. ${ }^{3}$ The latter decisions seem eorrect on theory. As was said in Hall v. Crandall, if the instrument contains language which does not in legal effect charge the pretended agent, "or, in other words, contains language which, in legal effeet, binds the principal only, the agent cannot be sued on the instrument itself, for the obvious reason that the contract is not his." He has falsely represented that he had authority to bind another, but he has not intended or attempted to bind himself, and courts which hold him liable on the contract itself "treat all matter which the contract contains in relation to the principal as surplusage, which is, in effect, to make a new contract for the parties concerned instead of construing the one which they made for themselves."

Judge Brewster's answer is: "One signing a note as agent for another should know and he able to show his authority. If he signs without authority, he alone in fact, and so in law, is the maker of the note, and he should he held liable accordingly." This view, though perhaps difficult to justify on the principles of contract, is supported by weighty authority. ${ }^{2}$ and important practical advantages. The rule

- Crawford. An. N. I. L. 26.

- In the following states the pretended agent appears to be held liable on the contract itself: Ormsby v. Korrall, 2 Ark. 338 (hut see Dale v. Donaldson, 48 Ark. 190): Richif v. Bass. 15 Ia. Ann. 66s: Terwilligrr v. Murphy, 104 Ind. 32; Keener v. Harrod, 2 Md. 33; Byas v. Doores, 20 Mo. 284; Wrare v. Gove, 44 N. H. 196; Clarke v. Finster, 8 Vt. 9S.

In the following states, the pretended ageut is held liable not on the contract itself, but for the lamage resulting from the breach of lis implied warranty of authority: Inll v. Crandall, 29 Cal. 567: Johnson v. smilh, 21 Conn. 627; Duncan V. Niles, 32 III. 532 (hut see F'rankland v. Johnson. 147 III. 520); Bartlett v. Tucker, 104 Mass. 336; Noyes v. Loring, 55 Me. 408; Shrffield v. Indue, 16 Minn. 388; White v. Madison, 26 N. Y. 117; Mryson v. Luras, 84 N. C. 680 ; Hopkins v. Mehaff!. II S. \&. R. (Ра.) 126.

J Hall v. Crandall, supra. Lieferring to the eases which hold the pretended agent liable on the inatrument. Wit.Tox, J., saill in Noyes v. Loring. 5., Me. 408: "The inconsistency of suell a loetrine, to uso uo stronger term, will be apparent by aluposing that instead of a promise to pay money the prefened agent had signed a promise that hia principal sbould marry the plaintift within a given time, or do sone otluer act which it was perfectly competent for the prineipal to perforn, but which the ngent eould not. What would be thought of a declaration charging the pretended agent as a principal in such a cane?"

2 To the decisions reforred to above, and the very high authority of the German Code, there may be arlded the opinion of Mr. Arthur Cohen, Q. C. 
will tend to increase negotiability, hy assuring the holder that if the

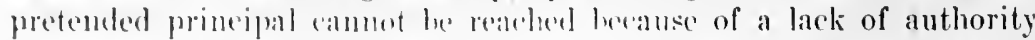
in the isent, a reeovery may he hat on l'we instrment itself against the agent. Then there is the additional alvantage - which on refleetion will appear to he of ereat importanes - that the liability of the anent can he casily proved and the amount to be recovered ascertained by a mere inspertion of the instrument, whereas if the only recovery were for damages resulting from a breach of warranty, a complieated set of disputed faets would often go to the jury, from which it would be diffienlt even to approximate the damage. The case which Professor Ames supposes, as proving the injustice of section 20 may serve as an illustration of this. He says, "For example, A., mistakenly believing that he is duly authorized, signs a note, 'A., agent for B.,' and delivers it to $($. , the payee. At maturity 3 . repudiates the note. He is, however, at that time a bankrupt. A. is rightfully chargeable to $\mathrm{C}$. on his implied warranty of authority, but only to the amount that $\mathrm{C}$. might have recoverel from B., if he hat authorized the note. But under section $20 \mathrm{~A}$. is liable to $\mathrm{C}$. for the face of the note." But, as Mr. Cohen points out, "It would be doubtful what could be recovered until the dividend was declared and the hankruptey concluded; and in the case of the principal not heing hankrupt, hut being a man in bad credit, the question would have to be left to a jury what amount could probahly be recovered from the principal. It may well be held that in actions on negotiable instrmments against a person who professedly acts on behalf of another person, $A$., it would be inconvenient to allow the former to attempt to prove that probably the whole amount could not be recovered from $A . "$

So the case stands about as follows: The rule disearded by the Commissioners works ont the riglits of the parties strictly on the rules of contract, and the balanec of anthority is in its favor. Under it, however, a plaintiff may encounter considerable difficulty and uneertainty in proving his casc. 'The rule they have cmborlied in the act while perhaps less clear on theory - is supporter by the authority of several states, by the German Code, by some of the best expert opinion of England, and (besides tending to increase negotiability) enables.

(one of the framers of the English act, and admittedly one of the leading experts in England on this subject), who regards section 20 as an improvement on the Pnglich aet. He says: "This section certainly alters the law as it exists in England, but I think it very likely that the alteration is an improvement. The wistom of the rule laid down in Cohen v. Wright has often heen doubted. . . I think the 20th section should be retained, and may be considered as a practical improvement of the law, unless there be reason to suppose that merchants and hankers think it unjust. I agree with Mr. Brewster that much indulgenee should not be shown in business to a person who profecaes to have authority when he is really acting without authority." Letter from Mr. Cohen to Judge Brewster, written March 31, 1901. 
a plaintiff to know and prove, with ease and certainty, the amount to be recorered. Of course, under such circumstances, individual opinion will differ somewhat as to which rule should have been chosen. ${ }^{3}$

$\S 40$ Stagi v. ElliotT, 12 Common Bench, N. S. 373. - 1862. Bill accepted "per pro. William Elliott, George Elliott." George was the son of the defendant, William, and manager of his business. Byles, J. - The words " per procuration" are an express statement that the party accepting the bill has only a special and limited authority, and therefore a person who takes a bill so accepted is bound at his peril to enquire into the extent and nature of the agent's authority. It is not enough to show that other bills similarly accepted or endorsed have been paid, although such evidence, if the aeceptance were general by an agent in the name of a principal, would be evidence of a general authority to accept in the name of the principal. * * * The result of the decisions seems to be this, that the way in which this bill was accepted is the legitimate way of showing the fact that the acceptor has only a special and limited authority. Further, it is to be observed, that this rule depends upon the law merchant, which extends over Europe and America; and this is the way in which it is understood all over the world.

$\S 40$ The Floyd Acceptances, 7 Wallace (U. S.), 666. -1868. Mr. Justice Mulfer. - An individual may, instead of signing, with his own hand, the notes and bills which he issues or accepts, appoint an agent to do these things for him. And this appointment may be a general power to draw or accept in all eases as fully as the principal could; or it may be a limited authority to draw or accept under given circumstances, defined in the instrument which ronfers the power. But, in each case, the person draling with the agent, knowing that he acts only by virtue of a delegated power, must, at his peril, see that the paper on which he relies comes within the power under which the agent acts. And this applies to erery person who takes the paper afterwards: for it is to be kept in mind that the protection which commercial usage throws around negotiable paper, eannot be used to establish the authority lyy which it was originally issued. 'These principles are woll establiahed in regard to the transaction of individuals. They are exprally applieable to those of the govermment. Whenever negotiable paper is found in the market purporting to hind

see also articie in 10 Law Notes, 104, entitled "Liability of an agent under the Negotiahle Instruments Law," and criticism of this article in 20 Harv. Law Rev. 159. - C. 
the government, it must necessiarily he by the signature of an officer of the government, and the purroliser of such paper, whether the first holder or another, must, at his peril, see that the officer had authority to bind the government.

¿40 Nixon $r$. Palmer, \& New York, 398. - 1853. Bill accepted “Jeremiah G. Palmer, by James L. Palmer." Defense, want of authority. Masos, J. - . The bill heing on its face accepted by James L. Palmer for the defendant, was notice that he professed to act under an authority, and imposed upon the plaintiffs the duty of ascertaining that he acted within it."

\section{Indorsement by infant or corporation.}

$\S 41$

\section{FRAZIER $x$ MASSEY.}

14 Indiana, 382 . -1860.

Wonden, J. - Action by Massey against the appellants upon a promissory note made by the latter to William T. Hess, and by Hess indorsed to the plaintiff.

Answer that said William T. Hess, the payee of the note, was, at the time he indorsed it to the plaintiff, a minor under the age of twenty-one years; wherefore, ete.

To this answer a demurrer was sustained, and the plaintiff had judgment.

The ruling on the demurrer raises the only question involved in the case.

We think it clear that the demurrer was correctly sustained to the answer. The disability of an infant to make a valid, binding contract, is a personal privilege intended for the benefit of the infant himself, and none but he, or his representatives, can take advantage of such disability. (1 Pars. Cont. 275.) Besides this, the defenrlant.: by making the note to Hess, asserted to the world his competen'y to negotiate and assign the paper, and they cannot be permitted to gair. say the assertion so made." (Edw. on Bills, p. 250; Story on Pron. Notes, \& 80, 5th ed.)

Per Curiam. - The judgment is affirmed with 6 per cent. damages and costs.

4 See Neg. Inst. I., \& 110 . A second indorser cannot deny the competency of the first indorser. Prescott Bank v. Caverly, 7 Gray (Mass.) 271. - H. 
WILLARD $v$. CROOK.

21 appeal Cases (Dist. of Col.) 237. - 1903.

APPEal by plaintiff from an order of the Supreme Court overruling his motion for judgment against the defendants for want of sufficient affidavits of defense, in an action on a promissory note against the maker and several indorsers.

The affidarit of defense of the last indorser was that the precerling indorser, a corporation, had indorsed the note solely for accommodation.

Mr. Justice Shepard delivered the opinion of the court:

*

The defense of Walter P. Wilkins, the last indorser of the note, is equally without merit. Whether the preceding indorser, Wilkins \& Company, incorporated, had the power to make an accommodation indorsement merely is a question of no importance so far as his liability under the suhsequent indorsement is concerned. If it were conceded that the corporation's indorsement of the paper was beyond its powers, and it ineurred no liability therehy, its effect was, nevertheless, to pass the property therein. Code, D. C., $\$ 1326 .{ }^{5}$ And the subsequent indorsement by Wilkins to Willard was a warranty of the genuineness of the paper, of his own title thereto, and of the capacity of all the preceding parties to contract. Idem, $\$ s 1339,13 \% 0 .^{*} * * *$

For the reasons given, the order will he reversed with costs, and the cause remanded for further proceedings in conformity with this opinion. It is so ordered. ${ }^{7}$

\title{
XIII. Forged signatures.
}

$\S 42$

\author{
1.ANCASTER $r$ BALTZELT. \\ 7 Cir., \& Joms son (Mn.) 468. - 1836.
}

Actons hy indorsee agrainst maker. Judement for plaintiff. Defenclant appeals. 'The farts appear in the opinion.

: N. Y., \$ 41, - C

"N. Y., $\$ \$ 115.116 .-\mathrm{C}$.

7 In Brown v. Domnell, 49 Me, 421, the court held that in an action by the indorses of a note against the maker. the plaintiol is only repuired to prove an indorsenent suffieient to pass the property in the mote. "The anthority to be proved ia not one to hind the corperationi by a contract of imlorsement, but simply an anthority to tronsfer the property of the eompany. . . If the indorsement is sufficient to pass the property, so as to protect the maker in paying the neite. that is all that is neesasary to render him liable to the indorser." I'. 425.

Sce also Opprnhrim v. Simm Reigel Cigar ro. 90 N. Y. Supp. 355. post, p. : Winer $\because$, Bank of Blyllerille, Si Ark. 435, and cases, post, under Neg. Inst. Law, \$\$ 110-112, 115, 116. - C. 
Buchanas, Сн. J., delivered the opinion of the eourt. A bill or note payable to order can only be transferred by indorsement; and as an action against the acepter or drawer can onty be sustained by one who has lecral title, which eannot he derived through the medium of forgery, it is incumbent on the plaintiff in such an action to show his interest in the bill or note, which nust be done by proving that it was indorsed by the person to whom, or to whose order, it is made payable.

This is an action by the second indorsee against the maker of a promissory note, payable to the payce or order, which was resisted at the trial on the gromud, that the first indorsement, purporting to be by the payee was a forgery, of which proof was offered by the defendant. On the part of the plaintiffs, it was proved, that the defendant on being called on by their counsel, after the indorsement to them, to pay the note, examined it, and said it was right, and he would settle it with them. Upon which the court instructed the jury that if they believed the defendant, when the note was presented to him by the counsel of the plaintiffs, had examined the indorsements and said it was right, the plaintiffs were entitled to recover, although they might believe the indorsement of the payee's name had been forged, and notwithstanding that acknowledgment had been made, after the transfer of the note by these indorsements to them; on an exception to which instruction the case is brought up.

Apart from the alleged conversation between the defendant and the counsel of the plaintiffs, it is very clear that the plaintiffs are not entitled to recover, if the first indorsement in the name of the payee of the note was forged; as the title was not and could not thereby be transferred, but continued in the payee, who on obtaining possession of the note, might sue upon it, and recover against the maker, notwithstanding he should have paid it to him, into whose hands it came, through the medium of forgery; for besides that in such case the payee has not parted with his title, the payee of a note whose name is forged knows nothing of it, and the maker before he pays it to the holder as indorsee should look carefully to the indorsements. And if one is to suffer, the loss should fall on him who is most in fault, or most negligent.

The only question then, in this case is, whether, if after the indorsements had been made, the defendant, on the note being presented to him by the counsel of the plaintiffs, examined the indorsements and said it was right, that nakes any difference. And we think it does not. By saying 80 , he gave no credit to the note; and did not thereby induce the plaintiffs to take it. 'That had heen done before, and not on the faith of what he said. The plaintiffs might before they took the note have inquired whether the first indorsement was by the payee or not, and not having done so, they must abide by the consequence and cannot throw the loss upon the defendant, who had done nothing to 
mislead them or induce them to take the note; and who if made to pay the amount in this action, may be made to pay it over again by the payee, whose right remains unimpaired.

It is not like the case of a drawce of a bill, who if on being asked if the acceptance is in his handwriting, says that it is and that it will be duly paid, cannot afterwards set up as a defense the forgery of his name; because by saying so he has accredited the bill and induced another-to-take-it, which being his own fault the loss ought to fall on him, and not on another, who has been induced to take the bill on the faith of his assurance. ${ }^{8}$

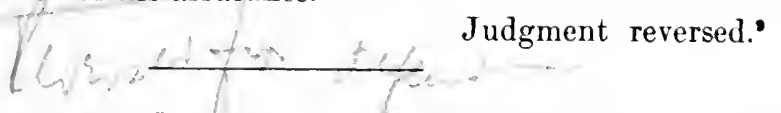

$\$ 42$ Wellingtox $v$. Jackison, 121 Massachusetts, 157.-(1876). GRAY, C. J.- "Although the signature of Edward H. Jackson was forged, yct if, knowing all the circumstances as to that signature, and intending to be bound by it, he acknowledged the signature and thus assumed the note as his own, it would bind him, just as if it had been originally signed by his authority, even if it did not amount to an estoppel in pais. (Greenfield Bank v. Crafts, 4 Allen, 447; Bartlett v. Tucler, 104 Mass. 336, 311.) "1

8 Nor like the case of a drawe who accepts or pays a bill upon which the drawer's name is forged. See National Park Bk. v. Ninth Nat. Bk., 46 N. Y. 77. - H. [See First Nat. Bank v. Bank of Wyndmere, 15 N. D. 299, post, and State Bank of Chicago v. First Nat. Bank of Omaha, 127 N. W. (Neb.) 244, post. - C.]

- Money paid to a holder deriving title through a forged indorsement may be recovered back. Chambers v. Union Bank, 78 Pa. St. 205; Espy v. Cincinnati Bank, 18 Wall. (U.S.) 604; Holt v. Ross, 54 N. Y. 472; Grcen v. Purcell N. B. (Ind. Ter.). 37 S. W. Rep, 50. Coutra: London, ctc., Bank v. Bank of Liverponl (1896), ] Q. B. I). 7.- - II.

IIn First Nat. Bk. v. Shaw, 14! Wich. 362, it was held that makers who actually signed a joint and several note purporting at the time of its delivery to have been signes] by twenty persons and baring nothing on its face to cast doubt upon any of the signatures, cannot eseape liability to a bona fidc holder upon the ground that the names of some of the purported makers were forged before the note was executed and delivered. See this pase reported with notes in 13 I. N. S. 426, and 12 A. \& F. Ann. ('as. 437. - ('.1

1 Accord: Hourard v. Duncan, 3 Jansing V. Y.) 174: IJfener v. Vandolah, 62 III. 483. liut non-repuliation is not enclusive evidenee of ratification. Traders' N. B. v. Regers, Ifi Mass. 315. Contra: Brook v. Hook, L. R. 6 Fx. 89; Workman v. I'right, 33 Oh. St. 405; I/rury v. /lecb, 114 Ind. 275 ; Henry Christinn, etc., Associntion v. Walton, 181 Pa. St. 201; Otesley v. rhilips, is Ky. 517.

While there is a sharp ennflet of authority as to the possibility of ratifying a forgery, all of the rases agree that one may hy his almissions or conduct estop himself from denying the genuineness of his signature as against one who has changed his logal position relying on such admissions, representations, or conduct. Huffeut on Agency, $\$ 43$; rases supra; Lancaster v. Haltzcll, ante, p. 221: - H. 


\section{Pacific hlonter (UTAi) 1069. - 1909.}

'T'HF Southern Pacitie ('ompany in Mareh, 1904, delivered to plaintill, for services rendered, its pay elieck payahle to his order, and drawn on the treasurer of the Sonthern Pacific Company. 'T'his aetion is to recover from deferdant the money which he collected on said eheek. Judgment for defentant and plaintifl appeals.

STRaur, C. J. * * * The court found the facts as follows: That the check was delivered to the plaintill on Mareh 23d [1904] at Montello; that it was stolen from him on March 25 th; that the plaintiff hatd not indored the eheck, nor had he anthorized anybody to do so; that the plaintiff had received no part of the money evidenced by it; that the defendant "became indorsee and indorser of said check on or abont the 1st day of $A$ pril, 1904, at Odgen ('ity, Utah; that said eheck, indorsed with the name of the payce, was transferred and delivered to said defendant on or abont $A$ pri] 1,1904 , by the holder, withont any notice of any infirmity, and on the same day the said defendant indorsed the said check to the Commereial National Bank of Ogden, who thereupon indorsed it to the Bank of California, at San Francisco, Cal., which said last-named hank on April 4, 1904, presented said check to the drawee, who paid it and took possession of it, and thereafter, to wit, in the spring of 1905 , returned it to the plaintitf herein, who thereupon learned for the first time that it had been paid by the drawee, and who immediately intrusted an agent of the sidid Sonthern Pacifie Company with the collection thereof; that the plaintiff failed to present the check to the Sonthern Pacific Company-for payment, and failed to demand payment of it or from any indorser thereon; that neither the defendant nor any subsequent indorser thereon had knowledge or notice of any defect in the cherk for more than one year and seven months after the check had been cashed by the defendant. As conclusions of law the court found that the plaintiff delayed an unreasonable time and was megligent in failing to notify the defendant of the foresed indorsement, and that the plaintiff was not entitled to reserer. Judement was arcordingly entered for the defendant, from which the plaintiff has appealed.

He entends that the enurt erred in its findings and eonclusions and in entering jurdgement for the refendant upon the farts found. We think the jurlgment is wrong. It is enentrary to the findings and to the evidener. It is shown beyond dispute that the rheck is payable to the order of the plaintiff, that it was stolen from him, and that the indorsement of his name thereon was a iorgery. The rourt so fouml. Under those conditions the eherk rame into the hands of the defendant, who admitted in his answer that he "collerterl thereon the sum of $\$(63.20, "$ the amount of the check. While the findings show that the eheck was 
delivered to the defendant without notice of any infirmity, yet there is no evidence to support it, and neither the evidence nor the findings show that he paid a valuable consideration for the check. The law generally is to the effeet that, "although the robber or finder of a negotiable instrument can acquire no title against the real owner, still if it be indorsed in blank, or payable or indorsed to bearer, a third party acquiring it from a robber or finder bona fide for a valuable consideration, and before-inaturity without notice of the loss, may retain it against the true owner. * * * But under a forged indorsement even a bona fide holder without notice acquires no title." Daniels on Neg. Insts. (5th ed.), \& 1469 . Where the negotiable instruments are stolen, the owner may pursue them and the proceeds of them, until they reach the hands of a bona fide holder for value before maturity. In like manner an action of trover lies without previous demand and refusal against one who possesses himself improperly of the bill stolen from the plaintiff, or against one who receives payment even in good faith of such stolen bill under a forged indorsement. 3 Randolph, Comm. Paper (2d ed.), $\$ \S 1682,1683$. Furthermore, though proof had been made that the defendant purehased the check for value and withont notice in due course, still, as shown by the authorities above cited. he acquired no right or title under the forged indorsement of the plaintiff's name. The general rules applicable to bona fide holders for value do not apply in such a case. To the same effect also is our statute. Sertion $1575,{ }^{2}$ Comp. Laws 1907.

The judgment of the court below is therefore reversed, and the eause remanded for a new trial. Costs to appellant.

Frick and McCarty, JJ., coneur. ${ }^{3}$

\section{$\S 42$ HOFFMAN $v$. AMERICAN EXCHANGE NATIONAL BANK.}

\section{Nembaska (UNOFFiciat) $217 .-1901$.}

Hastrass, C. The question in this ase is whether or not the defendant bank is liable to plaintiff for the ancmut of a draft to his order, procured at Elizahothtown, Pa., and indorsed to the order of Peter WT. Brubaker, and sent ly plaintiff to $m$ imposter at Linooln, Neb., who claimed to be Brubiker, and which was anshed for the imposter by the defemlant hank. 'l'he plaintifr was acting as dishursing agent for the executor of an estute, from which one Prtar W. Bruhaker was entitled to recrive $\$ 2064.15$. 'The plaintiff had male con-

2 N. Y., \& $42 .-\mathrm{C}$.

see article in 19 Bench and Bar, 63, entitled " ('onversion of chack negotiated on forged indoracments." - $C$. 
siderable exertions to find Brubaker for the purpose of making this payment, but had failed to do so. Plaintiff had made to Brubaker two previous payments from the estate - one paid by a draft sent to Illinois and recelpted for hy him, and one payment made to him in person at Elizabethtown, Pa., where plaintilf resides. With reference to this third and final payment plaintiff had written to Onaha and to Illinois, and received no response. He finally received a letter dated July 2, 1895, saying: “Lincoln, Nebr., July 2, 1895. Mr. C. S. Hoffman: I got a letter from my brother sade you wanted my address it is Peter W. Brubalier, Lincoln, Nebr." 'T'o this plaintiff replied as follows: "Elizahethtown, July 5, 1895. Mr. Peter W. Brubaker: This afternoon I received your letter. I have been writing around to the different places where you were before, but the letters eame back. Iou will take the release before a notary publie, sign and acknowledge and have some person to sign as witness, and then return it to me, and I will send you draft for your share, less expenses. Yours truly, C. S. Hoffman."

The release was executed evidently to plaintiff's satisfaction, for on July 12th he sent the following letter: "Elizahethtown, July 1", 1895. Mr. Peter W. Brubaker, Lincoln, Neb. Your release to Jacob Risser executor of the will of Peter Oberholtzer, dee'd, eame back all right. Inclosed you find draft No. 5774 for $\$ 264.15$, which with $\$ 1.75$ for the expense of release and draft is in full of your share in the final distribution of the estate. Please let me hear from you when you get this so that I know that all is right. Yours truly, C. S. Hoffman."

The draft mentioned was cashed by the defendant bank; the recipient being identified as Peter W. Brubaker by the notary, Walter A. Leese, of Lincoln, hefore whom the release had been executed, and in whose eare the final letter and rlaft were sent by the plaintiff. The eridence, however, shows conclnsively that the Peter IV. Brubaker who was entitled to this money was not in Lincoln at that time, but in Indiana. He says he received no money. Plaintiff had been ealled upon to pay it again. The draft cashed by the defendant bank was never indorsed by the Peter $W$. Brubaker who was entitled to a share in the estate of which Hoffman was disbursing agent. The draft was, by the defendant, transmitted to a New York correspondent, and collected through it from the drawer at Elizabethtown, Pa. It was drawn to the order of C. S. Hoffman, by him indorsed payahle to the order of Peter W. Brubaker. The Distrirt Court found that the above facts did not show any liability on the part of the defendant hank, and rendered judgment acrordingly. That judgment we are asked to reverse, as not being sustained by the evidence, and on the ground that the facts shown do constitute a liability against the defendant bank. 
The trial court found, first, that the plaintiff intended the draft to be paid to the individual who received-the money from defendant, and that defendant was not guilty of any negligence in paying it; second, that the defendant was led and induced to pay the draft by acts of plaintiff, and plaintifl's negligence prompted its payment; and,-third, that the plaintiff was not the real party in interest, and could not maintain the action, it appearing that he was simply the agent of Risser, the executor of the estate from which the money came.

The liability of defendant is asserted on the grounds set forth in section 42 of the Negotiable Instruments Act of New York, which has been enacted in effect in fourteen other states, and is claimed to be declaratory of the common law. Said section 42 reads as follows: "Where a signature is forged or made without authority of the person whose signature it purports to be, it is wholly inoperative, and no right to retain the instrument, or to give a discharge therefor, or to enforce payment thercof against any party thereto, ean be aequired through or under such signature, unless the party against whom it is sought to enforce sucl__right is precluded from setting up the forgery or want of authority.".

It is claimed that this signature is a forgery, and the defendant therefore liable. As above stated, there seems to be no doubt that the real Peter W. Brubaker who was among the heirs of this estate never indorsed this draft. But it also seems clear that the plaintilf is not entitled to set up this claim. A recent case in Rhode Island (Tolman v. American National Bank, 22 R. I. 462) seems to sustain plaintiff's contention. Its syllabus las the following: "A check drawn payable to the order of $\mathrm{A}$. was procured hy representations that the person to whom it was given was $A$, and the inclorsement of the latter was forged thereto, and it was paill ly the lank. Ileld, that the bank was liable to the drawer for such sum, both at the common law and under the statute." Rhode Island has anopted the statute abore cited. The weight of authority, however, seems to be decidedly in favor of the doetrine that where at rhere or draft is drawn or indorsed and delivered to a party, to be ashed hy him under the name in which it is made out or indorsed, that his signature ly way of indorsenent in that name is valid as between an innocent holder and the party delivering it to him. This is commonly put on the ground that the payer of the draft or the purchaser of it is simply carrying ont innowently the intention of the maker or indorser. Limporia Nal. Bank v. Sholuell, 35 Kan. 360: Meridian Nal. Bank v. First Nat. Banli, 7 Ind. App. 322 ; Robertson v. Coleman. 141 Mass. 235; lory v. liamk of Amerira, 2.4 La. Ann. 220; Land, Ektr., Co. v. N. W. Bant, 196 Pa. 230. It is also placed sometimes, as was done in a measure in this instance, by the trial court, on the ground of negligence on the part of the 
maker. It is sometimes held that the payee is a fictitious person, and the eleck or draft therefore payable to bearer.

It is suggested in defendant's brief that the exemption from liability is more properly placel on the ground of estopjel, or, as it is stated in the Negotiable Instrument Act, that the party is "preeluded from setting up the forgery or want of authority." It certainly would seem that in this case when Mr. Hothman was satisfied with the release he got and mailed the drait to the maker of that release, he asserted as detinitely as a man could his desire that this money should be paid where it was paid. After that desire had been acted upon, and the false Brubaker las received the money, it would seem too late for the phintiff to discover his mistake, and collect the money back from one who had paid it out to the individual he requested, though not the one he thought he was requesting to have it paid to.

It is recommended that the judgment of the district court be affirmed.

DaY and KirkPatrick, CC., coneur.

\section{On Reilearing.}

Albert, C. * * *

Affirmed.

The plaintiff insists that the sole question in this ease is whether the indorsement of the draft by the imposter was a forgery. We do not believe a determination of that question will dispose of this ease. That the indorsement was a forgery may be conceded; but it does not necessarily follow that the plaintiff is entitled to recover in this action. We think the majority of cases, certainly the best-considered eases, hold that, under the circumstanees shown in evidence in this ease, an innocent purehaser is protected by such indorsement. Meridian Nat. Bank v. First Nat. Bank, 7 Ind. App. 332 ; Emporia Nat. Bank v. Shotwell, 35 Kan. 360 ; Kohn v. Watkins, 26 Kan. 691; Land Title \& Trust Co. v. N. W. Nat. Bank, 196 Pa. 230 ; Robertson v. Coleman, 141 Mass 235; United States v. Nat. Exchange Bank (C. C.), 45 Fed. 163; Crippen, Laurence \& Co. v. Am. Nat. Bank of Kansas City, 51 Mo. App. 508 ; Forbes v. Espy, 21 Ohio St. 474.

It has been suggested that the cases just eited may be classified under four heads, the basis of such classification being the ground upon which the conrts place their respective decisions, which are as follows: First, that such indorsement effectuates the intention of the drawer; second, that the drawer has been guilty of negligence; third, that the drawer is to be treated as a fictitions person; fourth, estoppel. But such classifieation is unscientific, and is based on the language of the opinions, rather than upon any principle underlying them. A careful analysis of the ases will show, we think, that the controlling principle in each is that of estnppol, which, to our minds, is peculiarly applieable to cases of this character. 
The plaintiff had money which belonged to Peter W. Brubaker. An imposter assumed the name of Peter W. Brubaker, and claimed the money. His identity was a question for the plaintiff. Satisfied that he was dealing-with the real Peter W. Brubaker, the plaintifi indorsed and delivered the draft to the imposter. Of the contractual obligation thus created, the delivery of the draft was an essential element, and stamped the impostor as the person to whose order the plaintiff intended payment to be made. In other words, by the delirery of the draft to the imposter the plaintiff held him out to the world as his indorsee, and as the person to whose order he had, by his indorsement, directed payment to be made. He cannot now be heard to complain that the defendant acted on the indicia of identity with which he himself had clothed the imposter.

The plaintiff relies on the case of Rogers $\mathrm{v}$. Ware, $2 \mathrm{Neb}$. 29, wherein it is held that, "if a draft be payable to some person known at the time to exist, as the party to whose order it was to be paid, the genuine indorsement of such payee is necessary in order to a recovery thereon by an indorsee, even though he have no interest in it and the drawer knew that fact." That case would tell in favor of the plaintiff only on the theory that, when he indorsed and transmitted the draft to the imposter, he had in mind, as his indorsee, the real Peter W. Brubaker. But that theory is not supported by the facts. The name the plaintiff had in mind, undoubtedly, was Peter W. Brubaker; but the person whom he had singled out as the person bearing that name, and as the one entitled to the money in his hands, was the imposter. This becomes clear, when we remember that he insisted on a release before transmitting the $\mathrm{draft}$, and transmitted it on receipt of the release. The person he had in mind as his indorsee was the person who executed the release, which was the imposter. The real Peter W. Brubaker, under the eircumstances, was not entitled to the draft, because he was not the person who executed the release. His indorsement of the draft would have been a forgery.

It is recommended that the conclusion reached in the former opinion he adhered to, and that the judgment of the District Court be affirmed.

A mes and DufFie, CC., concur.

Per Curam. The conclusion reached by the commissioners is approved, and, it appearing that the adoption of the recommendation made will result in a right decision of the canse, it is ordered that the conclusion reached in the former opinion be adhered to, and the judgment of the District Court affirmed.

\section{Affirmed.}

- See critirism of this case in 3 Col. Law Rev. 580.

Sce exhaustive noto to Land Tille and Trust Co. v. N. W. Nat. Bk., 196 Pa. 230 , in 50 L. R. A. 75 , entitled " ('lueck or bill issued, or indorsed, to imposter - who must bear loss," continned in wote to Harmon v. Old Detroit Nat. Bk.. 
As interesting line of anses is involved in the discussion of this section [\$42]. Suppose A., falsely representing himself to be B., a citizen of $\mathrm{X}$. town, goes to $\mathrm{C}$. for a loan. C. makes inquiry concerning $B$., and, finding him to be a prosperous and responsible merehant of $\mathrm{X}$. town, hands $\mathrm{A}$. a eheek payable to the order of B., whom he supposes that $A$. is. A. indorses the eheck in B.'s name and A. or his indorsee has it eashed. The question then comes up between the bank and C. (the drawer) as to who shall bear the loss. This set of faets, with strikingly few variations, has been presented in numerous cases, all of them, prior to the case of Tolman v. American National Bank, (22 R. I. 462) holding that C. must bear the loss.

153 Mich. 73, in 17 L. N. S. 514. See also article on "Loss by eheck delivered to imposter" in Case and Comment for December, 1900, p. 75.

See also Cent. Nat. Bk. v. Nat. Met. Bk., 31 App. Cas. D. C. 391; Heavey v. Com. Nat. Bk., 27 Litah, 222; Jamieson v. Ileim, 43 Wash. 153; Heim v. Neubert, 48 Wash. 587.

It is important to note the distinction "lretween a case where the imposter assumes to be the person by whose name the payee is described in the check, and a case where he merely assumes to be the agent of such person; it being conceded even by the courts which hold that in the former case the loss must fall upon the drawer, that in the latter case it will fall upon the drawee, at least in the absence of negligence on the part of the drawer." Note in 17 L. N. S. at p. 516, citing Murphy v. Met. Nat. Bk., 191 Mass. 159, and Houser v. Nat. Bk., 27 Pa. Super. Ct. 613. - C.

- U. S. v. Nat. Bank, 45 Fed. R. 163; Meyer v. Indiana Bank, 61 N. E. Rep. 596; Emporia Bank v. Shotwell, 35 Kan. 360; Robertson v. Coleman, 141 Mass. 231; First Bank v. Ameriean Bank, 49 N. Y. App. Div. 349; Mereh. Bank v. Metropolitan Bank, $T$ Daly, 13T; Land Title and Trust Co. v. N.W. Bank, $196 \mathrm{~Pa} .230$; Metzger v. Franlilin Bank, 119 Ind. 359.

And see Mrridian Bank v. First Bank, 7 Ind. App. 322: Ellintt v. Smitherman, 2 Dev. \& B. (N. C.) 338 ; Forbes v. Espy, 21 Oh. St. 474, in which. though the name adopted by the swindler appears to have been really fictitious, the loss is thrown on the drawer for the same reason as that which governed the former cases.

The same rule prevails as to the sale of chattels: Edmonds v. Merch. Co., 135 Mass. 283; Samuel v. Cherey, 135 Mass. 278; Dunbar v. Boston R. R. Co., 110 Mass. 26; Alexander v. Swaekhamer, 105 Ind. 81.

A case interesting (though not quite in point) in connection with the rule here discussed is Graves v. The American Exchange Bank, 17 N. Y. 205, which holds that if a check be made payable to one person and another person of preciscly the same name or initials, so far as these are written out in the check, comes wrongfully or accidentally into possession of the same, indorses it, and obtains the money on it from the bank, still the bank is liable to make good the amount to the drawer. Possibly this carries the bank's liability to an excessive point. It would seem that the drawer, having represented that any inan named John Smith is the payee, should be estopped to deny that the particular Joln Smith who indorsed the check and had it cashed is the payee. 
This result may be reached in several ways, none of which is without difficulty.

1. You may hold that A., albeit he is representing himself by a name falsely assumed for the parpose of deceiving C., is the real payee, the person to whom $\mathrm{C}$. intended that the check should be paid. Under this view, any question as to C.'s negligence becomes immaterial. $\mathrm{He}$ must bear the loss, not because he has negligently trusted a stranger, but because the physical person who stood before him and with whom he dealt is the person whom he intended the bank should pay. The difficulty with this view is that although $\mathrm{C}$. intended that the money should be paid to the person standing before him, it is equally true that he intended that it should be paid to $\mathrm{B}$. of $\mathrm{X}$. town.

2. You may hold that the drawer is liable because he has negligently trusted a stranger, but this view is unsatisfactory because none of the cases in point go on this ground; and beeause the loss is thrown on C., even when he has admittedly exereised all reasonable diligence.

3. You may hold that the payee is fictitious, and that the eheck is therefore payable to bearer; but such an instrument is payable to bearer only when the drawer knows that the payce is fictitious. Moreover, if $\mathrm{B}$., of $\mathrm{X}$. town, is in existence and known to the drawer, such a view is clearly untenable.

4. You may hold that $\mathrm{C}$. is estopped to deny that $A$., to whom he gave the eheek, is the real payee. But estoppel cannot operate unless the fact represented be known to and acted on by the bank, and where the swindler indorses the check to a bona fide holder who eashes it (and this is what happened in most of the eases) the bank knows nothing of the delivery to $\mathrm{A}$. and does not rely on the drawer's representation that he is the payee. ${ }^{\circ}$

As a matter of fact, the courts hase their decision on the first ground, namely, that the bank has merely carriesl ont the drawer's intent. Here and there an expression may be singled out which secms to countenance one or more of the other views, but a fail reading of the opinions shows that one irlea dominates nearly all of them, namely, that the money has been paid to the person for whom it was really intended. The reasoning is briofly this: $A$ man's name is the verbal designation by which he is known, but the man's visible presence

- However, in an interesting note to Land Tille and Trust ro. צ. Banli. 50

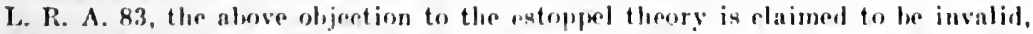
the argument lwing: When the bank pays n clece bipon a forged imborsment it aets on the belief that the person who indersed it was the persoss whom the drawer intended to designate as payee. This belief is largely - and when the person who presents the eherk is neit identified - is sololy iniluerel liy the fact that the elieek $i 4$, or was at the time of indorsement, in the imposter's posesession. The drawer - he deliwering the elacek to the impontar in the boliof that he is the person named as paye- crontes the appearnnes on which the bank acts. 
atfords a surer means of identification. C. was deceived as to the man he was dealing with, but he dealt with and intended to deal with the visible man who stood before him, identified by sight and hearing. Thinking that this man's name was B., he drew the check to B.'s order intending therehy to designate the person standing before him; so the bank has simply paid the money to the person for whom it was intended.

Such was undoubtedly the law prior to the act. By section 23 [N. Y., $\$ 42]$, when a signature is forged or made without the authority of the person whose signature it purports to be, it is wholly inoperative except as against the person who "is precluded from setting up the forgery or want of authority." In the light of the cases above referred to, the meaning of this section, as applied to the point under discussion, seems reasonably clear. The drawer (C.) "is precluded from setting up the forgery or want of anthority" and so the signature is not inoperative as to him and the law remains unchanged.

In 1899, Rhode Island adopted the Negotiable Instruments Law and in 1901 the case of Tolman v. American National Bank arose in that state.

In that case, one Lonis Potter, representing himself to be Earnest A. Haskell, went to the plaintiff, (Tolman) for a loan of money, giving the occupation and residence of Haskell as his own. The plaintiff made inquiry, and finding that Haskell was employed and was living as represented, gave Potter his check on the defendant bank payable to the order of Haskell. Potter indorsed IIaskell's name and delivered the check to one A. R. Hines, who had it cashed at the bank. In an action by Tolman to compel the bank to credit him with the amount of the cheek, the court held that the bank must bear the loss.

As Professor Ames remarks, "the decision is a surprising one, both from the standpoint of common law principles, and of Section 23 of the act. All the reported cases on the point of fraudulent impersonation are against the decision. As a statutory question, but for this decision, the liability of the drawer would seem elear under the last clause of the section."

TAfter analyzing the opinion of the court in the Tolman case, and reviewing Dean Ames' and Judge Brewster's discussion of it, Mr. Mckeelian continues:]

It is perfectly evident, then - and indeed this is Professor Ames' position - that the trouble is not with Section 23, but with the case of Tolman v. The Bank. Undoubtedly it is unfortunate that the only judicial interpretation that this section has received should serve only to throw doubt on what was previously well settled. ${ }^{7}$ But the blame

7 It is not denied that much might be said in favor of the result reached in Tolman v. The Bank, did the question arise de novo. The point is that when 
does not belong to the Negotiable Instruments Law. Section $23-$ copied from the English act - was, at the time of its adoption, an accurate statement of existing law, and in view of the unanimity that exists among the cases on which it is based, the doubts raised by Tolman v. The Bank will probably soon be dispelled and this section will be interpreted as having merely affirmed a well settled rule.

once so difficult and doubtful a point is clearly settled, mischief and not good results from reopening the matter and involving it in doubt. As matters stand to-day, no lawyer could advise a client, with any certainty, on this point. 


\section{AR'TICLE III.}

\section{Consideration of Negotialile Instruments.}

\section{Presumption of consideration.}

BRISTOL, v. WARNER.

19 Coxnecticut, $7 .-1848$.

Assumpsit on the following instrument:

"On demand, after my decease, I promise to pay Josiah W. Bristol, or order, eight hundred and fifty dollars, without interest."

The making of the instrument heing admitted, the plaintiff introduced the instrument in evidence and resterl his case. The court charged that the note imported on its face a valuable consideration: that it was a promissory note and not a testamentary paper. Conflicting evidence was given as to the consideration. Verdict for plaintiff.

Church, Ch. J. - 1. The question first presented by this motion, is whether the note in controversy imports on its face a valuable consideration? We think il does; and that the charge to the jury on this point was correct. It has now becone the settled law of this state, after a time of some doulit, that a promissory note not negotiable, and not purporting on its face to be for value received, does not imply a consideration; and that a plaintiff, prosecuting such a note, is left to prove one, or fail to recover.' (Edgerton v. Edgerton, 8 Conn. R. 6.)

But this note is, in form, negotiable, thongh not yot negotiated; and no ennsideration is expressed in it. And, therefore, it was claimed at the trial, that it should be treated as if it were not necotiable paper:that it. being a simple contract, and as yet confined in its operation to the original parties to it. refuired proof of consideration. But we believe that the necotiability of the note gave it a character and a rrelit at its inception. then importing a consideration, as well between payer and payee, as between the maker and indorsers or subsequent holders. We suppose this court so regarded it in the case of Camp v. Tomplins (9 Conn. R. 445), in which it is said, that such instruments. as well as bills of exchange. from their very nature, import a consideration. Our statute making a certain description of notes negotiable,

1. Contra: Carnworight v. Gray, 127 N. Y. 92. But see Neg. Inst. L., § 320. - H. 
intended to give to them the same effect here, as such paper was known to have in England, and in the commercial community generally. The most respectable elementary writers upon this branch of the law, treat this as a well established princhle. Mr. Chitty says: "In the case of bills of exchange and promissory notes, they are presumed to have been on good consideration; and it is not necessary for the plaintiff to state any in his declaration, or prove it, in the first instance, on the trial," etc. Erans, in his learned commentary on Pothier, remarks, that "the case of bills of exchange and promissory notes affords, in some degree, an exception to the general rule, which has heen under discussion, when they are indorsed over for a valuable consideration; the want of consideration, between the original parties is immaterial; as between them a consideration is presumed; but if the contrary is shown it is a sufficient defense." Chancellor Kent, in his commentaries, speaks thus: "It is usual to insert value received in a bill or note; but this is unnecessary and value is implied in every bill, note, or indorsement." (Chitty on Bills, 6r; 2 Pothier on Obligations, 22; 3 Kent's Com. 50 ; 1 Stephen's N. P. r66; Goshen d Minisink Turn. Co. v. IHurtin, 9 Johns. R. 217; Mandeville v. Welch, 5 Wheat. 2r7; 2 McLean, 212.) And yet, there is an essential difference between promissory notes before they are indorsed, and afterwards, in respect to their original consideration. In the former case, a consideration is implied, but may be denied in defense; while in the latter, only in special cases; it cannot be disputed if the holder be a meritorious one, receiving the paper hefore due. * * * New trial not to he granterl. ${ }^{2}$

2 The doctrine tlat a bill or note requires any concideration is of comparatively resent origin. It was unknown in the time of Blackstone (2 Comm. 446), and early American cases are to he found in which it appears to be denied or doubted. (Bowers v. Hurd, 10 Mass. 427: Livingston v. Hastie, 2 Cai. IN. Y.] 246.) But the moulern asses now uniformly hold that a bill or note executed and delivered as a gift is menforcenter for want of consideration. Hill v. Buckminster, 5 l'ick. (Mass.) 391: Parish v. Stonr, 14 Pick. (Masa.) 198; Schnonmaker ․ Ronsa, 17 Johns. (X. Y.) 301 ; Harris v. (Yark, $3 \mathrm{~N}$. Y. 93. Nor will a meritorioms consideration sustaill a promissory note even in equity. Whitaler v. Whitaker, 52 X. Y. 368. Ser also Hatter of James, 146 N. Y. 78 (hond and mortgage), but see $37 \mathrm{Nm}$. T., Reg. 337.

The eases are uniform that a bill and a negotiable note have presumptive consideration. I Daniel on Negr. In-t.. \$\$ 161-l63. Whether non-negotiable notes import a consideration is a matter of the eonstruetion of the statute gov-

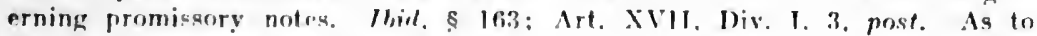
burden of proof, see Neg. Inst. I.. \$ $\$ 8$.

The courts do not inquire into thr alequacy of the eonsiderution; but inadequacy of consideration may he evidence of had faith or fraud. Joncs $v$. Gordon, L. R. 2 App. Cas. 6IB;; Huffeut's Anson-(8th Eng. ed.), pp. 90-92.-H. 
92 APrellate Division (N. Y.) 167. - 1904.

O'Bries, J. This case has already heen before this court. Hickok v. Bunting, 6r App. Div. 360. The artion is upon an instrument in the nature of a promissory note, a copy of which is as follows:

New YoRK, December —, 1893.

IIaving been eause of a money loss to my friend, Geraldine H. Hickok, I have given her three thousand dollars. I hold this amount in trust for her and one year after date or thereafter, on demand, I promise to pay to the order of Geraldine H. Hickok, her heirs or assigns, Three thousand dollars with interest.

216 East 12th St., N. Y.

Ella F. Bunting. $1,16, ' 94$.

Upon the former trial, after the plaintiff had proved the signature, and introduced the note in evidence, and given some testimony in sup-port of its validity, the lefendants on their part oflered evidence which it was thought by this court threw doubt upon the delivery of the note and raised the question as to whether or not there was consideration therefor. For these reasons a judgment directed for the plaintiff, from which the defendants appealed, was reversed, this court holding that there were presenterl questions of fact which should have been suhmitted to the jury. Upon the new trial the plaintiff contented herself with proving the signature and the amount of interest due, and, relying upon the presumption of delivery from the possession of the note, nffered it in evidence, and rested. The defendants moved to dismiss the complaint, and to the denial of their motion exrepted, and then in turn rested; and, the plaintiff having moved for a direction in her favor, that inotion was granted, and to this ruling the defendants excepted, so that it is these exceptions to the refusal to dismiss the complaint and to the direction of a verdict for the plaintiff which are now urgerl upon our attention.

Ilad this been a negotiable promissory note in the usual form, we do not think it would be seriously contended that upon such a record as is here presented a direction of a rerdict would not have been proper. The defendlants contend, however, that, though this instrument he regarded as a promissory note, it is of an unusual kind, and that all the parts of the instrument must be read together, and that, inasmuch as on its face it purports to state a consideration which is neither a legal nor a valid roncideration, the nne expressed takes the place of the ralid consideration which, if such a statement had not appeared upon the fare of the note, would he presumed. For this proposition the appellant claims support by taking certain language in our former opinion away from its entext. and consirlering it apart from the subjert in the dismssion of which it was userl. The portion from which the appellants get most comfort is the following: 
"The recital is that the deceased had been the cause of a money loss. This standing alone, would be insufficient to show the existence of a present legal consideration, or that an enforceable obligation had ever existed. * * * If we eliminate the declaration of the plaintiff that the-deceased owed ler a debt, then we have nothing in the oral testimony or in the recital of the instrument to establish that there at any time existed a legal enforceable obligation against the deceased in favor of the plaintiff, or that the facts were of such a character as would estop the deceased from denying her legal obligation for the payment of the money."

This language was not intended to be, nor was it, confined to stating that the recital which preceded the promissory portion of the instrument was conclusive either upon the plaintiff or the defendant. What the court was discussing was whether, upon all the evidence - that presented on the face of the instrument, together with such corroborating evidence as the plaintiff adduced upon that subject, as offset by the testimony offered by the defendants - the situation was one which, upon the question of consideration, required that their case should be submitted to the jury (which was the conclusion we reached), or whether the trial judge was right on the first trial in directing a verdict. As we have pointed out, upon the present trial there was practically no evidence given except such as was nceded to entitle the paper to be admitter in evidence. That the paper was a promissory note was expressly held upon the former appeal, and in the following language:

"Following the declaration of trust the instrument contains a promise to pay, one year after date, or on demand, to the order of the plaintiff, her heirs or assigns, $\$ 3,000$, with interest. There are no words of limitation of this promise in the language preceding it. The promise to pay is express, and is to the order of the payee, and contains every essential element to constiute a promissory note as defined hv the Negotiable Instmuments Law (chapter 612, p. 75.5, \$ 320, Laws 1897) and by authority. Carnuright v. Cray, 127 N. Y. 92."

The contention of the appellants may be well foumled that if, on the face of the instrument, it conclusicely appeared that there was no consideration, or that there was an invalid consideration, then the instrument could not be enfored. For the reason, however, that neither of these appeared upon the fare of the instrument, we think that, taking the legal presumption which arises in favor of there having heen a valid consideration for the note, and in the alsence of any evidence to rebut it, a prima farie case was made out.

In Hegeman v. Moon, 131 N. Y. 162, the deceased made an instrument as follows:

"One year after my death I herelyy direet my executors to pay to . Inesph Hegeman, his heirs, exeentors or assigns, the sum of $\$ 1,976$ 9 9 , being the balance due him for cash advanced at various times hy 
him to Adrian Hegeman, iny son, and others as per statement rendered by him this day withont interest."

In that ease, as in this, the inference was sought to be drawn from the langnage employed in the note that there was no legal consideration: but the court said:

"The addition of the worls that the money is due the payee "for cash adranced at rarious times by him to Adrian Hegeman, my son, anl others, as per statement rendered by him this day, does not alter the implication that the money is due the payee from the maker. It simply states the origin of the indebtedness of the maker. It was not for money adranced directly to her, but to her son and others. There is nothing inconsistent with her indelstedness to the payee in the fact of this acknowledged adrance of the money to the maker's son. An original indebtedness may have arisen against the maker by the payee adrancing at the maker's request moneys to her son. And when she says that a certain amount is due the payee, and signs the statement, with the addition of the origin of the indebtedness, the implication is neither forced nor unnatural that she means that the amount is due from her, or else she would not have signed the paper."

We think the respondent is right in asserting that the prineiple of the IIegeman case and the one at har are precisely the same, and that, as in the former, the court was bound to presume in support of the obligation that the money advanced to a third person by the payce was advanced at the maker's request, and thus constituter a legal obligation on the part of the maker, so, in the present case, the court is bound to assume that the money loss which the plaintiff, the payee, had suffered at the hands of the naker, was legally chargeable to the maker, and constituted a legal liahility on her part.

Our conchusion therefore is that the disposition made by the learned trial judge was right, and that the judgment appealed from should le affirmed, with costs.

All concur. ${ }^{3}$

\section{Affirmed 182 N. Y. 530 , no npinion.}

In Huntington v. Shute, 180 Mass. 371 , payee sued makers on a promissory note entaining the words "value reeeived." Defense was want of consideration. The trial judge instrueted the jury that the words "value received" were equivalent to a declaration and almission on the part of the defendants that they had reenived full value, and that where as here the makers had admitted consideration in the note itself, the burden of proof was upon the defendants to show that there was no eonsideration. Held error. "The rule is well settled in this Commonwealth that, in an action on a promissory note, the burden of pronf is upon the plaintiff to establish the fact that it is given for a valuable consideration. While the production of the note, with the admission or proof of the signature, makes a prima facie case, yet if the defendant puts in evidenee of a want of consideration, the burden of proof doee not shift, but remains upon the plaintiff, who must satisfy the jury, by a fair preponderance of the evidence. that the note was for a valid considera. tion. . . We can see no reason for changing the rule so well established merely becauce the note contains the words 'value received.' "LATHROP, J., on p. $372 .-\mathrm{C}$, 


\title{
II. What constitutes consideration.
}

\section{$\S 51$. RAILROAD COMPANY $v$. NATIONAL BANK.}

\author{
102 Uxited States, 14. - 1850.
}

Action by the bank against the railroad company on a promissory note. Defense, that the note was diverted by the defendant's agent, and that the bank is not a holder for value and therefore subject to the defence.

The note was male hy the company payable to William V. Le Count, its treasurer, and indorsed by him in blank and by Palmer \& Co., owners of the larger portion of the stock. The note thus indorsed was placed by the company in the hands of IIutehinson \& Ingersoll, note-brokers, for negotiation and sale in order to raise money for the company. Hutchinson \& Ingersoll pledged the note as collateral for a loan, and subsequently agreed that it should stand as collateral for a loan previously made. No agreement was made to extend the pre-existing debt, or to refrain from calling it in.

Mr. Justice Hantan, after stating the facts, detivered the opinion of the court.

The bank, we have seen, respived the note, before its maturity, indorsed in blank, without any express agreement to give time, but without notice that it was other than ordinary business paper, or that there was any defense thereto, and in ignorance of the purposes for which it had heen executed and delivered to IIntchinson \& Ingersoll. Did the bank, under these cireumstances, become a holder for value, and as such entitled, aceording to the recognized principles of conmereial law, to be protected agalinst the enuities or defenses which the railroad rompany may have against the other parties to the note?

This question was arefully cousidered, though, perlaphs, it was not absolutely necessary to be determined, in suift v. Tysom (16 Pot. 1.) ***

The opinion in that case has beon the subject of eriticism in some courts, beanse it sermed to go beyond the precise point necessary to be decided, when derelatring that the bermo fide boldere of a negotialile note, taken as collateral security for an anterestent deht, was protected against expitios existing betwern the original or antecerlent parties. The hrief disesent of Mr. Instice C'atron was solely npon that ground, which renders it quite certain that the whole conrt was aware of the extent to which the opinion carried the doctrines of the commercial law upon the sulyed of negotiahle instruments transferred or delivered as security for antecodent indehtedness. In the judgment of this court, as then constituted (Mr. . Iustice Catron alone excepted), the holder of a negotiahle instrunent, received hefore maturity, and without notice of any defense thereto, is unaffected by the equities or defenses of antecedent parties, equally whether the note is taken as 
collateral security for or in payment of previous indebtedness. And we understand the case of McCerly r. Roots (21 How. 432), to affirm suift r. l'yson, upon the point now under consideration. It was there said: "Nor does the firet that the bills were assigned to the plaintiff as collateral security for a pre-existing debt impair the plaintiff's right to recover." (p. 438.) "The delivery of the bills to the plaintiff as collateral security for a pre-existing debt, under the decision of Suift r. T'yson. was legral." (p. 439.)

It may be reminlied in this connection that the courts holding a ditferent rule have uniformly referred to an opinion of Chancellor Kent in bay r. Coddington (5 Johns. Ch. [N. Y.] 54), reaffirmed in Coddington r. Bay (20 Johns. IN. Y.| 63\%) There is, however, some reason to believe that the views of that eninent jurist were subsequently modified. In the later editions of his Commentaries (vol. III, p. 81 , note b.), prepared by himself, reference is made to Stalker v. McDonald (6 Hill.[X. Y.] 93), in which the principles asserted in Bay $r$. Coddington were re-examined and maintained in an elaborate opinion by Chancellor Walworth, who took occasion to say that the opinion in suift v. Tyson was not correct in declaring that a pre-existing deht was, of itself, and without other cireumstances, a sufficient consideration to entitle the bona fide holder, without notice, to recover on the note, when it might not, as between the original parties, be valid. But Chancellor Kent adds: "Mr. Tustice Story, on Promissory Notes (p. 215, note 1), repeats and sustains the decision in Suift v. Tyson, and I am inelined to roneur in that decision as the plainer and hetter doctrine." Of course it did not escape his attention that the court in suift v. Tyson declared the equities of prior parties to be shut out as well when the note was merely pledged as collateral security for a pre-existing debt, as when transferred in payment or extinguishment of such debt.

According to the very general concurrence of judicial authority in this country as well as elsewhere, it may be regarded as settled in commercial jurisprudence - there being no statutory regulations to the contrary - that where negotiable paper is received in payment of an antecedent debt; ${ }^{4}$ or where it is transferred, by indorsement, as collateral security for a lebt reated, or a purchase made, at the time of transfer; "or the transfer is to secure a debt, not due, under an agreement, express or to be clearly implied from the circumstances, that the rollection of the prineipal debt is to he postponed or delayed until the rollateral matured; or where time "s agreed to he given and is actualiy given upon a deht overdue, in consideration of the transfer of negotiable paper as collateral security therefor; ${ }^{\circ}$ or where

4 Accord: Maycr v. Heidelbach, 123 N. Y. 332. - H.

"Bank v. Vanderhorst, 32 N. Y. 553. - H.

a The agreement for extension must be definite and binding. Atlantic N. B.

7. Franklin, 55 N. Y. 235. - H. 
the transferred note takes the place of other paper previously pledged as collateral security for a debt, either at the time such debt was contracted or before it became due - in each of these eases the holder who takes the transferred paper, before its maturity, and without notice, actual or otherwise, of any defense thereto, is held to have received it in due course of business, and, in the sense of the commereial law, becomes a holder for value, entitled to enforce payment, without regard to any equity or defense which exists between prior parties to such paper.

Upon these propositions there seems at this day to be no substantial conflict of authority. But there is such conflict where the note is transferred as collateral security merely, without other ciremmstances, for a debt previously ereated. One of the grounds upon which some courts of high authority refuse, in such cases, to apply the rule announced in Suift v. Tyson (16 Pet. 1), is, that transactions of that kind are not in the usual and ordinary course of commercial dealings. But this objection is not sustained by the recognized usages of the commercial world, nor, as we think, by sound reason. The transfer of negotiable paper as security for antecedent debts constitutes a material and an increasing portion of the commeree of the country. Such transactions have become very common in financial circles. They hare grown out of the necessities of business, and, in these days of great commercial activity they contribute largely to the benefit and convenience both of delitors and creditors. *** Another ground upon which some courts have declined to sanction the rule announced in suift v. Tyson is, that upon the transfer of negotiable paper merely as collateral security for an antecedent debt nothing is surrendered by the indorsee - that to permit the equities between prior parties to prevail deprives him of no right or advantage enjoyed at the the time of transfer, imposes upon him no additional burdens, and subjects him to no additional inconvenienres.

This may loe true in some, hut it is not true in most eases, nor, in our opinion, is it rrere true when the note. "upon its delivery to the transferer, is in smen form as to make him a party to the instrument, and impose upon him the duties whide, areording to the commercial law, must lo discharged by the holder of negrotiable paper in order to fix liapility upon the indorser.

The bank did not take the note in suit as a mere agent to receive the amount due when it suited the convenience of the debtor to make payment. It received the note under an obligation imposed by the commercial law, to present it for payment, and gise notice of non-payment, in the morle preseribed by the sottlor rules of that law. We are of opinion that the undertaking of the bank to fix the lialility of prior partios, by due presentation for paynent and dur notice in case of non-payment - an undertaking necessarily implied by becom- 
ing a party to the instrument - was a sufficient consideration to protect it against equities existing between the other parties, of which it had no notice. It assumed the duties and responsibilities of a holder for value, amd should have the rights and privileges pertaining to that position. ****

Our conclusion, therefore, is that the transfer, before maturity, of negotiable paper, as security for an antecedent debt merely, without other circumstances, if the paper lo so indorsed that the holder becomes a party to the instrument, although the transfer is without express agreement hy the creditor for indulgence, is not an improper use of such paper, and is as much in the usual course of commercial business as its translor in payment of such debt. In either case, the bona fule holder is unatiected by equities or defenses between prior parties, of which he had no notice.

[Mr. Justice ClifFond concurred in an opinion of great learning, but of too great length to he reprinted here.]

Mr. Justice Bradiey. I concur in the judgment rendered in this ease, and in most of the reasons given in the opinion. But, in reference to the consideration of the transfer of the note as collateral security, I do not regard the obligation assumed by the indorsee (the bank), to present the note for payment and give notice of non-payment, as the only, or the principal, consideration of sueh transfer. 'The true consideration was the debt due from the indorsers to the indorsee, and the obligation to pay or secure said debt. Had any other collateral security been given, as a mortgage, or a pledge of property, it would have been erpully sustained by the consideration referred to: namely, the debt and the obligation to pay it or to secure its payment. If the indorsers had assigned a mortgage for that purpose, the title of the bank to hold the mortgage would have been indubitable. In that ase prior equities of the mortgagor might have prevailed against the title of the bank; because a mortgage is not a commerrial security, and its transfer for any consideration whatever does not cut off prior equities. But the bona fide transfer of commercial paper hefore maturity does cut off such equities; and every collateral is held ly the reditor by surh title and in such manner as appertain to its nature and qualities. Security for the payment of a drot actually owing is a good consideration, and sufficient to support a tramsfer of property. When such transfer is made for such purpose, it has lue effect as a complete transfer, according to the nature and incidents of the property transferred. When it is a promissory note or hill of exchange, it has the effect of giving absolute title and of cutting off prior equities, provided the ordinary conditions exist to give it that effect. If not transferred before maturity or in due course of business, then, of course, it cannot have such effect. But $I$ think it is well shown in the principal opinion 
that a transier for the purpose of securing a debt is a transfer in due course. Aud lhat really ends the argument on the subject.

Mr. Justice Millex and Mr. Justice Field dissented.

Judgment affirmed. ${ }^{7}$

69 NEw YoRk, 502. - 1877.

Appeal from judgment of the General Term of the Supreme Court in the first judicial department reversing a judgment in faror of defendants, entered upon the report of a referee. (Reported below, 7 Hun, 279.)

This action was upon two promissory notes, on which defendants Penfield and Stone were makers, which were made payable to defendant 'Truax, and by him indorsed and transferred to plaintiff.

The referee found, in substance, that the notes were executed by the makers without any consideration; were accommodation notes, and were received by plaintiff solely as collateral security for a precedent debt, without any agreement to extend the time of payment of the debt, and thereupon held that plaintiff was not a bona fide holder for value, and directed julgment dismissing the complaint as to said makers.

R.upsi.uo, J. We think that the orler in this ease must be affirmed on the ground stated by Braly, J., in his opinion delivered at General Term. Whaterur confusion may have existed upon the point, we think that we may now safely say, in the language of Professor Parsons (1 Parsons on Notre and Bills, 2!l(6), that it is universally conceded that the holder of an aremmorlation note, without restriction as to the mode of using it, may transfer it either in payment or as collateral serurity for an anteredent doht, and the maker will have no defense. (Sice, also, Story on Bills, s 192, note $m$, and Story on Notes, s 195, and authoritirs (ited.) The existing dobt is a suthicient consideration for the transfor, and no new consideration need be shown. It is only whep the note has been diverted from the purpose for which it was entrusterl to the payee, or some other equity exists in

7 "We are of the rupinim that a creditor to whom a negotiable security is piven on aceonel uf a properisting delit holds it by an indefrasible title, whether it be one payalile at a future time or on demand." Curric v. Misa, I. R. 10 F.x. 153, Joril roleridge, ( 2 . I. dliasenting.

It was prolually the intent of the framers of $\$ 51$ of the Neg. Inst. T. to aboliah the rule sifahliolsed in roddington v. Bay. 20 Jolins. 637, and ever since in force in New York: whrther the language used is apt for that purpose will be a question of iurlicial ietrermination. - H. IOn this point, see the New York cases referred to in Birket v. Elicard, 68 Kan. 295, post. - C.] 
faror of the malier, that it is necessary that the holder should have parted with value on the faith of the note, in order to cut off such equity of the maker. (Cole r. Saulpangh, is Barb. 104; Bank of Rutland v. Buck, 5 Wend. 66; Lathrop r. Morris, 3 Sandf. 7.) It has been held by high authority that an antecedent debt is sufficient even in the case of a note fraudulently diverted to constitute the holder a bona fide holder for value without any extension of time or surrender of securities or other new considerations. (Świft v. Tyson, 16 Peters, 1.) But in this State that doctrine does not pievail. (Stalker v. McDonald, 6 IIill, 93.) The learing authorities upon the subject are reviewed in the case of Mailland v. Cilizens' Bank (40 Maryland, 540). Whatever difference of opinion may have existed, as to the case of a note diverted or frandulently put in circulation, it must be regarded as settled that an indorsee of a negotiable note made for the accommodation of the indorser, but without restriction as to its use, taking the note in good faith as collaterial security for an antecedent debt, and without other consideration, is entitled to the position of a holder for value, and not affected by the defense of want of consideration to the maker. We should not have deemed it necessary to discuss the point so much at length, but for the reason that it does not appear ever to have been previously expressly adjudicated in this court.

The order should be affirmed and judgment absolute, ete.

All concur. Order affirmed and judgment accordingly. ${ }^{8}$

$\S 51$

BIRKE'T $v$. ELIVARD.

68 Kansas, 295 . -1904.

Plaintiff sues as indorsee upon a promissory note which he acquired from the payee as collateral security for an existing debt of the payee to him, without any agreement for an extension of time or other new consideration. Judgment for defendants and plaintiff brings error.

MAson, J. ***

It is obvious that plaintiff could only recover on the theory that he was an innorent purchaser, and the sole question here involved, therefore, is whether one who takes commercial paper as collateral security for an existing debt, without an agreement for an extension of time or other new consideration, is ever entitled to protection as a bona fide holder. If so, the judgment must be reversed; otherwise it must be affirmed.

The rule in the federal courts, as well as in those of England and Canada, is that the holder of a negotiahle note taken as collateral eecurity for a pre-existing deht is a holder for value in due course

- See also Continental N. B. v. Townsend, 87 N. Y. 8.-H. 
of business, and as such is protected against all latent equities of third parties. The state courts that have passed upon the question are in irreconcilable conflict. The cases are collected in $4 \mathrm{~A}$. \& E. Encycl. of L. (2d. Ed.), 290-293, and in 7 Cyc. 932-935. The lists there indicate with substantial but not absolute correctness the line of clearage. It is to be noted that in each of them Kansas is wrongly placed among the states that are committed to the rule stated, upon the strength, respectively, of the cases of Bank v. Dakin, 54 Kan. 656, and Best v. Crall, $23 \mathrm{Kan}$. 482. While these cases have a tendency in that direction, they do not go the full length indicated. In Bank v. Dakin the note involved was transferred as collateral security for a debt created at the time of, and in reliance upon, such transfer, which was therefore supported by a new consideration, sufficient upon any theory of the law. In the opinion a number of cases are cited as supporting the proposition that even a pre-existing debt would afford a sufficient consideration for the purpose, and among them was included Best v. Crall. In that case the collateral note was in fact transferred as security for a debt that already existed, but this was done pursuant to a promise made when such original debt was created, so that the effect was the same as though the transfer had actually been made at that time.

A careful examination of the cases cited in the lists referred to discloses that in the following states the rule of the federal court has been adopted: California, Colorado, Connecticut, Georgia, Illinois, Indiana, Louisiana, Maryland, Massachusetts, Minnesota, Nevada, New Jersey, Rhode Island, Sonth Carolina, Texas. Vermont, and West Virginia. In California and Nevala the matter is affected by statutory provisions that the acceptance of the security forfeits a right to attach. Nebraska is also now committed to this doctrine. Lashmett v. Prall, 96 N. W. 152. Such citations further show that in the following states the mle has heen denied: Alahama, Arkansas, Iowa, Kentucky, Maine, Mirhigan, Mississippi. Missouri. New Hampshire, New York, North Dakota, Ohio, Pemnsylrania, 'Tennessee, Virgimia, Wisconsin. North Carolina should aleo be placed on this list. hut there, as well as in 'Tennessee and Virginia, the legishature has lately changed the rule by statute." See Broolis v. Sulliran, 129 N. C. 190; Bank of Charleston v. Johnson, 105 T'enn. 521; Payne v. Zell, 98 Va. 294."1 In New York, in 1897, in a revision of the law of nego-

- Namely, the Negotiabe Inatruments Iaw. - C

10 Ser. also, to the same effect, Giraham v. Smith, 155 Mich. 65. At p. 68, Buarr, I.. says: "If, as entended by defendant's councel, the plaintiff received the note as collateral security for un cxisting debte and the Negotiable Instruments Act, Pub. Acts 1905, p. 389. No. 265, has introlueed no cliange in the law a to such instrumenta, platintiff was not a linlder for valur. Burroughs v. Ploof. 73 Mirh. fin7: Maynard v. Maris. 127 Mich 571 . Sertion 27 of the ect is a follows: "Value is any consideration sufticient to support a simple con. 
tiable instruments, it was enated that "value is any consideration sullicient to support a simple contract. An antecedent or pre-existing debt constitutes value." "It was held in Brewster v. Shrader, 26 Misc. 480 , that this statute changed the law as formerly administered in that state, and that under it " an indorsee of a note taken as collateral to a pre-existing indebtedness is a holder for value, unaffected by equities between the original parties." But in s'utherland v. Mead, 80 App. Div. 10:3, this was lenied, and it was said that the new statute was purely declaratory. We do not distover that the New York Comt of Appeals has passed upon the effect of this legislation.

What may fairly ba called the minority doctrine originated in New York in Bay $v$. Coddington, 5 Johns. C'h. $54,^{12}$ the opinion being written by chancellor Kent. The leading case in this country on the majority side is sifut v. Tyson, 16 Pet. 1, $10 \mathrm{~L}$. Ed. 865, the opinion being written by Justice Story. It was there declared that one who took negotiable paper in payment of or as security for a pre-existing debt was a lolder for value and in due course of business, and the argument was made in support of that express proposition. But the reference to paper taken as security was not recuired by the facts of the case, and Justice Catron dissented on this ground. In Railroad Co. v. National Bank, $10 \%$ U. S. 11 , the same reasoning was adopted and applied in a case where the transfer was made merely to secure an antecedent debt. The note there involved had several indorsers, and the obligation assumed by the last holder to give them notice of nonpayment was treated as a part of the consideration of the transfer, hut the decision dia not tum upon this treatment. And in American File Co. v. Garrett, 110 U. S. 288, the principle was applied where there were no prior indorsers. In the opinion in Railroad Co. v. National Bank it was noted (citing 3 Kent's Commentaries, p. 81, note ",$")$ that ('hancellor Kent, after the decision in Swift v. Tyson, indicatcl that he was inclined to concur in it, as the plainer and better doctrine.

tract. An antecedent or pre-existing delst constitutes value, and is deemed surb whether the inctrument is pavable on demand or at a future time.' See. tion 29 provides: "Whore the holdcr has a lien on the instrument, arising pither from contract or by implication of law, he is deemed a holder for value to the extent of his lien.' We are of the opinion that it was the intention of the Jegislature to change the rule theretofore prevailing in this state "so that any person to whom a negotiable security has been pledgad as collateral would le a holder for value to the extent of the amount due him.' Payne v. Zell, $98 \mathrm{Va}, 294$; Ifrsick v, Alderman, 77 Conn. 634; Brooks v. Sullivan, 129 N. ('. 190. Ser, also. Pelric v. Miller, 57 App. Div. 17, affirmed without opinion. 173 N. Y. $596 . "-C$

11 \& $52 .-\mathrm{C}$.

$12 \mathrm{~A}$ passing reference to this case in Bank of America v. Waydell, 187 N. Y. 115, serves, to some extrint, to continue the doubt as to what position the New York Court of Apprals will take on this question. See roditowil in the New York Law Journal for Jan. 18, 1907, at p. 1302. - C. 
The Bay-Coddington case and the Swift-Tyson case are cited in almost every opinion in which the merits of the question under consideration are discussed, and the state courts have ordinarily taken sides upon the matter as the arguments of the one decision or the other have appealed to them with the greater force. In the former case it is said: "It is the credit given to the paper, and the consideration bona fide paid on receiving it, that entitles the holder, on grounds of commercial policy, to such extraordinary protection, even in cases of the most palpable fraud. It is an exception to the general rule of law, and ought not to be carried beyond the necessity that created it." In the latter case it is said: "Receiving it [a negotiab]e instrument] in payment of or as security for a pre-existing debt is according to the known usual course of trade and business. And why, upon principle. should not a pre-existing debt be deemed such a valuable consideration? It is for the benefit and convenience of the commercial world to give as wide an extent as practicable to the eredit and circulation of negotiable paper, that it may pass not only as security for new purchases and advances, made upon the transfer thereof, but also in payment of, and as security for, pre-existing debts. The creditor is thereby enabled to realize or to secure his debt, and thus may safely give a prolonged credit, or forbear from taking any legal steps to enforce his rights. The debtor also has the advantage of making his negotiahle securities of equivalent ralue to cash. But establish the opposite conclusion, that negotiable paper eannot be applied in payment of or as security for pre-existing debts, without letting in all the equities between the original and antecedent parties, and the value and circulation of such seeurities must be essentially diminished, and the debtor driven to the embarrassment of making a sale thereof, of ten at a ruinous discount, to some third person, and then by circuity to apply the proceeds to the payment of his debts."

Among other arguments advanced in behalf of the majority view are that the question is really one of the law merchant - the custom of merchants - and that a "transfer by a debtor to his reditor of a negotiable instrument, to pay or only to seenre a prior debt, makes the creditor a holder for value, ly the custom" (Bigrelow on Bills, Notes \& Cheques, 2.17) ; that the creditor, in acrepting a nexotiable note, whether or not there are partios to he charged by motice, does undortake to exereise some degree of diligenee ( 2 liandolph on Commercial Paper, $\$ 804)$, therely alfording a new consideration, or at all events that le "is naturally lulled info sereurity and inativity loy erediting the face of the notro, and he should unt be made to suffer by the maker for confidence which lis own promise created" (1 Daniel on Neg. Inst., \& 8.31a); that the true consilleration for the transfer is the debt due from the indorser to the indorsee, and the ohligation to pay or secure said delst; that such transerer is a sufficient ronsideration, thecause "seeurity for the payment of a debt actually owing is a good 
consideration, and suflicient to support a transfer of property" (separate opinion of Justice Bradley in Lialroad Co. v. Nat. Bank, supra), 'That the policy of the law is to lacilitate the transfer of negotiable paper free of equities is illustrated by the fact that it is almost universally held that one who acquires it in paynent of an antecedent debt is a bona fide holder (Draper v. Cowles, af Kan. 484; 4 A. \& E. Eneyel. of Law [2d ed.] 2S5), whereas the ordinary rule in reference to protection under recording aets is that one who aceepts property in satisfaction of an existing debt is not an innocent purchaser $(4 \mathrm{~A}$. \& E. Eneyel. of L. [2d ed.] 190; Dolan v. Van Demark, 35 Kan. 304; Henderson v. Gibbs, 39 Kans. 680.) Even where the New Yorkdoetrine is accepted, an exception is made against the plea of lack of consideration when made by an accommodation party to tle paper transferred as security. Grocers'Bank v. Penfield, 69 N. Y. $502 ;$ Mailland v. Citizens' Bank, 40 Md. 540; Smith v. Wachob, 179 Pa. 260.

If the question were a new one, to be determined upon consideration of equitable principles, there would be strong reasons for holding that he who takes a note merely as security for an existing debt acquires no greater right than his debtor had. The reasons given in Mann v. National Bank, $30 \mathrm{Kan}$. 412, for applying this rule to a bank that receives a note from a depositor, and adds the amount to his aecount, which is not overdrawn, would seem to apply to the case of one who receives the paper as collateral for an indebtedness already existing. He parts with nothing, and is in no worse situation than he was before. It requires no variation of usual procedure to save him from loss. But on the other luand, the same arguments would reach the case of him who takes commercial paper in payment of an existing unsecured debt. He likewise is in no way placed in any worse situation than he was before, since, while the original debt may be regarded as technically eanceled, he at all events has his remedy upon the collateral against the person from whom he received it, whatever defense might be available to the maker. He stilf has a ralid elaim against his original debtor, and that is all he had in the first place. See Randolph on Commereial Paper, $\$ \S 461-465$. Yet, as has just been said, one acquiring commercial paper under such cireumstanees is held to be protected as an innocent purchaser.

But the question before us is peculiarly one in which great weight should be given to the authorities, and especially to the decisions of the eourts of the national government, which do not reeognize any local law in such matters. Oates v. National Bank, 100 U. S. 239, 25 L. Ed. 580. The question is one likely to arise frequently in transactions between inhabitants of different states. It is important that the law should be uniform in the different jurisdictions. It was doubtless in recognition of this ronsirleration that the legislatures of North Carolina, Tennessee, Virginia, and possibly New York, as already noted, have lately by statute brought their loeal laws on the 
subject into harmony with the general law as administered by the federal and by the greater number of the state courts. We prefer to hold, in accordance with the weight of authority, that an indorsee of negotiable paper taken as security for a pre-existing debt is a holder for value and in due course of business, and therefore, in the absence of any circumstances charging him with notice, is protected against a claim of payment made to the original payee. ***

The judgment is reversed, and the cause remanded for a new trial. All the justices concurring. ${ }^{13}$

\section{Holder for value.}

\section{$\S 52$}

\section{HUNTER $v$. WILSON.}

4 EXchequer RePorts, 489. - 1849.

THis was an action by the plaintiff, as indorsee of a bill of exchange, against the defendant, as acceptor. The defendant pleaded (in substance), that the bill of exchange was drawn by one McLean, at the request and for the accommodation of the defendant, and without any consideration or value whatever, and that the bill was indorsed by the said McLean without any consideration or value given by the plaintiff for such indorsement, to the defendant, or to the said McLean, or to any other person whomsoever. The plaintiff had signed interlocutory judgment upon this plea, the defendant being under terms of pleading issuably. A rule nisi was subsequently obtained, on the part of the defendant, to set this judgment aside, but without any affidavit of merits.

Willes now showed cause. - The plaintiff was clearly entitled to sign judgment, for the plea is not issuable. It is quite consistent with the plea that there was a good consideration given for the bill. It may have passed through many hands, each party having given consideration. 「RoLFs, R.- It may have heen indorsed to $\Lambda$. B., who made a present of it to the plaintiff.] Or the defendant may have owed a debt to some third party. The allegation that the bill was drawn for the accommodation of the defendant is ahsurd. [Rolfe, B. - The plaintiff may be the exeeutor of a person who gave full value for it.] He was then stopped by the rourt, who ealled upon

Barnard, in support of the rule, who contended that the plea was good upon general demurrer.

PAnKr, B. The plea is elearly nost issuable, and the plaintiff was entitled to sign judgement. There is not even an allegation in the plea, that none of the previous sorties to the hill hat given value

18 See this case reported with exhaustove note in 1 A. \& E. Ann. Cas. 272. - C. 
for the indorsement. 'The rule, therefore, ought to be discharged, and with costs, as the defendant is not prepared with an affidavit of merits.

Pollock, C. B., Aldekson, B., and Rolfi, B., coneurred.

Rule discharged, with costs. ${ }^{1}$

ARPIN $v$. OWENS.

140 Massachusetts, $144 .-1885$.

JUDGMENT for defendant and plaintiff alleged exceptions.

W. Aliten, J. This was an action by the payce of a foreign hill of exchange against the acceptor. The bill was dated February 23rd, payable in thirty days after date, and was accepted March 1st. There was evidence that the plaintiff took the bill from the drawer on the day of date, for value, in the regular course of business. The court ruled that the burden was on the plaintifl to prove that the defendant had received a consideration for the draft, and that, if the jury should find that he received no consideration, they should find for the defendant. There was evidence of want of consideration between the drawer and the defendant, and evidence bearing upon other grounds of defense, which is not material, as the ruling presented hut one question for the jury. For the purposes of the ruling the plaintiff must be taken to be a bona fide purchaser of the hill for value, and without notice of want of consideration; and the question presenter is whether, in an action by the payee of a hill, who took it before acceptance, against the acceptor, want of consideration between the drawer and acceptor is a defense; in other words, whether in such an action the rule to be applied as to want of consideration as a defense is that which obtains between the maker and payee of a note or that hetween the maker and indorsee. The rule is stated thus in Byles on Bills (6th Amer. Eil.) 206 :

"Between immediate parties - that is, hetween the drawer and acreptor, between the payee and drawer, between the payee and maker of a note, between the indorsee and indorser - the only consideration is that which moved from the plaintiff to the defendant, and the ahsence or failure of this is a good defense to an action. But between the remote parties - for exainple, between the payee and the acceptor, between the indorsee and acceptor, between indorsee and remote indorser - two distinct considerations, at least, must come in question : First, that which the defendant received for his liability; and, secondly, that which the plaintiff gave for his title. An action between remote

1 Accord: IIoffman v. Bank, 12 Wall. (U. S.) 181.-C. 
parties will not faii unless there be absence or failure of both these considerations."

The payce of an accepted bill holds the same relation to the acceptor that an indorsee of a note holds to the maker. There is a very close resemblance between an accepted bill and an indorsed note. The indorsed note is evidence of a debt originally due from the maker to the payee, and assigned and made due to the endorsee. The bill is evidence of a debt originally due from the drawee to the drawer, assigned and made due to payee; and the rule that the title of the assignee cannot be inpeached by showing want of consideration for the original debt is applicable equally to the indorsee of a note, and to the payce and to the indorsee of an accepted bill. The reason, applicable alike to payee and indorsee, is tersely stated hy Vaughan, J., in Low v. Chifney, 1 Bing. (N. C.) 267: "How was he to know what had passed between the drawer and acceptor." See Davis v. Randall, 115 Mass. 517.

It is contended by the defendant that the rule does not apply to the case at bar, because the acceptance was after the bill was purchased by the payee, and that, therefore, it was not taken by him on the faith of the acceptance. There is no ground for this distinction. It is immaterial when an acceptance is made; it may be male at any time, and the rights of the payce and of intorsces are the same after it is made whether they were aequired in anticipation of it or subsequent to it. It is held in this state that, upon the question whether a promise to accept marle by the drawee to the drawer is an acepptance as to other parties, the knowledge of the promise, and presumed reliance upon it in hecoming parties, is material. Exrhange Bank of St. Lonuis v. Rice, 98 Mass. 288. But where, as in the ease at har, there is an acceptance upon the bill, it makes no differenee in the rights of pavees or indorsees whether they hecome such before or after the acentance. See Grant v. IIunt, 1 C. B. 14; Wynne v. Railies. 5 East, 514 ; Povell v. Monnier, 1 Atk. 611.

The instrument is negotiahle hefore acreptance, and the acreptance is an acknowledgment of the deht it represents, and an alsolute promise to pay it to the person who is or shall become the bolder of the bill; and to allow a want of consideration for the areeptance to defeat the right of a bona fide holdere, whether he became such before or after the acceptance, would be contrary to the nature and purpose of bills of exchange, and to the uniform usage in regrard to them. Exceptions fustainel. ${ }^{2}$

2 In Heucrtemater v. Morris, 10] N. Y. fi3. 70, the enurt saya: "If a party becomea a bona fide holder for value of a bill lefore its acceptanes, it is not essential to his right to enforce it against a subsequent acceptor, that an adelitional consideration ahonld proceed from him to the drawer. The bill. itself implice a representation by the drawer that the drawee ia alrealy in receipt of funds to pay, and his contract is that the drawes shall accept and pay aceording to the terms of the draft. (Paraona on Bills, 323, 544; Arpin V. 
6 Cushixg (Mass.) $469 .-1850$.

Shaw, C. J. * * * In the present 'ase, it appearing that the note was negotiated to the plaintiffs before it was due, for a valuable consideration, and the jury having found that they took it without notice of the misapplication by the maker, it is clear that they have a right to recover; and the only remaining question is, for what anount they may recover. In general, the holder of an indorsed note will be entitled to recover the whole amount of the face of the note, because the presumption of fact, in the absence of counter proof, is, that he gave the full value for it, or that he took it from some other holder for value, to collect the amount, receive a certain part to his own use, and account to the party from whom he took it for the surplus. Having taken it to secure a pre-existing debt, of a less amount, he is a holder for value in his own right, only to the amount of the debt due him. If, therefore, it appears in proof, that the plaintiff is not accountable to any third person for any surplus, then there is no reason why he should recover any more than the balance of the debt, for which he is a bona fide holder for value. Here, it appears that the plaintiff received this note of the maker, for whose accommodation the defendant indorsed it. It being obvious that the plaintiff can recover nothing as trustee for the party from whom he received it, he is liahle over to nobody for the surplus, and therefore can have judgment only for the amount due to himself, for his own use and in his own right which is so much of the note

Chapin, 140 Mass. 144.) The drawee can, of course, npon presentment refuse to accept a bill, and in that event the only recourse of the holder is against the prior parties thereto; hut in rase the drawee does accept a hill, he becomes primarily liable for its payment, not only to its indorsees but also to the drawer himself.

"The delivery of a bill or check by one person to another for value implies a representation on the part of the drawer that the drawee is in funds for its payment, and the subsequent acceptance of such check or bill constitutes an admission of the truth of the representation, which the drawee is not allowed to retract. (Daniel on Neg. Inst., 534; Parsons on Bills, 323, 544, 545.) By such acceptance the drawee adnits the truth of the representation, and having obtained a suspension of the lolder's remedies against the drawer, and an extension of credit by his admission, is not afterwards at liberty to controvert the fact as against a bona fide holder for value of the bill.

"The payment to the drawer of the purchase price furnishes a good consideration for the acceptance which he then undertakes shall he made, and its subsequent performance by the drawee is only the fulfillment of the contract which the drawer represents he is authorized by the drawee to make.

"The rule that it is not competent for an acceptor to allege as a defense to an action on a bill that it was done without consideration, or for accommodation, as against a bona fide holder for value of such paper, flows logicalls from the conclusive force given to bis admission of funds, and is elomentary." - C. 
as may be necessary to satisfy the balance of the debt, for the security of which he received it.

Judgment on the verdict for the plaintiff for the smaller sum.s

\section{Effect of want of consideration.}

OSGOOD $v$. ARTT.

[Reported herein at p. $\$ 0 \%$.

STACY $v$. KEMP.

97 Massachusetts, I66. -1867 .

Contract upon a promissory note. Defense, partial failure of consideration in that plaintiff, having agreed not to peddle milk in H., had continued to do so, etc. The trial court held evidence of this inadmissible. Plaintiff alleges exceptions.

Chapmax, J., [after disposing of another question]. It was competent to the defendant to prove that the note was given as well in consideration of a sale of the good will of the milk route, and an agreement not to go into business which should interfere with it, as

In Mersick $\therefore$ Alderman, 77 Conn. 634, 637, the court said: "The defendants elaim that the complaint was inappropriate, in that it was in the ordinary form of one on behalf of an indorse of a negotiable note against the maker, and that the judgment did not conform to the complaint in that it was rendered for the amount of the indehtedness which it was given to sceure. It is well settled that the payee or indorsee of a note held as collateral may sue upon it, and such is the plain implication of our statutes. Gen. St. 1902. \$§ 4222-4227 [N, Y.. \$ฐ 91-96]; Daniels on Negotiable Instruments. \$ 833; Hodges v. Nash, 14] III. 391; Whittaker v. Charleston Gas Co., 16 W. Va. 717; Keed v. First National Bank, 23 Colo. 380. 'The fact that jurlgment is not in such cases rendered for the full amount of the note, but for the amount of the indebtedness secured therehy, does not establish that the recovery is not upon the note. True it is thut, generally speaking, a holder in due conrse of negotiable instruments is eutitled to recover the full amount thereof. Cien. St. 1902, \& $4227\left[N, Y_{.}, \S 96\right]$. But it has Inng heen an accepted principle limiting the operation of the general rule, but not repugnant to it. that one who takes such paper as collateral security for a debt will be limited in his recovery to the umount of that deht. Cromicell v. County of Sac, 96 U. S. 60; Duncan v. Gilberl, 2! N. I. Law, 521: Fisher v. Fisher, 9s Mas4. 303: Youngs v. Lee, 12 N. Y. 551 . The recovery, however, is none the less upon the paper. The plaintiff was justified in confining his allegations to such as disclosed his right prima facie to recover the amount of the note. and in lesving to the defendants to set up in their anuwer, as they did, the facts which sorves to limit that right. Vanlier v. Bank, 21 III. App. 126; Curfis v. Mohr. 18 Wis. 615; Duncan v. Gilbert, 29 N. J. Jaw, 521. The exeeptions to the finding need not be considered." - $\mathrm{C}$. 
of a sale of the articles enumerated in the bill of parcels. Agreements of this character are valid, and are often specifically enforeed in equity by injumetion, and at law by actions for damages. Evidence that the plaintill has interfered with the ronte in the mamner stated, would tend to show; that he has deprived the defendant of a part of the consideration for which the note is given. It was formerly held that such damages must be recovered by a cross-action, and could not be proved and allowed in defense of an artion on the note, by way of recoupment. But the doctrine of recoupment of damages was fully established in this court, in IIarrington v. Stratton, (22 Pick. 510.) (See Burnetl v. Smith, 4 Gray, 50.) It has since been applied in numerons cases, and was alrearly well established in New York. It is an equitable set-off of damages which ought to be deducted from the plaintiff's demand, and for the recovery of which the defendant ought not to be turned round to a cross-action. The court are of opinion that it should be applied to a case like the present. where the plaintiff has deprived the defendant of a valuable part of the consideration of the note in suit, if the facts whieh were alleged shall be proved.

The first exception must be orerruled; and the second sustained. ${ }^{*}$

\section{Liability of accommodation party.}

\section{§5 GREENWAY $r$. WILLIAM D. OR'THWEIN GRAIN CO.}

85 Federal Reporter (Cir. ('T. App., 8Th Cir.) 536. - 1898.

Sanbors, Cireuit Judge. On .June 2\%, 1894, for the purpose of enabling Ed. Hogaboom to borrow money upon it, and without consideration, the plaintiff in error, $G$ C. Creenway, signed, as one of the makers, a promissory note made by Ed. Hogahoom for $\$ 5,000$ and interest at 10 per cent. per anum after maturity, payable to the order of Hogaboom. ${ }^{5}$ On July 23, 1894, Ingahoom made his promisenry note for $\$ 5,000$ with interest at 10 per cent. per annum from its latr, payable seven months thereafter to the order of the defendant in error, William D. Orthwein Grain Company, a corporation. On that dav, Hogahoom indorsed and pledged the four-months noto to secure the paynent of the seven-months note. delivered them both to the defend-

4 Accorl: Torinus v. Burliham, 29 Minn. 128; 1 Danid on Neg. Inst.. \$\$ 201204. One who is " not a holder in due course" stands in the same relation as an immediate party. Thus a transferee of over-due paper is subject to the defense of failure of consideration. Bryan v. Primm. l III. 33: Diamond v. Harris, 33 Tex. 634: Sauyer v. Honvry, 5 Ia. Ann. 153.-H.

[See also Hathorn v. Whorlwright. 99 Me. 351, reported in 2 A. \& F. Ann. Cas. 428, with notr entitled "Partial failure of consideration as defense to action on bill or note." - C.1

s This note was payable fonr months after date. $-\mathrm{C}$. 
ant in error, and borrowed $\$ 5,000$ of that corporation upon them. Only $\$ 666.66$ has ever been paid upon either note. The grain cumpany sueü Greenway on the note which he signed, and his defenses were:(1) That he signed the note without consideration, for the accommodation of Hogaboom, and that the defendant in error was cognizant of this fact when it made the loan to him; $* * *$ the court peremptorily instructed the jury to return a verdict for the defendant in error for the face of the note and interest, less the $\$ 666.66$ which had been paid. This instruction is assigned as error. Accommodation paper constitutes a loan of credit, without consideration, by one party to another, who undertakes to pay the paper and indemnify the lender against loss on its account. It is paper which is made, indorsed, or accepted by one party, without consideration, for the accommodation of another, for the purpose and with the intention that the latter shall obtain money or credit upon it of some third party. The accommodated party can maintain no action upon it against the accommodation maker, because the latter has received no consideration for it from him. But. if the party accommodated uses the paper in the ordinary course of business to obtain money, eredit, or any other thing of value from a third party, the law imputes the consideration which he receives to the acommodation maker, indorser, or acceptor, hecanse the latter, by placing his name upon the paper, has, in effect, requested him who adrances the consideration upon it to pay that eonsideration to the party accommorlated. It was for that very purpose and with that intention that he placed his name upon the paper; and when a stranger has given a valuable consideration for it to the aceommodated party in reliane upon this purpose and intent, the arommodation maker cannot be permitted to say that he has nof himself recriver that consideration. It is therefore no defense against one who has arguired aceommorlation paper, with knowledge of its chararter, lust in good faith, in the ordinary course of husiness, and for value, that the aceommodation maker actually receised no ronsiderition for it. Lianli v. W'risiger. 2 Pet.

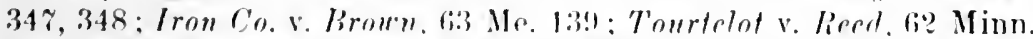

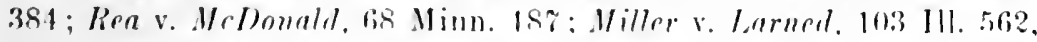

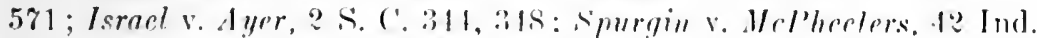
527. One who takes commereial paper by way of a pled ge to secure the repayment of a simnltaueous loan made in consideration of the pledge acrunires it for value. S'wift 8 . Tyson. If Pot. 1 : Oales v. Bank, 100 U. S. 239: linilroad C'o. r. Bank, 10\% I. S. 11. 28. The first refense of the plaintiff in error was therefore without foumbation.

The charge of the court below was right, and flo judgment inust be affirmed. It is so ordered." 
90 New York Supplenent (Sup. Ct., Apr. T.) 335. - 1904.

ACTIONs on promissory notes. Judgments for plaintiff and defendant appeals.

Bischorf, J.- The notes in suit were discounted by plaintiff's assignor for the maker, being in the latter's possession with the indorsement of the payee, the appellant corporation. The circumstances imported the finet that the indorsement was for accommodation (Stall $\mathbf{v}$. Bank, 18 Wend. 466; Ficlden v. Lahens, 2 Abb. Dec. 111, 116), and hence not within the powers of a manufacturing corporation, such as this. Nat. Park Bank v. G. A. Co., 116 N. Y. 281. The Negotiable Instruments Law (Laws 1897 , p. 719 , e. 612) does not affect this question of power. Section 41 provides for the passing of title by indorsement, not the incurring of liahility, and section 55 does not refer to corporations; therefore it is not to be implied that the Legislature intended to extend the powers of every corporation to the making of accommodation indorsements. Crawford, Neg. Instruments (2d Ed.) pp. 36, 3\%. Upon the facts presented, the judgment eharging the appellant with liability is without support, but it may be that upon a new trial the plaintiff might produce sufficient proof to bind the corporation upon principles of estoppel. Therefore an absolute dismissal will not be ordered.

Judgments reversed, and new trial ordered, with costs to appellant to abide the event. All concur. ${ }^{7}$

7 In Nat. Bank of Neuport v. H. P. Snyder Mfg. Co., 117 App. Div. (N. Y.) 370,373 , the court said: "It is to be borne in mind that the defendant in this case is a manufacturing corporation. When an individual signs a note, ejther as maker or indorser, for the henefit of another, and allows it to be put in circulation, he is liable to a holder for value, although such holder knew him to be an accommorlation party. Negotiable lustruments Law, \$ 55; National Bank of the City of N.Y. v. Toplitz, S1 App. Div. 593, affirmed 178 N. Y. 464. But a manufacturing corporation has no power to hind itself as an accommodation party. Central Bank v. Empire Stone Dressing Co., 26 Barb. 23; Bank of Genesce v. Patchin Bank. '13 N. Y. 309; National Park Bank v. German Am. N.W. \& s. Co.. I16 N. Y. 281. So that the rule adverted to [that the hurden was upon the defendlant to prove that the plaintiff knew or harl reason to suspect that the note was accommodation paper when it accepted it l does not ohtain in this ease, and the plaintiff must show both that it was a holder for value, and also that it did not know the accommodation charaeter of the defendant's signature."

See alsn Conk v. Am. Tubing and Webbing Co., 28 R. I. 41, reported in 9 J. N. S. 193, with note entitled "Power of corporation to issue accommodation paper." - C. 
75 Atlantic Reporter (N. J. Sup. Ct.) 550. - 1910.

THIs is a suit on a promissory note dated June 9, 1908, made by Virgil to the order of the plaintiff for the purchase price of brictis sold him through Austin, who was entitled to a commission upon the sale. Austin indorsed the note under the following circumstances: Upon his demand for payment of his commission, the plaintiff refused to pay until the bricks were paid for by Tirgil, unless Austin wonld indorse the note. Austin thereupon indorsed the note, and was paid his commission. The note was discounted at the bank, but was not paid at maturity, and Austin's liability was fixed by due notice of dishonor. The trial judge directed a verdict for the plaintiff for the full amount.

Swarse. J. * * * It was open to the jury to believe the testimony of the defendant that he indorsed the note to enable the company to get it discounted, and thereby raise cash out of which they would pay his commission. From this it was proper to infer that Austin was an aceommodation party (Vliet v. Eastburn, 6. N. J. Law, 627 ), and this is true notwithstanding the language of section $29^{8}$ of the act, which defines an arcommodation party as one who has signed the instrument as maker, drawer, arceptor, or indorser, without recejving value therefor. This language has been eriticised by Dean Ames, 14 Harvard Law Review, 248; and, if it must be eonstrued to mean that one who loans his name to another upon a negotiable instrument and receives payment for the accommodation loses as to that person the right of an accommodation party, it would be subject to very just criticism, since such a construction would deprive an aeconmodation maker of his rights, as against the person accommodated, if he had receiver any consideration, howerer slight. A careful reading of the section shows that this construction is not necessary. The words are not "without receiving valne," but "without receiving value therefor," The structure of the sentence is such that the last worl can only rufer to the negotiable instrument ifself, not to the loan of the name by way of acrommodation. This vicw was suggested by Mr. MeKeelian in 11 American Law liegister, 199, 561 (reprinted in Brannan on the Nergotiablo Instruments Art, at page 133). In this mese, noreover, Austin dif not reepive value in any sense. What he sesured was the payment out of the procesus of the discounted note of the commission due him. That was only the payment of a prior deht, not the giving of value for Austin's indorsement. The value recived within the muaning of section 29 must presede or he contemporaneous with the whigation upon the note: otherwise, the party would be an accommolation party when the note was griven and 
wonld rease to be such when the subseruent payment was made him. Nor an the promise to pay the commission ont of the proceeds of the note as distinct from the actual payment constitute value for the endorsement, for that promise was nerely one to perform an existing learal obligation, and wis therefore without consideration. If the jury found that Austin was an accommodation party, they would necessarily find that the plaintitl was the party arcommodated, for no one else was concerned. 'The maker had nothing to to with the arrangement. If Anstin loaned his name to the plaintiff corporation, it acquired no right of action against him. Messmore v. Meyer, 56 N. J. Law, 31.

A jury question was presented, and it was error to direct a verdict for the plaintitf. The judgment must therefore be reversed, and the reeord remitted for a new trial. *** * 


\section{ARTICLE IV.}

\section{Negotiation.}

\section{What constitutes negotiation or transfer.}

$\$ 60$ Crovch v. Credit Foncier, L. R. 8 Q. B. 374 . (1873.)

BLACKBURN, J. - In the present case the plaintiff has taken upon himself the burden of establishing both that the property in the debenture passed to him by delivery, and that the right to sue in his own name was transferred to him.

The two propositions are very much connected, but not identical. The holder of an overdue bill or note may confer the right on the transferee to sue in his own name, but he conveys no better title than he had himself.

But the two questions go very much together; and, indeed, in the notes to Miller v. Race (1 Smith, L. C. 9th ed., p. 491), where all the authorities are collected, the very learned author says: "It may therefore be laid down as a safe rule that where an instrument is by the custom of trade transferable, like cash, by delivery, and is also capable of being sued upon by the person holding it pro tempore, then it is entitled to the name of a negotiable instrument, and the property in it passes to a bona fide transferee for value, though the transfer may not have taken place in market overt. But that if either of the above requisites be wanting, $i . e$., if it be either not accustomably transferable, or, though it be areustomably transferable, yet, if its nature be such as to render it incupable of being put in suit by the party holding it pro tempore, it is not a negotiable instrument, nor will delivery of it pass the property of it to a vendee, however bona fide. if the transferor himself have not a good title to it, and the transfer be made out of market avert."

Bills of exchange and promissory notes. whether payahle to order or to bearer, are by the law merchant negotiablo in hoth senses of the worl. The person who, by a genuine indorsement, or, where it is payable to hearer, by a dolivery, becomes holder, may sue in his own name on the contract, and if he is a bond fide holder for value, he has a good title notwithstanding any defect of title in the party (whether indorser or leliverer) from whom he took it.'

"For a luminous discussion of "negotiability," see Willis on Negotiable Securities (1896), Iectures I and II. - II. 


\title{
I. Transfer by Deliveny.
}

$\$ 60$

\author{
BIT'KER थ. WAGER.
}

83 Michtan, $223 .-1890$.

Action on the following promissory note: $\$ 100.00$.

IIART, Mich., March 20, 1889.

Bight months after date 1 promise to pay to the order of Marget $A$. Bitzer (or bearer), one hundred dollars, at the Oceana County Savings Bank, value received, with interest at the rate of 6 per cent.
Bert Spellyan,
G. L. WAGAII.

Judgment for plaintiff. Defendant brings error on the ground that the court erred in admitting in evidence the note in question for the reason (a) that the note is payable to Margaret $\mathrm{A}$. Bitzer, and has never been indorsed or transferred by her to plaintiff; $(b)$ that said note is not competent evidence, for the reason that plaintiff has not shown that he owns or has property in said note.

Love, J., [after disposing of a nother matter]. - The note is plainly payable to bearer, and suit could be maintained thereon in the name of any holder.

\section{Judgment affirmed. ${ }^{2}$}

$\S 60$

\section{COCK $v$. FELLOWS.}

1 Johnson (N. Y.) 143. - I 806 .

From the return to the certiorari in this cause, it appeared that an action had been brought by the defendant in error against the present plaintiff, hefore a justice of the peace, in which he declared on a writing or note, in the following worls:

Due the bearer hereof, 31, 18s, 10d. which I promise to pay tn Ahraham Thompson, or order, on demand, as witness my hand, this $22 d$, 11 tl month, 1803.

[Signed] Jordan Cock.

The note was not endorsed by Thompson, and the declaration stated the note was made payahle to the bearer. The justice gave judgment for the plaintiff below, for the amount of the note.

Peir Curmam. The word bearer has reference to Thompson as the

2 Accord: Grant v. Vaughan, 3 Burr. 1516; Pierce v. Crafts, 12 Johns IN. Y.) 90 ; Ellis v. Wheeler, 3 Pick. (Mass.) 18; Matthews v. Wall, 1 Vt. 316. In Illinois promissory notes payable "to $\mathrm{A}$. or bearer" require indorsement, though not if payable "to bearer." Roosa v. Crist. 17 111. 450 ; Garfield v. Berry, 5 III. App. 355: ef. A very v. Latimer, 14 Oh. 542.

For meaning of "instruments payable to bearer." see $\$ 28$, ante.

As to effect of special indorsement see Johnson v. Mitchell, 50 Tex. 212, post. - H. 
payee, and as the promise is expressly to pay lim or order, another person could not maintain an action on the note without his endorsement. 'The judgment below must be reversed.

Judgment reversed.

\section{Transfer by Indorsement and Delivery.}

(a) Transfer by indorsing assignment.

$$
\text { MARKEY } v \text {. COREY. }
$$

108 Michigax, 184. - 1895.3

ACrion against Corey as indorser. The indorsement read: "I hereby assign the within note to Matthew M. Markey and Catherine Sundars." The note also referred to a certain contract which provided that in case of default in any one of five notes (of which the note in suit was one), all of the notes, at the option of the payee, might be declared due and payable. ${ }^{4}$ Judgment for plaintiff.

Lovg, J., [after stating the facts]. - The usual mode of transfer of a promissory note is by simply writing the indorser's name upon the back, or by writing also over it the direction to pay the indorsee named, or order, or to him or bearer. An indorsement, however, may be made in more enlarged terms, and the indorser be held liable as such. In Sands v. Wood (1 Towa, 263), the indorsement was, "I assign the within note to Mrs. Sarah Coffin." In Sears r. Lantz ( 47 Iowa, 658), the indorsement on the note was. "T hereby assign all my right and title to Lonis Meckley." And in eacl ease the party so assigning was held as indorser, the court in the latter case saying of Sands v. Wood: "He used no words that, in and of themselves, indieated that he had hound or made himself liable in case the maker, after demand, failed to pay the note. But it was held the law, as a legal conclusion, attached to the words used the liability that follows the indorsement of a promissory note." (See, also, Duffy's Adm'r v. O'Connor 7 Baxt. 498; Selly, v. Judd, 2.t Kan. 166: Brotherton v. Street [Ind. Sup.], 24 N. E. 1068.) The rule of the Amerion cases is well stated in Daniel on Neg. Inst., (\$ 688c), as follows: "The question arising in such cases, is a nice one, and depends upon rules of legal interpretation. The mere signature of the payee, indorsed on the paper, imports an executed contract of assigmment, with its implications, and also an executory contract of conditional tiability, with its

s Reported in 36 I. R. A. 117, with note entitled "Assignor of promissory note as an indorapr." $-C$.

- Neg. Inst. I., \& 21, subsec. 3. - H. 
implications." The assigmment would be as complete by the mere signature as with the words of assignment written over it. The conditional hability which is exerutory is implied by the exeented contract of assignment, and the signature under it, which carried the legal title; and the question is, does the writing over a signature an express assignment, which the law imports from the signature per se, exciude and negative the illea of conditional liability, which the law also imports if such assigmment were not expressed in full? We think not. When the thing done creates an implication of another to be done, we cannot think thint the mere expression of the former in full can be regarded as excluding its consequence, when that consequence would follow if the expression were omitted."

The language used in the assignment to the note in suit does not negative the implication of the legal liability of the assignor as indorser, and as the words are to be construed, as strongly as their sense will allow, against the assignor, he must be held as indorser. This rule is fully supported in Hatch v. Barrett (34 Kan. 230; 8 Pac. 129). (See, also, Adams v. Blethen, 66 Me. 19.) In the case of Aniba v. Yeomans (39 Mich. 171), the assignment read as follows: "I hereby transfer my right, title, and interest of the within note to S. A. Yeomans." Mr. Iustice Marston said in that ease: "The right or interest passing, therefore, under the usual and customary indorsement, is much greater than the mere right, title, and interest of the payee; and when the transfer, as made, only attempts to pass the title and interest of the payee of the note, no greater right or interest than he then held can pass." In other words, the learned justice seemed to think that the words used limited the transfer to the right and title he then held. While this holding appears to be at variance with the cases elsewhere, we think it readily distinguishable from the present, as here the words are, "I hereby assign the within note to Matthew M. Markey and Catherine Sundars" and do not purport to limit the liability of ('orey as an indorser. In Stevens v. Iannan (86 Mich. 307), the note sued upon was negotiable in form, and made prayable to Batchelder, and he assigned it hefore maturity, as follows: "For value received, 1 hreby assign all interest in and to this note to Ralph E. Watson." Hefendant insisted in that case that the plaintiff could not sue in his own name, but should have sued in the name of the payee. It was said by Mr. . Tustice McGrath: "I do not think the point well taken. If Batchelder's indorsement dir not affect its negotiability, then Watson's indorsement entitled the plaintiff, as holder of the note, to sue in his own name." It must be hold, therefore, that the memorandum on the note did not relieve Corey from his liability as indorser.

The court was not in error in admitting the contract in evidence, 
as its purpose was to show that the note was not in fact limited by its provisions, and those provisions of the contract cited did not destroy the negotiability of the note. (Daniel, Neg. Inst., § 48.)

The judgment must be affirmed. The other justices concurred. ${ }^{\circ}$

$\S 60$ Hall $v$. ToBy, 110 Pennsylvania State, 318. - 1885.

Action by D. B. Toby as indorsee under the following instrument and assignment :

$\$ 551.50$.

WARREN, Aug. 18, 1879.

For value received I promise to pay Wm. Toby, or order, five hundred and fifty-one $50 / 100$ dollars with interest.

Orais Hall.

[On the back of this paper was the following transfer or assignment]:

For value received $I$ hereby assign, transfer and set over to D. B. Toby all my right, title, interest and claim in the within note.

TIONESTA, Nov. 21, 1881.

WM. ToBY, D. В. Тову.

Per Curiam. - This note was negotiable. It contained an absolute and unconditional promise to pay to $\mathrm{Wm}$. Toby or order the sum specified. As no time of payment was therein expressed, the law adjudges the money to be payable immediately. A right of action accrued at once and would be barred by the Statute of Limitations at the expiration of six years thereafter. The note had all the essential language to constitute a promissory note.

The legal right of action thereon would have passed by indorsement and delivery. For purpose of transfer the assignment on the back of this note passed the legal title. ${ }^{7}$

(b) Transfer by indorsing guaranty. TRUST COMPANY $\because$. NATIONAI, BANK. 101 United States, 68. - 1879.

Bils. to compel surrender of note. The note with security was given by the Wyandotte Bank to the Cook County National Bank to obtain credit, and not to be negotiated. The latter did negotiate it to the 'Trust Company. At its maturity there was dne on it to the

- Accord: Maine Trust, ete., Co. v. Rutler. 45 Minn. 506; Datidson v. Porcell, 114 N. C. 575 ; A/rrill v. Hurley, of So. Dak. 592.

Contra: Lyons v. Diwelbis, $22 \mathrm{~Pa}$. St. 185; Spencer v. Halpern. 62 Ark. 595; Cf. Aniba v. Y'omans, 39 Mich. 171. - 11 .

'Cf. Aniba v. Ycomans, 39 Mich. 171. While the indorsement passes title it does not make the "asaignor" liahle as an indorser. Lyons v. Divelbis, $22 \mathrm{~Pa}$. St. 185. Contra: Ilenderson v. Ackrlmire, 59 Ind. 540; Adams v. Blethen, 68 Me. $19 .-\mathrm{H}$. 
Cook County National Bank \$13:, which the Wyandotte Bank offers to pay.

Il u. Justice Strong [after stating the facts]. - The note was not indorsed to the 'l'rust Company, and it was not, therefore, taken in the the usual conrse of business by that mode of transfer in which negotiable paper is usually transferred. Ilad it been indorsed by the Cook County Bank, it may be that the Trust Company would hold it unaffected by any equities between the maker and payee. But instead of an indorsement, the president of the Cook County Bank merely guaranteed its payment, and handed it over with this guaranty to the 'T'rust Company. 'T'he note was not even assigned. 'There was written upon it only the following:-

For value received, we hereby guarantee the payment of the within note at maturity, or at any time thereafter, with interest at ten per cent. per anmum until paid, and agree to pay all costs and expenses paid or incurred in collecting the same.

B. F. AldeN, P'res't.

In no commercial sense is this an indorsement, and probaluly it was not intended as such. Allen had agreed that the note should not be negotiated, and for this reason perhaps it was not indorsed. That a guaranty is not a negotiation of a bill or note as understoor by the law merchant, is certain. (Snevily v. Eliel, 1 Watts \& S. [Pa.], 203; Lamourieux v. Hewitt, 5 Wend. [N. Y.], 307; Miller v. Gaston, 2 Hill [N. Y.], 188). In this case, the guaranty written on the note was filled up. It expressed fully the contrast between the Cook County Bank and the Trust Company. Being express, it ean raise no applieation of any other contract. Expressum facit cessare tacitum. The contract cannot, therefore, be converted into an indorsement or an assignment. And if it could be treated as an assignment of the note, it would not cut off the defenses of the maker. Such an effect results only from a transfer according to the law merchant; that is, from an indorsement. An assignee stands in the place of his assignor, and takes simply an assignor's rights; but an indorsement creates a new and collateral contract. (2 Parsons, Notes and Bills, 46 et seq., notes.)

At best, therefore, the defendants below can claim no more or greater rights than those of the Cook County Bank, and the eomplainants are entitled to a return of the note and of the collaterals on payment of the sum of $\$ 132$.

Decree affirmed. ${ }^{8}$

8 Acenrd: Tuttlo v. Bartholomew, 12 Met. (Mass.) 452; Belcher v. Smith, 7 Cush. (Mass.) 482: Canfield v. Vaughan, 8 Mart. (La.) 683.

Contra: Myrick v. Hasey. 27 Me. 9; Heard v. Dubuque Bank, 8 Neb. 10; Delmer v. Bank, 25 Neł. 474; Kellogg v. Douglas Co. Bank, 58 Kan. 43: Dunham v. Peterson, 5 N. Dak. 414, where the question is fully discussed and authorities collected; Elgin City Banking Co. v. Zelch, 57 Minn. 487, infra. - H. 
57 Minnesota, 487. - 1894.

Action by indorsee against maker. The question was whether plaintiff was an indorsee, or an assignee and so subject to the defense of fraud or failure of consideration. 'The court directed a verdict for plaintiff. The facts appear in the opinion.

Miтchell, J. - The defendant executed his negotiable promissory note, payable to the order of one Daniel Dunham, who transferred it to the plaintiff, with the following indorsements: "Pay the Elgin City Banking Co. D. Dunham." "Payment Guaranteed. D. Dunham."

Whether these indorsements be construed as constituting a single contract, or two distinct and separate contracts, we are clear that they constitute an "indorsement," in the commercial sense, and that the transferee is an "indorsee," and entitled to protection as such, under the law merchant. The fact that Dunham enlarged his responsibility heyond that of "indorser," hy guarantying payment, did not change or affect the character of his indorsement.

\section{Order affirmed.}

- See note 1. above. "A guaranty of the payment of a note does not necessarily include a contract of indorsement, but when sucl, guaranty is written upon the back of the note in general terms and signed by the payee named therein, the universal custom is to treat such contract of giaranty as a transfor of the title of the payee to the person to whom the curaranty is made." National Bank of Commerce v. Gallant. 14 Wash. 502. 505. Such a guaranty c.snstitutes "an indorsement of the note with an enlarged liability." Donnerherg $\because$ opprnhcimrr. 15 Wash. 2!0. "I guarantee attorney"s fees up to 10 m... ente if this note lias to be collected by law. and its prompt parnent." liefd an indorement hy the payee with an enlarged liability. irattillo $\mathbf{v}$ lexander, 96 Ga. 60. For a distinction betwen the case wlere the guaranty i.s rxecuterl by the paye and where it is exceuted by a thirel person, see ran.

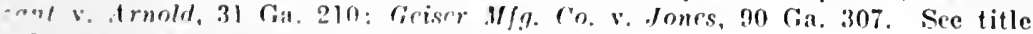
" Cularantor's Liability." prost. Art. VI. Div. VII.

DE:Liver. - "It had often lien deeided. thut the assignment [transferl of a note is not complet. withont a lelivery, and that where a promissory note is found in the hands of one who has made an indorsement thereon, which, if arcompanied by delivery. Would hase amounterl to an ascigument [transfer]. the presunuption will he that the assignment was never completed. and that he may, even after suit bromght, strik" ont surls indorsement." Wulsehner v.

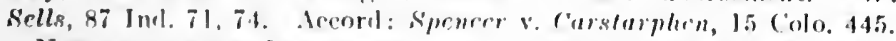

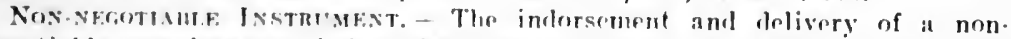
negotiable note deus not (independent of sfatute) authorize the loblder to bring an action in his own nume, and the lobdre is subject to all defenses that might have been set up against his transferor. Robinsen v. Broun, 4 Blackf. (Ind.) 128; Maule v. Ciairfort, i4 JIun (N. Y.) 193; post, Art. XVII, Div. I, 3. - H. 


\section{Indorsement : form required.}

\section{Must be Written on Instiument or Allonge.}

Brfese, J. - The first point made in this case is, that the note was not properly indorsed, the transfer heing on the face of the note. Literally, indorsement means a writing, in dorse. upon the back of the bill or note. But it is well established, that though such is its import. it may be on the face of the bill,' and numerous indorsements may he made on a separate paper, called an allonge. (Chit. on Bills, 227: Yarborough v. Bank of England, 16 East, 12; Rex v. Bigg, 1 Strange, 18 ; Story on Prom. Notes, $\$ 121$; Gibson v. Powell, 6 Howard [Miss.] 60.) And any form is sufficient which manifests an intention to transfer the note. (Morris v. Bird, 11 Mass. 436. $)^{2}$

\section{$\S 61$}

FOLGER $r$. CHASE.

18 Pickering (Mass.) 63. - 1836.

Action on three promissory notes.

WILDE, J., delivered the opinion of the Court. * * *

The last objection is, that the indorsement on one of the notes was not made on the hack of the original note, and therefore amounted only to an equitable transfer. The indorsement was made on a paper attached to the back of the note by a wafer, and it had been before thus attached for the purpose of entering thereon indorsments of payments, the back of the original note having been before covered with indorsements: and sereral payments had heen indorsed on the attached paper,

\footnotetext{
1 Accorla Young v. Filover. 3 Jur. N. S. 637; Haines v. Dubois, 30 N. J. L. 259: Shoin v. Sullimn, 10f ral. 208. See Neg. Inst. I., \$ 3f, subsec. 6. - H. 2 See Germania Nat. Bank v. Mariner, 129 Wis, 544. ante, p. - - - C,
} 
before the note was transferred by indorsement to the plaintiff. This paper thus attached had become a part of the note, and no good reason can be given why an indorsement made thereon should not be held a valid and legal transfer. The objection is, that such an indorsement

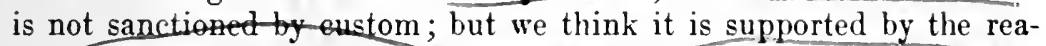
sons on which the custom was originally founded. Bills of exchange and promissory notes were indorsed on the back of the bills and notes, because it was a convenient mode of making the transfer, and in order that the evidence thereof might accompany the note. Such an indorsement as this will rarely happen, and no authority to support it could reasonably be expected; but there is no authority against it.

If a person write his name on a blank paper, to be used as an indorsement of a note to be written on the other side, and it be filled up as intended, the party would be held liable as indorser of the note, although such indorsements are infrequent, and are not according to the customary form of making a transfer; but they have been held to be within the reason of the custom, and are supported by principle. (Bayley on Bills, 92 ; Violett v. Patton, 5 Cranch. 142.) ${ }^{3}$

So in the present case, as there is no authority against the validity of the indorsement, we think we shall violate no principle in holding it to be a legal transfer of the note.

Judgment for the plaintiffs.

\title{
2. Must be of Entinf. Instroment.
}

$\S 62$

\author{
HUGIJES $v$. KIDDELL.
}

2 BAY (So. CAR.), 324. - 1801.

THIs was an action against defendant as indorser on a note of hand, in which there was a verdiet for defendant. The note of hand in question was given by David Bush, of Camden, to the defendant Kiddell, for 473l. sterling. Kiddell afterwards made the following indorsement, viz: -

"I assign over to IJudson Hughes, the sum of 1,930 dollars and 50 cents, as part of this note of hand.

(Signed.)

Benjamin Kiddell."

Afterwards he made another indorsement, and assigned over the residue of said note f to Hughes.l (Signed) Benjamin Kiddell.

The court, after hearing the arguments, ${ }^{4}$ refused to grant a new trial, on the ground that an indorsement for part of a noto or hill is

S Ser Neg. Inat. I... \& 33, ante. - II.

- Counsel for defendant argued that "if it were allowable for a man to indorse for part. he might indorse one hundred to $A$, another hundred to $B$, and oo on; and by that means. defendant might become liable to twenty dif. 
had. (Ifex Mereatoria, 45 Carth. 466.) And if so, then two vitious indorsements can never constitute a good one.

Rule discharged.

III. Indorsement: kinds of.

\section{J. Special Indorsfement.}

$\S 64$

REAMER $v$. BELI.

79 Penssylunia State, 292. - 1875.

ACTION by holder against makers of a note payable "to the order of William Dilworth, Jr.," and indorsed: "Wm. Dilworth, Jr.-Pay R. McCurdy, Caslı." Defense, want of title in holder (Bell). Judgment for plaintiff.

Mi. Justice Paxson delivered the opinion of the Court.

We think the alliclavit of defense filed in this case, while not as specific as it might l:ave been, was nevertheless sufficient to prevent judgment. The copy of the note filed by the plaintiff below goes to sustain the denial of his title contained in the affidavit referred to. It is indorsed " $\mathrm{Wm}$. Dilworth, Jr.; pay R. MeCurdy, Cash." This is a special indorsement, and upon its fare conveys no title to the plaintiff below.

The further allegation that the note in controversy was procured by false and fraudulent representations, and that the consideration therenf has failed. coupled with the denial of said plaintiff's title, was sufficient to put the latter upon proof that he is a bona fide holder. Judgment reversed and a procedendo awarded.

2. Bhank Indorsmant.

$\S 64$

CURTIS $\because$. SPRAGUE.

[Reported herein at $p .114 .17$

\&65 Frans $v$. Gre, 11 Peters (U. S.) 80.-183\%. Bill payable "to the order of Thomas Evans" was indorsed in blank by payce (defend-

ferent actions on the same bill. For these reasons, and to guard against this monstrous inconvenience, the law of merchants has established it as a rule, that a bill rannot be endorsed for part. Cunn. on Bills, 57."

To the same effect, see Lindsay v. Priee, 23 Tex. 280 , bottom of p. 282 . - C.

s See Neg. Inst. I.., \$ 98, post. - H.

- See also Lawrence v. Fussell, 77 Pa. St. 460. - H.

7 "I see no difference between a note indorsed in blank and one payable to bearer. They both go by delivery. and possession proves property in both cases." Lord Mansfield in Peacoek v. Rhodes, 2 Doug. 633. - II. 
ant). Plaintiff became a holder in due course and wrote over the indorsement, "Pay to Sterling II. Gee." Mr. Justice Wayne:-As regards the right of a bona fide holder of a bill to write over a blank indorsement to whom the bill shall be paid, at any time before or after the institution of a suit against the indorser, it has long been the settled doctrine in the English and American courts; and the holder by writing such direction over a blank indorsement, ordering the money to be paid to particular persons, does not become an indorser. (Eden v. East India Co., 2 Burr. 1216; Com. 311; Str. 557; Vincent v. Halock, 1 Camp. 6 ; Smith v. Clarke, Peake, 225.) ${ }^{8}$

\section{BELDEN $v$. HANN.}

\section{Iow $4,42 .-1883$.}

Question certified by Cireuit Court: Whether a holder of a note under a blank indorsement may write above the indorsement "guarantee payment at maturity to hearer," and proceed against the indorser upon the guaranty withont presentment, demand and notice.

RothRock, .J. * * * It is well understond that the blank indorsement of a promissory unte by the payee creates the liability of an indorser as understood in the law merehant. Such indorsement creates the same liability from the indorser to the indorsee, as if it were in full. (Bean v. Briggs \& Felthouser, 1 Iowa, 488.),

But the contract of indorsement is very different from a contract of guaranty, and the holder of a note witl a blank indorsement by the payee has no legal right to change the obligation of the indorser, by writing a contract of guaranty over the name of the payce, "with-y thene out the knowlerlge or consent of the payee."

What the rights of the parties may he to show hy parol the real contract entered into by the indorser, need not be considered here, berause no such question is certified to us. Wo are required to determine the questions certified, and not questions of fact or law in the case which are not certifind, and we cannot consider the question as to the rights of the parties upron a guaranty upon a chattel mortgage given to secure this note, as we are requested to do by commsel. Taking these questions as they are certified, we answer, unbesitatingly,

Accord: Lovell v. Euerteon. 11 Johns. (N. Y.) 52 . While it is proper. it is not necessary, for a holder to fill 11, the inclorsement before bringing an action or offering the note in evirlener. Rirh v. S'tarhurk, 51 [nd. 87: Frecuough v. Smeat, 3 Oh. St. 415: Palmer v. Nassau Bank, 78 Ill. 3S0. (ontra: Day v. L,yon, 6 Harris \& Johns. (Mrl.) 140; Praslec v. Robbins, 3 Met. (Mass.) 164. $-\mathrm{H}$. 
as lid the conrt below, that the guaranty written over defendant's name, without his knowledge or consent, was void.

Affirmed. ${ }^{\circ}$

$\S 65$

SCO'T'T \%. CALKIN.

139 Massachusetts, 529. - 1885.

Actiox against Calkin as maker and Cherrington as subsequent gruarantor of a note. Cherrington's name was in blank on the back of the note anct she defended on the ground that she had received no notice of dishonor. Calkin made and delivered the note, secured by mortgage, to Pieree and the latter indorsed it to plaintiff. Calkin then sold the real estate covered by the mortgage to Cherrington who assumed and agreed to pay the mortgage debt. In consideration of plaintiff's forbearance to foreclose the mortgage Cherrington agreed with him to pay the note and signed her name on it. She now pleads (1) want of notice as indorser; (2) statute of frauds as guarantor. Plaintiff was permitted to write ahove C's name, "I guarantee the payment of the within note," and had judgment.

W. Allen, J.-The indorsement of the note by the defendant Cherrington, under the circumstances proved, imported a guaranty of the payment of the note to the plaintiff, and gave him authority to write, over her name, the contract implied by law ; and this, if neeessary at all, conld be done during the trial. (Josselyn v. Ames, 3 Mass. 2rt; Tenney v. Prince, 4 Pick. 385. $)^{2}$

The finding of the court renders inmaterial the question whether demand and notice were necessary.

Judgment for the plaintiff.

$\S 65$

CLARKE $v$. PATRICK.

60 Minnesota, 269. - 1895.

CANTY, J.- This is an action against the defendant as indorser of a negotiable promissory note The answer admits the making of the note to defendant, and the indorsement of it by him to plaintiff for a valuable consideration before maturity, as alleged in the complaint; but alleges that the transaction between the parties was a Eale by defendant to plaintiff of the note and a mortgage securing the

2 The holder cannot enlarge the liability of the indorser. Hood v. Robbins, 38 Ala. 484 . - H.

1 The consideration need not he expressed in a contract of guaranty. Mass. Pub. St., c. $78, \S 2$. - 1 .

2 See Kistner $\vee$. Peters, 223 Jll. 607. - C. 
same, which was eridenced by a written assignment, and that said indorsement was not intended by the parties as a guaranty of payment of the note, but was made merely in aid of said assignment. Such written assignment is not inconsistent with defendant's liability as indnrser, and it is well settled that the legal effect of an indorsement cannot he thus varied by parol. ${ }^{3}$ The answer states no defense, and judgment on the pleadings was properly ordered for plaintiff.

The judgment appealed from is affirmed."

\section{REstrictire IndoRSEMENT.}

\section{$\S 66$}

POWER $v$. FINNIE.

4 CALL (VA.) 411 . 1797.

Action by Power against drawer (Finnie) and payee-indorser (Tabb) upon a bill indorsed by Tabb in these words: "Pay the within contents to Jack Power only." There is a good defense (of which evidence is offered and received against plaintiff's objection), unless plaintiff is a bona fide holder for value. Judgment for defendant. Plaintiff appeals.

Rosne, Junge. - In the case of a negotiable bill no consideration is necessary to be proved, and the indorsee is not affected by the want of it. But a negotiahle bill may he restrained by special indorsement, as was decirled in the case of Ancher v. The Bank (Dongl. $615)$ : and, in questions upon such restrictions, the intent must be collected from the face of the indorsement only. An absolute indorsement imports, upon the face of it, a valuable consideration received, and that the payee has transferred his right; after which receipt and sale, he can have no pretense for limiting the indorement, as it must be immaterial to him, to whom it is paid. But a limited indorsement is a presumptive evidence that the indorse is agent only; otherwise it would he his interest not to aceept of it in that form, as it would impede the future transfer of the hill.

Therefore, whenever such a prohibition appears, it may, I think, be inferred, that the indorsement was not intended to he absolute. If the transfer to Power had, in fact, been ahoolinte, his interest

3 This doe not apply to "irregular indoraementa." Peterson v, Russell, 62 Minn. 220. See Neg. Inst. I... \$ฺ̧ 113, 114. - H.

- Whetfer a blank indorsement is a written contract and no not to be varied by parol. or evidenee of a contract not yet reducerl in writing and sn subjert to establishment by parnl, is open to diapiite. 1 Daniel on Neg. Inst., ss 717-723. See post. p. 485. note. - J. ISee Johnseon v. Srhnabaum, 86 Ark. 82. reported in 17 I. N. S. 838 with note entitled "Right to ahow by parol that indorsement unrestricted in form was made for purposes of collection only." - C.1 
would have prompted him to ohject to the words restricting the negotiahility. When the restrietion would lave temied to kessen the ralue of the hill. 'The presimption, therefore, is fair, that no consideration was paid for it: hut that presumption might have been repelled by proving a consideration actually paid. 'That, lowever, was not done: and, therefore, I infer that Power was an agent only, and not a purchaser. I think, therefore, that the evidence was proper.

lileming, Junge. - " On the present oceasion, the indorsement is to Jack Power or his order only; which furnishes a strong presumption that he was but an agent, and paid no consideration for the hill, as there is no evidence to the contrary."

Garington, Jubge. - "Something must have been meant by this indorsement so out of the common way. It affords a very strong presumption that the endorsee was an agent only."

PExnletos, Presinent. - "The word only which is not commonly used, could have been used for no other purpose than to restrict the negotiability of the bill, and make Power an agent."

Judgment affirmed. ${ }^{5}$

$\S 66$

\section{LEAVITT $\because$ PUTNAM.}

3 NEW YORK, 494. - 1850.

IIurleut, J. - On the 29th day of August, 184t, Messrs. J. W. $\&$ R. Leavitt made their note for $\$ 1,5 \% 0.52$, payahle to the order of T. Putnam \& ( o. (the defendants), eight months after date. A few days after the maturity of the note the defendants indorsed it as follows: "Pay the within to $A$. Thacher, value received. May 21, 1845. T. Putnam \& Co." Thacher indorsed withont recomrse, and delivered the note for a valuable consideration to the American Exchange Bank, in whose hehalf this action is brought.

On the trial the defendants urged, among other grounds of objertion to the plaintiffs' recovery, that the defendants' indorsement was

: "If the worda "to A. B. only' were inserted, I should tlink it would not he restrictive; at loast it should be left to the jury . . . Where a man says 'pay to A.' the law says it is 'to A. or order.' He then says, I intend it should not he so. What signifies what you intend. The law intends otherwise." Desisos. J., in Edie v. East India Co., l Wm. BI. 295

"Whether this indorsemen; is only an authority to $A$. B. to receive the money for the $11-0$ of the indorser, or for his own use, if marle for value received, or whether in this last ease the restriction is not void, and A. B. may further negotiate it. serms not to he settled. If the property of the note be vested in A. B.. perhaps he will hold it with its negotiable grality, notwithstanding the restrintion. But of this we give no opinion." Pabsons, C. J., in Rice v. Stcarns, 3 Mass. 225 , post. - $\mathrm{H}$. 
in effect a new draft payable to Thacher only, and not negotiable, so that no action could be maintained upon it in the name of the plaintiff. In this they were sustained by the court, and the plaintiff was nonsuited.

The other ofjections taken by the defendants on their motion for a nonsuit were not considered by the eourt below, and under the cireumstances of the case cannot be noticel on this appeal: so that the only thing for us to consider is, whether the indorsement of a note malde after dur. differs from one made before maturity in respect to its negotiability? ${ }^{\circ}$

It was conceder on the argument that no express authority could be found sustaining the distinction upon which the derision of the superior court was hased; but it was urged that the defense conld be sustaincel upon the prineiple that a dishonored note loses its mercantile character, and its indorsement beromes an original contract which must he made expressly negotiable in terms, or it could not be held to prosetes the character of negrotiability. There is unquestionably a diflerence brtween the indorsement of a note after due and one while it is mmming to maturity, hut this relates only to a single point arising from the necessity of the case, to wit, the time of payment, which, in the latter indorsement, is fixed at a future day ly the express agreement of the parties, while in the former, it is declared ly law to be within a reasonable time, upon demand. But in all nother respects the contrict is the same as an indorsement in the usual onurse of trade: and it is difficult to peresive how the single dillerenes roforrul to can at all affect the necotiability of the indorsement. A lill for note does not lose its negotialile character by being dishonored. Lo forimally negotiable, it may still pase fromband to hand ad infinitum until paid by the Irawer. Moreoser, the indorser after maturity writes in the same form and is bound only upon the same condition of drmand upon the drawer and nofier of nonjayment as ante other inderer. Thus the paper preserves its merrantile extemen and retatns the main attributes of a proper hill or note, and cirwlates as surde in the commercial community.

lixerptious to a gentrial rule affeeting so important and numorous a class of transartions as the one mudor consideration must he pro-

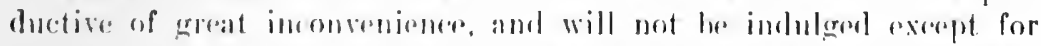
urgent reasons: amb wothing has heen marle to appear in the arentment or serems to exist in the cases. which warrants the court in treating the ordinary indorsement of a dishonorenl hill or wote as without the law merelant and not negotialsle. While it was questioned whether such a note was negotiable, and whether the imlorser was chargeable except upon the usual condition of demand and 
notice, there was perhaps reason enough to sustain the decision of the court below. But since both the note and its indorsement, by a long course of decisions, have been treated as within the law merchant in respect to their main attributes, the indorsement ought to he regarded as negotiable to the same extent as an indorsement before maturity. The latter follow's the nature of the original bill and is equally negotiable. (Edie v. Eust India Co., 2 Burr. 1216 ; Milford v. Walcott. 1 Ld. Raym. 574; Allwood v. Hazelton, 2 Bailey's S. C. R. $45 \%$; Bishop v. Dexter, 2 Conn. R 419 ; Berry v. Robinson, 9. John. 121.)

The note in the present case was upon its face transferable, and its character in respect to negotiability could only have heen changed by an indorsement containing express words of restriction. The defendant's indorsement was a full one, containing the name of the person in whose faror it was made, but omitting the words " or order," the legal effect of which was, nevertheless, to make the note payable to him or his order, and his indorsement therefore was effectual to transfer the note to the plaintiff. (Chitty on Bills, 136; Story on Prom. Notes, $\$$ 139.)

I am of opinion that the judgment of the superior court should be reversed, and a new trial awarded.

Judgment reversed.

\section{$\$ 66$ CENTRAL RAILROAD $\because$ FIRST NATIONAL BANK OF LY TCIIRUTR.}

73 Georgia. 383. - 1884.

Blandford, Justice. - The defendant in error brought its action for money had and received, against the plaintiff in error, alleging that plaintiff in error had received from one Mayer and Glauber a sum of money due on a draft of which the following is a copy: \$276.85.

I.y velhurg, VA.. Feb. 17, 1881.

Sixty days after date pay to the order of Allen W. Tally, Cashier, two hundred and seventy-six dollars and eighty-five eents. with current rate of exchange on New York, value receiverh and eharge the same to aecount of

To S. MAYer \& GiAuber,

IIUNTER \& Marshall.

Albany. Georgia.

[On the hack of the draft were the following indorsements: First]:

Pay W. H. Patterson. cashier, or order, for collection for account of First National Bank, Lynchburg, Va.

[Second] :

(Signed) Allen W. TAlly, Cashier.

“Pay to John A. Davis, agent, 7 or order, for account of Citizens' Bank of Georgia, Atlanta, Ga.

(Signed) W. H. Patterson, Cashier."

7 Davis was the agent of the railroad company, the plaintiff in error.- $\mathrm{C}$. 
The evidence showed that the plaintiff in error had collected this draft; upon demand being made on plaintiff in error for the payment of the money thus collected by the attorney for defendant in error, payment was refused; the railroad claimed that the Citizens' Bank was indebted to it, and that they had given that bank credit for the amount thus collected. It was further shown that the Citizens' Bank had failed before the money had been collected by the Central Railroad and Banking Company.

The court below held that the Central Railroad and Banking Company was liable to the defendant in-error, and this ruling is assigned as error.

1. The qualified indorsements on the back of this draft by the cashier of The First National Bank of Lynchburg, whereby he directs payment to be made to W. H. Patterson, cashier of the Citizens' Bank, or order, for collection for account of First National Bank, Lynchburg, Va., was nothing more nor less than a warrant of attorney authorizing the indorsee to collect the amount due on the draft for the indorser. It conveyed no title to the paper, but was notice to all persons subsequently dealing with this paper, that defendant in error had not parted with the title or intended to transfer the ownership of the proceeds to another. The legal import and effect of the indorsement was to notify the plaintiff in error that the defemdant in error was the owner of the draft, and that the Citizens' Bank was merely its agent for collection; that a qualified title for this purpose only, and no other, was in the Citizens' Bank. (More on Banks, 5i? Swift v. Ty/son, 16 Peters, 1:1 Howard, 234; 3 Penn. Stat. $348 ; 22$ Md. $148 ; 1$ Wall. $166 ; 102$ U. S. $658 ; 1$ Pond, $389 ; 11$ R. I. $119 ; 51$ Iowa, 15. $)^{8}$

2. But it is insisted that there was no privity between these parties respecting the transaction, so as to authorize this action. When the plaintiff in error received from Mayer \& Glaulor the money due on

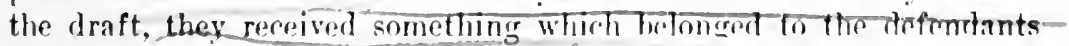
in error: it was their money, and this are put them in privity for the purpose of this artion. Where one person is in posession of money which of right and in equnity belongs to another, this action may he maintained for its recovery. 'The law implies a promise on the part of any person who has receiver the money of aunther to pay that person on demand. 'The reception of money hy one and the demand by the other makes all the privity that is necessary to maintain this action.

And we are clear that plaintiff in error lad no right to rutain the

- Accord: Commerrial Bank v. Armatrong. 148 U. S. 50: Butchers'. rete., Bank v. Hubbell, 117 N. Y. 384 ; Frecman's Bank v. National Tube Works, 151 Mass. 413. $-\mathrm{H}$. 
procerers of this draft as palyment of or security for any balance which the C'itizens' Bank might be due it.

Judgment aflirmed. ${ }^{9}$

58 New Jershy Law, $162,-1895$.

Vas Srckes, J. - This is an action to recover the anount due upon the following promissory note:

$\$ 4.196 .25$.

Trenton, N. .J., JeIny. 30. 1891.

Four montlis after date, we promise to pay to the order of ourselves, fortynine hundred and eighty-six $25 / 100$ dollats at the ofliee of Wm. 13. Brook \& Co.. at 40 John St., New York City, value received.

[Indorsed]

Brook. Oliphant \& Co.

For disconnt and eredit of the Central Rubber Solling (o.

Joun Il. Britton, Treas.

This note was executed by Bronk, one of the firm of Brook, Oliphant \& Company, in faror of said firm, and passed to the Central Rubber Company', withont consideration.

It was discounted in New York for the Central Rubber Company, and was taken up by that company before it was due and put in its safe at 'Trenton, in this State.

The manager of the Contral Rubler Company, after that and before the maturity of the note, passed it to Vannest, who is the plaintiff below.

The makers of the note set in in defense in the trial court - first, that the plaintiff below acquired no legal title to the note under the special indorsement of the treasurer of the Central Rubber Company; secondly, that the plaintiff below was not a bona fide holder for value. ${ }^{1}$

It is undoubtedly true that if the note had fallen into the hands of anyone before it lad reached the bank which discounted it, he could not have acquired or passecl to another any valid title to it.

The special indorsement would have been notice of an infirmity in the hrikder's title.

9 If a bill or mote be indorsed without restriction by the payce and deposited in bauk for eollection and the banker pledge or soll it, the pledgee or buyer gets goorl title. Collins v. Martin. I Posanquet \& Puller. 648; Ayer v. Tillden, 15 Gray (Mass.) 178: Bank v. Vanderhorst. 32 N. Y. 553. But if the hill or note be restrictively inlorsed "for collection" or "oll iceount of A." (indorser), or B. ia third person), the plodgee or buyer gets no title other than that held by the bank as agent or trustee. Treuttel v. Barandon, 8 Taunton, 100; Lloyd v. Sigourney, 5 Bingham, 525: First N. R. of Clarion v. Greeg!, 79 Pa. St. 384 (semble). - H.

1 The portion of the opjinion relating to this second point is omitted. - C. 
But after that indorsement had served its purpose, and the note eame back to the Central Rubber Company, that company, by passing it to Vannest, gave him as good a title as if the indorsement had not been special but general.

There is no error in the proceedings below, and, therefore, the judgment should be affimed. ${ }^{2}$

HOOK v. PRATT.

78 New YORK, $371 .-1879$.

THIs action was brought by plaintiff, as trustee of Charles $H$. Hook, against defendants, as executors of the will of James P. Haskin, deceased, upon a draft signed and indorsed by said testator, of which the following is a eopy:

$\$ 5,000$.

Srracuse, N. Y., September 13, 1872.

ORRIN WelciI, Treasurer Morris Run Coal Co. Pay to the order of myself, one year after date, five thousand dollars, for value receivers.

(Signed) J. P. Haskin.

[Indorsed] Pay to the order of Mrs. Mary Hook, $35 \mathrm{King}$, for the benefit of her son Charlie.

(Signed) J. P. Haskin.

Defendants waived demand upon the drawee and notice of protest.

Upon the trial defendants' counsel moved for a nonsuit, in substanee, upon the ground that the indorsement was restrictive and did not import a consideration, but imported a gift. 'The motion was denied and said comnsel excepted.

Rap.s.Lo, J. - The point mainly relied upon by the appellant is that the draft and indorsement npon which this action is brought do not on their face import a consideration. ${ }^{3}$ 'The draft was drawn by the defendants' testator upon the treasurer of an ineorporated company, payable to the drawrors own order and purported to be for

2 In Hoore v. First Nat. Bank, 38 Colo. 336 (quoting the hearnote), "a note, after havine locen indorsed to a bank, was indorsod by the bank to its

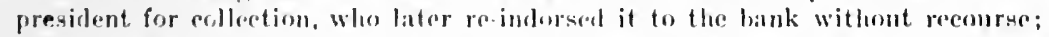
and the latter, without striking out ite indorsenout to the prosident, or aduling further indorsemont, transforred the note by dolivery to plantiof. The inclorse. ment was not loft by mintake, nceident, or overmight. Held, that the bunk is estopped to droy its liability, regardluse of whether the re-issur was luefore or after maturity; and that such indoroment mosed the lonal title. fixol the indorarer's liability, and authorizal un artion direct ngainat it as indorapr." Reported with notre in 10 1. N. S. 260 (where the correctures of the drecision

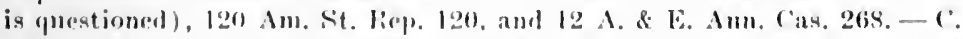

3 In the eourt holow it was said that "The only question in this mase is whether the paper sued on imports a consideration. in view of the restrictive character of the indorsmont, or if it does not, whether a consideration was proved." I4 IIun, 396, 397.-C. 
value received. It was indorsed by the drawer by a special indorsement " "ay to the order of Mrs. Mary llook, for the benefit of her son Charlie." 'Phe appellant chams that this is one of those restrictive indorsements which do not purport to he made for a consideration, and do not entitle the intorsce to maintain an action on the bill, without proving a consileration.

As a ceneral rule an indors'ment of a negotiable bill which purports to pass the tithe fo the hill to the indorsee, imports a eonsideration, and the hurlen of proving want of consideration rests upon the party alleging it. The restrictive indorsements which are held to negitive the presumption of a consideration are such as indicate that they are not intended to pass the title, lint merely to enable the indorsee to collect for the henefit of the indorser, such as indorsements "for collection" or others showing that the indorser is entitled to the proceeds. These ereate merely an agency, and negative the presumption of the transfer of the bill to the indorsee for a valuable consideration.

But where the indorsement purports to pass the title to the bill therein from the indorser, and divest him of all beneficial interest, a consideration for such transfer is presumed. All the cases cited by the counsel for the appellant rest upon these principles. The citation from 3 Kent Com. 92, states the prineiple to be that when the indorsement is a mere authority to receive the money for the use or according to the directions of the indorser, it is evidence that the indorsee did not give a valuable consideration for it and is not the absolute owner. This accords with the statement of the principle by Wilmot, J., in Edie v. E. Indir Co. (2 Burr. 122\%). So an indorsement "Pay to S. W., or older, for our use," (Sigourney v. Lloyd, 8 B. \& C. 622 : s. C. 3 Y. \& . . 220 ), was held to create a mere agency, and the addition even of the words "value received" to such an indorsement has been held not to vary its effect. (Wilson v. Holmes, 5 Mass. 543.) In Edie v. East India ('o. (2 Burr. 1221). the examples of restrictive inlorsements put by way of illustration are, "Pay to my steward and no other person," or "pay to my servant for my use." These show that there was no intention to pass the title to the bill: and the same effect has been given to an indorsement, "Pay to P. only." It was held that these words inclicated that the indorsee was agent only, and paid no eonsicleration for the bill, as a purchaser would not have accepted such an indorsement. (Power จ. Finnie, 4 Call [Va.], 411).

But an indorsement to one person for the use or benefit of another, affords no such indication. The indorser parts with his whole title to the bill, and the presumption is that he does so for a consideration. The only effect of such an indorsement, by way of restriction, is to give notice of the rights of the beneficiary named in the indorse- 
ment, and protect him against a misappropriation." When a bill is indorsed " Pay to A. or order ior the use of B.," A. cannot pass the bill off for his own debt, but he can by indorsing it transfer the title, and will hold the proceeds for the benefit of $\mathrm{B}$., and be accountable to hin for them. (Evans v. Cramlington, Carth. 5, affirmed in the Exchequer Chamber, 2 Vent. 309.) In Treuttel v. Barandon (S Taunt. 100), cited by the appellants, drafts payable to the drawer's own order were indorsed by him to De Roure \& Co., or order, "for the account of 'lrenttel \& Wurz." It appeared that De Roure \& Co. were the agents of Treuttel \& Wurz, and the latter were held entitled to maintain trover for the drafts against a party to whom De Roure \& Co. had pledged then for their own debt. There is nothing in this case to sustain the proposition that a draft thus drawn and indorsed does not import a consideration, or that the indorsee could not maintain an action upon it against the drawer and indorser without proving a consideration. The effeet of the special indorsement was simply to give notice of the interest of Treuttel $\&$ Wurz, and prevent De Roure \& Co. from appropriating the drafts to their own use. Blaine v. bouine (11 Rh. I. 119), is to the same point.

In the present case the indorsement did not purport to restrain the indorsee from negotiating the draft, for it was " Pay to the order of Mrs. Mary Hook" for the benefit of her son Charlie. She was constituter trustee of her son and held the legil title. (3 Kent's Com. 89.) The indorsement gave notice of the trust, so that if she had passed it off for her own debt, or in any ofluer manner indieating that the transfer was in violation of the trust, hre transferee would take it subject to the trust, but there was nothing reserved to the drawer and indorser. He retained no intorest in it. The presumption is that the draft was drawn and indorsed by hin for a consideration received either from the indorsen or the henoficiary. If the yonth of the beneficiary should be dremed to alford a prosmmption that no consideration was paid by him, thre presmuption would he that it emanated from his mother. 'The farets ardmitted on the frial do not establish that the consiblomtion was illerall. 'Thoy show that the hoy lived with his mothre and was taken rare of hy hror. Thore is nothing illegal in an mudertaking by a putative hather on support his illogitimate child, or to pay a sum of money in eomsideration of such suptport beine furnishal by another, thomgh it he the mother of the child. If such was tho eonsidration of this ololigation, and it was furnished by Mrs. Hook, shre was at liberty to take it, jayahlo to herself in her own right, or for the bunofit of her rhild. (I/irks v. Gregory, 8 C. B.

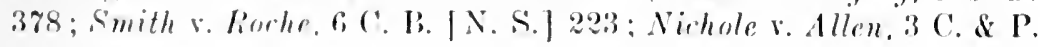

- Neg. Inst. L., \& \$1, post. - H. 
3t; denninys v. Broun, ! Mees. \& 11 . 496 ; Knowlman v. Bluett, 9 L. R. [Exeh.] 1, 30\%; Bunn v. II inlhrop, 1 J. Ch. 33\%, 338.)

'The judgment should be affirmed."

\section{SMITH $v$. BAYER.}

46 Oregon, $143 .-1905$.

'T'H is is an action on a pronissory note for $\$ 290$, executed and delivered by the defendants to the Concordia Loan \& Trust Company of Kansas City, No., on January 30, 1896, due on or before August 1st following. 'The complaint alleges the execution of the note, its indorsenent to the plaintiff before maturity, the naking of certain payments thereon by defendants, and prays judgment against them for the balance. 'The answer admits the gemmineness of the note, denies that it was indorsed to the plaintiff before maturity at all, and aflirmatively alleges that it remained the property of the payee named therein until after maturity, when it was transferred to the Fidelity Trust Company, and that thereafter the delendants paid the note to the trust company and satisfied it in full. 'The reply denies the allegations of the answer, and affirmatively pleads that at all the times mentioned the plaintiff was and now is the owner in his own right of two-serenths of the note. and since the 21 st day of fuly, 1896 , has been and now is the owner of the remaining five-sevenths for collection. Tpon the trial plaintiff produced the note, with an indorsement thereon as follows: "Pay to the order of Milton W. Smith for collection and return to Concordia Loan \& Trust Company, $\Lambda$. D. Rider, treasurer, O. K. F. Amelnng." He testified that he received the note in due course of mail from the loan and trust company, inclosed in a letter which the witness produced, and which stated, in substance, that the note was remitted for collection. $* * *$ The note was then armitted in evidence over defendants' oljection on the ground that the indorsement dil not transfer such title to the plaintiff as would support an action thereon in his own name, and because the genuineness of thr indorsinent had not been sufficiently proved.* The witness was also prrmittred to testify, over defendants' objection and exception, that he was in fact the ownor in his own right of two-sevenths of the note. and the court instructer the jury that any settlement made by the defendants with the paree or owner of the note after the indorsement therenf to the plaintiff would not be a defonse against the

"Whether the indorsenent "pay to A. B. trustee," is restrictive, sce discussion of instruments payable "to A. B. trustee," post, p. 354. - H.

- That part of the case relating to the genuinesess of the indorsement is omitted. - C. 
plaintiff's two-sevenths interest therein, although it would be such defense against the other five-serenths. The verdiet and judgment were in favor of the plaintiff, and the defendants appeal.

BEAN, J. * * * The only points of real importance on this appeal are: (1) Whether the indorsement. being on its face "for eolleetion and return" to the payce, vested plaintiff with such a title as will enable him to maintain an action theren in his own name: and, if so, (2) whether the conrt erred in admitting parol testimony tending to show that plaintiff was in fact the owner of two-sevenths of the note, and in instructing the jury that, if such was the case, any settlement with the payee or assignee subsequent to the date of the indorsement to plaintiff would be no defense as against plaintiff's two-sevenths.

The indorsement of a promissory note by the payee with the words "for collection," or the like, is not strictly a contract of indorsement, but rather the creation of a power, the indorsce being the mere agent of the indorser to receive and enforce payment for his use. The title to the note and the proceeds thereof remain in the payee, and he may maintain suitable actions and proceedings to enforce his right. White v. National Bank. 102 U. S. 658; Commercial Bank of Pennsyliania v. Armstrong, 1t8 IT. S. 50; Sweney v. Easter. 1 Wall. 166: Williams, Dencon of Co. v. Jones, ir Ala. 294: People's Banle of Lowisburg v. Jefferson County Sarings Banli, 106 Ala. 52.1; Con/ral Railroad v. First National Bank of lynchburg, Virginia. is Ga. 383.

There is, in the absence of a statute. some conflict in the decisions as to whether such an indorsee can sue in his own name. The weight of authority seems to he in favor of his right to do so. $4 \mathrm{Am}$. \& Eng. Eney. Law (2d ed.), 274: Freeman v. Lxehange Bank, 87 Ga. 45; Roberts v. Parrish, 17 Or. 583; Falcomio v. Larsen, 31 Or. 137; Selover, Bank Collections, $\$ 28$. And it is now so provided by statute in this state. B. \& C. Comp. \$ 4439;" Selover, Negotiable Instrmments Law, § 15is: Crawforl, Nerr. Inst. Law, § fir. We are therefore of the opinion that the present action was rightfully brought in the name of the plaintiff.

It was open, however, as against him, to all defenses which eould have been made if the notes had remained in the hands of the indorser,

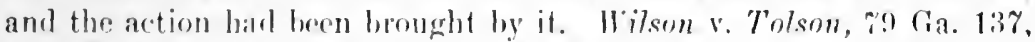

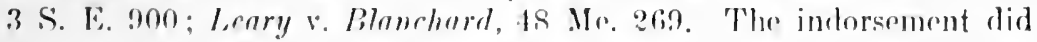
not pass the title, nor did it deprior the drefondants of any defense they may otherwise have against the note. It merely ereaterl the plaintiff the agent of the payee for collection with the right fo sure in his own name. The plain meaning of such an indorsement. as said by

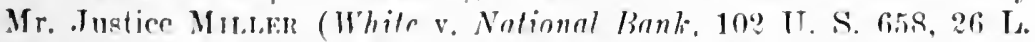
Ed. 250), is that the maker of the note "is to pay it to the indorsee

- N. Y., \$67. - C. 
for the use of the indorser. 'The indorsee is to receive it on account of the indorser. It does nof purport to transfer the title of the paper of the ownership of the money when received. Both these remain, by the reasomable and almost nocessary meaning of the language, in the indorser."

sirel heing the ellew of the restrictive indorsement and the character of the title arepuired hy the plaintiff by reason thereof, it necessarily foilows that lhe comt was in error in achitting evidence to combalict the combart of inclorsement by showing that the note was not transferred to the plaintill for collection as shown on its face, but that he actually owned two-serentbs thereof in his own right, and in instructing the jury that a settement made with-the payee after the indorsement to phaintill would be no defense against plaintiff's twosevenths. The contract of indorsement is in writing. 'The terms thereof' are plain and unambiguous, and parol evidence is not admissible to vary or contradict it. White v. National Bank, 102 U. S. 658, 26 L. Ed. 250 ; Lcary v. Blanchard, 48 Me. 269 ; Howe v. Taylor, 9 Or. 288.

The plaintiff's action is based on the indorsement, and not on any interest he may have in the note. He is made by the indorsement the mere agent of the payee for its collection. 'The defendants' obligation, notwithstanding the indorsement, is to the payee or subsequent owner of the note. and not to the plaintiff. If they settled and paid the note to the pave or assignee, such settlement is a complete defense to an action thereon by plaintiff as a mere agent for collection.

It may be suggested that, beeause the jury found a verdict in favor of plaintiff for the entire amount sued for, they must have found that the settlement alleged as a dofense was never made, and therefore the error of the court in cluarging the jury in relation thereto was harmless. The ruling of the court upon this point and its instructions to the jury injected into the case an issue not proper to be tried, the result of which was to confuse and mislead the jury, and we do not think it can be said that the error was harmless.

From these views it follows that the judgment of the court below must be reversed, and a new trial ordered. Many of the other questions argued in the briefs will probably not arise on a retrial, and nced not, therefore, be noticed at this time.

\section{\$ 67 BLeckley, C. J., in FREeman v. EXCHANGE BANK.}

$$
\text { S7 GeOrGiA, 45. - } 1891 \text {. }
$$

1. An indorsement for collection, or the like, is not a contract of indorsement, but the reation of a power, the indorsee being a mere agent to receive or enforce payment for the indorser's use. (Central 
Railroad v. First National Bank, 73 Ga. 383; Tiedeman, Com. Pap., $\S 268$; 1 Daniel, Neg. Inst., \& 698-698(d) ; ? Randolph, Com. Pap., $\S$ 724-5-6-ז, 1009; 1 Morse Banks, \$ 217 ; 2 Id. \$\$ 5\$3, 593; Bolles' Banks and Depositors, $\S \S 220,384(\mathrm{e})$, et seq.; Benj. Chalmers' Bills, Notes and Checks, (2 Am. ed.), 132; Commercial National Bank v. Armstrong, 39 Fed. Rep. 684 ; [s. c. 148 U. S. 50 ] ; National B. \& D. Bank v. Hubbell, 117 N. Y. 384.)

A suit is not maintainable by the indorsee against the indorser. (White v. National Bank, 102 U. S. 658. And see Lee v. Chillicothe Bank, 1 Bond, 38\%.)

To sue other parties in order to enforee payment is deemed within the delegated power of the agent; and by reason of the great faror shown by the law to eommercial paper, the restricted indorsee is allowed in some jurisdictions to sue in his own name. (Wilson v. Tolson, 79 Ga. 137; Boyd v. Corbitt, 37 Mich. 52; 2 Randolph, Com. Pap., § 726 ; Benj. Chalmers' Bills, Notes and Checks [2 Am. ed.], $133,149.)^{7}$

The maker of a restrieted indorsement ean follow the bill or its proceeds over any number of subsequent indorsements, the terms of his indorsement being notice of his title. (Elementary Works eited supra: First Nat'l Bank v. Reno. Co. Bank, 3 Fed. Rep. 25\%; Bank of the Metrop. v. First Nat'l Bank, 19 Id. 301; First Nat'l Bank v. Bank of Monroe, 33 Id. 408: In Re Armstrong, Id. 405; Commercial Nat'l Bank v. Hamilton, 42 Fed. Rep. 880.) The last ease is criticised from the standpoint of bankers, but only with reference to transmitting the proceeds of collection from the collecting hank to the intermediary through whom the hill was reeeived. 'The expert opinion seems to be that transmission according to enstom, hy correspondence and proper entries of dehit and credit founded thereon, the entries being made after collection, will serve commercially, and therefore legally, as the equivalent of paying over the money or forwarding it by, mail or express: and (ennseguently that transmission hy such entries, each bank making the appropriate entry itself, will discharge the collecting bank. (See 15 Bankers' Magazine, 241: 4 Banking Law Journal, 3.) The learnerl Unitorl States rircuit jurlge who decided the ease which is thus criticisol took a different view.

A deposit of paper in bank ly a enstomer, he indorsing it "For deposit," may operate to clothe the bank with title under ecrtain circumstances. (Wational Commerrial Bank v. Miller, if Ala. 168; 2 Morse on Banks, \& 5\%7.) But the general rule is, that by a restrietive indorsement the depositor retains the title. (Bolles on Banks and Depositors, \&220.)

TContra: Rork County N. B. v. Inllister, 21 Minn. 385. In any rvent, only the special indorsee can sue, Lairence v. Fussrll, $77 \mathrm{~Pa}$. St. 460. - H. 
[Held: 'That where A. deposited a bill with B. indorsed "for depesit to the credit of $A, "$ and B. indersed it, "Pay C. for collection ancount of $13, "$ and ('. collected it, the funds were subject to gamishment in C's hands by the creditors of $\mathrm{A}$., for as yet they had not actually been deposited in the hands of B. The legal import of the indorsement is to make B. an agent for collection and deposit. "'The proceeds would be inpressed with A.'s ownership until they were actually so deposited." ${ }^{s}$

\section{Qualified Indorsemen't.}

3 Massachusetts, $225 .-1807$.

Assumpsit by indorsee against makers, upon a note payable to Jonathan Symonds, or order, and indorsed by him in these words: "for value received $\mathbf{I}$ order the contents of this note to be paid to Merrick Rice at his own risk." The defendants denied their signatures, and Symonds was offered as a witness to prove the exeention of the note, and was objected to as a witness on the ground that he was interested. Objection overruled. Judgment for Plaintiff. Defendants appeal.

Punsoxs, C. J.-The interest of Symonds must depend on the effect of his indorsement.

A security negotiable in its creation must, furing its negotiation, preserve its negotiable ruality; otherwise, when assigned, the assignce would hold a contract by the assignment different from the contract assigned. It is for this reason settled that a negotiable note indorsed in blank, or by a direction to pay the contents to $\Lambda$. B., omitting the words, "or his order," is further negotiable by the holder under sueh indorsement. It is also settled that when a negotiable security is indorsed, " pay the contents to my use," or, "to the use of a third person." or, "carry this bill to the credit of a third person," such an inrlorsement is not an assignment of the security, but is only an anthority to pay the money agreeably to the direction of the indorsement. There are other restrieted indorsements also made: as "pay the contents to A. B. only." Whether this indorsement is only an anthority to $\Lambda$. B. to recive the money for the use of the

\& There is some conflict as to the legal effect of an indorsement "For Deposit." Some enurts hold that title pasces under such an indorsement. Diteh v. Wrstern N. B., 79 Mrd. 192: S. C.. 47 Am. St. Pep. 375 and nofe. Others hold that title toes unt pass. but that the hank is a hailee for collection until the money is actually in its hands, when it becomes a debtor as in the usual case of money deposits. Beal v. City of Somerville, 50 Fed. Rep. 647.- H. 
indorser, or for his own use, if made for value receired, or whether in this last case the restuituon is not roid, and $A$. Li. maly further negotiate it, seems not to be settled. If the poperty of the note be rested in A. B., perlaps he will hold it with its negutiable quality notwithstanding the restriction. But of this we give no opinion.

The case at bar is a restricted indorsement of anotlier lind, and which in practice is very common. The promisee of a negotiable note indorses it to a third person, or his order, for value received, stipulating that the indorser is not to be responsible, if the maker does not pay it. If, notwithstanding this stipulation, the indorser is answerable, if the maker do not pay the note, then the witness, Symonds, is interested, and ought not to have been sworn.

Upon consideration we are of opinion that the promisce, indorsing the note under this express stipulation, is not eventually holden to pay the note, if the maker should not. As the promisee had the property of the note, he might dispose of it on what terms he pleased, with the assent of the purchaser, and the latter cannot complain of the necessary effect of his own agreement; and the indorser cannot be charged upon his own contract, directly against the express intent of it. If this opinion is correct, Symonds, after this restricted indorsement, had no interest in the event of the suit, and was a competent witness.

Another point of some importance arises, which involves the question, whether, by this restricted indorsement, the property of the note passed to the indorsee, so that he may sue upon it in his own name. If the restriction applied to the quility of the contract, so as to render a negotiable security no longer negotiable, there would be some diffienlty in allowing, consistently with legal prineiples, an indorsement of this effect to oprerate as a transfer of the note. But this is not the effect of the restrietion; the note remains nexotiable in the hands of the indorse, although he has no remedy against the indorser: and in whose hands soever the note may enme, the maker is still liahle, aceorling to the terms of his original entract. to pay to the promises or his order. 'The note, therefore, boing the absolute property of the plaintiff, and symonds lwing a competent witness, the verdict must stand, and judgment be chtered accordingly.

Puacterte sued upon a negotialike instrument which had been transferred to him by the following indorement: "For value receiverl, I hereby transfer and assign all my right, title and interest in and to the within note to I. I). Evans," etc. Judgment for plaintiff and defendant appeals. 
WALKEl, J. * * *

'There is one other matter which reguires some attention. The defendant contended that the phintill was not a holder in due course,

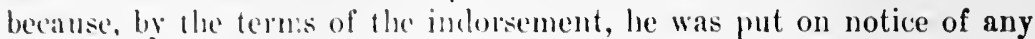
and all equitics amel defonses of the maker as against the payee, Askew, the reason heing that only the right and title of the payee was transferred and the indorse ancuined no better title under such indorsement than his indorser limsolf hal, but, ex ri termini only his right and title, which were sulject to the defense set up in this action.

There was at one time very stoong and convineing authority for such a position, Aniba v. Ieomans, $39 \mathrm{Mich}$. 171, and there was much also said against it, 1 Daniel Neg. Inst. (5th ed.) $\S 688 \mathrm{c}$. But we think the controversy has finally heen settled by the "Negotiable Instruments Law" as recently adopted, Revisal 1905, c. 54.

Ođrs is a qualified indorsement, under Revisal 1905, section 2187, and while the indorser is constituted a mere assignor of the title to the instrument, it is provided that such an indorsement shall not impair its negotiability. A qualified indorsement may, by the express terms of that section, be made by adding to the endorser's signature the words " without recourse, or any words of similar import." It has been settled in commercial law that a transfer by indorsement of the "right and title" of the payee or an indorser to a negotiable note is equivalent to an indorsement "withont recourse" and words such as were used in this case are therefore in their meaning or "import" similar to such an indorsement, and this is their reasonable interpretation. 1 Daniel, supra, $\$ \$ 700$ and 700a ; Norton on Bills and Notes (3d Ed.) 120; Hailey v. Falconer, 32 Ala. 536; Rice v. Stearns, 3 Mass. 225; Randolph Com. Paper (2d Ed.), $\$ \$ 721,722,1008$; Goddar v. Lyman, 14 Pick. (Mass.) 268; Borden v. Clarh, 26 Mich. 410; Eaton \& Gilbert on Commercial Paper, $\S 61$.

However the law may have been, it is now true, as it appears from the statute and the anthorities just cited, that such an indorsement does not, in law, discredit the paper or even bring it under suspicion, nor does it in any degree affect its negotiability. The indorsee is supposed to take it on the credit of the other parties to the instrument, Revisal 1905, $\$ 218 \%$, thongh the indorser may still be liable on certain warranties specified in the statute. Revisal 1905, $\$ 2214 .^{1}$ This conclusion we helieve to be in accord with the intention of the Jegislature in enacting the Negotiable Instruments I aw, as the leading purpose was to afford as much protection to the holders of commercial paper as is consistent with a just regard for the rights of other interested parties, and, by freeing its transfer of unnecessary fetters, to

- N. Y., \& 68. - C.

1. Y. 115. On this point, see also State v. Corning St. Sav. Rk., 139 Iowa, 338. - C. 
promote its easy eireulation and to give it greater currency as a medium of exchange. Our decision on this part of the case is confined to the particular evidence rejected and does not extend to any other offer of proof made by the defendant. If the defendant is able to show that the note was indorsed to the plaintiff after its maturity or that the latter is not, in fact, a purchaser for value and without notice, his defense will be available to him, but the burden to establish either of those facts is upon the defendant, as the plaintiff is deemed prima facie to be a holder in due course if he has possession of the note under the indorsement. ${ }^{2}$

[On other grounds, however, the judgment was reversed and a new trial granted.]

\section{Conditional Indorsement.}

Srofford, J. - This suit is brought against the indorser of a promissory note of the following tenor:

Dovalosonville, 30th Oct., 1851.

One year after date, I promise to pay to the order of Robert R. Barrow the sum of five hundred dollars, for value received, payable at the office of the Recorder, Donaldsonville.

[The indorsement is in these words:]

(Signed) Jorr Hutson.

Hovma, Parish of Throbenne.

I indorse the within note for the henefit of Mrs. Hutson in the purchase of a tract of land from Gov. H. Johnson.

(Signed) R. R. BArrow.

The defendant pleaded that this restrictive indorsement does not bind him, inasmuch as the special object for which it was given was never consummated, Mrs. Hutson not having purchased a tract of land from the plaintiT. Johnson.

There was judgment in the defendant's famo, and the plaintiff has appealed.

It is needless to recapitulate any other facts than that Mrs. Hutson did not buy a tract of land from Henry Johnson, nor contract to do so in any manner that could bind her.

The condition with which the defendant elogged his indorsement of the note never having been accomplished, the plaintiff has no action against him.

The judgment is, therefore, affirmed with costs.s

2 Accord: Lomax v. Picot, 2 Randolph (Va.) 247. - C.

"In Kobertaon v. Kensington (4 Taunt. 30), the imborament was " Pay the within sum to A., or order, "pon my name appenring in the 'Gazette" an 


\title{
IV. Indorsement: Methods and effect.
}

\section{Indorshanet of Instrumen't Payable to Bearer.}

$\$ 70$

\author{
lIIELR v. 'TAINTOR.
}

4 ALLF (MASS.) 356 . - 1862.

Costract upon the following promissory note: Silor.

LEE, Dec. $1,1860$.

Six months from date, for value received, I promise to pay Stephen $\mathrm{F}$ Avery, or leater, one lundred and seven dollars, with use.

М.BERT J. TAINTOR.

['The note hore the following indorsement:]

lay L. A. Bliss, cashier, or orter.

Warrex Newton, Cashier.

At the trial in the superior court, it appeared that the plaintiff had purchased the note in suit before it hecame due for a full consideration. but the bill of exceptions stated that " there was no cridence that F. A. Pliss, to whom said note had been indorsed, had transferred or indorsed said note to the plaintilf;" or "that the plaintiff had any title in said note from said Bliss, or that said note was sued with the knowledge or assent of said liliss." Rockwell, J., ruled that the plaintiff was entitled to recover, and the jury returned a verdiet aceordingly; and the defendant alleged exeeptions.

Bigetow, C.J.- The entract of the promisor of the note declared on is to pay the sum due on the note at its maturity to the person who shall then be the bearer. 'The production of the note by the plaintiff is therefore evidence of his title; and, aceompanied as it was in the present case with proof that the plaintilf lad beeme the owner of the note hy purchase before it became due, established a conclusive right to recover against the defendant.

en-ign in any regiment of the line, between the lat and the b4th, if within two montlis from this date." In thi-form the bill was acerpted by defendants, who suberpuently paid the hill to F... a remote indorsee of $A$. The payer's name did not appear in the 'Gazette', and he brought an aetion against the acceptor. Mrld: plaintiff could recover. It is the rule of this ease that is changuel iy \& 69 of the Nog. Tnst. Law. A comblional indorsement does not affect the negotiahility of the in-trument. Tappan v. Fily. 15 Wond. (N. Y.) 362. The indorsen is a truster for the conditional indorser if the condition is not fulfillerl. - 11 .

["The paree intorses to A., specifying in the indorsement that it is upon the pxprese erondition preeedent that the indorse shall within two days deliver to inrorser a errtain horse. The endition is not fulfilferl. At maturity the maker pays the indorsee. At common law the maker's payment would not he availing, and the indorser could collect from lim. Robertson v. Fensington, 4. Taunt. 31. The section ehanges this and protects the makel'. The indorger must lonk to the indorse for redress." Professor I. M. Greeley in 2 Ill. Law Rev., at p. 151. - C.1 
The indorsenent of a third person, directing the payment of the note to be made to the order of another, did not ehange the contract of the promisor, or enable him to set up in defense that the plaintiff's title was imperfect, merely because he had not obtained the signature of the person to whom some intermediate holder had ordered the note: to be paid. (Wilbour v. Turner, 5 Pick. 526; Waynam v. Bend, 1 Camp. 175; Story on Notes, § 132.)

Exceptions overruled.

\section{JOHNSON $v$. MITCHELL.}

50 Texas, 212 . -1878.

THE facts are stated in the opinion.

Gould, Associate Justice. - This suit was brought by B. F. Mitchell against appellants. W. L. Johnson and C. R. Bedford, the makers of a promissory note, payable January 1,1873 , to $\mathrm{J}$. W. Crabtree, or bearer, and against Crabtree, who had indorsed the note as follows: "I hereby assign the within note to S. L. Gilbert for value received, and guarantee the solvency of the makers of said note, 11th of September, 1873. J. W. Crabtree."

'The averments of Mitchell's petition as to his right or title to the instrument sued on were, that he was the legal holder and owner of the note; that Crabtree sold and transferred it to Gilbert, setting out the assignment as indorsed, and that, after said transfer, he, (plaintiff) purchased the note from Gilbert, who transferred it to him by delivery. The only evidence of ownership introduced by Mitchell was the note and indorsement. The defendants harl all filed a general denial, but produced no evidence. A jury heing waived, the court gave judgment against Johnson and Bedford as principals and Crabtree as gualrantee. Johnson and Bedford asked for a new trial, claiming that the evidence was insufficient to support the judgruent: and their motion being overruled, they alone have appealed.

It is insisted, on their part. that the production of the note, transferred as it was to Gibert, did not establish that Miteholl was the legal holder or owner.

As Crabtree Inos not complain, the sole question is as to the legal effect of poserssion of a note payable to bearer and indorsed in full by the payere, as against the makers.

Feeling that miformity of derision, in all cases important, is not least so in questions of commereial law, and failung to find decisions directly in point, we have given the anthorities bearing on the question a eareful examination.

According to the elementary authorities, a bill or note payable to order and indorsed in blank, so long as the indorsement continues 
blank, "is in effect payable to bearer." (Chitty on Bills [11th ed.] :.? ; 3 Kent [9th ed.] side $\%$. 89; Story on Bills, $\S 60$; 2 Pars. on Notes and Bills, 1. 19, note w; Edws. on Bills and Notes, 131, 269 ; 1 Din'l. on Neg. Inat. $\$$ 6933; Greeneaux v. Whecler, 6 Tex. 522; Wothered v. Simith, 9 Tex. 6ist; Whithed v. MeAdams, 18 'Tex. 553; Ross r. smith, 19 'Tex. 19?.)

Lord Mansfield said, in Peacock v. Rhodes: "I sce no difference between a note indorsed in blank and one payable to bearer;" and Chancellor Kent said, in Conroy v. Warren: "A note indorsed in blank and one payable to bearer are of the same nature. They both go by delivery, and possession passes property in both eases." (2 Dong. $636 ; 3$ Johns. Cases, 263.) So " a note payable to the maker's order becomes, in legal effect, when indorsed in blank, a note payable to bearer." (Byles on Bills, ch. 7, p. 68; Brown v. De Winton, 6 M. G. \& S. [60 Eng. Com. Law], 336.)

From these authorities, we conclude that Mitchell's possession was at least as satisfactory evidence of his ownership as it would have been had the note been payable to Crabtree or order, indorsed in blank by Crabtree, and then indorsed in full by Gilbert and someone other than Mitchell.

The negotiability of a note payable to bearer is certainly not further restrained by an indorsement in full than would be, by the same indorsement, the negotiability of a note payable to order and indorsed in blank by the payee. But the rule is well settled, that " if a bill be once indorsed in blank, though afterwards indorsed in full, it will still, as against the drawer, the payee, the acceptor, the hlank indorser, and all indorsers before him, be payable to bearer, though as against the special indorser himself title must be made through his indorsee." (Byles on Bills [5th ed.], 109; cited by Pollock in 2 Exch., infra; Chitty on Bills, 228, 230a; 3 Kent, side p. 90 ; Story on Prom. Notes, $\S 139 ; 2$ Pars. on Notes and Bills, 19, 26; Walker et al. v. McDonald, 2 Exch. [Welsby, H. \& G.], 531 ; citing Smith v. Clark, 1 Peak. N. P. C. 295 , and 1 Esp. 180; Mitchell v. Fuller, 15 Penn. 270 ; II uie v. Bailey, 16 La. 213; Liltle v. O'Brien, 9 Mass. 423; Dugan v. The Cnited Sitates, 3 Wheat. 172; Edw.'s on Bills and Notes, 275 ; citing Dolfus v. Frosch, 1 Denio, 367; Savanah National Bank v. IIaskins.)

We conelude, then, that however it might have been as against Crabtree, on which point we express no opinion, as against the makers of the note, its production by Mitchell was sufficient evidence of title.

It may he objected that the safe transmission, hy mail or otherwise, of notes and bills payable to bearer requires a different rule. The answer is, first, that such a consideration will not justify a departure by the courts from established prineiples and precedents, second, that what is known as a "restrictive" indorsement stops the currency of negotiable paper. (Chitty on Bills, 232; Story on Prom. 
Notes, $\S 142$, et seq.; 2 Pars. on Notes and Bills, 21 ; 1 Dan'l. on Neg. Inst., §698.)

Whilst we have disposed of the case on the assumption that Crabtree's transfer was equivalent to an indorsement in full to Gilbert or order, it is not intended to pass upon that question. Looking to the original nature of the note, which was that it should pass by delivery, and following what was long since said to be the settled rule, "that the assigninent follows the nature of the thing assigned," it may be questioned whether that indorsement does not receive full effeet by treating it as intended to secure Crabtree's liability as guarantor to Gilbert or bearer. (See Edie v. East India Co., 2 Burr. 1216; Lane v. Krekel, 22 Iowa, 400.)

The judgment is affirmed.

Affirmed.

\section{§0 MckeEhaN, The Negotiable Instruments Law.}

[41 A м. Law Reg., N. S., pages 454-462.]

Section 9 [N. Y., $\$ 28]$, par. 1-5:

"The instrument is payable to bearer (1) when it is expressed to be so payable; or (5) when the only or last indorsement is an indorsement in blank."

Section 40 [N. Y., $\S 70]$, which is involved in the discussion of Section 9, par. $1-5$, reads:

"When an instrument, payable to hearer, is indorsed specially, it may nevertheless be further negotiated by delivery; but the person indorsing specially is liable as indorser to only such holders as make title through his indorsement."

One or two preliminary obeervations may aid to a proper understanding of the eriticisms made of these sactions.

Blank indorsements were unknown to the early law of Bills and Notes, which required that the name of the indorsee should he contained in the indorsement. A practice later arose by which the payee often wrote only his own name on the hack of a bill, leaving a blank ahove his signature for the name of the intorser. Hence the term "blank indorsement." 'The hill lwing transfered in this condition, the transfere or any subsequent holder has an implied authority "to write above the signature an order of payment to himself, or to bearer, or to anyone to whom he may wish in turn to transfor the bill; and the blank indorsement, when so filled up, takes effect by relation from the time of the original delivery by the indorser." "The trangferee or any subserquent holder is the indorser's agent for this purpose.

4Ames' Cages on "Bills and Notes," Vol. 2, p. 837. 
For a long time it was necessary to exereise this authority and fill out all the hank indorsenents on a bill at or before trial. Gradually this last requirement was dispemsed with, and thus a bill payable to the orter of A.- with A.'s name witten on the back (no indorsee being named) eould be recovered on by the holder." Such instruments are said to be payable to bearer, and indeed they are so while the indorsement remains blank, but although the necessity of filling up a blank indorsement has been dispensed with, the right to do so has never been abridged, and the holder of a bill or note has to-day, as he always had, the right to fill up any or all blank indorsements on the instrument and lhus make it payable only to order.

It is to be olserved - and this is important - that these rules in no way violate the original tenor of the instrument. 'The maker has promised to pay "A or order" and $A$., by signing his name with a blank ahove it and handing it to B., authorizes B. or any subsequent holder to desiguate the person entitled to receive payment. Until. they do so designate him, the hokler is the man entitled. Now, suppose B. indorses specially to $\mathrm{C}$. or order, and then C. transfers the paper to D. hy mere delivery. Should D. be allowed to sue the maker as on a note pavable to hearer? No, for since the naker has: promised only to pay to A.'s order - and since $\mathrm{A}$. has given $\mathrm{B}$. or any holder anthority to designate the one to whom the sum shall be paid and since 13. has designated that it shall he paid "to C. or order"plainly no one who cannot trace title through $\mathrm{C}$. comes within the terms of the maker's promise. That is the locrical view, and it is the view that the merchants and bankers adopted, $i$. $e$., a blank indorsement of a note payable to order is controlled by the subsequent special indorsement.

But the courts held otherwise. In the ease of Smith v. Clarke, decided in 1:94, a bill originally payable to order, was indorsed in blank by the payee and was subsefuently indorsed specially. Lord Kenyon held that the bill was payable to learer as long as the first indrisement remained blank, and that the holder might therefore strike out the special indorsement and recover as on a bill payable to bearer. Smith v. Clarlie has been generally followed both in England and Anerica. ${ }^{7}$ This derision was opposed to the view held by

'This addrol a new torm to tlie indorser's order. $i . c$, that until the blank was filled up the instrument should be parable to hearer.

B Prake, 225. Although in a case which arose some years earlier. Ancher v. Bank of Englanl. 2 Douglas, p. 637 (1781). Lord Mansfield evidently agreed with the understandine of merchants that a blank indorsement was controlled by a suberquent sperial indorsement. However, the exact point decided in Smith v. Clorke was not involved in that ease.

7 Walker v. Macrlonald, 2 Wels. Hurl. \& Gordon. 52f (1848); Houie v. Bailey, 16 La. 213 (1840): Tational Bank v. Haskins, 101 Mass. 370 (1869); Bntry v. Eppinger, 34 Mich. 31 (1876); Watervliet Bank v. White, J Denio, 
the business community, and so, in 1882, framers of the English act, in order " to bring the law into accordance with the mereantile understanding, by making a special indorsement control a previous indorsement in blank," " provided in section 8, par. 3 :

"A bill is payable to bearer which is expressed to be so payable, or on whicl the only or last indorsement is an indorsement in blank."

The provisions of section 9 [N. Y., § 28], par. 1-5 of the American act are the same as those of the English act and werf inserted for the same reason.

It is further to be observed that Smith v. Clarke and all of the cases which follow it are eases of instruments originally payable to order. None of these cases contains a syllable about instruments originally made payable to bearer. There is an important distinetion between the two kinds of instruments. For reasons which I have referred to above, the eustom of merehants, which has now been adopted by both the English and American acts, says that in the case of an instrument originally payable to order, a blank indorsement is controlled by a subsequent special indorsement, because in such a case the maker's promise embraces only those who make title through the special indorsement. But a note originally payable to bearer is another matter. It is a violation of the plain tenor of such a note to treat it as other than payable to bearer. That is the maker's absolute promise to pay the bearer. His promise cannot be qualified or changed in any way hy a subsequent holder. The only effect of a special indorsement on such a note is that the indorser can be held only by those who make title through his indorsement. ${ }^{9}$

This distinction between instruments originally payable to hearer and instruments originally payahle to order and then indorsed in llank is preserved both in the English and American acts. Under loth acts, a note originally payable to bearer and specially indorsed continues payable to bearer, while an instrument originally payable $\therefore$ order is payable to bearer only when the last indorsenent is in l.lank. Professor Ames says that this distinetion is "illogieal and undesirable" though he gives us no reasons. Julge Brewster's reply is equally hrief: "The reison why such a rule is "illogieal and undesirable' is not "lear." It is submitterl that for the reasons noted above, this distinction is decidedly "logical," and inasmuch as it appears to olfain generally throughout the husiness rommmnity, its rontinued observance by the Code would seem to he "desirable."

Professor Ames further ariticises this sub-section, as follows:

608 (19.5): Prutz v. Winterlinttom, 5 Denio, 51 (18.17): French v. Barney, I Iredall, 219 (1840); Mitchell v. Fuller, 15 Pa, 268 (1850): Rand v. Dovey, 83 Pa. 280 (1877). Contra: Myers v. Friend, I Randolph, 12 (1821).

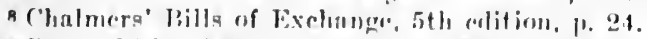

- Story, Bills of Fichange, \$207; Wond's Byles on Bills and Notes, 151. 
"If an instrument indorsed in blank and subsequently indorsed specially, so that it is no longer payable to bearer, is transferred by the special indorse by delivery merely, the transferee cannot sue parties prior to the special indorser in his own nanc, but only in the name of his assignor. 'This puts the assignee to unnecessary inconvenience. As owner of the instrument, although not, according to this subsection, holder, he ought to have the right to strike out the special indorsement, thus making the instrument once more payable to bearer, and as bearer to sue upon it in his own name." I. e., A. makes a note to B. or order. B. indorses in blank. C. indorses it "to D. or order" and D. delivers it (without indorsement) to F. Professor Ames thinks that E. should have the right to strike out C.'s indorsement and sue $A$. or $B$. as on a note payable to bearer.

Why should he have this right? It has long been the law (and still is under section 48)' that the holder may strike out any indorsements which are not necessary to his title. 'The law has never permitted him to strike ont indorsenents which are necessary to his title. ${ }^{2}$ Now, so long as Lord Kenyon's doctrine ${ }^{3}$ prevailed, the holder had the right to strike-out all indorsements subsequent to the first blank indorsement because the instrument was by that first blank indorsement payable to bearer and a subsequent special indorsement did not change its tenor and was therefore not necessary to his title. But this sub-section was inserted for the express purpose of doing away with Lord Kenyon's doctrine. Everyborly agrees that a blank indorsement of an instrument originally payable to order ought to be affected by a subsequent special indorsement. What does this change mean, then? Why it means (taking the case Professor Ames supposes for us) that by virtue of the special indorsement by $\mathrm{C}$. the note has again become payable only to order, and therefore C.'s indorsement cannot be stricken out by a subsequent holder because it is necessary to his title. Suppose D. had in his turn indorsed specially to F. The latter (though now a holder within the meaning of the act) could not strike out the indorsements of C. and D. Why? Because the instrument being now again payable to order only, the indorsements of C. and D. are necessary to his title, and so section 48 gives him no right to strike them out. Professor Ames says, "As owner of the instrument, he ought to bave the right." But ownership of a bill or note gives the holder no right to alter it - to change the tenor of any of the promises which it evidences.

1 Section 48 [N. Y., $\$ 78$ ]: “The holder may at any time strike out any indorsement which is not necessary to his title. The indorser whose indorsement is struek out, and all indorsers, subsequent to him are thereby relieved from liability on the instrument."

2 Story, Promissory Notes, \& 208.

3 mith v. Clarke, supra. 
Judge Brewster answers this criticism, however, in another way. IIe first agrees with Professor Ames that E. (in the case supposed) ought to be allowed to strike out C.'s special indorsement, and then he tries to give him this right. He first points to section 48 , which gives the right to strike out indorsements not necessary to title. But Professor Ames reminds him that section 48 confers this right only on holders and that $\mathrm{E}$. is not a holder, for "holder" is defined in section 191 [N. Y., $\$ 2]$ to mean "The payee or indorsee of a bill or note who is in possession of it, or the bearer thereof," and "bearer " is defined by the same section to mean "The person in possession of a bill or note which is payable to bearer." Both ignore the fact that in the case supposed C.'s indorsement is necessary to E.'s title.

In order to give $\mathrm{E}$. the right to sue the maker, Judge Brewster next refers to section 40 , which provides inter alia that "When an instrument payable to bearer is indorsed specially, it may nevertheless be further negotiated by delivery."

"This section," says Judge Brewster, "which authorizes a transfer by delivery seems to give the transferee the right to sue in his own name, otherwise the note would not be negotiated within the meaning of the act." But if section 40 applies to a note originally payable to order - then indorsed in blank and made payable to bearer - and then indorsed specially - if such an instrument may still be negotiated by delivery, then the rule of Smith v. Clarke is still in full force, and section 9, par. 5, which was inserted to overthrow Smith v. Clarke is a nullity. That carries us to the next criticism.

Professor Ames insists that section 40 completely nullifies section 9, par. 5, and that for this reason only may $\mathrm{E}$. sue the maker in the case supposed. His position is that sertion 9, par. 5, was inserted to change the old rule that an instrument "payable to bearer (or indorsed in blank)" "although afterwards specially indorsed, was still negotiable by delivery - that "then, in apparent forgetfulness of the effect of section 9, par. 5," section 40 was inserted providing that an instrument payable to bearer and indorsed sperially is still negotiable by delivery, the special indorse heing liable only to such as

- Mr. Farrell answers Professer Ambes as follows: "In muswr to this, it is necessary only fo say that in most jurisolictions he may hring suit in his own name, being the real party in interest." (The Negotiable Instruments Law, by Jno. Jawrence farrell. Brief of Phi Delia Phi, Vol. III, No. 2, First Quarter, 1901.) But the statutes which pormit an assignee to sue in his own name have effected merely a preeclural elange. It is still an assignee merely and can le met by any defenar arising ont of the instrument which eould be pleaded againat the ascignor. The question is not in whose name shall F. bring snit (a minor point), hut it is what right can E. assert.

s These are I'rofessor Ames' worls: lwt if by "Iayable to learer" he meana originally payable to hearer, it is submitted that neither smith v. Clarke nor any of the cases which follow it anv fny thing about such instruments. They are all cases of instruments origirally payable to order. 
make title through his indorsement, and that this seetion (40) thus elanges the law back to its former state.

Julge Brewster's answer is :

"Section 10 is claimed to be repugnant to section 9, par. 5, but this is not so. Seretion 9, par. 5, declares a note to be payable to bearer whou its last indorsment is in blank; 40 relates to a note when the tast indorsement is special, and provides that it ma!y then be transfered by delivery," in order to cover cases of good faith where title is frequently passed in that way, by persous ignorant of mercantile usage."

It is submitted that that is no answer, and for this reason. If a bill may be transferred by delivery, it is payable to bearer. Section 40, on Judge Brewster's reading, permits a bill whose last indorsement is special to be payable to bearer, yet section 9, par. 1-5 was inserted to permit only bills originally payable to bearer or whose last indorsement is in blank to be payable to bearer. ${ }^{7}$

I submit that in one way and one way only can these two sections be harmonized. If section 40 be interpreted as applying only to instruments originally payable to bearer, there can be no difficulty as to either section. ${ }^{8}$ True, it reads merely "When an instrument payable to bearer is indorsed specially," etc., and there is no denying

6 The italies are the reviewer's.

- Judge Brewster cites the following passage from the new Norton Horn Book by Mr. Tiffany, p. 116 , to prove that section 40 and section 9, par. 5, are in harmony: "An instrument which is originally payable to bearer, or which las been indorsed in blank. though afterwards specially indorsed, is still pay. able to bearer; except as to the special indorser, who, on such an indorsement, after such an indorsement, is only liable on his indorsement to such parties as make title through it."

It is submitted that the above tends to prove just the reverse, because if by section 40 an instrument originally payable to order, then indorsed in blank, and then specially indorsed, is still payable to bearer, section 9 , par. 5 (which intended to make only instruments whose last indorsement is in blank payable to bearer) is nullified.

ilr. C'rawford. the draughtsman of the Act, actually regards section 40 as emborlying the decision of smith v. Clark (Crawford's Annotated Negotiable Instruments Law, p. 41). Yet admittedly scetion 9, par. 5, was intended to overthrow that decision.

8/Supplementary Note. In commenting upon the above suggestion, Pro. fessor Ames las pointed out that section 9-1 includes, not only instruments originally payable to bearer, but also instruments originally payable to order and indorsed by the payce expressly "lay to bearer." 16 Marvard Law lReview, 257. This srems clearly right, and it would seem to show that the writer's suggestion should be modified to this extent, that section 40 should be construed as applying only to instruments expressly payable to bearer, thus including instruments originally so drawn, and also instruments originally drawn to order and then expressly indorsed by the holder "Pay to bearer." With this modification, the writer is still of opinion that the suggested construction of section 40 would satisfactorily harmonize that section with bection 9-5.) 
that if it meant only an instrument originally payable to bearer it slould have said so. At the same time, the words used are commonly understood to describe an instrument originally payable to hearer, and there is the additional reason that unless these words are so interpreted here, the section is diansetrically opposed to section 9 , par. 5, a conclusion plainly to be aroiled if possible. Again, section 9 , par. 5 , can be constrmed in only one way, while section 40 may be construed either as heingr opposed to or as being in harmony with it. Moreover, such an interpretation would be good law. At the opening of the discussion of these sections, some reasons were submitted why the distinetion between instruments originally payable to bearer and those originally payable to order and indorsed in blank, was both logical and desirable. However this may he, such a distinetion is certainly made in section 9 , par. 5 , and it has been made without complaint for twenty years in the English act. The suggested interpretation of section 40 preserves this and the two sections would be harmonious. By section 9, par. 1, an instrument originally payable to bearer continues to he payable to bearer even though specially indorsed. But if it is specially indorsed, then by section 40 "the person indorsing specially is liable as indorser only to such holders as make title through his indorsement," and this has always been the law. By section 9, par. 5, on the other hand, a bill originally payable to order is payable to bearer only when the only or last indorsement is in blank. Every one of these propositions is good law and accords with the understanding of merchants.

The remaining criticism of this subsection is unimportant. "If it is to be taken as it stands," says Professor Ames, "a note payable by $A$. to the order of B., and bearing the anomalons blank indorsement of $C$., would be payable to hearer. This, of course, would be an absurdity, hut it is certainly true that the only indorsement is an indorsement in blank."

Professor Ames does not suggest that any merchant, any lawyer, any court would ever give the section such a construction. Nor does it require any streteh of the English language to arrive at its proper meaning. An anomaloms indorser is not strictly an indorser at all. He is caller one for converiener salie, and a liability closely resembling that of an indorser is fastened upon him. But a section which uses the word "indorsement" with refereme to the transfer of an instrument, could scarcely be regarded as having any reference whatever to an anomalous indorser. The words user in section 3 , par. 5, of the American ant have been found entirely satisfactory in the English act throughout fwenty years' experience, and there can be no reasonable doulit as to their meaning with reference to an anomalous blank indorsement. 
:. Indohsenent Where Paymhe to Two or More Persons.

3 Mcleax, 94 (s. c. 8 FEv. CAS. 186 ). -1842.

[1]. S. Circuit Court, Dist. Wich.]

Orixion of THE Collit. - This action was brought upon the following promissory mote:

Detroit, January 1, 18.37. Two years after date, I promise to pay to the order of Walter Chester. and l'eise, Chester and Co., one thousand and five hundred dollars, for value received, at the Farmers and Mechanics' Bank of Michigan, with interest.

[lndorsed:] Pease, Cinester \& Co.

(Signed) JoHN Chester.

[and also] D. E. Joxes (in blank).

The declaration contained three counts, to the first of which there was a demurrer. 'This count states that one John Chester, on the 1st of January, 183\%. made his note payable to order of Walter Chester, and Pease, ('hester \& ('o., and that Pease, Chester \& Co., under their partnership name. indorsed and relivered the said note to the plaintiff. John Chester, the maker, was a member of the firm of Pease, Chester \& Co. Denand of the note when due, and notice to the defendants, was proved.

Walter Chester, one of the promisees in the note, seens not to have indorsed it, and this is fatal to the riglit of the plaintiff. The interest of the pronisees is joint in the note, and not being in partnership, they must eich transfer the note. (Chitty on Bills, 123; Tayl. 55; Carvick v. Tickry, Doug. 653; jones v. Radford, 1 Camp. 83; 21 Eng. C. L. Rep. 41.)

Only one-half of the mote was transferred by the indorsement of Pease, ('hester $\&$ Co.. and this does not give a right to their or any sulseguent assignee to sue on the note. lieenurse against the maker eanunt thus be divided and suits multiplied. The plaintiff seeks by this action to reover the full amount of the note against the defendants, as indorsers. But as he holds but one-half of the note under the ascionment, the indorsement, at most, can only be evidence of that amount.

The declaration is defective in not averring that Walter Chester, one of the payees, did indorse the note. Denurrer sustained. The plaintiff dismissed his action. ${ }^{1}$

1 In Allen v. Corn Exchange Bank, 87 App. Div. (N. Y.) 335, 337, it was sail that "where comnercial paper is payalle to two or more persons, who are not co-partners, it must be indorsed by all to give good tlita to a trans. feree. . . In Hood v. Hond. 16 X. .T. T. 428 , it was held that one joint payee of a promissory note caunot indorse it either in his own name alone or 


\section{Indorsement Where Payarle to Cashier, Etc.}

\section{$\S 72$ JOHNSON $v$. BUFFALO CENTER STATE BANK.}

134 IowA, 731. - 1907.

Action on certificate of deposit issued by the Clay County Bank of Felton, Minn., to "E. E. Secor, Cashier," and by indorsement of "E. E. Secor, Cashier," transferred to the State Bank of Dows, and by that bank to plaintiff. It is alleged that Secor, to whom as cashier the certificate of deposit was issued, and by whom it was indorsed, was the cashier of the defendant bank, and, acting in that capacity, transferred the instrument to the State Bank of Dows. In the answer of defendant it is admitted that Secor was its cashier at the time of the transaction in question; hut it is alleged that the Clay County Bank was a copartnership of which Secor was a partner, and that the certificate was made use of hy him for his own personal benefit, and not for the use or henefit of the defendant bank, which received no consideration therefor, and that Secor acted without the knowledge or consent of any officer or agent of the defendant bank and without its authority. 'The court directed a verdict for the plaintiff, and from the judgment on that verdict defendant appeals.

McCrarn, J. 'The first contention for the appellant is that the question whether plaintiff was a holder of the certificate of deposit in due course - that is, a purchaser for value before maturity without notice of any defenses - should have been submitted to the jury. * * We think that, had the question been submitted to a jury, there could have been no other finding than that plaintiff was a bona fide holder without notice before maturity on good consideration, and therefore in this respect there was no error in directing a verdict.

The next contention is in sulstance and effect that Secor was, in fact, negotiating the ertificate of deposit in his own interest. and not

in his own name and that of his en payee. They are not encidered partners either in the commercial or legal sonse of llye trim." See this case for other authorities.

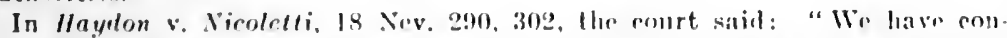

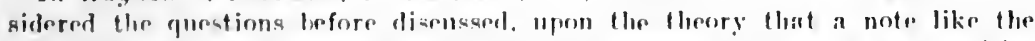
one in suit, indoraed hy one only of two juint payers. is subject to any equitiea existing in faver of the maker. the same ne thollgh it had not been indorsed by either; and such, we think, is the litw. Silch a uote is payible to hoth, or

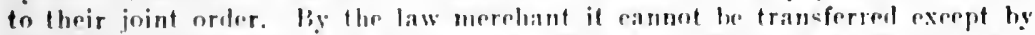

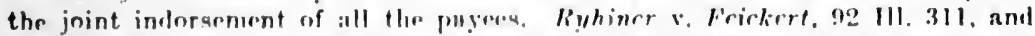
authorities there eitefl. If a note unindorsed is not transforred in good faith, then one inclorsel by a part only is in the same situation. Such a note is surely only trinafereml in part."

See alao Kanfmann v. State Sar. Bank, 151 Mieh. 65, reporterl in 18 I. N. S. 630, with note entitled "Indorsement by ne of two joint payes or indorsers of a bill or note." - C. 
for defendint bank, and it is insisted thnt, as the name of the defendant bank is not inserted in the instrument as payec, nor placed npon the back of it as indorser, mothing was imported in the transaction involving liability on the part of defentant bank. But it is conceded in the record that secor at the time the certificate was issued payable to him as cashier, and at the time it was indorsed hy him as eashier. was in fact the rashice and managing oflicer of the lefendant bank, and that the eertilicate was transfered apparently as a part of the business of the bank. In sertion 1:2: of the Negotiable Instruments Aet (29th Gen. Assim., p. S.), (. 130; ('orle Supp. 1902, \$ 3060at2), it is provided: "Where an instrument is drawn or indorsed to a person as 'rashier' * * * of a bank, **** it is deemed prima facie to be payalile to the bank **** of which he is such officer, and may be negotiated by either the indorsement of the bank, * * * or the indorsement of the oflicer." Under this provision it was competent for the plaintiff to show that Secor was the eashier of the defendant bank, and was acting in that generul capacity in transferring the instrument, and as arainst plaintiff, a bona fide holder without notice, it was not competent for the defendant bank to show that as a matter of lact he was making use of his ofticial title and anthority in his own individual interest. Even were this not so, it clearly appears that the State Bank of Dows pail for the certificate of deposit by a Chicago draft payable " to the order of E. E. Secor, Cashier," and that the proceeds of this limft became a part of the limols of the hank. It seens to us that, as against the plaintiff, no further inquiry could be permitted. We inust look at the whole transaction with reference to the position of plaintiff, an immocent lolder for value. He was not chargerl with notice of the dealings between "Secor, Cashier," and the refondant bank which he represented, and in whose interest he appeared to art. T'noler the sorction of the Negotiable Instruments Act just quoted the relations of the parties were not different from what they would have heen har the eretificate of deposit been issued to the defondant bank and indorsed in its name by Secor, acting as its cashier. * * *

'The judgment is therefore affirmed. ${ }^{3}$

2 N. Y.. \$ 72. - C

3 "The usage is universal for presidents and cashiers of incorporated companies, aeting as the executive oflicers and agents of such companies, to make. in their lohalf. indorements aud transfors of uecotiable paper, by simply indorsing their names, with the additions of their titles of office. I cannot doubt that such an indorsement is suflieient to sharge the corporation under whose authority the indorsement is made, and to transfer the note to the indoreer, so that the latter can maintain an action tbeseon in lis own name." HAI.,. ... in State Bank v. For. 3 Biateh. (I. S.) 431. - I.

IIn First National Bank v. Mrfullough, 50 Or. 508, 512. the court, after citing certain decisions, says: "The rule to be extracted from these decision 


\section{Innorsement Where Name Misspelled, Etc.}

11 Cushixg (Mass.) $320 .-1853$.

From the auditor's report, it appeared that Stearns was the holder of a note executed by Bolles payable to "John P. Reed, or order," and indorsed "Joseph P. Reed." There was, when the note was given, a person living in the same town whose name was "John P. Reed," but it was proved that the note was in fact given by Bolles to Joseph P. Recl for money lent him by the latter, and that it was indorsed by Joseph P. Reed to Stearns.

MEtcalf, J. * * * The court are also of opinion that the note given by the plaintiff, payable to John P. Reed, or order, and indorsed to the defendant by Joseph P. Recl, cannot be allowed to the defendant by way of set-olf. 'That note, though given for money' lent to the plaintiff by Joseph P. Reed, was made payable, not to him, but to John P. Reed, a person in esse. Now it is certain that the legal interest in that note was not transferred to the defendant by .Joseph P. Reed's indorsing his name on it. Te was not the payee nor the legal representative of the payce. And a transfer by indorsement can be made in the first instance only by the payce. or by some one claiming in his right, as his executor. administrator, or assignee in bankruptey or insolvency. (Kyd on Bills [1st Amer. ed.], 106, 10\%.) If there had been no such person as John P. Reed, perhaps the note might have been regarded as payable to bearer. and might have been passed to the defendant by lelivery, as if it had in terms heen made payable to bearer. Of this, however, we give no opinion. But as the note was made payable not to a fictitions person, hut to a person in being, the indorsement of a third person transferred no legal title to it.

If the indorsement and delivery of this note to the defendant by Joseph P. Reed, conld be regarded as an exputable asignment of it, still the defendant would not be entitled to set it off agrainst the phaintiff's elaim on him, heeanse it is not shown that notier of suld assign-

has been embodied in our statute, known ns the "Uniform Negotiable Instru.

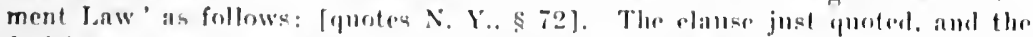
decisiona aslierted to are undouldowly based on the lhery that the employment of the qualifying word 'eashier' or other designation of a fiseal olliee. appented to the name of a payere or indurere of eomurepeial paper, creates all ambiguity as to the real party intented, (a) explain which parol evidenes is admissible to slow who is the prineipal for whose benefit such agent reseiver or accepted the promise ta pay a stipulatod knm of money."

For another ease deciderl under the Negotinble Instruments law, see Griffin v. Erskine, 131 Iowa, 444, - C.l 
ment was given to the plaintill before this action was commenced.

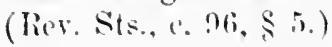

[Set-off on the note not allowed.]

\section{Prisgmption as to 'lime of Indorsement.}

\$75 Ravgeli 2 . Calis, 1 Metealf (Mass.) 369. - 1840.

Dewry, J. - The instruetions of the court of common pleas, to which exceptions were taken, embraced substantially the following propositions: 1. That the burlen of proof was on the defendants to show that the note was transferred after it was due and when dishonored, if they would avail themselves of a defense only open to them as upon a dishonored note. *** Upon the first point, the law is very fully settled according to the rule stated by the judge at the trial. A negotiable note being offered in evidence, duly indorsed, the legal presumption is that such indorsement was made at the date of the note, or at least antecedently to its becoming due; and if the defendant would avail himself of any defense that would be open to him only in case the note was negotiated after it was clishonored, it is incumbent on him to show that the indorsement was in fact made after the note was overdue.

\section{Presumption as to Place of Indorsement.}

\section{$\S 76$ \\ CHEMICAL NATIONAL BANK OF NEW YORK $v$. KELLOGG.}

183 NEw YORK, 92. - 1905.

ACTION on a note dated "New York, June 7th, 1898," and payable at "No. 4 Warren Street, New York."

The defendant is an accommodation indorser, who indorsed the note at her residence in Oak 'T'ree, New Jersey, at the request of the maker, her hushand, and there delivered the same to him. solely for his benefit. The plaintiff, a banking corporation in the city of New York, discounted the note in the ordinary course of business, without notice that the indorser was a non-resident or that the indorsement was made in another state, and used the proceeds to take up a prior note held by it. The defendant " did not authorize said note to be negotiated in New York State, and had no knowledge that it was to be used in that state." By the laws of the state of New Jersey a married woman is not liable as an aecommodation indorser, guarantor or surety unless it appears that she or her separate estate has derived some benefit from the contract.

Upon these facts, which were found or stipulated, the trial court held the defendant liable on the ground that her indorsement was a 
New York contract. 'The Appellate Division unanimously affirmed and the defendant cance here.

VANN, J. Each indorsement of a promissory note is a separate contract. standing apart from that made by the maker or any other indorser. (Spies: Nutional City Bank, 1rt X. Y. 222, 225.) The validity of a contract of indorsoment is ordinarily determined by the law of the plice where the indorsement is made. (Union National Bank v. Chapmen. 169 X. Y $538,543$.

As the note in question was indorsed by the defendant in the state of New Jersey. where she resided, under ordinary circumstances she would not be liable thereon, berause the laws of that state do not permit a marriel woman to hecome a simple accommodation indorser. The laws of the state of New York, however, authorize a married woman to contract, even with her husband, the same as if she were unmarried, and it is insisted that the defendant is estopped from denying that hes indorsement is a New York contract, inasmuch as the plaintiff, in good faitl, purlased the note for value, before maturity, withont notice of anything to put it on inquiry and in reliance upon the fact that it was dated and made payale in the state of New York, with nothing on the face of either the note or the indorsement to suggest that the contract was made in the state of New .Tersey We think this position is somm. Whoever conceals facts repuired by good faith and fair dealing to be disclosed, acts inequitably and will not be permitter to assert those facts to the injury of one misled by such conduct. The defendant could not make her coverture a trap to eatch innocent persons. She could not deliberately give the appearance of validity to her contract and then as against a bone folde holder plead that it wis invalid. Sho knew that the note was dated and payable in New York, and that the presumption from those facts was that it was indorsed there. She also kmew that if she delivered the note in this condition to her homband to emahle him to negotiate it, any one who acterl on such presmontion, as le law fully might in the absence of notier, would be iujurel if she shonld pleal her coverture and that she actuilly indorsel it in New Insery. It was, therefore, her duty, if she wished to ald homestly toward others. Io attall some notice to her indorsement. or geive notiere in some ofleor waye so that.

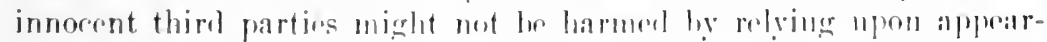

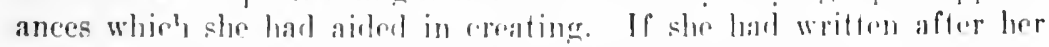

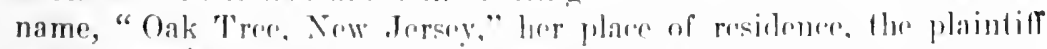
would have heren put upon injuire as to the valislity of such a contract. marle in that state. With no alf mpt to erive untien, by her imdorsement in blank she gave roremey to the note as ome mate and indorsed in New York. Plogding leer indorsement as a New Joreey contract. ander these cirrumstanes would be an attempt to take advantage of her own wrong, which the law will not permit.

The business of the country is done so largely by means of com- 
meleial paper that the interests of rommere require that a promissory

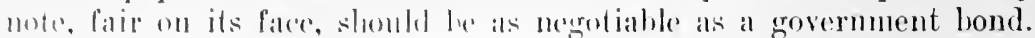
livery restrition upon the rilemblion of megotiable paper is an injury to the state, for it tends to derandere trate and himder the transaction of hosiness, ('ommereial neressity repuires that only slight evidence smold be insisted upon lo establish an estopple in pais as to the validity of commerial paprer. 'l'he only prictionble rule is to make the filce of the paper itsolf, when froe from suspicion, sufficient evilence, in the alseder of notioe, anainst all who aiderl to put it into circulafion in that comblition, unless the note is void hy the positive command of a statute. surh as the alet anainst usury. No other rule would work well, for it womld be intolerable if every bank had to learn the true history of each piece of paper presented for discount before it could act in safety. It is better that there should be an occasional instance of hardship than to have doubt and distrust hamper a common nethod of maliner commereial exchanges.

While it is mmecessary that the defendant should describe herself as a guarantor by adding the word "surety" to her signature, for possssion by her hushand, who was prior in order of liability to herself, was notice that sle dirl not imlorse in the ordinary course of business, still if she regarded her indorsement as a New Jersey contract she shomld have given notice of that fact in some way so that a purlaser in good faith might know that it was not what it appeared to hr, a Now York contract. (Smith v. Ireston, 159 N. Y. 194; Rank: of Monongahela Talloy v. Mrston, 159 N. Y.201.) Even in the state of New .Jersey, where the common-law disabilities of married women have not been wholly remosed, her indorsement would be enforced as a New Jork contract. (Thompson r. Taylor, 66 N. J. L. 253.)

Independently of the statute which will be cited presently, the argument in favor of an e(puitable estoppel rests mainly on the presumption that a note datel and parable in New York was made and indorsed in that state. While flis question las seldom been before the courts, Mr. Daniel in his useful work on Negotiable Instruments says it is the law and the autliorities support the assertion. (Janiel on Neg. Inst. [5t] en].] \& 728; Haxuell v. Vansant, 16 111. 58; Toune v. Rice, 122 Mass. 6r; Bedford v. Bangs, 15 Apl. (1. Rep. 76; Lennig r. Ralston, 2.) Penn. St. 13\%; Snailh v. Mingay, 1 M. \& S. 87; Edwards on Bills,

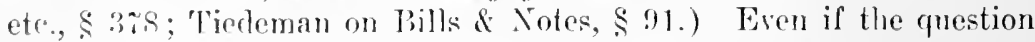
wore contirely new, somnd reasoning would learl to that conclusion. While the contrant male hy an indorser is independent of that made by the maker in the sense that it is of a lifferent nature, and can be serarately mforerer, still it is rependent on the promise of the maker, because it is an acreement to, perform his promise, upon certain conditions, if he does not. 'Throrfore, the plaer where the maker promised, as staterl in the note itself, must with all the other provisions thereof be read into the promise of the indorser, and it thus becomes 
by fair presumption, in the absence of notice to the contrary, the place where the indorser promised also. The purchiser has no other guide as to a fact which may involve the ralidity of the contract, and hence it is a commercial necessity that both contracts, so closely connected that the second cannot exist without the first, should be presumed to have been made at the same place, unless the one with power so to do rebuts the presumption by timely notice.

The learned counsel for the defendant seems to recognize the existence of this presumption, as he says in his points that, "If we examine the note alone, then the negative inference might possibly arise that the defendant intended the note should be governed by the laws of another state." IJe insists, however, that as the plaintiff stipulated the facts at the trial, it knew the defendant did not so intend. The rights of the parties do not depend on what the plaintiff knew at the time of the trial, but on what it knew when it discounted the note, and at that time, owing to the absence of notice, which was the defendant's fault, it had no information but what the note gave. The defendant knew that her husband conld use the note in any state, and the place of date and payment indirated the state where he expecterl to use it. Unless she intended that it shonld be used in a state where her indorsement would bind her, she must have intended to defrand and hence is estopped.

But, to elinch the argument, we have only to refer to the Negotiable Instruments Law, which provides that: "Except where the contrary appears, every indorsement is presumed primu foride to have heen made at the place where the instrument is dated." (L. 189\%, ch. 612, \$ 76.) This statute was prepared for uniform artion in all the states, and it lias already heen adoptorl in many. It is regarded as simply declaratory of the common law 11 on the subject under emsideration. (Eaton \& Gilhert on Commerrial l'alper, s gic.) 'Therefore, when the note was presented for discomnt in Sow York, the plaintiff lad the right under the statute to presume that it was imdorsed in the state

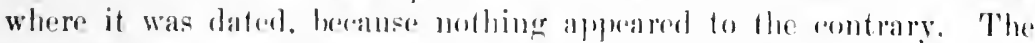
defendant, by her indorserment, alded in the meretiation of a rote cilrrying with it that presumption, lwoth at common law and alderorling to

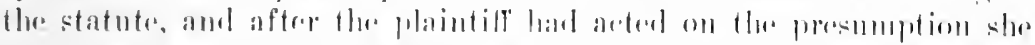
cannot he heard when she atfompts lo say that she indorsed in a state where her indorsement is not binding, and that she did not intend to he bound hy lerer promise whers she miale it.

The judgument shombl be allimml, with custs.

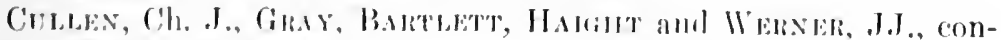
cur; O'busw, l., absent.

\section{Inderment aflirment."}

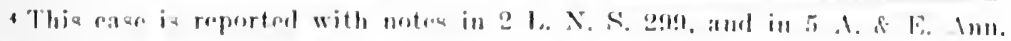
Cas, 158.

On the question of the ennfliet of laws as applied to the liability of parties 


\title{
7. Continuation of Nigotiabli Cuaracter.
}

\author{
LEAVI'T" v. PU'TNAM.
}

[Reported herin at p. 2\%2.]

\section{S. STRIKING Ot'T Indorshment.}

ACros on note against maker, and against payee Jerman who had indorsed in blank. Following the blank indorsenent were the words: "To ace't of Benjamin F. Edwatro," and on the face of the note appeared the stamp of the Washington Savings Bank. Whether the worls just reeited were witten by Edwarls, or were indorsed by the sarings bank as an indieation of the credit to be entered by it in case of its collection of the note, did not appear. Plaintiff produced Edwards as a witness, who proved the signatures of the maker and indorser. 'The defendants objected to the note on the ground of variance. Plaintifl then, willont any ruliug by the court, struck out the words "To ace't of Benjamin F. Edwals" in the presence of the court and again offered the note. Objection was again made on the ground that this was a restrictive indorsement, that it was stricken out without right, and that the plaintiff was not the bona fide holder of the note as she was not the indorsce of the same, and was not entitled to maintain an action thereon. Plaintiff claimed the right to strike out the indorsement under section 1352 of the Code." The comrt overruled the objection, anc permitted the note to be read to the jury. Defendants offering no evirlence, the court instructed the jury to return a verdict for the plaintift.

Mr. Clifef Justice Silspand relivered the opinion of the court:

We think there was no error in the action of the court. Assuming, as contended by the appellants, that the note had been actually indorsed by Benjamin F. Fdwards to the savings bank for collection for his accoint. the hank failed to collect it, and returned it presumably

to negotiable intruments, sce the following cases: Union Nat. Bank v. Chapman, 169 N. Y. 539, 57 L. R. A. 5I3 (note), ss Am. St. Rep. 614 (note); Spirs v. Nat. ('it. Pink, 174 N. Y. 222, 61 L. R. A. 193 (with exhaustive note); Amsinel v. Rogers, 189 N. Y. 252. 12 I. N. S. 75 (note), 121 Am. St. Rep. 858 (notr), 12 A. \& E. Ann. ('as. 450 (note); Sylkes v. Cit. Nat. Bank, 78 Kan. 688, 9 I. N. S. (605) (note): Brown v. Gates, 120 Wis. 349.

Sep alog the following notru discrsaing some of the alove cases: $2 \mathrm{Col}$. Law Rev. 253.257; 8 id. 134; 1 Mich. Law Rev. 508; 2 id. 627; 6 id. 338. - C. 5 N. Y., $\$ 78 .-\mathrm{C}$. 
to him. Plaintiff"s title as holder did not pass under that indorsement, but through the delivery to her by Benjamin F. Edwards, who appeared as a witness on her behalf. She took title by delivery under the blank indorsenent of the payee, Jerman, the effect of which was to make the note payable to bearer, and pass by delivery.* Code, $\S 1338^{6}$ (31 Stat. at L.. (h. 85t). Whether the further indorsement, if in fact made by Benjamin F. Edwards, was a restrictive one, as defined in section $13.1^{\text {i }}$ is a question of no materiality, as the plaintiff did not claim the title thremnder, and there was no defense to the note as against cither Prnjanin F. Edwards, the savings bank, or the plaintiff. 'This indorsement not being neeessary to the title of the jlaintiff. she had the riglit to strike it out. Code, $\S 1352 .{ }^{8}$ This provision of the Code is but declaratory of the law as it was recognized before the adoption of the Negotiable Instruments Act. See Vanarsdale v. Hax, 10r Fed. 8r8, 880, and eases cited.

It follows that the judgment must be affirmed, with costs. It is so ordered.

Affirmed. ${ }^{\circ}$

\section{Transfer without indorsement.}

17 Feiprat. Reporter, 575. - 1883.

[From Circuit Court, N. D. Illinois.]

A RTT gave the R. \& M. R. Co. his negotiable note for $\$ 2,500$ secured ly mortgage. 'T'he li. \&.M. K. C'o. gave Osgood a bond for $\$ 2,500$ and in it "assigned anl transferred" Artt's note and mortginge as sururity, and speceified that "said note and mortgage are hereto ap|.ruled." The lond, mote and mortgage were attached firmly together

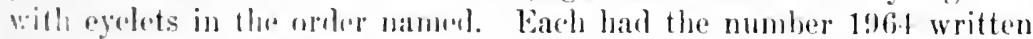
1.) it. ()sgonl at this timu hanl no notire of any defense to Artt's note. subsequently oseroml learmel of the defense (failure of consideration

- The note was originally payable, not to bearer, but to the orrler of Irorman. - - r.

B. X. Y.s B. - C

T.Y., \$67. Roference shomlil apparently be to $\$ 1340$, which in N. Y. in \$ bif. - C C

8.N.Y. S S R. - ( .

" 'The note had heen indoraed hy the plaintiff hefore maturity to a bank. and depusiterl with it fur mollechiou. It was protested, and then returneal to the plaintiff. When produceol at the trial, it bore this indorsement to the bank, uneanceleal. Thre defendant eontends that upon these facts it appears that the link has the legal title. and was the only proper party to sure. The bank received the title for the sols: benefit of the plaintirf. When it returned 
and frand), and thereafler the R. \& M. R. Co. indorsed the note by writing its natme mpon the back.

Hollax, J., (after stating the facts). - These facts have been especially found by a jury, and the sole question for determination is whether, upon this tinding. the plaintills are entitled to judgment. 'The only issue of fact mate on the third plea is whether Osgood, prior to the indorsement of the note, had notice of the alleged fraud and failure of consideration.

1. It is a settled doctrime of the law merchant that the bona fide purchaser for value of negotiable paper. payable to order, if it be indorsed by the payee, tilkes the legal tille unaffected by any equities which the payer may have as against the payee.

2. But it is equally well settled that the purchaser, if the paper be delivered to him withont indorsement, takes, by the law merchant. only the rights which the payee has, and therefore takes subject to any defense the payer may rightfully assert as against the payee. The purchaser in such case becomes only the equitable owner of the claim or debt evidenced by the negotiable security, and, in the absence of defense by the payer, ma demand and receive the amount due, and if not paid, sme for its recosery, in the name of the payee, or in his own name, when so anthorized ly the local law.

3. As a general rule the legal title to negotiable paper, payable to order, passes, according to the law merchant, only by the payce's indorsement on the security itsolf. The only established exception to this rule is where the indorsement is mate on a piece of paper, so attached to the original instrment as, in eflert, to become part thereof, or be incorporated into it. 'This adtition is called, in the adjudged eases and elementary treatises, an allonge. That device had its origin in eases where the hack of the instrument had been evered with indorsements. or writing, leaving no room for further indorsements thoreon. But, perhaps. an indorsement upon a piece of paper, attached in the manner indicated, wonld now he dermed suflieient to pass the legal title, although there may have been, in fact, room for it on the original instrument.

4. But neither the general doctrines of eommercial law, nor any established exception thereto, make words of mere assignment and

the note protested, the plaintiff became an indorsere in possession, and invested with the rights belouging to all lobders of commereial paper. Gen. St. 190-3, $\$ 4170$ [X. Y.. \& 2]. One of these was to cancel the indorsement which it bad made. Gen. St. I902. \$ $1218[\mathrm{~N}$. Y., \$ 78]. Whether it exereised this right or not was immaterial. Its mere possession of the note was sulfieient evidence of ownership to sipport thr suit. Fen. St. 1902, \$4221 [N. Y., \$90]; Dugan v. United States, 3 Wheat. 172." Palmwix, J., in Teu Haven Mf. Co. v. Teio Haven Pulp and Board r'o., 76 C'onn. 125, 131.

See also Berney v. Steiner Bros., 108 Ala. 111, and Midalleton v. Griffith, 57 N. J. L. 442 . - C. 
transfer of such paper - contained in a separate instrument, executed for a wholly different and distinct purpose - equivalent to an indorsement within the rule, which admits the payer to urge, as against the holder of an unindorsed negotiable security; payable to order, any valid defense which he has against the original payee.

5. The transfer of the note in suit, by words of assignment in the body of the railroad company's bond, did not, in the judgment of the court, amount to an indorsement of the note, although the bond, note, and mortgage were originally fastened together by eyelets. The facts set out in the third plea, and sustained by the special finding, constitute, therefore, a complete defense to the action, unless, as contended by plaintiffs, the subsequent endorsement. in form, by the railroad company, after Osgood was informed of Artt's defense, has relation back to the time when the former, without notice of such defense, purchased the note for value then paid.' If, at the time of Osgood's purchase, it had been agreed that the company shonld indorse the note, but the indorsement was omitted by accident or mistake or fraud upon the part of the company, a different question would have been presented. In such case, the company might, perhaps, have been compelied to make an indorsement whieh would have been deened effectual as of the time when, according to the intention of the parties, it should have been made. But no such case is presented by the special finding. It is entirely consistent with the facts found that the indorsement by the company was an afterthought, induced by notice of . Irtt's defense, and was not within the contemplation or contract of the parties when Osgood purchased the lond. Moreover. and as a rircumstanee significant of an intention to restrict. in some degree, the assignability of the note and mortgage. it is expressly stipulated, in the company"s bond, that they are transferable in connection with the bond, and not otherwise.

I am of opinion that the facts which came to Osgood's knowledge prior to the indorsement, and which. in substance. constitute the defense set out in the third plea, furnisherl notice that the company had, by reason of framd and failure of considelation, lost its right to demand payment of the note from Artt. By the indorsoment. after such notice, Osgood could not acrouire any greator rights than the company possessed. He did not hecome the holder of the note by indorsement, as required by the law morelant, until after loc had notice that the company could not rightiully palss the legal title, so as to defeut Artt's defense.

While the adjulged asses are not in harmony upon some of these fropositions. the conclusions indienterl are, in thre opinion of the conrt, consistent with somed reason, and are sustainod ley the great woight of

1 As to this controntion, sen Watkins v. Maule, 2 .Tac. \& W. 244, and Baggarly v. Gaither, 55 N. C. $80 .-\mathrm{C}$. 
authority. (Chief Justice Marshall in IIophirk v. Page, 2 Brook, 41 ; Siluryes" sons v. Met. Nal. Banh, 19 Ill. 231; Melendy v. Keen, 89 Ill. 40.4; Ilastell v. liroun, lis HI. 3\%: Lancaster Nat. Bank v. Taylor, 100 Mass. :4: Bacon r. C'ohea, 12 Smedes \& M. 522; Grand Gulf Bunk v. Ilood. Id. 48: Clark v. Whitaker, 50 N. H. 474; Maskell v. Milchell. 53 Me. I6s; Frunklin v. Twogood, 18 Iowa, 515 ; French v. Turner, 15 lud. 59: Folger v. C'luse, 18 Pick. 63; Whistler v. Forster, 14 C. B. 246 (108 E. (C. I. 2.48) ; Harrop v. Fisher, 10 C. B. [N. S.] 196; Gibson V. Winct, 1 H. Bl. s. p. 606; Story, Notes, § 120; Story, Bills, \$201: Chitty, Bills | 12th Amer. from 9th lond.7, 252; 2 Pars., Notes and Bills, 1, 1\%, 18; 1 Daniel. Neg. Inst. |3d ed.|, $\$ \$ 664 a$, $689 a, 690,7+1$, and 748. .) 'The facts specially found do not authorize a judgment for the plaintifi."

\section{Retransfer to prior party.}

ADRIAN $v$. MCCASKILL.

103 North Carolina, 182. - 1889.

Action against defendants, McCaskill \& McLean, as indorsers on a promissory note executed and delivered January 10, 1884, payable to $\mathrm{IV}$. C. Patterson or order. Plaintiffs purchased the note for value

2 In Lyon, Potter of Co. v. First Nat. Bank, 85 Fed. 120, 124, the court said: "A mere assignee of a promissory note, like an assignee of any other close in action, takes his title subject to all the equities and defenses which exist between the ascignor and the other parties to the instrument. An inclorsee for value, without notice, before maturity, takes the title to a promissory note, according to the eustom of merelunts and the now established law of the land, free from all those equities and defenses. The discount and delivery of this note without its inclorsement effected a mere assignment of the note, and under that assignmant the bank took and held it subject to the original equities botwon the partics. Neither the delivery before nor the indorsement after maturity could exempt the bank from the defenses of the original makers or inlorsers, because the bank was a mere assignee before maturity, and the indorsenent after maturity transforred the legal title subject to all the deforiss of which the overdue eharacter of the paper gave notics. The faet that the indorsment was omited ly mistake could not deprive the bank of notice of the character of the paper, and carry the effect of the sub-epuent indrosmunt back to the date of the delivery, because the omission itsilf - tlo mistake itself - was notiee, and the knowledge which that notice imputerl momld not he subsequently axtracted from the mind of the caslieer of the bank as of the date of the discomt. Bank v. Taylor, lo0 Mass. 18, 22, 23: Jounkor v. Martin, 18 Iowa, 143. 145: Franklin v. Tuogood, id. 5l5; Grimm v. llarner, 45 lowa, 106; Haskell v. Milchell, 53 Me. 468."

Sie also First liat. Isk. v. Hctullowgh, 50 Or. 508, reported in 17 I. N. S. 1105, with note entitlel "Pight of transferee, without indorsement, of bill or note payable or indorsed to order of transferrer, to protection as a bona fido purchaser." - C. 
from Patterson in January, 1885, after its maturity, without any actual notice of the defenses set up in the answer of the defendants.

In February, 1884, Patterson indorsed the note in blank and delivered it to the defendants to secure them for such sums of money as he might owe them at the end of 1884. Later, on February 23, 1884 , defendants indorsed the note in blank, and with the knowledge and consent of Patterson, delivered it to Williams \& Company, to be held by this company as security for money loaned to the defendants in 1884 , said indorsement being solely to secure the company as above stated. In October, 1884, defendants paid Williams \& Company the money borrowed of the latter, and the company returned the note to the defendants. The defendants held the note until December 5, 1884, when they returned it to Patterson, being satisfied to trust him for the balance then due them without said security; but by accident, oversight and mistake they failed to erase their names as indorsers. At the time the note was returned to Patterson, he knew that the defendants were not liable as indorsers on the note, and they believe that he knew they failed to erase their names through accident, oversight and mistake. Patterson also knew that the names of the defendants, as indorsers, were not there for his accommodation and that he had no legal or moral right to use their names as such; and he knew that he had no right to deliver the note to the plaintiffs with the indorsement of the defendants on the same.

The plaintiffs oljected to the introduction in evidence of the above facts, and insisted that, as it was admitted that they had no actual notice of them, the evidence of said facts was not competent or admissible against them. 'The trial judge held that the evidence was competent, and thereupon gave judgment for the defendants. From this judgment the plaintiffs appraled.

Davis, J. The note is dated January 10,1884 , and is payable to "W. (C. Patterson or order," on the ist day of November. It is indorsed by the payee and by the defendants, the name of the payee appearing as first in order. On the 25th day of Jamuary, 1885, niore than twelwe months after its date, and long after its maturity, the plaintiffs became the purchasers from the payee, with the indorsement as set forth.

Were the facts, admitted to be true, allnissible to explain the character and nature of the indorsement of the defendants?

The plaintiffs say that, as they had no actual notice of "any such equitices of lefense," and were purchasers for value, the evidence was not competint as against them.

By statute, promissory notes, whether with or without seal, are made assignahle, "in like manner as inland bills of exchange are hy custom of merchants in England." "They are, in the language of the mereantile law, "negotiable" and may br (raneferred and neentiated, free from any equities which exist between the original parties to 
them. " Each indorser, inchuding the payee, down the line, has and passes the legal title, and his indorsenent in legal import is a contraet "ith his indorsee, and all subsequent holders by indorsement, that the maker will pay the note, or *** * le will." Mill v. Shields, S1 ‥ ('. 250 , and the eases there eited, and innumerable decisions, English and American, aited in l'arsons, Daniel, Randolph and other alementary writers upon the subject, indicate the solicitude of courts to protect bona fide purchasers and innocent holders of negotiable paper, so essential to commerce and trade; and the construction placed upon section $1 \% 8$ of the code (C. C. P., \$ 55. in Marris v. Bururll, 6.) N. C. 58t, and Martin r. Richardson, is N. C. 225, has been limited to the makers of promissory notes, ete, and held not to apl'? as between indorsers.

Conceding the importance of protecting bona fide holders of commercial paper " in its mnchecked cireulation," what are the liabilities of the defendants in the present case? 'That the holder of a negotiable note is presumed to be the owner admits of no question, and that, after such a note is put in circulation, indorsers are liable in the order of succession, is equally clear, if the indorscment be not limited or qualified. No prior indorser can look to any subsequent indorser. "One who obtains possession of a bill or note, after indorsing it, is restored to his original position, and cannot, of course, hold intermediate parties, who could look to him again." 2 Ran. Com. Pa. S. 719. It must be equally clear that one who derives possession from him, with notice of this fact, cannot hold such intermediate indorsers liable, and, when such indorsements are in hlank, parol testimony is admissible to show the relation in which they stand. Ihid., $\$ \S \% 8,8+1$ and 883 .

When the note was returned to Patterson, be beeame again the owner, and, as between him and any subsequent indorsers, the relation of indorser and indorsee ceased. 'The plaintifis were not the indorsers of the defendants. It is clear that Patterson could not, by reason of the blank indorsement of MeCaskill \& Molean, hold them liable for the note, for he stond in the relation to them of a prior indorser. The plaintifis derived their title directly from Patterson, the original paver, who had re-acquired the title, and not as sucessive indorsers, drriving title thromgh the indorsement of the defendant; and this distinguished this ease from I/ill v. Shields, supra; Parker v. Slallings, Phil. 590, and similar cases.

The plaintiffs were affected with, and bound by, notice of what appeared upon the note itself, and they took the note from the original payee, bearing upon its face the fact that he was the first indorser, and that the dofendants were his indorsees.

An indorsement in blank by the payee is presumed to have been intended as a transfer, and, though this may he rebutted by parol proof (Davis v. Morgan, 64 N. C. 570 ), the admitted facts in this case 
show that the indorsement by the payee was in accord with the presumption - a transfer to MeCaskill \& McLean.

But it is insister that, as between the indorsers in blank, the holder may fill the blank by making it payable to himself, or to any one he may choose. This is so where he obtains the note, not from the payee, or a prior indorser, but holds it as a bona fide purchaser, without any knowledge or notice of the relation sustained by prior indorsers to the note. In the present case, if the plaintiffs, purchasing the note, not fiom the defendants, but from the prior indorsing payee, had filled the blank indorsement of McCaskill \& McLean to themselves, it would not have been in accordance with what they knew the fact to be, and would have been a gross wrong. if not fraud, upon the defendants.

'The plaintifls further rely upon the well-settled rule " that whenever one of two imnocent persons must suffer loss by the acts of the third, he who, by his negligent conduct, made it possible for loss to oceur, must bear the loss, for it is against reason that an innocent party should suffer for the negligent conduct of another," and that the defendants, by neglecting to erase their indorsement, "induced the plaintiffs to rely on the legal import of the indorsement, and ought not to be allowed, against the plaintiffs, purchasers for value and without notice, to make pron of the alleged facts."

Thongh the plaintiff's had no "actual notice," we have already seen that they were charged, in law, with notice of facts apparent upon the face of the paper which they purchased from Patterson.

But the defendants may have been indorsers for accommodation, or as sureties or guarantors. True: and the indorsement of a note by a third person, made at the time of its execution. hinds him, acenrding to the intention of the parties. either as joint prineipal or as surety. Balier v. Robinson, 63 N. C. 191.

If the plaintiffs lonker to the defendints as accommodation indorsers, or as guarantors. then, as they purchased the note from the payee after maturity, thry were not "bona fide holders before naturity," hat harl motice, as appeared upon the face of the paper, of its dishonor. Rev. Com. Paper, \$6r: : Bank v. Lutterloh, 95 N. (. 495 ; Chaddoch v. Vanness, 35 N. .I. $51 \%$.

So, whether by the onc way or the other, the plaintifs cannot hold the defendants liable. No crror.

\section{Amirmorl. ${ }^{3}$}

a See post. Art. IX, Div. I. I. Sere $\$ 202$, post. If an indorser reissue the paper after maturity withont striking out his indorsement le remains liable and is estopped to reguire a new presentment and demand. Williams $v$. Mattheirs, 3 ('ow. (N. Y.) 252; s't. John v. Roberts, 31 N. Y. 441. - II.

ISee also Curtis v. Sprn!ne, 51 ('al. 23!. ante, 1. 144, and Brooks, Oliphant \& Co. v. Vanncst, 58 N. J. L. 162, ante, p. $276 .-$ C.1 


\section{ARTICLE V. \\ Riguts of HIOLDER.}

\section{To sue and to receive payment.}

74 NEW YoRK, $486 .-1878$.

ACTios on a promissory note alleged to have heen made by defendants (Hathorn \& Southgate), payable to the order of one of them (Frank H. Hathorn), and by him indorsed in blank and transferred to plaintiff. Judgment for plaintiff.

HAND, J. - In their answer, the defendants denied that the note on which the action was brought was ever transferred to the plaintiff or that he was the legal owner or holder thereof. They further denied that the plaintiff was the real party in interest; alleged that the Saratoga County Bank was the real party in interest and the owner and holder and should be the plaintiff, and that the note was duly transferred to it instead of to the plaintiff. ${ }^{1}$

Upon the trial, the plaintiff having produced the note which was payable to the order of F. H. Hathorn and indorsed in blank by him, rested. The defendants then offered to prove that the note "was not the property of the plaintiff, that the same was never transferred to him, that he was not the real party in interest, that the note was the property of the Savings Bank who is the real party in interest." The evidence was objected to by the plaintiff as immaterial and was exeluded. This ruling I think was erroneons and renders necessary a reversal of the judgment.

Under the answer and this offer, the defendants unquestionably proposed to show substantially that the plaintiff had no title legal or equitable to the note, and no right as owner to its possession. This might have been done by proving that he was the mere finder or the unlawful possessor, or that the right to its possession and ownership was in the bank to whom they were liable thereon, or in some other way. This they had a right to show.

It may be that, had their offer heen admitted, they would have pro-

1 "Fery aetion must he prosecuted in the name of the real party in interest." N. Y. Code Civ. Proc., § 449. - H.

[See Am. Soda Fountain Co. v. Hogue, $17 \mathrm{~N}$. Dak. 375, reported in $17 \mathrm{I}$. N.S. 1113 , with note entitled "Holder of unindorsed note as real party in interest within meaning of statutes defining the partics by whom the action must be brought," ennfinuing note on the same subject in 64 I. R. A. 581. - C.] 
duced in fact no evidence to sustain it or prevent a recovery, but in considering the validity of their exception to the exclusion, we must issume that the evidence would have fully covered the propositions rontained in the offer. And, as remarked in the dissenting opinion in the court belon, "unless the defendants are to be precluded altogether from giving any evidence of a matter confessedly issuable, I do not see how this offer could be rejected."

The cases relied upon as justifying the exclusion of the evidence do not go that length. In Cummings v. Morris (25 N. Y. 625), it was held that the maker of a note could not defeat the plaintiff, not a payee, by pronf that the consideration of the transfer to him was contingent upon his collecting the note. Such plaintiff was declared to be the real party in interest on the express ground that the transfer was complete and irrevoeably vested in him the title to the note.

In City Bank: v. Perkins (29 N. Y. 554), there was no question of exclusion of evidence, but all the ciremstances being proved, it was held that where the cashier of a bank holding commercial paper, pledged it "duly indorsed" to the plaintiff as security for a loan by the plaintiff to his hank, and it had been actually transmitted under his direction to the plaintiff so indorsed, it was no defense to one admitting his liability upon such paper to show lack of authority in the eashier alone to contract a loan for the hank; or the fraudulent diversion by him of the funds received from the plaintiff on such loan. Some remarks in the opinion in that case, not necessary to the decision, are perhaps ton broad to be entirely approved. hit it is fully conceded in it that proof that the plaintiff had no right whatever to the possession but was a mere finder or had obtained it by some "positive breach of law" would be a defense.

Brown v. Penfield ( 36 N. Y. 473), holds merely that proof, by the party liable on a hill, of gross inadequacy of the consideration for the transfer of such bill to the plaintiff does not impeach the validity of such transfer as to the party so liahle.

In Allen v. Brown ( 44 N. Y. 228 ), it was decided that. as against the plaintiff holding legal title to the claim by written assigmment. valid upon its face, the delotor canuot raise the question as to the consideration for such assignment or the equities betwen the assignor and assignee.

In Eaton v. Alger (47 N. Y. 3.15), the note being payahle to hearer and produesd hy the plaintiff upon the trial, it was proverl that the payee had delivered it to the plaintiff upon his undertaking to colloct it at his own expense and pay in surh payee upon its collection a certain sum of money. This was held to show suffieiently that the plaintiff, and not the payee, was the real party in interest under the Code.

Sheridan $\nabla$. The Maynr ( 68 N. Y. 30), reiterates the doctrine that, as against the debtor, the plaintiff holding a written assignment of 
the claim to himself valid on its face, ohtained the legal title and was the real party in interest notwithstumling the fact that the assignment was without consideration and merely colorable as between him and the original claimant. Such assignment is expressly declared to protect the debtor paying the assignee against a subsequent suit by the assignor.

In Gaife v. Lindall (15 Wend. 640), the fact that the prosecution of the note was by its ouner and holder in the name of the plaintiff, a stranger to it, without his consent or knowledge, was sought to be set up as a defense, but it was ruled out on the ground that the nominal plaintitl need have no title to or interest in the paper sued upon. We apprehend the Code has changed this and that such facts would now be fatal to an action. Such a plaintiff could not in any view be the real party in interest. Indeed, he would not even have manual possession of the paper.

From this glance at the eases, it appears that it is ordinarily no defense to the party sued upon commereial paper, to show that the transfer under which the plaintifl holds it is without consideration or subject to equities between him and his assignor, or colorable and merely for the purpose of collection, or to secure a debt contracted by an agent without sufficient authority. It is sufficient to make the plaintiff the real party in interest, if he have the legal title either by written transfor or delivery, whatever may be the equitics between him and his assignor. ${ }^{2}$ But to be entitled to sue, he must now have the right of posession and ordinarily he the legal owner. Such ownership may be as equitahle trustee, it may have heen acquired without adequate consideration. hut must be sufficient to protect the defendant upon a recovery against him from a subsequent action by the assignor.

As we understand the scope of the offer in the present case, it went to entirely disprove any ownership or interest whatever or even right to possession as owner in the plaintill. It should therefore have been admitted. It may be true that the plaintifl, if this note had been delivered to him with the intent to transfer title, might lave lawfully overwritten the blank indorsement with a transfer to himself; it is also true that the production of the paper by him was prima farie evidenen that it had been delivered to him by the payee and that he lad title to it, but the defendants' offer was precisely to

2 A transfer merely to enable the transferee to sue upon the instrument is valid. Lau v. Parnoll. 7 ('. B. N. S. 282; Wheeler v. Iohnson, 97 Mass. 39; Boyrl v. Corbitl, 37 Mich. 52: Brattie v. Lett, 28 Mo. 596; Bank v. Senior, 1] R. T. 376; Woller v. Woit. $50 \mathrm{Vt}$. 6fis. If acting by authority of the beneficiary, such transfere is the real party in interest. The anthority may be revoked. Comstock v. Hoag, 5 Wend. (N. Y.) 600 ; Best v. Nokomis Bank, 76 Ill. 608. - H. 
rebut this very presumption, and for anght that we can know the evidence under it would have done so.

The judgment must be reversed, and a new trial ordered, costs to abide the event.

All concur, except Millsir and Eari, JJ., absent.

Judgment reversed.

Mison, J. * * *

In jurisdictions where, as in Kansas (Manley v. Park, 68 Kan. $400 ;^{3}$ Gruham v. Trolh, 69 Kin. 861 ), the holder of the naked legal title to a promissory note may sue nyon it, even althougl he maly be muder whligation to accomt in some third person for the entire proceds, it is often said that in suld an action the defombant connot challen the plaintit"s right to maintain it. exeept by a showing of bar faith in the transaction (llyer s. Selperll, 135) Cill. sir. and cases eited;

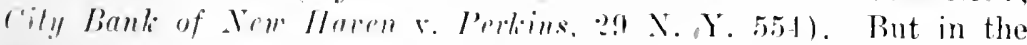
dereisions there is a sonmwhilt siugular lawk of explanation or illustration as to just what might he considered had laith, in this connection. boubtless the phatas is sometimes need with reference to a merely colorible transfore of title by llere real nowere to a stranger. had for the fmpose of emharrasing the maker of the note in lis defense. Marrin v. Lillis, (C. ('.) ! lind. Bar. But this example hatrdly meets the rexplurements of the situation. for it is also sail that upon a showing

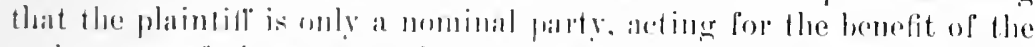

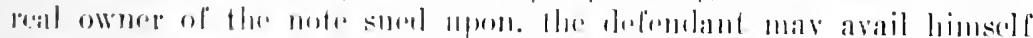

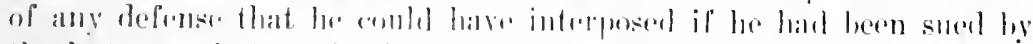

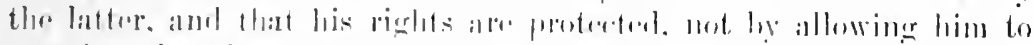

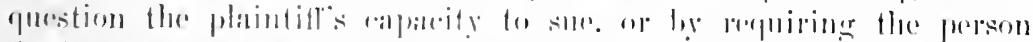

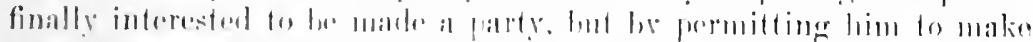

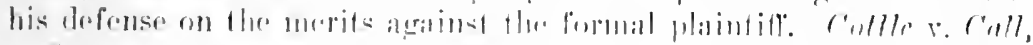

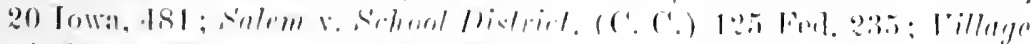

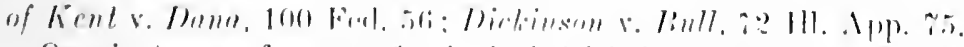

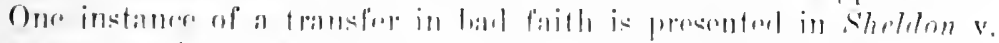

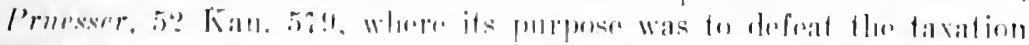

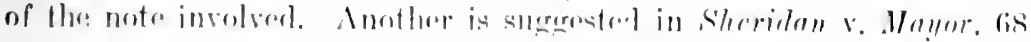

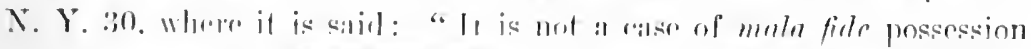

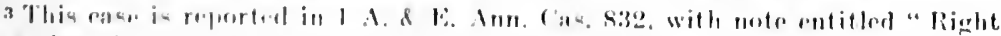
of action thrown of mominal lushler of prominsory note."

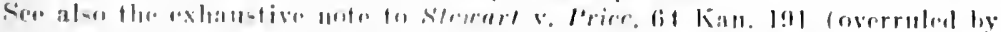

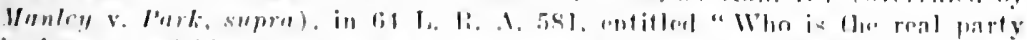

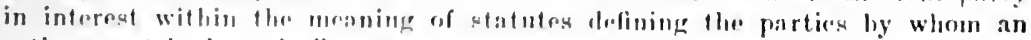
astion muat be bromoht." - 
which the defendant can avail itself of, as if a thief should bring an action upon a promissory note which le hat stolen." In Daniel on Negotiable Instruments (rol. $:, \S 1191$ ), it is said: "If it were shown that the plaintitr, upon suing upon a note payable to bearer or indorsed in blank, has no interest in it, aml, in addition, that he is suing against the will of the party heneficially interested, he eould not recover, as his comlunet would be in bal faith." In support of this statement the author rites Toune r. W'ason, 128 Mass. 51\%. the syllatums to which reads: "It is a good defense to a promissory note that the plaintiff. although in the possession of the note, has no interest in it, and is prosecuting the action, not for the benefit of the person beneficially interested. hut against his objection."

But in that ease the lefense made was that the plaintiff had wrongfully, and without the consent of the owner, obtained possession of the note sued on, which was indorsed in hlank: that he had no title to it, and never had had any: and that he was not authorized to sue in behalf of the owner - in effect. that he had stolen the note. Ancl the ground of the decision was that under the facts stated the plaintiff lad no authority to receive payment of the note, and a payment to him would not have released the maker. And this sugrgests what we conceive to be the true rule, of general if not of universal application that, so far as affects the question of the right of the plaintiff to maint:in the action, the only inguiry open to the defendant is whether the plaintiff had such title to the note that a payment made to him would be a complete protection to defendant from any further liahility. Sturgis v. Baker, 43 Or. 230: Broun v. Powers, 53 App. Div. (N. Y.) 251: Hays v. Hathorn, it N. Y. 486. Any investigation which goes further than this merely involves questions between the plaintiff and other elaimants of the note or its proceeds, and with these the defendant has no concern. It was said in r'ity Bant of New Haven v. Prrtins, 29 N. Y. 5.5t: "The defondant claims no title to the paper, and does not pretend to have any interest in it, except as a promisor, liahle to pay to any proper lonlder. There is no party before the court who has any legitimate interest in questioning the plaintiffs' title, or who has, as it seems to me. under the circumstanees of this ease. anv right to be heard on that question. The defendant stands here. therefore, as a mere volunteer, in behalf of others not before the court, and who make no claim on their own account. *** It will be time enough to determine whether any other person has a better title, when such person shall come before the court to claim the bills in question, or their proceeds, from the plaintiffs."

1" It is the sertled law of this enmmonwealth that a holder of a negotiable promisoory note payahle to hearer or payable to order and indorsed in blank can sue on it in his own name. liftle v. O'Brien. 9 Whass. 423: Beekman $\mathbf{v}$. Wilson, 9 Metc. 434; Peaslee v. McLoon, 16 Gray, 488; Whitton v. Hayden, 9 


\section{Holder in due course.}

\section{Requisites to Constitute Holder in Due Course.}

(a) Instrument must be complete and regular.

$\S 91$ Daris Sewing Machine Co. $v$. Best, 105 N. Y. 59. - 1887. detion to recover the value of certain notes diverted by plaintiff"s president. At the time defendant purchased the notes they were complete and regular and signed by the plaintifl"s treasurer, except that they were not signed by the president although a blank space with a diagonally ruled line, with the title of his oflice printed thereunder, was left at the foot of each instrument.

Ruger, Ch. J. - It is not seriously questioned, lut that the notes were unlawfully eonverted by $\mathrm{W}$., and that the plaintiff was entitled to recover their posecssion. unless the defendant beeame the bona fide holder thereaf, by virtue of their purchase from the Security Bank.

The authorities sem to he ennsistent and uniform to the effect that the defendant cannot be ennsidernd such a holder.

The suggestion that a party issuing negotiahle paper with blank spaces therein, apparently intended to be filled up to make a complete contract, impliedly anthorizes its holder to insert appropriate worls in such blanks, may be dismissed as inapplicahle to such a case as this.

It has sometimes been held that a party signing such paper and delivering it to a third party unfilled ly implieation confors such authority, but it an harfly he elamed that one drawing the form of a promissory note which is unsignet, and lalls into the hamds of another, therehy anthorizs the holder to attarh the maker's signalture or to adel anything which is incomplete in its corention.

The rule that a party luving commerejal paper whind remains in some esential particular incompleto and imperfect. does wot acquire

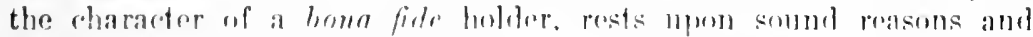

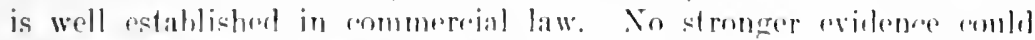

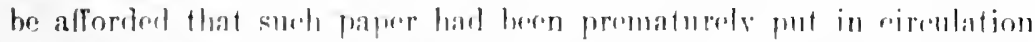
contrary to the will and intention of its maker. Haln the fanct that it

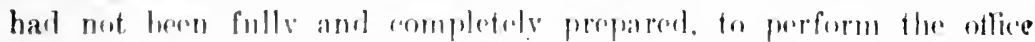
for whinh if was designed. It is apparent that such paper mose nave heren taken from the posesesion of its makre lerfore an introtion to part with it had hem fully formenl. and that he still designed to

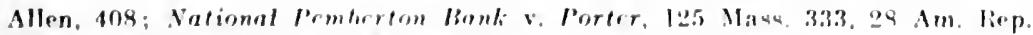
235: Spofford v. Vortom, 126 Ma-4.533. It is mot neoreasery for hen to prove that he owns the note or if not that he has the conent of the true owere to bring suit on it in his own name." looswo, J., in Lowne v. Birkford. 20] Mass. 543, 545. - C. 


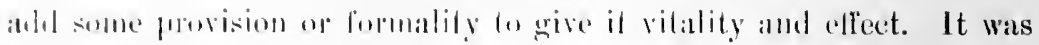

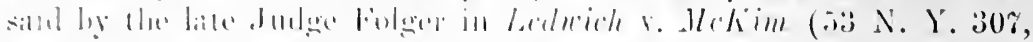

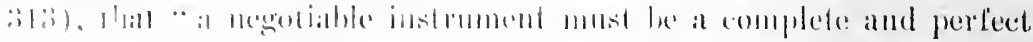

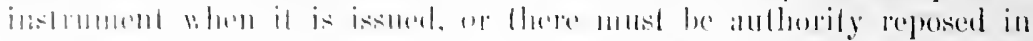

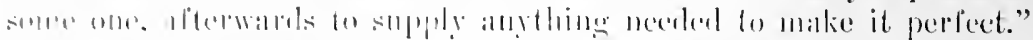

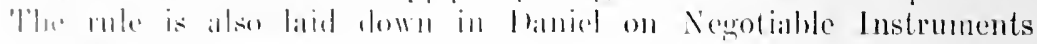
$(5: S 11,21:)$.

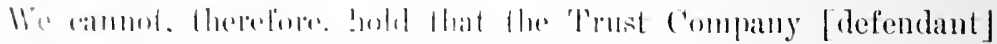

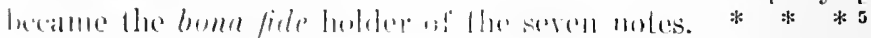

\section{(b) Inxtrument must not be overtue, etc. ${ }^{6}$}

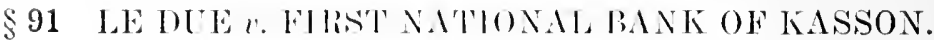

31 MIxxenti. 3:3. - 1883.

Mitrinela, I. At Kisson, Minmesula, on the fifteenth of October,

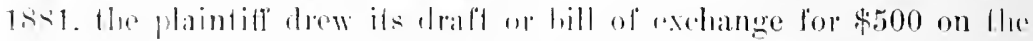

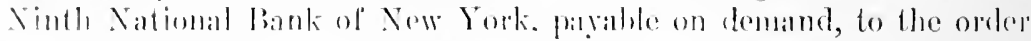

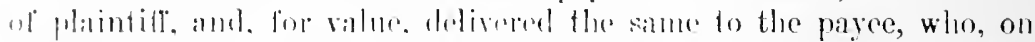

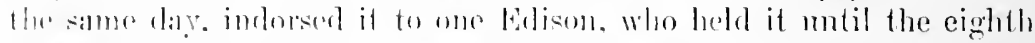

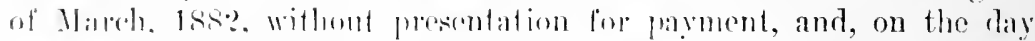
last nimml. imborsen it to one. Iorran, who. nu the eleventis of the

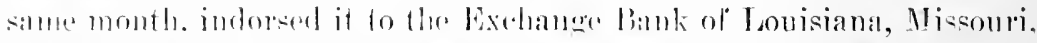
which ansorl it to he presented for payment on the fifteenth of the mombl. whell parment was pofused and the draft protested. On the

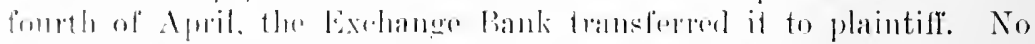

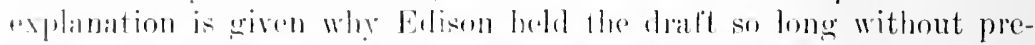

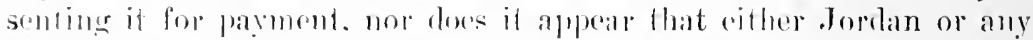

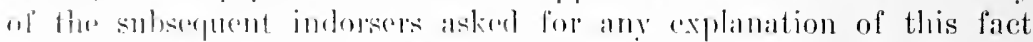

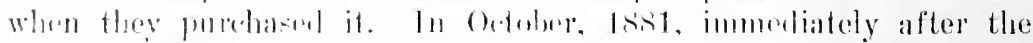

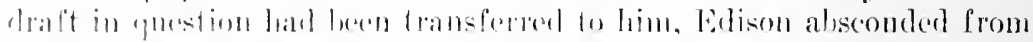

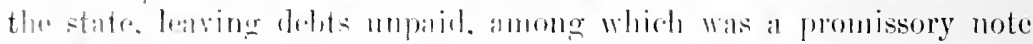

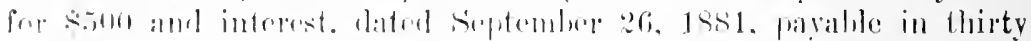

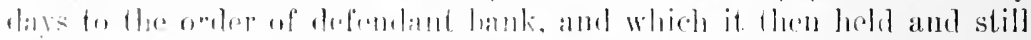

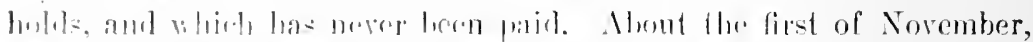

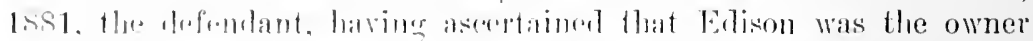

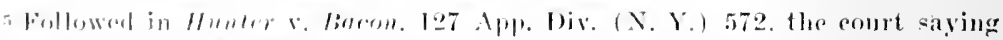

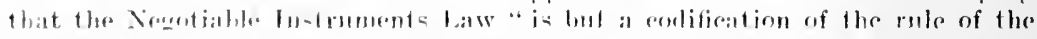

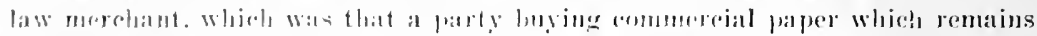

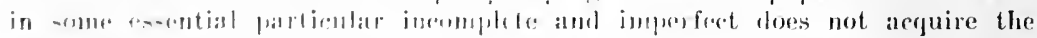

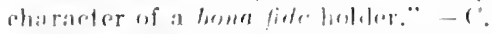

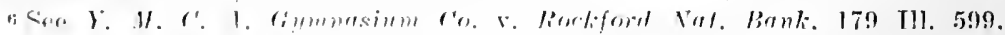

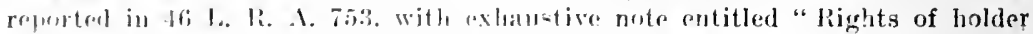
of numotiable paper transferred after maturity." - C. 
of the lraft in question. notifich the drawce not to bay it. This last fact is, periaps, not material. Tpon being sued upon the dralt. the

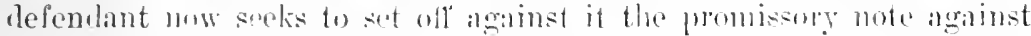
Edison alroady reforred to, and the only pluestom in the rase is

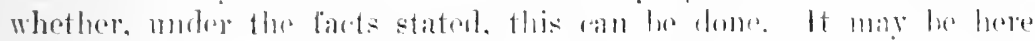

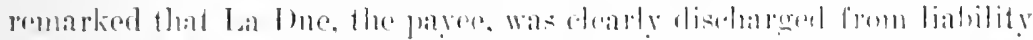
as indorser. by the delay of tire monthe in presentime the dralt lor

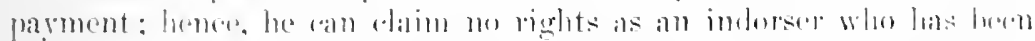

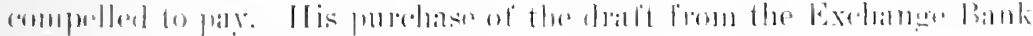

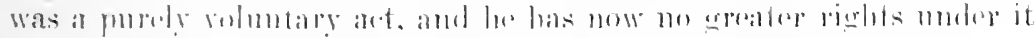

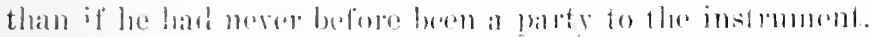

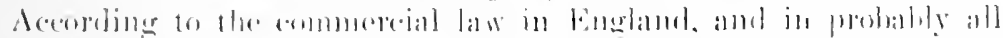

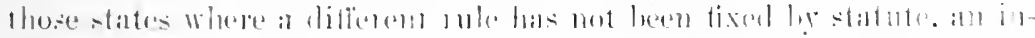

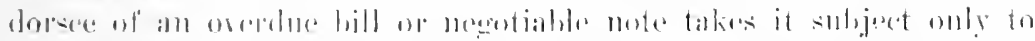

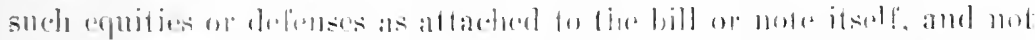

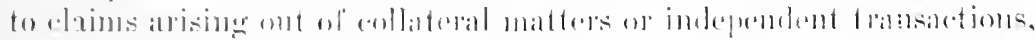

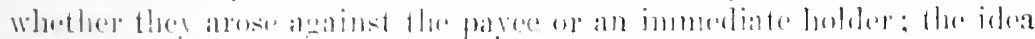

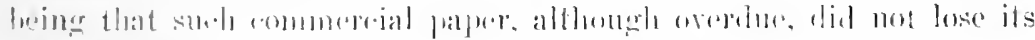
negentialiility.

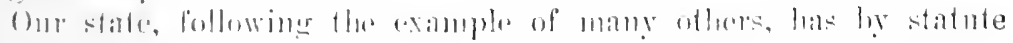

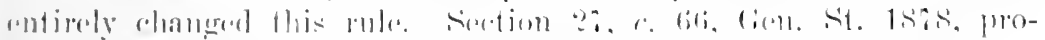

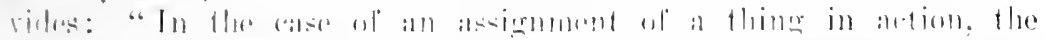

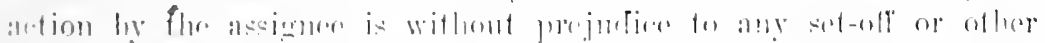

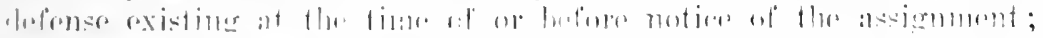

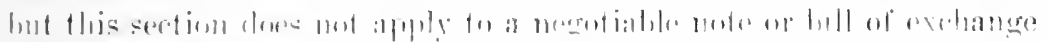

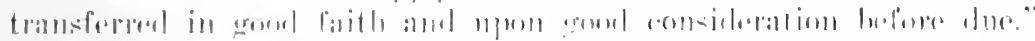

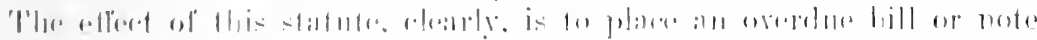

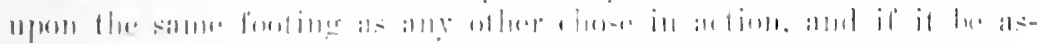

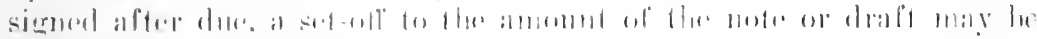

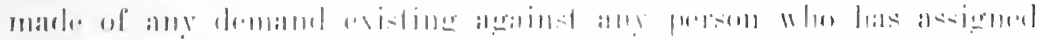

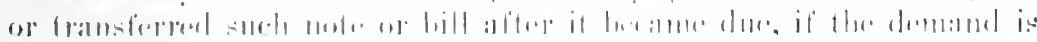

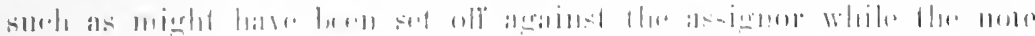

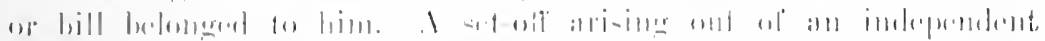

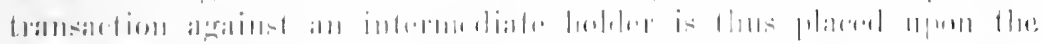

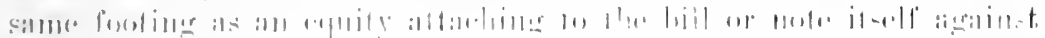

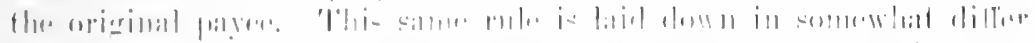

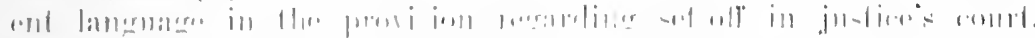

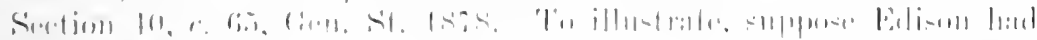

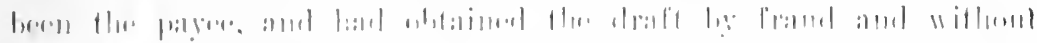

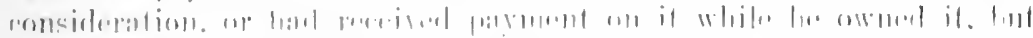

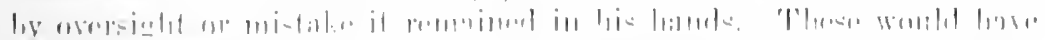

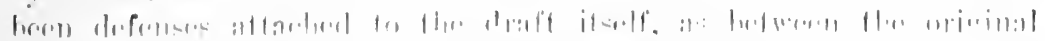

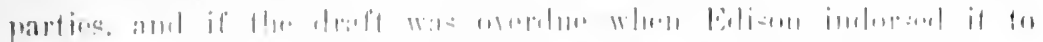

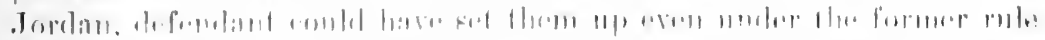

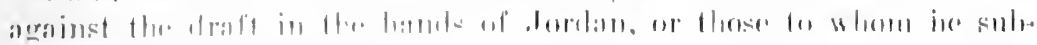

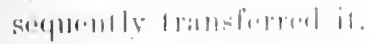


But now, muler the satule, dofomdant could set off this note, although it arises ont of an independent matter, against an intermediate holder. bevaluse it is a demand which might have been set off against Elison whild lle draft helomged to him, had he sued on it. limn r. lilly! 1! Minn. Ist (tiil. 1.ti) : Marlin v. Pillsbury, 23 Minn.

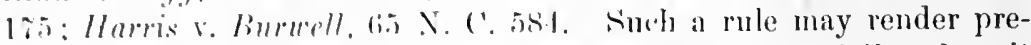
rarious the husimess af dealing in overdue paper, especially when it has pased alter malurily through the hands of several holders. 'The policy of such a law is exclusively for the Legislature, but we may sugrest that we ser mo reason why overdue commereial paper should not be placeel on the same foofing as any other chose in action. Notes and hills of exchange are only treated as business paper when negotiated belore maturity. When overdue they are dishonored. In the principal commercial states of the Union, such as New York, ${ }^{7}$ this same rule has long been ustablished by statute. Ilence our state cannot be charged with having adopted a rule in opposition to the judgment or usages of the business world.

The only question left, then, is whether this draft was "overdue" when Edison indorsed it to Jorian on the eighth of Mareh, 1882, four months and twenty-three days after its date. In the case of a bill, note, or check, payable on demand, no exact day of payment is fixed in the instrument. The general rule is that it must be pre-

i See N. Y. Code of Civil Procedure, $\$ 502$. - C.

8 On this point Mr. Crawiold says: "It was not deemed expedient to make provision in the Negotiable Instriments Law as to what equities the trans. fore will be suljeet to: for the matter may be atfectrol by the statutes of the various states relating to set-off and eounterelaim. In an act designed to be uniform in the varions states, no more ean be done than fix the rights of holders in due course. On the question whether only suel requities may be asserted as attach to the paper. or whether equities arising out of collateral matler may also be asserted, the decisions are conflicting. In England it was decilpel in Purroughs v. Moss, 10 Barn. \& Cress. 55s, that the indorsee of an overdue hill is liable to sueh equitios only as attach to the bill or note itself, and not to claims arising ont of eallateral matters. such as a general set-off is. This is a leading ease, and has since been miformly followed in that ecuntry." Crawford's Nog. Inst. Law, 3d ed., p. 76.

In Edney v. Willis, 23 Nob. 50, at p. 61. MAxwer., J., says: "Section 3\} of the eode provides that "In the ease of an assignment of a thing in action, the action by the a-signee shall he without prejudice to any set-off or other defense now allowerl but this section shall not apply to necotiable bonds, promissory notwe, or bills of rxhange, transferred in gool faith and upon good considration, bofore lue.' This elearly implies that sot-off may be allowed againt a note transforrod after due. . . 'The English rule seems to be based upon the doctrine of recupment, and is not applieable in any state having a satute sinilar to our own, wherr independent and collateral claims may be set off against an overdue note in the lands of a payer."

For a very instructive and learned diseussion of this mattri. see Cumberband Bank v. IJann, 18 N. J. L. 222. See also Davis v. Miller, 14 Gratt. (Va.) 1. $-\mathrm{C}$. 
sented for payment within a reasonable time, having in view ordinary business usages, and the purposes which paper of that class is intended to subserve.

The term "overdue," as applied to a demand bill of exchange, is used in different connections, in each of which it has a different meaning; and the failure to keep these distinctions in mind, has perhaps led to some misapprehension regarding the present case. Sometimes it is used in reference to a right of action against drawer or indorser. In that connection a hill is not overdue until presented to the drawee for payment, and payment refused. Sometimes the term is used in considering whether in indorser has been released by a failure of the holder to present the bill for payment, and to give the indorser notice of its dishonor within a reasonable time.

Again, the term is applied to a bill which has come into the hands of an indorser so long after its issue as to charge him with notice of its dishonor, and thus subject it in his hands to the defenses which the drawer had against it in the hands of the assignor. It is in this last connection that the term "overdue" is considered in the present case. That in this case a bill may be said to be overdue, although it has never been in fact presented to the drawee for paymont, is recognized everywhere thronghout the books, and will be apparent, we think, on a noment's reflection. Suppose a draft has been held by the payce five years, withont ever having been presented to the drawee for payment, and is then indorsed to another party. It would not be due so as to give a right of artion against the drawer, because his contract is only to pay in rase it is not paid by the drawee on presentation. But there would be no doubt that it would be overdue or dishonored, so as to charge it in the hands of the indorsee with any defenses which the drawer had against it in the hands of the payee, although, when he took it, it had nubre heen presented for payment. The retention of a demind draft so long a time without presentment, when no defense exists against it, is so unusual and rontrary to business usiges that this circumstance would be hold to charge the indorsee with notice when he purchased the draft that it was dishonored. The lapse of time would in such cise he so great as to put a purchaser upon inquiry as to the reason why it was still outstanding and unpaid.

The rases are almose imnumerablo in which it has been beld that paper payahle on demand hall heren outstanding so long, when transfrrede as to bo dermed overdme and dishonored, so as to suljoet it, in the hands of the purchasere, to any dofenes which the maker or drawer had against it in the hamls of the payer: and in nome of these cases is thr question whether or not the paper had been. We fore the transfer, prosented for prayenent to the maker or drawee. mererred to as at all material. Joren v. Halling. I Barn. \& r'. 330: First Nat. Bank of

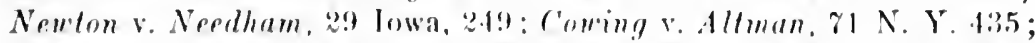
Sylvester v. Crapo, 15 Pick. 9'; Ranger v. C'arey, 1 Metc. 369; Her- 


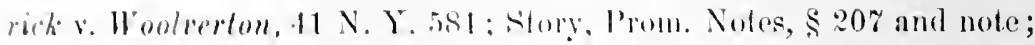

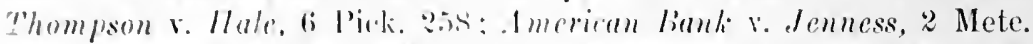

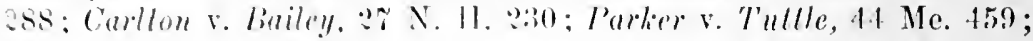
Serims r. Tounsend, 6 Conn. $5:$ Camp v. Scoll. 11 Vt. 387; Morey r.

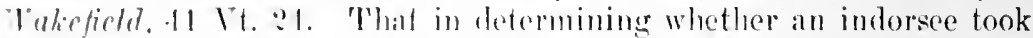
: demand note or hill as dishomogerl and overdue paper, subject to all

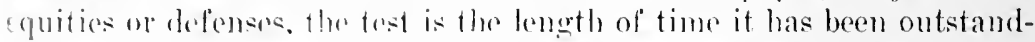

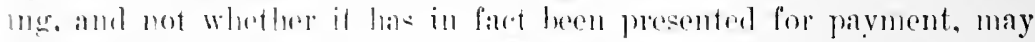
he illusllated in anoflor way. Suppose a dallt hal in fart been presentrel lor parment. and jarment rofusod on the repy day it was sesued, it would then he overelue as to the drawer, so that an action woukl then lic asilust hims. lint suppose immoliately after such presentation, and on the sume lay, the holler should imborse the dralt to another, who took it in rood fajth for value, withont notice of this aretual dishonor, clearly such iulorece would not take it as overelue paper, suliject to the equities or dofonses against it in the hands of the former lobler, because, a pasonalile time lor ils presentation not having expined, there was nothing fo put him upon inguiry, or to

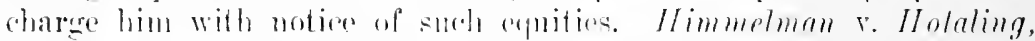
40 Cal. 111. In laret, in leternining whether an inclopse takes such paper as overtue paper, subject to smeli dofonses or equities, the question of actual demand and dishonol does not enter into the discussion. The point of inguiry is, hald the paper leen outstanding so long after its date as to put the purchaser mon incuiry, and charge him with notice that the ere is some lofomse to it? lo riew of the well-known fact that bills of exchange are not always transmitied immediately for

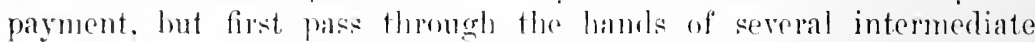
holders in the ordinary rourse of business, and in of her cases are purchased ly travelers to fwa arierl with them instead of eurency or coin, to be negotiated as orestion may repuire, wo are not disposed to lay down any narrow rule on this subjort. Put in this rase we think that the fact that this llaft was, whlont any explanation of the reason, fommentstanding mearly five momtls altore its date, lnlly justified the

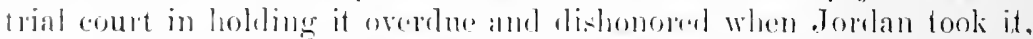
of as to rharese it in his hamds, or the hamels of those who hold muler inin, wht any defense or set-off which the drawer had against it in the hambli of Edison.

Order demying new trial affirmed.

190 MAssurut'setTs, $27 .-1906$.

Morton, J. - This is a bill in arpuity buroment ly the plaintiff. a minor, by her next fremel and enarrian, to rompel the defenclant the Beacon Trust Company to assign and deliver to her a mortgage and 
the note thereby secured, alleged to have been frandulently ohtained from the plaintifl's guardian by one Elwin M. "Thayer, since dereased, and fraudulently assigned hy him to the trust romliny. As to certain of the defendants the hill was dismissed, and a decree was entered in favor of the plaintiff agranst the trust company and other defendants. The cas is here on appeal hy the tomst company. All of the evidence is reported.

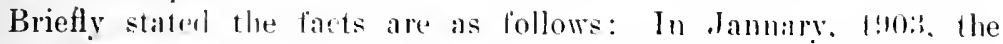
plaintiff was the owner of a moltgage and the note thereliy soned tor $\$ 1,500$, on land in Quiney, eriven hy the relemelant biown to one

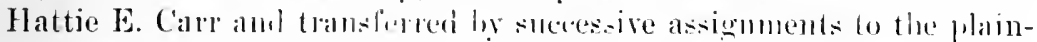
tiff. Her motlere, Mary E. Candner, now Mary E. Wiales, was her guardian. The bote and mortgage had been long overdue. By means of framdulent mistepresentations that the owner of the expity wished to pay ofl the mortwigre, 'Thayer obtilined from the platintiff"s guardian an assigmment of the note and mortgage to himedi, and subsequently assigned them to the thist rompany as security for a note of $\$ 2,000$ for money horower ly him of the complany. The trust company took the assigmont in good faitlı, for value, am without any notice of Thayer s laml. or of any defeet in his title, muless the fact that it took thom when overdue ronstituterl such notice.

We assume, in favor of the plaintilt, that the fart that the note was secured by mortgage does unt alferet its charieter as an overdue negotiahle instrument when talien by the trust rompany, although it is

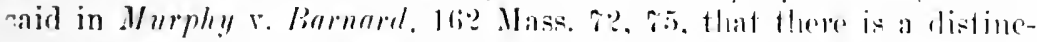

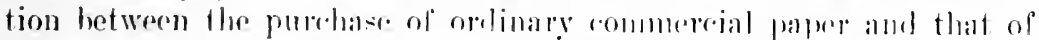

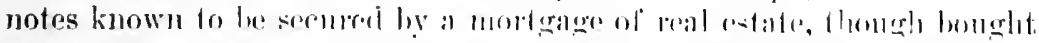

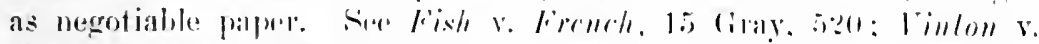

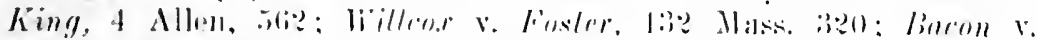

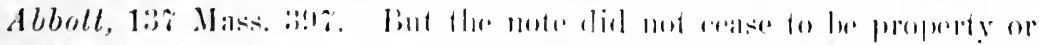

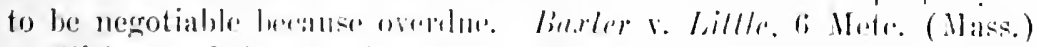

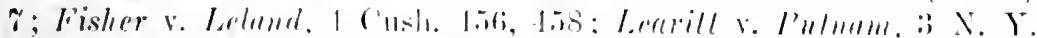

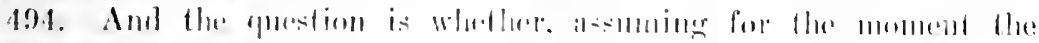

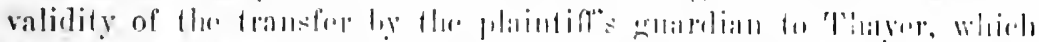

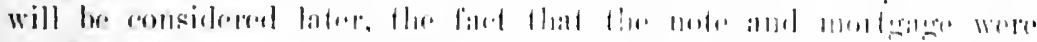

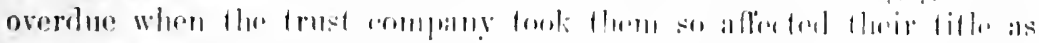

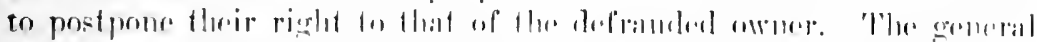

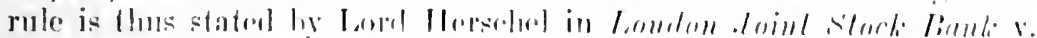

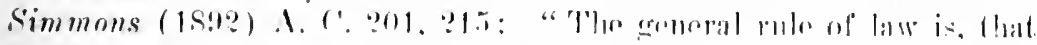

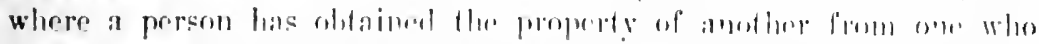

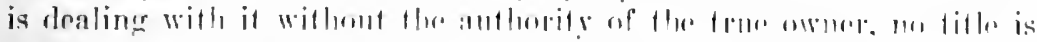

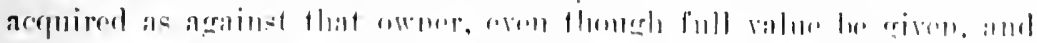

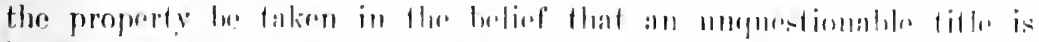

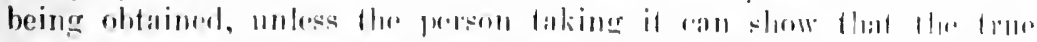

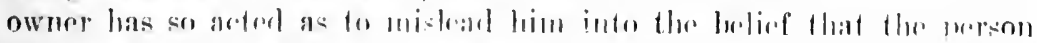
dealing with the property hat antherity to do so. if this ean be 
shown, "good title is acpuirerl by personal estoppel against the truo owner." He then goes on to say that there is an exception in the case of negotiable instruments, manifestly meaning those not yet due, and that as to them any persun in possession of them can convey a good title, even if ating in fraud of the true owner. This is the only exception mentioned by him to the general rule which he lays down, an.t which would sem, therefore, to have been regarded by him as applying to overdue negotiahle notes as well as to other property when eireumstances brought them within it. Applying the rule thus laid down, or the rule that, where one of two innocent persons must suffer in consequence of the fraud of another, the loss must fall upon the one who, by his tiust and confidence, has enabled the perpetrator of the fraud to commit it (Easter et al. v. Allen, 8 Allen, 7; McNeil v. Tenth Nat. Bank, 46 N. Y. 325), it would seem plain that the loss in this case should fall upon the plaintiti, unless the fact that the note and mortgage were overdue makes a difference. She had assigned the note and mortgage to Thayer by an instrument valid upon its face, and had delivered possession of them to him. As a consequence of her conduct, he had possession of them as apparent owner, with full dominion over the property which they represented. This apparent ownership was obtained from the guardian by 'Thayer's fraud, it is true; but, although that would have enabled her to avoid the transaction as between her and him so long as the note and mortgage remained in his hands, his apparent ownership was not affected thereby.

Does, then, the fact that the note and mortgage were overdue when the trust company took then, make a difference? 'The purchaser of an overdue negotiahle note takes it subject to all the equities, if any, that are attached to it at the time of the transfer in favor of the maker, the owner, or of third parties. Vinton v. King, 4 Allen, 562; Vermilye o Co. v. Adams Express Co., 21 Wall. 138; In m European Bank, Ex parte Oriental Commercial Baml (18\%0) 5 Ch. Apr. 35s; In re Overend, Gurney \& Co., Ex parte Swan (1868) 6 Fq. $: 11$. If there are no equities attached to the note the purchaser gets as good a title after as before maturity. In re Overend, Gurney $\mathfrak{\alpha}$ ('o., Ex parte Swan, supra. And it makes no difference that the note is dishonored. If there are equities attached to it, he takes it suliject to them. 'This is what is meant when it is said that the purchaser has no better title, legal or equitable, than his transferror had, and that the note is subject in his hands to the same infirmities of title as against the true owner, and to the same defenses as against the maker, that it was subject to in the luands of his transferror. 1 Daniel on Negotiable Instruments (3d ed.) \$\$72-74, et seq. If, for instance, an overdue note is stolen from the owner, a subsequent purchaser acquires no title as against the true owner (Vermilye $\&$ Co. $v$. Adams Express Co., supra), or if an overdue note has been paid by 
the maker, and is frandulently put in circulation by the payee, a purchaser, though for value and in good faith, takes it subject to the defense of payment hy the maker. In such a case the very fact that the note is dishonored is sufficient to put the purchaser upon inquiry as against the maker. Fold v. Eddy, 1 Mass. 1; Brown v. Davis, 3 T. R. S0; Losee v. Imnkin. 7 Johms. 70. But the case is very different where the owner of an overdue note transfers it, under circumstances which enable his transferee to deat with it, though obtained by frand, as if he were the true owner, and when an innocent purchaser for value takes it from such transferee before the transfer has been aroided. In such a case no equity attaches to the note in favor of the true owner as against the innocent purchaser for value, since it was by his own act that the perpetrator of the fraud was enabled to commit it. The true owner of an overdue note may deal with it as with any other property, and the mere fact that the note is overdue does not, in such a case, in the absence of anything in the transaction to suggest suspicion, put a purchaser upon inquiry any more than a purchaser is bound in any other case to inquire into the titlo of his vendor. See White v. Dodge, 187 Mass. 449. The possibility that the title may have heen obtained by frand exists in all cases; but that is not enough to put a purchaser upon inquiry. Any other view would put upon the innocent purchaser for value of overdne negotiable paper the onus of a defective title, no matter how much he may have been misled by the condurt of the true owner. Wre do not think that such is the law. Cochran v. stewart, 21 Minn. 435, 438, 440: Moore v. Moore, 112 Ind. $149 ;$ Neuhoff v. O'Reilly, 93 Mo, 161: Etherilge v. Gallagher, 55

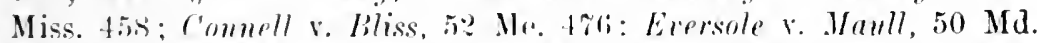
95: 1 . Jones on Mortgages (3d od.) 58 : Ames (ases on T'rusts (2d ed.) p. :310. In Foley $v$. simith. "W Wall. t9:?, the ahore principle was recoguinel, though it was held that the facts did not hring the case within it. So far, therefore, as the planintior relies upon the fact that the note and mortgage were oreplese when taken ly the trust company, her contention must liail. The note bering daland lafure January 1, 18:9:), the Nogotialile Instruments Act does not apply. See Rev. Laws, $4.73, \$ 211$.

The result is that so much of the Hecere as adjutges that the mortgage remains and still is the progerty of the plaintiff, and orders the trust company to assign and courcy its interest in the same to her, is reversed, and the rist is affirmed.

So ordered. ${ }^{\circ}$

- See the very eareful noters to this rase in 2 L. X. S. 767 , and in 5 A. \& E. Ann. ('a4. 583. analyzing the authoritios and formting ont the diatinetions necesary to be grasperl in order properly to understaud the authorities. It is recognized, however, that it may not be possible to harmonize all the casey. $-\mathrm{C}$. 


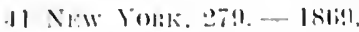

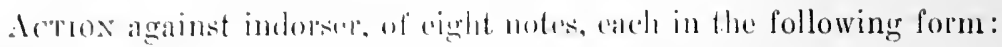
S.jo) (1). 141.

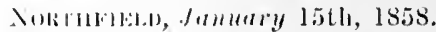

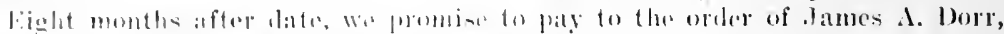

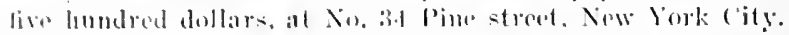

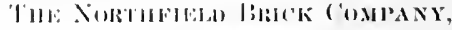

liy damb i. Dolk, Treasurer.

|minssed|: Profert wativel,

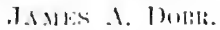

bor indorsed the moles soldely for the acrommondation of one Myels,

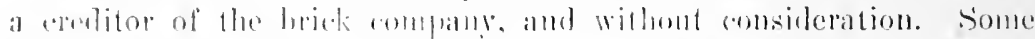
two or thee reals alter the matherity and lishonor of the wotes Myers translerered them to platutill.

Wonmeri. J. - Mr. Mnstion Story, in his treatise on Promissory

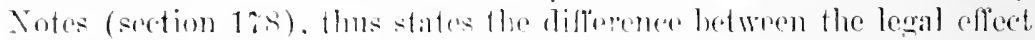
of the transfer of a promiseory motr. lsefore and after maturity:

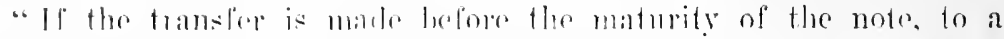
boma fide holder, for a valuahle ensidel'ation. he will take it free of

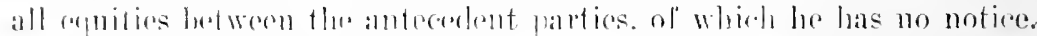

"If the trinster is allar thr maturity of the note, the holder takes it as a dishonoperl notr. and is atterefed he all the equities between the original parties. Whether he has any notier therent or not. But.

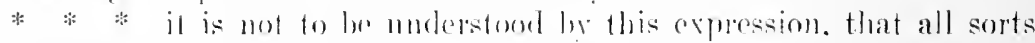

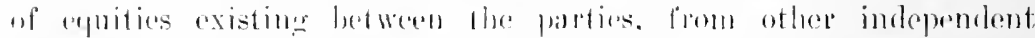

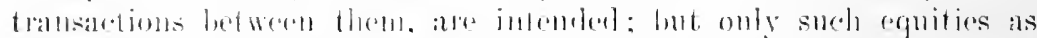

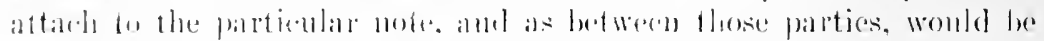

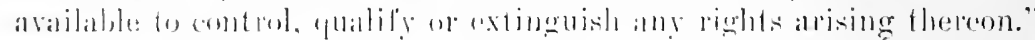

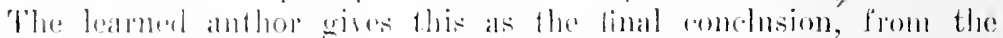

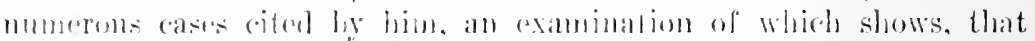

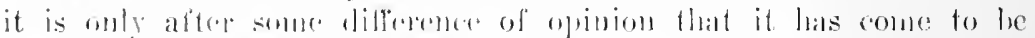

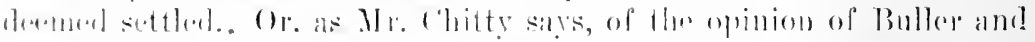

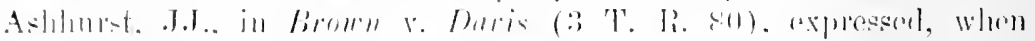

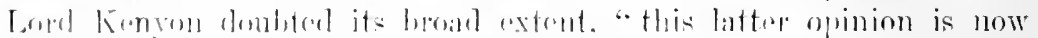
the latw:" "That ophinion was to the reforet:

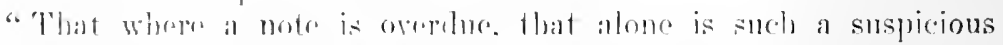

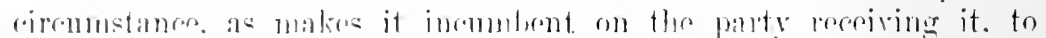

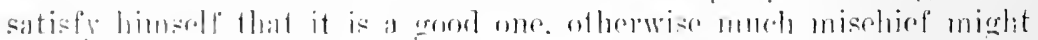
arise." - If a mote indorserl. he not low at llae time. it carries no

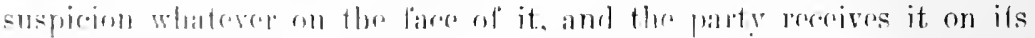

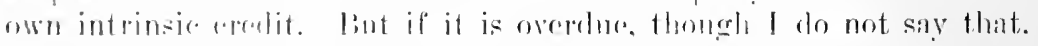

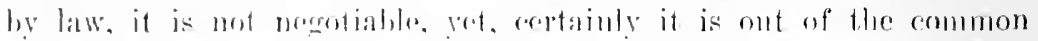

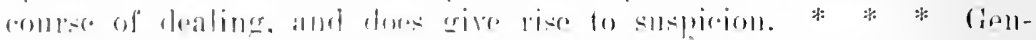

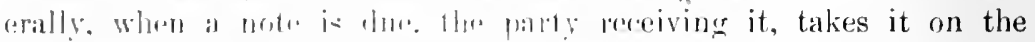
eredit of the person mho gives it to him." 
The foundation of the rule, which distinguishes commercial paper from ordinary connon-law choses in action, is in halmony with the law thus stated; the indeler of the former is protected against any incuiry into ito perions history, and is warranter in giving it full

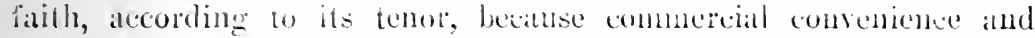
the importance of the free and unembatrassed use of commercial cre lits reyuired it: and on this, the mereantile customs, which ripened into the law merehant. vere founded. These reasons, howerer, conld lave no application to falper which had becen dishonored. 'The eredit it was alopited to invite is spent. and the rery fact of dishonor is inconsistent with the purposes which the rule wis intended to sulserese.

'The rule is simplo and convenient of application, is in no sonse inconsistent with the usefulness of negotiahlo paper for the purposes for which it is intembleml. and, as it soems to me. is a just security against mischief and frand.

In the terms in which it is ahore stated it inchules the rlelense of want of consideration. whenever that rencless the note invalid in the hands of him who holds it. when it heromes dur. Simels want of consideration is an inherent defiret in the enntrate itselt. (or, in fhe language of the rule. attaches to the note itself. in the hambls of one

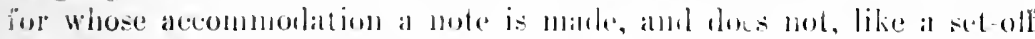
or other collateral matter afart from the note, arise out of an indepardent transaledion.

But the sime leaned writer, above roferien to, states that the mere

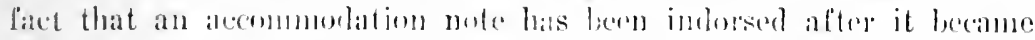

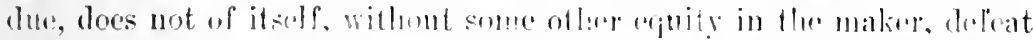

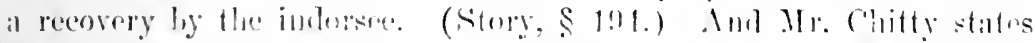

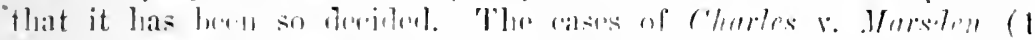

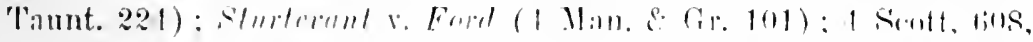

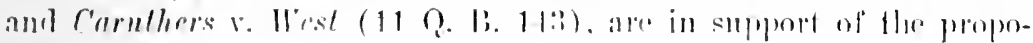
sition.

These are the mese upon thre antherity of which the present anse was docidol loclow.

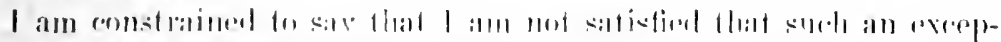

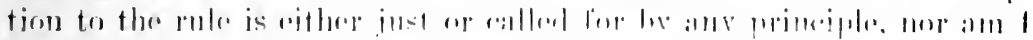

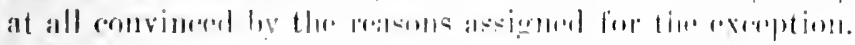

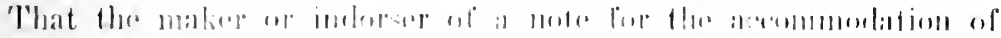

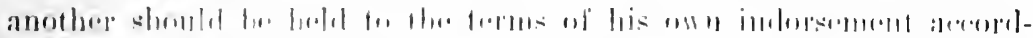

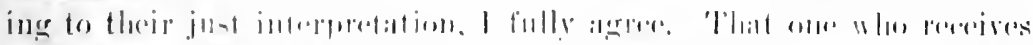

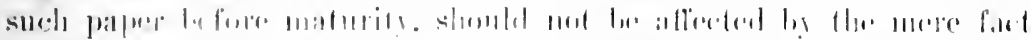

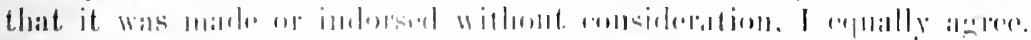

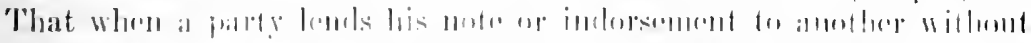

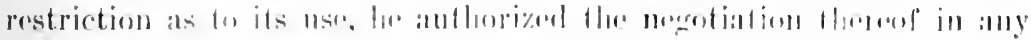

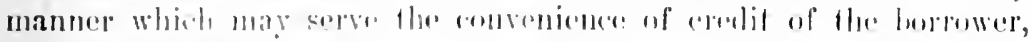
may be conceded. 
From this latter enneession it is argued, that such a lending of one's

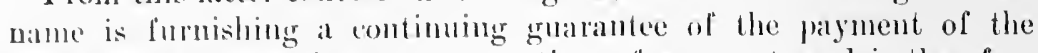
note, irrespetive of its terms as to time of payment, and is therefore binding whencrer it is transfermd, and however long after it has beeme payable and been dishonored. That the absence of express restriction warrants the inferenee, that the making or indorsement wis to enable tiro borrower to use it whenever thereafter it suited his pleasure, and so "enforring its payment is in aceordance with the objeet for which the note was, as matter of aceommodation, made or indorsed:" and in the discussion in England, it has heen suggested, that supposing an atcommodation acceptance to remain in the hands of the party aceommodated. it may he treated as giving authority by implieation to use it thereafter, as his eonvenience or needs may require.

In respect to the last suggestion, two observations are pertinent; first, it hegs the question, for assuming the rule to be that he who receives the note or bill, after dishonur, acquires no better title to recover thereon than he has from whon it was received, then there is no reason why the acconmolation maker or indorser should not treat the note in the hands of the borrower, after maturity, as functus officio, and mere waste paper. And, second, how is the maker or indorser, in such ease, to withdraw his note or indorsement? Is he to be driven into a court of erpuity, and to praying out an injunction, to prevent a subsequent transter? I think not. Take the present ase; the note itself was the property of the holder at maturity (Myers), and was a valid note in his favor against the maker. The indorsement of the defendant (the appellant's testator) was material as a transfer of title. altluough, heing made for 11 yers' accommodation, it could not be enforred against such defendant as indorser. I cannot agree that it was incumbent on the defendant to go into a court of chancery to compel Myers to suffer a writing of the words, "without reconrse." or an equivalent expression, as a qualification of such intorsement.

As th the other reason, it is even less satisfactory, because it proceeds, I think, mpon an entire miseonstruction of the act of making or indorsing a note for the accommodation of another. 1ts purpose and olject, is to obtain crerlit for such other, or to enable him to do 8o. The very terms of the note declare the credit it is intended to proeure. that is to say, until the maturity of the note. Within that range, the making or indorsement heing unrestricted as to its use, the borrower may use it as his exigencies require, and a transferee may receive it in reliance upon the undertaking which is inported by its terms.

But the very term of payment, entained in the note, imports that the aceommorlation party undertakes that the note shall he paid at its maturity; and that he who then holds the note, shall have recourse 
to him, if it be not then paid. Where the accommodation (as in the present case) is by indorsement, that is the precise contract, viz., that the note shall be paid at maturity, and not that it shall be paid at any future lime. If the note be not paid at maturity, the contract is broken, and if he who then loolds it ean recover thereon, then his right of recovery may be transferred to another; and the recovery of the latter will be, not becanse the aceommodation indorser undertook that the note should be paid to him, or should be paid at some date after it was due, but becaluse a valid cause of action, existing in favor of the holder at maturity. has been transferred to him.

It is not according to the intent or meaning of an indorsement for another's accommodation, to say that the indorser intends to give the use of his eredit for any other period than that limited in the note; or that such an indorsement imports authority to use it, when that period has elapised.

One may be willing by indorsement, to guarantee the solveney of another for sixty days, or for six months, and yet he would wholly refuse to do so for a period of two years. And accordingly, when such accommodation is given, it is a most material eireumstance that the time during which the borrower is at liberty to olitain eredit on the note, is fixed hy the limitation of the time of payment therein.

I deem the just view of the subject to be, that when a note has hecome due and is dishonored, the rights and responsibilities of the parties thereto are fixed. The note then loses the chief attribute of eommercial paper. It is no longer arlapted to the uses and purposes for which such paper is marle. and in respect of which it is important that it should circulate freely. And thereafter, he who takes, it, takes it with knowledge of its dishonor. with ohvions reason to believe that there exists some reason why it was not paid to the holder: and takes it with just such right to enfores it as such holder himself has, and no other.

In thus stating my views. I am not insensible of the apparent anthority for the dericion mado below. Int I am also aware that the judges in England have not leen at all agreed 11 pon the suhjoet. and have expressed dould of the correctness of the decision in Chartes v. Marsden, upon which the other two eases alove refered to were decided. The eases, largely collerterl in the notes to chitty in the recent edition, warrant. I think, the dissatisfaction I have expresserl.

No ease in this statre has alled for a derision of the runestion : and

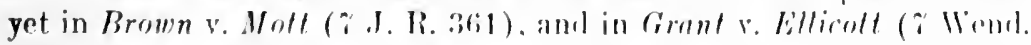
227), the ease of Chartes y. Morsten is referred to withont disapprobation, and the propesition to he derived therefom is stated: lut in neither case was the point now raised hefore the rourt, for in neither did it appear. that the plaintiff took the note after it berame due.

And that in other states in this enntry. surly an exception to the general rule first above stated is repuliated, sec Brown v. IIastings 


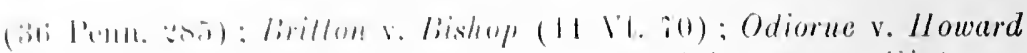

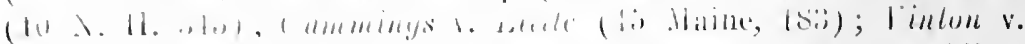

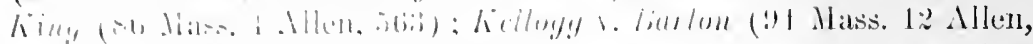

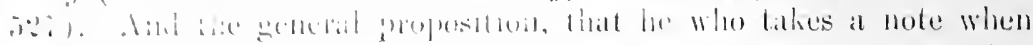

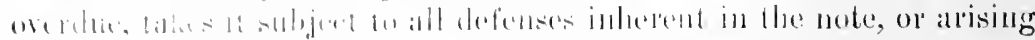

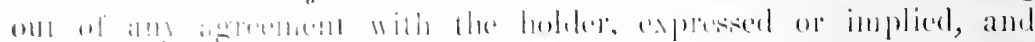

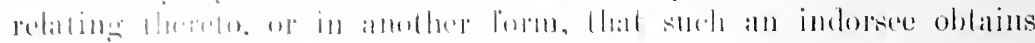

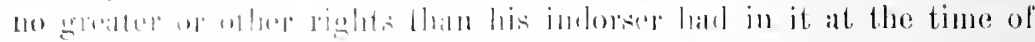

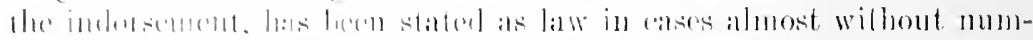

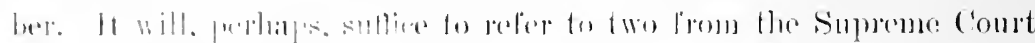

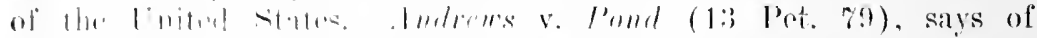

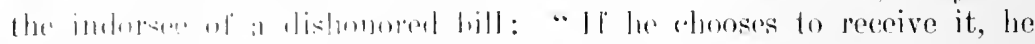

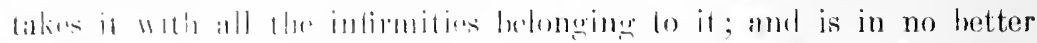

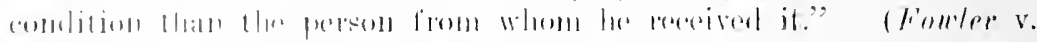

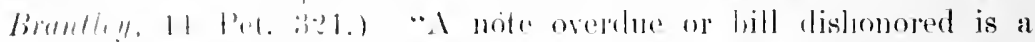

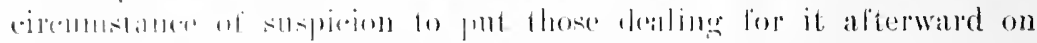

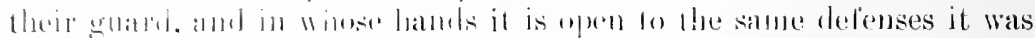

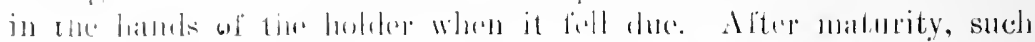

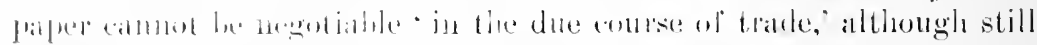

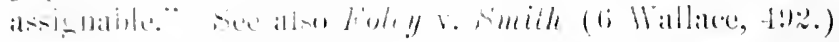

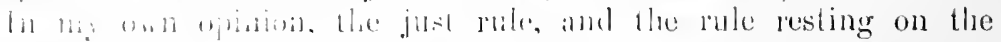

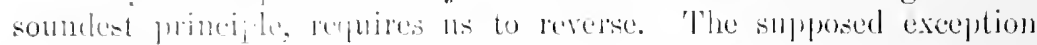

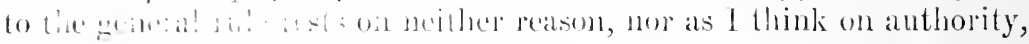

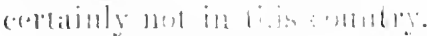

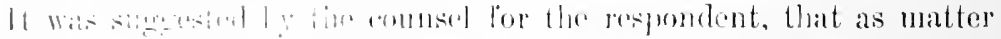

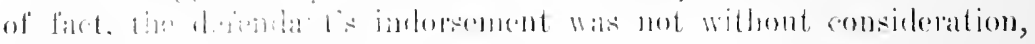

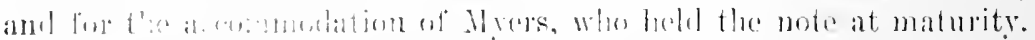

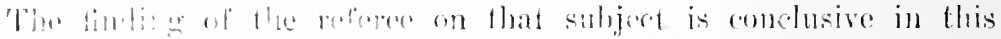

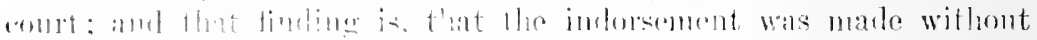

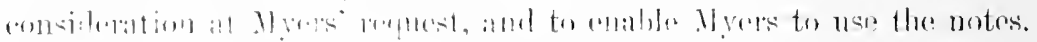

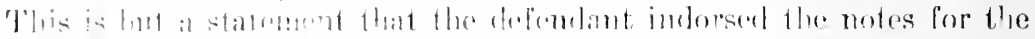

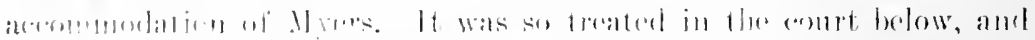

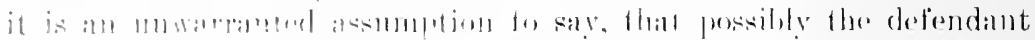

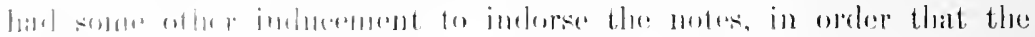

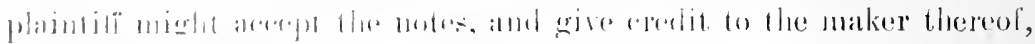

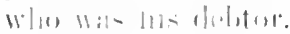

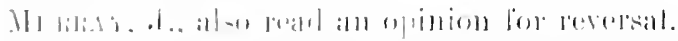

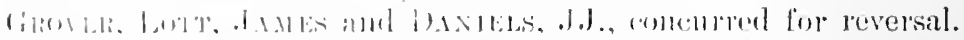

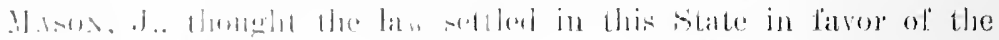

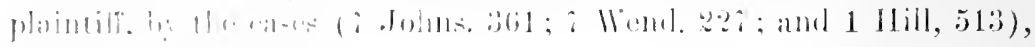

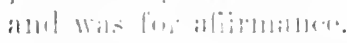

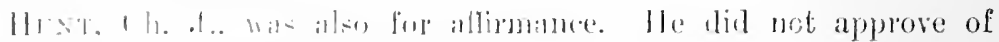

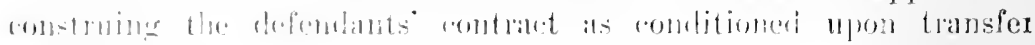

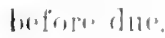




\section{MARLING $v$. JONES.}

138 Wisconsin, 82. - 1909.

\section{Timlin, J. * * *}

The accommodation note in question was transferred by the party acconmodated, namely, the payce therein, after it hecame due. Does this circumstance permit the accommodation maker to aroid the note on the ground that he received no consideration? If the ellect of a transfer, after due, is merely to leave the transferee subject to notice or knowledge of the true circumstances attending the execution of the note in question, and for this reason subject him to defenses, then, as actual knowlerge that the note was accommodation paper would be no defense hy the accommodation maker as against the transferce for value from the party accommodated, it would seem that it could make no difference in the liability of the acconmodation maker upon this ground whether the note was transferred before or after due. Aside from this imputed notice or knowledge, or artual notice or knowledge, it is not true that the taker for value from the party accommodated stands in the shoes of the latter. The difference between them is that one has parted with value for the note and the other has not. In neither case has the maker rereived a consideration moving to him. So that between the party acenmmodated and the accommodation maker there is no considuation parted with or recoived !y either, while betwen the transforen for value and the aceommodation maker there is a consideration moving from the fornor at the instance of the latter sufficient to support the rontract. 'There is considerable conflict among the decisions on this point. and those text-writors who profess to have made a thorough examination of the cases seem to incline to the belief that the weight of authority upholds the view that the transferee of aceommodation paper alter lue mave cuforce the same against the accommodation maker. Joyee on Defouses to ('ommercial Paper, \$282; 1 Dan. Neg. Iristruments (5ith ed.) \$ ref; : Randolph, Comm. Paper (20l od.) \& diz; Story, Prom. Notes (rth od.) \$ 194; 2 Parsons, Notes \& Bills, p. 2!) ; Mersicl v. Allerman, " ir C'onn. 6.31; Black v. Tarbell, 8!) Wis. 3900; 1 Am. \& Vingr. Vincy. I alw, 361.

The muform Nomotiable Instruments Law (Simborn's St. Supp. $1906, \$ \$ 16 \% 5-168.1-\%)$ enactol hy the Iegislature of this state, and in like mamore arlopterl by thirty-four states of the Union, and by Congress for the District of C'olmmbia, in the effort to bring alont more uniformity of berision regarding these instruments of commeree, appears to distinguish low ween a holler for value and a holdor in due course. Rranuan on the Negntiablo Instruments Law (A. I). 1908);

in This ease is reported in 2 A. \& V. Ann. Cas. 254, with note entitled "Right of transferee of acemmodated party after maturity as against aceommodation party." $-r$. 
Bunker on the Negotiable Instruments Law (A. D. 1905). Section 16i5-55." simborn's st. Supp. 1906 to St. 1898 , defines who is an atcommodation party, and provides that such party is liable on an instrument to a holder for vahe, notwithstanding such holder at the time of taking the instrument knew him to be only an accommodation party. Section 1655, Sanborn's St. Supp. 1906, defines "holder" to mean the payee or indorsee of a bill or note who is in possession of it, or the bearer thereof, and defines "value" to mean a valuable consideration. On the other hand, a holder in due course is defined in section 1666-22; Sauborn's St. Supp. $1906^{2}$ [giving substance of this section.]

In the hands of a holder otherwise than in due course such note is subject to the same defenses as if the notes were not negotiable. Section $1636-28,{ }^{3}$ Sanborn's St. Supp. 1906. A negotiable instrument is diseharged by the payment in due course by the party accommodated. It is not discharged by payment by a party secondarily liable thereon, but remits such party to lis rights against him primarily liable (section 1609-2, Sanborn's St. Supp. 1906), except where it is made for accommodation and paid by the party accommodated (Id.). On the other hand, there are the cases of Chester v. Dorr, 41 N. Y. 279; Peale v. Addichs, 1 it Pa. 543 ; Bacon v. Harris, 15 R. I. 599 ; Battle v. Weems, 44 Ala. 105, and Simons v. Morris, 53 Mich. 155. See, however, in Alabama, the later case of Connerly v. Planters' \& Mer. Ins. Co., 66 Ala. 132; in Michigan the later case of Warder et al. v. Gibbs, 92 Mich. 29.

No doubt there exists a elass of defenses in favor of the accommodation maker of negotiable paper which may not be urged in eases where the note is fair on its face and negotiated in due course before due to a purehaser for value, without notice or knowledge of any infirmity, but whicis might be urged in favor of the accommodation maker if the note were overdue when negotiated, but the fact that the accommodation maker received no consideration is not one of these defenses, so long as the note was negotiated by his express or implied authority. 'The fact is here established that this note was in its inception acrommodation paper. Jones nade to IIerman no express restrietion upon its use for that purpose. We do not overlook the testimony of Brand with reference to conversations between him and Herman not in hehalf of Jones, which the court below from its findings must have rejerted as incredible. We approve this rejection. The testimony is overhorne by the circumstantial evidence. It is a question

11 N. Y., \$55. - C.

1 N. Y., \& 2. - C.

2N. Y.. \$91. - C.

3 N. Y., \$97.-C.

4 N. Y., \& 202. - C. 
upon which the precedents are at some variance whether or not the agency of the party accommodated to use the accommodation paper to raise money thereon (no express agreement appearing) expires with the maturity of the paper. The greater number of courts seem to favor the view that the agency to negotiate an accommodation paper and raise money thereon is not so limited. See citations supra.

The courts of this state are not yet committed upon the question presented, and it seems more in harmony with the uniform Negotiable Instruments Law, and with the weight of judicial authority, to hold, as we do, that the mere fact that the accommodation note was transferred by the party accommodated after due to a holder for value does not permit the accommodation maker to defeat recovery at the suit of the holder for value merely upon the ground that the note was an accommodation note, and without consideration moving to the accommodation maker. This necessitates a modification of the judgment of the court below so as to permit the appellant to take judgment against the accommodation maker, Jones. ${ }^{5}$

\section{\$91 FIRST NATIONAL BANK OF WAVERLY, IOWA, $v$. FORSYTH.}

67 Minvesota, 257, - 1897.

JUnGMENT for defendants. From an order refusing a new trial, plaintiff appeals.

Mitchell, J. The only question presented by this record is whether the promissory note in suit was dishonored paper at the time it was indorsed to the plaintiff, and therefore subject, in its hands, to defenses existing between the original parties. 'The note was executed $A$ pril 4, 1891, and was payahle .July 1, 1891, with interest payable annually. The court finds that it was indorsed to the plaintiff on the $22 d$ of May, 189t; that on that day the plaintiff paid for it $\$ 243$; that at that time there was interest overdue and unpaid on the note; and that that fact was known to the pla intif at the time of the purchase. The evidence amply sustains these findings. No interest had ever been paid, and hence there were, at the time of the purchase, two yearly insta.'ments of interest overdue and unpaid. 'The sum which was paicl for the paper fully justified the court in finding that the plaintiff knew of this defanlt. 'Therefore the case is not distinguishable from Bank v. śroll r'o., 1.1 Minn. F7 (Gil. 59). We are asked, however, to overrule that rage, for the reason that it stands

s. See also Viarf v. Intter, 226 III. 628, reported in 11 I. N. S, 1034, with note entitled "Effect of tranufer, after maturity, of accommodation paper whicl has been diverted from the uar for which it was intended by the accommodating party." - C. 
alone, and is contraly to the uniform current of authorities in other jurisdictions. If this was true, it would probahly be suflicient reason for werruling the case, berase uniformity is eminently desirable in rules governing negrotiable paper.

All the anthorities agree that, when the principal of a note is payable by installments, and one installment is overdue and unpaid at the time the paper is indorsed and transferred, the whole paper is dishonored, and suljeet to all equities between the orginal parties. Whether or not the same rule applies when there is an installment of interest overdue is a contro. verted question - at least, the authorities are not all agreed on it. The cases holding, either directly or impliedly, that the indorsee for value of negotiable paper is within the protection of the law merchant, although interest is overdue and unpaid at the time of purchase, are the following: Bank v. Kirby, 108 Mass. 497; Cromuell v. County of Sac, 96 U. S. 51 ; Kelley r. Whitney, 45 Wis. 110 ; State v. Cobb, 61 Ala. 127 ; Brooks v. Mitchell, 9 Mees. \& W. 15. The first three are the only cases in which the question is discussed, and of these the last two arlopt substantially the line of reasoning used in Bank v. Kirby. Among the text writers Daniels, Bigelow, and Tiedeman favor this rule. The Supreme Court of Wisconsin had held the same way in Boss v. II witt, 15 Wis. 260, but held differently, or at least expressed dilferent views, in Hart v. Stickney, 41 Wis. 630, but finally overruled this distum in Kelloy $\mathrm{v}$. Whitney, supra. 'The anthorities on the other side of the question are Newell v. Gregg, 51 Barb. 263; Bank v. Scott Co., supra, and Chonteau v. Allen, 70 Mo. 290-339. While Newell v. Gregg is not the decision of a court of last resort, we do not find that it has ever been overruled in the state of New York, or that the Court of Appeals of that state has ever passed upon the question.* These are all the cases we have been able to find on either sile. 'The line of reasoning in Newell v. Gregg is that, as to notice of dishonor, there is no Jifference between an overdue and unpaid installment of principal anl an overdue and unpaid installment of interest; that payment of

*In Citizens' Sav. Bank v. Couse, 124 N. Y. Supp. (Sup. Ct., Trial T., Wayne (o., June 23, 1910) 79 , it was held that where a note provided that interest was payable annually, a default of interest appearing thereon when it wat transferred to plaintiff was sufficient to put plaintiff on inquiry as to aly defects : nd to require submission of plaintiff's bona fides to the jury. After disenssing Newell v. Gregg, 51 Barb. 263, the eourt said: "I am unable to distinguish that ease from this. . . The authority of the ease of Newell v. Firegg has not been nverthrown by subsequent decisions in this state, so far as 1 an aware, and I feel bound to follow it, notwithstanding the fact that a different rule prevails in other jurisdictions." Referring to a dictum to the entrary in Town of Ontario v. Hill, 33 Hun, 250, affirmed 99 N. Y. 324. the court said: "Newell v. Grogg was not cited by the court or in the briefs of counsol, and apparently was not brought to the attention of the court. Certainly there was no intention shown to overrule that case." - C. 
one is as micis a part of the agreement as payment of the other; and that, i:s eiticer case alike, the indorsee takes the note with warning that tiese lats been a default, and that the maker may have a defense; and leinec, if the one renters the paper dishonored, there is no reason for holding t?.at the other does not. The reasoning in Bank v. Kirby is that, in their effcet upon the credit of a note, there is a manifest difference between a failure to pay interest and a failure to pay prinripal; that interest is an incirlent of the debt, and differs from it in that it is rot sul ject to protest and notice to indorsers or to days of grace; that the statute of limitations does not run against it unti] the principal is due, ete.

If the question were a new one in this state, we might, possibly, be inclined to adoph the Massachusetts doctrine, as founded on the better reasoning. But Bank r. scoll Co. has stood unchallenged in this state for twenty-seven years, and the decisions are not so numerous or so uniformly in favur of the opposite doctrine as to clearly prove that it is the established rule of the commercial world generally. If the rule ought to be clanged, it is a very easy matter for the Legislature to do it. The practical difference between the two doctrines is not as great as might at first scem, for, even under the Massachusetts rule, the nonpayment of interest is a fact proper to be considered, in connection with other circumstances, upon the question whether the holder is entitled to the position of one who has purchased the paper in good faith and without notice of existing defenses. And we do not think any conrt has ever gone so far as to hold that the defaults in payment of interest may not he so mumerous and of such long standing as to be sulficient, of thenselves, to justify a court or jury in finding that the holder was not a purchaser without notice. For these reasons we thiuk that Bank $v$. Siroll C'o. should be followed, upon the gromnd, if no other, of slare decisis.

Order aflirmed. ${ }^{\circ}$

(c) Must be tulien in good faith and for value.

DrWIT'T $v$. PERKINS.

20 Miscossin, 473. - 1868.

Actros on defondiut 's promissory mole. The jury, hy direction of the court, found for the platintiff: and the defendant apperaled from the judgment. The questions in dispute will sufficiently appear from the opinion.

o Contra: Inion Investment ro. v. Wrlls, 39 Can. Sup. Ct. 625. II Am. \&

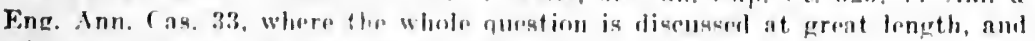
where there is also a long diascuting opinion. - C. 
Dixon, C. J. - The plaintill, knowing the defendant, and that he was in fair credit and able to respond, purchased, shortly before its maturity, a promissory note against him for three hundred dollars and interest for six months, paying therefor only the sum of five dollars. As between the defendant and the payee, the note was invalid for want of consideration. Is the plaintiff a bona fide holder for value, so as to protect him arainst the defense of a want of consideration? We answer, no. 'The consideration paid by hin was merely nominal. It is as if the note had been given to him, and he should clain the protection afforded a bona fide holder for value. It appears on the face of the transaction that it was not a negotiation of the note in the usual course of business, but that the sum exacted on the one side and paid on the other was to give that the semblance of a sale, which otherwise was intended as a mere gift, or, what is worse, a shift to get the note out of the hands of the payee so as to eut off the defense of the maker, for the payee's benefit. Either view is equally fatal to the action of the plaintiff, provided the defense of a want of consideration is established.

Again, the buying of a note against a solvent maker, the purchaser knowing him to be such, for a mere nominal consideration, is very strong, if not conclusive, evidence of mala fides. It is constructive notice of the invalidity of the note in the hands of the seller - such as to put the purchaser upon inquiry, which if he fails to make, he acts at his peril. (Brown v. Taber, 5 Wend. 566 ; Mathews v. Poythress, 4 Ga. 28r, 299 et seq., and cases cited; Anderson v. Nicholas, 28 N. Y. 600; Whitbrad v. Jordan, 1 Younge \& Collyer [Exch.], 303, 328: Jones v. Smith, 1 Hare, 68: 1 Parsons on Notes and Bills, 254, 259-60.) The proof offered to show a failure of consideration should have been received, and the case submitted to the jury on this ground.

[Omitting a question of evidence.]

By the Court. - Judgment reversed, and a new trial awarded. ${ }^{7}$

Lord BlackBurn in JONES $\because$. GORDON.

I. R. 2 Appeal Cases, 616. - 1877.

Fartifer, my Lords, I think it is right to say that I consider it to be fully and thoroughly established that if value be given for a bill

7 Acenrd: Smith v. Jansen, 12 Neb. $125(\$ 100$ for \$30); Hunt v, Sandford, 6 Yerg. (Tenn.) 387 (\$333.33 for $\$ 125)$; Gould v. Stevens, $43 \mathrm{Vt} .125(\$ 300$ for $\$ 50) .-H$.

[See Bailey y. Smith, 14 Oh. St. 396, and exhaustive note to this case on "what amount paid constitutris purchaser for value" in $84 \mathrm{Am}$. Dec. 401404. $-r .1$ 
of exchange, it is not enough to show that there was carelessness, negligence, or foolishness in not suspecting that the bill was wrong, when there were circumstances which might have led a man to suspect that. All these are matters which tend to show that there was dishonesty in not doing it, but they do not in themselves make a defense to an action upon a bill of exchange. I take it that in order to make such a defense, whether in the ease of a party who is solvent and sui juris, or when it is sought to be proved against the estate of a bankrupt, it is necessary to show that the person who gave value for the bill, whether the value given be great or small, was affected with notice that there was something wrong about it when he took it. I do not think it is necessary that he should have notice of what the particular wrong was. If a man, knowing that a bill was in the hands of a person who had no right to it, should happen to think that perhaps the man had stolen it, when if he had known the real truth he would have found, not that the man had stolen it, but that he had obtained it by false pretenses, I think that would not make any difference if he knew there was something wrong about it and took it. If he takes it in that way he takes it at his peril.

But then I think that such evidence of carelessness or blindness as I have referred to may with other evidence be good evidence upon the question which, I take it, is the real one, whether he did know that there was something wrong in it. If he was (if I may use the phrase) honestly blundering and careless, and so took a bill of exchange or a bank-note when he ought not to have taken it, still he would be entitled to recover. But if the faets and cireumstances are such that the jury, or whoever has to try the question, came to the conclusion that he was not honestly humdering and careless, but that he inust have had a suspicion that there was something wrong, and that he refrained from asking fuestions, not becallse he was an honest blunderer or a stupid man, but hecause he thought in his own secret mind - I suspect there is something wrong, and if I ask questions and make further inquiry, it will no longer be my suspecting it, but my knowing it, and then I shall not be able to recover - I think that is dishonesty. I think, my Iords, that that is established, not only by good sense and reason, but by the anthority of the cases themselves."

" "It may be true in this case that the plaintiff bught lefor" maturity for value, and without notice of any dofonse; and yet he may not be a purehaser in good faith. 11, may, when he hought, have lial knowleclge of facts which excited in his mind such suspicions as to the paper that he fenred to make an investigution last it womld discluse a drefonse, nond therefore he rarefully shut his eyes and bought in the lark. In much a case he would not be a purchaser

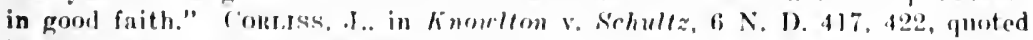
in Walters $v$. Rork, $115 \mathrm{~V} . \mathrm{W} .(\mathrm{X}, \mathrm{D}) .1511$.

The following extract from a elarge was held correct in Mack v. starr, 78 
I think, my larels, that since the repeal of the Usury Laws we (an never inpuire into the question as to how much was given for a bill, and if somby was in such a position that le could have proved against the estate it would have heen no objection at all that he conveyed these hills to amother for a nominal amomt, that he sold bills

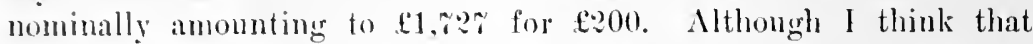
could not have been inquirol into, yet the amount given in comparison with the apparent value is an important picee of evidence guiding us to a conchusion as to whether or not it was a bona fide transaction. I am sure of this, that in criminal cases the greneral evidence that is given to show that the receiver of goods which were stolen knew that they were stolen is that he has given a great undervalue for them. That is not by any meams conchusive, because it may very well be that he has given the undervilue under circumstances which do not sulfice to prove that he had a felonious intention, or a felonious knowledge, which would be repuired to make him guilty. In like manner, I think if it is shown that a considerable undervalue was given for bills, although that alone would probably not be sufficient, it is an element, and an important element, in considering whether the man who gave that undervalue was bona fide doing it because he was in honest blundering and stupidity taking the thing without knowing that he was comnitting or assisting in fraud, or because he had a suspicion that he wonld deprive himself of a good bargain if he made too much inquiry and so had it brought home to him that there was fraud.

\section{(d) Must be talien without notice of infirmity or defect.}

\section{HAMILTON $v$. VOUGIIT.}

34 NEW Jeksey Law, 187. - 1870 .

Beaslfy, Chiff .Justice. - We have presented to our consideration in this case but a single question, viz., whether the title of a holder of negotiable paper, acyured before it was due, for a valuable consideration, is affected by the frand of a prior party, without proof of bad faith on the part of such holder.

Conn. 184, 157: "If there was a wilful or fraululent failure to inquire into facts inviting inquiry, the jury might regard such fajlure as notice, if they thought the failure was due to the belief that inpuiry would result in knowialre of the framl. Notice may be of two kinds - explicit notice of the frand or illegality, and implieit or greneral notiee. If the plaintiff, whon he bought the notes. hall notice or knowlelge of some illugality, or knowledge of some illegality or framl which vitiated them, though he was not apprised of its nature, this would be such feneral notice as would affect his title. Mere negligenes, howeror gross. not amounting to this wilful and fraudulent blind. ness. will not of itsolf amount to noties: but the jury may and should consider the fact of such negligence, as it may tend to prove such general notice." - C. 
At the trial of this eause, the jury was instructed that if the holder of the note sued on - the plaintiff in the action - al quind his title under circumstances which should have put a pereon of oidinary prudence upon his guard, the note was invalid, if its inceltion hand been fraudulent.

The verdict was in faror of the defense, and the plairtitf now insists that the judicial instruction should have beer. t'at suepicious circumstances attending the acquisition of his title were no! sulficient to defeat his claim, unless of a character to raise a conviction of actual fraud on his part.

Counsel who so ably argued this ease in behali of defendant, did not deny that the modern English anthorities were hostile to their position, but they went upon the ground that the rule thus sanctioned was an innovation, and consequently would not be followed by this court. The ancient rule, it was maintained, is that declared in Gill v. Cubitt (3 Barn. \& C'ress. 466). 'This decision was made in the year 1824, and, beyond all question, it sustains the principle now claimed by the defense, for in the reported case referred to the jury were explicitly told that "there were two questions for their consideration: first, whether the plaintiff had given value for the bill, of which there could be no doubt; and, secondly, whether he took it under circumstances which ought to have exrited the suspicions of a prudent and careful man." The authority is directly in point, and the only question which can arise is, whether it correctly states the ancient rule of the cornmon law upon the subject.

My first remark in this connection is, that from the opinion of the judges in the case of Gill v. Cubitt, it appears that the doctrine adopted was intended to be an innoration upon the antecedent practice, and that it was avowedly opposed to a decision of the greatest weight. 'Twenty-three years brefore, in the year 1801, Lord Kenyon, in Lawson v. Weston (4 lisp. 5fi), had expressly repudiated the idea that suspicious circumstances, in the absence of artual frand, would avoid a note in the hands of a loliler for value. But this doctrine did not harmonize with the vicus of the judges in the case of Ciill v. Cubitt, and it was aceordingly overruled. 'Thus, ('hief. Iustice Abbott says, in his opinion: "I think the sonner it is known that the case of law'son v. Weston is doubted, at least by this rourt. the better. I wish doubts had been cast on that case at an carlier time." And he concludes: "For these reasons, notwithstanding all the unfeigned reverene I feel for everything that foll from Lord Kenyon, hy whom Lauson v. Weston was deciderl, I cammot think that the visw taken by that learned lord was a correct one." Nor is this rejection of this anteredent derision attempted. in the slightest degree, to he put upon the foumdation of pre-existing authority. Not a ease is reforred to for its justifiration, nnd although in Lan'son $\mathrm{r}$. W'pston. the aluthority of Jord Mansficld, in Miller v. Race, was mooted, no remark is made on that circum- 
stance. I think a perusil of the opinions in Gill v. Cubitt will satisfy anyone that it was a well-understood intention to deviate from the legral rule upon this subject which had previously existed; or, if any doubt should remain, such doubt will certainly be dispelled by a reference to the case of Slater vest (3 Carr. \& Payne, 325), deeided in the year 18:8, in which Chief Justice Abbott (then Lord 'T'enterden), in laying down the doctrine that a person is not entitled to recover who takes a bill of exchange "under circumstances which ought to excite suspicions in the mind of a reasonable man," says: "This doctrine is of modern oligin. I helieve I was the first judge who decided this point at nisi prius. 'The court to which I belong confirmed my decision, and the other courts have, I believe, acted on the same principle." And Chief Justice Bayley, in his opinion in Gill v. Cubitt, is equally explicit. "But, it is said" - such is his language - " that the question usually submitted for the consideration of the jury in eases of this description, up to the period of time at which my Lord Chief Justice's direction was given, has been whether the bill was taken bona fide, and whether a valuable consideration was given for it. I admit that has been generally the case."

From these citations, I think it is manifest that the judges who participated in the decision of the case of Gill $v$. Cubitt were aware that by the views expressed by them, they introrluced a novelty, and departed from the older practice of the eourts. That the principle adopted in that case was an inmovation, seems to me unquestionable. I have shown that it is irreconcilable with Lawson v. Weston. So it plainly occupies the same relation to the case of Peacock v. Rhodes (Doug. 632), decided by Lord Mansfield in 1781. The rule which it endeavors to overthrow will be found sustained in Miller v. Race, (1 Burr. 452) ; Price v. Neal (3 Burr. 1355); Grant v. Vaughn (3 Burr. 1516); Anonymous (1 Lord Raymond, 738) : Morris v. Lee (2 Lord Raymond, 1396.) There was not a case cited upon the argument, nor have my researches led me to one anterior to the decision of Gill v. Cubitt, which sustains the doctrine there propounded. I confidently conclure, therefore, that the case above criticised cannot stand on the ground of aneient authority. In my apprehension, the original rule as it existed in the time of Lords Kenyon and Mansfield was, that nothing short of mala fides would vitiate the title of the holder of negotiable paper taking it for value, before maturity. It is entirely out of the question, therefore, for this court to regard Gill v. Cubitt as imperative anthority. It is true that that ease was followed for a time to a considerable extent by the English courts. But, as I have alrearly said, in England the original rule has been reinstated. In Backhouse v. Harrison (5 B. \& Ad. 1098), Mr. Justice Patterson says: "I have no hesitation in saying that the doctrine first laid down in Fill v. Cubitt, and arted upon in other cases, has gone too far and ought to be restricted." And in Goodman v. Harvey (4 Ad. \& El. 
8i0), Lord Denman thus forcibly expresses the rule at present prevailing in the courts at Westminster: "The question I offered to submit to the jury was, whether the plaintiff had been guilty of gross negligence or not. I believe we are all of opinion that gross negligence only would not be a sufficient answer where the party has given consideration for the bill. Gross negligence may be evidence of mala fides, but it is not the same thing. We have shaken off the last remnant of the contrary doctrine. Where the bill has passed to the plaintiff without any proof of bad faith in him, there is no objection to his title." The following cases recognize and enforce the same rule: (Uther v. Rich, 10 Ad. \& El. 784; Artbouin v. Anderson, 1 Ad. \& El. (N. S.) 498 ; Stephens v. Foster, 1 Cromp., Mees. \& Ros. 894; Palmer v. Richards, 1 Eng. L. \& Eq. 529 ; Marston v. Allen, 8 Mees. \& Wels. 494; Raphael v. Bank of England, 17 C. B. 161.)

An examination of the American reports will disclose a similar mutation of judicial opinion upon this subject. For a time, in several of the states, the rule broached in the case of Gill v. Cubitt has been acted upon; but now, in most of them, and in those of the most commercial importance, that rule has been entirely discarded. ${ }^{9}$ (34 New York, 24\%, Magee v. Badger; 7 Bosworth, 5t3, Bel. Bank of Ohio v. Hodge et al.; 10 Cush. 488, Worcester, etc., Bank v. Dorchester, etc., Bank; 4 Geo. 28\%, Mathews v. Poythress; 6 Md. 509, Ellicott v. Martin; 36 New Hamp. 273, Crosby v. Grant.)

The subject has also recently been settled, after an elaborate discussion and full consideration in the Supreme Court of the United States, in the case of Goodman v. Simonds (20 How. 343), the result being an explicit repudiation of the doctrine that suspicious eircumstances will, per se, vitiate the title to commercial paper.

From this brief review of the rases, I think it may be safely said that the doctrine introduced by Lord Tenderden stands at the present moment marker witl the disapproval of the highest judicial authority. Nor does such disapproval rest upon merely speculative grounds. That doctrine was put in practice for a course of years, and it was thus, from experience, found to be inconsistent with true commercial policy. Its defect - a groat defect, as I think - was, that it provided nothing like a criterion on which a verdict was to be based. 'The rule was, that to defeat the note, circumstances must he shown of so suspicious

- The carlier Masachusetts casus which wore in aceord with the rule of

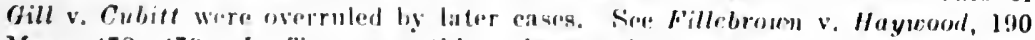
Mass. 470, 47!). In Trumessee this ruls was in fores mutil changed by the enactmont of the Noretiabl. Inatrumants Law. Sie Vnaka Nat. Bank v. Butler, 113 T'rnn. 55.4.

The rule of Gill v. Cubitl is atill followed, lowerer, in Vermont where the

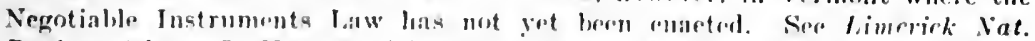
Bank v. Adam, io Vt. 132: followrol in 'apital Sim. Bank v. Montprlier Sav. Bank, $77 \mathrm{Vt}$. 189, and l'ierson v. IIutington, $82 \mathrm{Vt} .482 .-\mathrm{C}$. 
a chatracter that they would put a man of ordinary prudence on inyuiry - and by foree of such a rule it is olvious every case possessed of unusual incidents would, of neeessity, pass under the uncontrolled discretion of a jury. An incident of the transation from which any suspicion conld arise was sullicient to talie the case out of the control of the court. 'There was no judicial standard by which suspicious eireumstances could be measured before committing them to the jury. And it is precisely this want which the modern rule supplies. When mala fides is the point of inquiry, suspicious circumstances must be of a substantial character, and if such eircumstances do not appear, the court ean arrest the inquiry. Under the former practice, circumstances of slight suspicion wonld take the ease to the jury; under the present rule, the circumstances must be strong, so that bad faith ean be reasonably inferred. 'Thus the subject has passed from the indefinite to comparatively definite; from the intangible to the comparatively tangible. From a mere matter of fact, the question, to some extent, has become one of law.

I cannet doubt, when we recollect that inquiries of this nature ahways attend that class of cases where judgments are sought against innocent and unfortunate parties, that the change is most beneficial. All experience has shown how hard it is to prevent juries from seizing on the slightest circumstance, to avoid giving a verdict against the maker of a note which had been obtained by frand or theft. To preserve the negotiability of commercial paper and guard the interests of trade, it is absolutely necessary that large power should be placed in the judicial hand when the question arises as to what facts are sufficient to defeat the elajn of the holder of a note or bill which has been taken before maturity, and for which value has been paid. It is only in this morle that the requisite stability in transactions of this kind can be retained.

But I do not think the difference between the two rules above discussed is as great as some persons have supposed. In my apprehension, the entire variance consists in the degree of proof which the court will require in order to submit the inguiry to the jury. Mere carelessmoss in taking the paper will not, of itself, impair the title so acquired; but calelessness may he so gross that bad faith may be infered from it. Nor is it necessary, in order to refeat the title of the holder, that ho have actual knowledge of the facts and circumstances ronstituting the particular frand; it is sufficient if he have krowledge that the papor is tainted, with any fraud, although he may be ignorant of the nature of it. In the ease of May v. Chapman (16 Mres \& W. 35i), Paron Parke says: "I agree that "notice and knowlorge' mrans not morely express notice, but knowledge, or the means of knowledere to whirll the party wilfully shuts his eyes." Reviewed in this sonse. ns I have alrosily remarker, the nrinciple seems to me a lighly salutary one, and, in the language of Professor 
Parsons, is well " adapted to the free circulation of negotiable paper and the true interests of trade." (1 Par. B. \& N. 259.)

I think a new trial should be granted.

\section{\$95 NATIONAL BANK OF COMMONWEALTH $v$. LAW.}

127 Massachusetts, $72 .-1879$.

Contract, against maker and indorsers of the following instrument :

$\$ 3000$.

New Yokk, January 20, 1877.

Four months after date I promise to pay to the order of Charles F. Parker \& Co. three thousand dollars at the National Bank of Commerec, Roston, Mass. Value received.

[Indorsed]: JoHx SAYERY's SoNs.

Alexander Law.

Chiarles F. Parker \& Co.

Law was a member of the firm of Charles F. Parker \& Co., and also of the firm of John Savery's Sons. Law indorsed the firm name of "John Savery's Sions" and one D. (a partner), indorsed the firm name of Charles F. Parker \& ( o.., and deposited the note as collateral for a loan at plaintilf bank. The note was in fact made without authority of the firm of John Savery's Sons and in frand of the firm. The trial judge ruled that, from the form of the note itself plaintiff was, as a matter of haw, alfected with notion of the defense existing to the note on the part of the defendants (John Savery's Sons), other than Law, and diuceter a verdict for such defendants. If this ruling was incorrect, a urw trial was to be ordered; ollerwise, julgment on the verdirt.

Gras, C. J. [After deriding that the liability of John Savery's Sons was secondary to that of Law. $]^{\prime}$ One partner has no anthority, without the assent of his copartners, to sien the name of the partnership to a note for the inclividual reht of himself or of a strancer: and all persone who take such a noto with knowledge, either fom its appearaner or ntherwise, that it was made for the separate acenmodation of one partuer or of anotlier person. caunot reoper against the other partners withont proving their anthority or assent. In the present ease, the defendants' name being wpon the hark of the note ahove that of the payers, it was apparent upon the note itself, read in the light of the statute, which erergone was hound to know, that the liability of the partnership was lut ronditional and secondary, and therefore that, prima farie at least, their signature was affixed for the accommodation and henfit of Law: and the ruling at the trial was

1 Mass. St. of 1874 , c. 404. Sce Nig. Inst. I., § 114.- H. 
correct. (Angle v. Northwestern Ins. Co., 92 U. S. 330 ; West St. Louis Sarings Bank v. Shawnee Bamk, 95 U. S. 557; Chazournes v. Eduards. 3 lick. 5; Sweetser v. French, 2 Cush. 309; Rollins v. Sterens. 31 Maine, 451 ; Fielden v. Lahens, 2 Abbott, N. Y. App. 111; Lemoine v. Bamk of North America, 3 Dillon, 44.) Judgment on the verdict. ${ }^{2}$

CHEEVER $r$ PITTSBURGH, ETC., R. CO. 150 NEW Yolк, 59. - 1896.

Acrion by holder against maker. Judgment for defendants. Plaintiff apjeals.

O'BRIEx, J. - The complaint in this action contained four separate causes of action, each upon a promissory note of the defendant. The last two causes of action were not defended, and upon these the plaintiff recovered, but was defeated upon the two notes embraced in the first and second causes of action. The defense to these two notes was that they were made by the defendant's president, one M. S. Frost, and by him wrongfully diverted from the uses and purposes for which they were intended to his own personal or private benefit, or the benefit of a firm of which he was a member, and that the plaintiff is not a bona fide holder, but chargeable witl notice of these facts.

The following are copies of the two notes in controversy, with the indorsements thereon when put in circulation by the defendant's president:

2 Similar notes were made by Law and indorsed first, in the name of Charles F. Parker $\&$ ' 'n., and sccond, in the name of John Savery's Sons, and discounted for D. by plaintiff. The trial judge made the same ruling as above. Held: error. "ITpon the face of the note in this case, there is nothing which indicates any irregularity or invalidity in the origin or negntiability of it." The note indicates that Charles F. Parker \& Co. had transferred it to John Savery's Sons. and the latter hy blank indorsement to a new holder. There is no conelusive evidenere that plaintiff knew it was disenunting the note for C. F. Parker \& $c 0$. The inference is quite as natural that D. was the owner. Freeman's National Bank v. Savery, 127 Mass. $75,78$.

Where one of four partners signed in lis inclividual name a note payable to his firm. and another partner indorsed the firnı name, and the first partner then tonk the note to the plaintiff. filled in eertain blanks in plaintiff's presence, and trancferred the note to plaintiff to take up another similarly executed, but plaintiff testified that he had no knowledge that the loan was not for the benefit of the firm, held, that there is no conclusive proof, as matter of law, from tive form of the note or other circumstance. that plaintiff had notice that the inforsement was for the nuker's accommodation. It was a question of fact for the jury. Wait v. Thayer. 118 Mass. 473.

1). loaned money to the firm of Stewart. Hammond \& Mead, taking a note signed by Hammond and indoreed by the firm. This firm was dissolved, and the firm of Hammond \& Seripture was formerl. Hammond arranged with D. to retain the money for the benefit of the firm of Hammond \& Scripture, and 
$\$ 5,000$.

Greenrille, Pa., Feb'y 24th, 1888.

Four months after date the Pittsburgh, Shenango and Lake Erie Railroad Company promises to pay to the order of John T. Bruen tive thousand dollars, at the American Exchange National Bank, New York City. Value received.

Attest: E. S. TeMpletox, Secretary.

The Pittsbubgh, Shenango \& Lake Erie Railroad Company,

[Indorsed] :

By M. S. Frost, President.

Pay to the order of M. S. Frost \& Son.

JOHN T. BRLEN.

M. S. Frost \& Son.

$\$ 5,000.00$.

Greenville, Pa., Feb'y 24th, 1888.

Three months after date the Pittsburgh, Shenango and Lake Erie Railroad Company pronises to pay to the order of John T. Bruen five thousand dollars. at the American Exchange National Bank, New York city. Value received.

Attest: E. S. Templetox, Seeretary.

'Tie Pittsbugit, Sinenango \& Lake Erie Railroad Company,

[Indorsed] : JoH T. BRUEN,

By M. S. Frost, President.

M. S. Frost \& Son.

The body of these notes, and every part of them except the signature of the president, was in the handwriting of 'Templeton, the secretary. The president was authorized by the board of directors to issue the corporate notes to the extent of $\$ 10,000$ for the purpose of purchasing flat cars. In Mareh, 1888, before the notes became due, Frost went to Boston and there negotiated a cash loan of $\$ 30,000$ from Francis A. Brooks for the benefit of M. S. Frost \& Son, giving the firm note therefor and delivering to him the two notes in question, indorsed as they now appear, with other obligations, as collateral security for the payment of this loan. Subsequent to the maturity of the notes Brooks became the absolute owner by consent of the pledgor and the proceeds applied upon the deht, and still later he transferred them to a third party, and they have rome to the hands

gave D. a new note signed by Hammond and indorsed in the firm name. Seripture had no knowledge of this. I/fld: Seripture not liable. "We do not think a partner can shift his private indebtedness from his own shoulders to those of his firm by offering to his crollitor to pay lis deht, and then asking him to lend the a mount to the firm of whieh he is a member, and thereupon, on the creditor's asuenting, giving him without anything more a firm note for the amount. unless it is shown that the transaction is in some way brought to the knowledge of and asuented to by the other member or uembers of the firm. It certainly would open a wide door to fraul to admit such a doctrine." Daniels v. Ilammond, 154 MaQd. I65.

The resulta of the easea on eonatructive notice from the form of the paper in the case of partnerchip signatures umom bills or notes negotiated by or for $x$ partner for lis own benefit, are fully staterl in Ames' ('ases on Partnership, pp. 526, 527-529, 533-534. Sie the same work (Pp. 496-521) for a discussion of the subject of the suthority of a partner to execute or tranafer negotiable instruments in hehalf of hia firm, and the manner in which such instruments must be executed in order to bind the partnership. - H. 
of the plaintifl for value. It is not claimed that the plaintiff occupies any other or different position than Brooks would if he had hronght the action upon the notes at maturity. Bruen, the pnyee of the notes, was the private secretary of lyost, the president, and the notes were made payable to him by Templeton, the secretary of defendant, who drew them in that form at the suggestion of the president. 'There is not and eannot be any dispute with respect to the anthority of Frost to make the notes. They were made with sufficient anthority, the fraud upon the defendant consisting in the wrongful use of them, when male for a legitimate purpose, by the president for his own private lusiness.

Nor is there any dispute with respect to the fact appearing on the plaintifl"s case, that Brooks paid value for the notes and made present adrances in cash to Frost in the sum alrealy stated. It is equally clear upon the record that Brooks had no actual knowledge of the facts surrounding the origin of the paper or of the diversion of it by the president. Ie received the notes and made the advances in Boston, whereas they were made and the transactions stated with respect to them took place in a distant state, where the office of the company mas, and is indicated on the paper as the place where made.

The learned trial judge held as matter of law that the plaintiff could not recover upon the notes for the reason that he was chargeable with knowledge of the facts and circumstances that rendered them invalid in the hands of Frost. 'The plaintıf' is, doubtless, chargeable with such knowledge or notice as to the antecerlent equities of the defendant as Brooks, his assignor, had, but with no others. If the notes were valid obligations in the hands of Brooks the plaintiff may assert every right that he could have asserterl. It needs no argument to show that if Brooks had knowlerlge or notice or is in law chargeable with knowledge or notice of the frand by means of which the notes were diverted from the purpose for which they were authorized to be made, that the plaintiff cannot recover. But it is not rlaimed that he knew anything about the origin or diversion of the paper in fact. All that is claimed is that when it was presented to him in Boston by Frost, whom he knew to be the president of the railroad, there was enough upon the face of the paper to put him upon inquiry anr, therefore, to charge him with knowledge of all the facts that such inquiry wonld have disclosed. He knew nothing, so far as appears, ontside of the paper itself, except the fact that the party presenting it was refendant's presirlent, and that he was proposing to pledge the notes for his own debt, or rather for the debt of his firm, which for all the purposes of the question may be assumed to be the same thing. The question in the case is, therefore, reduced to a very narrow inquiry, and that is, whether Brooks, standing in all other respects in the position and sustaining the character of a bona fide purchaser of negotiable paper, is deprived of that character and the 
benefits of that position by reason of anything appearing upon the face of the notes themselves.

The mind, at the threshold of the inquiry, encounters two principles that point in opposite directions and lead to different conclusions, as the one or the otleer is allowed to preponderate in the mental process of determining the legal rights of the parties. On the one hand is the principle whicl protects a bona fide holder of commercial paper from existing antecedent equities between the parties, and on the other the principle which protects a corporation from the unauthorized and fraudulent acts of its own officers. There is not much difficulty in stating the rule of law defining the duties and obligations of a party to whom negotiable paper is presented for discount or sale before due. He is not hound at his peril to he on the alert for circumstanees which might possibly excite the suspicion of wary vigilance; he does not owe to the party who puts the paper afloat the duty of active inquiry in order to avert the imputation of bad faith. The rights of the holder are to be determined by the simple test of honesty and good faith, and not by a speculative issue as to his diligence or negligence. The holder's rights cannot be defeated without proof of actual notice of the defert in title or had faith on his part evidenced by circumstances. Though he may have been negligent in taking the paper, and omitted precantions which a prudent man would have taken, nevertheless, unless he acted mala fide, his title, according to settled doctrine, will prevail. (Magee v. Badger, 34 N. Y. 249; Am. Ex. Nat. Bank v. N. Y. Relling, etr.. Co. 148 N. Y. 705: Knox v. Eden Musee Am. Co., 148 N. Y. 151: Canajoharie Nat. Banli v. Diefendorf, 123 N. Y. 202 : Vosburgh v. Diefoudorf. 119 N. Y. 357; Jarvis v. Manhattan Bearl r'o., 148 N. Y. 6.5.)

Applying these mles to the concerled facts of the ease, it seems to me to be impossithe to impute bar faith to Brooks in the transaction. He advanced a large sum of moury on the faith of the paper, without any actual knowledge that the relations of the party with whom he dealt to the paper were different from what they appeared to be on the face of it. 'The question now is, not what the falets were, hut what they appeared to be, and what he harl thre right, from the notes themselves, to assume. He had the right to assumb flat the mations to the paper of every party whuse name ajpeared on it were precisely what they apperared to tee. (Hoge S. Lansing. $35 \mathrm{~N}$. Y. 136.) He

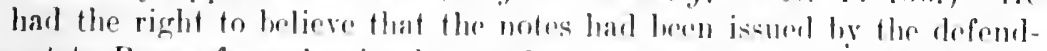
ant to Bruen for value in the regular course of business, and were ly him transferresl to Frect \& Son in like manner. Tle we was nothing to suggest to him that frost was dealing with paper that belonged to the railroad for his own lomefit. The appearances were that the defendant had put the notus in rivenlation hy delivery to bromen, and that they came to Frost's firm in the recular course of husiness for value and were then the property of the firm. It is quite true that all 
these appearances were deceptive and that the actual facts were otherwise. But how was a banker or business man in Boston to know or suspert that Bruen was only the nominal payce and a mere instrument in the transaction to enable the president to divert the paper to his own use. The name of the party who presented it and had it in his possession appeared on the face of the paper to have signed it as president. The name of another officer of the corporation was upon it also, attesting its regularity, and everything was in his handwriting except the signature of the president and the indorsement of the payee. Sio far as Brooks was concerned, the paper showed that it had been issued to a stranger in the regular course of business, and, through his indorsement, had come to the hands of a mercantile firm of which the president of the corporation was a member. If this were the fact, there is no doubt as to his right to use it in the business of the firm. 'The holker of a note who has no actual knowledge or notice of a lefect in the title, or other equities between the parties, when circumstances come to his knowledge suffieient to put him upon incuiry, is chargeable with knowledge of all the facts that such inquiry would have revealed. The difficulty in this case is to find the circumstance which can be said to be sufficient to put Brooks upon the infuiry. There was absolutely nothing on the face of the paper except the signature, as president, of the party who was dealing with it, and that, we think, was not snfficient in view of the fact that the appearances were that he was a purchaser from a third party.

The principle that applies in a case where an officer of a corporation makes the corporate obligation pavable to himself, and then attempts to deal with it for his own henefit, does not aid in solving the question in this rase. When paper of that character is presented by the officer or agent of the corporation, it bears upon its face sufficient notice of the incapacity of the officer or agent to issue it. ${ }^{3}$ (Hanover Bank v. Am. Dock of T. Co., 148 N. Y. 612; Bank of N. Y. v. Am. Mork of 'T Co., 143 N. Y. 559; Hilson v. M. E. R. Co., 120 X. Y. 115: Gerona v. McCormich, 130 X. Y. 261.) There are numerous cases that belong to that class cited by the learned counsel for the defendant on his hrief. There is a manifest distinction between them and the case at bar. IIere the officer was not dealing

3 " Indouldedly the general rule is that one who receives from an officer of a corporation the notea or securities of such corporation, in payment of, or as security for, a personal debt of such oflicer, does so at his own peril. Prima facie the act is unlawful, aurl, unless actually authorized, the purchaser will be deemed to have taken them with notice of the rights of the corporation. (Garrard v. r. \& C. R. R. ro., 29 Penn. St. 154: Pendlrton v. Fay, 2 Paige, 202; Shain v. Spencer, 100 Mass. 388)." - Wilson v. Metropolitan El. Ry., 120 N. Y. 145, 150. Contra: Doe v. Northuestern Coal, fo.. Co., 78 lied. Rep. 62, 68. - H.

[But sce Borough of Montvale v. People's Bank, 74 N. J. L. 464, reported herein at p. 352. - C] 
with the corporate notes payable to himself, but with notes that had been regularly issued, so far as appeared from their face, to a stranger and by him transferred to a firm of which the officer was a member, and for which he acted as agent in procuring the loan from Brooks and pledging them as security. The presence of Frost's name upon the paper, as one of the agents who issued it, was not naturally or reasonably calculated, under the circumstances, to arouse suspicion in the mind of Brooks, or to lead hin to believe that the president was attempting to defraud the corporation in disposing of the notes. None of the cases eited by the learned counsel for the defendant sustain the proposition that such a circumstance is sufficient to put the purchaser of negotiable paper upon inquiry or charge him with knowledge of the fact in ease he fails to make it, and there are many cases that tend to support the contrary view. (Am.Ex. Nat. Bank v. N. Y. B. \& P. Co., 148 N. Y. 698; Miller v. Consolidation Bank, 48 Penn. St. 514; Walker v. Kee, 14 S. C. 142.)

It is said that if the plaintiff's right to recover in this case is sanctioned by this court an easy way will be opened for the perpetration of frauds upon corporations by officers intrusted with its negotiable obligations, and that the device of making the paper payable to the order of a nominal payee, interested or aiding in the fraud, will be a favor. ite one to accomplish the end. We must leave all such cases to be dealt with upon the peculiar facts and cireumstances as they arise. It is more reasonable and just to assume that corporations will be able to protect themselves by proper vigilanee from the dishonesty of their own officers, than to impute to parties who have taken the paper for value, ignorant of its origin, ronstructive knowledge of the facts upon such circumstances as exist in this case.

We think that there was nothing on the face of the paper or in the facts shown to warrant the court in holding, as matter of law, as it did, that the obligations were received by Brooks and the advances made on them mala fide. That is the effert of the ruling at the trial, and the conclusion was not supported hy the facts.

It follows that the judgment must be reversed and a new trial granted, costs to abide the event.

BARTLETT, J., delivered a dissenting opinion.

Andmews, Ch. J., GMay and Martin, J.J., concur with O'Bnien, J ; HAIGHT and VANN, J.J., coneur with BARTtETT, J.

\section{Jurlgment reverserl.4}

- In Orr v. South Amboy Terra Cotta Co., 113 App. Div. (N. Y.) 103, it was held that the fact that the payee of a note executed by a corporation is a director of the corporation does not put a purehaser of the note upon inquiry as to whether its isguance was uuthorized. Forcill.s, .I., said in part: "The rule applicable to notes made hy oflicers of a corporation to their own order, and used to pay their individual obligations, has no applisation to notea made by the duly alsthorized officers, and payable to a director. It is not uncommon 


\title{
\$95 BOROUGH OF MON'TVALE 2 . PEOPIA'S BANK.
}

\author{
it New Jerser Iaw ('T. ERr, a No Alp.) 464. - 1907.
}

GeMmene, ('. J. This is an action of replevin brought by the borougle of Montrate to recover l'rom the possession of the Peoples Bank

for directors to have business dealings with the erporation, and it is perfectly leritimate if they refrain from voting, and do not use lheir personal intuenee with their follow directors for their own advantage at the expense of the corporation. But the oflicers of a corporation individually make the contracts in helalf of the eorporation and issue its obligations. They may not lawfully contract with themselves, or nse the crelit of the corporation for their own benefit individually. There is reason, therefore, for the rule that one taking the negotiable japer of a eorporation in payment of an indivilual obligation of an oflieer is chargeable with notien and is put upon inquiry as to whether

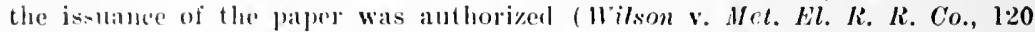
S. I. J50; Hanoecr liat. Bank: v. Am. Dock of Trust Co., ItS N. Y. 612;

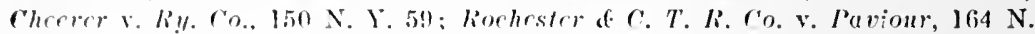
Y. 281): but the reason does not exist in the ense of a director, and therefore the rule is not applieable. The plaintifls. llorefore, were entitled to have the jury instruetel, as matter of law. that the fact that the payee was a director of a eorporation was not notice to lhe plaintifrs of any infirmity in the note, and did unt put them upon any inguiry enneerning the cireumstanecs under which it was iscued or eame into the hands of the payce. Any other rule womlel serionsly impair the negotiability of the corporate securities."

In llatana cont. R. r'o. v. Kinickerbocker Trust ('o., 198 N. Y. 422, it was held (quoliug the healnote) that "Where the treasurer of a corporation, authorized to sien elecks for it as treasurer, drew checks to his own order and cleposited them in a bank to his own acconnt, the bank on which the checks were drawn paid them, and the bank in which they were leposited, and which collected then, eredited the proceeds thereof to the individual account of the treasurer, who thereafter drew out such proeesls, the latter bank is not liable to the enrporation. 'The deposit bank of the eorporation upon which the checks wero drawn was its agent to determino whother the checks were properly jayable or not. When it recided that they were and pairl them to anntluer bank. in which they had been deposited by the treasurer for his individual acenunt, which latter bank receiver the proeerls in good faith, this was an acknowledgment that its treasurer in fact possessed authority to draw sucle elecks, and the corporation has no riglit to recover the proceeds from thr bask in which thry were deposited." WiLlarn B.sirert, J., on p. 42!), saif: "The distinguishing feature between this case and the eases relied upon to support the judgment which has been rendered herein is that in the cases citel the form of the transaction was notice to the party receiving the check or ntleer instrument that it was sought to be used to pay an individual debt nut of trust funds. How the eheeks were not designed to diseluarge any obligatinn owing to the refendant. The defendant merely eollected the amounts thereof and plaeed the same to the credit of the payee. . . It seems to me that when a cerporation open, an account with a banking institution it confers upon that institution the prower to determine whelher auy eleck drawn upon the aceount conforms to the contract between the deprisitor and the depository. When it makes a mislake in the determination of suel a question the depository may br liable to thr elepositor: but the depositor cannot recover back the money paid on such eheck to a third person who has reeived it in gond faith relying on the rejresentation of the deposit bank that the check was all right and has subsequently parted with the money." - $C$. 
certain coupon bonds, dated July 1, 1903, payable to bearer on the first day of July, 1913, and made and exeeuted by the borough, but which it avers were never issued or delivered by it. The case was tried in the court below upon an agreed state of facts, from which it appeared that the bonds in suit were two of an issue of thirty $\$ 500$ bonds, each of which was signed by the nayor of the borough, one Alfred M. Crotty, sealed with the corporate seal of the municipality and duly attested by the borough clerk; that some of the bonds were sold by the borough, and the remainder were left by it in the custody of the mayor until some further disposition of them should be made by the borough; that the bonds in suit are two of those which were left in the custody of the mayor; that while in his custody the latter hypothecated them with the defendant bank to secure the payment of a loan made by it to him; that the bank had no knowledge, until long after the making of the loan and the pledging of the bonds, that Crotty was not in lawful possession of them and authorized to sell and dispose of them; and, finally, that the loan made by the bank to Crotty still remains unpaid. Upon these facts, the court held as matter of law that there was never any delivery of the bonds in suit such as to impress upon them the quality of negotiable instruments, and that they had no legal force or existence in the hands of the defendant, and directed judgment to be entered in favor of the borough.

It will be observed that the bonds in suit were made and executed about a year after the act of the Legislature, entitled " A general act relating to negotiahle instruments (being an act to establish a law uniform with the laws of other states on that subject)," approved April 4, 190\%, went into eflect. P. I. p. 58.3.

It is suggested that, although the bank had no knowledge of any lack of authority on the part of Crotty to dispose of the bonds, the fact that he signed them as mayor charged it with notice of the defect in his title within the meaning of the fifty-second section "of the statute. Rut it is provided by the fifty-sixth section ${ }^{\circ}$ of the act that " to constitute notice of an infirmity in the instrument or lefect in the title of the person negotiating the sinne, the person to whom it is negotiable must have had ardual knowlerger of the infirmity or defect, or knowlerge of such, fants. that his action in taking the instrument amounted to bad faith." Knowledge on the part of the hank that the person to whom they made the loan was the mayor of the borough, if it harl such kuowledge, affords no gromml for holding that its artion in faking the homds amounterl to had faifl. Notwithatanding that c'rotty exeruted them in his official capacity, he had as complete a right as any other citizen of the horongh or any member of the publin at large to herome a purchaser of its securities, and the

B N. Y.. \$ !11.-C.

B N. Y., §!5. - $C^{\circ}$. 
fact that he assumed fo deal with them ats his own in his transaction with the bank, instead of being notice to it that he was betraying the trust reposed in him by the municipality and was fraudulently putting upon the mitrket securities which had not been issued by it, justified the hank in helieving that he was in lact just what he represented himself to be by his conduct, namely, the owner of the securities. The bank is therefore the holder in due course of the bonds in suit, as such holder is defined by the statute.

The rights of the holder in due course, and the liability of the maker of a negotiahle instrunlent which has been put into eirculation by a person other than the maker and without the authority of the latter, are preseribed by the fifteenth section ${ }^{7}$ of the act, which is as follows: [Quoting it.] Applying to the borough the conclusive presumption which this last-cited section of the statute prescribed for the protection of a holder in due course, it must be held to have made a valid delivery of these bonds, so far as the defendant bank is concerned, and the latter is therefore entitled to retain possession of them as outstanding obligations of the municipality.

The judgment under review will be reversed. ${ }^{8}$

\section{$\$ 95$ FOX $v$. CI'TIZENS' BANK AND TRUST COMPANY.}

37 Socthwestern Reporter (TenN.) 1102. - 1896.

BiLl to enjoin defendants from further prosecuting suits on notes executed by complainants to J. C. Anderson, trustee, and indorsed by him to defendants. Decree for defendants. Complainants appeal.

It is conceded that there is a total failure of consideration, and that there would be a perfect defense against Anderson.

7. N. Y..\$35. - r.

8 This case is commented upon as follows in 24 Panking Law Journal, at p. 673: "Bankers are aware of many cases under the law morchant where the fact of the peron negotiating an instrument signed by him in lis official capacity for a personal debt or transaction - as for example. a cashier of a bank or treasurer of a eorporation paving his private dobt by a check signed by him in his official capacity - has been held to put the taker on inquiry and charge him with notice of the offierr's want of authority, if sueh be the fact; llepriving such taker of the rights of a holder in due comrse. But in this case the New Jersey court holds the pledgee bank not charged with notice by reason of the faet that the prorom personally negotiating the bonds was the official who had signerl them. It bases its decision upon. . . the Negotiable Instruments Law $[X . Y . \$ 95] .$. . If this eonstruction of the act in it seffeet on the free transferability of paper by persons who cign such paper officially and negotiate it perennally. is to be universally followed. it will mean a sweeping away of all the old cases which hold purcha-ers eloarged with notice where they take paper signed by an official. which is given in his private transaction. It is a construction which enlarges the negotiability of paper in this class of cases, and it may be the best rule or policy for commercial interests."

See also Fillebroun v. Haykood, 190 Mass. 472. - C. 
Wilson, J. (After stating the facts and holding there was no actual notice given the bank.) - It is next insisted that the notes, being payable on their face to Anderson, trustee, carried notice of the equities of complainants. (Hilliard, Vend. \$ 408, 1 Story, 99, §§ 399, 400, and Corington r. Anderson, 16 Lea, 310, are eited.) Beyond question, a trustce converting trust assets to his own use is liable to the beneficiaries: and equally liable is any one purchasing from him knowing of his fraudulent intention, as having knowledge of facts that would put a reasonably prudent man on inquiry as to the power and dishonest ends of the trustce, and which inquiry, if properly prosecuted, would discorer the truth. This is the extent to which the authorities cited go. But we are unable to perceive the direct connection and application of the principle cited to the facts of this case. It is well settled that the fact that the consideration for which a note is given is stated in it will not destroy its negotiability, unless the recital qualifies the promise to pay, or renders it uncertain either as to the time of payment or the sim to be paid. And if the note be received before maturity, and before a failure of consideration, it will be held free from the equities, although, from the recital, it was known to the indorser that the consideration was future and contingent. (Goodloe v. Taylor, 10 N. C. 458; Stevens v. Blunt, 7 Mass. 240; Davis v. McCready. 17 N. Y. 230 ; Bank v. Cason, 39 La. Ann. 865, 2 South. 881 : Siegel v. Bank, 131 III. 569, 23 N. E. 417; Danicl Neg. Inst. $\$ \$ 790-796$.$) \quad In other words, says the Louisiana Annual (2$ South.) case and the eases in 131 IIl. 569, and 23 N. E. 417, "it cannot affect the negotiahility of a note that its consideration is to be hereafter realized, or that, from contingency, it may never he enjoved."

The argument or proposition is advanced by implication, at least, that the fact that these notes are made payable to Anderson, trustee, impaired their negotialility, or put a transferee on notire of all equities existing as between the maker and the trustee. In a contest between the beneficiaries of these notes assuming that Anderson was not their real owner, and the transferee of Anderson, the fact that the notes appeared on their face to he payahle fo him as trustee would put the transferee on notice, and the claim of the heneficiaries would be superior (Cardueth $v$. Cheatham, ? Ifead, 1.1; Duncan v. Jaudon. 15 Wall. 175; s'haw v. Spencer, 100 . Mass, 38! : Alerander s. Alderson. 7 Baxt. 4033), becanse the notes gave direet information that they were trust property, and the direet purpose of the transfer was to pay his individual deht. (Corington r. Anderson. 1f Lea, 310.) ${ }^{\text {9 }}$

9 For an illuatration of the proposition laigl down in this paragrapla, see

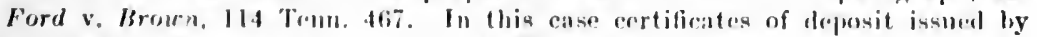
the P. Bank (one payahlo to "S. N. Woorlworth, tru-fere" uml the other to "C. N. Woodworth. "Trustere to lintty Ford"), had heen indoraed he Wonduorth, "C. N. Woorlworth. "Trustere for Betty Fordl." and sold for his iwn lesuefit to A., who indorsed them in blank and sold then for cash to the C. Bank who 
T'lue question as to whether a note payable to one as trustee is negotiable is a sulpject of dispute in the authorities or adjudged cases. In Maryand it serms to have been held that such a note is not commercial paper, and that an inforsement of it hy the trustee transfers it. subject to the trist, and that, alter such tramsfer, it is open to the equitable defenses between the original parties. (Bank v. Lange, 51 IId. 139.; But it is holden in other jurisolictions that a note to and indorsed by one as trustee of a named person does not earry to an innocent pirchasel any notice of a restriction upon the payee's right to transfer it. (Douner r. Read, 17 Minn. 493 [Gil. 470]: Bush r. L'echard, 3 IIar. |Del.] 385; citing Rand. Com. Paper, \$ 158, p. 24:; Dar is 1 . Garr, 6 N. Y. 124; s. c. 55 Am. Dee. 387, and note; Pierce r. Rubie, 6? Am. Dec. 61.t Conner v. Clark, 73 Am. Dec. 529.)

As a general thing, the addition of the words "trustee" and the like will be treated as descriplio persone. (Authorities supra; 2 Am. and Eng. Finc. Law, p. 358, notes on pages 358 and 359.) We take it that the recided weight of anthority, and, it seems to us, of sound reason, supports the position that the addition of the word "trustce" to the name of the payee of a note of itself does not destroy its negotiability. Under the rules of the common law, all conveyances by a trustee, whether to imnocent purchaser or not, even if made in contravention of the trust, operated upon the legal title, and rested it in the grantee. The beneficiary lad to go into equity,

sought to enllect them from the B. Bank. Betty Ford bronght an action against A., the B. Bank and the (C. Bank to enjoin the B. Bank from paying the certificates. A decree in favor of the complainant was affirmed on appeal.

MCAllister, J., said in part: "These authorities sustain our position that the word 'trustep.' in an indorsement of this character, is express notice to a purehaser that there is a cestui que trust or beneficiary. and that his rights may not he saerificed by the trustee in the sale or pledge of the note for his own bencfit. In other words, our holding distinctly is that such an indorsement is actual notice to the purchaser of such paper within the meaning of section $56[X$. Y.. \$ 95$]$ of the Negotiable Instruments Law." P. 479. "We are therefore of opinion that the indorsments and recitals of these certificates communicated artual knowledge to the [C.] bank that they represented a trust fund and, "Yon under the Negotiable Instruments Act, no title was acquired by the [C'.] bank to the paper." P. 492.

A note to this ease in I I. N. S. 188, says: "Some confusion has existed between the flustion of the effect of the use of the word 'trustee,' in describing the payes or holder of an instrument, upon its negetiability, and the other question of the rffret of the use of that worl to give notice to subsequent takers of the trust rharacter of the instrument and of the rights of the beneficiaries. In some of the troatises on the subjects of trusts and of negotiable instrument: thro has bern a falure to distinguish between these quite different guestions. The question of the effect of descriling a payee as a 'truster' upon the necortiability of the inctrmment relates to the defenses of the makers or obligors as against those to whom the trustee has transferred the instrument, while the otber question relates to the rights of the beneficiaries as against such transferees." - C. 
and there he could compel the grantee to respect the trust, as the original trustee should have done. (Gale v. Mensing, 20 Mo. 461 ; s. c. 64 Am. Dee. 197, and notes; see, also, Tyler v. Herring, 67 Miss. 169, 6 South. $8+0$; s. c., 19 Am. St. Rep. 263, and extended note where the subject with the authorities, is fully presented.) The substance or real rule, in the absence of a statute, in respect to unanthorized sales or transfers of property by trustees, is that they are voidable at the election of the parties in interest, and, until so avoided, the grantee has all rights in the property as to third parties. In this case there is no evilence that the notes did not belong to Anderson, or that he did not have the right to deal with them as he pleased. The result is that as to these complainants, the defendant bank is an innocent purchaser of the notes, for value, without notice of any equities in their favor; and, this being so, the decree of the chancellor is correct, and nust be affirmed, with costs. ${ }^{1}$

\section{(e) Notice before full amount paid.}

\section{DRESSER $v$. MISSOURI, ETC. COMPANY.}

93 United States, $92 .-1876$.

Mr. Justice Hunt delivered the opinion of the Court.

This action is brought upon three several promissory notes made by the Missouri and Iowa Railway Construction Company, dated Nov. 1, 1872, payable at two, three, and four months, to the order of Willian Irwin, for the aggregate amount of $\$ 10,000$.

The defense is made that they were obtained by his fraudulent representations.

But a single point requires discussion. Conceding that the present plaintiff received the notes brfore inaturity, and that his holding is bona fide, the question is as to the amount of his recovery.

1 The addition of the trerm "trustee," "agent," etc., to the name of the payee is restrictive in effret. It merrly gives notice of the rights of the cestui or the principal: it cannot loginally lo lorld to give motice of a defense in favor of the maker. See as to restriefive inclorsements. Nog. Inst. L., \& 66. See alan \& 27, subarc. 6: Davis v. Garr, f N. Y. 124, ante, P. 121.

$\Lambda$ qualified indorsement is not notiee of any infirnity in the instrument. Lomax v. Picot, 2 Pand. (Via.) 2.47. Thr death of the maker, known to the buyer, does not deprive the huger of the gosition of a loblder in due course. Clark v. Thaser, los Mas. 218.

The doetrine of notice by lis peulons has no application to negotiable paper. County of Warren v. Marey. IT I'. S. 100. Nor should the maker. Lefore maturity. lo liablo to garnishment at the suit of a creditor of the puyere for a purchaser from the payee in due course should be protected. 1 Danicl on Neg. Inst., § 800a. - H. 
Under the ruling of the count lie lecovered $\$ 500$. His contestation is, that he is sntitled to recover the face of the note, with interest.

After the evidence was conclubled, the plaintifl asked the court to charge the jury, that if they believed, from the evidence, that the plaintiff purchased the notes in controversy of William Irwin for a valuable consideration, on the 1 st of November, 1872 , and paid $\$ 500$, part of the consideration, on : 1 st day of January, 1873, before any notice of any frand in the contract, he was entitled to recover the whole amount of the notes; and the court refused this instruction. But the court clarged the jury, -

". 'That, in the first place, the jury must find that there was fraud in the inception of the notes as alleged; and that if the defendants failed to satisfy the jury of that fact, the whole defense fails.

"That if the fact of fraud be established, and the jury find from the eridence that the plaintiff paid $\$ 500$ upon the notes without notice of the fraud, and that after receiving notice of the fraud the plaintiff paid the balance due upon the notes, he is protected only pro tanto; that is, to the amount paid before he received notice."

It does not appear that, upon the purchase of the notes in suit, the plaintiff gave his note or other obligation which might by its transfer subject him to liability. His agreement seems to have been an oral one merely, - to pay the amount agreed upon, as should be required; and he had paid $\$ 500$, and no more, when notice of the fraud was brought home to him.

'The argument of the plaintitf in error is that negotiable paper may be sold for such sum as the parties may agree upon, and that, whether such sum is large or small, the title to the entire paper passes to the purchaser. This is true; and if the plaintiff had bought the notes in suit for $\$ 500$, before maturity and without notice of any defense, and paid that sum, or given his negotiable note therefor, the authorities cited show that the whole interest in the notes would have passed to him, and he could have recovered the full amount due upon them. (Fowler r. Stricliand. 10\% Mass. 552; Parl Bank v. Watson, $42 \mathrm{~N}$. Y. 190; Bank of Michigan v. Green, 39 Iowa, 140.) The present case differs from the rases referred to in this respect. 'The notes in question were purchased upon an unexecuted contract, upon which $\$ 500$ only har lieen paid when notice of the fraud and a prohibition to pay was rereived by the purchaser. The residue of the contract on the part of the purchaser is unperformed, and honesty and fair dealing require that he should not perform it; certainly, that he should not be permitterl, by performing it, to obtain from the defendants money which they ought not to pay. As to what he pays after notice, he is not a purchaser in cood faith. He then pays with knowledge of the fraud, to which he becomes a consenting party. One who pays with knowledge of a fraud is in no brtter position than if he had not paid at all. He has no gratcr equity, and receives no greater pro- 
tection. Such is the rule as to contracts generally. In the case of the sale of real estate for a sum payable in instalments, and circumstances occur showing the existence of fraud, or that it would be inequitable to take the title, the purchaser can recover back the sum paid hefore notice of the fraud, but not that paid afterwards. (Barnard v. Campbell, 53 N. Y. 73 ; Leuis v. Bradford, 10 Watts, 82; Jurenal v. Jachson, 2 Harris, 529 ; Id. 430 ; Youst v. Martin, 3 S. \& R. 423,430 .)

In Weaver v. Barden (49 N. Y. 291), the court use this language: " To entitle a purchaser to the protection of a court of equity, as against a legal title or a prior equity, he must not ouly be a purchaser without notice, but he must be a purchaser for a valuable consideration; that is. for value paid. Where a man purchases an estate, pays part and gives bonds for the residue, notice of an equitable incumbrance before payment of the money, though after giring the bond, is sufficient. (Touville v. Naish, 3 P. Wms. 306; Story r. Lord Windsor, 2 Atk. 630.) Mere security to pay the purchase price is not a purchase for a valuable consideration. (Hardingham v. Nicholls, 3 Atk. 301: Maundrell v. Maundrell, 10 Ves. 246, 271; Jackson v. Cadwell, 1 Cowen, 622; Jewell v. Palmer, 7 J. C. 65.) The decisions are placed upon the ground, acrording to Lord Hardwicke, that if the money is not actually paid the purchaser is not hurt. He can be released from his bond in equity."

The plaintiff here occupies the same position as the bona fide purchaser of the first of a series of notes, of which, after notice of a fraud, he purchases the rest of the series. He is protecter so far as his good faith covers the purchase, and no further.

Upon receiving notice of the fraud, his duty was to refuse further payment; and the facts hefore us required such refusal by him. (Authorities supra). Crandell v. Viclery (45 Barb. 156), is in point. * * **

'To the same purport in principle, althougl upon facts somewlat different, are the cases of Ciarland $x$. Ther Salem Bank (9 Mass. 108); The Fullon Bank v. The Phornir Bank (1 Hall, 562); and White v. Sipringfield Bank (3 Sandf. S. C. 227).

The cases are numbrous that where a bona fide bolider takes a note misappropriatorl, frambulently obtained, or without consideration, as collateral serurity. lie holds for the amount advaused upon it, and for that anount only. Williams v. Simith. 2 Itill, 301; Allaire v. Marlshorn. I Zahr. figio.)

The ease hefore us is coverued hy the rule that the portion of an unperformed rontract which is rempleterd after notice of a frand is

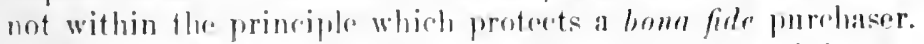

No respertablo authority has beren rited to us sustaining a coutrary

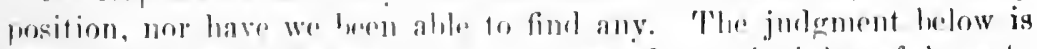
based upon authority, and uprol llw somidest primciples of honesty and fair dealing. It has our concurrence, and is affirmed. 


\section{¿. Holder Deriving 'J't'tel from Holder in Due Course.}

33 Iows, 537. - 1871.

Acrion by the holder of a promissory note against the maker. 'There was a verdict and judgment for defendant. Plaintiffs appeals.

BEck, ('h. J. * * * Anong other instructions the court gave the jury the following: "If you find from the evidence that the note in question was obtained of the makers by fraud and deception, and if you further find that the plaintifl, Simon, knew of such fraud and deception, or if he had reason to know or believe that said note was fraudulently obtained of the maker, and that it is void, and if, because of such knowledge or belief, he refused to receive or purehase it of Leggett until an indemnifying bond was executed to him by Leggett, then the law of the case is with the defendant, and if you so find then your verdict should be for defendant." And the instruetion directed the jury that if plaintiff, "in good faith, for a valuable consideration, obtained the note in the ordinary course of business, before maturity, without notice of fraud, or without having reason to know or believe that the note was obtained by fraud of the maker," they should find for plaintiff.

These instructions are erroneous. They leave out of view the wellsettled doctrine that if Leggett, the transferer of plaintiff, was such an innocent and bona fide holder of the paper, that in his hands it could have been enforcerl against defendant, plaintiff, although he may have taken the note charged with notice of its infirmities, may recover in this action. ${ }^{2}$ If Leggett so held the note, his title and rights thereto were such that they could not have been defeated by defendant. In the transfer, the title and rights held by him passed to plaintiff. The notice which plaintiff may have had of the fraud in the original transaction does not defeat the rights he acquired by the transfer.

2 This doctrine applies to a purchase after maturity as well as to a purchase before maturity. Barker v. Lichtenbrger, $41 \mathrm{Neb}$. 751. But it does not apply to a purchase from a subsequent holder in due comrse by a prior party who when he held the instrument was chargeable with notice of its infirmities. Thus, in Kost v. Bender, 25 Mich. 515, 516, Cooley, J., said:

"It is perfectly true as a general rule, that the boma firle holder of negotiable paper has a right to sell the same, with all the rights and equities attaching to it in his own hands, to whoever may see fit to buy of him, whether such purchaser was aware of the original infirmity or not. Without this right he would not have the full protection which the law merchant designs to afford him. and negotiahle paper would crase to be a safe and reliable medium for the exchange of commerce. For, if one can stop the negotiability of paper against which there is no defense, by giving notice that a defense once existed while it was held by another, it is obvious that an important element in its value is at once taken away. But I am not aware that this rule has ever been applied to a purchase by the original payee, nor can I 
One reason of the rule is obvious. The maker of the note would be liable to the transferer; his condition is made no harder by the note coming into the hands of one laving notice of its infirmities. We do not understand that there is any conflict in the authorities upon this point. (Hoskell \& Gervey $\mathrm{x}$. Whitmore, 19 Me. 102; Smith v. Hiseock, 14 Id. 449 ; Prentice $\mathfrak{f}$ Messenger v. Zane, 2 Gratt. 262; Boyd r. McCann, 10 Md. 118 ; Howell r. Crane, 12 La. An. 126; see authorities cited in Story on Prom. Notes, $\S 191$.)

The instructions ahove set out, heing in conflict with this doctrine, ought not to have been given. For this reason the judgment of the District Court is reversed.

\section{Rights of Holder in Due Course to Reconer Full Amount.}

\section{$\S 96$}

\section{BISSELL $r$. DICKFRSON.}

\section{Convecticut, $61 .-1894$.}

Balnwin, J. (After disposing of another matter.) - The plaintiff's appeal is based on the instruetion given to the jury, that in the action against the maker of a negotiable accommodation note by an indorsee, who took it in good faith for value before maturity, and without notice of any infirmity, if the defendant proves that it was obtained from him by the payee and indorser ly frand, the rule of damages is the amount paid by the plaintiff. A note given for the accommodation of the payce, which he has thus negotiated to a bona fide purchaser, stands, as between the holder and maker, on the same footing as if it were business paper. ${ }^{3}$ The jury should therefore have been

perceive that it is esaential to the protection of the innoent indorsee. that it should be. It eannot te very important 10 him, that there is one person incapable of sucererling to his equities, and who ensequently would not be likely to beeome a pureliaker. If he may sell to all the rest of the community, the market value of his security is not likery to be alferted by the cireumstunce. that a single iudividual canuot eompete for its purchase, especially when we ensider that the nature of negotiahle serurities is such that their market value is very little inllueneed by competition. Sor do I pereeive lhat any rule or prineiple of law would bre violated by permitting llue maker to set up this defener aginat the payer, when he beenmes inforsee, with the sime effect as he might have don hefore it had hern sold at all, or that there is any valid reagon againat it."

Kost v. Bewder, suprn, is approverl in dragon Coffec Co. v. Rogers, 105 Va.

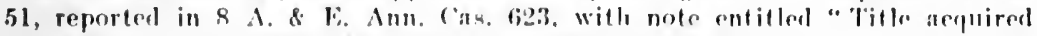
by payer of instrumenl fraublulently procuresl from miker, or subjeet to other defenaes, hy repurchase after tranafur to innoeent third peraon." - (".

3 Business paper las diatinguished from acommorlation paper), may le purchased for any prief withoul involving any puestion of usury, for the trang. action is a sale and murehase and not a loan. Fram v. Hewlrielis, 7 Wend. (N. Y.) 569; Corning v. Pond, 29 Hun (N, Y.), 129. But a trangfer of accom- 
instrueted thit the rule of damiges muler the eiremmstances stated in the chatere, was the late of the mote, with interest lrom its maturity.

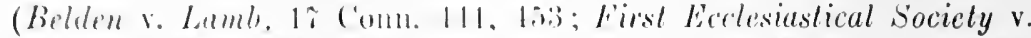
Loomis, 1: Comn. ifo, nil: lioulundr. Fouler, 18 Conn. 347; Crom-

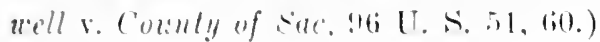

'lhere is errol, and a new trial is ordered upon the plaintiff's appeal, in case one should not le cranted by the City Court, on the ground that the remliet was against the evidence.

\section{\$96 JEFFERAON BAXK $\because$ ('HAPMAN-WIITE-LYONS CO. 123 Sucthwesters (TeNx.) 641. - 1909.}

Actiox on mote. Julgment for plaintiff and defendant appeals.

MCAISTER, I. * * * *

It is said, howerer, by counael for apmellant, llat in no event is the complainant entitled to recover exceeding the amomt it paid for said note. With interest. It appears that the decree below was for the fult amount of the note, with interest and attorney's fees amounting to 4251.85 . ('omsel, in support of his position, invokes the principle annonncerl in Oppenheimer v. Bank, of 'T'enn. 19, wherein it was said:

"We hold, howerer, that, blose notes heing fraudulent in their inception and without consideration between the original parties, the bank will only be entitled to recover to the extent of the smm actually paid ly it. to wit. the sum of $\$ 1,200$ and interest. In other words, we loil there was a negotiation of the notes in due course of trade only to the extent of the amsomet aetually pait."

Again, in Camplonll v. Proun, 100 Tem. "sit, it is saikl:

"The purchaser of a note at a rate of discomut equiralent to 40 per crut. jer annum cannot, though innocent of any wrong, recover more than the amomnt artually paid awainst the maker in fraud of whose riglits the note was transferred." * * * But we are of opinion that this rusetion is now settled by secotion $5 \mathrm{f}^{4}$ of the nego-

modation paper by the acemmodated party to one knowing the fatets, is a loan and not a purvluibe and sule, and if it be at a rate of di-comnt greater than that allowed ly the Helly law- iq usurious. Ibid; 1 Doniel on Neg. Inst.,

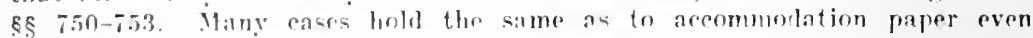
thongh the luyer does not know it to be accommorlation paper; but this view has heen criticiest. Mlid.

Thre has been grest conflict among the authorities as to the amount a holden in dus course may recoure from an areommolation party or a party whose assent to the paper has beren procured by fraul. I Daniel on Xeg. Inst.. \&\$ 754-759. The Neg. Inct. Law. \& 96. celtles the law in conformity to the rule of the Supreme Court of the Cuiter States. Cromwell v. County of Sac, 96 I. S. 60: R. ro. v. Sirhutte, 103 [. S. $118 .-11$,

4 ․ Y., $\$ 96 .-l^{\circ}$. 
tiable instruments law, which provides that the innocent holder " may enforce payment of the instrument for the full amount thereof against all parties liable thereon."

Judgment affirmed. ${ }^{5}$

\section{§96 NATIONAL BANK OF MICHIGAN $v$. GREEN.}

33 Iowa. 140. - 1571.

Actios by holder against indorser. The answer set up a sale for less than the face value. Demurrer to this defense overruled. Judgment for defendant.

DaY, Cr. J. - In objection to the second count ${ }^{6}$ it is claimed that the holder of negotiable paper is entitled to recover of the indorser the whole amount thereof without reference to the amount pairl therefor. Upon this question the decisions are not in harmony.*** Without attempting a review of the authorities bearing upon this branch of the denurrer, we deem it sufficient to state as our opinion that the indorsee in good faith of a promissory note, is entitled to recover of the indorser the amount of the note.

This view has the mnqualified indorsement of Mr. Parsons. (See 2 Parsons, Notes and Bills, 198. Also, Durant r. Banta. 3 Dutch. $623,635$.$) It follows that the demurrer to the second count should$ have been sustained.

Reversed. $^{7}$

\section{$\$ 96$}

MERRIT'T r. BENTON.

10 WFinft, $116 .-1833$.

ACTios against indoreer. Julgment for amount of note and notary's fees. Defendant moves for new trial.

5 "It is insisted by defordant's connsel that as plaintif paid only $\$ 1,000$ for the note and mortgage, the rexention of whieh was indued hy fralld. the sum so paid and interest thereen is the limit of his recovery. and unt the sum apecified in the note. A diversity of iurlicial utteranee exicts on this important

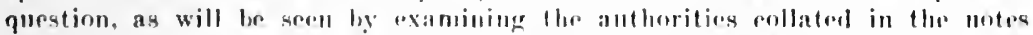

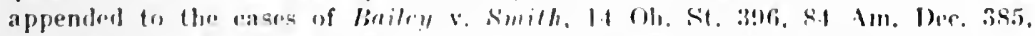

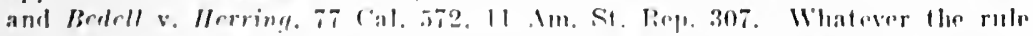

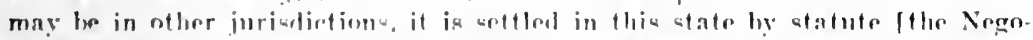

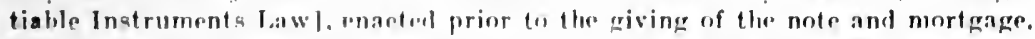
that the holder of a negentialde instrument in due course may enforee payment

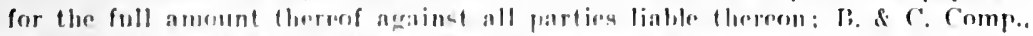

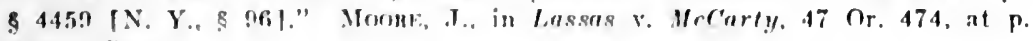
484. - $r$.

- Only so murh of the opinion is given as relutes to this. - H.

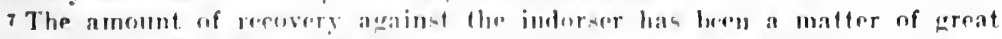

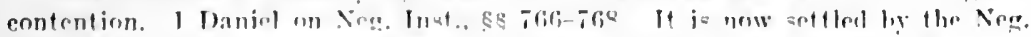
Inst, Iaw, \&96, in enformity with the view of the principal case. - II. 
by the Court, S.Ivark, C. I.-T'he remaining question is, whether the foes of protest wore properly rlatracible to the defendant. ${ }^{8}$ is to dlis we have not been relerred to amy deeided ase, and we understame that the practice at llue rimeruit is not molorm, though the fees of protest are genelally alluwed. It is an expense to which the holder of a note is subjered hy reison of the default of the indorser, whose duty it is to pay the note at maturity, and it is right, therefore, hat the holder should recover it. It may fairly be considered as a charge incident mpon the indorser's failure to perform lis contract, and should be allowed to the plaintiff's in the assessment of damages.

New trial denied. ${ }^{9}$

$\$ 96$

\section{SIMPSON $v$. GRIFEIN.}

\section{JoIInson (N. Y.) 131. - 1812.}

Is enror, on certiorari from a justices conte

Griffin sued Simpson before the justiere, and reclared for money had and received to his use, and for money lent. The defendant pleaded non assumpsit. The plaintiff proverl, that he had been sued as indorser of a note drawn by the defendant, and had been obliged to pay, besides the amount of the note, nineteen dollars, costs of suit. The taxed bill was produced to the justice, who gave judgment for the plaintiff, for the amount.

Per Curian.- If the inderaer of a note he duly fixed, he ought to pay it, without waiting to be sued, but if he finds it more convenient to delay taking up the note, mutil he is prosecuted to judgment and execution, the drawer ought not to pay for that convenience. It is his own fault or misfortune that subjects hin to costs, and he cannot resort to the drawer for indemmity against those costs. The mere fact of drawing the note does not imply a promise to save the payee harmless from all rosts ind charges that he may be subjected to, as indorser. There must he a sperial pronise to save harmless before the payee can call npon the rrawer for costs accued by the default of the payee himself. As payee, he ran only look to the ilawer for the amount of the note. The jurlgment must, therefore, be reversed. . Turlgment reversed.'

* Only so much of the opinion as relates to this question is loere given. $-\mathrm{H}$.

a For reenvery of "re-exchange" see Bills of Exchange Art. \$ 57. subsec. 2; 2 Danicl on Neg. Inst. $\$ \$] 444-1447$; Bank of U. S. v. U. S.. 2 How. (U. S.) 737. - П.

1 Accord: Warch v. Barmot. 114 Calif. 375. "A surety including a drawer or indorser. may recover. in an action againct his principal. . . . his reason. able costs aud other expenses, incurred necessarily and in good faitl, in the prosecution or defenor by the express or implicd consent of the prineipal . . of an action or -perial procerding, relating to the rlemand secured," N. Y. Code Civ, Proc., \$ $1916 .-\mathrm{H}$. 


\section{Burden of Proof.}

73 Atlantic (Conn.) 785. - 1909.

BaLdwin, C. J. The result of a former trial of this cause, in which a verdict was rendered for the plaintiff, is reported in 80 Conn. 58 . On a second trial there has been a verdict for the defendant, and error is claimed in respect to the charge to the jury.

The complaint contained two counts, each alleging (as in Practice Book, form 334) that $\$ 2,000$ is due to the plaintiff from the defendant on an instrument under seal, of which a copy is annexed and marked as an exhibit. The first defense to each count was a general denial. A second defense to each was that the honds, which were payable to bearer and matured January 1, 1S90, more than 16 years before the suit was brought, were owned, in 1587, by the Continental Life Insurance Company, and were then fraudulently taken from its possession by the plaintiff's husband, who was its president, without any consideration moving to the company, and came into her possession with notice of that fact, without any consideration moving from her, and that she was never a bona fide holder. These allegations were denied by the reply.

On the first trial the jury were instructed that, as the plaintiff had possession of the bonds, the burden of proof was on the defendant to show that she was not a bona fide holder, and that to do this it must satisfy them, by a fair preponderance of evidence, that she acquired the bonds, either without paying any value, or knowing that her husband had taken them from the insurance company improperly and fraudulently. It having been an undisputed fact, during that trial, that her hushand's title was defective, we held this charge erroneous, since the burden was upon her to show value paid or want of notiee of the defect, not on the defendant to show no value paid or the existence of notice. In support of this conclusion we referred to the Negotiable Instruments Art ((ien. St. 1902, \$\$ 4171, 1222, 4229).2 Our attention is now called to the provision in Gen. St. 1902, $\$+11 \% 0,{ }^{3}$ that the succeeding sections of the rhapter, which include those above mentioned, shall not apply to negotiable instruments made and delivered prior to $189 \%$.

Tine Negotiable Instruments Act, in most respects, was simply a corlification of the common law in reference to the subject in hand. It was such in respect to the provision of section $4229^{4}$ that "every

2 N. Y., §̧ฐ 20, 91, 98. - C.

s N. Y., s 6. - C.

4. Y., $898 .-$ C. 
holder is deemed prima facie to be a holder in due course; but, when it is shown that the title of any person who has negotiated the instrument was defective, the hurden is on the holder to prove that he, or some person under whom he claims, acrunired the title as a loolder in due course." In Byles on Bills (chapter 4, p. *60) the common law on this subject, with reference to the burden of proving a consideration, is thus stated: "The defendant is not in general permitted to put the plaintiff on proof of the consideration which the plaintift gave for the bill, unless the defendant can make out a prima facie case against him by showing that the bill was ohtained from the defendant, or from some mitermediate party, by undue means, as by fraud, felony, or force, or that it was lost, or that he received no consideration."

Where, as here, it appears that the negotiable paper in suit, though there was nothing wrong in its original issue, was obtained from an intermediate party by frand, proof of consideration is only called for from the plaintiff because it would tend to show that he nevertheless is a "bona fide" holder within the meaning of that term in the law merchant. Whether he acquired the paper by purchase or gift would, under ordinary circumstances, he of itself unimportant. But after proof that it was once in the hands of a fraudulent holder, it may justly he presumed to continue in the hands of a holder of that character until the contrary be proved. Collins v. Gilbert, 94 U. S. 753, 761, 2.4 L. Ed. 170 .

The position of the holder of negotiable paper is of an exceptional character. He may acquire a title through a thief, and yet maintain it against the original owner. But his possession is not enough to support a recovery, after it once appears that he must trace title through fraudulent practices and unclean hands. Totten v. Bucy, 57 Md. 452. This is erjually true whether the fraudulent practices were connected with the original inception of the paper, or, as in the present instance, occurred subsequently, to the prejudice of an intermediate holder. Fulton Pank v. Phœnix Bank, 1 Hall (N. Y.) 562 ; 2 Parsons on Notes and Bills, *283;4 Am. \& Eng. Encycl. of Law, 322. The case of Kinney v. Kruse, 28 Wis. 183, asserts the contrary, but is opposed to the strong current of authority.

The cause went to the jury, as respects each count, on two issues. One was on the truth of the complaint; the other was on the truth of the sperial defence. As to the former issue, the plaintiff had the hurden of pronf from the ontset and to the end. Lockwood v. Lockwond, 80 Conn. 513, 521. As to the latter issue, her production of the hond, its due execution being armitted, raised a presumption of title, which made out a prima farie case. But as soon as it appeared, either by her witnesses or those of the defendant, that this bond was fraudulently ahstracted from the assets of a third party to which it originally belonged, this presumption no longer availed her, and her original burden of pronf, only temporarily satisfied by its aid, rested 
upon her again, and now required her to show a title by affirmative evidence that she obtained the instrument both in good faith and for a valuable consideration. Her good faith she could only show by proof that, when the bond came to her, she had no knowledge of such fraud, and was not equitably chargeable with notice of it. Baxter v. Camp, 11 Conn. 245, 253; Fulton Bank r. Phœnix Bank, 1 Hall (N. Y.) $57 \%$.

The defendant, it is true, had the burden for certain purposes of proving that she took the bond with such notice, and without consideration; but these purposes were accomplished when the fact was established of its fraudulent abstraction from the assets of the insurance company by her grantor. One legal presumption established by the law merchant was thus met with another legal presumption established by the same law, which by that law was sufficient to destroy it. In a coneurring opinion, often quoted, given in a case of similar character, in which a ruling of his at nisi prius was pronounced erroneous, Baron Martin observed that he did not profess to understand how, when several facts were alleged in a plea, all necessary to make it good, and all put in issue, proof of one could relieve a defendant from the burden of proving the rest: but that, whatever might be the philosoplyy of that matter, the rule was so, and it was a useful one because it threw a difficulty in the way of fraudulent indorsements. Harvey v. Towers, 15 Jur. 544; 4 Fng. Law \& Equity, 531.

The charge to the jury in the Superior Court, which followed the rule as stated by us when the cause was previously here (Parsons v. Utica Cement Co.. 80 Conn. 60), was in conformity to the principles of common-law procedure prior to the adoption of the Negotiable Instruments Act. The instructions thus given were that, while the plaintiff, as holder of the honds, was prima facie their owner in good faith, if the defendant had satisfied them by a fair preponderance of eridence that they were framblently obtained from the true owner, the insurance company, then the hurden rested on the plaintiff of proving that she acquired them in good faith and for a valuable consideration, without knowledge of the fraud, or without being dhargeahle with knowledge of it.

The law merehant, which gorerned the disposition of the cause, gave to bona fide holders, in llue conrse, of newotiable bonds payable to bearer the valuable privilege of suing on them in their own name, with all the rights for the purposes of the action of an absolute owner. But it deemed no one a bona fide lodder in due course who ohtained possession without giving any valuahle consideration in return. Brush v. Serribuer, 11 Conn. 388, $29 \mathrm{Am}$. Der. 303 . It reengnized the bona fide holder in due course, not as owner, but as having the rights of an owner for the purposes of suit, to be protected mo farther than the necescity of maintaining the free negotiation of eommercial paper requires. Olmstead v. Winsted Bank, 32 Conn. 278, 287. There was 
no necessity of that description to call for the allowance of actions by holders of stolen securities who paid nothing for them, even if they accepted them before their maturity, and with no notice of any infirmity in their grantor's title. 'They might be bona fide holders, but they were not "holders in due course;" for that term refers to due ('ourse of trade, and trade rests on an exchange of values. Roberts $\mathbf{v}$. Itall, $3 \%$ Conn. 205, 212. * * * There is no error. The other judges concur."

$$
\text { CIAAR v. PEASE. }
$$

[Reported hercin at p. 370.]

$\S 98$

VIOLET $v$. ROSE.

39 Nebraska, 660. - 1894.

\section{Invine, C. * * *}

It is a universal principle that, in the absence of any attack upon the validity of a negotiable instrument, as between its original parties, the holder bringing the action upon it is presumed to be a bona fide holder for value. When, however, the holder or acceptor, in an action against him upon the instrument, sets up matter in defense which would constitute a valid defense were the action brought by the original payee, it is frequently a question of difficulty as to where the burden of proof lies upon the issue of bona fidcs. The writer is unable to perceive why, upon different defenses, there should be any distinction as to the burden of proof upon that issue, whatever the defense pleaded. It may be urged, upon one side, that the policy of the law merelant in favoring the free negotiation of hills and notes demands that the maker, in order to defend against an indorsee, should prove affirmatively that such indorsee is not a bona fide holder for value; and to this argument there may he added that the plaintiff in such a case has already in his favor a presumption of bona fides, and that no evidence of a defense growing out of transactions between the original parties has a natural tendency to rebut such presumption; but, upon the other hand, whatever may be the fundamental defense, it would seem that the proof of a bona fide purchase for value before maturity lies peculiarly within the possession of the plaintiff; that such facts are always easily susceptible of proof by him, whereas proof of mala fides or want of consideration, even where the facts exist, is

s For other cases decided under the Negotiable Instruments Law, see McNight v. Parsom, 136 Iowa, 390, and Keene v. Behan, 40 Wash. 505.

The English Pills of Exchange Act is construed to the same effect in Tatam จ. Haslar, L. R. 23 Q. B. D. 345. - C. 
frequently beyond the knowledge or reach of the defendant. These arguments upon either side apply with equal foree, whatever may be the fundamental defense; but unfortunately the courts have drawn distinetions between defenses. The numerous decisions disclose a general tendeney to cast the burden of bona fides upon the plaintiff, where illegality of consideration or fraud is alleged, and in other eases to east the burden of showing notice or want of consideration upon the defendant. But even the test suggested by this general tendeney of authorities is not trustworthy, for the elassification thus resorted to has not been strictly reeognized, and possibly it has not been absolutely observed, by the courts of any state. While this confusion of authorities is to be regretted, the distinctions referred to, whether well or ill founded, have been recognized everywhere, and our own decisions probably approach the general elassification referred to as nearly as those of any state. Thus, it has been held that, where usury is established, the burden is upon the plaintiff to show bona fides. Wortendyke v. Meehan, 9 Neb. 221; Olmsted v. Security Co., 11 Neb. 487; Darst v. Backus, 18 Neb. 231; Sedgwick v. Dixon, 18 Neb. 545; Cheney v. Janssen, 20 Neb. 128; Knox v. Williams, 24 Neh. 630; Bank v. Davis, 25 Neb. 376; Blackuell v. Wright, 27 Neb. 269; Richardson v. Stone, 28 Neb. 137; Bank v. Miltonberger, 33 Neb. 847; Colby v. Parker, 34 Neb. 510. So, also, where the evidence established the theft of a note payable to hearer. Ilooper v. Browning, 19 Neb. 420. So, too, where frand in the inception of the note is proved. Haggland $v$. Stuart, 29 Neb. 69. On the other hand, where the defense was in the nature of failure of consideration, and the plaintiff, as a part of his ease in elief, hal introduced evidenee tending to show a bona fide purchase, it was held that no testimony in support of the fundamental defense was proper unless the defendant introduced evidence tending to show that the plaintiff was not a bona fide purchaser. Organ Co. v. Boyle, 10 Nel. 109. In Camon v. Canfield, 11 Neb. 506, the inference is that, where want of consideration is shown, the burden is also upon the maker to prove notice to the indorsee. 'The same inference is to be drawn, in case of failure of consideration, from Banli v. Ryman, 12 Noh. 511. But a contrary inference wight be drawn fom a closing paragraph of the opinion in Bank r. Edlostm, 25 Xob. 741. In Coaliley v. Christip. 20 Neb. 509, it was distindly derided that, in the ase of a mote given in payment of a piano sold with a waranty, evidenere of the fundamental defense was properly exclubed, for the reason that there was no tender made of proof that the plaintilf was not an innorent purehaser.

It would seem, from this review of the anthorities, that the defendant, where frand is pleaded, makes out his case simply he pronf of the fraud, and that the plaintiff must nflirmatively estahlish bonn fides; but that, where the defonse is failure of consideration, the defendant 
must restahlish both failure of consideration and mala fides on the part of the plaintitl, or the fact that he wats not a purchaser for value." Now, in the case hefore us, the dedendant pleaded both fraud and failure of consideration. When he opened his ease, the situation was this: Shonld he sueced in showing that the instrument of assignment, brought to him by Mecurday, purporting to be signed by hoth Mecurday and wife, did not in faet bear Mrs. MeCurlay's genuine signature, and that the note was procured through the representation that such signature was gemmine, then fraud would be established, and it would lie with the plaintiff to show his bona fides in the purchase of the note. If on the contrary, the proof of this defense should fail, hut the defendant should succeed in showing that he failed to obtain the property in question hecause Mrs. McCurday refused or failed thereafter to acknowledge the instrument, then there would be merely a failure of consideration, and the defendant, to prevail, would be required to attack plaintill's bona fides. The burden of proof, therefore, depended upon the evidence introdnced upon these issues. The order of proof rests within the discretion of the trial court. Consaul v. Sheldon, 35 Neb. 24. The court, therefore, did not err in allowing evidence of the fundamental defense to be introduced before evidence was offered as to the good faitl of the purchaser. The court instructed the jury that the burden of proof was upon the defendant upon this issue, so there was nothing in this procedure of which the plaintiff ean complain. ${ }^{7}$

\section{Defenses to negotiable instruments.}

$\S 94$

\section{CLARK $v$. PEASE.}

41 New Hampsinte, $414 .-1860$.

Actios by indorsee against maker on a promissory note. Defenses: duress by imprisonment; illegality because given to compromise a crime. The defendant offered evidence to substantiate the defenses.

The plaintiff excepted to this evidence, as no defense against the indorsee, without proof that he was not the bona fide holder of the note. But the court ruled that if the note was obtained by duress, it was void in the hands of an innocent indorsee, and thereupon the

- This was also held to be the rule under the Negotiable Instruments Law in cole lanking Co. v. S'inclair, 34 Utah. 454, where the court, after quoting sections numbered in Now York 91, 98, 94, and 96, says that "the defense pleaded was not illugal, hut merely partial failure of eonsideration. Failure or want of consideration does not eonstitute a defective title within the meaning of the foresoing provisions." P. 45f. - C.

7 The above case was approved in Norwood v. Bank of Commerce of Lincoln, 77 Neb. 205. - C. 
plaintiff, admitting for the purposes of this trial that the defendant's witnessis liould testify to the facts stated, a verdict for the defendant was taken by consent, subject to the opinion of the court; and the questions thus maised were reserved, and assigned to the determination of the whole court.

Sarciry, J.-- That the case presented is elearly one of duress, there an le no question. The abuse of any process, either civil or criminal. to compel a party, by imprisonment, to do any act against his will evcept to pay the debt for which he is arrested, is entirely illegal, and the act may be aroided on the ground of duress. (Richardson v. IMun'an, 3 ‥ H. 508; Severance v. Kimball, \& N. H. 386; shaw v. s'pooner, 9 N. H. 197; Burnham v. Spooner, 10 N. H. 523; Beck v. Blamcharl, : N. H. 303.) Here the arrest was without any warrant or lawful authority. Such duress is a perfect defense, upon all the anthorities, to an action hetween the riginal parties.

'The note in this case was not only void as between the original parties. on the ground of duress, but was given to compromise a charge of (rime, and wils wholly illegal upon that ground. (Plumer v. Smill, 5 X. 11. 55ir.)

But the principal question raised here by the ruling of the court is, whether such a note is ahsolutely void in the hands of any holder; and if not, then anutloer question arises upon the exception which was taken by the plantiff, which is this: After an indorsee has marle out a frima facie ease by proving the indorsement, ete, and the defendint has shown thit the note was olitained from him by duress, upon whom rests the hurden of proof? Must the defendant prove that the plaintiff was not the bona fide holder, and that he did not par a valirl consiluration for it, as the plaintiff claimed? or, the duress being proved, does that throw the burden of proof upon the plaintiff, to prowe how he ame hy the note, and the consideration he pairl, etro.. as the dofondant rlaims? We will examine these questions in the order in which wre have staterl them.

I. Is this rotre alsolutely wid in the hands of ans holder, however innocent. Who has paicl a vilid considuration for it hefore it was due?

|'Tlue court hre disiossese the grounds for avoiding contracts genrally.

Now hills and nutes stand upon the same foundation as all other

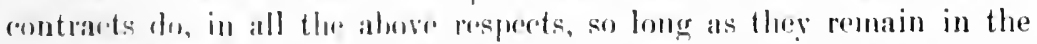
hands of the original payer. But hills and notes have mother attribute, which other montrants ordinarily do not possess - that is, negotiability. Where a hill or moto hats leren megentiated, and passed into the hands

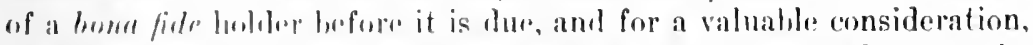

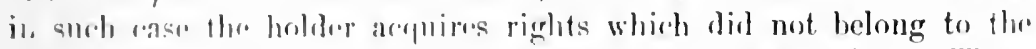

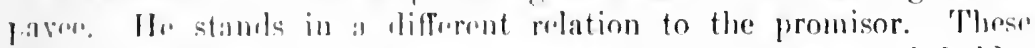

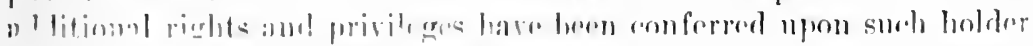
by law, for gond and suffirint reasons, too well known and understood 
to need to he stated, but which are incident to, and dependent upon, the attribute of negotiability, which these instruments possess.

And it may be laid down as the general rule, as the general principle applying to this chass of cases, lhat such a note, thus negrotiated and in the hamds of such a holiler, is not liable to any defouse which the maker had as against the original payec. 'To this general rule there are some exeptions, among which are-

1. When a statute not only prohibits the making of a contract, but provides that the same shall be void to all intents and purposes; or where the law provides that any contract male or securities given upon any illegal consideration shall be ahsolutely void, then the note which embodies such contract, or is based upon such consideration, is held roid everywhere and in the hands of every holder. In England, and in most of the United States, there are or have been laws against usury, which not only, by a general prohihition of usury, made that an illegal consideration tor a note, but also provided that all bills or notes founded upon such a consideration should be absolutely void. Such, however, is not the law in this state on that subject, and it is believed that we have no statutes with similar provisions. Hence, here usury may be a good defense to a note as against the original party, but not as against an innocent indorsee, for value, etc.

2. When the note is a forgery, it is void everywhere.

3. When the maker belongs to a class of persons who are ordinarily, and as a general rule, on grounds of publie policy, held incompetent to contract at all, such as infants, married women, alien enemies, and insane persons, ${ }^{9}$ including spendthrifts and others under guardianship, who have been by some statute declared incompetent to contract.

4. Notes signed by agents withont anthority.

In none of these cases (except the first, which, as we have seen, does not apply in this State), is a note valid in the hands of anyone; and the party who discounts such paper is bound to inquire, at his peril, whether the note offered to him is signed by a party capable and competent in law to bind himself, or by an agent duly authorized to bind lis principal. Besides this, he is bound to inquire whether the party from whom he receires it is competent to make such transfer in his own right, or is authorized to do it for his principal, for whom he assumes to act.

If there is a failure in either of these points of capacity or authority, it will not avail the party that he is a bona fide holder, for value, without notice. He must look to his indorser if he has one, and if he has not he must suffer loss.

s These exeeptions ennstitute what are known as real or absolute defenses. See Bigelow. Bills, Notes and ('hecks (Students' ed.), pp. 174-205. - H.

9 See Walker v. Winn, 142 Ala. 560, reported in 4 A. \& E. Ann. r'as. 537, with note entitled "Validity and effect of negotiable paper signed or indorsed by lunatic." $-\mathrm{C}$. 
5. Another ease might be mentioned, which has been made an exeeption to the general rule above stated by express provisions of the statute, - as where a note is attached by the trustee process. There, by operation of the statute, the maker of a note may have a perfect defense against an indorsee, for value, without notire, and before due. So notes discharged by operation of insolvent laws might afterwards be transferred, by possibility, so as to form another exception, where the indorsee, holding the note bona fide, ete., might be met with a perfect defense on the part of the maker. But these last eases throw no light npon the question we are eonsidering.

These are the principal, perhaps all the exceptions to the general rule stated above, that no defense is available against an innocent indorsee, for value paid before due. ${ }^{1}$ But where the contract was illegal, being prohibited by law, or the consideration was illegal, as usury, wagers, compounding a felony, restraint of trade or of marriage, etc., or where there was a want or failure of consideration, and even where the note has been paid, - all these defenses, ${ }^{2}$ and many more, cannot be made against the note in the hands of such a holder. And the question here raised is, whether, in case of duress, or fraud, where there is mala fides, but it is all on one side, and the other party to the note has been induced to sign it by force or by fraud, and is in rery respect an imnocent party, such defense shall arail him as against such a holder, for value, ete, who seeks to colleet it.

And we think sucle a defense cannot avail the maker against such an indorsee of the note. The authorities faror this view. $* * *$

Suppose an indivilual, thru, were abont to purchase a note payable to bearer, before it was due, and pay a fair equivalent for it, with a view of collecting it of the maker, and where he is to have no indorser to rely minn, - what would be his duty in order to proceed safely? First, ho must assure himself of the gemuineness of the signature, or, if it purported to he signed by an agent, he must

To these should be addod the extimguishment of the instrument by eancellation or alteration. Sre Neg. Inst. I.. \$s 204-206, post. The ease of want of delivery, or want of delivery as aul for a nogotiable instrument, calls for special comment and may or may not be an abolute defonse accorling as the

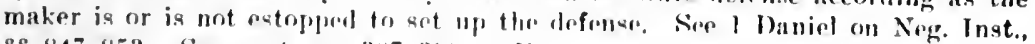

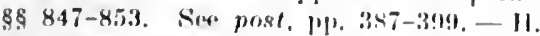

2'These defornese ure known as personul, comditional, or "equitable" de-

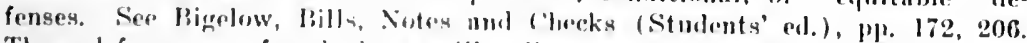
These defolles aro fraud, durese, illogality, want or failure of consideration, releage or payment, di-charew of porty primarily liable, ete. Whether a right of set-of existing at the time of the tranafor is an "equity" is in dispute. 2 Daniel on Neg. Inst.. \$\$ 1.43.w-1437. In Now York it is an cpuity in case of the transfer of an overilue note. N. Y. Coufo Civ. I'roc., \$ 502. - II. [On this last point, see ante, IP. 321-322, - C. 
gssure himself that the agent was duly anthorized to hind his prinripal in that particular: secondly, he must mise such inpuiries, which, ortinarily, he may asily do, as to ascertain that the signer is not an infant. a married woman, an alien enemy, an insane person, ete., that he does not belong to a rlass of persons who are always presumed by the law to be incompetent to eontract; and thirdly, he might need, for his own safety, to infuire whether the signer of the note had heen trusteed, or whother any other speeial statute could affect his claim to it. When he has satisfied himself upon these points, if he learns of no other deferts, and the signer is of sufficient ability to respond, he may purchase: and there is generally very little trouble in ascertaining these facts. They are wsually matters of public notoriety, ahout which there ean be little room for mistake.

But, suppose that after being satisfied upon all these points, and having purchased the note, it should prove that it was an illegal contract, or was for an illegal consideration, - who shall suffer? - the maker or the indorsee? 'This is settled on the best of authority. The original parties stood upon equal ground, both being in fault, and could neither of them enforce the contract; yet neither shall be allowed to talie advantage of his own wrong as against an innocent indorsee.

And suppose it should turn out that his note was obtained of the maker by fraud or by duress, a case in which the maker was in no fault, - what rule shall be applied here? - the long established one, that where one of two innocent persons must suffer, the loss should fall upon him who has suffered a negotiable security, with his name attached to it, to get into circulation, and thereby mislead the indorsee. Such rules, and such an application of them, are necessary to give security to negotiable paper.

The exception to the ruling of the court upon this point must be sustained; but we shall find that the numerous authorities which bear upon the next question to be considered have also a direct bearing upon this point.

$\$ 98$ II. Next lot us inquire, upon whom is the burden of proof: after rluress, or fraul, or illegality of ronsideration is proved? Must the defendant not only prove that he had a perfect defense to the note originally, hut also show that the indorsec had notice of the defect, or that he paid no consideration for it, or that he is not in some way the bona fide holder of the note? Or must the plaintiff, after such drofense to the original contrart is proved, assume the burden of proving that he is a bona fide holder, for a valuable consideration, withont notice of any defert, and that it came seasonably into his hants:"

[After dierossines varions anthorities.]

The same doctrines very generally prevail in this country, wherever 
the subject has received judicial consideration. (Munroe v. Cooper: 5 Pick. 412; Woodhul v. IIolmes, 10 Johns. 231: Vallett v. Parter, 6 Wend. 615; Small v. Smith, 1 Den. 583 ; Worcester Co. Bank v. D. \& M. Banli, 10 Cush. 488; Wyer v. D. \& M. Bank, 11 Cush. 52; Rockwell v. Charles, 2 Hill, 499; Bissell v. Morgan, 11 Cush. 198; Crosby r. Grant, 36 N. I. 273.) So in Smith on Cont. (3d Am. ed. 277), in a note by Rawle, it is said that in New York it has been held that, as soon as the defendant shows there has been usury between the prior parties, he casts on the plaintiff the burden of proving that he is a holder for value, - as is the ease in every instance where fraud, duress, or illegality is shown between the prior parties.

These authorities would seem conclusive, that the plaintiff's exception, - that the evidence offered would have been no defense unless it were proved that he was not the bona fide holder, - must be overruled. When the defendant had proved the duress, he had made a good defense as against the original party: and because of the legal presumption that in such ases the payee, being guilty of such illemality, would dispose of the note and place it in the hands of some other person to sue upon it (Bailey v. Bidwell, ante), he had thereby cast a suspicion on the plaintiff's title, which threw the burden upon him of showing affirmatively that he was a bona fide holder for value. For can we see that the fact that this evidence was offered under the general issue alters the position of the parties or the state of the ease.

Trese authorities also bear directly upon the first point taken by the defendant. that duress is a lefense against any holder, however innocent he may he, and however valuable a eonsideration he may have paid for the note: and if other antborities on this point were needed. they are not wanting. In Powers v. Ball (27 Vt. 662), Redfield. C. J., says, "Illegality, duress, frand, and want or failure of consideration, are no defeuse as against a bona fide holder for value." (See, also, St. Albans Bank v. Dillon. 30) Vt. 122; Ellicott v. Martin, 6 Md. 509: Minell v. Reed, 26 Ala. $730 ;$ Norris v. Langley, 19 N. H. 423: Knight v. Pugh. 1 Watts \& Serg. 445.)

'The verdict must be set asile, and a new trial granted.

123 Kintuckr, 677. - 1906.

Action on note. The answer sot up as one defense that the note

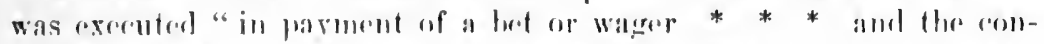
sideration * * * nnder the law of kentncky is vicions, illegal, 
and void." Plaintifl's demurrer to this defense was overruled, and as he declined to plead further, judgment was rendered against him, and he appealed.

Nune, J.

The real question to be determined is whether a negotiable note executed for money lost on a bet or wager can be successfully defended, when owned and held by an innocent purchaser for value without notice of the infirmity or illegal consideration of the note. As we understand the appellant's petition, he eoneedes that prior to the passage and the taking effect of the Negotiable Instruments Act, referred to, such a note conll be successfully defended in the hands of an innocent purehaser: but sinee that act took effect he contends that all laws ineonsistent with that act stood repealed. He claims that under section $57^{3}$ the question of consideration eannot be inquired into as against the holder in due course. He takes the paper free from defenses. And in support of this position we are referred to the case of Wirt v. Stubblefield, 17 App. D. C. 283 . In that ease it was held that the section, the same as section 57 referred to above, changed the law of the Distriet of Columbia as to a note given for a gambling debt in the hands of a holder in due course; the court saying: "We know, moreover, that the great and leading object of the act, not only with Congress, but with the larger number of the principal states of the Union that have adopted it, has been to establish a uniform system of law to govern negotiable instruments wherever they might circulate or be negotiated. It was not only uniformity of rules and principles that was designed, but to embody in a codified form, as fully as possible, all the law upon the subject, to avoid conflict of decisions, and the effect of mere local laws and usages that have hitherto prevailed. The great object sought to be acromplished by the enactment of the statute is to free the negotiable instrument as far as possible from all latent local infirmities that would otherwise inhere in it to the prejudice and disappointment of innocent holders as against all the parties to the instrument professedly bound thereby. This elearly could not be effected so long as the instrument was rendered absolutely null and void by local statute."

It has been the policy of this state to suppress gaming, and the statutes making gaming contracts void are founded upon what the Legislature has for many years deemed to be sound public policy. It is inconceivable that the General Assembly, in the passage of the Act of 1904 for the protection of innocent holders of negotiable instruments, intended to or did repeal section 1955, Ky. St. 1903, which declares all gaming contracts void. ${ }^{4}$ In our opinion, the disappoint-

8 N. Y., § 96. - C.

1 Similarly, it was held in Lauson v. First Nat. Bank of Fulton, 102 S. W. (Ky.) 324, that $\mathrm{Ky}$. St. 1903, § 4223, making void a pedler's note unless 
ment now and then of an innocent holder of a negotiable instrument would not be as hurtful and injurious to the best interests of the state as the removal of the ban from gaming contracts. Mr. 1)aniel in his work on Negotiable Instruments (section 19\%) says: "The bona fide holder for value, who has received the paper in the usual course of business, is unaffected by the fact that it originated in an illegal consideration, without any distinction between cases of illegality founded in moral crime or turpitude, which are terms mala in se, and those founded in positive statutory prohibition, which are termed mala prohibita. The law extends this peculiar protection to negotiable instruments, because it would seriously embarrass mercantile transactions to expose the trader to the consequences of having a bill or note passed to him impeached for some covert defect. There is, however, one exception to this rule - that when a statute, expressly or by necessary implication, declares the instrument absolutely void, it gathers no vitality by its circulation in respect to the parties executing it." In the case of Sondheim v. Gilbert, 117 Ind. 71 , the court said: "In order, therefore, to uphold a judgment which invalidates commercial paper in the hands of innocent holders, such as plaintiffs are conceded to be, it is essential that a statute should be shown governing the case, which in direct terms declares that transactions such as those here involved are unlawful, and that notes given under circumstances exhilited by the facts in this case are absolutely void. 'The principle may be considered as well established that when a statute in express terms pronounces contracts, bills, securities, and the like, resulting from or growing out of wagering or gambling transactions, which are prohibited by statute, absolutely roid, no recovery can be had thereon; and the doctrine that transactions which a statute in direct terms declares to be unlawful cannot acquire validity by the transfer of commercial paper based thereon, which is also under direct legislative denunciation, is fully supported by authorities." And the authorities are referred to, and the court continues: "In

indorsed with the word's "Podler's noto" is not repealed by implieation by the Negotiable Instruments law. Sipeaking of this latter statute the court said: "The whole scope of it is slown to be the dealing with commercial paper. so is to protect innocent purchasers of such ngainst mere defenses avajable as betwen the original parties. It gives such paper eurrency, free from original defenses. But it applies only in paper that might have bees: obligatory between the parties. Jist, where the parties were never bound becanse the law made the note void, as enntrary to public policy as expressed in tbe statutes, the Negetiable Instruments Art doss mot apply, and ought not to. The prevention of erime is of more importance than the fostering of eom. merce. 'lhe latter act should tre read in view of its purpose, and not as intending to repeal oflier statutes pascorl in the exercise of the police power of the state to suppresa crime and fraurl."

See also the extract from the opinion of rutu,s, C. J., in Schlesinger v. Filhooly, 189 N. Y. 1, given in note on 5. $379 .-\mathrm{C}$. 
such a case, the note will be declared void in the hands of an innocent holder." In the "ase of Bohou's Assignee's v. Brown, ele., 101 Ky. 355, the court said: "In the rase of Cochran v. Cerman Insurance Bank, 9 Ky. Law liep. 196, the Suprior' ('ourt held that 'a bill or note hased upon a gambling consideration is absolutely roid, and the drawer or maker is not bound to even an innocent holder.' And in the ease of Farmers' of Drovers' Bank of Louistille v. Unser, $13 \mathrm{Ky}$. Law liep. $: 966$, the court says: "The whole current of authority is that the obligor may insist upon the illegality of the contract or consideration, notwithstanding the note is in the hands of an innocent holder for value, in all those cases in which he can point to an express declaration of the Legislature that such an illegality makes the contract void.'"

For these reasons, the judgment of the lower court is affirmed."

\section{SCHLESINGER $v$. LEHMAIER.}

\section{NEW York, 69. -1908.}

HaIGHT, J. This action was brought by the receiver of the Federal Bank, a domestic eorporation engaged in the banking business in the city of New York, to recover the amount of two promissory notes made by the defendant for $\$ 500$ and $\$ 454.50$, respectively, each made payable to the order of the maker and indorsed by him. The complaint alleges that before maturity the notes were discounted by the Federal Bank, and that the plaintiff as receiver now holds them. The answer, in substance, alleges that the notes described in the complaint were marle by the defendant and delivered to the Globe Security Company in payment for another note of the defendant held by that enmpany and for the sum of $\$ 135.50$ interest, which sum was far in excess of interest at the legal rate and was, therefore, usurious, and that the Federal Bank subsequently discounted the notes and received them, with full knowledge of the payment of such usurious rate of interest. Upon the trial the City Court awarded judgment for the plaintiff, holding that the facts alleged and set forth in the answer did not in law constitute a defense to the action.

We are again called upon to construe the provisions of the National Banking Act, so called, and our own Banking Law, based thereon, which is as follows: "Every bank and private and individual banker doing business in this state may take, receive, reserve and charge on every loan and discount made, or upon any note, bill of exchange or other evidence of deht, interest at the rate of six per centum per annum; and such interest may be taken in advance, reckoning the days

3 See exhaustive note in $119 \mathrm{Am}$. St. Rep. 172, entitled "Defenses to noter and otber obligations given for gambling debts." - $C$. 
for which the note, bill or evidence of debt has to run. 'The knowingly taking, receiving, reserving or charging a greater rate of interest shall be held and adjudged a forfeiture of the entire interest which the note, hill or evidence of debt carries with it, or which has heen agreed to be paid thereon. If a greater rate of interest has been paid. the person paying the same or his legal representatives may recover back twice the amount of the interest thus paid. from the hank and private or individual banker taking or receiving the same, if such action is brought within two years from the time the excess of interest is taken. * * * The true intent and meaning of this section is to place and continue banks, and private and individual bankers on an equality in the particulars herein referred to with the national banks organized under the act of Congress entitled 'An act to provide a national currency secured by pledges of United States bonds, and to provide for the circulation and redemption, thereof, approved June the third, eighteen hundred and sixty-four." (L. 18\%0, ch. 163; L. 1892, ch. $689, \S 55$, as amended by L. 1900 , ch. $310, \S 1$.)

The general statutes of our state forbid the taking of interest upon the loan of money in excess of the rate preseribed by law, and also render void all bonds, notes and other contracts given to seeure a loan made in violation therenf. (2 R. S. $\%$ \% $\$$, $\$$ 2, 5; L. 183\%, ch. 430, $\S 1$.$) These statutes still remain in full force as to individuals { }^{6}$ and corperations except in so far as they have been modified or superseded by the Banking Jaw macted for the honefit of banking corporations and private and individual hankers, but the precise extent of sweh modification is a question involving some diffieulty in its solution and has already been the subject of discussion in this enurt. In the case of Schlesinger $v$. Gilhooly (189 N. Y. 1) the construction of the National Banking Aet and of our state Banking law was disenssed in two opinions, one written by Cullen, Ch. J., and the other by Vann, J., in which the chice juidge reached the conclusion that the statutes referred to only applied to ases where the banks had been pairl an unlawful rate of interest and that they harl no application to negotiable paper purchased by the hanks which haul previously been tainted with usury; while Vann, J., reiched the conclusion that these statutes extended to and covered negotialile paper purchised by the bank before maturity in good faith withrut knowledge of its previous taint. Two of iny associates concencerd with the chicf judge and two coneurred with .Judge Vann. Willard Bartlett, J., concurred with Judge Vann in the result, upon the ground that, under the Nereotiable Instruments Law, a bona fide purchaser takes a note free from the defense of usury.7 The jutgment was, therefore, attirmed, thus hold-

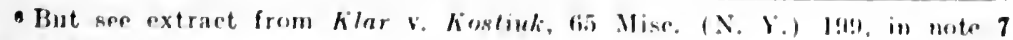
on p. 380 . - $\mathrm{C}^{\prime}$.

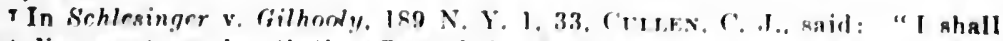
not discuss at any length the effect of the Negotiable Instruments Law. . . 
ing that, where a bank has in good faith discounted negotiable paper for value before maturity without notice that it was already void for usury, the defense of usuly is not available, and that must now be regarded as the law of this state.

The question we now have presented was not disposed of in the former case, and is quite different. It is now contended that the bank may purchase void paper of the holder, with full knowledge that the maker has becu compelled to pay a usurious rate of interest, and that by such purchase the paper becomes validated, and in the hands of the bank may be collected of the maker. If such an interpretation is adopted, then it practically nullifies our usury laws, for any person who has exacted usury for the loan of money may take his paper into a bank and arringe for its prosecution and thus evade the defense of usury. The decision of our court in the case of Schlesinger v. Gilhooly (supra) has already eliminated from our usury statutes their most drastic features, so far as banks are concerned, and no longer can a person put in circulation negotiable paper void for usury, which may be transferred to innocent banks who purchase in good faith without knowledge of its taint, and thus be deprived of the right to collect it from the maker.

I think that under well settled principles of statutory construction we cannot construe its general language as repealing the provisions of the usury, gaming and lottery laws. which render obligations given on such considerations absolutely void. The Negotiable Instruments Law applies only to commercial paper, and the effect of the usury and gaming statutes, like that relating to patent riglits, is to withdraw notes given on such considerations from the domain of negotiable instruments. (Eastman v. Shaw, 65 N. Y. 522.)"

But see the following extract from the case of Klar v. Kostiuk, 65 Mise. (N. Y. Sup. Ct., App. T.) 199, decicled in November, 1909, where the court took the contrary view of the effect of the Negotiable Instruments Law:

"Gildersiesws, J. . . . Intil the enactment of section 96 of the Negotiable Instruments Law, in respect to notes having a usurious inception, and the decisions in Schlesinger v. Gilhooly, 189 N. Y. 1; Schlesinger v. Lehmaier, 191 id. 69, and Schlesinger v. Kelly, 114 App. Div. 546, there was no uncertainty abont the law in this state in respect to notes usuriously given. It was plainly declared in Glaflin v. Bonrum, 122 N. Y. 385. The court said: "A note void in its inception for usury continues void forever, whatever its subsequent history may be.' Section 96 of the Negotiable 1nstruments Jaw provides as follows: "A holder in due course holds the instrument free from any defect of title of prior parties and free from defenses available to prior parties among themselves anil may enforee payment of the instrument for the full amount thereof against all parties liable thereon.'

"We think it was the purpose of the legislature in enacting this provision to make a radical change in the law of this state affecting negotiable paper, and that the law now is that a bona fide holder in due course holds the note free from any taint of usury. The Schlesinger cases, supra, unmistakably and specifically declare the law to be that a hank acquiring in good faith, for value, commercial paper, virl hetween the parties for usury, may recover thereon. We see no reasnn why the provision under consideration does not apply to, and may not be invoked by, individuals as well as banks. In Wirt v. Stubblefield, 
Until a recent amendment of section 378 of the Penal Code the acceptance of an unlawful rate of interest for the use or loan of noney was a misdemeanor and punishable criminally. 'The taking of usury is still a wrong and against the public policy of the state. If the statutes are to receive the construction contended for, then the officers of a bank may become parties to a wrong and, against the poliey of the state, aid the wrongdoers in their receipt of usury by the taking of such paper and practically collecting it for them. Assuming, for the purposes of the argument, that national and state banks are governmental agencies, and that among the powers given to banks, either state or federal, is that of purchasing negotiable paper, and that in the discharge of such powers they are entitled to protection, evidently such protection was only intended to apply in so far as the officers of such banks acted in good faith in accordance with the law, and not where they departed therefrom and knowingly and intentionally joined with wrongdoers in an attempt to evade the laws.

The learned Appellate Division appears to have entertained the view that the purchase of commereial paper with knowledge that it was void for usury did not place the bank in a worse position than it would have been in had it taken usurious interest itself. 'The answer to this is that the statute makes it different. 'The usury laws, as

17 App. D. C. 283 , the court, in construing the same provision enacted by Congress for the District of Columbia as the Negotiable Instruments Law, took the view that we have adopted and made no distinction between individuals and hanks.

"We think Mr. Justice IAdemLIx, in Schlesinger v, Kelly, supra, correctly stated the law of this state. when he said: "The usury laws remain in full foree, but to facilitate the free cirrulation of negotiable paper by protecting holulers theresf in she course for value in their right to enforce the same, the usury laws are to that extrnt superseded by the provisions of section 96 of the Negotialide Instrmments Jaw.'

"SEAHCR. J. (eoneurring). I coneur in the opinion of Mr. Tustice Funer. SLFEVE in so far as that opinion holls that the enaetment of section of of the Negntiable Instruments Law changed the existing law, and that under the provisions of the Negotiable In-truments law the defense of nsury caunot be set 1 p against a bona firle holler. I llink that the correct interpretation of that law was first given by Mr. Instier Jaughlin in sehlesinger v. Krlly, 114 App. Div, 546. It serms to me that serhlesinger v. Gilhooly, Is9 N. Y. 1, Jeft this question undetermined, and that wre are now at liberty to adopt the views expresserd hy Mr. Juatier Laughlin in thr Kolly ease and by Judge Willard Bartlett in Sohlesinger v. Gilhooly. supre."

Lausas, .J., whote a diskenting opinion.

It muat be oburverl, howerer, that the deeiaion in Klar v. Fostiuk, supra, is that of an inferior appellate eourt, and in the faee of the eontrary aloctrine maintained hy the $\mathrm{N}$. Y. Court of Apprala prior to the rnactment of the Negotiable Instruments Iaw. and the dieta in the opinions of that eourt in the Schlesinger cases in $189 \mathrm{~N}$. Y. 1, and lal N. Y. Go (reported herein at p. 378). sulusequent to the enactment of that statute, it is doublful whether that decision will be followed by the latter court when the question comes squarely before it $-c$; 
between individuals, have not been changed, and as between the maker and the holder, if usury is exacted, the paper is still roid and no recovery ean be had thereon." Not so, however, with banks which have received unlawful interest; the paper is not allected or rendered roid, but the hank is subjected to a forfeiture of all interest and to penalties for that which it has received. In c'aponigri v. Allieri (165 N. Y. 255) we hold that the penalties conld be collected in an action bronght for that purpose, but how could such an action be maintained against the lederal Bank upon the paper in question? It has received no mulawful rale of interest. It has not violated any statute in this regard. The unlawful interest was collected by the Globe Company before the bank lad become the purehaser of the paper. 'That company was not a hanking eorporation, and consecunently is not liable for the penilties provided by the Banking Law. 'T'rue, it forfeits its right to collect the balance remaining due upon the paper, and it may be liable for the interest received in excess of the legral rate; but, unler the view of the Appellate Division, the maker would be deprived of his defense of usury, and also of his right to maintain an action for the penalties provided by the Banking Law. To my mind, the legislature never intended such an interpretation of the act. It pertains to negntiable instruments, and should be construed in commection with the other legislation upon the same subject. In the Negotiable Instruments Law it is expresely provided that a holder. who beeomes such before maturity in good faith and for value without notice of any infirmity. holds the same "free from any defeet of title of prior parties and free from defenses available to prior parties among themselves. and may onfore the payment of the instrument for the full amount thereof against all parties liahle therenn." Here we have the legislative intent expressed in (lear and ummistakable language. It estahlishes a just and proper rule which protects the hank in making purchases of enmmereial paper in gond faith lofore maturity, for value and withont notice of infirmity. But where it purchases with actual knowledge of the infirmity or defect, or knowled ure of such facts that its artion in taking the instrument amounterl to bad faith, it is not proterterl.

I am. therefore, of the opinion that the matter set forth in the answer is sufficient in law in constitute a defense and that, consequently, the judgment of the Appellate Inivision should be reversed and the nerder of the Appellate Term affirmed, with eosts to appellant in the Appellate Jivision and this court.

C'LleEx, ('h. J. I roneur in the opinion of my lirother Haigit for reversal, but deem it proper to arde a wold explanatory of my position. In the mase of Srhlessinger v. fillhooly (189 N. Y. 1) I dis-

- But sec extract from Klar v. Kostiuk, 65 Misc. (N. Y.) 199, in note 7 on p. $380 .-\mathrm{C}$. 
sented frow the decision in an opinion. While I retain the views then expressed, I recognize fully the effect of the decision there made and accept it as a binding authority deelaring the law to be that a bank acquiring, in good faith for value, comnereial paper void between the parties for usury, may recover thereon. In that ease, however, the recovery was sought to be upheld on two separate grounds, the Banking Laws, state and national, and the Negotiable Instruments Law. Had a majority of the court placed their decision on either ground I should have felt the decision binding not only as to the point actually deeided, but as to the propositions on which the decision was founded. I understand, however, that while my opinion in its entirety commanded the assent of two only of my associates, the memher of the majority who based his decision on the effect of the Negotiable Instruments Law expressed his approval in that part which dealt with the effect of the Banking Laws, though it may he that approval was obiter, his action proceeding on a diflerent question. Therefore, for the reasons stated in iny former opinion as well as for those stated in the opinion of my brother HAIGHT, now rendered, I concur in the reversal of the judgment appealed from.

Willatio Bartelet, .J. I concur in the opinion of Haigut. J., for reversal - having concurred with the opinion of the chief judge in Schlesinger v. Gilhooly (189 X. Y. 1), except as to the effect of the Negotiable Instruments Law, although the stintement of such concurrence was inadrertently onitted from the report of that ease.

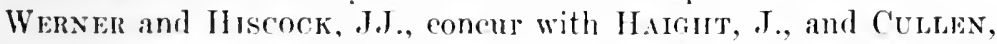

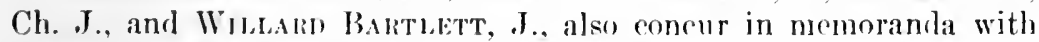
Haight, J.; Gray and Chase, JJ., dissent.

Judgment accordingly.?

$\S 96$

ARAD r. SAOBLOM.

131 Wiscossis, 642. - 1907.

Surt on promisonry note. Plaintiff gave cridrne that he was an innocent purchaser for value hefore due with no notice of any defense or invalidity. It was stipulated that the notr was in fact geiven in payment for lightuing rods ereoterl apon defendant's huildings in accordance with a prior written eont tart made hy the defondant, whereupon, on motion of elefombant, jurlement of nonsuit was enered rismissing the action, from which the plaintiff apprals.

Dowers, J. The comstitutionality of ch. 138, Laws of 1903, as applied to motres given for liglitning rods, is sotlled by Quiggle v. Ior-

9 This case is reported with a note in 16 I. N. S. 626, and the Gilhonly case, $189 \mathrm{~N}$. Y. 1. is reporterl witl, a note in 12 A. \& F. Ann. Cas. 1138 . For a dis. cusaion of these two cases, spe 15) ('ase and Comment, 130.-C. 
man. 131 Wis. 379, marking the distinction from its application to patent' rights considered in $\%$. 11 . Clark C'o. v. Rice, 127 Wis. $451 .^{1} * * *$

Concerling, for the purposes of the diseussion, that beeanse the giving of a note for lightuing rods without red-ink declaration of its consideration upon its face is in defiance of cli. 1:38, laws of 1903, it is thereby rendered invalid, as we have decided is a note executed on Sunday (Houe v. Ballard, 113 Wis. 375, and Brown v. Gates, 120 Wis. 349), does it necessarily follow that an innocent holder for value cannot recover thereon? It was early decided by this court that a negotiable note, invalid between the original parties beeause given in defiance of a statutory prohibition accompanied by a penalty $-i$. $e$. one given on Sunday, but dated on Saturday,- would be enforced in the hands of an innocent holder laving no knowledge of the illegal fact upon the ground of estoppel against the maker to assert such fact. Knox v. Clifford, 38 Wis. 651. The same principle has been inroked to support a usurious negotiable note in the hands of an innocent holder, although the statute declared it "void." Sage v. McLaughlin, 34 Wis. 550, 556. 'The general grounds upon which estoppel in pais rests are described in Marling v. Nommensen, 127 Wis. 363. 369. Hardly anything is more to be antieipated than that a negotiable note will be negotiated upon the faith of what appears upon its face (Loizeaux v. Fremder, 123 Wis. 193, 198); and the very issue of such paper without suggestion of any facts affecting its validity must be experted by every reasonable person to lead any purchaser to assume their nonexistence. The doctrine of Knox v. Clifford, supra, has been acted on by numerous other courts. Cranson г. Goss, 107 Mass. 439 ; Vinton v. Peech, 14 Mich. 287; Hall v. Parker, 37 Mich. 590, 594; Johns v. Bailey, 45 Iowa, 241, 245; Leightman v. Kadetska. 58 Iowa, 676; New v. Waller, 108 Ind. 365, - the last ease being derided under substantially the same statute as the one now

1 chapter 43S. Laws of 1903 , is now to be found in the following sections of the Wieconsin Negotiable lnstruments Law:

"Section 1675-la. All promissory notes and other evidences of indebtedness, taken or given for any lightning rod, patent, patent right, stallion or interest therein, as the case may be, shall have written or printed thereon in red ink the words: "The consideration of this note is the sale of a lightning rod, patent. patent right. stallion, or interest therein. as the case may be."

"Section Ifi,5-lb. Any person who shall sell a lightning rod, patent, patent right or stallion. or any interest in a lightning rol. patent, patent right, or stallion, who shall take a promicsory note or other evidence of indebtedness for the whole or any part of the consideration thereof, and who shall fail to state the consideration for said note as provided hy section 1 of this aet, or in words of similar import, shall be liable to a penalty equal to the face of the note so taken.

"Section 1fi5-le. All notes or other evidences of indebtedness taken as the whole or a part of the ernsideration for any lightning rod, patent, patent right, stallion, or interest therein, which shall express upon their face tho 
invoked. Other decisions affirming the ralidity of commercial paper in hands of innocent holder, notwithstanding illegality and consequent original invalidity, are Union T. Co. v. Preston Nat. Bank, 136 Mich. $460 ;{ }^{2}$ Traders' Bank v. Alsop, 64 Iowa, 97 ; Johnson v. Meeher, 1 W is. 436, 441; Mack v. Prang, 104 Wis. 1; Keller v. Schmidt, 104 Wis. 596, 602. We feel no doubt that the principle of Knox v. Clifford is sound and supports the right of this appellant to recover upon the facts as they appeared at the time of the nonsuit.

consideration for which they are taken, as required by section 1 of this act, shall he non-negotiable, and be subject to all the defenses in the hands of an innocent holder that the same wonld have if not transferred."

The above statute was held unconstitutional so far as it relates to patents and patent rights in. . H. Clarke ('o. v. Rice, 127 Wis. 451; lmt eon-titution:al as to the provision relating to stallions in Quiggle v. Ilerman, 131 Wis. 379. and as to the provision relating to lightning rods in the case to which this is a note.

Several states have provisions of a similar nature relative to negotiable instruments given for patent rights either incorporated in their Negotiable Instruments Acts (as, for example, N. Y., \$ 330) or found in independent statutes. The Arkansas statute (Kirhy's Dig.. \$\$ 513-516) was held constitutional in Foods v. Carl, 203 IT. S. 35s. affirming 75 Ark. 328, and in () zan lumber Co. v. Unicn Co. Bank, 207 U. S. 251, reversing 1.15 Fed. 344. The New York Act (now Neg. Inst. Law. $\$ 330$ ) was held constitutional in Ilerdic v. Roessler, 109 N. Y. 127. For decisions on the constitutionality of similar acts in other states, see the eares in the note to Woods v. Carl, 75 Ark. 328, in 5 A. \& E. Ann. Cas. $426 .-C$.

2 In Union Trust Co. v. Preston vat. Batuk, 136 Nieh. tho, it was held that certain sections of the Michigan Banking law forbidding and making it a crime for a bank officer or employes to certify a clieck when the amount thereof does not stand to the ererlit of the drawer on the books of the bank, do not make a check so eertified invalid in the hands of a bona fisle holder for value. Carsenter. J., sail: "It ly no menne followe, however, leseause a contract made in violation of law, eommon or statutory. is void between the original parties, that, if given the form of megotiable piaper, it is void in the? hands of a bona firle holder. Inelesel. it is the distinguishing characteristic of the law of negotiable paper that, when a contraet takes that form, it is not, in the hands of a bona fide holder. suliject to the defoneo whieh avoicled it in the hands of the original parlies. Negotiable paper in the hands of a boma fide holder is not open to the defonge that the contract from which it arose was illegat or forbidlen ly the principles of the common law. . . Notling

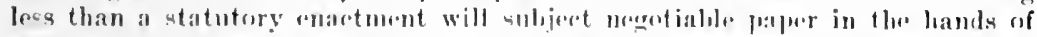
a bona fide holder to the deformen of illewality in its inception. What. then, is the effect of a statule which merely prohibits the making of a partientar eon-

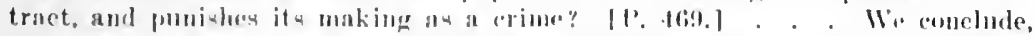
therefore, that, though the making of a eontrotet is prohibitend and made a crime by statufe, yet that eemtract, if it takes the form of negotialile paper, is valid in the hande of a bond fold holder for welue." 1'. 470. Sie this case

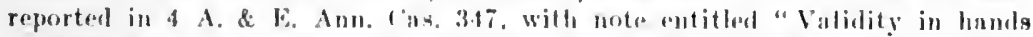
of bona fide holder of negotiald, contrate void ly statute betwen original parties."

In Groy s. Bonle, 5.5 Wiah. 578, it was held that (quoting the heabnote): "Laws 1905. 1. 373. prohibitung insuraner rebates does not invalidate n note given for the premiums in violation of the statute, as against a holder of the 
Further than this, omr negrotialile imstrmments statute, section

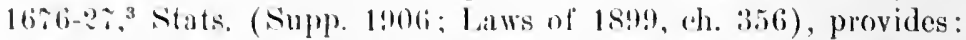

"A holder in due tourse lobls the instrmuent free from any defect of tille of prior parties, and free from defenses available to prior parties among themselves, and may enforce payment of the instrument for the full amount thereof against all parties liable thereon except as provided in sections 194.1 and $19 \% 15$ of these statutes, relating to insurance promiums, and also in eases where the title of the person negotiating such instrument is roid under the provisions of section 1676-25 of this act."

Section 16 ia-25: applies only to the case where the signer did not know the nature of the instrument and could not have obtained such knowledge by the use of ordinaly care. Sections 1944, 1945, refer to a note griven for an insurance premium, which by said sections is required to hear upon its face a declaration of its consideration, and omission thereof is penalized. But for these express exceptions the provision is general that the innocent holder may enforce payment for the full amount free from defenses available between the original parties. Surh specific exceptions strongly indicate that no others were intended. We cannot escape the conclusion that this statute supports plaintifl"s right of recovery. ${ }^{5}$

note in due course: since it is not the policy of the law to render negotiable paper void in the hands of imocent holders where the statute has not so expressly declared."

Similarly. it was held in Citizens'st. Bank v. Nore, 67 Neb. 69, that (quot. ing the heachote): "In this state a statute will not be construed so as to make a negotiable instrument void in the hands of a bona fide purchaser unlres the act specifically so declares. A note griven for medical services by an unlicensed practitioner may be recovered on by a bona file purchaser, notwithstanding the provisions of chapter 55 of the Compiled Statutes, prohibit. ing the prantice of medicine withont a license." - C.

3 This section is thr same as section 96 of the $\mathrm{N}$. Y. Neg. Inst. Law through the worls "against all parties liable thereon;" the balance of the section is found only in the Wisconsin statute. - C.

4 'lins section is in substance the same as section 94 of the $\mathrm{N}$. Y. Neg. Inst. Law sxept for the addition of the following words found only in the Wis. consin statute: "and the title of such person is absolutely void when such instrument or siguature was so procured from a person who did not know the nature of the instrument and could not have obtained such kuowledge by the use of ordinary care." licferring to these additional worls, the court, in A ukland v. Arnold, I3] Wis. 64, at p. 67, saje: "In terms it expresses the rule of law reconizel in the lecinioms of this court when it was enacted, which was to tha fffert that. when a signature to a negotiable instrument is obtained by falm and fraudulently misrepresenting its character, and the person signing it rould not have obtained knowledge of the falsity and fraud by the use of orlinary care, this makes the title to the instrument absolutely voirl as to such signer. Butler v. Carns, 37 Wis. 6l; Walker v. Ebert, 29 Wis. 194 treported herwin at 1. 387 ; Killer v. liupold, 115 Wis. 536; Franklin v. Killilea, 126; Wi-. $8 ., "$ - 6

* As an authority in uthrer statrs upon the proper construction and effect of the Negotiable Instruments Law, this decision loses much of its value 
By the CourT. - Judgment reversed, and cause remanded for new trial. ${ }^{\circ}$

WALKER $v$. EBERT.

29 Wisconsin, 194. - 1871.

Action against maker of a promissory note, by a holder who elaims to have purchased it for full value, before maturity. Defense: that defendant is a German unable to read and-write the English language; that the payees fraudulently induced him to sign an instrument represented to him to be a contract of agency, but which in fact was the promissory note in question. Evidence to establish this defense rnled out, and judgment given for plaintiff. Defendant appeals.

Dixos, C. J. - The defendant, haring properly alleged the same facts in his answer, offered evidence and proposed to prove by himself as a witness on the stand, that at the time he signed the supposed note in suit, he was unable to read or write the English language; that when he signed the same, it was represented to him as, and he believed it was, a certain contract of an entirely different eharacter, which contract he also offered to produce in evidence; that the contraet offered to be produced was a contract appointing him, defendant, agent to sell a certain patent right, and no other or different contraet, and not the note in question; and that the supposed note was never delivered by the defenlant to any one. It was at the same time stated that the defendant did not claim to prove that the plaintiff did not purchase the supjosed note before maturity and for value. To this evidence the plaintilf oljected, and the ohjection was sustained by the court, and the evidnoce excluded, to which the defendant exeepted; and this presents the only question.

We think it was arror to reject the testimony. The two cases cited by counsel for the defendant (Foster v. McKinnon, L. R. 4 C. P. 704, and Whitney v. S'myder, "Lansing, 477) are very clear and explicit upon the point, and demonst rate, as it seems to us, beyond any rational doubt, the invalidity of such palper, even in the hands of a liolder for value, before maturity, without notice. The party whose signature to such paper is ollained hy fraud as to the character of the paper itself, who is igmorant of such character, and has no intention of signing it, and who is gnilty of no negligence in aflixing his signature, or in not ascertaining the character of the instrument, is no more bound by it than if it wree a total forgery. the signature included.

because it is basel, at last in part, upon the provisions in the Wisconsin statute referrel to in notes 3 and 4, supra, not found in the statutes of the other states. - $\mathrm{C}$.

- This case is reported with notes in 10 I. N. S. 842, and in 11 A. \& F. Ann. Cas. 1179 , continuing note in 4.1 \& 1 \%. Aun. ('as. 353. - C. 
'The reasoning of the above anses is entircly safisfactory and conclusive upon this point. 'T'he inpuiry in suchl cases groes back of all questions of negotiability. of of the transter of the supposed paper to a purchuser for value, infore maturity and without notice. It ehallenges the origin or existence of the paper itself; and the proposition is. to show that it is not in law or in faut what it purports to be, namcly. the promissory note of the supposed maker. For the purpose of setting on foot or pursuing this incuiry, it is immaterial that the supposed instrument is negotiable in form, or that it may have passed to the hands of a bona fide holder for value. Negotiability in such eases presupposes the existence of the instrument as having been made by the party whose name is subseribed; for, until it has been so made and has such actual legal existence, it is absurd to talk ahout a negotiation, or transfer, or bona fide holder of it, within the meaning of the ha merchant. That which, in contemplation of law, never existed as a negrotiable instrument, eamnot be held to be such: and to say that it is, and las the qualities of negotiability; beranse it assmmes the form of that kind of paper, and thus to shut out all incuiry into its cxistence, or whether it is really and truly what it purports to be, is petilio principii-logging the question altogether. It is, to use a homely phrase, putting the eart before the horse, and reversing the true order of reasoning, or rather prerenting all correct reasoning and investigation, by assuming the truth of the conchusion, and so preclurling any inquiry into the antecedent fact or premise, which is the first point to be inquired of and ascertained, For the mrposes of this first inquiry, which must be always open when the uljeretion is raised, it is immaterial what may be the nature of the supposed instrument, whether negotiable or not, or whether transferrol or negotiated, or to whom or in what manner, or for what ronsideration or value paid by the luolder. It must always be competent for the party proposed to be charged upon any written instrument, to show that it is not his instrument or obligation. 'The principle is the same as where instruments are made by persums labing no aluacity to make binding contracts; as, by infants, married wonlen, or insane persons; or where they are roid for other cause, as, for usury; or where they are executed as by an agent, but without anthority to hind the supposed principal. In these and all like (ases, no arlditional validity is given to the instruments by putting throm in tlan form of nexptiable paper. (See Veeder v. Town of Lima, 1!) 11 is. 25\% to 2!?, and authorities there cited. See also Thomas v. Watkins, 1f Wis. 51!).)

And idrutiral in principle, also, are those cases under the registry laws, where the bona fide piurchaser for value of land has been held not to be protectrol whin the recoriled deed under which he purchased nnd rlaims, turns out to have bren plocured by fraud as to the signature, or purloined or stolen, or was a forgery, and the like.

(See 
Everts $v$. Agnes, 4 Wis. 343, and the remarks of this court, pp. 351353 , inclusive.)

In the case first above cited (Foster v. Mchinnon), the defendant was induced to put his name on the back of a bill of exchange by the fraudulent representation of the acceptor, that he was signing a guaranty. In an action against him as indorser, at the suit of a bona fide holder for value, the Lord Chief Justice, Boville, directed the jury that, "If the defendant's signature to the document was obtained upon a fraudulent representation that it was a guaranty, and the defendant signed it without knowing that it was a bill, and under the belief that it was a guaranty, and if he was not guilty of any negligence in so signing the paper, he was entitled to the verdict;" and this direction was held proper. In delivering the judgment of the court upon a rule nisi for a new trial, Byles, J., said:

"The case presented by the defendant is, that he never made the contract declared on; that he never saw the face of the bill; that the purport of the contract was fraudulently misdescribed to him; that when he signed one thing, he was told and believed he was signing another and an entirely different thing; and that his mind never went with his act. It seems plain on principle and on authority, that if a blind man, or a man who cannot read, or for some reason (not implying negligence), forbears to read, has a written contract falsely read over to him, the reader misreading to such a degree that the written contract is of a nature altogether different from the contract pretended to be read from the paper, which the blind or illiterate man afterwarl signs, then, at least if there be no negligence, the signature so obtained is of no force: and it is invalid, not merely on the ground of fraud, where fraud exists, but on the ground that the mind of the signer did not accompany the signature; in other words, that he never intended to sign, and therefore, in contemplation of law, never did sign the contract to which his name is appended."

And again, after remarking the distinction between the case under consideration and those where a party has written his name upon a blank piece of pajer, intending that it should afterwards be filled up, and it is improperly so filled, or for a larger sum, or where he has written his name upon the hack or across the back or across the face of a blank bill stamp, as indorser or acceptor, aml that has been fraudulently or improperly filled, or in short, where, under any circumstances, the party has voluntarily affixed his siguature to commercial paper, knowing what he utas doing, and intending the same to be put in circulution as a negotiable security, and ufter also showing that in all such rases the party so signing will be liable for the full amount of the notr: or hill, when it has once passed into the hands of an innocent indorece or holder, for value before maturity, and that such is the limit of the protection afforded to such an indorsee or holder, the learned judge proceeded:- 
"But, in the case now muler consideration, the defendant, according to the eridener, if helieved, and the finding of the jury, never intended to indorse a bill of (xellange at all, but intended to sign a contract of an entirely diflerent nature. It was not his design, and, if he were guilty of no nerligenere, it was not even lis fault, that the instrument lo signed turned out to be a hill of exchange. It was as if he had written his name on a sheet of paper for the purpose of franking a letter, or in a lady's allmm, or an order for admission to 'Temple Chureli, or on the fly-leaf of a book, and there had already been, without his knowledere, a hill of exchange or a promissory note payable to order inscribed on the other side of the paper. To make the case clearer. suppose the hill or note on the other side of the paper in eacl of these ases to be written at a time subsequent to the signature, then the frudulent misapplication of that genuine signature to a diflerent purpose would have been a counterfeit alteration of a writing with intent to defiaud, and would therefore have amounted to a forgery. In that ease the signer would not have been bound by his signatule, for two reasons - first, that he never in fact signed the writing declared on, and, secondly, that he never intended to sirn any such contract."

"In the present ease, the first reason does not apply, but the second does apply. The defendant never intended to sign that contract, or any such contract. He never intended to put his name to any instrument that then was or thereafter might become negotiable. He was decived, not merely as to the legal effect, but as to the actual contents of the instrument."

'The other case first above cited (Whitney v. Snyder), was in all respects like the present, a suit upon a promissory note by the purchaser before maturity, for value, against the maker; and the facts offered to be proved in defense were the same as here; and it was hold that the evidence should have been admitted.

In Vance v. Larey (5 Ala. 370$)$, it was held that where one writes his namo on a blank piece of paper, of which another takes possession withut authority therefor, and writes a promissory note above the signature, which he negotiates to a third person, who is ignorant of the ripumstances, the former is not liable as the maker of the note to the holler. In that case the note was written over the signature ly one I angford, and hy him negotiated to the plaintiff in the action, wh, slew the defendant as maker. Collier, C. J., said: -

"The making of tlue note by Langford was not a mere fraud upon the dofendant; if was something more. It was quite as much a forcery as if he had fomml the blank, or purtoined it from the defendant's possession. If a recovery were allowed upon such a state of farts, then wery on who ever indulges in the idle habit of writing his name for mere pastime, or leaves sufficient space between a title and his subscription, might be made a bankrupt by having promises 
to pay money written over his signature. Such a decision would be alarming to the community, has no warrant in law, and cannot receire our sanction."

And in Putnam v. Sullivan (4 Mass. 54), Chief Justice Parsons said:-

"The counsel for the defendants agree that, generally, an indorsement obtained by fraud will hold the indorsers according to the terms of it, but they make a distinction between the cases where the indorser, through fraudulent pretenses, has been induced to indorse the note he is called on to pay, and where he never intended to indorse a note of that description, but a different note and for a different purpose. Perhaps there may be cases in which this distinction ought to prevail. As, if a blind man had a note falsely and fraudulently read to him, and he indorsed it, supposing it to be the note read to him. But we are satisfied that an indorser cannot avail himself of this distinction, but in cases where he is not chargeable with any laches or neglect, or misplaced confidence in others." (See also 1 Parsons on Notes and Bills, 110 to 114 , and cases cited in notes.)

The judgment below must be reversed, and a venire de novo awarded. ${ }^{7}$

By the Court.- It is so ordered. ${ }^{8}$

Tris action was upon a promissory note of $\$ 270$, signed by defendant, payable to E. A. Miller or bearer.

Defendant entered into a contract with Miller to act as agent for the sale of a patent hay fork and pulley. A contract was filled out by Miller and signed by both; also an order, which was signed by defendant, for one of the hay forks and two pulleys, for which, by the order, defendant agreed to pay nine dollars. 'These were delivered to defendant. Another paper was then presented to defendant for his signature, which Miller represented to be but a duplicate of the order.

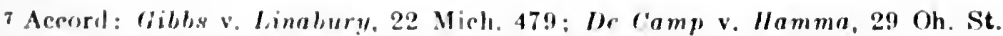
467; Puffer v. Smith, 57 III. 527; Giren v. Hilkie, 98 Iowa, 74. - II.

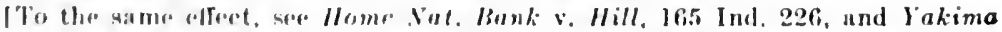
Valley Bank v. Medllister, 37 Wash. 5fo. In a note to the latter ease in I $\mathrm{L}$. N. S. 1075, it is uaid: "lhere are a fow easeq, however. which hold that, if the signatur. was actually aflixol by tha maker with the intention of signing some kind of a paper. the mere fuct that he: was lefrauded as to what he was actually signing would lo no defense te a note in the hanls of a bona fide holder. F'irst Not. Bank v. Johns, 22 W. Va. 520 . 46 Am. Rep. 50h: Phelan v. Iloss, fit Pa. 5!, 5 Am. Rep, 402; Batlles v. Laullomslager, 84 P'a. 446; Loomis vo Uetralf, 30 Iown, 382." - r'.

R The principle of this derision has lwern codified in section 1066-25 of the Wisconsin Negotiable Instruments Law. See note 4, ante, p. 386. - C. 
Defendunt without reading or cxamining it, signed it and delivered it to Miller; the paper so signed was the note in suit. Plaintiff purchased in good fuith hefore maturity, laying therefor $\$ 245$.

'The court charged the jury: "If you find that this paper was never delivered as a note, plaintiff fails in lis action; if you find that it was delivered but this plaintitl failed or neglected to make the proper inquiry, then he is not entitled to recover for he fails as a bona fide holder."

Phintitf excepted generally to the whole of the charge.

Plaintitf requested the court to charge:-

First. That if the signature upon the note is the genuine handwriting of defendant, circumstances of fraud in its inception constitute no defense to the note in the hands of an innocent purchaser.

The court refused to so charge.

Second. That if the plaintiff purehased said note in good faith and for a valuable consideration, the plaintiff is entitled to judgment for the full amount thereof.

Third. That if defendant negligently and without sufficient care and precaution put his name to the paper and delivered it to Miller, he is liable for its amount as a promissory note.

Fourth. That there are no ciremustances in this case indicating a fraud in the inception, and which were calculated to put the plaintiff on his guard, and therefore he is a purchaser in good faith.

The court declined to charge either of these propositions.

Verdict and judgment for plaintifl (defendant?)

Johsson, J.- The judge cliarged the jury that if the paper sued upon was never delivered as a note, the plaintiff must fail in the action; and that even if it was delivered, and the plaintiff neglected to make proper inquiry as to its origin, he was not a bona fide holder and could not recover. The exception to the charge was general, but if both propositions were erroneons the error can be reached and corrected; especially as the attention of the judge appears to have been called, by requests to charge, to the precise grounds on which the charge is now clained to be erroneous.

The latter branch of the eharge presents the question of notice to put a party on inquiry, as affecting his right to be regarded as a bona fide holder. It is now, however, the settled law that mere negligence, however gross, is not sufficient to deprive a party of the character of a bona fide loolder. There must be proof of bad faith. That alone will deprive him of that character. (Welrh v. Sage, 47 N. Y. 143; Seybel v. National ('urrenry Bank, Commission of Appeals, 54 N. Y. 288; Murray v. Lardner, 2 Wall. 110 ; Ciogdman v. Simonds, 20 How. 452.) This part of the rharge, therefore, 'annot be sustained. If, then, the appellant ran maintain the position that the other branch of the charge is also ermnous, he will be entitled to the reversal of the judgment, notwithstanding the generality of the exception. 
The evidence tended very strongly to show that the signature of the defendant to the note sued upon, was obtained from him through a very gross and fraudulent representation perpetrated upon him by one Miller. That when he signed it, he supposed he was signing a paper of a very different character, and not an engagement to pay money absolutely. He had, just before, signed an order for the delivery to himself of a hay fork and two grappling pulleys, amounting together in price to nine dollars, for which he engaged to pay; and this paper now in suit was presented to him as a duplicate of that order, and was signed as such without examination or reading it, upon the statement of Miller, with whom he was dealing, that such was its character. There does not appear to have been any physical obstacle to the defendant's reading the paper before he signed it. He understood that he was signing a paper by which he was about to incur an obligation of some sort, and he abstained from reading it. He had the power to know with certainty the exact obligation he was assuming, and chose to trust the integrity of the person with whom he was dealing, instead of exereising his own power to protect himself. It turns out that he signed a promissory note, and that it is now in the hands of a holder in good faith, for value. The question which arises on the branch of the eharge now under consideration is, whether it is enourh, as against a bona fide holder, to show that he did not know or suppose that he was signing a note, unless it also appears that he was gnilty of no laches or negligence in signing the instrument. To that inquiry the attention of the judge, at the trial, was distinetly called; and the instruction which he gave and which was excepted to, did not submit, but excluded the consideration of it from the jury. It is quite plain that if the law is that no such inquiry is admissible, a serious blow will have fallen upon the negotiability of paper. It will be a premium oflered to negligence. 'To insure irresponsibility only the utmost arelessness, coupled with a little friendly fraud, will be essontial. Paper in ahmondanee will be found afloat, the makris of which will have had no idea they were signing notes, and will have trusterl readily to the assurance of whoever procured it that it created no obligation. 'l'o aroid such evils it is necessary, at least, to hold tirmly to the doetrine that he who, hy his carelessness or undue contidemere has cnabler another to obtain the moncy of an innocent persoll, shall answer the loss. If it he objected that there must he at dufy of eare, in order to found an

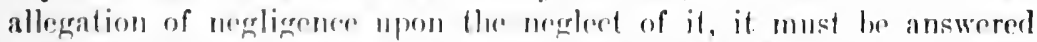
that every man is bouml on know that he may be dereived in respeet to the contents of a paper which he signs without reading. When he signs an obligation withont asertaining its character and ertent, which he has the means fo do. "lpon the representation of another, he puts eonfidenen i: that person: and if injury ensues to an innoent third person hy reasom of that confirtence, his art is the means of the injury, and he ought to answer to it. 
[After discussing Foster v. Mackimmon, I. R. 4 C. P. 704; Whitney

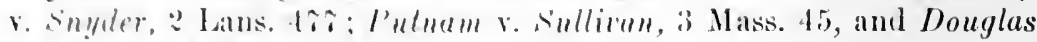

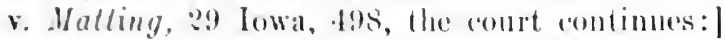

In all these cases. the real ground of decision is not that the party neant to make a promissory note, hut that nueaning to make an obigation in writing, and which was put in writing that it might of itself import both the fact and the form and the measure of the obligation, he trustod another to fix that form and measure, without exercising that supervision which was in his power and by which perfect protection was possible. In such cases, the rule is, that he is bound hy the act of him who has been trusted in favor of a holder in good faith.

'The julgment must be reversed and a new trial granted, costs to abide the event.

\section{AlI concur. Judgment reversed. ${ }^{\circ}$}

42 Solicitors' Joukval (JAN. 1, 1898) 151, 67 L. J. Q. B. 224.

Actios by payee against defendant as one of two makers of two

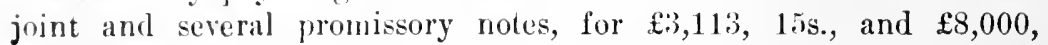
respectively. It is ahmitted that defendant's signatures are genmine and that his signatures to two letters authorizing plaintiff to pay the proceeds to I,ord William Nevill, the other maker, are also genuine. Plaintiff gave value in good faith for the notes. Defendant's signatures to the notes and letters were proeured by Lord William Nevill in this wise: The latter came to defendant and asked him to witness some doemments, producing a roll of papers covered by blotting or other paper in which there were four openings; defendant asked what the documents were and was answered that they concerned private family matters, that defendant could see them if he insisted, hut it was profored that he should not: defendant did not insist and

" The law of the state is. that where a party is indueed to sign a negotiable instrument by reason of fraud, artifice or deeption practiced upon him by another as to the nature of the instrument, ancl the maker signs the same innocently and under the lwelief that it was a contract of a different character, then there ean he no reseire upen the note. although the holder may be an innocent purchaser for value before maturity, unless the maker was guilty of laches or carelessnes, in omitting to read the same, or by some other means ascertaining the truc nature and import of the instrument. (National Ex. Bk. v. I'rneman, 43 IIun. 24], cited with approval in I'agr v. Krokey, $137 \mathrm{~N}$. Y. 3131."- Iutknff $v .170 j r .20$ Mise. (N. Y.) 6.32 (1897). Negligenee on the part of the rone signing renclers him liable to a holder in due eourse. Shirts v. forjohn, 60) Mo. 305: r'ilizrns" Iat, Bank v. Smilh, 55 N. H. 593; Kellogg v. rurtis. fi5 Me. 59: Arbeler v. Cutsinger, 48 Ind. 436; Ort v, Fowler, 31 Kans. 478. - H. 
signed his name four times through the openings. Lord William Nevill also signed, and defendant believed he was signing as witness to the former's signatures. Defendant had just come of age, had known Lord William Nevill intimately for some years, and had no reason to doubt his honor.

The following questions were put to the jury, who gave the answer appended to each:- (1) Did the plaintiff take the promissory notes in good faith? [It is admitted he took them for value.] Answer.Yes. (2) Is the defendant's account of the circumstances under which he signed his name substantially true? Answer.-Yes. (3) Was the defendant, in signing his name as he did, recklessly careless, and did he thereby enable Lord William Nevill to perpetrate the fraud? Answer.- No; not under the circumstances. (4) Were the signatures to the documents given by the defendant in misplaced confidence in the statements of Lord William Nevill as to their nature? Answer.- Yes. (5) Did the defendant sign his name to be used by Lord William Nevill for any purpose he chose? Answer.- No. (6) Did the defendant attach his signature to the documents without due care? Answer.- No; not under the circumstances.

On these findings the case was reserved by the Lord Chief Justice for further consideration.

Lord Russell of Kirlowex, C. J.- I have now to consider in the light of these findings which of the parties is entitled to judgment. It is clear that the proof of the signature of the defendant to the promissory notes, coupled witl proof of their delivery to the plaintiff under the apparent authority of the defendant, makes out a prima facie case for the plaintiff. Is it a condusive case? IIere two questions arise - (1) Is the defemlant predulded or estopped from setting up the true circumstances nnder which his name came to appear on the documents in question? (?) If not, do those true rircumstances afford an answer in point of law to the plaintill's claim?

I. As to the first ruestion the Irefondant is not, in my judgment, estopped or precluded from setting up the actual facts upon any principle of law. Apart from statute such preclusion or estoppel can only arise (in circumstanes like the present) where the defondant had so condured himself that if would he contrary to matural justiee to permit him to assume a presition inmonsistent with that which he had ostensibly orempied, or which he led others to believe he oceupied, and upen whieh others had, misted hy his coundurt, been suffered to act. In the present rase the sugerestion on the part of the plaintiff is that the defondant had wot used due care in signing his name, and that he had signed in misplacerl confistemere in lond William Nevill. 'The jury have found that there was, in Pact, no want of due eare in the cirenmstanese in signing his name as he did:

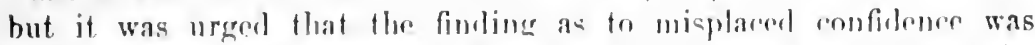
sufficient, and the autherity of a distingurished $A$ merican jurles in the 
case of l'uinam v. Sulliran (.t Mass. 45) was cited. What does misplaced confidence mean? It may mean confidence placed where you know or ought to know it is not safe, or confidence placed where you have every riglit to belicve it is safe, but where it is afterwards betrayed. 'The former, I think, is the ease the learned juage had in his mind, and the facts there may afford evidence of want of due care: but that elearly is not here the meaning attributed by the jury to misplaced confidence, for they have found that there was in the circmustances no want of due eare on the part of the defendant. Taking the findings together they amount to this - that the defendant was in the eircumstances guilty of no want of due eare in placing confidence in the statement made by Lord William Nevill, and acoordingly in signing his name as he did; and I decline to hold that the placing of confirlence as here shown, which is afterwards betrayed, where it is not recklessly or negligently so placed, in any way precludes the defendant from setting up the true facts as a defense. I conclude, therefore, the defendant is not, upon any principle of law, estopped or precluder from setting up the true facts.

How, then, is the plaintiff's case put? It was argued that whatever was the law before or apart from the Bills of Excliange Act, 1882 the facts here did not under that Act afford a defense as against a "holder in due course," which, it was said, the plaintiff was within section 29, and that the question must be detemined by reference to that Act alone. I think this argument involves a misconception both of the plaintiff's position and of the scope and effect of the Act of 1882 . It will be apparent from a consideration of the facts of the case that the plaintiff was not a "holder in due course" at all, but that he was, in fact. simply the named payee of two promissory notes. Further, an examination of sections $20,21,29,30$, and 38 , relating expressly to bills, and sections $83,84,88$, and 89 , relating to promissory notes, will make it quite clear that "a holder in due course" is a person to whom, after its completion by and as between the immediate parties, the bill or note has been negotiated. In the present case the plaintiff is mamed as pavee on the face of the promissory note. and therefore is one of the immediate parties. The promissory notes have, in fact, never been negotiated within the meaning of the act. ${ }^{1}$

I lesire to say here that, even if the plaintiff were "holder in due courke," it would, in my jurlgment, make no difference in the result.

But is the contention right that the Act of 1882 must alone be lookerl to: I think not. That act was intended to be mainly a codi-

IOn the print discusced in this paragraph, see Boston Steel of Iron Co. $\mathbf{v}$ Steuer, 183 Ma\&s. 140, ante. J. 174: Vanter Plofg v. Ian \%uuk, 135 Iowa, 350, antr. P. 179; Lloyd's Bank, Limited, v, Cooke, [1907] I K. B. 794, ante, p. 185. - C. 
fication of the existing law, but it is not merely a codification act, for some alterations of the law are clearly effected by it and it does not purport to be exhaustive, for, by section 97 , the rules of the Common Law (including the Law Merchant), save in so far as they are inconsistent with the express provisions of the act, continue to apply. But I agree that in determining questions of liability on bills or notes it is proper to examine the act before turning to the cases declaratory of the Common Law decided before that act.

It is unnecessary to set out the provisions of the act and to comment in detail upon then. It is enough to say that there is nothing in the act which prevents the defendant from setting up the defense that he never made the promissory notes in question - which is the real defense here. It would, indeed, be strange if it did. For the purposes of the present case the question is precisely the same as if any other contract than one by promissory note had been written on the documents to which the defendant was induced to sign his name - for instance, if it had heen a contract of guarantee or suretyship. Then the question would have been - Did the defendant make the contract of guarantee or suretyship? Here it is - Did he make the promissory notes sued upon?

II. The question, then, is, on the facts as they are now found to be - Did the defendant make the promissory notes in question? If he did not, then the finding of the jury that the defendant was not guilty of any want of due care estahlishes that he is not precluded from saying so. 'That there is a prima facie ease on the plaintiff's evidence that he did, I have already said; but is that prima facie case rebutted and displaced by the defendant's evidence? According to that evidence it must, after the findings of the jury, he taken to be the fact that he was witnessing a deed or document; that he was so told; that he had no idea of sirning, and was not asked to sign, any bill or promissory note, or to undertake any contractual obligation of any kind. A promissory note is a contract by the maker to pay the payee. Can it be sail that in this case the lefendant contracted to pay the plaintiff? Il is mind never went with such a transaction : for all that appears, he har never heard of the plaintiff, and his mind was fraudulently directed into a ditferent channel by the statement that he was merely witussing a deed or other document. He had no rontracting mind, and his signature obtained, by untroe statements fraudulently made, to a doemment of the existenee of which he had no knowledge, rannot hind him. It is as if he had written his name for an autograph collector, or in an allum. The case differs in no material respert from one in which a genuine signature is deftly transferrel by delisate contrivance from one document to another, and so skillfully as to eseape notice under ordinary examination. Or, again, if the body of the promissory notes had been fraudulently written above, and after his signature had been 
made. it would have been forgery, and in such ease it is clear no recourse could he lad mpon it. ('an it malie any difference as to resulting contractual ohligation that the hody of the note was, without his knowlelge, filled up hefore he was fraudulently induced to put his name in the belief that it was something wholly different? I think not. In plain reason it must he said that the use to whish the defendant's signature was applied was in substance and effect forcery, whether or not it amounted to the criminal offense of forgery.

I think it well to point out that cases like the present differ widely from those in which the party sought to be charged has agreed and intended to enter into contractual obligation by bill or note, but has heen defrauded into agreeing, or been defrauded in the manner in which the hill or note has been dealt with. In such cases he is liable on principle and authority, to any one who has dealt with the bill or note in good faith and for value.

It was in argmment admitted that the case of Foster v. Mackinnon ( $1 \%$ II. R. $1105,+$ I. R. (. P. 701$)$, is in point, and is an authority binding on me if the Bills of Exchange Act of 1882 has not altered the law as there declared. I find that the law has not been so aitered. I see nothing in the act to warrant the suggestion that it has heen altered, and it is noteworthy that all the text-writers dealing with the Bills of Exchange Act, 1882 (including, indeed, the draftsman of the a(t), treat that case as an existing authority. The facts in Foster v. Mackinnon were, that an old man of feeble sight was inducerl - without, as the jury found, any negligence on his part - to sirn his name on the hack of a bill by the fraudulent statement that it was a gmarantee which, in fact, he had undertaken to sign. The C'ourt of Common Pleas (consisting of Bovill, C. J., and Byles, Keating, and Montagu Smith, J.J.), held that he was not liahle, and this in an action by what was then called a bona fide holder for value and witlout notice, of which "holder in due course" is now the legal equivalent.

In these istands, cases in litigation of frauds such as that here practiced are of rare occurrence, partly because of the existence and character of our stamp laws, lut in the United States of America, where no sucls laws exist, there are many anthorities dealing with points similar to that in the present case. (Douglas v. Matting, 4 Am. Rep. 238 [29 Iowa, 498]; Taylor v. Atchison, 5 Am. Rep. 118 [5t Jll. 196]; Whitney v. Śnyder, 2 Lans. 477; Walker v. Ebert, 9 Am. Rep. It [29 Wis. 194]; Griffiths v. Kollogg, 20 Am. Rep. 48 [39 Wis. 2901). The great weight of United States anthorities supports the view of the rommon law expressed by the English judges.

I have thought it right to say so murb, but in truth these authorities are not necessary for the purposes of this ease. 'They are all cases where the bills or notes had heen regotiated to persons now 
called "holders in due course." It fellows, if such a holder cannot in a case like the present recover, a fortiori that the plaintiff - who, as named payee, is one of the immediate parties - cannot recover.

In the result, therefore, my judgment must be for the defendant, and the plaintiff must be enjoined from in any way dealing with the notes, and the same must be canceled so far as they purport to be the notes of the defendant. 


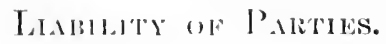

โ. Maker: absolute, primary liability; admissions.

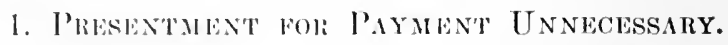

See Ner. lnst. Law, \$ 130, post, pp. 47\%-480.

2. Liability on Lost or Dastroved Instienment.

$\$ 110$

MCGREGORY $r$ MCGREGORY.

107 Missiculoults, 543. - 1871.

Aст10x against makers on notes allegeel to be lost. Verdict for plaintill, who filed a bond for protection of defendants from liability on lost notes, to the alpuroval of the judge.

GiruY, J.'-Destruction ly fire is one mode by which property may be lost, and an allegation that a note has been lost is fully supported hy proof that it has been destroyed liy fire.

It is well setterl in this commonwealth, that an action at law may be maintaned on a lost promissory note, whenever a bond of indemnity will afford complete protection to the defendant; and that such an action may be maintained against the maker of such a note, upon filing a sufficient bond of indemnity. All the makers of the notes described in these three counts are defondants in this action; and they du not stand like an indorser of a promissory note, who is antitled. upon taking it up to the posession thereof, in oriler that hre mav have his reroulson over asainst the maker, or negotiate it again; or like llo areceptor of a bill of exchange, who may need it as a voueher in sortling his ancomnt with the drawer. (Fales v. Rassell, 16 Piek. 31.): Almy r. Lemel, 10 Cush. 121; Roston. Lefad Co. v. McGuirk, 15 liray, si; Tomer v. Appleton Bamti, 3 Allen, 387: T'uttle v. Standish, 1. Illwn, 181; saramuh National Bank: v. Maslims. ${ }^{2} 101$ Mass. 370.) Jilement on the verdirt for the plaintitr. ${ }^{3}$

1 Chentting rither gumetions. - II.

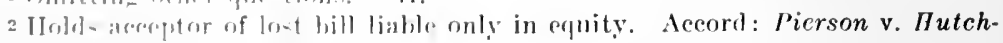
inson. 2 ramp. 211. - II.

3 If a note rir hill ia shrown actually to have been destroyed, most courts allow an artion at law. Irs irts v. lergyett, l6 N. Y. 582: Dean v. Speakman, T Blatehf. (1ml, 317 . liut not if it is voluntarily destroyed by the holder.

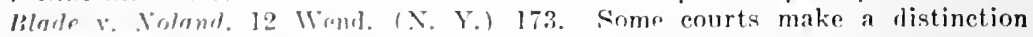
hetwern instrument = lost hofore maturity and those lost after maturity, allowing an actirn at law on the latter. Thingre v. King, 15 Ohio, 242; Movery v. 


\section{Aumission of Existence and Capacity of Payee.}

31 Colokano, 261. - 1903 .

T'HE defendant in error executed and delivered his promissory note, in the city of Denver, payable to the Sprague Collection Arency. The payee was a loreign corporation, and at the time of this transaletion had not, nor has it since, complied with the law recpuiring surh corporations to pay certan fees before engaging in business in this state. (Sess. Laws, 14:\% . p. 15\%, e. 51.) Before maturily, the plaintitls in error, for value, and withont notice that the payee had not complied with the law relative to foredgn corporations, purchased the note from the payee in the eity of Inorer. In an action hy the purchasers against the maker to enfores its collertion, the trial conrt held that the note wals void, and remlered judgument for the defendant. The plaintiffs bring the ane lacer for peviow on error.

Ganitin't, J. |aftor stitting the facts.] - The only question neeessary to determisu is whether or not a negotiable promissory note in the lands of partics ohtaning it for value, in good faith, before maturity, from a forrign copporation in this state, to which it was erion in this state, is invalid as anginst the maker hecause such corporation, at the time of the execution and delivery of surb note or subsernently, had not romplied with the laws relative to the comlitions which would anthorize it to engage in business witlin the stalle. The question is one which hass heon discossed hy the ronts of seseral states, with the result that the derisions

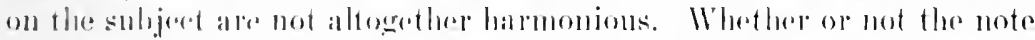

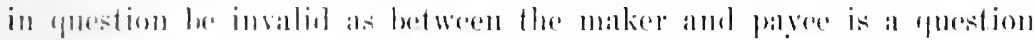

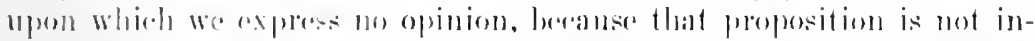

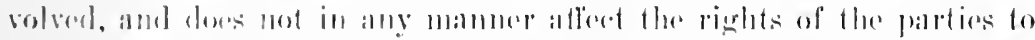
this ardion. The statute which the makere involes does not provide

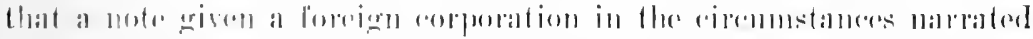

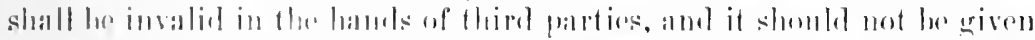

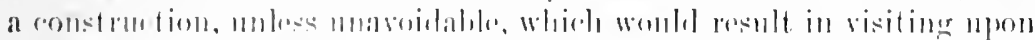

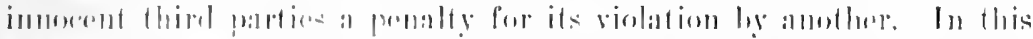

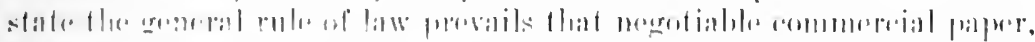

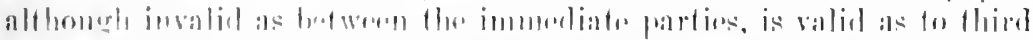

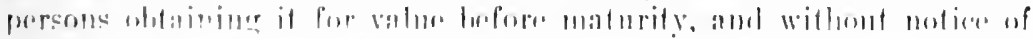

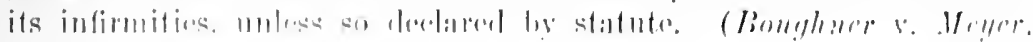

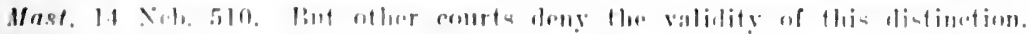

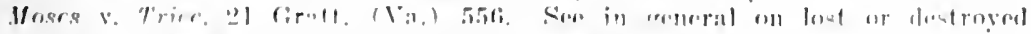

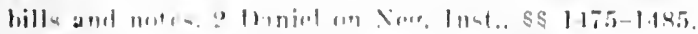

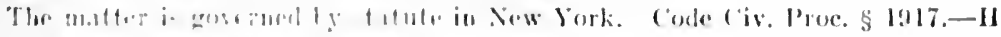
NKGOT. INATHUMENTA - 26 
5 Colo. 71.) See, also, Sondheim v. Gilberl, 117 Ind. 71, where the subject is quite fully discussed and many anthorities cited."

The defendant, by griving a note which is not the subject of statutory enactment, thereby comelusively admitted as to third parties purehasing before maturity, and in good faith, the legal existence of the payce, and its authority to take such note, and to negotiate and transfer it by indorsement. Section $60, "$ Negotiable Instruments Act (Sess. Laws 1897, p. 223, c. 6.t) ; 4 Enc. Iaw (2d Ed.) 47., 475; Wolke v. Kuhne, 109 Ind. $313 ; 1$ Edwards' Bills and Notes (3d Ed.) $\$ 363$; Bigelow on Estoppel (th Ed.) 512 .

The plaintiffs were in no manner comnected with the original transaction, mal they violated no law in purchasing the note from the payee. 'They purchased it in good faith, hefore maturity ; it was negotiable in form; and the maker camnot be heard to say, as against them, in these circumstances, in the absence of a statute to the contrary, that the payee committed an illegal act in taking, or had no authority to dispose of, it, in the usual course of business, because by its execution and delivery he is precluded from raising any of these questions as against the purchasers, who ohtained it for value, before maturity, without notice of the fact upon which he relies to defeat it. The courts camnot undertake to render the statute relied upon by defendant effective by imposing penalties which it has not provided, or placing them where they do not belong. If defective because no sufficient provision is made for its enforcement, that is a matter for the Legislature to remedy. According to the undisputed facts, the plaintiffs were entitled to a recovery on the note. The jurlgrment of the County Court is therefore reversed, and the cause remanded, with directions to render judgment in favor of the plaintiffs.

Judgment reversed. ${ }^{\circ}$

4 Ser also Alexander v. Hazelrigg, $123 \mathrm{Ky} .677$, ante, p. 375, and Arnd v. sjoblom, 131 Wis. 642, ante, 1. 383.-C.

\. Y., \$110.-C.

- Maker of a note payable to the order of "A. B. Attorney-General" cannot dispute his right to transfer it. Wolke v. Kuhne, 109 Ind. 313. Maker of a note payable at "A. B." cannot deny the existenee of such a place when the statute requires negotiable instruments to le payable at a place certain. Broicn v. First I. B., 103 Ala. 123. Contra, where the statute requires it to be payable at a bank. P'arkinson v. Finch, 45 Ind. 122. - II.

In r'astor v. Jeferson, 2 Wash. 204, it was held that the maker of a promissory note payable to the order of a married woman guaranters her capacity to imbrse and tran-for thw same; and the fact that the note is community property will not affect thre titlo of a bona fide indorsese for value before maturity, where he has no notice that the notr is community property. HoYt, J., said: "The maker promised to pay Mrs. Wliza F. Pool, or order, and in making the note so payble he guaranteed, to avery person taking such notr in gond faith. hrr ability to orler the same paid to another - that is, to indorse it - and as to every such person buying in good faith and for value such guaranty was conclusive. That the maker of negotiable paper thus guar- 


\section{Acceptor: absolute, primary liability; admissions.}

\section{Presentment for Payment Unnecessart.}

See Neg. Inst. Law, § 130 ; post, pp. 477-480.

\section{Admissions as to Drawer and Payee.}

\section{$\S 112$ FIRST NATIONAL BANK OF LISBON $v$. BANK OF WYNDMERE.}

15 NoRth DAKota, 299. - 1906.

Action by the First National Bank of Lisbon against the Bank of Wyndmere. Judgment for defendant, and plaintiff appeals.

Exgerud, $J$. This is an appeal from an order sustaining a demurrer to the complaint on the ground that it does not state a cause of action. The complaint states the following facts: The plaintiff and defendant are banking corporations, loeated, respectively, at Lisbon and Wyndmere, in this state. On July 1, 1905, the defendant caused to be presented to plaintiff for payment a forged check purporting to have been drawn by Bixby \& Marsh upon the plaintiff bank in favor of 'Theodore Larson for $\$ 60.25$, dated June 27,1905 , and indorsed in blank by the payee. It also bore the indorsement of the defendant, and each of the several banks through whose hands it had passed in the usual course of transmission from defendant to plaintiff. Each indorsing bank had expressly gruaranteed the gemmineness of previous indorsements. Bixhy \& Marsh were depositors in plaintiff bank, and had to their credit subject to check a sufficient. amount to pay the check in question. The plaintiff bank bolieving the check genuine, pain it and charged it to the aromnt of lixby \& Marsh. The name of this firm had been forged, hut this fact was

antecs the capacity of the payee to indorse and transfor the same soema to arise from the necessity of the ense. and the rule is therefore fommed upon reason. It is likewise abmolantly supported hy muthority. Ser Daniel, Neg. Inst., \$ 93, and cases there eited. This rule has been frequently applied to notes mude to und transferrel by infants. Ses section 227 of the anllority above citerl. I,ikewise to marriel women under the disabilities of the onmmon law." P. 207. - $: .1$

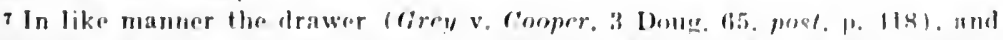

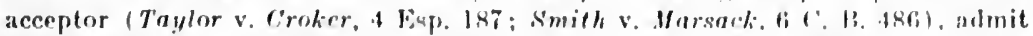
the existener of the parer and his then capacity to contract. Sien two following gections of Neg. Inst. Iaw. - H. 
not discovered mntil July ?oth, when Bixhy \& Marsh, who were ranchmen living more than ?0 miles from lishon, (alled at the bank and examined the eanceled vouchers. Bixhy it Marsh declined to allow eredit to plaintity for the spurions voucher. Immediately on that day, the plaintill notifiod the defendant bank of the forgery, and demanded repayment: at the smone time retmrning the forged check to defendant. 'ihe defondant rofuserl to rofund. Judgment is demanded for the amomut of the check and interest.

'T'he question presented hy this ase is one that has never heretofore come hetore this rourt. It will be noticer] that the complaint does not charge the defendant with any bad faith or neglect of duty in indorsing and putting in rirculation the forged check, and we must therefore assume that tho defendant indorsed, and caused the check to he presented for payment in good faith in the mistaken belief that it was uemune. 'The plaintifl upon whom the check was drawn, accepted and paid the cherk under the same mistaken belief that the drawer's signature was genuine. If we had not read the numerous cases which have been cited dealing with this question, we would have thought the proposition was a very plain one, readily solved by the application of fundamental principles of law and common sense. The defendant had receised from the plaintiff without consideration a sum of money which it was not rightfully entitled to, and the sole moving clause which indured the exchange of money for the spurious check was the mutual mistake of the parties to the transaction with respect to the genuineness of the writing. In the absence of any showing that the defendant had heen misled or prejudiced by the plaintiff's mistake so as to render it inequitable to compel repayment, the defendant ought to refund the money had and received. Unfortunately, however, this just and simple solution of what seems to us a plain proposition, has not generally prevailed. A number of courts have laid down the nnqualified rule that where the drawee of a check to which the name of the drawer has heen forgerl, pays it to a bona fide holder, he is bound hy the act, and cannot recover the payment. National Park Bank: v. Ninth National Bank, 46 N. Y. 7\%.

s l'This case was rejorted herein in the first edition of this work with the following note: ]

In the ease of a bill pavable to lrawer's order the acceptor admits the capacity of the drawer to liraw and to indorse; he admits the genuineness of the signature as drawer. but it seems not the genuineness of the signature as indorspr. Sraithuate v. Gardiner, 8 Q. 13. 473; Smith v. Marsark, 6 C. I3. 4S6, 18 I. .J. C. I'. 65; IIalifax v. I,yle, 3 Exch. 446; Becman v. Wurk, It M. \& IV. 25]; Farland v. Jacomb, J. R. 8 Exch. 216. See Bills of Fxchange Act, \$54, subsec. 2(b). In like manner he admits the authority of an agent to draw, but not his authority to inlorse. Robinson v. Yarrow, 7 Taunt. 455.

The acceptor done not admit the conuineness of the body of the bill. Hence if it has been raised lie is not bound on his acceptance, and if he has paid a 
The reason generally assigned to justify the adoption of this rule is stated in Germania Bank v. Boutell, 60 Minn. 189, as follows: "The money of the commereial world is no longer coin. The exchanges of commerce are now made ahmost entirely by means of drafts and checks. It was largely in deference to this fact that the recovery of money paid on paper of this kind to which the drawer's signature was forged, was made an exeeption to the general rule as to the recovery of money paid under a mistake of fact. In viow of the use of this elass of paper as money, it was considered that public jolicy required that as hetween the drawee and good-faith holders, the drawee bank shonld be deemed the place of final settlement, where all prior mistakes and forgeries shonld be eorreeted and settled once for all, and if not then corrected, payment shonld he treated as final; that there must be a fixed and definite time and place to adjust and end these things as to innocent holders; and that time and place should be the paying hank and the late of payment and that if not done then, the failure to (Jo so must he deemed the constronetive fault of the payee bank, which must take the consequences." Acording to this line of cases the whole duty and risk of determining the genuineness of a draft or eheck rests upon the drawee, and as Lord Mansfield is reported to have said in Price v. Neal, : Burr. 135t, the holder "need not in:puire into it," provided he acquired the paper for value in good faith. Bank of St. Albans v. Farmers' d. Mechanics" Bank, 10 Vt. 141; Neal v. Colum, 92 Me. 139; Deposit Baml. v. Fayelle National Bant, 90 Ky. 10: Rernheimer v. Marshall. : Minn. 78 (Gil. 61). Of this extreme vinw it is woll said in 2 Morse on Banking (4th El.) \$ lfi: "This doctrine is fast fading into the

raised bill or chesk, he may recower the money. Marine $N$. li. v. Vat. city

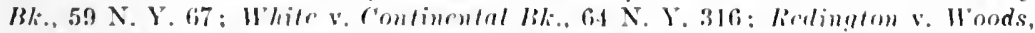

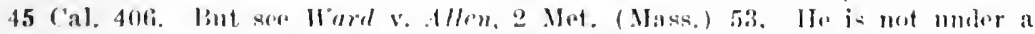
duty to take presuntions againet sulsespuent frambulent alterations: it is the Irawer who has control over its form. Scholfichl v. lomdesborongh, ls? A. C. $514 .-$ II.

- In anotler part of this case Mrerretr., J.. said: "From what examination we have lowen alse to make of the anthoritios, we latwe arrivel at the con-

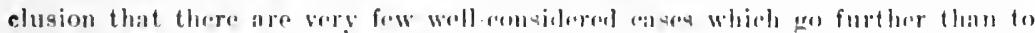
hold that the hank may jerenere latek momey paid on a check fo which the

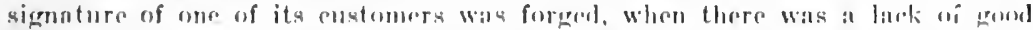

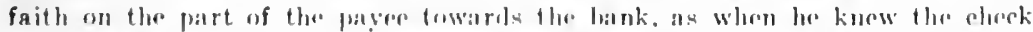

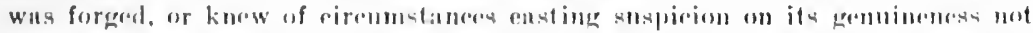
known to the bank, sul which he diol not pommonicate to it, or where the

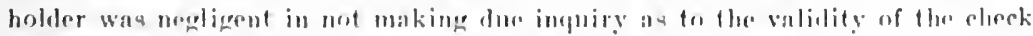
hefore he took it, and the drawere, having a right to foresume that lac latal male such inguiry, was itself therely exoused from making inpuiry befure pay ing it. In the first case the holdar is reslly at party to tlor frambl, and is not a gromel

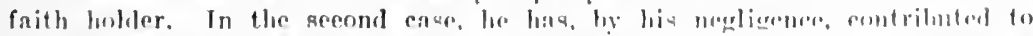
the ennalummation of the miatake on the part of the drawere by misloading him." lio Minn., at p. 134.-C. 
misty past, where it belongs. It is almost dead, the funeral notices are ready, and no tears will be shed, for it is founded in misconception of the fundamental principles of law and conmon sense."

Most of the courts now arree that one who purchases a check or draft is bound to satisfy himself that the paper is gemuine; and that by indorsing it or presenting it for payment or putting it into circulation before presentation he impliedly asserts that he has performed this duty. Consequently it is held that if it appears that he has neglected this duty, the drawee, who has, without actual negligence on his part, paid the forged demand, may recover the money paid from such negligent purchaser. The recovery is permitted in such cases, because, although the drawee was constructively negligent in failing to detect the forgery, yet if the purchaser had performed his duty, the forgery would, in all probability, bave been detected and the fraud defeated. Gloucester Bank v. Salem Bank, 17 Mass. 33; Bank of $U$. S. v. Bank of Georgia, 10 Wheat. 333; National Bank of America v. Bangs, 106 Mass. 441; First National Bank of Danvers v. First National Bank of Salem, 151 Mass. 2S0; First National Bank v. Richer, $\% 1$ Ill. 439 ; Rouvant v. Bank, 63 'Tex. 610; Bank v. Bank, 30 Md. 11; People's Banh v. Franklyn Bank, 88 'Tenn. 299; Ellis \& Morton v. Trust Co., 4 Ohio St. 628; Bank v. Bank, 58 Ohio St. 207 ; Bank v. Bank, 22 Neb. 769; Canadian Bank v. Bingham, 30 Wash. 484. While all these anthorities agree that negligence on the part of the purchaser in taking a forged check subjects him to liability for the loss, they are not in accord as to what constitutes such negligence. 'These authorities, it seems to us, have had the effect of substituting uncertainty and confusion for a rule which, although manifestly arbitrary and unjust, had at least the merit of simplicity and clearness. It must be conceded that the majority of the courts that have passed on the question are committed to the doctrine that the drawee who has paid a spurious check can recover the payment from a good-faith holder only when the latter has been negligent. If the law of this state is to be determined by the mere weight of authority alone, as evidenced by the decisions in other states, then we should be constrained to hold that this complaint shows no liability on defendant's part, because it does not show that the defendant has been in any degree negligent.

IIowever valuable the decisions of courts in other jurisdictions may be as guides to aid us in coming to a correct decision, it camnot be admitted that such decisions, however numerous and uniform, conclusively establish the law for this jurisdiction. They are, after all, only arguments in support of the views entertained by the judges who uttered them. Unless the doctrines advocated hy them have become part of the law of this state by the adoption of them by positive law or general usage and opinion, they must he received and considered by us merely as arguments to be weighed, and adopted or rejected 
according as we deem them sound or unsound. If, in our opinion, a doctrine advocated by the courts of other states is an unwarranted departure from the fundamental principles of law, it is our duty to reject it, unless the rule so advocated, even though fundamentally erroneous, has become part of our common law by general usage and custom; or has been expressly or impliedly made part of our law by statute. There has been no statutory adoption of such a rule, and we have no hesitation in saying that there is no general usage or custom prevailing in this state that the checks and drafts of individuals shall circulate, and he treated and dealt with as bank or government currency. Yet, as indicated by the langnage quoted from the Minnesota decision (Germania Bank v. Boutell, supra), the rule that the drawee must, save in exceptional cases, bear the consequnences of his mistake in honoring a spurious check, was adopted in deference to such a supposed usage. The fact that the cases advocating this doctrine all cite as authority Bank of U.S. v. Bank of Georgia, 10 Wheat. 333, and Gloucester Bank v. Salem Bank, 17 Mass. 33, which involve forged bank notes, shows that the rule rests on the assumption that the checks and drafts of individuals are to be placed in the same elass with bank bilis which are issued and intended to circulate as money. There is no statute or business usage in this state to warrant that assumption. The decisions which adzocate the rule that a drawee may recoser in alse of nocrligence on the part of the holder who presents and recrives pilyment of a spurious elseck, all recognize the fallacy of those lonisions which apply the same rule to checks and drafts as is n! inalik to hank notes which cireulate as money. Yet, strange to $:$ : (inly all of them expressly or impliedly accept as true the frow it an t'al a drawee of a check or draft should be excepted from the wation of that fondamental rule which permits one

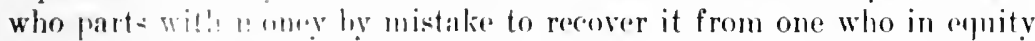

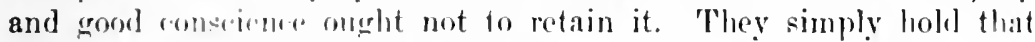
this exception stomld not apply in alses where the purchaser or in-

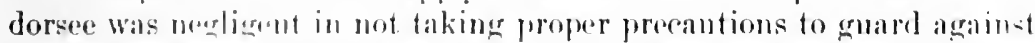
forgery. It is wident at a glane that this proposition, which these cases thus ancrpt as proper, has no other fomulation than the same premise which they wery properly hold to he fallacions - namely, that checks ald diafts on lanks or individuals shomld be governed hy the same rulus as alply to hank motes which cireulate as money. If it is

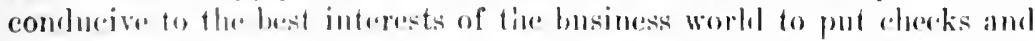
drafts on the salle foreting as bank currency, and if it would tond to make chackis and drafts a more safo and convenient cireulating medinm of exchange, to shift the whole risk of loss log forgery upon the drawee insteacl of ledting it rest upon those who are credulous enough to assume the risks of partine with value for such paper, the

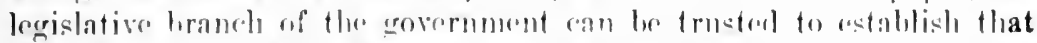
rule, if such a radical departure from fundamental principles of law is deemed wise. The court has no power to do so. 
Being comvinced, as we are, that this doctrine adroeated by the great majority of the eases which have come to our attention, to the edrect that a drawee of a clacek shomld be axcepted from the ordinary rules relating to the right to recover money pald by mistake, is musound and has never been adopitod in this slate hy usage or statnte, it would be nothing less than msurpation of legrislative power by this coupt to declare that rule to he the law of this state hecause courts in other states have so held. 'l'hat the rule in question is mosonnd in principle and unjust, is almost universally almilled, and fle courts are showing an increasing tembeney to discalel it. We think, therefore; that we are slowing no dispespoet to presolent in taking the stand towards which the modern decisions are mmistakably tending, and from which it is arenclally comeoded there should have never been any departure. We, therelore, reject as unsomed the doctrine that a drawee of a check slould be exiepted from the grenemal rule in relation to the recovery of money paid by mistake. 'The drawee is presmued to know the signature of the dribere of the check or araft; and the holder of streh rherk or draft who has acpuired it in good faith has the risht to aret in relianer on that presumption, povided he himself has omitted no duty, the performane of which would have prevented the success of the fraud. Conseruently, if the drawee pronounces the cherk gemnine by paving if or otherwise honoring it, the holder who lus actud in good faith and without negligence, may safely rely upon the judgrment of the drawer, and art areolingly. The drawee cammot, under sureh reireumstances, recall his aceptance or payment to the detriment of the party who has rightfully relied upon his decision. In such a case the party who reoved the money has the superior equity, and hr may jusily rotain the money although he was not originally entitlen to resoive it.

But, as is msully the ase. when the party who has collected the eheck had provionsly ashed it or taken it in exchange for commodities, there is no lesson why he shomlul not rofund. Every one with even the least experionere in liminess know's that no business man would accept a roherek in exrhanere for momer or eroosls unless he is satisfied that the

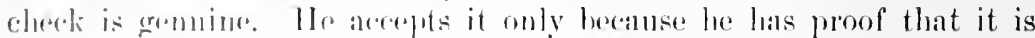

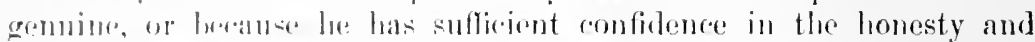
financial resumsthility of the preson who vomeles for it. If he is deroiverl he las sufforoul a boss of his asth or groods through his own mistake. His own arednlity or reklessness, of misplaced confidence was the sole ramse of the loss. Why should he be permitted to shift the loss due to his own fanlt in assming the risk, upon the drawee, simply hreanse of the areidrontal riremmstance that the drawee after-

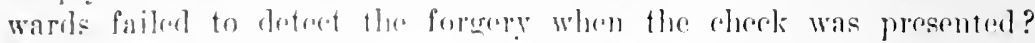
Our viows find much smppert in many of the cose which still cling

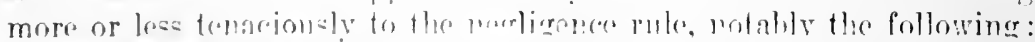
Bank v. Bank, 151 Mass. 'sos; E'llis of . Worton v. Trust Co., 4 Ohio St. 
628 ; Bank v. Bank, 88 Tenn. 299; Bank v. Bingham, 30 Wash. 484 ; Bank v. Bank, 22 Neb. 769; Bank v. Bank, 4 Ind. App. 355. The case of McKleroy \& Bradford v. Southern Bank, 14 La. Ann. 158, 74 Am. Dee. 438 , directly supports our views, and we are gratified to note that our riews are in aceord with those generally adrocated by the text-writers. We, therefore, hold that drawees of cloecks and drafts are not to he excepted from the general rule which permits the recovery of money paid by mistake. We hold that a drawee who loas by mistake paid a spurious check or draft may recorer the money paid unless the party receiving the money has heen mislod to his prejudice by the drawee's mistake. If any such facts exist, they are best known to the defendant, and it is his duty to prove them. The complaint discloses prima facie eause of action by alleging the payment by mistake.

The order appealed from must be reversed, and the demurrer overruled. All coneur. ${ }^{1}$

\section{$\$ 112$ STATE BANK OF CHICAGO $v$. FIRST NATIONAL BANK OF OMAIIA.}

127 Nortw esthri (Nebraska) 244. - 1910.

Root, J. 'This is an andion ly the drawce of a forged draft to recover from a holder thereof money paid to satisfy that instrument. The plaintiff prevailed upon the defendant's demurer to the petition. The defendint apperils.

The plaintill allewes in it: putition that the defendant, throngh its agent, the Contincontal Sational Bank of ('hicago, on November 89,

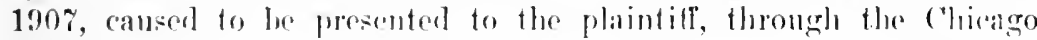
Clearing House, a certain traft of which the following is a coly": $\$ \$ 00$.

THE GERMAN IBANK. io. $9,0,39$ lin век.1, Soutu Dakota, Non, 223, 1907.

Pay to the order of (has. Viterna, sto0.00, eight humlred ...... dollars.

To the State lank of ("licang), ('hican's, Ill. li. Moog, A. Cashior.

The instrument was indorsed: "Clats. Vitorna. Pay fo the order of continental National liank, ("hicagon, Ill., First National Bank,

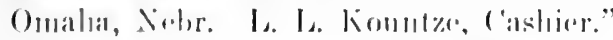

The plaintill fortlere allewes that, helieving the instrument to be

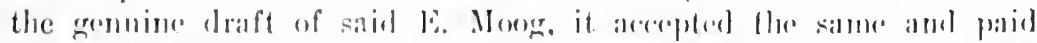
it to the defondant through the (ontionental National lank: "that

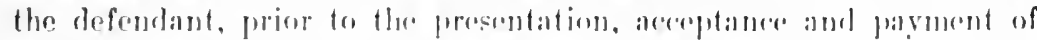

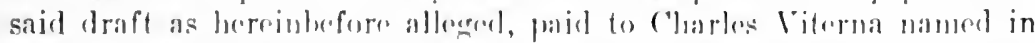
said draft as payee, kuowing him to he said Viterma, cight humbled

This ease is reportod in 10 L. $\mathcal{X}$. S. 49. with axhanstive note entilled "Right of drawer of forged chere or draft to recover money paid thereon."- (. 
dollars $(\$ s 00)$, the amonnt named in said draft, without any knowledge or information as to whether said draft would be aceepted or paid by the plaintitf, and withont taking any steps to ascertain whether or not said draft was a genmine ilraft of the above-named E. Moog, assistant eashier of the German Bank of Wureka, South Dakota." The plaintiff also alleges the draft was forged, but its true character did not hecome known until December 12, 190\%. Immediately thereafter the plaintiff advised the defendant of said fact and demanded repayment of the $\$ 800$, which demand was refused. Counsel for the respective litigants stated at the bar that the negotiable instruments statute does not control this case, and we shall treat their statement as correct for the purposes of this case."

2 But see Nafional Bank of Rolla v. First National Bank of Salem, 125 Southwe-tern (Springtield ('t. App., Mo.) 513. At page 5l6, Gray, J., said:

"From a review of these authorities, we are satisfied that leaving out of view our Negotiable Instrument Act of 1905 (Laws 1905, p. 243 [Ann. St. 1906 , $\$ \$ 463-1$ to $4633-197])$, the great weight of the modern cases sustains the theory that the payee [drawee?] cannot recover from the purchaser without hasing his action upon the negligence of the latter. In Germania Bank v. Boutell, supra, the demurrer to the petition was sustained because there was no allegation of negligence on the part of the defendant.

"In addition to the anthorities, the Negotiable Instrument Act of 1905 contains the followiag sections:

"'Section 62. [N. Y., \$ 112.] The acceptor, by accepting the instrument engages that he will pay it according to the tenor of its acceptanec; and armits: The existence of the drawer, the genuineness of his signature, and his capacity and authority to draw the instrument; and the existence of the payee and his rapacity to indorse.'

"Section 188. [N. Y., \&324.] Where the holder of a check procures it to be accepted or certified, the drawer and all indorsers are discharged from liability thereon.'

"Juige Prosoncs, in Bank v. Bank, 109 Mo. App. 665, supra, in answer to the argument that absolute payment was not an acceptance, said: 'An acceptance binds the acceptor to pay the bill, and he cannot be heard to deny that he has funds in his hands for the purpose. A payment of the bill is more than an acceptance, for the one is an obligation to pay the other a discharge of the indebtednes represented by sueh bill. If the one concludes the drawee it is inernceivable why the other would not.' We fully concur in the views of Judge Broaddus, as quoted above. If a mere promise to pay a check is binding on the bank, why should the absolute payment of the check not have the same affect? The arloption in this and other states of our Negotiable Instrument Law was for the purpose of having in the statutory laws of the states a uniform law in regarl to commereial paper. A confusion was known to exist on many of the everyday transactions coneerning such paper, and it may be sairl that there was no question upon which the courts were more in conflict than upon the question involvers in this ease. After a careful examination of the new law. we are inelinel to beliese that it was intended to adopt the law as leclared in I'rice v. Neal, supra."

Followed in Sational Bank of 'ommerce v. Mechanics' Am. Nat. Bank, 127 Somthwestern (St. Lonis (t. App., Mo.) 429.

These two cases are criticised in 70 Central Law Journal (June 10, 1910) 117-418 
1. The great weight of authority sustains the proposition that as between the drawee and a good faith holder of a draft, the drawee bank is to be deemed the place of final settlement, where all prior mistakes and forgeries shall be correeted and settled once for all; and if not noticed and payment is made, the money cannot be recovered back. Price v. Neal, 3 Burrows, 1355. Germania Bank v. Bmutell. 60 Minn. 189. The eases are annotated in a note to First National Bank v. Bank of Wyndmere, 15 N. D. 299, 10 I. R. A. (N. S.) 49, $125 \mathrm{Am}$. St. Rep. 588 「reported herein at p. 403.〕 Courts and textwriters generally recognize that the preponderance of authority is in favor of the rule, but it seems to conflict witl a well-established principle of law that money paid by mistake may be recovered back, and has not been accepted withont qualifieation by all of the American courts. North Dakota refuses to follow Price v. Neal, supra, and has held that the principles of equity should control a transaction

The court in Nal. Bank of Rolla v. First Nat. Bank of Salem, supra, stated that "In support of our views, we are sustained by the late case of Title Guarantee \& Trust Co. v. Ilaven, 126 App. Div. (N. Y.) S02." While this latter case was reversed in $196 \mathrm{~N}$. Y. 487, nevertlieless the $\mathrm{N}$. Y. Court of Appeals, in a dictum, also expressed the opinion that section 112 of the $\mathrm{N}$. Y. Negotiable Instruments Law codified the rule enunciated in Price v. Neal. WilLARD BartLETT, J., at p. 492, said:

"Both the referec and the judge who wrote the prevailing opinion below thought that the case was entrollol ly section 112 of the Negotiahle Instru. ments Law which proviles that the aeceptor of a negotiable instrument admits 'the existence of a drawer, the genuineness of his siguature, and his capacity and authority to draw the instrument.' This enactment is merely declaratory' of the common law. The leading English case in which it is entunciated is Price v. Neal (3 Burrow, 1354), decided by Lord Mavsfifin in 1762. The leading Now York case to the same effect is National Park Bank v. Ninth National Bank $(46 \mathrm{j}$ N. Y. 77). But the doctrine of these decisions, now fount in the rule formulated ly section 112 of the Negotiable Instruments Law. applies only in favor of one who is a lolder for value of the inctrument which turns out to have bren forered. Thus, Iord Maxsfiben in Prier v. Nral (supra) dwelt upon the fact that the bill of exehange there in question had been indorsed to the defondant 'for a fair and valuable consideralion which he had bona frof paid:' and in the leading New York case ( Notional l'ark Bank v. Ninth National Bank, supral it appeared that the draft had leen discounterl by the Livingston National lank and indorsed to the defendant which was a bona fide holder. 'The rule, therefore. that he who acerepts a negotiable. instrunent fo whicle the drawer's name is forged is hound he the act and ears neither repurdiate the aeeptanes mor recover the money paicl, has no applieation in twhalf of owe who has aepuired the paper in the absence of any eon. sideration whatever therefor either present or past. Such was the ease here according to the finding of the referen. So far na apuears, the cherk of the Green estafe, which proverd to be forgerl. was not given in payment of any exiating or anteredent indebtednesa rither on the part of that ratate or ever of the forger. For these reasons we agree with the learnerl judge who wrote: for the minority in the Appellate Division, saying: 'Sretion 112 of the Negotiable Instruments Law upon which the referee based his decision has nothing to do with the question." '-C. 
hetween the drawee and a holder of a forged eheek or draft. First

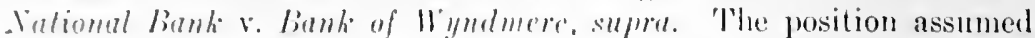
hy Sorth Dakota is in harmony with sugresestions made by many textwriters but, so lat as we are aceved, is not sustained by the opinion of any other eont. Intermediate the cases allhering to the ancient

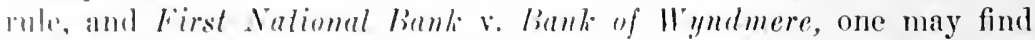
abes pualifying the broal rule promulgated in l'rice v. Neal, supra.

The Massachusetts supreme court holds that the failure of the drawer to deteet the forerery at the time the draft is presented and baid will not predude it from recovering the money from a holder "who took the rheok under circumstances of suspicion without proper precaution, or whose comburt has heen such as to mislead the drawee or induce him to pay the rheck withont the usual security against fraud." Janvers Baml: v. Salem. Bank, 151 Mass. 280, 283. In the cofted case the cashing hank recoived a check from an unknown person bavale to bearer and wibhont requiring him to identify bimself, although there was a loal enstom requiring identification in sueh (ases. It was held that the negligence of the cashing bank lulled the drawee into a false sense of security, and the latter could recorer back the money pail. In Sational lianle of North America v. Bangs, 106 Ifass. $111,+11$, the court lokls the drawee should be permitted to revover if the party reseiving the money in any manner contributed to the sureess of the fraud, or to the mistake of fact under which the parment was marle.

'The plaintilf relies upon our decision in First National Bank of Orleans y. Slale Bank of Alma, 22 Noh. 769. That ease was decided upon a statement of facts to the effect that B. R. Claypool maintained a loposit in ean of said banks. A stranger presented to the Orloans lank a check upon the Alma bank bearing the name of claypool as drawer, and payable to A. J. Gype, or bearer. The ()rloans rashieg rompared the signature to the check with Claypool's Emmine signature mon the bink's book and without requiring the holfor to idcutify himself of to aceount for the manner in which he sormpol posesing of the rheck. pail it. In due course, through a hank whroin the litionnts ench maintaned a leposit, the check was paid and rialurerl to the areomint of the Alma hank and later was deliveruel to clayponl, who denomnerl the instrument as a forgery. We held that the drawere shomld rerover the money paid. Some remarks in the aremmont of our late Chiof Justice, taken apart from the facts in the ease, lend rolor to the plaintifl's argument in the instant one. At the har it was aremed that since the check on the Alma bank was parable to bearer. ilentification of the holder was an immaterial fact, and the entire aremment in the opinion should he considered with rolation to the oldigation of the cashing bank to ascertain at its peril that the eherk was a cemmine instrument. The prineiple underlying the opinion is that the eashing bank was negligent in not availing 
itself of all means at its command to ascertain whether the cheek was genuine. Business men and courts alike recognize that ordinary prudence forbids the purchase of a check from a stranger, regardless of whether the paper was payable to order or bearer. 'The instrument considered in the Alma ease was an ordinary check not desinned for circulation but for immediate presentment. First Tationul Bank of Wymore r. Miller, 3r Neb. 500. As stated by Judge Maxwell, the Alma bank did not know but that Claypool had been present when the check was presented by the holder to the Orleans bank. and had the cashing bank marle inquiries coneerning the identity of the boller or the manner in which le became possessed of the instrument. the probabilities are that he would not have withstood the ordeal, lint the fraud would have been discovered. In Germania Banli v. Bontell, supra, the duty of the eashing hank to require the holder to identify himself is recognized. The rule stated in the Orleans case has been adopted in Massachusetts. in People's Bank v. Frantlin Bant, 88 Tenn. 299: Canadian Banli of Commere v. Bingham. 30 Wash. 484, and has heen recognimerl in First National Bank of Marshalltown v. Marshalltown S'tate Banli, 10\% Iowa, 327.

In Ellis v. Ohio. I. I. \& T. ('o., t Ohio St. 698, 6+ Am. Dee. 610, a local custom obtained among the banks of Cincinnati repuiring the cashing bank, before purdusing a check presented by a stranger and drawn upon another bank, to make careful inquiry concerning his identity and to ascertain whether the paper was genuine and the holder was the owner thereof. 'The opinion turus upon the holler's negligence in faling to comply with this local custom.

In the case at hatr, Viterma was payee of the forged draft and was known to the defondant at the time it purchaserd the bill. The draft purports to be a forreign liell of exchanere, an instrument that for many purposes is intended to reverolate as momery for a limited period of time; the forerery consistonl in forerine the batme of the drawer and not in raising the amount of a eremuine hill. and the drawer maintains its

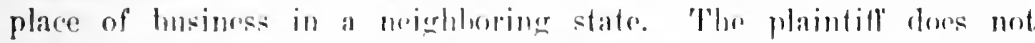

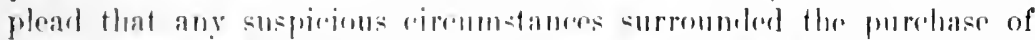

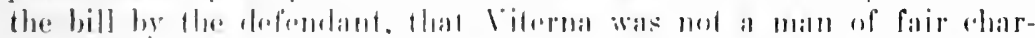
acter or so situated that the puseseson and presentation be him of a

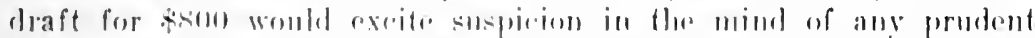
banker. one dewes the plaintifl where that at any lime prior fo the

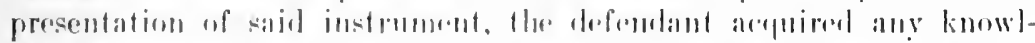

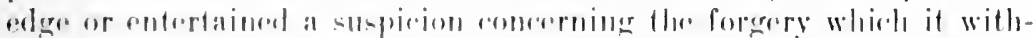

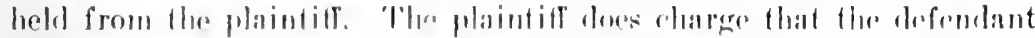
did not take any stepe to aserertain whether the draft was genulue or

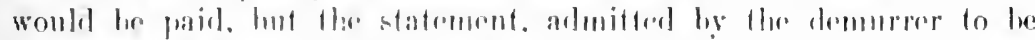

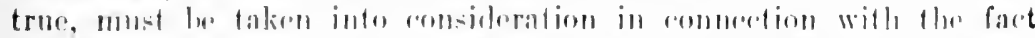

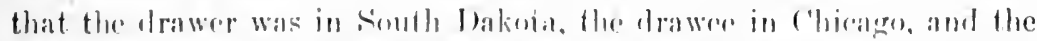
payee was known to the defondant, a resident of Neldaskas. It is not 
plealed that there was an agreement between the litigants that drafts drawn on each other should not be asshed if presented for sale by a payee known to the cashing hank, unless it first made infuiry concerning the instrument, or that any such enstom obtained in Omaha or Chicago, or that the defenlant had any means at hand whereby it could have ascertained the genuineness of Moog's signature. In fact, so skillfully was that signature forged that it deeeived the drawee so that had Viterna been acquainted with the paying teller or other employe or officer charged by the plaintiff with the duty of identifying simnatures to its enstomers' drafts, it is more than probable that it would have cashed the lraft if the payee had presented the instrument for payment.

In the Orleans ease the eashing bank had the drawer's genuine signature to compare with the name attached to the check, and it also had the power to demand that the holder should identify himself; it arailet itself of but one safeguard against fraud and we are entirely satisfied with our opinion holding that under the circumstances the Orleans bank was guilty of negligence. But in the ease at bar it is not alleged that the defendant had any means other than the identity of the payee to prove the genuineness of the draft. Until the legislature shall provide that a bank is guilty of negligence in purchasing a foreign draft, fair on its face, from a known payee, unless it first communicates with the drawer and the drawee to learn whether the draft is genuine, we do not feel justified in extending the rule announeed in the Orleans case, supra. Drafts aggregating many billions of dollars in value have heen issued, negotiated, accepted, and paid by merchants and hankers in reliance upon the rule announced in Price v. Neal, supra, and to the general satisfaction of the commercial world. So far as we are advised, in but one state of the Union, Pennsylrania, has the legislature morlified that rule. ${ }^{3}$ Merchants and bankers in the great centers of the English speaking world, have not mover the legislatures to morlify this prineiple of the law merchant, and the courts should hesitate hefore substituting the philosophy of logicians for a practical rule evolved from the necessities of eommerce.

The plaintitf also cites First National Bank of Crawfordsville v. Indiana Sational Bank, 4 Int. App. 355, but it should not be seriously considered as an authority in the case at bal beeanse it refers to a forged school order which the learned judge writing that opinion states, at page 36.3 of 1 Ind. App.. is not negotiable according to the law merchant. The court also holds the indorsement "for collection" by the holder of the order tended to divert scrutiny by the drawee of the drawer's signature, because such an indorsement would indicate the instrument was not rirrulating as negotiable paper.

3 For the terms of this statute and the construction placed upon it by the Pennsylvania courts, sec Iron City Nat. Bank v. Fort Pitt Nat. Bank, 159 $\mathrm{Pa}, 46,-\mathrm{C}$. 
The plaintifi further cites First National Bank of Chicago v. Northwestern, $N$. B. of C., 40 Ill. App. 640. This case was appealed to the Supreme Court of that state and is reported in 152 Ill. 296. In that case checks purporting to have been drawn by the Central Union 'Telephone Company upon the Northwestern National Bank of Chicago, payable in four instances to "F. P. Ross, Manager" and in one case to "C. H. Wilson, A. G. Supt." were received by the First National Bank through the clearing house. The proof established that the payees were employes of the telephone company but were not entitled to the checks, knew nothing about them, and their indorsements, as well as the signature of the drawer, had been forged. The court holds that while the drawee by paying a draft is estopped from thereafter denying the drawer's signature, it does not warrant the signature of any indorser, but the indorser warrants the genuineness of all preceding indorsements: that the parties stood as though the bills were genuine but the indorsements of the payees forged, and the drawee for that reason could recover the money paid by it to the holder of the paper. The opinion is sound but has no application to the instant case, because there were no forged indorsements upon the bill in question.

Ford v. People's Bank, 74 S. C. 180 , is cited by the plaintiff. In that case the plaintiff's drawee paid a forged draft and charged in his petition to recover back the money: "That the plaintiffs paid the said draft upon presentation, upon the faith and credit of the indorsement of the said defendant." A general demurrer to the petition was sustained and the Supreme Court of that state holds that a general indorsement of a forged bill by the holder therenf is a representation that the drawer's signature is genuine upon which the drawee may rely, and, in ease the instrument is forged, may recover back money paid the holder. ${ }^{4}$ The opinion is against the weight of

In the case just referred to, JONEs, J., at p. 184, said: "The question whether the demurer was properly sustained depends upon the meaning to be attached to the alleged pensentation and indorsement of the draft hy the defendant. Does susch presentation and indorsement to the drawe represent that the signature of the Irawer is genuine, or cloes it merely represent that the instrument is genuine as it purports to be in all respects, except as to the signature of the (lrawer, which the drawee is presumed to know? Mr. Manicl. in his work on negotial, instruments, takes the riew that an indorse. efent engages that the hill or note is fenuine. Volume 1. \$s 672. 673; volume 2 , \$1361. The caas of Germanin Bank $v$. Boutell, Go Minn. 189, takes the viow that an indorsement by a bolder other than the original payee constitutes no representation or guarantere to the drawe that the signature of the drower is genuine, but we think that the wright of reason nnd authority is against that view, at least to the extent that an unrestrieted indorsement is ealeulable to mislead the drawee into a helief that the paper was what it purportecl to lie. People's Bank v. Franklin Bank, 88 Tenn. 299!: Bank of llanlers r. liank of Salem, 15l Mase. 280: First lational Bank v. First National Bank, 4 lnd. App. 355: Wonds of Malonc v. Colony Bank. 114 (ia. 683. 'The :ase of National 
authority and is not supported hy any of the cases cited by that court

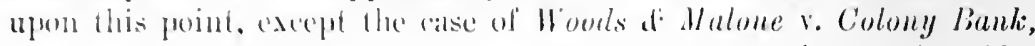
111 Gat. lisi, and the opinion filed in the latst-mamed ease ciles $\mathrm{Na}$ lional buteli r. Jiengs, supre, in support of the principle announced by

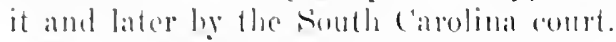

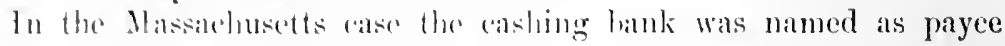

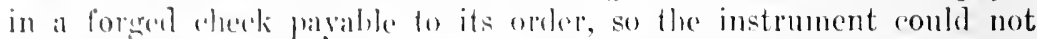
herome anrent exeret by the hank's indorsement. The romet holds that the bayee was negligent in taking the cherk from a stranger whthout proul of his illoutity, and hy indorsing the check, save it curreney and stamling. In the Genreria ease the draft was payable to harer. and thr opinion is somml. hased njon the negligenee of the rashing hank in not repuinger the party from whom it purehased the motrmment to identify himself, hut so far as it holels upon the reported fares, that the julorsement ly the holeler was a warranty to the drawe that the drawer's siernature was eremune, it is unsomnel in

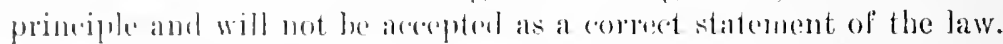

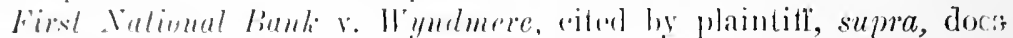
sustain its arenutent, But we ale of opinion that the Orleans case,

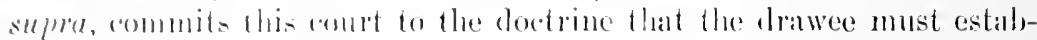
list, the atsing hank"s negligence, or bad latith, to justily a recovery. since the llatree shombl only recover in this suit in ase the cashing

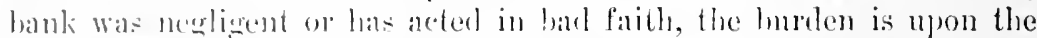
former (1) plead surh newligene or mala fides. The pleader in the

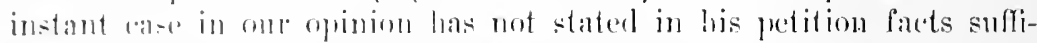
(jont to estalylish that the dofendant was negligent, of that it areded in bad faith in purehasing from Viternat the forged duaft in question.

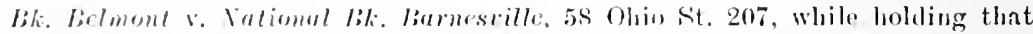

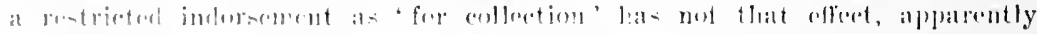

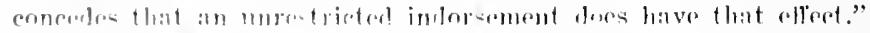

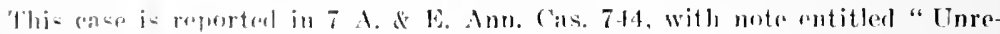

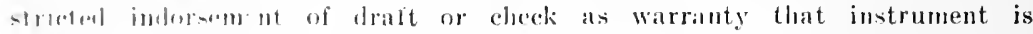

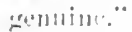

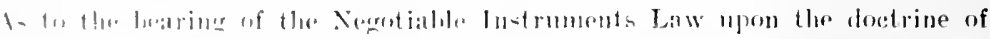

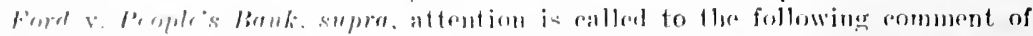

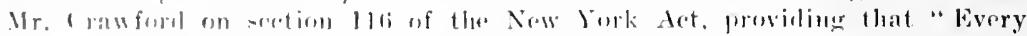

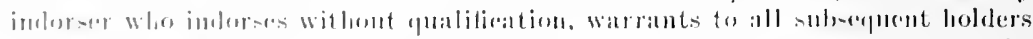

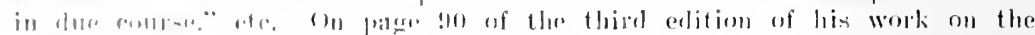

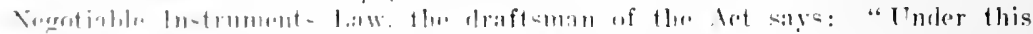

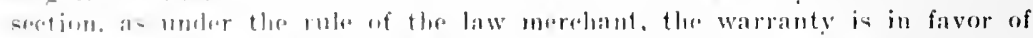
suldseruent holelers anly. and simer the aloption of the statute, as well as

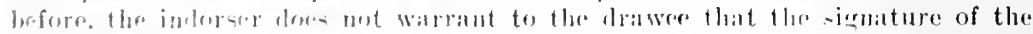

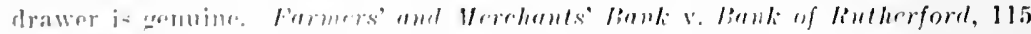
Tonn. 6;. 711-71. '1lus, if a rhoek purpurtime to be drawn ly A. slyould be

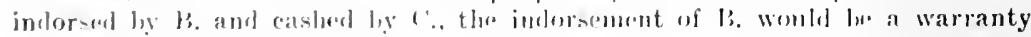

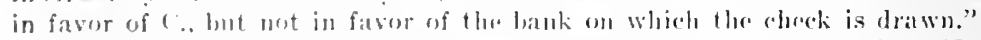

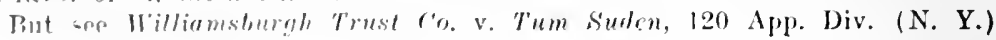

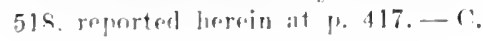


The judgment of the District Court, therefore, is reversed, and the cause remanded for further proceedings. ${ }^{5}$

\section{\$112 WILLIAMSBURGH TRUST COMPANY $\imath$.TUM SUDEN. 120 Appellate Divisiox (New York) 518. - 1907.}

Appeas by the plaintiff, the Williamshurgli Trust Companr, from a judgment of the Municipal Court of the city of New York, horough of Brooklyn, in favor of the defendant, rendered on the 10th day of January, $190 \%$.

WOODWARD, J.:

This is an artion to recover money paid by mistake - the amount of four certain checks payalle to bearer which were forgeries, purporting to he siguen by L. F. Raud and inflorsed ly Peter R. 'Tum suden. Thr rherks with 'T'um Suden's single and munalified indorsement were presented and paid to him by the plaintift. It was show at the trial that 'T'um Suden had heen in the habit of cashing checks for Ranu, and that the forgend rhecks were coslsed. in part. for a maid servant in the rmploy of Rand, the other part of their face value being retained ly 'T'un suden for groceries previously tumished to Rand. As the cherts were negotiable without indorsement, it is evident that 'T"um Suden's indorsement would divert the trust rompany from that rareful scruting which otherwise it would have been likely to give them. It was 'Tum sumlen who negotiated the checks

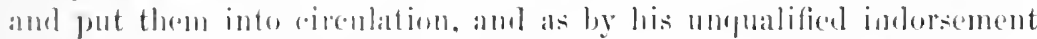
he far.jitated the forgery his perition is mot that of an indorse who holds a forged rederek sametioned by a prior indorsement.

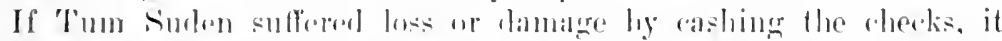

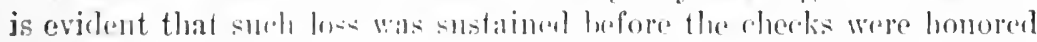

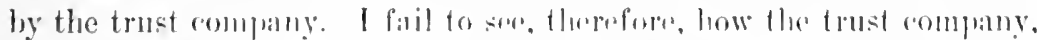

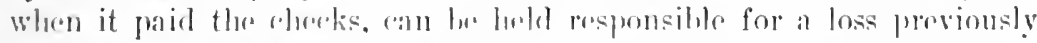
sustained. As there is ne prowf that the mistake of the fruse combany has beren to the projudion of the respondent, it is but right that

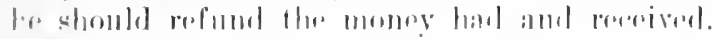

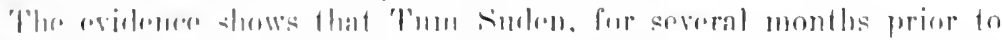

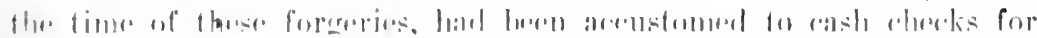

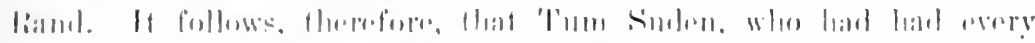

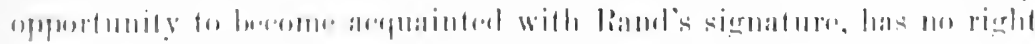

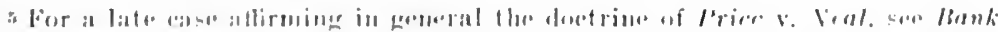

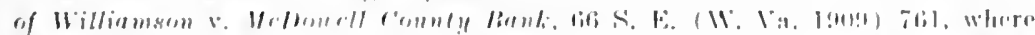

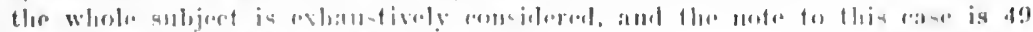

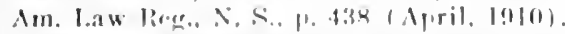

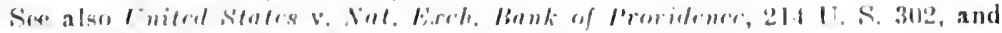

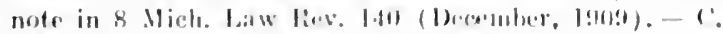


to shift the loss resulting from his own faull, b.ersight or negligenee, upon another. On the other hand, it was but natural for the bank to assume that Tum Suden's indorsement warranted the genuineness of the signature. It was 'Tum Suden who had the first contact with the forger, and who first failed to detect the forgery, and upon him, therefore, must fall the burden of loss. From the foregoing it will appear that the ease at bar presents an interesting exception to the ease of Price v. Neal (3 Burr. 1354), which ruled that the bank must bear the loss when it pays a eheek to which the drawer's name is forged. Such exceptions, however, have long ceased to be unusual.

In National Bank, etc., v. Bangs (106 Mass. 4.1) the court said: "We are aware of no case in which the principle that the drawee is bound to know the signature of the drawer of a bill or eheek, which he undertakes to pay, has been held to be decisive in favor of a payee of a forged bill or check to which he has himself griven eredit by his indorsement." The same principle should be applied here. Upon the first indorser is the burden of the first precaution, and his negligence or omission will exonerate, as in the present instance, the bank. Had a third party presented the check, already in circulation, for payment, the bank would have been put upon inquiry, and for any negligence in that case it would have been responsible.

In First Mational Bank of Danvers v. First National Bank of Salem (151 Mass. 281) the court uttered a principle of construction which justifies my view: "The indorsement, which was not necessary to the transfer of the check, was a guaranty of the signature of the drawer, and the plaintiff had a right to believe that the indorser was known to the defendant by proper inquiry."

The judgment should be reversed and a new trial ordered, costs to abide the event.

JENks, Hookler and Rich, JJ., concurred.

Judgment of the Municipal Court reversed and new trial ordered, costs to abide the event. ${ }^{6}$

\title{
III. Drawer: secondary, conditional liability.
}

1. Conditions: Plesentment ; Nónice; Protest.

[SEe ART. VII, VIII, XIII, post.]

2. Admissions as to Payee.

\section{$\S 111$}

\author{
GREY $v$. COOPER.
}

3 Dougias (K. B.) 65. - 1782 .

Actios against drawer hy indorsee. Plea, that the payee-indorser at the time of his indorsement was an infant. Demurrer.

6 See criticism of this case in $47 \mathrm{Am}$. Law Reg., N. S., 122 (February, 1908). See also note 4 , ante, p. 415 . - C. 
Lond Mansfield. - The gromnd on which the drawer is charged is that he drew a bill by which he engaged to pay according to the order of the payee, whoever that payce might be. Ile might give the infant an authority which the law itself does not give him. In the same manner he may give a bill to his own wife. The drawer says, "Let anybody trust the payee on my credit." The arts of an infant are roid or not, accordingly as they are for his benetit. The privilege of an infant is personal, and there is no question here as between the infant and another person. The infant sets up no claim, and the drawer is liable to pay.

Judgment for the plaintiff. ${ }^{7}$

IV. Seller: warranties.

1. Instrument Gexune axd What it Purports to Be. $\S 115$ MEYER $v$. RICHARDS.

163 Uxited States, $385 .-1896$.

Actios to recover back the purchase price of thirteen bonds of the State of Louisiana, payable to bearer, sold by defendant to plaintiff, and afterwards discovered to have been issued without anthority of law and declared by the constitution of the state to be null and roid. The bonds were in the state treasury for cancellation and were fraudulently issued ly the state treasurer, who put them on the market surreptitionsly and without anthority. The signatures and seal were gennine. Julgment for lefendant.

Mr. J'stick WinTe, after stating the ase, delivered the opinion of the court.

We will *** consider the case upon the theory that the only warranty, if any, is one to le implied from the nature of the contract.

It is olvious from the facts just detailed that the thirteen honds which were sold by the defendant in error to the plaintiff in error were at the time of the sale ahsolutely roid. The twolse which originally bolongerl to the two collang funds wore in express torms declared by the constitution of the state to he " mull and roid," and the General Ascrmbly was forbidden to make any provision "for their payment," and they were ondered to he "dostroyed in surh manner as the remeral Assembly may direet." 'This provision of the constitution was in existenere while the honds wore in the hands of the state, and hefore they were framblubutly and surreptitiously sold. Indered, theso bonds were never lawfolly fut into rimlation,

TSee alen Hrazirr v. Masery. 11 Ind. 382, antr, 1. 220; Mr.1fann v. Walker, 31 Colo. 261 ante, p. 401, and notes to those cases. - C. 
Lecanse, having leen originally issuent to rejeresent trust funds belongring to the state, they were helil hy olticers of the state for its account. 'The remaining bond was also void nuder the eonstitution of the state, since it had heen, under fle express terms of that instrument, surrendered to the state treasurer for cancellation and another bond issued in its stead.

'The bonds were undoubtedly sold hy the defendant in error as lawful obligations of the state. Both parties to the contract of sale so considered. 'I'he plealing and the statement of facts leave no question on this suhject. 'The controversy here presented is wholly between the rendor and rendee as to the nature and extent of the obligation of warraty resulting from the sale. We are therefore not concerned with whetlere the defendant at the time of the sale stood in the attituce of a thiml holder of negotiable paper tor value before maturity. Even if he were in such a condition, and at the time of the sale there was a constitutional provision which rendered the bonds void and incapable of enforcencut, it is clcar that the delivery by the vendor to the remlee of homls strichen with constitntional nullity was not the delivery of an existing obligation within the meaning of the contract if it inported a waranty of the existence of the bonds which it covered. 'l'he admission being that both parties contemplated the delivery of valid olligations, honds of that character being ontstanding, if warmenty of rxistence was implied by law, such purpose was not fultillen he the delivery of a mere equity, which one of the parties, the sollor, wams was existing in his behalf. Valid honds, and not the mere chain by the seller to enforce invalid honds, was the object of the contrut. This is especially trme in riew of the fact just referred to, that at the date of the sale the constitution of the state in express terms forbale the enforement of twelve of the bonds, and practically stipulated to the same effect as to the other.

The sale was a Ionisiana contrat. We must consequently determine the rights and obligations of the parties by the law of that state. By the civil law, which prevails in lomisinna, wallanty whilst not of the essenfer, is yel of the nature of the contract of sale, and is, therefore, implicet in every such contract muless there be an express stipulation to the contrary. (Bayon r. Vavessentr, 10 Nartin, 61; Strawbritge r. Warfield, 1 Ionisiana, 20.) The following provisions on the subjoct of warranty are fomm in the louisiana code:

"Thr"sallo" is lomm to two principal ohligations, that of delivery and that of warranting the thing which he sells." (C. C. 2475.) "Although at thr time of the sale no stipulations have heen made respecting the warranty, the sollor is ohligerl, of eourse, to warrant the buver against the ruvition suffered by him from the totality or part of the thing sold and against the charges claimed on such thing which were not reclared at the time of the sale." (C. C. 2501.) "Even in case of stipulation of no warranty, the seller in case of 
eviction is liable to a restitution of the price, unless the buyer was aware, at the time of the sale, of the danger of the eviction, and purchased at his peril and risk.” (C. C. 2505.)

These articles of the Louisiana Civil Code, which do but formulate the principles of the civil law as to warranty, are not wholly in ac zord with the doctrines of the common law. The distinction between the two systems may be briefly summed up by saying that the ors, the civil-law doctrine, finds its expression in the maxim caveat venditor, whilst the rule of the common law is conveyed by the aphorism caveat emplor. It is unnecessary to determine the scope, under the Louisiana law, of the obligation of warranty as to property crenerally, since we are in this case concerned only with its himit when arising from the sale of a credit or other incorporeal right. The code of that state contains express provisions defining the extent of the obligations arising in such case:

" He who sells a credit or an incorporeal right, warrants its existence at the time of the transler, though no warmanty be mentioned in the deed." (C. C. 26t6.) "The seller does not warrant the solvency of the delitor unless he has agreed so to do." 8 (C. C. 26+\%.)

These provisions, instear of causing the obligation of waranty in a sale of an incorporeal right to be broader than in the case of tangible property, on the contrary makes its narrower.

As then, under the law of Iouisiana, the seller under the contract of sale was obliged to warrant the existence of the thing sold, the case of the defendant in error involves the practical contention that a bond which at the time of the sale was declared by the constitution of the state to he nom-existing, is yot for the purposes of the sale to be treated as an existing obligation. 'This proposition is an obvious contraliction in tems, and of course refutes itself. FCiting authorities from Lonisiana and French conrts.| * * *

Of course, this warranty of existence, as established lyy the law of Iouisiana and as found in France and other civil-law roumtrics, does not govern a contanet of sale when fle ohject contemplated ly a salo is a thing whether existing or not resisting: in other words, where the parties luy, not an existing obligation, hut the chance of there

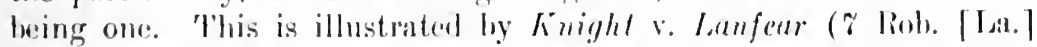
172), where the eourt, per Martio, o., said, in spesking of the thing sold: "Whatever may he its value, if it le: not in substamer what floc

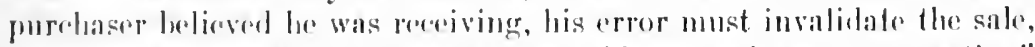
hecanse it prebontod his comsent ; mon videtur, qui erral, comsentire." And, in sponking of a salo of doubtenl or non-existing things. this great julgresaid: "This claim was a fair object of salo if its nature had been disclosed, but that was romeralod and was probahly mnknown

B Sec Browon v. Montgomery, 20 N. Y. 287, post, P. 435. - I. 
to them, and what was offered for sale was something quite different from this claim." 'I'le sanne distinction has heen eonsidered and applied by the courts of firanee. (I)ulas: c. Clusel et Cie., Isyons, Nor. 30, 18t!), Journal du Palais, 1, 185. 38.)

I'he defendant in error does not dispute that the foregoing principles exist in and are controlling under the Louisiana law, under the law of France, and also under the civil law generally from which the law of Louisiani is derived. liut whilst thus admitting, he denies that the contract of sale, involved in this ase, was governed either by the Louisiana cole or the general principles of the civil law. This proposition rests on the contention that when the Civil Code of Louisiana was compiled, its framers contemplated the simultaneous enactment of a Commercial Code which was then drafted, and therefure onitted from the former code the necessary provisions to govern commercial contracts, under the hypothesis that the latter would also be enacted; that in consequence of the failure to adopt the Commercial Code, the courts of Louisiana have held that cases arising under the law merchant are governed by that law in the absence of an express statutory repuirement to the contrary. From this premise the conclusion is drawn that as the contract in question involved the sale of negotiable bonds, the olligations resulting from the sale are commereial in their nature, and are controlled by the law merchant, by which it is asserted the vendor in such a case, when selling in good faith, warrants only that the signatures to the paper sold are not forgeries. In a restricted sense the part of the proposition relating to the operation of the law merchant, in the state of Louisiana, is well founded. (IIarrod v. Lafayre, 12 Martin, 29; Wagner v. Kenner, ' Rob. La. 122; Barry v. Insurance Co.. 12 Martin, 498; McDonald v. Milloudon, 5 Louisiana, 403.) Whilst this is true, the contention is yet erroneous in a twofold sense; first, in presupposing that a mere contract of sale of commereial paper, without recourse, is governed as to the obligations, between the vendor and vendee, by the law merchant; second, in assuming that in such a sale, either under the principles of the civil law or what the argument presumes to be the law merchant, the only warranty resting upon the vendor is that of the genuineness of the signatures to the paper sold. [Citing authoritice from Lonisiana and French courts.]

Xone of the anthorities referred to by counsel for defendant in error sustain the projosition heretofore stated with reference to the supposed existence and applicability of the law merchant, and the results whirh it is claimed flow therefrom. On the contrary, both in England and in the United States the doctrine is universally reconnized that where commercial paper is sold without indorsement or without express assumption of liability on the paper itsolf, the contract of sale and the obligations which arise from it, as between vendor and vendee, are governed by the eommon law, relating to 
the sale of goods and ehattels. So, also, the undoubted rule is that in such a sale the obligation of the vendor is not restricted to the mere question of forgery rel non, but depends upon whether he has delivered that which he contracted to sell, this rule being designated, in England, as a condition of the principal contract, as to the ssence and substance of the thing agreed to be sold, and in this country being generally termed an implied warranty of identity of the thing sold.

Benjamin on Sales (tth Am. ed., sec. 600), says:

"When the vendor sells an article by a particular description, it is a condition precedent to his right of action" [to recover the price agreed to be paid by the rendee] "that the thing which he offers to deliver, or has delivered, should answer the description;" 「and, in sec. 607, the author says:] "Under this head may also properly be included the class of cases in which it has been held that the rendor who sells bills of exchange, notes, shares, certificates and other securities, is bound, not by the collateral contract of warranty, but by the principal contract itself, to deliver as a condition precedent that which is gemuine, not that which is false, counterfeit or not marketable by the name or denomination used in describing it."

It is upon this general principle of the common law, not upon any peculiar doctrine of commercial law, that the eases in the common law courts proceed. [Discussing Jones v. Rydle, 5 Taunt. 488 ; Fenns v. Harrison, 3 T. R. 757 ; Willinson v. Johnson, 3 B. \& C. 428; Young v. Cole, 3 Bing. N. C. 724; Lamert v. IIeath, 15 M. \& W. 486 ; Gompertz v. Bartlett, 2 El. \& Bl. 849 ; Gurney v. Womersley, + El. \& B]. 133.]

The cases in the American courts, whilst declaring the same rule as that recognized in England, place it upon a theoretiral basis differing somewhat from that pronounced by the English courts: that is, instead of pronouncing it a condition of the principal contract that the thing sold, in its csisonce and sulstance, must be delivered, declare that thare is an implied warranty of identity, or, in other words, that the thing sold is what it purjorts to he. Daniel, in his treatise on Negotiable Papror (s risan), calls attrution to the different defonitiens given to the same ohligation hy the Ameriand and English rentes and indieates the virw that the form of expression used

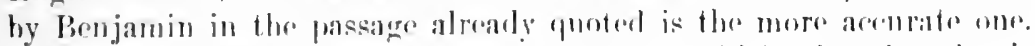

Asidre, lowerere, from the mere garh in which the thonght is clotherl, the Ameriean and English courts are in full alerord. This

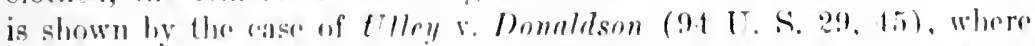
Benjamin on Siales is approvingly reforterl to as ako Flynn ve dllen

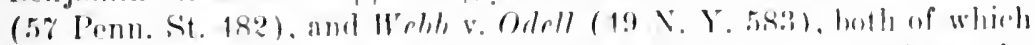
cases, as also the line of Amerienan aljudiontions which anforce the same doctrine, are noled in Ho marein of this opinion.?

9 Thrall v. Newell, 19 Vit. 202; Lyons v. Miller, f Gralt. 127; Aldrich v 
Many of the controversies rovered lyy the cases refered to arose in somsequence of the sale of a formal note, hut the principles upon which all the anthorities prosed do not confine the right of recovery to such a ase, but rest upon the general doctrine to which we have alreaty referred. In late no case is reported wherein the obligation, as between vendor and rencler, in the sale of negotiable paper, is claimed to be rontrolled other than by the reneral principles of the common law, though in three cases, Barter v. Huren (29) Maine, 434), Fisher r. Kieman (1: Marylame, 197 ) : and lillis v. Wild (6 Mass. $321)$, the deduction was mate from the law respecting the sale of goods that on a sale of nerotiable parrer there was under the principle of caveat emplor no implied warranty even that the signatures to the paper were not fored. Ellis r. Will was, however, expressly overruled in Iferriam v. Holcoll (3 Allen, 258, 260); and from the allusions to Ba.rler v. Duren, contained in the later Maine decisions previonsly noted in the maroin, it is doubtful whether the early ruling in Jaine would now be followed there. The three cases referred to, it is needless to say, are practically disregarded by the entire enrrent of American and Fnglish anthority, and stand alone. They a disarowed ly the defondant in error lore, since lis argmment almits that there is a warmanty of the genuineness of the signatures to an apparent negotiable instrument, therely concelling the subsistence of the olligation to warrant the existence or identity of the thing sold, and yot sueking to aroid its consequences by limiting it to non-existenee resulting from a particular mullity.

There is an exceptional "ase (Lillauer v. Coldman, 72 N. Y. 506, $18 \mathrm{~s})$, which holds that the common haw obligation, as to the implied wardanty of identity in the thing sold, in the case of commercial pancre extents only to the gennineness of the instrument. 'The case was one involving the mullity of a usurious note, and, if correctly deridul, womld be anthority for the proposition that there was a ferolian spures of warranty in the sale of commerejal paper, differine from all others; in other words, that there was a law merchant of warranty where there was no commercial contract. The opinion

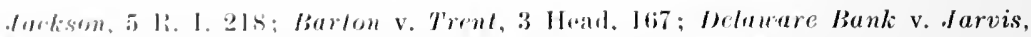

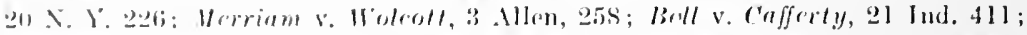

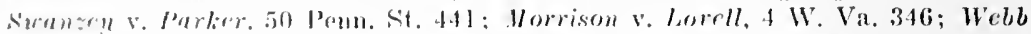

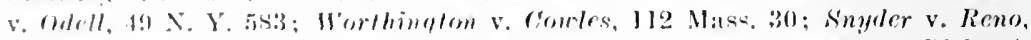

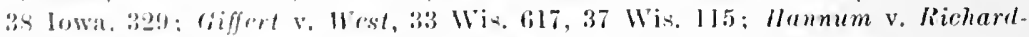

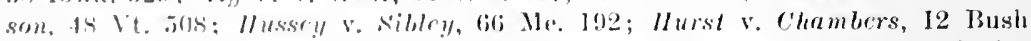

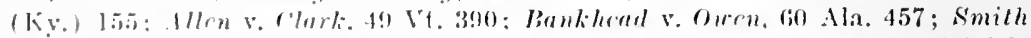

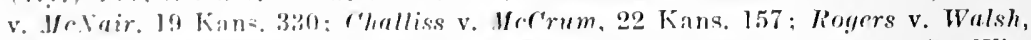

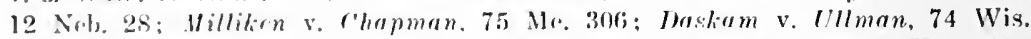
474: I'almer v. Courtnry. 32 Neb. 773; Ware v. McCormack, $96 \mathrm{Ky}$ 139; Broun v. Ames, 5!) Minu. 476. 
in this case illustrates the same contradictory position presented here by the argument of the defendant in error, to which we have just called attention, that is, that it admits the common law rule and then denies its essential result by eliminating conditions of nonexistence which are necessarily embraced by it. It follows that this New York decision leads logically to the view expressed in the Maine and Maryland eases just referred to, for either the principle of warranty of identity must be accepted or rejected; it cannot be accepted and its legitimate and inevitable results be denied. The rule there announced was in conflict with previous decisions in New York, and the decision is strongly criticised by the Court of Errors and Appeals of New Jersey in Wood v. Sheldon (42 N. J. I. 421, 425.) $)^{2}$

In Giffert v. West (33) Wisconsin, 617, - 1873), where a note was sold which was void for usury, the vendee was allowed to recover the consideration paid by him, and his right to do so was based upon the general doctrine that one making a sale is bound as a condition of the principal contract to an implied waranty of the existence of the thing sold.

[After discussing IIanum v. Richardson, reported herein at p. 432, the court continues:]

Nor is there any fommlation for the assertion that Otis r. Cullum (92 U. S. $41 \%$ ), and the cases of Orleans v. Platl (9!) U. S. Gr6), and . Vitna Life Ins. ('o. v. Middleporl (1:1 IT. S. 531), both of which rite Otis v. Cullum, support the dowtrine that a sale of commercial paper withont recourse is not, als leetwen the rembor and vendee, soverned by the ordinary rule of the common law. On the contrary, that aase expresely iresterl its conclusion on the decision in lamert v. Ileath, supra. Which latter ase, as we have seen, whilst enforring

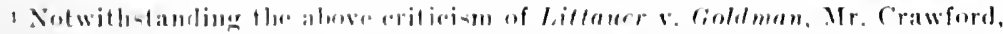

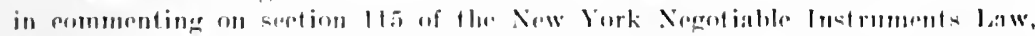
sily: "It will la noted that the warranty mentioned in the mext section. that the instrument is valis, in amifterl from this setion. The inference from

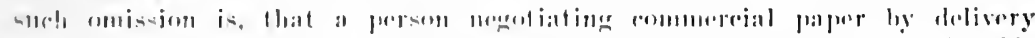

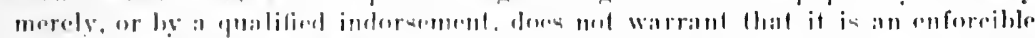

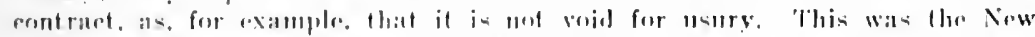

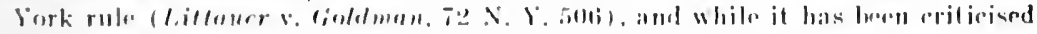

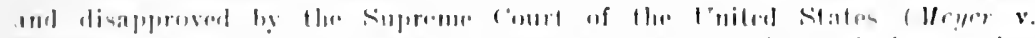

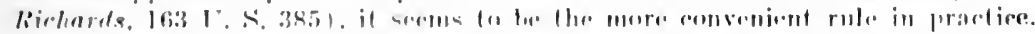

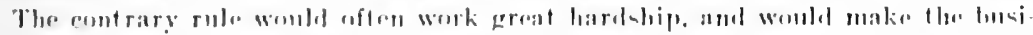

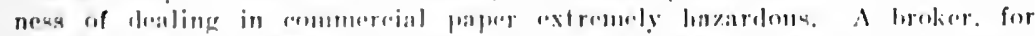

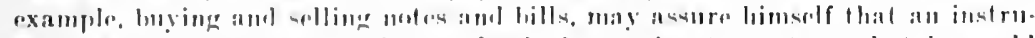

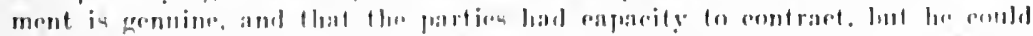

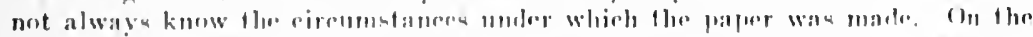

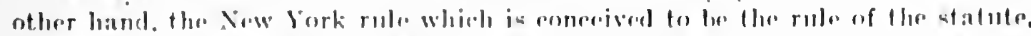

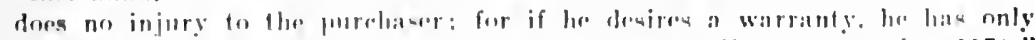

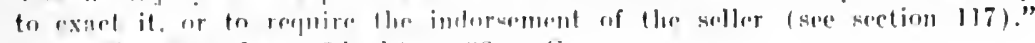
Craw. Neg. Inst. Law (34 ed.). 1. 88. - (', 
the principles of the common law, considered that under the particular facts there presersted it was a yusetion for the jury to determine whether the serip delivered was the kind of serip which the defendant hat ordered purchised. That case not only, as has already been stated. concermed non-megrotiable paper. but its decision involved no question of the seope of the warranty, lunt solely what was the thing bounht. Nor does the rase of Otis $\mathrm{v}$. ('ullum justify the assumption that this count laid down the rule that a mere sale of eommereial paper, as between vendor and vender, when the sale was made without recourse, created some peculiar and exceptional warranty to be considered in this partinlar a the law merehant. It is true that in expressing the general loctrine Mr. Justice Swayne said: "The seller is liable p.r deticto for lad faith, and ex contractu there is an implied warranty on his part that they belong to him and are not forgeries. Where thre is no express stipulation there is no liability beyond this." But in using this language, as to the extent of the warrants, the mind was directed to that form of non-existence which more commonly ohtains, and the expression is a mere illustration of the rule de eo quod plerumrne fit. If this were a case where a vendee elamed to recover back the price paid by him on a purchase of nesotiable securities, which pass by delivery from hand to hand, on the arement that after the sale it had developed that they were not valid (although not forgerics), because the law under which they had heen issned was constitutionally void or ullra vires, the claim of implied warranty of existence would be without merit, for the reason that such a state of fict would present a case of a sale of securities whether valis or invalid, henee engendering no implication of warranty of existence. Under the state of facts thus supposed, the purpose of the parties to make a contract of that nature would legally result from the fant that they wre both neressarily equally chargeable with notice of want of power. and therefore would be both presumed to have arterl with reference to surch knowledge. This is Olis v. Cullum. But it is not the ease at lar, since it is here admitted that both parties, in entering into the contract of sale, contemplated valid securities, of which there were many outstanding, and those delivered were void, not because of a want of power to enact the law under which they were iswuet, or hecause they were ultra vires for some other legal canse, but lecause they were stricken with nullity by a ronstitutional provision adopted after the act authorizing the issme of the sectrities, and where nothing on the fare of the bonds indieaterl that they were illegal. The distinction pointed out by the foresoing statement not only illustrates the correctness of the decision in Olis $\mathrm{B}$. C'ullum, but alon demonstratos the error of attempting to extend it to the state of farets presenterl in the ease under consideration. Inders?. in examiniug and applying Otis $r$. Cullum the fact that it dnes not entrol a mes like this has heen reengnized. (Daniel, 
Neg. Inst., $\S 734 a$ : Rogers v. Walsh, supra; Cincinnati, New Orleans, etc., Railway r. C'itizens' Nationai Bank, zt Week. Law Bull. [Ohio], 198, 211.)

The foregoing analysis of the principles and review of the authorities governing the law of sale of negotiable paper, transferred without recourse, as between vendor and rendee, clearly demonstrates the unsoundness of $t \mathrm{it} ; \mathrm{o}$ itions upon which the defendant in error relies, since it affirmatisly ustablishes that there is no peculiar warranty. in a sale of commercial paper, and that the reasoning by which it is attempted to prove its existence is a mere misconception of the principles of the common law relating to the sale of goods and chattels.

In passing, however, it is worthy of note that whilst the civil law enforces in the contract of sale generally the broadest olligation of warranty, it has so narrowed it. when dealing with eredits and incorporeal rights, as to confine it to the title of the seller and to the existence of the credit sold, and, e converso. the common law, which resiricts warranty within a narrow compass, virtually inposes the same duty by broadening the warranty as regards personal property so as to impose the obligation on the vendor to deliver the thing sold as a comlition of the principal contract or by implieation of warranty as to the identity of the thing solil. By these processes of reasonirig the two great sistems, whilst apparently divergent in principle practically work sulstantially to the sanse salutary conclusions.

There are nany questions discussed in the brief of counsel which we do not notice, and which we content ourselves with saving are without merit. The views alove stated are controlling and decisive of the case and lean neessarily to the reversal of the jurlgunent. As the case was hould upon a stipulation waiving a jury and upon an agreed statement of farcts. it is our duty, in reversing, to direet that the proper judgment lo entored below. (Fort Scott v. Hicleman. 112 U. S. 150 , and (alies there rited.)

It follows that -

The judgment of the ('ireuit C'ourt must be reversed, and the ease he remanderl with rlirestions to rntor jurlgment for plaintiffs for eight thousand throe hundrerd and oighty-three dollars and seventy-five cents $(\$ 8,383.75)$, with interest from judicial lemand and costs.

\section{$\S 115$}

VIHALJASA M. MCCRUM.

22 Kissas, 157 - 1879.

Actios to recover damages upon an impliesl warranty in the sale of eertain notes. Demurrer to the petition overruled. Defendant sppeals, 
The opinion of the court was delivered hy -

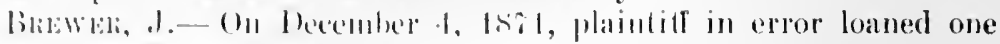

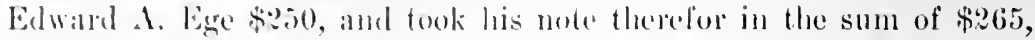
palyable to Richard l'robessio or beilrer, and secured by mortgage. bomgr after its maturity, and in ling, soveral payments laving been mate thereon in the s!cantinne, plaintill in error sold the note for its then face value fo delemelant in errot. At the fime of suels sale he indorsed it, " Without reomrse. - W. T. Challiss." Mr.Crum sued on the note. Fige pleaded usury. The plea was sustained, and MeCrum reeoverel \$2:9.90, less than the face value of the note, for which sum he broment this action. $A$ demurres to the petition was overuled, and this ruling is now presonted for review.

Can the action be sustained? Of eonrse no action will lie on the indorsement, for hy his written contract ('halliss expressly declines to assume the liabilities of an indorser. If sustainable at all, it must be as arainst him as a rendor. and not as an indorser, and upon the doetrine of an impliod warranty. The theory of the defendant in error is, that every vendor of a bill, bond or note impliedly warrants that it is what it purports on its face to be - the legal obligation of the parties whose names appear on the instrument; and that the character of the indorsement or the lack of an inclorsement in no manner affects this implied warranty. On the other hand, the connsel for paintiff in eror lays down the broad proposition that "there is no surh thing as implied waranty in the sale of chattels;" and that, in the absence of express warranty, the maxim caveat emptor is of miversal appliontion. It is clear that the character of the indorsenent ruts no firure in the puestion; as stated, no action will lie on it. But further, the restrietion is only as to his liability as indorser, and in no manmer affects his relation to the paper as vendor. An muquatitied indorsment is the assumption of a ronditional liability. 'The indorece becomes a new drawer, and is liable on the defanlt of the drawer. "Without reoourse." does away with this conditional liability. It loaves the indorsement simply as a transfer of title, and thr indorser liable only as rendor: yot it leaves him a vemulor. and dirests him of none of the liahilities of a rendor. It makes the transaction the equivalent of a lelivery of paper nayable to bearer, and transforable by delivery. (I/ammum v. Richardson, 48 Vt. $\approx(1 \mathrm{~s}$.

Indepentent, thorefore, of any matter of indorsement, what inplied warranty is there in the transfer of a promissory note? Two things are clair under the anthorities: First, that there is an implied warranty of the genuineness of the signatures; and, second, that there is no waranty of the solvency of the parties. It is unnecessary to more than refor to a fru of the anthorities upon these propositions: (Byles on Pills. Pl. 13.3, 195, and rases in notes; Jomes v. Ryde, 5Taunt. 188; Gurnoy r. Womersloy, 1 El. \& Pl. 132; Gompertz v. 
Bartlett, 24 Eng. Law and Eq. 156; Terry v. Bissell, 26 Conn. 23; Merriam v. Wolcott, 3 Allen, 259; Aldrich v. Jackson, 5 R. I. 218; Lobdell v. Baker, 3 Mete. $469 ; 1$ Addison on Cont., p. 152; Ellis v. Wild, 6 Mass. 321; Eagle Bank v. Smith, 5 Conn. 71; Shaver v. Ehle, 16 Johns. 201; Dumont v. Williamson, 18 Ohio St. 515; 2 Parsons on Notes and Bills, ch. 2, § 2.) But in the case at har, the signature of the maker was genuine. The objection is, that it was never his legal obligation to the full amount for which it purported to be. How far is there any implied warranty in this respect? A reference to some of the leading cases will throw light upon this question.

In Thrall v. Newell (19 Vt. 203), it appeared that one of the makers of a note was insane. The vendor made a written assignment, in which was a description of the note, and the court construed this as an express warranty that the instrument was the legal obligation of the apparent makers, and one being incapable of contracting, gave judgment against the vendor on account of this breach for the amount received by him. While the judgment of the court is rested upon the fact of an express warranty, the judge who writes the opinion expresses his individual conviction that the same result would follow on a mere transfer without any express warranty, and quotes approvingly an extract from Rand's edition of Long on Sales, that "there is an implied warranty in every sale that the thing sold is that for which it was sold."

In Lobdell v. Baker (3 Mete. 469), it appeared that the owner of a note procured the indorsement of a minor, and then put the paper in eireulation. He was held liable to a subsequent holder. Chief Justice Shaw, delivering the opinion of the court, says:

"Whoever takes a negotiable security is understood to ascertain for himself the ability of the contracting parties, but he has a right to believe, without inquiring, that he has the legal ohligation of the contracting parties appearing on the lill or note. Trexplained, the purchaser of surh a unte has a right to believe, upon the faith of the security itself, that it is indorsed by one capalale of binding himself hy the contract which an indorsenent by law imports."

In Hanmum v. Richardson ( $18 \mathrm{Vt} .508)$, a note was grion for liguor sold in violation of law, and was by statute rois. Defomlant knew its invalidity, fansformel it by an indorsement without recourse, and he was held liable to his vender.

In Delavare liank v. Jarris (20 N. Y. 220), a usurious note was sold, and the ventor was arljulged liable, not merely for the money received by him, but also the costs paid by his sender in a suit against the makers of the note. Tn the opinion, Mr. Justice Comstock uses this language:

"The authorities state the doctrine in general terms that the vendor of a chose in action, in the ahsence of express stipulation, 
impliedly warrants its legal somnlness and validity. In peculiar circumstances and relations, the law may not impute to him an engagement of this solt. Lut if there ale exeptions, they eertainly do not exist where the invalidily of the deht of security sold arises out of the rendor's own dealing wilh or pelation to it. In this ease, the defendant held a promissory note which was void. heranse he had himself taken it in viobation of the statutes ol msury. When he sold the note to the plaintills and rereived the eash therelor, hy that very act he athimed in judgment of law that the instrument was unattainted so far at least as he had heen connected with its origin."

In Young v. Cole (3) Bingham N. ('. Fet), wrtain bonds were sold as Guatemala bombls. Which tumed out alterwarl to be lacking the requisite seal, and the rendor, thongh ignorant of the defect and innocent of wrong, was compelled to refund the money. The thing in fact sold was not the thing supposed and intended to be sold.

In Gompertz v. Bartlett (2+ Eng. Law and Eq. 156), the plaintiff discounted for the defendant an unstamped bill, purporting on its face to have been a foreign hill, drawn at Sierre Leone and accepted in London, but which was in fact drawn in London. If aetually a foreign bill, it required no stamp, and was valid; but being an inland bill, it required a stamp to make it a valid hill in a comrt of law. The acceptance was gennine, and the acceptor had previously paid sinilar bills. But the acceptor becoming hankrupt the commissioner refused to allow it against his estate berause not stamper. Thereupon the plaintiff, who had sold the bill and heen compelled to take it up, brought his action to recover the price he had paid for it, and the artion was sustained. Lord C'ampleell, before whom the ease had been tried, and who then held adversely to the plaintiff, said:

"I then thought that the rule cavent emptor applied; but after hearing the argument and the authorities cited, I think the action is maintainable, and upon this crround: 'That the article sold did not answer the description muder which it was sold. If it lad been a foreign bill, and there had been any secrot defect, the risk would have been that of the purchaser; hut here it must be taken that the

2"The defendant in the ease eited [Marvin v. Jarris] land knowledge of the usury, which was not the fart here, and henee it differs from the case at lar, and is not decisive of the question. . . . The law in regard to the transfer of negotiable bills of exchange and promisenry notes, as lairl down for a century or more, only exerpts two eases as coming within the doctrine of an implied warranty, vi\%. a warranty of title. and that the instrument is genuine and not forged. There is no precelent and not a single reported case in the books in favor of the loctrine that where a promiscory note is infeeted with usury, and that fact is unknown to the party who transferres it, that is an implied warranty of the validity of the note." - Littauer v. Goldman. 72 N. Y. 506.

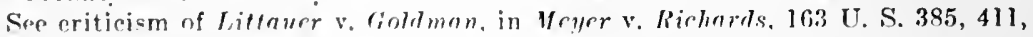
and Wood v. Sheldon, 42 N. I. J. 421, 424. - H. [But see Mr. Crawford's approval of Littauer v, Gollman. in note 1, ante, 1. 425. - C.] 
bill was sold as and for that which it purported to be. On the face of the bill it purported to be drian at Sierre Leone, and it was sold as answering the description of that which on its face it purported to be. That amounted to a warranty that it really was of that description."

In Tieonic Bank v. Smiley (2r Me. 225), an overdue note was transferred with this indorsement, "Indorser not holden;" yet it was decided that the indorser was liable to his vendee for any payment made on the note before the transfer, or any set-off existing against it of which the note gave no indication and the vendor no information.

In Snyder v. Reno (38 Iow: 329), it was held that there is an implied warranty that there has been no material alteration in the paper since its execution. The court says: "We have no doubt that there is an implied warranty of the transferer that there is no defect in the instrument, as well as that the signature of the maker is genuine." (See also, Blethen v. Lovering, 58 Me. 49\%; Ogden v. Blydenburgh, 1 IIilton, 182; Fake v. Smith, 2 Ab. [N. Y.] App. 76; 2 Parsons on Notes and Bills, clı. 2, $\S 2$, and cases in notes; Terry v. Bissell, 26 Conn. 23; 1 Daniel on Neg. Inst., $\$ 6 r 0$. )

In this, the author thus states the law:

"When the indorsement is uitlenut recourse, the indorser specially declines to assume any responsibility as a party to the bill or note; but by the very act of transterring it, he engages that it is what it purports to be - the valid obligation of those whose names are upon it. He is like a drawer who draws withont reconrse: but who is, nevertheless, liable if he draws upon a fictitious party, or one without funds. And, therefore, the holder may recover against the indorser wilhout recourse, ( ${ }^{*}$ if any of the prior signatures were not genuine: or, (2) if the note was invalid betwen the original parties, hecanse of the want, or illegality of, the consileration or. (3) if any prior party was incompetent: or, (1) Hoe inderser was without thtle."

These authorities fully sustain the ruling of the district conrt. The note was not the legall obligation of the maker to the full amomut. As to the usurious portion, it was as it were no note. 'This was a defect in the very inceptinn of the note. It was known to the verntor and arose out of hisewn dealingre in the matter. ${ }^{3}$ by all these anthorities there is an implied waranty against such a dofort, and the rendor is liable for a bremelh tlowerof.

The sugerestion of commed that the change in the usury law, by the legislation of $18 \%$. affectod the right of recovery upon the note, has been already derided adversely, in the rase of ienness $v$. Cutler (12 Kas. 500$)$.

All the justiers enourring. Iuderment affirmed.

a It will be olserved that this brings the case within subl. 4 of $\S 115 .-\mathrm{H}$. 
48 VевMONT, $508 .-1875$.

Assumpsit for false warranty in sale of a promissory note. The note was made by Lincoln payable to Vletntosh, for an illegal consideration rendering it roid by statute; was indorsed without recourse by Helutosh to defendant and without recourse by defendant to plaintilf. Indgment for plaintiff.

The opinion of the court was delivered by

l'menpost, Cn. I.- It may be observed in the outset, that this action is not brought by the plaintiff as the indorsee of the note referred to against the defendant as the indorser, and the action is not based upon the indorsement, but is brought upon an alleged warranty by the defendant that the note was a valid and binding note. hased upon a valid and lawful consideration, when in fact it was given for an illegal consideration, and was at its inception void. On trial the plaintulf introduced evidence in support of his declaration. After the evidence was in, the defendant insisted that as it appeared from the note that it was indorsed by the defendant "without recourse," the legal effect of the indorsement could not be varied or controlled by evidence outside of the indorsement itself - that the same was conclasive in that respect; but the court held that such indorsement was not of itself conclusive of its legal effect in sueh sense as to exclude the evidence aliunde; and submitted the case to the jury in accorlance with such ruling, and it is upon this decision and the charge of the court in respect to it, that the only question that has been raised and diseussed by the defendant's counsel arises.

What would have been the effect of this objection if the retion had boen luased upon the indorsement, it is not necessary now to inquire. By indorsing the note "without recourse," the defendant refused to assume the responsibility and liability which the law attaches to an unqualified indorsement, so that in respeet to such liability, it may perhaps be regarded as standing without an indorsement. If it be so regarded, then in what position do these parties stand in respect to the transaction? The principle is well settled, that where personal property of any kind is sold, there is on the part of the seller an implied warranty that he has title to the property, and that it is what it purports to be, and is that for which it was sold, as understoor by the parties at the time; and in such rase, knowledge on the part of the soller is not necessary to his liability. The implied warranty is. in this respert, like an express warranty, the scienter need not he alleger or proverl. Edwards, in his work on Bills and Promissory Notes (p. 188), says: "One who transfers a negotiable instrument by delivery or by indorsement, impliedly guarantees that it is genuine, and that he has title to it. The rule is the same in 
regard to personal property. The vendor of a chattel always gives an implied warranty of the title. (15 Johns. 240;6 Cow. 484; 4 Duer [N. Y.] 191; 6 Johns. 5.) Though the indorser transfers the note upon condition that it is to be collected at the risk of the indorsee, he is, nevertheless, responsible if the note proves to be a forgery." (Edwards, 289.)

In this case the note in question was given for intoxicating lipuor sold in this state in violation of law, and therefore was roid at its inception; in short, it was not a note, it was not what it purported to be, or what it was sold and purehased for; it is of no more effect than if it had been a blank piece of paper for which the plaintiff had paid his fifty dollars. In this view of the case we think the defendant is liable upon a warranty that the thing sold was a valis note of hand.

The plaintiff has declared as upon an express warranty. If he could prove one, very well; if he eould not, the implied warranty is just as available to him, the declaration being according to its legal effect.

'This view of the case relieves it from all embarrassment growing out of the question as to the admissibility of parol testimony to vary the indorsement, as the effect of the indorsenent is really not involved in the ease. And the ruling and eharge of the entrt were really more favoral,le to the defendant than he had the right to ask.

The exceptions to the overriling of the motion in arrest were waived. The exceptions to the relusal to set aside the verdict as against the evidence, this court refuses to hear, the decision of the County Court being conclusive in such cases.

Judgment affirmed. ${ }^{4}$

2. Titis: of Sei.lier.

\section{§115 WILLIAMS $r$. TISHOMINGO SAVINGS INSTITU'TION.}

57 Mississipiel, 633. - 1880.

Geomer, C. J., delivered the opinion of the rourt.

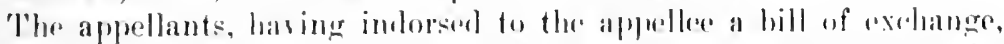
to which they alamed titlo. throught a forged indorsentent, now insist that they incurred no responsibility hy their indorsoment, exerpt at guaranty that the drawere would pay it on presentation. But the rula is well settled that an imlorser warrants the genumeness of the prior indorsements on the bill, and also his title to the paprer. Shomld it he ascertained, even after payment of the hill, that any of the

- Where the state conatitution forbide the enforrement of ally atel the consideration of which was a slave, the indorser of a note is mevertheleme liable oul

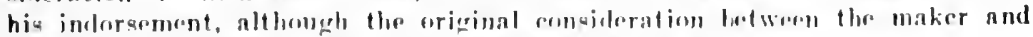
the payee was a slave. Giraham v. Maguire, 39 Ga. $531 .-11$. 
indorsements are forged, the drawee an recover back the amount of the hill from the person to whom he paid it; and so each preceding indorser may recorel from the person who indorsed the bill to him. 'The drawee is houmel lo know the signalure of the drawer, but not of the indorser. 'Thu judgment. which is in aceorlanre with these viells, is

\title{
Alfirmed."
}

\section{Capatity of Pligr Partes.}

\section{$\S 115$}

\author{
ERIIN $v$. DOWNS.
}

$15 \mathrm{~N}$ К Уовк, $575 .-1857$.

Actor against inforsur of motes signed by a firm of married women, and indorsed hy defendant for their accommodation. Plaintitf tomk the motes wilh knowledge that the makers were married women. Indenent for plaintifl.

SHaxkindi, J.- The note was void, as against the makers, because they were married women, and incapable of contracting obligations in that form. But when the defendant indorsed the note, he impliedly contruted that the makers were competent to contract, and har legally contractod. the ohligation of joint makers of the note. He also assmed the legal olugation, in most respects, of the drawers of the bill. 'The faret, known to the plaintilf' at the time he took the note, that the makres were married women, did not deprive him of the charactor of a bond firle purchaser. Nor does the payee's knowlerlge that the drawee is a marlied woman, distharge the drawer in case of mon-payment of the lill by the drawee. Nor is the indorser dischalenel, thomen the name of the maker is forged. (1 Comst. 113.) The fact is not found that the plantilf was aware the note was accommorlation paper. The phintill was a boma fide purchaser within the law merchant. Noither the complaint, nor the finding of the referee, tell ws who transforrest the notes to the plaintifl. 'The legal presumption is, that lie recejod them from some legal holder in the course of business.

'The judement shombl be affirmed.

Parow. . ., dolivaral an opinion to the same effect.

All the other jutges comenrring.

Tudgment affirmed.

sccord: State Bank v. Fearing, 16 Pick. (Mass.) 533.-H. 


\section{KNowledge of Invalidty or Valuelessness.}

20 New York, 287. - 1859.

Actios on a note. Defense, fraud. Plaintiffs sold defendants a post-dated check drawn by Farnham \& C'o. to the order of I. R. Farnham, ont of the firm, and by him indorsed. On the day of the sale plaintiffs emplovid ('utting, a bill broker, to sell the check. Cutting ollened it to me. ('hald, who declined it on the ground that he held one lrawn and indorsed by the same parties which had just been protested for non-pryment. Cutting then sold it to lefendants without disclosing the conversation with Chard. The drawers were, mnknown to defendants, insolvent. The note in suit was given for the purchate prier of the " heck.

The court charod the jury that the non-payment and protest of the check, on the 11th Amil. Was evidence tending to show insolveney in the drawers: that it was the duty of Cutting to communieate to the defendants what he hall heard Chard say about the protest of that chere, without regard to what he may have thought about the solvency of the drawers: and if he did not do so, and they were really insolvent, the plaintilts wull not recover on the note. The plaintitfs' comnsel exceptrinl to hoth hranches of the rharge. There was a verdict and julgument for the defemlants, which was affirmed at a gremeral term. 'Thr plaintill appealed.

D)kxlo, J.- I think throe was no error in the charge to the jury

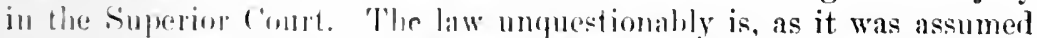
on the aroment, thal nolioe to the plantills' agent, Cutting, while

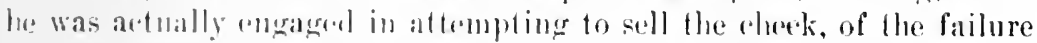

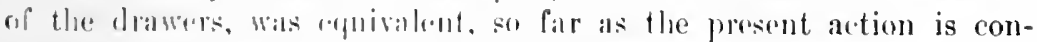

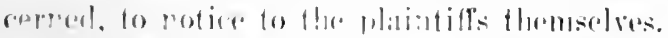

What rlatel informol him. Was not procisely that Farnham \& Co.

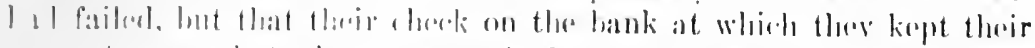

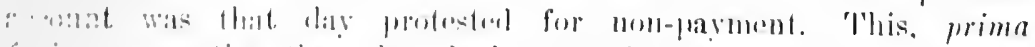

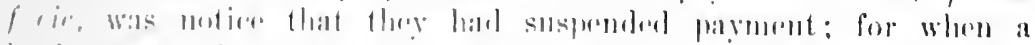

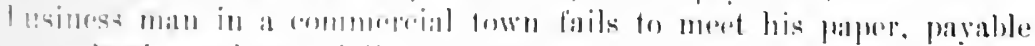

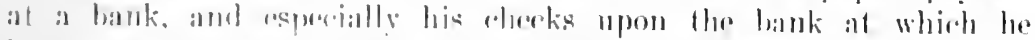

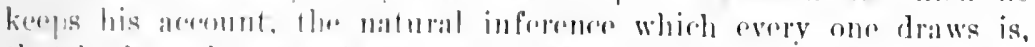

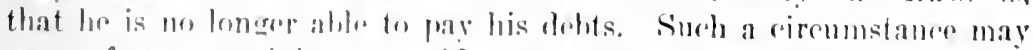

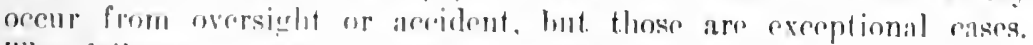
The failure to meret the papere is itsolf a suspension of parmont. and notioe of such a fact. manerompaniod with any oxplanation which

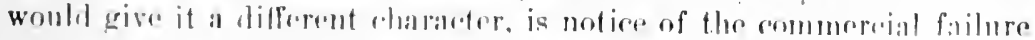

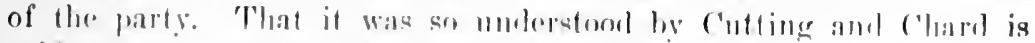

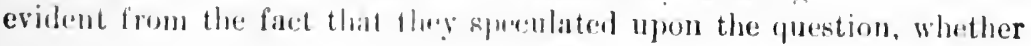


the members of the firm drawing the check would ultimately be able to pay. Tpon that question, Chard, as a creditor is apt to do, took the most farorable view. It is apparent that neither of them expected the eheck to be paid on presentation when it should mature, five days afterwards. 'The Superior Court considered that the confidence which Chard expressed in the ultimate solvency of the members of the firm, did not relieve Cutting from the duty of eommunieating to the defendants the fact that its check had not heen met. I am of the same opinion. ITp to that time the drawers were in good eredit, and their paper of this kind. we are to presume, was promptly met. Thereafter, the holders of such paper were to he put upon their legal diligence in the courts. with a fair expectation, perhaps, that they might ultimately be able to obtain payment. The difference between a bank eheck having five days to $\mathrm{mm}$, and which is then to be paid, and a suspended debt against parties who have failed, is suffieiently obvious. The defendants purchased this check as one of the former class, while the plaintifl's' agent well knew that it belonged to the latter, and withheld that knowledge from the defendants. 'The plaintifis' conduct is less censurable, morally, than it would be had it been proved that they personally knew of the failure of the drawers; but in point of law, the case is the same as though, after hearing that Farnham \& Co. had failed, they took the paper which they held against them into the street, and sold it to parties who had not heard of that event. Such an act could not he justified at law any more than in the forum of ennscience.

The jurdge was therefore perfectly correct in instructing the jury that it was the duty of Cutting to communicate to the defendants what he had heard Chard say as to the protest of the other check. He was also eorrect in advising them that the consequences of omitting to do so was that the plaintiffs could not recover on the note. Where a party negotiates commercial paper, payable to bearer, or under the blank indorsement of another person, he eannot be sued on the paper because he is not a party to it; but he nevertheless warrants that he has no knowledge of any facts which prove the paper to be worthless, on arcount of the lialure of the makers, or by its being alseady paid, or otherwise to have become void or defunct; for, eays Judge Story, any concealment of this nature would be a manifest fraud. (Story on Prom. Notes, § 118.)

The plaintiff"s counsel argued that, according to the case of Nichols v. Pinner (18 X. Y. 295), the plaintiffs and their agent were warranted in maintaining silmes as to the failure of Farnham \& Co., though they knew it and the defendants did not. But the cases are essentially different. There we decided, that where a merchant, knowing himself to be insolvent, purchases gonds without disclosing the fact, there being no inquiry marle, he is not necessarily guilty of fraud, as he may honestly believe that he can go on and retrieve 
his affairs. Where so much of the trade of the country is conducted without invested capital. or on borrowed eapital, it must often happen that a merchant who is ultimately successful has known periods of commercial disaster when his property would not pay his debts. It would be too strint to hold, that under such circumstances he must in all cases go into liquidation, or expose himself to probably bankruptey by disclosinu his condition. But the case does not countenance the position, that a lealer who has been of known standing, but who has suddenly failed in business, can go to those who were acquainted with his former character, but who have not heard of his failure, and innocently purchase their property on credit. Judge Selden, in his opinion, puts that case as one not covered by the judgment.

The judge was also right in stating to the jury. that the non-payment of the check, spokin of by Chard, was evidence upon the question of the insolvency of the drawers. I have already stated what I consider the necessary inference from such a circumstance among business men. The judgment must be affirmed.

Johnson, Ch. J., Comstock, Gray, and Grover, JJ., concurring. Judgment affirmed. ${ }^{\circ}$

\section{Indorser: Instrument Valid and Subsisting.}

$\S 116$ HOROWITZ $v$. WOLLOWITZ.

59 Miscellaneous (N. Y. Sup. CT., App. T.) 520. - 1908.

Giegreicil, J. The complaint alleges that on the 28th day of December, 1906, the defendant Barnet Cohen made and delivered to the defendant Jacob Jormack his promissory note, in form as follows:

“ $\$ 500.00$

Dec. $25,1906$.

"Six monthe and five days after dat" I promise to pay to thr order of myself five hundred dollars at $161 / 2$ C'armine St.

"Value received.

13. CoHrin."

- and that at the time of making eaid note, and prior to its delivery to the plaintiff, the defendant Inols Wollowitz indorsal it, for the purpose of giving ceredit theroto with the defondant Ioruack, and with the intent to charge himesalf as first imlorser. It is further alleged that thereafter and hofuro maturity the defondant . Jormack indorsed the note to the plaintitf. who on the eredit of the prior indorsements, gave value threrefor. 'Then follow appropriate allegations of presentment, nonpanyme protest, and notice. The answer, among

- Cited with approval in Rothmiller v. Sitcin, 143 N. Y. p. 592. lut the seller is not hound to disclose that the instrument is accommolation paper drawn by a rlerk and acepted ly the aceommodated party. People's Bank v. Bogart, 81 N. Y. 101.- H. 
other things, sets up that Jormate exacted and reeeived usury from Cohe'n, the malker of the note, and that the defendant signed his nane to satid note after such wstrious ingerment had been consummated and exeeuted between dormald and lohen, and that the note was tainted with nsury in its inception, and merer had any legal and valid inception, and was roid for 1 indry.

At the elose of the phintitl"s ase a concession was male that there was usury in the inception of' the note betweren Cohen and Jormack. The defondant put in mo cridenere but nowed to dismiss the complaint on the ground that it allirmatively apprand that the note was roid in its inception. The court reserved derision, and subsequently rendered julgment in firor of the defendant. *** * *

On bethalt of the appenlant it is rilaimed that section 96 of the Negotiable Instruments Iaw (Jaws 189\%, e. 6il: p. 732) has entirely swept away the defonse of usury as against holders in due course, citing schlesinger v. Kelly, 114 App. l)iv. 546; Wirt v. stubblefield. 18 App. Cas. D. (C. 284; Rroaduray Trust Co. v. Manheim, is Mise. Rapp. 1]5, and the coneurring memorandum of $\mathrm{Mr}$. Justice Willard Bartlett in schlesinger v. (iilhooly, 189 N. Y. 1, at page $31.0^{7}$

It is not necessary in the present case, however, to pass upon the question of the arailability to the maker of a note of the defense of usury as against hollers in due course, becanse the liability involved in this apjual is that of an intorser, not of the maker, and the liability of an indorser is lealt with in other prortions of the act; section 116 providing :

"That every indorser who indorses without qualification warrants to all suberpuent hollars in lue conres: * * * (2) That the instrument is at the time of lis indorsement valid and sulssisting."

In Peckard r. Wimlholz, ss App. Div. 365, one Truman made his promissory note to one biton, and then forged Eaton's indorsement, and next prosured the dofondant Windhol\% to indorse it. The note with these two imbrements upon it, was presented to the plaintiffs, who were note brokers: and by flem was nergotialeet for the benefit of

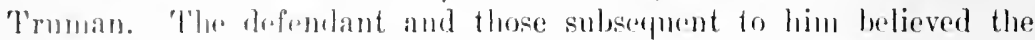
indorsement of liaton wals gemuine, and the plaintifl's learned he was

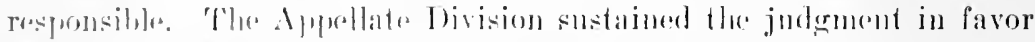
of the plaintitts. holding that the defendant by his contract of indorsement guasunterd the gemminneses of the signature of Waton, the prior indorser on the note, and that the note was a valid and subsisting obligation, aiting sertion 116 of the Vegotiable Instruments Law. This ruling was uphwer ly the court of Appeals without opinion. 180 X. Y. 519.

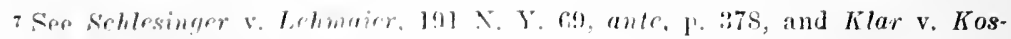
tiuk, fi5 Mise. 1!9, ante, note 7, D. 380. - r: 
In Lennon $v$ Grauer, 159 N. Y. 433 , it was held that the fact that the name of the maker of a note was forged did not discharge the indorser; the ground of the decision being that the indorsement of a promissory note implies a contract by the indorser with a subsequent bona fide holder that the instrument itself and all the signatures prior to the particular indorsement are gennine.

Under the language of the statute, as applied hy the above decisions, it must be held that in indorsing the note the defendant warranted its validity, and that he cannot be heard now to assert that it is void for usury, any more than for forgery or any other canse. Furthermore, apart from the provisions of section 116 , it is an established rule that the obligation of an indorser is a new and independent contract, separate and distinet from the eontract evidenced by the note. $4 \mathrm{Am}$. \& Eng. Ency. I. (2d Ed.) p. $4 \%$, and cases rited: Morford v. Daris, 28 N. Y. 481 ; Donolion v. Meelier, 35 App. Div. 43.

The judgment should he reversed, and a new trial ordered, with costs to appellant to abide the event. All concur. ${ }^{8}$

\section{§116 UNITED STATES $r$ AMERICAN EXCFANGE NA- TIONAL, BANK.}

70 Federai, Rerorter (I)ist. CT., S. D., N. Y.) $232 .-1895$.

Actons to recover the amount of a pension dralt which defendant had collecterl, as rollerting agrent of another bank; it appearing that the name of the payee hand heon forged upon the draft after leer death. 'The rourt directed a verolict for defendant, and plaintill moved for a new trial.

Brows, J). J. The pension late in this wase wath gaid to the defendant bank hy the subtrasury, upon the fored indorsenent of the

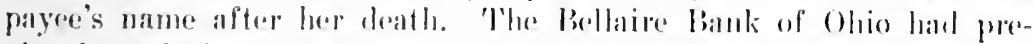

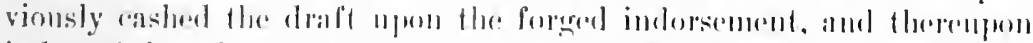
iodresed it "for collention" to the defentant hank at New York. The batter wats the colleneting correspendent of the Bellatre bank as

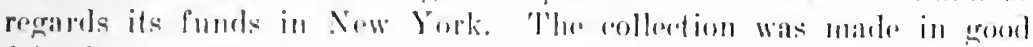

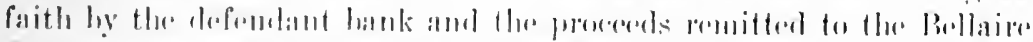

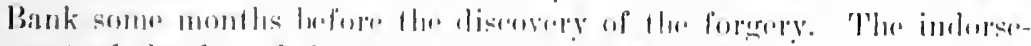

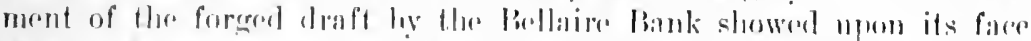

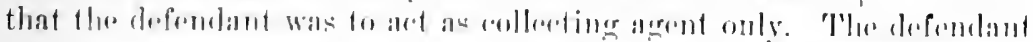

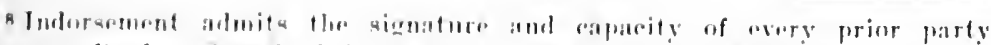

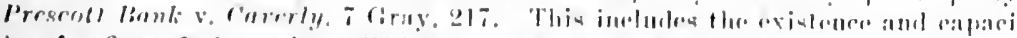

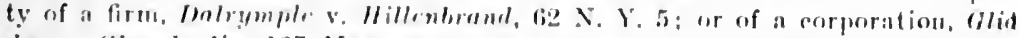

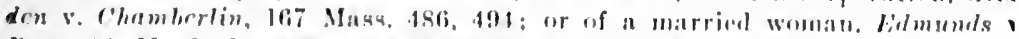
koss, 51 X. I. I. 547. Sine Hanmum v. Richardsom, 48 Vt. 508, ante, A 432. - II. 
never had any property in the dralt or its proceeds. 'The later authorities sustain the proposition that in such a case where the collecting agent pays over the funds before any notice of irregularity or fraud, the remedy is against the principal alone. Bank v. Armstrong, 1.t8 U. S. 50 ; White r. Bank, 102 U. S. 685; Sweeny v. Easter, 1 Wall. 166; Wells, Fargo of Co. v. U. S., 45 Fed. 337; National Park Bank v. Seaboard Bank, 11+ N. Y. 28.

In such cases the indorsement by the collecting agent, who has no proprietary interest, loes not import any guaranty of the genuineness of all prior indorsements, but only of the agent's relation to the prineipal, as stated mpon the face of the draft; and as this relation is evident upon the draft itself, the payor cannot elaim to have been misled by the indorsement of the agent, or any right to rely upon that indorsement as a guaranty of the genuineness of the payee's indorsement.

In the ease of Onondaga Co. Sav. Bh. (64 Fed. ro3), as I find upon examination of the record on appeal, no question like the present arose. The Onondaga Bank was in the same situation as the Bellaire Bank in the present case. It had cashed the forged draft and was colleeting the money for its own benefit as owner of the draft. Its indorsement imported a guaranty of the prior signatures; and the defendant's remedy here is against the Bellaire Bank.

The direction of a verdict for the defendant upon the undisputed facts was, I think, correct, and the motion for a new trial should be denied. ${ }^{9}$

$9 \mathrm{Mr}$. Crawford says that the doctrine of this ease has been changed by the Negotiable Instruments Law. In commenting upon $\$ 116$ on page 89 of the 3rd edition of his work on this statute, he says: "As this and the preceding section inelude the case of every indorser, the warranty as to genuineness will apply to one to whom the paper has been indorsed rectrictively, as, for example, where the indorsement is 'for collection.' This undoubtedly ehanges the law; for the former rule was that the indorsement of a bank to whieh paper had been inforsed 'for collection' did not import a guaranty of the genuineness of all prior indorsements, but only of the agent's relation to the principal as stated upon the face of the paper; and it was held that, in such a case, the eollecting bank was not liable after it had paid the proceeds to its prineipal, though a prior indorcement was a forgery. Unitel states v. American Exchange Nat. Bank, 70 Frd. 232; Nat. Park Bank v. Seaboard Nat. Bank, 114 N. Y. 29. But this rule was exeeedingly ineonvenient in practice, and hence it was deemed expedient to make every indorser a warrantor of genuineness. There is no hardship in this rule, for each indorser has a right of recourse against all prior parties. The former rule, however, introduced such an element of uncertainty that the elearing house associations throughout the country adopted rules to obviate its effeets, and the bankers sent letters to their eustomers requesting that they discontinue the use of the indorsement 'for deposit,' 'for eollection,' ftc. In this, as in several other instances where the law was ehanged, the needs of the business community were deemed of more importance than teehnical prineiples."

For a statement of the action of the elearing house associations, referred to above by Mr. Crawford, see al so First Nat. Bank of Belmont v. First Nat. Bank of Barnesville, 58 Oh. St. 207, at p. 214. - C. 


\section{Liability of Agent as Seller.}

\section{WORTHINGTON $v$. COWLES.}

\section{Massachusetts, $30 .-1873$.}

ACtion to recover back money paid by plaintiff to defendants for a promissory note signed by one Hanson, the indorsement upon which was forged. Defendants were note-brokers, who sold the note for Hanson, and paid him the purchase money, less commissions, before the forgery was discovered. Judgment for plaintiff. Defendants allege exceptions.

Mortox, J. - This is an action of contract upon the implied warranty of the genuineness of the signature to a note sold by the defendants to the plaintiff. The plaintiff clained that in the purchase of the note he dealt solely with the defendants, and upon their eredit. The defendants claimed that they were acting as agents of Hanson in the transaction, and that their prineipal was disclosed to the plaintiff. Upon these points the evidence was eonflicting. 'The defendants asked the court to rule "that if the defendants were in fact agents for Hanson, and disclosed their ageney to the plaintiff, or the plaintiff knew it, or had reasonable cause to know it, the defendants would not be liable."

Considered as an abstract proposition of law, this is too broad. It omits the necessary element that, in the dealing or transaction in question, they were acting as such agents. It may he true that the defendants were agents of Hanson, and known to be such by the plaintiff, and yet if, in the purchase of this note, it was understood by the parties that the plaintiff was dealing with and upon the credit of the defendants, they would be liable. An anent may deal so as to hind himself personally; it is always a question of the intention and understanding of the parties. The presiding judge properly refused to give the instructions in the form requested hy the defendants. Instead thereof, he ruled in substance that the question was, from whom did the plaintiff understand that he was buying the note - from the brokers or from Ilanson? and that if such a state of facts oecurrel. that the plaintiff understond, or ought to have understond as a man of reasomahle intelligenee, that be was dealing with Hanson, the defondants would not be liahle.

Thee instructions were correct, as applied to the facts of the rase. The plaintitf dealt with the defendants. His evidener tended to show that he coutranterl with them as principals. 'T'o ment this prima facie case, the defendants undertook to show that in this transaction they were dealing as agents of a liselosed principal. Unless from their diselosures or other soures the plaintiff understood, or ought as a reasonahle man to have understool, that he was dealing with IIanon, he 
had a right to assume that he was dealing with the defendants as princepals. The instrutions griven were to lhis oflecet, and were as favorable to the defendants as the instructions requested, with the addifion of the necessiry qualitiontion that the defendants were in this transaction dealing is the aruts of Ilanson. (Wilder v. Coules, 100 Mass. As? : Merriam v. Holcoll, is Allen, 25s.)

Axceptions overruled.'

\section{Indorser: secondary, conditional liability.}

\section{Indokslit's Contrac'l as Seller.}

[See precenling subdivision IV, Pl. +19-142.]

2. Indorser's Contract as Assulier of Payment.

$\S 116$

IONG $\bullet$ S'TETHENSON.

72 Nortil Carolina, 569.- 1875 .

Actor acrainst indorser. Plaintifl alleged that the drawee refused to acrept or pay, and that delemblant on demand also refused to pay. Jefemiant allewed non-presentment to drawee and want of notice of dishonor. Inderment for defendant.

SETTıE, J.- The anthorities eited ly the defendant's counsel establish heyond cont roversy:

1. That the rinft should have been presented for payment.

2. That motice of nom-payment should have been given in reasonable time to the dofendant.

As loth of these escential requisites to the maintenance of this action are wanting, we concur with his lonor that the plaintiff is not entitled to reover.

Juderment affirmed. ${ }^{4}$

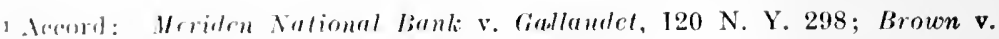
Ames, 5! Minn, 476; Huffent on Agency, \$ $186 .-\mathrm{H}$.

2 Prost. Art. V'II. - H.

3 Post. Art. VIII. As to protest as a third requisite, see Art. XIII, post.-H.

4"The liability of the indorser is strictly conditional, dependent both upon due demand of payment upon the maker or acceptor, and also due and legal notice of the non-payment. The jurpose and object of such demand and notice is to enable the indorser to look to his own interest, and take immediate measures for his indemnity. The demand and notice being conditions precedent to the indorser's liability, it is incumbent on the holder to make clear and satisfactory proof of them before he can recover." Lawson $v$. Farmers' Bank, 1 Ohio St. 206.

"The indorser of a bill of exchange, whether payable after date or after gight, undertakes that the drawee will pay it, if the holder present it to him at maturity and demand payment; and if he refuse to pay it, and the holder 


\section{$\S \mathbf{1 1 7}$ BRUSH $v$. ADMINISTRATORS OF REEVES.}

\section{JoHnson (N. Y.) 439. - 1808 .}

THE plaintiff declared on a promissory note, given by one Spring to Reeves, the intestate, and payable to him or' bearer. 'The note was indorsed over by Reeves, and the present suit was bronght by the indersee agalinst his administrators. There was a general lemurrer to the declaration, which was in the usual form against the indorser.

Per C'urum.- The note was negotiable under the statute. and transferahle without indorsement: hut if the payce chose to put his name on the hack. he hecame as much hound as an indorser, as if the note had heen made payable to him or order.

It was ruled by Chief Justice Holt, in the ease of The Bank of England :. Lirmian (1 Lord Raym. 442), that if a person indorses a bill parahlo 10 hearer, he hecomes a new seeurity, and is liable on the indorsement. The declaration at least is good on a special demurrer. But the defendant may withdraw the demurrer, on payment cf costs, and pleading forthwith.

Judgment for the plaintiff."

$\S 116$

OOTHOUT $r$. BALLARD.

41 B.umour (N. Y.) 33. - 1864.

ACTIOn against indorsers on note dur Nov. 29 (Saturday). Totice of dishonor received about $6 \mathrm{f}$ P. M. of that day. Service of summons and romplaint in this action soon after on the same day. Imlgment for plaintitf.

By the Court, Masox. I.- The only question presented in this case is whether a suit can he maintained agrainst the indorsers of a note payable at a lank, and which has heen duly protested. where the suit is commenered on the day of the protest, or the thicd day of grace. The rule in England, as understood by Chilly. is that the

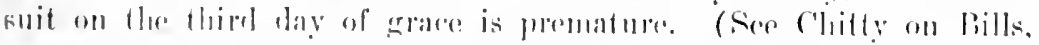

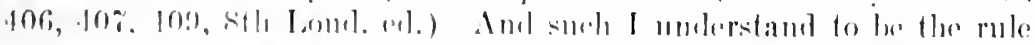

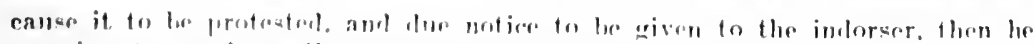

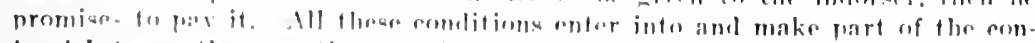

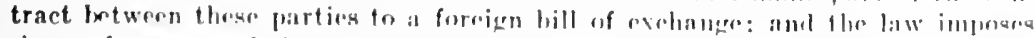

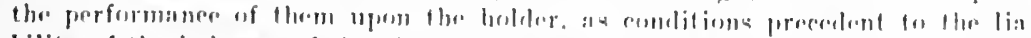

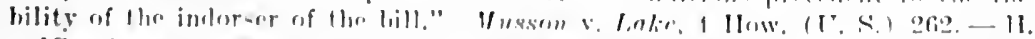

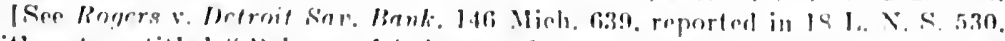
with note entitlol " lieleisur of inderser of note by failure to enforce linbility of maker." - $r$ '.

s Sec j. Hit, note (2), post. -11 . 
held in West:minster Hall. (Castrique v. Bernabo, 6 Queen's B. R. 498: lifferty r. Mills. \& T. R. 170.) The rule is so understood by Byles. (Sce his late work on Bills, p. 181.) In this country there is eertainly considerable conflict of authority over the question, in the courts of the different states. The courts of Maine, New Hampshire, Massachusetts, South ('arolina, and some others, have held that the suit could he commenced on the third day of grace, at any time after the close of banking hours and proper protesting of the note. (1 Pick. 401:21 id. 310:8 id. 414; 1 Metcalf, 43, 48; 4 Greenl. Rep. 479; $千$ N. Hamp. Rep. 199; 8 Foster, 302; 4 Humph. 241; 5 Shep. $230 ; 31$ Maine Rep. $580 ; 40$ id. 62; 15 id. 67; Wilson v. Williamson, 1 Nott \& McCord, 440.) While on the other hand the courts of Pennsylrania, Ohio, lllinois, Mississippi, Alabama and some others have held the suit prematurely brought if commenced on the third day of grace. (Thomas v. Shoemaker, 6 Watts \& Serg. 179; Walter v. Kirk, 14 Illinois Rep. 55; Wiggle v. Thomason, 11 Smedes \& Marsh. 452; Bearan v. Eldridge, 2 Miles, 353; Randolph v. Cook, 2 Porter, S65; 5 Serg. \& R. 318.)

The rule in this state has long been regarded as settled that the suit rommenced on the third day of grace was prematurely brought. The question came before the Supreme Court in IIogan v. Cuyler (8 Cowen's Rep. 203), when it was held to be premature to commence the suit on the third day of grace. The question was distinctly presented again in Osborn v. Moncure (3 Wend. 170), when it was distinctly held the suit could not he maintained, when commenced on the third day of grace. Chief Justice Savage regarded the rule so well settled with us, in this state, that he held in Hopping v. Quin (12 Wend. 517), that where an attorney commenced a suit upon a note on the third day of grace and was beaten and then brought suit against his client to recover for his services, he was not entitled to recover; and in speaking upon this question he says: "It was the duty of the plaintiff to have known that a suit could not be brought on the last day of grace; and his hringing such a suit mist be imputed either to negligence or ignorance. In either case it lays no foundation for an action against his client, who has been the sufferer." There is no case in the courts of this state to the contrary of these eases, while all the elementary hooks have treated our law in this state as settled in conformity to these cases. Judge Cowen so regarded it when ho wrote his treatise. (1 Cowen's Tr. 220, ed. 184t), where he lays down the doetrine distinctly, that the suit cannot he maintained if commenced on the last day of grace. And so Edwards regards it in his treatise on Bills and Notes (see pages $525,526,527)$; and the rule in this state is so regarded by Parsons in his treatise. (Sce Vol. 1, page 440, and also note i.) Chief Justice Shaw regards our rule in this state as different from theirs. (1 Metcalf, 54.) 
The rule in England seems to have conformed to a general practice - the practice to postpone notice of the dishonor and other proceedings, till the day following - so that it has been regarded amongst merchants as a right to have all of the last day of grace in which to pay In Hartley's case (1 Carr. \& P. 555), Abbott, Ch. J., on a motion to show cause, said, "I think the notice of dishonor given on the day on which the bill is payable, will be good or bad as the acceptor may or not afterwards pay the bill. If he does not afterwards pay, on that day the notice is good, and if he does it of course comes to nothing." And Byles, in his late valuable treatise on Bills. page 131, says: "The acceptor of a bill, whether inland or foreign, or the maker of a note, should pay it on demand made at any time within business hours on the day it falls due, and if it be not paid on such demand the holder may instantly treat it as dishonored. But," he alds, " the acceptor has the whole of that day within which to make payment, and though he should in the course of the day refuse payment, which entitles the holder to give notice of dishonor, yet if he subsequently on the same day makes payment it is good, and the notice of dishonor becomes of no avail." "This is precisely as I understand the rule with us. Now if we admit that the courts of Massachusetts, Maine, New Iampshire, etc., have the better reason for their decisions, there is no such great principle involved in the case as would justify us in overruling our own cases and following theirs; especially so where we are supported by equal weight of authority on our side; and Parsons, who is an earnest advocate on the other side, admits that "there is strong reason for holding that a party bound to pay has the whole of the day of maturity." (Parsons on Notes and Bills, vol. 2, p. 460.) And our rule has certainly one advantage; it tends to uniformity in the law by conforming to the general rule with reference to all other contracts, which holds that when a day is appointed for the payment of money the payer has the whole of the day, down to the last moment, in which to tender the money.

It is proper to remark that none of the cases make any difference or distinetion between the case of the maker or indorser. None can be made. As regards this question of the right to bring the suit, there is not and ought not to be any distinction between a note payable at bank and one payable at large, or at the counting house of the merchant; and none seems to have heen recognized in this state. (2 Cowen, 766.)

Nẹw trial granted. 


\title{
3. Irregular Indorser.
}

\section{$\S 114$}

\author{
COUI'TER v. RIOHMOND.
}

59 New York, 478. - 1875.

- [The following note was in the first edition appended to the ease of Coulter $v$. Richmond, $59 \mathrm{~N}$. Y. $47 \mathrm{~s}$, which is omitted in this edition. It will of course be ohserved that the note gives the law as it existed prior to the enactment of the Negotiable Instruments Law. - C.]

IRREGU IaR IXDORSER. There is a hopeless conflict of judicial authority as to the nature of the contraet of the irregular indorser, e.g. where a negotiable instrument payable to $\mathrm{A}$. is indorsed first by B., delivered to A., and then (per. haps) indorsed by $A$. and transferred to ( . The matter is solved, first, by a presumption from the appearance of the paper, and, sceond, by parol evidence as to the time of R.'s indorsement or ats to that and also as to the actual contract intended by the parties. The contlieting rules may be thus stated:

I. Presumption that $B$. is an indorser. (1) The presumption from the appearance of the paper is that $B$. is a second indorser. (a) Upon proof that the indorsement was made before delivery to the payee (A.), the irregular indorser (B.) is treated as the first unqualified indorser and is liable as such to the payee (unless he signed for the aceommodation of the payee), and to subsequent parties. It is as if the payee (A.) indorses without recourse to the irregular indorser (B.), and the latter then indorses in blank to the payee. In theory, therefore, the payee (A.) is the first (qualified) indorser; the irregular indorser (B.) is the second (unqualified) indorser; and should the payee (A.) then indorse in blank he becomes the third (unqualified) indorser. It is a short ent to say that the irregular indorser is the first indorser, because he is the first unqualified inlorser. Moore v. Cross, 19 N. Y. 227; Wade v. Crcighton, 25 Ore. 455; Blakrslee v. llewett, 76 Wis. 34l. (b) Upon parol proof as above the same rule follows, but parol proof is further admissible to show the actual contraet, as that the irregular indorser signed as maker or (if statute of frauds ean be eseaped), guarantor. De lauw v. Bank of Salem, 126 Ind. 553; Schafrr v. Farmers', etc., Bank, 59 Pa. St. 144; Central N. B. v. Dreydoppel, 134 Pa. St. 499; Hayden v. Weldon, 43 N. J. L. 128; Neal v. Wilson, 79 Ga. 736 . (c) But if the instrument is non-negotiable, the irregular indorser is held to be a maker or guarantor. Cromucll v. Ilevitt, 40 N. Y. 492; First N. B. v. Babcork, 94 Cal. 96; Pool v. Anderson, 116 Ind. 88 ; Gorman v. Krtchum, 33 Wis. 427.

(2) In Alabama it seems that the irregular indorser is treated as a regular first indorser. Hooks v. Anderson, 58 Ala. 238. See also Fucn Lung v. Burke, 9 Ilawaiian Rep. 142.

(3) By statute in snme jurislictions the irregular indorser is treated as a regular indorser. I3ills of Exchange Aet (Eng.), § 56, and Chalmer's Notes, p. 188 et seq.; Dominion Bills of Exehange Aet (('anada), § 56; California Code, § 3117, and see Fessenden v. Summers, 62 Cal. 484; Massachusetts St. of 1874 , c. 404 . In Massachusetts the original doetrine that the irregular indorser is liable as a co-maker (Union Bank v. Willis, 8 Met. 504), seems to be modified only to the extent of requiring that the irregular indorser have notice of dishonor. The irregular indorser in Massachusetts is therefore a co-maker with a right to notice of non-payment the same as an indorser. Mulcare v. Welch, 160 Mass. 58; Legg v. Vinal, 165 Mass. 555; Connecticut Gen. St., $\S 1860$. a construed in spencer v. Allerton, 60 Conn. 410 (now governed by Neg. Inst. L.). 


\title{
$\S 114$ ROCKFIELD $v$. FIRST NATIONAL BANK OF SPRING- FIELD.
}

\author{
77 Oнio State, 311. - 1907.
}

Action on note indorsed by defendants Rockfield, Snyder and others before delivery to plaintiff. Defendants answered that they were not notified of the nonpayment of the note by the maker at maturity. Plaintiff's demurrer to answer was sustained, and defendants not pleading further, judgment was rendered against them. Defendants bring error.

II. Presuimption that B. is a co-maker. (1) The presumption from the appearance of the paper $i$ s that the irregular indorser (D.) i- a comaker. Good v. Martin, 95 I. S. 90: Coonl v. Marlin, I Coln. 165: Tabor r. IJiles, 15 Colo. App. 127; Jféallum v. Drig!ls. 35 Fla. 27T: Bralford v. Prescott, 85 Me. 482; Schroeder v. Turner. GS Mhl. s06: Gumz v. Giraling. 10s Mich. 295 ; Peninsular Bank r. Ilosif. 112 Miel. 351; Irnnis v. Jarksm. 57 Minn. 2S6; Schaltz v. Howard, fi3 Minn. 196: Rirhardson v. Foster. 33 Miss. 12: Mastin Bank v. Hammerslom!h. i2 Mo. 274 lef. First Mat. Bl. v. Iayme. 111 No. 291): Salisbury v. First T. B.. 37 Neh. si2: Sargent v. lioblins. 19 X. II. 572; Meletrich v. Woolmow, 6i X. II. 17t; Hoffmm v. Joore, 82 X. Car. 313;

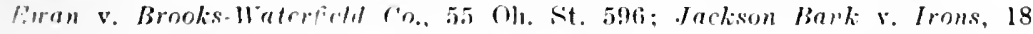

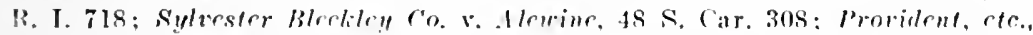
Sior. v. Edmonrls, 95 Tinn. 53: Barton v. Ameriean X. B.. \& Tex. Civ. App. 223; Bank v. Dorset IIarble ro., (il Vt. Inti; Donohoe-Kelly Banking r'o. v. Pugft Sound Sar. Bank, 1:3 Wash. 407. (a) Mont of the alwe juristictions allow parol evilonce to show the real eontract. I banicl on Neug. Inst.. \$\$ Tlo. i12. (b) A fow stalos do not if in fact B. siened lowere delivery to the payee. Dennis v, Jarksom. 57 Minn. zsti.

(2) But if the paper is payalile to the drawer's or maker's own oriler and indresed by B. lefore mencetiation, the irregular indorser is treated as a first

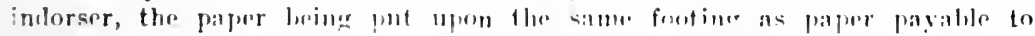

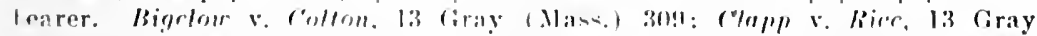

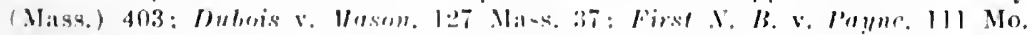

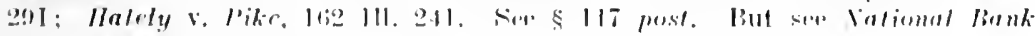

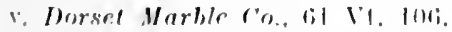

(3) In one or two talles it areme immaterial that the payes actually

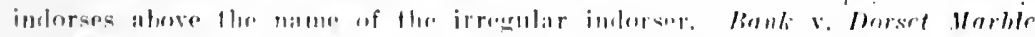

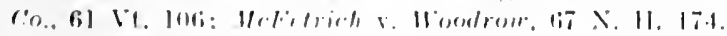

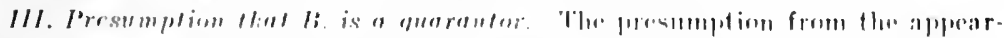

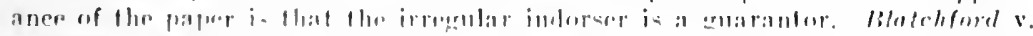

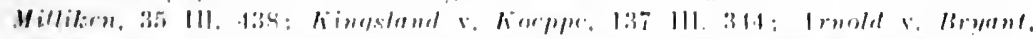

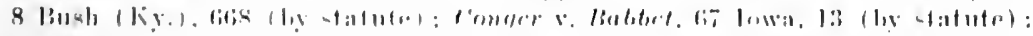

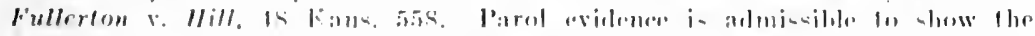

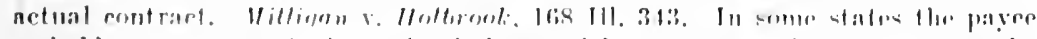

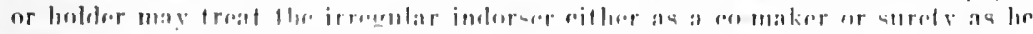

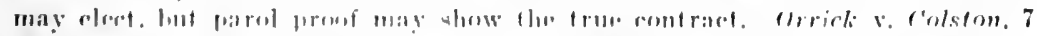

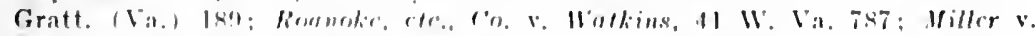
Clendennin. $12 \mathrm{~W}, \mathrm{~V}: 11 \mathrm{li}$

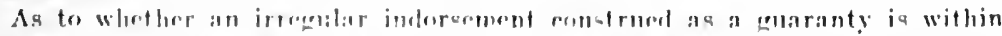

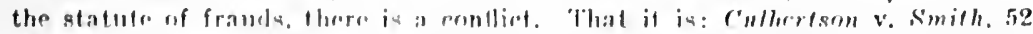

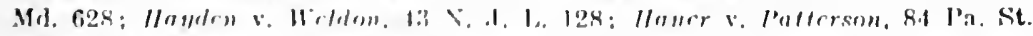

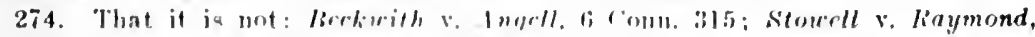
8. III. 120; Peterkon v. Russ.ll, lis Minn, 220, - H, 
Spran, I. Whether or not the answer avers a defense to the cause of action set up in the petition is the question here. 'The theory of the defendants plealing is that lockficld and Snyder, hy writing their names across the back of the note, beame indorsers in the commereial sense, and therefore entitled to notice of demand at maturity of the maker and of nonpayment, and, failing that, no liability attached. 'The theory of the petition is that these defendants, having signed the note before delivery, must be held to have signed with the purpose of giving it credit and of aiding negotiability, and therefore stand as makers, and althongh their names appear on the back of the instrument, and they are in law sureties, yet they are not indorsers in the commercial sense, and therefore not entitled to notice of demand and nompayment. 'This view is the one adopted by the trial court, which incorporated in the judgment entry a finding that the defeudants are indebted as joint and several makers of the note, and this is the view taken of the question by the Circuit Court in affirming the judgment of the common pleas. Which is the correct view is the question we have.

'That the conclusion adopted by the lower courts is in accord with the law as held in this state from early times, and with all decisions of this court thus far made, is conceded. 'The latest deliverance on the subjert is the case of Euan v. Broolis-Wraterfield Co., 55 Ohio St. 596, opinion by Williams, C. J. It is there held that where the name of a third party, a stranger to the note, appears in blank upon the back of the note at the time it takes effect, his undertaking rests upon the consideration which supports the note, and the presumption is that he inteuded to be liable as a surety, and he will be held accordingly unless it is shown that there was a different agreement between the partics. 'This conclusion is reached after a careful and somewhat extended review of authorities, many of them rlecisions of this court, and is supported by strong and convineing argument. While a contrary doctrine, holding such party to be an indorser in the commercial sense. har been held in a number of states, notahly Alabama, California, Connectiont, Indiana, Mississippi, New York, Oregon, Pennsylvania, and Wisconsin, the Ohio rule, as above indicated, had been the settled common law rule of the states of Arkansas, Colorado, Delaware, Maine, Maryland, Massachusetts, Michigan, Minnesota, Missouri, New Mampshire, North Carolina, Rhode Island, South Carolina, Texas, Utalı, and Vermont.

The statute referrer to is the act of April 17, 1902, known as the Negotiable Instruments Act (95 Ohjo Laws, p. 162), carried into the Revised Statutes of 1906 as sections 3171 to $3178 \mathrm{~g}$, inclusive, the particular sections relied upon being $3171,3173 h, 3173 i, 3173 k$, $3173 q, 3174 \mathrm{~g}$ and $3178 a .^{7}$

7 N. Y., $\S 20,113,114,116,132,160$, and 3. - C, 
[After giving the substance of these seetions, the court continues:]

The question at issue very largely turns upon what is meant by the terms of seetion $31 \% 3 i$, , the substance of which we here repeat: "Where a person not otherwise a party to an instrument places thereon his signature in blank before delivery, he is liable as indorser," etc. It seems to have been the view of the learned Cirenit Court (see opinion by Dustin, J., 8 O. C. C. [N. S.] 290) that, inasmuch as the liability defined by the rules following the abovequoted portion of section $3173 i$ does not differ essentially from the liability attaching to such party under the decisions of this court, no change in the law can be presumed to have been intended by the General Assembly in the enactment of the statute. Also, that the subsequent provisions of the sections relating to indorsers and providing what shall be done to fix liability, etc., are not inconsistent with this conclusion because the later sections apply only to general indorsers, and in those sections everv indorser is deseribed as such is called an indorser - while in the earlier section the party described is only to be deemed an indorser, and has the liability of an indorser only to a limited extent. The contention, further, is that the terms of section $3173 h^{9}$ forbid the conclusion that such party is to he deemed an indorser in the commercial sense, hecause he must, in order to have that effect, place his name on the back otherwise than as maker, and the rule is, and was, that the person so placing his name is a maker unless he shows a different agreement between the parties.

There is muck plansibility in these contentions, and they would seem to be sound were it not for the incorporation of the worls " ns indorser" in section 3173i. Ilad these words heen left ont of the section the construction claimen would not secm an munatural one. But we are required, by the inexorable mule of construction, to grive to them some signification - some moning consistrut with a rational purpose in placing them in the statute. 'The lawnakers were making law. They camot he presumed to have lecen simply dealing with

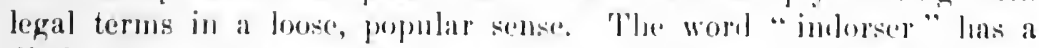
distinct, elearly defined legal meaning. An indorser is one who modertakes to be responsibse to the holder of the palper for the amount thereof, if the latter shall, at maturity, make legall demand of the payer, and, in defanlt of payment, grive proper notice thereof to the indorser. The languago of the seretion is plain and free from ambiguity. The words express a clear memuing. The party has placed his name upon the instrument, where general indorsurs sient. Ho is not a party to the notr, luit is a stranger. Sertion $31 \% 11$ sars he shall be decomed to be mu indorser unless he reanly indiutus by appro-

N. Y. \$ $114 .-C$.

- N. Y., \$113. - C. 
priate words his intention to be bound in some other eapacity. IIe has not so indicated. He has used no words appropriate or otherwise. His status on the paper is, therefore, fixed hy the emphatic words of the statute. 'Ihen follows the fixing of liability. He is liable "as indorser." And how is that? Why, he must pay when, and only when, proper demand has heen made of the maker at maturity and legal notice given him. This is clearly shown by what follows. Every indorser who indorses without qualifieation engages that on due presentment and dishonor, and due notice to him, he will pay. 'This expresses the extent of his liability; without these requisites being complied with he is discharged. And, then, as though to cover a doubtful situation, the provision is (seetion $3171 p)^{1}$ that, where the language of an instrument is ambiguous, because of the signature being so plared that it is not elear in what capacity the person intended to sign, he is deemed to be an indorser. Of the rules preseribed by section $31 \% 3 i$, it is enough to say that they are not ineonsistent with the obligation of the general indorser. He, too, is liable to those who come after him as indorsers or holder. The important question is, not to whom is such party liable, but in what capacity in what retation - is he liable?

The contention that the provision (section $3173 k)^{2}$ to the effect that every indorser undertakes to pay if the instrument is dishonored and he has due notice applies only to general indorsers, we think untenable. The language forbids it. It is: "Every indorser who indores withont qualification," ete. "The word "every" is a term of inclusion. It embraces every party who, by previous provisions, is classed as an indorser unless his indorsement has been qualified hy appropriate words. Nor is the obligation as indorser imposed on the stranger an mreasonable one, for, if not content to assume the position of indorser, the opportmity to indieate upon the paper his intention to be bound in some other aparity is given him.

The contention that these later provisions relate only to general indorsers rests wholly on the assumption that in placing his name on the back in blank the stranger himself fixes lis own position and that he has ronclusively declared himself a maker; that is, that he has placed his name as maker. But it seems a sufficient answer to this to say that lif has not and could not, by a mere blank indorsoment, so plare himself, herause the statute fixes his position. That position is important only as it relates to his liability, and the statute has sain that that liability is "as indorser." An indorser is not a maker or a ilrawer; not one primarily liable. This eonelusion ignores neitlar the words, "A person placing his name upon an instrument otherwise than as maker," ete., nor the words, "Where a

1 X. Y., \& 3fi. $-\mathrm{C}$.

2 N. Y., §116. - C. 
person not otherwise a party to an instrument places," etc. Both sections must be construed together. Thus construed, they simply describe a person who is not a party by the terms of the instrument. And he is not, in fact, such party, in any possible sense, at the time he places his signature. He remains a total stranger until he has placed his name on the back, and then the statute says he is an indorser.

But other considerations enter into the question. It is so much a matter of common knowledge as to make it proper to take judicial notice of the fact that the act herein considered was enacted because of an effort on the part of the bar of many, if not all, of the states of the Union to bring about a uniform system of law respecting negotiable instruments. In a substantial measure the effort has been successful. Of the states which had, by judicial decision, adopted the rule prevailing in this state, the legislatures of the following have enacted a Negotiable Instruments Act substantially like that of Ohio, viz.: Colorado, Maryland, Massachusetts, North Carolina, Rhode Island, and Utah. And it has been enacted also in the states of Connecticut, Florida, Iowa, New Jersey, New York, North Dakota, Oregon, Pennsylvania, Tennessee, Virginia, Washington, and Wisconsin. Joyce on Defenses to Commercial Paper, at page 859, gives a list of 32 states and territories which have passed the act. All of these several statutes are not framed, in the particular here under investigation, in the exact language of the Ohio act, but it is believed that they all emborly the same principle, and it is manifest that one prominent motive leading to their enactment was the desire to establish a uniform law on the subject of negotiable instruments. And wherever these acts have recelved judicial interpretation in the several states this purpose has been recognized. See Fessenden v. S'ummers, 62 ('al. 481 ; Fisk v. Miller, 63 Cal. 367; Downey v. O'Keefe, 26 R. I. 571 : Thorpe v. While, 188 Mass. 333, 7 Cyc. 673; Bank v. Law, 127 Mass. 72;'Toole v. Crafts, 193 Mass. 110; Cibbs v. Guaraglia, 65 N. J. L. 1 68' Banmeister v. Kuntz, 53 Fla. 810 : Farquhar Co. v. Kigham, 16 N. Dak. 106: Vander Iloeg v. Van Zuuk, 135 Jowa, 350 .

That this purpose was prominent in the minds of the members of our General Assembly in the chactment of the Ohio act is shown

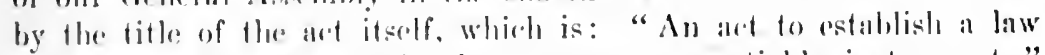
uniform with the laws of other states on negoliable instruments." The desirability of such legislation hat heen long folt by commorecial people of our state ns well as by the judiciary and the har at large. Indeed, the learned jurist who reported the case of Eiran r. BrontesWalerfield Co.e supra. erives axpression to that sentiment in his opinion. True, it is, as sugeresterl hy the cirenit court. that the act (overs many phases of the subject, ind that the title does not apply especially to the sulijert of indorsement, hut inasmuch as this very 
subject had been the source of irreconcilable conflict between judicial utterances in so many states, and that such diflerences of judicial interpretation of the common law had been so marked, and these differences so recently emphasized by this count, and the importance of uniformity in the law on this particular phase of the general subjects had been so recently pointed out, it is inconceivable, it seems to us, that the General Assembly, while treating the subject at large, should have failed to endeavor to estahlish uniformity respecting the position of indorsers and their liability to others connected with the paper. 'T'hese considerations. if they stood alone, and if the language of the act were less plain than it is, would impose a duty upon this court to look for ground in the statute warranting the conclusion that the purpose of the act is to bring Ohio into harmony with the other states of the Union on so important a branch of the law as the relation of parties to commercial paper, but we are not compelled to resort to such an effort, for the plain, natural meaning of the language of the sections cited, as we think, fully warrants, if, indeed, it does not compel, the conclusion hereinbefore indicated, which conclusion is also supported by a number of the cases hereinbefore cited. See Fessenden v. Summers: Fish v. Miller; Downey v. O'Keefe; Thorpe v. White; 7 Cyc.; Bank v. Lau'; Toole v. Crafts; Gibbs v. Guaraglia; Baumeister v. Kuntz; Farquhar Co. v. II igham; Vander Ploeg v. Van Zuuk.

But another purpose seems to us to be indicated by this legislation. Not only were the courts of the country in conflict respecting the attitude and liability of a third party - a stranger - who placed his name in blank on the back of commercial paper, but the situation was in itself an anonialous one, calenlated to lead, as it often did lead, to confusion respecting the duty of the holder of such paper with regard to demand and notice. Mistakes in this respect were easy and were frequently marle, often resulting in litigation, and, not infrequently, loss. To clear this situation up, and to establish a plain, easily understood rule, and one of universal application, was surely a result of high importance to all who deal in commercial paper, and it seems to us that the desire to accomplish this purpose had much to do with inducing the enactment of the Negotiable Instruments Act by our General Assembly.

It follows from these conclusions that by force of seetions 3171 , $3173 h, 3173 i, 3173 k, 31 \% 3 \%, 317+g$, and $3178 a$ of the Revised Statutes of 1906, a person who, heing a stranger to a promissory note, places his name on the hark by blank indorsement, is an indorser of the paper and rannot bo held in any other capacity. As such he is entitled, in ordor to render him liable, to notice of demand upon those who are primarily liable, and, failing such demand anil dhe notice to him, he is discharged. The answer, therefore, stated a defense, 
and the sustaining of the demurrer and rendering judgment for the bank upon the note was error. Judgment reversed, and cause remanded.

Shadck, C. J., and Price, Crew, Summers, and Davis, JJ., concur.

Reversed. ${ }^{3}$

\section{§ 114 HADDOCK, BLANCHARD \& COMPANY v. HADDOCK.}

192 NEW YORK, 499. - 1908.

The Lenape Coal Company executed its promissory note payable to plaintiff. Plaintiff executed several bills of exchange payable to its own order and drawn upon certain coal companies. Said note after it had been signed by said Lenape Coal Company and each of said bills after they had been accepted by the corporation on which they were severally drawn were indorsed by the defendant before delivery, and thereafter before maturity delivered to the plaintiff as payee, and the plaintiff indorsed and procured them to be discounted. The above instruments were indorsed by the defendant for the accommodation of the maker of said note and the acceptor of said bills respectively and for the purpose of giving such maker and acceptors credit with the plaintiff, and the plaintiff was induced to take said instruments by reason of the indorsement of the defendant and pursuant to an agreement that the defendant would be liable thereon to the plaintiff in ease the corporations primarily liable thereon should make default.

Thereafter the plaintiff was compelled to take up the above instruments, and this action is brought to compel the defendant to pay the amount of said instruments pursuant to his agreement with the plaintiff when he indorsed them. 'The plaintiff has succeeded in the courts below, and the defendant has appealed.

Chase, .J. * * * As the facts are found, if the intention of the parties is to prevail, the defendant should he required to pay to the plaintiff the amount of such note and bills as established by the judgment.

The defendant contends that the position of his name upon the note and bills conclusively establishes that he indorsed the seseral instruments without liability to the plaintiff and that parol evidence should not have been received to affect or overeome the allewed ronchusive presumption arisiag from his indorsements as made. * * *

3 This case is reported in $14 \mathrm{~J}$. N. S. 842. with n note entitled "character under uniform negotiable instruments law of one who places his name on the back of a note prior to or at the time of delivery."

See nlao the notea on the liahility of an anomabus indorser at eommon law and under the Negotiablo Inatruments Act in 5 Nich Inw. Lev. 189 (Janunry, 1907), and in 23 Harv. Law liev. 396 (Mareh, 1910). - C. 
There has always been conflict among the courts of the several states both in asserting the principles upon which irregnlar indorsers upon commereial paper ale to he held and in the conchusion arrived at in particular eases litinated. The number of cases is so great, and the possibility of even a partial reconciliation of them so remote, that we will confine unr eitation of authorities wholly to those in this state.

It was well settled in this state for many years prior to the enactment of the Negotiable Instruments Law that a person who puts his name on the back of a bill or note before its delivery, is presumably a second indorser and not liable to the payee, but the presumption could be rebutted by parol evidence to show that the intention of the indorser was to become surety for some prior party to the instrument.*

The Negotiable Instruments Law was first enacted in this state in 189\%. (Laws of 18.)\%, chapter 612.) Section 113 of the said law provides: "A person placing his signature upon an instrument otherwise than as maker, drawer or acceptor is deemed to be an indorser, unless he clearly indicates by appropriate words his intention to be bound in some other capacity."

The defendant was within this definition an indorser of each of said instruments.

Section $11+$ of the said law provides: "Where a person, not otherwise a party to an instrument, places thereon his signature in blank before delivery, he is liable as indorser in accordance with the following rules:

"1. If the instrmment is payable to the order of a third persoi, he is liable to the payre and to all subsequent parties.

"2. If the instrument is payable to the order of the maker or drawer, or is payable to bearer, he is liable to all parties subsequent fo the malier or diawer.

A riting Morre v. roross. supra: Bacon v. Burnham, 37 N. Y. 6l4; Meyer v. II:bsher. 47 N. Y. 265: Phrlps v. Vischer, 50 N. Y. 69: Clothier v, Idriance, 51 V. Y. 322: Hubbard v. Uatthers, 54 N. Y. 43; Coulter v. Richmonl. 5!! N. Y. 47s: Easterly v. Barlorr. fif N. Y. 433: Jaffray v. Broun. 74 N. Y. 393:

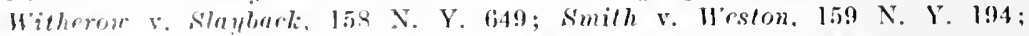
Jamis v. I:ly, 32 App. Div. 124: affd.. 164 X. Y. 527; f'ar Rorkanay Bank v. Norton, 146; X. Y. 484: Lester v. Praine, 39 Barb. 6il6; Forrster v, Siquier, 46

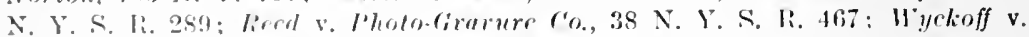

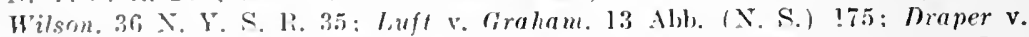
Chase Uf\%. 'o.. 2 Abb. (N. ('.) 7!: Holz v. Woolside Broring Co.. 93 IJun, 192; Hrise v. Woscher, fie Hun. 557: Bank of Port .Jeffersom v. Darling, 91 IIun, 236: Hrndrie v. Kimmer, 84 IJun, 141; Hontyomery v. Schenk, 82 Hun, 24; Mel'hillips v. Jones, 73 Ilum. 5lf: Staiger v. Theiss, 19 Mise. Rep. 170; Rose v. Prackard, 4 Wupkly I)igest, 27; Cuming v. Roderiek, 16 App. Div. 339; Me.Joran v. Lange, 25 Ajp. Div. 11; Howard v. Van Gieson, 46 App. Div. 77; Nagel v. Lutz, di Ajp. Wiv. 193. 
" 3 . If he signs for the accommodation of the payee, he is liable to all parties subsequent to the payee."

By this section of said law the presumption as established by the courts in this state was changed, and an irregular indorser is now presumed to be liable in aceordance with the express language of the statute. Questions relating to the sufficiency of the pleadings are settled by the statute. A complaint upon a note or bill without alleging a collateral agreement between the parties whose names are on the instrument seeking to recover against a person except as provided by the statute, would clearly be demurrable.

The note of the Lenape ('oal Company was payale to the plaintiff, a third person, and the defendant, according to the provisions of said section 114, is liable to the plaintiff, the payee therein. No serious contention has been made to the contrary. The serious question for consideration arises from the fact that the bills were payable to the maker and drawer thereof respectively and the defendant as an indorser thereon before delivery is not under the statute prima facie liable thereon to the plaintiff. Should parol evidence have been allowed to show the intent of the parties? We have not discovered any exception to the rule as estahlished by the courts of this state allowing parol evidence as between the parties whose names appear on the bill or note to determine their lialiility as between themselves. It is frequently stated that where a note is payahle to a person other than the maker and is indorsed by a third person before delivery the intention of the indorser is ambignoms and uncertain on the face of the paper and such uneertianty justifies the receipt of parol evidence to determine the truc intention of the parties. We ro not see that any greater certainty exists upon the face of a hill as to the true intention of the praties where it is drawn to bearer or to the order of the maker, and it is indorsen by a third person after areeptance hy the arceptor and before delivery to the payee and maker. There is a certain rule of presumption determined ly common law or by statute, but the allewerl reason for the rule in either cisce is not very

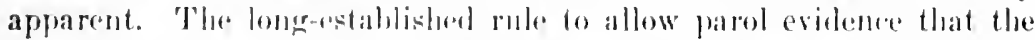
intention of the parties maly presail serons to have met with some-

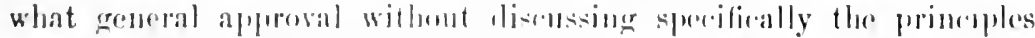

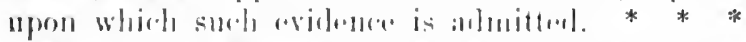

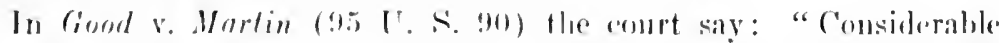
derersity of deeision, it most be andmitted, is found in the reporterl cases where the record presents the also of a hank indorsement by a thirel party, mals hefore the instrument is indorserd by the payce and before it is deliverest to take effect. the question being whether the party is to he dowmorl an oriecinal promieor, enuantontor or in-

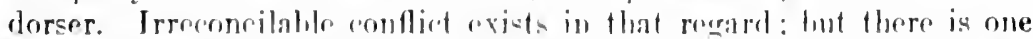
prineiple nyou the suliject almoet univereally almitent hy them all, and that is, that the interpretation of the contract oughit in every 
case to be such as will carry into effect the intention of the parties, and in most cases it is admitted that proof of facts and circumstances which took place at the time of the transiction are almissible to aid in the interpretation of the language employed. (Denton v. Peters, L. R. [5 Q. B.] 475.) " * * *

It must constantly be borne in mind that the aceptance of a bill makes the acceptor the principal debtor. A bill when aceepted becomes similar to a promissory note, the acceptor being the promisor and the drawer standing in the relation of an indorser. (Daniel on Negotiable Instruments [5th edition], seetion 53\%.) There is nothing in the Negotiable Instruments Law to indicate an intention on the part of the legislature to change the rule as established in this state relating to the receipt of parol evidence to determine the prinary liability as between the persons whose names appear upon the instrument or as between those secondarily liable thereon.

By section 55 of the Negotiable Instruments Law it is provided: "An accommodation party is one who has signed the instrument as maker, drawer, acceptor or indorser, withont receiving value therefor, and for the purpose of lending his name to some other person. Such a person is liable on the instrument to a liolder for value, notwithstanding such holder at the time of taking the instrument knew him to be only an accommodation party."

Parol evidence is necessary to determine whether a party to an instrument, including an indorser thereon, is an accommodation party, and also to determine which other party to the instrument he had accommodated. The plaintifl was the holder of the note for value, and the evidence showed that the defendant was an accommodation indorser for the benefit of the acceptor.

The last subdivision of section 114, as we have quoted, makes parol evidence neressary to establish whether the indorser signed the instrument for the accommodation of the payee. It is true that this section does not expressly state that if the indorser signed for the accommodation of the acceptor he is liable to all parties subsequent to the acceptor, but the fact that such a provision is not included in section 114 does not prevent the admission of parol evidence to determine generally the questions relating to an accommodation party as provided by sertion 55.

The Negotiable Instruments Law by section 7 provides: "In any case not provided for in this act the rules of the law merchant shall govern."

By section 118 of the Negotiable Instruments Law it is provided: "As respects one another, indorsers are liable prima facie in the order in which they indorse: but evidence is admissible to show that as between or among themselves they have ngreed otherwise."

As we have seen, upnn the arceptance of the bill the acceptor becomes the principal debtor and the one primarily liable to pay the 
amount of the bill, and all other parties to the instrument, including the maker and indorser, are secondarily liable. We are of the opinion that the maker of the bill is in legal effect and within the intention of this section an indorser, and that as between the plaintiff and the defendant parol evidence is authorized to determine the liability as between them.

The articles of the Negotiable Instruments Law relating to the presentation of bills and notes for payment and notice of dishonor (Articles $i$ and $s$ ) further show an intention by the legislature to leave the order of liability among those whose names are on the instrument subject to determination hy any competent evidence. [Quoting sections 130,139, 140, 160, 186, subd. 3.]

There is no reason that we can conceive why the legislature should intend to change the rule in regard to the arlmission of parol evidence as it had existed in this state for many years. All of the quotations that we have made from the Negotiable Instruments Law show that it has enlarged rather than restricted the rules allowing parol evidence to show the true liahility and relation of the parties whose names appear upon the bill or note in all actions between themselves. It is certainly very material to the drawer of a bill whether an indorser signs it at his request or at the request and for the benefit of the acceptor. We do not think it was the intention of the legislature by the enactment of section $11 . t$ of the Negotiable Instruments Law to establish a rule as to the liability of an irregular indorser conclusive on the parties to the instrument as between themselves in an action where the facts sliowing a different intention are fully alleged. All of the decisions of our rourts since the enactment of the Negotiahle Instruments Law tom to sustain thr views herein expresed. (Corn v. Lery, 97 App. Div. 48: Kolln v. Comsolidated Buller of Egg Co., 30 Mise. Rep. 725.) In the rase last mentioned MeAnom, .T., said: "Prior to the statute of 1897 (supra) the allegation referred to was a neressary one in such coses, and. if denied, the onus of proving the allegation was on the plinintiff, for the payee was presumably the first indorser. (Daniel's Nog. Inst. | Hth ed.l sece 701: Woorl's Byles Bills, 151, notre and ('ases hefore eiferl) Since the statute the legal presumption is changerd wher the complaint allegres that the irregular indorsels indored the papere 'hefore delisery' to

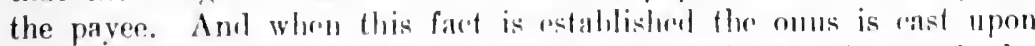
such indorsers to alloge and prowe Hoal. motwithstanding surh de-

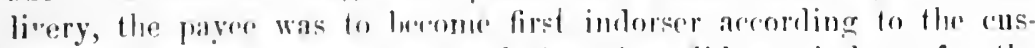
tomary form of the contract and that they did not indorse for the purpose of lending their aredit to the makcer or with the intention of becoming liable to the payere. That this is flw proper interpretation of the act is ntwioms. Fhe true intention of imborsers as hetwens thenselves an aiways be shown by oral revidener. (Daniol's Neg.

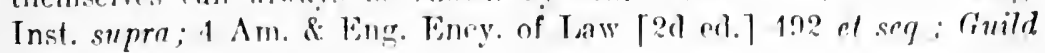


צ. Butler. 129 Mass. 386; Cady v. Sheperd. 1? Wis. ti39; Benjamin's C'lambers [iills |:mal Am. al.|, :50: II ilherow v. Slaybach, 158 N. Y. (il:!.) 'To so further and decinle that the statute intended to ereate an incontestable liability ananst irregular indorsers would be to impute to the legistative wislon a design repugnant to every notion of juliadal procedure, esporially in a provision enacted in the juterest of liw reform."

'The judgment slould he aflimed, with costs.

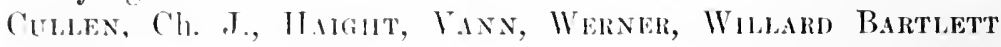
and Hiscock, T., coneur.

Judgment affirmed.5

\section{\&113 NATIONAL EXCIIANGE BANK $\because$ LUBRANO.}

29 RHODE ISIAND, 64. - 1908.

Arton on mote. Plaintifls declatation alleged "that D. I)i Imalio and Michael Imbrano, doing businese as D. Di Tuglio Company, * * * hy their noto * * * by thrm signed as D. Di Jugrio Company * * * promiserl said plaintift to pay it or order * * * and the salil defendant individually then and thero indorsed and delivered said note to said plaintiff." "The declaration then allegerl presentment to makers when due, failure to pay, amel due notice to lefendant of the dishonor of the note. Defendant ele murred to the dectaration on the ganomal that by the declanation it

5"This case is reported in 1! I. N. S. 136. with note ontitled "Admissibility of parol avilence to vary the liability of an irregular party to a bill or note from that declarml hy thr Nogotiable In-trmments Act."

Sre also Verrantile lianti of Hemphis v. B. I. Busby. at al.e 120 Tenn. (i5:2. where the court, on pase tit6;, says: "We are of opinion that the real

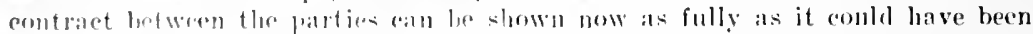

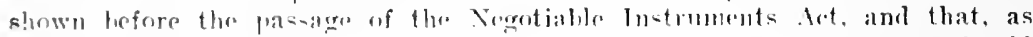
hetwern the immediate parties. it is not nereseary that the indersement should he aceompanied ly alperopriate worls in writing. showing an intention to be

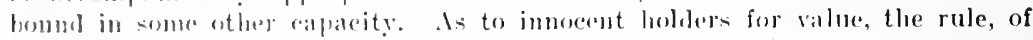
cour

But in lianmeister v. Kuntz. 53 Fla. 340. at p. 3.15, the court said: "The main question for delormination is: Jose the imborsament in hank before delivery of a promisenry note for tho purpuse of griving eredit to the maker. so fix a - matile of law not the status but the liability and rights

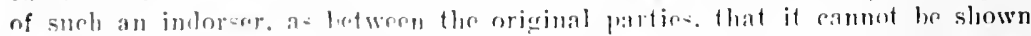
that we the eoures of enduef of the parties atfemliner the indorsement, that the right of the indorare lo las lomand marle on the maker of the note for payment at maturily, wa- waivol or as to make the imblorser's liability not

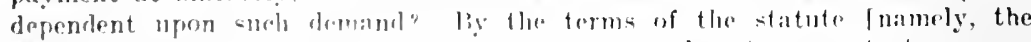

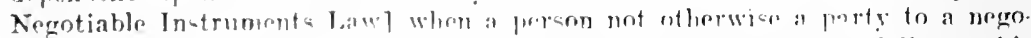
tiable instrument plaros flerene his simntume in hank hefore ilelivery, his status is fixed as that of an indorer. Where the safufe tixac the status of a

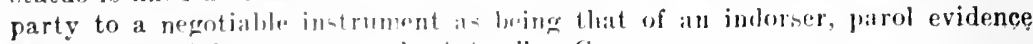
is not admissible to vary such status." - C. 
appeared that defendant's liability on the note was a joint liability with one D. Di Luglio, and not a several liability. Demurrer was overruled and defendant excepted.

Parkiurst, J. * * * The first exception must be overruled. The declaration shows that the defendant, Lubrano, wis a maker of the note as a partner with one D. Di Luglio, under the firm name of "D. Di Luglio Con!nany," as signed on the note. If Lmbrano had placed his name npon t?r hack of the note before delivery. under the law of this state, as it rxised prior to the passage of the "Negntiable Instruments A.t" (rlapter 6it, p. 2e?, Jan., 1s!9)), he would simply have become a joint maker of the note. As he was a maker already, his relation to the note would not have been changed, and his liability thereunder would neither have increased nor diminished. His act would simply have been nugatory. Under the Negotiable Instruments Act, however, we think he may fairly be held to have

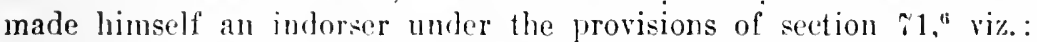
"A person placing his signature upon an instrument otherwise than as maker, drawer, or aceptor is deemed to he an indorser, unless he clearly indicates by appropriate words his intention to be bound in some other capacity." See, also, Negotiable Instruments Act, P. 22S, c. 6ĩt, \$25, cl. 6. ${ }^{i}$ See HeLeron v. Bryer, 24 R. I. 599; Douney v. O'Keefe, 26 R. I. 501; Deahy r. Choquel, 28 R. 1. 338. In other words, we are of the opinion that the defendant, by so indorsing said note, added to his liahility as maker a several and distinct liability as indorser, thereby making himsolf imlividually liable for the payment of the note, after due notice of dislionor, and thereby also guaranteeing the signature on the fare of the note. and that the plaintiff had a right, if it saw fit, fo sur him as such iurlorser, als it has done. 'The demurer to the derlaration was therefore properly overruled. ${ }^{\mathrm{n}}$

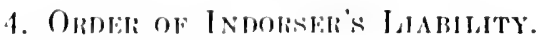

$\$ 118$ MOOLE $r$ R'TSIIING. 162 Massachustit's, 594. - 1895.

Contnaet, against Lomis 'T'. ('ushing and Harvey H. Pratt upon the following promiseory notr:

$\$ 500$. $2.4 .1 \% 1 \%, 1593$.

Three monlhs after date. I promiure to pay to the order of William Moore five hundred dollare. layable at any bank in Bostom. Value receiverd.

(Indorsed): Ioniq T. Fushing, William Monre.

HanVEY H. PritT.

6 N. Y., \&113. - $\mathrm{C}$.

T N. Y.. \& $36 .-C^{\circ}$.

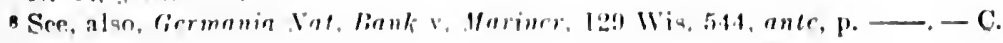


The case was submitted to the Superior Court, and, after judgment for the plaintill, to this court, on appeal, on agreed facts, in substance as follows:

Before the delivery of the note l'ratt requested the plaintiff to gret it discounted, and the plaintill rofused unless there was a satisfactory indorser. 'Therempon the plantifl aceompanied Pratt to the othice of Cushing, whom the plaintiff told that he was going to have the note discounted for 'ratt, provided Pratt olstained a satisfactory imbores. The plaintiff aslied Cushing if he was good for the amount, and Cushing said that lie was, and that the note would be paid when due: and that he was willing to inlore the note for the accommodation of Pratt. so that the note might be discounted for his benefit. The note was then indorsed by Cushing at the request of Pratt, and was delivered to the plaintilf, who thereafter himself indorsed it and had it discounted, and the proceeds were used for the benefit of Pratt. 'The plaintifl was obliged to pay the note, and Cushing alone defended. Pratt having been defaulted.

Hor.ses, J.- This is a suit upon a note between two persons, who both became parties on it for the accommodation of the maker. The defundant Cushing indorsed the note before delivery; the plaintiff is the payee, and indorsed after the defendant. If the plaintiff had not known that the defendant indorsed the note for accommodation, he would have been entitled to recover. (Ioods v. Woods, 127 Mass. 141.) Knowlerge of that fact under the circumstances stated does not affert his rights. In the absence of agreement, successive indorsers for the aceommodation of a third person are liable in the same order as indorsel's for value. (Shaw v. Knor, 98 Mass. 214; Danl. Neg. Inst. [3r ed.], \& 703.) The conversation which took place hotween the parties. so far from pxpressing a different agreement. aave notice to the defendant that the plaintiff required his indorsement as the condition of hecoming a party. It fortifies the presumption arising from the face of the paper. The suggestion on belsalf of the defondant. that he signed also for the acrommorlation of the plaintiff, perverts, if it does not contralict, the agreed facts. It was urcerl that the plaintiff took the note when overdue. But his rights and liahilitios wore fixed at the time of his indorsement. If the argument was sound, the judgment ought to have been for the defendant-indorser in Woods v. Woods.

Judgment affirmed.

S Successive indorsemento import a several, and not a joint, liability. A joint action cannot be brought against sureesaje indorsers except by aid of statute. Wolf v. Hostetter. 182 Pa. 292. Such statutes anthorizing the joining of all parties to a negotiablo instrument in one action are common in the American States. N. Y. Corle ('iv. Proe.. \$ 454 ; Pomeroy, Remedies, \$\$ 402410: 3 Pandolph, Comm. Paper, \& 1669, - H. 


\section{GEORGE $v$. BACON.}

\section{Appellate Division (N. Y.) 208. - 1910.}

Acrios by Elizabeth IV. George, as committee of the person and property of Clara G. Barnabee, an incompetent person, against ('harles R. Bacon. From a judgment for plaintiff and from an order denying defendants' motion for a new trial, he appeals.

Scotr, J. This is an action for eontribution by one indorser upon a promissory note against a subsequent indorser. The defendant appeals from a jurlgnent upon a verdict directed by the court. The note was signed in the name of "The Bostonian's Incorporated," by its president. The corporation was engaged in giving operatie performances. Its principal oflice was in the city of New York at the office of Loudon G. Carleton (also an indorser), who was an officer and general director of the company. The defendant, Bacon, was manager of the eompany, and acted as treasurer while the company was traveling. Barnabee, the president, was one of the performers, as was also MIcDonale, an indorser. The incompetent plaintiff was the wife of Barnabee, and it was she who ultimately paid the note. The company appears to have been stranded in Pittshurgh and needed money to get home. The note, after it had been indorsed by all of the indorsers, was discounted at the New Amsterdam Bank, and the proceeds were checked out by the defendant, Bacon, in pursuance of the purposes for which the note was made. Bacon made the arrangements with the bank for the disonnt of the note, and procured it to be signed by the president. It does not appear whether or not the incompetent signed at his request. The incompetent's indorsement is the third in order, and Baren's is the tifth. 'The defendant relies solely upon section 118 of the negotiable instruments law (Consol. Law, c. 38), which reads as follows: "Order in which indorsers are liable. $A$ s resperts one another, indorsers are liable prima facie in the order in which they indorse: hut evidence is admissible to show that as between or among thenselves they hase acreed oflepwise. Joint payes, or joint indorsers who indorse are dermed to indorse jointly or severally."

If there was suificient evidence in the sase to justify a finding that

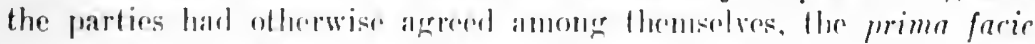
presumption disappears, and the inderser who artually palys the noto is entitled to contribution. And it is unt neressary that the re shall he proof of an actual formal contract in so many words. It is sulficiont if the surrounding ciremonstaneres indieate that the indorsenents were made upon the common understanding that all the indorsors should participate in the liability.

"Their lordships see no reason to douht that the liahilities inter se of the sucessive indorsers of a hill or promissory note must, in the ahsence of all evidence to the contrary, be determined according 
to the ordinary primciples of the law merelant. He who is proved or admitted fo haw male a prior indorsement must, according te these prindiples, imbomily subsement indorsers. but it is a wellestablished rule ol ha that lla whole lades and eireumstances attemdant mpon the malimer. istur. and translerence of a bill or note may

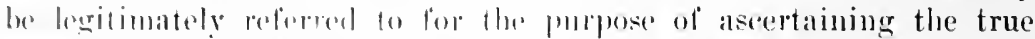

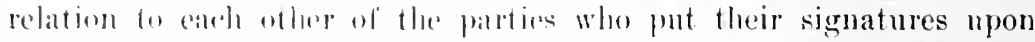
it. cither as maliors or as imlursers. and that reasonable inferences

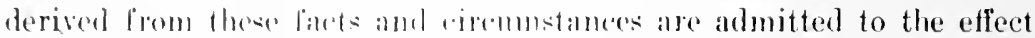
of qualifying allering. 110 (1) inveling the relative liabilities which

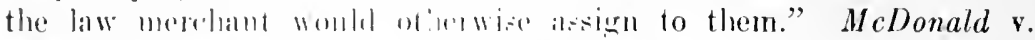

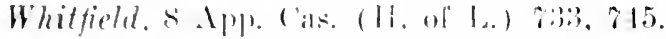

"It is mot mexsilly llat thele shomld be a contract in so many" mords to sign as a sulutin. II was sullicjent if it appeared, taking

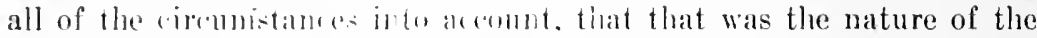

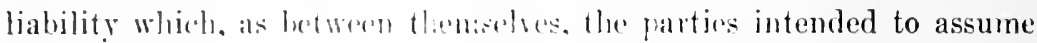

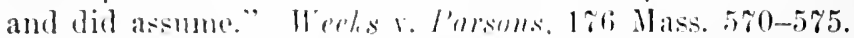

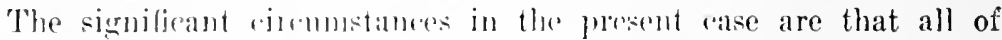
the indorsers we engarent in a common enterprise; that the money to be raised on the note was for the furtherance of that enterprise; and, so far as appeiles, thal whe indorser was as much interested in the enterprise and as much to bo benefited by raising the money as was any other. It is likewise a rery significant eircumstance, as hearing upon the mutual obligations of the indorsers to each other, that all the indorsments were put on the note before it was issued, and solely to give if credit with the bank, and that no indorser gained any profit or advantage from the note except such as was shared by all in the pursuit of the common enterprise. IIagerty v. Phillips, 83 Me. 336.

"The indorsements upon bills of exchange or promissory notes rest upon the theory that the liability of indorsers to each other is regulated by the position of their names, and that the paper is transferred fiom one to the others by indorsement. But this rule has no practical application to acrommodation indorsers, where neither of them has owned the paper, and no such transfer has been made." Easterly v. Barber, 66 X. Y. 133, $13 \%$.

We are therofore of the opinion that enough appeared to justify a finding that the indorsers upon the note. as between themselves, became joint sureties for the payment of the note, and that the incompetent, having pajl it, was entitled to rontribution from her co-indorsers. The defemlant offered no evidence and made no request to go to the jury, contenting himself with a motion to dismiss the complaint upon the plaintifl's proofs.

It follows that the judgment and order appealed from must be affirmed, with costs. All concur. 
74 New Jersey LaW (CT. Err. \& Apr.) 640. - 1907.

Pla intiff was nonsuited on the trial and brings error.

Pitsey, J. - On May 12, 1904, one Walter D. Wilson made his promissory note for $\$ 920$ payable to the order of the Vineland $\mathrm{Na}$ tional Bank. Prior to its delivery to the payee the note was indorsed successively by Charles W. Wilson, the plaintiff herein, and by the defendant Hendee, for the accommodation of the maker. The paper having gone to protest at maturity, the plaintiff was obliged to pay, and did pay, the whole amount of it to the bank.

The present action is based upon an alleged agreement made between Hendee and the plaintiff prior to the indorsement of the note by either of them, to the effect that, if plaintiff would become indorser, Hendee would likewise indorse, and would pay the note at maturity, and indemnify the plaintiff and save him harmless against all loss by reason of his indorsement, in consideration of eertain raluable personal property to be placed in his hands by the maker. * * * It will he well to consider whether either the common-law rule or the Negotiable Instruments Act (P. L. 1902, p. 583) excludes the parol evidence upon which alone was rested the proof of the agreement for whose breach recovery was sought in the present case.

The note in question was made by Walter D. Wilson to the order of the bank, and was indorsed by the parties to this suit prior to its delivery to the bank. As the law stood in this State before the enactment referred to, their signatures would per se have created no implied or commercial contant whatever, their liability to the payee would have dependerl upon extrinsire evidence to show the intent with which they berame parties, and parol criblence would have been eompetent for the purpose of showing surb intent. Chaddock v. T'anness, 35. N. J. Law, 51\%. IIanl the payee afterwards indorsed the note, and had it come to the hamble of a bema fide holder hefore maturity, the irregular indorsers might hase been subjecterd to the liability of

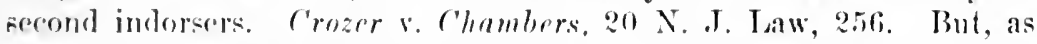
hetween the original parties, the puestion whether any contract was madre, and, if so, what was the rharacter of that contract. was to be determined hy the intention of the parties as asertained by parol evidener of the ciremmstances under which the indorsement was made; cridenere of this sort not being objectionable on aceount of a tendoney to vary a written entract, when no rontract would arise exeept for surh ravidenere. C'haddorle v. Vanness, 35 N. .J. Law, 523.

Even with recperet to uecotialile paper regular in form, our decision recognized the ardmiscilility of parol evidence as between the immediate partios for the purpuse of showing that a note or indorsement was made for acconmorlation, or made without consideration, or upon 
a ennsideration that was conditional and was not performed. Gilbert

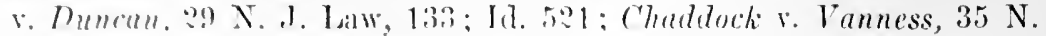
๖. I

lint, as a cenceral rule with resperet to paper regular in form, our derisions did not. wen as between the partics, admit of the introduetion of parol evilence to vary the rommereial contract that was held to arise from the torms of the instrument: for instance, as between successive accommodation indorsers, Johnsom v. Ramsey, 43 N. J. Law,

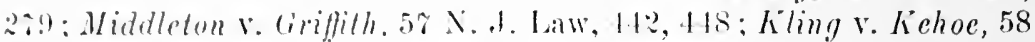
‥ J. Law, 5:9; Foley v. Emerald Brewing Co., 61 N. J. Law, 4 S. 431 .

In other jurislictions the rule adopted in this state with respect to exchdine palol evidence of the intent of the parties to a negotiable instrument regular on its fare, where such evidence would tend to vary the contract that the law merelant implies from the form of the instrument, was not miformly adhered to, it being held in many states that in actions hetween the parties parol evidence was adnissible to show that they had agreed otherwise than as would appear from the face of the note. 1 Dan. Negr. Inst. (6th Fd.) \& 717 , and

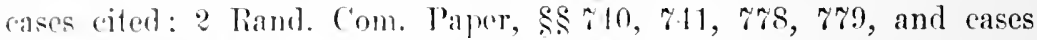
(ited: Crawf. Ann. Negr. Inst. Law (2d Ed.) \$ 118.

In this state of the law our new Negotiable Instruments Act was passed, P'. L. 190\%, p. 58. Prior to its enactment a similar act, or one substantially similar. had been adopted in 16 American states, and had been enacted by ('omgress as the law of the I)istrict of Columbia. ('rawf. Ann. Xeg. Inst. Law, preface to second edition. We must attribute to our Legislature an intent to render the law of this state respecting negotialile instruments conformable to the law in these other states. And at the same time it is ohvious that the act was intemeler to do awa with some of the distinctions establisher or recognized by our arjulingated cases respecting the form and mode in which a contract of indorsemont might be entered into, amd the offect of making such an indorsenent, whether as between the parties or with respect to subsepuent holders of negotiable paper. By section $6.3{ }^{1}$ of that art ( $\mathrm{P}$. I. 1902, p. 591), " a person placing his signature unon an instrument otherwise than as maker, drawer or acceptor, is deemer to he an indorser unless he elearly indicates by appropriate words his intention to he hound in some other capacity." "This, of rourse, abrorates so much of Chadrock v. Vanness, 35 N. J. Law, 517, $10 \mathrm{Am}$. Pep. 25f, as held that an irregular ind?orsement of itself imported no implied or commereial contract whatever.

Section $6 t^{2}$ is as follows:

[Quoting it.]

$1 \mathrm{~N} . \mathrm{Y}, \& 113 .-\mathrm{C}$.

2 N. Y., § 114. - C. 
It will be observed that this section deals with the rights of the payee and subsequent parties, and has not the effect of defining the rights and liabilitics of several irregular indorsers as between themselves. These are set forth in section $6 s,{ }^{3}$ which reads as follows: "As respets one another, indorsers are lialile prima facie in the order in whicl they indorse; but evidence is almissible to show that as between or among themselves they have agred otherwise." ete.

This loes not, hy express mention, sanction farol criblener: neitler does it expressly ixclude any kind of evidence. whether witten or

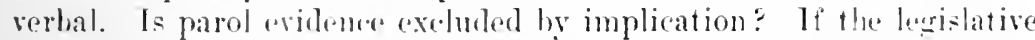
design was to admit only witten evidence for the purpose imdicated,

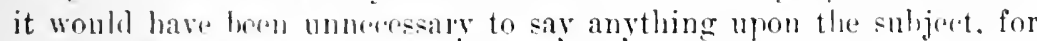
by the rommon-law rules ol pridence other writings cxplanatory of the real agreement would. of comrse, have been admissible. When we recall that a previous section has brought irregular and regular indorsers into a sinerle callugrory in the absence of an expressel intention to the contrary, that the first ranse of section $6 s^{\prime}$ renders the mere act of indorsement only prima facie evidence of the rontratet as between sucessive indorsers. and llat by previous decisions palol evidence as between irregular imbrects was for all purposes admissible, and as between regular indorsers was for some purposes admissible and for other purposes not, it is asy to arrive at the comclusion that the section was intenderl to adnit parol evidence in all cises between indorsers for the punposes of showing what was the acreement amongst themcelves. 'This riew brings our state into accord with the rule alrealy laid rown in somm otler jurisdictions as the rommon-law rule. At the same time it does not destroy the ralue of the instrmment as a commereial instrumbut. lor it is mot against those who sulsespuently

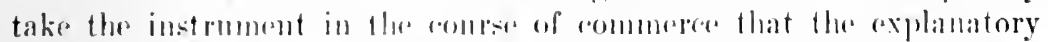

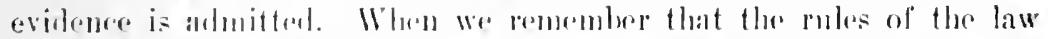

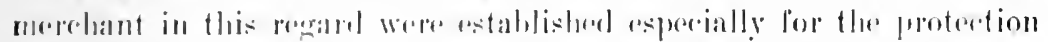

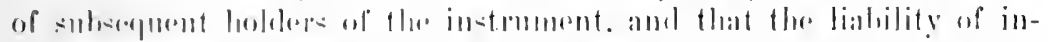

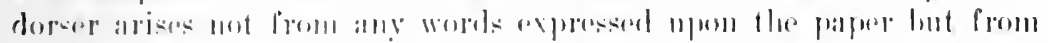

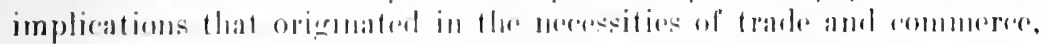

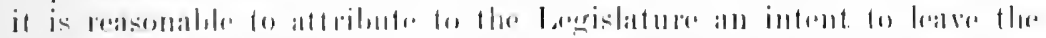

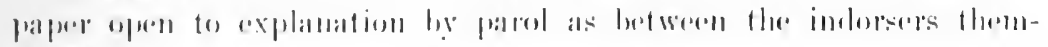
selves:

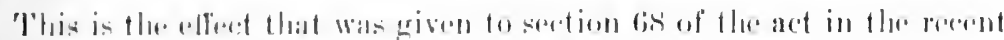

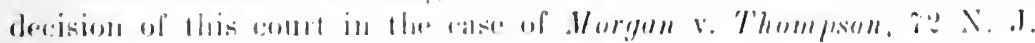

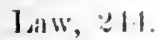

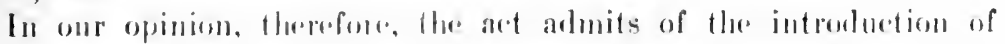

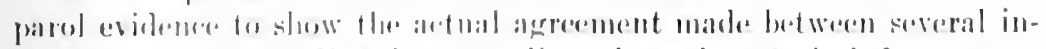
dorsers, notwithetandines it contraliets the prima facio imference ap-

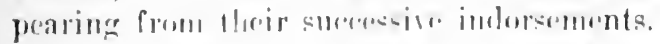

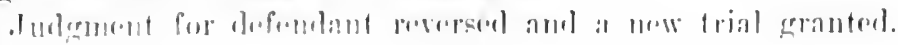

3 N. Y., \$ $118 .-\mathrm{C}$. 
Bru, in equity to compel defondant to assign to plaintiff one-half the security given to protect plinintiff and defendant's intestate as payce-indorsers of a note. The note was made by the mortgagor to plaintiff and the intestate, and by them indorsed. The mortgage was given to the intestate withont plaintilf's knowledge.

Hoar, J. - it is not denied by the defemlint that a surety is entitled to share in the benetit of the security taken by his co-surety. But he contends that his intestate was not the co-surety of the plaintiff: and relies mon the well-settled rule that the liability of sucessive indorsers npon a note is fixed by the contract which the position of their names upon the papel establishes, and that, unless by express agrecment. one is not homel to contribute to a payment of the note by the other, aren if both are accommodation indorsers. The principle is somul, but has no application to the ease at bar. Staey and Lane ale not snecessive indorsers. They are joint indorsers. The note was makle payalule to their joint order, and conld only be transferrer by their joint act. Which name is first put upon the paper is therefore immaterial. as by the indorsement they incurred a joint responsibitity for the del, of the promisor. Each is therefore entitled to share in the serurity taken by the other.

Decree according to the prayer of the plaintiff's bill.'

\section{Acceptor for honor.}

See $\S 284$, post., pp. 701-706.

\section{Guarantor.}

1. (a) Does a Guaranty-Indomsement by tife Molder TransFlit TITLE?

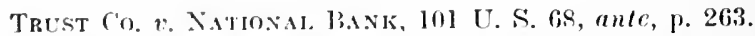

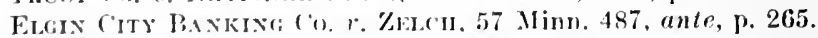
Johisow v. Mitchifil, 150 Tex. 212, ante, p. 289.

1. (b) May a Guabanty be Whitten above a blank IndorseMENT?

Brinke v. Haxi, fl Towa, 42, ante, p. 269.

SCOTt v. ('ALKIN, 139 Nass. 529. ante, p. 270.

ClaAKE 2 . PATHICK, 60 Minn. 269, ante, p. 270.

1 Ser Neg. Inst. I... \$ 7 . Thi- cretion (11S) rhanges the law to the extent of rendering the obligation joint and several instead of joint. - H. 


\section{Is a Transferee a Holder in Due Course?}

Trust Co. v. National Bank, 101 U. S. 68, ante, p. 263.

Eloin City Banking Co. v. Zelch, 57 Minn. 487, ante, p. 265.

Dunham v. Peterson, 5 N. Dak. 414.

\section{What is the Contract of the Guarantor?}

\section{BROWN v. CURTISS.}

2 NEw YORE, 225. - 1849.

Action against defendant as guarantor of a promissory note. Defendant was payee of the note. He wrote upon it, "I guaranty the payment of the within; Charles Brown," and transferred it to plaintiff in payment of a debt. No demand on the maker, or notice of non-paynent to defendant. Defendant oflered to show that for several years after the note fell due the maker was solvent; that he then failed, and was insolvent at this time. Evidence excluded. Judgment for plaintiff.

Bronson, J. - It is said, on the one side, that the defendant is the maker of a promissory note, and liable as such; and on the other side that he is an indorser, and has been discharged for the want of demand and notice. And strange as it may seem, there are eases in the books which go to uphold both of these positions. But they are both wrong. The defendant is neither maker nor indorser of a promissory note. On the contrary, he has in very plain terms made a contract of a different kind from either of those - one well known to the law; and by that contract he must either stand or fall. He has guarantied the payment of G. F. Brown's note: and we have no right to turn that contract into one of a different kind. 'This is so plain a principle that it would seem to be enough to mention it, without saying anything more. And yet there are eases which hold, that the guarantor of a promissory note may sometimes be troated as maker, and some times as indorer. This lias usually been allowed for the purpose of giving effect to the supposed intention of the parties, as ascertained from extrinsie avidence: though there has not always been so fair an apology for altering the contract. That on whatever ground the courts may have acted, it is a dangerous proceding. $\Lambda t$ the very best, it violates the salutary rule, that all prior negotiations between the parties are to be deemed merged in the final written agreement; and allows that agreement to be overruled by the conversations which preceded it. If the parties have male a mistake in drawing up their contruct, the instrument may be reformed in equity. by a direct proceeding for that purjose. But the courts can have no right, under color of construing the agrement, to say that it menas something else from what the language of the instrument plainly imports. 
I have contended earnestly, thomgh not always with success, for this doctrine. (seubury \&. Mumgerford, 2 Hill, so; Miller v. Guston, Id.

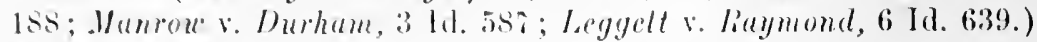
But the side of truth and principle will sooner or hater prevail; and the decisions of the court of errors in //all v. Newcomb (7 IIill, +16; :3 Id. 23:3, s. (.), and of this court in sipies v. Gilmore (1 Comst. 3?1), have greatly shaken, if they have not entirely overthrown the eases in which the courts have taken the liberty to remodel the contract of the parties. 'Those cases have never had any rround of prinriple to stand on, and I trust they will never again be cited as authority in this state.

I do not mean that the very words of an agreement are always to be followed. Construction is ulten necessary for the purpose of ascertaining what the parties intended by the words which they used. But when the meaning of the instrument has been ascertained, the office of construction is at an end; and the contraet can only be enforced as the parties have made it. The defendant has very plainly contracted as a guarantor. If he is not liable as such, he is not liable at all; and if he is liable as such, he cannot get rid of the obligation by calling himself an indorser, or anything else.

The undertaking of the defendant was not conditional, like that of an indorser; nor was it upon any condition whatever. It was an absolute agreement that the note should be paid by the maker at maturity. When the maliel failed to pay, the defendant's contraet was broken, and the plaintiff har a complete right of action against him. It was no part of the agreement that the plaintiff should give notice of the non-payment; nor that he should sue the maker, or use any diligence to gret the money from him. The eases in Massachusetts. Maine, and Pennsylvania, which bold a different doetrine, (Orford Banl v. Ilaynes. 8 Pick. 49: Talbot v. Gay, 18 Id. 534; Ciamage r. Ilutrhins, 23 Naine, 565; Gibbs v. Cannon. 9 Serg. \& R. 198; Isett v. Iloge.2 Watts, 128), are not law in this state. With us, procendings anainst the maker ase ouly necessary where there is a guaranty of collerliom." The point was decided long ago that a guaranty of payment, like the one in question, is not conditional, but an absolute mirlertaking that the maker will pay the note when due. (Allen v. Rightmere. 20 John. 365.) ${ }^{3}$ All of our cases go npon that

2 Sylluester v. Howrmer, is Vt. 32: Forest v. Stevart, 14 Oh. St. 246. - H.

3 Accord: Bemk v. Hopson. 53 (comll. 453; Hance v. Miller, 21 111. 636; Studa-

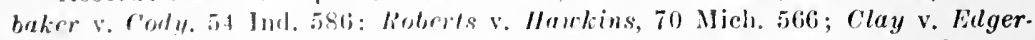
ton, 19 Oh. St. 549. [Elgin rily Bking. Co. v. Hall, 119 Tenn. 548. - C.]

('ontra: (contract condilional) r'rooks v. Tully, 50 Calif. 254; Roekforl A. B. v. Gayford. 3t fowa, 246; Nerton Wagon Co. v. Diers, 10 Neb. 284;

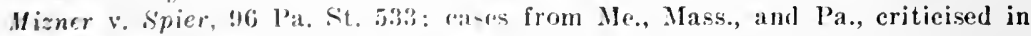

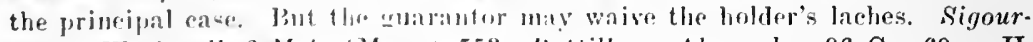
ney v. Wetherell, 6 Met. (Mass.) 553; P'attillo v. Alexander, 96 Ga. 60. - H. 
ground. Some of them go so far as to hold, that the guarantor may be treated as the maker of a promissory note. (.lanrow v. Durham, $3 \mathrm{Hill}$, 5s. L Luqueer r. I'rosser, 4 IIIll, 4:0 ; 1 Id. 256.) 'That doctrine cannot be defenderl. Although the undertaling is absolute, it differs escentially from a promissory note. The grarantor does not promise to pay himself, but that the maker will pay. Still, such cases prove that our courts are far enough from holding the contract to be conditional. It follows from what has heen sail that the evidence offered by the lefentant was properly excluded. Proof that when the note became due, and for several vears afterwards, the maker was abundantly ahle to pay, and that he had since become insolvent, would be no answer to this action. The defendant was under an absolute agreement to see that the maker paid the note at maturity.

If there had heen an indorser on the note prior to the guaranty, and the plaintiff had allowed him to be diseharged by neglecting to demand payment and give him notice, it may he that the defendant would have had a good answer to the action. But it is not necessary to consider that question; for there was no indorser, and nothing has been done or omitted to discharge the maker. If the defendant wished to have him sued, he should have taken up the note, and brought the suit himself. 'The plaintiff was under no obligation to institute legal proceedings.

The only remaining question is on the statute of frauds. (2R. S. 135 , \$ 2.) If the rase is within the statute, it is impossible to get over the objection that no consirleration is expressed in the guaranty.

[See the exerllent article hy William P. Rengers, Fesf.. in 6 Col. Law Rev. 229 (April, 1906), entitlod " Demand on prineipal before action against guarantor," where the anthorities are carrfully analyzed.

On page 236. Mr. liogers says: "lhe ianguage of the court in Meyman v.

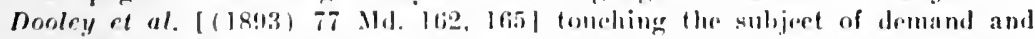
notice, areords with the writer's virwe of the law on this subjert. The court there said: "It is to he regeretted that upon such a question there should be such a conllict of jullicial opionon. 'This confliet has mainly arisen from a departure from the firmly setfled rule of the commen law in regatrol to con. traets of guaranty. and the aftempt to cheraft upou such eontracts, in a modiferel form it is true. the law of demand and notiere by which the liability of an indorser of negotiable palyer is gowerned. . . . In the ease of an

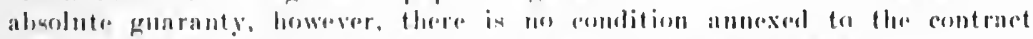

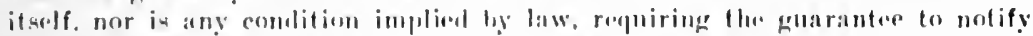
the guarantor of the default of the principal. On the eontrary, his liability is governed by the same rules of law by which the ordinnry diability of one who has broken his contract is determined. And this lueing so, if ome guar. anteres in absolute ferms the performanee of a sperifie art or rontract by another. his liability being eommenaurate with that of the prineipal. Whatever pronf is necesary to suppurt an artion ngainst the prineipal will lw anfliciont in nn action againut the guarsutor. And nu demand upon the principal is not

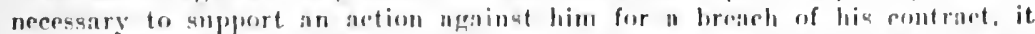
is not nereqary to allene or prove mefier of domand upon and lofault of the principal to charge the guarantor." - 
1 know it was held in Manrow v. Durham (3 1lill, 58.1), that a guaranty like this was a promissory note, which imports a consideration, and was therefore valid. liut that case, which has been questioned alsewhere (Story, lrom. Notes, 59\%), as well as at home, eannot be law. An undertaling that another man will perform his contract is not a promissory note. It is not within any definition which was "rev griven of a promissory liote, and it ramot be held to be such, without confonmling all legal distinctions in relation to the nature of contracts.

But I think the statute of frands does not apply to this case. Although in form this is a promise to answer for the debt or default of another, in substance it is an engagement to pay the guarantor's own debt, in a particular way. He does not undertake as a mere surety for the maker: hit on his own account, and for a consideration which has its root in a transaction entirely distinct from the liability of the maker. The defendant was a debtor to the plaintiff, and gave the note, with the guaranty, to satisfy that debt. This belongs to the third chass of cases mentioned hy Kent, Ch. J., in Leonard v. redenburgh (8 John. 38, 39). There was a new and distinct consideration, independent of the debt of the maker, and one moving between the parties to the new promise. In such cases, where the party undertakes, for his own benefit, and upon a full consideration received by himself, the promise is not within the statute. It would be good without any writing. 'The point was derided ly the Supreme Court in Johuson v. Gilbert ( 1 Hill, 178), and I do not tlink it necessary to refer to other cases holding the same doctrine.

'The case of Manrow v. Durham might have heen placed upon the same ground on which I have put this, if Durham alone had signed the guaranty. He made the promise npon a new consideration, moving between the plaintiff and himself. But Moulthrop, the other defendant, was a mere surety, and as to him the case was clearly within the statute.

Sirroxg, .T., also delivered an opinion.

JEWLTr. ('H. J., and GARDNLR, J., were of opinion that the guaranty was within the statute of frauds, and therefore void.

Judgment affirmed.

4 "The rosoning to take this promise ont of the statute is quite subtle, and I should bave muel difliculty in yiclding it my assent, but for the authorities which I think onght now to control."- Eari, J., in Mills v. Rich, $80 \mathrm{~N}$. Y. 2fi. 27]. Se also Darst v. Pattes, 95 Ill. 493; Shleldon v. Butler, 24 Minn. 513: Wyman v. Goodrich, 26 Wis. 21; Massinger v. Newman, 83 Ind. 124; ef. Doues v. Surtt, 134 Mas- 140.

One who signs as surety with the maker is liable as an original promisor; the statute of frauds does not apply to the ease. Casey v. Irabason, $10 \mathrm{Abb}$. Pr. (X. Y.) 368; Frech v. Fruger. 47 N. J. L. 157; l'aul v. Stackhouse, $38 \mathrm{~Pa}$. St. 302 . 


\section{Is the Guaranty Transferable?}

\section{(a) Is it negotiable? ${ }^{5}$}

\section{TRUE $r$. FULLER.}

\section{Pickering (Mass.) 140. -1838.}

SHaw, C. J., delivered the opinion of the court. The facts bearing upon this question may he thus stated. Morse made three promissory notes to Elisha Fuller. or his order, payable in two, three and five years, respectively, from date, and gave a mortgage to secure the payment of them. 'The notes were indorsed in blank by the payee. On the same notes was inlorsed al guaranty in this form: "I guaranty the payment of semi-amminl interest on this note, as well as the principal," and signed by the defendant. The notes thus indorsed were transferred, and the mortgage assigned. The mortgaged premises were entered on for brench of condition, and the mortgage foreclosed. The notes have regularly come to the hands of the plaintiff.

The court are of opinion that the plaintiff is not cutitled to recover, because the guaranty in question was not made to him, or whilst he was holder of the note: that it was not negotiable in itself, and was not made so hy hingre written upon and intended to serure a negotiable instrument. 'Tluis instrument heing filled up and signed, is complete in itself, and it cannot be altered either by striking out words so as to convert it into a general indorsement, or by filling up, as in ease of a blank indorsement. In the latter ease, an indorser, by leaving a blank over his uamm, tacitly agrees that any subsequent lawful holder may insert snitahle words to render him liable in the same manner and to the same extent, implied hy his indorsement and the usages of husiness.

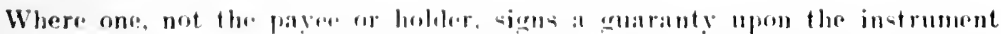

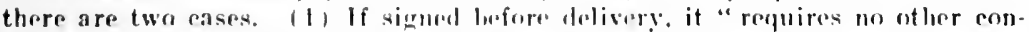

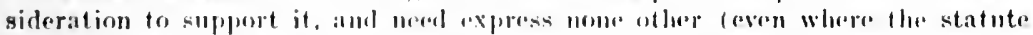

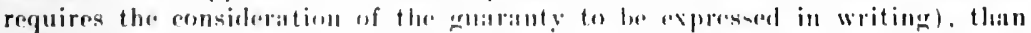

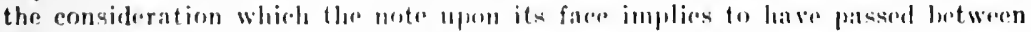
the original partios. (2) lint a gllaranty writtall

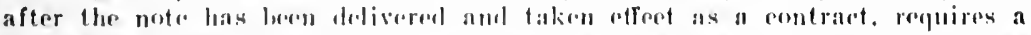

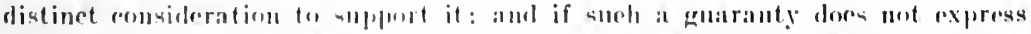
any consideration. it is wid. where the statute of framls repoires the cousialera-

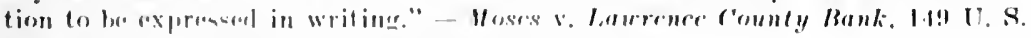

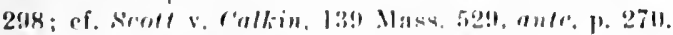

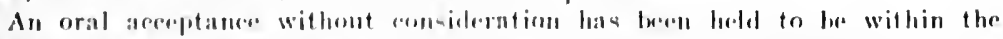

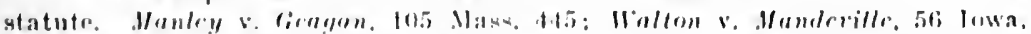

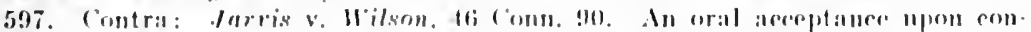

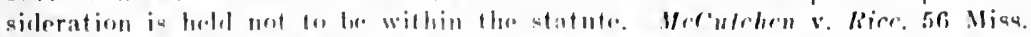

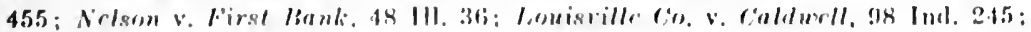

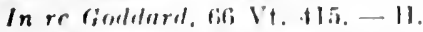

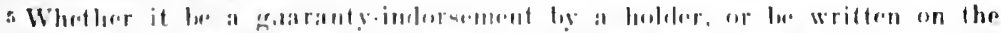
bill by a third party, some immaterial when this gucstion is involved. $-U$. 
'This gruaranty expresse's no consideration, nor does it name any person as the guarantece, to whom it is male. But suppose these could be supplienl by parol prool, it could onty enure to the person who was the holder at the time the gruaranty was given, who was not the paintitl.

Ilad the defendant intended, by the credit of his name, to give a general corrency to the note, as a negotiable sorelrity, there was no reason why he should not have indolsed it arenerally, in which anse be would have been responsible to any gerson who might afterwards become the holder. As it is, it is no mole a negotiable promise than it it had been written on a separate paper, reforring to the note, and guarantying it to the then holder. (Tyler v. Binney, 7 Miss. R. I79); Lamourieux v. Heuit, 5 Wend. 30\%.)

Plaintitf nonsuit. "

(b) Is it assignable?

COOPER \%. DEDRICK.

22 BaRBOT'R (N. Y. SUP. ('T.) 516. - 1856.

By the Court, Marrin, J. - The action was upon a guaranty, writien upon a promissory note. 'The note reals thus:-

\$58.26. Due Dedrick \& Bronson, or bearer, fifty-eight and twenty-six one hundredths dullars, for vilue received.

[The gruaranty is. that]

J. S. StrLlinan.

For vilue received. I hereby guarantce the payment of the within note. Feb. 19, 1849.

(Signed by Defendant.)

Upon the trial the plaintills produced the note and proved the guaranty writon upon it, and rested. I Defendant asked for nonsuit: (1) 'That there was no evilence of the maker's signature: (2) that plaintiffs showed no title or intrest in the guaranty. ${ }^{7}$ 'The justice gave judgmont in faror of the plantilfs.

Several ohjerelioms ale male to the judgment. It will not be necessary to state them faldienlarly. It was not necessary to prove by witnesses the signaturn of the maker of the note. 'Jhis was sufficiently proverl, as acminst the defementat, by proving his execution of the guaranty. (cowren \& Hill's Notes, notes 168, s69, 912.) * * *

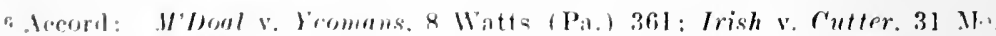
536. Contra: Wrbster v. robls. 17 111. 459: Domnerberg v. Oppenheimer, 15

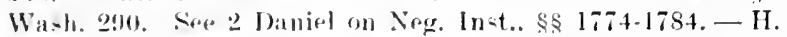

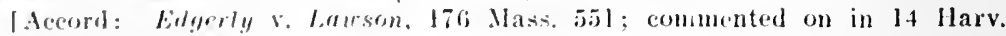
Law Rev. 299. - - : 1

TOther questions omitteil. - II. 
As to the evidence of their title to the guaranty, the note was payable to Dedrick \& Bronson, or bearer, and the guaranty was written upon it. The possession and production of the note wis prima facie

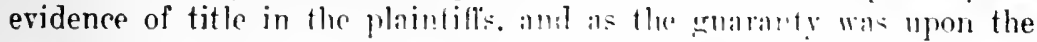
note, in my opinion, the posession of the note and the wharanty were prima farie evirlene of right in the plaintifls to the gallatanty. Since the code. the real party in interest is to hring the artion. "The old question, therefore. Whether the form of the contrant justifies the action in the name of the plaintitis, no longer exists: hut the gutestion is, has the plaintitl the title on right to the contrant or the rause of action? If he has. he may maintain the suit, upon the contract, in his own name. In my opinion, when a gualranty is written upon a note and the note is transferred, nothing being said touching the guaranty, the contact of guaranty passes with the note. In other words, the sale and delively of the note with the guaranty upon it furnishes prima facie evidence of a sale of the contract of guaranty. In the present case the defendant was one of the payees of the note, and the note was also payable to bearer. He transferred the note and guarantied the payment. In my opinion, any one who should hecome the holder of the note conld miniain an action upon the guaranty, unless it should be shown that the contrant of guaranty was not transferresl at the time the note was transferred. (See McLaren r. Watson. 26 Went. 425.)

The statute of limitations dirl nof rommence running in favor of the defendant until the cause of action acerued upon the contract of guraranty.

The eontract of guaranty was not within the statute of frands. The ronsideration, "for value received," was sufficiently expressed to satisfy the requirements of the statute. (1)ouglas v. Howland, 24 Wenl. 35: Hatson's lidr res ve Mraren. 19 11. 557.)

The judgment should be alfirmed. ${ }^{8}$

Eyerson $r$. Gine, 129 N. Y. 290. - 1590. A. inlorsed and delivered a negotiable promisenry note to r.e attached to which wats an allonge containing this grubainty" "For payment received of $\mathrm{C}$., we do herely guarantere to said (i. the payment of the mote lowereto annexed, etr." (Signerd hy defomlants.) C. indorsed the note to plaintiff "without recenurse," and exerenterd and delivered an assignment of the same and the guaranty. In an aetion ly plaintif against defendants on the gualsanty. the trial count granted a nonsuit on the ground that the guaranty was special, personal to 6 ., and licl not

Accord: Harbord r. Conper. 43 Minn. 466: Mhelps v. Sargent, 69 Minn. 118. $-\mathrm{H}$. 
pass to plaintitr, and that no (antere of andion land acerued on the guar-

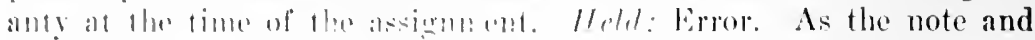

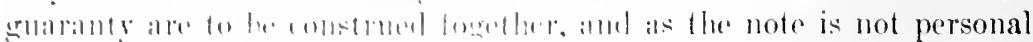

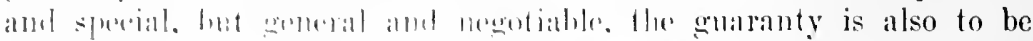
regaraled as general and will therelone pass hy assignment.

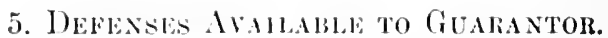

PU'TNAM 2 . SCIIUYLER.

$4 \operatorname{HUN}($ N. Y. SUP. CT.) $166 .-1875$.

Learifed, P. J.:-

Mrs. Henriques, in her lifetime, made two notes to Dr. Allen, the plaintifl's testator. After her death the defendant guaranteed them, by writing moler each, as follows:

For value reeived I hereby guarantee the payment of the above note.

L. W. SCHUYLER.

On the trial the defendant oflered to prove that Dr. Allen was the medical attendant of Mrs. Henriques; was in the habit of advising her as to financial and other matters; that she reposed confidence in him in relation to her affairs; together with certain other matters tending to show that the notes were obtained by frand, and that they were without consibleration. The avilence was ohjected to on the ground that. hy excouting the guarantee, the dofendant had admitted the notes, and was estopled: that the defense of frand was personal to Mrs. Ifonriques and lier representatives; that the defendant eould not impearh the settlement between maker and payee. The evidence was excluded, and the defendant excepted.

I assume, from the nanmer in which the ease is presented, that it was not really raimen on the trial that these matters would not have been rompetint in behalf of the representatives of Mrs. Henriques. Their exclusion was on the gromul that they were not competent in behalf of the guarantor. On this subject, of the right of a guarantor to set up defronces which would undoubtedly be valid in favor of the principal, there is an apparent conflet. But a little diserimination will show that the confliet is only apparent.

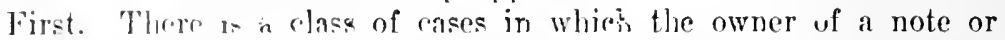
bond has ascigned it, with a guamanty. In these, it has been held that the guarantor comld unt show that the instrument was invalid. Jt would be minst to normit him to assign an invalid instrument; to

3 For the di-tinetion befwern sprecial (non-assignable) and general (assignable) guaranties. cere Eronsrille Yat. Bank v. Kaufman, 93 N. Y. 273; Sawyer จ. Hopgood, 13 N. Y. St. Rep. 711.-H 
guaranty its payment or collection; to receive the value, and then, when sued on his guaranty, to assert that the original instrument was invalid. He is estopped. (Remsen v. Graves, 41 N. Y. $475 ;$ Zabrishie v. C. C. and C. R. R. Co.. 23 How. [U. S.] 399.) The ease of Mann v. Eckford's Executors (15 Wend. 502), is of this character. 'T'he Life and Fire Company, of which Eckford was president, assigned to the Western Insurance Company a bond and mortgage. Eckford guarantied the bond and mortgage, and the money paid for it, expressing the amount. The defendants, his executors, were not allowed to set up usury in the bond and mortgage, against the plaintiff, the receiver of the insurance company.

Second. The guarantor is held liable in those eases in which the debt is justly owing, although, from some defect or incapacity, the principal is not liable in an action. Thus, where the makers of a note were married women, incapable (then) of making a note, the accommodation indorser was still held liable. (Erwin r. Douns. 15 N. Y., 5r6; see Kimball v. Nevell, 7 Hill, 116.) The guarantor of a lease is liable, although only one of the two lessees executed the lease. (McLaughlin v. McGovern, 31 Barb. 20S.) In that ease, .Iudge Bacon speaks of this elass of cases, mentioning, among others, the guaranty of goods sold to an infant. So the guarantor of a note purporting to be marle by two, where the signature of one is unauthorized, is liable. (Sterns v. Marh's, 35 Barb. 565.) In all these cases the deht is justly owing to the plaintiff: and through no fault of his, he is unable to recover against the principal, or one of the principals. '

Third. A guarantor cannot set up. hy way of set-off, a rlaiun distinct from that on which he is sued. The right of sot-off (that is, as distinguished from a defense arising upon the (laim itself) belongs only to the principal dobtor, and can he used only at his option. Sinch is the doctrine of fillespie r. Torrance (95 N. Y. 3016). and hlis is all which that rase decides on this point. By indiredion, howerer, it implies that a defense to the claim (as distinguished from a sot-off), is available to the guarantor. 'T'o the same efferet is Lewis v. Mrdillen (41 Barb. 420).

Fourth. But there are still other eases which are not cmbraced within either of these precerling "lasses: ases where the platutilf is the original party to the contract, and therefore has oot received it by assignment from the gruarantor; where the proposed defonse is not the incompetency of the principal to contract: and where it arises

1 A guarantor is not diecharged merely lwealles flee primcipal has a gend

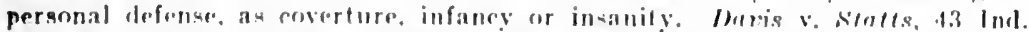

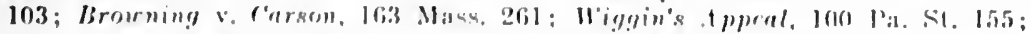

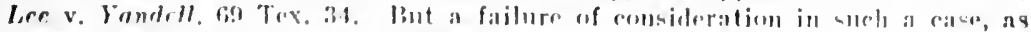
between the principal and paincit. discharges the surety. Bulerer v. Kennett, 54 .10. S2. - II. 
out of the contract itself, and not by way of set-off. In these the gruarantor has heen permitted to malie the defense.

He has thus, as to the original contract, heen allowed to set up usury (.lorse 1 . Howy, 9 l'ilige, 19\%; I'urshatl v. Lamoreaux, 37 Rarh. 1s!l) : luress of his primeipal (Osborn v. Robbins, 36 N. Y., 365; strong v. (imannis. 26 barl. 129) ; partial failure of consideration (samyer v. Chambers. 1:3 barl. live). And I find no case which intimates that when a person has ohtained an obligation from a principal by fraut, he can wipe out the fraud by obtaining a surety to the obligation. Assuming that, in justice and equity, the obligee, by reason of fradulent acts on his part, has either no claim, or a less elaim, against the principal, I see no reason why he should stand in a better position against the cruarantor.

The distinetion which has been pointed out, viz., that inability on the part of the principal to contract is no defense to the guarantor, while frand in the contract is, may be found in the eivil law. This says that personal defenses do not pass to others, but that defenses, inherent in the thing, such as, among others, fraud and duress, are arailable to sureties. (Dig., 44, 1, de cxceptionibus, c. 7, \$ 1; Cod. $2,24[23]$ de fidejuss, 2.) "If, in the principal obligation, there is any essential vice which may annul it, as if it has been contracted by force, if it is contrary to law, or to good manners, if it be founded only on a fraud, or on some error which may suffice to annul it; in all these cases the obligation of the surety is likewise annulled." (Strahan's Domat, bk. 3, tit. 4, \$ 5, art. 2 ; id., bk. 3 , tit. 4 , $\$ 1$, art. 10.)

The defendant offered to prove acts of the plaintiff's testator, tending to show that be obtained the notes improperly from the maker; that he took adrantage of her confidence in lim, and that she did not owe him. If these facts be true, he ought neither to recover of her representatives on the notes, nor of the defendant on her guaranties.

The judgment shonld be reversed, and a new trial ordered, costs to abide the event.

Present - Lliarned, P. J., Boardian and James, JJ.

Jurlgment reversed, and a new trial ordered, costs to abide the event. ${ }^{2}$

2 Accord: Bryant v. Crosby, 36 Ne. 562 (fiaud); Surift v. Becrs, 3 Denio (․ Y.) 70 (illegality) : Girifith v. Nitgrates, !0 P'a. St. 16I (duress). For an enumeration of the circumstances which will discharge a surety, see Neg. Inst. L., $\S 201 .-\mathrm{H}$. 


\title{
ARTICLE VII.
}

Duties of Holder: Presentanent for Payment.

\section{Necessity of presentment.}

\section{Not to Charge Acceptor on Maker.}

\section{$\S 130$}

\author{
HARPISBURG TRUST CO. $r$. SHUFELDT.
}

is Federal Reporter, 292. - 1897.

[Circuit Court, Dist. Washington, N. D.]

Haxford, District JUDGE, - This is an action to recover a balance due after deducting partial payments upon a negotiable promissory note, made payable on demand. The defendant has demurred to the complaint, his contention being that the same is insulficient, for failure to allege a demand prior to the commencement of the action. There is a rule of loug standing, and supported by the weiglit of anthority in this country, that the commencement of an action is itself a demand, ${ }^{1}$ and that failure to request payment, prior to the commencement of the action, affords no ground of defense. (Bank v. Fox, Fed. Cas. No. 2683; 5 Am. and Eng. Enc. Law, $528 z^{46}$ [2d ed. v. 4, p. 351.]).

It is insisted, howerer, that the courts and the text-books in this country have fallen into error by following early derisions, which were controlled by peruliar facts, and which are insulfirient of themselves to establish a general rule upon the subjert. ${ }^{2}$ It is mwise to depart from business anstoms and practices which have been sanc-

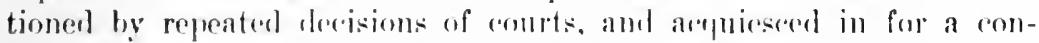
siderable time, and which may fairly le smppoesl to have been contemplated by the partices at the time of makine their contract. This

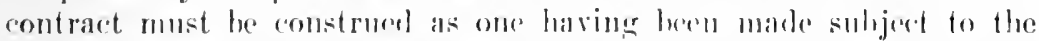
rule above stateml, and the maker of the mote is. ly the terms of his contract, liable without any demaml, prior to the enmencement of an action.

\section{Deminrere oremenles}

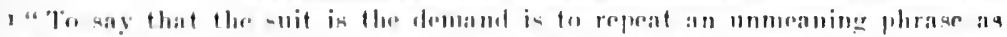

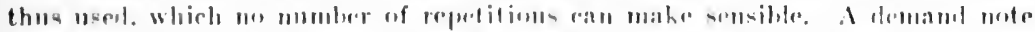

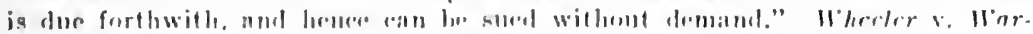
ner. $47 \mathrm{x}$. Y. 51 !. Lohling that the stutute of limitations begins to run from the date of the notere - II.

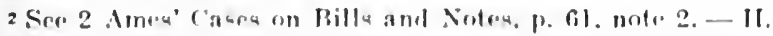

a But a certifieate of depesit is not due until demand is made and the erer-

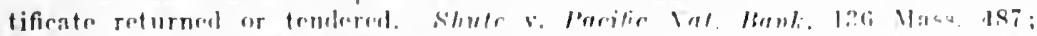
Bmiley v. Fru. 100 X. Y. 262: Mrlimenh v. Jamisom, 107 Pa. St. 33ก. Contra: 
6 \$1..11.

'This action was commenced belume a justice of the peace, by the defembant in error, on two notes, for lwenty dullars each, in the following form:

The Real Fistate Bank, No. 52. of Caledeniat. Misismippi, promise to pay John lillintt. or hearer. twenty dollars, on temand, at their banking house, Caledonia, Mi-sissippi. - May 8. 1538.

R. Dowblt, Cashier.

W. G. Wright, l'resident.

Inderment being remdered for the defembant, the plantiff appealed to the cirruit court, where judgment was renelered for the plaintiff.

The defemlant moved the court to charese, that the plaintiff, to entitle himself to a lecosury, must prove a demand at the banking hom: of the company - which the court refused, and he excepted.

The assignments of eror present for revision rejection of the testimony and the charge of the court.

(limoxb, J. - The puestion, whether a demand was necessary before suit, is one of considerable difficulty. Upron this subject, a great contrariety of opinion lomedy prevailed in Fugland, as to the necessity of averring and proving a demand as a precedient condition to ithe right to recrer, when the instrument was made payable on its face at a particular time and place, or where it was accepted, payable at a particular place, which was finally settled on appeal to the House of Iords, that such demand was neressary in the mase of Rowe v. Foung (? Brod. \& Ping. 180). ${ }^{4}$

In the Thited States a diflerent doctrine has generally prevailed, it heing considered matter of defense, and therefore, not necessary to be proved by the plaintiff. (Wallace v. MaConnell, 1: Peters, 133. Ser:

Curren v. Witter, 6s Wis. If; Lynch v. Goldsmith, 64 Gal. 42; Munt v. Divine, 37 Ill. 137: Tripp v. Furtonius. 36; Mich. 194. There is also a conflict as to whether bank notes muit le proented for payment lefore suit brought. 3 Am. \& Eng. Ene. Law $12 \mathrm{l}$ (al.) p. $778 .-\mathrm{H}$.

inn the conflict of anthurity upon the question whether a demand is nec. essary to mature a cortifiente of leposit. and, if necessary. when the demand must be mate. see the note to Ellioft v. Copilal City stale Bank, 128 Iowa, 275, in 1 L. X. S. 1130 . - ( . .

4 This was changed by Onclow's tot (1 \& 2 Goo. IV.. c. 78) which, as construed, remlers prenentiment unneressary to chare the aceeptor of a bill, drawn payable at a partieular place aud accepted generally. or drawn generally and

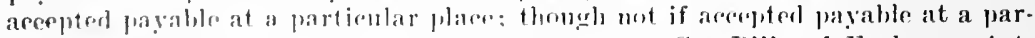
ticular place only. Sirlby s. Erlon. 3 Jing. Gll. See Bills of Exchange Act, \$ 52, and Neg. Inst. I.. \$ 228. "The same rule applies to a promissory note. See Bills of Exchange Aet. $\$ 87$. suhsec. (I) ; Price v. Milehell, 4 Camp. 200; Exon v. Russell, 4 M. \& S. 507.- H. 
also, Chitty on Bills [9 Am. ed.] 393, and Story on Bills, 416 ; and note, where the (alses alle collected.) "

In this state, it hals alwalys been cousidered malter of defonse, when the suit is against the maker or acceptor. The desetrine is so stated by

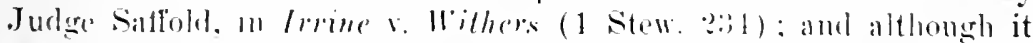
was not alepuiesed on his the whole bench, it has heen considered and acted on as settling the law from that time to the present. (Roberts Mason. 1 Ala. Rep. 33:3.)

The question in this ahe is. whethen the same rute is to be applied where the note is payable on demand at a particular place. We are unahle to perreive any sulsimtial difference between the two rases. The same rensons whele leal to the conclusion that it is a matter of defense when the note is pravilule at a specified time, at a particular place, apply with the sane fores when it is payble on temand. " In

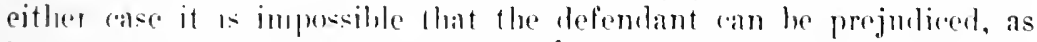
he can alwilys defond himsell he proving that he was ready at the

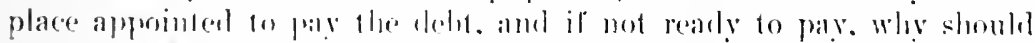

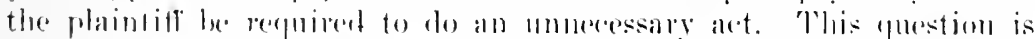

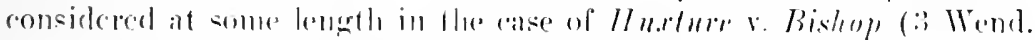

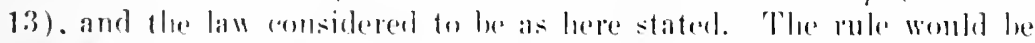

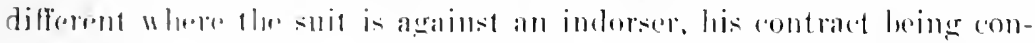

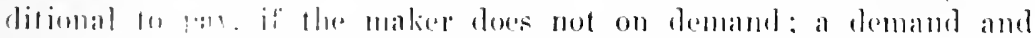

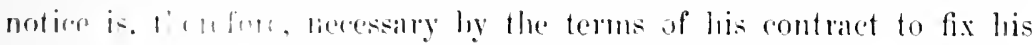
liabilit?

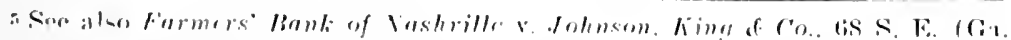
Sup (1.) s.5 (1):19. 19111). -

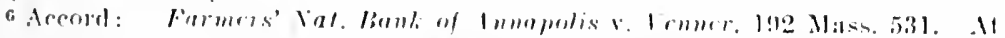

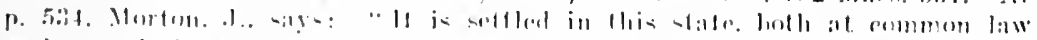

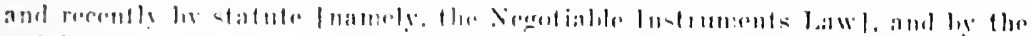

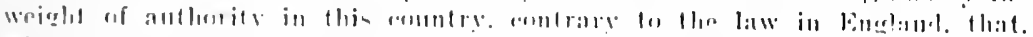

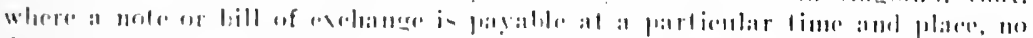

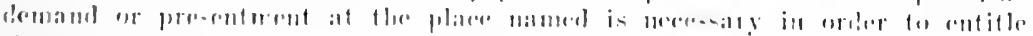

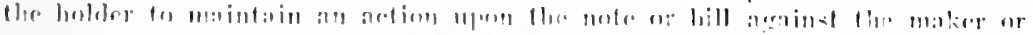

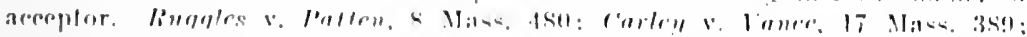

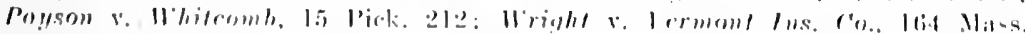

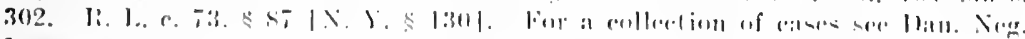

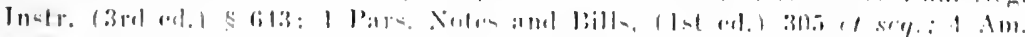

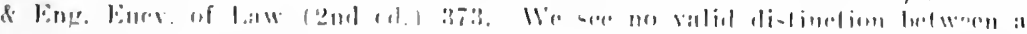

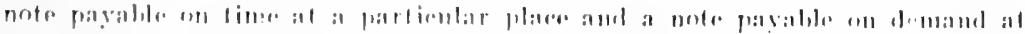

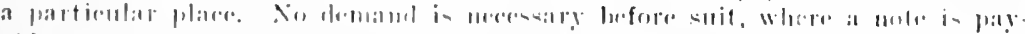

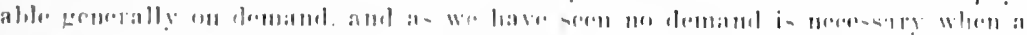

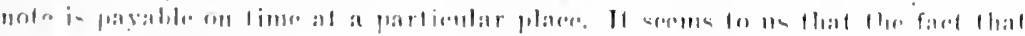

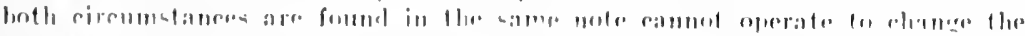

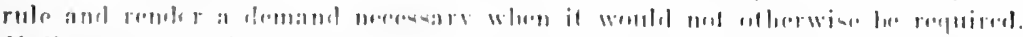

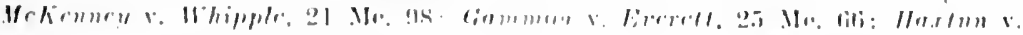

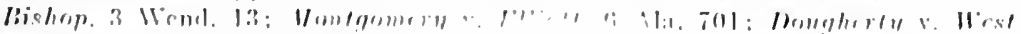

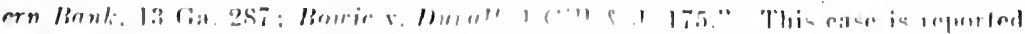

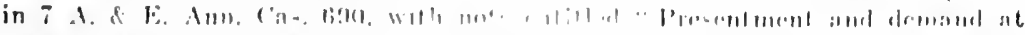

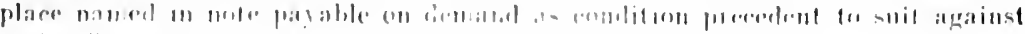
maker," 
It results from the view here taken, that there is no error in the judgment of the Circtit comt, and it is therefore ationed.?

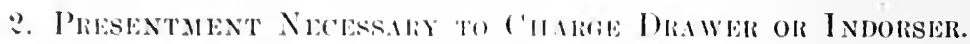
$\$ 130$ LONG U. STEPIIENSON. [licported herein at p. ild.]

\section{What constitutes sufficient presentment.}

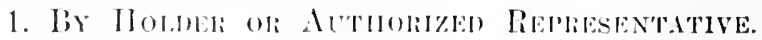

$\$ 132$

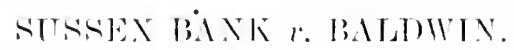

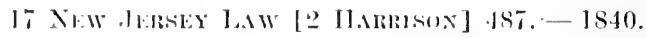

DoYTox. I.- This mase was tried at the Susese ('irenit of May, A. D. 1sis, and verdict had for the plaintifi". Sumdry reasons are now redied upon to set the same aside, and I will consister them in their orter.

The defendants are the indorsers of a promissory note made by

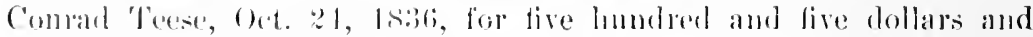
sixty-one ents. parable six menths after date to the order of $\mathrm{Wm}$. A. Paldwin \& ('o. (the defomlants), and by them indorsed to the plaintitl. 'The first renson ascigned is, that the note was mot duly presenterl to the maline for priyment. That if was presented at an improper place, to wit, the offier of 'Texese, the maker, and hy an immoper perane, to wit, one Demmis, who swears that he acted as the

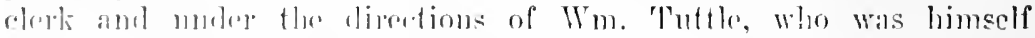
merely the aserent of tames Heddem. the notary publix.

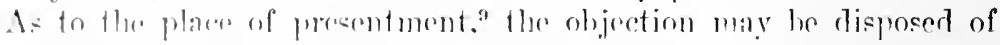
rere hidfy. It is a point not properly arising mole the evidence

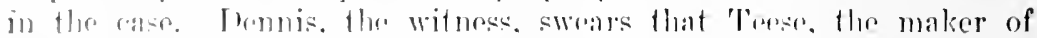
the note. fold him, lomolis, to present his notes for payment at that

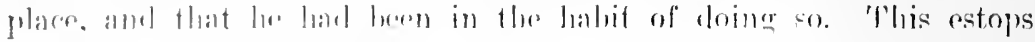

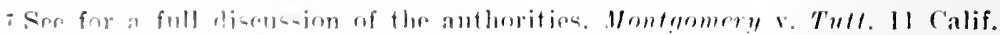

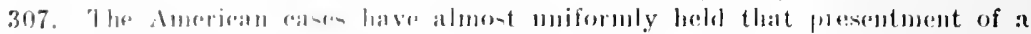

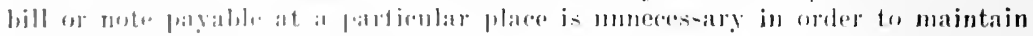

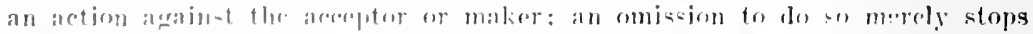

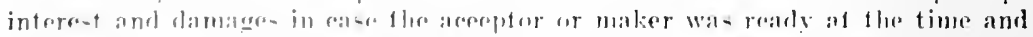
place to pay. Hills v. Plare. 4s X. Y. 520; I'r.x v. National kank. 100 U. S.

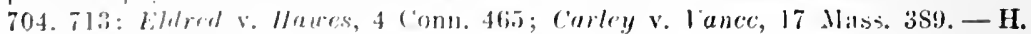
Q Sise $14: i-111 .-11$.

o Sere $133 .-\mathrm{H}$. 
Teese from objecting to the place of presentment; and that which is good against the drawer, is good against the indorser. (State Bank v. Murd, 12 Mass. 172; Whituell v. Johnson, 17 Mass. R. 449.) But it is thought adrisable that this point be put at rest in this State by an expression of opinion by this court.

It appears by the evidence that the office in question was the regular place of business of the maker; and I have no doubt where a person has an office or a known and settled place of business for the transaction of his moneyed concerns-whether he be a banker, broker, merchant, manufacturer, mechanic, or dealer in any other way, a presentment and demand at that place (as well as a presentment and demand at his residence), is good in law. It must not, however, be a place selected and used temporarily for the transaction of some particular business, as settling up some old books or accounts merely, but his regular and known place of business for the transaction of his monered concerns. The counting room of a banker or merchant may be a proper place for a demand, though the manufactory or workshop would not. Yet if the manuficturer or mechanic have an office, or known place of business for the purpose aforesaid, a good demand may be made there. (Banli of Columbia v. Laurence, 1 Peters, 582; Williams v. The Banl of Initel States, 2 Peters, 100: Byles on Bills, 118; State Banl v. Murd, 12 Mass. 173.)

Nor is there anything in the oljection that the presentment was made hy an improper person. It appears by the evidence that Tuttle did the husiness of Hedden, the notary publice, and it must have heen with the consent and knowledge of the bank that he employed and directed Demis, who was his clerk, to present the note in question to the drawers, and put him in possession of the note for that purpose. If the note harl bren paid on presentment, he contl and would have delivered it up to the drawers, and that would have exoneralded them from further liability. An authority to make a demand, may he created loy parol, and the mere possession of the paper, is eridence enough of surh anthority. (3 kent. (: 108: Bant of Utica v.

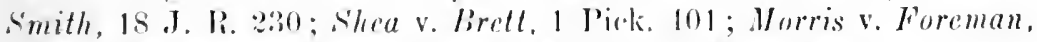

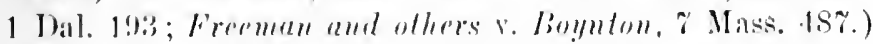

There is an inprossion current in some degreen, aren with the har, that a prescritument of a mole must he hy a motary, or at least on his

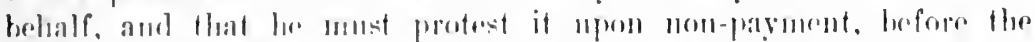
indorser is liable. Put this is not so.' There record of a demand and notice, e.te., by a motary, rulared in his hook, areording to our

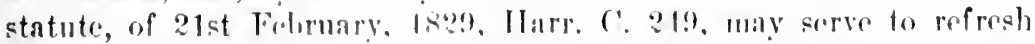
his memory, or in ase of his alsenere or death it may he nest as

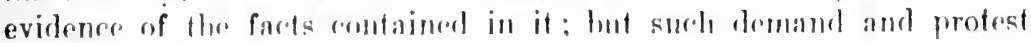
by a notary are unt esential to a recovery against the indorser. It

1 See $\S 189 .-H$. 
was not so by the common or commercial law, nor is it required by our statute. If a notary aet in the premises, and make the protest, although sanctioned by general custom, it is not strictly an official act (Nichols v. Webb, 8 Wheat. $326 ; 3$ Kent C. 93-4; 1 Saund. on Pl. \& H. 295.)

Any person may present at its maturity, a promissory note of which he is put in possession, and if paid in the ordinary conrse of business, and taken up, the payment is good: and if not paid, the demand is good as a grotnd work for notice to the indorsers, and that without any protest." The rule is otherwise as to foreign hills of exchange, which must he protested by a notary, and their oflicial seal is plenary evidence in all forejgn courts and countries, of the dishonor of the bill (ride rases above eited).

?. The next objection, is to the notice to the indorsers. ${ }^{3}$ The name of James Iledlen, the notary public, was printed at the foot of the notice, not written; and this is assigned for error. There is nothing in this objection. 'l'he law preseribes no form of notice, its object is merely to appraise the party of the non-payment - to put him upon inquiry, that he may protect his rights. This is as well done by a notice with a printed as with a written name.

The signature of the notary would warry with it in a large majority of eases no higher degree of certanty than the printed name; for it must in most eases be unknown to those to whom notices are sent. The notice in this ease eame from a proper source, and stated the proper facts; that is enough. It is needless to cite authorities upon this point.

['The learned judge then decides that the notice was sent in due time, and that there was no usury. Nevins, J, dissented on the last point.]

Rule made absolute."

2 Baer v. Leppert, $12 \operatorname{Hun}$ (N. Y.) $516 .-11$.

3 See $\$ 166 .-11$.

4 The drawer may provide in the instrument that it shall not he presented ly a specified person. Com. Nat. Bk. v. Jirst Nat. Bk., 118 N. C. 783. - H.

I In F'armers' Bank r. Johnson, King of Co., (is S. H. (Ga.) 85. it was held that whare a check was Irawn on a bank located in another town that that in which the drawer residerl, and immediately following the direction to the drawe liank there were stamped, at the time when the eleck was drawn, the words, "Payable through Ia named hank in another eity of the sine statel at current rate," thi- was a material part of the direction; and the drawe bank was not reguirril to piy the check when not presented through the bank thus named, but directly by a third bank. - C.] 


\section{At The Proper 'l'me."}

Action by holder against indorsers.

Spencer, J, delivered the opinion of the court.

On the second point, the defendants are entitled to judgment. The third day of erace fell on the 2!th day of November, and payment was not denanded of the maker until the 30 th. The law is perfectly settled, that a note must be demanded on the third day of grace, unless that falls on Sunday, and then it must be demanded on the second day of ariace. (2 Caines, 343 ; 16 Wast, 250).) Here there is no excuse for delaying the demand on the maker, and there is a palpable want of due diligence, which discharges the indorser. Judgment for the defendant.

\section{§131 COMMERCIAI, NATIONAI, BANK r. ZIMMERMAN.}

$185 \mathrm{NEW}$ Yokк. 210.- 1906.

Appeas, from a judgment of thr Appellate Division of the Supreme Court in the fourth jurlicial department, enteres Inne 5, 1906, affirming a judgment iu favor of defondant Zimmerman enteres upon a derision of the cont on trial at Special T'rem.

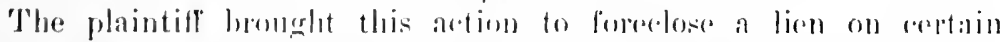

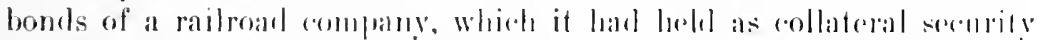

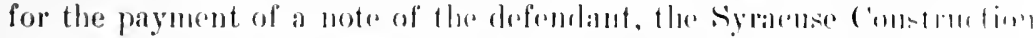

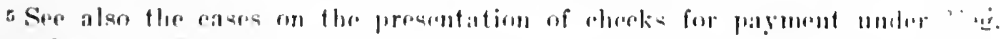
Inst. latw, \$ 32.2, prest. - 1 .

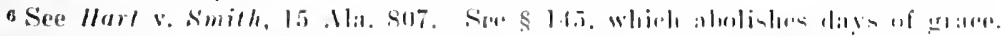

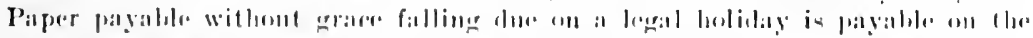

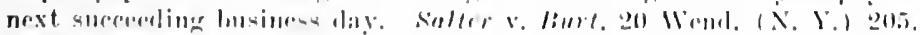

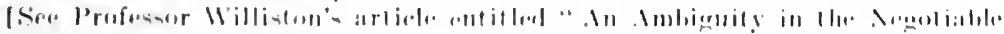

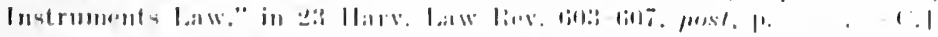

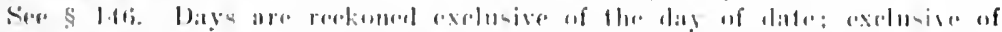

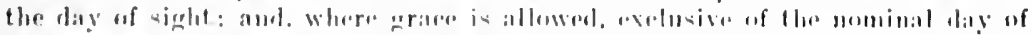

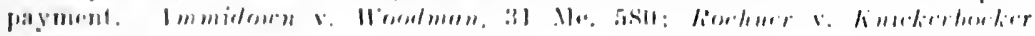
Co... in/ru.

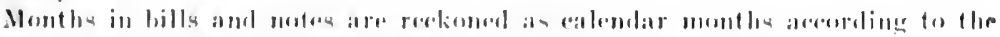

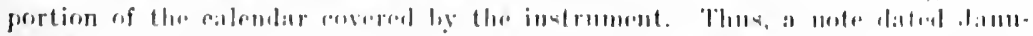

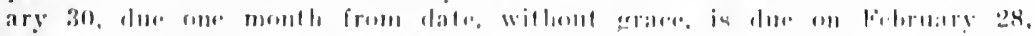

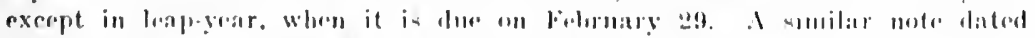

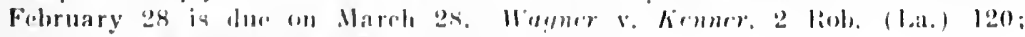

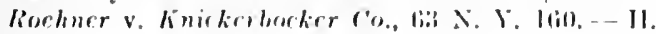


Co.. indorsed by Josph Zimmerman, and to recover a judgment for any deticieney, arising upon the sale of the boudt, against Zimmerman's estate. The note reals als follews:

" $\div 10.000$

Srmacesti. N. Y., Sept. 16. 1899.

"On demand after date we promise to pily to the order of Joseph Zimmerman ten thonsand dollars at commercial Pank. Valne received with intereat. " srrbaclese Coxstructon Co.

"per J.S. Kavmann, Treas."

Upon the trial of the issue. Which was had without a jury, the trial judge fouml, als the farts of the risc, that the note was indorsed by Zimmerman, withent consideration and for the areonmodation of the maker: that on september :0, 1s!)9, the plaintifl discomted the note for the maker, the defendant construetion company, receiving the houls: of the railroad company as collateral securily for its payment; that, in January, 1908, Kimmerman died intestate and his widow, this defendant, was appointed his administratrix; that on April 9, 1903 , the note was presented to the maker for payment and, payment being refused, was duly protested for nompayment; that "said note was not presented within a reasonable time after it was issued and that sair plaintiff did not demand the payment thereof, or give notice of the dishonor thereof, within a reasonable time." Upon these facts. he reached the legal conclusion that the plaintifl was entitled to enforce a lien upon the bonds by the sale thereof; but that, as the "prescntment of said note was not made within a reasonable time alter the disomnt," the inclorser, Zimmerman, and his estate wre released from all liability thereon. Upon the plaintiff's appeal from so much of the judgment thereupon entered, as adjudged that it was not entitled to judgment against the estate of the indorser for the deficiency 11001 a sale of the bonds, the Appellate Division, in the fourth department, by manimous rote, alfirmed the judgment as rendered. 'The plaintifl' now appeals to this court.

Gins', J. The only guestion of importane, which this appeal pre sents, is of the arrecturses of the derision that the presentment of the note for payment had not been made by the plaintiff within a reason! able time. "That must, neressarily, turn upon the effert of the ellart ment of the provisions of the Negrotiable Instruments Law of 18!); (Jaws of 189\%, wap. fi1?.) Seetion 131 of that law provides that. where the instrument " is payahle on demand, presentment must be made within a reasonahle time after its issue, except that in the case of a bill of exchange. presentment for payment will be suffieient if mafle within a reasonahle time after the last negotiation thereof." By section 4, it provided that "in determining what is a "reasonable time, or an 'unreasonable timn". regard is to be hat to the natare of the instrument, the nsige of trade or business (if any) with respect to such instruments, and the facts of the particular case." 
Prior to this legislative enactment, the decision of this court in Merritt v. Todd, (23 N. Y. 28), was regarded as having settled the rule of law applicable to the determination of such rases. In that case, the note was payable on demand, with interest, and the question arose as to the continuance of the indorser's liability. where three years had intervened between the making and presentment for payment. Chief Judge Comstock, with the concurrence of the majority of the judges, undertook to resolve what he regarded as the existing uncertainty as to the rule, which conflicting decisions had brought about, by referring the interpretation of the contract to the adoption of one of two principles. By the one principle, a promissory note, payable on demand with interest and indorsed, is to be regarded as a continuing security and no dishonor attaches until payment is required and refused. By the other, or opposing rule, the holder, if he wishes to eharge the indorser, must make his demand of the maker without delay. Judge Cosstock finds no intermediate ground to stand upon and holds "that questions of this kind ought to be determined according to one of the two rules which have been mentioned; in other words, that the demand may be made in due season at any time so as to charge the indorser, or else that he is discharged unless it be made with due diligence, in the general sense of the commereial law. Between these alternatives, we are to select the one which will best harmonize with the langnage of the contract and the intention of the parties. A demand note may be payahle with or withont interest. If the security he not on interest, it may be a fair exposition of the contract to hold that no time of credit is contemplated by the indorser, and that the demand should he made as quiekly as the law will require upon a check or sight-draft $* *^{*} *$ but $* *^{*} *$ we think that a note payahle on denand with interest is a contimuing security, from which none of the parties are discharged until it is dishonored by an actual presentment and refusal to pay. * * * If the parties declare in the written instrument, which is the ouly evidence of their agreement, that the money shall be paid on call, with interest in the meantime, a productive investment of the sum for some perior of time is plainly intended. What, then, is that period? 'The only answer which can be given is, that it is imlefinite or indeterminative, and ascortainable only by an actual wall for the money; and if that he the menning of the principal parties, the indorser must he deemed to lond his name to the entract with the same intention. * * * Wr see no grood reason why a note, like the one now in question. should not be anstrued preeisely aceording to its terms and. if wo follow thent enstmetion, such instrumente are not dishonored by the mere colluxion of time." Although the derision in Merrilt v. Thodd was sulsepquently discusesed and, in somr rases, criticised, its anthority was not shaken as establishing a rule of law and it was expressly followed as late as in l'arker v. S'troud, (98 


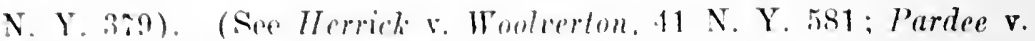

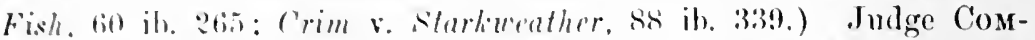
suck followed the doutrine of the buelish courts, in differentiating notes payahle on demamel with interest. from those payable on demand morely. He soment to grive ellewt, in the former ease, to what sermed to be an intention of the parties that, notwithstanding the tems. there should he no immediate lomand, and that the time of parment should be future: thus makimer the instrument a contimuing oblination.

The law being thus sottlen in this state, the Negotiable Instruments Law was passed, in list. as thr ontrome of a general movemont to bring about a mulorm law in this comntry, covering the subject of "Bills and Notes." It was a codification of the law and, in the respect which we are consideriug. it modified the rule as formulated in Merritl re Todd. It established one rule, which was to be applicalile to all ases. that where an instrument "is payable on demant, presentment must be male within a reasonable time after issue." To distinction was to be made, as theretofore, when the instrument was an interestharing ohligation. While, therefore, it most he regalded as changing the rule upon the subject of the time for the presentment of such instruments, hy placing them upon the same fonting. the fonrth sertion of the law has to be given eflect; which requires, in retermining what is a reasonable time, a consideration to he had of the nature of the instrument, any mage of trade and the facts of the particular case. 'That would, certainly, be suffirient to authorize the clillorentiation of hills, or promissory notes, from other instruments for the proment of money; but, even where it is a grestion of the lime within which a demand note must have been presented, the farts and riscumstances of the case must be regarderl. If a note is payblole on lemand, it is always mature and may at any time be demanded. The statute of limitations eommonces to pun aguinst the maker from its issue. (Ilemicliv. Woolverton, 11 N. Y. 5s\%) After its issue, what ronstitutes reasonableness of time for its juesentmont ammot be detemined hy any fixed rules: for. plainly, the particular reiremustances may be such as to widence some intention of the partios as to its entinuance. And, extainly, they may besufreient to justify an inference of unreasonable Anily. In my opinion. What the lecrislature intended to aceomplish hy the jervisins of the Xoentiablo. Instruments Law, in question, was to do aw with tha distinction hetween notes, or hills, payable on dumand, which Mrrill s. Todrl had reated, and to leave the question of throp reasomalile presentonent for payment, in order to charee the matis: to them. as one for the determination of the conrt upon the facts. That furetion. if the facts were unsettled and the testimony was comflime. mierht he a mixed one of law and fact, which the jury should decile, under the instructions of the court as 
to the law; but, where they are ascertained and are not in Jispute, the question is one of law. (Aymar r. Befrs, i Cowen. 705, 709; Mohawk Bank v. Broderick, 10 Wend. 304, :30s: C'arroll r. Upton,

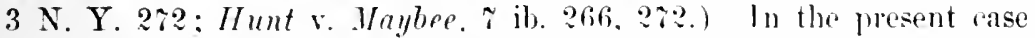
the defendant offered no evidence and there was no dispute about the facts. The trial judge had before him the facts of the discount of a demand note. learing interest: that the indorsoment by Zimmerman was without ronsideration and for the makers accommodation; that its payment was secured by the deposit of ecetain securities: that notwithstamling that, some two years after the making of the note the plaintiff had complained to Zimmerman of its non-payment and twice, a rear later, harl written that the maker was in default as to the interest. no steps were taken to charge the indorser. by presentment of the note for payment and hy protest for non-payment, until more than three and a half years had elapsed. If the finding that the note was not presenton within a reasonable time depended for its justification npon the eridene, we should be, undoubtedly, concluded from reviowing it by the rule of nuanimons affirmance. But viewing it, as I think we minst, as a ruestion of law to be decided by the court upon the asertained facts. it rependerl upon the interpretation of the statute as applied to the facts and, in my opinion, the decision of the trial court was colrect.

It is argued by the appellant that the defense. that the note was not presented within at reasonahld time after its issue, was one which should have heen specially plendod in the answer. 'This ohjection was not taken upon the trial: hut. assming that it rould properly be raised upon the appeal. it is untenable. The lurden is on the

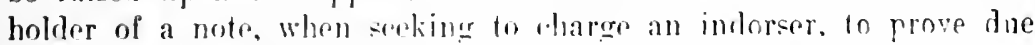
and timely presentulent and the erivine of notion in the iroderser of its dishonor. The ohligation of the imlursere is amblitional upon all the steps havine heen taken hy the holiker. Which the statute has pre-

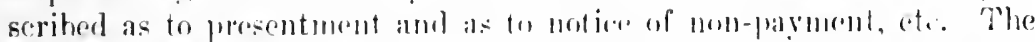

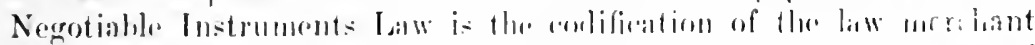

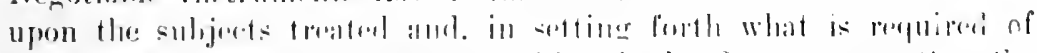

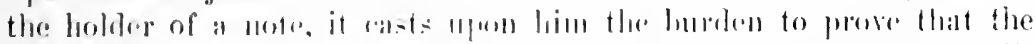

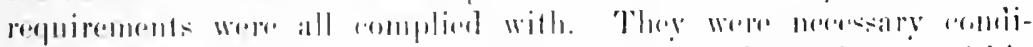

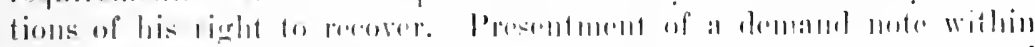

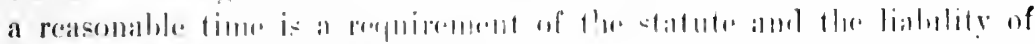

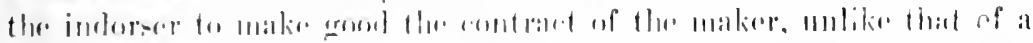

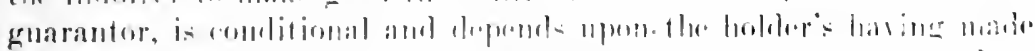

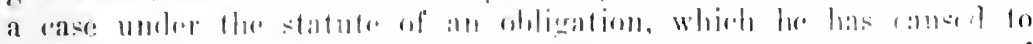

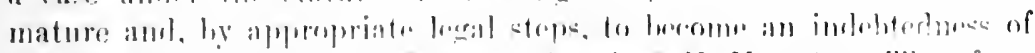

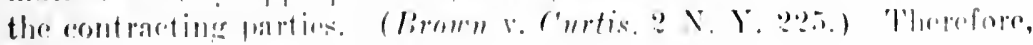

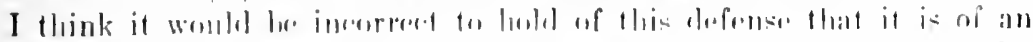

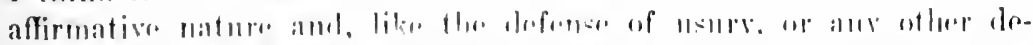

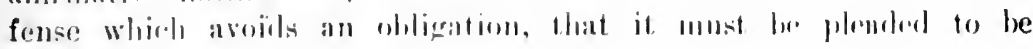
available. 
No oflucr fuestion demands considration and, for the reasons given, I advise the allimmane of the judgument, wilh rosts.

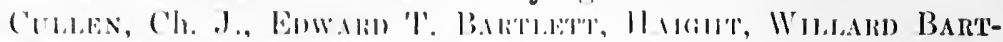
LET'L and CHASE, JJ, concur: V.I.N, J., concurs in result, Judgment aflirmed.

$\S 131$ PARKER v. REDDICK.

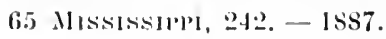

On Sept. 22, 18st, W. J. Palker bonght from Snider \& Son an instrument as follows:-

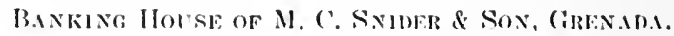

$\$ 200.00$ Grenam, Miss., Sept. 22, 1884.

lay to the order of W. J. Parker, two humberl dollars.

J. 13.' SNIDer, Cashier.

To Latham, Alexander \& Co., New York, N. Y. No. 50.665.

On the same day Parker indorsed this instrument and forwarded it to F. M. Lamon, Brooksville, Florida. On October 1, 1884, Lamon indorsed it to J. M. Rodilick. On Oct. :, 1851, Reddick inclorsed it to A. N. Chelf. On Oet. 13, 1SSI, Chelf indolsed it to Itancock \& Edrington, who indores it to Witz, Bidlle \& Co., Who indorsed it to the Union Bank of Baltimore, who indorsed it to the "Republic" Bank of New York, who, on Oct. 21, 188I, precented the same for payment. Which was refused on the ground that Snider \& Son had no funds in the hands of the drawees. The instrument was duly protested. and notice was forwarded to the indorser Parker, at Crenada, Miss, and also to the otler several indorsers. All the indorsers of the paper in enestion resided in the town of Brooksville, Floricla, except Wit\%, Biddle \& C'o., and the two banks referred to; and it was held in that town until the indorsement to Wit\%. Biddle \& Co., Who resirled in Baltimore, Md. There were daily mails from Brooksville by which a letter eonlal realch New York in five days.

I. M. Lirdiliek, one of the indorsers, ans well ans an indorsee, after hasine paid the aluonut of the check or bill of exchange to his inlorsere lorought this awtion against J. B. Sniker, surviving partner of Suritar \& Son, and W. J. Parlier, to recover the value of said inctrument.

On the first trial the jury found for the defendants. This verdiet was set aside ly the rourt. On the second trial the jury found for the plaintiff. The defendant, Parker, appealed from the judgment of the court.

7 See also Turner v. Iron Chief Mining Co., 74 Wis. 355, and Leonard 8. Olson, 99 Iowa, 162. - C: 
Arnold, J., delivered the opinion of the court.

It is uncertain from the evidence whether the drawees of the in. strument upon which appellants were sued were bankers or not; but whether the paper be called a check or bill of exchange, it expressed no time for payment, and was, therefore, payable on lemand. A bill or check, payable on demand, must be presented for payment within a reasonable time. What constitutes reasonable time in surl ease, is a question of law to be determined by the court, when the facts are ascertained. (Baslierrille v. Harris, 41 Miss. 5.35.)

No delay in making presentment of paper payable on demand, ean be termed reasonable, if it is more than is fairly required, in the ordinary course of business, without special inconvenience to the holder, or by the special circumstances of the ease. (Phœnix Ins. Co. v. Gray, 13 Mich. 191.) Such paper contemplates immediate payment. It cannot be said that it is intended for cireulation. One who holds a bill or eheck payable on demand, beyond the time necessary, in the usual course of business, for its presentation for payment, does so at his peril. The general rule, derived from the anthorities, but subject to modification by special cireumstances, is, that if the drawee of such paper, resilles in a different place from that in which it is drawn, and the instrument must he sent by mail for presentment, it must be mailed on the day next after that on which it was receiverl by the looliler. (1 Daul. on Neg Inst., $\$ 605$ : 2 id., \$\$ 1586, 1592; Pyles on Bills [\%th Am. ed.7, 211, 212, 213: Chitty on Bills [13th Am. ed.], 133: Fortuer v. Parham, 2 S. \& M. 151.)

Paper payable on demand. while not commonly intended for that purpose, may be put into circulation; lut its ultimate presentment for payment camut be delayed leyeond a reasonahle time, by transfer or suceessive transfers, any more than it can hy heing lowed up. or held an unreasonahlo time. liy the first or any subsequent holder.

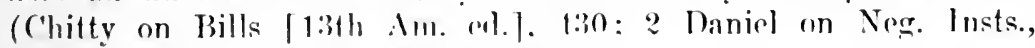
\& 1595; Story on Prom. Notes, s 191.)

If the paper sused on lo regarded as a bill. the drawer, as well as

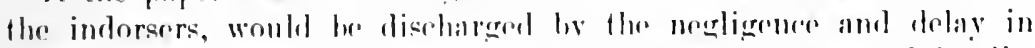
respeet to the presentment: hut, if a cherek. inclorsers would he dis-

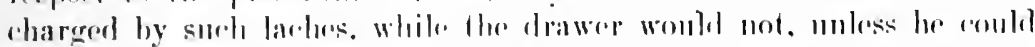

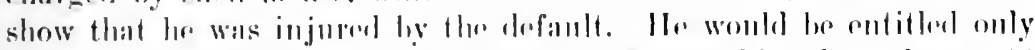

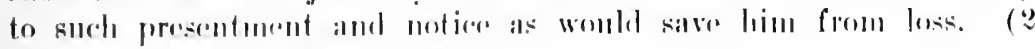
Daniel on Norg. lusta. . \$ 158\%.)

No excuse is slown ly the renerd for the delay which intoroned in presenting the paper in poustion for payment, and the logs therelyy occasioned rannot le imposed on the indorser. larker. As to him, the last verdict was rontrary to the law and the evidenese. 'l'he court below erred in instruetine the jury that the presentmont was mate within a reasonahle sime, and in refusing to instruct the fury to the contrary. The judgment is aftimed as to the drawrer, Sinider, who 


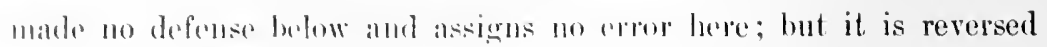

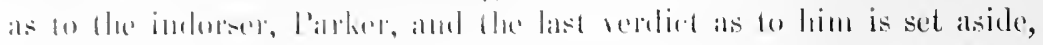

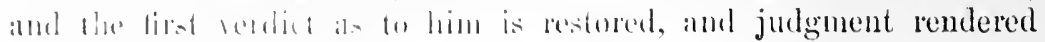
thereon, here, in lisilinul:"

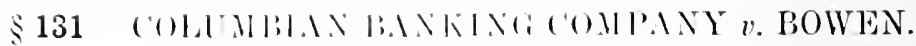

1:31 11 1.

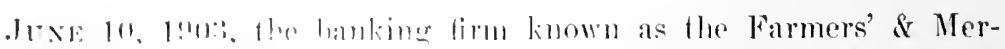

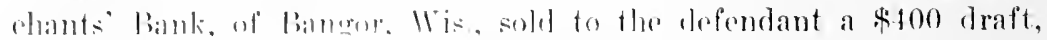

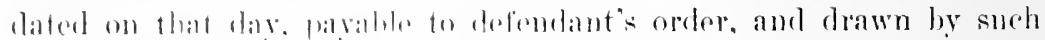
firm on the Xational biank of Xoth Ameriat, at Chieago, Ill. 'The draft was sent to the defombant at barom, llis., and was indorsed by lim to A. R. Tahlere, 10 whom it was forwaled hy mail, at Spokane, Wish., June 16, 190:3, and was there received by him June 20th thelealter. He was at sipokane temproraly and was on his way to the city of Sin Francisco, (a). July 14, 1903, he indorsed the draft and sold the same to the plaintifl at such eity, receiving $\$ 400$ therefor. On that day, in due rourse, paintiti sent the draft by mail to the Bankers, Sational Bank, of (hicago, Ill., by which it was received July 1sth thereaftor, and was then, as repuested, duly presented to the llawee for payment, which was refusel, whereupon it was duly protested for nompayment ly a luly authorized notary public, who forwarierl a manilest thereof with notices of protest for A. R. Tabbert, the plaintiff and the Aefentant, to the plinintifl at San Francisco, Cal., and also sent due notion to the National Bank of North America at Chicago, Jll., and to the drawer at Bangor, Wis., July 19, 1903. Plaintiff upon receipt of the manifest and notices duly sent the one for defendant to him at Barron. Wis., ly whom it was duly received, and sent the one for 'Tabhert hy mail to his post-office address and reputed place of resilenee, that heing San Francisco, Cal. Thereafter due demand was made on defendant for payment of the draft, and the same was refuscrl. Inly 28,1903 , the property of the drawer was placed in the possession of a recoiver, who duly paid upon the

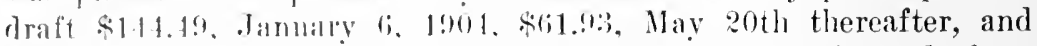
s.30.96. Jums oth following. Plantifl was the owner of the draft at the time of the commensement of the action, and at the time of the trial thereof there was bue thereon $\$ 210$.

8 A note indoresl when orerdue mu-t le presented within a reasonable time.

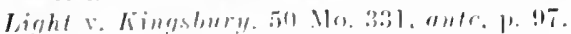

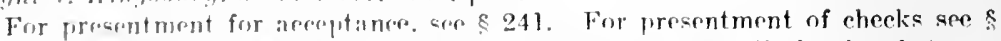

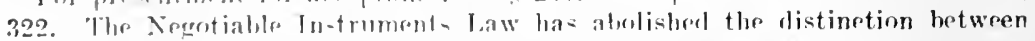

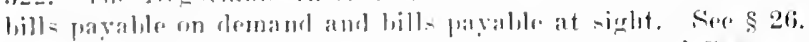

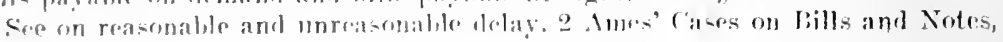
275 , notr. - H 
The pleadings presented issues for decision involving facts as above detailed. The casce wis tried by the court resulting in findings of fact in accordance with the statement, and a comblusion of law that plaintiff became the owner of the drat in due conlse, and was entitled to julgment for s:elo, witl costs. Jurlgument was areordingly rendered.

Marsiate. I. (after stating the facts as ahove). Commel for appellant hase presented quite an extended arwment, reforring to many anthorities, is to the law antedating and indepmentently of the negotiable instrumont satute (chapter 356. 1. 6s1. Laws isg9) to support the proposition. that appellant was releaser from lialility on the instrument in question. hecause of the period intersoning between his parting therewith and the presentation thereof in the drawee for pilyment. Sisch statute was enarted for the purpose of furnishing in itself. a certain suide for the determination of all

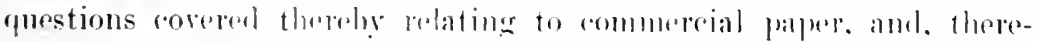
fore, so far as it speaks withont ambliguty as to any such puestion. reference to case law as it existed prior to the emactment is momessary and is liable to he mistending.

The Negotiable Instruments Law is mot merely a legislalive codification of judicial rules previonsly existing in this stalle makinge that written law, which wis hefore unwritten. It is, so far als it enese, an incorporation into wrilton law of the commont law of the stalle, so to speak, the law mejehant generally as rerognizerl here, with sum rlanges or modifieations and additions as to milko a system harmoniz-

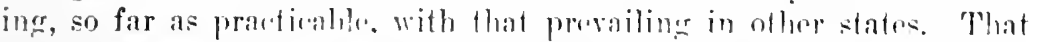

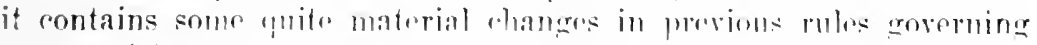

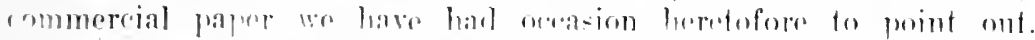

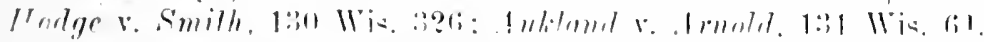

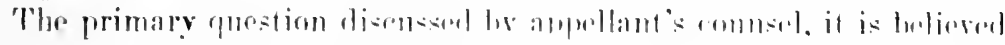

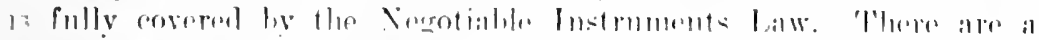

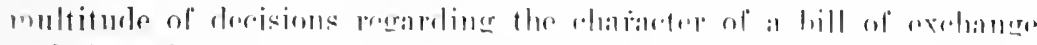

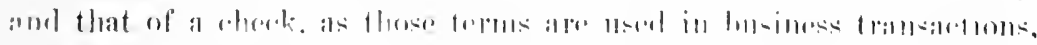

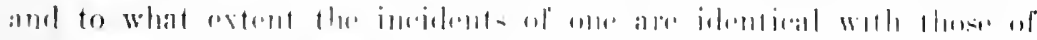

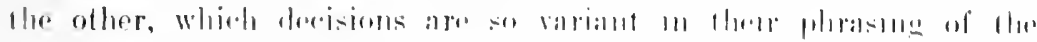

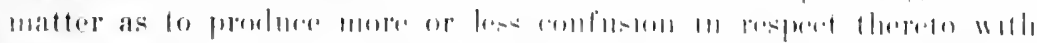

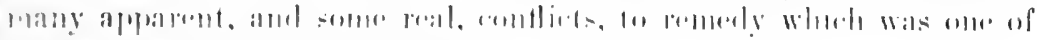
the principal ohe geets of the lans.

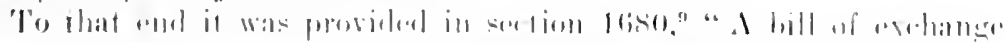

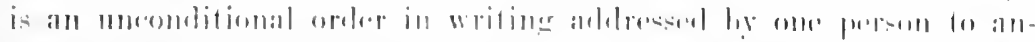

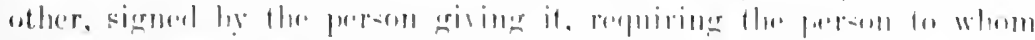

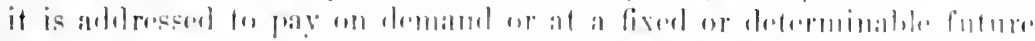

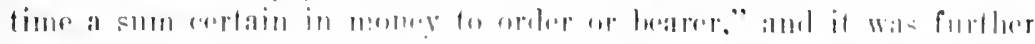

ค. Y. \$ $210,-r^{\prime}$ 
provided in section 168.1-1," "A rherk is a bill of exchange drawn

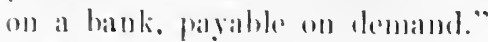

As to whether the imeichents of the speries of bills of exchange last mentioned are the sinme as those of hills of exclange generally, it was further provided in lle soution last referred to, "Except as berein oflerwise providerl, the provisions of this and applicable to a bill of crobage payahde on drmand apply to a check." The ouly exception refered to material to this case is contained in section 1684-2, ${ }^{2}$ in these words: "A rheck must be presented for payment within a roasonable time after its issue or the drawer will be discharged from liahility thereon to the extent of the lose eaused hy the delay."

Keeping in mind that the discharge from liability above referred to because of unreasonable delay after the issuance of a check in presenting it for payment. is of the drawer only, and that this action is against the payee who indorsed the instrument in question without qualification and put it in rireulation, we turn to section $16 \% 8-1 .^{3}$ which provides, as to a bill of exchange payable on demand, which from the foregoine obvionsly includes a check or draft on a bank of the character of the one in question, " presentment for payment will be suflicient if made within a reasonable time after the last negotiation thereof."

From the foregoing it seems plain that as regards the payce of such an instrument as we have here, who puts the same in circulation with his unqualified indorsement thereon, and all subsequent parties thereto so iudnrsing the same, presentment for payment is sufficienl, as regards their liahility. if made within a reasonable time after the last negotiation. A hijl of exchange payahle on demand, recardless of its character. put in eirenlation, so long as its circulating character is preserved may he outstanding without impairing the liability of indorsers thereof. Formerly the length of time within which a bill of exchange might (irenlate withont impairing such liability was more or less meertain. rendering it very diffieult to determine any one rase hy the defision in aunther. 'That diffieulty was removed, so far as practionble. hy the provision that only the time need be considered intervaning hetwern the last negotiation and the presentment. That is roognized as a radical change in the law as it formerly existed. Suction 195. Selover's Negotiable Instruments Law.

As to an oplinary bill of exclange put in circolation, it was quite anciently helt that the period between .July $18+h_{1}$ of one year and January lfith of the next year was not noessarily unreasonable. Gowan v. Jarlison, 20 Johns. (. . Y.) 176. Perhaps one might now keep a bill of exrhange for such length of time as to destroy its

1 N. Y. \& 321. - C.

2 N. Y. $\$ 322 .-\mathrm{C}$.

3 N. Y. $\$ 131,-\mathrm{C}$. 
rirculating character notwithstanding he ultimately passed it along to another person, hut that situation, as we view the ease, does not exist here.

Applying the law as aforesaid to the facts of this ease it is readily seen that the delay in presenting the paper for payment hetween its date and the negotiation to the bank at San Francisco is immaterial. Appellant unqualificully inclorsed the paper and put it in rirculation by sending it to Tabliert at a distant part of the country. probably knowing that he was a traveler. 'Tablert received the paper while journeying with the intention of going to San Francisen and held it till he arrived there and then negotiated it. It was promptly presented for payment thereafter and so in time, as regards that eircumstance, to preserve the liability of appellant.

The court decided, as indicated, that Tabbert was a traveler with San Francisco as his destination and properly held that such circumstance sufficieutly explained, if any explanation were necessary, the lapse of time between his reception of the paper and his negotiation thereof, preserving its circulating character and warranting the finding that the respondent ame thereby in due course.

The point is made that the instrument was not presented to the drawee for payment during hanking hours. The Negotiable Instrument Law at section 16\%8-2.4 provides that "Presentment for payment to be suffieient. must he made: $* * *$ at a reasonable hour on a busines day. ***" The evidence shows that the paper, after taking its course through the clearing house, was presented to the drawee for payment on the afterunon of the same day between the hours of 3 and 6 o'elock. The pronf is to the effeet that sueh wis the customary way of loing such lmsiness in Chieago, where the drawe was located. 'That is, as we understand it. that the husiness day of the hank contiunerl after the rosing of the elearing house transactions so as to enable hanks holding paper for eollection, refused recognition in such transuctions, to be presented for prament as was done in this case. That satisties the statute. What constitutes lusiness lours of a hank, within the meaning of the statute, has reforence to the general enstom at Hore place of the particulat transation in question. In case of a transiction ocemering in a foreign juristliction, as in the instance in question, the rourt cammot talie jullicial notice of what constifutes reasoniblu homse on a lusiness diy. Daniel ou Negotiabl. Instruments (5th cel.) s gol. It is a matter of proof, though in ense of the notarial certifieate of the transaction, as here. heing regular so as to furmish frime facie proof that the paper was duly presented for payment. that raises the presumption that the pre-

4. Y. § 132, - C. 
sentment was male at a proper time. Cayuga Counly Bank v. II unt, 2 Ilill (N. Y.) 635.

Juigment aflirmed. ${ }^{5}$

$\S 131$

ROBINSON 1 A AMES.

[Reportad hercin al p. 633.]

$\S 132$

FARASITOR'TII $r$ ALLEN.

4 GRAY (MAss.) 453. - 1855.

Actios hy holder against indorser. Defense. presentment and demand insufficient. Verdict for plaintiff. Defendant alleges exceptions.

The agent of the holder did not know the maker's place of residence. After inquiring it, le gave the note to a notary, who went to the house of the maker and arrived there about nine o'clock in the evening. 'The maker and his family hat retired for the night. but the maker answered the hell, and, upon the note being presented, refused payment.

Bigelow, J. - The note declared on, not heing payable at a bank, or at any place where business was transacted during certain stated hours in each day, was projerly presented to the maker at his place of residence. It was also the dinty of the holder to present it within reasonable hours on the day of its maturity. No fixed rule can be established by whicl to determine the hour beyond which a presentment, in surh rase, will be unreasonable, and insufficient to charge an indorser. Generally, howerer, it stould be made at such hour that, having regard to the habits and usages of the rommunity where the maker resides, he may he reasonably expected to be in a condition to attend to ordinary husiness. In the present ease, taking inte consideration the distance of the place of resirlene of the maker from Boston, where the note was dated, and where it was held when it herame due: the means that were taken to ascertain the residence of the maker. and the season of the year at which the note fell due, we are of opinion that a presentment at nine o'clock in the evening was seasonable and sufficient. It is quite immaterial that the maker and his family had retired for the night. The question whether a presentment is within reasonable time cannot be made to depend on the private and pornliar hahits of the maker of a note, not known to the holder: lont it must be determined by a concideration of the rircumstances which, in ordinary rases, would render it seasonable or

$\checkmark$ See also Plover Sav. Mank v. Mordic. 335 Jowa, 685, post, under $\$ 322 .-\mathrm{C}$. 
otherwise. (Barciay v. Bailey, 2 Campb. 527; Triggs v. Newnham, 10 Moore, 24?, 1 Car. \& P. 6.21: Wilkins r. Jurlis, ? B. \& Ad. 1ss; Cayuga County Bank v. Hunt, 2 Hill [N. Y.], 6i35.)

Exceptions overruled. ${ }^{1}$

\section{$\S 135$ NEWARK INDIA RUBBER MFG. CO. . BISHOP.}

3 E. D. Smiti (N. Y. City C. P.) $48 .-1854$.

Action by holder against two indorsers. Iudgment for plaintiff. Defendants move for a new trial, which is granted as to Griffin, but denied as to Bishop. Bishop appeals.

The note was payble at the Bowery Bank. On the day of maturity Bishop left his check with the teller to take up the note. The note was not presented during banking hours and at the close of banking hours the teller left the bank having the check still in his custorly. After banking hours the note was presented to a clerk who was at the bank and who examined the ledger and said there were no funds. Due notice was given.

At the trial the jury were instructed as follows:

"If funds were provided and set apart to pay the note, and if it was not paid for the reason that the note was not presented for payment in the usual business hours of the bank, the indorsers are discharged.

"A presentment of the note for payment at the bank, but not within the usual hminess hours. to a rlerk who rould not pay the note, is not a good presentment which will hold the indorser.

"It is not enough that the elerk to whom at such a time the prosontment is made, hare powre to hind the bank to pay the note by reptifying in writing on the note that it is goofl.

"In order to make a presentmrent at sureh a time, a sufficient one, the pereon to whom it is mate must have the power to pay the note aud take it up, by aretual payment to its holder of funds that are provided in the bank for that purpose."

Womniter, J. - I did not foel a allod upon to order a new trial in this aso in favor of the appellant Bishop, who harl himself withdrawn the money providerl to moet the note. Ihe knew that the maker womlel not pay the motre as early as the morming of the day it becam. due, for lie had himsolf molertaken to provile fumls for its payment. On learning that the note was not presented till aftor business hours, he himself takes the momey which had bern set apart for the use of the plaintiff, and appropriates it. Imoler such rireumstances, the jury having rendered a verdiot against him on the trial,

1 Compare Dana v. Saryer, 22 Me. 244, holding the hour unreasonable. - H. 
I did not think, and I do not now think, that the court should set that rerdiet aside as against erideme for his benefit, and to enable him to keep that money, when he has not been in any manner or by any possihility injured hy any defeet in the presentment.

The asse of the defendant Grithith is very different. It is an undisputed fact that if the note had been presented at the bank within the usual husiness hours it would have been paicl. It is equally elear that at the time the note was presented, there was no person in the bank who eonld pay it. 'The mulertaking which the note and its indorsements imported was. that there should he at the bank during the usual hours of business on that day, funds in the hands of proper persons competent to pay them over, sufficient and ready to meet that note. Not that every person who might be employed about the bank, from the president down to the porter, and who might happen to be in the bank after it was closed, should at all hours, so long as the door was unlocked, be ready to pay the note.

I do not question that there nay be a good presentment at hank after banking hours, by which I mean after the hour until which banks are open for the purpose of paying notes which may be presented. But I think that he who delays presentment until after that hour takes the risk of finding at the bank a person who can pay the note if the funds are provided, or who is authorized to refuse if they are not.

The ease of Garnett v. Woodcock (1 Stark. 475), which has been referred to in support of the sufficiency of this presentment, proceeds upon the distinct ground that if a banker appoint a person to attend in order to give an answer, a presentment would be sufficient if marle hefore 12 o'clock at night, and that in that case it did not appear but the person was stationed there for that express purpose; while the general rule that presentment must he made within the usual hours, is not at all repudiated hut rather affirmed by that same case. And see Parlier v. Gordon, y East, 385; Barclay v. Bailey, 2 Camp. 527; Willins v. Fadis, 2 B. \& A. 188; Elford v. Teed, 1 M. \& S. 88 ; Bank of Utica v. Smith, 18 J. R. 230.)

In this rare it does affirmatively appear that the person to whom the presentment was made was not stationed there to give an answer. The funds were there, but he could not pay the note. IIad he known that the funds were there, provided for the express purpose, still he could not pay the note, so that it was by reason of the omission to present within the uswal hours, and for that cause alone, that the note was not paid at its maturity. I think that the charge was in this respect correct.

[INGRainam, P. J., also wrote an opinion for affirmance.]

DALY, J., coneurred in affirming the order, but wrote no opinion. nrrler affirmed and a new trial denied.2

\footnotetext{
2 Approved in salt springs N. B. v. Burton, 58 N. Y. 430, 436.
} 


\section{$\S 135$ GERMAN-AMERICAN BANK OF ROCHESTER $v$. MILLI- MAN.}

31 Miscellaneous (Monroe County Court, N. Y.) 87. - 1900.

Sutherland, J. - This action was brought upon a promissory note dated January 6,1899 , made by the defendant, payable three months after the date thereof to the order of W. F. Williams, at the Central Bank. Rochester, N. Y., for $\$ 39$ and interest. Pefore maturity the note was indorsed by Williams, the payee, and transferred to the plaintiff. The day the note hecame due (.Ipri] f, 1s.9), shortly after 10 o'elock, a messenger from the plaintiff presented the note at the Central Bank, and requested payment, which was refused because the defendant's account was not good. 'The banking hours at the Central Bank are from 10 a. m. until + p. m; the banking hours of the plaintiff are from $10 \mathrm{a} . \mathrm{m}$. until $3 \mathrm{p} . \mathrm{m}$. At about half past 3 of the afternoon of the same day the assistant eashier of the plaintiff, who is a notary public, presented the note at the

If the bill or note is presented at a business office or a bank, it must be presented during customary business hours. Parker v. Gordon, 7 East (K. B.) 385. But if the holder finds a person at such office or bank after business hours upon whom demand may properly be made, such demand is good. Garnett v. Woodcock, 6 Maule \& Selwyn (K. B.) 4t; Sult Springs Nat. Bk. v. Burton, 58 N. Y. 430. See post, § 135. A notary's ecrtificate ueed not name the time of day when presentment was made, for it will be presumed to be a reasonable hour. Cayuga County Bk. v. Hunt, 2 Ilill (N. Y.) 6i35. But where the notary's certificate states that he presented the instrument at the office of the maker at 5:20 p. m., and found the door locked, it is arror to refuse to hear evidence that this is not within the customary hu-iness hours. Clough v. Iolilen, 115 Mo. 336.

Where an instrument is payable at a hauk it is sullicient that the instrument be in the bank on the day of maturity; the formal demund is male by the bank upon the maker's account, and if that be not suflicient to moet the note or bill, the instrument is diwhonored. I Dinnirl on Nog. Inst., \$ fisti. lBut it is held that the physeal presenes of the instrument in the hank, unknown to the officers (as where the letter in whicls it was sent was mislaid mopenod), is not a presentment and demand. Chicopee Bank v. Mhiladelphio Bank, 8 Wall. (U.S.) 6.11.

\$ 147. Whether, if a mote is payable at a bank and is there presinted. the laak is found to pay it in ease the maker has a suflecent deposit. has foen

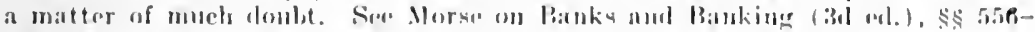

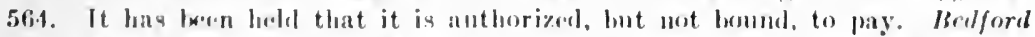

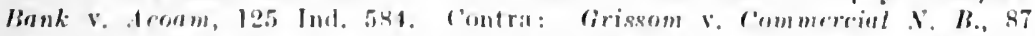
'Tenn. 350. It has bern held thent it is bound to pay ont of the depouit if the

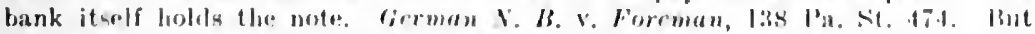
not out of the deposit of an indora.r. though he is knowe to be the prineipal flebtor. First N. R. v. Prlt: 17fi Pa, St. 513; though it may do un, Brohonirs',

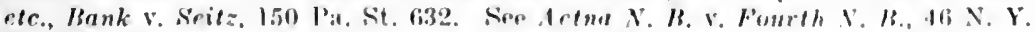
82; Indig v. National rity Rank, 80 N. Y. 106; National kank v. Simith, 86 N. Y. 271. - H.

NROOT, INETROMENTS - 32 
('ontral bank, and demanded fayment, which was refused beeause the defendant's atcomt was not good. 'The notary immediately protested the note, and about 1 o chock mailed notices of protest to the imborser and maker. Ifler the notary had presented the note, and payment had been refused, Milliman deposited in the Central Bank cash, and a check which was trated as ealsh, sulficient in amount to malie his arcount good for the note in suit. Nhout 5 minutes before 1 ovlock Milliman leposited enourh in the C'ontral bank to pay the note, ame then wont to the German-inerican Bank, and told its cashier that he had made his aleromt grool. 'l'he ashier told him that, as the note hat alrealy gone to protest, he would have to pay the fare of the note and interest, and $\$ 1.50$ protest fees, whieh protest fees the defondant derlined to paly. The correct amount of the protest leos was \$1.11.

This aldion was commenced April 15, 1899. The defendant's a." comt remained good for the amount of the note from 5 minutes of 4 p. m. of April bith motil the morning of the day when the summons; was returnable in this artion, when defendant withdrew from the bank the amomnt of the note, with interest up to the date of its maturity, which amomnt he at once paid into court when he filed his answer pleading a tender. The municipal court gave judgment for the face of the note and interest to the date of the judgment, besides $\$ 1.14$ protest fees and the costs of the action.

The defendant insists that by making his account good for the note and accrued interest before the close of banking hours at the Central bank he fulfilled his contract, and that the two demands and refusalis which had been made carlier in the day did not put upon him the duty either of making a tender of the amount at the German-American Bank, or of paying the protest fees, and that the judgment appealed from is excessive in awarling plantilf interest from the maturity of the note to the date of jum gment, with protest fees, and that defendant not plaintiff, should have been awarded costs.

The rrspondent contemls that it was not necessary for the notary to wait motil the close of hanking hours at the Central Bank, but that, thre note hatring loren ones presented there for payment within banking hours, and payment being refused berause of the want of funds, the note was throbe immeriatuly dishonored, and was properly protested before 4 orlork: and that, if the maker desired to fulfill his obligation after one presentment and refusal, he was bound to bring the money to the plaintidt"s bank, and there tender the amount due, with the protest fees.

The question thus presented is not free from doubt, and there is no reported caso in this state which is precisely analogous to the one at har. Tumerous expressions may be found, however, in the opinions of the rourts pronounerel during a long sories of yoars, which, although obiter dicta, deserve respect, and serve to indicate with some 
degree of certainty the views of the judges on the point inrolved here.

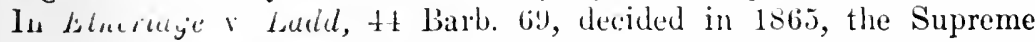
Cotirt hich that, where a note was made payable at the store of one ('hild, and a demand was made between 8 and 9 a. m., during the crlinary husines lours at the store, the holder was at liberty at once to treat the rote as dishonored, and immediately give notice of nomproment to the indorser, without wating until the close of busiJuss liours of that day. Judge Bockes, in the opinion, refers to the general lule that: "If payment be refused during the last day, the holde: may wive notiec of its dishonor: yet, if payment he subsequently madr or: that day, such notice hecones of no avail. True, the maker bas the whole of the last lay of grace within which to pay : but, after due demanl and refusal, followed ly notice to the indorser, the maker, if he wisher to make payment, must seck the holder for that purpose." He recognizes, however, that more latitule is allowed the maker of a note paralile at hank flam is permitted the maker of a note payable at some other place, for at page 82 he says: "IIe [the holder] was not rejuiresl to remain all day at the place to receive payment: nor was he boumd by any contom-as, porluaps, he might have been had the note bees payable at a hank-to leave the note until the close of the day. But his luy vis at an end when he made presentation of the note for payment, at the proper place, at a reasonable hour, followed by immediate notier to the indorser." Again, at page 73 , he says: "Thliere is a mitom at banks which gives to the maker all of hank hours within whic! to pay, and, in order to meet this custom, the note when payalde at a bauk. is usually left there, and demand is made at the alose of the diy y." * * *

TAfter discossing banl v. Elderlin, 25 N. Y. 1\%, the court continues:]

Reference is malu in Hare opinion to the ase of Cillell $r$. Arerill, 5 Denio, 85, in which latter ease, in the opinion of Justice Whlittlesey, written in 18to, it is sald: "It is understood to be the anstom of banks holding promicsory notes payable at their own counter to wat, on the day of the matrierity of the note, motil the close of hosiness loners, and then, if llwe malier has no fouds, to grive notion of nompayment. without making any other demand of payment." 'This rustom

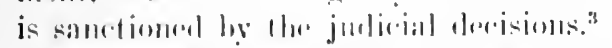

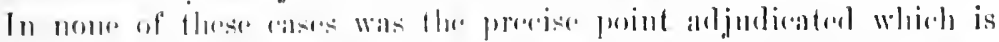

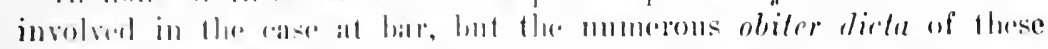

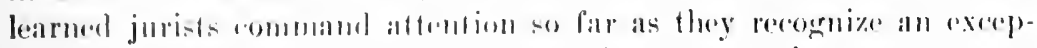

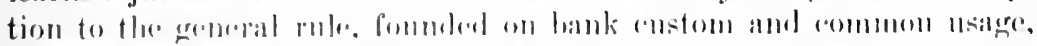
giving the maker of a mote payable at a bank motil the close of banking hours to deposit momery there to moent it, notwithetanding a :resentation be the holder and weforal marlier in the day.

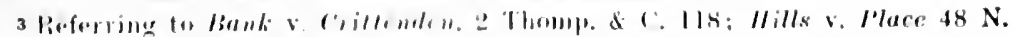

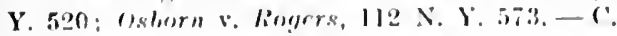


Some of the text-book writer's say this bank usige must be recognized and enfored by the courts. Mlr. 'Tiedeman, in his work on Bills and Notes (published in 1s?s, which contans a discussion on the Negotiable Instmments Law passed in New Jork in 189\%), at section 121, says: "The areptor or maker has the whole day in which to make payment. But a secomd lemand cammot be reguired of the holder. If the paper is payalile in a bank, it rould serm to be mecessary to keep the hill or note at the bank, so that the acerptor or maker may make payment there at any lime during the business hours of the day. It it is payble at the plare of business or resiclence of the obligor, he mmst seek the holder, in order to make payment, where he fails to pay when the presentment is made."

Mr. 'liedeman refurs, in a mote to this section, to Marrison v. Crouder, 6 smedes \& M. Itil. In that case it was athirmatively proven upon the trial that the bank where the note was payable had a custom by which makers had mutil the expiration of banking hours to pay, and that no note was comsidered dishonored if payment was made at the last moment. The cont there says: "The law undoubtedly is that, ly making a note payable at a particular bank, the parties are presumed to consent to be goveried by such eustoms as may prevail in the bank, with regard to making demand of payment. A greater strictuess must be olserved in making these constructive demands than is necessary in persomal demamels. A pelsomal demand may be made at any time during the third day of grace, but a constructive demand at hank having regular business hours must be made at the elose of the business hours, for the maker has until that time to deposit the money for the payment of the note."

The same court, in a previous case (Bank v. Markham, 6 Miss. 397), said, where bank nsage had been proven; "It follows, as a necessary conscuuence of this doctrine, that a note or other security thus payable at a bank camnot be consirlered as due until the expiration of the bour allowerl for paymont hy the invariable usage of the bank, and that it must be left at the bank until the completion of the allotted period."

Obiter dicla may he fomnd in reported ases mpon the other side of the question. Wrifarland v. I'ico, 8 Cal. 626 (opinion written by Jurlge Field); Thorpe v. Pecks, ¿s It. 1:2. But in McFarland $\mathrm{r}$. P'ice the note was not payable at the bank, and in Thorpe v. Pechs no money was erer put in the bank to neet the note, and the note was protester about the tinne the bank closed; presenting facts quite sinilar to thos: in liank v. Elderlin, 25) N. Y. 1\%s, supra.

In the case at har the woller of the Central Bank was called as a witness and gave this testimony: "Q. At what hour does the Central Bank protest promissory uotes in the possession of the bank and payable at the C'entral Bank" A. At fomr o'rlork."

But the rlaim is madr in this rase on hohalf of the plaintiff that the Negotiable Instrunents Law of 1897 has enacted that a demand 
made at the bank where the note is payable at any time during banking hours on the day of maturity is sufficient, and that the note may be protested at once, if not immediately paid, and the protest fees charged to the maker of the note; and that the maker must seek the holder of the note after such presentment to make a legal tender of the amount due, even before the bank eloses. But I do not think the statute discloses any intent to modify existing rules in this respect.

Section 130 provides that presentment for payment is not necessary in order to charge a person primarily liable; and, if the note is payable at a special place, the alility and willingness to pay it there at maturity a re equiralent to a tender of payment. Section 131 provides: "Presentment of an instrument not payable on demand must be made on the day it falls due." Section 132: "At a reasonable hour on a business day." Section 133: "At the place of payment specified in the instrument." Then comes section 135, which is relied upon as establisling the rule contended for by plaintiff: "Where the instrument is payable at a bank, presentment for payment must be made during banking hours, unless the person to make payment has no funds there to meet it at any time during the day, in which case presentment at any lour before the bank is closed on that day is sufficient." In my opinion it was not the intention of the legislature, by section 135 , to change the law as it stood up to that time, giving the maker of the note all of the banking hours to meet his note payable at the bank. The language of section 135 is taken almost word for word from the opinion of the Court of Appeals in Bank v. Burton, $58 \mathrm{~N}$. Y. 430, in which case no funds were left in the bank to meet the note, and the note was not actually presented during banking hours, but an hour after, when the holder was admitted into the bank, where he found the ashier, of whom he demanded payment, who refused, on the ground that no funds had heen left with which to pay. The indorser defended upon the ground that this presentation was insufficient to hold him, and that was the whole controversy. The eourt was not called upon to deride at what time during banking hours presentation should be madr. Aml seretion 135, it seems to me, was incorporated into the Negotiable Instruments Law, not for the purpose of derlaring that presentment at any time during banking hours is sufficient, but to codify the rule annomed by the court in kank $v$. liarton, that, caen though no domand be male during banking homs, if no funds are left to meet the note, a demand will hold an indorser, if made upon a bank oflicer at the bank on the snme dia hofore the outer doors are colosed. Seretion 1:30, requiring presentument in goneral to be "at a reasonilub. homr on a business day," is intender fo provent demands at unreasmable hours; for instance, 1 il. m. On the dily of maturity. It does not declare what is a reasonahle hour, amd, miless the maker has until the roce of hankine bours to make his anowit, any time during bonking hours must be considered reasonable. Fif- 
teon mimmtes after fho bank opuns is as reasonable time for present-

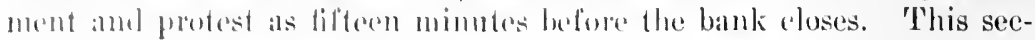
tion works no whange in the law.

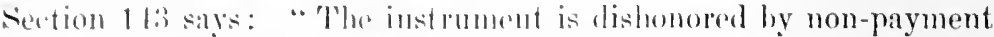
when: (1) It is duly prosonted lor payment and payment is refused

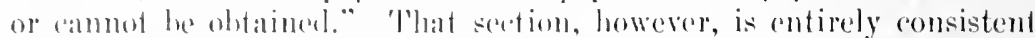
whith the proposition that a mote payaho at a bank is not dishomored prosident tmuds to meet it are deposited before the close of banking inomrs.

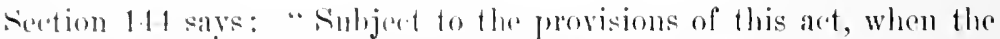
instrument is dishomoled by nompanyout, an immodiate right of le"oulse to all partics sommlarily liable thereon arerues to the holder." 'This sortion is not inconsistent with the dofendant's position, heranse the mote is not dishomored alsolutely if the deposit is made before the elose of hanking homrs. If sortion 1.11 is to he construed as applying to notes javible at a bank, it might be argued with much fore that the lexistature intended to permit an indorser to be sued on the day the note lalls dure, and even before the close of banking hours, provided an early drmand be male. I hardly think any such startling innovation was intended. Simith $v$. Aylesworth, 40 Barb. 104.

Seetion 1\%: says: "Notice fof protest $\rceil$ may he given as soon as the instrmuent is dishomored." In Crawford's Ann. Neg. Inst. Iaw, the wlitor says, in a note to this section: "The holder need not wait until the (lose of husiness hours, but may send notice at once:" and rites lianli $\therefore$ Swamn, 9 Pet. 33; Lenox v. Roberts, 2 Wheat. 3\%?, and Ex parte Woline. 19 Ves. 216. But I do not think the learned author in this note intended to ind hele promissory notes payahle at a bank, for the cases cited by him are quite inapplicable io such paper.

In Fank v. Smann, 9 Pot. 39. !) L. Ed. 40, the question was as to

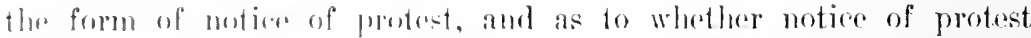

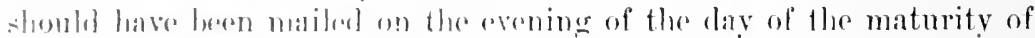
He notw, of the following lay. In lalet, the note in that rase was in the hank doring the wholn of the hanking hours, and was not protested nutil alter the lank aloser]. 'The anot does not intinate that notice

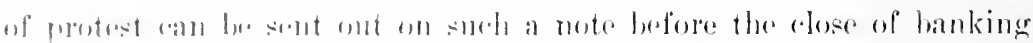

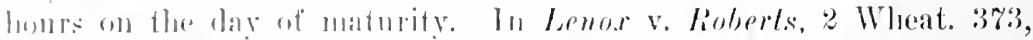
1 1. El. efil, the moto was not palyble at the hank, and there is

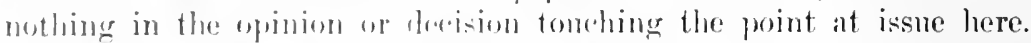

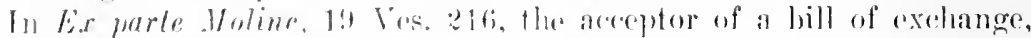
when the hill was preselited to him at 11 rielork on the morning of the day it beramo dure rofused payment, and derelared that it never

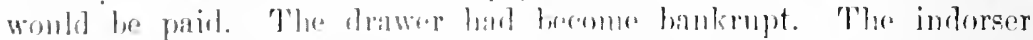

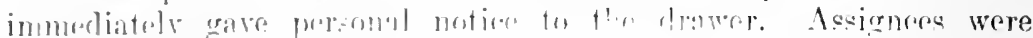
thereafter, and on the same day, appuinted for the bankrupt, and the 
assignees objected to the allowance of the claim against the drawer on the ground that he had been discharged beeanse the notice of dishonor was premature. Lord Chancellor Eldon said: "I to not recollect any decision that, if an acceptor declares at eleven o" olock in the morning that he will not pay, notice of that to the drawer is not good. If the law does not impose on the holder the duty of inquiring again before fise o'elock, it would be extraordinary that this information to the drawer of an answer, precluding any hope of ohtaining anything hy alling again, should not bave effect. If a bankir says he will not accept, I ammot imagine that the holder is olliged to apply again at ton mimutes hefore five."

Now, there is nothing in that decision or in the words of the lort chancellor militating agrainst the contention of the defendant here. The bill of exchange in that anse does not appear to have heen marde payable at a bank. Lord Eldon's reference to a banker is by way of illustration only: and probably he refors to a binker who refuses to honor a check when it is presented. Of course, the cheek (an be protested, and an aldion commenced immediately against the driarer on behalf of the holder.

The language of Mr. Justice. Story in Mills v. Bank, 11 Wheat, 131, would seem to inlieate that in the opinion of that leamed jurist the parties to a note made piyalule at a hank are homb by the usage of that bank as to the time griven to the maker of the note to pay the same, without having the note go to protest.

My conclusion is that the maker of this note in suit was allowed, by commercial usage, mutil 1 ridork to deposit at the Central Bank the money necessiry to wow the note: and, such deposit having been made fifteen minntes before 1 cirlock, the maker is not in defanlt. Although demand for the payment of the note was previously marle, and the note protesterl for non-payment, the protest berame of no avail on deposit of the amount of the note and interest, and the maker

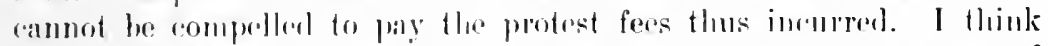
this should be held to he the rulde whether we regind the protest of

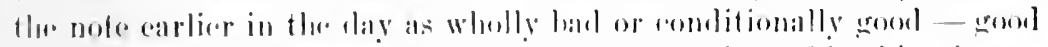

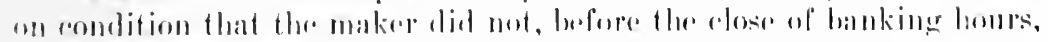

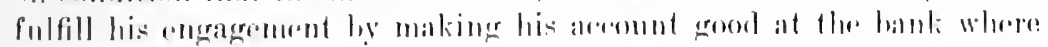

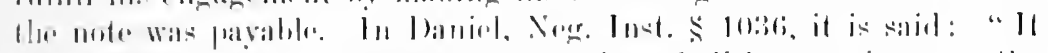

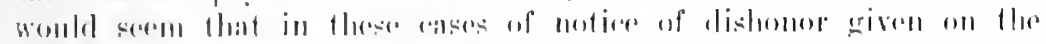

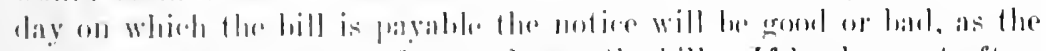

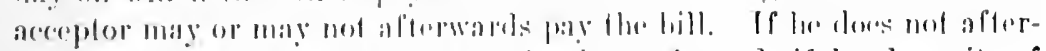
wards pay it on that diy, the notire is gromel: and, if he dows, il, of rourse, comes to nothine."

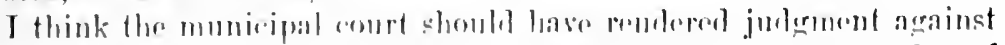
the defendant for the alloment of the mete. with interest for the day of

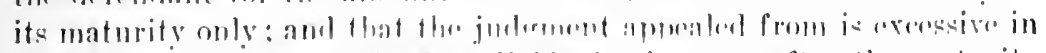
so far as it aljudges defondant liable for interest after the maturity 
of the note, or protest fies, or costs of the action. 'The judgment appealed from is, therefore, modified so that plaintifl shall recover of the defendant $\$ 39.5$ !) damages as of May 5, 1899, and no more; and by striking out the allowance for eosts, $\$ 9.90$. The defendant (appellint) is allowed on this appeal $\$ 10$ costs, hesides disbursements.

Julgment modified, with $\$ 10$ costs to appellant.

\section{\$ 145 AN AMBIGUITY IN THE NEGOTIABLE INSTRUMENTS LAW.*}

[23 H.RWALD LAW Revifw, 603-607.]

Whes it is considered how carefully the Negotiable Instruments Law has been examined by critics, ${ }^{5}$ and how long the practical working of the act lias been tested, it may seem odd to discover now an ambiguity in a section of the statute which involves a question arising every week in the business of every large bank. But such a discovery emphasizes the difficulty under which the draftsman of a statute labors in attempting to foresee all questions that may arise and in expressing clearly the rule which he wishes to have enacted.

A section of the Negotiable Instruments Law which has recently been found to be either ambiguous or to mean something which bankers have not suspected until recently is section 85 . This section is as follows:

"Section 85. Every negotiable instrument is payable at the time fixed therein without grace. When the day of maturity falls upon Sunday, or a holiday, the instrument is payable on the next succeeding business day. Instruments falling due on Salurday are to be presented for payment on the next succeeding business day, except that instruments payable on demand may, at the option of the holder, be presented for payment before twelve o'clock noon on Saturday when that entire day is not a holiday." "

The words in the section which have been italicised are those to which the following discussion relates; they are contained in the draft as recommended by the Commissioners of Uniform State Laws, and have been adopted in the law as enacted in most of the states.

4 This article is by Professor Samuel Williston of the Harvard Law School. $-\mathrm{C}$.

S See the articles by Professor Ames, 14 Harv. L. Rev. 241, 442, and the article by Mr. Mckechan, 41 Amer. Law Reg. N. S. 437, 439, 561. These articles together with defenses by Judge Brewster on the points criticized are reprinted in Profegsor Brannan's work on the Negotiable Instruments Law.

B This section is numbered as seetion 145 in the New York Statute, and in Mr. Crawford's book which reprints the statute as enacted in New York. It is enacted in the Massachuetts Peviserd Jaws as section 102 of Chapter 73.

7 In a few states changes have leen made. Arizona, Kentucky, and Wisconsin omit the clause altogether. In Colorado the following words have 
It has been the practice of banks, at least in the eities of New York and Boston, sinee the enactment of the Negotiable Instruments Law, to present on the following Monday all notes or bills whose date of maturity falls on Sisurday. No presentment of such paper has been made, customarily, on Saturday. The propriety of this procedure was called in question in a case which arose not long ago in Boston. A large issue of interest-bearing notes of a railroad company was held by a trust company. By their terms these notes matured on Saturday and were payable at a specified bank in Boston. On the Saturday when the notes matured the railroad company had on deposit in the bank, where the notes were payable, sufficient funds for their payment. 'The notes were not presented until the following Monday, and when presented interest was demanded to the day of presentment. 'The bank, however, deelined to pay interest for the interval between Saturday and Monday.

By the provisions of the Negotiable Instruments Law, ${ }^{8}$ where an instrument is made payable at a bank it is equivalent to an order to the bank to pay the same for the account of the principal debtor, and further, by another section, ${ }^{3}$

"If the instrument is by its terms payable at a special place and he [the person primarily liable] is able and willing to pay it there at maturity, sueh ability and willingness are equivalent to a tender of payment upon his part."

It was claimed by the bank at which the notes in question were payable that the notes were due on Saturday and that the presence of funds in the bank where the notes were payahle operated as a tender of payment and therefore stopped the running of interest. 'The large amount of the notes involved made the question of interest for even two days one of consequence, hut even more serious cases may be sup-

been substituterl: "Instruments falling due on any day, in any pluce where any part of such dily is a holiday, are to be presented for pityment on the next succerding business day." In New lork the year after the enactment of the Negetiable Instrmments Law the worle "or hecoming payable" were inserted after the words "falling due." 'This ehange has been eopied in Kansas. In Masuachusetts this clause of the statute as originally passed was identical with the draft reounmonded hy the Commissioners on finiform state

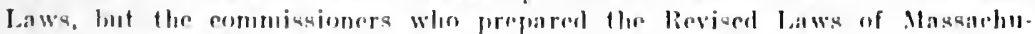
setta inserted the worls "or payahle" after the worls "falling due," and the New Hamplahe statute his followed the form of the Masabehusetts Reviser laws. The insertion of the words "leerming payable," or "ar

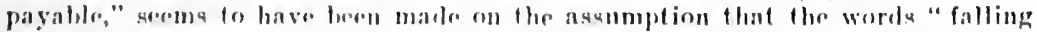
due" moant something other than "breoming payable." lhis aseumption seems unfounded. - See Mr. (rawford's note to seetion lds of his hook on the Negotiable Inatruments Jow.

Bection 87; Crawford's Neg. Inst. Jaw, gee. 147; Mass. Reve. Lawe. r. 73 , nec. 104.

- Section 70; Crawford's Neg. Inst. Law, sec. 130; Mass. Rev. Iaw4, c. 73, nec. 87 . 
posed involving the same question. A note matmring on Saturday

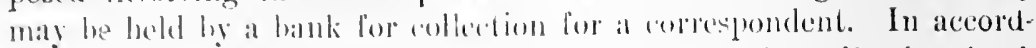
ance with the "ustom which hats heen prevalent the collecting bank would make no presentment until Monday. It may be supposed that on Siturday the note would bave been paid had presentment been malde, hut that owing to supervening hankruptey, or other camse, the note is dishonored when presented on Monday. If the note was legally due on siturday the collecting bank bas beeng guilty of negligence and is liable to its correspondent. 'l'he same question may be rased in letormining when a right to interest acerues upon a note which matures on saturiay, and which does not bear interest according to its telins.

'The case of the railroal notes alluded to above was submitted to the combel both of the railroad and the trust company. The lawyers consulted agreed in the opinion that the trust company was not entitled to interest after tle Salurday on which the notes matured. In support of this conclusion it was jointed ont that by the terms of the Negotiable Instruments Law ${ }^{10}$ presentment for payment is not necessary to charge the makcr, and that the provisions in regard to presentment seem to relate to the steps necessary for charging indorsers and other persons secomblaty liable. Furthemore, if it had been the intent of the statute to male a mole maturing on Saturiay for all purposes like a note matmmer on Monday, the second sentence of section 85 would probalily lave heen framed so as to read "when the day of maturity falls mpon Saturday or Sunday, or a holiday, the instrument is payable on the next succeeding busines day." The contrast between the worls "when the day of maturity fills upon Sunday or a holiday" as used in the second sentence of the section with the words in the third sentence, "Instruments fulling due on Saturday," is a strone indicition that the words "falliner due" mean something other than having the day of maturity fall upon Saturday. That i.: the words lo not mean as the worls in the precorling sontence do, falling lue areorling to the literal tenor of the instrument, but acererling to its legal effoct. A slight additional argument also may b. hult upon the failure to mention Saturlay in a subsequent section of the Act whinh provides that "Where the day, or the last day, for froing any act lierein repuired or permitted to be done falls on : Sumlay or on a lonliday, the aret may be done on the next succeding serular or husiness day."

On the other hand it was urged on behalf of the trust company that the miform custom of hanks, since the enactment of the Nego-

in Sertion 70: ('rawforl's New. Inst. Law, sec. 130; Mass. Rev. Laws, c. 73, see. 87 .

1. Section 194; Crawford's Neg. Inst. Jaw, sec. 5; Mass. Rev. Laws, c. 73, sec. 210. 
tiable Instruments Law, had been to treat instruments maturing on Saturday as if they were payable on Mondiyy. The anomaly was also strongly urged of regarding a note as dishonored by the maker so far as his own liability was concerned on Saturday, when. so far as the liabilities of parties secondarily liable were concerned, the maker had not dishonored the note. and could not dishonor it until Monday. An action brought against the maker on Monday morning would then not be premature, though so far as the indorsers were concerned the maker had not yet dishonored the note. The law merclant prior to the Negotiahle Instruments Law rertainly contained no precedent warranting such a result. 'The practical inconvenience which would follow from the construction given ly counsel to the statute was also noticed. If that construction is sound every instrument falling due on siaturday and bearing indorsements must be presenter on Mondily in order to charge the indorsers, lut in order to start interest running, and in order to make sure that no chance of securing payment is hot, presentment must also he made on Saturday, if the instrument is hy its terms payable at a particular place.

Though the question is not free from doubt, since cloar language must be required to justify a result which is rertainly an anomaly in the law of nesotialle pajer, yet on the whole the anstruction given by the eminent rommere ronsulted in the mattor soems somml. The opinion of $\mathbf{M l}$. C raw ford is in conformity with this vew, although he does not secm to have peresived the anomaloms result of not only authorizing but repuirine presentmont for payment in order to allarge indorsers on a day other than that on which the instrument was legally due. ${ }^{2}$

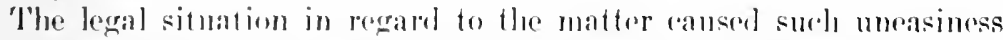

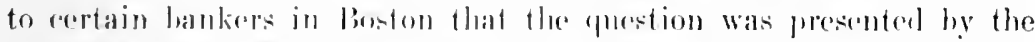

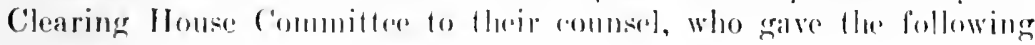
opinion:

"The languager of the statute is mot cleatr, and until it has bern

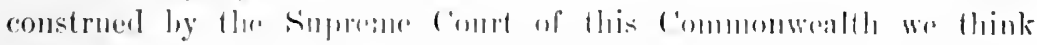

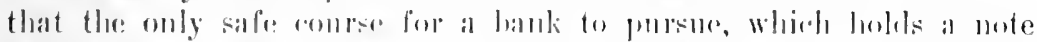

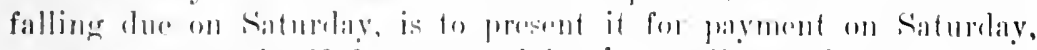

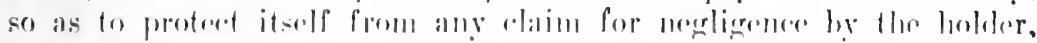

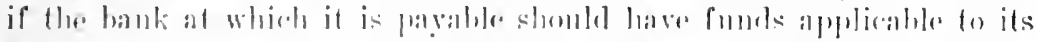

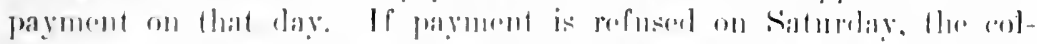

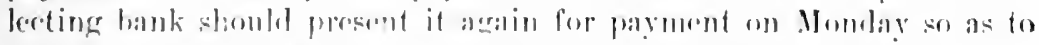
charge the indoreses, whe are entifled to a presentment on that daye."

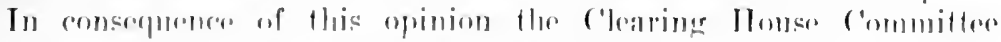
instructed their connsed to prepare an amendment to the law with a view to make it both prese from ambignity and in enformily wits banking enctom. Amerdingly in the present sescion of thr Massa-

2 Crawford's Nig. Int. latw, 3t. idl, P. 110, sec. 1.55, note (a). 
chusetts Iegrislature the section muler discussion has been amended so that the portion rolating to imstruments fallinger due on Saturday reads as follows:

"When the day of maturity falls upon Saturlay, Sunday, or a holiclay, the instrument is payable on the next suceeding business day whith is not a Silurlay. Instruments payalile on demand may at the option of the holder he presented for payment hefore 12 o'elock noon on saturlay when that rutire day is not a holirlay; provided, howerer. that no person rerejving any check, draft, bill of exchange, or promissory note payble on demand shall be deemed guilty of any negrlect or orission of duty or incur any liability for not presenting for payment or aceeptance or collection such elseck, draft, bill of exchange or promissory note on a Saturday; provided, also, that the same shall be duly presented for payment or aceeptance or collection on the next succeeding business day." 3

\section{At tile Proper Place.}

11 HuN (N. Y. SUp. CT.) 235. - 1877.

Action by holder against indorsers. The bill was drawn on $\mathrm{N}$. F. Mills, 114 South Main street, St. Louis, and by him accepted. The notary's certiticate slated that the bill was presented "at the place of business of N. F. Mills. St. Lonis." It appearerl in evidence that Mills had two places of business in St. Louis. Defendant moved for a nonsuit, which was denied. Turgment for plaintiff.

Simti, J. - As the draft was addressed to the drawee at a particular place in the city where he resided, and was thus accepted by him, the particular place thus designated was the place of payment, and a dne presentment and demand of payment at that place was necessary in orler to charye the indorsers. (Story on Prom. Notes, $\$ 227$ and note 3, and cases there cited.) The certificate of the notary stated norely that the draft was presented and payment demander "at the place of husiness" of the acceptor", without specifying the place. As it appeared that the acceptor had two places of business in Sit. Iouis, the certificate furnished no evidence whatever that the presentment and demand were at the place where the draft was payable. The proof was fatally defective, and the motion for a nonsuit should have been granted.

The responflent's counsel proposed to supply the defect on the argument at bane by the produrction of a fresh certificate of the notary showing that the draft was presented at No. 114 South Main street. 
The rule allowing evidence of a fact imperfectly proved at the trial tc be exhibited at bar, in opposition to a motion for a new trial, is, in general, confined to records or documentary evidence which proves itself, and on which no question can arise in the cause, exept such as is apparent on its face. (Bunk of Charleston v. Emerich, "Sandf. 718; Dresser v. Brools. 3 Parh. 429; Burt v. Place, + Wend. 591; Armstrong v. Perey, 5) It. 5) : litchie v. Putnam. 13 Id. 524; II ugh v. Wilson, 2 Johns. 16). Under the statute of 1833 , a notarial certifieate is but presumptive eridence, and may be explained or contradicted by the party against whom it is produced. The new certificate offered in this case cannot be received at bar to conclute the defendants; if it is to be used against them they are entitled to an opportunity to meet it at the trial.

We are also of opinion that the eridence required the submission of the question of usury to the jury.

Judgment and order should be reversed and new trial ordered, costs to abide event.

Present - Mullex, P. J., 'Talcote and Smitit, JJ.

Judgment and order reversed and new trial ordered, costs to abide event. $^{4}$

4 A bill is drawn, accepted, and indorsed in Kentucky, where all the parties reside, hut is arldressed "To C., New York, N. Y." The holder knows these facts. The bill is in New York on the day of maturity. Ifold: Presentenent was sufficient. If the instrument is payable in $A$., and the residence of the maker is in B., presentment should be in A. Cox r. National Bank, $100 \mathrm{U}$. S. 704. - 11 .

IIn Iron Clad VIg. Co. v. Sackin. 129 App. Div. (N. Y.) 555, a note was marle payahle at the "Jenkins Trust Company, Bath Beach Branch. Brooklyn." The trust company maintained principal olliees in the business section of Brooklyn, N. Y., and plaintiff elaimod that presentment at the principal ofliees of the company on the late of maturity was sullicient. Jomkr. J., sail: "Section 133 rif the Negetiable Instrunuruts Iaw. . . provides: "Present. ment for payment is male at the proper plice: (1) Where "plice of payment is epecified in the instrument and it is there presented.' It must io olserved in reference to this statute that it mentions a "place of paynent, and a place dres not mean an individual, a eorporation or inctitution. The Bath Beach Praneh of the lenkins Trust ('ompany, as these words wore need in the instrument, reforred to the plate of pityment, and not the corpuration.

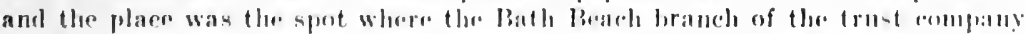

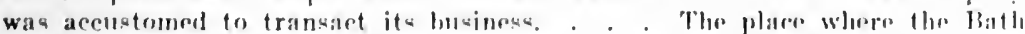
Ibach branch. . . dis huliness wis not the place where the principal oflices of the trust company, nt which the note was presentwe nu the due ditte. were maintaineil. It, therefore, was not presenterl at the place designatud for its payment, and there was no sufficient presontment to charge iy. torsers." - C.] 
60 Misceli.anfous (X. Y. SuP. CT., Lrib' ('o. Thial T.) 605. - 1908.

WnEElak, I. - This action is brought against the indorser of a promissory note made by his soln, Walter Savage, and by its terms made payble at the residence of the maker, No. 50\% Prospect avenue, in the city of Butlislo, N. I. 'The note is held by the indorsee of the original payee and was forwarded by him for collection to the Columbia National Bank of Buflalo.

On the day of the maturity of the note a elerk in the employ of the bank called up the maker on the telephone. The maker responded to the call at his house. The elerk then stated to the maker that the bank held the note for collection, deseribed it, and asked the maker what he proposed doing with it. The maker replied, in substance, that he could not pay it; that he had an understanding or agreement that the note should be renewed, and if the bank would return the note it would be taken care of at the other end of the line. The elerk replied that they knew nothing about such an arrangement, and then called to the telephone the assistant cashicr of the bank, who in turn talked with the maker. The maker repeated in substance what had been said to the clerk and was informed by the cashier that the bank would, under the cireumstances, have to protest the note. No other presentation at No. $50 \%$ Prospect avenue was marle, but the note was protested, and notice of the protest mailed to the indorser, this defendant.

The defendant contends that the necessary steps were not taken to charge him as indorser, and that the failure to present the note at its place of payment discharged him from liability.

The question is, therefore, faily presented for determination whether the demand over the telophone was a sufficient presentation, and whether the hank was relieved of the obligation, under the facts, of actually going to the maker's house and making a further presentation and flemand there. 'The researches of comnel and court are unable to discover any decirled case directly in point. The ease is novel in its features, and its recision of importance both to the parties and to the banking rommunity.

As suggested, two lines of inquiry present themselves: First, was there a presentation at No. 507 Prospect avenue, and, if not, was its presentation exrusent so as to still charge the indorser? [After quoting eections $122,133,134,112$, and 144 of the New York Negotiable Instruments Law, the court continues:]

It was the evident mirpose and intent of the framers of the statute to incorporate into the statute the provisions of the rommon law, although there follows the usual emharrassment which all codifiers encounter in framing a statute to meet all possible cases. 
Was the note in this case presented at No. 507 Prospect avenue, the place of payment named in the note, within the reasonable meaning of the statute? Ne think it was. At the time of the conversation between the maker and the bank officials over the telephone, the maker was actually at the place of payment. The talk was inmediately between him and the holder of the note. For every purpose of demand and refusal, it was just as effective as though the conversation had taken place between the parties when all were within the walls of the house itself. The maker knew perfectly well that a demand was then and there made upon him for the payment of the note in question, and he was then and there called upon to act. He did act, and treated it as a demand for payment, and declined to pay. He did not question the mode or manner of presentment, but declared his inability to meet the note, and made claim to some arrangement for its renewal. Of course, the maker had the right to have insisted on the exhibition of the note to him as evidence of the bank's authority to collect. That right was a right, however, personal to the maker, and, by not demanding its production, he waived it. If, on demand of payment, exhibition of commercial paper is not asked, and a party to whom demand is made declines to pay on other grounds, a mere formal presentation by actual exlibition of the paper will be considered waived. Daniel Neg. Inst. \$ 654; Loclwood v. Crawford, 18 Conn. 361; King v. Crourell, 61 Me. 244; Porler v. Thom, 40 App. Dir. 34 ; affirmed, $167 \mathrm{~N}$. Y. 584.

It seems to the court that all the essentials of a good presentation were met. It was made on the day of the maturity of the note. The note was described to the maker, in a conversation with the maker at the place of payment, payment was asked and declined. So far as the maker was concerned all that he reguired was done. The indorser could not well demand more for his own artual protection. All that remains to the indorser is the purely technieal gromed of a failure to produce the note itself at the house, ing Prosperet avenne, which would have resulted in the same we fusil of patrment matde over the telephone.

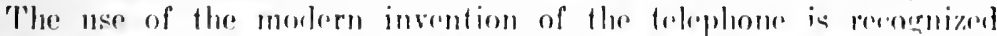
by the conrts. ('ommereial transindions and conversations hand over

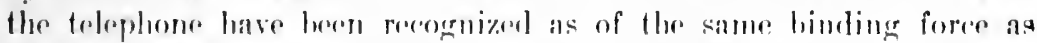
where the parties talked face to falce. Cilolde lerinting r'o. v. Stahl,

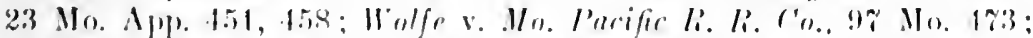

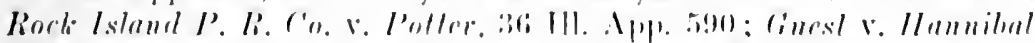

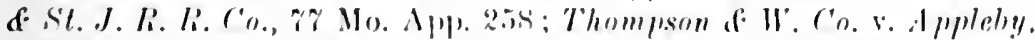
5 Kane. Apl. 680; Murphy v. Jarli, 112 X. Y. 215; Detaring v. shumpik, 67 Minn. 3.18.

The telephone is simply an instrument hy which two persons may talk directly to rach other. Suppose the holder of a notre shomld raill to the maker from arrose a street as the maker stoml in his dowrway and notify him that he had his note and ask payment. Would not sucl, 
a demand be deemed in law a proper presentment, although the street separated the person holding the note and the actual place of payment? Can it make any substantial difference because the person holding the note happens to be some blocks away, provided he is able to reach the maker over the telephone and talk directly to him in that way? The law simply requires substantial compliance in reference to proper presentment, and will not strain to fine grounds for releasing an indorser, where there has been snch a substantial compliance, and any omission to observe the more technical rules does not work to the prejulice of the indorser.

Actual and formal presentation of notes has been held unnecessary to eharge the indorser under many varying circumstances; as where the maker dies before the maturity of the note, and no representative of his estate has been appointed (Daniel, Com. Inst. § 1111), or where the maker has absconded (Id., §1125), or where the maker has removed from the state and taken up his domicile in another state or country. Id., $\S 1145$; Foster v. Julien, 24 N. Y. 28; Eaton v. McMahon, 42 Wisc. 487; Whitney v. Allen, 56 Iowa, 224; McGruder v. Bank of Washington, 9 Wheat. 598.

It has been held a sufficient demand and refusal to constitute a dishonor of a note if the inaker, on the day it is due, calls on the holder where the note is, and declares his inability to pay, and desires the holder to give notice to the indorser. Gilbert v. Dennis, 3 Metc. (Mass.) 495.

So, too, in an action against an indorser, it appeared the holder met the maker of a note on the street and was refused payment, making no objection to the place of demand, and the court said: "If demand be made upon the maker elsewhere than the place appointed, and no objection be made at the time, it will be deemed a waiver of any future demand." King v. Crowell, 61 Me. 244. * * *

The weight of authority, therefore, seems to be that the law is not over exacting as to the mode or method of presentation. so long as an opportunity is given the maker to pay the note or refuse its payment.

For these reacons we think the presentation made in this case, although over the telephone, met the substantial requirements of the law. ***

Judgment foi plaintiff.

$\S 133$

BARNES $v$. VAUGHAN.

6 RHODE IsLAND, 259. - 1859.

Action by holder against indorser. At the trial hefore the court, to whom the ease was submitted in fact and law, under the general issue, it appeared that the notes, which were not made payable at any particular place, had heen left by the plaintiff at the Mount Vernon 
Bank, in Foster, for collection; and that the only demand of payment made upon Northup, the maker, was by the usual printed bank notice, mailed to him by the cashier of the bank, and directed to him at. Providence, where he lived, in the early part of the month in which they respectively fell due, although at what time precisely, the eashier of the bank could not recollect. Due notice of non-payinent by the maker was proved to have been given to the defendant.

Boswortr, J. - The defense to this suit is, that no legal and proper demand was made on the maker of the note; and that therefore the indorser, who is here sued, is discharged. The rule of the common law is, that in order to charge the indorser, demand must be marle on the maker for payment on the very day on which the note becomes due. In case the note on its face is made payable at a particular place, as at a bank named, it is necessary, and only necessary, to make demand at such place; but if no place of payment is named in the note at which the note is payable, it is necessary to present the note to the maker personally, or at his place of abode or business, before the indorser can be made chargeable. In this ease, no place of payment was mentioned in the notes. The notes were left at the Mount Vernon Bank for collection; and it is agreed, that the maker had notice before the day of payment that they were there for that purpose. This notice could not avail to make the notes payable at sail bank. The maker had not hy the terms of his contract agreed to pay the notes at that bank, and a demand there was no demand upon him. It was necessary that demand should be made upon him personally, or at his dwelling, or place of business, on the last day of grace. No such demand was made, and the indorser, therefore, was never charced."

Judgment must, therefore, be rendered for the defendant, for his rosts. ${ }^{\circ}$

12 GHAY (MAss.) H69. - 1S59.

Action by holder against indorser. Note made and dated in Boston, but maker's residence and place of business then and ever sine in North Carolina. 'This was known to holder's agent at maturity. No demand on maker in North ramolina.

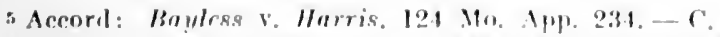

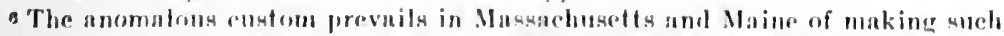

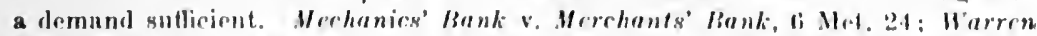
Bank v. I'arker, 8 (iray, 221; Gallagher v. loblerts, 11 110. 489); Maine liank v Smith, 18 Me. 99. So in New Fugland there serms to be a loeal ellstom of drawing notes "payable ut any hank" in a given rify and in sueh rase it is sufficient that the instrument is at any bank in the place named on the day of maturity. Malden Bank v. Balduin, 13 Gray, 154 ; Langley v. Palmer. 30 Me. 467; Jarkson r. I'arker. 13 r'onn. 342. - H. [On this point ser note in 13 L. N. S. at p. $305 .-$ C.] 
Mrocul. J. [Aftor stating the farts.] - On these facts the question is, whether the defendants are liable as indorsers. If they are, it is not because seasomble demand wats made on the promisor and seasonable notice of non-payment griven to them. The note fell due on Saturday, May 3d - the last day of grace being Snuday - and no lemand was made on the promisor until nine days afterwards. 'lhis delay discharged the defendants f'om thej liability to the plaintiffs muless the fact that the promisor always residerl in North Carolina excused the holders from making personal demand on him, or from using due ellorts to make such demand. 'The plaintiffs rely on this fact to sustain their action, and aite the decision in Smith v. Philbrick (10 Gray, 25:), as conclusive in their favor. That was an action by an indorser against a prior indorser of a note made in Boston by one whose only residence and place of business were in Texas, and on whom no demand was made; and it was decided that no demand on him was necessary to eharge the defendant. The court said there was no evidence to show whether the plaintitf, or any of the subsequent holkers of the note, knew where the promisor's residence was; that if his residence had been known to the holder, at the maturity of the note, it might perhajs have been incumbent on him to forward it to Texas for presentment, as was held in Taylor v. Snyder (3 Denio, $1+5)$.

In the case hefore us, the plaintiff's agent, whom they employed to purchase and also to rollect the note, knew where Moore's residence was, and the legal effect of his knowledge of that fact is the same as would have been the effect of their knowled re of it. Notice to an agent, whilst he is concernel for the principal, is notice to the principal himself. And we are of opinion, as intimated in S'mith v. Plilbrick, that hy reason of the plaintiff's knowledge (through their agent) of the place of Moore's residence, a demand on him there, and sea. sonable notice of his dofault, were prevequisites to the defendants' lialility as indorsors. Wo think this ase is within the general and familiar rul. which applies to the holders of indorsed notes, and not an excoption to that rule.

Whan a rosilant in the state, after giving a note, removes from the state and takes up a residence ont of the state, it has heen repeatedly drejalerl that it is not neressary, in order to charce an indorser of the note, to romand payment of the promisor at his new residence. ${ }^{7}$ This

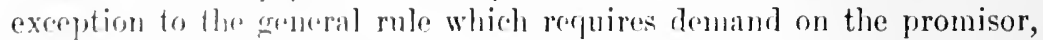
and notice to the indorser, seems to he established. But we see no sufficient reason for taking the present ase out of that rule. And we hold, that where the maker of a note, when it is male and indorsed, has a known residence out of the state, which residence remains unchanged at the maturity of the note, demand must he made on him,

7 M'Gruder v. Bank, 9 Wheat. (U. S.) 598. - H. 
or due diligence used for that purpose, and notice of non-payment given to the indorser before the indorser can be charged. So it was decided by the Court of Appeals in New York, in Taylor v. Snyder, before referred to, and in sies v. Gilmore (1 Comst. 321). In this last case, Bronson, J., said:-

"The only excuse which has been offered for not making demand is, that it would have been inconvenient to go or send to Matamoras for the purpose. It is often inconvenient to present the note for payment, when the maker and holder both reside in the same state; and yet, when the maker has a known place of residence, and there has been no change of eiremustances after the giving of the note, mere trouble or inconvenience to the holder has never been held a goorl exeuse for mitting demand. And this is so, however wide asmder the maker and holder may live. If the plaintiff wished to avoid the inconvenience of sending to Matamoras, he should have made the note payable in New York, or got an indorsement with a waiver of demand. He has no right to change the contract which the indorser made, for the purpose of promoting his own convenience."

Judgment for the defendants. ${ }^{8}$

158 Massachusetts, 90. - 1893.

Actios by holder arainst indorser. Defense, want of demand on maker. The notes sperified no place of payment. Presentment was made to the miker promally at the oflice of the indorser.

Fieto, C. .J. * * * Whether the defendant's oflice was Hart's place of business or not, if the plaintilf made a demand upon Hart personally at this office during fusiness hours of the last day of grace, and produced the motes, and llart said that he was malule to pay them, and made no olyowtion to the place of the demand, this womld he a sulficiont demand, and to this aflect were the instructions given by the court. (King v. C'rowell, fil Maine, 211; I Dannl. Neg. Insts, $\S(i 38,[1 t h$ bil. ]).

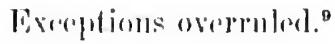

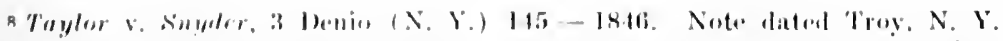

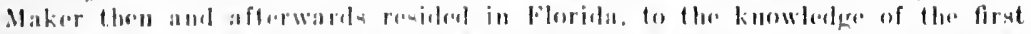

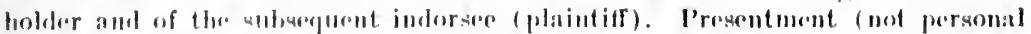

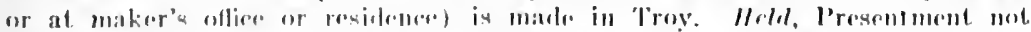
surficient. "Where no rhange has taken place in the residenee of illu maker, brtweres the making of the note and the time of its payment, the indervention of a state lime drow not dispense with the necressity of making due demand of paymen1." - H.

- See Sussex Bank v. Baldioin, 17 N. J. L. 487, ante, 1. 480.- 11. 


\section{4. 'To the Prophe Person.}

Action by holder against indorser. Demurrer to declaration sus.tained. Plaintitls appeal.

Cooper, J., delivered the opinion of the court.

the demurrers to the original and anended declarations were properly sustained. Lee was the payee in a promissory note, subseribed by the maker thereof, "A. C. Cunningham, Ag't, " nothing appearing on the face of the note indirating for whom he professed to act as agent. After the maturity of the note he indorsed the same to the plaintiffs, who some time thereafter presenter the note to S. A. Cunningham, wife of A. G. Cunningham, and who, the declaration avers, was his principal, "and demanded payment thereof, and sued out an attachment for rent against her, in order to collect said note, of all of which said Lee had immediate notice."

The present suit is against S. A. Conningham as maker and against lee as indorser of the note.

The liability of Lee rested wholly upon his indorsement, and that liability was to pay the note, if seasonahle presentment to the maker shonld be made and payment refused, and Lee notified thereof.

A. G. Cunningham, and not S. A. Cunningham, was the maker of the note, the word "agent" following his signature being - in the absence of the name of the principal-merely descriptio personce. (1 Danl. on Neg. Inst. $\S \S 303-305$.) We are not ealled upon to decide whether, in a proper action, Mrs. S. A. Cunnniglam might be made liable on the consideration for which the note was given; nor whether, as between the original parties, $A$. C. Cnnningham was liable on the note. The sole question is whether Lee, who indorsed the note signel by " $\Lambda$. (. Cumningham, Ag't," can be held on his indorsement by virtue of a presentment to one whose name nowhere appears on the note, and we think that he camnot, because such person was not the maker of the note, for whose default only was he bound by his indorsement.

Judgment affirmed.

Actios against indorser. Defense, want of due presentment. Judgment for plaintiff on the anthority of IJale v. Burr (12 Mass. 86.)

Matis, .J., delivered the opinion of the court. 
The defendant is sued as indorser of a promissory note, for one thousand dollars, executed by Peychaud. Judgment was rendered against him for the amount claimed. He now claims a reversal of the judgment, on the ground that he was condemned as indorser to pay the sum demanded, when payment was never demanded from the maker, nor from any person representing him, or succeeding to his rights and obligations.

'The record shows that the maker died on the last day of grace, or during the night preceding it. That when the notary's elerk called at the house and late domicil of the drawer of the note sued on to demand payment, he found no person present except a mulatto woman, who informed him of the death of Peychaud, and pointed him to the corpse in the coffin. The note was then protested, without any inquiry or demand being made of any heir or representative of the deceased.

It is clear that no recourse ean be had against the indorser of a note until a demand has been made on the maker, if living, or on his heir or legal representative after his death, unless the impossibility of making such a demand is made apparent. This has not been shown in the present case. The authorities on this point, and which support the position here laid down, are numerous, of the highest character and authority, and conclusive on this subject. (Chitty on Bills. 317 ed. 1828; Bayley, do. 128; 2 Practical Abr. of Am. Cases, 2ss, 292; 3 Peters, 89; 7 Id. 287 ; 7 Martin, 364 ; I Pardessus, 392 ; Pothier, Contrat de Chance, No. 146.) ${ }^{1}$

It is therefore ordered, adjudged, and decreed, that the judgment of the District ('ourt be annulled, avoided and reversed: and that judgment be entored for the defemlant, with costs in both courts. ${ }^{2}$

[Reported herein at p. 69.4.]

$\S 138$

BHAKEr. MIIIILAN.

33 IOWA, $150 .-1871$.

AreTon against indorser of a note made hy $\mathbb{W}$. G. Itarding and Danicl Van Patter. Presentment and demand on Ilarding aloure. Judgmont for plaintiff.

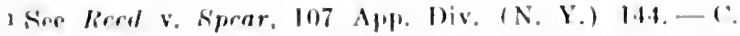

2 Although the inclores low the noluinistrator or executor of the decased maker, demand must he made upon hius as executor and notiere given to him as

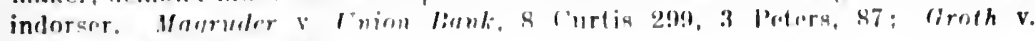
Gyger, 31 Pa. 271. - II. 
Mntar, J.- On a former appeal in this alse, it was held that a presentment to one only of the two joint maker's was not sufficient to charge the indorser, muless some lenal excuse he shown for the failure to make presentment to the other. (Blake v. MeMillen, 22 Iowa 35s.) The agreol lancts show that lowid Van Patter died before the maturity of the note: that Eliza Van Patter was his legal representative when the note heraluse ho and no exeuse is shown for a failure to make presentment to her. Following the ruling on the former appeal the judgurent is

Reversed. ${ }^{3}$

\section{Br Exhibiting The Instiument."}

$\S 134$

WARTNG v. BETTS.

[Reported herein at p. 524.]5

$\S 134$

GIIJIN $v$. SAVAGE.

[Reported hercin at p. 510.]

\section{When delay in presentment excused.}

$\S 141$

PIER $r$ IIEIXRITISIIOFFEN.

67 Missotri, 1633. - 1877.

Hoten. J.- This was an action brought hy the plaintiffs, as holders of a negotiahle promissory note, arainst the defendants. as intorsers thereof. 'The questions presented for determination are, whother the plaintiffs used due diligence in making demand of pay-

3 Aecorll: Arnold v. Mresser, 8 Allen (Mass.) 435; Shutts v. Fingar, 100) \. Y. 539: Lenedirt v. Nrhmieg, 13 Wasls. $476 .-\mathrm{H}$.

- Sop rilizrns' liank v. First Mat. Bank, l3a Iowa, 605, reported in 1.3 I. . S. :3.3. with note entitlol " Necesity of actual presentation of commareial papur to afferet its dishonor." -

" "No valid presentment and demand ran be made by any person without having the mote in his posisusion at the timce so that the maker may receive it

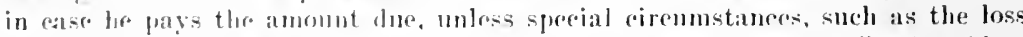
of the note or it a dretrubtion. are shown to rxemse its alsenee." Arnold v.

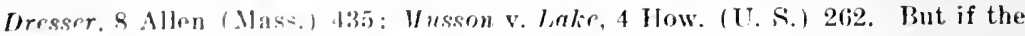
one making domand lad the in-trmment but loes not exhilsit it, the presentment is good where the makrer lows not ask to sor the instrument, but refuses payment on other grounds. Legy v. Linal, 165 Mass. 555. - H. [See also

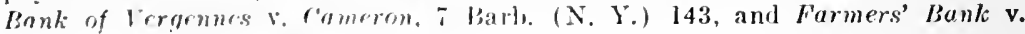
Luvall, 7 (iill \& .J. (.Md.) 78. - ('.] 
ment, and gave the requisite notice of non-payment to the defendants. The facts are as follows: The note in question matured on the th day of July, 1861 , and was payable at the banking house of $\mathrm{F}$. and G. Willins, in the city of St. Paul, Minnesota. Some time in April, 1861, the plaintifls delivered the same to the bank of Cooperstown, at Cooperstown, New York, for collection. At that time a letter, in due course of mail, would reach St. Paul from Cooperstown in about six days. The cashier of the hank of ('ooperstown sent the note by mail to its regular correspondent, the Bank of St. Paul, in the city of St. Paul, for collection, in ample time, as the cashier stated, for it to reach its destination by ordinary course of mail. loctore the maturity of the note. When the letter reached St. Paul, the Bank of St. Paul had made an assignment, and the enrelope having printed on it the worls "From the Bank of Cooperstown," the postmaster at once returned it to the Bank of Cooperstown, with the indorsement "bank failed." The letter was received by the Cooperstown Bank in the original envelope, mopened, on the 9th day of July, 1861, and on the same lay the note was returned by mail to St. Paul in a letter direrted to F. \& G. Willins, who cansed it to be prosented and protested on the 15th day of July, 1S61, the day on which it was received.

The defeudants contend that there was a want of diligence in not sending the note in time to guard against such contingencies as the evidence discloses, and that the action of the postmaster in the premises is no sutlieinent exruse for the failure to present for payment on the day of the maturity of the note. lerofossor Parsons, in his treatise on Notes and Bills, says: "O molinarily any failure to present a note at the propere time, by reason of the necrligenes of an agent, womlle disclarege an imborser, but where the holeler makes nse of the public mal for the prorpuse of transmitting the note to the

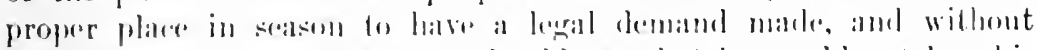

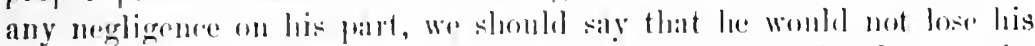

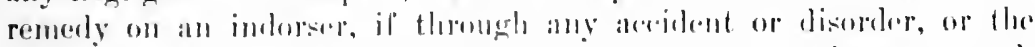

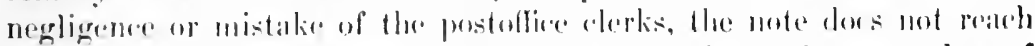

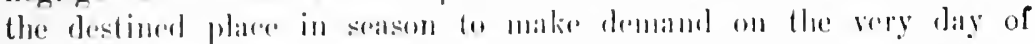

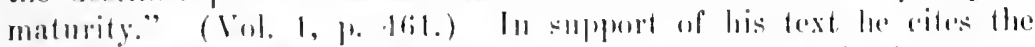

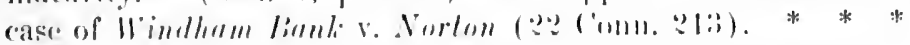

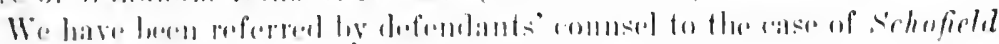

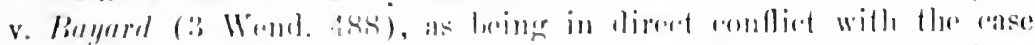

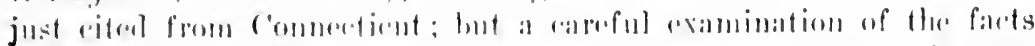

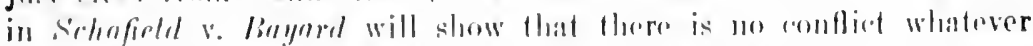

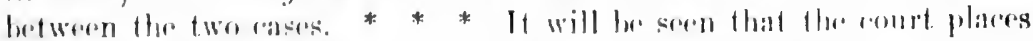
its jurlement aspresely upon the gromme that the loblar was guilty

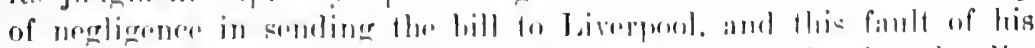

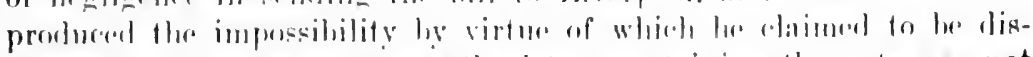
charged. In the present case the letter containing the note was not 
misdirected; it was properly directed; it actually reached St. Panl in time, and but for its unauthorized return by the postmaster, the probabilities are that some agent or representative of the suspended bank would have received it in time to make due presentment, as the testimony tends to show that the representatives of the bank contimned to receive letters addressed to it, alter its suspension. The holders therefore exereised due liligence in sending the note when they did: its arrival in time demonstrates that fact; and they were not required to make provision in advance for a possible, hut wnanticipated suspension of the Bank of St. Paul before arrival of their letter, or for an unwarrantable interference with the same by the public oflicer in charge of the mails, after its arrival. We are of the opinion, therefore, that under the cireumstances of this case, the demand was seasonably made.

TThe court then decides that a notarial certificate stating that the notices were "put into the postoffice at St. Paul directed as follows," is sufficient without a statement that the postage was prepaid. $]^{\circ}$

\section{Reversed. $^{7}$}

\section{When presentment dispensed with.}

\section{When no Right to Require or Expect It.}

\section{$\S 139$}

\section{BEAUREGARD $v$. KNOWLTON.}

156 MassachusftTs, 395. - 1892.

JUDGMent for plaintiff. Defendant excepts.

BARKER, J. The action is upon checks which have never been presented to the hank upon which they were drawn. The only question argued is as to the correctness of the ruling that, if the facts were as testified to by the president of the bank, the plaintiff was excused from presenting them. 'The checks were dated on December 16, 1889, - one for the sum of $\$ 250$, hearing a pencil memorandum. "Draw Dec. 19th:" one for $\$ 125$, hearing a similar memorandum, "Draw Dec. 26th;" and one for \$125, with a memorandum, "Draw Dee. 28th." 'They were signed hy the defendant with the name of J. G. Knowlton \& Co., which was the style under which he did business. The president of the bank testified that on December 16, 1889, and during the remainder of that month and the following January, J. G. Knowiton \& Co. had no funds in the hank, but that one M. E. Knowiton had an account at the bank, and the bank had written authority from him to pay checks signed by J. G. Knowlton \& Co.,

- See Neg. Inst. L., \& 17 §. - II.

7 See also S'chofield v. Bayard, 3 Wend. (N. Y.) 488, post, p. -04; 1 Daniel, 5 $478 .-\mathrm{H}$. 
charging the same to the account of M. E. Knowiton, and that acting upon this authority the bank had been in the habit of so doing, and that on December 16,1889 , the deposit of $\mathrm{H}$. E. Knowlton was $\$ 51.15$; on December $19 \mathrm{th}, \$ 117.28$; on December $26 \mathrm{th}, \$ 61.13$; and on December 28th, $\$ 8.18$.

We assume that under ordinary circumstances the drawer of a check is not liable to a suit upon it without presentment to the bank, and dishonor. Kelley v. Broun, 5 Gray, 108; Tassell v. Lewis, 1 LA. Raym. 743 ; Cruger v. Almstrong, 3 Johns. Cas. 5 ; Conroy 5. Warren. 3 Johns. Cas. 259 ; Murray r. Judah, 6 Cow. 484,190 ; Little r. Banli. 2 Hill, (X. Y.) 425; Case v. Morris, 31 Pa. St. 100, 101 ; Purcell v. Allemong, 22 Grat. 739: Woodruff r. Plant, 11 Conn. 311, 31\%: Foster v. Paulk, 41 Me. 425 . But the cases eited, and many others, hold that a check is in the nature of a bill of exchange, payable on demand, and that many of the same rules apply to both. Barnet v. Smith, $30 \mathrm{~N}$. H. 256, 264; Bickerdike v. Bollman. 1 Term R. 405: Boehm v. Sterling. 7 Term R. 423, 426. The drawer of a bill of exchange is liahle without presentment, if he has no effects in the hands of the drawee, unless the drawee has something equivalent to effects, or has agreed to acrept and pay, or the drawer has some ground for a reasonable expectation that the bill will be accepted and paid. Kinsley v. Kobinson, 21 Pick. 327, 328, and cases cited: Bank v. IIughes, 17 Wend. 94, 97. The same general principles are applied to checks, and presentment is excused where the making of the check was a fraud upon the part of the drawer; he having no funds in the bank, and no ground for a reasonable expectation that it would be pilid. Byles, Bills, (11th Ed.) 216; Chit. Bills, (Amer. Ed. 1836,) 129; Franklin v. Vander-

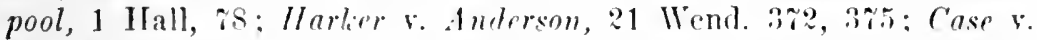
Morris, 31 Pa. St. 100,101 : Sterrett v. Resemeranz, :3 Phila. 51 : IInyt v. Secley, 18 Conn. 35?, 360; True v. Thomns. 16 Mre. 36: Foster v. Paulh, 11 Me. 125, 198: Terey r. Parker. fi Adol. \& E. 50?: Wirth v. Austin, I. R. 10 C. P. 689. In this ase the llawer had no funds in the hank, and no authority from thro hank to draw upon it. One M. F. Knowlton had a deposit arenent with the hank, and had ofiren it authority to pay and charge to his aecount dhecks siened by .I. f. Knowlton \& ro., and the hank harl heen in the hahit of so doing.

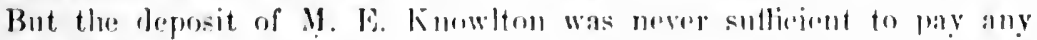
one of the checks in suit. and the hank had no authority to allow the

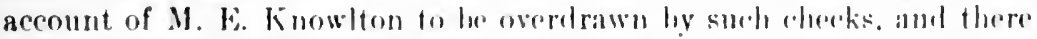
was no evidenere that it had eser mursued such a rourse. So that the

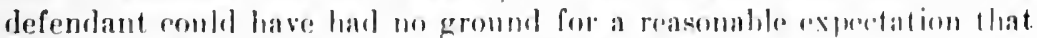
the checks would be homored hy the hank. When the deformlant made them, he knew they would not he paid if prosunterl, as well as though there had been no arrangenent as to his deeres befwern the hank and M. E. Knowlton. Sotice of non-payment wombl hase grisen him no new knowledge. The fresentment of either of the checks would not 
have entitled the plaintitl to demand from the bank the actual balance

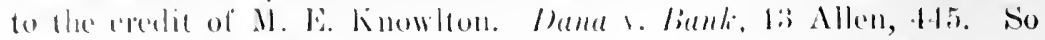
that the facts testilied to show allimatively that no loss happened to the defendant by the omission ol presentment.

Exeeptions overruled. ${ }^{8}$

\title{
CATHEEL, $r$ GOODWIN.
}

\author{
[Reported hercin at p. 576.$]^{3}$
}

$s$ "It is next argued that the eourt should have directed a verdiet for the flaintir, and that in refusing to to so there was reversible error. This contontion is grommled. first, mpon the proposition that no presentment of the check or drift to Gilman. Son \& (o. for payment has been shown; and, if such fresentment is an indiepensable emelition of the drawer's liability to the

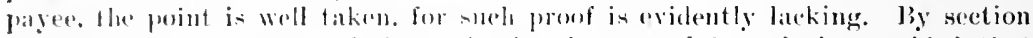

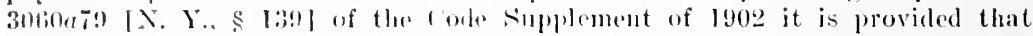

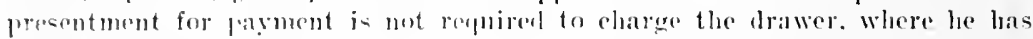
no right to expect or require the drawe to pily the instrument. The appellee invokes the lenetit of thi- provision. It is alleged, as we have seen, that appellant knw Gilman, Son \& ( o. to be in a faling eomelition when it sold

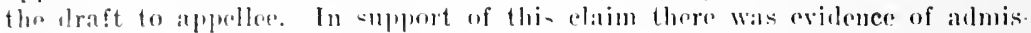
sions hy the easlier to the affect that he had for some time been douldful of the fimaneial somendues of sail firm: that the hank had suspected the stability of sad lim, but had entinned to we it as correspondent because of the halit or enstom ari-ing from a long husiness acpuaintaned: and that the bank guardol itself against great risk ly lierping a suall balanee only in the hands of its corresendent. Theor almicsions, some of which were shown to have Leen malle prier to the date of this tran-action, were testified to without objection ly three or more different witnereses. It was shown, also, that, talking

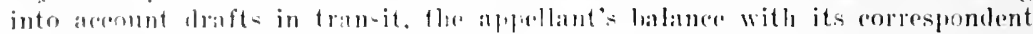
was fromently overilrawn. or redueed to a comparitively trilling sum, and

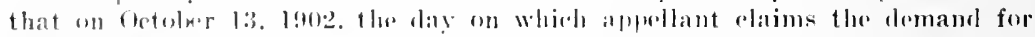

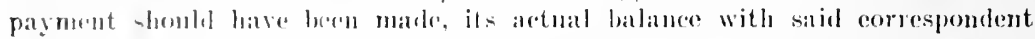

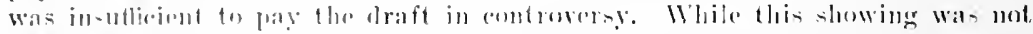

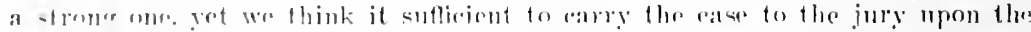

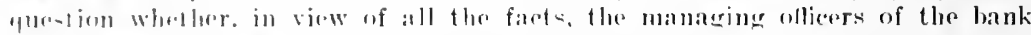

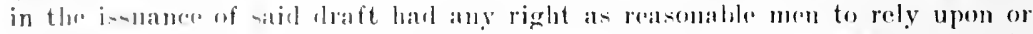

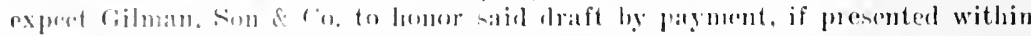

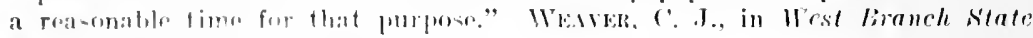
Bank v. llnimes. 135 Jowit. 313. - ('.

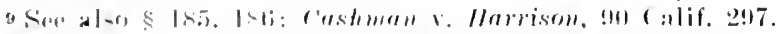

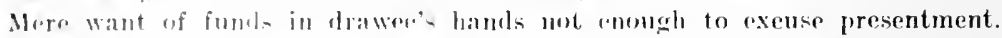

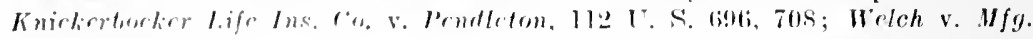
Co.. S2 III. 57?

If drawer or indoreer las receivel funds or assets from the aceeptor or maker undrer an agrerement to pay the bill or note. he has no right to expect or

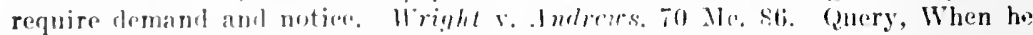
has repeived serurity lut with no agrement to joy. 2 Daniel on Neg. Inst., \$§ 1129-1143; 4 Am. \& Eng. Enc. Jaw (2d ed.), 447-448. - H. 


\section{Accommodation Indorsers.}

\section{$\S 140$ MORRIS $v$. BIRMINGHAM YATIONAL BANK.}

93 AlabaMa, 511. - 1S90.

ACTION on a promissory note. Judgment for plaintiff and defendant appeals.

Ciopton, J. - The note sued upon was made ijy Jolu W. liead, payible to B. C. Scott, defendant's intestate, at the Birminglam National Bank, and by him indorsed to the bank. It heing arlmitfed that payment of the note was not demanded of the maker, amb that due and legal notice of its lishomor was not given, so as to charge the indorser, it devolved on plaintith to show a sultieient excuse for failure to give the notive. Fot this purpose the depositions of licarl, the maker, were introdued to prove that the note was male for the accommodation of Sicolt, the iuclorser. * * *

The material question is, whether the indorser of a note. male for his accommorlation, is discharesed foom liahility on his imelorsment by the failure of the holder to demamel paymont of the maker, and to give the indorser notice of the nom-falment of the mote. 'la this question a negative answer must lo given, on primeiple and anthorily.

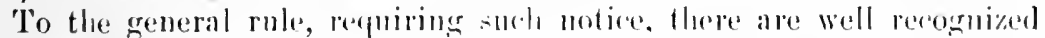
exceptions. In its application fo bills of exchange, the failure to grive notice will be excused as to the drawer, where he has no funds in the hands of the drawere, and no reasollable gromud to expece that his libll

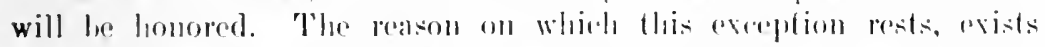
where a note is male for the areommonation of the indorser, for the

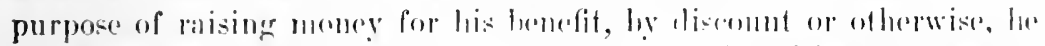

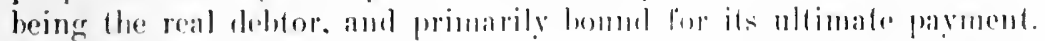

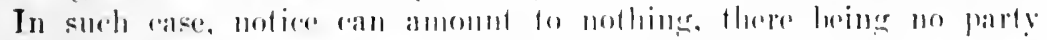

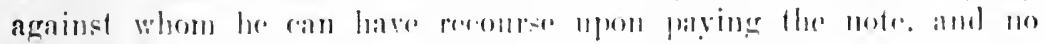

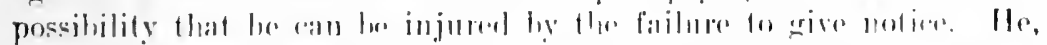

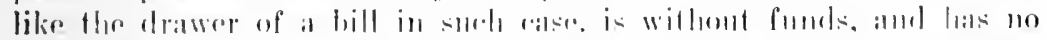

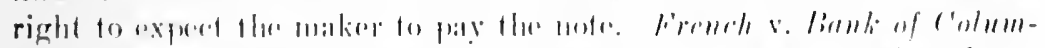

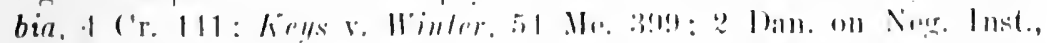

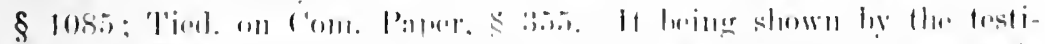

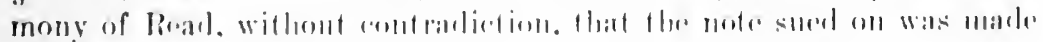

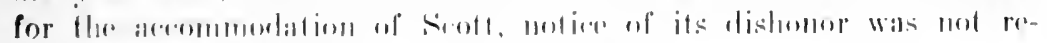
quisite to rharene the imborser.

\section{Jurlermont allimmol."}

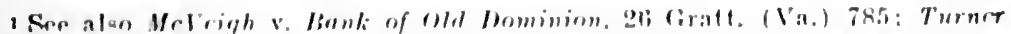

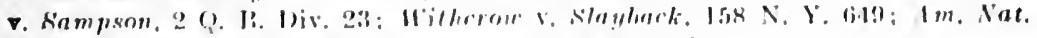

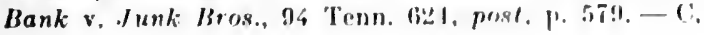




\section{WHEN I MPOSSIBIH.}

Acrios against imdorser. Judement for defendant.

HAL, J. * * * It was proved that Best, the maker of the obligation, was a seafaring man, and at or ahout the time the obligation became payable, sailel from Washington, as master of a vessel bound to New York: and it did not appear that he had a domicil, or any estahlishnent within the state, at which payment could be demanded. The maker heing at sea, in his usual employment, and the indorsee not being bound to follow him beyond the state, it follows, that if he had no such domicil or establishment, a demand should be dispensed with.

In this view of the ease, the dofendant was liahle upon his indorsement, without any express promise to pay, and the jury should have been so instructed - and consequently, for the judge's onission to give such instruction, there must be a new trial.

Pen Cuniam. - Judgment reversed and a new trial awarded. ${ }^{2}$

\section{WARING $v$. BETTS.}

90 VirGiNiA, 46. - 1893.

Actuos against indorsers of a note payahle at the Business Men's Bank, Richmond. At maturity the hank was defunct. Demand (without presentment) was first made on W.. a former offieer of tluat bank (aud also one of the indorsers), who replier that the funds had been distributorl and there were no assets. Iater in the day, at $5: 30$ P. Y., the notary with the note in his possession went again to the nffice of $\mathrm{W}^{\circ}$, but it was closerl he then went to the residence of W., but he was not there. We then protested the note and gave due notice to the indorsers. 'The maker lived at Danville, Va, at which place the note was dated.

LACY, J. (after stating the case), delivered the opinion of the court.

The first question arising here is that raised by the demurrer. The declaration states a grome ase, and sots forth that on its due day it was duly presented for payment of the sum of money therein specified, required, payment refused, and that it was duly protested, etc.

2 But if the maker have a residence, presentment must be made there. Dennie v. Walker, 7 X. II. 199.

Demand is not excuserl beause the maker is an infant. Wyman va Adams. 12 rush. (Mass, 210.-H. 
And the defendants' demurrer to the plaintiff's declaration was properly overruled.

The elaim of the defendants is that there was no presentment of the note, because when payment was demanded of the indorser, W. L. Waring, Jr., manager of the late Business Men's Bank, Mr. Glenn did not have the note in his possession. and could not have presented it, but as has been scen from the facts found by the jury, payment was refused by Waring, and the note not asked for, hut payment refused, and the statement made that he was not authorized to represent the bank, which had ceased to do business and had distributed its assets.

Presentment of the bill or note and demand of payment should be made by an actual exhihition of the instrument itself $;^{3}$ or at least the demand of payment should he accompanied by some clear indication that the instrument is at hand ready to be delivered, and such must really be the ease. This is requisite in order that the drawer or acceptor may be able to judge (1) of the gemuineness of the instrument; (2) of the right of the bolder to receive payment; and (3) that he may immerliately reclaim possession of, upon paying the amount. If, on demand of payment the exhibition of the instrument is not asked for, and the party of whon demand is made decline on other grounds, a formal presentment by actual exhibition of the paper. is considered as waived. (Daniel on Neg. Inst., p. 485, \$ 651, citing Lockwood v. Crauford, 18 Conn. 361, and Fall River ITnion Bank v. Willard, 5 Metcalf, 216.)

All the parties subsequent to the prineipal payer are bound only as his guarantors, and promise to pay only on condition that a proper demand of payment he made, and due notiee be grimen to them in case the note or bill is dishonored. And we repeat this as oue of the fundanental principles of the law of nexotiable paper: and the infrequency and the character of the rimemstames which will exemse the holder from making this demand, and still preserve to him all his rights as effectually as if it were matre, will illustute the stringency of the rule itsolf. (Parsons on Notes and Pills, vol. 1, 14.) The question of exruse, then, will degend npon whether due diligrence has been used, and presents the ordinary iuruiry as to muligence. The principal excuses resolve themsendes into two classes -

First. The impossibility of ldmand.

Second. The acts, words, or presition of a party, proving that he had not right, or waived all right to the demand of the waisor of which he would avail himeself.

That impossibility should exches non-demand is obvioms, for the law compels no one to do what he cannot perform. But it must be actual and not merely hypothetieal: and thought it beed not he ahsolute, no slight diffienity will bave this offert. (I $\left.\boldsymbol{H}_{\text {. }}\right)$ 
'The ciremmstmoes which will axise a lemand are such generally as apply to a failure to presout amel demamel fayment within the repuired time, not alsolutely. (l'atroms, $111,115$.

In this ase the preschtment of the mote was not made at bank within the usual hauk hours, with the mote in possession, but as we

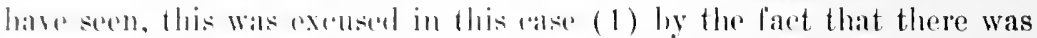

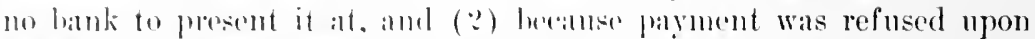
the gromme that the bank hatd reatied to do husiness, and its assets distributed, and the note was mot asked for. nor repuired, payment being refinsen on other errommls: the right to have it produced must he considered as witivel.

The note. however, was rarlied, during the day, to the place of business of the late mamaner ol the lank, ambl the indorser sought to

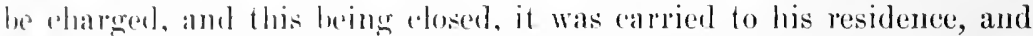
that heing also $\left[\cdot l_{0 s}+1\right.$, if romld not be presented to him, and although it was not in lanking hours, it was dming the daytime and before the hours of rest.

When the note is payalule at a hank, it is to be presented during hamking homs: and the payer is allowed until the expiration of banking hours for payment. But when not to be made at bank, but to an imbividual, mesentment may lo make at any reasonable time during the day during what are termed business homs, which, it is held, rane thromely the whold day to the loors of rest in the evening. (l'alsons, H\%, riting r'myuga r'ommly Lianli v. IJunt, 2 Hill, 635; Nelsoln v. Follerall, o loigh, 191.)

And in the ato of Farmsmorlh v. Allen (t Gray, 45.3), a presentment mares at ! \%. m. at the maker"s resilence, ten miles from Boston, when he and his family had refired, was held sullicient.

And in Rarrlay v. Bailey (: ('amph. 5:2) Lord Ellenhorough sustained a presentment mache as late as 8 p. m. at the house of a trader.

It is only where presentment is at the resindence that the time is extended juito the lomers of rest. If it is al the place of lumsiness, it must be during smeh lonrs when such places are customarily open, or. at least, while some one is there competent to give an answer. ( Parsons, Hs.)

In this (nis there was no presentment to the maker, who could not lo fomml, which, lowerole, was monerestary moler section 2812 of the crole of Vimerinia. The protest was in due form, and duly protested, which was anthorizul by sution este of the rode, although the said note was payblo at a hank in this state. And under section 2850 is prima farie pronf of the facts stated therein, and is substantially in areordanee with the finding of the jury. It therefore appears that such presentment as was repuisite was marle to the indorser and late manager of the hank, and that it was impossible to present the same at the bank named therein, as it had ceased to exist. We must, there- 
fore, conclude that there has been sufficient diligence on the part of the plaintiff, and that the judgment of the court below in his favor was right, and should be affirmed.

Judgment affirmed.

\section{BY WaINER.}

\section{$\S 142$}

\section{J. W. O'BANNON $r$. CURRAN.}

129 Appellate Division (N. Y.) 90. - 1908.

Action by the J. W. O'Bannon Co. against James M. Curran. A demurrer to parts of the complaint was overruled, and defendant appeals.

McLavghuin, J. - This appeal is from an interlocutory judgment overruling a demurrer to the second and third causes of action set forth in the complaint. In each case the demurrer was upon the ground that the facts stated did not eonstitute a cause of action. The second eause of action alleged is to recover upon a promissory note made by the James Freeman Brown Company, a domestic corporation, dated October 12, 190:3, and pavable three montlss after date to the plaintiff at 73 Franklin street, New York. It is alleged in suhstance, with referenee to this eause of action, that the defendant indorsed the note, and it was then delivered, before maturity, to the plaintiff, which gave full value therefor, relying on the credit of said indorsement; that before the note became due, and on the rth of December, 1:903, an involuntary petition in hankruptcy was filed against the Janes Freeman Brown Company, and a receiver appointed; that on the same day the defendant, as president of the company, pursuant to a rote of the board of directors, filed a written admission of its inability to pay debts and a willingness that it be anjudged bankrupt; that it was so adjudged on the oth of Fohruary, 1901; that at the maturity of the note the maker was insolvent, its business suspomled, its plare of business elosed, its property still in the possession of the rereiver, and that the note was not paid, of all which facts the defondant then had actual knowledge: that no part of the note has bern pail, exeept a dividend derelared in the bankruptey procedinges and that the hatanee is now due and owing to the plaintitr from the defondant, for which sum jurlgment is asked. Tho thiod alles of action allegent is an another unte, and the allegations resperting it are substantially the same.

The apperlant contends that no cause of action is stated against him as judorser upon the notes, because it does not appear that they were presented for payment and notice of nonpayment given to him. P'rior to the enactment of the Negotiahle Instruments Law (laws 1897. p. 719 , c. 612), it was beld that an indorser of a note or the drawer of a draft was not discharged by an omission to demand payment and to 
give notice of nonpayment, where such omission could not possibly operate to his injury, hut sum injury was presumed, until it was made to appear that no dimage could have resulted; that mere proof of insolveney of the maker and Arawer was not suthicient, and would not ex("use the neglect. Smith v. Miller, 52 N. Y. 5t5; Clift v. Rodger. 25) Hun, 3:9: Commercial Bank of Albany v. IIughes, 17 Wend. 94; Mechanics bank of $N^{\prime}$. Y. v. Cirisuold. 7 Wend, 165. If this were to he here appliert, then it is quite evident, under the facts alleged, the plaintiff would be entitled to rerover, beause the defendant was in no way prejudied by the failure to present the notes for payment, or to give him notice of nompanent. The Negotiable Instruments Law, however, provides that due presentment and notice of dishonor ale necessaly to charge an indorser $(\$ \$ 130-160)$; but either presentment for payment or notice of nompayment may be dispensed with by waiver, which may be express or implied ( $\$ 112$, subd. $3 ; \S 180)$; so that the real question here presented is whether the facts show such waiver.

I think they do. Prior to the maturity of the notes the maker had been adjudicated a bankrupt, and the arljudication was based at least in part upon the written almission of the defendant of its inability to pay delits, coupled with a willingness that it be aljudged a bankrupt. It is true the defendant signel this admission in his official caparity as presilent of the corporation, while he is only liable as indors: $r$ as an individual: but as an indivilual he knew when the notes fell due that the corporation rould not pay them, hecause it lad then been adjudicated a bankrupt and all of its property was in the hands of a receiver in the hankruptey proceedings, in which he participated. Under such circumstances the defendant must be deemed to have waived, at least inpliedly, within the meaning of the sections of the Negotiable Instruments Law above referred to, presentment of the notes and notice of dishonor. By his consent and with his co-operation it had been rendered impossible for the maker to pay-all of its properly being then in eustodin legis. 'This view is also sustained hy what this court decided in Hoore s. Alexander, 6:: App. Div. 100. 'There Mr. Justice Ingraham, in considering the liability of an indorser where no presentation had been marle, said:

"* * * It is only when, because of some act of the indorser, the nonpayment by the maker and a failure of notice to the indorser cannot possibly operate to the injury of the latter, that the omission is cxcused. The mere fact of insolvency of the maker is not enough. * * * The fact which would exmuse this presentation must, as I understand it, be some act in which the indorser participated, by reason of which the knowledge of the fact that the maker would not pay the bill could be of no hemefit to him."

When the notes in question foll due the maker could not pay. The indorser knew it, because he harl participated in the act which marle it 
impossible for it to pay; and for that reason a failure to present the notes for palyment and give him notice of nonpayment could not by any possibility have injured him.

The judgment appealed from, therefore, is aftirmed, with costs, with leave to the defendant to withdraw demurrer and answer, on payment of costs in this court and in the court below. All concur. ${ }^{*}$

V. Payment in due course.

See Article IX. - Discharge of Instruments.

4 Ser also In re suift, 106 Fed. 65; Baumeister v. Kuntz, 53 Fla. 340; Torbert v. Hontague, 87 Pac. (Colo.) 1145; Gove v. Vining, 7 Mete. (Mass.) 212, post, p. 5\&0. Xeg. Intt. Lalw, $\$ \$ 180-182 .-C$.

NEGOT. INETKUMENTS-34 


\title{
ARTICLE VIII.
}

\section{Dutifs of Hol.der: Notice of Disilonor}

\section{Notice necessary to charge drawer or indorser.}

\author{
LONG $v$. STEVENSON.
}

[Reported herein at p. 442.] 1

$\S 160$

MARSIIALL, $\because$. SONNEMAN.

216 Pennsylinala state, 65. - 1906.

JUDGMENT for plaintiff, and defondant appeals.

Mestreza't, J. - 'J'lis is an action by an indorsee against an indorser to recover the balance due on a promissory note. One of the defenses interposed at the trial was an alleged failure to give the defendant notice of the dishonor of the note. The plaintiff proved the execution of the note by the maker, and introduced testimony to show that the defendant had indorsed it. A notary public was then called and he testified that he had protested the note at maturity for nonpayment, and that on the same day he had delivered notices of protest personally to both the plaintiff and the defendant, who were the indorsers. ***

The defendant denied that he had received notice of the dishonor of the note. He testified that the notary delivered to him an envelope addressed to L. A. Marshall, the plaintiff, which contained the follow-

Jotice of non-aceptance, whether nresentmant for aceptance be necounry or not (\$ 240) must be given in ease presentunent for acceptance is in fact made, (\$ 247). Blesard v. Ilirst, 5 liurr. 2670; Thompson v. Cumming, 2 J.righ (Va.) 321: Watson v. Tarpley, 18 llow. (U.S.) 517. The negleet is not cured by a subseduent presentment for payment followed by notice of dishonor. Smith v. Roach, 7 P. Mon. (liv.) 17. But if the bill pass into the hands of a holder in due course after a dishonor by non-aceptance he may charge a drawer or indorer by a sulseguent notice of dishoung for non-acceptance or non-payment. Dunn v. OKerffe, $5 \mathrm{M}$. \& $\mathrm{S}$. 282. See $\$ 188$. If after a note is overdue it is indorsed and transferred, the indorser is entitled to notice the same as the indorser of a note payable on demand. Beer v. Clifton, 98 Ca). 323. See lequitt v. Putnem, 3 X. Y. 494, antr, p. 272.

The indorser of a non-negotiable note is not absolutely entitled to notice of dishonor, as his contract $\mathrm{i}$ i that of guarantor. Cromuell v. Ierill, $40 \mathrm{~N}$. Y. 131; (ef. Newman v. Frost, 52 X. Y. 422): unless in jurisdictions where a guarantor is absolutely entitled to notice. Sutton v, Owen, 65 N. Car. I23. Sce ante, pp. 263-265. - II. 
ing notice: "Notice of Protest. York, Pa., March 1, 1904. L. A. Marshall: Please take notice that the note of M. Fink for four thousand dollars in faror of A. Sonaman, dated York, Pa., Nov. 2, 1903, payable March 1, at L. A. Marshall \& Co., Bankers, York, Penna., and by you endorsed (being due this day, payment having been demanded and refused), is protested for nonpayment, and that the holders look to you for the payment thereof. Respectfully yours, Henry K. Kraber, Notary Public." The defendant further testified that the notary gare him no other notice, paper or envelope.

If the holder of negotiable paper desires to charge antecedent parties with its payment, it is incumbent on him to give them notice of its dishonor. He may notify either or all of the prior indorsers, but he can compel payment only from those who have received notice of the maker's default.

Notice of nonpayment, however, is not sufficient; nor is mere knowledge of protest all that is required to charge the indorser. Says the author [Byles on Bills] above quoted (page 276): "Notice does not mean mere knowledge, but an actual notification. For a man who can be clearly shown to have known beforehand that the bill would be dishonored is, nevertheless, entitled to notice." In Tindal v. Brown, 1 Term Rep. 167, Ashhurst, J., says: "Notice means something more than knowledge, because it is competent to the holder to give credit to the maker. It is not enough to say that the maker does not intend to pay, but that the holder loes not intend to give credit to such maker. The party ought to know whether the holder intends to give credit to the maker or to resort to him."

We are of opinion that the written notice which the defendant alleges was delivered to him was not sufficient to charge him with the dishonor of the note. It was in proper form, signed lyy a notary, and was delivered in due time. But on its face it rluarly discloses the fart that it was not intended for the defendant. It was directed to L. $\Lambda$. Marshall, the plaintiff, and the envelope containing it bore the same arddress. Marshall, like the defendant, was also an indorser of the note, and, if the holder intended fo impose liability on him, it was neressary that he should have notice of dishomor. It is therefore apparent that this notice was intenderl for Marshall, and was, of couree, for the purpose of apprising him of the dishonor of the mote, and was frepared by the notary with that intention. 'The notary does not.

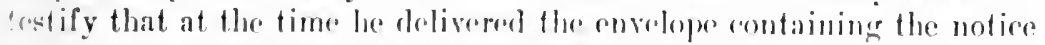
les told the deformant what it contained, or sairl anything to him conrerning its contents. Ile did not apprise the defendant that the note had been dishonored or that the notiere was interded for him. Ho gave the defendant no verhal notier whatever, and henee all the information the latter had of the dishonor of the note and the intention of the holder to guard his rights and to a void responsibility ly fixing liability on antecedent parties was what was rontained in the enverope add ressed 
to Marshall. 'This, as we have observed, was a notice to Marshall that the note "by you indorsed "was protested for nompayment, " and that the holders look to you for the payment thereof." Whiy should the defendant aceept this as a notice of dishonor to him and take eare of the note? There is no intimation in the pajer that the holder intended to look to him for payment. On the contrary, the notice is that the holder will look to Marshall, his immediate prior indorser, for payment. This he had a legal right to do, and was not compelled to notify the defendant or any other indorser or to demand payment of him. If Marshall desired to hold the defendant responsible as a prior indorser it was inemmbent upon him to give the latter notice of dishonor. 'The defendant was justified in treating the paper delivered to him by the notary as a notice to Marshall, as the address on the envelope and notice disclosed, and that the purpose was to notify Marshall of dishonor for the purpose of charging him with paynent of the note. If either the envelope or the notice had been addressed to the defendant, or if neither had been addressed to him, the plaintiff's contention that the notice was for the defendant would have some ground for its support. If, when he delivered the paper, the notary had notified the defendant verbally that the note had been dishonored or that the written notice was for him, there would be suffieient to charge the defendant with notice of dishonor. But none of these facts can be found in the case. Assuming that the defendant opened the envelope and read its contents, he simply obtained the knowledge that the note was dishonored and that the holder would look to Marshall, the last indorser, for payment. This, as we have seen, is not suffieient under the cases to fix the defendant, as an indorser, for the payment of the note.

Judgment reversed, with a venire facias de novo. ${ }^{2}$.

2 But see Wilson v. Pcck, 66 Mise. (N. Y.) 179, where it was held that notice of dishonor erroneously addressed on its face to the maker but sent by mail to and received by the indorser is sufficient in the absence of proof that the indorser was misled thereby. Whitney, J., said:

"The first objection is that the notice was addressed on its face, by mis take, to the maker instead of the indorser. It described the note correctly. The envelope was correctly addressed and was personally received and opened by appellant. By section 166 of the Negotiable Instruments Law a misdescription of the instrument does not vitiate the notice, unless the party 'is in fact misled thereby.' This but states the law as previously settled. Mills v. Bank of the United States, 11 Wheat. 431 ; Gates v. Beceher, 60 N. Y. 518. By analogy, we think that the same rule should be applied where the instrument is misdirected instead of being misleseribed. Carter v. Bradley, 19 Maine 62. Whether Marshall v. Somneman, 216 Penn. St. 65, where the misdirfetion was on the envelope as well as on the face of the notice, would be followed in this state, it is unneessary to discuss. Appellant was a lawyer. He knew that he had indorsol a note for that maker for that amount, which was outstanding. He know the notary and knew that the notary was the indorsee's attorney. He made no claim on the witness stand of having been misled."-C. 


\title{
II. What constitutes sufficient notice.
}

\section{By Whom Notice Must be Given.}

\section{$\S 161$}

\author{
CHANOINE $v$. FOWLER.
}

3 WeNdell (N. Y.) 173. - 1829.

Action against drawer of a bill. Judgment for plaintiffs.

By the Court, MakcY, J. - - A After deciding that there was no sufficient proof that the protest in France, which did not conform to the rules of the law merchant, did conform to the rules of the French Commercial code.]

To determine whether the defendant had legal notice of the nonacceptance of the bill, it will be necessary to see when it was given, and from whom it came. Messrs. Sewalls had transmitted the bill to France, and received information of its non-acceptance on the fourth or fifth of April. II. D. Sewall says he did not himself give notice thereof to the defendant, nor does he know that notice was given by his house; although it was their custom to give notice in such cases, and he has no doubt the defendant received it. He learned, from a conversation with the defendant between the time of receiving notice and on the 14 th of April, that he had knowledge that the bill was dishonored. The judge, at the trial, ruled that if the defendant had notice in due time of the non-acceptance of the bill, it was no matter whence it came, it was available to the plaintiffs. The rule of law in relation to the notice was, I apprehend, laid down in a manner too broad and unqualified. The rule has heretofore fluctuated; but it never has been authoritatively stated, as I can find. to he as the judge laid it down on the trial, except in the case of shaw $\mathrm{v}$. Coates, at the sittings before Lord Kenyon, mentioned in Selwyn's N. P. 320, n. 25. Repeated decisions since, hoth in ferm and at nisi prius, have qualified and restricted the hoad proposition of the judge in this case, and of Lord Kenyon in the case of shaw v. ('oates. In some instances, it has been decided that the liolders or their anents are the only persons to give notice of the dislonol of hills; hut it seems to be now settled that it is not alsolutely merossiry that the notice should conc from the holder of a hill, hut may he griven hy any person who is a party to it, and who womld, on the same leing renturmed to him, have a right of action on it. (Chitly om Pills, ?29?: ? Camph. 373; 1 Stark. R. 29: Bayley on Bills, t6il.) A notiere from a mere stranger is not sufficient: and the charge of the judge was hood enough to sanction such a notiere. For the insuflicieney of the pronf of the Fench f'ommercial ('orle and of the protest of the hill, and the misdirection of the judge as to the notice, a new trial ouglit to be granted.

New trial inanted.s

3 Notien ly the maker is not unflicient. Jagger v. Naliomal firrman-1m. Bank, 53 Minn. 386. Nor by the Irawee. Stanton v. Blossom, la Mass. 116. Nor by the acceptor. Harrison v. Ruscoe, 15 M. \& W. 231. The contrary 


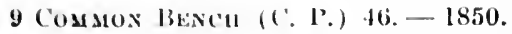

Action by holder against drawer. Dofemdant drew the bill to his own order and indorsed it to L. is s., who indorsed it to plaintiff, hut [. continned to hole] it as phantifl"s awent. The bill was presented hy 1. and dishonoperl, whermpon I. S S. gave defendant notice in their firm name. Verdict for plaintill. Defendant moves for a rule nisi to enter the veruliet for the defendint.

Malk, J. - I am of opinion that the notice of dishonor that was griven in this ase. Was sullicient. Lysaght, the younger, appears to have acted as the agent of his father, the plaintill. In that character, he received the hill from lysaght \& Smitheth, hy whom it was sworn to have been indorsed hefore it hecame due; and Lysaght the younger proved that it had ever since been bept by him amongst the doeuments which were held by him for his father. It was undoubtedly his duty to see that his father shonld have all proper remedies upon the bill. The bill, it seens, was presented on the day it beeame due, and was dishonored; and due notice of dishonor was given by Jysaght $\&$ Smithett to the defemlant, as drawer. Lysaght, the younger, having duc notice of the dishonor, which operated as a notice to Lysaght \& Smithett, it was clearly competent to the latter. aecording to the decided eases, to give notice to all prior parties to the hill, and a notice so given would enure as a notice hy the jarty who had given notice to them. I therefore think the defendant has had a sufficient notice of dishonor. ***

Clisswili, J. *** It seems, from the cases, that the holder of a bill may avail himself of a notice of dislonor given in due time by a prior indorsee, provided he himsalf is in a condition to sue the party he whom the notion was given. Hele. Hysaht the younger, holding the bill as his father's agent, duly presented it, and had it returned to him dishonomed. Notire of that faret to him, therefore. operating as a notice to the fim, the present phantio was entitled to sue them, and, consequently, is in a condition to avail himself of the notire of rlishonor given by them to the dofendant.

doctrine bat no fomnlation in principle, and may now he regarded as ended by the Neg. Int. Law, wherever that is in force. See, however, 2 Daniel on Seug. Inst., § 9900. - IJ.

[" So far as I am able to discover. the doetrine of this case [chanoine v.

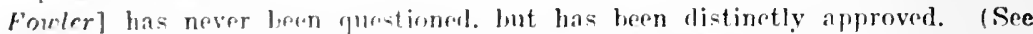

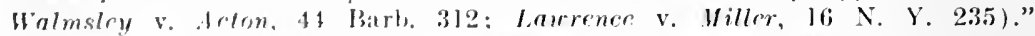

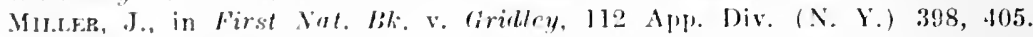

"It is not ensugh that the indorser knew that the note had not been paid. The notice, to be effectual. must ermo from the lenal source." DEWEY, J., in Cabot Bank v. Warner, I0 Allen (Mass.) 522, 525. - C.] 
I find the rule thus laid down in Byles on Bills (5th ed., p. 214): "The object of notice is twofold; first, to apprise the party to whom it is addressed, of the dishonor; and, secondly, to inform him that the holder, or party giving the notice, looks to him for payment. (Tindal $r . B r o m, 1$ 'T. R. 16i.) llence, it follows that notice (an only be griven ly sonete party to the instrument, thomgh he need not be the actual holdur of the hill at the time (Chapman v. Keane, 3. Ad.

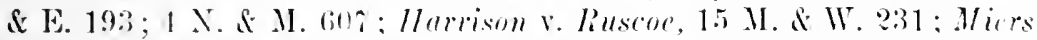
v. Bron'n, 11 II. \& 11 . :39): lut that a stranger is incompetent to

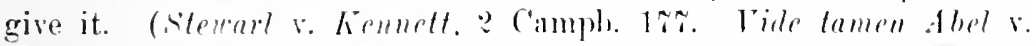
Potts, 3 Esp. X. P. ('. ?:i.) And it has been hehl by Lord Eldon, that notice by the first imlorsee, who had not himself receiverl notice from the second indorsere, and who was not, therefore, obliged to talie back the bill, was insulliciont as hetween the seconl indorsee and the

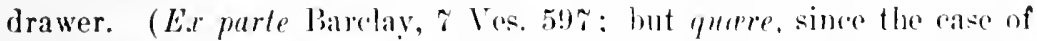
Chapman v. Keane, supra.) And it seems clear, that even a partr to the bill, who has been alrearly discharged hy laches, or who conld not in any event sue, is incomputent to grive notice. (llarrisom r. linseor.

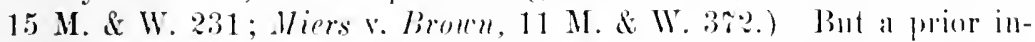
dorsee, who has himself received dne notire, may transmit it. (Jameson v. Suinton, 2 Campl. 33.3, 2 Taunt. 2:24 ITilson v. Śmabry, 1 Stark. N. P. C. 31.) And notice by the holder, or by a party who is liable to be sued, and may be entitlid to sne, will enne to the benefit of all antecedent or subserguent parties. So that a notice ly the last indorsce to the drawer, will operite als a notice from each imlorsec to the drawer; and, if the payce, or first intorsere, has duly recoived notice, a notice ly him to the drawer will be enguvalent to a notice from each indorser, and from the holder to the drawer. (Bayley on Bills, 209.) And a notime from an intermeliate party may, in pleat-

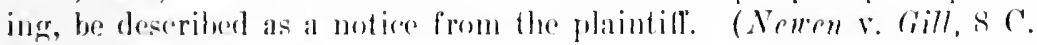
\& P. 36\%.)"

liule refinend."

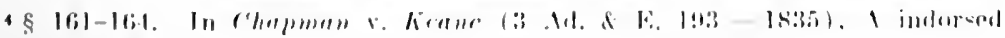

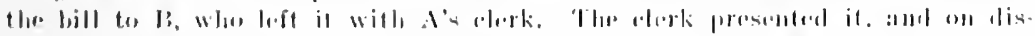

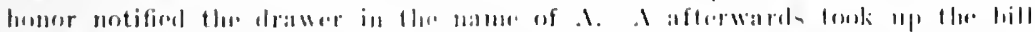

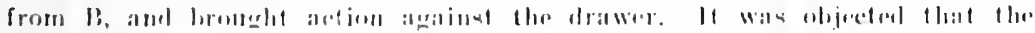

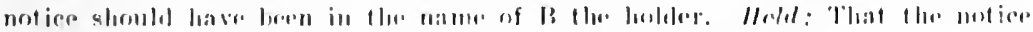

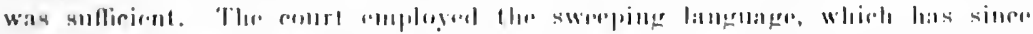

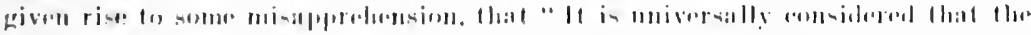

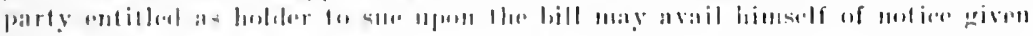

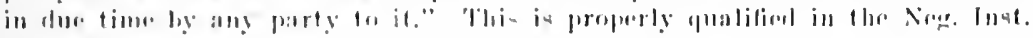
I.., \$ุ [is].

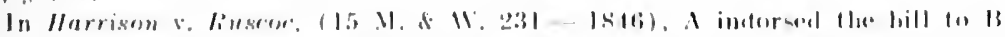

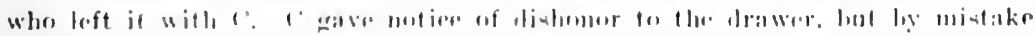

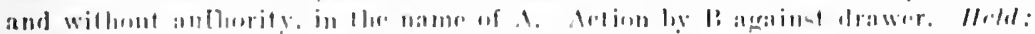

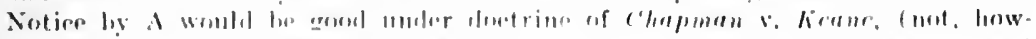

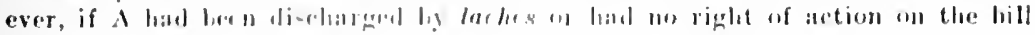




\section{$\$ 162$}

\section{'TRADELS" NATIONAL BANK U. JONES.}

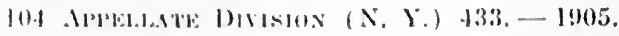

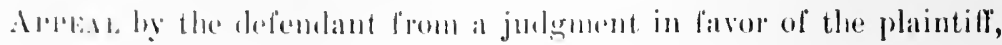

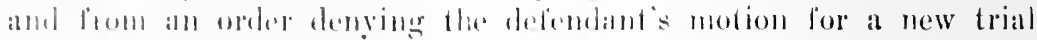
mate month the minutes.

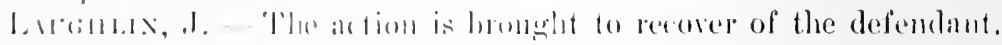

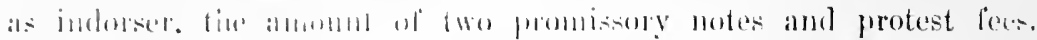

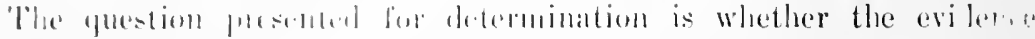

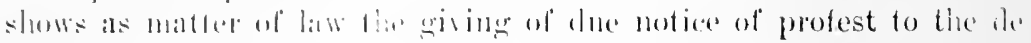

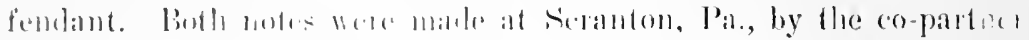

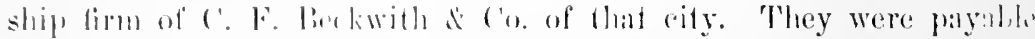

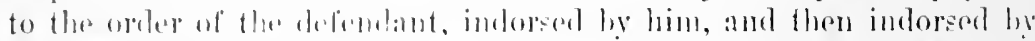

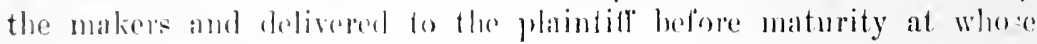
bank they wrere paylle. *** * *

The notary arow dur ame timely notion of protest to the defemdant's firm, who were lwh makess, and in form at latet, subsequent indorsers. If the plaintill had allewerl that the delembant was a member of the firm I mon of mpinion that les would he dhargeable with notice of the dishonor and with the notice given to his firm as indorsers (fiowan.

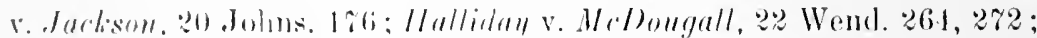

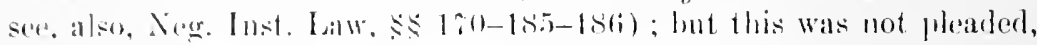
and, since it was net an isene, there is no justice or propriety in seizing upon this jtom ol evidenen, althomels admited without ohjoction that

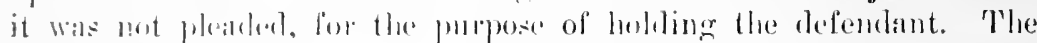
replint sionle] stumb or fall npon the issurs as tried. The notice to

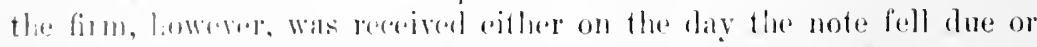

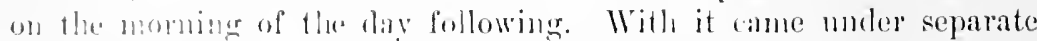

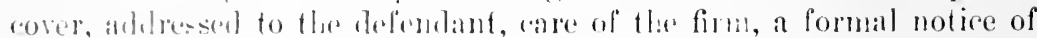
protest liy the notary in helalle of the platintilf directod to the defend-

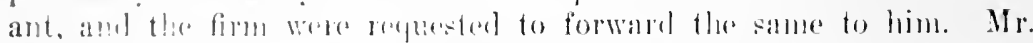

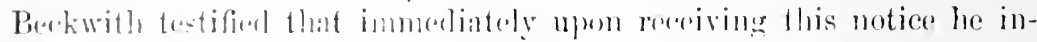

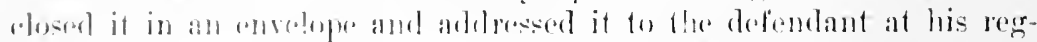

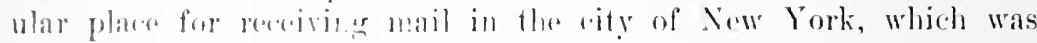

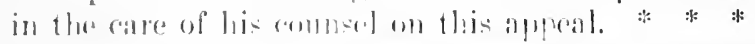

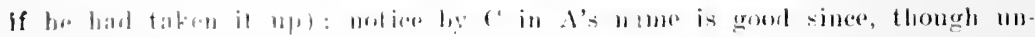

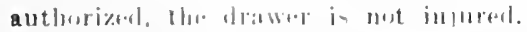

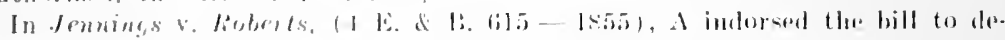

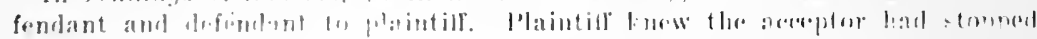

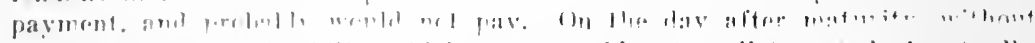
knowing whellore the hill (which was payalole at a listance) babl actuall!

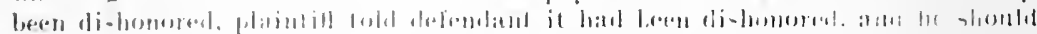

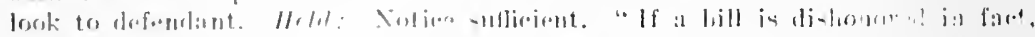

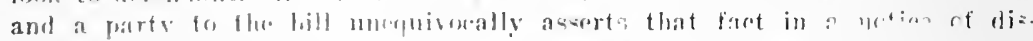
honor. I think vour rannor iurpuire into thr state of the party's mind, or his means of knowlerige." - 11. 
Although it presumptively appears from the face of the notes and the indorsements that the defendant was an accommodation indorser for the makers (Smith v. Weston, 159 N. Y. 194; Nat. Park Bank v. German American .H. W. \& S. Co., 116 N. Y. 281), and, therefore, would not be liable to them and consequently they could not in their own hehalf give him a valid notice of protest (Neg. Inst. Law, $\$ 161$; Cabot Bank v. Warner, 10 Allen (Mass.) 522; Harrison v. Rusrne, 15 II. \& IV. 231: Stanton v. Blossom, 17 Mass. 116, 120; Story, Prom. Notes, 7th Ed., $\$ 303)$, yet they could on behalf of the bank and as its agents give the notice by forwarding it immediately as was done. (Neg. Inst. Law, $\$ \$ 162-163$; Sewall v. Russell, 3 Wend. $2 \pi 6$; Chanoine v. Fowler, 3 Wend. 173; Lawrence v. Miller, 16 N. Y. 235; Smith v. Poillon, 87 N. Y. 590 ; Eagle Bank v. Hathaway, 5 Mete. (Mass.) 212 ; Rowe v. Tipper, 13 C. B. 249; Chapman v. Keane, 3 Ad. \& El. 193 ; Lysaght v. Bryant, 19 L. J. C. P. 160 ).

It follows, therefore, that the judgment and order should be affirmed, with costs.

Ingrahà and McLatghlix, JJ., concurred; Patterson, J., concurred in result; VAx BRUNT, P. J., dissented.

Judgment and order affirmed, with costs.

18 Jornson (N. Y.) 327 . 1820.

ACTION by second imlorser against first indorser. Defense, want of notice. Judgment for plaintilf.

The note was inclorsel for the accommodation of the maker. It was discounted at bauk, and on dishonor at maturity due notice was given by the agent of the bank to both intorsers. No notice was given by plaintiff to drefoudant. Plaintiff took up the note.

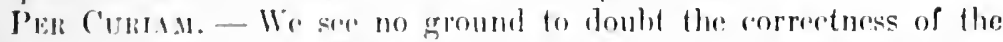
decision at the eirenit. T pon anthority, as well as sound reason, it is sufficient that the first iudorser had notiere from any subsequent holder of the note, of the default of the maker, and that he would he looked to for payment: provided such notice were given immediately after such default. The only ohject in requiring notion is, that such indorser may have resourse to the maker, to indemnify himself. And whether, after sueh notiee, the first indoreser be sued by the serend, or third indoren, is immaterial: and notier of nompayment, etce, from rither of them, enures to the benefit of all who stand hehind him on the note. 


\section{\$165 OHIO LIFE INSURANCH AND'TRUST CO. v. M'CAGUE.}

is (0110, 54. - 1849.

Arron against drawer of a bill payable to his own order and indorsed by him to plantill and ly phaintiff to its agent in New York. Julement for platintill.

sidmaci, J.- There are rally but two questions presented in this case for our consideration: First. Was the notice of protest for nonpayment transmitted with sullicient diligenee and directness to the defendant?

'The bill matured and went to protest on the 19 th day of June, 1846. It was then in the hands of an agent of the plaintitf in the eity of New York. Armit that agent to have been the actual eashier of the "Trust Company." Ile was then attending to an agency in the City of New York, and so far as it roncerned the bill in question, which was discounted at the bank in Cincinnati and sent to him in New York for collection, he may as well be called an agent as any indilferent person. This agent, on the very next day after the protest in New York, sent the notice hy mail to his principal in Cincinnati, where it arrived on the 25th of . June, and on the sane day was again placed in the mail, directed to the defendant at lipley. The most stringent rules of the law merehant will repuire no more than this. 'The whole ohjection of commsel is lased upon the fanciful iclea that the Ohio Life Insurance and 'Trust Company at Cincinnati was embodied in the person of its cashiel, Wm. M. Yermilye, in the City of New York; and that it was sending the notice of protest from itself in New York to itself in ('incinnati. We are not inclined to indulge in subtleties of this sort, and hold that Mr. Termilye in New York, whether he be called agent of ashier, was employed by the holder of the bill in Cincinnati to present the same for payment; aml, on payment being refused, to roturn it in lur tinse, with the ordinary notice of protest, to his employer in ('incinnati, whose duty it would be to communieate with the ofher parties to the bill.

[Omitting a question of statutory construction.]

Jurgment affirmed.

5 Acord: IJouarl v. Ires, I Hill (N. Y.) 263; Churoh v. Barlow, 9 Pick. (Mas-) 5t7: línshaw v. Triplett, 23 Mo. 213.

It has recently been ledd by the English Court of Appeal (Collins, L. J., dissenting), that where a hill is forwarded by the $A$. Branch of the $X$ Bank, lue notice to the. B. Branch of the same bank is sufficient to satisfy sec. 49 subsec. (12) and (13) of the Pills of Exchange Act, since the $X$ Bank is the principal, and unt a particular branch of that bank. Firlding \& Co. v. Corry, [1898] ] Q. P. 26s. These provisions are substantially the same as $\$$ If5, and $\$ 175$ of the Neg. Inst. L.aw. $-\mathrm{H}$. 


\section{Form of Notice.}

$\S 166$

KING $v$. IIUPLEY.

S5 MaIne, 525. - 1893.

Emeri, J. - This was an action by an indorsee against the indorser of a promissory note. At the maturity of the note, payment was duly demanded of the maker, and was refused, and notire thereof was seasonably sent to the defendant indorser. The defendant makes but two objections to the notice. First, that it did not state who were the other indorsers of the note. Second, that it misstated the amount of the note.

T'he defendant, however, loes not show that he was in the least misled or confused by the omission, or ly the mistake. On the contrary, it clearly appears that he understood the notice to refer to the note in suit. He was, therefore, fully informed of the dishonor of this note and that the holder looked to him for payment. This was sufficient to fix his liability. (Cayuga Co. Bank v. Warden, 1 N. Y. 113 ; 6 N. Y. 19.)

Exceptions overruled. ${ }^{6}$

11 WHEATON (U.S.) 431.-1826.

Action against indorser on a mote dated :o .July. 1819, payable 60 days after date at the ofliee of discount and deposit of the Bank of the United States, at C'hilicothe. The following notire of dishonor was sent to the indorser:-

('mencothe, 22nd september, 1819.

Sir, You will herely take notier, that a nete drawn by Woosl \& libert, dated

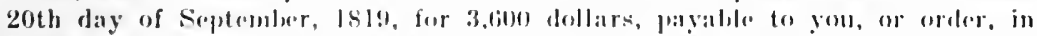

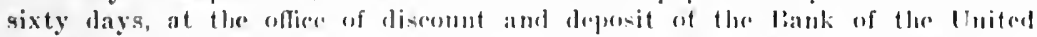

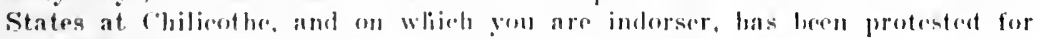
non-payment, and the holders thereof look to your.

PETRR MILLS, Esq.

jours respertfully, LAVIN liat. Mayere of chilieothe.

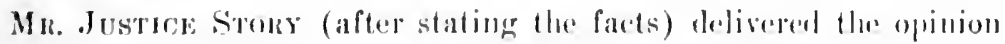
of the court.

The first point is, whether the notice sent to the dofendant at

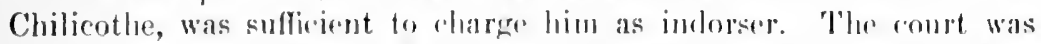
of opinion, that it was sufficicut, if there was no ofluer note payable: in the office at C'hilicothe, drawn ly Wool \& Ehert, amd imelosed by the refondant.

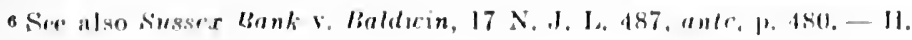


It is contended, that this opinion is erroneous, because the notice was fatally defective hy reanon of its not stating who was the holder, by reason of its misdescription of the date of the note, and by reason of its not stating that a demand had been made at the bank when the note was due. The first oljection proceeds upon a doctrine which is not admitted to be correct: and no anthority is produced to support it. No form of notice to an indorser has been prescribed by law. The whole object of it is to inform the party to whom it is sent, that payment has been refused by the maker; that he is considered liable; and that payment is expected of him. It is of no consequence to the indorser who is the holder, as he is equally hound by the notice, whomsoever he may be; and it is time enough for him to ascertain the true title of the holder, when he is called upon for payment.

'The objection of misdescription may be disposed of in a few words. It cannot be for a moment maintained, that every variance, however immaterial, is fatal to the notice. It must be such a variance as conveys no sufficient knowledge to the party of the particular note which has been dishonored. If it does not mislead him, if it conveys to him the real fact without any doubt, the variance cannot be material, either to guard his rights or avoid his responsibility. In the present case, the misdescription was merely in the date. The sum, the parties, the time and place of payment, and the indorsement, were truly and accurately described. The error, too, was apparent on the face of the notice. The party was informed that on the 22d of September, a note indorsed by him, payable in sixty days, was protested for non-payment; and yet the note itself was stated to be dated on the 20th of the same month, and, of course, only two days before. Under these circnmstances, the court laid down a rule most favorable to the defendant. It directed the jury to find the notice good, if there was no other note payable at the office at Chilicothe, drawn by Wood \& Ebert, and indorsed by the defendant. If there was no other note, how could the mistake of date possibly mislead the defendant? If he had indorsed but one note for Wood \& Ehert, how could the notice fail to be full and unexceptional in fact?

The last oljection to the notice is, that it does not state that payment was demanded at the bank when the note hecame due. It is certainly not necessary that the notice should contain such a formal allegation. It is sufficient that it states the fact of nonpayment of the note, and that the holder looks to the indorser for indemnity. Whether the demand was duly and regularly made, is matter of evidence to be established at the trial. If it be not legally made, no averment, however accurate, will help the case; and a statement of non-

7 Followed in Derham v. Donohue, 155 Fed. 385, reported in 12 A. \& E. Am. Cas. 372, with note entitled "Effect of misstatement in notice of protest as to time of dishonor." - C. 
payment and notice, is, by necessary implication, an assertion of right by the holder, founded upon his having complied with the requisitions of law against the indorser. In point of fact, in commercial cities, the general, if not universal, practice is, not to state in the notice the mode or place of demand, but the mere naked nonpayment.

Upon the point, then, of notice, we think there is no error in the opinion of the Cirenit Court.

['The court then decides that a usage to demand payment on the fourth day of grace, is good, and some other points immaterial here.] Judgment affirmed. ${ }^{8}$

\section{§ 167 SALOMON $v$. PFEISTER \& YOGEL LEATHER CO.}

\section{Atlaxtic Reporter (N. J.) 602. - l895.}

Action against indorser. Julgment for plaintiff.

Van Srckel, J. - The only question which it is deemed necessary to discuss in this case is whether a notice of protest must contain an express statement that the holder of the protested note will look to the indorser for payment. This question was hefore our Supreme Court in Burgess v. Freeland ( 24 N. J. Law, 71 ), in which case there was a failure to state in the notice that the holder looked to the indorser for payment. The chicf justice in deeiding the case said: "The object of the notice is to apprise the indorser that the note is dishonored, and that he is looked to for payment. It is not necessary to state, in terms, that the holder looks to the indorser for indemnity. It is enough if that fact appears ly just and natural implication. The modern cases agree that the fact of griving notice to the indorser that the note is dishonored for nonpalyment is in itsolf a suflicient notice that the indorser is lonked to for payment." Many authoritirs supporting this rule are cited in the npinion. In the later aase of II ouland $v$. Adrian ( $30 \mathrm{~N}$. I. Law, 11 ) the rute recognized was that the notice must he sutficient to inform the party, rither in express terms or hy neressary implination, that thro hill ar moto hard heen dishonomerl, and that he was inokerl to for priyment. In the alse in hand the notice mailed to the indorser statert that payment of the note had heren duly

* An omisaion or misdecapription of the maker's name may render the notice

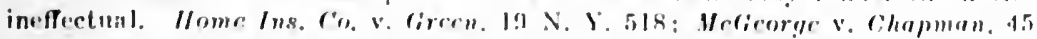

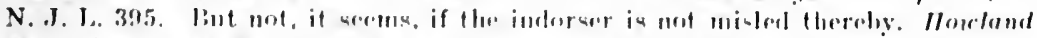
v. Adrian. 30 N. I. I. 4I: Ilod!ges v. shuter. 22 N. Y. 11.4.

Where the notiere may alply to any nur of two or more notes indorsed by the defendant, the notice may he ineftertual. Conk v. Litrhfiefd. a N. Y. 27!. But not, it serms, if the indoraer in not mialed therely. s. (.. (on retrial), 2 Bosw. (N. Y.) 137.

It is unneceseary that the notiere shombl include a eopy of the protest. Dennistoun v. Stcrart, 17 llow. (I). S.) biog, post. - 11 . 
demameled of the maker. that payment was refused, and that the note was protested for non-paynuent. The only inlerence which the indorser could reasomably have drawn from such a notice was that be hokler of the note intenderl to look to him for payment. 'The liability of the maker to the holder was fixed without presentment and protest, and therefore the only purpose which the holder could have had in sembling such notice was to elatre the indorser. 'The notice in this case was, in my opinjon, sullicient, and the judgment below should be aftirmed. ${ }^{9}$

\title{
3. MOIN OF Notice.
}

\section{(a) Iersonal delivery.}

\section{$\S 167$}

\author{
IIORBS $v$. STRRINE.
}

149 MAssichusetTs, 212 . 1889.

Acrion against iudorser. Verdiet for plaintuff.

Mortos, C. J. - Notice of the dishomor of a note is sufficient to charge an indorser if it is delivered to him personally, or is left at his place of residence or of business, or is deposited in the mail addressed to him at his plare of residence or of business, the postage being prepaid. (Pub. Sts., (. \% $\%, \$ 16$; Banl of America v. Shaw, 142 Mass. 290: Importers d 'Traters' National Bank v. Shaw, 144 Mass. 421.) The underlying principle of all the decisions upon the sulject is, that reasonable diligence must be used by the holder in getting notice of the dishonor to the indorser.

In the case at bar, the evilence temed to show that the plaintiffs, in due time, took a witten notice of the dishonor, addressed to the defendant, to his office, which was his place of business, and, finding no one in, left it there. The precise place in the offece where it was left was not fixed with certainty, and the court instructed the jury, that, if they found that it was left in a conspicuoms place in the office, it was a sufficiont notice. 'This ruling was correct. The jury might well find that the notion wis loft in gond faith in the refendant's office, in surh way that he would he likely to see it when he eame in. Such a morle of riving the notion would ordinarily be as effectual as if it. were sent ly mail throngh a letter carrier. We think the evidence shows a compliance with the rule of law refuiring the holder to exer-

9 An indication of dishonor: "IIas not been paid and I request (or demand) payment." Arnold v. Kintoch, 50 lBarb. (N. Y.) 44; Page v. Gilbert, 60 Me. 485; Armstrong v. Thurston, $11 \mathrm{Md}$. 148; Pinkham v. Macy, 9 Met. (Mass.) 174. - H. 
rise reasonable diligence, and t!ant the notice was sufficient to charge

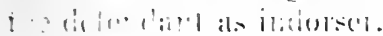

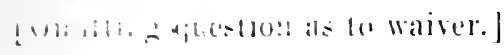

Exceputions oreruled.'

(b) Mail delivery.

167

SIIELDON 2 . BEXIIAM.

+ HII.I. (N. Y.) 12!!. - $18+3$.

Actoos against indorser. Note payable in Cieneva. Holder and indorser reside in Penn lan. Sotr distionorerl in Geneva ; noticessent by mail from Geneva to bolder in Penn Yan: holder deposits uotice for indorser in Penn Ian pustollice. Jndorser asks nonsuit on the ground

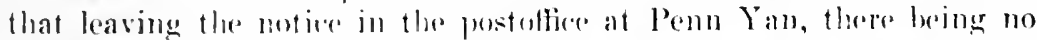
cridence that the defomelant rexpived it, was insulliejent. Motion for nonsuit deniul. Vereliet for plaintifl.

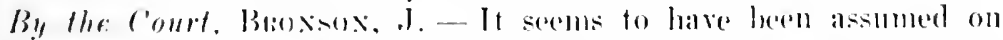
the trial that Babereli winerl the note. and sent it to the bank, where it was made payable, for collention. Notice was sent to Palueock, the last indorser, with notiens for the othere indorsers: and if he was not

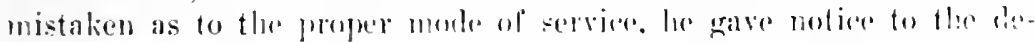
fendant Benham on the same day of the day after he receired adrices

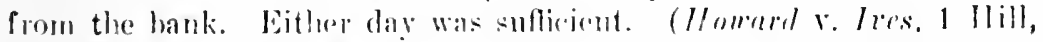

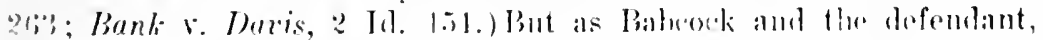

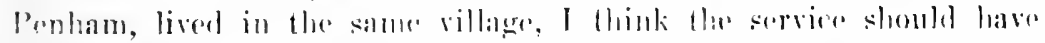
lecen personal, or be laving tla noties at the dwolling homse or

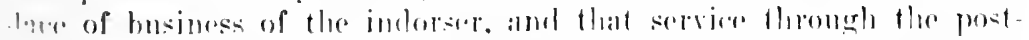

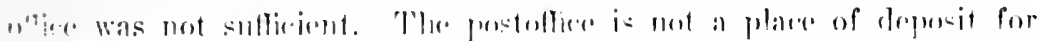

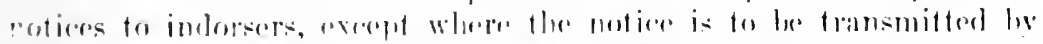

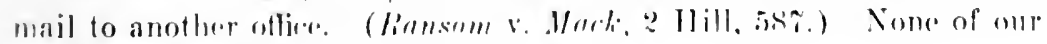
ases have grome furthrer than that.

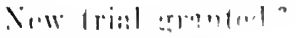

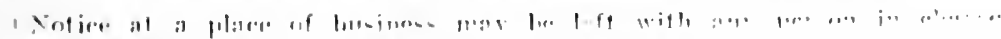

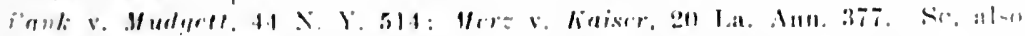

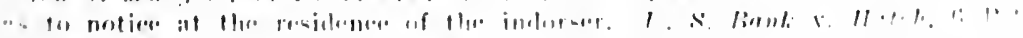

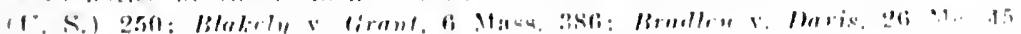

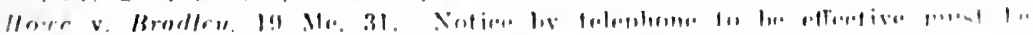

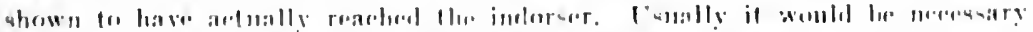

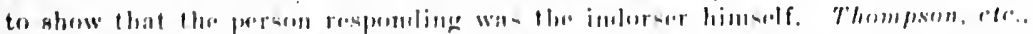

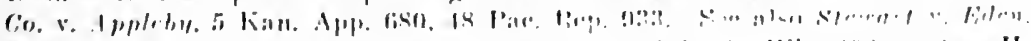

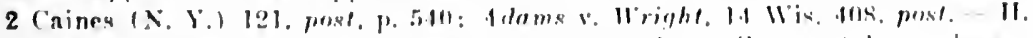

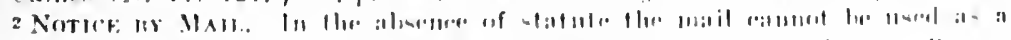

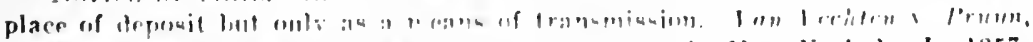

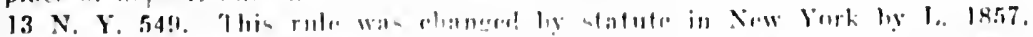

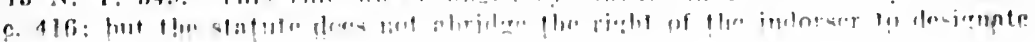




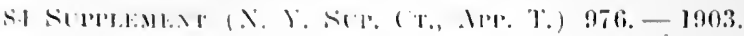

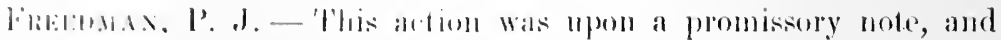

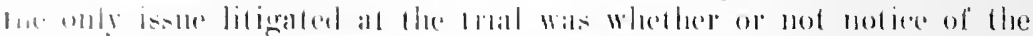

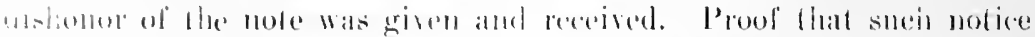

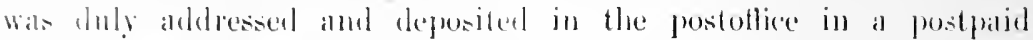

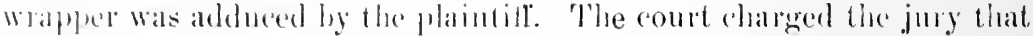
the only question for them to dedele was whether the defendant reevivel notice of the presentation and protest of the note. "If he diel," sail the court, "your verdiet will he in lavor of the plaintifl; oflerwise it will he in fasor of the defendant. It is the duty of the plaintiff to ostablish hy the woight and preponderance of evidenee that a motice of presentation and protest of this note was served upon the defentant in this action." The plaintifl"s coumsel thereupon asked the court to wharese the jury "that it is not mecessary for an jurlorece to recejve a notiee of protest. The more leposit of a notion in a postuad wrapper in the postothice of Vew York ('ity is sufficient." 'To this request the eourt responded: "It is not sutfieient. Tt is prima farie evidence of the farts stated ly the witueses." 'To this ruling the plantilf's commel duly excopted. The jury rentered a verdict in favor of the defenclant, and the plaintifl now appeals.

This ruling of the court was in ilrect conflict with section 176 of the Negrotiahle Instrments Law (Laws 189\%, p. 741, c. 612). 'Tluat. stretion frovides: "Where notice of dishonor is duly ardressed and deposited in the postollice, the semder is deemed to have griven dhe notice, notwithstambing any miscarriage in the mails." The testimony of the plaintifl"s wituess's as to the athlressing, mailing, elc., of the notice was undisputed. If the jury belicred that testiman.,

the parlieular address to which the notice shall be sent. Burthetl v. Robinson,

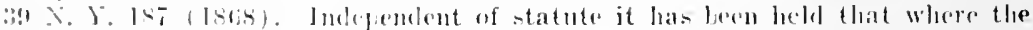

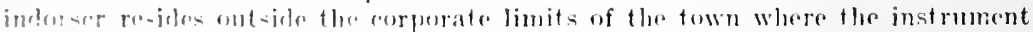
$i$ is dishomored and $i=i n$ the hahit of reseivine his mail there. the post olliee mate low used as a place of deposit in order to relieve the holder of the burden and

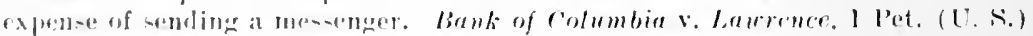

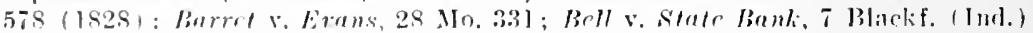

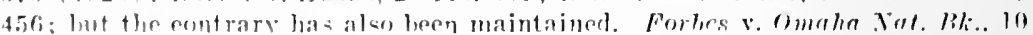

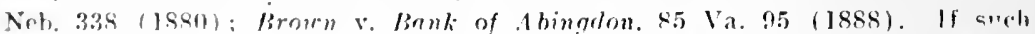
notice is actually receiver? in due time it is unquestionably grod. lliclps v.

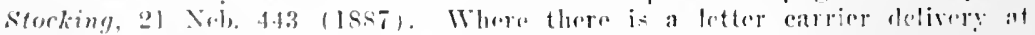

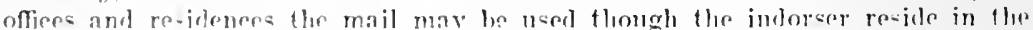
place where the instrument is Jishonored, for in such ease the mail is nserl

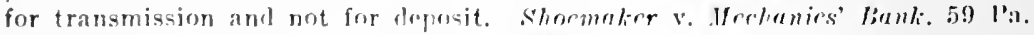
St. 83 (JS6S) : Ilalters i. lirown, 15 Md. 285 (1859); but in such ease a

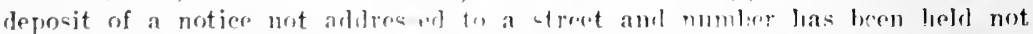
within the rule. Benediet v. Serlmirf. 13 Wash. 476 (1896). By the statute above, notice by deprosit is now suflicient. See $\$ 174$, subsec. 3, post. - H. 
whether the defendant received such notice is not material. The court should have so charged. 'I'o refuse so to charge constituted reversible error, for which a new trial must be granted.

Judgment reversed, and new trial ordered, with costs to the appellant to abide the event. All concur. ${ }^{3}$

PEARCE $v$. LANGFIT.

101 Pexssyana State, 507. - 1882.

Action against indorser. Holder handed notice duly addressed and stamped to a United States mail carrier, who was then in the bank to deliver mail. Judgment for plaintiff.

Mr. Justice Grees delivered the opinion of the court, December 30 th, 1882.

We think the delivery of a letter to an official letter carrier is the full equivalent for depositing it in a receiving box or at the postoffice. When left in the former it is for the purpose of being taken therefrom by the carrier, and if left at the postoffice it must be taken from the receptacle there provided for its deposit, either by the postmaster or by some one of lis agents, to be placed in the mail. In either case the letter must come into the personal eustody of some one lawfully authorized for the purpose, whose function it is to participate in the transmission of it from the sender to the mail.

It certainly can make no difference whether the letter is handed directly to the carrier, or is first deposited in a receiving hox and taken from thence by the sane earrier. In the case of sliblberl v. Ciarbett (7 Ad. \& El. N. S., p. S.tfi), in which the very point was decided, lord Denman, C. J., sairl: "If a publice servant belonging to the postollice. takes charge of the letter in the exoreise of his pullic duty it is the same as if it were carried to the office." The postal regulations of the United States require that carriers while on their rounds shall mocene

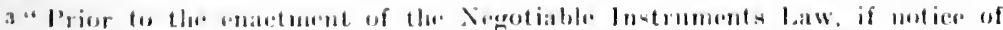

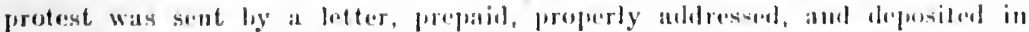

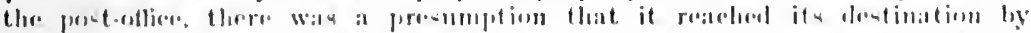

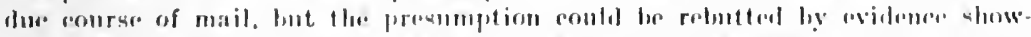

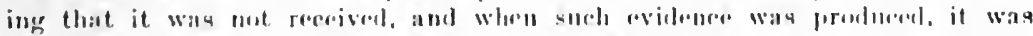

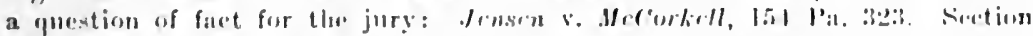

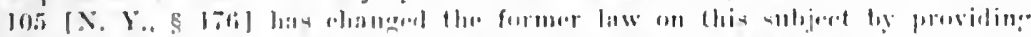

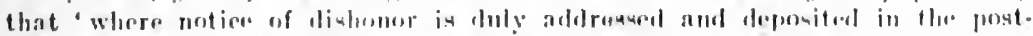

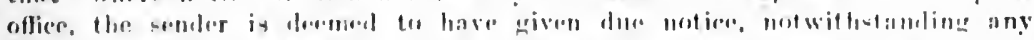

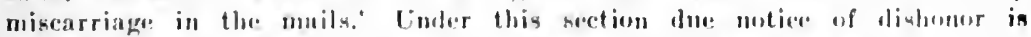

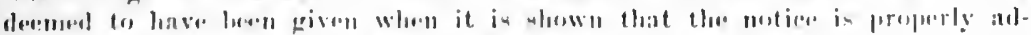

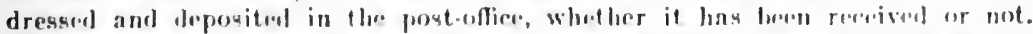
In other words, the purpose and offact of this section of the sot were amply to protect the sender of the mutier againut mincarriage of the mailu." Mls.

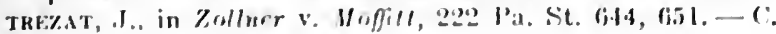

NROOT, INSTHUMENTS - 35 
all letters prepaid that may be handed to them for moting. It follows that when such a carrier receives a prepaid letter from a estizen for the purpose of heing mailed, he is in the strict performance of his otficial duty.

[Omitting other questions.]

\section{Judgment affirmed.}

\section{To Whom notree May Be Given.}

$\S 169$

$$
\text { STEWAR'T } v \text {. EDEN. }
$$

a CAINES (N. Y.) 121. - 1804 .

Action against executor of indorser. Shortly after the note was intorsed the indorser remosed to his country residence and there died. His will was not proved until after the maturity of the note. At its maturity the holder, upon dishonor, sent a messenger with a notice of dishonor, directerl to the indorser, to the town house of the indorser, but, an it was closel, the notice was rolled up and put into the keylole of the door.

Lmixistox, J., delivered the opinion of the court. ***

Ought notice of the maker's lefault to lave been sent to the indorser's country house? The note heing daterl in New York, the maker and indorser are presumed to have resiled, and contemplated payment, there. It is admitted, indeed, that the indorser did reside in the city at the time of its date, for it is stated that shortly thereafter he went to his conntry seat. shutting up his house in town. We must take care that, while proper diligence be imposed on the holder of negotiable paper, we do not exact from him every possible exertion that might have been male to affeet an indorser with knowledge of its being dishonored. If he has done all that a diligent and prodent man could

4 "The deposit of the notire in a post.office box on the street was just the same. in legal affect, as if it had been deposited in a lox at the postorlice. (skillerk v. Garbell. 7 Q. B. S46: Praree v. Langfit, 101 Penn. St. 507)."Johnson r. Brourn, 154 lla-s. 105 (1S91). Aceord: Casco Nat. Bh. v. Shate,

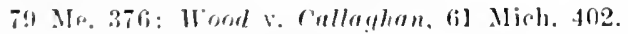

1" The attorney tentifies that be put it [the notice of protest] in the mail chuste on the day of protect. . . The chute was a letter box under the control of the po-t nffies Department, and therefore equivalent to the postoffere itsolf. Nugntiable lu-truments Law, § 177." W'ilson v, Peck, 66 Mise. 179. $180 .-r \cdot 1$

The notarial certiticate need not state that the address to which the notice is sent is the correct residener or address. In the absence of evidence to the contrary. the prosumption is that the notary, who is a public officer, has correctly stated the allurses. Ley! v. T'inal. 165 Mass. 555, citing contrary hollings. As to sulliciency of notarial certificate as evidence of notice, see jost. pl. 589-590.- 11 .

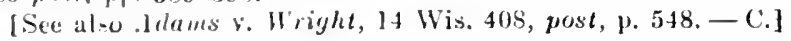


naturally and fairly do under like eircumstances; if the law has prescribed no certain way of sending a notice in the given case; if the indorser's own conduct has rendered it somewliat difficult to determine in what way the notice ought to be given; and especially, if from what has been done, it may reasonably be presumed that notice has reached the parties concerned, we should be satisfied, and not ask for more. Indorsers, therefore, cammot complain, if notices of this nature are permitted to be left at their houses in town notwithstanding their removal into the country during the hot months. It is more reasonable that they leave a person in town to attend to their business, than that the holders of their paper be put to the trouble of fincling out to what part of the country they have removed and sending after thent. It is also probable, especially when the distance between the two honses is only four miles, as it was here, that some communication will be kept up between them, and that a letter left at the dwelling in town will not be long in finding its way to the country. I speak now of a temporary residence in the country; for a permanent removal from the city might render a different course necessary. Nor was it fatal to direct the notice to the indorser himself; for as it was not known whether he had made a will, nor who his executors were, until long after, it was full as probable that it would reach the parties interested by this address as by any other: some one of the deceased's family wimld either open it, or see it safely lelivered to an executor. 'The notice, therefore, was well served, ani its address proper. ${ }^{5}$

[Reversed on a point of pleading.]

12 MIssissIPH. 7.19. - 18.40.

ACtion against administratur of indorwer. Indorsement hy Thomas

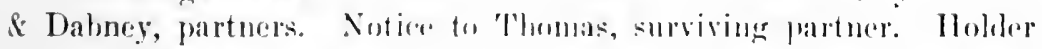
knew of Dahney's death and that the partuership was theredy disolved. Julgment for plaintilf.

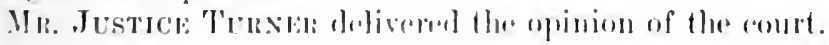

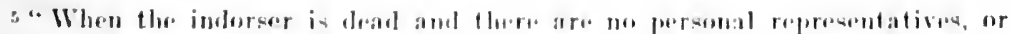

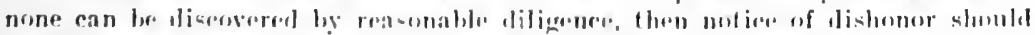

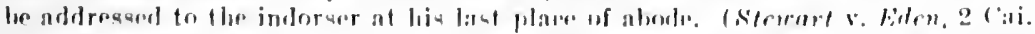

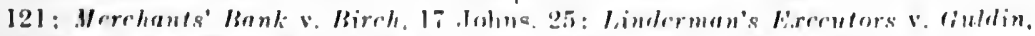

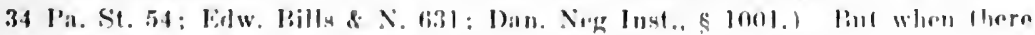
are peronal repreaentation and lluy are known or diseoverable by due dili.

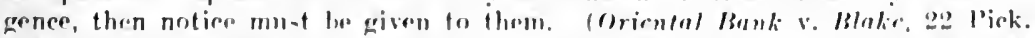
20fi: Smalley v. Wright, 11 Vroom. 471: Story. Prom. V.. E 310: Eilw. Hille t N. 631; Dan. Neg. Inst., \& l000: ('hit. Bills, 295)."-Domlson v. Thylor, 56 ‥ J. I. 11, 19. - II. 
The only question raicul in this ease is whether the executor or administrator of a deceasuel partuer is entitled to notice of the nonfayment of a note indersent hy the fatrtures as such.

The anthorities are clear, and are beliesed to be miform, that notice to one is notice to all. (liayley on Bills, ests; 1 Con. R. 368; 4 Cow. 1:6: 6 Lonisiana, (ist: 3 i itit. 25il. $)^{6}$ But it must appear that they ale partners. In this ase it so appears. lersons being joint payees of a note, who severally indorse it, are entitled each to notice of nonbayment. 'They being joint, loes not necessarily constitute them partners. The act of assembly relied on hy the appellant, found in Statute l.aws of Mississippi. II. $\mathbb{E}$ H., 595, merely aflects the remedy and not the right, and was passed to farilitate creditors in obtaining judgment for their just demands against oue or all of several partners.

\section{$\$ 172$ MORELAND'S ADMINISTRATOR $v$. CITIZENS' SAV- INGS BANK.}

[Reported herein at $p$. 696.]

\section{5. 'Time Within Which Notece Must Be Given.}

(a) Where partics reside in same place.

$\$ 174$

ADAMS r. WRIGHT.

14 Wiscoxsin, 408. - 1861 .

This was an action against Wright as indorser of a promissory note, payable at the Bank of () khkosh. The note was protested for nonpayment, and the complaint alleged that due notice of protest and non. payment was given to the defendant; which allegation was denied by tl:e answer.

s. Acord: Mubbard v. Hatthrus, 54 N. Y. 43 ; Fourth N. B. v. Heuschen, 52 M1,. 207.-. H.

[In figanspan v. MpDonncll, 201 Mass. 341 , it was hold that where the indorsement on a promiscory note is in the name of a copertnership, by the

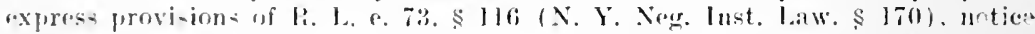
to one of the partners of the dishonor of the note "is notice to the firm, even

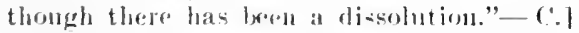

i Aceord: Hillis v. Grem, 5 llill (N. Y.) 232; Sheparl v. Ifazoley, l Conn. $367 .-11$.

8 If notice is given to a hankrupt hefore a trustee or ascignar is appointed it must, of course, be given to him personally. Ex parte Moline, 19 Ves. 216 . If given after the aypointment of the truster it may lw given to the bankrupt or to the trustee. In ro Bellman. I. R. 4 ("h. D. 795: Callalian v. Kontucky Bank, 82 Ky. 231; |Woroland's .Iaministrator v. Kit. Nav. Bank, 114 Ky. 577. post.-C.]; American N. R. V. Jumk Bros., 94 Ky. 624, post, p. 579.-H. 
endeavoring, by the oral testimony of the notary, to fortify the case made by the record, the plaintiff should, as afterwards happened in this action, call forth facts which tend to disprove it and to falsify the certificate, it would become a question of veracity between the notary as a witness upon the stand, and as a public officer acting under the sanetity of an official oath, to be settled by the jury. He being a competent witness, and the certificate being open to explanation and contradiction, it is, of course, possible for him to dispute it, and if he does, the jury must weigh his account on oath against the official document under his seal, and determine between them. This was so held under a similar statute of Pennsylvania, in the case of Stewart v. Allison, 6 Serg. \& Rawle, 324. That ease, indeed, goes much further, and sanetions a doctrine which the facts of this do not present. 'The majority of the court held that the protest of the notary under his official seal was competent evidence to go to the jury, notwithstanding he was produced as a witness and testified positively that he had no knowledge whatever of the transaction, and that the protest was written and sealed by his son, who acted as his clerk or agent, and who silid he had given the notice. The dissenting opinion of Gibson, J., is a powerful argument against its admissibility in such a case, and the Supreme Court of New York, in Onondaga County Bank v. Bates, 3 Hill, 53 , under a statute like ours, held that the office of notary was one of personal trust and confidence, and that its duties could not be performed by a clerk or third person. It seems obvious from the nature of his duties and the provisions of the statute, that his official oath is substituted for the ordinary judicial oath taken in the presence of the court and jury, and that he cannot lawfully and conscientiously certify or record as matters of fact things which he wonld he incompetent to testify to as a witness if called to the stand in the trial of a cause, and which would be excluded as mere hearsay. Still, we think the reasoning of the majority of the court in stewart r. Allison applicablo. to a case like this, where the notary does not directly deny a knowl$e^{-1}$ ge of the facts stated in his certiticate, but only by infercuce and hy testifying to circumstanees which, though not absolutely inconsistent with them, tend to draw them into doulat and remove therir ollert. 'They say that the jury may possibly give more credit to the oflicial cortilieate than to the oath of the notary; that he may have heen tamperest with after grving his certificate; or the jury may think that the certificate and parol evidenee are not inconsistent, or that he may he mistaken after the lapse of many years, or confound one transuction with another.

The record of the notary was properly admitted. The oljection taken to it was, that the erertificale which hard lesen alrealy introduced, showed no servies upon the defemdant, peremally or otherwies of the notice of which it purporterl to contain a ropy. So far as the objoction was founded on the supposed requirement of the statute, that notice 
l gave him the notiee, and asked him to hand it to his father; he turned and went towards the house; I did not see him go in, as I could not see the door from where I stool; this was between the gate and the front door."

'The defendant requested the court to instruct the jury as follows: "1. [unless the jury find from the evidence that the notice of protest was personally serred on the defendant, the plaintiff cannot recover. 2. Leaving motice at his house was not a personal serviee, unless it was left with some nember of the family to whom its contents were explaines. 3. Giving the notice to a boy in the defendant's front yard. and requesting him to hand it to the defendant, was not a personal service." These instructions were all refused; and the court instructed the jury that if the notice of protest was heft at the defendant's homso, that was equiralent to a personal service, and that it made no difference that the defendant did not receive the notice, or that he never heard of it, or that he never had any knowledge that it had been so left, or whether he ever heard of the protest of the said note.

Verdict and julgment for the plinintiff.

By the Court. Dixox, (C. J. - The motion for a nonsuit was properly denied. At that time the plaintiff had made out a sufficient prima facie case to charge the defendant as indorser. Nor was there any error in the previons proceedings. The certificate of the notary showing presentment and protest for non-payment, and service of notice upon the defendant, togather with the tiue and mode of griving it, was received withont objection. 'There was no improprioty in the question put to the notary as to whether he gave notice to the defendant of the protest of the note. It was obviously asked for the purpose of laying the foundation for the introduction of his official record of protests and notices, which was immediately produced. But if it had been jut for any other purpose, we cannot perceive why it should have been rejected on the grounds urged, or what other good oljection there was to it. The notary's certificate is not the only evidence by which the service of notice of the dishonor of a note can be established. It may be shown by other evidence, and the notary himself may be called to prove it. The cortificate and record are hut presumptive evidence by statute ( R. S., (hap). 1:, \$\$ $4-6$ ), and, being so, are liable to be rebutted or disprosed hy the testimony of witnesses. And if by other witnesses, then why not lyy the notary? It is bardly to be supposed that a plaintiff who has made a good case by the record, would, at the risk of shaking or destreying it, ecok to go further into the facts by an oral examination of the notary: lout if, not being content with the record, he should desire tro strengthen it by the oral testimony, we can see no ohjection to it. of the several modes of establishing notice, all are open to him, and he may resort to one or more at his option. The only possibie ground of objection there can be is, that having made a sulficient prima facie ase, further proof is unnecessary. If in thus 
On the trial the plaintiff gave in evidence the note, with the certificate of protest annexed. This certificate, after stating that the note was presented at the Bank of Oshkosh on the 12th of December, 1859, which was the day it became due, and that payment was refused, contained the following: "And I, the said notary, do hereby certify that on the same day and year above mentioned, notices of the foregoing protest were put into the postoffice at Oshkosh as follows: Notice for James Freeman, Oshkosh, Wis.; notice for W. Wricht (left at his house), Oshkosh, Wis. Each of the ahove named places being the reputed place of residence," ete. The plaintiff then called as a witness the notary by whom the protest was made, and asked him the following question: "Did you give notice to the defendant of protest of the note?" The defendant objecter to the question because the certificate and record of the notary, required by statute, were the best evidene, and because the certificate conld not be explained or contradicted by parol evidence. The oljection was overruled, and the witness answered, "that he had no particular recollection of this notice," and produced his official record of protests and noties. The planintift offered this record in evidence; the defendant oljected to it on the ground that there was no proof that the notice of which said record purported to contain a copy was ever served on the defendant personally or otherwise; but the oljection was overmbed, and the record given in evidence. It contained a copy of the note, and of the certificate of protest, etce, previously read in evidenre, and also a copy of a notice of protest for non-payment of the note, addressed to the defondant. It was arlmitted flat the defendant residerl, at the time of the protest of said note, within two miles of the resilence and place of business of said notary; and the plaintill rested. 'The defendant mored for a nonsuit, npen the groment that the was mo proof of the personal eervice of the notice of profest upon hins: lut the motion was dented.

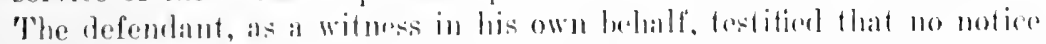

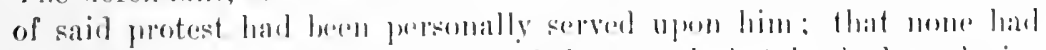

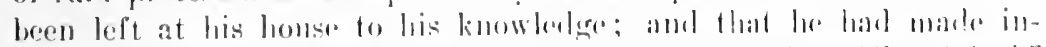

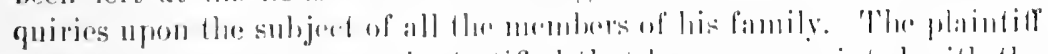

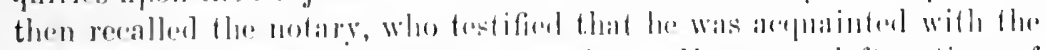

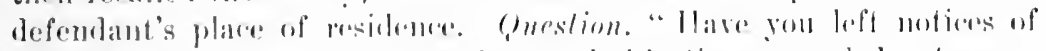

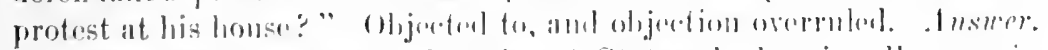

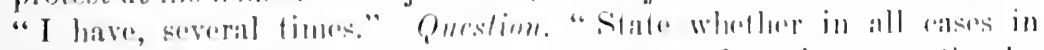

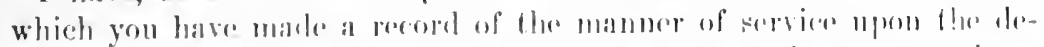

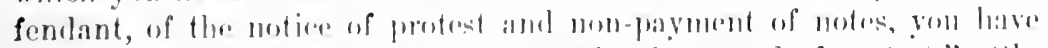
made the same in the manner indiated ly the mend of protest." (1),

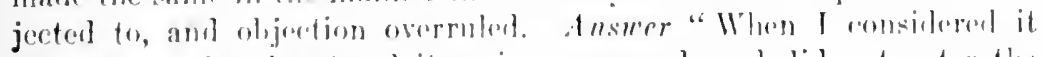

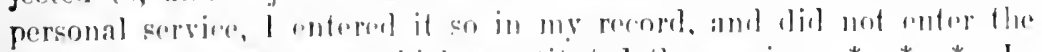

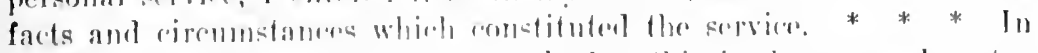
one instance only - 1 anenent toll whenther this is the one I wed a

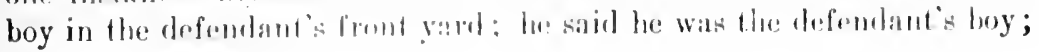


must be actually delivered to the person of the indorser where he resides within two miles of the residence of the notary, it has been already answered by this cout, in the case of IVestfall v. Farwell, 13 Wis. 50. It was there held that the words " personally serve" were designed to inchule service by leaving the notice at the indorser's residence or place of business, as well as by actual delivery to him, and that they were nsed in contradistinction to service by mail. As to the certificate being uncertain in not showing whether the notice was sent through the postohice or left at the defendant's house, we think that the words " left at his house, Ushkosh, Wis.," placed immediately after his name, indicate that the latter was the mode of service adopted as to him. 'The omission to say " duelling house" diel not vitiate the eertificate. Nolaries are only to be lyeld to reasonable certainty in the use of language, and when they say that notice was left at the house of the indorser, all men wonld molerstand it to signify his dwelling house. Neither is the certificate defective in not stating the lour of the day when the notice was left, or with whom it was deposited, whether a member of the family or other person, or the particular circumstances attending the service, or that the defendant was absent. It is very generally said in the hooks, and the doctrine is laid down without any apparent limit or qualification, that the service by leaving the notice at the dwelling house or place of business, is equivalent to a personal delivery to the party to be notified. Jurge Story says: "If it be not personally given, then it will be sufficient if it is given or left at or sent to his domicil or place of business." Story on Promissory Notes, $\$ 312$. Mr. Chitty says: "With respect to the mode of giving the notice, rersonal service is not necessary, nor is it requisite to leave a written nutice at the residence of the party, but it is sulficient to send or to convey verbal notice at the counting house or place of abode of the party, without leaving notice in writing; and the giving such verbal notice to a servant at lis lome, the defendant having left no clork at his counting house, as it was his duty to do, suffices." Chitty on Bills, 502. 'This is the language of the books grenerally, and no case las fallen under our olservation where it has been held that the absence of the party to be notified was a condition necessary to sustain servire by leaving the notice at his place of aborle or business; thougl it is said in Ireland v. Kip, 11 .John. 2?1, that the notice must be personal, or something tantamount, such as leaving it at the dwelling house or place of himsiness of the party, if absent. See authorities eited by Judge Story, supra. Nor does any case seem to have arisen requiring an areurate definition of the manner in which service by leaving notice at the domicil or plare of business, when found open and occupied, shall be performed. Where the particular mode of service did not appear, I suppose the cases have gone off on the reasonable assumption that an officror engaged in a duty of that kind wonld perform it with proper care and prudence, and use the means most likely to attain 
the object in view - that he would go to the place of serviee and inquire for the party to be notified, and, if present, deliver it to him in person, or, if that should be unsuitable or inconvenient, that he would band it to a servant or some inmate of the place with a request that it be so delivered; and, if absent, that he would in like manner leave it with some person residing or doing business therein, with a similar request. Serrice at the place of business must be during business hours, but service at the residence is not so regulated. ${ }^{9}$ It will be sufficient if made during any of the hours when members of households are attending to their ordinary affairs. But these particulars of service need not be stated in the certificate. It will be sufficient if it shows serrice at the residence or place of business, which constitutes legal diligence, and the special cireumstances will be presumed until the contrary is shown.

We are not ealled upon to express any opinion as to the admissibility of the testimony of the defendant. He was permitted to testify witlout objection, that no notice in fact came to his possession or knowledge. It seems to be well settled law that it is no answer to service properly made at the dwelling house or place of business, that the party to be notified did not in fact receire it.

After the defendant lad given his testimony, the notary was recalled by the plaintiff, and testified, among other things, that he had protested several notes against the defendant, and that on one oecasion, but whether on that of giving the notice in question he could not say, he met a boy in the defendant's front yard, who said he was the defendant's boy, and gave him the notice and asked him to hand it to his father; that the boy turmed and went toward the honse, but that he did not see him go in, as the door was not in sight from where he stood. The defendant thereupon requested the court to instruct the jury that giving the notice to the boy and requesting him to lamel it to the defendant, was not personal scrvice. Inderstanding the torm "personal service" areording to the definition given in II'es/fall $r$. Farwell, we are of opinion that the defendant was entitled to the instruction. The testimony of the motary clearly tended to impeneh his certificate, and, within the principles alowe stated, it was the legal right of the defomdant to lave it submitted to the jury to determine whether the notier was given as staterl in the cerfificate or in the cral testimony, or, in other words. whether the oceasion of which the notary spoke was that of giving the notice under consideration. If it was, the rertificate must fall. Boing the stalement of a matter which the notary did not know, and false in fact. it rould no longer he relied upon as evidence showing due service of notice. And as to the de-

- Pat if the notiere is in fart perennal. it serems that it need not le during

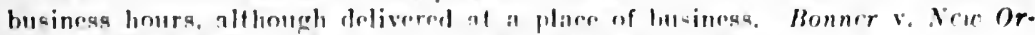
leans, 2 Woods (U. S. C. C.) 135; 3 Fed Cas, 853. - H. 


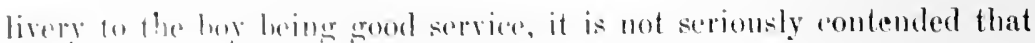

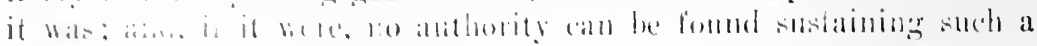

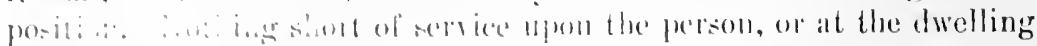

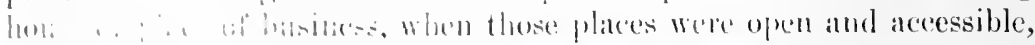

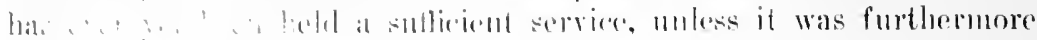

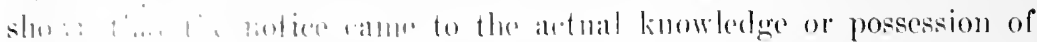

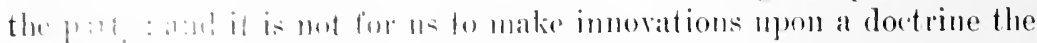

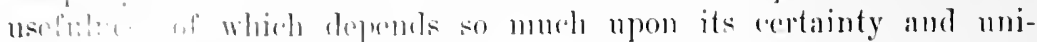

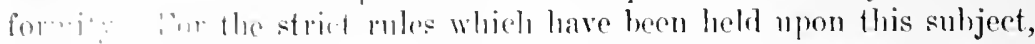

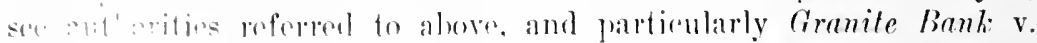

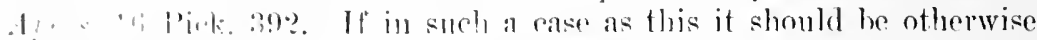
siue "1 int the indorser artually roceived the notice, it would present a dillerent puestion. The plaintitl"s case would not then stand on the sromen of the ofleial act ol the notary.

'Plu instruction should have been given to the jury, and because it was not the judgment is reversed and a new trial awarded.

(b) Where puties reside in different places.

$\S 173$

IINTENPERGER $r$ BEALL.

6) WHE.tTox (I+.S.) 101. - 1821.

Actiox against indorser. Fividence that on the last day of grace the notice to the indorser was put into the postoffice properly addressed, ete. 'The and held the proof of notice insulficient. Plaintiff hrings error.

The court were manimously of opinion, that after the demand of thre maker on the thirel day of erace, notier to the indorser on the same day was sufliciont. ly the geneml law mepohant: and that evi-

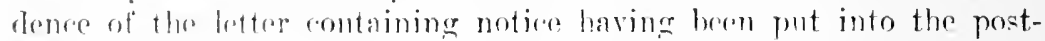

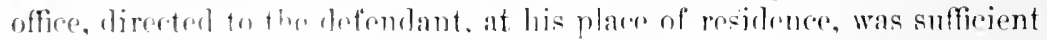

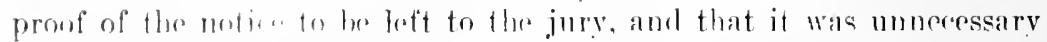
to give notion to lla drefurlant to produce the letter betore such evidence (omld be armitted.

Judgunent reversed.

$\S 175$

WHTWELA, .JOHNSON.

17 MAssaCHCETTS, $449-1821$.

Artos on promissory note gayable to the order of defendant, in-

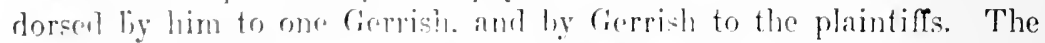
notr was Inderer he the plaintiffe in the Nassarlusetts Bank for collec-

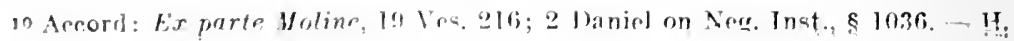


tion. On the 14th of February, 1820, the day when the note became due, after making demanci on the maker for payment," the messenger of the bank carried two notifications for the indorsers (directed to them, but without any directions, to Newburyport, the town in which they lived), to the store of the plaintiffs; and there was evidence tending to show that these notifications, after being directed to Newburyport, were put into the Boston postoflice the same afternoon. That directed to the defendant was produced, and the postmark upon it was the 15 th of February. The post officer at Newburyport testified that it did not arrive at his office until the morning of the $16 \mathrm{th}$; and an officer of the Boston postoffice testified that if the note had heen put into the office on the $1 \mathrm{tth}$, before eight oclock in the evening. it would have been stamped the 14 th, and if received after that lonr, it would have been stamped the $15 \mathrm{th}$, and would have gone into the morning's mail of that day, which arrives at Newhuryport about noon.

The jury were instructed that, if they were satisfied from a comparison of the eridence, that the notice to the defendant as indorser was put into the postoffice on the 1/th of February, before ejght orlock in the evening, the defendant was liable. A verdict was returned for the plaintiffs, and the defendant moved for a new trial, on account of the directions to the jury.

Parker, C. J. * * * Supposing, then, the demand for payment on the maker] to have heen sulficient to charge the indorser, the question remaining is, whether seasonalile notice was given to him of nonpayment. The note herame due on the 11 th, and, areording to the finding of the jury, the point is settled against the defendant.

But, on the supposition that it was neressary that the notice shonld have heen put into the postoffice on the diy when the note hecame doe. a petition has been presented for new trial, on the ground that evidence since the trial has been disecovered which has a bearing on that point.

As the evidence at the trial was by no moans of a conclusive nature.

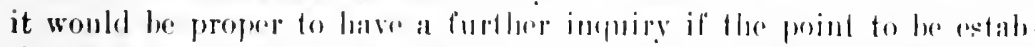
lislied was essential to the dorision of the rallese. After some dombts. and looking into the anthorities, we are sit istiod that it was not meressary for the plitintifl to show that notice to the indersion was put

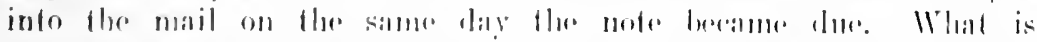

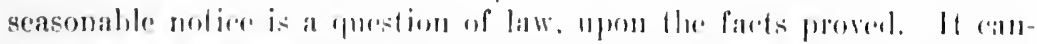

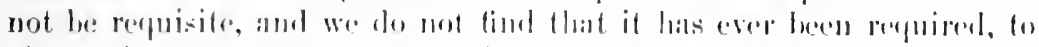
give notice fo: an indorser, living in another town, ly the sery next mail after the dishonor of the motre ar on the same daye This would be an unreasonable hardship on bolders of uotes, espercially as the maker

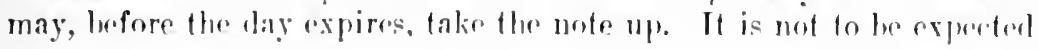

- Thr part of the case relating to the demand on the maker for payment in omitted. - $($. 
that merohants will leave everything else to altend to this one subject un the rery dily the note is dishonoren. The nest daly is early enough, and if there shomld he two mails a day, whether the notice goes by the list or the serond of these mails, we think is immaterial, provided it was put into the postothice early enough to go lyy a mail of that day.

II" molerstand, from enom anthority, that the Supreme Court of the Inited States have alopted the sume rule, and it is desirable that the same law should prevail on commereial subjects in all states.

Judgment on the verdict."

\section{$\S 175$}

\section{SMITII v. POILLON.}

87 NEW YORK, 590.- 1882.

Actios against indorser. The holder notified the third indorser hy mail and inclosed notices for the second and tirst indorsers. 'The thind indorser notitied the second indorser and inclosed notien for the first. 'The second indorser received notice on the 6th and mailed notice to the first indorsers on the rth, in time for the second mail of the day closing at $1: 30 \mathrm{r} . \mathrm{s}$. The first mail of the day closed at $9: 30 \mathrm{~A} . \mathrm{s}$. The first indorsers (defendants) contend that they were not notified with due diligence. Judgment for plaintiff.

EArs, J. - [After deciding that the presentment and prior notices were suflicient.]

Smith was an aged man, upward of eighty years old. On the morning of Jlarel $\%$ he took the notices for the defendants and drove to Thomaston, for the purpose of consulting his comnset, and there, under the advice of his eomsel, he wrote a letter addressed to the defendants, and inelosed it with the notice for the defondants in an envelope astrossed to them, and caused it to be mailer at Thomaston, in time for the mail which left there for New York, the residence of the defendante, at $1: 10$ P. M. That mail passed through Warren, on its way to Now York. at 2 r. .r. There were 1 wo mails each day from Warren, one

11 I'st: of P'ost. - Prior to the statute it was held that where there are suc. ces-ive indorsers and the holder sends notice to the last indorser by mail inclosing therewith notices to prior indorsers, the last indorser may use the postoffies as a plaee of rrposit for the notices to the prinr indorsers who live in the same town as he. (lint soe shollon v. Isnham. \& IJill. 129. ante. p. 543.) Under this rule, it is held that suel redejosit must be in time to reach the prior indorser in the usual conrse on the rlay following the day of recipt. Thus, if the last indorser recrives the notices on the $10 t h$, they must he redeposited in season to reach the prior indersers in the usual eourse on the 11 th. If deposited on the Jlth ton late to reach the prior indorsers on that day, the indorsers are discharged. Shelburne lalls Nat. lik. v. Townsley, I02 Mass. 177 ; s. c. 107 Mass. 444. It is this rulr. ristablished for the exceptional ease where Irop letters were permitted indepenilent of statute, that is now extended to the use of drop letters generally under the statute. - H. 
closing at about $9: 30 \mathrm{~A}$. M. and the other at about $1: 30 \mathrm{P}$. M., and that letter went in the same mail that closed at Warren at $1: 30$. The contention on the part of the defendants is, that the law required that that notice should have been mailed by the first convenient, practical mail on the ith, and hence that it should have been mailed by the first mail on that day; and, to sustain their contention, our attention is called to various authorities. (Smedes v. Utica Bank, 20 Johns. 372 ; Mead v. Engs, 5 Cow. 303; Seuall v. Russell, 3 Wend. 276; Howard v. Ives, 1 Hill, 263; Haskell v. Boardman, 8 Allen, 38; Sussex Bank v. Balduin, 2 Harrison (N. J.), 487; Burgess v. Vreeland, 24 N. J. L. 71 ; Lau'son v. Farmers' Bk., 1 Ohio St. 206 ; Freemans' Bank v. Perkins, 18 Me. 292.) These authorities, while not entirely harmonious, undoubtedly tend to sustain the rule that the notice must be sent on the next day by the first practical and convenient post.

The counsel for the plaintiff, however, contends that the rule is, that notice of dishonor in such cases may be sent to the prior party by any post of the next day, and he calls our attention to several authorities which tend to sustain his contention. (Chick v. Pillsbury, 24 Me. 458; Whituell v. Johnson, 17 Mass. 449; 2 Daniels on Neg. Inst. 87; Story on Bills, § 288; Story on Prom. Notes, § 32.4; 3 Kent's Com. 106.)

From a careful examination of all these authorities and many others it is clear that the law is not precisely settled. It appears that at first it was supposed to he necessary that notice of dishonor should be given by the next post after dishonor, on the same day, if there was one. That rule was found inconveniently stringent, and then it was held that when the parties lived in different places. between which there was a mail, the notice could be posted the next day after the dishonor or notice of dishonor. Some of the authorities hold that the party required to give the notice may have the whole of the next lay. Some of them hold that when there are several mails on the next day, it is sufficient to send the notice by any post of that day. Other authorities lay down the rule, m general terms, that the notion must be posted hy the first practical and convenient mail of the next day: and that rule seems to be supported by the most anthority in this state. What is a convenient amb practical mail depends upon direumstances. It may be comtrolled by the usages of business and the customs of the people at the place of mailing, and the "omlition, situation and husiness engagements of the person resuires to give the noties. The rule should have al reasonable applieation in erery case, and whether sufficient diligenee has been used to mail the notiee, the faets being undisputed, is a question of law.

In Wead v. Eings (5 Cow. 30.3), notiens of dishonor of a bill reacherl the post-offiee at the iesidener of the last indorser at $5 \mathrm{r}$. M. and actually came to his hanris the next morning. The first mail 
thereafter for the residence of the prior party left at 1 r. M., but the motices for that party were not mailed mutil after that hour. Sutherland. I., said: "libe cashier was not bound in the exereise of ane diligence to have preplated and forwarded notices by the one oclock mail: it is not reasomalule to demand from lim the neglect of his other oflicial duties to prepare his letters and notices during the usual hanking hours:" and further, that "the law does not require the holder of a hill or note to grive the earliest possible notice of its dishonor; it requires of him only an ordinary and reasonable dilisence: nor is he homml, the moment he receives notice of the dishonor of a bill, to lay aside all other business and dispatch notice to the prior parties to the bill; if reasonable diligence is used it is sufficient

In Darbishire v. I'arker (6 East, 3), Lord Ellenhorough observes: "There must be some reasonable time allowed for giving notice, and that, too, aceommodating itself to other business and affairs of life; otherwise it is saying that a man who has bill transactions passing through his hands must be nailed to the post-office, and ean attend to no other business, however urgent, till this is dispatched."

It does not appear here how far Mr. Smith lived from the postoffice at IIarren: he was an aged man and wanted some adrice about the matter. Farly on the day after he received the notices he went to Thomaston to see his comsel, and thus he missed the mail, which closed at 9:30. We think it rannot he said that the delay was urreasonable, or that there was the ahsence of that proper diligence which the law repuires. There was, therefore, no error in holding as matter of law that due diligence was used hy smith in posting the notice to the refenrlants.

The jurlgment should be affirmed, with costs.

\section{All roneur. Judgment affirmed,'}

\footnotetext{
1 A mail whieh eloses at 9:10 A. M.. bejng the only mail of the day after the day of dishonor, is not at an unreasomable or ineonvenient linur. Iarson v. Farmers' Bani, 1 Oh. Sit. 206 (155:3). Six $\Lambda$. . . is an inconvenient hour. rhick v. Jillsbury, $24 \mathrm{Mr}$. $45 \mathrm{~s}$ (1844). "The next day is arly enough; and if there shomle be two maili a day. whether the notice goes by the first or the seennd of those mails. we think is inmaterial, provided it was put into the postoffice marly cuougl, to go ly a mail of that day." - Whitwrell v. .Iohnson, 17 Mass. 449 (1821). Tho second lay after dishonor is too late unless the mail of the first lay after eloses before bilsinese langrs. Banle v. Bradley, 17 N.C. 526. If the day after dishomor is a holiday or sumbly it is excluded from the computation. See Nore. Inst. L... \& 5 [Gomeral Provisions]. It has heen held that a notice given on Sunday is ineffective. Khem v. Curlisle Deposit Bank, 76 Pa. St. 132. But not one given on a holiday. Jeblieux v. Bullard, 1 Rob. (I.a.) $66 .-\mathrm{H}$.
}

[See a]so temis, Hubbard of ro. v. Montgomery Supply Co., 59 W. Va. 75, reported in 4 I. N. S. 132 . with case note entitled "lills and notes; time allowed for mailing check or notice of dishonor, as affected hy the hour at which the mail closes and departs."

In First Nat. Bank v. Millrr. 139 Wis. 126, 128, Marchall, J.. said: "The law relating to proceedings to fix the liability of an indorser of a promissory 
11 Grattax (VA.) 260. - 1854.

Acrios against indorser of bill drawn on a drawee in London and protested for non-acceptance on April 5th. ${ }^{2}$ Notice was sent in a mail learing Liverpool on April 19 th by a Cunard steamship, that being the first steamship leaving England for the United States after the dishonor of the bill. But between the 5th and the 19th several sailing packets carrying mails left England for the United States. It was the usage of the London post-office to forward all mail by the Cunard line unless specially directed to be forwarded by otlier ressels. Judgment for plaintiff.

Simues, J. * * * The law requires notice of dishonor of commereial paper to be transmitted to the parties thereto for the purpose of enabling them to do what is needful to protect their interests; to this end it may be important to have early notice, and the law requires it to be given. In the case before us the notice was sent in a mode which would bring it to the hands of the plaintiff in error at the earliest practicalse day. Yet it is alleged that it should have been sent by another mode, which, although it might have commenced the transmission at an earlier day, yet would not have delivered it so soon as the mode adopted. If we could yield to the arguments of the plaintiff's romsel, we should sacrifice the object of the law. 'The notice was transmitted in the mail by an ocean steamer belonging to the C'mard line, which line carried the mail from Great Britain to the United States. It was sent ly the first steamer which started after the hill was dishonored. This hrings the case within the stringent rule of requiring that the notice be sent by the first mail. It appears, however, that there are regular lines of sailing parkets from London (the plare of the drawee sesulence)

note, in case of dishonor ly the maker, was different in some slates than in others, and for harmony on that as to the time and manner of griving mice of dishonor to the indorser it was providorl ly sululivision $34, \$ 1678$, (N.)., \$ 175), of the Negotiable Instrument Sitatute, that, where the ferson giving and the person to receive notice reside in elifferent places, the motice must be given - * if sent by mail' hy depositing it "in the postoflies in time to go by mail the day following the day of dishomor.or, if there he no mail at a envenient hour on that day, by the next mail thereafter.' Here notice was not sent till after time for mail on the first secular any after dishonor. thomgh there was ample. opportunity to do so. The drparture timo for the mail was betwen! nud io nelock of such day. That way cortainly a conveniont time within the moaning of the statute. No excuse is found in the evidener for not repositing the notice with postage fully paid on gu to have reached the respondent hy anch nail. The deposit on the evening of that day, after ordinary hissiness hours and long after the closing of the mail for such day, as regaria the route lyy which it must have heen known the notice would reach reapondent, if at all, clearly was ton late." - r.

2 Foe Neg. Inst. I., \$260. - H. 
to the United States; that these packets carried letter bags made up at the London post-oflice; and that the times for their sailing from Great Britain oceurred between the day of the dishonor of this bill and the day of the stcamer's leaving. It further appears, that althongh a sailing packet should leave on the regular day for her departure, and thereafter a steamer should leave on her regular day of depariure. the steamer wonld probably arrive first in the United States. It further appears. that the line of mail steamers is used by a very large majority of husiness men for the transmission of letters from Great Britain to the Inited States. There can be no question, that of these two modes of transmission, the proper one was adopted. This one has in its faror the facts that it carries the mail, that it is the ordinary mode of transmission, and that it may be expeeted to deliver a letter at an earlier day than the other; that other having in its favor the facts that it starts at an earlier day, and carries a letter bag. There is nothing to counterbalance the fact that the other line will deliver the letter at the earliest day. I think the notice of dishonor was duly transmitted.

I am of opinion to affirm the judgment. The other judges concurred.

\section{Judgment affirmed. ${ }^{3}$}

\section{JARVIS $v$, ST. CROIX MFG. CO.}

\section{MaIne, 287. - 1843.}

Assumpsit against the defendants as drawers of a bill of exchange, dinced Aug. 10, 1839, on N. Dewey of the eity of New York, payable in 60 days after sight, accepted liy Dewey on Aug. 26, 1839, and indorsed by the defendants, and by the plaintiffs.

The plaintiffs resided at St. John, New Brunswick; the place of husiness of the defendants was at Calais in this state; and the areeptor resided in the city of New York.

The hill was protested in the city of New York, for non-payment by the acceptor, on Oet. 28, 1839, and a notice, arddressed to the defendants, informing them of the dishonor and protest, was, at the request of the plaintiffs, placed in the post-office at Eastport on the eleventh day of November, 18.39. It was agreed, that the mail was at that time five days in passing from New York to Eastport; that the mail between St. Andrews and St. John passed three times each week, leaving the former place on Monday, Wednesday, and Friday, and returning on 'Tuestay, Thursday, and Saturday, leaving each

8 Notice must be sent by the first usual mail ship whether it sail direct to the port of the drawer or indorser or to some nther port of the United States. Fleming $v$. MrC'lure, 1 Brevard (S. Car.) 428 (1804); Lenox v. Leverett, 10 Mass. 1 (1813). - H. 
place early in the morning and arriving late in the evening; that the mail between Eastport and Calais then passed on alternate days, and on said eleventh day of November passed from Eastport to Calais, leaving before the notice was put into the office; that letters to and from the Province of New Brunswick meet through that mail; and that letters from St. John for Calais would not go by the way of Eastport, but directly from St. Andrews to Robbinston and from thence to Calais. The court, upon this evidence, were authorized to draw any inferences which a jury would be authorized to do, and to order a nonsuit or default, as justice might require.

The opinion of the court was by

Whitman, C. J. - Notice of the non-payment of the draft in this case could not have reached the defendants before the 16 th or 1 th day after its dishonor. Instead of sending it direetly from St. John to Calais, by due course of mail, the plaintifls seem to have preferred sending it to Eastport; and there to have mailed it for the defendants at Calais. This was on the 16 th day after its dishonor in New York. The mail was five days in reaching Eastport from New York. This accounts for five days of the time. How it should happen that eleven days more were necessary to forward it from thence to St. Joln and back to Eastport does not appear. It does not seem, by the course of the mails between Eastport and Sit. John, that more than four or five day's need be occupied in the transmission of a letter and the return of an answer. It is true that the plaintiffs had a right to adopt a private conveyance for the receipt and transmission of notice. But it is clearly incombent on them to show that due diligence was used. The evidence in the ase is antirely silent as to how it should have happened that so much greater delay took place than we ean see, from the evidence, to have been necessary. It was incumbent on the plantiffs to have remover any reasonible doubts upon this point; and, not having done so, we think a nonsuit must be entered.

(c) S'uccessive notices.

LINN v. HOR'TON.

17 Wracosist, 151. - 1863.

Action against irregular indorece ${ }^{4}$ by payee. The note was payable in Janesville, Wis. Plaintits were morelants in Now York. Plaintiffs indorsed for collection to K., in Now York. K. imlorsend for collection to central Bank in Janesville. 'The latter, on dis. honor on Nov. 22, mailed notieres to K., who receivent them on

- See Neg. Inst. I., \& 114. - II.

NROOT. INATUUYRATR - BB 
Nor. ??, and delivered them to plantitis on that day. On the same day plantits mailed notice to defomlant at Janesville, but it was never received hy him. Judgment for defendant.

by the Court, Itxox, ('. J.- It is an established principle of nercintile law, that il the holder of a bill or note chooses to rely upon the responsibility of his immediate indorser, there is no necessity for his giving notioe to any previous party; and if such notice be properly wiven, in due time, hy the other parties, it will inure to the hemefit of the holder, and he may recover thereon against any of them. 'Thus, if the holler notifies the sixth inclorser, and he the fifth, and so on to the first, the hatter will be liahle to all the parties. (1 Parsons on Bills and Notes, 50:3, 501; and Elwards on Bills and Notes, $4: 3,4.4$, and the ases citod.) And it is no objection to such motice that it is not in fact received so soon by the first or any prior rmborser, as if it had been transmitted directly by the holder or motary, provided it has been seasonably sent by aach indorser as he receives it. (Colt r. Noble, 5 Mass. 16\%; Mead v. Lngs, 5 Cow. 303;

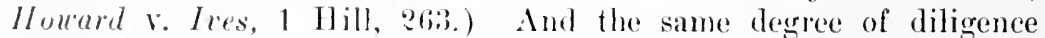
must be exeroised on the pant of the indorser in forwarding notice as is rexpired of the holder. Ordinary diligence must be used in both eases. The is not bound to forward notice on the very day upon which he receives it, but may wait until the next. (Ioward v. Ives, and the authorities (ited.)

For the purpose of receiving and transmitting notices, those who hold at the time of protest, and those who indorse as mere agents to colleet, are regarded as real parties to the bill or note; the former as lindlers in fact, and the latter as actual indorsers for value. (.Ioral v. Engs; Howarl v. Ives, supra.)"

It follows from these principles, that the jroper steps were taken to charge the defendant IIorton as indorser. Notice for him was forwarled hy mail, postpaid, on the day of the protest, to the agents and last indorers in New York, and dolivered by them, on the day it was rerejved, to the plaintifl's, their immediate indorsers, who, on the same rlay, deposited it, inclosed in an envelope, postpaid, in the post-olline at New York, direrterl to the defendant at Janesville, Wisronsin, his proper post-oflice.

Enler these circumstances, the onty question which can possibly arise is, whether the defendant ought to be discharged by reason of the notice not having heen in fact received by him. Ile testifies that it was not. Professor Parsons olserves, that in all the cases of constructive notires, where notice given ly a subseruent to a prior indorser has heen held to inure to the benefit of the immediate indorser, it has appeared that the notice was actually received; and

¿See also Farmers' Bank v. Tail, 21 N. Y. 485; Rosson v. Carroll, 90 'Tenn. 90. $-\mathrm{H}$. 
he raises a question whether this would be so if the notice was sent to the wrong place. (1 Parsons on Bills and Yotes, 504, note, and 62\%.) But liese the notice was sent to the right place. Besides, the plaintiffs, who scek to arail themselves of the notice, are the indorsers Who sent it to the defendant as the indorser next immediately precerling them. We have already seen that the rule of diligence as to them is the same as in the case of the holder.

Let the judgment breversed, and the cause remanded with directions to enter julgument in fasor of the plaintiffs according to the demand of the romplaint.'

\section{HUMPHREY (TEXX.) 419. - 1844.}

Rarse. T., delisered the opinion of the court.

The Branch Bank of the State of Tennessee was the holder of a promissory note, payahle at said bank, made by James II. Jenkins, to Anthony lihindl, and cmlorsed in the following order: A. Dihrell, S. 'T'urney, and Jno. W'. Simpson. T'urney's residence is within one mile of the bank, at Sinarta, so known to be to the bank, and to all the other partice to the note. The note was legally due on the 1st

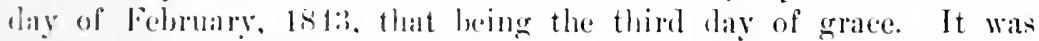
on that day protested. On the second day of Fehruary no notice of the protest for the non-payment of the note was either served on 'furmey personally ol left at his residence. He had notice from the

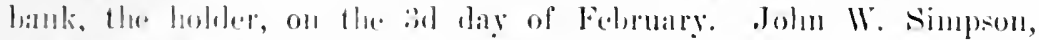

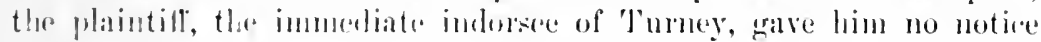
whatroer.

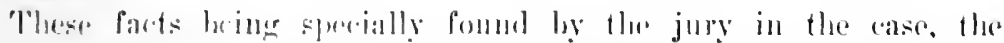

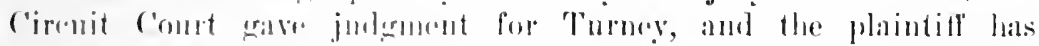
apporaled in crour to this court.

It is not insisted for the plantiff lere that the notien of the hank

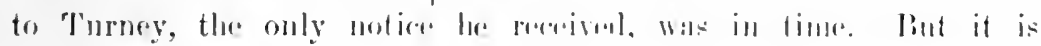

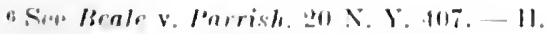

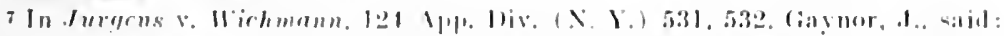

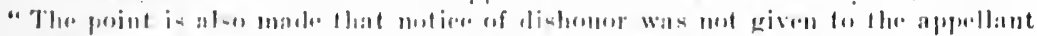

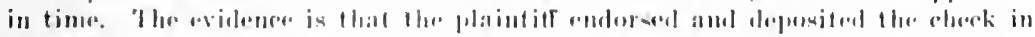

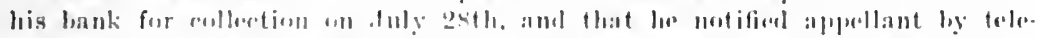

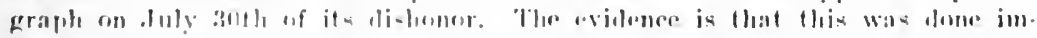

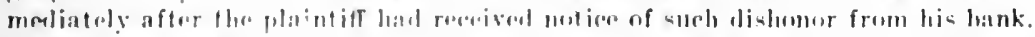

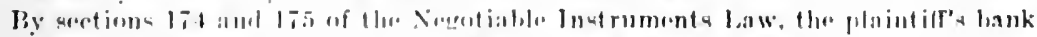

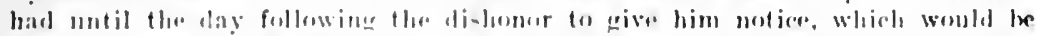

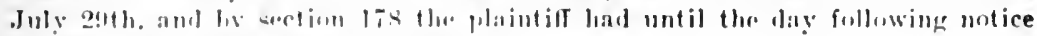
to him to , rive the ai lullant notion."

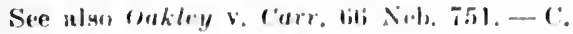


urged, that if Simpson had griven him notice on the day he reeeived notice from the bank, such notice would have been grood; and that is certaiuly so; and the plantill further insists that the notice given by the bank slall inure to his benefit. If the notice laad been in time and valid, it would by law have innred to his benefit, he being an infermediate party. But a notice of no benefit to the bank, because not fixing the liability of the party notified, cannot immre to the benefit of another. So to hold would be to introduce a new principle into the law merchant. Suppose there were ten indorsers upon a note: if the bolder, ten days after the protest, gave notice to the first indorser, this. acororling to the argument, wonld fix all the indorsers, for it would be just the time necessary to them to have given notice to each other suresesively.

It is perhaps a minersal principle, where substitution exists at all, that the matter or thing to be sulsetituted to must be valid and effective in hehalf of the principal; if it be inelfectual in his behalf, It is difficult to see how it "in inure to the benefit of others.

Upon the direct question raised in this case, Bayley on Bills expressly says: "Nor is it any excuse that there are several intervening parties between him who gives the notice and the defenclant to whom it is given: and if the notice had been communicated through those intervening parties, and each had taken the time the law allows, the defendant wonld not have had the notice the sooner." The same principle is also lecided in the case of Turner v. Leech (4 Barnwall \& Aldrenon, 451).

We have been referred by the phintiff, to what has been said by this court in the ase of Mcilsil v. Iryalt (3 IJumphreys, 12S). The bank at Lagrange in that ase gave notice to one Glover on the 1tth to be served on Wratt \& MrNeil. Wyatt was served on the 11 th, and Mc. Neil on the 15th. But Glover proved in the Circuit Court that he was the seneral agent of Wratt to serve notices for him when his name was on paper. And the Cireuit Court left it to t'se jury to say whether Gloser, who served the notice, was not Wyatt's agent as well as thr agent of the bank: ant if he was, then the notice to $M(\cdot$ Neil on the 15 th, one day after Wyatt received notice, was sufficient.

This court held that there was not any error in this part of the charese and placing the validity of the notice, as this court did, upon that special ground, is a distinct recognition of the general prineiple maintained by us in this case.

Upon the whole, we afirm the julgment. ${ }^{8}$

- Accord: Rowe v. Tipper, 13 C. P. 249. - H. 


\title{
$\S 178$ FIRST NATIONAL BANK $v$. FARNEMAN.
}

\author{
93 Iowa, 161. - 1894.
}

Action against indorser. Defendant indorsed to plaintiff. Plaintiff indorsed for collection to Valley Bank. The latter indorsed for collection to German Bank, at Carroll, which place, unknown to German Bank, was the residence of defendant. 'The German Bank, on dishonor on Nov. 10, mailed notices to Valley Bank, which forwarded them to plaintiff, who received them on Nov. 12, and on that day gave personal notice to defendant. Of the indorsements on the bill all except that by the defendant are erased. Judgment for defendant.

Granger, C. J. * * * Appellant relies, mainly, in argument on a. rule that the holder need only notify his immediate indorser, and this indorser the next, and so on, and then claims that the German Bank did notify the Valley Bank. How such a rule might affect the rights of parties were the German Bank seeking to recover, it is not for us to say. Defendant is the immediate indorser of the plaintiff bank, and, becaluse of the erasures, there are no other indorsers; and the rule eited, if a correct one, is without force. It is to be kept in mind that, as to the indorsers other than the defendant, they were such for collection only, and the indorsements were erased. We treat the case on the theory of but a single indorser, and that one the defendant.

The judgment is affirmed.

\section{Place at Which Nótice Must Be: Given.}

$\S 179$ Monus 2 . Husson, 4 Sandford (N. Y. C'ity Superior ('rt.), 93. - 1850. Masos, J. - "The addition by the defendant of the words, "1:3 Chambers street,' heneath his indorsement. comlel have no other meaning than a direction as to the place where notice should be sent in case of the dishonor of the notre and the notice put in the postoflice addressed to him, als was the notice in this case, to No. 1:3 Chambers street, was given strictly in compliance with his directions."

\$179 Bantefte 2 . Romisson, 39 Now York, 18\% - 1868. WoonRUFF, J. - "As well when the parties do not reside in the same rity or town as when (accordiner to our statuto) they do, or in short whenever notier is sent by mail or deposited in the post-office, the notice must he directerl to the indorear. not only at the rity or town, but to the specific place designalor be llw underwriting. * * * I think * * that the words "directed to the indorser at such city 


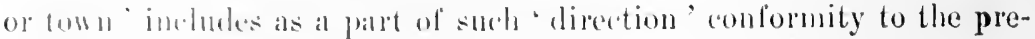
soription whill the sperial indorsenent imports." |llence, a notice alllessul to "A. D., city of New York," is not sufficient where the inclorsement is "A. B., $\because 1+$ F. 1sth st."].

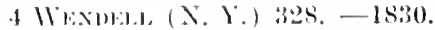

Actor against indorerer. Virdict for defendant.

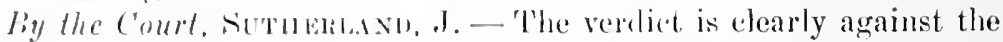
weight of evidence. ('harles $\Lambda$. ('ook, the cashier and notary of the bank, testified that he regularly protested the note on the day it beame due, and sont notice thereof on the same day to the delendant, rireeted to him at cierdesburgh, and put the notice in the postoflice at (ienera. Ihe did not recollect whether he put the comnty on the notier of protest. hut it was his eustom to do so.

It was shown, on the part of the defendant, that the legal name of the post-ollice near which the defent: ' resided was Geddes, not Gedheshurgh: hut all the witnesses concurred in stating that it was known as well by the one name as the other, and that at least half the people called it Gedleshurgh ; and Mr. Fark, the postmaster at Onondaga IIill, within a l'ow miles of Cieddes, testified that until lately he supposed the name of the post-office was Geddeshurgh, and if a letter was put in his ollice directed to Geddeshurgh, he should forward it to Gedkles. Io further stated that there was no postoflice, either in this state or in the United States, of the name of Geddesbnrsh. John Wrikinson, the postmaster at Syracuse, testified that packiares in the mails wre as frequnently directed to Geddeshmegh as cieddes, except from the large offices. Upon this testimony there can be no question, if the notice was clirected to Gedlesburgh without the name of the rounty, that it was sent to Geoldes. But the fair intendnent from the testimony of the notary is, that the name of the comnty was also part of the superendiption. It was his: general anstom so to dirend his motices, and no circumstance is stated to indure the leclief that he departed from it in this

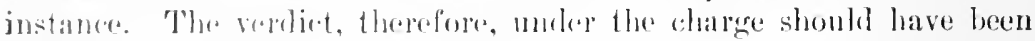
for the platintill.

The judge fereidnd. as a question of law, that the notice was good, if it was sent to the fiodrles or fieddeshurgh post-office. It was properly assumed as a cumestion of law, and the opinion of the judre was corrert.

The evidenee shows that although the drefondant rosided a mile

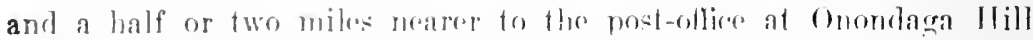

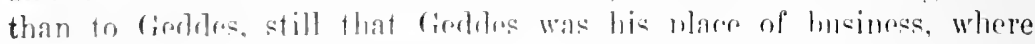
he arried on thre mambiaturing of salt and the slaughtering and 
packing of beef; that he received letters at both offices. More letters for him individually were received through the oflice at Onondaga C. H. than at Geddes; but all the company letters were directed to the latter oflice. The defendant or his sons were in the habit of ealling for letters at the Geddes ollice, and he liept a postage account there.

Under such circumstances, notice directed to either ollice would be good. It is not indispensalble that the notice should be sent to the oflice nearest to the residence of the party, nor even to the town in which he resides. It is sntirient if it he sent to the oflice to which he usually resorts for his letters, and where he would probuhly receive it as soon as at the oflice nearer to him. (Reid r. l'ayne, 16 Johns. R. 218; 1 Peters, 5\%s: 10 Johns. R. $411 ; 11$ Id. 190.) When a party has a dwelling honse and counting room, of other place of business in the same place or town, notice sent to rilher is sullicient. (Bank of Columbia $v$. Laurence, 1 Peters, 5is?, sisi) : and it eamot be material whether the residenes of the pally and his phace of business be in the same town or not, if it apprals that he is in the daily or constant halit of recoiving letters at both wares. The notice, therefore, was suflicient, and the defendant was legally charged.

It has been decided ly this cont that dedurtingr interest by way of discount at the rate of seven per cent., upon commercial or husiness paper, is not usurious. (Janhallan C'ompany v. Os:youd, 15 Johns. R. 168; Bank of Ulica v. Wager, ? C'owen, r6fi, rfiz: Bank of Utica v. Phillips, 3 Wendell, 40S. Sore, also, Flerliner v. The Bank of

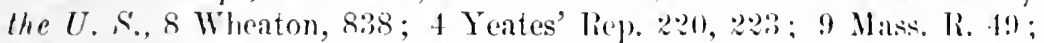
3 Bos. \& Pul. 154.)

A new trial must be granted, on the ground that the vereliet is against evidence. ${ }^{9}$

IOGET, r. STIARR.

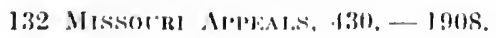

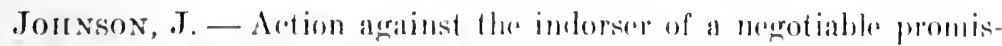

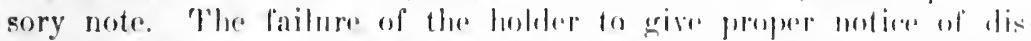

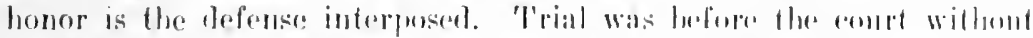

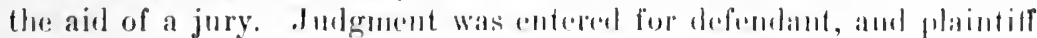
apporalierl.

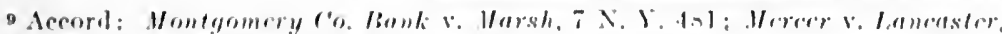

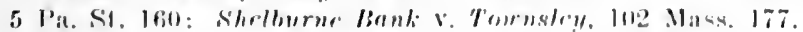

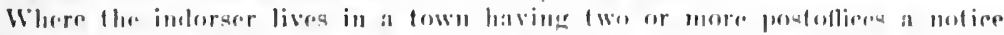

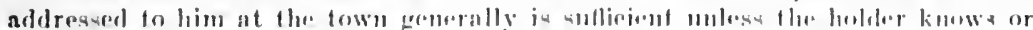

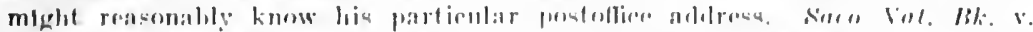

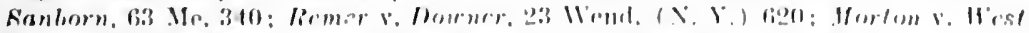

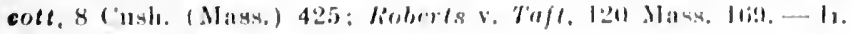


The note in question is as follows: “\$15. Trenton, Mo., Oet. 7, 1895. One year after date, 1 promise to pay to the order of $\mathbf{O}$. $\mathbf{J}$. Starr, forty-five dollars, for vahu received with interest at the rate of eight per cent. per annum from date, until paid, and if not paicl ammully, the same to heeome a part of the prineipal and bear the same rate of interest as the principal debt. Payable at the First National Bank, Trenton, Mo. C. Millard."

A few days after the execution of the note, and long before its maturity, Starr, the payee, sold it to plaintiff for value, and indorsed it in blank. Later plaintiff deposited it with the Trenton National Bank for collection. On the last day of grace, October 10, 1896, and within proper hours, the hank handed the note to a notary public for demand and protest. Millard, the maker, had moved to Wisconsin, and Starr, the indorser, lived in the country about 12 miles from Trenton. The notary testified: ${ }^{10}$ “* * * $M_{y}$ impression is that in regard to Mr. Starr's address the bank's best information; that is, they told me they were not certain about it. That's the way I remember it; that it was Spickards, Mo. And I took the note. It was payable at the First National Bank, Trenton, Mo., and I took this note to the building that had been oceupied by the First National Bank. The First National Bank at that time had gone into liquidation in connection with the old Grundy County National Bank. It had its first banking room at the five corners; and the First National and the old Grundy County National consolidated and liquidated through the Trenton National Bank. *** This protest shows that I took it to that building and presented it there, and found no one there to pay the note. And, after that, ont of an abundance of precaution, I went over to the Citizens' State Bank, which was diagonally aeross the street from the building formerly occupied by the First National, and I presented the note there, to the caslicer of that hank, as the protest shows, and demanded payment there. I think Walter P. Fulkerson was eashier at that time, and there was nobody there that would pay the note; so from there I went to the Trenton National, or might be probable I made the demand there before I went to the other place, at any rate, I presented the note as the protest shows to the caslier of the Trenton National Bank, Mr. R. M. Cook, and demanded payment of the note. Ti. M. Cook had already heen the eashier of the First Tational Bank, at which this note was payable, and he was winding up the atfairs of the old First National at the time, and also cashier of the Trenton Tational. Then I made inquiry as to where Mr. Starr lived, and marle a diligent seareh, as I thought. * * They thought Mr. Starr lived near or got his mail at Spickards, Mo., and so I made some other inquiries as to where 
Starr lived, at the banks, Mr. Cook and the Citizens' Bank also, and I wouldn't say positively as to who else I did inquire of $*^{*} *$ I mailed the notice to Starr at Spickards, Mo. * * * "

Starr did not receive the notice until some three months after it was mailed, for the reason that Tindall, and not Spickards, was his post-office. The farm he occupied as a tenant was abont one mile nearer Spickards than Tindall, either by wagon road or as the crow flies, and Spickards, though a small town, was much larger than Tindall. But Starr had made the latter place his post-office address while living on a farm nearer to it than to Spickards, and continued to get his mail there. No doubt is suggested in the evidence of the good faith of the notary and of plaintiff's collection agent in mailing the notice to Starr's nearest post-office, nor do we find anything indicative of bad faith on the part of plaintiff, the owner of the note. He was not in Trenton on the date of the protest, nor had he imparted to his collection agent the information he possessed respecting Starr's post-office address. Had he done this, we perceive nothing in the facts known to him to support the conclusion that his collection agent and the notary might have acted differently. The farm where plaintiff lived was, perhaps, two miles from that oceupied by Starr. While the note was maturing, they met occasionally and casually on the public road, at Tindall, or at a neighborhood church, but plaintiff did not know that Starr receired his mail at Tindall, and it appears that he and Starr were acquainted only slightly.

While it is true that the holder of commercial paper for collection must be regarded as a separate and independent holder for the purposes of presentment, demand, protest, and notice of dishonor (Renshaw v. Triplett, 23 Mo. 213; Griffith v. Assmann, 48 Mo. 66; Irory v. Bank, 36 Mo. 475; Bank v. Briedow, 31 Mo. 523; Young v. IIudson, $99 \mathrm{Mo}$. 102), we are willing to concede for argument that it was the duty of plaintiff to communicate to his collection agent the facts in his knowledge relating to the post-office arddress of the indorser, but we do not sanction the contention that he was chargecl by law with the further duty either to notify the indorser personally of the dishonor of the note or to make inquiries in the neighborhool to ascertain the place where the indorser received his mail. 'The note, by its terms, being payable at Trenton, it was very natural that plaintiff should employ an agent at that plice to look after its collection, and that he should rely on his agent to take the necessary steps to hold the indorser. We are going far enough when we assume that it was his duty to enmmunirate to his agent the knowledge of facts material to the suhjeet of the employment he harl or might acquire during the course of the employment. It was not his duty to perform personally the very duties he had delegated to his acent. When a person employs an agent to do a thing, he should not be held to be remiss for relying on his agent and only may be 
heth liable for the negligent or wrongful acts of the agent in the performanee of the delesated duly under the principle that what one does be the hand of another he does himself.

luputing to the colvertion agent ant the notary knowledge of the farcts known to plaintitl, our chict concern is with the question of whether the notary exereised reasonable diligence in the giving of notien to the indorser. Since we tind in the record no controversy orer material facts, the question is one of law, not of fact. $\Lambda$ s early as the ease of linville v. Weteh, 2!) Mo. 20.3, it was deeided by the silpreme court that what is due diligence in giving notice of dishonor of a bill of exchange is a question of law when the facts are undisputed, and, when they are in dispute, the court should give hypothetical instructions, leaving the facts to be determined by the jury. sanderson's .1dmir r. Reinstadler, 31 Mo. 483; Fugitt v. Nixon, 4 Mo. :295.

Considering the case, then, from the standpoint presented by the facts known to plainfiff, knowledge of which we aseribe to the notary, and by the facts acrguired by the notary from his own inquiries, and treating the fuestion of due diligence as a question of law, we next turn to consider the principles and rules by which the holder of a bill of exchange must be controller in giving to an indorser notice of dishonor. 'The liability of the indorer is conditioned upon the existence of two facts, viz: (1) That the maker has made default in the raymens of the bill at maturity: (2) that due notice of that fact be given the indorser. As to what will constitute sufficient notice, it is well settled that personal service of the notice is not required. Constructive service will sulfice if reasonable diligence he exereised to make it in the manner best allapted to convey actual notice. "Where the party to he served is a resiclent of the city or town where the protest is made, the course repuired is to give him personal notice or to leave it at his dwelling or place of husiness. But if he lives in the country, then a notice by mail to his postoffice will he sufficient." Rarrell $v$. Erans, 28 Mo. 331; Sanderson's Adm'r v. Reinstadler, supra. When the indoreer lives in the rountry and his postotlice address is not known to the bolder. it is the duty of the latfer to make reasonalile inquiries in the fown or eity where the bill is payable, and, in default of more spereifie information, to address the notice to the postoffice nearest the residenere of the indoreer. But the holder is not justified, in all cases, in sending the notice to the nearest postoflice. He must act in good faith always and with reasonalle diligence to learn the place where the indorser receives his mail, and, learning it, must send the notice there, regardless of whether it he the nearest postoffice.

With these principles hefore us, we do not hesitate to declare as a matter of law that the notary, whose good faith is not questioned, exerciserd reasonable diligence and arterl on the information he received in a way which would have commended itself to any reasonably careful 
and prudent person in his situation. IIe made inquiries of several persons, all of whom appeared to possess some information on the subject, and all expressed the belief that spickards was the proper address of the indorser. Taking these opinions, in connection with the facts that Spickards was the nearest town to the indorser's farm and was a much larger plat than Tindall, we think any person in the situation of the notary woukl have come to the conclusion, as he dir, that the notice should be sent there. Finding, as we do, that the notary ateted properly, it is immaterial that the indorser failed to receive the notice within a reasonable time. That was his misfortune, for which, in a sense, he was responsible. He was justified in standing strictly on his right to legal notice, but presumably lie knew of the lact of the maturing of the note, and from all the circumstances must have anticiputml that notice of dishonor likely would be addressed to him at spickards. 'T!he notice was sufficient.

The case was not tried in accordance with the views expressonl, and it follows that the judgnent must be reversed and the cause remanded. All concur.

14 Missouri APlists, 152. - 1883.

Acros against maker and indorser. Indorser sets up a want of notice. The indorser (Frost) had a general residence or domicil in St. Louis and a general pline of business in St. Lomis, but his fomily were sojourning at Selma, Mo., a place without a postoflice, while he was sojourning at Washington, as a member of congress. Notiens were mailed to him, addressed to St. Lonis, Washington aml Solma, respectively. Jurlement for plaintifr.

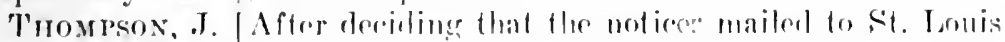
were insufficiont berable holder and indorses both residerl in sit. lonis.]

We are of opinion that the general notieresent hy mail and andresesed

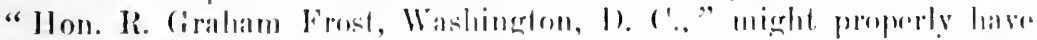

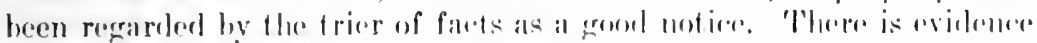
tending to show that, lwe fore the motary sent this motien. he went to the

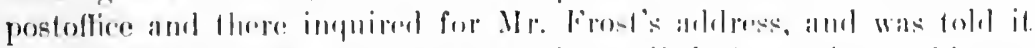
was Wiashington, I). ('., wherempon lwe mated the notiere to him as stated.

This was on the 2:in of Derember, 18so. 'The Congeress was then in regular session, but it had, on the ding previons, falken the usmal holiday recess, as was shown by a ropy of the Compressional limorol

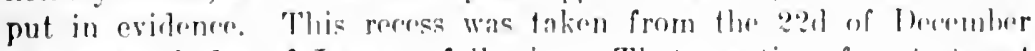
until the 5th day of January following. That a notice of protest sent 
by mail to a member of Congress while engaged in discharging his

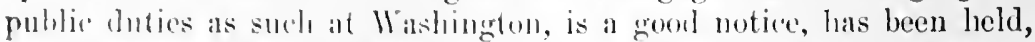
both in Massachusetts and Mississippi. (Choulene V. Mebster, 6 Mete. 1; Tunstall v. Walker, ? Smenl. it. II. 6.38.) In the former of these cases, Maniel Wobster, a senator from Massachusets, was, when the notice of protest was sont to him ly mail, at Washington, D. C., attending a sperial session of ('ongress at Washington, and he hall at Boston, just as .1/r. Frost had at St. Louis, a place of husiness and an agent to atrend to his husiness: and yet the court, Chicf . Iustice Shaw delisering the opinion. held that the notice thus mailed to him was a good notice.

'The fact that ('ongress had taken this temporary recess may not have been known to the motary, and, if known, it would not necessarily indieate to him that Mr. Frost would he alsent from the eapital cluring smele recess. If it slould indicate this it wouk not impair the legal suttirenency of the notice : becanse the controlling rule is that where the intorser has diflerent residences and different places of business, the notice must be sent to the plare, where, upon diligent inguiry, it seems most likely to reach him with critainty and promptness. (Cabot Bank v. Russell, I Gray, 169, 1io, per Shaw, C. J.)

Nor can the circumstance that the indorser was in the habit of rereiving his mail, not at the gencral postoffice in Washington, but at a spreial postoflice in the capital huilding, impair the legal sufficiency of 1 lis notice. unlese this fact were linown to the notary or would have leen disclosed to him unon reasonalile inquiry. That he did not know this appears from the evidenee. and that it was not disclosed to him i.mon the inquiry which be mate at the postoffice in St. Louis also sulliciently appears. It seems that this postoflice was the most proper place at which to make such an invuiry, for it must be supposed from the nature of Mr. Frost's pullie duties at the time that numerous letters were constantly reecived at the St. Lonis postolfice for transmission to him at his official residence at Washington. At all events, it rannot be said that this testimony was not sufficient to take the case to the trier of the fact upon the question of diligence. It has been helel several time, that where there are two or more postoffices in the town whre the inderes resides, a notice sent by mail to the town generally will be a gond notiee, mulese a reasonal, le inquiry would have disclosed to the holler or the motary the actual postoffice at which the indorser commonly receivel his mill. (Burlingame v. Foster, 128 Mass. 125; Morton $x$. Westcoll, \& C'ush. 425; Cabol Bank v. Russell, 4 Gray, 16\%.)

The "towns" here spoken of are not rities or villages, but New England towns, which corresement to townshipe in Missouri and Illinois, each of which frequently entains several villages and several postoffices. 
[The learned judge then holds that notice addressed to Selma was good, in riew of the evidence that mail addressed to Selma was regularly sent to Crystal City, the postoflice nearest Selma. ${ }^{1}$

Judgment affirmed. ${ }^{2}$

III. When delay in giving notice excused.

$\S 184$

JAMES $r$. WADE.

21 Louisiana Anvual, 548, - 1869 .

Howe, J. - The defendant is sued as the indorser of a bill of exchange drawn by $\mathbb{W}$. R. Hughes on Moore and Browder, of New Orleans, and by the latter accepted, payable on the fifteenth February, 1863 .

On the day of its maturity the bill was protested by a notary in New Orleans, and a notice deposited in the postoffice in that city addressed to the defendant, at Winnfield, parisl of Winn, Louisiana.

The record shows that in February, 1863, all postal and commercial intercourse was suspended between New Orleans and Winnfield. The war was then raging, and the deposit of the notice in the postoffice in New Orleans had no effect in converting the conditional obligation of the indorser into an absolute liability. (19 A. 43, 63, 64, 72, 90; 20 A. 399.)

If the holders of this bill desired to bind the indorser, it was their duty to have given him notice of dishonor within a reasonable time after the close of the war, and the resumption of commercial intercourse. There being no evidence that any notice except the one deseribed above was ever given, the indorser must be held to have been discharged.

Judgment aflirmed.?

\section{§ 184 UNION NATIONAL BANK $v$ MARR'S ADMINTSTPRATOR. 6 Busu (K. 6.) 614. - 1869 .}

ACTion againet drawer of a bill drawn in Missouri upon a drawee in New Orleans and presented July 17, |861, and dishonored. Julguent for defendant.

Junge Harmon delivered the opinion of the court.

I See Bonk v. Houmlett, a Wiend. 328, ante, p. 566, - II.

2 Acerd: Graham v. Sangston, I Na. 59. But if the indorser simply viuita a place for a purpose clearly temporary ame sperial, he is not "sojourning" within the rule of the ahove cases. Waller v. Stetson. 14 Oh. St. 89. - II.

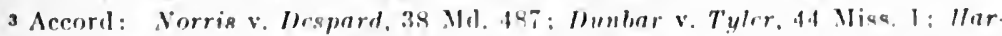

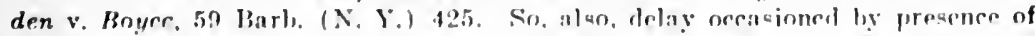
malignant disease. Tunno v. Lagur. 2 .Johns. ('as. (N. Y.) 1. - II. 
This was an ordinary action by the appellant, as the holder of a bill of exchange for $\$ 1,26: 50$, dated at ('harkeston, 3 issouri, the 10th day of Jume, 1s61, drawn by L'. N. Marr upon simumel Y. 'Thomas, New Orleans, Louisiana, payahle to the order of thomas Allen, and indorsen by him and Shelly sheeks.

It appears that the bill was presented for acceptance in New Orleans on the 1rth day of July, 1s6it, and thereupon protested for nonacceptanee of which notices addressed to the parties were mailed by the notary to the agrents of the plaintiff, hut it does not appear they were legally forwarded to the defendants, who in their defense denied that due notice of said protest was given, and elaimed exoneration on that gromd.

The prineiple is well settled, that, although the holder of a bill of exchange, payable at a given time, is not bound to present it to the drawee for acceptance until it becomes due; yet if he does so, and the bill is dishonored, he is bound to give due notice of the fact to the parties whom he intends to hold bound. (Landrum v. Trowbridge, 2 Met. 281; Story on Bills, $\$ \S 227-228-284$.$) But the appellant ques-$ tions the correctness of the judgment dismissing the petition, on a trial of the ease by the court, mainly on the ground that at the tine of said protest the civil war had become flagrant, and so suspended commercial intereourse between the hostile sections of the comitry as to dispense with the necessity of notice of protest to lind the drawer and indorsers of said bill; and especially so as the bill was not protested till after the passage of the act of Congress of the 13th of July, 1861, authorizing the President to issue his proclamation interdicting eommereial intercourse between the citizens of certain belligerent states, although the proclamation was not issued till the 16th of August, 1861 , near one month after the bill was protested.

But this ease must be ruled by the (ase of Leathers v. The Commercial Insurance Co. (2 Bush, 296), in which, upon a careful consideration of the subject, this court, referring to the proclamation of the 16th of August, 1861, as public notice of the congressional recognition of a state of war, helil that "bofore that time contracts and other acts of commercial interourse were not made illegal by the war."

Notwithstanding the disturbed condition of the country, which we know jurlicially to have existed when the lill was protested, it does not appear that there was at that time such obstruction of inter-communication between the southern and horter states as to prevent the transmission and delivery of notice of the dishonor of said bill.

Wherefore, it not appearing to have been either illegal or morally or physically impossible to give notice of said protest, the judgment is affirmed. ${ }^{4}$

\footnotetext{
- See criticism of this doctrine in 2 Daniel on Neg. Inst., $\$ 1062 .-\mathrm{H}$.
} 


\title{
IV. When notice may be dispensed with. ${ }^{5}$
}

\section{When Nótice Need Nót Be Gives to Drawar.}

\section{$\S 185$}

\author{
GOWAN $v$. JAC'RSON. \\ 20 Johxsox (N. Y.) 176. - 1 se2.
}

A tron against drawer of hill drawn on Jackson and Brothers. 'Theie was no notice of dishonor, but to excuse this plaintiff offered to prove that defendant was a member of the firm on which the bill was drawn, and was allowed to do so. Judgment for plaintiff.

Srexcer, Ch. J. *** Considering it, then, as established, that the partnership existed when the bill was drawn and presented, the question arises, whether notice of non-acceptance was required to tie given to the defendant. It was proved that the hill was presented for payment on the 16itl of January, 1818, and was then protested for non-aceptanee; and it was presented on the 16ith of April, 1sis. ferr payment, and protested. In the alsence of all other proof. the hill must be considered as drawn by one partner of the firm, on the firm itself, in relation to the partnership business: and, if so, then a kuowledge by ne of the firm of the dishonor of the litl, is, in point of law, knowledge by the whole firm. Daniel Jackson, the partner in Iondon, had notice that the bill was refused areeptance and pavment, for ise was the person who thus refusul. In l'orllowse v. Parlier and others (1 Camp. N. l'. S2), Lord Ellenboromerh held, that where a hill hat been areepted hy one of the defombants, this was sulfirient evidence of its having heen regularly drawn: and that. the aceeptor leeiner likewise a drawer, there woulel he no oreasion for the plaintift to frove, that the defendants had received express notice of the dishonor of the hill, as this must neressarily hase lexen known to one of them, and the knowledge of one was the knowlerlene of all. This is a rerye just and reason-

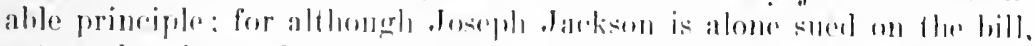

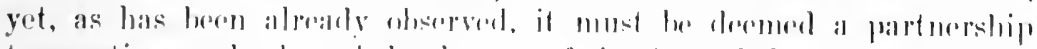

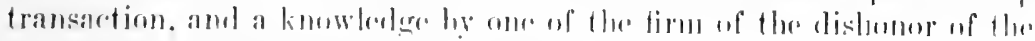
hill was all that omght to lare perpuirul.

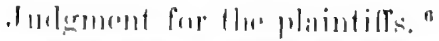

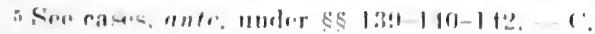

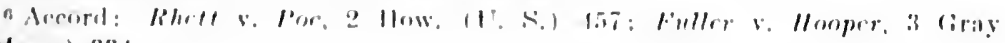

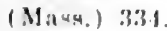

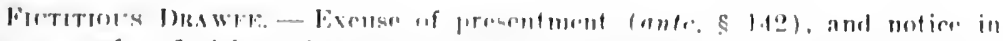

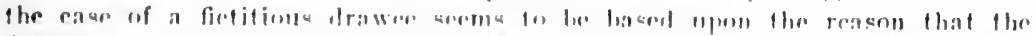
drawer mat know that the drawere is fictiliolla and. Hherofore, that the hill can

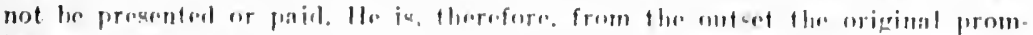

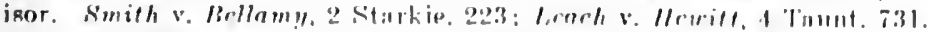

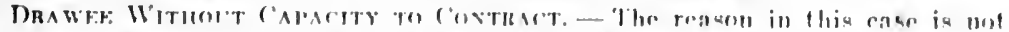

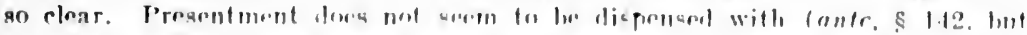

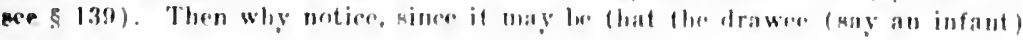




\section{CA'THELL $\because$ GOODWIN.}

1 HARRIS \& GILl, (MU.) 468. - 1827.

Aстіох by payee against drawer of bill of exchange. No notice of dishouor. Judgment for defendant.

Dorsty, I. * * * 'The third position was that most obstinately contended for, which was conceived to be inpregnably fortified by that part of the rule established in Eichelberger v. Finley and Van Lear (i Ilarr. \& Johns. 381), which dispenses with notice only where the drawer had no reasonable grounds to expect that his bill would be honored. 'The reasonableness of suel expectation is matter for the court, and uot for the jury, to decide. If the facts, upon which the question arises, be admitted or be undeniable, then the question becomes exelusively a matter of law to be pronounced by the eourt; but if the faets be controverted, or the proof he equivocal or contradictory, then it becomes a mixed question hoth of law and fact, in which case, the court hypothetically instruet the jury as to the law, to be by them pronounced accordingly as they may find the facts. What are the facts to be found in this case juistifying the drawer's expectation that his draft would have been paid? So far from having funds in the drawee's hands, he was his rlebtor - no proof of such a commercial intercourse between them as would imply a mutual eredit - no previous promise by the drawee to accept this or any other draft for the drawer's accommodation - no consignment of goods to the drawee, which the drawer had any reason to expect would be received in time to meet his bill, but the only proof is, that the drawee informed the payee that he expected funds of the drawer would shortly come to his hands, with which, when received, he would pay. That funds afterwards did arrive, but whether in one month, or five years after, does not appear. What may have been the expectations of the drawee, as to the receipt of funds from the drawer, is immaterial; they are not even admissible evidence in this cause. But if they were, they can have no influence on those of the drawer - into whose expectations only is the inquiry to he made. 'The facts in the ease of Logge v. Thorpe (12 East, 170), and Claridge v. Dallon ( 1 Maule \& Selw. 226), afford much stronger evidence of a reasonable expectation in the drawers that their bills

will honor and pay the hill? Sep the reasoning in Wyman v. Adams, 12 Cush. (Mass.) 210, which, howevrr, was a case of indorsement. See post, \$186.

PRESENTMEXT TO DRAWFR. - This elause seems to cover the case where the drawer is, hefore the presentment, appointed the executor or trustec of the drawee's pstate, and presentment is, therefore, marle to him in his representative capacity. Actual knowledge here is, therefore, equivalent to notice. Caunt v. Thompson, 7 C. B. 400 . Put presentment must, to insure this result, be made to him in his representative capacity. Magruder v. Bank, 3 'et. (U. S.) 87. And, it seems, to him personally. Groth v. Gyger, $31 \mathrm{~Pa}$, St. 27I, See post, ร 186. - H. 
would be honored, than those in the present case; yet there they were adjudged insufficient. The "reasonable grounds" required by law are not such as would excite an idle hope, a wild expectation, or a remote probability, that the bill might be honored, but such as create a full expectation, a strong probability of its payment; such indeed as would induce a merehant of eommon prudence and ordinary regard for his commercial eredit, to draw a like bill. 'The facts in this case constitute no such reasonable grounds. We therefore think that the County Court erred in instructing the jury that the plaintiff was not entitled to reeover, and consequently reverse their judgment.

Judgment reversed, and precedendo awarded. ${ }^{7}$

\section{When Notice Need Not Be Given to Indorser.}

90 Grongia, 674. - 1892.

Action by one indorser against a joint indorser for eontribution. Defense, want of notice and protest.

Notes were made by the Augusta Athletic Association and indorsed by plaintiff, defendant, and others, being a majority of the directors of the association. At maturity, the association was insolvent.

Bleckley, C'mef Justice. - Ciood sense, good morality, and good law are one and the same so long as they are not sundered violently by legislation or ignorantly by judieial error. Their unity and identity, so far as ane of the questions in this case is concerned, we find still intact. 'There is no statute to drive, neither is there any precedent to lear, derision into ahsurdity or injustice. We can and do hold that aecommoration indorsers who represent their insolvent principal in procuring a loan of money for the principal's use, upon a promisisory note which they cause to be made in his name and which they indorse in their own names, they laving at the time full control of his lusiness and all his asseds, and their rolation to him hoing such as to malie it their duty to sue that the unte is provided for and paid at maturity. are not entitled to notice of its dishonor. Nay lwe they do not stand in his shoes; if they do mot, it is beranse they arre his shomentakers and hase suffered him to berome ausl remain harefooted. Though the doht is his and not their own, primarily, put. having all his assets and full power

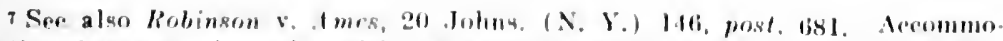
Jation drawers, who wnite with the areommodaterl party in drawilly the bill, are entitied to notien if they has resane to beliese that the latter would pro. vide funda to meet the bill. Miser v. Trovinger's Exerutors. 7 Oh, Nt. $281 .-11$.

[Sire extract from Wiest Branch liank $v$. Haincs, 135 lowa, 313, in note 8 , intc, p. 522 . - C.1

NEROT, INBTHUMENTB -37 
over them, and over all his business, they are bonnd to know all that he wonlel be bound to know were his husiness and assets in his own hands and under his own manarement. In this instance the principal being a corporation, and the indorsers the corporate directors, the latter could have no right or reason to expect that funds would be provided for liepuidating the doht muless it was done by their procurement or thromerh theip asency. 'I'he chater of the "Augusta Athletic Association" is not before 11, and in its absence we must take it for granted that the dirextors of that compolation had the powers and were under the duties which appertain to corporate directors according to the genral rules of law. Siperial provisions in the charter might vary these powers and duties in the given instance, hut such provisions would, in order to gain recosnition, have to be brought to the attention of the court. The usual rule is that all the assets and operations of a corporate husiness are muler the govermment and control of the direetors. A single director, or eren a minority of the directors, indorsing a note for the corporation, mirrlit be entitled to notice of dishonor; for one only, or a small number, mirht have a right to suppose that the note would be attended to at maturity; lut when the whole board, or a majority of its memhers, mite in the indorsement, each and all so indorsing should be rluared with the duty and responsibility of protecting the paper, since the power to control the concluet of the corporation in respect to paying or not paying would be in their own hands. On the ruestion of notice, the present ase is fairly and fully within the principle of Cormey v. Da Costa (1 Espinasse, 302), in which it was held that where the indorsor of the notes of an insolvent jerson took effects of the insolvent to the full amount of his indorsement, he could not avail himself of the want of notice of nonpayment of the notes at maturity. The facts of the case are meagerly stated in the report, but they indicate that the indorser took the maker's effects, not merely to hold them for his protection, lut for use in raising funds with whirh to discharge the indorsed paper. He was treated as if he were primarily liable and the deht were his own. Following the reason and syirit of that decision, these directors onght to be treated in the same way. ${ }^{8}$

With respect to the want of protest, it is true that the letter of the Corle, $\$ 2781$, makrs protest noressary in order to hind indorsers upon any hill or promissory note payable at a bank, thus, in effect, putting all such palyor on the footing of foreign bills of exchange as to this commercial solemnity. Put the reyuirement as to protest was not. we think, intronded to be more comprehensive than the requirement as to notier. ${ }^{9} * * *$

B Contra: Phipps v. Harding, 70 Fed. Rep. 468. - H.

- Protest not necessary where notice dispensed with. Legge v. Thorpe, 12 East, 171. - H. 
[The court then holds that the action is barred by the statute of linitations, being for money paid to the defendant's use and not founded directly on the notes.]'

\section{$\$ 186$ AMERICAN NATIONAL BANK $v$. JUNK BROS. 94 '1 ExNESSEE, 624. - 1894.}

Beard, J. - This suit was instituted against the Junk Bros. Iumber and Manufacturing ('o., a corporation with its situs in Nashville, as the indorser for value of certain domestie negotiable notes. The lefendant resisted recovery on the ground that notice of dishonor of the paper was not given as the law requires. A decree having been pronounced against the corporation, it has filed the record in this court, and the action of the court below in overruling this defense is assigned as prror.

Before coming to the general question raised by the assignments, it is proper to dispose of five of these notes, which are shown by the proof to have heen male for the accommodation of this corporation and afterwards indorsed by it to the complainant. As to these notes, their makers stood in the sitnation of sureties to the indorser, and it was the latter's duty to provide funds to meet them at maturity, and it was, therefore, hound to the holder without presentment, protest, or notire. (? Am. \& Encr. Ency. of Law, 399; 2 Daniel on Neg. Inst.. S 1085: 3 Randolph on Com. Paper, s 1205; Black v. Fizer, 10 Hois. 4h.) Thus disposing of those five notes, the question reenrs as to the liability of the defendant as indorser of the remaining thirty-five.

['The court then lobles that as to these, notice addressed to the company and recejoed by its assignere for the benefit of reditors is sulfirient, and that notice addressed to the assignee is equally sulfi(ient. ${ }^{2}$

\section{Julgument aflirmedl. ${ }^{3}$}

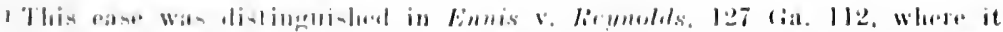

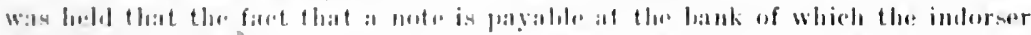

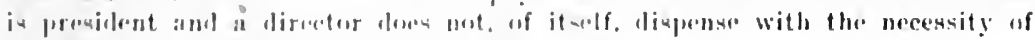

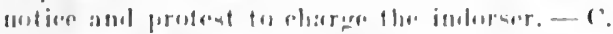

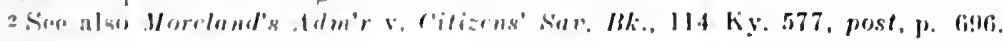
- 1 .

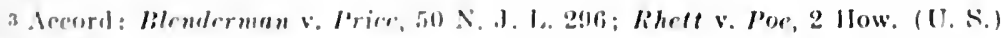
$45 \%$. -11 .

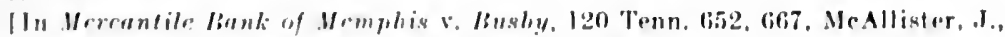

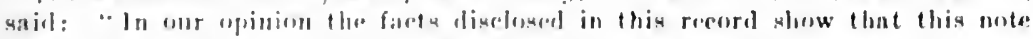

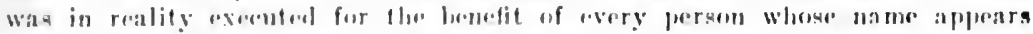

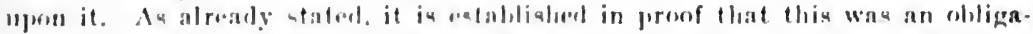

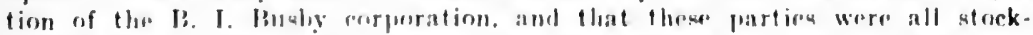
holders and directors, and that the note was executed for the purpose of re- 


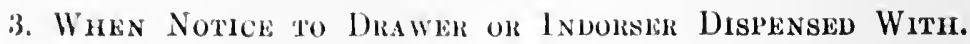

(a) Due diligence.

\$ 183 Raxsom $t$. Mack, ¿ Hill (N. Y.), 587, 592.-(1842). By the Court, Brosson, I. - T'be next inquiry is, whether the difendant was discharged in consequence of the misdirection of the notice. It was sent to North Adams, when it should have been sent to the Appling oftice. 'l'he defendant's place of residence not being known. the notary made inquiry of Robbins, the second indorser, who professed to be able to give the necessary information, and was interested to speak truly. The answer of Robbins was, that the notice should be sent to North Adams - that being the office where the defendant got lis letters and papers. Although Robbins was mistaken, the notary was well warranted in acting upon information thus obtained, without pushing his inquiries further. There was due diligence, and that is enough. (Bank of Utica v. Bender, 21 Wend. 643.) That case was affirmed on error bronght in June, $18+1$. Drawers and indorsers can easily prevent mistakes of this kind, by writing under their names their places of residence or the place where they desire notice should be sent in case the bill or note is protested. ${ }^{4}$

(b) Waiver.

$\S 180$

GOVE $v$. VINING.

\section{Metcalf (Mass.) 212. -1843.}

Action against indorser. Defense, want of demand and notice. The indorser, shortly before maturity, requested the lolder not to sue the note until the maker saw the holder.

SHAw, C. J. * * * The court are of opjinion that when the indorser, at or shortly before the time when the note becomes due, says to the holder, that an arrangement for its payment is about being made, and in direct terms, or by reasonable implication, requests the holder to wait or give time, it amounts to an assurance that the note will be paid - that the promisor or indorser will pay

newing an outstanding indehtedness of the corporation. . . . Our conclusion on this branch of the case is that C. B. Blacklurn was not entitled to notice of dishonor, since lie was a joint maker and equally interested in the note with his co-makers and indorsers." - C.]

4 Aceord: Lambert v. Ghiselin. 9 How. (U. S.) 552; Central N. B. v. Adams, 11 S. Car. 452. Merely consulting a directory is not due diligence. Bacon v. Hanna, 137 N. Y. 379 . Nor casual inquiries. Sipencer v. Bank, 3 Hill (N. Y.) 520. See 2 Daniel on Neg. Inst., §§ 1114-1123. - H. 
it - and is a waiver of demand and notice. It tends to put the holder off his guard, and induces him to forego making a demand at the proper time and place; and it would be contrary to good faith, to set up such want of demand and notice - caused perhaps by such forbearance - as a ground of defense. (Leffingwell v. White, 1 Johns. Cas. 99 ; Mechanics' Bank v. Griswold, 7 Wend. 165; Leonard v. Gary, 10 Wend. 504: Taunton Bank v. Richardson, 5 Pick. 436; Thornton v. Wynn, 12 Wheat. 183; Wood v. Brown, I Stark. R. ?17.) Judgment for the plaintiffs. ${ }^{5}$

5 A waiver in the instrument itself binds all subsequent indorsers. Phillips v. Dippo, 93 Iowa, 35. It is not therefore a material alteration in such a case to write above the indorser's name, "l'ayment guarantied." Iowa Valley state Bank v. Sigstal, 96 Iowa, $4 ! 91$.

Parol Waiver at Time of INdorsemext. - In some jurisdictions it is held that a parol waiver made at the time of the indorsement may be shou'n on the theory that such evidence does not vary the terms of the written contract but establishes the waiver of a condition otherwise imported into the contract by the rules of the law merchant. Sehmird v. Frank, 86 Ind. 250 ; Lane v. Stevard, 20 Me. $98 ;$ Dye v. Scott, 35 Oh. St. 194; Annville Nat. Bk. v. Kettering, 106 Pa. St. 531. In other jurisdictions it is held that such evidence does vary the terms of the written contract, and is therefore inadmissible. Goldman v. Danis. 23 Cal. 256; Farwell v. St. Paui Trust Co., 45 Minn. 495; Rodney v. Wilson, 67 Mo. 123; Beeler v. Frost, 70 Mo. 185; Bank v. Smith, 47 Barb. (N. Y.L 48. Some jurisdictions now provide by statute that all waivers must be in writing. Maine R. S., c. $32, \S 10$.

A parol waiver, subserquent to the time of the indorsement, is (independent of statute) good. Marliland v. If chaniel, 5] Kans. 350; Rodney v. Wilson, 67 Mo. 123; 2 Daniel on Nog. Inst., \& 1098.

A promise to pay the instrument, made by an indorser after maturity and after he is discharged for want of demand or notice, is, in analogy with the promise to pity a debt barred ly the statute of limitntions, held to be binding. Ross v. Hurd, 71 N. Y. 14: Rindlye v. Kimball, 12.1 Mass. 20!) Brerel v. Ilill.

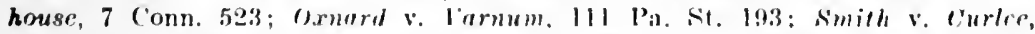
59 111. 221; Persons \&. Dickinson, 23 Mish. 5ti. Contra: sebree lleprosit Bonk

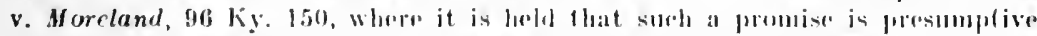
evidenee that demand and netice were had, but that the prosumplion may he rebutted.

In order that the indorsir may be bround by such suloserpunt promise ho

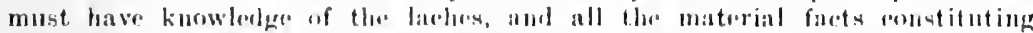

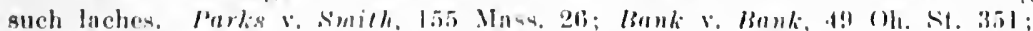

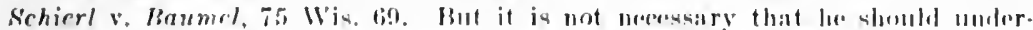

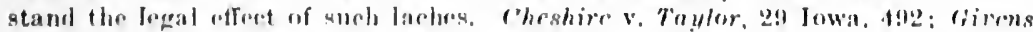

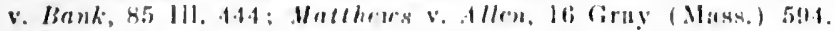

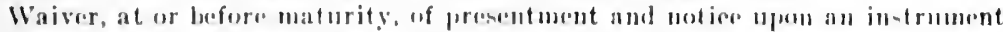

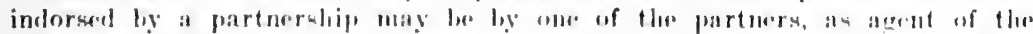

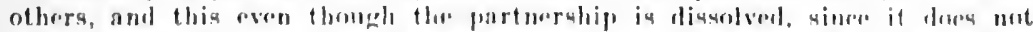

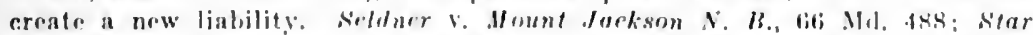

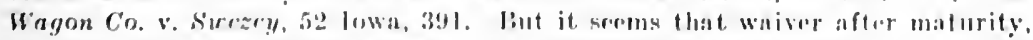
the firm lieing dierharged for want of presentment or notien, would not revive

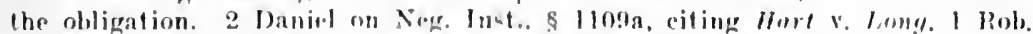
(Ia.) 83; Mauney v. Coit, 80 N. C. 3(K): Baer v. Leppert, 12 IIun (N. Y.) 5I6. - H. 


\section{S180 BURGE'TSTOWN NATIONAL BANK v. NILL.}

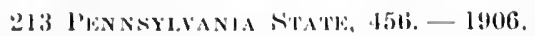

Acroos against indurser who eightecn months alter maturity indorsed on the note a waiver of protest. Julgment for plaintitl and defombant appeals.

MestriztT, J. * * * 'The plaintill's rashier called on the defomdant in Mareh or April, fa() t, and secured his signature to the wring on the back of the note waiving protest. Until that time the detembint says he han no notice that swaney, the maker, had not paid the note. Ie was then told, as averred in the aflidavit, "that the note in the form in whinh it then was, not having been protested and no notice of Aishonor laving been given to alfiant or demand made upon atliant for the payment thereof, was objected to by the bank examiner." The tefendant, thurelore, knew before he signed the wairer of protest that no lenand.for payment had been made and that no notice of the rishonor of the note had heen given him as the indorser. Hence he had full knowleilge of the laches of the holder of the note when he waivel protest of the instrument. Under these facts, which are disclosel hy the athidavit of defense, the defendant conld nave the laches of the holder in making demand for payment and in grving notice of the lishonor of the note. $4 \mathrm{Am}$. \& Eng. Ene. Law (2d Ed.) 453; Day v. Rilgway. 17 Pa. 303; Annville National Bank r. Lellering, 106 Pa. 531. "An intorser is entitled to notice of protest ol a nogotiahle note," says Mr. Justice c'outler in delivering the opinion in llay v. Ridguay. "because the contract is that the makre will pay at maturity; and the strict punctuality, which is the life of the commercial law, authorizes the indorser to presmme that lur has paid, in the ahsence of any notice to the contrary. But the rienth to rewive motive in orker to make him liable, like any other rinht, may be waired by the inclorser." In the Ketlering Case, Sterrett, J., rlolivering the opinion, says (page 5.3.) : "No principle of the law menedant is hetter settled than that demand and notice of the nonpasment of a nogetiable note may be waivel by the indorser, either comally or in writing, or ly acts clearly ealenlated to mislead the holine and prevent him from treating the note as he otherwise would; lut there is some diversity of mpinion as to what constitutes a waiver of three nereseary prererpicites to rharge the indorser."

'l'ke inforser may waive porotest aftor the date of maturity of thr notr. with like coflect as if done prior to that date. Barclay v.

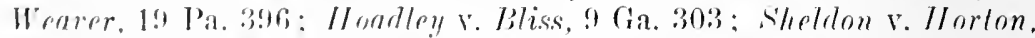

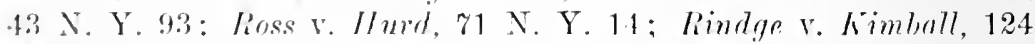
Mass. 209: : 1 Parsons on Notes and Bills, 594: 2. Randolph on Commerrial Paper, \$ 145f. In liarclay r. Weaver, this court said (page 401): "It sorems, therefor". that the duly of lemand and notice, in order to hold an indrisure is met a prit of the contract, but a step 
in the legal remedy, that may be waived at any time in accordance with the maxim "Quilibet potest renunciare juri pro se introducto.", In some jurisdictions it is held that the waiver, when made after the maturity of the note, must be with full knowledge of the indorser's laches and that it requires a new consideration. But it is settled by numerous American anthorities that a waiver of protest need not be supported by a new consideration. Neal v. Woml, 2s? Ind. 5e?; Hughes v. Bouen, 15 Iowa, 446; Cheshire v. Taylor, 29 Iowa, 492; Sheldon v. Horton, 43 N. Y. 93; Tebbets v. Dou'd, 2:3 Wend. 379; Wall v. Bry, 1 La. Ann. 312; Lane v. Steuard, 20 Me. 98.

We know of no decision of this court holding that such waiver must be supported by a new consideration. The contrury rule, however, is distinctly recognized in Barclay v. Weaver, $19 \mathrm{~Pa}$. 396. In that (ase Mr. Justice Lowrie, in construing the contract of an indorser of negotiable paper, says (page 400): "The most, thercfore, that can be said of an indorsement of negotiable paper, is that from it there is implied a contract to pay, on condition of the usual demand and notice, and that this implication is liable to be changed on the appearance of circumstances inconsistent with it, whether those cir'umstances be shown orally or in writing. But it may well he questioned whether the condition of demand and notice is truly part of the contract, or only a step in the legal remedy unon it. If it is part of the contract, how can it be effertually dispenserd with withont a new rontract for a sufficient consideration, (specially after the maturity of the note? Yet there are deeisions without number that a waiver of it during the currency or after the maturity of the note will sarr from the consequences of its omission. This could not he if it was a endition of the contract, for then the omission of it would discharge the indorser both morally and legally: and no now promiso afterwards, even with full knowledge of the fards, conll he of any validity. If. how-

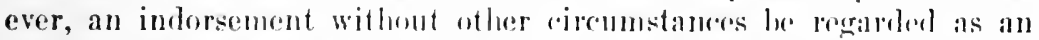

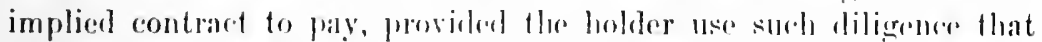

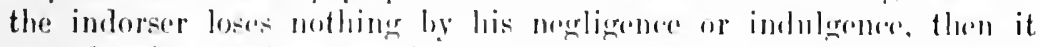
accords with all these dewisions. Then the law, and not the rontrant,

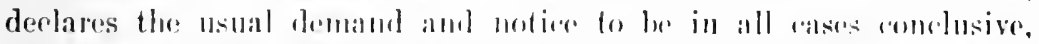

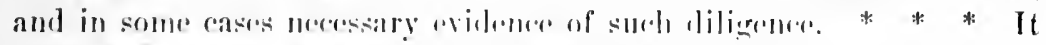

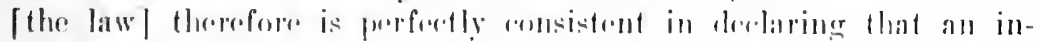
dorser is bouml hy a new promise, after loe knows of the omiscion

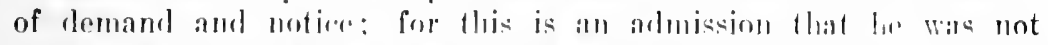

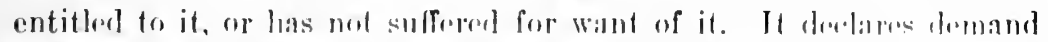
and notice neerseary, in some cases, to save an indoreser from loss, and it declares that his own ardmission may be subunittol for them." It is manifest, therofore, that from the nature of the inderser's ront raet a new consideration is not reppired to support a waiser of protest before or after maturity of the paper. 
The assignments of aror are overruled, and the juclgment of the rourt below is afhimed."

95 Nortu Carolina, $535 .-1886$.

3ction against indorser of inland bill of exchange for $\$ 90$ upon the margin of which were the words "No protest." Ther was no notice of dishonor. After dishonor defendant offered to pay $\$ 60 \mathrm{for}$ the draft. Judgment for plaintiff.

Asine, $J . * * *$ Ilis Ilonor charged the jury that they might consider the words "No protest," on the draft, and the language and conduct of defendant when he was informed by the plaintiff of the non-payment, and the offer to pay $\$ 60.00$; and that if the defendant had offered to pay $\$ 60.00$, as alleged by Shaw, it amounts to a waiver.

We find no such error in the charge as entitles the defendant to a new trial. There is some fluctuation in the decisions of the courts upon the question, how far a promise to pay a part of a draft is a waiver of demand and notice of non-payment. For instance, it has been held by some of the authorities, that when the promise is only as to part of the sum, it is only a waiver pro tanto, and the plaintiff could only recover that amount. (Fletcher v. Froggart, 2 Car. \& P. 569, 12 E. C. L. R.) On the other hand, it has been held, that " a promise to pay generally, or a promise to pay a part, or a part payment made with a full knowledge that he has been fully released from liability on the bill by the neglect of the holder, will operate as a waiver, and bind the party who makes it for the payment of the whole bill." (Dixon r. Elliot, 5 Car. \& P. 437; Margetson v. Aithin, 3 Car. \& P. 388; Horeey v. Troupe, 23 Miss. 538.) So it would seem, that the weight of the authorities, supported the charge of the judge in this particular.

But aside from this, his Honor, in his eharge to the jury, told them they might consider the words "No protest," written on the margin of the draft, as evidence of a waiver of notice of presentment and non-payment. The words "No protest," written on the margin of this rraft, must have heen put there with an object, and we can conceive of none other than to dispense with the notice of presentment and refusal to pay, otherwise it is unmeaning.

- This case is reported with notes in $3 \mathrm{~L}$ N. S. 1079 and in 5 A. \& E. Ann. Cas. 476 .

See also Sebree Deposit Bank v. Moreland, $96 \mathrm{Ky} .150$, reported in $29 \mathrm{~L}$. R. A. 305 , with exhaustive note entitled "Necessity of new consideration to support a waiver of failure to give notice of dishonor or subsequent promise by indorser." - ('. 
It is well settled that protest, being a part of the custom of merchants which is essential in foreign bills to fix the drawee and indorsers with liability, is not necessary for such a purpose in inland bills. (Hubbard v. Troy, : Ired. 134; 1 Parsons on Notes and Bills, 643.) But even in foreign bills the protest may be waiced. There the words, "I waive protest," or "Waiving protest," or any similar words, infer that the protest is waived, and when applied to foreign hil!, was universally regarded as expressly waiving presentment and notice, the protest being, according to the law merchant, the formal and necessary evidence of the dishonor of such an instrument. In waiving "protest," the party is considered not only as dispensing with a formality, but as dispensing with the necessity of the steps which must precede it, and of which it is merely the formal, thomgh necessary, proof of what the law required. (2 Daniel on Neg. Inst., $\S 1095$.) But when the waiver of protest is applied to inland hills, the protest having no application to such instruments, there is a diversity of opinion in the courts and text-books, whether such a waiver would have the effect of dispensing with notice in an action upon an inland hill. But the better opinion is, that as the word "protest" has by gereral usage a well-known signification, and wherever it is used. it is supposed to mean sometling more than the formal declarations of a notary. Hence, Mr. Daniel, who is a very high authority on the subject, says, "The weight, as well as the number of authorities, predominates in favor of construing a wairer of 'protest' to signify as inuch when applied to inland bills and notes, as when used in respect to a foreign bill."

"Inland hills and promisenry notes may be protested, by statutory enactments, in many states, and the protest is accorded the same effect as to them, when it is marle, though it is not necessary to make it, and the weight, as well as the number of authorities. predominate in favor of construine a waiver of protest to sirnify as much when applied to inland hills and notes, as when need in respect to a foreign bill." (\$ 10!5ia, and the ases citel in note 2.)

'The doctrine there laid down, must then apply to this hill, for we have a statute which provides that when it may he necessary to prove a demand upon, of motien to, the drawer or indorser of a bill

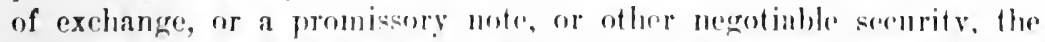
protest taken hefore a proper oflierer shall be prima farie evilloner that such demanl was malne, or notice given, in the manner sot forth in the protest. ('The C'orle, \$ 19.)

Our conchesion is, threr was no error. The judguent of the Superior Court is therefore aftirmed.

No error.

A firmel. ${ }^{\top}$

7 Waiver of proteat is waicer of presuntment and notier. There aereme to he

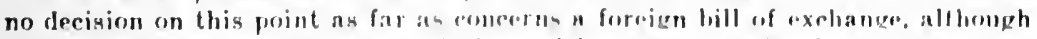
the text writers lay down the rule in positive terms. 2 Hanicl on Neg. Inst. 


\title{
(c) Solice of non-ponment where areptunce refused.
}

\section{$\$ 187$}

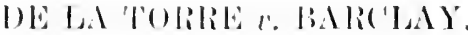

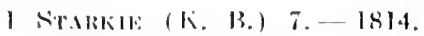

derros agaimst drawel of a bill. Delense, want of protest and notien.

" Bint on further infuriry, it turned out that the defendants' objertion dief not refate to the want of protest mon the first dishonor of the hill. Wut to the want of protest on the bill heing refused payment

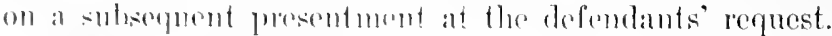

"Ipon this explanation. Tord Ellenhorough was of opinion that the answer amomntorl to an andmission of lialiility, sine the secomel protest was perfeetly gratuitous and munecessary."

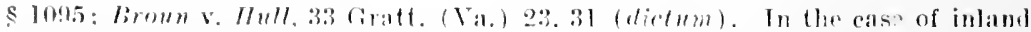
bills and promissory notes. thw enelu-ion is cremeral that "waiving protest"

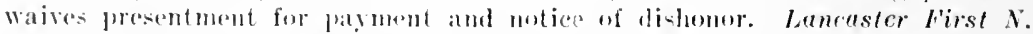

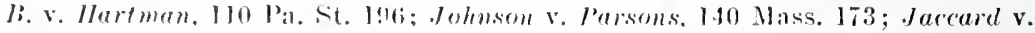

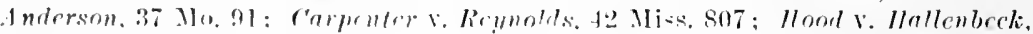
71110 (N. Y.) 364: Porter v. Krmball, 53 Barb. (N. Y.) 467; Coddington v. Daris, 1 N. Y. $180 .-11$.

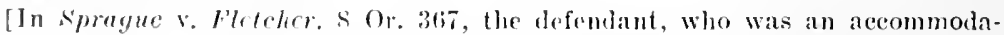
tion indorser. indorsed on the hack of a mote hefore lue these words: "I hereby waive notier of protest for monpayment." Ilele, not to be a waiver of demant of payment from the maker when due. Aerrements of this eharacter are to be construed strietly, and not extended beyond the fair import of the

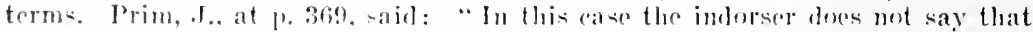
he will waive demand of payment. But that he will "wave notien of protest for nonpayment.' Demand and notice are two distinct thines, both of which are necessary to eharge an indorser, and only one of them is waived by the indurer in this cate. lint it is chamal by appellant that the indorsement operated as waver of hoth, and the following devisions are eited to suctain

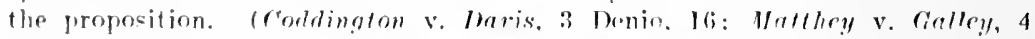
(al. 63: 19) Ind. 110). In Comblington v. Maris, the indorser wrote to the holder as follows: "You neel not protest. '1. B. l''s note duce de. l will waive the nereseity of protest.' This was held sulieient to dispense with a presentment and noties of non-payment. on the gromed that the word 'protest, as used ly the inderaser. in esonneetion with the promissory note, was understood to mean the taking of such stoge a were reguired by law to eharge an

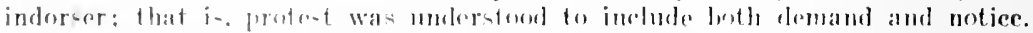

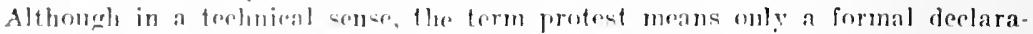

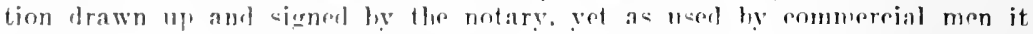
includes all the -tepe mepessary to warac an indorser. (Murrill's Law Diet. 349: 20hio, X. S. 315.) The "as in 1 california is in proint. but not a single case is eitcl in the opinion to slstain it. The ose in 19 Inelianal does not come up to this ease. There the aserement was that "protest and notice of protest were waived.' and were hald sullieient to include waiver of demand. 'Thus it will be seen that none of the cases citel sustain the proposition of appellant except the ralifornia ense. While there are mumerous derisions holding the contrary doetrine. (f Wass. 524: Freman v. O'Brien, 38 Jowa, 406; Scott v. Green, 10 Penn. St. I03.)" - C. 
(d) Effect of omission lo give notice of non-acceptance.

DUNN $v$. O'KEEFE.

5 Maule \& Selwin (King's Bencil) 282. - 1816.

Defendants drew a hill of exchange on Rickets. Thorme, George \& Co., dated June 1!), 181:3, and payable one montl after date to the order of one Sinclair. Before the matmity of the hill, Sinclaitr indorsed it to the plaintilf, who on July 1:3, 1sis, presented it to the drawees for acreptanee. The drawees refused to accept, and plaintiff therempon duly notified defendants of the dishonor of the bill.

The defendants pleaded in bar of the action that hefore the indorsement of the bill to the plaintill and its presentment by the latter for acceptance, the hill had heen presented by Sinclair to the drawes for acceptance, that they han refused acceptance. and that notice of such refusal had not herell griven to the defendants.

Judgment for plaintiff, and defendants bring error.

Lono Eldexioforgit, ('. J. - It a very late perion, after the law merehant, as it regards the suliget of hills of exehange, had oltained

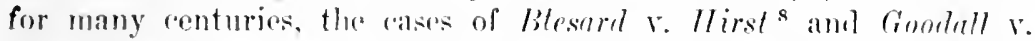
Dolley ${ }^{\circ}$ were decider. I lo not mean to insinuate anything a gainst the authority of those Acricions. They establish this, that if the party holding a bill of exchandere receive notien of its dishonor, he is homnd to communiente this to the drawer. But it has not yet heen determinot that the want of notion operates further than a personal discharere of the drawer, as against the farty failine to grive the mecessary notion, nor that an innocent indoreser shall lo barrerl of his action ley any latent defeet in the transfure or concoction of the hill, exeept in the two cases of the bill being given on a graming or usurious ansideration.

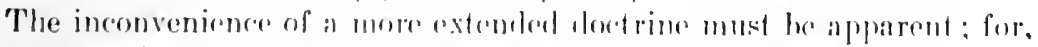

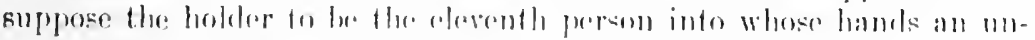

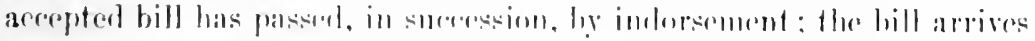
at maturity, and is presented, in lone indere for payment, and pilymont is refused, and motion is grimen to the drawer. Areopding to the

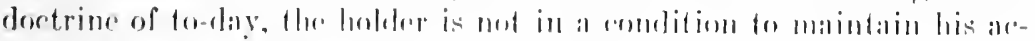

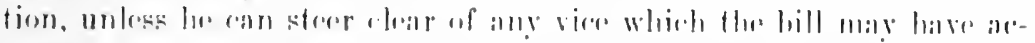

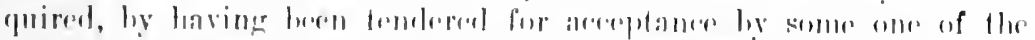

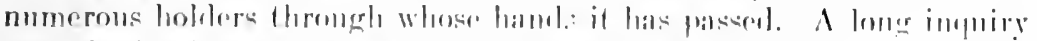

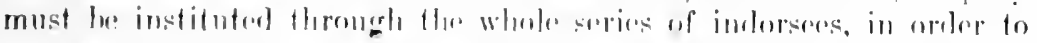
ascertain if any previoms presentment was marle, and in whal manner it was dealt with. Womlel it lw presilde to comdunt the necotiation of hills of exrotange if all this imrestigation were neresesary? What

Q5) Burr. 2670. - C.

Q 1 Term liep. 712. - C 
lueans has the holder of gaining this information? Must it be obtaimed by pinate inpuiry? 'That, as il ecems to me, would tend to

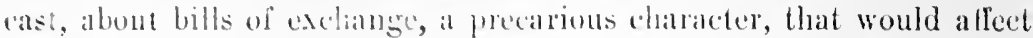
their credit, and, perhaps, totally exchule them from circulation. The cases of lifesered $x$. Ilirst and ciomdull $x$. Molley, decoded, that the indorser shomld be discharenel, hut dhat was as between the indorser and the party guilty of laches, which the plaintilf, in both those eases, was. It may he material to grive the hawer notice, in order to enable him to withilraw his elforts. 'This, therefore, may form a sound exception as anginst the party grulty of laches, but it is a very different consideration. whether it shall vitiate the bill in the hands of an innocent indorsee. like the cases of usury or gaming. It is argued that the drawer is only comditionally liahle, if the bill be dishonored by nonacceptance or mompayment, provided he has motice. But it is no part of the condition, that he shall be discharged quoad every holder, if the dishonor be not within the knowlectge of the holder. Such a position, I helieve, is not lind down in any ase, and would, as it scems to me, be carrying the doctrine further than is necessary or convenient, involvingr. perlaps, the negotiation of bills of exchange in precarious un. certainty. The drawer who jssues his bill into the world, without procuring its aceptance, is not without some degree of blame. He issues it in an imperfect state, and ammot justly complain of the neglect of any indorsee who takes the hill in this state, heing cognizant of no circumstances to vitiate it, and looking merely at the names upon it. Upon the whole, it appears to me. that no authority has pronounced that a bill of exchange shall he void security, in the hands of an innocent imborsen, who has no knowledge that the bill has ever heen dishonored, because a former holder has omitted to give notice to the drawer that the drawee has refused acentance: and that such a doetrine would be destructive of the very poliey and eflect of this species of instrument, by renrlering its redit of so precarious a nature, that no person would be found willing to trust to it, especially if a number al names were indorsed npon it.

BAYLEx, J. * * * The drawer might avoid all difflenlty by drawing the bill payable to his own order, and procuring an acceptance before issuing it. If he draw it payble to a third person, and issue it in its unaccepted state, the imperfection lies at his door, and he must take the enensequence. * * *

Homsorb, J. - I am of the same upinion, that there ought to be jurlgment for the defendant in error. This conchusion, T think, follows from some of the principles laid down in argument on the other side. I agres in the mation that the drawer undertakes that the drawe shall areept and pay. If the bolder tender the hill for aceeptance, and aremptaner is rofused. lir knows that the drawer is therehy defenterl in his expertation: therefore, it locomes his ruty to rive notion on the rlawer. and if lin noglect thic. las is antilty of laches, 
and ought to suffer for his negligence rather than the drawer. This was the ground on which the ease of Blesard v. Hirst was determined. But such is not the present ease, where the bill, in its unaceepted state, has passed into the hands of a bona fide indorsee to whom no laches is imputable. Upon the principle already laid down, the drawer, in such a case, holds out to the indorsee that the bill will be accepted and paid; and if this fails, ought he not to suffer rather than the indorsee who hath no knowledge whatever that the bill has been dishonored? The case of Roscow v. Hardy ${ }^{10}$ differs from this, because there the plaintiff took up the bill of his own wrong, after the holder by his laches harl discharged the drawer and prior indorsers, and therefore it was properly holden, that the plaintiff could not recover against a prior indorser. The greater part of the learned counsel's argument would apply to the case of a stolen bill, where the felon has indorsed it to a bona fide holder; but what says the law in such case? Not that the indorsee takes the bill on the individual credit of the felon, so that he must stand or fall by the felon's title, but that he shall recover on his own title, secing that he miglit take the bill on the credit of all the names which appear on the hill. Usury and gaming considerations render the bill void in its original formation. I remember the cuse in Douglas ${ }^{11}$, where the court reluctantly yielded to that doctrine. 'This is not the case of a void bill; the inulorsee is chargeable with no negligence, and I, therefore, think that the drawer is still liable.

Judgment affirmed.

\section{Duties of holder: protest.}

[Reported herrin at p. \{so.]

Action against indoreer. Defonse, want of notice. The bill was drawn in Rochester, N. Y., payable in Boston, Mass. It was presented by a notary in Boston and on dishonor a rertificate of protest was

1012 Fiast, 434. - C:

"Sier Loure v. Waller. Nown. 736.

12 When protuat ia neresas ry. the protest fora mny be recovereal as damages. Morgan v. Lintzel. 7 ('runch (I.S.) 273: Tirknor v.. Branch Mank, 3 Ala. 135.

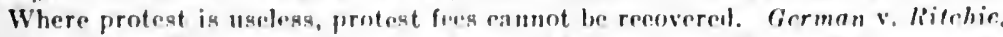

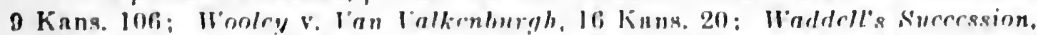
44 La. Ann. 361. Where proteat is proper. hat not neereasy, as where it is authorized by atatute in case of lisbonor of an inluml bill or a promissory

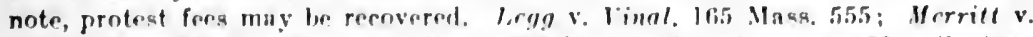
Benim, In Wencl. (N. Y.) 117; 2 Daniel on Nog. Inat.. \$ 933. Contra: Johnson v. Bank, 29 Fa. 260: 1 Thranns N. \& J. 6.46. - H. 
drawn up in lue form, stating, among other things, that the notary transmitted notice of dishonor to the drawer and indorsers, ete. This certiticate was the only proof of notice of dishonor offered by plaintiff.

liy the court, Cowes, J. I Ifter deciding that a notarial seal stamped directly upon the paper, without the use of a wafer, is not a good common-law seal]. Suppose the protest had been duly authenticated, was the addition of a certificate stating notice of protest to the defondant admissible? It was said to be evidence by Johnson, J., in Cape Fear Bank v. Stinemetz (1 Hill's Law Rep. S. Car. 45); and what I said in IIalliday v. Mcl)ougall (20 Wend. 85), is now relied upon, and perbaps rightly, as intimating an impression that he was right. The point decided in the last case was, however, that the giving of notice being the usual, not official duty of the foreign notary, and he being leat, the entry in his official record of notice being sent might he received by way of memoranium as secondary evidence. I admitted that it might not be his official business; and instituted no particular examination whether it was or not. The learned counsel for the plaintiffs has not been able to furnish anything more than what I have there mentioned, going to support the notary's certificate as evidence of notice. I have been equally unsuceessful after considerable search. On the contrary, I find it expressly asserted in Brooke's Office of Notary (pp. 79 and 139), that the giving of notice is no part of his province or duty as notary. In the late case of Fitler v. Morris (6 Whart. 406, 415, March T. 1841), this very question was a good deal considered by the Supreme Court of Pennsylvania; and they held, that though by the local law of that state, the giving of notice is a notarial act, and on that ground proveable by his certificate, yet this is an exception to the common law. They therefore refused to receive a notarial certificate made in Alabama, as evidence of notice, or anything beyond the presentment and non-acceptance. I am entirely satisfied that such is the law of England and this state.

It is scarcely necessary to ohserve, that our statute (Sess. 56, p. $395),{ }^{13}$ relative to proof of notice by certificate, applies to none other than notaries of this state. '

There must be a new trial; the costs to abide the event.

New trial granted. ${ }^{2}$

13 J. 1833, c. $271, \S 8$. Rirenated in substance in N. Y. Code Civ. Proc. $\S 923 .-11$.

1 It is now provided (Code Civ. Proc. $\$ 925$ ), that proof of dishonor, and notice of dishonor, of an instrument payable in another state or country, may be made in any manner authorized ly the law of the state or country where it is payable. MeAndrow v. Raduay, 34 N. Y. 511 ; Lawson v. Pinckney, 40 N. Y. Super. Ct. 187. - II.

2 A notarial certificate is not competent proof of service of notice in the ahsence of statute. Rral Estate Bank v. Bizzell, 4 Ark. 189; Rives v. Parmley, 18 Ala. 25f; Sehneider v. Coehranr, 9 La. Ann. 235: Sehorr v. Woodlief, 23 La. Ann. 473; Swayze v. Britton, 17 Kans. 625. Statutes now generally 


\section{ARTICLE IX.}

Discharge of Negotiable Instruments.

\section{Discharge of the instrument.}

\section{Payment and Re-transfer.}

$$
\text { STODDARD } v \text {. BURTON. }
$$

41 IowA, 582. - 1875 .

Action against the maker on a lost or stolen promissory note payable to $\mathrm{A}$, the bearer, on or before Jan. 6, 1868. Defense, payment to the holder (Thompson) on Oct. 11, 1866. Judgment for plaintiff.

DAY, J. * * * The defendant asked the court to instruet the jury as follows:

" 12 . The note in controversy was payable on or before a certain date. This made the note payahle at a fixed time absolutely, and sooner if defendant saw fit to pay it sooner. Such were the express terms of the contract, and, therefore, no presumption of had faith can arise from the simple fact that defendant paid when he did, though by its terms payment could not have been demanded or enforced at the time. Defendant had the riglit to pay whenever he chose to do вo."

The court refused this instruction, and gave the following:

"8. A promissory note, payalile on or hefore two years after date, is due at the end of two years and not before; the rule of law heing that the note becomes due at the time when the payce or legal holder or owner of the same has the right to demand payment, and this is true, although the note provides that the payor may at his option pay the same before the time fixed when it shall alsolutely hecome due."

"9. The payment of a note by the payor before it becomes due, to a stranger who may have possession of the note, will not protect and discharge the maker, if said notu has heen stolen, or notherwise surreptitiously eomes into the hands of the party presenting the same."

Other instructions given cimlirace the same doct rine.

make a notarial certificate prima farie evidenee of the giving of notice. As to these statules and their conetruction. ser $4 \mathrm{Am}$. \& Fing. lincye. Jaw 1 and ed.). pp. 389-393. Where a notary's certificate may inclusle a certificate of notice of dialionor, such certificate of notice may he written lulow tlie hody of the certificate and even below the acal. Olcotf v, Tinga R, Co., $27 \mathrm{~N}$. Y. 646; Jorian v, long. 109 Ala. 414. - II. 
'There was errol in gring these instructions, and in refusing that asked. The note was pilable to the hearer, and there is a presumption that the person in persession of it, and who presented it for payment, was the owner. It has luen derelarel in general terms, that the nayment of a note which has ben lost or stolen, hefore it is due, does not dischare the maker from liability to the real owner, because the parment is ont of the orlinary course of business. (2 Parsons on Notes and Bills, 25is, and cases (ited.) ${ }^{1}$

Bint the note in fuestion, by its express provisions, at the option of the maker, is parable at any time within two years from its date. Whilst the holder conlal not enlorce payment before Jamuary 6,1868 , yet the malier miglat daim the right to make payment before that time. It cannot be said to be out of the ordinary coulse of business for the maker to insist upon a provision which was incorporated for his henefit. To promption atrainst the bona fides of the defendant can arise from the time of making payment.

The defendant askel the court to instruct in substance that, if Burton pairl the note to 'Thompson in good faith, 'Thompson being in possession of it, and believing him to be the owner, withont actual notice or knowledge that it was stolen, then Burton was protected by such payment, and that mere suspicion on Burton's part as to 'Thompson's right to demand payment or negligenee in making inquiries was not enougl to invalidate payment; hut to lo so, it must appear that Burton har acted in bad faith. The court refused this instruction, and in sulsstance directed that a payment made under eircumstances that would put a reasonably prudent man upon inquiry as to Thompson's right to receive payment would not protect nor discharge defendant.

l'his action was erroneous. Mere suspicion that a person in possession of a note payable to hearer may not be the owner, will not exonerate the maker from payment; but there must be cireumstances amounting to clear proof that he is a fraudulent holder. ${ }^{2}$ (Story on I'rom. Totes, $\$ 613$, and cases cited; Gage v. Sharp, 24 Iowa, 15; Lake v. Reed, 29 Id. 258; Goodman v. Simonds, 20 IIow. 343; 1 Parsons on Notrs and liills, 238; 2 Id. 212, 279.)

For the errors discussert, the judgment is

Reversed. ${ }^{3}$

1 Disapproved in Bainbridge v. City of Louisville, $83 \mathrm{Ky} .285 .-\mathrm{H}$.

2 See $\$ 95 .-\mathrm{II}$.

3 See \& 148. ('f. Buehler v. MeCormick, 169 Ill. 269. If an instrument is paid hefore maturity and a canellation legend stamped upon it, and it is afterwards stolen, the cancollation mark effaced, and the instrument put into circulation, a jurchaser for value without notice cannot recover on it against the maker. District of Columbin v. Cornell, 130 U. S. 655. [Distinguished in Ehrlich v. Jennings. 78 S. r'. 269.- - '.7

If a negotiahle instrument is lost or stolen and the true owner duly notifies the maker, the latter must, at his peril, make sure that a subsequent payment 


\section{$\S 200$ AGAWAM NATIONAL BANK $v$. DOWNING.}

169 Massachusetts, 297 . - 1897.

Acrion against Edward B. Downing as maker of a note. After the note matured, plaintiff took a new note for $\$ 450$ from the indorser, Willian B. Downing, which included the amount of the note in suit and another note of $\$ 200$ given by $\mathrm{X}$. Plaintiff retained possession of the note in suit and sail note of $\$ 200$.

Monton, J. - The defendant is the naker of the note in suit. As between him and William $\mathrm{B}$. Downing, the indorser, it was an arcommodation note. But there is nothing to show that this was known to the plaintill, or that it tuok the note otherwise than in good faith and for value. Whether the $\$ 50$ note operated as payment of it was a question of fact depending on the intention of the parties, and the other circumstances surrombling the transaction. (Rrigham v. Lally, 130 Mass. 485; Dodge 1. Emerson, 131 Mass. 467; Green v. Russell, 132 Mass. 536; Eumes v. C'ushman, 135 Mass. 5r: ; Woods v. Woods, 127 Mass. 141 ; Cotton v. Bank, 145 Mass. 45, 12 N. E. 850.) The court must have found that it lid not, and its finding is conclusive. (Brigham v. Lally, supra.) There was nothing, we think, in the arrangement between the plaintiff anc? William B. Downing that operated to release the defendant. Ilis liability to the plaintiff was an absolute one. Delay on its part to enforce payment, from whatever motive, or however long continume, if not for six years, would not release him. We do not see that the rilse is altered because the delay was at the request of the indorser, ambl accompanied hy an agreement between the plaintiff and him that the defendant's overibue note should be regarded as serurity for the new note given by William B. Downiug.

\section{Exceptious overruled. ${ }^{4}$}

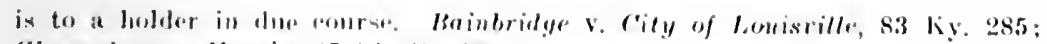

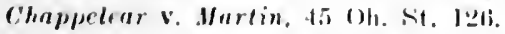

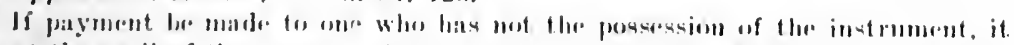

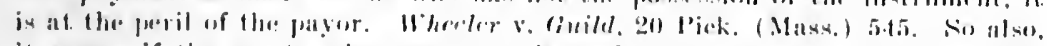

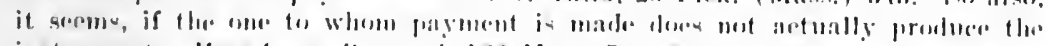

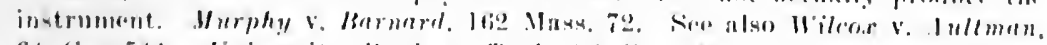

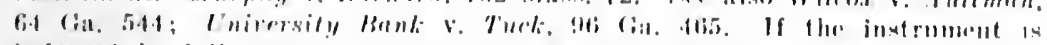

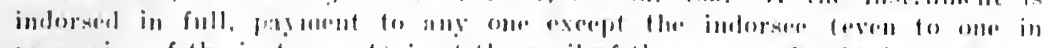

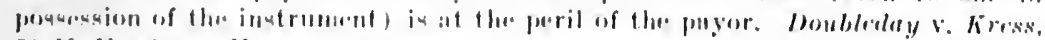
50 X. Y. $110 .-11$.

- Whelleer a renewnl note is taken in payment of the former nofe, or merely in extension of the obligation of lan former mote. is a fluention of the intention

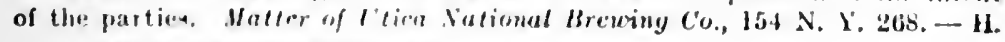

N KOOT. INBTHUMKNTH - 
Acrion on a promissory note. Defense, part payment by indorser. Judgment for plaintiff.

Finch, J. - We have a novel and interesting question before us on this appeal, althongh its apparent importance will lessen as we pass from first impressions to some slower reflection. It arises upor. facts which are very brief and simple and may at once be stated. 'The defendant, Pieree, made his promissory note payable to his own order and indorsed it to the Bates, Co., Limited, which indorsed it to the plaintiff bank; the latter discounting it and paying the proceeds over to the inmediate indorser. Thereafter the Bates Co. became insolvent and passed into the hands of a receiver, who paid to the bank upon the liability of the indorser seventy-three and one quarter per cent. of the amount secured hy the note. Later, the bank sued Pierce, the maker, and recovered judgment for the full amount of the note in spite of the proof showing the payment made by the receiver, and in disregard of the claim asserted by the defendant that he should only be held liable for the balance remaining unpaid. 'That judgment has been affirmed by the General Term, Judges Daniels and Barrett each writing very strong and valuable opinions in support of their doctrine, and relying upon the authority of Jones v. Broadhurst (9 M. G. \& S. 177; 67 Fing. ('om. L. 175), which fully warrants their conclusion. The question does not seem ever before to have arisen in this country, and we are left at liberty to examine the English rule and to follow it or not as we approve or disapprove its logic and its consequences.

We are not to regard the note as being accommodation paper, but must assume its transfer for value. The form of the transaction is equivalent to what it would have been if the Bates Co. had been named as payee, and loses none of its force by the intervention of the maker as first indorser. 'That indorsement, in the form adopted, was needed for the regular transfer of title, but does not change or affect the nature and character of the maker's liability. He remains the ultimate debtor, the person who ought to pay the debt, in preference to and in exoneration of all other parties to the paper, who in some form or other are entitled to have final reeourse to him.

And it is to the rase of such a maker of the note or such an acceptor of the bill of exchange that the English rule alone applies; and it is explicitly declared inapplicable where the indorser or drawer is the real debtor, although in form only secondarily liable.

Pierce, the refore, was the ultimate dehtor, and the party who ought to pay the note, both in discharge of the obligation to the holder and in exoneration of the indores. When the bank sued on the note, it was the legal holder and the legal party in interest. Upon production 
of the paper and the usual proof, judgment against the maker for the full amount was inevitable, unless some defense should be interposed. The only possible one for Pierce was part payment, and he was compelled to assert, and his counsel are compelled to argue, that the money paid by the indorser to the holder inured to the benefit of the maker as a payment on his debt. But that doctrine cannot prevail for very obvious reasons. The indorser's payment did not in the least lessen or satisfy the maker's debt. He owed it all exactly as before. What had happened possibly changed somewhat the real creditor, but left the whole debt due and unpaid. To whom he should pay might become a new question, but how much he should pay in discharge of the note was not made doubtful in any degree. What the receiver advanced to the holder is familiarly deseribed as a payment; but it was such relatively to the indorser's liability alone; while relatively to the obligation of the maker, it was an equitable purchase instead of a payment. That view of it was taken in a very early case, the decision of wnich depended necessarily upon it. In Callow v. Lawrence (3 Mau. \& Sel. 95), it appeared that one Pywell drew a bill upon Lawrence to his own order, which Lawrence accepted. The drawer indorsed the bill to 'Taylor, who discounted it and thereafter indorsed it to Barnett. It was protested for nonpayment. The drawer paid Barnett the full amount and took the bill, and, striking off the indorsements of Taylor and Barnett, transferred the bill to Callow, who sued the acceptor upon it. The latter claimed that the bill was paid and extinguished, which the court denied, saying that the drawer "became the purchaser of the bill" when he paid and took it out of Barnett's hands; that it was not paid by the drawer, animo solvendi, in order to extinguish it, but only to redeem himself from the situation in which he stood. That must always be true of payment by indorser to holder, where the maker is the ultimate debtor. To the extent of the money paid, the indorser becomes equitably entitled to be substituted to the rights and remedies of the holder, and becomes pro tanto, the beneficial owner of the lebt; so that the maker's obligation to pay the note in full, at first due to the holder solely in his own right, becomes, after the part payment by the indorser, still wholly due to the holder, but partly in his own right and partly as trustee for the indorser. A court of law cannot split the note into parts, and must act upon the legal interest and ownership.

In the present ease there was no privity between maker and indorser as it respects the action of the latter. He paid not as the agent of the maker, nor at his request, not for his benefit, and under no duty to relieve him, but independently, upon his own obligation, to lessen his own responsibility, and not at all to discharge the ultimate debt which it was the maker's duty to pay. It seems very clear, therefore, that the maker cannot utilize for his own benefit a payment which, as to him, is not a payment upon the deht. It becomes, as I have said, merely a question to whom he shall pay and who may sue for and collect the 
whole unpaid smm. In that question the maker has no eoncern beyond the inyniry whether he may hecome liable to different persons for the same debt and encounter the damger of paying it twice. I can discover no sueh peril. The judgment in favor of the holder is a bar to any other suit on the same note, and payment to the holder discharges the note utterly. Ordinarily, the indorser eannot recover except upon the note and as holder and in accordance with the law merchant. If he ever has any othel right of action against the maker, it is either in equity or hy force of some facts beyond the hare relation established hy the paper. And where the note is merged in the holder's judgment or paid in full to him by the maker, the indorser's ouly right is through the judgment or against the proceeds, if he has marle a partial payment to the holder. 'That does the indorser no wrong. If he is not content that the holder shall collect to some extent as his trustee, he may prevent it by payment in full to the holder and so entitle himself to the possession of the rote on which to sue, or if jurgment has been obtained, to be subrogated to all of the rights of the plaintiff therein.

I think this result is elearly indicated by our own decisions. In Mechanics' Bank v. Irazard (13 John. 353), the maker of the note had been arrested in an action upon it and his hail sought to relieve themselves by force of a payment made by the indorser to the holder, but such effect was denied to it; the court saying that it was not a payment by or on hehalf of the maker, or of which he or his bail could avail themselves. And in Guernsey v. Burns (25 Wend. 411), where the suit was hy the holder, representing the legal title and interest, it was said to be no defense to the maker and no concern of his that some property in the note was in another.

It thus becomes apparent that there is no very great importance in the question which method of securing payment from the maker is adopted, since the same result follows from each, and that it narrows down to the inquiry whether, as matter of correct doctrine and of convenience in practice, the holder may recover the whole debt against maker or acceptor for himself and as trustee for the indorser to the extent of his acquired interest; or whether he shall take judgment only for the balance, leaving the indorser to sue in some way and on some theory, which apparently could not be upon the note, becanse already merged in the judgment, but might be for money paid for the use of the maker, since lie gets the benefit of it in the reduction of the judgment, as was held in Pownal v. Ferrand (6 B. \& Cress. 439), where the holder deducted the indorser's payment from the levy against the maker. The former seems to me to be the logical and convenient method and so I think we should follow the English doctrine.

I have not underrated the assault made upon it by the appellant. He asserts that Jones v. Broadhurst is contrary to the earlier cases and has bern criticised and shaken by the later ones. T have examined them all, with some wonder at the amount of learning and ingenuity 
expended upon the subject. (Pierson v. Dunlop, Cowper, 571; Waluyn v. St. Quintin, 1 Bos. \& P. 652; Bacon v. Searles, 1 H. Bl. 88; Hemming v. Brook, 1 Car. \& M. 57 ; Randall v. Moon, 12 C. B. 261 ; Cook v. Lister, 13 C. B. [X. S.] 543 ; Solomon v. Davis, 1 Cahabe \& Ellis, 83; Thornton r. Maynard, 10 Com. Pl. L. R. 695.) The prior cases were very fully and carefully reviewed by Baron Cresswell in the opinion rendered in Jones $v$. Broadhurst, and of the subsequent eases I deem it only necessary to say that, along with some eritieism and occasional doubt, the doctrine has remained substantially unshaken, and the case last cited was declared by Lord Coleridge to be the accepted law.

It nust not be forgotten, however, and I may prudently repeat, that the doctrine has no application to aecommodation paper, and rests wholly upon the actual and ultimate indebtedness of maker or aeceptor as the party who ouglit to pay. In such a case as that, which correctly describes the one now before us, and where no disturbing facts affect the relations of the parties as fixed by the paper itself, I think the holder may sue and recover the full amount, receiving so much of the proceeds as represents a part payment by the indorser as trustee for him.

It follows that the judgment should be affirmed, with costs.

All concur, except MaYviku, J., dissenting.

Judgment affirmed. ${ }^{5}$

$\$ 200$

\section{LANC'EY r. ('LARKE.}

64 NКW УИвк, $209 .-1876$.

Acroos by lokder against milker. Iudgument for plaintiff at eireuit

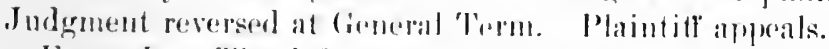

Easu, J. - The defendant makle the note in suit for the benetit and accommodation of the firm of lambert and lineoln. It was discounted and the proceeds passod to their arentit by the North River Bank. Each member was therefore homml, as to thre maker, to pay the note, and thus save him from liability on arromet thereof. Before the note beeame due flue firm wis dissolval, and Lincoln was to close up its business. Plantitf lived in ('anada, and Lincoln wrote him, requesting him to take up the note and furnish the money for that purpese. Plantiof, a few diyse hefore the maturity of the mote, sent Lincoln the money, which he placed in the bank to his indivicual credit. On the day the note foll due he went to the bank, and, by his individual aheck, paid the note to the discount rlerk, who knew at the time that it was an acrommodation note. He

\footnotetext{
306. $-\mathrm{H}$.
} 
did not assume to act as agent for any one, and did not ask to have the note transferred to any one, and did not mention plaintiff's name in any way. It is true that he asked to have the note protested so that he could hold the indorser and maker, but he did not disclose why he wanted to loold them. After he had thus paid and taken it, he sent it to the plaintiff.

Upon such a state of lacts, did plaintiff take his title from the bank or from Lincoln? If he took it from the bank, he took the Hace of the bank, and his title and right to enforce it were as good as those of the bank at the time he took it. But if he took it from Lincoln, it being past lue, he took it subject to any defense defendant could have made if sued by Lincoln, and in such ease defendant's defense would have been perfect. He could not be successfully sued by either of the persons for whose accommodation he made the note.

Plaintiff did not take title from the bank. It matters not that he furnished the money, and that Lineoln promised to use it in taking up this note for hin. It matters not that the note was protested so that the indorser and maker could be held, or that the bank did not intend absolutely to discharge and cancel the note. The question is, did the bank transfer or sell the note to the plaintiff? To make a sale or transfer takes two parties, one to sell and the other to buy, and the bank could not be made a seller without its knowledge or consent. It was not bound to sell or transfer the note. All it was bound to do was to surrender it upon payment by the person liable to pay it. A seller in such a case incurs some obligation by the sale, although he does not indorse the paper. Ile impliedly warrants that the paper is genuine and all it purports to be on its face, and he cannot be drawn into this implied warranty without his consent. (Eastman v. Plumer, 32 N. H. 238; Delaware Bank v. Jarvis, 20 N. Y. 226; Morrison v. Currie, 4 Duer, 79; Aldrich v. Jackson. 5 R. I. 218; 2 Parsons on Notes and Bills, 2d ed. 37.) All the bank did in this ease was to take payment of the note, and deliver it up to a party paying and liable to pay, after protesting it, so that he could make such use of it as the law and the facts would authorize. It did not transfer or intend to transfer it. 'The plaintiff, therefore, took no title to it from the bank, but he took it from Lincoln, and cannot, therefore, enforce it against the defendant.

The order of the General Term must, therefore, be affirmed, and judgment absolute ordered against the plaintiff, with costs. All eoneur.

Order affirmed and judgment accordingly. ${ }^{\circ}$

- If an instrument is retransferred to the maker or acceptor at or after maturity, the transaction is treated as a payment, and the instrument cannot be reissued or negotiated. IIarmrr v. Steele, 4 Exch. Rep. 1; Ballarel v. Greenbush, 24 Me. 336; Ferree v. New York, etc. Co., 74 Fed. Rep. 769 . But if it be transferred to the maker or acceptor before maturity, the transaction may be 


\section{WOLS'TENHOLME $v$. SMITH.}

[Reported herein at p. 634.]

\section{Cancellation or Renunciation.}

90 NEW YoRK, 333. - 1882.

THIs action was brought to recover the amount of a promissory note executed by defendant to Isaac C. Loper, plaintiff's testator, which the complaint alleged had been lost or destroyed.

The referee found that said Loper execnted to defendant a deed of certain premises, and in consideration thereof, the note in suit was executed, and delivered to the grantor, who thereafter voluntarily and intentionally canceled, destroyed, and surrendered up the same to the defendant.

Miller, J. - The note deseribed in the complaint was given by the defendant to the plaintifl's intestate, upon the conveyance to him of certain real estate, and as a consideration therefor, on the 11 th day of October, 1870 . The referee before whom the trial was had has found that in or about the month of January, 1871, the grantor voluntarily and intentionally canceled, destroyed, and surrendered up to the defendant said security and note, and as a conclusion of law, the intestate discharged the defendant thereon, and that no recovery could be had either on the note or on the original consideration. We think that the finding of fact by the referee is sufficiently supported by the evidence, and that the conchnsion arrived at was the legal and necessary result of said finding. The rule seems to be well settled by the anthorities that where an obligee delivers up the obligation which he holds against another party, with the intent and for the purpose of discharging the debt, where there is no fraud or mistake alleged or proven, that such surrender operates in law as a release and discharge of the liability thereon; nor is any consideration required to support such a transaction when it has been fully executed. (Bonv. Law Dict., title release; Albert's Ex'rs v. Ziegler's L'r'rs, 2!) P'rnII. St. 50; Beach v. Endress, 51 Barb. 570 ; Doly v. Wilson, 5 Lans. 10.)

shown to be a purehase and not a pasment and the instrument may be reissurd. Altenboromgh v. Markenzir, 25 H. J. lix. 24.4; Rogers v. Gillagher, 49 III. 182: Wrest Boston Bank v. Thompson, 12.4 Mase. 50ti: Swopr v. Ross, $40 \mathrm{Ia}$. St. I86; Eekert v. C'ameron, 43 P'a. St. 120. Contra: Long v. Cynthiana Bank, I Litt. (Ky.) 290; Stark v. Alford, 49 'T'x. 260).

If an instrument is retransferrell to one of two or more joint makers, before maturity, and re-issued hy him, it secms that his transferer gerts only a right of contribution againat the other joint makers. The ease in distinguished from that of a single prominor. Strurns $\mathrm{V}$. IImnnon, 86 Nich. 305; H. C., 88 Mich. 13; Kneeldan v. Miles, ('Jex.) 24 S. W. Rep. 1113.-H. 
'llere rertainly andil not be higher evidence of an intention to distharge and abua a debt tham by a destruction and surrender of

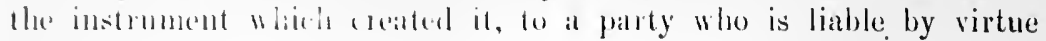
of the salle. * : *

Judgment affirmed.

$\S 203$

Sil.ille $x$. IIUThIs.

150 M.1s

Acrios to recorer the bilance of a promissory note. The defendant paid the plaintifls $\$ 125$ amel received a receipt "in full settlement of all areommts to datre," and the mote. Cluarge: 'That if the plantitys surrendered the note to be ancelled intending to give the defendant the balance of the debt, plaintills could not recover; but if the note was delivered in order that defendant might exhibit it and upon defendant's promice to pay the lalance, plaintifls could recoter.

The jury returned a special finding that the plaintiffs intended to receive the one hundred and twenty-live dollars " in full for the debt then whe," and further returned a general verdict for the defendant: and the plaintills alleged exerptions.

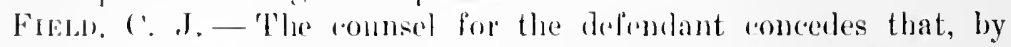
the law of this commonwealth, thr payment of a part of a debt alter the whole debt has become payable is not a sufficient consideration to supprot a promise not moler soal to discharge the remainder of the doht. (Broolis v. While, 2 Met. 28:3; Marriman v. Marriman, 1: Giay, 341; Poller v. Green, 6 Allen, 412; Giunel v. Sipiul. 12s Mass. ¿j; Lathrop v. Page, 129 Mass. 1!; Tylor v. Odd Fellows' lielief Issociation, 115 Mass. 184, 137; Foalics v. Beer, 9 App. Cas. 605$.

The jury, in returning a general veriet for the defendant, must have found on the judge's charge that the note was surrendered by the plaintifts to the defendant that it might be rancelled, and that the plaintiffs intender by delivering the note to the defendant to give him the note and dischange the remainder of the debt.

For certain purposes, a bill of exchange or a promissory note is regarderl in this commonwealth, not morely as evilence of a debt, but as the representative of a debt, or the debt itself. Wach may be the subject of a gift, but to constitute a gift there must be a delivery by the owner to the donee, with the intention of passing the title. (Grover V. Grover, 21 I'ick. 26il; Sessions v. Moseley. 4 Cush. 87; Bales v. Kemplon, 7 Gray, 3s2; Chase v. Rerlding, 13 Gray. 418. See sheedy v. lionch, 124 Mass. 172; l'ierce r. Boslon Five Conts Savings Banl, 129 . Mass. 125; T'aft v. Bouler, 132 Mass. 277; McCann v. Raudatl, 119 Mass. 81: Corkrener. Mone, 25 Q. B. D. 57; Gammon Theological Sem. v. liobbins, 128 Ind. 85.) 
It follows from this, that the delivery of a promissory note by the ho!:ler to the maker, with the intention of transferring to him the title to the note, is an extinguishment of the note, and a discharge of the obligation to pay it. (Hale v. Rice, 124 Mass. 292; Stewart v. Hidden, 13 Mion. 43; Ellsu:orth v. Fogg, 35 Vt. 355: Vanderbeck v. Vanderbeck, 3 Stew. 265 ; Jaffray v. Davis, 124 N. Y. 164, 170.)

Exceptions overruled. ${ }^{\top}$

$\S 203$

\section{LEASK $v$. DEW.}

102 Appellate Division (N. Y.) 529. - 1905. 8

Actiox on note given by defendant to plaintiff's testator.

The defendant offered proof that after testator's death the note in question was found among his papers, inclosed in an envelope together with the following paper, all in the handwriting of the testator, except the signature of the witness:

"To my executors.

"New York, Nov. 25, 1901.

"Gentlemen: The enclosed note I wish to be cancelled in case of $\mathrm{my}$ death, and if the law does not allow it I wish you to notify my heirs that it is my wish and orders.

“Witness: "Truly yours,

Oliver W. Buckingham.

"Fraxk IV. WOGLOM."

Judgment for plaintiff and defendant appeals.

НАтсн, J. * * * This brings 11 s to the main question in the case - the construction of the written declaration of the testator, which was found in the envelope which contained the note after his death. It is probably true that this declaration was suflicient to discharge defendant's obligation upon the promissory note, within the anthority of Weleell $v$. Raby, 2 Brown's Homse of Jords Rep. 386. The declaration therein was made a few days bofore the death of the lestator, in these words: "I halve Rahy"s homd, which I lieepl: I dou't deliver it up, for I may live to want it more than hre: helt whon I die he shall have it, he shall not he askerl or tromberd for it." Suit having been brought upon the bond, it was ordered to he delirered up and canceled, and such decision was aflirmed hy the House of Lords upon appeal. The derlaration in the present ase is, in one view, stronger than the declaration in that ase, for therrin there was the express intention of the testator to keep the hond al a enhesicting

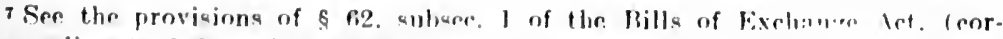
responding to $\$ 203$ of the Nerg. Inst. L.), construed in Eidurals v. Malters, 1896, 2 r'h. 157, where it was beld that a delivery to the dovisen ni f'e maker was not a delivery to the maker, though, semble, a delivery to the everutor or adminiatrator would im. - II.

* Affirmed in 184 N. Y. 599 , no opinion. - C. 
obligation against Raby, and it was not to be enforeed save in the event of his death, when it was to take effect. In the writing under consideration in this case there is no such expression in terms. A similar doetrine was announced in Brinckerhoff v. Lawrence, 2 Sandf. Ch. 412. Therein the Raby case is eited with approval. The declaration therein was, like the present, limited in its operative force to events which might happen subsequently to the death of the declarant. These eases applied the common-law rule, and, while they are authoritative deelarations of the efleet of this instrument at common law, they are not controlling in its eonstruction at the present time, for the reason that the force and effeet of an instrument of renunciation is now governed by the provisions of seetion 203 of the Negotiable Instruments Law (Laws 1897, p. $\% 44$, e. 612). It reads: "The holder may expressly renounce his rights against any party to the instrument before, at or after its maturity. An absolute and unconditional renunciation of his rights against the principal debtor made at or after the maturity of the instrument, diseharges the instrument. But a renunciation does not affect the rights of a holder in due course without notice. A renunciation must be in writing unless the instrument is delivered up to the person primarily liable thereon."

'This statute was taken from an act passed by the British Parliament in 1882, known as the "Bills of Exchange Act." It has been quite generally adopted in various states of the American Union. Its provisions are as follows:

"(1) When the holder of a bill at or after its maturity absolutely and uneonditionally renounces his rights against the aceeptor, the bill is discharged. The renunciation must be in writing, unless the bill is delivered up to the acceptor. (2) The liabilities of any party to a bill may in like manner be renouneed by the holder hefore, at, or after its maturity, but nothing in this section shall affect the rights of a holder in due course without notice of the remunciation."

It is readily seen that these two statutes, in character and import, are alike. The only difference is ciange in the form of phraseology, but it affects neither the sense nor the construction. A single case has arisen in England under the provisions of this statute. In re George, L. R. 44 C'. Div. 627, decided in 1890 . Therein it appeared that the testator desired to have destroyed a note for $£ 2,000$ given by Mrs. Francis. Search was made for the same, that it might be destroyed, but it could not be found. At the instance of the decedent, the nurse in attendance upon him wrote at his dictation: "30th August, 1889.

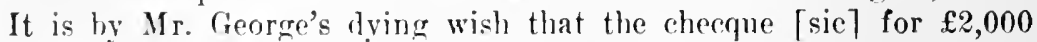
money lent to Mrs. Francis be destroyed as soon as found." The nurse added to this declaration the words: "Mr. George is perfectly conscious and in his sound mind. 「Signed $\rceil$ Nurse T." This transaction took plare two or thre hours hefore death. The testator therein left a will, in which he bequeathed to Mrs. Francis, his niece, the sum of 
£6,000. The executors of the will declined to pay the bequest in full, and thereupon the legatee brought an action to determine the question as to whether the promissory note had been duly canceled. The court, under the provisions of the statute above quoted, determined that the renunciation was insufficient to discharge the note. Upon the case there presented, I should be disposed to hold that it amounted, within the terms of the act, to an unconditional renunciation of the rights of the testator against the maker of the note. 'The expression that it was the testator's wish that it be destroyed would seem to constitute an announced declaration to destroy the instrument, and, as such, it was a clear expression of a renunciation of his right to enforce it. In the declaration of renunciation, it is stronger than the instrument relied upon in the present case.

There is some obscurity in the provisions of our statute. In its first sentence it provides for the renunciation of the rights of the holder against any party to the instrument which may be made before, at, or after its maturity. In the second sentence it provides for an absolute and unconditional renunciation of the rights of the holder against the principal debtor at or after the maturity of the instrument, and discharges the instrument. The first relates to the party; the second, to the instrument. It is somewhat difficult to see how there could be an absolute discharge of a party to an instrument without discharging the instrument as an obligation, so far as he is concerned. We do not clearly perceive why this distinction should have been made. It is immaterial, however, to the riglits of the parties to the present action. The instrument of renunciation contains no express declaration of the testator to renounce his rights in the note against the party, or of his right to enforce it as a subsisting obligation. 'The expression is: "I wish [the note] to be eanceled in case of my death." 'There is nothing in these words which can be construed as expressing a renunciation of any rights either against the party or upon the instrument. Ilad it been delivered to the defendant during the lifetime of the testator, it would not have precluded the latter at any time upon maturity from enforeing the note. There is nothing indicating an intent mpon his part not to enforce it during his lifetime. There wis no delivery of it to anybody, and, while doubtless, it was sufficiently anthenticated to accomplish a renunciation, it had no operative effect whatever, as it did not fall within the statute or emply with its terms.

In principle, the question raised by this ease has been decided by this court. Dimon v. Keery, 51 App. Div. 318. Therein the plaintiff's intestate loaned to the defendant a sum of money, taking her promissory note in writing, wherein she agreed to pay the same, with interest, on demand. At the time the note was delivered, the testator indorsed thereon the words: " $\mathrm{At} \mathrm{my}$ death the above note becomes noll and void. Stephen C. Dimon." Dimon continued to retain possession of the note, and the defendant paid interest thereon, but no 
principal. Dimon died about three years after the execution and delivery of the note. In an antion to cnforce the same by his administrator, the defendant was held liahle thereon, as the indorsement was a mere declaration by the palyee of the note as to his intention concerning it, lunt that it was insulficient as constituting either a gift of money, or an agreement to discharge it as an obligation. 'The court therein lid not diseuss the statute which is here the subject of consideration. It is manifest, howerer, that the declaration indorsed upon the note was not a renuneiation of the liability of the maker during the lifetime of the deceased, or of any renunciation of the obligation of the instrument; and, as it did not constitute a gift or an agreement, it neither fell within the terms of the statute, nor exempted the defendant, for either reason, from liability thereon. In the instrument relied upon in this case, so far as the direction for cancellation in the event of death, and a command to his heirs to obey his wish and follow his orders, the language is no stronger than the indorsement upon the back of the note in the Dimon case. Nor is it as strong, hecause the language there used was a declaration that the note at death "becomes null and void." ITere there is simply the expression of a wish to have it cancelled, and a direction to the heirs to obey the wish. Consequently the Dimon ease hecomes a rlirect and controlling authority in the disposition of this controversy. As there was no ralid renunciation of right of the testator to enforce the note against the party, or of renunciation from liability upon the instrument, and as nothing contained in the declaration otherwise operates to relieve the defendant from liability, it follows that the note remains a valid and subsisting obligation.

The judgment enforcing it should therefore he affirmed, with costs. All coneur. ${ }^{3}$

9 In Baldrin v. Daly et al., 41 Wash. 416 , it was held that the defendant Peter, in an action against hiu as surety on a note, could not show by parol evidence that the plaintiff had released him from liability on the note. After quoting \$ 122 of the Washington Negotiable lnctruments Law [N. Y. \& 203], Fullerton. J., on page 419 , said: "This plainly provides that the renunciation of a debt must be in writing where the debt is eviflenced by a negotiable instrument, and if 'renunciation' is used therein in the sense of 'release, there can be no question that appellant must show a written renuneiation in order to prove the allegations of his answer. Counsel for the appellant argues that the word is used in a sense different from that of release, and that while a renunciation must be by a writing, a release may be proved by parol. But we cannot think that the statute permits of this distinction. 'The words, "The holder may expressly renounce his rights against any party to the instrument,' must refer to the release and diccharge of a party from his obligation to pay it, else they can have no legitimate meaning."

Followed in Pitt v. Iiltle, los Pac. (Wash.) 941, where it was held that the maker of a promisanry note could not show by parol that the payee had released him from liability on the note. - C. 


\title{
§ 204 LYNDON VILLE NATIONAL BANK $v$. FLETCHER.
}

\author{
68 VERMONT, 81. - 1895.
}

Action against a surety on a promissory note. Judgment for plaintiff.

Rowell, J. - The defendant was surety for Walter on a second renewal note to the plaintiff bank. Walter harl put $\$ 20,000$ of securities into the defendant's hands, in consideration of which he agreed to and did indorse for him to that amount, of which said note was a part. The bank knew that the defendant was surety, but did not know that he had security. Said note was taken up by a note that Walter sent to the bank, signed by him and purporting to he signed by the defendant, but on which he had forged the defendant's name. 'There were several like forged renewals, but the defendant had no knowledge of any of them till the hank notified him of the approaching maturity of the last one and informed him that it would not be renewed; whereupon he went to the hank, saw the note, pronounced his name thereon a forgery, and refused to pay it, and thereupon, at its maturity, this suit was brought thereon and on the three genuine notes and another of the forged renewals.

When the last genuine note was thus taken up, the bank stamped it "Paid," and sent it to Walter, who carried it to the defendant, who, when he saw it, was thereby induced to believe and dirl believe that it was paid and extinguished and he released therefrom, and thereupon, relying on that belief, he signed another note for Walter for the same amount, which otherwise he would not have done, and whereby he was damnified.

The defendant never had anything to do with the bank eoncerning any of the notes except as aforesaid, hut the business was all done by Walter.

The defendant conceded that the hank believed the forged renewals were genuine, and acterl npon that belief in taking them, and otherwise would not have taken them: hot he rlaimed that the enshier was negligent in taking the forst fored renewal and stamping and giving up as paid the last gemulue rencwial. for that the forgery was so manifest that, as a careful and pruclent man, with both notes before him, he oughte to have deteredel it: and he asked to go to the jury on that question, rlaiming that if the negligenee was fouml, the plaintiff would be therehy estopperl from recovery on the last genuine note.

The defendant also relaimed that ly stamping said last mentioned note "Paid" insteal of "limewed," as the fact was, the hank made a false statement, to its knowledger, and that when it sent the note to Walter thons stamper, it ought to have known that he would show it to the defendant, and that the clofomlant womld the therehy indueed to believe it was paid and extinguisher, and to art necord- 
ingly, to his prejudice, ol, at last, that it ought to have known that smeli womld matmally amel pobmbly he the fact, and that if the jury should find that the bank, in the exereise of the requisite eare and prudence, ought to have so known, then what it did in this behalf amomnted to a representation by it to the defendant that the note was in fart pail and extinguished; and if it was further found that the defondant acted upon that representation to his prejudice, the phantill wombl he estopled from recovery on that note.

'l'he dofemelant firther claimod, that if the parties are to be resarded as aqually imnocent in the matter, and the taking of the first forged renewal and the stamping and giving up as paid of the senuine renewal Were a mere mistake on the part of the bank, then the loss must sill rest mon the plaintiff, which made the mistake, and on whide the rhances of business have placed it.

But the court ruled against the defendaut on all his elaims, and directed a verdict for the planititl for the amount of the last genuine renewal, to which the defendant exeruted; and he now makes substantially the same claim that he made below.

It was nudoubtedly the duty of the bank to act in good faith towarls the defentant in the matter, but it was under no further duty to him. (Bank of Newbury v. Richards, 35 Vt. 281, 284.) The presentation hy Walter of the first forged renewal was a representation by him that it was gemune, and the hank, certainly with nothing to arouse its suspicion, owed the defendant no duty to distrust Walter and to examine the two notes to see whether his representation was true or not. No case is cited nor principle suggested requiring that. A bank is bound to know the signature of its depositor, and, therefore, if it pays a forged check purporting to be his, it must hear the loss. So the acreptor of a bill is bound to pay it although the drawer's name is forgel, for the presentation of the bill is a direct appeal to him to areept it or to reject it. It is an inquiry as to its gennineness, adrlressed to the one who, of all others, is supposed to he best able to answer it, and whose answer is most satisfartory. We is, moreover, the person to whom the bill itself points as the lecritimate soure of information to others, and if he were permitted to dishonor the bill after he has once honored it, the very foundation of confidenre in commereial paper would be shaken. But the drawee of a hill is not bound to know the signature of the payer, nor to cxamine and aserertain whether the indorsenent is genuine: and if lye pays on a forged indorsement, though to an innocent holeler, he ran recover the money. (Corn Exchange Bank v. Nassau Banli, !1 X. Y. \%1: Insurance Co. v. Bank, 60 N. H. 442.) Nor is a bona fide indorsue, whether hefore or after acceptance, bound to inquire into the genuineness of a bill, in order to retain the money received hy him from the drawee in paynent thereof. (Price v. Neale, 3 Burr. 1354, a case that has never been departed 
from.) So if a bank receives as genuine, fraululently altered bills of its own, and passes them to the eredit of a depositor who acts in good fait', it js bound by the eredit thus giren, for it was its duty to know its omn bills. (Banli of the Uniled state's. Bank of Georgia, 10) Wheat. 333.)

But the erse at bar is unlike the ease of a drawee who pays or acepts a forged bill, or of a bank that receives as gennine, forged notes punported to be its own, for here the bank was not hound to know the defendant's handwriting, and it was not its duty to examine with reference to ascertaining a thing that it was not bound to know. But by this we do not mean to say that it could shut its eyes that it might not see, or turn away lest otherwise facts might he disclosed at variance with what it represented to exist, for that would be bad faith and breach of its duty. It follows, therefore, that as here was no duty to examine, there was no negligence in not examining.

Nor was the representation of payment that the hank made, false to its knowledge, as claimed, but true in its belief, in substance and effect, for had the forged note heen genuine it would, in law, have paid the other note and extinguished it as aflording a cause of action against the defendant; and as knowlerlge of the falsity of the representation is not imputable to the bank, as it was not in a position that it onght to have known, there can he no estoppel on this score.

The case comes to this, then, that said representation was a mistake on the part of the bank, arising from its non-culpable ignorance of the truth, and brought about hy the fraud of IValter: and it would seem that a representation induced by framd will not estop. (Big. Fstop., 31. ord. 491.)

But it is claimed that if a mistake, the rase is one that calls for the appliention of the mule that when a mistalio has been made from which one of two innorent parties must suffer, he must suffer who made the mistalie. especially when, as here, the chances of husiness have plared the loss upon hion: and The Gilouesester bank v. The

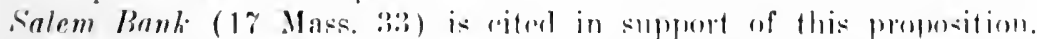
That was a case in which the plaintife had paid to the defondant,

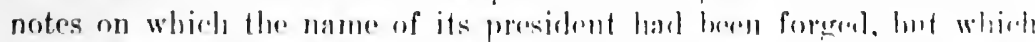

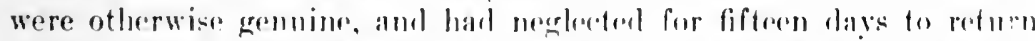
them; and the court stated the gunestion to be, whether, as between the parties who were equally inmerent and imorant, the loss should remain on the plaintiff, where the chanees of business had placed it. or he shifted lack upon the defendant, which harl, ly groot fortume. rid itself of it. It then went on to sare, that in all surle eases the just and sound prineiple of derision hard lwen, that if the loss conld be traced to the fault or neglere of either party, it shonld be fixerd on him; but that generally, when bo fanlt or nerlierence was imputable to either party, the lose hasl heren sufferent to remalin where the course of business had placed it. Bull lloe first part of that 
principle is not applicable lere, for the loss is not traceable to the fand nor the negled of the plaintitl. Sor is the second part any more applicable, for it ean hardly he said that the chances of business have placed the loss on the plaintill, hut bather on the defendant, hut if it can, the plaintifl, in lowal ellert, holds the defendant's mote, am it has not been pial, and the plaintill is not estopped from collecting it of him. In these cirrmmstances, the chanes of husiness can arail the defendant nothingr.

Jurlgment allirmed.

$\S 204$

MCCORMICK $r$ SHEA.

[Reported herein at p.696.]

3. Altiphition.

\section{\$205 IZORN ANT TONG $v$ NEW'TON C'T'Y BANK. 32 KANSAS, $518 .-1894$.}

Acrox arainst makers of a promissory note. Judgment for plaintiff against hoth defendiants.

The note was given by defendants to a named payee for the purchase price of a threshing machine which defendants intended to run as partners. Ilorn and the paree authorized the nole to be changed so as to make one IIiddreth the payee. Long did not know of or afterward consent to the change.

The opinion of the rourt was delivered by -

Innerns, ('. J.- It is the entention of Long. one of the plaintifls in error - a defendant below - that there had been a material alteration in the note sued on without his consent, therehy releasing him from all liability nom it. The note was originally drawn payable to "II. A. P'itts" Sions Manufarturing ('ombany," and after having heren given to that rompany it was altered by substituting the nume of " (). B. Jlidereth" for the original paree. 'Tluis alteration was made without the knowlerge or consent of Long, and he has neser consented to or ratified the same. Within all the anthorities, the substitution of O. B. Ilidath in ihe place of the original payee was at changere of the presentality of one of the parties to the note, and therefore a material alteration. (Boml. r. I/thll, 1 IIalst. N. J. L. 215; Stoddard v. Pemmiman, 108 Mass. 36 in; Mroper v. I"ood. 112 Id. 315; 17 Am. Rep., pp. 92, 106; 2 Danicl on Neg. Inst., \$\$ 13871390.) ${ }^{2}$

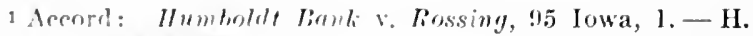

2 See s. 206. 411)-ec. 4. - H. 
If Horn and Long had been associated together in a trading partnership, then either member of the firm might have bound his co-partner by executing a promissory note in the name and on behalf of the firm, in any transaction pertaining to their partnership business. We suppose that under such circumstances, the material alteration of a note executed by the firm, with the knowledge and consent of one partner, would bind his co-partner, if the note had been given within the apparent scope of the business of the firm, as it is a general principle relating to trading partnerships that each partner is the lawful agent in the partnership in all matters within the scope of the business. (Deitz v. Regnier, 27 Kans. 94.)

A non-trading partnership, however, is controlled by rules differing from those controlling a commercial or trading one. (Deilz v. Regnier, supra.) Under the findings of the court, Horn and Long were partners onl $y$ in the running of a threshing machine, and such a partnership is one of occupation or employment only. It is not a commercial or trading partnership. There was joint ownership between Horn and Long in the threshing machine, and there was a co-partnership between them in the matter of operating the machine, with the intention of dividing the profits and losses equally; but yet their business did not require the exceution of negotiable paper as the proper, convenient, and usual mode of conducting it. In a partnership to operate a threshing machine there does not exist the implied power in the severat-members-to-make promissory notes, and thereby bind the firm. - Whoever deals with an individual jointly interested with another in the operation of a threshing machine must, at his peril, inform himelf of the nature of the partnership. The note in suit was signed by the makers in their individual names, and not as a firm. 'Therefore, upon the fare of the note one of the makers had no right to bind the other without his consent to any material alteration. Horn had no authority to make a promissory note in the name of the firm or to bind Long, unless the latter harl been previousty consulted, and consented to the transaction. (Lanier v. McCabe, 2 Fla. 32; Prince v.

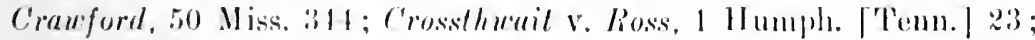
smith v. Sloane, 30 Wis. 285, 19 Am. Rep. $75 \%$ : Dederlorf v. Thatcher, 78 .110. 128; 1 Inuriel on Neg. Inst., ss 355-358.) If he harl not the authority to make promissory notes and draw hills of exchange amel the reby hind the firm, he had ne right to anthorize a change of payee in the notre exerated by him and longers as to hind Lomg therehy. The material alteration of a notre with the comsent of a maker is virtually making a new note and antr-dating it.

We therefore conclude that the material alteration of the note in question released Long. (Broughton v. Fuller, 9 Vt. 3\%3.) That the hank purchased the note before maturity, for a valuable consideration, and is, therefore, a hona fide holder of the notre. does not prevent 
Long from asserting the material alteration of the note as a defense. ${ }^{3}$ (llait v. l'omeroy, :0 Mich. 4:5; benedict v. Cowden, 49 N. Y. 396; bank 1. Stouell, 1:3 Mass. 196; 2 Daniel on Neg Inst., \$§ 14101413$.

\section{[Omitting a question of practice.]}

The judgment against Long will be reversed and the cause remanded, with direction to the court below to render judgment in his favor upon the findings of fact."

3"It is urged. lowever, that the plaintiff, being an innocent holder for value, can recover notwithstanding the alteration, because they propose to recover only the amount of the note as it was before the alteration. If such were the law forgeries by alteration would be protected by the law. 'l'he fraudulent payce would run no risk of loss because he would only have to transfer the note to an indorsce who might recover the original amount of the note by sim. ply proving that he was innocent of the fraud. But the law is not so charit. able to this elass of persons." - Gettysburg Nat. Bk. v. Chisolm, $169 \mathrm{~Pa}$. St. 564, 569: C'itizens Nat. Bk. v. Williams, 174 Pa. St. 66 (donbting the eorrectness of Kountz v. Kennedy, 63 Pa. St. 187, contra).

There is some authority for the proposition that a banker after payment, has the right to hold an altered check for its correet amount as against the maker. llall v. Fuller, 5 B. \& C. 750; Susquehanna Bk, v. Loomis, 85 N. Y. 207: (ef. Crauford v. West Side Bank, 100 N. Y. 50, 57); Redington v. Woods, 45 ('al. 406. Compare Bills of Exchange Act, $\S 60$, as to payment under forged indorsement.

Under $\$ 205$ the holder in due course of an instrument fraudulently altered is now permitted to enforee payment aceorting to the original tenor. Prior to the statute this could not be done, though it secms to have been allowed in the exceptional case of Worrall v. Ghemn, 39 Pa. St. 388. Where the alteration is by a stranger, or, if by a party to the bill, is innocent, many Ameriean courts allow a recovery upon the original consileration. See cases following. $-\mathrm{H}$.

4 There may, of course, be a subsequent ratifieation of an unanthorized alteration. 2 Daniel on Neg. Inst., \$§ 1401-1403; Dickson v. Bamberger, 107 Ala. 293; Hatlock v. Wherler, 29 Ore. 64. Jilanks left in an instrument import a prima facie authority to the holder to lill them. Neg. lnst. L., \& 33. But an alteration, although made in order to correct a mistake, and conform the writen instrument to the actual intention of the parties, is fatal and destroys the validity of the instrument. Newmon v. King. 54 Ol. St. 273, citing eases eontra; Erans v. Forrman, (i0 Mo. 449. Ilint see Wallare v. Tice, 32 Or. 283, post, P. 612, and Osborn v. $11 a 1 l, 160$ Ind. 153, in note 8, post, p. 614. - C.]

A restoration of the instrument to its oricrinal form will not revive liability upon it. C'itizens' Yat. Bank v. Richmond, 121 Mass. 110 ; Locknane v. Emmer. son, 11 IBush (Ky.) 69) Fulmer v. Seitz, 68 Pa. St. 237 (doubting Kountze v. Kennedy, 63 P'a. St. 187); Citizens' N. B. v. Williams, 174 Pa. St. 66; McDaniel v. Whitsett, 96 Tenn, 10.

Materiat, Aiteration. - As to what changes constitute a material alteration, see $\$ 206 ; 2$ Danit.1 on Neg. Inst., \$\$ 1373-1404; 2 Am. \& Eng. Encyc. L. (21) ed.), pp. 222-248; Ives v. Farmers' Bank, 2 Allen (Mass.) 236.

Bernes of Profr. - There is a hopeless conllict as to the presimption and burden of proof in the ease of the apparent alteration of an instrument. ()ne class of eases requires the one offering the paper to explain any apparent alteration. C'rosucll v. Labree, 81 He. 44; Simpson v. Stackhouse, 9 I'a. St. 186; 
Actios on a note and upon original indeltedness. After the note was given by defendant, with Fuller as surety, the plaintill innocently procured IV. A. R. to sign also as surety. The court held the note void, but allowed a recovery against defendant upon the original consideration. Action dismissed as to fuller.

ВЕск, J. - This court has held that the signing of a promissory note by one as a joint maker, after the exerution by the original maker, without his knowledge and consent, is a material alteration, which will defeat the instrument. (I/amilton r. Horpere, it al.e to Iowa, 515; Diclerman r. Miner, 43 11. 50s; Hall's Adm'x r. McHenry. 1!1 (1. 5:1.) "

It has ako hem ruled by this count that, when a promissory note has been innocently altered, without any fandulent purrose, the parye may recover in an action bronght upon the original consideration.

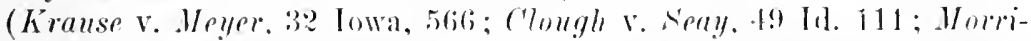

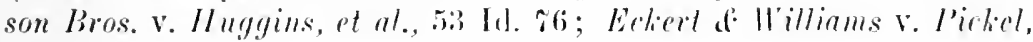
59 Id. 545.$)$

Upon the farts found by the referee, which are not hrought in question, and moler the petition which songht to recover mpm the original consideration, the (irenit court rightly rendered judgment for plaintifi."

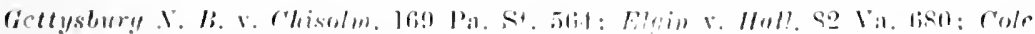

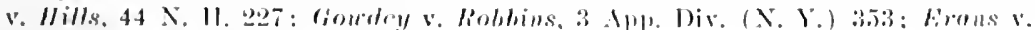
Irmin!, 20 Wkly. Jig. (N. Y.) 7 l.

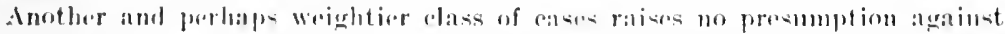

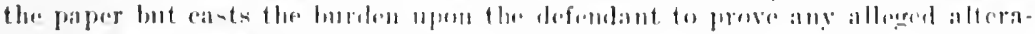

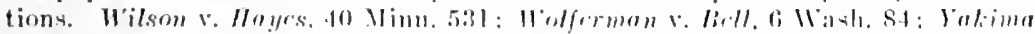

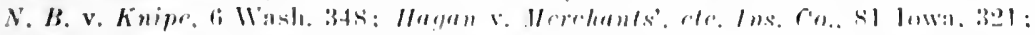

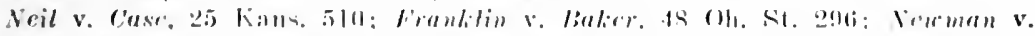

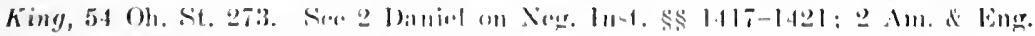
Encyc. J. (2mil rol.). 119. 272 29!1. - II.

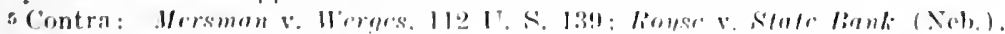

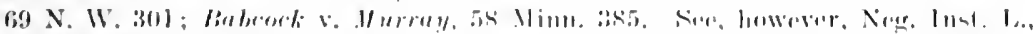
\$ 206, smbsir. 1. 11.

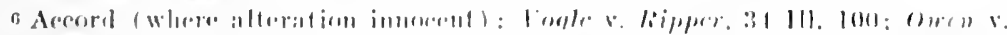

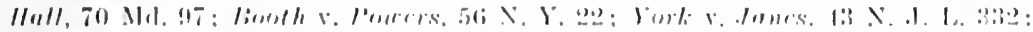

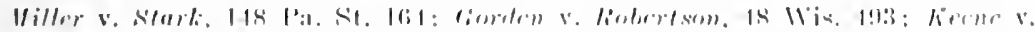

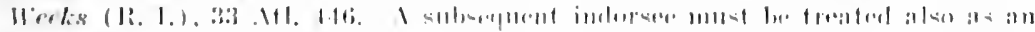

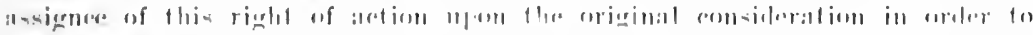

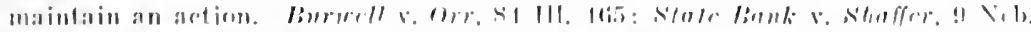

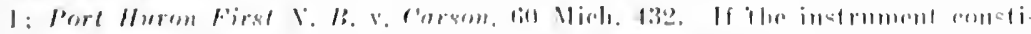

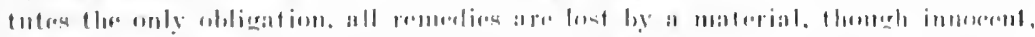

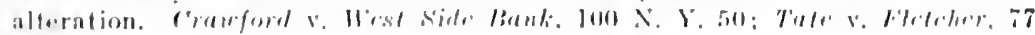
Ind. 1112.

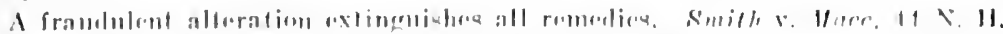

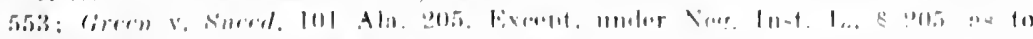

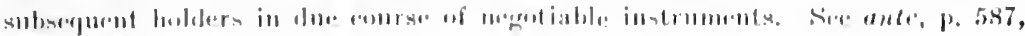
note. - II. 
320 Heroon, 2s3. - 1895.

ON August 11, 1891, defendant 'liee arranged with plaintiff for a lo:m, angeeing to give his note with one Herrall as security. Plaintiff wrote out the note, dating it "Ang.11," and making it payable one year after date. 'Tice took it to Herrall the same day, signed it, procured Herrall's signature, and returned to plaintill with the note the following day. Before delivering her cheek for the money, plaintiff clanged the date in lis presence l'rom " 11 " to "12." Plaintifl testified that she made the change to correspond with the anreement of the parties, and Tice testified, in substance, that plaintiff made the change without objections from him.

In an action on the note against Tice and against the administrator of Herrall, deceased, judgment was rendered for plaintiff, and the arministrator appealed.

Wolverton, J. - This is a suit to restore the original conditions of a promissory note which it is alleged were changed by the payee, under mistake and misapprehension of the rights and agreements of the parties, and to reener thereon against the makers.

Three questions remain for solution: (1) Has a court of equity jurisdiction of the cause, as it remains dismembered of the alleged trust relations? (2) Can a recovery be had upon the altered note? And (3) is the name "Geo. Herral," appended to said note, his genvine signature? ?

It may be conceded that the alteration made is material, and upon this premise we will determine the legal eflect thereof. The rule may be said to be settled that a material alteration made fradulently, and with vicious intent, ly the party claining a benefit under it, will avoid the note, and extinguish the liability, and lenceforth no recovery can be had. Vogle v. Ripper, 34 Ill. 100. There is a strong current of anthority, however, which holds to the doctrine that while an alteration, though material and unauthorized, which was innocently and honestly made, and withont any fraudulent or improper motive, avoids the note, nevertheless an action will lie upon the original indebtedness if it is indenendent of the notr, and has not been discharged by its execution. (Bonth v. Powers, 56 N. Y. 22, 30, 31; Lewis v. Schench, 18 X. J. Eq. 459 ; Panl. v. Shaffer, 9 Xeb. 1 ; Hunt v. Gray, 35 N. J. Law, 227: Vogle v. Ripler, supra.) And many authorities permit the action to be maintained nom the note itself. (Horst v. Hagner, 43 Iowa, 373; 2 Pars. Notes \& B. 570; Dukrr v. Franz. 7 Bush, 273; Adams v. Frye, 3 Metc. (Mass.) 103; S'mith v. Dunham, 8 Pick. 246; Milbery v. Storer, 75 Me. 69: C'roswell v. Lubree, 81 Me. 44 ; Rogers v. Shaw, 59 Cal. 260; Murray v. Graham, 29 Iowa, 520; McRaven v. Crisler, 53

T The portion of the opinion relating to the third question is omitted. - C. 
Miss. 542; Foote v. Hambrick, 70 Miss. 15\%.) It was early held in Bowers v. Jewell, (2 N. H. 545,) that "it is reasonable and just to permit a party to show that the alteration was by consent of those interested, was by accident, or under circumstances rebutting every presumption of improper motives." In Lewis v. Schenck, supra, the agent of the payee altered the note soon after its exeeution, in the absence of the makers, by inserting the words "with interest from date," honestly believing that he could legally make the change to correspond with what he supposed to be the real agreement of the parties, entered into prior to the execution of the note; and it was held that the alteration was under a mistake of fact, and the plaintiff was permitted to recover. In Croswell v. Labree, supra, the words "or bearer" were inserted by the payee after delivery, and without the knowledge or consent of the maker. It was ruled by the lower court that if the alteration was made innocently, without any fraudulent or improper motives, it would not aroid the note, and the ruling was sustained by the Supreme Court. And in Duker v. Franz, supra, the change was from " 1868 " to " 1869 ," by making a " 9 " over the " 8 ," and it was held that it did not destroy the legal effieacy of the note.

We think the following deduction is within the eases: That where the alteration is prompted by honest and pure motives, with a purpose of correcting the instrument to correspond with what the party honestly and in perfert goor faith believed to be the trne engagement of the parties at the time of the exerution, the act does not destroy the legal efficacy of the note, and rerovery may be had upon it when restored. See Rogers v. S'haw, supra: Kountz v. Kemnedy, 63 Pa. St. 187 , and Horst v. Wagner, supra. We come the more readily to this (onclusion in view of our statute, which makes it incumbent upon the party producing a writing appearing to have been altered after its execution, in a part material to the question in dispute, to accomnt for the alteration before he will be permitted to give it in evidence. He may explain the alteration by showing that it was made by another withont his concurrence, of was made with the consent of the parties affected by it, or otherwise properly or innocently made. (Iill's Amn. Laws Or. § 788.)

Now, it is perferetly apparent that Mrs. Wallace was not impellerl by any framlulent motior in making the rhange in the date of the note sued upon. It is also just as apparent that she was acting under an honest misapprehension of her right to make the ehangre to correspond with what she supposed to he the arerement with 'Tire and Herrall to loan them $\$ 2,000$ for one year, and that, in order to make the contract conform to what she understoot the agresunent to be - that is, to ban the monoy for a full year - she made the ehame, intending it for the henefit of the makers. It was of no benefit to her, but. on the contrary, operaterl as a real dotriment ; of smoll proportions it may be, but it was actual and patent. If it were adjudged that for such 
an act, prompted solely by the purest motives, yot involving a misapprehension of the right and anthority to lo the ant, the suitor should he turmed ana remediless, the result would be an obvious and palpable failure of justice in a creat majority if not in every instance.

'The remaining question, fouching the jurisliction of a court of equity to rntertain the suit, is not entirely free from doubt. But as the art which it is claimed avoids the instrument was done under mistake and misapprehension, and the suit involves a discovery which is in some degree necessary to show the agreement and the mistake, the jurisdiction onght to he sustained. Such is the exact ruling of Lewis v. Schenck, supra. Sec, also, Nickerson v. siwett, 135 Mass. 514. The deeree of the court below will therefore be affirmed. ${ }^{8}$

\section{\$205 MeKEEHAN, TIIE NEGO'TIAPLE INSTRUMENTS LAW.}

[41 Am. Law Reg., N. S., pp. 580-582.]

THF criticism of this section $\left[\mathrm{N} . \mathrm{Y}^{\mathrm{T}}, \S 205\right]^{9}$ is contained in a note published subsequent to the articles in the Harvard Law lieview and is based upon the case of Jeffrey v. Rosenfeld, ${ }^{1}$ decided by the Supreme Court of Massachusetts in September, 1901.

8 "We concede and affirm as a legal proposition that the payee or holder of a promissory note has no right or antluority, without the consent of the maker or makers thereof, to make any material alteration of the note for the purpose of correcting any mistake that may late been marle in the execution thereof, unless it is shown that the alteration or change is made to correct the note so as to make it conform to what all of the parties thereto agreed or intended it should have been. An alteration for such purpose and to such extent the great weight of anthorities sanction, and hold that it may be made without elestroying the legal effect of the note or instrument." Jordan, J., in Osborn v. Hall, 160 Ind. 153, 159, where recovery was allowed on the note itself.

Contra, Merritt v. Dewey. 218 Ill. 599, where Seott, J., at p. 605, said: "One party to a written instrument which does not speak the actual contract of the parties does not have the right to alter the inctrument to make it accord therewith. If the right to so make such an alturation existed, the jurisdiction and power of a court of clancery to reform writen contracts which inaccurately state the undertakings of the partios would be entirely useless." - C.

9 Section 64 of the English Bills of Exchange Aet reads:

"Wherr a bill or acceptance is materially altered withont the assent of all parties liable on the bill, the bill is avoided, except as against a party who has himself madr, authorized, or assented to the alteration, and subsequent indorsers.

"Provided, that where a bill has heen materially altered, but the alteration is not apparent, and the bill is in the hands of a holder in due course, such holder may avail himself of the bill as if it had not been altered, and may enforce parment of it according to its original tenour."

1179 Mass. 506. 
At the common law, the material alteration of a negotiable instrument without the assent of all parties liable thereon aroided the instrument except as against a party who made, anthorized or assented to the alteration, and sulsequent indorsers. The rule applied to an alteration made by a stranger as well as to an alteration made by a party to the instrument. Section 64 of the English act perpetuates the common law rule with the exception of a proviso inserted for the benefit of a holder in due course, under which he may enforce, according to its original tenor, a bill which has been materially altered, if the alteration is not apparent. 'The proviso, however, does not concern us in this discussion.

The American courts early changed the common law rule to the extent of holding that an alteration made by a stranger was a mere spoliation or tresprass, and that the holder could still enforce the instrument in its original form. Now section 12t of the American act is practically the same as section 64 of the English act. Therefore, says Professor Ames, we are in this dilemma: "Either the English and American sections, although expressed in the same terms, must be interpreted differently, or else the American law is changed, and, as it seems to the writer, for the worse. To avoid the second horn of the dilemma involves great straining, not to say perversion, of simple English words."

How one can see any ambiguity in section $124\lceil\mathrm{~N}$. Y., \$ 205] is a mystery. It reads: "When a negotiahle instrument is materially altered *** it is avoided," etc. An alteration made by a stranger is not excepted, and certainly it is none the less an alteration hecanse made by a stranger. 'To say that such an alteration is not covered hy section 12.1 womld he, as Professor Aines says, "a creat straining, not to say perversiou, of simple Euglish words." .Tudg:" Brewster agrees with the critie on this point. The only person who has ever suggesterl a donbt as to the meaning of this sertion is Mr. Instice Morton, who wrote the opinion in Jeffrey v. Rosenfold. supra. In that ease, a note secured by a mortgage was altered, though by whom did not appear. On a bill in equity to rest rain the forerelosule of the mort aratere, the court sustained the holdar's right to foredose without interpreting section 12.1 of the codse, though Juetice Mortom, in an obiter dictum of some length, remarked that the anestion of its interpretation was one that deserved serious considerations. After peferring to the anthorities in this country which derided that a matorial alteration made by a stranger will not aboill the instrument, lar alle: "It would seem not unreasomalile to suppose that it was the intention of the framers of the Ameriean art that section 194 should be construed aferording to the law of this country ruther than that of Fugland." As a gruerality, that remark is profoundly true and applies to all the sections of the new art. Thro shomla he conctrued areording to Amerioan law rather than English law. As applieahle to the particular point under dis- 
eussion, however, the remark is of small value. If the language of section $1: 2$ is clear and nmmistakable, it shonld be given its plain meaning. 'To construe it according to American law does not mean to knock it down simply because it changes American law somewhat. 'The learned judge points ont no ambiguity in the language of this section. His sole reason for dombting its very plain meaning is that it changes the law. As a matter of fact, we learn from Judge Brewster that it was intended to rhange nne law; that Mr. Crawford reported to the conference in 1896 in faror of adopting the common law rule as to alterations by a stranger, in order that the law of the two countries might be uniform on this important point, and in order that the benefit of written evidence might be preserved. 'This view was approved by the conference, and section 124 was inserted to restore the English rule.

Professor Ames thinks that the change is for the worse, though he vouchsafes no reasons. Under such circumstances, the profession cannot be blamed for accepting without question the judgment of the learned and experienced experts who drafted the new act. But at all events there is no ambiguity in this section. Its meaning is ummistakable.

\section{§205 NATIONAL EXCHANGE BANK $v$. LESTER.}

194 New York, 461. - 1909.

Appeal from a judgment of the Appellate Division of the Supreme Court in the third judicial department, entered May 16, 1907, affirming a judgment in favor of plaintiff entered upon a verdict and an order denying a motion for a new trial.

The defendant was sued as the accommodation indorser upon a note for $\$ 375$ made by one Frank L. Fancher and acquired by the plaintiff bank before maturity in the regular course of its business.

The defense was that the note as originally made and indorsed was for $\$ 55$ only; that the maker thereafter, without the knowledge or consent of the indorser, altered the note by insorting in the body thereof the words "Three humbred" immediately in front of the words "Seventy-five" and the figme " 3 " immerliately in front of the firmes "75," thereby making the instrument apparently a note for $\$ 375$ instead of $\$ 75$ : and that the maker thereafter eaused the note as thus altered to he discounted by the plaintiff bank. The answer prayed judgment that the complaint he dismissed except as to the amount of the note before alteration, together with interest and protest fees, to wit, \$78.66. The defendant also served an offer to allow the plaintiff to take judgment for that amount.

Upon the trial the rourt charged the jurv that if the note indorsed by the defendant was in fact a note for $\$ 375$ on its face, the plaintiff was entitled to recover that anount and interest. 
The trial judge further charged the jury that if they found that there were spaces upon the note " so carelessly and negligently left by this indorser, Mr. Lester, that a person having custody of the note might run in a figure 3 and the words 'Three hundred' so as not to occasion in the mind of the indorser [evidently meaning indorsee] any inquiry into its validity," they might find that the indorser conducted himself carelessly and negligently in the premises and thus invited the liability which the face of the note called for when presented to the bank.

The defendant duly excepted to that part of the charge to the effect that if the defendant was negligent in leaving blank spaces, the jury must find a verdict for the plaintitf for the full amount of the note as it stood. The court then reiterated the proposition, saying that "if the jury find that the defendant was careless and negligent in leaving vacant spaces for the words and figures, such earelessness and negligence on his part would still make him liable for the note; " and to this the defendant also excepted.

The jury found for the plaintiff in the sum of $\$ 375$, with interest. The judgment entered upon the verdict has been unanimously affirmed by the Appellate Division.

Wiliard Bartiett, J. - As this case went to the jury, they might well have found that the note in suit was a note for only seventy-five dollars when originally prepared by the maker and indorsed at his instance by the defendant, and that it had subsequently heen altered to a note for three hundred and seventy-five dollars when discounted by the plaintiff bank. They were instructed in substance, however, that the indorser was liable for the amount of the note as raised by the alteration, if he had been eareless and negligent in placing his name upon the instrument while there were spaces thereon which permitted the insertion of the words and figure whereby it was transmuted from a note for seventy-fice dollars into a note for three hundred and seventy-five dollars. C'onceding that the contract which he actually signed bound him only to pay the smaller amount, the jury were permitted to find that in conserpuener of his negligence in the respect indicated it had herome a contract which bound him to pay the larger amount to a subseguent innowent holder of the paper.

In support of the enreetness of this ruling. the learned rounsel for the respondent asserts the doctrine that "a party to a note who puts his name to it in any rapacify of liability, when it rontains blanks uncanceled facilitating an alteration raising the amount, is liable for the face of the note as mised to an innorent holder for value;" and he declares that this doctrinc has been approved and apparently adopted in Alahama, California, Coloralo, Mlinois, Kansas, Kentucky, Louisiana, Michigan, Missouri, Nobraska and Pennsylrania.

In considering his proposition. it is important on bear in mind a radical distinction which exists hetween two classes of notes to which 
the adjudicated cases relate: (1) Those notes in which obvious blanks are left at the time when they are mate or indorsed, of such a character as manifestly to indicate that the instruments are incomplete until such blanks slatl be filled up; and (:) those notes which are apparently complete, and which can be regarded as containing blanks only because the written matter loes not so fully ocempy the entire paper as to preelude the insertion of additional words or figures or both. It is a note of the latter class that we have to deal with here. One who signs or indorses a note of the first dase has been held liable to bona fide holders thereof, in some of the cases eited hy the respondent, according to the terms of the note after the hanks have been filled, on the doctrine of implied aulhority, while in other cases, relating to notes of the second class, the liability of the maker or indorser for the amount of the note as increased hy filling up the unoceupied spaces therein, is placed upon the loctrine of negligence or estoppel by negligence.

The cases cited by respondent in which parties to commercial paper executed by them while obvious hanks remained unfilled thereon have been held liable upon the instrunent as completed by filling out such blanks on the ground of implied authority, require no further consideration here, as there is no suggestion that there was any blank of this character upon the note in suit. These eases are Winter $\mathbb{E}$ Loeb v. Pool (104 Ala. 580 ;) Statton v. Stome (61 Pac. Rep. 481, Colorado); Cason v. Grant Co. Deposit Bank (9r Ky. 48\%), and Wcidman v. Symes (120 Mich. 657). There were obvions blanks also in the notes under consideration in Tisher v. Webster (S Cal. 109) and Lowden v. S. C. Nat. Bank (38 Kan. 533), and the derision in each of these cases appears to have proceded upon the doctrine of implicd authority rather than negligence.

It must frankly be coneerled, however, that the respondent finds support for the doctrine which it asserts in the case at har in the decisions of Pennsylvania, Illinois and Missouri, so far as the maker of commercial paper is concerned, and in those of Kentucky and Louisiana, in respect to the liability of a party who has indorsed or become surcty on a note in which there were spares (not obvious blanks) that permitted fraululent insertions enlarging the amount. (Garrard :. IIaddan, 67 Pa. St. 8: ; Yocum v. S'mith, 6:3 Ill. 321 ; Scolland Co. Nat. Bank v. O'Commel, 23 Mo. App. 165; Hackett v. First Nat. Bank of Louisville, $114 \mathrm{Ky} .193$; Isnard v. Torres of Marquez, 10 La. Ann. 103.)

In Farrard r. IJaddan (snpra) a space was left between the words "one hundred" and the word "dollare" in which "fifty" had been inserted after the maker had signed and delivered it; and the court held the maker answerable to a bona fide holder for the full face of the note as altered on the aromud of the negligence of the maker in leaving the space in the note which was thus filled up after execution. 
"We think this rule is necessary," said Chief Justice Thompson, "to facilitate the circulation of commercial paper and at the same time increase the care of drawers and acceptors of such paper, and also of bankers, brokers and others in taking it." It is a little difficult to see how the rule tends to make bona fide purchasers more careful, as this last observation suggests.

The ease of Yocum v. Smith (supra) held the maker liable upon a note which had been raised after execution from one hundred dollars to one hundred and twenty dollars, the words "and twenty" having been inserted in a space left between the worl "hundred" and the word "dollars." The court said that the maker had acted with unpardonable negligence in signing the note and learing a blank which could so easily be filled: that he had thus placed it in the power of another to do an injury and that he must, therefore, suffer the resulting loss. This decision moloultedly sustains the position of the respondent, although there was another element of negligence in that ease which is not present here. It appeared that the maker there was informed by letter by the purchaser, very soon after the date of the note, that he had bought it and of its late and amount; yet he made no objection as to the amount until nearly a year later.

In Scotland Co. Mat. Bank v. O'Connel (suma) the defendants executed and delivered a note for $\$ 100$ to one Smith, the borly of which was in his handwriting, in a condition which enabled him to add the worls "thirty-five" after "one lundred" in the written part and put the figures "\$135" at the hear of the note in the space where the amount is usually indicaterl by figures. The St. Louis Court of $\mathrm{Ap}$ peals held that the dofondants wre liable for $\$ 135$ beeause they had delivered the note to Smith, whlo was their ro-worker, "in such a condition as to enable him to fill blank spares without in any manner changing the appearaner of the untr as a genuine instrument."

The rases thus far dierussed were all of them actions against the makers of the raisel paper. 'l'he same rule, howerer, was applied

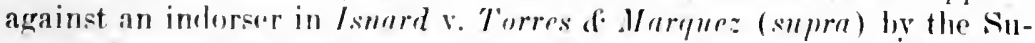
preme Court of Lotuisiana under the following riremuntanes: Marquez indorsed a note for $\$ 150$ for the areommolation of 'lorres. 'The

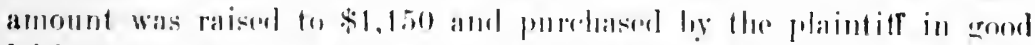
faith as a mote for that sum. The report states that there was frestimony of experieneed persons to the effere that if at the time of the indorsement the word anse (for eleren. the note heing in Fremch)

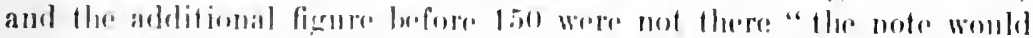
have exhibited blanke whicll at last with regard to the written part were umusual and colenlated fo altract attontion and would have renclered the note mesalahle in the market." In this opinion, "pon inspection of the note, the rourt expressed its full concurreme. Tha inclorser was held liable for the amount of the note as raised on the ground that he had not exercised the proper enution, 'To the same 
effect is Ilachett v. First Nat. Bamk of Louisville (supra), where it was held that a surety who had signed a note in which were written the words "five humdred" with spanes before and alter them, which tho maker had filled up by wriling "twonly" before and "fifty" after them, thereby making a note for $\$ 2, x 50$, was liable thereon to a purchasel in grood faith. In this case the attention of the Kentucky Court of Appeals was ealled to the lact that the great weight of anthority was the other way, hut in riew of the fact that the rule had been so estahlished in Kentucky for a quarter of a century the court determined to arlhere to it. in observance of the principle of stare decisis.

This court is not thus ronstrained. 'The question involved in the present appea! has not been authoritatively decided in this state and we are at liberty to allopt that view of the law which secms to us most consonant with sound reason and best supported by well considered adjudications in other jurisdictions.

The outcome of these adjudications is accurately set forth, as t seems to me, hy Mr. Randolph in his treatise on the Law of Cons. mercial Paper as follows:

"Where negotiable paper has been exeeuted with the amount blauk, it is no defense against a bona fide holder for value for the maker to show that his authority has been exceeded in tilling such blank. and: greater amount written than was intended. 'l'his was also once lield to be the rule where no blank had been actually left, but the maker had negligently left a space either hefore or after the written amount. which made it easier for a holder fraudulently to enlarge the sunı fir:t written. It has now, however, become in America an established rule that if the instrmment was complete without blanks at the time of itdelivery, the fraudulent increase of the amount by taking advantage of a space left without such intention * * * will constitute a material alteration and operate to discharge the maker." (1 Randolph on Commercial Paper, \& 18\%.)

The rule thus stated is sustained by the decisions of the courts of last resort in Massachusetts, Michigan. New Mampshire. Inwa, Marvland, Mississippi, Arkansas and South Dakota. In my judement it rests on a sounder hasis than the opposite doetrine and accords better with such adjudications of this court as bear more or less directly on the question involved.

The leading case sustaining this view is Greenfield Savings Bank: v. Stoucll (12.) Mass. 196), in which the opinion was witten by Chief Justice Gray, afterward an Associate Justice of the Supreme Court of the United States. The diseussion is careful and exhaustive, reviewing all the important cases in England and America hearing upon the subject which had heen decided up to that time $(18 \% \%)$, including that of the Supreme Court of Pennsylvania in Carrard v. IIaddan (supra), which was the principal antliority the other way. I shall not undertake to review the same authorities here or paraphrase the opinion of 
Chief Justice Gray, which deals with them in such a manner as fully to justify his rejection of the doctrine that the makers of a promissory note apparently complete when they sign it are liable for an amount to which it may subsequently be raised, without their knowledge or consent on the ground that they were negligent in permitting spaces to remain thereon in which the figures and words which effeeted the increase could be inserted. In support of his conclusion, however, he quotes some passages from the opinion of Christiancy, J., in Holmes v. Trumper ( 22 Mich. 427 ) which will bear repetition as suggestive of some of the reasons why the forgery of a promissory note should not be held to create a contract. which the party sought to be charged never conseiously made himseli or authorized anybody else to make in his behalf. Speaking of the alleged negligence in leaving spaces on the note, Mr. Justice Christianey said: "The negligence, if such it can be called, is of the same kind as might be claimed if any man, in signing a contract, were to place his name far enough below the instrument to permit another line to be written above his name in apparent harmony with the rest of the instrument; * * * Whenever a party in good faith signs a complete promissory note, however awkwardly drawn, he should, we think, be equally protected from its alteration by forgery in whatever morle it may be accomplished; and unless, perhaps, when it has been committed by some one in whom he has authorized others to place eonfidence as acting for him, he has quite as goor a right to rest upon the presumption that it will not be criminally altered, as any person has to take the paper on the presumption that it has not heen; and the parties taking such paper must be considered as taking it upon their own risk, so far as the question of forgery is concerned, and as trusting to the character and credit of those from whom they receive it, and of the intermediate holders."

While a general reference to the cases cited and reviewed by Chief Justice Gray in Greenfield Sarings Bant. v. Stowell (supra) will suffice, there are some later decisions to which attention may be called. In Knorville Nat. Bank v. Clark (51 Iowa, 261) will be found a strong and well-reasoned opinion against holding a party to a note which has been fraudulently raised, after it left his hands, liahle for negligence, because when he exerntel the instrument there were spaces left thereon (not heing obvions hanks designow to be filled) whieh would permit of forgery. The trial court had rendered judgment against the maker for the amount of the note as raised from $\$ 10$ to $\$ 110$ on a finding of negligence in leaving a space before the word "ten" and the figures "10." "On this ground," said the Supreme Court of Iowa, "the court proceseded and the decision is hased on the reasoniner of the civil lawyres. But could it he anticipated that such negligence would calise another to rommit a crime, and ran it he said a person is negligent who does unt anticipate and provide against the 
thousand was throwgh or hy which crime is committed? Is it not repuiring of the ordinary husiness man more diligence than ean he mantained on principle, or is praticalse, if he is repuired to protect and grund his husiness transactions so that he camnot be held liable for the criminal acts of another. If so, why should not the negligence of the owner of goods which are stolen excuse the bona fide purchaser:" And referring to the argument that such a measure of liability is required to promote the free inferrlange of commereial paper (a viow which secms to have been influential in the Pennsyliania case of fiamed r. Iladelan) the court well said: "At the present day negotiable paper is not orlinalily freely recoived from unknown persons. Forgeries, however, are not coufined to such. But the necessitics of trade and commeree do not repuire the law to be so construed as to rompel a person to perform a contract he never made and which it is proposed to fasten on him because some one has committel a forgery or other crime."

In Burrou's v. Klunl: ( 50 Md. 451) the Maryland Court of Appeals emphasizes the distinction between a note in blank as to the amount, when signed and delirered to another for use, and a note complete on its face when signed and delivered, in which has been written the sum payable, the date, time of payment and mame of the payee. "In such case," it is beld, "there ean be no inference that the defendant authorized any one to increase the amount, simply because blank spaces were left in which there was romm enough to insert a larger sum."

No one questions the proposition that where a party to commercial paper intrusts it to another with a blank thereon designed to be filled up with the amount such party is liable to a bona fide holder of the instrument for the amount fillel in, though it he larger than was stipulated with the person to whom immediate delivery was made. (Van Duzer v. Howe, 21 N. Y. 5i31.) So, also, a note executed with a blank therein for a statement of the place of payment is not a voided in the hands of a boma fide holder for value by the insertion in the blank of a place different from that agreed upon by the original parties. (Redlich v. Doll, 54 X. Y. 234.) But where there is no blank for that purpose when the note is indorsed, the insertion of an obligation to pay interest is a material alteration which invalidates the instrument as against the indorser. (MeGralh v. Clark, 56 X. Y. 34.) In the case last rited the note when indorsed ended with the word "at," followed by a space in which the maker, after indorsement, inserted a place of payment, arding the worls "with interest;" hut no suggestion appears to have bren marle that hecause the space left was large enough to allow the insertion of these words, the indorser was negligent and could be rharged with the amount of the note, including the interest, on that ground. On the contrary, as the law then stood, he was relicved of all liability whatever as the effert of the unauthorized alteration, Now, however, under the Negotiable Instruments Law. 
( $\S 205$ ) he would be liable on the paper according to its original tenor.

To sustain the judgment in the case at bar in view of the instructions under which the issues were submitted to the jury, we must hold that the indorser of a promissory note, the amount of which lias hoon fraudulently raised after indorsement, by means of a forgery, is liable upon the instrument in the hands of a bona fide holder, for the increased amount, because of negligence in indorsing the same when there were spaces thereon which rendered the forgery easy, though the note was complete in form. To do this would be to create a contract through the agency of negligence; for the action is not in tort for damages, but upon the contract as expressed in the note. But apart from any question as to the form in which the indorser is sought to be charged, I am of opinion that no liability on the part of the indorser for the amount of such a note as raised can be predicated simply upon the fact that such spaces existed thereon. This conclusion I base upon the authorities to that effect which I have already discussed and upon what seem to me to be considerations of sound reason independent of judicial authority. An averment of negligence necessarily imports the existence of a duty. What duty to subsequent holders of a promissory note is imposed by the law upon a person who is requested to indorse the paper for the accommodation of the maker and who complies with such request? It is a complete instrument in all respects - as to date, name of payee, time and place of payment and anount. There are, it is truc, spaces on the face of the instrument in which it is possible to insert words and figures which will enlarge the amount and still leave the note apparently a genuine instrmment - in other words, there is room for forgery. On what theory is the indorser negligent because he places his name on the paper withont first secing to it that these spaces are so occupied by cross lines or otherwise as to render forgery less feasible? It can only he on the theory that he is bound to assume that those to whom he delivers the paper or into whose hands it may come will be likely to commit a crime if it is comparatively easy to do so. I deny that there is any such presumption in the law. It would he a stigma and refleretion upon the character of the mereantile community and constitute an intolerahle reproand of which they might well complain as without justifieation in practical experience or the conduet of business. That there are miscreants who will forge commercial paper by rasing the amount originally stated in the instrument is too true and is evidenered ly the cases in the law reports to which we have hat oceasion to refer: but that such misconduet is the rule, or is so general as fo justify the presumption that it is to be expected and that husiness men must govern themselves aceordingly, has never yet been aseerted in this state. and I an not willing to sanction any such proposition either directly or by implication. On 
the contrary, the presumption is that men will do right rather than wrong. (sice Bradish v. Bliss, 35 V't. 896.) As was said by Judge Cullen in Critten $\mathrm{S}$. Chemicul iat. Benle. (171 N. Y. 219, 224), it is not the law that the drawer of a check is hound so to prepare it that nohody else ean smeresfully tamper with it. Neither is it the law that the indorser of a promissory note complete on its face may be mate liable for the ensequences of a forgery thereof simply beeause there were spates thereon which rendered the forgery easier than would otherwise have been the case.

I think the judgment of the Appellate Division should be reversed and a new trial granted, with costs to abide the event.

Cullex, Ch. J., Gray, Haight, Werner, Hiscock and Cerase, J.J., concur.

$\S 205$

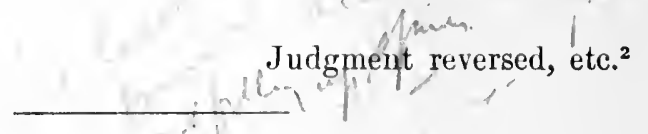

NOLL $v$. SMITH.

64 INDIA NA, 511 . - 1878.

Action against maker by indorsee. Defense, that the notes had when executed a condition annexed that they were not to be paid unless defendant sold machines equal to the amount of the notes, and that the notes had been altered by cutting off the portion containing the condition. Judgnent for plaintiff.

Niblack, J. [After stating the facts.] - We understand the general rule to be that the removal or detachment of a material condition annexed to, or forming a part of, a negotiable note, without the knowledge or consent of the maker, will ordinarily be a sufficient defence to such note, even in the hands of an innocent holder, and especially when such removal or detachment is made under circumstances which put the purchaser of the note fairly upon his inquiry as to the altered condition of the note, and this we construed to be the doctrine of the ase of Cochran v. Nebeler (48 Ind. 459), cited and discussed by the appellant; but that, when the note and condition are negligently so executed by the maker that the condition may easily be removed, without in any manner mutilating or defacing the note, and the note is thus, without objection, put in circulation in that form, the maker cannot he heard to deny his liability to pay the note in the hands of an innocent holder, notwithstanding the condition may have been detached from it before such innocent holder became the owner of it. Such was, in substance, the decision of this conrt in the case of Cornell v. Nebeker (58 Ind. 425). See, also Woolen v. Ulrich (61 Ind. 120), approving and following that case.

2 This case is reported with notes in 21 L. N. S. 402 , and in 16 A. \& E. Ann. Cas. 770. $-\mathrm{C}$. 
Upon the authority of these last named cases, the judgment in his case will have to be aftirmed.

'The judgment is attirmed, with costs.'

$\S 205$ Brown $v$. ReEd, 79 Pa. St. 370. -1875 . The original instrument was as follows:

NuRTh EAst April, 3d, 1872.

Six months after date I promise to pay to J. B. Smilh or bearer fifty dollars when I sell by order Two Hundred AND FifTr DOllars worth of Hay and Harvest Grinders, for value received, with legal interest, without appeal, and also without defalcation or stay of execution

T. H. Brown. Agent for Hay and Harvest Grinders.

s Such an alteration is material and will prevent recovery by boma file holders. Scofield v. Ford, 56 Iowa, 370; Hait v. Pomeroy, 20 Mich, 425; Benedict v. Couden, 49 N. Y. 396 ; Gerrish v. Glines, 56 N. H. 9; Stephens v. Davis, 85 Tenn. 2il. Negligence of the maker may, however, estop him from setting up the alteration. Harvey $r$. Smith, 55 Ill. 224; Seibel v. Vaughan. 69 Ill. 257; Phelan v. Moss, $67 \mathrm{~Pa}$. St. 59; Zimmerman v. Rote, 55 Pa. St. 18s. - H.

IUnder $\$ 205$ of the Negotiable Instruments Law, the holder in due course is, of course, permitted to recover on the instrument " according to its original tenor." See Bothell v. Schweitzer, 120 N. W. (Neb.) 1129. A note to this case in 22 L. N. S. 263, says in part: "Prior to the adoption of the uniform Negotiable Instruments Law, which permits a bona fide holder not a party to the alteration of the instrument to recover according to its original tenor, it seems that the detachment of a paper originally attached to a bill or note, and modifying the terms thereof, either had the elfect to render the instrument void, even in the hands of a subsequent bona fide holder, and prevent any recovery thereon, or to entitle such a bona fide holder to recover according to the tenor of the bill or note, and without reference to the conditions in the detached paper. In other words, the courts did not adopt the middle ground contemplated by the provision of the Negrotiable Instruments law already referred to. In some of the cases holiling that there could he no reovery at all, for the reason that the detachment of the paper constituted a material alteration avoiding the bill or note even in the hands of a bona fide holder, the conditions contained in the detached paper would themselves have propented a recovery, so that the result was the same as if the eourt had been of the opinion that the bona fide holder touk the instrument subject to the conditions in the detached paper. This fact, however, can scarcely limit the offect of the express language putting the decisions on the other ground. A reference to the ease note to National Exch. Bank s. lester, 2l l. L. A. (N. S.) 4(B2, as to the duty of the indorser, maker, or surety of the emmereial paper to see that spaces are filled so as to prevent raising. discloses the same trindrney on the part of the courts, prior to the aldeption of the Negutiable Instruments Law, either to fermit a recovery aceoreling to the tenor of the instrument as a)tered, or to deny a recowery aven aneorling to the oripinal fenor. There is some conflict among the courta as to the citfect of the removal of such a piajer upon the rights of a subserpunt bona fide holder, some holding liat it vitiatos the instrument exen in the handes of a bena fold holdere, while others allow a recovery. Doubtles the faets with respet fo megligures will lisejpate some, though not all, of the apparent conlliet among the eases on this point." See also the note on "Instruments ko executed that a portion thereof may be detached or altured," in $11 \mathrm{Am}$. St. liep. 317.-C.]

NEOOT. INATRUMENTB - 10 
The instrument offered in evidence was the left hand portion of the above, which bore the indorsenent " J. B. Smith." The paper had been ant in two without Browns knowledge. Paintiff was a hokler in due comlso of the negotiable portion. Defendant offered to prove the alteration, and the ollere was rejected.

Ileld: "Ilhother there was negligence in the maker was elearly a question of lact for the july. 'The line of demareation between

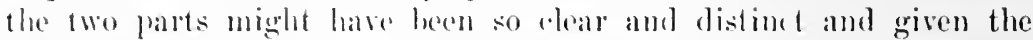
instrument so mustal an aplualumere as ought to have arrested the attention of any prublent man. But it may have been otherwise. If there was no nergligence in the malier, the rood faith and absence of negligence on the part of the holder rannot avail him. 'The alteration was a forgery. and there was nothing to estop the maker from alleging and proving it. *** $*$ We think then that the evidence offered by the defendant below should have been received." "

\section{Discharge of party secondarily liable.}

50 Miscellaneous (N. Y. SUP. C'T., APP. T.) 592. - 1906.

Appeas by the plaintiff from a judgment for the defendant and also from an order denving plaintiff's motion for a new trial.

Gilderslenve, J. - The action is on a promissory note against the defendant, 'Thomas J. Shea, as maker, and defendant, Annie A. Shea, as indorser. Said 'Thomas.J. Shea, the maker, does not defend the action. There is a very sharp conflict of evilence as to the facts, and the jury found for the defendant. Plaintiff appeals. It is conceded that, before maturity, the indorsement of said Annie A. Shea was canceled. 'This was done by a representative of defendant's attorney who seratehed ont the indorser's name in the presence of plaintiff. The parties were negotiating with respect to claims of each against the other, and it is the contention of defendant that as a part of a compromise plaintiff eonsented to the cancellation of said indorsement. Plaintitf, on the other hand, claims he never authorized such cancellation and protested arrainst the same. He further claims that there was no consideration for such cancellation. Even so, if he did, in point of fact, authorize and agree to this cancellation, the indorser was released, as a person secondarily liable on a negotiable instrument is discharged "by the intentional cancellation of his signature by the holder." Neg. Inst. Law, \$ 201; Larkin v. Hardenbrook, 90 N. Y. 333; Sichuartzman v. Post. 94 App. Div. 474. The

4 See the preceding note as to the effect of the Negotiable Instruments Law. $-\mathrm{C}$. 
fact that the erossing out of the indorser's name was made not by the plaintiff personally, but by defendant's representative in his presence, was a fact which the jury might have considered in determining whether the plaintifl"s or the defendant's version of the facts was the correct one. 'They believed the defendant's version. It is not sufficient for the purpose of a reversal, on the irround that the result is against the woiglt of eridenee, that the Appellate ('ourt maly have rearhed a different conclusion upon the facts than that arrived at by the jury, if there is sulficient evidence to support the verdict. In orrer to justify a reversal it must clearly appear that the fair preponderanre of proof is really on the side of the defeated party. (Lorenz v. Jarkson, so Hun. 200: ('linton v. Frear, 10\% App. Div. 571.) In the rase at har, there is comsilcrable evidene, which. if lelieved, justifies the verdict. 'This ardence the jury were at liberty to believe, and the Appellate Cont does not feel warranted in setting aside the verdict. The learned rommere for the alpellant ureses that the court erroneously (charged as follows: "Whenever any signature on a note appears to have leden canceled, the burden of proof lies upon the party who alleges the cancellation was made under mistake or withont anthority; and, therefore, the platintilt in this case has the burden of proof to estal,lish that firet." There was no error here. 'The Negotiable Instruments Law, cortion 201, provides that: "A cancellation marle unintentionally, or imler a mistake, or without the authority of the boleler, is inoperative: lunt where an instrument, or any signature thereon, apprar: to have been canceled, the burden of proof lies on the party who allerese that the aneellation was made muntentionally or under a mistalie. or without anthority." In the rase at har, the sig-

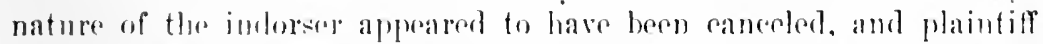

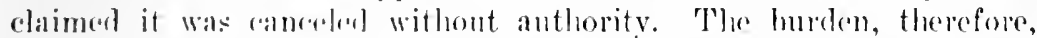
was on lim to show that it was so canceled without authority. There are no other exerptions that reepuire disconssion.

'The judgment and onder appealed from must he allirmed, with costs.

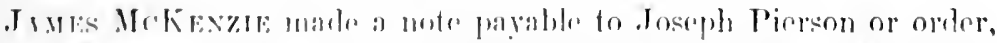

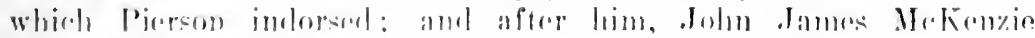

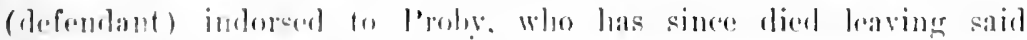

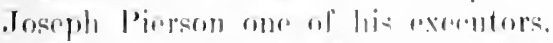

Piorson is now, as Prolyes cyecontor, plaintiff in an action neainst

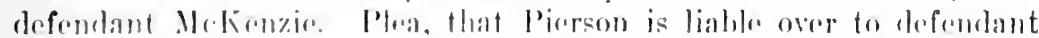

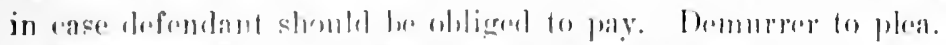

Rousisos, C. J., delivered the julgunent of the court. 
The plea does not take the exception, that Pierson is discharged by being made exeentor by Prohy. It would seem to be quite elear, that if l'ierson were the maker, the debt would be discharged, for it would, als to the creditors, be regarded as assets in his hands, as executor, and so there conld be no remedy against this indorser."

We cannot hold the effect to be different, becanse Pierson, instead of being maker of the note, is an indorser, but prior to this defendant's indorsement. The effert is the same as if Pierson had paid the debt to the executors, or had been released without payment, after which there could he no remedy against any subsequent indorser.

As we see this to be the state of facts on the record, we must give judgment on demurrer for the defendant: for the objection is of that nature, that it goes to the very right of action and cannot be overlooked by us. (4 Scott's N. R. 287; 3 Esp., c. 46 ; 2 B. \& P. 62; 9 B. \& C. $130 ; 4$ M. \& Ry. 22 ; Co. Lit. 264 (b), note 209 ; 1 Wil. 46 ; 2 BI. Rep. 1236 ; + T'. R. 825 ; 2 Showers, 481 ; Story, Prom. Notes.)

Per Curiam. - Judgment for defendant on demurrer. ${ }^{6}$

s Discharge by Operation of Law. - A transfer to acceptor or maker as executor of holder extinguishes the paper. Freaklcy v. Fox, 9 B. \& C. 130 . To the wife of the aeceptor or maker at conmon law. Abbott v. Winehester. 105 Mass. 115. Or, after the marriage of a woman who has previously, while single, issued negotiable paper, a transfer to the lusband. Chapman v. Kellogg, 102 Mass. 246.

It seems that negotiable paper is not extinguiahed by a discharge in bankruptcy or the running of the statute of limitations, but is revived by a new promise so that a subsequent transferee is entitled to enforce it. Way $\mathrm{v}$. Sperry, 6 Cush. (Mass.) 238, citing eases contra.

So a debt barred by law is a sufficient consideration for a subsequent bill or note given for its payment. Wislizenus v. O'Fallon, 91 Mo. 184; Giddings v. Giddings, 51 Vt. 227; Stafford v. Bacon. 25 Wend. (N. Y.) 3S4; Jull v. Van Trees, 50 Cal. 547 ; In re Merriman, 44 Conn. 587.

A statutory bar to the enforcement of the con-illuation is not a bar to the enforcement of the hill or note, $c . g$., the statute of frauds. Jones v. Jones, 6 M. \& W. 84; Edgerton v. Edgerton, 8 Conn. 6; I'aul v. Stackhouse, 38 Pa. St. 302. Contra: Hooker v. Knab, 26 Wis. 511 ; Combs v. Bateman, 10 Barb. (N. Y.) $573(\mathrm{srmble})$. ('f. Raubitschek V. Blank, 80 N. Y. 479. - H.

- Any voluntary aet, or perhaps omission, of the holder which discharges a prior party (principal) will discharge a subsequent party (surety). Allowing statute of linitations to run in favor of principal or prior party. A uchampaugh v. Sehmidt, 70 Iowa, 642; Bridges v. Blake, 106 Ind. 332; Shutts v. Fingar, 100 N. Y. 539. Contra: Villars v. l'almer, 67 Ill. 204; Bull v. Coe, 77 Cal. 54; Banks v. State, 62 Md. 88; Moore v. Gray, 26 ()h. St. 525. Bringing an action against prior party resulting in judgment for, and consequent discliarge of, sueh prior party. Ames v. Maclay, 14 Iowa, 281; Baker v. Herriam, 97 Ind. 539; State v. Coste, 36 Mo. 437. But a discharge of a prior party by mere operation of law will not discharge the surety. Discharge in bankruptey. Phillips v. Wade, 66 Ala. 53; Lackey v. Steere, 121 Ill. 598; Post v. Losey, 111 Ind. 74; Cochrane v. Cushing, 124 Mass. 219; Linn v. IIamilton, 34 N. J. I. 305: Ilall v. Fouler, 6 Ilill (N. Y.) 630. Discharge by war. Bean v. Chapman, 62 Ala. 58. - H. 
46 VerMoxt, 258. - 1873.

Action on a note of which Hall was maker and defendant surety. Hall's administrator had tendered payment to plaintiff, which had been refused. Judgment for defendant.

The opinion of the court was delivered by -

RoYce, J. * * * The important question is, whether the defendant can avail himself of the benefit of the tender which the jury have found was made to the plaintiff. The obligation of the surety being accessory to that of the principal, the surety could not be called upon as long as the principal had done all that could be legally required of him in the performance of the contract. The tender which the jury have found was made, was legally sufficient, and would have been availahle as a defense in any suit the plaintiff might have instituted seeking a recovery out of the estate of IIall, and we think it is equally available to the defendant. When a dehtor tenders payment of the debt for which the surety is obligated, and the creditor declines to receive it, he thereby discharges the surety. The judgment of the county court is affirmed. ${ }^{7}$

\section{$\S 201$}

\section{ROCKVILLE BANK $v$. HOLT.}

58 Cosiecticur, 526. -1890.

Action against the defendant as indorser of sundry notes and hills of exchange; brought to the Superior Court in Tolland county, and tried to the court hefore 'Torrauce. J. Facts found and judgment rendered for the plaintiff, and appeal by the defendant. The ase is fully stated in the opinion.

Axonews, C'.J. - The L. B. Sinth Rubber Company, a corporation doing business at Setanket, Now York, heing indehted to the dofondant, gave him three promisooly notres, and accepted three hills of ex-

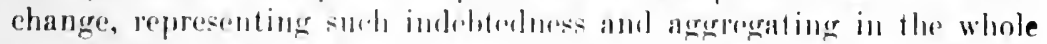
something more than five thomsand follars. All of the notes and billo were payahe to the order of the defomblant, were hy him indorsed, and at his rerguest were disounterl for his lunefit hy the plaintif?. Shortly thereafter the Rubluer fompany failed. 'Thait faibure compelled the defomlant to ger into insolviney. The plaintiff presented its claim against his insolvent estate and rercived a dividend thereon. The defendant having since that time arouimed other property, the plaintiff hrought this suit and altached such other property. Since the

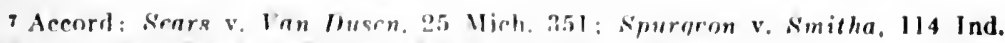
463. Contra: Clark v. Sickler, (it N. I. 231. - 11 . 
bringing of this suit the plaintill, in common with nearly all the creditors of the 1. B. Simith linhber ('ompany, incholing the defendant, signed an aglerment whichl is fully sef out in the finding, but which it is not necessily here to repeat. For the purposes of the present distussion it is sutlicient to sily that that arreement provided, among varions of her thines, that the creditors of the rubber company should assign their raims to ectain jersons called a reorganizing committee, and that this committer should proceed to reorganize the company and should issue to atch of the several areditors in payment for their respertive chims the stock of the reoreanized company, which the creditors andered to areat. When the plaintiff signed the agreement it added to its signature: - "reserving all rights against R. G. Holt, or against his astate, or assignee for the henefit of his creditors." 'l'hese words did not appear in the body of the instrument.

The defendant insists that hy signing the agreement the plaintiff assigned all its chams against the L. B. Smith Rubler ('ompany to the reorganzing committer, and that as he is liable to the plaintifl only as a surety for that company the assignment of the claim against the principal debtor discharges him.

That an mnyulified relase of a principal debtor will be a discharge also of the surcty is almittedly good law. The plaintiff, however, claims that by the reservation appended to its signature it is not afferefel by that rule. The defondant cites two eases, either of which by its tems fully supports his contention. But the authority of each of these eases is greatly weakened, if not entirely overturned, by later decisions in the same juriseliction. Webb r. IJewitl (3 Kay \& Johnson, 138), is substantially overmled by Green v. Wym (T. R. 7 Eq. Cas. 31, and T. R. \& ('h. Apleals, 201), and Farmers' Banl. v. Blair (14 Barbour, 611), by lorgan r. Smith (70 X. Y. 5t5) ; Colvo v. Daries (73 N. Y. 211): Nol. Banli v. Bigler (83 N. Y. 51), and Shutts v. Fingar (100 N. Y. 5.3!. )

It is stated in I)e Colyar on Principal and Suroty (118), that such a reservation as was made by the plaintill prevents there heing any discharge of the surety. and grives as authority: (Kearsley v. Cole.

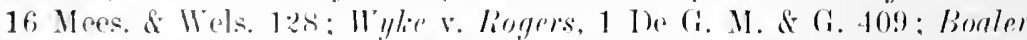
v. Mayor, 19 ('. P. X. S. 76, S1: Ompn v. Homan, 4 II. L. Cases, 997;

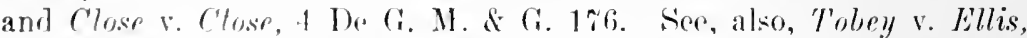
$11+$ Mass. 120; Kenworthy 5 Sanyor. 125 Id. 29: Banli v. Linelserger,

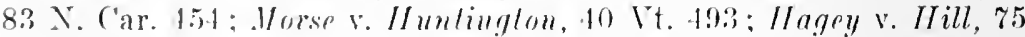
Penn. St. 108: Wueller v. Mobselluelz, s.) Hll 186.) The weight of authority seems to us to be strongly adverse to the defomdant's claim.

There is anothror siow of the rase which makes it rear that the defendant is not entitleel to a dischareo by reason of the plaintiff's signing the agreement. Whenever a ereditor gives time to, or makes a 
new contract with the principal debtor, of which new contract the surety has knowledge and to which he assents, he is not thereby discharged. (Adams v. IVay, 32 Conn. 160; Corlies v. Estes, 31 Vt. 653; Smith v. Winter, 4 Mees. \& Wels. 45t.) The tomposition agreement was beneficial to all the reditors of the L. B. Smith Rubber Company, provided all entered into it. The defendant and his trustee in insolvency signed it before the plaintiff did. It was obviously for the advantage of each that the other should sign. Without some such arrangement neither could ever hope for any payment from that company. With such an arrangement there was a chance that they might both be paid in full. 'The plaintiff signed with the knowledge that the defendant and his trustee hal previously signed. A romposition deed implies not only an agreement of the dehtor with each of his creditors, but also an arrangement by earb ereditor with each of the others. The signing of such a deen by any ereditor is in some measure a request to all the others to sign also. 'The circmustances of this case show pretty clearly that the defendant knew of and assented to the act of the plaintitl in signing the agreement.

There is no error in the julgment complained of.

In this opinion the other judges coneurred. ${ }^{8}$

\section{§ 201 CONTINENTAL IIFE I NSURANCE CO. v. BARBER.}

\section{CoNAECTICUT, $567 .-1883$.}

Carpenter, J. - This is an action against the executors of the estate of the late Gardner P. Barher, deceased, who, when in life, indorsed a note for $\$ 8,000$. 'The simperior C'ourt found the facts and rendered judgment for the plaintiff. 'The defendants appealed. 'The reonet presents three questions.

1. Was the indorser discharged hy the act of the plaintiff? The note fell due July 20 th, 18it. On the 2:d of October, 18\%t, the maker

sone who takes a bill as a hobler in due course. and afterwarals laarns that the drawer is the principal and the aceommonation areptor the surety. may nevertheless releass the drawer withont therehy discharering the ace

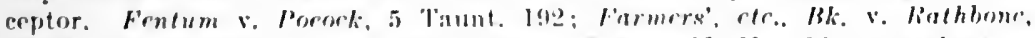
26) Vt. 19: Howrard ('o. v. Horlemisn, i limw. (X. Y.) 280; S'trphens v.

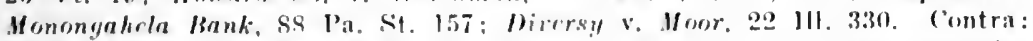

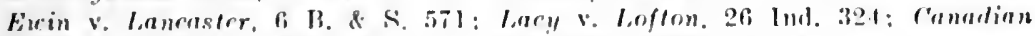
Bank v. Coumbe, 47 Micl. 358: Hall v, ronital Bank. 71 Ga. 715: Shellon v.

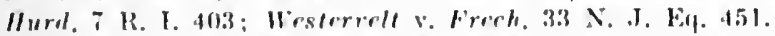

But if there aro two joint ard soveral makers of a note, and, aftor learning that one is surely for the ofluer. the liolfler releases or gives time to tlen pristcipal, the surety is diachargel. Ilulhard v, Gurmen. 0.4 X. Y. 457: IIarris V. Brooks, 21 l'ick. 195): IIhitrhomse v. Manson, 4' X. II. !: Flynn v. Mudd, 27

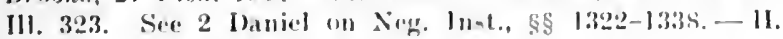


paid $\$ 1,000$, which was duly indorsed 'n the note. In December, following, being urged to pay the balance, and not being able to do so, he excerted another note for the sum of $\$ 1,000$, payalib to the order of the plaintiff, on demand, with interest semi-annually, and executed a mortgage of certain real estate to secure the payment thereot: and, having callsed the same to be reeorded, delivered it with the note to the plaintiff, without the knowledge of Barber. The plaintiff accepted the note and mortgage as artlitional seeurity, but not in payment or satisfaction of the original note or any part thereof.

The elaim is that the legal eflect of accepting the note and mortgage was to give time to the maker of the note for $\$ 8,000$, and so discharge the indorser.

The law is well settled, hardly requiring repetition, much less the citation of authorities, that in order to discharge the indorser by giving time to the maker there must be a contract to that effect, express or implied; that is, the holder must have put it out of his power for the time being to proceed against the maker. The indorser cannot be deprived of the right, even for a short time, to pay the holder and proceed forthwith against the maker for his indemnity. The holder may not, during the time for which he has agreed to extend eredit, bring a suit, for that would be a breacl of his contract. He may not accept payment from the indorser and thereby subject the maker to an immediate suit by the indorser, for that would violate, if not the letter, certainly the spirit of his contract. Hence such a contract operates to discharge the indorser.

But here is no express contract, and we think none can be implied. It is expressly found that the second note was taken as additional security for the balance due on the original note and not in satisfaction of it nor as a substitute for it. Both notes were liable to be sued at any time, the one being overdue and the other on demand. of course, the indorser could have paid the first note and could at once have brought a suit against the maker. He was also entitled to the additional security, and could at once have brought a suit on that note, and could also have proceeded to foreclose the mortgage. Instead of being prejudiced by the transaction, it was, in theory at least, a benefit to him.

The only features of the transaction which give any color to the defendant's claim are the facts that the collateral note, although on demand, was on interest payable semi-annually, and was secured by a mortgage; and it is urged with considerahle force that these circumstances indicate an understanding between the parties that that note was to run at least six months. They certainly indicate that the parties contemplated that it might run six months, but that possibility does not change the character of the note and convert it from a note payable on demand to a note payable on time. It was still a 
note due presently, and might be sued at once by the payee, and the indorser of the prior note might at any moment have placed himself in a position to sue it.

The supposed analogy to notes ordinarily taken by savings banks, insurance companies, ete., does not hold good. The object in those cases is to loan money, to make investments; the object here was to give additional security to a loan previously made and long since overdue, and which, we may add, was of a doubtful character. In the former cases the payee contemplates a present loan of money to continue for an indefinite time in the future; in the latter he is endeavoring to collect a loan previously made. It may be a breach of fair dealing to attempt to collect a note of the former description at once, but it by no means follows that it would be sucli a breach to attempt to collect one of the latter deseription. Moreover, the very object of making a note payable on demand is that the holder may collect it at any time if he sees good reason for doing so; and, legally speaking, he is the sole judge of the sufficieney of the reason; and that applies to the notes referred to as well as to the note in this case; so that the analogy, even if it exists, or so far as it does exist, does not avail the defendants. ***

There is no error in the judgment of the court below. ${ }^{9}$

\section{$\S 201$}

\section{BRICK $v$. FREEIIOLD NATIONAL BANK.}

\section{NEW Jersey LAW, 30i. - 1875.}

THE opinion of the court was delivered by

DALRIMPLE, J. - The defendant in this case is sued as indorser of a promissory note. 'The defense is, that the plaintiffs, the holders of the note, received from the maker a conveyance of certain property as collateral security for the paynent of the note, and that becanse of their failure to sell the collaterals and appropriate the proceeds of the sale to the liquidation of the deht, coupled with the fact that the property held as collateral, hat somewhat depreciated in value, between

The agresment for delay muat be binding upon the holder in order to operate as a discharge of the inderser. Melemore v. I'ovell. 12 Whent. (U. S.) 554; Smith v. Erwin, 77 N. Y. 466; Cory v. White, 52 N. Y. 138. The taking of a new note or hourl payalie at a future day is eon-truer as sufficient rvislenere of a hineling agrerment to sucpend the enforesment of the original obligation until the maturity of the new obligation. English $v$.

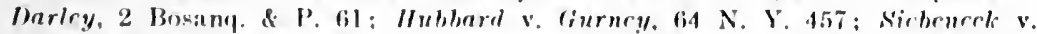
Anchor Bank, 111 Pa. Sit. 187; IItmilton v. Prouty. 50 Wis. 592. lint a reservation of rights against the sllrety is effective. Tohey v. Whllis, 114 Mags. 120: IIngry v. Hill. 75 Pn. St. 108: Buper v. IB/nke, 148 III. 465: Snhier v. Loring, o C'ush. (Mass.) 537; National lankl v. Bigler, 83 N. V. 51. lix. tension to the inaker of time to answer in an action hrought ly the holder, is not an extension of time of payment. Germantmerican Bonk v. Ningara, ctc., Co., 13 App. Div. (N. Y.) 450. - I. 
the time of the maturity of the note and the commencement of the suit, the pight of action is anginst the defendant, who is an accommodation indorser, is lost. 'This proposition annot be maintained. It is well settled that mere lelay by the creditor to sue the principal debtor will not discharge the surety, lor the obvious reason that the surety may at any time discharge his obligation to the ereditor, and thus made the principal his debtor. The same rule holds when collaterals are pledged by the principal dehtor. The surety nay at any time after the deht hecomes dne and owing, discharge it and take the collaterals. The law implies no contract on the part of the ereditor to proceed on the collaterals before he can sue the surety. Nor are the rights of the parties affected by the fact that the collaterals have depreciated between the time of the maturity of the debt, for payment of which they were pledged, and the commencement of suit against the surety. These principles are recognized as sound law by the Court of Appeals of New York, in the well-considered case of Schroeppell v. Shaw, reported in 3 Comstock, 416, 5 Barb. 580.

Rule to show eause should be discharged. ${ }^{1}$

$\S 201$

WOLSTENHOLME $v$. SMITH.

34 Utan, 300. - 1908.

Actios on promissory note payable to the order of Joseph P. Megeath and signed by Grant II. Smith and .T. E. Darmer, the defendants in this action. The note was indorsed to James Megeath, and this action is brought by his administrator.

Straup, J. * * * The defendant Darmer, answering the complaint, alleged that his co-defendant, Smith, was the principal debtor; that he (Darmer) received no part of the loan or consideration for which the note was given, and that he signed it only as surety, which facts were known to both Joseph P. and James Megeath when the note was executed; that by a binding agreement Simith, and the holder of the note, extended the time of payment to October, 1902, without his knowledge or consent; that no demand was marle upon him for payment until more than four years after the note became due; and that, by reason of the extension of time and of the delay in payment, he was prevented from protecting and securing himself. The court

1 If a secured creditor part with the securities, the surety is discharged. 2 Daniel on Nog. Inct., \$ 1311.

In New York the doetrine prevails that a surety may call on the creditor to proceed promptly against the principal, and failure to do so will discharge the surety to the extent of the loss suffered by the delay. Pain $v$. Packard, 13 .Johns. 174; Xewromb v. Hale, 90 N. Y. 326, 329. But the doctrinc does not extend to indorsers for value. Trimble v. Thorne, 16 Johns. 152; Teurcomb v. Hale, supra. - H. 
found the facts substantially as alleged in the answer, but as eonelusions of law found that the defendant Darmer was a maker and primarily liable on the note, and therefore rendered judgment against him. From this judgment the defendant Darmer has appealed.

There is no doubt that under the decisions of this court prior to the enactment of chapter 83, p. 122, Laws 1899 , relating to negotiable instruments, the facts alleged in the answer and found by the court constituted a defense, and discharged Darmer. It was the law generally in this country that a binding anreement between the principal and holder of a negotiable instrument, whereby the time of its payment was extended, relieved the surety, though he apparently sigued as maker, if the holder had knowledge or notice that he was in fact a surety. It is, however, contended hy the respmelent that the law in this respect has been changed by the act in question. On the other hand, the appellant rontends that it has not been changed, and that the law in this regard is now as it was before the enactment. We cannot agree with the appellant in this contention. The Tegotiable Instruments Law enacted in 1899 is like that of the Bills of Exelange Act of 1882 of England, and of the Negotiable Instruments Law of New York, adopted in 1\$97, and of alout 19 other states.

The particular sections pertinent to the question are:

[Qunting $\$ \$ \$ 29,60,63,119,120$ and 192 of the [tah statute. ${ }^{2}$

By subdivision 6 of section $120^{3}$ it will he seen that a person seeondarily liable on the instrument is dicroarged by an agrecment binding on the holder to extend the time of payment. If, therefore, the appellant was only secondarily and not primarily liable on the instrument, he is discharger. Otherwise not, unless the instrment was discharged. Section 192 ${ }^{4}$ makes a person primarily liable on the instrument who by the terms of the instrument is alsolutely repuired to pay it. And by section $29^{5}$ an arcommodation party in fact is liable on the instrument to the holder, notwithstanding such holder at the time of the taking of the instrument knew him to he only an aceommodation party. Mress. Faton \& Gillort, anthors of a rent work on negotiable paper, in considering the Negotiable Instruments Latw in question, say in section 12:3f: "The statute only prevides for the discharge by an extension of time of a persoll secomblarily liable on the instrmment. liy the terms of the statute a person is primarily liable who by the terms of the instrument is absolutely reguired to pay the same. All others are seromblarile lialde. . In aceommotation maker or aceeptor is absolutely liable on the instrument to a holuler for value, notwithstanding such holder at the time of taking the instrument knew lim to he only an accommoliation party. It womld secen to fol-

$2 \times, Y, 8 \$ 55,130,113,200,201$, and $3 .-\mathrm{C}$.

2. Y.. \& $201 .-r^{\circ}$.

4. Y. Y $3 .-\mathrm{C}$.

s N. Y., § $55 .-\mathrm{C}$. 
low that the statute has disposed of the conflict of authority upon this yuestom by holiling the acrommolation arepptor or maker to his apparent engagement as a principal dehtor, and making lim liable, notwithstanding an indulgence given to the endorser or drawer for whose benefit he beeme a party to the insirmment."

The same question raised here was considered in the ease of Cellers r. Meachem. ti) Or. $186,{ }^{\circ}$ and the conclusion was there reached that, under the new law, an acrommolation maker was primarily liable, notwithstanding any knowledge the holder of the instrument might have had as to his relationship with the principal. 'To the same effect are the cases of Vanderford v. Farmers' \& Mechanics' Nal. Bank, 105 MA. 164, and Nationat Citizens' Bank r. Toplitz, 81 App. Div. $593 .^{8}$

"This ease is reported in 13 d. \& E. Anu. Cas, 997, witl note entitled, " l)ischarge of accommolation joint maker by extension of time to co-maker." See next note. - C.

7 This case is reported in 10 J. N. S. 129, with note entitled "Effect under Negotiable Instruments law of rxtension of time to principal, to release one who, on the face of the instrument, is primarily liable, but who is in fact a surety."

For notes on Cellars v. Meachem, 49 Or. 186, and Vanderford v. Farmers', ctc., Bank, 105 Md. 164, see 7 Col. Law. liev. 432, 5 Mich. Law Rev. 683, and $12 \mathrm{Law}$ Notrs, 122. Referring to these two decisions, a note in $47 \mathrm{Am}$. Law Reg., N. S., at page 343. says: "Not the least interesting thing about these decisions is the fact that such an interpretation was foreseen and warned against by $\mathrm{Mr}$. Ames in his famous controversy with Brewster when the act was passed. He says, "Comments and Criticisms upon the Negotiahle Inctruments Law, 14 Harvard Law Review, 24l'), with reference to section 120 sub-sections 5 and 6 [N. Y., \$ 201] that 'another sub-section should be arlded, to the effect that an accommodation acceptor or maker, although the party primarily liable on the instrument, will be discharged if the holder, with knowledge of the accommodation, releases, or by a valid agreement undertakes to rive time to the accommodated drawer or indorser.' And he adds: 'The authorities are almost unanimous on this point also, although in a few jurislictions the accommodation party must resort to equity for his relief.' The failure to add the sub-section recommended by him rendered posible, and perhaps inevitable, the conclusion reached in these 1907 decisions. I say. 'prrhaps inevitable' for a possible way out has been indicated by Mr. Thomas A. Street in a briof note on these sam. cases in the eleventh volume of law Notes, page 105. He eriticizes the decisions in unmistakable terms, and points out the introduction of rlause 4 in section 119 IN. Y.. \$ 200] - "by any other aet which will discharge a simple entract for the payment of money.' - contemplated the arising of situations unprovided for by a definite section of the statute, and rendered possible their decision upon common law principles. 'This, he says, is such a situation. . . Mr. Street ends his article with a short hut cogent invective against what he ealls smooth but dangerous defining clauses (of the nature of section 192 (X. Y.. \$ 3]), in all uniform corles, which clog the free play of judicial interprotation. Certainly if sucl a clause permits a construction contrary to the design of the draughtsmen (see address of A. M. Faton - Reports of American Bar Association for 1907-page 1164) and subversive of a fundamental and generally accepted rule of the common law, the moral is not without its roint." - $\dot{C}$.

8 Affirmed expressly on other zrounds in 178 Y. Y. 464. - C. 
These cases are criticized by the appellant. He contends that the prorisions of subdivision 4 of section $119,{ }^{9}$ which proride that a negotiable instrument is discharged "by any other act which will discharge a simple contract for the payment of money," was disregarded. He urges that a contract of suretship is a simple contract, and the making of a binding agreement for an extension of time to the principal debtor has long been held to be an "act" sufficient to discharge the contract of the surety, and hence the facts alleged in the answer and found by the court were clearly a defense which is included in the general language of subdivision 4 of section $119 .{ }^{1}$ To reach such a conchusion one must assume that the appellant was not primarily, hut secondarily, liable on the instrument - the rery thing to be decided and the law that a person signing a negotiable instrument is not hound by his apparent obligation, but by his obligation in fact, has not heen changed. Under the new law the appellant's apparent engagement as a maker and principal debtor is his real and actual engagement. He signed the note as a maker. By the terms of the instrument, he is absolutely required to pay it. The statute in such case makes him an actual principal and renders him primarily liable. though in fact he received, with the knowledge of the holder, no part of the consideration, and only signed the note for the purpose of lending his name to another. Haring signed the note as an apparent maker and principal debtor, he cannot thereafter be heard to assert the contrary so as to affect his liability on the instrument. Section 119 deals, not with the discharge of parties, but with the discharge of the instrument. Of course, if the instrument is discharged, all parties are discharged, whether primarily or secondarily liahle. If it was meant that a binding agreement to extend the time of parment should discharge a person, whether primarily or secondarily liahle, and is included, as is contended, in the general language of subdivision 4 of section 119 , then there was no oceasion to insert the provision in section 120 making it a ground of discharge as to a person secontarily liable. Being so inserted strong!y indicates that it was the intention to make it a ground to discharge a person only secondarily liahle, and not a person primarily liable. While an agreement hinding on the holder to extend the time of payment was generally held sufficient to discharge a surety, yet it did not discharge the instrument, nor the princinal debtor. It was not surh an act as will discharge the instrument itsolf within the meaning of subdivision 1 of section 119 .

Being of the opinion that the appellant is primarily liable on the instrument, and that the facts alleged in the answer and foum hy the court do not constitute a discharge of the instrument. i: enllows

- N. Y.. \& 2M. - C.

1 This is the same contention as was made hy Irofessor Street in his article in 11 Iaw Notes. 105. See note 7 , ante.-C. 
that the judgment of the court below must be atlirmed, with costs. It is so urdered.

Mc C.nTy, C. J., and Fkick, J., coneur. ${ }^{2}$

In atdition to the cases cited in the principal case, see also the following cases in alceord: Bradtey Engin. \& Mfg. Co. V. Heyburn, 56 Wash. 628; and Richards v. Market Bxch. Nat. Bk, 81 Oh. St. 348 (eriticized at length in S Ohio Law Reporter, 25-20).

In Richards v. Market Exch. Bank, supra, the additional argument was made that the extension of time worked a material alteration in the instrument, thus discharging the defendant. On this proposition, Spear, J., said: "The question thus made is: Does the extension work a 'material alteration' in the instrument? 'The argument in support of the claim that it does is rested upon the proposition liad down by Brandt on Suretyship as follows: 'Any agrement between the creditor and prineipal which varies essentially the terms of the eontraet by which the surety is hound without the eonsent of the surety will release 'him from responsibility.' We think this does not satisfy the repuirements of the sections above quoted. It does not imply an ilteration of the instrument. It is but a statement of the equitable rule hereinhefore stated and eonsidered. It numst be borne in mind, as an absolute controlling condition, that it is the instrument itself which the foregoing sections of the statute treat of, not the contract which the instrmment is intended to evidence. This, it seems to us, is so manifest on the face of the printer word that it eannot be more clearly shown by comment, and hardly needs authority in its support. Nevertheless the question has been considered by text-writers and passed upon in a number of adjudicated cases. See I Bowvier, Law Dictionary, 153, under title 'Alteration,' and authorities there cited; also 2 ('yc. of Pl. \& Pr. 142, under heind of 'Alteration of Instruments,' and authorities thers eited; also $2 \mathrm{Am}$. \& Eng. Eney. of Law, 184, under same head, and authorities. Again, if these sections were intended to apply to a eondition other than a physical alteration of the instrument, we would expect to find the provisions under section $3175 \mathrm{j},[\mathcal{X}$. Y., $\$ 200]$ where the subject of discharge of instruments is specially treated, and we would not expect to find it elsewhere repeated. We should be slow to aseribe careless and needless tantology to the lawmaking body."

But in Northern State Bank of Grand Forks v. Bellamy, 125 N. W. (N. Dak.) 888 (April, 1910), it was held that the defendant, who had signed a note as an absolute guarantor of payment of the same. and not, as a surety, was released from liability on the note by the act of the plaintiff in extending the time of payment to the prineipal debtor without the knowledge or consent of the defindant. It was eoneeder that this was the rule prior to the Negotiable Instruments Iaw. As to the effort of thic ruactment. Ells. worth, J., said: "The terms 'primary and secondary,' when they apply to the parties to an obligation. "refer to the remedy provided by law for enforcing the obligation, rather than to the charaeter and linits of the obligation itself.' Kilton v. Prov. Tool Co., 22 R. I. 605. Therefore, however closely analogous may be the ultimate liability upon the instrument of surety and guarantor, the clear distinction in the character of their respective contracts, and the procedure by which their obligations must be enforced, operates to place these parties in different classes of the persons liable as defined by the new law of negotiable inctruments. The purpose in making a clascification not provided by the former law would seem to be to strengthen the credit of negotiable paper by protecting the holder against a claim that persons 


\section{Payment by party secondarily liable.}

Contract against the acceptor of a draft for $\$ 1,000$, drawn by Sandford C. Gardner, in favor of J. \& C. Levy \& Co., upon the defendant. The draft was duly indorsed and accepted.

At the trial in the Superior Conrt, before Allen, C. . ., it appeared that the draft was protested for non-payment, and returned to Lery \& Co., and was afterwards returned to the drawer, who assigned it hy bill of sale to the plaintiff, with the indorsement of Lery \& Co. remaining uncancelled. A witness testified that he silw the draft indorsorl by one of the firm of Lery \& Co., and did not see any mone! paid at that time.

Upon these facts, the chicf justice directed a vordict for the tefendant, which was accordingly rendered; and the plaintiff allegenl exceptions.

Metcalf, J. - These exceptions must he overuled and jurgment rendered on the verdict for the defendant. upon the authority of Beck v. Robley, 1 II. BI. 89, n. That case and this are alike in all particulars. In both, the lill was made payable, not to the drawer's own order, but to a third party, who indorsed it, was accepted hy the drawee, but afterwards was dishonored by his refusing to pay it, and was taken up from the indorser by the drawer, with the indorser"s name remaining uncancelled. In that ase it was decilled that the bill was not negotiable, and that the lrawer conld not reissue it. And that decision has never been overruled or denied, but is (ited as estal)lished law in all the hooks that treat of bills of exchange. (Siee, 1 Steph. N. P. 863 ; Story on Pills, \&223; Guild v. Eager. 17 Mass, 615: Opinion of Patteson, J., in Williams v. James, 15 Ad. \& El. N. S. 505.) The doctrine of that decision is, that a bill of exchange cannot be indorsed or negotiated, after it has mene heen paid, if such inforsement or negotiation would make any of the parties lialsle, who would otherwise be discharged. (Bayley on Bills, fith ed. 1fif, Ifir: ('hit, Bills.

directly and absolutely liable ly the troms of the iustrument had in fiuct signed, not as joint makers, hit in some oflere capacity. As the law now stands, these questions of primary and seromlary diability are to be resolved only upon the face of the instrument. All pereons by its terms alesolutely

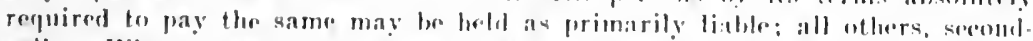
arily. When a party on signiug clearly indieates upon the inctrument the capacity in which he is willing to be berind, the holder in acenting it ealnnot misapprehend its true quality, for he then knows that the party may he held in that capacity and no other. Appollant sigmed as guarantor, amb as in that capacity he was secondarily liable neren the inctrument, loe was releasef. as under the former law ly an extension of time to the primeipal dether with. out his asant. As afferting him the prineiple governing the relation of loulder and guarantror under the former law is unchanged," - $C^{\text {; }}$ 
12th Am. ed. 25. 255.) As the first indorser of a bill is liable to every subsequent bona fide holder, although the bill be fraudulently cireulated, it follows that if he leaves his name thereon, after he is entitled to a discharge, he exposes himself to liability to such holder. 'Therefore the bill is held not to he negotiable in such case.

This rule of law applies only to cases in which the negotiation of a bill by the drawer, after he has taken it up on its being returned to him dishonored, would expose a discharged party to a new liability. See Callow v. Lawrence, 3 M. \& S. 95; IIubbard v. Jackson, 4 Bing. 390; Bayley, Chit., and 17 Mass. ubi supra; Mead v. Small, 2 Greenl. 20\%.)

Exceptions overruled. ${ }^{3}$

$\S 202$

BLENN $v$. LYFORD.

70 Maine, 149. -- 1879 .

Appleton, C. J. - This is an action of assumpsit on the following note :-

St. Albans, Me., Dec. 2, 1871.

Seven months from date, value received, I promise to pay M. E. Rice, or order, three hundred dollars, at any bank in Bangor.

[The note was indorsed in blank] M. E. RicE.

H. H. LYFORD.

[The following words were also on the back of the note, erased with ink but legible]: Holden without demand or notice. M. E. Rice.

Granting the presumption that the plaintiff is a bona fide holder for value of the note hefore maturity, that presumption may be overcome by proof.

It appears from the testimony that the note was indorsed to one Richardson, for value, in the April following its date; that it was not paid at maturity, and that about three months after its dishonor he delivered it to Rice, the payee.

The plaintiff then received the note in suit, when overdue. The note remaining unpaid after maturity was dishonored, and it was the duty of the indorsee to make inquiries concerning it. If he takes it, though he gave a full consideration for it, he does so on the credit of the indorser. He holds the note subject to all equities with which it may be incumbered. $\Lambda$ s the plaintiff is the indorsee of a dishonored note, it was competent for the defendant to show that it was an accommodation note, and that it had been paid by the party for whose accommodation it was given.

That the note was for the accommoration of the payee is abundantly shown by his receipt of the late of February 22, 1872, as well as by the testimony offered and excluded.

Accord: Price v. Sharp, 2 Ired. Law (N. C.) 417.-H. 
The note heing for the accommodation of Rice, it was his duty to pay it. The note being found after dishonor in the hands of the one bound to pay it, the presumption is that he paid it. (2 Par. N. \& B. 220.) It was competent to show that in fact he paid it, but the answer to an inquiry whether the note was paid by Rice was excluded. This was erroneous.

Assuming the note to have been paid by Rice, it was the same as if paid by the maker. It was paid by the party whose duty it was to pay it. The purpose for which it was given has been accomplished. The negotiability of a note ceases after its payment by the party who should rightfully pay it. "Now it cannot be denied," says Denman, C. J., in Lazarus v. Cowie (43 E. C. L. 819), "that if a bill be paid when due by the person ultimately liable on it, it has done its work, and is no longer a negotiable instrument. *** But the drawer of an accommodation bill is in the same situation as the acceptor of a bill for value; he is the person ultimately liable, and his payment diseharges the bill altogether."

Rice, when he took up the note in suit, had no right of action against the maker, and could not transfer to the plaintiff any better right after maturity than he had. (Edwd. B. \& N. 56t; Fish v. French, 15 Gray, 521) ; Tucker v. Smith, 4 Maine, 415.)

In the eases eited by the plaintiff there are most important differences from the one under consideration. In Baml. v. Crew $(60 \mathrm{~N}$. Y. $85)$, the plaintiffs were the indorsees of the note for value and before maturity, and were consequently to be protected. In Thompson v. Shepard (12 Met. 311), it was held that the indorsee of a note, who receives it for value from the second indorser, after it has been dishonored by the maker, ean recover thereon against the maker, although he knew when he received it that as between the maker and first indorser it was an aecommodation note. But this is upon the principle affirmed by the court in Woorman v. Churchill (52 Maine, 5s), that where the first indorsee of a promissory note acquires a right of action against the maker, by being a bona fide purchaser, without notice and before maturity, he ean transfer a gool title as well after as before the note beromes due.

Exceptions sustained.

Action to stand for trial."

\section{Payment for honor.}

Ser: Arт. XV. post. pip. 707-708.

- Accord: Merrill v. First I. L., II Cal. 50; Cottrell v. Watkins, 89 Va 801. - II.

Viout. INBTILUF,TS - 41 


\section{ARTICLE $\mathrm{X}$. \\ Billis of Exchange: form and Interpretation.}

\section{Form.}

$\S 210$

1. Formal Requisites Generalty.

See Article 1I. Ante, pp. 34-161.

2. The Drawee or Drawees.

(a) Must be certain.

$\S 210$

See Article II. Ante, pp. 148-150.

(b) May be joint, but not alternative or successive.

$\S 212$ TOMBECKBEE BANK $\because$. DUMELL \& LYMAN.

[Reported herein at p. 687.] 1

$\S 212$

JACKSON $v$. HUDSON.

2 Camprell, 447.-- 1810.

THIS was an action against the defendant as acceptor of a bill of exchange, which was drawn and accepted in the following form:

London, 30th December, 1809.

Two months after date, pay to my order $157 l$, for value received.

To Mr. I. Inving

F. JACKSON.

Accepted, I. Inving

Accrpted, Jos. IIvoson, payable at Mr. IIudson's, 132 Oxford street.

The first eount of the declaration stated, that the bill was directed to Irving; the second took no notice of there being any drawee; and both averred that the defendant accepted it, "aceording to the usage and custom of merchants."

Garrow for the plaintiff stated, and undertook to prove, that the plaintiff having dealings with Irving concerning the sale of goods,

1 An acceptance by some one or more of several drawees, but not by all, is a qualified acceptance. See Neg. Inst. I., $\$ 229$, subsec. 5. - H.

[642] 
refused to sell him any more, unless the defendant would become his surety; that the defendant agreed to this; that goods to the value of $15 \%$. were in consequence sold by the plaintiff to Irving; that the bill in question was drawn for the price of them, and that the defendant with a knowledge of all these facts, had put his name upon the bill as acceptor. He must, therefore, be eonsidered as having accepted the bill jointly with Irving; and as he had not pleaded in abatement, he was separately liable in the present action.

Lord Ellexborocgh. - If you had declared, that in consideration of the plaintiff selling the goods to Irving, the defendant undertook that the bill should be paid, you might have fixed him by this evidence. But I know of no custom or usage of merchants, according to which, if a bill be drawn upon one man, it may be accepted by two. The acceptance of the defendant is contrary to the usage and custom of merchants. A bill must be accepted by the drawee, or, failing him, by some one for the honor of the drawer. There camnot be a series of acceptors. ${ }^{2}$

The defendant's undertaking is clearly collateral, and ought to have been declared upon as such.

Plaintiff nonsuited.

\$212 Axon. 12 Mod. $44 \%$ (1701). A bill of exchange was directed to $A$, or, in his absence, to $B$, and began thus: "Gentlemen, Pray pay." The bill was tendered to $A$, who promised to pay it as soon as he could sell such goorls: and in an action against him for nonpayment, the declaration was of a bill directed to him without any notice of $\mathrm{B}$, and Holt held it well. ${ }^{3}$

3. Referef in ('ase of Need.

\section{\$215 C'HIT'YY ON BHLS OF E.SCIIANGE, FTC, p. 188.}

Wues the drawer has any approheneion that the drawe will either not areept. or not play the hill, hre maye als a matter of presantion. to

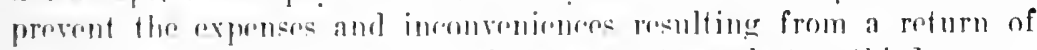
the hill, repuice the holder in surh an exent, to apply to a third person,

2 There serems to he no direst all bority upon this proposition of the Neg.

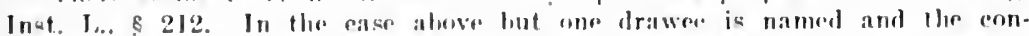

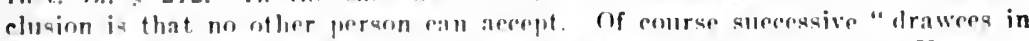
rase of need" may loe named in the lill. Nes. Inat. I.. \$ 215. - II.

3 In this case li, may have lween a "drawee in ease of neerd:" if not. it is entrary to the statutory rule. A note cannot bre made payalle hy two makers in the alternative. Ferris v. Bond, \& T. \& All. 679. - II. 
named in the bill for that purpose. This requisition is intimated by writing in the corner of the bill, under the drawee's address, these words. "Au besoin chez Messrs. - - at - - " or, in other words, "In case of need npply to Messis. - - at - - "' 'lhis, in effect, points out one or more persons whom the drawer is desirous, in case of refusal or failure by the drawee, to become parties to the bill, in the nature of an acceptor or payer for honor; and is valid and usual on the Continent, though we have just seen that there cannot be a series of acceptors. (1 Pardess. 351, 394, 437-8: Jackson v. IIudson, 2 Campb. $4+7$.$) The holder is bound to apply to the parties so addressed, (1$ Pardess. 4i3s), and who may accept and pay withont previous protest, in which respect he diflers from an acceptor supra protest (1 Pardess. $438)$; and the party so paying has a right to sue the drawer for the amount. (1 Pardess. 438.) It should seem, however, that the introdurtion of these words rather imports an apprehension that the bill will not be regularly accepted or paid, and therefore tends to diminish the eredit which night otherwise be attached to the bill without such desire being expressed.

\section{Interpretation.}

\section{Bill Not an Assignment of Funds.}

\section{Massachusetts, 383. - 1890.}

Plaintiff by "trustee process" attached funds in the hands ai the town of Winchester belonging to defendant. Alexis Cutting intervened as clajmant of the funds.

The town owed defendant $\$ 217.27$ on an account stated. Defendant gave Cutting this order: "Winchester, July 12th, ' 88 . Town of Winchester. Pay to the order of $A$. Cutting ninety and thirty-two hundredths dollars, value received, and charge the same to account of H. B. Payne." He gave similar orders amounting to $\$ 65.27$ to four other persons, who also appear as claimants. 'The orders were all left with the selectmen of the town, where they continued to remain, but were never formally accepted.

How mes, J. - The defendant in this action has been defaulted, and the question before us is whether the plaintiff or the claimant Cutting

4 This seems to have been so before the enactment of the Pills of Exchange Act, $\S 15$, and the Neg. Inst. T., § 215. See Chalmers, Bills of Fxchange Act (5th erl.) pp. 38-39. - II.

"There is little English or American anthority upon the "referee' in case of need." See Leonard v. Wilson, 4 Tyrwh. 415 ; in re Lreds Banking Co., L. R. 1 Eq. 1. - H. 
is entitled to a certain part of the debt due from the trustee to the defendant.

There is no doubt that an order for a specific fund, identified by the order itself, may he a good assignment. (Kingman v. Perlins, 105 Mass. 111). We assume in faror of the claimant that an equitable assignment to him of a part of the debt would be good as between him and the plaintiff upon trustee process. (Dana v. Third National Bank, 13 Allen, 445, 447; James v. Newton, 142 Mass. 366, 374.) Our difficulty is to discover any ground for saying that the instrument relied upon constituted such an assignment.

On its face, the order given to the claimant by the defendant does not refer to a particular fund or debt, but is an ordinary negotiable draft, or unaccepted bill of exchange, drawn upon the town on the general credit of the drawer. An indorsement of the instrument by the claimant would have given the indorsee a right of action in his own name against the drawer, if the draft should be dishonored. But the fact that the order is a negotiable instrument on its face shows that it is not drawn against a particular fund. If it were drawn against a particular fund, it would not be negotiable. ${ }^{6}$ (Wheeler v. Souther, 4 Cush. 606, 60\%; IJarriman v. Sanborn, 43 N. H. 128.)

The case is stronger for holding a check upon a bank to he an assignment, than it is for holding an ordinary draft to be so. A eheck is supposed to be drawn against a fund deposited, for which, to be sure, the bank is no more than a dehtor: but a dehtor on the implied term that the creditor has a right to split up the debt at will, and to require part paymonts in such amounts, at such times, and to such persons as he chooses. In general, the creditor has no right to draw above the amount of his deposit, and would be guilty of a framl if he obtained money or goods for a check knowingly so drawn. Yot the weight of authority is that a cherk is not an assignment either at law or in equity. " Bullard v. Randall. I Gray, G05: Dana s. Third Na-

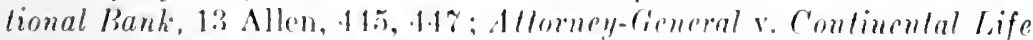

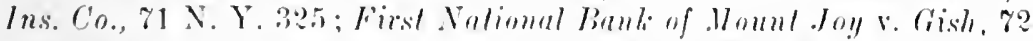

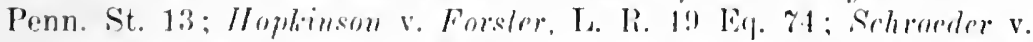

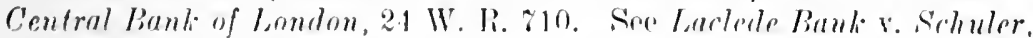
120 U.S. S. $11,514$.

A fortiori. the same rule must hold enod of an ordinary draft mas-

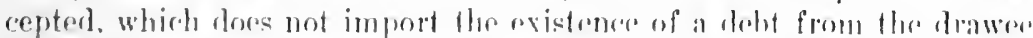

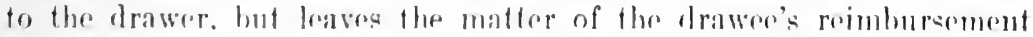
to such privato arrangentents as may oxiof betwon the drawer and himself. And so are the dreisions: (Whituen v. Whliot Nat. Bank.

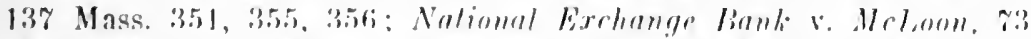

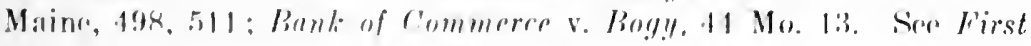

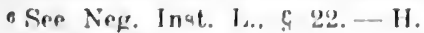

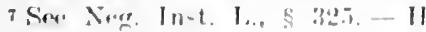


Nat. Bank of Canton v. Mubuque Southwestern Railway, 52 Iowa, 3is.)

There is no extrinsic fact in the present ase which gives the doeument a diflerent effeet from that which results from its tenor, if it be possible that its eflect shonld be varied by parol. (See Whitney v. Étiot Nat. Bank, supra; Ciriffin v. Weatherby, L. R. 3 Q. B. 753, 759; First Nat. liank of Canton v. Dubuque Sonthwestern Railway, 52 Iowa, 3is.) 'The defendant had done work for the town, and his only right to draw was in respect of the price of his work. If we assume this tact to have been known to all parties concerned, still it only shows that the town was known to have means of indemnifying itself if it saw fit to pay. It does not enlarge the meaning of the draft beyond that which it hears on its fare, of a general request to the town to pay. Even a reference to a fund out of which a drawee may indemnify himself will not take away the negotiable character of the draft. ${ }^{8}$ We may remark that the conchuding words of the draft in question are "charge to account of." In some of the others, they are "charge to the acrount of," which is slightly more specific. But we do not see any somnd distinction in filvor of the latter. If the town had accepted the order, having power to do so, it would have become liable on a direct and absolute contract to the elaimant, very likely having a right to withhold an equal amount of its debt to the defendant. But mere retention of the draft was not acceptance. ${ }^{9}$ (Overman v. IIoboken City Bank, 2 Vroom, 563.)

Trustee charged. Judgment for plaintiff. ${ }^{1}$

\section{Inland and Foreign Billus.}

$\S 213$

\section{YALE $v$. WARD.}

30 Texas, $17 .-1867$.

'T're bill on which suit was brought was in these words, with the indersenent of "Henderson, 'Terry \& C'o." across the face of the note: -

8 Neg. In-t. L.. \& 22; ante, pp. 50t-54. - 11 .

s. Sire Non. Inst. T., \& 225. - II.

1 As to whetler a bill is an assignment tluere has beren a conflict of authrority, copecially where the bill is drawn for the whole of the fund. See I Daniel on Yog. In-t. \$\$ 15-23: $2 \mathrm{Am}$. \& Fing. Eneyc. 1. (2nd ed.), jp. 10621064. That a bill drawn for the whole of a fund is not an assignment, see Shand $\because$. Du liusson. 18 Eq. Cas. 283; First N. B. v. Dubuque S. R. R., 52 Iowa, 378: Bush v. lrorte. 58 Mise. 5; Bank v. Brogy. 44 Mo. 15. But. an order for a payment of a particular, speeified dobt in full, is an assignment. Lewis V. Bank, 30 Minn. 135: Brady v. Chadbourne, 68 Minn. 117; Monre v. Daris, 57 .Mich. 255.- H. 
$\$ 307.78$.

New Orleaxs, 2d May, 1861.

On the 12th day of December, after date, pay to the order of C. Yale, Jr. \& Co., $\$ 307.78$, value received, and charge the same to account of

Matt. Ward.

To Messrs. Hexierson, Terry \& Co.

To it was attached the usual formal protest, dated "United States of America, State of Louisiana," by a "notary of the parish of New Orleans, State of Louisiana," 1+th December, 1861.

Willie, J. * * * There being no allegation to the contrary, we must treat the draft upon which this suit is fonnded as a domestic bill of exchange. Neither the place where the draft was drawn. nor where it was accepted, is stated in the petition. The instrument itself, made part of the petition, purports to liave been drawn at New Orleans: but there is no averment that this place is beyoud the limits of Texas. This court has held, that it will not take judicial notice of the division of other states into towns, cities, etc., and that knowledge of the fact that any place is within a different state of the Union must he derived from the allegations of the parties or the evidence contained in the record. (Andrews v. Hoxie, 5 Tex. 185; 4 Tex. 420.)

The rights of the parties to this contract, therefore, must be ascertained, and their liabilities fixed according to the law of our own state. $^{2}$

3. Bill Theiten as Promissory Note.

FUNK r. BABRI'T'

[Reportal herrin al p. 1:00.] ।

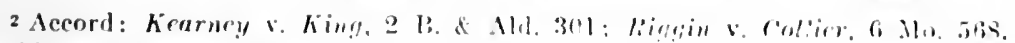

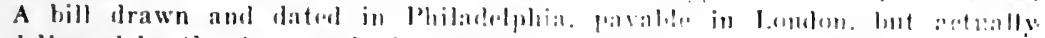

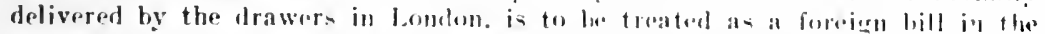

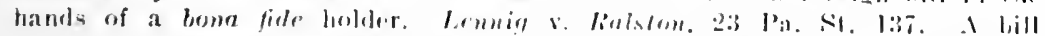
drawn and delivered in IViseon-in, but dated and payabla in lllimois. i. an

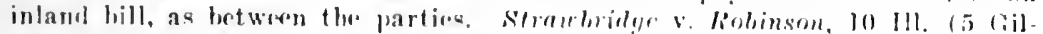
man) 470 . II.

1 "Where a party frames his instrumont in sucl a way that it is ambigmoms whether it les a bill of exphange or a promissory note, the party lobling it in entitlon to trat it ritluer as one or the othere and the plaintiff ought not to be defeated hy the party who framed the instrument being alfowerl to say that it is a hill of exchaner" fwhere slleh party has had no

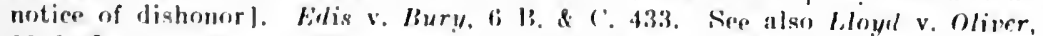
18 Q. 13. 471 ; H.ise v. Bumpass, 40 Ark. 545; 4 An. \& Eng. Encyc. Law 12d ed.). PP. 119-123. - II. 


\section{AR'TICIE XI.}

\section{Acceptance of Bills of Exchinge.}

\section{Form and effect.}

\section{Acceptance Must Be in Writing and Signed By Drawee.}

(a) Writing and signature.

2 HILL (N. Y.) 582. - 1842.

Action against Pratt as acceptor. Jurgment for plaintiff. The defendant's name was written across the face of the bill; and the question was whether this was such an acceptance as is required by statute.

By the Court, Cowes, J. - Any words written by the drawee on a bill, not putting a direct negative upon its request, as "accepted," "presented," "scen," the day of the month, or a direction to a third person to pay it, is prima facie a complete acceptance, by the law merchant. (Bayley on Bills, 163, Am. ed. of 1836, and the eases there cited.) Writing his name across the bill, as in this case, is a still clearer indication of intent, and a very common mode of acceptance. This is treated by the law merchant as a written acceptance - a signing by the drawee. "It may be," says Chitty, " merely by writing the name at the bottom or across the bill;" and he mentions this as among the more usual modes of acceptance. (Chitty on Bills, 320, Am. ed. of 1839.)

It is supposed that the rule has been altered by 1 R. S. 757 ( $2 \mathrm{~d}$ ed.) $\S 6$. This requires the acceptance to be in writing, and signed by the acceptor or his agent. The acceptance in question was, as we have seen, declared by the law merchant to be both a writing and a signing. The statute contains no declaration that it should be considered less. An indorsement must be in writing and signed; yet the name alone is constantly holden to satisfy the requisition. No particular form of expression is necessary in any contract. The customary import of a word, by reason of its appearing in a particular place, and standing in a certain relation, is considered a written expression of intent quite as full and effectual as if pains harl been taken to throw it into the most labored periphrase. It is said the revisers, in their note, refer to the French law as the basis of the legislation which they recommend; and that the French law requires more than the drawee's name - the word acrepted, at least. 'That may be so; hut it is mough for us to see that both the terms and the spirit of the act may be sintisfied short of that 
word, and more in aceordance with the settled forms of eommercial instruments in analogous cases. The whole purpose was probably to obriate the inconveniences of the old law, which gave effect to a parol acceptance.

New trial denied. ${ }^{1}$

\section{(b) Ouly the drawee can accept.}

\section{WALTON $v$. WILLIAMS.}

44 Alabama, 347. - 1870.

Acrion against James W. Walton as acceptor of a bill addressed to James .T. Walton. Defendant offered to prove that he signed as indorser, hut the court excluder the evidence. Judgment for plaintiff.

SAFFoL, J. - The only evidence that the defendant accepted the bill, is his signature across $i t s$ face. It is where the acceptor's signature is usually found, and in the absence of proper rebutting testimony this would be sufficient proof of the fact, if it was directed to him, or without direetion to anyone. But the name of James J. Walton is also found in the position on the bill usually oceupied by the drawee, and he must be considered the drawce as well as the drawer.

Where a bill is directed to a particular person, no one but the person to whom it is directer can accept it, except for honor. (May v. Kelly 8. Frazier, 27 Ala. 497.) If the defendant was an acceptor, be was one supra protest, and his obligation was, that if the bill was not paid by the drawee upon dur presentment at its maturity, then upon protest for nonpayment, and due notice thereof to him, he would pay it. (Story on Bills of Ex., $\$ 123 ; 3$ Wend. 4!1.)

There was no proof, in this case, of protest and notice, and for this reason the charge of the eourt was erroneous.

The plaintiff was the payee. It was, therefore, clearly competent to show by parol the intention of the partios, at the time the contract was

I By the English and Amerian decisions parol aeceptane of an existing bill

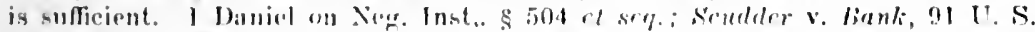
406, 413. In Fongland, siner 19 and 20 Vict., e. 97. Hhe alceptanes must he: written on the bill. Jills of Exehange Aet. $\$ 17$. suldere. (2). In the U.S. where there are slatutory provicions they erenerally proville for an acespence in writing: but this need net be npon the bill. An aceeplance by tolentaph

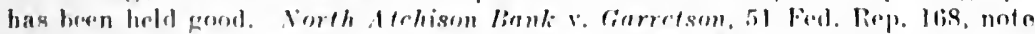

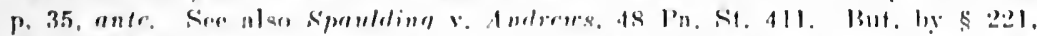

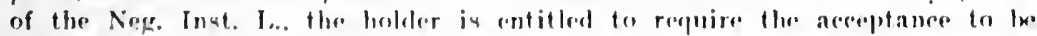

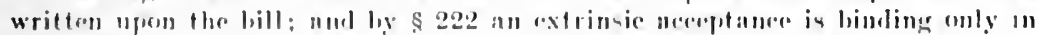
favor of one to whom it is shown and whe takes the hill on the fath therens. This latter provision is a doparture foom the indieial decinions upom this moint. Snaulding v. Andrews, 48 Pa. St. 411 ; Jones v. Council Bluffs Bank. 34 III, 313, - II, 
entered into, with rearard to their several liabilities among themselves, and the relation which they were to beis lo the hill (Branch Bank al Mobile' r. ('oleman, :20 Ma. 1.10.)

'lle aideme of the defomlant, who was a competent witness moler sertion :30) of the lievised corle, onght to have heen ardmitted.

The judgument is reversed and the cause remanded. ${ }^{2}$

JACKSON \% HUDSON.

[Reported herein at p. - . I

\section{(c) Delivery Neressary.}

Dunaras v. Firien, 118 Mass. 5i37. - 1875. Gray, C. J. - It was rightly held that the mere writing of the acceptance upon the bill, not commimisaled to the drawer or holdre, and the detention of the bill in the defendant's custody, did not hind him, or operate as a payment of his debt to the drawer. (('lavey v. Dolbin, ('as. temp. Hardw. 2) 8 ; Jeme r. Ilard, 2 Stark. 3206: s. ‘, 1 B. \& Ald. 6.5:3; Mason v. Barff, 2 B. \& Al. 26: ('o. s. Troy, 5 13. \& Ald. 471, s. c., 1 Dowl. \& Ryl. 38; Overman v. Iloboten Cily Bank, 1 Vroom, 61, and \& Vroom, 563.) ${ }^{3}$

2 Aceord: Datis v. Clatie, 6 Q. B. R. I6: Smith v. Lockridge, 8 Bush (Ky.) 423. In Harkham v. IIasen, 48 Ga. 570, the stranger-acceptor was held as guarantor.

If a bill is directed to an agent ( $A$. ) and accepted by him in the name of his principal (X. Co., by A.), no one is bound: not the agent, for he has not accepted: not the primeipal, for it is not the drawee. Walker v. Bank, 9 N. Y. 582.

If a bill is direeted to a partnership (A. B. \& ('o.) and is accepted by one partner in his own name, it has been hold that no one is bound: not the partnership, for it has not acepted; not the partner, for he is not the drawee. Mernan v. Mash, 8 Minn. 40\%. Contra: Orrn v. Van I'ster, 20 L. J. I. I'. 61. Sop note p. 30f, antr. This is to be distinguished from the case of a bill dirceted to two or more drawees and accepted by one. See $\$ 212$, \$229, subsee. 5. - II.

3 Leceltane withont ro-telivery is ineffective. Fround v. Importers' Bank. 3 Hon (X. Y.) fis?. Fxeept a: provided in \$ 225, post. But ese 2 Imos' Cases on Bills and Notes, p. 7 ?o. An aeceptaner onee eompleted by delivery is, in the ab-enee of frand on the part of the holder in procuring the aeceptance, irrevocable. Trent Tile ro. v. Fort llorborn N. B., 54 N. J. L. 33, 599; Fort Dearborn N. B. v. Carter, 152 Miss. 34. - H. 


\section{Acceptance By Separate Instrument.}

\section{§222 FIRST NATIONAL BANK OF ATCHISON v. COMMER- CIAL SAYINGS BANK.}

it Kaxsas, 606. -1906 .

Demurrer to petition overruled. Judgment for plaintiff, and defendant brings error.

Burch, J. - J. F. Ionald, having funds on deposit with the First National Bank of Atclison, Kan., drew a check upon it for $\$ 350$, payable to Maria C. Donald or hearer, which he delivered to the payee. The payee indorsed and delivered the check to $(\therefore$. B. Bennett, who, in turn, indorsed and flelivered it to the Commercial Sarings Bank of Adrian, Mich. Donald stopped parment of the check hefore it was presented for payment, and the Michigan bank sued the Kansas bank for the face of the check and interest, claiming it land been accepted in writing, and that it had been purchased for value on the faith of such acceptance. The petition was framed upon the theory that an arceptance is disclosed hy the following telegrams:

"Adrian, Mich., Oct. 15, 1!nos. First Tational Bank, Atchison, Kansas. Is J. F. Donald's check on you $\$ 350$ good? Commercial Savings Bank."

"Atchison, Kas., Oct. 15, 190\%. Commereial Savinge Bank, Adrian, Mich. J. F. Donald's aleck is good for sum named. First National Bank."

Of course, there is no lispute that the transaction is governed by sections 517 and 518 , Gen. St. 1901, which reat as follows:

"No person within this state shall bo charged as an acceptor of a bill of exchange, moness his anceptance shall be in writing, signed ly himself or his lawful agent. *

"If such aceeptane be written on payer other than the bill, it shall

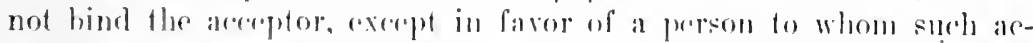

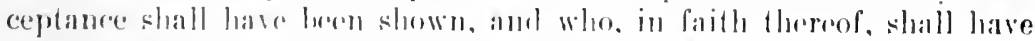
received the hill for a valuahlo ronsideration."

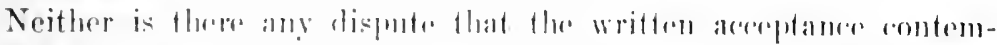

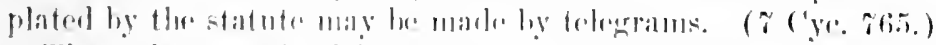

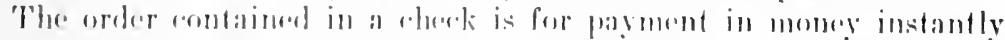

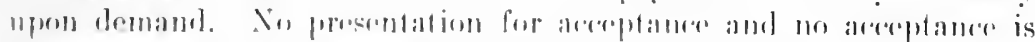

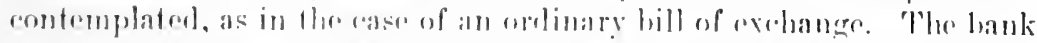
is umber no ohligation to den othere than pay, and the obligation to pay runs to the maker, and not to the loblelor. If it refose to pay when

- Ser N. Y. Virg. Inat. larw, E 220. - r.

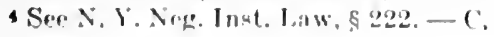


it has funds of the maker in its possession subject to check, the holder has no remedy against the batuli. He mus look to the malier.

When an ordinaly bill of exchange is presented for aceeptance, the drawee is moler the positive duty of aterepting or relusing to acept, and, if atevetance be not plainly negatived by whatever he does, he will he bound as an aceeptor, herause aceeptance is something contemplated by the bill itsell. A repuest upon a bank that it accept a cheek is a request for the reation of a legal relation between the holder and the hank, wholly without and heyond the purvew of the paper. If sueh relation be establisher, it imposes upon the hank a liability to a party to whom it was not helore bound at all, and it converts the privilege of the bank to pay if in funds into an absolute and unconditional duty to pay. no matter what may be the state of the depositor's account. Any one claiming to be the beneficiary of a contract of this kind indepeijlent of and collateral to the check must clearly show that the bank intended to make it.

Neither law nor 'ustom binds parties to the use of any set formula in arranging an atceptance. They may choose their own words. Brevity is not simply allowable, it is commendable: but in all cases there must be no doubt that an absolute promise to pay was made. If the transaction involve two writings, a proposition and a response, they should be construed together. The true principle governing the interpretation of communications like the telecrams between the parties to this suit was grasped and stated in the case of Rees v. Warrick, 2 Barn. \& Ald. 113. In that case the drawer wrote to the drawee as follows: "Yesterday we valued upon you, faror W. Johnson and Co. two months for 100 l. which please to honor." The drawee replied: "Your bill 100 l. to W. Tohnson and Co. shall have attention." It was held by Abbott, C. .J., that, to make a letter an acceptance, it ought to be in terms which armit of no douht; that the phrase "shall have attention" is at least ambiguous: that it may moan the drawee would examine and inguire into the state of the drawer's aecount for the purpose of ascertaining whether or not the hill would be accepterl: and that, unless the worls used import a clear and unerpuivocal arceptance, no recowery may be had. Holroyd. .T., said: "The very circumstance that it has been so ofton lamented that anything short of a written acceptance on the face of the hill should he held to make a party liable as acceptor shows the inconvenience that arises from the great uncertainty which is thereby introrlured. In this rase the worls contenrled to be an accoptance are that the bill 'shall nect attention.' 'The defendant does not say, as in Wynne v. liailies, that the bill 'slall be paid and areeptrel: " lint, in fart, only that he will attend to it. Consistently, then. with threse words it might dopend on the state of the account brotwen them. whother he would accent the hill or not."

Tested by this rule, the defendant's telegram does not express an 
acceptance. The inquiry indicates no clear intention to extiact from the bank a new contract to pay independent of its duty to Donald. It is entirely consistent with the expression of a simple desire for information relating to Donald's standing at the bank. It fairly means: "Is J. F. Donald's account with you sufficient to make his check for $\$ 350$ good?" 'The answer is strictly responsive to the inquiry. It indicates no clear intention to make Donald's check good whenever presented and whatever the condition of his account. It is entirely consistent with the simple purpose to state Douald"s standing at the bank on the day of the telegram. It fairly means: "Donald"s account is now sufficient to meet a check for the sum named." 'The writings are not equal to the unambiguous and unequivocal, "Will you pay?" and "We will pay."

Other cases recognize the principle here applied. In the case of Kahn, Jr. v. Walton, 16 Ohio St. 195, the inquiry was: "Are M. A. Walton's checks for $\$ 2,000$ good?" The answer was: "Yes, sir." The court, in denying that an acceptance was disclosed, said: "The telegraphic correspondence between the bank and Kaln's agent zmounted to no more than an assurance that valid checks to the amount stated, drawn by Walton, or that might be drawn by him, were then good. No particular checks were mentioned in the inquiry, nor any intimation given that the inquirer had received, or was alout to receive, such ehecks: nor had the bank any means of ilentifying the cheeks to which the inquiry related. Its telegrams, therefore, did not rommit the bank to the payment of any particular check. At most it was information that Walton had, at its late, money on deposit to the amount stated, subject to check."

In the case of Cook v. Baldwin, (120 Mass. 31\%), it was held that the words, "I take notice of the above," writton upon a bill of exchange and signed by the drawee, do not of themselves necessarily import an acceptance.

In the case of Myers v. Umion National Baml. 29 Ill. Apl). 251. the inquiry was: "Will drafts for thirty-eiglot humbed lollars, mate by J. R. Snyder on you, he paid if presented Mombly?" 'l'he answer was:

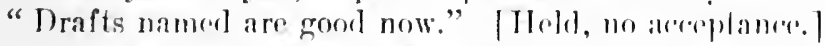

These authorities are suffieient to illustrate the rule that the drawee

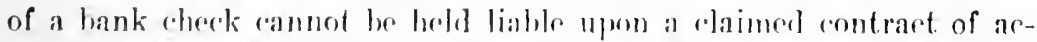
ceptanee external to the hill, mulese the lameruage used clearly and unequivorally jmport an alsohute promise to pay.

The derision in the raso of Corretson v. North dtehison Banle (C. C.) 39) Fed. 163, relied upon hy comsen for plaintite, was allirmod by

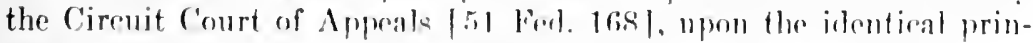
ciple discussed ahove. The tolegrams in that case were as follows:

"Will you pay James 'Tatris rhere oll roul, twonty-lwo thousand dollars? Answer."

"James Tate is good. Send on your paper." 
The court said: "The question put to the bank was wholly free

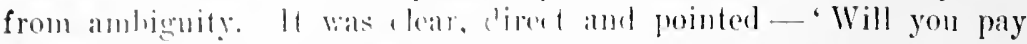

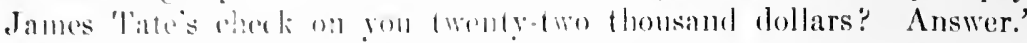
There ean he no tombt that it was stroper's purpose in sending this telersam to asceptain whether the lank womld hind itself to pay the

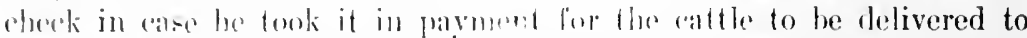

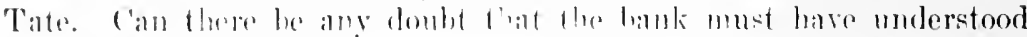

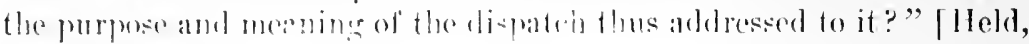
an acreptance.

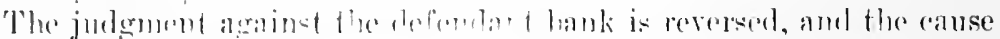

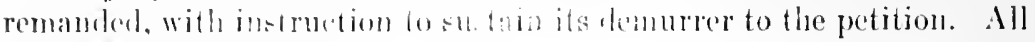
the justices comeurringr."

3. Promise to Accert Must Brin Mriting, etc.

\section{$\S 223$} BANK OF MICHIAN

17 Wenhil. (N. Y.) $508 .-1837$.

ACTION of assumpsit against defoulant as acceptor. Defendant wrote his agents: "If you want move funds, you can make drafts on me payalue at the oflice of $A$. S. Marvin \& ('o., $N$. York, due in August next. * * * I lave authorized Mr. D). D. I'atch to aceept these drafts for me." The anents wrote plawhitt comanuicating the contents of defendant's letter, ame sulecencut!y trasunited bils drawn on dofemlant, which phantill discomnted and paseed to the drawer"s credit. 'Ihere was no cvidence that defordant's letter was ever shown to plaintitt. Rieferees' report for defendant.

By the Court, Xessox, C'11. J.- It is oljerefod that the aceeptance of the clefendant. under the rieremstanees of the rase, is not within the provisions of the lievisod statutes. however obliratory it may be upon the principles of tho rommeledal law. The provisions of the statute, 1 R. S. ibs, are as follows:

\$ 6. No person within this state shall be rhareal, as an acceptor on a bill of exchanere, muless his aceeptauce slatil be in writing signed by himsolf or his lawful aerut.

$\S \%$. If such aceeptance le writen on a panes ofluer than the bill, it shall not hind the aceeptor exe'pet in favor of a jerson fo whom such aceptance shall have been shown, and w!on, on the faith thereof, shall have received the lill for a valuable ensileration. ${ }^{-1}$

\$8. An unconditional promier, in writine, to acept a bill before it is drawn, shall be deemed an actual aceeptance in favor of every

5 This case is reporterl with notes in 119. 1 . St. Jiep. 340, and in 11 A. \&

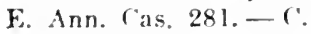

Peenacted in substance in Neg. Inst. J., \$ 222. - H. 
person who, upon the faith thereof, shall have received the bill for a valuable consideration. ${ }^{5}$

A brief recurrence to the law as it stood in this state before the adoption of these provisions, will aid in comprehending their object and effect. It was settled, (1) that a parol pronise to accept a bill already drawn, was valid and binding, and amounted to an actual acceptance; and $(2)$ that a parol promise to accept a future bill, or one not in existence, was not binding, unless the bill was taken by the holder upon the faith and credit of such promise. If it was so taken, then it was binding and amounted to an actual acceptance according to some of the cases. (1 Holt, 181; 2 Kent's Comm. 85; 12 Wendell, 598.) There are other authorities which require the promise to be in writing. Now by the Revised Statutes, no person, within this state, can be charged as an acceptor of a bill, unless the acceptance be in writing, signed by himself or his agent; and if such acceptance be in writing, but not on the bill, still the party is not charged, unless the fact be disclosed to the person taking it, and he on the faith of such acceptance, pay a valuable consideration for the same. The acceptance here referred to relates to a bill already drawn.

By $\S 8$, an unqualifier promise in writing to aecept a bill to be thereafter drawn, is decmed an actual acceptance in faror of any one who, upon the faith of such promise, takes it for a raluable consideration. There is some difference in the phrascology of $\S r$ and $\$ 8$, in respect to the circumstances under whicl the credit is to he given to the promise to accept. The language of the former, is " in favor of a person to whom such aeceptance shall have been shown, and who on the faith thereof," ete., whereas, the sth seetion contains only the latter branch of the sentence; the other was in the section as reported hy the revisers, lut was subseguently stricken out. No reason can he perenved for a distinction in this respect between the two cases, and we do not believe that any was intended by the legislature: and that the difference in the phraseology is altogerther aceidental. It can be of no possible conserpuenoe to the acceptr s in what morte the holdar comes to the hoowledge of the areeptance, whether by inspedion or by oral communieation: it is a matter that can only conern the latter. If he acts upon the representation of a thied prson, lo incors the risk of being inposed upon, as he must, as to the gemoneness of the w riting upon an inspection. The languager, "shall have been shown," blans nothing more than to express the idea that the holder must know of the aceeptance: this is, inderel, the only effect of it. All this is undoubtedly implied in the mext sentenee, and the clanse, fherefore, might as well have heen omitfed altogether, as it is in the next section.

In l'ierson v. Dunlop (C'owper, 5r1), the first ease in which this

s Re enacter in kubst ance in Nog. Inst. J., $\$ 223 .-\mathrm{H}$. 
doctrine is stated, Lord Minsfield remarked: "It has been truly sait, as a cromeral rule, that the mere answer of a mereliant to the drawer of a hill, saying he will duly honor it, is no acceptance, unless aceompanied with circumstances which may indnce a third person to take the bill by indorsement; but if there are any such circhmstances it may amount to an aceptance," ete. In Mason v. Hunt, (Moug. 2999). Lord Mansfield used languige from which, probably, the phraseology of the statute was taken; hut it is manifest he intended to do no more than repeat the principle he had hefore stated in P'ierson v. Dunlop. In Clark v. Cock: (4 East, 57), this very oljection was taken by Gibls, (p. 6r), namely, that the letter, itself, ought to have been shown, and not merely the purport of it given; but it was disregarded by all the judges. The communication of the fact of the promise, was deemed the material eircumstance.

Now it must he concerled in this case, that the promise to accept is in writing, and, in my judgment, it is an unqualified promise. "If you want more funds, you can make draft on me, ete., to the amount of $\$ 10,000 . "$ Who was to determine whether more funds were wanted? Undoul,tedly, Beach \& Hudson. The question was referred to their sole discretion; and when decided and the drafts drawn, the obligation to aceept became imperative. As the diseretion to draw was thus left solely with them, the terms of the letter are equivalent to an ahsolute promise to accept whenever they drew upon him in the manner sperifind. It is not for him to set up an abuse of this discretion to avoid the obligation, unless it be hrought home to the plaintiffs, of which there is no pretence.

Did the plaintiffs receive the hills upon the faith of the defendant's promise to accept them, and for a valuable consideration? It must he concerlerl, that most, if not all, the money now relied on as the consideration for these bills, was actually received by the agents, and therefore paid to them by the bank, before the written anthority to draw, and promise to accept was given; and henee, it eannot be said, strictly speaking, that it was arlvarred upon the faith of this promise. So much must be admitted. But as we have alrearly shown, the agents possessed authority to raise funds for the purchase of the wheat upon the defendant's paper, and in this case, no doulit rould he entertained of his liability as drawer, if he had heen so chareced. It is true, that regularly, the rlafts should have been drawn in the name of the principal, but Iudson's practice was uniformly otherwise, and was sanctioner by the defendant. He cannot be permitterl to arail himself of that ohjection. It mar then be confidently sairl, that the money when taken from the packages by Hudson operatert as a loan to. or charge upon, Fiy, the prineipal: that the rlebt was his, and if no drafts had been given he would have been holden to discharge it, upon the plainest law applicable to the 
relation of principal and agent. Now, assuming the adrance to have stood on this footing on the 1 Sth January, when the written authority to draw the bill was given, and the drafts in question were subse-

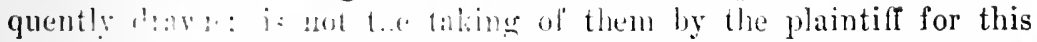
debt, a takinger upon the faith of the promise to aceept and for a valuable comideration: A man's own debt or accomt owing by

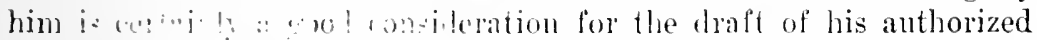
agent, and there can be no doubt of the fact that the paper was receivel on the credit of the engagement of $\mathrm{Ely}$ to accept, or which is the same thing, in julgment of law, mpon the authority to draw upon him. Here, then, are the three ingredients required by the statute: 1. A written promise to accept: 2. 'Taking the drafts upon the faith of it; and 3. A valuable consideration, to wit, the debt existing against the defondant, ereated by an agent with full authority.

It is to be legretted the attorney had not inserted the common counts in lis declaration, and then the question upon the statute might have been avoiderl; the defendant would have been eharged as drawer of the drafts in question.

Prudence would, perhaps, require that the pleadings should be amended in this particular.

Motion to set aside the report of referees granted; costs to abide the event.

- Sere aloo Exchange Bank v. Ilubbard, 62 Fed. Rep. 112.

Virtuar Accertacess. - An uneonditional writton promise to acept a bill to be therenfter drawn is hinding in favor of holders in due course who take the bill upon the faith of the promise. Coolidge v. Payson, 2 Wheat. (U. S.) 66: 1 Danied on Xrg. ln-t.. $5 \$ 551,560 ; 4 \mathrm{Am}$ \& Eng. Fnege. I. (2d ed.), Pp. 233-245. But the promiso must bo nneonditional. Merehants' Bank v. Criswoll, 72 N. Y. 472: Germania N. is. v. Tanks, 101 N. Y. 442; Bank v. Rerlenagle, $109 \mathrm{X}$. $\mathrm{Y}$. The promise must be in writing. fohnson v. (1/ark, 39

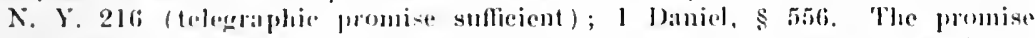

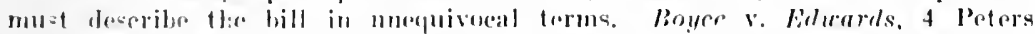
(L. S.) 111: franklin kank v. l.yneh. 52 Mll. 270 lof. flora first x. B. v.

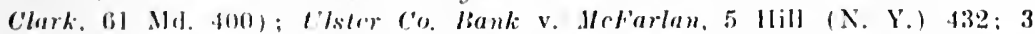

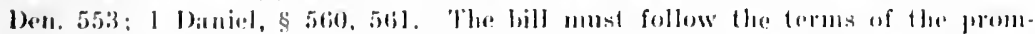

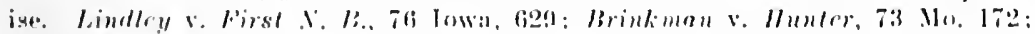

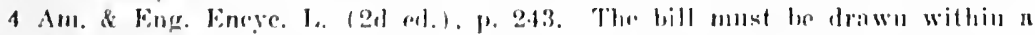
reasronable time after the riving of the promise. first N. B. v. Brnsteys 2

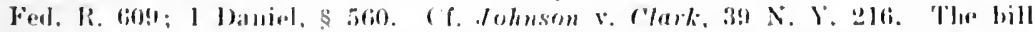

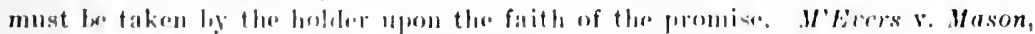

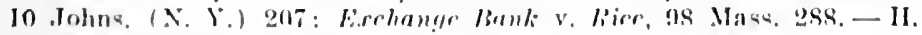

[Spe alon lankl of llortanton v. Hay, 143 N. C. 326. - C.]

NeGot. INaTnUMLNT - 42 


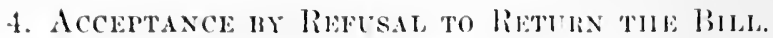

$$
\text { MATTESON } 2 \text { MOULTON. }
$$

\section{$11 \operatorname{IIT}($ N. Y.) $268 .-1877.7$}

Actrox against defendant as acceptor. Judgment for plaintiff.

Talcorr, J.-This is a motion for a new trial on a verdict directed by the court at the Cattaraugus Cireuit. Exceptions sent to the General 'Term in the first instance.

The action was upon an inland bill of exchange, drawn by one MeDonald on the defendant for $\$ 526.76$. The bill was never accepted by the defendant in writing, as required by the statute, which provides that no person within this state shall be charged as an acceptor on a hill of exchange unless his aeceptance shall be in writing, signed by himself or his lawful agent. (1 li. S., 2d. ed., $75 \%, \S 6)$; and unless he is made liable as an acceptor under the subsequent eleventh section, he is not liable upon the bill. The said section 11 is as follows:

"Every person upon whom a bill of exchange is drawn, and to whom the same is delivered for acceptance, who shall destroy such hill, or refuse within twenty-four hours after such delivery, or within such other period as the holder may allow, to return the bill accepted or non-accepted to the holder, shall be deemed to have accented the same."

The bill was sent by a third party with directions to leave it at the office of the defendant, which was done, and, so far as appears, no demand of acceptance was ever made. The defendant did not destroy the bill, for he produced it on the trial. The defendant never refused to return the bill; in fact, he was not directly required to return it, and no direct demand of the bill was ever made upon him. Two days after the making of the bill and the delivery of it to his agent at his office, the plaintiff called at the office and ascertained that the bill had been left there, and was informed by the agent that they were hard up and would not pay that day, but received no promise that the hill should be paid at any future day. The plaintiff went awa and left the lill mareepter at the office of the defendant. 'Two or three days after this, the plaintiff met the defondant at the hoter, in the same plare in which the office of the defendant, before spoken of, was located, and had a conversation. with the refendant about the bill. informing the dofendant that he (the plaintiff) had such a bill and that it was at defondant's office. The following conversation. as testified to by the plaintiff, then ensued between the parties:

7 Affirmed 79 N. Y. $627 .-11$. 
"I wanted to know whether he was going to pay it or not, and if not, I wanted the order; and he (the defendant) said he could not pay it then, but as soon as he had completed five miles of the railroad running into Jamestown, he should have the money. I asked him how long that would be, and he said ten days or two weeks. I told him it was considerable of an amount, and I wanted to know whether I should get my pay on it or not. He said I would get my pay on it inside of two weeks. I told him I wanted my pay on the order, and he said I would get my pay on the order as soon as he completed five miles of the railroad. Buffalo eity was going to pay him, and that he would get done inside of two weeks." This conversation occurred in June, and it does not appear that anything else took place between the parties until the sixth day of Oetober, when they again met, and the plaintiff asked the defendant about pay on the bill, and the defendant stated that "he had been disappointed about pay." The plaintiff also stated that the defendant never returned the bill or offered to return it.

We do not think that the evidence established a refusal to return the bill, within the eleventh section of the statute above referred to. The refusal mentioned in the statute, as it seems to us, refers to something of a tortious eharacter, implying an unauthorized conversion of the bill by the drawee. In this case it is obvious that the plaintiff willingly left the bill in the possession of the defendant, and in no way gave the defendant to understand that a redelivery of the bill was required, relying probably upon the expectation that it would be ultimately paid. The attempt to charge the defendant with the payment of the bill upon the ground of a promise is, as it appears to us, simply an attempt to charge the defendant with a liability on the bill upon a parol acceptance. If an action ean be maintained under such circumstances, the provisions of section 6 of the statute before referred to would be rendered wholly mugatory.

Besides, as to the promise, there was no evidence to show that the five miles of railroarl, on the completion of which the promise to pay the bill was conditionerl, had been completed.

The defendant moved for a nonsuit on the ground: First. That there was no acceptance of the bill in writing. Second. 'That there was no demand of the hill brfore suit. Third. That there was no refusal to deliver the bill. Fourth. That the plaintiff had failed to make out a cause of artion. The court held that the defendant was liable hecause he was indebted to McDonald, the drawer, because he had received and rotained, aud derlined to return the bill, and had promiser to pay it: to which ruling and to the rofusal of a nonsuit the defendant exerepted. We think the nonsuit should have been granted for the reasons stated by the drfomlant. 
'The verdict is set asile and a new trial obdered, costs to abide the eveut.

WISNER $v$. HIR']' NA'TIONAL,BANK.

200 Pexnivluiata STATE, 21. - 1908.

Mestrezat, J. Samuel R. Bullock drew six checks on the defendant hank in faror of Charles W. Gallare, Jr., who deposited them in plaintifl bank in New York city, which redited them to his accomnt in that bank. The first cheek is dated December 27, 1901, and the last . Junuary 3, 1905. The plaintiff sent these aluecks for collection to the defendant hank, two of them through the First National Bank of Altoona, Pa., and the remaining four through the Farmers' Deposit National Bank of Pittsburgh. On the day they were received the defendant bank handed the several checks to a notary public usually employed by it for the purnose of protest. and he held the checks without protesting them or giving notice of dishonor. On Janmary 9, 1905, some days after the checks had been delivered to the notary, the cashier of the Altoona bank went to Gallitzin, olotained the checks from the notary, took them to the Gallitzin bank, whose cashier gave the eashier of the Altoona bank a letter to a notary public in Altoona inclosing five of the Bullock checks with the request that they be protested for want of sufficient funds in the Gallitzin bask to pay them. One of the two checks sent by the Altoona bank to the defendant bank was returned to the former bank on the same day. It was conceded by the plaintiff on the trial below that there conld be no recovery for this check. The other check sent by the Altoona bank and the four checks sent by the Pittsburgh bank to the defendant bank were not returned by the defendant to the collecting banks for more than two days after their delivery to the latter bank. With the one exception, the Bullock checks were not returned to the defendant bank ly the notary public to whom they were delivered for protest within 24 hours after their receipt from the transnitting hank. The checks therefore, with the one exception, were not returned to the collecting banks within 24

\& Sce alko Ilolbrook v. Jayne, 151 Mass. 383. ante, J. 644; Overman v. Hoboken C'ity Bank, 31 N. J. I. 563: Colorarlo X. B. V. Boettcher, 5 Colo. 185: Jrune v. Haral. I P. \& Al]. 65.3.

The drawer has twenty-four houra in which to decide whether to accept or not, if presentment is made before the day of inaturity. Montgomery County Bank v. llbany r'ity lionli, \& Barb. (N. Y.) 396; l Janiel, \$ 492, - H.

[Matteson $\because$. Ioulton. ] ] IIm (X. Y.) 269, is followed in St. Louis S. W. Ry. ('o. v. James, is Ark. 190, in ennstruing a similar statutory enactment

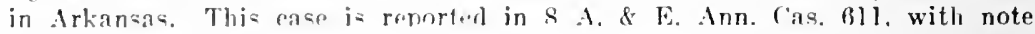
entitled "Protention of, or refusal to return, bill of excluange as acceptance thereof." - C.] 
hours after their delivery to the drawee bank, the defendant in this action.

This is an action of assumpsit brought by the plaintiff, the holder of the checks, to recover the amount of the checks on the ground that the drawee bank, the defendant, had accepted the checks by its refusal and failure to return them within 24 hours after their receipt, as required by section $13 \gamma^{9}$ of the Art of Assembly of May 16, 1901 (P. L. 213; 3 Purd. Dig. [13th Ed.] p. 3250), known as the "Negotiable Instruments Law." The defendant claims that it is relieved from liability on the checks because it had refused to accept them, and had on the day of their receipt delivered them to a notary public for protest and dishonor. The learned trial judge was of the opinion, and so instructed the jury, that the defendant had not hy its conduct " relieved itself from the presumption that it had accepted these checks by any evidence which it had produced in the case," and that the verdict should be for the plaintiff for the amount of the five checks. Subsequently the court, on motion of defendant's comsel, entered judgment for the defendant non obstanle veredicto on the entire record. The learned court in its opinion entering judgment for the defendant held that under the Negotiable Instruments Law it was necessary for the holder, in orler to recover against the drawce bank, to prove a conversion of the checks, and that the mere retention of them for more than 24 hours, witlout a demand for their return, is not a refusal within the meaning of the statute. The plaintiff has taken this appeal.

We come now to the principal and controlling question in the case, and that is whether the failure to return the checks to the holder or the collecting bank within 21 homrs after their delivery to the defendant was a refusal to return the checks within the meaniug of section 137 of the act: or does the act contemplate a tortious refusal to return, amounting to a courersion of the checks, as claimed by the defendant and as held by the rourt below?

The drawee to whom a bill is delisered for areptance is deomed or taken to have aceeptod it under this soction of the act (a) where he destroys it; (b) whope ho rofuses within 21 hours after delivery to return the bill anepepted of nonalecepted to the holder; and $(c)$ where he rofuses within surelo of hor perioul as the holder may allow to

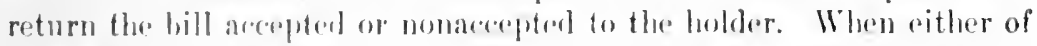
these conditions exists, the drawer lueromess an arepetor of the bill, and assumes lialifity as surh. An implied or a verbal areeptance

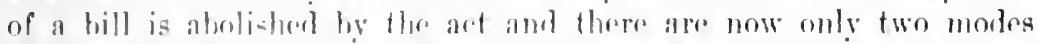
of accopting a bill: (i) liy writing. signed ly tho drawer, as provided in soretion 1:3: ' and (?) ly a nompeturn of the hill, which is

จ.

IN.Y., $3200 .-\mathrm{C}$. 
declared by the section under consideration to be the equiralent of an acceptance.

The manifest purpose in requiring the prompt return of the bill is in the interest of and for the protection of the holder. It is immaterial to the drawer when the bill is returner, as he is protected by notice of dishonor: and henee this section of the act requiring prompt action in returning the bill was ohvionsly enacted for the benetit of the holder of the bill. 'The act deelares in section $136^{2}$ that :-t hours is sufficient time for the drawee to deeide whether or not he will accept the bill, and the section under consideration, laving allowed this time, it rexuires him to return the bill aceepted or nonaccepted. If a demand and refusal are conditions precedent to an acceptance under this sation, then the holder must not only present the bill for acceptance, but he must make a demand for its acceptance, and await a specific refusal before the drawee is deemed an acceptor. This would certainly not he to the convenience or the interest of the holder, but in direct opposition to both. It would afford the holder less protection, and would in effect prevent the return of the bill within 24 hours; or it would require the holder in transmitting the bill with instructions to present it for acceptance to send at the same time a demand for its acceptance. It is obvious that such demand accompanying a presentation of a lill for acceptance is wholly unnecessary, and certainly was not in contemplation of the legislature in enacting the section.

The presentation of a hill for acceptance is a demand for its acceptance, which, if the hill is retained $b$ the drawee, implies a demand for its return if acceptance is declinerl, in contemplation of the Necrotiable Instruments Law. The purpose of presenting a bill of exchange to the drawee is to require him to accept and assume liability for its payment, or to refuse its acceptane, and therely aroid liability. Whon the hill is presented, artion by the drawee is therefore demanded of him, and he cannot remain silent and inactive withont incurring the statutory penalty preseribed for such conduet. If he is permitter to retain the bill, he must return it accepter or not accepter at the expiration of 21 hours. If he arcepts, he is required to do so in writing, and must return the bill. If he refuses, he must return the lifll not arcepted. If he fails to to either-return it aceepted or not acrepted - he is "decmod to have alcepted the bill" under this sertion of the act, and is liahle thereon to the holder. It is apparent, we think, that in the enactment of this sertion of the statute the lecrislature recarded the presentation for aceptance as a demand for an arereptaner, which, when the hill is retaines by the drawee, implies a demand for its return within the time specified, and that, therefore. the necrlent or failure to return is a refusal to return

2 N. Y., § $224 .-$ C. 
the bill. As said by this court in First National Bank of Northumberland r. McMichael, supra, if a bank does not pay or accept a check, it is bound to refuse it. And this is more clearly disclosed as the true interpretation of the word "refuses" in this connection, when we consider that the consequences to the holder of the nonreturn of the bill are the same whether it follows a demand, additional to the presentation for acceptance and a refusal, or simply a neglect or failure to return after the demand implied by its presentation for acceptance. If the section has in riew the protection of the holder as it manifestly has, then it was evidently the intention of the legislature that the nonreturn of the bill within the specified time, regardless of the cause, will make the drawee an acceptor.

The law merchant discourages laches in parties to negotiable paper, and demands prompt action in the performance of the duties imposed upon them. It was not the intention of the legislature in the cnactment of the Negotiable Instruments Law to abolish this rule, and to encourage delay or inaction in the holder or drawee of such paper. The intention of the section in question was to cxpodite action low the drawee in accepting or refusing a bill presented and retained hy him, and to fix a definite time, which had previously been uncertain, in which he should act on the bill. IJe is granted 24 hours after delivery, and not after a demand for a return of the bill, in which he must accept or decline to honor it. The time for roturning the lill to the holder does not hegin to run from the demand for it rotum, but from the date of its delivery. The drawee must, therefore, act within 24 hours from the date of the delivery of the bill, whether his action be an acceptance or a refusal. The section gives no other alternative, and makes no other provision either for failure or neglect. Hence, action heing reguired of the drawere, and one of the two altermatives being open to him. if he does not aecept and return the bill. it will be deemed acrepted if tho bill he his dofanlt romane in his hands beyond the time limit. Ho refuses in return the hill in contemnlation

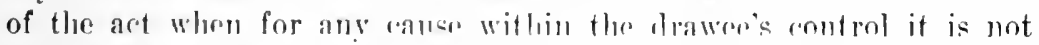
sent to the holder in the sperilierd time. There an be no reason, and we will not assume that the lecislature intenderl to do an unreasonahle

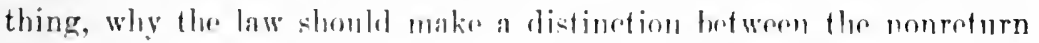

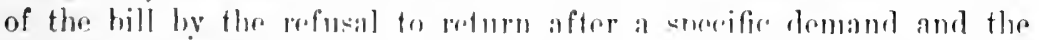
failure or neeglece to return after a dromand implied be presenting the

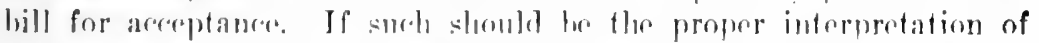
the seretion and a formal demand len nereseary, then there is no provision in any part of the entipe and imposing a penalty for the default

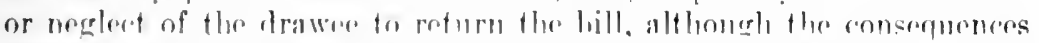
of surch act on the part of the drawere are as prejudicial to the londer as if a rofusal to return the hill harl followed a preine sencifie domand. There is. lowwerer, no such casus omissus in the art: hut the enfore- 
ment of the return of the bill, accepted or nomacepted, within the time designated, being the primal ohject of the sertion, the eause of its detention is wholly immaterial, and eannot anlect the drawee's liability as an aleceptous.

The construction we place on section $13 \%$ is necessary to protect the holder of checks and other nerotiahle paper, it furnishes a complete statutory remedy for any default of the drawee in acting on the paper when retained by him, and does no riolence to the language employed in the section. It carries out the obvious intent of the legrislative mind in the enactmont of the section, and establishes a fixed and certain rule to govern the drawee and the holder in the former's action on negotiable paper presented to and retained by lim.

Onr interpretation of the statute coincides with the legislative construction placed upon a similar statute in the state of Wisconsin. In enacting a Negotiable Instrmments Law the legislature of that state added to a section of it similar to section 137 of our act a proviso "that the mere retention of the drawee will not anount to an acceptance." * The lowical inference is that the mere retention of the bill would be an acceptance within the meaning of the language of our statute which contains no such proviso.

It is not accurate to say, as suggested by the appellee, that under the Negotiable Instruments Law a bill can only be accepted by writing signed by the drawe. It is true that verloal and implied acceptances have been abolished by section 192 , which provides that the acceptance must be in writing and signed lyy the drawec. But section $13 \%$, involved in this ease, declares that the action of the drawee in destroying a bill or in not returning it, as required by the section, shall he deemed an areeptance of it. A constructive acceptance of a bill under this section is as effective to charge the drawee as an acceptance in writing under section 132. Nor do the two sections in any way conflict. The former section requires affirmative action on the part of the drawee by assuming liability by a witing. 'The latter section declares his liability if he destroys the bill, or if by inaction he retain the bill beyond the specified time. An acceptance under either section oblicates the drawee to pay the bill.

In the state of New York a Negotiable Instruments Law has been enacted, and a section similar to section $1: 3 \%$ of our act is included in the statute. The Supreme Court of that state in State Bank v. Weiss, 46 Misc. Tep. 93, las construed this section of the statute in conformity with the maning we have given onr own act. The case was deciled in 1904, and it does not appear to have been raried to the Court of Appeals of the state. Matteson v. Moulton, 79 Х. Y. 627, relied upon by the rourt helow and the appellee here, was decided by

* The actual wording of this arldition to tho $W^{*}:=n n n=i n$ statute is simply: "More retention of the bill is not acceptance." - C. 
the Court of Appeals in 1880, and the syllabus of the case states that the court held that "refusal" in the New York statute is " an affirmative act, or is made up of condnct tantamount to one, [and] it is also a willful or wrongful act." But the facts of the case did not require the court to determine whether the failure or neglect to return the bill within 24 hours was a refusal to return it within the meaning of the act. The bill was sent to the office of the defendant, who retained it for three or four months with the consent of the plaintiff, and under a promise to pay, relied on by the plaintitf. It will therefore he observed that the facts of the case did not require the court to determine whether the mere retention of a hill of exchange for 24 hours after its delivery to the drawee would eonstitute an acceptance. Again, if the case is still authority in that state for an interpretation of the act, it is singular that it is not cited or referred to in the very recent case of State Bank v. Weiss, supra, in which the court gave an interpretation of the same section of the Negotiable Instruments Law of that state diametrically opposite to the construction of the act announced in the Matteson ease.

We are of the opinion that, under scction $13 \%$ of the Negotiable Instruments Law of this state, the failure or neglect of a drawee to whom a bill is delivered for acceptance to return the bill, accepted or nonaccepted, to the holder within $2+$ hours after delivery, makes the drawee an acceptor of the bill. It therefore follows in the ease in hand that, the defendant hank having failed to return the five checks to the collecting hank within 24 hours after their delivery to the drawee, the latter must be deemed to have accepted the checks, and is therefore liable to the plaintiff for the amount of them.

The judgment non obstante veredirto in favor of the defendant is reversed, and judgment is now directed to be entered by the court below on the verlict in favor of the plaintiff and against the defendant. ${ }^{3}$

3 This case is reporterl in 17 I. X. S. 126f, with notr entitled, "Detention of hill of exchange or clicele ly drawee as acerptauce."

A note to this case in 8 ("ol. Jaw Ros. 508 (.June, lans), save: "Mrre retention is elearly not rofusal when it is the lubler's duty to demand its return. \$ 225 Neg. Iust. Jaw has been coustruel as requiring a tortious

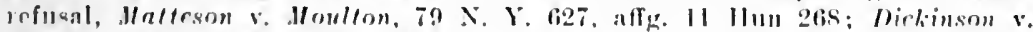

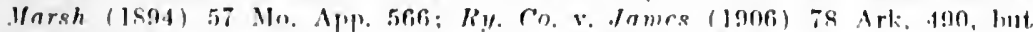
retention in the face of a customary dealiug or notifiention that the drawer shall return a bill, or check, $\$ 321$. would som to tor a rofusal within the meaning of the section. Sinco banking usage requires prompt roturn of the check if payment is refu-ed. ita retention in the principal rase slomld be suf ficient to charge the drawe as acerptor. But. While porrect in realt. the decision serms erronenus in holding thot a non-tortious refusal will so charge the drawer."

Mr. Crawford eriticize the principal rase as follows: "It is difieult to ser how the statute could apply to such a state of facts. It refers only to 


\section{ACCeptance of Incomplete ol Dishononed Bill.}

69) Maryanil, 513. - 1888.

Action against defendant as acceptor. Defendant accepted the draft before the drawer (Waddy) signed it. The draft, payable " to order of myself," was then indorsed to plaintiff by Waddy. Plaintiff presented it to defemlant who refused to accept or pay it and pointed out that Waddy had not signed it as drawer. Plaintiff then procured Wadely's signature as drawer. Julgment for plaintiff.

MiliEli, J. [after stating the facts] delivered the opinion of the court. *** The material facts are undisputed. Ilopps wrote the draft himself, accepted it, and then gave it to Waddy for the

cases where the palper is presented for aceptance; but where checks are renitted to the drawe lank, the obvious pmpose is to present them for payment. and not more acreptance. What the holder desires in such a case, is that the bank shall remit the moncy, not that it shall return the check with its acceptance placed thereon." Craw. Neg. Inst. law, 3rd ed., p. 156.

An article in 25 Banking Law Jour. 638 (Angust, 1908), discussing the principal case, says: "It scems incorrect, in a way, to apply to checks the section which provides that [quoting \$ 225.] A check is not presented for acceptance. hut for immediate parment; a bank is not obliged to accept or certify a check, only to pay it, and a check cannot be protested for refusal to certify, hut only for refusal to pay. The delivery for acceptance provided by this section crintemplates bills of exchange other than checks. But the Negotiable Instruments Law defines a check as a lill of exchange drawn on a bank payable on demand, and declares that, except as otherwise provided, the provisions of the act applicable to a bill of exchange payable on demand apply to a check, and the Supreme Court of Pennsylvania says that there is no provision in the act which makes the section in question inapplicable to bank checks presented for payment, and that there is every reason why the section shoulil apply." p. 641.

Section 137 of the Penusylvania Negotiable Instruments Law [N. Y. \& 225] was amended by laws of Pennsylvinia, 1909. No. 169, p. 260, by atding the following: "lioviled, that the mere retention of surh bill by the drawec, unless it return has been demanded, will not amount to an acceptanec; and provided further. that the provisions of this section shall not apply to checks." Conmentine on this amendment, the Pennsylvania Comnittec on Uniform State Laws, in its 1909 report to the Pennsylvania Bar Association, says: "As was pointel nut by the learned editor of the Legal Intelligencer (May 7. 1909), this act was passed probably to overcome the effect of the decision of the Supreme Court in Wisner v. First National Bank.

While of course, anything that destroys the uniformity of any section of the act. whether by judicial decision or hy statute, is to be deplored, it has been sajd in relation to this particular act, by eminent anthority, that in thus ehanging the law as interpretel ly the Supreme Court, the statute but follows the weight of anthority in othor statrs. so that substantial uniformity has not been affected," Report of Pa. Bar Ass'n for 1909, p. 136. 
express purpose of enabling him to raise money upon it. It is true it was delivered to him before Wadkly had signed it as drawer, but there can be no doubt as to the fact that Hopps intended Waddy should sign and negotiate it. In such case the law implies an anthority from Hopps to Waddy to sign his name as drawer. Four days after its date, and long before its maturity, Waddy indorsed the draft to Sarage, and received from the latter its full face value. That Savage thereby became a bona fide holder for value is undeniable. Even if he had then known that, as between Hopps and Waddy, it was without consideration and merely an accommodation bill, his position as such holder would not have been affected by such knowledge. (Maitland v. Citizens' Nat. Bank of Balto., 40 Md. 540.)

It is also true that Waddy's signature was not put to the draft until after Sarage had become the holder. In other words, the draft, when indorsed to Savage, was in blank in respect to the drawer's name, but this blank was afterwards filled up in accordance with the intention of the parties when the bill was written and aecepted. We are clearly of opinion the law anthorized this to be done. In fact the authorities go to the extent of holding that Savage would have been authorized to fill the blank by inserting his ow'm name as drawer. Such was the decision of the Common Pleas Division in IIarvey v. Cane (34 Law T'imes, N. S. 6t) ; and in scard and Wife. v. Jactson, reported in a note to the same case, it was held that the name of the holder conld be thus inserted after the maturity of the bill. (See, also, schullz v. Aslloy, 2 Bing. N. (. 5 t.t.) In the rase before us the suit is hy a bona fide holder for value before maturity, against the acceptor, and the drawer's name was sirnerl in strict accordance with the intention of the parties. We hold that in such a case it makes no difference whether the blank was filled bofore or after the maturity of the draft.

Fron these views it follows there was mo error of which the appellant is entitled to complain in the rulings of the conte npon the instructions, and the jurlgment must be affirmed.

Judgment affirmed.

STOCKWELI, $P$. PRAMPIS.

3 Iงmลงห, $428,-1852$.

Actuos against defendant as acreptor of a bill. Judgment for defendant.

Plaintift offered to prove that defendant stated that he wonld aceept the hill, but lir not want it generally known that he was accepting the drawer's bills, and would therefore writr "protested" 
across the face, which he did and signed his name; that afterward on the same day delendant again promised to pay the bill. This evidence was excluded.

BıAскrolis, J. |after stating the factsl. We think that the parol evidence offered hy the plaintilf was admissible, on the gromnd that it showed a valid acceptance of the bill by the defenclant, after he had written on it the word " Protested."

suppose the word "Protested," as written on the bill, to mean that the defendant refused to arept the bill, and the holder so understood that word; and suppose, also, that evidence of what the defendant said, at the time of such refusal, was objectionable as contradicting the word "Protested," still the subsequent parol acceptance would be good. We know of no reason why the drawee of a bill, who has refused to accept the same, may not afterwards accept it. It frequently happens that a bill, after being protested for nonacceptance, is accepted by a third person supra protest. The following case is cited by Mr. Chitty: A foreign bill drawn on defendant was protested for non-acceptance, and returned, and afterward defendant told the plaintiff, "if the bill comes back I will pay it," and this was held a good acceptance. (Chitty on Bills, 216, note 7 .) It is clear, therefore, that the fact of a bill's having been protested, does not prevent its being afterwards accepted by the drawee.

The acceptance is not objectionable merely because it was by parol. By the law merchant, a bill, whether foreign or inland, may he accepted by parol as well as by writing, (Chitty on Bills, 316) ; and that is the law here.

PER Curiam. - The judgment is reversed with costs. Cause remanded."

\section{Kinds of acceptances.}

1. General Acceptance.

$\S 227$ MEYER\& CO. $v$. DFCROIX, VERLEY ET CIE.

L. R., 1891, APpeat, Casfis (H. L.) 520.

Arтios hy indorsecs against acceptors, upon the following instrument: ${ }^{5}$

4 "A promise to accept, even after a protest for non-acceptance, is binding: and a promise to accept made after the bill becomes due according to its tenor. amounts to a promise to pay immediately." Grant v. Shaw, 16 Mass. 341 (1820). - H.

5 In fac-simile in 59 I. J. Q. B. $539 .-\mathrm{H}$. 
No. 501. £7is $4 s .2 d$.

Roubaix, Sept. 12th, 1859.

On Oct. 31 st after date pay to __ order 6 Mr. L. Delobbel Flipo seven hundred and seventy-eight pounds $4 s$. $2 d$. Value received.

To Messrs. H. Merer \& Co., Limited,

L. Delobbel Flupa

London, Eng.

[Across the face was uritten and stamped:]

In favor of Mr. L. Delobbel Flipo only.

No. 28.

Accepted payable at Alliance Bank, London, for H. Meyer \& Co., Limited.

B. Maving, Abthur Manisg, Direetors. Arthub Maxing, Secretary.

The word "order" in the bill was struck out, but when or by whom did not appear.

Plaintiffs, bankers at Lille, in France, discounted the bill for Flipo. They did not understand English and their attention was not ealled to the form of the acceptance until after the dishonor of the bill by the Alliance Bank.

The Divisional Court (Cave and A. L. Smith, JJ.) held the acceptance was a qualified one, rendering the bill non-negotiable, and gave judgment for defendants. The Court of Appeal (Lord Esher, M. R., Lindley and Bowen, I. J.J.) reversed that decision and entered judgment for the plaintiffs.' Defendants appeal.

Lord Herscinell. - My Lords, the respondents in this ease seek to recover from the appellants the amount of a hill of exchange accepted by them. 'The defense set up is that the acceptance was a qualified one, and restricted the right to require payment to the payee alone, and that the acceptors are therefore moler no obligation to the respondents who took by indorsement from him.

It was not disputed at the bar that the arecptor of a hill of exchange may make his aceeptanee a qualified one. If he to so, the drawer may, of conrse, refuse to take surbly an acreptance. and treat the bill as dishonored: but if he takes the hill, the obligation of the areeptor is not absolute, lut subjeref to the qualifiation which he has introdueed. I think, further, that it is lryomel disumte that if an aneptor seeks to qualify his arreptance, and thms to modify the ohligations which an areptanere orlimarily imposes, he must do so on the face of

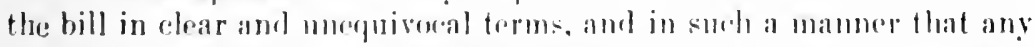
person taking the bill, if le arterl reasomalily, rould not fail to understand that it was arerepterl subjoet to an expersecel qualifiontion.

Atout these propositions I lo mot think there ran bo any difference of opinion: the difliculty lies in applying them to the facets of the

- This word was struck out hy a pen mark. Hy the provisions of the Bills of Exchange Act (s 8, sulusere 4) the Wrids "order" or "bearer" are not necesary to renter a bill negrtiable. - H.

ร See 59 I. J. Q. B. 539 : I.. R. 25, Q. I3. I). 343.- II. 
particular case. The bill in question was drawn in France by a person named lelobbel filipo upon the appellants, and forwarded to London for their aceeptance. 'The bill is drawn on a printed form containing the word "order" immediately preceding the name of Delobbel Flipo, which has been inserted as the payee of the bill. This word "order" las been erased, but by whom does not appear, nor do I think it matcrial. 11, as suggested, it was dome by the aceeptors, they were not justified in making the erasure, and in any case there would be nothing to show a person taking the hill that the word had not been struck out by the drawer at the time he inserted the name of the paree. I lo not think, therofore, that the erasure of the word "order" can in any way assist the contention that the acceptance was a qualified one. 'That must be determined by a consideration of the effect of the words written across the bill by the acceptors.

For the purpose of accepting the bill the appellant company impressed upon it by means of a stamp the words "accepted payable at Alliance Bank, London," melerneath which the signatures of two directors and the secretary were written. The acceptors wrote across the bill above the word "accepted" the worls "In favor of Mr. I. Delobbel Flipo only:" between these words and the word " accepted" was written "No. $28 . "$ In consibering whether the effect of the words "In favor of Mr. L. Delobbel Flipo only" was to make the aeceptance a qualified one in the manner suggested, regard must be had both to the words used and to the situation in which they are placed. It may be that if the same words had been found in the body of the acceptance following the word "accepted," they would have amounted to the qualifieation contended for. The presence of any words in the body of the acceptance would of itself suggest the idea that some qualifieation of it was intended; but where the words are not inserted in the body of the acreptance, I do not think the same impression is likely to be produced, thougl the words may, of course, be so elearly intended to qualify the acceptance and so incapable of any other reasonable construction that they would be as offectual for the purpose. But in the present case the worls written above the acceptance are not "Pavable to Delobhel Flipo only," whichls is the meaning sought to be attached to them, but "In favor of Delobbel Flipo only," which do not seem to me neressarily to bear the same meaning. "The words "in favor of," when used in relation to a bill of exchange, do not ordinarily mean that it is payable only to the person in whose favor it is said to be drawn; the words are equally applied when the bill is made payable to his order. The words "In favor of," therefore, are properly paraphrased by " payable to, or to the order of ; "but then it is said that the insertion of the word "only" after Flipo's name would show that this rould not be the meaning intended. It must be remembered, however, that between these words and the ac- 
ceptance " No. sS" was inserted, which separates the words which it is suggesterl qualify the aceeptance from the neceptance itself.

Under these cireumstances I do not think that it is impossible that a person taling the acceptance by way of indorsement might suppose that these worls "In favor of Delobbel Flipo only" were, like the "Nr. 28," a mere memorandmm inserted by a party to the bill, and not intenderl to atleet the acceptance. It might be supposed to indiate that it was the 2sth bill, or No. ss of the bills acrepted " in favor of Delobbel Flipo only," as distinguished from bills acrepted in faror of Flipo and some other persons. I do not say that this would be the interpretation given to it hy a person who carefully and eritically considered it. But that is not the question. It is impossible, as I have sail. to disassociate the worls used from the position and collocation in which they are found, and if these he such as to suggest that the words are a mere memorambum, a person taking the bill, even if he axereised the ordinary are to he rxpected in such transactions, would not lie likely to examine or weigh them with the same care as if they were found in the body of the acceptance.

In my opinion the sualification was not made in clear and muequivocal terms, and in surll a mammer that any person taking the bill, if he acterl reasomalyly. romld not fail to molerstand that it was aceepted subject to that qualification. I think, therefore, the judgment ought to be atfirmet. ${ }^{s}$

Lomo Bisuwed.. - My Jords. I consider what was written and printed by the defembants on the face of the bill as one - one thing only - an acereptaner and no more, not an areeptame amol sometluing

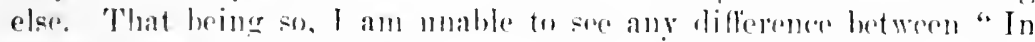

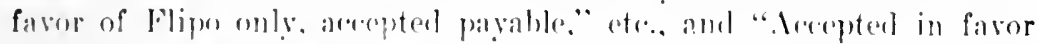
of Flipo only. masable," ate. I to not kmow where the borly of the

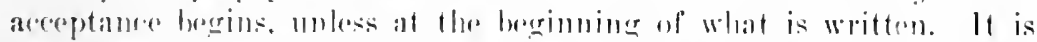

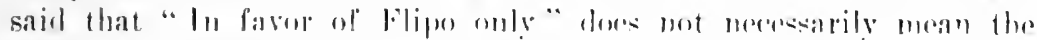

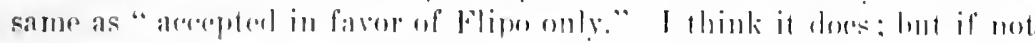

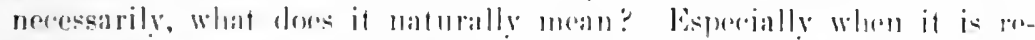

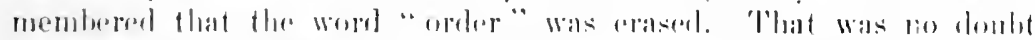

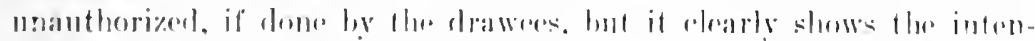

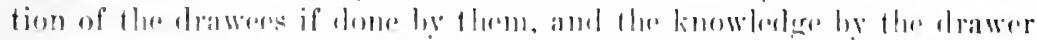
of that infontion if alom hy him. The striking ont of " oreler " was

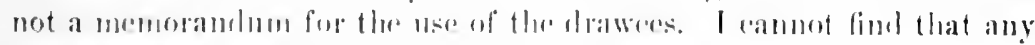

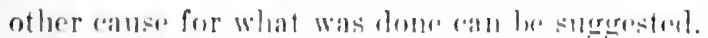

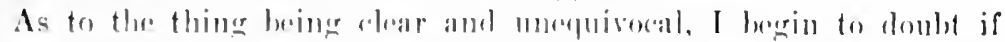

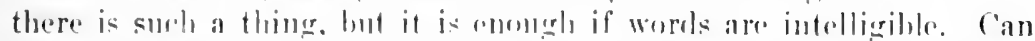
there be a dombe that this bill might have hem protestorl for non-

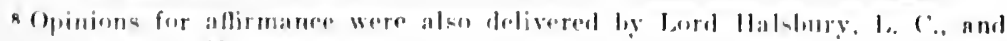
Jord Watson. - II. 
acceptance according to its tenor? I suppose from the form of the alceptatuce that the appellants thomglat they hate or might have,

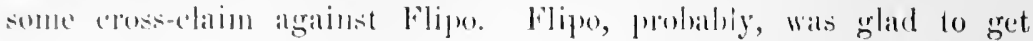

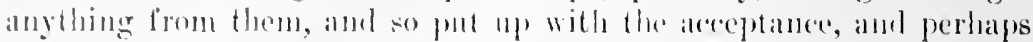
indersed it in satisfaction of a bad doht to those grlad to get anything [rom hims.:

Oster appealed from aflimed, and appeal dismissed with costs.

$\S 228$

TROY CIT'Y BANK $v$. LAUMAN.

19 NEW YดRK, 477. - 1859.

Acros against indorsers of bills addressed to the payee at New York, and accepted hy the payee "payable at Continental Bank, New York." Presentment at the continental Bank; paynent refuserl; due notire. Indgment for plaintitf.

S. B. Srroxa, J., |after disposing of other questions|. The two drafts were respectively addressed to the drawee in New York, and were accepted by him, payable at the Continental Bank in lhat eity, where the demand of payment was mate. The defendants' counsel contended on the trial that the dralts were not duly areepted or demand of payment properly made, and they vited the case of Woodworth v. The Bank of Americe (19 Jolun. 391), to sho\% !'att sucli practices were irregular and did not attach any responsilility to them. In that ease, however, the note was in fact pavable in Albany, and there was a marginal memorandum, signed by the maker, that it was pavable in New York. That memorandum was made after the note had been indorsed by Jurlge Wondworth, and without his knowledge. It was held, and perlays properly, that the memorandum was an alteration of the note, and discharged the indorser. 'l'he alteration consisted in making it pavahle in a diflerent eity, and that rendered it matrial. It is not of course an alteration of a deaft to areept it as payable at a designated place in the same rity. and if it rould be dremen a rhange at all, it is not made by the payec or indorsee, nor is it at all matrial.

Sio, tow, in the case of Hallier v. Bank of the state of New York (13 Barl), (i,ifi), the dralt was directed to the llawee in New York and aroepterl ly him, payable at Clayrille Mills, in Oneida iounty. It was properly lied that the change was material and rendered the acceptance voirl, and that as no notice of such acceptance was given to the indorsees, they were dischatred.

If, in the rase under consideration, the drafts had been marle payable at a particular store, counting house, or office in New York, it would have been a change, althongh I do not think that it would

- Opinion for reversal was also delivered by Lord Morris. - H. 
even then have been a material one, to have accepted it as payable at another place in the same city. No possible injury ean result to the drawer or indorser by making a bill of exchange, directed to the drawee in a city generally, payable at some particular place in the same city. It becomes pro hac vice the place of business of such drawee. 'The cases differ' as to whether the holder may not, nevertheless, present the bill for payment at the ordinary place of business, or if he has none, the residence of the drawee; ${ }^{1}$ but I have seen none which decides that he is bound to do so. I am confident that the practice pursued in this instance corresponds with commercial usage, and think that it should be sustained.

[The court then holds the notices sufficient.]

Judgment affirmed. ${ }^{2}$

\section{Qualififd Acceptance.}

\section{(a) Conditional acceptance.}

\section{\$229 STEVENS $v$. ANDROSCOGGIN WATER POWER CO. 62 Marve, 498. - 1874.}

Appleton, C. J.-This is an action of assumpsit against the defendants, as acceptors of the following order, drawn on them by James Hibbard:

Androscogeis Water Power Co.,

Sineliburne, Feb. 25, 1873.

Edward Pivmaner, Agent.

Please pay to .Janes $\mathrm{A}$. Stevens, for cutting and hauling lumber, the sum of one hundred and thirty-four dollars, and charge the same to my account.

JAMES Humino.

If a particular place is speeified in the acceptance, the presentment for payment must be made at that place or the drawer and inclorsers are dis. clarged. Brokn v. Jones, 113 Ind. 46. Contra: Niagara District Bank s. fairman, etce, Co., 31 Barb. (N. Y.) fot. where it is liell that if the bill is addressed to the drawe in Town A., and ho aceppte it payable in Town R., it is improper to make presentment in $B$.. lut it should be presented to the aceeptor in $A$. Otherwise if he acepts it payable at a particular platee in Town A. - H.

2 "Before the I \& 2 Geo. 4, e. 78 (Sergeant (Inslow's Aet). it was a point much diaputed wheller, if a hill payable generally was aceppled pasahle at a particular place, such an acepptance was a pualified one. That statule. howeser, has now settled that nn acenplaner payablo at a baluker's or other

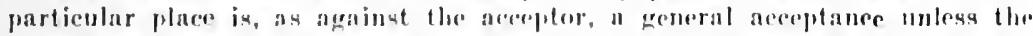
neceptor exprese in hiv aceeptaner llat the bill is payahle there only, and not otherwise or "lsewhere." liyless on lijlls, p. 197. Rover v. Young. 12

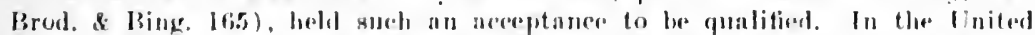

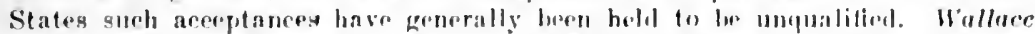
v. Mecomnell, 13 Petere (1). S.) 136: 1 Daniol. $8 \$ 520,641-643$. The Neg. Inst. L.. \& 228, enacts anloutuntially the proviujoms of Sergeant Onslow's Aot, now found in lills of Exchange set, sै $19,-$ II.

NEGOT. INGTHCMENTS - 43 
In answer to a letter from the plaintifl, the defendants on March 18,1893 , wrote the following letter to him:

Mr. JaMES A. STEVENS:

Lishov Falls, ME., March 18, 1873.

bear Sir: Yours of the thirteenth inst., is reeeived. We shall not pay any orders of Mr. Hibbard until we settle with him. If there is anything over, 1 will keep it back for the purpose.

Yours truly,

E. P'Lum Mer, Agent.

The order of February 2.5 was retained by the defendants in their possession. On March 25, 1873, the defendants were summoned as trustees of James Hibbard, in a suit in which one Bean was plaintiff, returnable at the September term of the Supreme Judicial Court for the county of Androscogerin, and for the sum of $\$ 356.70$. On April $28,18 \% 3$, the plaintifl's attorneys were notified that this action would be entered at the September term, and that the trustee would make a full statement as to all orders drawn, and leave the question of liability to the decision of the comt. Prior, lowever, to the September term, Ilibbard settled the suit of Bean, and directed the defendants to pay the amount due, without notifying the plaintif in this suit. At the time of this settlement there were due IIbbard from the defendants, four hundred and four dollars and forty-seven cents, out of which sum they paid Bean three hundred and sixty-nine dollars and fifteen cents, and the balance of thirty-five dollars and thirty-two cents they paid Hibbard. 'This payment was on August 2, 18\%3.

An acceptance may be absolute or conditional. $\Lambda$ conditional acceptance at once becomes absolute upon the performance or happening of the condition.

In the present case the defendants' promise is to pay if in settlement "there is anything over." When the arceptance is conditional, the holder may accept or refuse the offer. ${ }^{3}$ 'The plaintiff acceded to the proposition of the defendants - permitted the order to remain with them, and did not sue out a trustee writ, by which his whole debt would have been secured. There was a settlement and the amount due exceeded the annount of Hibbard's order. The defendants then becane liable, and this liability, conditional in the first instance, accrued long before the trustee suit of Bean. 'The payment to Bean by the defendants was in their own wrong, and cannot defeat the prior right of the plaintiff.

Defendants defaulted. ${ }^{4}$

3 See Ncg. Inst. I., $\$ 230 .-\mathrm{H}$.

4 Any condition clearly varying the tenor of the bill renders the acceptance conditional. I Daniel on Neg. Tnst., \$ 509-515; $4 \mathrm{Am}$. \& Eng. Encyc. L. (2nd fd.), pp. 227-232. The conditional acceptance becomes absolute upon the happening of the condition. Ilid. An acceptance "when in funds" is conditional. The bill is payable when the acceptor has in his hands funds which 


\title{
(b) Partial acceptance.
}

$\S 229$

\author{
PETIT $v$. BENSON.
}

Cомвенваси, 452. -1697 .

A BILL was drawn upon the defendant, who accepts it by indorsement in this manner: "I do accept this bill to be paid, half in money and half in bills." And the question was, whether there could be a qualification of an acceptance; for it was alleged that his writing upon the bill was sufficient to charge him with the whole sum. But 'twas proved by divers merchants, that the custom among them was quite otherwise, and that there might be a qualification of an acceptance; for he that may refuse the bill totally, may accept it in part. But he to whom the bill is due may refuse such acceptance, and protest it so to charge the first drawer; and tho' there be an acceptance, yet after that he hath the same liberty of charging the first drawer as he before had."

(c) Local acceptance.

$\S 229$ TROY CITY BANK $v$. TAUMAN.

[Reported herein at p. 6r?.]

Halstead $v$. Skeiton, 5 Q. B. 86 (1843). Tindal, C. J. - The statute "enarts that, where a bill is accepted payable at a banker's, without further expression in the acceptance, such acceptance shall be deemed and taken to be to all intents and purposes a general acreptance of such bill; but the meaning of this enactment is not that in such a case, presentment at the hanker's shall he an invalid presentment, but that, in an aretion against an aeceptor, presentment to him shall be good, and ronsequently that it shall be unnecessiry to present or to aver presentment at the banker's. A hill of exchange drawn generally on a party may be acepted in three different forms: Wither generally, or payathe at a partirnlar banker's, or payable at a par-

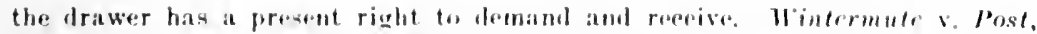

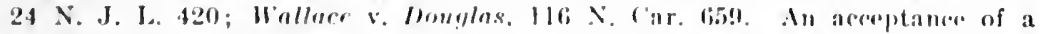
sixty-day bill "payalole on giving 11 h hill of latling. etc.." is a qualifienl acceptance: but the acerptor is lomul aven though the bill of lading in not tendered until after the maturity of the bill. Smith v. Vertur. 30 L. I. ( . P. 56. - H.

" "In Molloy and the other book there in a whole paragraple about the partial acerptanee of " hill of rxchange, and they allow it to tee grond." Wegersloffe v. Krene. I Strangw, 214. 225. - II.

- Namely, Sergeant Onslow's Act, I and 2 Ger. 4, c. 78. Sere note on page 478 , ante. $-\mathrm{C}$. 
ticular banker's and not elsewhere. If the drawee aceepts generally, he mulertakes to pay the bill at maturity when presented to him for payment. If he alcepts payale at a banker's, he undertakes (since the statute) to pay the hill at matmrity when presented for payment either to himself or at the banker's. If he aceepts payable at a banker's and not elsewhere, he contricts to pay the bill at maturity provided it is presented at the bankers, but not otherwise.

Here the bill was accepted aceording to the second of these three forms: $i$. é, payable at a banker's, withont any restrictive words; so that presentment at the banker"s (thongh if made it would have been a govd presentment) was yet not, as against the acceptor, necessary.

\section{(d) Acceptance qualified as to time.}

\section{HATCHER $v$. S'TALWOR'TH.}

\section{Mississippl, $376 .-1853$.}

Acrion by payee against acceptor on a bill payable at sight. Plaintiff presented the bill to defendant, who wrote to plaintiff that he (defendant) would pay the order, but conld not say when. Judgment for plaintiti.

Mr. Justice Yerger delivered the opinion of the court.

We see no error in this record. Where a party, on whom a bill is drawn at sight, offers or promises to pay at a future day, that amounts to an acceptance, if acceded to by the holder. ( 7 Pick. R. 34; Story on Pills, $\$ \$ 243,244$.

The proof in this ease shows this to have been the state of facts; and we, therefore, must affirm the jurgment. ${ }^{7}$

(e) Acceptance by one or more drauees, but not by all.

\section{§229 TOMBFCKBEE BANK $r$ DUMELL \& LYMAN.}

[Reported herein at p. 68\%.]

If the hill is Jrawn payable on a griven date it may be accepted payable at a different late. Russell v. Phillips, 14 Q. I3. 891: Green v. Raymond, 9 Neb. 295; Vanstrum r. Liljengren. 37 Minn. 191.

If a bill is drawn payable two monthe after cight, and is presented on Sept. 14, and accepted "payble Nov. I4," this is not a qualifieation whether there be days of grace or not. So, if there $\mathrm{h}_{\mathrm{H}}$ days of grace, and it is accepted "payable Nov. 17." this is alen treated as an acceptance according to the tenor of the bill. But an acceptance payable on any other day than the nominal or peremptory day of payment is a qualified acceptance. Kenner $\mathbf{v}$. Creditors, 7 Martin N. S. (La.) 540.-II. 


\section{Effect of Qualified Acceptance.}

(a) Holder may refuse qualified acceptance.

$\S 230$ BOEHM $v$. GARCIAS.

1 CAMPBell, 425, note. - 1808.

ACrion on a bill drawn on Lisbon, "payable in effective, and not in vals reals." "The defendant was the drawer of the bill; and the question was, whether it had been dishonored for non-acceptance? The drawees offered to accept it, payable in vals denaros, another sort of currency, which was refused. 'The defendant now proposed to show, that vals denaros was sufficient to answer what was meant by "effective."

Lord Ellenbonough. - The plaintiff had a right to refuse this acceptance. The drawee of a bill has no right to vary the acceptance from the terms of the bill, unless they be unambiguously and unequivocally the same. Therefore, without considering whether a payment in denaros might not have satisfied the term "effective," an acceptance to pay in denaros was not a suffieient acceptance of a bill drawn payable in "effective." The drawees ought to have illusted generally, and an action being brought against them on the gineral acceptance, the question would properly have arisen as to the unesning of the term.

$\S 230$ Wintermete v. Post, 24 N. J. L. 420, 423 (1854). HAINEs, J. - The remaining and principal point arises from the tenor of the acceptance, "when in funds." This is a conditional acceptanee, and the plaintiff was not bound to take it. If he were not satisfied with it, he might have protested the note for non-acceptance, and looked to the drawer for its payment. But having taken it without objection, he must subnit to its terms, and before he can enforce it against the aeceptor he must show funds of the drawer in his hands. ${ }^{8}$

(b) Qualified acceptance discharges non-assenting antecedent parties.

$\$ 230$ WaLker v. Bank, 13 Barbour (N. Y.) 636 (1852). ${ }^{9}$

Action against the bank, as agent. for negligence in not giving

B Accord: Stevens v. Androseroggin Water Power \%o., 62 Me. 498, ante, p. 673; Petit v. Benson, ('omb. 452, ante, p. 675: Hatcher v. Stalucorth, 25 Miss. 376, ante, p. 676; Groen v. litymonl, ! Noh. 295; Gibsom s. Simith, 75 Ga. 33. If an agent, as a bank, recrivis a qualified acceptanee without authority, the agent becomes liable to the principal for any lose ensuing therefrom. Walker v. lank 9 N. Y. 582. - H.

- Affirmed 9 N. Y. 582, - H. 
notice of dishonor of certain bills. The bills were drawn upon E. C. Ilamilton and were acepted in this form: "Accepted, payable at the Am. Ex. Bank: Empire Mills by E. C. Hamilton, 'Treas."

Hlums.n. . J.- The only question presented is whether Hamilton, the drawee, eam be charged as aceptor. If he cannot, the defendants' liahility is undisputed, hecause of their neglect to give notice of dishonor. It is an umblonbted rule that an acceptance dispensing with notice, must be absolnte alcording to the tenor of the bill; not qualified, on varying in any material partieular. (Story on Bills, $\$$ :10, and cases cited in note 2: (Chitty on Bills, 329.) 'The obvious reason is, that antecedent parties, if made liable, are entitled to full reeourse algainst the acceptor, which they cannot have if the aceeptance is combitional. It is atso woll settled that no one but the drawee named can become an aceptor, except for honor supra protest. (Story on Bills, $\$ 121$, et seq.) |'The court then holds that no one was bound by this acceptance.] It follows, therefore, that the defendant should have treated the bills as dishonored, and given notice of non-acceptance to the indorsers, who by the omission are discharged from liability. ${ }^{10}$

10 See also judges' ancwers to the $3 d$ question in Rowe v. Young, 2 Brod. \& Bing. 165; 1 Daniel, §§ 510-511.-H. 


\title{
ARTICLE XII.
}

Presentment of Bills of Exchange for Acceptance.

\section{In what cases presentment for acceptance necessary.}

$\S 240$

\author{
IIART $v$. SMITIH.
}

I5 Alabama, 807. - 1849 .

DARGAx, J. - This was an action of assumpsit, on a bill of exchange, drawn by the defendant in favor of the plaintiff, on Desha \& Smith, dated the 26th February, $18+6$, payalite at sight. The only evidence introduced to charge the drawer was the hill, and protest, showing a demand of payment made of the drawees, on the ith of March, 18t6, and notice to the drawer. The court charged the jury, that the plaintiff could not recover.

A bill, payable on demand, or at any fixed time, need not be presented for acceptance. lut a demand of payment, at the time the holder has the legal right to demand payment, is all that is necessary. And if the hill he not paid, the holder may protest it for nonpayment, and on his griving dne notice to the drawer and indorsers, their liability is fixed. (Erans v. Bridges, 4 Porter, 3.5: 1 Peters, 25, 2 Ib. 170: ('hitty on Bills | 10thed.], 2ro.) But when the time of payment is uncertain, and a presentation of the hill is necessary, in order to ascertain and fix the time of payment, as if the hill lee payable at a number of days after sight, then the lill most be presented for acceptance before payment is demambled. (Ntory on Bills. $\$ 112$, 227; Chitty on Bills / 10th el.7, 272: Bayley on Bills |5th ed. $1,21 \%, 218.)^{\prime}$

It is contenderl that a hill payable at sight is ontitlent to dalye of grace, and therefore if must ire presenterl for afeceptame hefore payment ran be demanderl.

I am free to endess, that my opinion, untrammelod hy anthority,

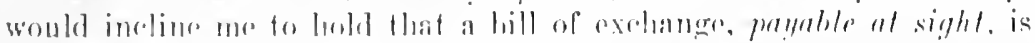
not entitlerd to daye of graere, and that palyment may be demanded on presenting the hill: which, if refused, wendel anthorize the holder forthwith to hase it pentestod for mon-parmont. and. on siving no-

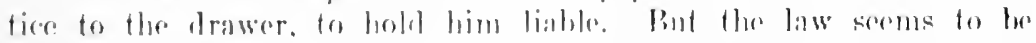
settled oflerwise. Intere Story, in his treation on hills, sayss "that days of graee are allowed on all hills, whether payable at a rertain time after date. after sight, or "sen at sight. And althomgh there

1 Neg. Inst. I. \& 2.10. - It. 
has been some diversity of opinion, whether bills payable at sight are entitled to days of grace, it is now settled by the decisions, both in Engrame and America. Ihat days of grace are allowable on smch bills." (S $31:$, p. 19!.) 'T'o the same effect, see Chitty on Bills 1 10th ed.|, :3rt; Bayley on Bills 15th ed.1, 244, 245; Selwyn's N. P. [!th al.|. 351; Coleman v. Sayre, 1 Barmarl, 303; Dehers v. llarriot. 1 Show. 16is: Stephen's N. P., 8r6.) ${ }^{2}$ Under the influence of these authorities, I foel constrained to hold that a bill payable at sight is entitled to days of grace; conseguently a demand of payment made of the drawer, upon the first presentation of the bill to him, is insutlicient to charge the drawer, for the bill is not then lue. As there was no evilence of any previous presentation of the bill for acceptance, nor notice given of non-acceptance, the demand of payment was prematurely made and was, therefore, a nullity. ${ }^{3}$

As the evilence fails to show a demand of payment on the day the bill was payable, the court correctly instructed the jury that the plaintiff could not recover.

Let the judgment be affirmed.

\section{PLA'T'O $v$ REYNOLDS.}

27 New York, 586. - 1863

ACTION against drawers of a hill. Judgment for plaintiff.

Wright, J. - The bill which was drawn, payable one day after date, was presenterl to the drawee for acceptance on the day it matured; acreptance was refused, and it was protested for nonaceptance. The certificate of the notary states that on the same day (12th seltember) he forwarded written notice, by mail, to the drawers (the defendants) and indorsers (Miles and Bartlett), informing them of the non-areeptance thereof. It was also proved that on the following day the payees (Miles and Bartlett) received the original draft, with notices of protest for themselves and the defendants, and caused such notice to be served on the latter that day. The Irawee also informed one of the defendants, on the 12th September, at the office of the payees, that he had not accepted or paid the dralt. In view of this proof, I think the referee did not err in refusing to lismiss the complaint, and in deciding that the bill was duly pre-

2 Accord: Knotl v. Irnable, 42 Ala. IsG; Cribbs v. Adams, 13 Gray (Mass.) 597: Walsh v. Jart, 12 Wis. 635; Lucas v. Ladew, 28 Mo. 342.

Contra: Trask v. Martin, I F. D. Smith (N. Y. ('. P.) 505, where a very full and learned discuswion of the subject will be found. - H.

3 Under the Neg. Int. Law, lays of grace are abolished, \& 145 , and such a bill would not, under the Law, have to be presented for acceptance. - H. 
sented and protested, and that due notice was given to the defendant to charge them as drawers.

The defendants elaim that the draft being due when presented, and demand made ly the notary, it was then too late to present it for acceptance; and presentment for acceptance of a bill which is due, is not sufficient to cluarge the drawers. But it is well settled that the holder of a bill, payable a specified length of time after date, or on a day certain, need not, for the purpose of charging the drawers and indorsers, present it for acceptance until it hecomes due and payable. It may be presented before or at the time of its maturity. (Edwaris on Bills, 387; Story on Bills, $\S 231$; Allen v. Suydam, 20 Wend. 321 ; s. C., 17 Id. 368.)

All the judges, except Marvin, J., agreed that a refusal to accept on the day payment is due is equivalent to a refusal to pay, and renders a demand of payment unnecessary." On the question of evidence, all the judges concurred.

Judgment reversed, ${ }^{5}$ and new trial ordered.

$\S 241$

\section{ROBINSON $v$. AMES.}

\section{JoHnson (N. Y.) 146. -1822 .}

TuIs was an action of assumpsit, on a hill of exchange drawn by the defendants, merchants in Augnsta, in the state of Georgia, on the 6th of March, 1819, "1pon 'Jownsend and White, merchants, in the city of New York, for five humberl dollars, payahle sixty days after sight, to Starr and Ross, or orrler, by whom it was indorsed to the plaintiff. 'The rause was tried at the New York sittings, in June, 1821, hefore the chicf justice. The hill was presented for acceptance on the eoth of May, 1sis, and notice of non-acepptance sent, hy mail, on the next lay, to the drawers, hy a notary, diented to them at Augusta, in Cienrgia. On the ped of July, 181?, the same notary presented the bill to the drawers for payment, which they refused, alleging the want of funds. Notice of non-payment was sent through the post-ofliere, fwo or three days afterwards, addresesel to the defomlants, at Siavinnalh, in Georgia.

Townsend, one of the drawe'se, who was a witness for the plaintiff, testified, that on the a0th diy of 11 ay, 1819, the drawees harl no funds in their hands bodonging to the dofeudauts, and harl then acrepted drafts to the amount of there or four thousand dollars nore than they had funds of the defendants, and that this was the last bill drawn

- Acord: Philpoll v. Bryant, 3 rar. \& P. 244; Washington Bak V.

Triplett, I Pret. (IT. S.) $25 .-11$.

s On a question of armission of evidence. - H. 
by them. 'l'hat the want of fumbs proceeded from a fall in the price of cotton shipled by the defendints to 'T' and $\mathrm{W}$.; that by an agreement befween them, the defembats were anthorized to make purchases of colten, on the joint aleomnt of themselies and ' $\mathrm{l}$ '. and $\mathrm{WV}$., and to draw on ' $T$ '. and 11 . for the amomet. 'Phat, on the 26th of April, lsi:?. 'T. and W. stopmed payment. 'That after the 6th of Mach, and hefore the failure of 'T'. amb W., they had received a consiberable amount of cotion from the defendants, lut had aceepted the hills of the defendants to a larere amount than the value of the cotton so shipperl, and the diflerence was owing to a loss on the cotton shippert: that, if the defendants were to pay all the bills, 'T. and W. womld owe them tive or six thousand dollars; hut if 'T. and W. were to take up all the bills, the drawees would owe them three or four thomsand dollars.

It was proverl, that the mail which lelt Augusta about the 10th of Mareh, was lost; and that the mail goes from that place to New York, in ten days, and leaves the former place three times a week. That where bills are remited by merchants, it is the usual course to send the bill by one mail, and to advise by the next.

A rejdict was taken for the plaintill, for five humdred and serentytwo dollars, subject to the opinion of the rourt on a ease, as above stated.

Spexcer, Cu. J., delivered the opinion of the court.

The questions in this ase are: (1) Whether the bill was transmitted in due time; and ( 2 ) Whether the want of fund in the hands of the drawees, will excuse the delay in presenting the bill, or the irregularity in the notice of the non-payment of it.

1. I am entirely saticficl that there is no foundation for saying the defendants are precluded from setting up laches, beeause they had no right to draw the bill. The ase of Birlierdilie v. Bollmar (1 Term liep. 105), is considered the first ase deciding that notice to the drawer of the dishonor of the hill was mnecessary: and in that case the drawer had no funds, and knew he had none, in the hands of the drawee. 'The drawing the hill was considered a fraurl, and it was held that he was not entitled to notice, and rould not be injured by the want of it. It has, howerer, since that rase, repeatedly been decided. that where there are any funds in the hands of the rirawee, so that the flrawer lus a right to expect the bill will be paid, or where there are not any funds, yet if the bill was drawn under sneh cireumstances as indured the drawer to entertain a reasonable expertation that the bill would be accepted and paid, the person so drawing it is ontitlod to notion: and, " fortiori, he is entitled to have

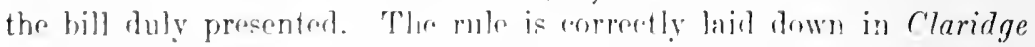

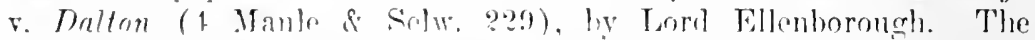
principle which las leen sofol is very ably supported by chief

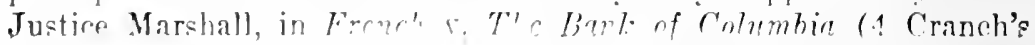


Rep. 153), where the principal authorities are reviewed. There is nothing more important, than that, in questions of a general mereantile nature, there should be a uniformity of decision; and, although the justice and equity of this rule may not, in some cases, be perceived, where the pavee has purchased a bill, and it is drawn in good faith, and no conceivable loss has happened by the want of notice; yet, as there may be eases where, though there were no funds in the hands of the drawee, the drawer may be injured by the want of notice, it is better that the rule on the subject should be general and uniform throughout the mereantile world. ${ }^{6}$

In the case of Hiller r. Hackley (5 Johns. Rep. 3r5): Weldon and Furniss v. Burl and another ( 4 Johns. Rep. 1+4); and Mason and Smede v. Franklin (3 .Johns. Rep. 202), it was decided that if a bill was presented for acceptance, and the drawee refused to acept it, and notice thereof was duly given, a demand of payment, and notice of a refusal to pay, was unnecessary, because the drawer was fixed already. ${ }^{\top}$

2. 'The only remaining question, then, is, whether there was laches in presenting the bill for acceptance: for there is no doubt that regular notice was given of the refusal to accept the bill, the day subsequent to the demand. I do not find, that where a bill of exchange has been drawn payable at sight, or any specified number of days after sight, that there is any definite or fixed rule when the bill shall be presented for acceptance, other than this, that due diligence must be used. And it is certain, that with respect to such bills, and particularly where they are negotiated by the payee, there is much more latitude, as to the time of presentment, than where the bill has a fixed period of payment. In the ase of Muilman $r$. D'Eguino (2 II. B1. Rep. 5ots). Which is a very londing case on this subject, the judteres folt the difficulty of saving at what time such a bill should he precented for payment. ('h. .I. Exre olserved, that the rourts had been very antirns in fixing any time for an inland hill. payable at a certain period after sight, to be peesented for areeptanee.

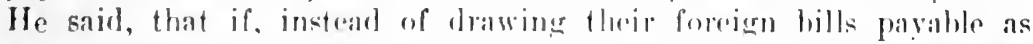
usances, in the olel way. merchants chose, for their own convenience, to draw them in this manner and to make the time commenoe when

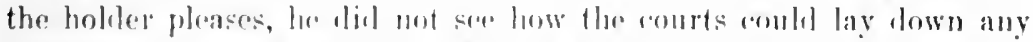

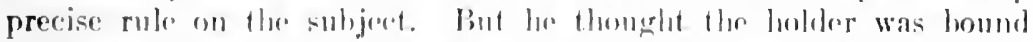
to present the bill in a ressemable time. in order that the period

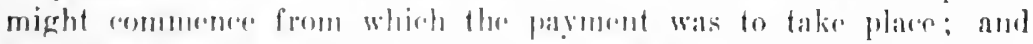
that what was reasonahle time must depend on the partioular cirrumstanees of the asse. Buller, fl., sald, that he thomght a rule might, thus far. he laid down as to lawlus, with regard to hills pay-

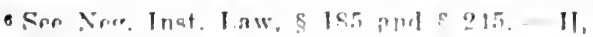

TS S. 248, - H, 
able at sight, or a certain time after sight, namely, that they ought to be put in circulation. If they are cirenlated, he said, the parties are known to the world, and their credit is looked to; and if a bill, drawn at three days sight, was kept ont in that way for a year, he could not say there would be laches; but further than that, no rule conld be laid down. Ifath, I., ubserved that no rule could be laid down as to the time for presenting bills, payalule at sight, or a given time after: that in the Fromeh ordinance of 1673 (Postlethwaite's Dict. tit. Bills of Exchange), it is said, that a bill, payable at sight, or at will. is the same thing, and that this agreed with Marins.

Now, here, the bill was put in cireulation by Ross and Starr; and although it is prohable. that the first of exchange was lost, by the loss of mail, we are not anthorized to consider that as a faet in the case: hut I cannot say, that upon such a bill there has heen laches. We perceive how extremely cautious the judges were, in the case citerl, in laying down any rule. The evident inclination of their minds was, that when the payee put the bill in eirculation, the subsequent holder was not bound to any strict presentment. 'The drawers of the bill evidently did not mean to limit the time of presentment, by making the bill payahle at sixty days after sight. 'They meant to give a latitude, as to time, to the holder; and my conclusion is, that there is not such laches as will discharge the drawers. Judgment for the plaintifl. ${ }^{8}$

\&. Acenrd: Wallace v. $19 r y, 4$ Mason (U. S. C. (C) 336 ; s. c.. 5 Mason, 118 , in which a "sixty days after sight" hill drawu June 18 at Havana, Cuba, on W. in London, and there presented Oct. 31. having heen loeked up in the bolder's hands in Boston, from July 6 to Sept. 29, was, on the second trial, found by the jury to have been presented within a reasonable timo; Aymar צ. Brers. T Cowen, (X. Y.) 705 , in which rase a "thee days after sight" hill drawn Dee. 12 in New York, presented Jan. 10 in Richmond. Va.. having been in the payee's hands during that time, was held by the court to have Jorn presented within a reasonable time. under the eircumstances of the ease; Bo'ton v. Marrort. a Mart. (Ja.) 326; Ciniran v. Jarbsom, 20 Johns. (N. Y.) 176: Montelius v. Charles, 76 Ill. 305.

In the following rases the delay was deemed to be unreasonable: Mullick

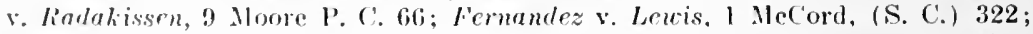
Dumont v. Prope. 7 Plackf. (Ind.) :3fit; Phocnix Ins. (o. v. Allen, 11 Mich. 501: r'hambers v. IIIll, 2f Tox. 472.

Whether what is a reasonable time is a question for the jury or for the cont has necasioned some eonflict. The question was left to the jury in Whallarer s. Agry, supra; it was decided by the court in Aymar v. Beers, supra; it was held to be "a mixed question of law and fact" in Presentl Bank v. Caprly, 7 Gray, (Mass.) 217. See 1 Daniel, \& 466; note, $17 \mathrm{Am}$. Dec. 544-549, - H. 


\title{
II. What constitutes sufficient presentment.
}

\section{$\S 242$}

\author{
SHARPE $v$. DREW.
}

9 Ixdiana, $281 .-1857$.

Struart, J. - Suit on a bill of exchange by Drew, indorsee, against Sharpe, the indorser. The action was instituted before the mayor of the city of Evansville, where the plaintiff had judgment for the bill and interest. Sharpe appealed to the Cireuit Court, where it was tried with the like result. Sharpe excepted to the rulings of that court, and now appeals to this.

Two points are made and argued -1 . The evidence of presentment to the drawee for acceptance. 2. The evidence of notice of protest to Sharpe.

1. It is correctly contended that the presentment for aceeptance should be to the drawee himself, if he can be found. (Chitty on Bills, 278.) If to an agent or other person authorized to accept, the fact should appear.

In the present case the only evidence of presentment is the certificate of protest. The notary certifies "that on, ete, I did present the annexed draft of T. C. Wetmore on W. W. Peters, at the store of Silliman and Gardiner, and demanded acceptance of the same, which was refused." ete. It is contended that this is not evidence of a presentment to Peters for acceptance.

The statute makes notarial certificates evidence of the facts therein stated (2 R. S., F. 91.) The notarial certificate is clear as to the facts of presentment, the place of presentment, the demand of acceptance, and the refusal. 'T'o whom was it presented? Who refused to accept? It cannot admit of doulst that Peters himself was the person. The plain English of the protest is that the notary found Peters at the store of Silliman and Gardiner, Troy, N. Y., and there demanded of him acereptance, which Peters refused. The form here used seems to he the rommon one preserihed by the books. (Cliitty on Bills, 333; Byles on Bills. 191.)

The language is not even abseure. The presentment, the demand, the refusal, all elearly mean, that it was the drawee who was the object and actor. We are not at liberty to dombt the sufficiency of the evidence that the hill was duly presented for acceptanee.

[The Court then holds the notiee of dishonor sufficient.]

Pen Comsu. - The judgment is affirmed, with 5 per eent. damages and rosts. ${ }^{\circ}$

It would arem that presentment for acreptance must be made to the drawer or his authorized agent in person and that difigent inquiry should be made for the drawee if no pereon ia found at his office or residenes having authority to accept for him. Bank v. Triplett. 1 I't. (I. S.) 25. 34: Wise- 
5 Mletcalf (Mass.) 216. -1842.

A crios against indorser of bill. 'The jury were instrueted that if the drawes were informed he the bank that it helel snch a bill drawn on dhem by A. (and indored by defendant), and they thereupon informed plaintitl that they should not aceept nor pay it, and if no motice thereof was given to the indorser (defendant), he was discharged. Verdict for defendant.

Hubsisul, J. - It is a well established principle of the law regulating bills of exchange, that the holder of a hill, payable at a certain lime after date, need not present it for acceptance prior to the day of payment. And though it is usual and safe so to do, as he therehy strengthens his security, or, in case of non-acceptance, acquires an immediate right to call on the other parties to the bill, yet he is under no legal obligation to do it, nor can the omission be taken advantage of by the drawer or indorsers. (Goodall v. Dolley, 1 T. R. 7112; Chit. on Bills, Part I., c. 5 ; 3 Kent, Com. [4th ed.] 82; O'Keefe ๖. Dunn, 6 Taunt. 305; s. C., 1 Marsl. 613.)

[The court then deeiles that an agreement by the holder made with the drawer not to present the bill for acceptance, but only for payment at maturity, will not discharge the accommodation indorser, although such agreement was not known or assented to by the indorser.]

The evidenee which was introduced tended to show that the cashier of the Fall River Union Bank (the plaintiffs in this suit) met Chace, one of the house upon which the hill was drawn, and informed him that the bank lad the draft (now in suit), upon which Clace told the eashier that they should not accept or jay it. And the instruc-

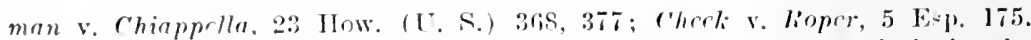
It has, howrer, lxen lirld that it will be presumed that a elerk in the Jrawer's counting louse has authority to acepent or refuse to accept. Nelson v. Fottrall, T Leigh, (Va.) lso; Stainbalk v. Stale Bank, 11 Gratt. (Va.) 260. "Comparing presentment for aceptance with prosentment for payment, it is clear that the two cases are governed by somewhat different considerations. Spraking generally, presentment for acceptance should be personal, while frexintment for payment should be local. A lill slonld be presented for payment where the money is. Any one ean then hand over the money. A hill should be presented for acceptance to the drawee himself, for he has to write the acerptance: but the place where it is presented to him is eomparatively immaterial. for all he has to to is to take the bill. Again (exeept in the case of demand drafts), the day for payment is a fixed day; but the drawee eannot tell on what day it may suit the holder to present a bill for acceptance. These encillerationa are material as bearing on the question whether the indler has used reasonable diligenee to effect presentment." Chalmers, Bills of Exchange Act (5th ed.), pp. 137-138. - H. 
tion to the jury was, that if no notice thereof was given to the indorser, he was discharged. Waiving the question whether the cashier was agent for the plaintiffs for the purpose of presenting the draft for acceptance, or not, we are of opinion that this was not a due presentment of the bill for acceptance. The term presentment imports, not a mere notice of the existence of a draft which the party has in his possession, but the exhibiting of it to the person on whom it is drawn; that he may see the same, and examine his accounts or correspondence, and judge what he shall do; whether he shall accept the draft, or not. Here there appears to have been nothing more than a casual meeting of the parties, and the conversation on the subject of the draft ensued. If this had been communicated, it would have created no obligation on the part of the indorser to make present payment, and consequently such conversation imposed no present duty on the holders, as to the other parties to the bill. With this view of the case we are not satisfied with the instruction given to the jury. To confirm it, would tend to introduce a looseness of practice on the subject of presenting bills for acceptance, which will lead to disputes and difficulties greater than now exist.

Verdict set aside, and a now trial granted. ${ }^{1}$

\section{§242 TOMBECKBEF BANK $v$. DUMELL \& LYMAN.}

\section{Mason (U. S. C. C.) $56 .-1828.2$}

Assumpsit on a bill of exchange drawn on 17 th of March, 1827, in Alabama, by Stone, Ellis \& Co., at sixty days' sight, on the defendants, for $\$ 3,000$, parable to Moses Sewall or order, and by him indorsed to the plaintiffs. The declaration averred a presentment for aeceptance, and an acreptance and a subsequent non-payment. There were other counts on other similar bills. Plea, the general issue.

At the trial, the sole defense relied on was, that the acceptance was made by Jaenb Dumell after the dissolution of the partnership between him and his en-defendant, John Lyman. It appeared in evidence, that the firm was dissolverl on the 1st of January, 1827: but it was not advertised in the newspapers until the sth of April, 1827, when it was publisherl at Providence. where the firm carried on business. The acreptances of all the hills were after the dissolntion was so arivertiserl.

I But it arems that the actual exhibition of the bill is not necessary if the drawee is enabled, without sering it, to give an intelligent responer. 1 Daniel, \$ 462; Fisher v. Brekwith, 19 Vt. 31; Burlington First N. B. v. Hatch, 78 Mo., 13. Otherwise an extrincie acceptance, as by telegram, would serve no needful purposr. Sir Nirg. Inst. I. \& 222, - II.

s. c., 24 Fed. Cas. 18. - 11. 
STowx, J.- Upon this statement of facts, which is not controrerted, I an of opinion, that the plaintiffs a lo not entitled to recover. No partner has any anthority after $n$ dissolution of the partnership to bind his copartners by any new contract. The acceptance of these bills is altogether a new contract. It is true, that if the partnership is still ostensibly carried on in the name of the firm, and no public notice is given of the dissolution of the partnership, though it is secretly dissolved, third persons, dealing with the firm upon the faith of the partnership and joint responsibility, are entitled to hold all the partners. But it is otherwise, where the dissolution is made public. Here, before the aceeptance, the dissolution was publicly announced. The partners had not held out to the payee, or the present holders, that they would accept the bill. Every non-aceepted bill is neeessarily taken upon the faith and eredit of the drawer; and no person can bind the drawee by his acceptance, except a person having an express or implied authority for that purpose. After the dissolution of the partnership, and a public notice of it, there was a withdrawal of all such authority; and consequently the acceptance, as to John Lyman, is roid. Upon principle then, the action, being joint upon a joint acceptance, fails as to botlı.

Mem. By consent of the parties, the plaintiff discontinued as to Lrman, amended lis decłaration, and took a judgment against Dumell alone. ${ }^{3}$

\section{When presentment for acceptance excused.}

\section{$\S 245$ CintTy on Bills of Exchange, p. 307.}

If the drawee of a bill cannot be found at the place where the hill states him to reside, and it appear that he never lived there, or has absconded, the bill is to be considered as dishonored (Anon. Ll. Raym. 7+3); but if he has only removed, it is incumbent on the holder to endeavor to find out to what place he has removed, and to make the presentment there (Collins v. Butler, 2 Stra. 1087); and he should in all cases make every possible inquiry after the drawee, and if it he in his power present the bill to him: though it will he unnecessary to attempt to make such a presentment if the drawee has left the kinglom, in which case it will be sufficient to present the bill at his house (Cromwell v. IIynson, 2 Esp. 211), unless he have a

3 Such an acceptance is a qualified acceptance (Neg. Inst. L., \$229 subsec. 5 ), and binds the one accepting (Smith v. Milton, 133 Mass. 369), but if receiver by the holder diccharges prior non-assenting parties, ante, p. 677. If one of the drawees refuses to accept it would seem unnecessary to make a further presentment upon the others; but the language of $\$ 242$, subsec. 1 , provides for presentment to all. $-\mathrm{H}$. 
known agent, when it should be presented to him. (Ibid; Phillips v. Astling, 2 Taunt. 206.) If on presentment it appears that the drawee is dead, the holder should inquire after his personal representative, and, if he live within a reasonable distance, should present the bill to him. ${ }^{*}$ (Molloy, b. 2, c. 10, 34 ; Poth. pl. 146.) ${ }^{\circ}$

\section{Duty of holder where bill not accepted.}

UNITED STATES $v$. BARKER.

24 Federal Cases (Cir. Ct., Dist. Pa.) 1004. - $1824 .^{\circ}$

Actions on bills of exchange.

Washington, J. [charged the jury as follows]: * * * The law merehant, as settled by judicial decisions in England, and in New York, requires that, in all cases of bills which must be presented for acceptance, due notice of the protest, in case acceptance is refused, must be given, withont waiting for the maturity of the bill, and a demand of payment; such too is the rule in Massachusetts and South Carolina. And the rule is the same in Fngland, even in eases of bills which need not be presented for acceptance, if in fact they be presented, and acceptance be refused. It is supposed that the rases of Brown v. Barry, 3 Dall. 365, and Clark v. Russel, id. 415, have established a different rule as to the law merchant of the United States. We do not so understand those eases. $* * *$ The necessity of giving due notice of the dishonor of a bill which has been refused acceptance, is not, in our opinion, dispensed with in those cases.

\section{Effect of dishonor of bill presented for acceptance.}

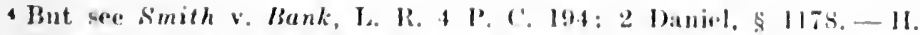

s Fxcuse for delay is to te distinguished from cxcuse from presentment altogetler. U.S. v. Barker, I Puine, (U.S. C.C.) 156, 163; Aymar v, Becrs, 7 (Cow. (N. Y.) 705; I Dunirl, \$ 478. - II.

- Reportel also in 4 Wasli. (C. (C.464.- $\mathrm{C}$.

TSe also Nat. Park Bank v. Saitta, 127 App. Div. (N. Y.) 624. - C. 
$1 \mathrm{BAY}$ (SO. CAR.) 468. -1795 .

[ACTION against drawer of bill, brought before time for payment had expired. 'The bill was presented for aceptance, dishonored, and duly protested.]

Upon the first gromud, the court were elearly of opinion, that the action lay upon the protest for non-acceptance, although the time for pilyment of the bill was not expired. Every man, by the law of merchants, who draws a bill, undertakes by the very act of drawing that the bill shall be accepted and paid, when at maturity, agreeable to the terms of the bill. And the very end and design of a protest, is to grive notice of non-acceptance; or, if accepted, of non-payment: in either event, the drawer becomes liable. And the holder, in case of a protest for non-acceptance, is under no obligation to wait till the time for payment expires; because the drawer has broke part of his original contract, that is, that the bill should be accepted; and because also (if the bill should even be paid when due), the holder would lose the henefit of the eredit in trade, which the acceptance of a bill would give him, as well as the use of the money, which he might obtain at a small discount. The obligation in every such case would be on the part of the defendant to show that the bill was afterwards paid, which might be given in evidence by way of mitigation of damages. Put in this case, no payment, even at this day, is alleged; therefore, the plaintiff is entitled to a recovery. (Dong. 5s; 3 Will. 17; Kyd, 17.)'

If a right of action arises on presentment for aecptance, no new right arises on presentment for payment. Whitehead v. Walker, 9 M. \& W. 506. See Robinson v. Ames, 20 Johns. 146, ante, p. 681; Sterry v. Robinson, 1 Day, (Conn.) 11. But if there is an acceptanee for honor or a reference in ease of need, there must be a presentment for payment, and protest for nonpayment, before presentment to the aeceptor for honor or referee in ease of need. Ner. Inst. L., \& $286 .-H$.

[See also Nat. Park Bank v. Saitta, 127 App. Div. (N. Y.) 624. - C.] 


\title{
ARTICLE XIII.
}

\author{
Protest of Billos of Excilange.
}

\section{What instruments must be protested.}

\section{What constitutes sufficient protest.}

\section{$\S 261$}

\section{DENXISTOUN $r$ STEWART.}

17 HOW

inn. iustice finen delivered the opinion of the court.

The plaintiffs declaren atrainst the defendant, as drawer of a bill of exchange, he the name and style of James Reid and C'o, of which the following is al cople:

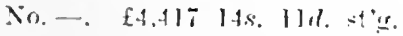

Morite, Sfpt. 9, IS50.

Sixty daye after sight of this first of exchange, (secomd and third unpaid), fay to the order of mursolves, in london, forty-four hundred and seventeen

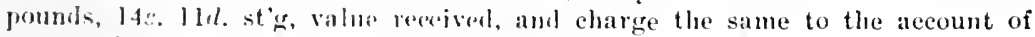

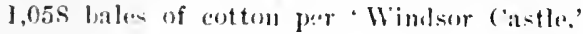

Your obedient servants,

l'r. pro. JaMes Rem axp Co.,

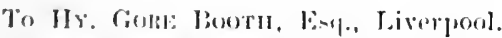

Wis. Movlt, JR.

locepptance aroses the falce of the hill: ]

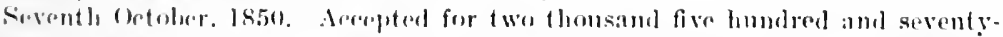

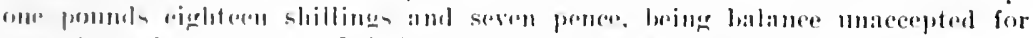

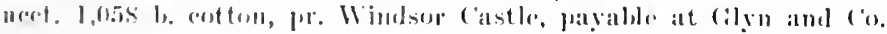

i'r. pro. Heine (ions: Bontu.

ANm. F. Birse.

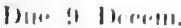

[ Imlorind: ]

Pay Mrssus. A. Dexistory axu ('o., or order.

P'r. pro. Jask lime and co.

Win. Morte, Ir.

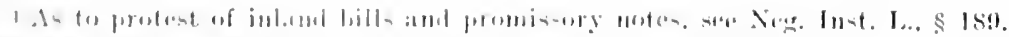

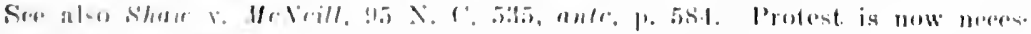

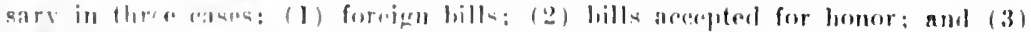

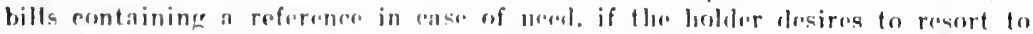

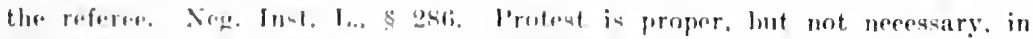
two easos (1) inland hills allal promiusory notos; (2) for lontor security. 5 26f. The proted for mon payment aftor protest for non-arerptaner is

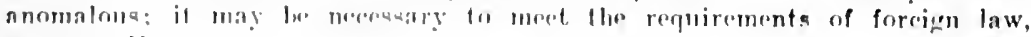
$\$ 26.5 .-11$. 
After reading this bill, with its indorsements, the plaintill oflered in evidence a regular protest, indorsed on a copy of a bill agreeing in every particular with the above, except that for "And. E. Byrne" was written "Chals. Byrne."

The defendant objected to the reading of the protest in evidence, becanse it did not deseribe the bill of exehange produeed by the plaintifls, but a different bill. The court sustained this objection, and excluded the protest from the jury, which is the subject of the first bill of exceptions.

A protest is necessary by the custom of merchants in case of a foreign bill, in order to charge the drawer. It is defined to be in form " a solemn declaration written by the notary under a fair copy of the bill, stating that the payment or acceptance has been demanded and refused, the reason, if any, assigned, and that the bill is, therefore, protested."

A copy of the bill, it is said, should be prefixed to all protests, with the indorsements transcribed verbatim. (1 Pardess. 444; Chitty on Bills, 458.)

IJowever stringent the law concerning mereantile paper, with regard to protest, demand, and notice, may appear, it is nevertheless founded on reason and the necessities of trade. It exacts nothing harsh, unjust, or unreasonable. A protest, though necessary, need only be noted on the day on which payment was refused. It may be drawn and completed at any time before the commencement of the suit, or even before the trial, and eonsequently may be amended according to the truth, if any mistake has been made. ${ }^{2}$

The copy of the bill is connected with the instrument certifying the formal demand by the public officer, as the easiest and best morle of identifying it with the original. Mereantile paper is generally brief, and withont the verbiage which extends and enlarges more formal legal instruments. Henee, it is much easier to give a literal copy of such bills, than to attempt to identify them by any abbreviation or deseription. 'The amount, the date, the parties, and the conditions of the bill, form the substance of every such instrument. Slight mistakes, or variances of letters, or even words, when the substance is retained, cannot and ought not to vitiate the protest. A lost bill may be protested, when the notary has been furnished with a sufficient description, as to date, amount, parties, ete., to identify it.

In indictments for forgery, it is not sufficient to state the "substance and effect" of the instrument; it must be laid according to the "tenor," or exact letter: but the law merchant demands no such stringency of construction. The sharp criticism indulged when 
the life of a prisoner is in jeopardy cannot be allowed for the purpose of eluding the payment of just debts.

It is unnecessary that a copy of the protest should be ineluded in the notice to the drawer and indorsers. ${ }^{3}$ The object of notice is to inform the party to whom it is sent that payment has been refused by the maker, and that he is held liable. Hence, such a description of the note as will give sufficient information to identify it, is all that is necessary. What was said by Mr. Justice Story, in delivering the opinion of this court, in Mills r. The Bank of the United States," with regard to varianees and nistakes in notices, will equally apply to protests: "It eannot be for a moment maintained that every variance, however immaterial, is fatal. It must be such a variance as conveys no sufficient knowledge to the party of the particular note which has been dishonored. If it does not mislead him, if it conveys to him the real fact, without any doubt, the variance eannot be material, either to guard his rights or avoid lis responsibility."

In the case before us, the protest had an aceurate copy of every material fact which could identify the bill - the date, the place where drawn, the amount, the merchandise on which it was drawn, the ship by which it was sent, the balanee on the cotton for which it was accepted, the names of drawers, acceptor, indorsers; in fine, everything necessary to identify the bill. The only variance is a mistake in copying or deciphering the abbreviations and flourishes with which the christian name of the aceeptor's agent is enveloped. The abbreviation of "And." has been mistaken for Chas., and the middle letter E. omitted. The omission of the midale letter would not vitiate a declaration or indictment. Nor conld the mistake mislead any person as to the identity of the instrument described.

We are of opinion, therefore, that the objection made to this protest, "that it does not describe the bill of exchange produced, but a different bill," is not true in fact, and should have been overruled by the court.

This renclers it unnecessary for us to notice the offer of testimony to prove the identity, which was also overruled by the court.

The judgment of the ('ircuit ronrt is reversod, and venire de novo awarded.

3 Nor even mantion of protent. Lix parte loneculhal, I. R. !) ('h. 591. Nor is the certificate of protent avilenes of notice, except by statute. Bank v. Gray, 2 Hill (N. Y.) 227, ante, p. 589. - 11 .

Ante, p. 539.- H. 


\section{HiLl (N. Y.) 635. -1842.}

Assumpalt. * * * 'lhe alction was by the plaintifis as indorsees anainst the defendant as indorser of a bill of exchange drawn by James 'Treat on Stephen sicard d Co., New Jork, and aceepted by thems.

'The bill, which hore date January 16th, 1839, was payable to the order of the defendant at ninety days; and no place of payment was mentioned therein. On the trial, after proving the signature of the defendant as indorser. the plantiffs gave in evidence a notarial certificate of protest, stiting that on the 19th day of April, 1839, the notary presented the hill in question at No. 1 Wall street, the office of the acceptors, But fomnd the same closed and no person there of whom payment could be demanded: that he then presented the same to the widow of Strphen Siraril. for payment, which she refused, saying that the partner of her late hushand was at the Sonth, and she knew nothing of it. 'The plaintifls also read in evidence a notarial certificate, stating that notice of protest of the bill in question had been duly given to the dofendant. 'This certificate was rated February 9th, $18+1$, mealy two yous after presentment and protest. No further eridence was offered by the plaintiffs. The defendant's counsel moved for a nonsuit, on the ground, 1. That the presentment of the bill in question to the widow of Stephen Sicard, deceasef, was insufficient to charge the indorser: 2. 'That it did not appear from the rertificate of protest that the bill was presented for payment to any person at the office of $S$. Sicard \& Co., or that the notary called for that purpose luring offire hours; and 3 . 'That the certificate of notice of protest was not given till nearly two years after protest was marle. The julge denied the motion, and the defendant excepted.

By the Court, Cowex, J. - The bill of exchange was payable generally, mentioning no plare. The drawees were Stephen Sicard \& Co., who areepted the bill as a firm, thus hecoming joint debtors. On the death of Sirard, he was discharged at law, the liability developing on the surviving partner (Story on Partu., $\$ 361,362$ ), to whom alone the plaintiffs were hound to have the bill presented for payment. The mole, therefore, in which the hill was presented to the widow and supposerl personal representative of Sicard, or whether she were in fart lis representative, heromes entirely unimportant.

No objection was made at the trial that the presentment, which was at No. 4 Wall strect, where the survior transacted business, should have been at his residrnee or any other place. 'Jherefore the question on the place of presentment does not arise. It must be 
taken to have been proper. Nor was the manner of presentment denied to be proper; nor the day.

But it is objected that the time of day should have been mentioned in the notary's certificate; for perhaps it might have been after the hours of rest. The certificate states that it was presented on the third day of grace. This, coning from a witness on the stand, would be deemed prima facie evidence of presentment at a proper time in the day; and if an improper hour were in truth selected, it would lie with the adrerse party to show the fact by cross-examination or otherwise. It would not be intended that a late hour was resorted to. We think, therefore, that the certificate, in fair construction, imports a presentment during the proper hours of business. These, except where the paper is due from a lank, generally range through the whole day down to bed-time in the evening. (chitty on Bills, 421 [r.], Am. ed. 1839, and cases there cited.) It would be quite a forced presumption on the words of all officer saying he presented on such a day, to fix the honr either before or after that when business is usually transacted. It wonld be to suppose the notary, at the expense of his own convenience, going at an improper hour for the mere sake of loing wrong. ${ }^{5}$

It is no objection that the certificate of notice was drawn up by the notary two years, or any othre length of time, after notice was given. The statute gives it as a substitute for his personal testimony at the trial. It is properly called for and may be drawn up when it happens to be wanterl as evidence. The notary cannot be expecter always to prepare it as a matter of course; for non constat it may ever be wanterl. It was sairl on the argument, that ordinarily it is drawn up and transmitter to the holder at or about the time when the business is done. That is the hetter practice; but it is not essential.

[Ornitting a question of neury.]

New trial denied.

" "Wint with the draft to the hank amb demanded paymunt," is sufliciont. Bank v. Cameron, 7 liarl, (N. Y.) 1.3. "Wint with tha moto and mado

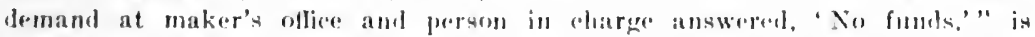

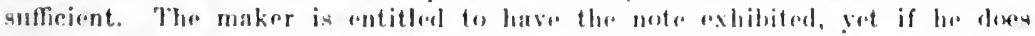

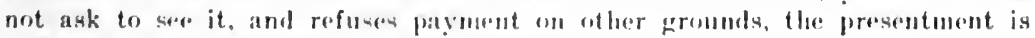

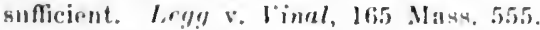

A cortifirate that the netary promested the draft to "ond of the firm of Warren, ("lark \& ("o.", is insuffuciont for nit statimg the name of the person on whom demand was male. Otsego C'o. Bank v. Warren, 18 Barb. (N. Y.) 290. - H. 


\section{$\S 263$}

\section{MORELAND'S AIMINIS'TRA'TOR $v$. CITIZENS' NATIONAL, BANK.}

\section{Kextucky, $577 .-1903$.}

\section{Opinion of the court by Judge Paynter -}

'The issue herein arises over certain bills of exchange. 'There is no issue as to the drawing, acceptance, and indorsement of them. In this action it is sought to hold the aceommodation drawer and indorser responsible on them. The payment is sought to be avoided by the drawer and indorser of same on the grounds that the law was not observed in noting protest, giving notice of protest, and writing the instruments of protest by the notaries public. 'Two of the bills over which there is a controversy are for $\$ 5,000$ each, one for $\$ 3,685$, one for $\$ 3,000$, and one for $\$ 3,200$. 'T'hese bills were drawn by J. P. Moreland, accepted by S. D. Walden, and indorsed by J. P. Fuqua. It appears that the bills (unless the one for $\$ 3,685$ was not) were protested on the days that they matured. As to that bill it is insisted that it was not protested until the day after its maturity. 'That defense is interposed in addition to the others heretofore stated. I. N. Parish, notary public, protested the bills for $\$ 5,000$ each on the days of their maturity, and indorsed on them, "Protested for nonpayment," and, in addition to that, gave the day of the month and year, to which indorsement he affixed his official signature. W. H. Moore was the notary who protested the bill for $\$ 3,000$ and the one for $\$ 3,200$. No memorandum noting the protest was left attached to either of the bills by the notary, nor was such indorsement made upon them. Either on the day the bills were protested or on a subsequent day the instruments of protest were written, but the evidence leaves no doubt that the notices of protest were duly mailed to the drawer and indorser of the several bills on the days they were protested.

The first thing which we will consider is whether the noting by Parish was sufficient. The authorities seem to be agreed that the noting of initial protest was unknown to the law as distinguished from the protest, but that it has grown into practice within recent years. It seems to be well established that, if the instruments of protest are not written shortly after the demand and protest, the noting or initial protest is necessary as a basis for the instrument of protest. 2 Dan. Neg. Inst. (4th Ed.), section 939. This court in Read v. Bank, 1 T. B. Mon., 93, 15 Am. Dee., 86, had under consideration the question as to the necessity of noting. The court said: "The protest was drawn up so soon as the ordinary course of business would permit, or at least in sufficient time to supersede the necessity of noting the bill at the moment." The court seemed to be of the opinion that, if the instrument of protest was written as 
soon as the ordinary course of business would permit, or at least in sufficient time to supersede the necessity of noting the bill at the moment, then those sought to be held liable were bound. We are of the opinion that the incorsements which Parish made on the bills were sufficient.

The facts as to the bills protested by Paris differ somewhat from those protested by Moore. We will not go into the discussion of the question of the competency of eridence to prove the course of business of notaries in protesting paper; neither is it necessary for us to determine whether the instruments of protest were written on the day the bills matured, or on a subsequent day; hence the necessity is obviated of determining whether the proof is sufficient to impeach the dates of the instruments of protest, they bearing dates that the bills matured. If the noting of protest was made, the instruments of protest could have been prepared thereafter. Moore testified that when he protested the bills he attached to each of them a memorandum showing the protest, but when the instruments of protest were written he destroyed it, as he had no further use for it. Counsel for appellee urges that the preservation of these ships was essential to the validity of the protest in extenso, as they form a necessary part of the record in establishing the steps that must be taken in order to fix liability upon the drawer and indorser. The object of noting is to have a record from which the instrument of protest can be written, so a notary will not be required to rely upon his memory as to the facts. If the noting was made, the destruction of it, whether it was purposely or accidentally done, could not invalidate the instrument of protest which was based upon it. It preserves the right of the notary to prepare that instrument, and, when done, the essential steps have been taken to fix the liability upon the accommodation drawer and indorser. 'The hill having been protested for non-paymont and notice laving been given to the drawer and indorser, the noting having taken place, and the instrument of protest having heen executed, the liability of the drawer and indorser was fixed. The destruction of the paper upon which the noting was made could not relieve them of the liability that had attached hy the necessary act of the notary.

After the several bills were drawn, and hefore their maturity, Moreland made an assignment to E. P. Tayler for the henefit of his creditors. When the hills were protestrd, notices of protest were not sent to the assignee, lut to Moreland. It is insisted that, as the assignee aecepted the trust, and qualified as such assigne, notions of protest should have bern griven to him, instead of to Moreland, in order to bind the trust estate. The exart question here presented has not been before this eourt, although this court, in Callahan v. Bank, $82 \mathrm{Ky}, 231,6 \mathrm{~K}, 188$, held that notice of the dishonor of a bill to one who is the assignee of the payer was sufficient. But the 
court said: " He must not be umierstood as determining whether a notice of the dishonor of negotiable paper sent to the bankrupt or insolvent alone, and not to the assignee, would or would not be sulficinnt, as that question is not presented in this case." The text-writers upon this question are extremely unsatisfactory. 1 Pars. Notes \& B., 50() , in speaking of the person to whom notice of protest should be griten in the "ase of a bankrupt, says: "T'hat perhaps the notice should be given to the assignee, if the holder knows or might know, by the exercise of due diligence, that the estate is in his hands:" but he adds: " liut notice might perhaps even then be sufficient if given to the bankrupt." Byles, Bills, page 216 says: "If the drawer of the bill become bankrupt, notice must nevertheless be given to him, in all events, before the ehoice of assignees. If the assignees are appointed, perhaps notice should be given to them." Daniel, Neg. Paper, section 1002, says: "If the party be bankrupt, it is best to give notice to him, and to his assignee also. If there be yet no assignee appointed, notice to him is sufficient, and perhaps it might be sufficient, even if one had been appointed. If given to the assignee alone, it would probably be suffeient." When a "party assigns all of his property for the benefit of his ereditors and places it in the hands of a trustce for distribution, all of his creditors are entitled to participate in the distribution of it. This is true whether the debts have matured or not. Moreland's liability on these bills existed at the time of the assignment, and, if it was preserved, then the holder of them was entitled to participate in the distribution of the proceeds of the assigned estate. Ile heing personally liable to the holder, it was important to it that he receive notice of protest that that liability might be preserved. When that liahility was preserved, it seems to is to necessarily follow that the holler of the bills is entitled to participate in the trust estate, becanse the very purpose of his assignment was to pay his liabilities in full or pro rata, as the case may be. We conclude that notice to Moreland was sufficiont to preserve his liability, and, if his liability continued, there is no curape from the ronclusion that the holder of the hills which evidenced it was entitled to participate in the distribution of the estate.

'The judgment is affirmed.

\section{By whom protest should be made.}

$\$ 262$

CAR'TER $r$. UNION PANK.

7 HUMPHREY (TENX.) 548. - 1847.

Grefs, J., delivered the opinion of the court.

'This is an action against the plaintiff in error, as the indorser of a bill of exchange drawn iu Memphis, Tennessec, by Arthur Bowen 
on Fort and Wileox, New Orleans, in favor of plaintiff in error, for $\$ 2,500$, and hy him indorsed. The bill was presented at maturity, payment demanded and was protested for non-payment by $\mathrm{A}$. $\overrightarrow{\mathrm{B}}$. Cends, a notary publie of New Orleans. The instrument of protest states, that the notary " by his deputy, JeDime, Jr., presented said draft to Mr. Fort, one of the members of the firm of Fort and Wilcox, the acceptors, at their office, and demanded payment thereof, and was answered that the same would not be paid." 'The protest was marle the 11 th . Iunc, 1845 .

$\mathrm{By}$ an art of the General Assembly of Louisiana, passed the 1+th of March, 184. it is made lawful, for each and cyery notary puhlic in New Orleans, to appoint one or more deputies, to assist him in making of protests and delisery of notices of protests of hills of exchange and promissory notes: P'rovidel, that each notary shall be responsible for the acts of eall deputy employed ly him; and provided, that each deputy shall take an oath, faithfully to perform his duties as such, before the judge of the parish in which he may be appointerl; and provided, the certificate of notice of protest shail state by whom marle or served.

The defendant. at the trial bulow, ohjected to the protest which was offered as evidence, which oljowtion was overruled by the court, and the evidome was adnitted. The jury foumd a verilist for the plaintiff, and the defondant appealore to this comert.

It is now insisted. that this protrst is mot eridene of the presentment and demand of the hill, heranse it states that the demand was made by the deponty of the motary.

It is certainly truce, as the general rule. that a foreign bill must be

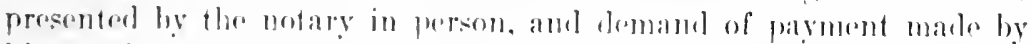
him, and that the demand lye his deputy is not suflicient. But it is seen, that the law of Lomisiana, where this hill was payalue, authorizes the employment of a deputy in this serviere, and that the protest must certify by whom the demand was marle.

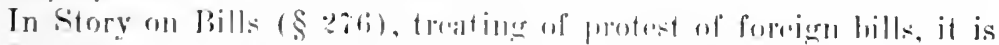
laid down, that the protest "shomld he minle ont and drawn up in

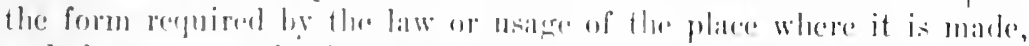
and that so esesential is the probluetion of the protest, that it rammot

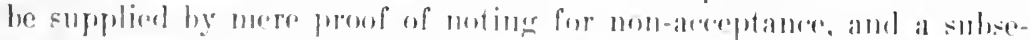

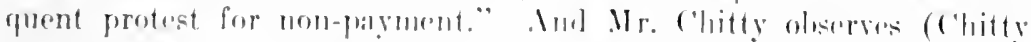

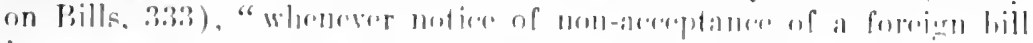

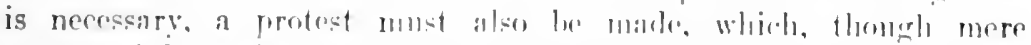

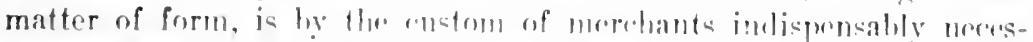

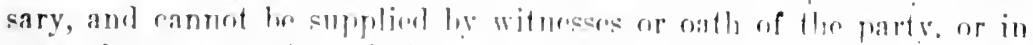
any other way, and, as it is saill. is a part of the conctitution of a

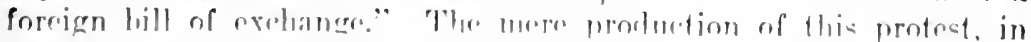

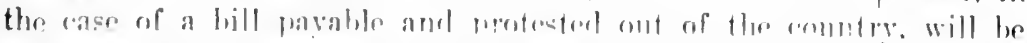
evidence of its dishomor, "and to it all forrign "ontes erive credit." 
And at page 456 , he says: "With respect to the protest, it should atways be male according to the law of the place where the payment ought to have been made, though, with regard to notice of dishonor, it must be given to the drawer within the time, and according to the law of the place where the bill was drawn, and to the indorsers according to the law of the place where the indorsenents were made."

These authorities settle the question, and establish the following propositions:- -

1. 'That a protest is indispensable to the dishonor of a foreign bill of exchange.

?. That the protest is to be made according to the law of the place where the bill is payable.

3. 'That the protest properly authenticated, is evidence by its mere production, of the presentment and demand, in all foreign courts, where the dishonor of the bill is required to be proved.

4. 'That no other evidence of the facts stated in the protest is competent.

The protest in the present case was made according to the law of Lonisiana, where the bill was payable, and, therefore, is evidence here of the dishonor of the bill.

It is objected, that there is no evidence that Memphis was the defendant's place of residence.

It appears, that annexed to the name of the defendant on the bill is added "Nemphis, Tennessee." This we regard as part of his indorsement, and as sufficient authority to authorize the holder to send the notice to Memphis.

Affirm the judgment. ${ }^{\circ}$

a "In many cases, even with regard to forrim hills of exchange, the protest may, in the absence of a notary, be made by other functionaries, and even by merchants. But where, as in Mississippi, a juntice of the peace is authorized by positive law to perform the functions and duties of a notary, there is no ground to say that his act of protest is not equally valicl with that of a notary. Quond hoe he acts as a notary."-Mr. Justice Story in Burke v. Mrkiau, 2 How. (U. S.) 66. 72 (1844). ('onf. Torld v. Neal's Adm'r, 49 Ala. 273 ; Read v. Bank, 1 T. B. Mon. (Ky.) 92. Costs for protest cannot be allowel where the protest is hy a private individual not authorized to charge tees. Read v. Bank, supra.-II. 


\title{
ARTICLE XIV.
}

\author{
Acceptance for Honor. ${ }^{1}$
}

BYLES, BILLS OF EXCHANGE, ETc. (13Th ED.), 1879.

\section{[Chapter NX.]}

WhEN acceptance is refused, and the bill is protested for nonacceptance, or where it is protested for better security, any person may accept it supra protest, ${ }^{2}$ for the honor of the drawer or of any one of the indorsers. The method of accepting supra protest is said to be as follows, viz.: The acceptor supra protest must personally appear before a notary publie, with witnesses, and declare that he accepts such protested bill in honor of the drawer or indorser, as the case may be, and that he will satisfy the same at the appointed time; and then he must subscribe the bill with his own hand, thus "Accepted supra protest in honor of A. B.," ete.," or, as it is more usual, "Accepts S. P." And a general acceptance supra protest which does not express for whose honor it is made is considered as made for the honor of the drawer. ${ }^{4}$

Any person may accept a bill supra protest; and the drawee himself though he may refuse to accept the bill generally, may yet accept it supra protest, for the honor of the drawer or of an indorser." And

' Called in French, "Acceptation par Intervention," Code de Commerce, 126. Byles, Ch. XX.

2I am not aware of any anthority to show that there may be an acceptance for honor without a protest, and the statute $6 \& 7 \mathrm{Will} 4$, c. 58, sems to assume that bills acepteil for honor are always protested: see Vaudruall v. Tyrrell, M. \& M. 87; Geralopulo v. Wieler, 10 C. B. 690; Bayley (6th ed.), 181; Nonguier, Lettres de (hange, $\$ \S 584-591$. Unless, indred, there be a direction to another person in ease of need: Chitty 165, 236. Where the direction, in case of neel, is appended, it is said to lie necessary to present a foreign hill to that other person. But then he is more properly an original alternative drawer than an acceptor for honor. As to a direction "in caso of need" on an indorsement, kee leconerel v. Wilson, 2 ('. \& M. 589. There seems from that case no obligation to present an inland bill (where the direction in case of need is given by an inlorser) to thr party to whom, in case of need, it may be presented. The referere, in ease of need, appointed by the indorsar, though agent to p:ay the bill is not agent to receive notice of dishonor: In re Leeds Banking Company, law Rep. 1 liquity $76 ; 35$ L. I. Ch. 33.

a lieawes, pl. 38.

- Chitty (oth ed.). 344; Beawes 39.

B Beawes 33. And it has leren lielel in America that it is no objection that the acceptor supra protest takes the guarantee of the drawee, Byles on Bills (6th American ellition), 403. 
though we have seen that, after one general aceptance, there cannot be another aceeptance," yet, when a bill has heen acepted supra protest. for the honor of one party, it may, by another individual, be acepted supra protest, for the honor of another. In ${ }^{7}$ one ane is the holder obliged to take an aceeptance for honor."

The holder of a dishonored bill, who is ollered an acceptance for the honor of some one of the preceding parties to the bill, should first canse the bill to be protested, and then to be acepted supra protest, in the manner alove described. At maturity he should again present it to the drawee for payment, who may, in the meantime, have been put in funds by the drawer for that purpose. If payment by the drawee be refused, the bill should be protested a second time for non-payment, ${ }^{9}$ and then presented for payment to the acceptor for honor.' Doubts having arisen as to the day when the bill should be again presented to the acceptor for honor, or referee, in case of need, for payment, the 6 and 7 Will. 4, e. 58, enacts that it shall not be necessary to present, or in case the acceptor for honor or referee live at a distance, to forward for presentment, till the day following that on which the bill becomes due. ${ }^{2}$

In a case which attracted much attention, it was proved that where a foreign bill, drawn upon a merehant residing in Liverpool, payable in London, is refused acreptance, the usage is to protest it for non-payment in Jondon. The bill is put into the hands of a notary, and he formerly used to make protest at the Royal Exchange, but that custom is obsolete: the notary now is merely desired by the holder to seek payment of the bill, and on a declaration by the holder that the drawce has not remitted any funds, or sent to say where the bill will be paid, the notary at once marks it as protested for non-payment. The court (with the exeeption perhaps of Mr. J. Bayley), seemed to think this might, if the bill were payable in London, be, in ordinary cases, sufficient. But they were all agreed that it would not have been sufficient in the principal case to charge the acceptor supra protest, hecanse the acceptance was in these words, "If regularly protested and paid when due," and they said the drawees could not he said to refuse unless they were asked. The court also appear to have heen clear that, though there might be cases in which an exhibition of the bill to a notary in London is suffi-

- Jackison v. IIudson, 2 Camp. 447.

7 Beawes, pl. 42.

S Nutford v. Walcott, 12 Mod. 410; 1 Ld. Raym. 575, s. C.; Beawes, 37; Gregory v. Walcup, Comb. 76; Pillans v. Van Mierop, 3 Burr, 1663.

- Hoare v. Cazrnove, 16 Fast, 391.

1 Williams v. Grrmaine, 7 P. \& ('. 477,1 M. \& R. 394, s. c.

2 Acenrding to the French law, the acceptor for honor is bound to give notice to the person for whose honor he accepts. Code de Commerce, 127, 128. 
cient, yet that in all cases a bill may be sent to the drawee, and indeed that such is the more regular course. ${ }^{3}$

By the 2 and 3 Will. 4, e. 98 , it is enacted that all bills made payable by the drawee in any place other than his residence are, on nonacceptance, to be without further presentment protested for nonm mment in the place where they are made payable.

The undertaking of the acceptor supra protest is not an absolute (1) ragement to pay at all events, but only a collateral conditional "' gagement to pay if the drawee do not. "It is," says Lord Ellenhorough, "an undertaking to pay, if the original drawee, upon a presentment to him for payment, should persist in dishonoring the bill, and such dishonor by him be notified by protest to the person who has accepted for honor." " The learned judge proceeds to lay down the doctrine that a second protest is necessary; observing: The use and convenience, and, indeed, the necessity of a protest upon foreign bills of exchange in order to prove, in many cases, the regularity of the proceedings thereupon, is too obvious to warrant us in dispensing with such an instrument in any case where the custom of merehants, as reported in the authorities of law, appears to have been required." And a second protest, for non-payment by the drawee, is, after acceptance supra protest, equally necessary, in order that either the holders may charge the acceptor supra protest, or the acceptor supra protest may charge the party for whose honor the acceptance was given. The object of an acceptance for honor is to save to the holder all those riglits which he would have enjoyed had the bill been aecepted in a regular manner. If the bill be drawn payahle at a certain period after sight, and aecepted supra protest, a second presentment for payment, and a protest and notice, is still essential for the purpose of enabling the holder to sue either drawer or acceptor supra protest, or enabling the latter to sne the party for whose honor he has accepterl. And the time which the bill has to run is computed, not from the date of the exhibition to the drawee, hut from the late of the aereptanes supro protest. ${ }^{\circ}$ Presentment to the drawer, and protest, must be avered in the

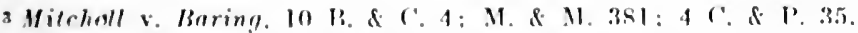

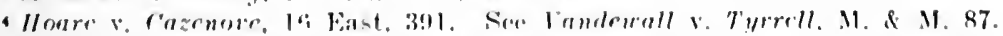
In America it is held thas where a draft bat liene protested for mon-acepetance, the holder ie not lomend to present it at miturity for payment: E.reter Bank v. Gorrlon, 8 New Hampe fifi. But this is not su when there has heen an accoptanes supre protest. An neepeptor for the houor of the drawer cannot recover againgt him without prowf of presentment for acerptanee or payment, and refuaal, and notice to the drawer: Baring v. Clark, 19 Pick. 220. He who arerpts supre protest is unt liahle unleses demand of parment is made on the drawee and notice of the refusal given: Selhofield v. Bry 491.

5 Jhid.

- Williams v, ficrmninf, 7 R. \& C., 468: 1 19nn, \& R, 394, 403, s, c, 
declaration.7 'The aceptor supra protest becomes liable to all parties on the bill subsequent to him for whose honor the aeceptance was made."

The acceptor supra protest admits the genuineness of the signature, and is bound by any estoppel binding on the party for whose honor he accepts. 'Thus, where a bill was drawn in favol of a nonexisting person or order, but the name of the drawer and the name of the payee and first indorser were both forged and the defendant accepted for the honor of the drawer, it was held that the defendant was estopped from disputing that the drawer's signature was genuine, and that the bill was drawn in favor of a non-existing person, was negotiable, and had become payable to bearer. ${ }^{9}$

By acceptance supra protest, the party for whose honor it was made, and all parties antecedent to him, become liable to the acceptor supra protest for all damages which he may incur by reason of his acceptance. ${ }^{1}$ 'The acceptor supra protest, where the bill has been protested for better security, has his remedy also against the acceptor. ${ }^{2}$ It was once held ${ }^{3}$ that a party paying for the honor of the drawer lad no claim on the assignees of the accommodation acceptor, hecause the drawer himself had none; but in a recent case it was decided that he could recover against the acceptor whether the acceptance were given for value or not. ${ }^{4}$

\section{SCHOFIELD $v$. BAYARD AND OTHERS.}

3 Wennell (N. Y.) $488 .-1830$.

THis was an action of assumpsit, tried at the New York circuit in January, 1828, before the Ion. Ogden Edwards, one of the circuit judges.

The defendants drew a bill of exchange in the name of Le Roy, Bayard \& ('o., (the name of their firm), dated New York, 15th August, 1925, upon Messrs. ('rowder, Clough \& Co., of Liverpool, for $£ 1,000$ sterling, payable in Lonrlon, at 60 days after sight, to Mr. E. Peterson, or order, and by him indorsed to the plaintiffs, merchants of

7 Ibid.

\& Hoar v. Cazrnope if Fast, 391: Bayley (6th ed.), 178; Beawes, 33; Marius, 21; Fx parte Wackerbath. 5 Ves. 574.

9 Phillips v. Im Thurm, I. R., 1 C. P. 220.

1 Beawes, 47.

2 Fis parte Wackerbath. 5 Ves. 574.

3 Fix parte Lambert. 13 Ves. 179.

4 Ex parte Swan. L. R.. 6 Eq. 344. In America it is held that if a third party takes up a bill at its maturity for the honor of the drawer, and at his request, he thereby releases the areommodation acceptor of such bill, whether he intended it or not. See Byles on Bills (6ith American ed.), 406. 
Birmingham. The bill was protested for non-acceptance on the 10th September, and notice given to the defendants on the 17th October, after which Baring Brothers \& Co., of London, accepted it supra protest in these words: "Accepted under protest and account for honor of the drawers, and will be paid for their account if needful, and regularly presented when due." 'The bill was subsequently sent to Liverpool to be presented to the drawees for payment. The correspondents of the plaintiffs at Liverpool, on the 10th November, enclosed the bill to the plaintitfs in a letter, with advice that the presentation should be made in London, and the letter was put in the post-office on the same day, in season for the mail for Birmingham on that day, but by some oversight of the clerks in the postoffice it was not sent until the next day, and consequently did not reach the latter place until the 12th November, which was Saturday. The bill could not be forwarded to be presented in season on that day, and Monday after was too late. IIad the letter been forwarded from Liverpool on the 10th by the mail which left there on the evening of that day, it would have reached Birmingham about 11 o'clock A. M. of the next day, and might have heen forwarded from thence to London by mail on the aftemoon of the same day at $4 \mathrm{P}$. M., and would have reached London in sufficient time for the general delivery of letters, between 9 and 10 o'clock on the following morning, which would have been in season. The bill reached London on the 14th November, and payment was demanded of Messrs. Baring Brothers $\&$ Co., who gave the following answer in writing: "Baring Brothers \& Co., accepted this hill conditionally, vi\%, to pay it if needful and regularly presented when due. The hill is expressly made payable in Lonfon, where payment slould have been soight on the 12 th inst.; that has not been done, and therefore they consider their friends, Messers. Le Roy, Bayard \& ('o., as well as themselves, are acquitted from all liability by such irregularity." 'The bill was protested for non-payment, and noties given to the defendants on the 10th Jannay, 1826. Messis. ('rowder, ('lomgh \& Co. were bankrupts when the bill was drawn, the drawer's hat no funds in their hands, and the bill wemld not have been paid hy them had it been presented to tham for payment when dure. A rerlict was taken for the plaintiffs for the primcipal, damagres, exchange, and interest, sub-

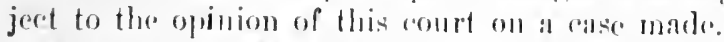

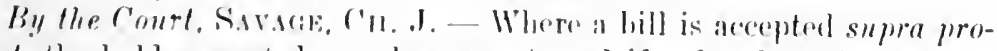
test, the holdor most dernand payment, and if refued, untire of such refusal must he given. Surb arewptanere is a condlitional engagement: and to render such acreptor nbeshutely liable, the hill must be duly precented for payment to the drawee, and protested in case of refusal. (Chitty on Bills, 212: 16 last, 391.) The ahove anthorities say the payment must be demanded of the drawees; but if the 
bill is payable at a particular place, payment must be demanded at that place.

In this case the only real question is, whether the holder is exeused by reason of the mistake in the post-oflice at Liverpool, from not making demand in season. ${ }^{5}$ It is proved in this case that the drawees were bankrupt when the bill was drawn, and had no funds of the drawers at that time or since, and that at no time would they have accepted or paid the bill. It does not appear, however, that the bill would not have been paid by the acceptors had it been regularly demanded. In the ease of Patience v. Townley (2 Smith, 223), a bill drawn on Leghorm, due the 10th September, 1800, was not demanded till the 31 st December; Leghorn being then oceupied by the enemy, or in some such critical situation, it was impossible to present it in season. The plaintiff had a verdict, which the court refused to set aside, Lord Ellenborough saying: "Duly presented, is presented according to the eustom of merchants, which necessarily implies an exception in favor of those unavoidable accidents which must prevent the party from doing it within the regular time;" and it was left to the jury to say whether, from the situation of the country, it was impossible for the plaintiff to present it in due time. That cause presented a case of impossibility; but this case presents no impossibility, if due diligence had been used. The plaintiff should not have sent the bill to Liverpool at all. It is true, that after the letter containing it had been left at Liverpool on the 10 th November, it could not have reached London in season: but it was the fault of the plaintiffs to have parted with the bill in the manner they did. Instead of sending it to Liverpool, they should have sent it to London, and then it would have been in season, and probably would have been paid.

I am of opinion, that, by the law merchant, payment should have been demanded in London on the 12 th of November; and that not having been done, and there being no impossibility to prevent it but what is attributable to the want of due diligence on the part of the lolders, the defendants are legally discharged, and are entitled to judgment.

¿ See Neg. Inst. L., § 141, - H. 


\title{
ARTICLE XV.
}

\author{
P.TMEXT For Hoxor.
}

BYLES, BILLS OF EXCHANGE, ETC. (13TH ED.) 1879.

[Chapter XXI.]

Parment supra protest is where a bill of exchange, having been protested for non-payment, is paid by another person for the honor of some one of the parties. Any party to a bill of exchange, whether drawer, drawee, payee or indorser, may pay for honor. So may a mere stranger, without any previous request or authority from the party for whose honor lie pays. This right is not founded on the English common law, but is a provision of the general law merchant, introduced to aid the credit and circulation of bills of exchange. It extends to no other instrument. Such payment should be preceded, on the part of the payer, in the presence of a notary public, by a declaration for whose honor the bill is paid, which should be recorded by the notary, either in the protest or in a separate instrument. ${ }^{2}$ It is clear that there can be no payment for honor till the bill is dishonored by non-payment.; ${ }^{2}$ and a protest is essential, ${ }^{3}$ though it may be drawn out in due form afterward. ${ }^{*}$

A party paying a bill of exchange supra protest has his action against the party for whom the payment was made, and against all other parties to whom the party could have resorted for reimhursement. ${ }^{5}$ Iut he thereby discharges all the subsequent parties, although that discharge does not prevent his relying on any title they may have."

A man paying for honor of an indorser may, if he choose, give immediate notice to the prior indorsers. Wut he is not bound so to do. He may. if he please, send the protest or the bill or notice to the indriser for whine lonor he pays, and any subsequent regular notice grimen low that party will suffire.

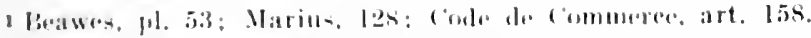

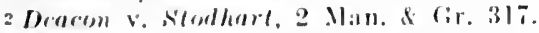

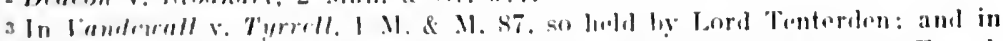

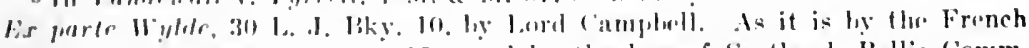

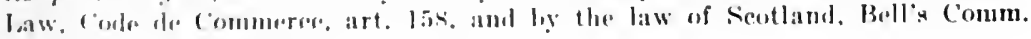
1. 3. pt. 1, c. 4, ถุ: :36.

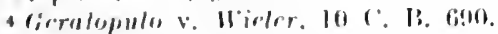

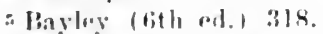

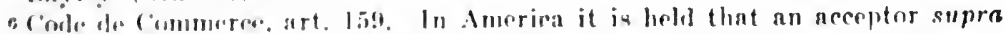

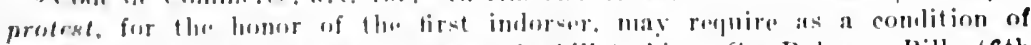

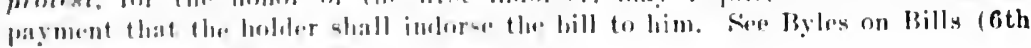
American m. ). dost.

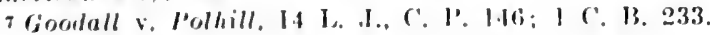


It is conceived that a man annot, hy paying supra protest, revive the liability of an indorser already discharged by laches.

And where a party pays generally for honor, without a protest, a bill already indorsed in blank, he, as an indorsee, may, it seems, sue any party on the bill. ${ }^{8}$

The most obvious and advantageous course to be pursued by a man desiring to protect the credit of any party to a dishonored bill is simply to pay the amount to the holder and take the bill as an ordinary transferee.

But the holder may possibly object; for example, the bill may not have been indorsed in blank, and the holder may refuse to indorse even sans recourse. In such an event a payment supra protest becomes essential.

The party laying supra protest has also his remedy against the acceptor, and that whether the acceptance was given for value or not, unless there be an equity attached to the bill amounting to a discharge. $^{9}$

It is neeessary that the protest should be made before payment. ${ }^{1}$

The law merchant as to payment supra protest does not extend to promissory notes, which are not, like bills of exchange, instruments calculated or intended for circulation all over the globe. Whoever, therefore, pays a note for another person without anthority, express or implied, does so at his peril."

In ordinary eases, however, where the note is indorsed in blank, he of course becomes a transferee of the note. ${ }^{3}$

B Jertens $\mathrm{x}$. Wimningtom, l F.sp. 113. But see the observations on this case by Lord Campbell in Ex parte Wylde, $30 \mathrm{~L}$. J. Bky. 10.

${ }^{9}$ Ex parte Wackerbath, 5 Ves. 5it; bix parte Sican, L. R., 6 Eq. 344, explaining and overruling Ex parte Lanbert, 13 Ves. 179. A party taking up a bill for the honor of any party to it succeels to the title of the party from whom he took it, and is in efrect an indorsee by the law merchant. though he cannot himself indorse: J'othier, vol. 4, pt. 1, $\$ \S 113,114$; Nouguier, Lettres de Change, \$\$ 584-591.

1 Vandevall v. Tyrrell, 1 M. \& M. 87. Although it need not be lrawn out in full, or extended, as it is called, till afterwards: Ceralopulo r. Wicler. 10 C. B. 690 .

2 Story on P'romissory Notes, § 453.

s Payment supra protest is a peculiarity of the law merchant. The payer for honor is practically in the position of an indorsee. except that he discharges all parties subsequent to the one for whose honor he pays. It has been held that one who pays for the honor of the drawer cannot recover against an accommodation acceptor. 1/cDowell v. Cook. 14 Miss. 420; (jazzam v. Armstrong. 3 Dana ( $\mathrm{Ky}$. ), 554; 2 Daniel, \$ 1255. But this doe. trine was founded upon a misapprehension of the facts of Ex parte Lambert (13 Ves. 179), and the doctrine is distinctly repurliated in Ex parte Swan, L. R., 6 Eq. 344. By Nig. Inst. I., \& 304, the payer for honor succeeds to the rights of the holder, both as to the party for whose honor he pays. "and all parties liable to that party." The clanse quoted seems to leave the question of the liability of the accommodation acceptor still in doubt. $-\mathrm{H}$. 


\title{
AR'TICLE XVI.
}

\author{
Billis in a Set.
}

BYLES, BILLS OF EXCHANGE, Етс. (13тн Ed.) 1879.

\section{[CHAPTER XXX.]}

Foreigis bills ${ }^{1}$ are often drawn in parts, all the parts together making what is called a set.

Exemplars or parts of the bill are made on separate pieces of paper, each part being numbered, and referring to the other parts. Each part contains a condition that it shall continue payable only so long as the others remain unpaid. 'These parts should circulate together'; or one may be forwarded for aeceptance while the other is delivered to the indorsee, thus relieving him from the necessity of forwarding his part for acceptanee, but giving him the indorser's security immediately, and diminishing the chances of losing the bifl." Every transferor is bound to hand over to his transferce all the parts of the bill in his possession, and he may even be liable to hand them over to a subsequent transferec, if he have them still in his possession. ${ }^{3}$

The whole set, of how many parts soever it be composed, eonstitutes but one bill, ${ }^{4}$ and the regular payment and eancellation of any one of the parts extinguishes all."

A firm, who were both payees and acreptors of a foreign bill in three parts, indorsed one part to a creditor to remain in his hands until some other serurity was given for it, and then indorsed another part of the same bill for value to al third person. They afterwards gave the first indorsee the proposed serurity, and took back the first part of the hill from him. Held, that the holier of the second part was not preduded from recovering anainst the firm: First, because the substitution of the acearity for the first part was not al payment: and secondly, beranse the firm worr. as lwotwen themenlyes and the serend inderesere estopperl from dispoting the regularity of their aceceptance and inforsement of the second part."

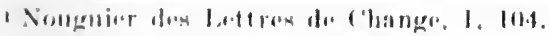

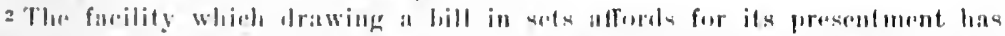

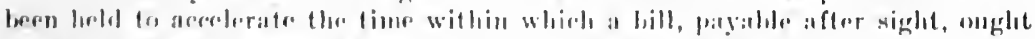

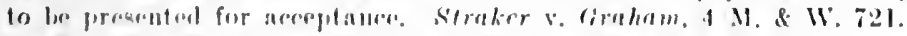

sinaral v. Klorkman, 32 I. J. (2. B. 82; 3 13,4l \& Simitl, 388.

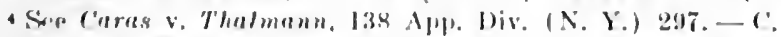

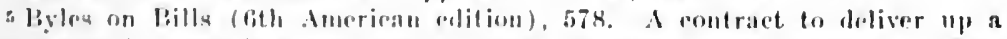
bill drawn in parts is n contract to doliver up avery part. Krarney ve West Granda Mining fompany. I II. \& N. 412.

[Sese Caras v. Thalmana, liss Apl. Div. (N. Y.) 297. - C.]

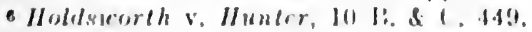


But as between bona fide holders lor value of dillerent parts of the same bill, he who first obtains a title to his part is entitled to the other frats, and might, it has heen salid, maintain trover for them, even arainst a sulserpuent bona fiele holder."

If a man be moder an ohligration to deliver a loreign bill, it seems he is bound to deliver as many parts as may be applied for."

An omission on one part to express the beference to the others, and the condition relating to them, may have the eflect of obliging the drawer to pay more than one part.'

'The drawer should accept only one part. For if two accepted parts should eome into the hands of diflerent holkers, and the acceptor shomld pay one, it is possible that lue may be obliged to pay the other yart also.

And he should not pay without taking back tle part which he has accepted, 3 lor, having paid the malcepted part, he may be obliged afterwards to paly the accepted part also.

And if the indorser improperly circulate two parts to distinet holders, he may be liable on each." 'The forgery of the payee's indorsement on one of the parts will of course pass no interest even to a bona fide holder."

It is comecived that an inlorser is not bound to pay any one part unless every part bearing his indorsements be delivered up to him. ${ }^{\text {. }}$

Copies of bills are not, it is believed, much used in this country. A protest may he male on the copy of a bill in some eases. ${ }^{7}$ But abroal, when a bill is not deaw in sets, it is sometimes the practice to negotiate a copy, while the original is forwarded to a distance for acreptance.

In surh a case the person who circulates the copy should transcribe the boty of the bill, and all the indorsements, including his own, literally, and, after all, he should wite " Copy: - the original being

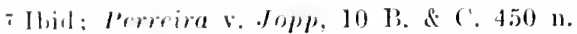

a For it is the duty of a person taling one of the several parts to inguire after the others. Lang v. Smyth. 7 Ping. 284. 294, 5 .I. \& P. 78; and he is arloretinel by the part which he does take that he takes it withont the others at his proil.

9 l [and. 394. Jut since cach part is now subject to a stamp, if issued or

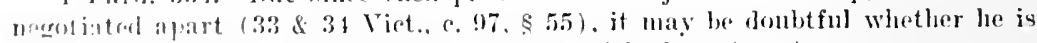
so homul. unlese the party applying will furni=h the extra stamps.

1 Jolison v. Kobertson, 3 J)ow, 218, 228; Beawes, 430; Potli. III; 2 Pard. 367 . But not an inaceurate reference or an omission to nane one part obviously by mistake. Jayley (6ith aet.). 30.

2 Sire Iloldsucorth v. Ilunter, 10 B. \& C. 449.

3 corle de commires, art. J48.

4 Sire lloldsueorth v. Hunter, supra.

"rheap v. Marley. 3 T. R. 127. Ses Smith v. Mercer. 6 Taunt. 80; I Marsh. 45.3, s. C.; Fuller v. Smith. 1 ('. \& 1'. 197; Ry. \& M. 49, s. c.

6 Cour do Cassation, 4 Avril. 1892; Sirey, t. 32, 1. 29.

T Lehers $v$. IJarriot, I Show. 163. 
with such a person." If he should omit to state that the bill is a copy, or to write his own indorsement after the word copy, he may become liable on the copy as on an original. ${ }^{8}$

It is a common but not a safe practice for a drawer, to whom a negotiated part has come back with many indorsements on it, to substitute a new part withont such indorsements. The holder of such a substituted part may be deprived of his remedy against the acceptor by the intermediate act of the drawer. ${ }^{\circ}$

\section{$\S 310$}

\section{WALSH $v$. BLATCHLEY.}

\section{Wiscossix, 422. - 1853.}

THe plaintiff declared in trespass on the case upon promises, for money lent; money laid out and expended; money paid and received by the defendants for the use of the plaintiff, etc; and gave notice of the cause of action, the indorsement by defendants upon the bill of exchange, copied, and served with the declaration as follows:

\section{Ada Mrs \& Co.}

Exchange for $\$ 250$.

$$
\text { No. } 9,917 \text {. }
$$

\section{Express Exchasge Office.}

Dowienill.e, San Fraxcisco. Oct. 6, 1854.

At sight of this second of exchange - first and third unpaid - pay to the order of Phebe Blatchley, two hundred and fifty dollars value received, and place to account of exchange.

To Mrsses. Adams \& Co., New York.

ADnss \& Co.

(Countersigned),

S. W. Laxoworthy, C. B. Macy, Agents.

Indorsed by Phube Blatehley to Ilenry Dart or order, and ly J. Menry Dart to P. O. Strang or order, and by Strang to P. Walels or order.

The defendants plead the gomeral issue: and by mutual agreement of counsel the rause was triorl heforr the rircuit judge, without the intervention of a jury, who found, and reporterl in writing with his decision, the farts and conclusions, and recited in full in the opinion of the court therein.

By the Conrt, ('ots, J. - This rase was tried by the rourt without the intervention of a jury, and the jublese found the following facts:

First. That the artion is lirought upon the hill of exclange introduced in evidenere, and descrilued in the plantiffs declaration. That this bill, which is the second of the set, was indorsed by the defendants on a Siumlay.

Second. That the first of the set was sold by defendants to plaintiff about the Ist of Jammry, 185i. 'That the plaintifr, without delay,

- Conr loyale de Paria, I4 Ianvior, 1830; Sirey, t. 30, I. 172.

- Kalli v. Dennistoun, 6 Exelt. 483. 
sent the same by mail to his correspondent in New York eity, the residence of the drawee, for presentation for payment. 'That by some delay in the mail the letter did not reach New York until the ath of April following, at which time the letter, with inclosure, was duly received by the said correspondent. 'That the bill was not presented tor payment.

'Third. 'T'hat in the last of March, the plaintiff, fearing the said first bill was lost, procured the defendants to indorse and deliver to him the second of the set, and had it presented on the third day of April following for payment, to the Arawee, and payment was refused. The bill was duly protested, and proper notice given to the defendants, who were indorsers.

The conclusions of law which the court drew from these facts, were, "1st. 'Tlat the liability in this action, if any at all, is upon the second bill of the set, and not on the first; 2d. That because the said bill was indorsed on Sunday, that therefore such indorsement was absolutely roil."

We have examined with considerable care the authorities, and have not been able to find a case precisely like the present, although it would seem as if the point must frequently have arisen in the courts in this country, and in England. 'The case of Perreirav. Jepp et al. (cited in a note on page 449,11 B. and C.), would seem to have a strong bearing upon the case at har. It was there held that he to whom any part of the set is first transferred, acquires a property in all the other parts, and may maintain trover even against a bona fide holder, who subsequently, by transfer, or otherwise, gets possession of another part of the set. That is, decirling that the first indorsement of one of the set vests in the indorsee the absolute riglnt to the possession of the whole set. And we suppose it wonld follow, from this doctrine, that the indorsement of the second in this case was entirely unnecessary. 'The liability of the indorser arose from indorsing the first of the set for value. We think her liability was not increased one jot or tittle by indorsing the second of the set. Suppose she had indorsed all of them in January, at the time she indorsed the first, is it not obvious that her liability would not have been different from what it is? It is conceded that the indorsement of the first was good, and this indorsement was entirely adequate to earry with it the serond and thiml. (See Folwards on Bills, 304 and 162; Holdsuorth v. Iunter, 10 T. C. 149 ; Kenworthy v. IIopkins, 1 Johns. Cas. 10\%.) Either of the set may he presented for acceptance, and, if not acrepterl, a right of action arises upon due notice against the intorser. (Downes and Co. v. Church, 13 Peters, 205.) 'The bill upon which the protest was made was declared on and producerl, and it also appeared that the first har not been presented for payment. The court says, and we think properly and correctly, that 
if the first had been presented for payment and protested, even as late as April 9th, that upon proper notice the indorser would have been held, for the delay in the mail would have been a sulficient excuse for the apparent neglect in not presenting it for acceptance before. The case might have been relieved from all doubt or difficulty, had the indorsee declared upon the first of the set, and produced on the trial the second, which had been presented for acceptance and dishonored. (Wells v. Whitehead, 15 Wend. 527.) This he did not see fit to do, but we think he was entitled to recover even as the facts appeared before the court.

The judgment is reversed, and a new trial ordered. ${ }^{1}$

1 It seems that an indorse has no right to demand the other parts except from his immediate indorser. Thus, the fourth indorsee cannot maintain an action against the second indorser for outstanding parts of the set. Pinard $v$. Klockmann, 3 B. \& S. 38s; s. C., 32 L. J., Q. B. \&2.

In an action against the aceptor on one part of the set, the holder need not file the other part or parts. Johnson v. Offutt, 4 Met. (Ky.) 19. In an action against the indorser on the second part, after dishonor by non. acceptance, the holiler need not account for the first part; it is a matter of defence "to show either that some other bill of the set has been presented and accepted, or paid; or that it has been presented at an earlier time and dishonored, and due notice has not been given: or that another person is the proper holder, and has given notice of his title to the party sued; or that some other ground of elefener exists, which displaces the prima farie title made out hy the plaintiff." Dorenes v. Church. 13 Pet. (IT. S.) 205; Miller v. Palmer, 58 Id. 452 . But where the seeond of the set is protested for nonacceptance, the holder must produce that number of the set, because other. wisc it may have been accepted supra profest for the honor of the defendant, and he he liable upon it. Wrlls v. Whitrlerad, 15 Wend. (X. Y.) 527. If the drawee accepts more than one part, he js liable on each to holders in due course. Holdsworth v. Hunter, 10 li. \& ('. 44!! Bank v, Neal, 22 llow. (U. S.) 96. If the drawee disiomoss one palt. but stobecouently honors and Irays $1: \cdots$ other part, the drawer is discharged. I'nge v. Warner, 4 Calif. 395. - H. 


\title{
AR'TIClE XVII.
}

\section{Plomissoliz Noplss ann Checks.}

\section{Promissory notes.}

\section{OHIGIN AND IlISTORY."}

\author{
[Nice pages $2 \gamma-28.1$
}

\section{Forat AND INTERPRETATION.}

\section{See Article II, Pr. 31-3:3;, ante.}

1 The statute of $3 \&+$ Anne, c. 9, $\$ 1$ (1704), provided that, "Whereas it hatl, been hold, that notes in writing, signes by the party who makes the same, whereby such party promices to pay unto any other person, or his order, any sum of money therein mentioned, are not assignable or indorsable over, within the custom of merehants, to any other person; and that sueh ferson to whom the sum of money mentioned in such note is payable cannot maintain an aetion, wy the cu-tom of merehants, against the person who first nade and signed the same: and that any person to whom snch note should be assigned, indursed. or made payable, could not, within the said eustom of merehants, maintain any action upon such note against the person who first lrew and signed the same: Therefore, to the intent to encourage trade and commeree, which will he mueh advaneed if such notes shall have the same effect as inlaul bills of exchange. and shall be negotiable in like manner, be it cnacted, cle., (1) That all notes in writing that, after [May 1-t. 1705], shall be made and signed by any person . . . whereby such peran . . doth or slatl promice to pay to any other person or persons, - . his, her or their order, or unto bearer, any sum of money mentioned in such note, wall be taken and construed to be, by virtue thereof, due and payalule to any stele presen or persons. . to whom the same is marle payalile: (2) and alue every such note payable to any person or persons, . his, her, or their order, shall be ascignable or indorsable over in the same manuer as inlaud lills of exchangu are or may be, aceording to the eustom of merchants; (3) and that the person or persons. . . to whom such $\mathrm{wm}$ of moncy is or shall be by such mote made payable, sliall and may maintain an action for the same. in such manner as he, she. o" they might do the euntom of mereliants, against the person or persons. . . who signed the same; (4) aml that any peron or fersons. . . to whom such note - . is insorerel or ascigned. or the money llerein mentioned ordered to be paid by indorement thereon, shall and may maintain his, her, or thejr action for such sum of money, either against the person or persens. . . who inned such note. or agrainst any of the persons that indorsed the same, in like manner as in ca-res of inland litls of pxchange."

The statute was hold to apply to forrign. as wall as domestic, notes. dlilne v. Graham, l Barn. \& ('ress. 192. Statutes of like tenor have been passed in the American states. I Daniel. \$5. Independent of statute, some of nta have held promissory notes to be nearotiable by force of common law. Dunn ․ Adams. I Ala. S27; Irrin ․ Mrury. I Mo. 194. See I Farsons, Bills and Notes $(2 d$ ed.), pp. 9-13; Story on Prom. Notes, $\$$ 6. - H, 
58 Misceldaveols (N. Y. Sur. ('T., APr. T.) 561. - 1908.

Dexurrer to complaint on promissory note overruled and defendant appeals.

Grlofrslefve, P. J. * * * 'The appeal from the interloeutory juilgment rendered on January 3, 1908, is well founded, and that judgment must be reversed. The plaintiff's cause of action rests upon a promiscory note made by the defendant and payable to the "order of myself." Although the complaint alleged the making and delivery for value of the note to the plaintiff, and that the plaintiff was the lawful holder and owner of the note, and its presentation and demand for and refusal of payment, it contained no allegation that said note was ever indorsed by the defendant, its maker. The Negotiable Instruments Law of the state (Laws 189\%, p. 755, c. 612) repealed all prior statutes regarding lills and notes, and provides ly section 320 therenf as follows:

"A negotiable promissory note within the meaning of this act is an unconditional promise in writing made by one person to another signed by the maker engaging to pay on demand or at a fixed or determinable future time, a sum certain in money to order or to bearer. Where a note is drawn to the maker's own order, it is not complete until indorsed ly him."

The note, unlese indorsed by the defendant, was therefore incomplete, and the failure of the romplaint to allege such indorsement rendered it demurrahle. Odell r. C'yde, $5.3 \mathrm{~N}$. Y. Supp. 61, 6.2.

Interlocutory judgment of . Tambry 3, 1908, reversed, and demurer sustainel, with costs. with leave to the plaintiff to amend the complaint within five days mpon payment of said costs. C'osts of one party to be offet against those allowed the other. All concur.

3. Nox-Notormbu Notes.

$\S 320$

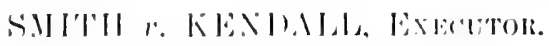

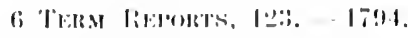

Assimuser on the following instrument, given by defendant's testator:-

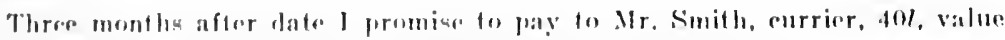
received in trust for Mrs. li.. Thompun, as wituess my hand.

25) IYne, 1787.

1. AsKEW.

The artion was commeneed September 26, 1793. Defendant ohjected that the instrument was not a promissory note within the 
statute (3 and 1 Anme, c. 9), and, if not, the eause of action acerued Sept. Si, 1isi, three montis aller the date of the note, and consequently that six gears had elapsed before the suing out of the writ, and that the canse of action was barred by the statute of limitations.

Ferdiet for defendant, with leave to plaintiff to move to set that verdiet aside, and to enter a rerdict for him, if this court thought he was entitled to recover. Motion aceordingly.

Iond Kixvox, C. J., silil, If this were res integra, and there were no decisions upon the subject, there would be a great deal of weight in the defendant's ohjection; hut it was decided in a ease in Lord Raymond (2 Lord haym. 15:5), on demurrer, that a note payable to B., without arling or to his order, or to bearer, was a legal note within the act of Parliament. It is also said in Marius that a note may he made payable either to $\mathrm{A}$. or hearer, $\mathrm{A}$. or order, or to $\mathrm{A}$. only. In addition to these authorities I have made inquiries among difierent merchants respecting the practice in allowing the three days grace. the rwollt of which is that the Bank of Fngland and the merelaants in Lomilon allow the liree days' grace on notes like the present. The opinion of merchants indeed wond not govern this court in a question at law, but I an glad to find that the practice of the commercial world coincides with the decision of a court of law. Therefore, I think that it woutl be dangerous now to shake that practice, which is warranted by a solemu decision of this court, by any sperilative reasoning upon the subject; and consequently this rule must be made absolute to enter a verdict for the plaintiff.

Rule absolute. ${ }^{2}$

CARNWRIGITT 2 . GRAY, ExECUTOR.

$127 \mathrm{XEW}$ York, 92. - 1891.

Actons on the following instrument, exceuted by defendant's testator:-

QUARRYULLe, September 2, 1871 .

Thirty' days after drath, I pronise to pay to Cornelius Carnwright fifteen hundred dollars, with interest.

Sanufi. P. Freditit.

Plaintiff gave no evilence of ensideration, lut proved the genuineness of the sigmature, put the note in evirdence, and rested his case.

Judgment for plaintiff. Defendant appeals.

Browx. J. When the plaintiff rested his ease and again at the close of the testimony the defendant moved to dismiss the complaint

2 Grace is allowed on non-negotiable notes. Mnncan v. Marylanl Savings Inst., to Giil \& J. (Md.) 29! ; Dubuys v. Farmer, 22 Ja. Ann. 478; Cox v. Reinhardt, 41 Tex. 591. ('ontra: Lure v. Shoff. 70 Ind. 152. The matter is now unimportant where days of erree are abolished. Neg. Inst. I., \& 145. - H. 
upon the ground that no proof had been given that the instrument sued upon had any consideration. These motions were denied and the court instructed the jury that the instrument was a promissory note and imported a consideration, and that the burden rested upon the defendant to show that it was without a consideration.

The exceptions to these rulings present the principal question argued upon this appeal.

The statute of this state in reference to promissory notes provides as follows ( 1 R. S. 768$)$ :

$\S 1$. All notes in writing, made and signed by any person, whereby he shall promise to pay to any other person or his order, or to the order of any other person, or unto the hearer, any sum of money therein mentioned, shall be due and payable as therein expressed; and shall have the same effect and be negotiable in like manner as inland bills of exchange, according to the custom of merchants.

$\S 4$. The payees and indorsees of every such note payable to them or their order and the holders of every such note payable to bearer, may maintain actions for the sums of money therein mentioned, against the makers and indorsers of the same respectively, in like manner as in cases of inland bills of exchange, and not otherwise. ${ }^{3}$.

Our statute is a substantial reenactment of the statute of Anne (3 and 4 Anne, c. 9), which provided that: "All notes signed by a person promising to pay to another his, her, or their order or to bearer" should be construed to be by virtue thereof due and payable to any such persor to whom the same is made payable, ete., etc.

This statute was held by the courts of England to include within its terms a non-negotiable note. (S'mith v. Kendall. 6 D. \& E. 123; Burchell v. Slococh, 2 Lal. Raym. 1545: 3 Kent's Com. 7\%.) In the case first eited Lord Kenyon said: "A note may be marle payable to 'A.' or hearer, 'A.' or order, or to 'A.' only." Similar decisions were made by the courts of this state under our own statute. (Downing $\mathrm{r}$. Backenstoes, :3 ('aine, 1:30: P'resillent v. IMutin, 9 .Johns. 217;

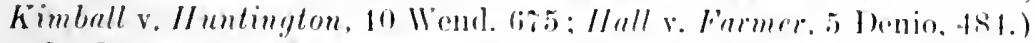

In Downing v. Backenstoes a non-negotiable note was declared on as within the statute and the defendant demured on the ground that the declaration dicl not allege the transaction and ronsideration upon which the note was griven. The comrt gave judgment for the plaintiff, saying: "The very point was settled in firen v. Long ( $A_{\text {pril }}$ Term, 1798), in conformity to the aljulieations in Westminster Hall."

In President v. Iurlin it was sairl: "The note set forth is a good promissory note within the statute. though it has no words bearer or

3 This statute is now repealed by N. Y. Neg. Inst. L., $\S 340$, and is replaced by $\$ 320$. - H. 
order. 'This is the established English law, and the same rule is recognized by this court."

In Kimball v. Huntington the action was upon a due bill in this form: " Dne Kimball \& Kenston three lundred and twenty-five dollars payable on demand." Judge Nelson said: "The instrument is a promissory note within the statute. Neither the acknowlerlgment of value received or negotiable words are essential to bring it within the statute." (See also Carver v. Llayes, 47 Me. 257; Franklin v. March, 6 N. H. 361.)

No anthority is cited in the courts of this state or of England holding that a non-negrotiable note is not within the terms of the laws cited, and we are of the opinion that the language of our statute includes a note payable to a person without words of negotiability.

'Tle instrument sued upon being, therefore, a promissory note within the statute of this state, it follows that it imports a consideration. By the express terms of the statute the sum of money therein mentioned is declared to be "due and payble as therein expressed." That it is "due and payable" according to its terms is the legal conclusion which the court must draw from the instrument itself. A valid contract is thus declared to exist, and of course a consideration nust be implied. Hence "value received" need not appear on the face of the note, as those words express only what the law implies. (IIatch v. Trayes, 11 Ad. \& El. 702 ; Hall v. Farmer, 5 Denio, 484.)

'The effect of laws which make promissory notes negotiable, or which authorize actions of debt upon then, though non-negotiable, is to take them out of the common-law rule which requires that every contract must be shown by the party who sues upon it, to be supporterl by a consideration, and enables the holder to maintain an action thereon without alleging or proving a consideration. In other words, a consideration is implied from the claracter of the instrument. (I'easley v. Boatwright, 2 Leigh, 195; Hatch v. Trayes, supra.)

'The English statute was enacted to settle the controversy that prevailed, whether under the customs of merchants promissory notes were negotiable. They were thereby declared to be assignable or indorsable over in the same manner as inland bills of exchange were according to the customs of merchants, and holders were empowered to maintain actions thereon in the same manner as they might do upon any inland bill of exchange made or drawn according to the custom of merrhants.

Our statute contains similar provisions. Promissory notes and inland bills of exchange were, by virtue of these laws, put upon an equality. They were made negotiable if they contained words of negotiability, but whether negotiable or not, and whether they expressed value received or not, it was no longer necessary in actions thereon to aver and prove consideration.

Such was and is the rule as to inland bills of exchange. (1 Daniel 
on Negotiable Inst., § 161; Raubitschek r. Blank, 80 N. Y. 479; Averett's Adm'rs v. Booker, 15 Gratt. 163; Wells v. Brigham, 6 Cush. 6.)

And the same rule under the statute was made applicable to promissory notes. (Tounsend r. Derby, 3 Metealf, 363; Dean v. Carruth, 108 Mass. 242; Bank of Troy r. Topping. ! Wend. 27\%; 13 Id. 557; Chitty on Bills [9th Am. ed.], 78-181; l'aine v. Nalke, 57 How. Pr. 273: Story on Promissory Notes, § 51; 3 Kent's Com. 77,$78 ; 1$ Parsons on Conts. [6th ed. ], 249; 1 Parsons on Bills, 193.)

'The statute does not remuire a note to express value received upon its face, and no definition of such an instrument requires the expression of that fact.

The note sued upon, although hy its terms payable after the death of the maker, was a valid instrument.

A promissory note is defined to he a written engagement by one person to pay absolutely and unconditionally to another person therein named, or to the bearer, a certain sum of money at a specified time or on demand. (Story on Prom. Notes., \$ 1: Coolidge v. Ruggles, 15 Mass. 38\%.) It must contain the positive engagement of the maker to pay at a certain definite time and the agreement to pay must not depend on any contingency, but be absolute and at all events. Tried by this standard the instrument set out in the complaint was a valid promisory note. The fact that it was payahle after the death of the maker did not affert its character. (3 Kent's Com. 76.$)$

It follows from these views that the motion to dismiss the complaint was properly denied, and there was no error in the charge of the court.

The point made by the appellant that the court erred in its charge as to the hurden of pronf on the question of monsideration, assuming that evidence pro and rom upon the question was given, was not raised at the trial. 'The pronosition madre lye the defendant at the elose of the judge's eharge, and the only one to which an exception appears in the rerord, was as follows: "I oreler that there may be no doubt about our position we ask the rourt to charge the jury that there has heen no evidence griven of consideration, and to direct a resdiet for the defendant upon that gromml." 'The defundant having thus squarely planterd himself on the gromen that there was no evidence of consideration, and asked the combt to direct a serdiet in his favor. cannot now claim that there was evidene for the jury and that he was entitled to a different instruetion from that given.

The defendiant's daim all through the trial was that the note did not import a consideration, and that the plaintift could not rerover without pronf of that faret, and his motion to dismise the eomplaint and to direet a verdict in his favor, and his exerpetions to the rharge, all sharply present that fuestion; but he nowhere chaimed that he 
Jad given eridence which, if believed by the jury, overcame the presmmption arising in lanor of the note. This chearly appears from the

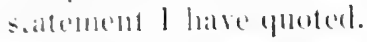

'The ascepions to the admission of evidence present no error, and the judgrment slomld be aftirmed.

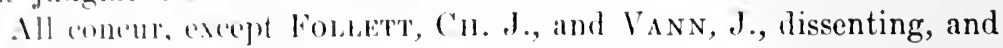
l'Akikili, l., not roting.

Judgment affirmed."

40 NEW YORK, 491. - 1869.

ACTrox against payee-indorser of two instruments as follows:New York, March 22d, 1861.

\$7.5.

Sixty days after date 1 promise to pay to Richard Hewitt seventy-five dollars, valie received.

[Indorsed] :

William Ryan.

IAMES R. HEWITT,

Richard Hewitt.

Another of like tenor for four months was made and indorsed as above.

4 Accord: Hegeman v. Joon, 131 N. Y. 462. Contra: Bristol v. Warmer, 19 Conn. 7. ante. p. 234: Currirr v. Lorkwoor, 40 Conn. 349, ante, p. 42. The question as to whether a non-negotiable promiscory note imports a consideration must turn upon a coustruction of the statute governing promissory notes. Apparently the Neg. Iu-t. L., \$ 320, has cluanged the law in New York, as the section referred to includes only negotiable promissory notes. - H.

[]n Dryo v. Thompsom. 53 App. Div. (X. Y.) 9, it was held that under the provicions of the Negotiable Instruments Law a note in the following form. "On denand I promise to pay Helen beyo three hundred dollars," dowe not import a consideration, and the burden is upon a party suing on such note to prove the existenee of a consideration therefor by extrinsic evidenee. Merwin. J.. sibil: "The note was not negrotiable and did not express eonsidration. In f'arnuright v. Gray (I27 N. Y. 92) it was hed, of such a note. that it importerl a consideration and that the hurden of showing a want thereof was upon the defondant. This decision was based on the provisions of the Revised Statutes (lart 2, ehap. 4, tit. 2, l R. S. 768) on the subject of pronissory notes. These provisions were repealed by the Negotiable Instruments Law (chap. 612, Laws of 1897), and I find no provi-ion in that law that will allow us to hold that a note, like the present one. imports a consileration. In the Carnwright ease it was evidently considered that. in the absence of a statutory provision. there was no presumption of consideration and that the burden of proving it was upon the party who brought the action. And that seems to be the rule. (1 Daniel Neg. Inct.. 4th ed. \$ 1f2)." P. 12. 'This point does not seem to have been passed upon as ret by the New York Court of Appeals. - C.] 
James Hewitt was originally made a defendant, but the action as to him was discontinued, and this action is against Richard llewitt, the payee-indorser.

The plaintifl testified that the defendant was owing the plaintiff, and that it was molerstool between them that when these notes were passed over by him in payment, that they were taken solely upon his responsibility, and that he assured plaintifl that they should be paid.

The action was to charge defendant as guarantor. No presentation to the maker for payment or notice of non-payment to Hewitt was sliown. The court below held the suit could not be maintained, and dismissed the complaint. Plaintiff appeals.

Mason, J. - This action was brought to recover of the defendant the amount of two non-negotiable notes of seventy-five dollars each, upon the following facts: One William Ryan made the notes payable to defendant by name, and the defendant transferred the notes to the plaintitl for value, and indorsed them over by writing his name upon the back. The notes were not presented for payment when they fell due, nor was any notice of non-payment given to the defendant, and the only question in the cance is whether the plaintits are entitled upon these facts to recover of the defendant the amount of the notes. 'The "ase of Richards' E.r'r v. Warrings (1 Keyes R. 575), is an authority in point, and decilles the very question in favor of t':e plaintiff. The "as holds that the holder may overwrite the indorser's namu with a contract of guaranty, or as maker of the note. That case must he regarilers als controlling, even should we think the lonacons assigurel for the decision unsatisfactory.

Thie judgment of the Supreme Court must be reversed and a new trial aranterl, with rosts, to abide the event. ${ }^{6}$

"This wate a raso of "irrounlar iulorsement." - II.

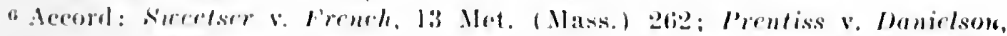
i) (

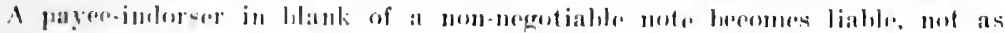
imborser. but if at all as gualantor. ln some sfates no presumption ariages

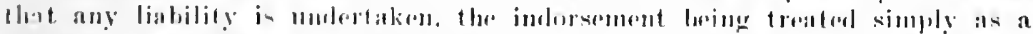

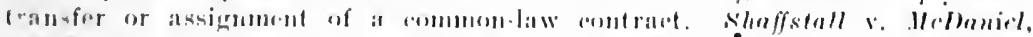

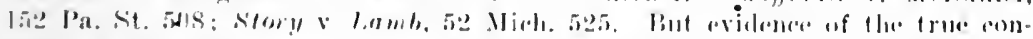

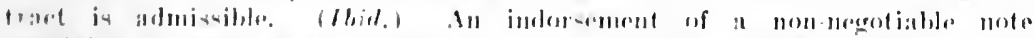

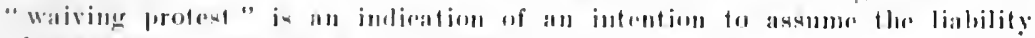

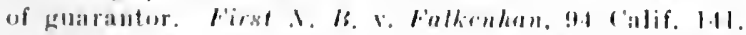

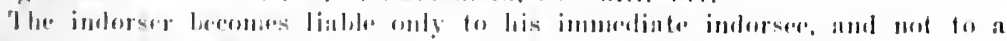

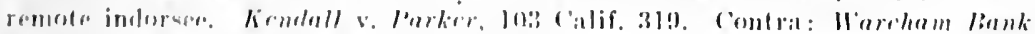

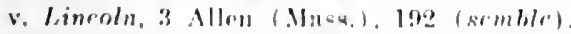

An irregular indorwer of a mon megotiable note is a gunrantor. liehards'

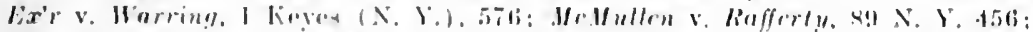

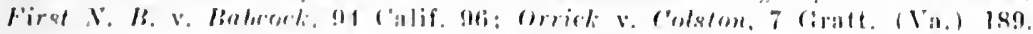

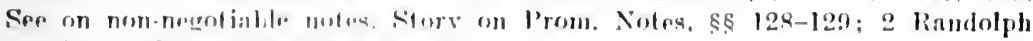

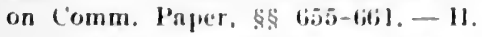




\section{Checks.}

\section{Check Distinguished from Bill of Exchange.}

$$
\text { HARRISON } v \text {. NICOLE' NAT'BANK. }
$$

41 MinNinoma, 4S8. - 1889.

APpear by plaintiff from an orter of the District Court for Hennepin county, Ra, J., presilling, sustaining a fenurrer to the complaint. 'The action was to recover $\$ 20,000$ damages for that the defendant, on April 11, 18s8, and before the maturity thereol, did "falsely, wrongfully, and maliciously" cause to be protested the following instrument, which had been indorsed and forwarded to defendant for collection, thereby injuring plaintiff's credit, ete.:

$\$ 199.92$ 45 Washington Ave., South,

Harmison, the 'TaILor. Mismeapolis, Minn., Mch. 27, 1888.

On April 14th pay to the order of E. Harrison one hundred and ninety-nine 92-100 dollars.

To Citizens' Bank.

J. T. HARRISON.

Minneapolis, Minn.

No. 2,884 .

Mitcneis, J. - This appeal presents the question whether a written order on a bank or banker to pay a sum of money at a day subsequent to its date, and subsepuent to the date of its issue, is a "check," or a "hill of exchange," and hence entitled to grace. 'The question is one which has given rise to considerable discussion and some conflict of opinion.

About all the law there is on it, as well as all the arguments on each side, will be found in Morse, Bank (3d ed.), § 381 et seq. The two principal authorities holding such an instrument a check are $I n$ re Brown (2 Story, 50:2), and Champion v. Gordon (70 Pa. St. 47.4). Both of these are entitled to great weight, but they stand almost alone; the supreme courts of Rhode Island (Westminster Bank v. Wheaton. 4 R. I. 30), and perhaps of 'T'ennessee, being, so far as we know, the only ones which have adopted the same views. ${ }^{7}$ All other courts which have passed upon the question, as well as the textwriters, have almost uniformly laid it down that such an instrument is a bill of exchange, and that an essential characteristic of a check is that it is payahle on demand. This was finally settled, after some conflict of opinion, in Now York, - the leading commereial state of the Union, - in the ase of Powen v. Newell, several times before the courts, 5 Sandf. 326; 2 Dner, 584:8 N. Y. 190, and 13 N. Y. 290, 64 Am. Dece. 550. (Seer, also, Morrison v. Bailey, 5 Ohio St. 13, 64

7 See also Way v. Toule, 155 Mass. 374. - H. 
Am. Dec. 632; Woodruff v. Merchants' Bank, 25 Wend. 673 ; Minturn v. Fischer, 4 Cal. 35; Bradley v. Delaplaine, 5 Har. [Del.] 305; Georgia National Bank v. IIenderson, 46 Ga. 487 ; Ivory v. Bank of State of Mo., 36 Mo. 475, 88 Am. Dee. 150; Work v. Tatman, 2 Houst. 304; Hawley v. Jette, 10 Or. 31; 2 Daniel Neg. Inst., $§ \S 1573-1575$; Morse, Bank., supra.)

Nearly every definition of a check given in the books is to the effect not only that it must be drawn on a bank or banker, but that it must be payable on demand. (1 Rand. Com. Paper, \& 8; Byles, Bills, 13 ; 2 Daniel, Neg. Inst., § 1566; 1 Edw. Bills, § 19; Bigelow, Bills and N., 116 ; Chalm. Dig. Bills and N., art. 25t; Shaw, Ch. J., in Bullard v. Randall, 1 Gray, 605 ; Bouv. Law. Dict.; Burrill, Law Dict.) Oecasionally the expression is used "payable on presentation," but evidently - except perhaps in Story on Bills - as synonymous with "payable on demand."

As the question is a new one in this state, we would not feel compelled to follow the majority if the better reasons were with the minority. Perhaps the weightiest argument in favor of holding such an instrument a check is the practical one advanced by Sharswood, J., in Champion v. Gordon, supra, viz, that if held to be a bill of exchange the holder might immediately present it for acceptance, and if not accepted he could sue the drawer, or if acepted it would tie up the drawer's funds in the hands of the bank, and thus, in either case, frustrate the very object of making it payable at a future day. In answer to this, it may he said that the drawer, if he wished, could very easily avoid such consequences by inserting ajpropriate provisions in the instrument. On the other hand, if we hold that an instrument not payable on demand may be a lleck, we are left without any definite or precise rule by which to determine when the paper is a check, and when a bill of exchange. The fact that it is drawn on a hauk is not alone enough to distinguish a cheek from a bill of cxchange, for nothing is better settled than that a bill of exchange may be drawn on a banker. Neither will the fact that the maker writes it on a "blank check" be any test, for the kind of paper it is written on cannot control the import and lengl offeret of its words. Neither ean the question whother it is drawn agrilust a previous deposit of funds by the drawer with the drawee furnish any criterion, for nothing is clearer than that a bill of exrblange, as well as a rbeck, can be drawn against such a depesit, and that an instrument may be a check although the drawor has no funds in the hands of the drawee. Neither will it do to say that if it is antitled to grare it is a bill, but if not entitled to grace it is a chece, heeause the legal waracter of the instrument has first to lo determined before it an be known whether or not it is entitled to grace. In short, if we omit from the definition of a cherek the clement of ite being payshble on demand, bankers and business men are left without any definite rule by 
which to govern their artion in al matter where simplicity and precision of rule are especially desirable. It might he expedient to enate, as has been done in Xew lork and some other states, that all checks, bills of exchange, or drafts, appeanting on theil face to be drawn on a bank or binker, whether payable on a specified day or any number of days after date or sight, shall be payable on the day mancel in the instrmment without grace; or, what might be better still, to abolish clays of grace altogether as a usage which has already long ontivel thr combition of things ont of which it had its origin. But this is a matter for legislatures and not for courts. We are therefore of opinion that the better rule is to hold that such an instrument is a hill of explamere, and hence entitled to grace. We may add that it is always desimble that the decisions of the courts should be in accord with the husiness usages and eustoms of the comntry. Such usages are entitled to special weight on a question like this, for the whole matter of grace on bills and notes had its origin in the usage of bankers. Anl, so lar as we are advised, the general practice of bankers in this state has been to treat instruments like this as hills of exchange and not checks.

Counsel for respondent sugrestis that, eren if we hold that payment of this paper was demanded and protest made prematurely, yet the action of the court below in sustaining the demurrer to the complaint should be affirmed on other grounds, viz., that the act of protesting, ete., was the act of the notary and not of the bank; that the protest could not have damaged the finaneial standing of the plaintifl because the certificate of the notary shows on its face that it was done before maturity; also, that the instrument, being of doulstul classification, insolving a legal question on wlich courts differed, the defendant would not be liable for an honest mistake of law. Whatever force there might be in these suggestions, either by way of defense or in mitimtion, we think they are unavailing in support of a demurrer to a complaint which alleges that the defendant "falsely, wrongfully and maliciously caused" the paper to be protested for non-payment, and notices of protest sent out, and which also shows that sich notices - which were presumably what, if anything, injured plaintifl's standing and crelit - contained nothing indicating that payment was prematurely demanded.

Order reversed. ${ }^{8}$

8. A post-daterl rhrek is to be dietinguished foutside of Mass., Pa., and l. I.), from a chuck payable hy its terms after the rate of issue. 2 Daniels, \&\$ 157-1578; Cratrforil v. IVest Side Bank, 100 N. Y. 56. A post-dated check is to lye treated as if i-sured on tle day of its late. Frazier v. Trow's, Printing, Etc., Co., 24 IHun, 281, 90 N. Y. 6ï8. 一 H. 


\section{Presentment of Check.}

\section{(a) Effect of delay upon drawer's liability.}

GRANGE $r$. REIGH.

93 Wiscoxsix, 552. -1896.

Action against the drawers of a check. Defendants, after banking hours on July 20 , llew and delivered to plaintiff in Milwaukee, where plaintilf residerl, a check for $\$ 1,211$ upon the South Side Savings Bank, located in Milwaukee. The check was not presented on July 21, during all of which day the bank was open and would have paid the check had it been presented. The bank did not open after July 21, by reason of which the eheck was not paid. Judgment for defendants.

Marshald, J. - The settled law applicable to the facts of the ease is that, if a person receives a cheek on a bank, he must present it for payment within a reasonable time, in order to preserve his right of recourse on the drawer in case of non-payment hy the drawee; ${ }^{9}$ and that, when such person resides and receives the check at the same place where such bank is located, a reasonable time for such presentation reaches, at the latest. only to the close of banking hours on the sucreerling day, oxeluding Sundays and holidays. (Tiedeman, Com. Paper, $\S 443$ : 2 Daniel, Neg. Inst., $\S \S 1590,1591$, and cases cited: Lloyd v. Osborne, 92 W'is. .93.) Plaintiff failed to comply with the law in this respect; hence defendants were discharged from all liability to answer for the default of the bank. Such was the decision of thr trial court, and it must be affirmed.

By the Court. - Julgment affirmed.'

9 It was held in Lewis, Mublurd of Co. v. Hontgomery sumply Co., 59 Va. 75 , that failure to present a check dors not har recovery from the drawer, if the time intervening between ildivery thereof and the failure of the bank, is not sufficient for presintment by the expreise of such diligence as the law requires, citing Co.r $\therefore$. Buone. 8 II. Va. 500.- ('.

'But delay whieh oceasions no loss to the drawer will not discharge the Arawer; in this respect a check differs materially from a bill of exchange. syracuse, etc., R. R. v. Collins, 57 N. Y. Gill: Woodin v. Frazer, 38 N. Y. Super. Ct. 190; Cogsurll v. Siavings Bank, 59 N. 11. 43; Bull r. Bank, 123

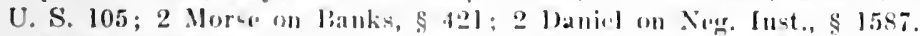

A banker's draft. that is a cherek or alraft by one hank upom another, nead not be presented with the same promptiturle as the choek of an indivilual: it is intended to circulate for a limited perind. Bull v. Bank, 123 U. S. 105;

2 Daniel, $\$ 15$ 15iat.

The rule of dilienese as to notier of dishomer and the rules as fo excuses for delay, ete.. are the a ame as in thr case of hills and notre. 2 Danirl, sg 15961698; 2 Morse. \& 428.

An indorser of a check is elltitlad to due presentment and notice, and the 
46 Miscellaveuvi ( $N$. Y. Sur. ('T., Ar'. T.) $603 .-1905$.

Jubimist for plaintitl and defentants appeal.

OGommas, J. - The defendants made a eheek to one Goldbergr under date of september 2 l. On the following day the payee represented to the defendants that he had lost this check, whereupon payment thereof was stopped at the lank, and five or six days later he received from the defenlants another check for the same amount, which was duly ashed. A day or two alter September 12th, the original check of September "2l with a " 1 " inserted before the " 2 ," making the date september "12," was indorsed over to the plaintiff by Coldher. and alshed. 'l'he plinintill now sues the drawers, and the defense is a general denial and forgery. 'That the date of this check has been altered by cioldberg, or at his instance, is too clear for dispute. Such an alteration is material, constitutes forgery, and destroys the validity of the check, except as provided by section 205 of the Negotiable Instruments Law (Laws 1897 , p. 745, c. 612), which declares that, "when an instrument has been materially altered and is in the hands of a holder in due course, not a party to the alteration, he may enforce paynent thereof according to its original tenor." If it be assumed, therefore, as the court below has found, that the plaintiff is an innocent holder for value in due course, he may assert such rights as are conferred by the check as it was before the alteration. Wo then have a case where a check dated September $2 d$ is cashed by the plaintiff and presented for payment more than 10 days thereafter. As all the parties resided, and the bank was situated in the rity of Now York, the delay in the presentment of the check was unreasonahle, and was sufficient to discharge the defendants as drawers from liability thereon to the extent of the loss, if any, incurred by them in consequence of the delay. But the only way in which a drawer of a cheek can be exposed to injury by such delay is where the bank becomes insolvent subsequent to the delivery of the check and prior to its presentment. Faton \& Gilbert on Commercial Paper, 6.30, and cases cited; Andrus v. Bradley (C. (.) 102 Fed. 51, affirmed 107 Fed. 196. The loss suffered by the defenlants must he attributed not to delay in the presentment of the check, but to their imprudent reliance on the false and fraululent representations of the payee. Bofore giving the new check,

question as to whether he is injured by the delay sems immaterial. Murray v. Judah, 6 (ow. (N. Y.) 494; Johavk Bank v. Broderick, 10 Wend. (N. Y.) 304 ; Kirkpatrick v. P'uryear, 93 'l'enn. 409; 2 Morse on Banks, \$ 422. The same rules of diligence apply as in the case of the llawer. Gifford v. Hardell, 88 Wis. 538; Smith v. Janes. 20 Wend. (N. Y.) 192; Carroll v. Sweet, 128 N. Y. 19. - H. [See cases, post, pages 734-743. - C.] 
the defendants might have insisted upon full indemnity from Goldberg, and thus escaped the loss of which they now complain. By their conduct, Goldberg found it possibie to perpetrate a fraud, and the consequences of their misplaced confidence in him should be borne by them, and not visited upon the plaintiff, an innocent party to the transaction. Upon the facts, the plaintiff was entitled to judgment.

Judgment affirmed, with costs.

All eoncur.

GREGG $v$. BEANE.

69 Vermont, 22. - 1895.

Grineral assumpsit by the firm of Gregg \& Co., against J. H. Beane. Defendant pleaded the general issue, payment, and notice of special matter. There was a trial by the court. Plaintiffs had judgment, and defendant excepts.

Munson, J. - The plaintiffs claim to recover the amount of a check drawn in their favor by the defendant on S. M. Dorr's Sons, private bankers at Bristol, Vt., and mailed them in payment of an indebtedness. The check was received by the plaintiffs at their place of business in Trumansburg, N. Y., on the 9th of August, and was forwarded on the same day to the First National Bank of Ithaca, N. Y., for collection. On the 10th of August the bank at Ithaca mailed the eheck for collection to its reserve agent, the Fourth National Bank of New York city. This bank received it on the 11th of August, and on the 12th mailed it for collection to the Merchants' National Bank of Burlington, one of the banks through which it made its collections in Fermont. The 13th was Sunday. The Burlington bank received the check on the morning of the $1 . \mathrm{th}$, at an hour which did not permit of its being sent to Bristol hy the morning mail of that day. 'The hanking house of S. M. Dorr's Sons closed its doors on the 1.th, at 10 o'clork in the forenoon.

It is found that 21 hours is required for the transmiscion of mail hetween 'I'rumanshurg and Bristol; and, in the alsence of any statement as to the hours of foparture and arrival, it must he assumed from this soneral finding that a letter mailed in 'Trumansburg to a correspondent in Bristol would be receives on the following day. 'There is no special finding in regarel to mails from Ithaen, hut it is evident from its location and commertions that it is within the facts found in regarel to 'Trumanshure. It appears then that, if the Ithaca hank had mailed the rheck directly to some one in Bristol, it would have been received on the 11th, and would have bron presented by the 12th, and paid. No claim inconsistent with this view is made in argument. 
It is found that, in collecting a check in the usual way, the puyee deposits it in a local bank, and that the local bank sends it to its reserve bank in Boston, New York, Albany, or 'Jroy, and that the reselve bank sends it to its correspondent bank nearest the bank on which the check is drawn, ame that the correspondent bank sends it to the drawee. It is fombl, howerer, that in some cases a reserve bank receiving a check for collection sends it directly to the bank on which it is drawn; but it is also found that, if this course had been pursued in the present instance, the check would not have reached Bristol in due course of mail until alter the suspension. It is further found that, in collecting this check, the plaintiffs pursued the usual and ordinary comse, and that there was not in that course any unusual or umecessary delay.

The plaintifl's claim that the finding of the court below that this check was forwarded for collection in the usual way is conclusive upon the question of diligence. But this eannot be so, unless it be considered that any change of method which grows into a settled practice of itself works a modification of the law. It can hardly be clained that custom is so exclusively the test of diligence that the adoption of a particular practice by any class of business men leaves nothing for the determination of the court. When the custom of one period has resulted in the adoption of a definite legal rule, the development of a new custom will not eflect a modification of the rule in advance of judicial sanction. ${ }^{2}$ 'The rase shows the manner in which this rleck was forwarded for presentment, and, when the facts are found, due diligence is a question of law.

The rule, in its most general statement, requires the payee of a check to present it for payment with reasonable diligence. But the law goes further than this creneral statement, and determines what reasonable diligence is under ordinary circumstances. When the ease presents only the simple facts of time, location, and stated means of communication, the ruestion of liability is to be retermined by an application of the more definite rule. It is only when the case presents special circumstances which are claimed to warmut further delay that the court is left without other guidance than the general requirement. This ease discloses nothing in the nature of an excuse for delay.

It is well settled that a check must be presented to the bank on which it is drawn if the lank be in the same place with the holder, or forwarded by mail if the bank be in another plare, by the next serular day after it is loreived, and that the depositing of the check in a lonal hank for rollection does not give the holier the benefit of an additional day. Sio this check was forwarded neither earlier nor

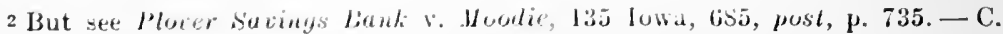


later than the law required; and the controversy is confined to the question whether it was forwarded in the proper manmer.

As presented by the findings, the question is whether the local bank was justified in forwarding the check through its New York correspondent. The defendant sustained no harm from the course taken by the New York bank in sending it to Burlington. It is said in Daniel on Negotiahle Instruments ( $\$ 1592$ ) that, when the paree receives a cherk from the drawer in a place distant from the place where the bank on which it is drawn is located, it will be sufficient if he forward it by post to some person in the latter place on the next secular day after it is received, and if the person to whom it is thus forwarded present it for payment on the day after it has reached him by due course of mail. If this be accepted as a correct statement of the rule, it would seem not to permit the collection through a correspondent so remote as to delay the presentnient a day beyond the time so allowed. It is true that the rule is sometimes stated to be that the check should be forwarded for presentation on the day after it is received, and that the agent to whom it is forwarded must in like manner present it, or forward it, on the day after he receires it. This phrascology might seem to contemplate the collection of a clieck hy means of several agents. But statements regarding the forwarding of a check by successive holders will ordinarily be found to refer to checks drawn for the purpose of being put in eirculation, or to questions arising between indorser and indorsee where a check given in payment has heen diverted from its proper use. Statements applicable to snch eases must not he taken to indicate that the requirement of diligence, as between payee and drawer, will be satisfied hy a regular transmission upon successive lays, if an improper number of agents be employerl.

The rule is ordinarily stated to be that the payee or the local bank receiving it for collection must forwarl it directly to the place of payment. It is said in Byles on Bills that the bank receiving it for rollection cannot postpone the time of presentment by circulating it through agents or liranches of the bank. In Moule v. Brown (4 IBing. N. C. 266), the right of a hancl office of the plaintiff bank to send throngh the home office, in accordance with the custom of the hank, was considered and denied.

We do not find that any modifieation of the rule as before stated

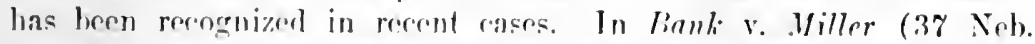
$500),{ }^{3}$ the ruestion was as to the liability of the payee on his indorsement to the hank. The eloerk was dejosited on Saturday, the 31st day of May, and was drawn on a hank Joeated at Courtland, 2y miles distant from the hank of deposit, and aceessible by two daily mails.

* Afirmed on rehearing, 43 Neb. 791. - H. 
On receiving the cheek, the Bank of Mymore mailed it to a bank in St. Joseph, Mo., for collection, and this bank mailed it to a bank in Omaha for collection, and the latter bank mailed it to the bank on which it was drawn. The court said the evidence did not show that this method of presentment was in accordance with any custom of bankers, but said, further, that, if such a custom harl been shown, it wonld not have relieved the hank from liability. Without undertaking to lay down any general rule, the court said that, in this case, 'Tueslay, Jime 3 , would have been a reasonable time within which to make presentment. 'This was in accordance with the rule as stated by Danie!.

In Gifford v. IIardell ( 88 Wis. 538), a check indorsed by the defendant was delirered to the plaintiff's agent at Dousman on July 1ith, and was at once mailed to the plaintiff at New Richmond, who received it on the $18 \mathrm{th}$, and at once delivered it to a loeal bank for collection. This bank had no correspondent in Milwaukee, and immediately mailed the cheek to its correspondent in Chicago. From Chicago it was forwarded to Milwankee, and presented on the 21st. If the eheck had been sent directly to Milwaukee from New Richmond, it would have arrived in time for presentation on the 20th, and would have been paid. The trial court held that sending the check for collection by way of Chicago was not reasonably diligent, and directed a verdict for defendant. On appeal the judgment was sustained, the court saying that, when the defendant delivered the check at Dousman, he had a right to expect that the plaintiff or his agent would present it for payment within a reasonable time, instead of which it was sent to New Richmond, several hundred miles northwest of Milwaukee, and then sent hack through Milwaukee to Chicago, and from there returned to Milwaukee. 'The court then stated how a check should be forwarded and presented in such eases, its rule corresponding to that given by Daniel. The rule is similarly stated in Holmes r. Roe (62 Mich. 199).

In First National Bank of Grafton v. Buchhannon Bank (80 Md. $475)$, the plaintiff hank, located at Grafton, W. Va., received on the 12th of January, in payment of a balance due it, a eheck on J. J. Nicholson \& Sons, of Baltimore, and on the same day forwarded it for collection to its correspondent bank in Philadelphia. The Philadelphia bank received it on the $13 \mathrm{th}$, and at once mailed it to its correspondent bank in Paltimore. This bank received it on the 14th, and presented it to the drawee on the same day. The court sustained this presentment. on the ground that the Grafton bank, having sent out the rheck one day sonner than was necessary, had it in Baltimore for presentment on the day required, notwithstanding its transmission through Philadrolnhia.

We think that if this rute of enmmercial law, stated in the various text-books, and affirmed by these recent cases, is to be modified in 
derogation of the rights of drawers of checks, it should be done by legislative enactment.

Judgment reversed, and judgment for defendant."

\section{322 WEST BRANCH STATE BANK $v$. HAINES.}

135 IowA, $313 .-1907$.

Acrion at law to recover upon a promissory note. Judgment for defendant, and plaintiff appeals.

Weavel, C. J. The making and delivery of the note sued upon is admitted by the defendant, but he denies the plaintiff's right to recover thereon on the following grounds: He alleges that said note, with $\$ 200$ in eash, was delivered by him to the plaintiff in payment or exchange for a draft or check drawn by the plaintiff on Gilman, Son \& Co., of New York city, under the following eircumstances: Defendant had entered into a contract for the purehase of land in the vicinity of Ortonville, Minn., and to avoid a forfeiture of such contract he was required to be ready to pay the sum of $\$ 2,600$ thereon upon the 8th day of Octoher, 1902, or as soon thereafter as the seller was able to present an abstract showing good title to the land. On the near approach of said date there was a prospect that the seller would be delayed for a time in making the proper showing of title, and defendant, as lie alleges, was advised by the plaintiff bank and its officers that it was better, for the protection of his own interests, that he avoid any appearance of default on his part and have the amount of the agreed payment forwarded to Ortonville, realy to be delivered to the seller on the day'named or as soon thereafter as the abstract of title should be perfected. To that end he says the said bank on October 7, 1902, issued to him a check or draft on Gilman, Son \& Co., of New York eity, for the sum of $\$ 2,600$, in consideration of which he then and there pais said bank $\$ 200$ in money and executed the note now in suit. Said draft or cherk, it is claimed, was issued by the bank with the express knowledge and understanding

- Laws of Vt., 1896, No. 38: "In order to lold the maker. indorser, guarantor. or surety of any elicek or draft deposited with or forwarded to any individual or hank for enllertion, or owned by any individual or hank, it shall be suffieient for said individnal or bank fo forwitel the same in the menal eommercial way now ill use, according to the regular course of husiness, and the a ame shall be ensidered dur diligener in the eollection of such eherk or draft." - H.

s There is some suthority for the proposition that the usual or eustomary

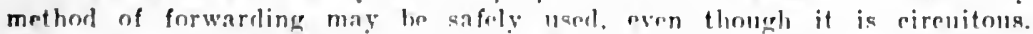
Wallare v. Agry. 4 Wasnn (T. S.) 33r: 5 Th. 118: Smith v. Jalles, 20 Wend. (N. Y.) 1!3: Tavlar v. Sip. 30 N. 1. I. 28.4. 291. - II. ISee Ilover Sav. Bk. v. Moodic, 135 Iowa, 685, post, p. 735.-C.1 
that its presentation for payment wals likely to be delayed a few days

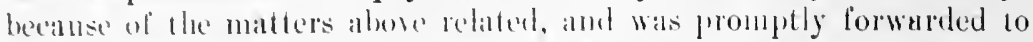
Ortomrille, where it was received on Oetober 9, 190:. Seven days thereafter, and hefore the sale and transter of the land had been perfected. and before any presentation of said eherk or demand made for its payment, (iilman, son \& C'o., being insolvent, made an assignment in bankruptey. It is further alleged that, when the insolveney and hankruptey of said drawee was discovered, said eleck was presented to the plaintill bank for payment, and payment thereof was refused, thus causing an entire failure of the consideration of the note in suit. It is further alleged that at and prior to the issuance of said eheck or draft the plaintitf bank knew that Gilınan, Son \& Co., were insolvent and liable to suspend payment at any time, but fraudulently concealed such fact and information from the defendant." The court having refused to set aside the verdict of the jury in defendant's favor, a reversal of the julgment is songht in this court upon grounds hereinafter considered.

According to the general tenor of the testimony a draft purchased and forwarded from West Branch to Ortonville, Minn., on October ith, and forwarded thenee without intermediate negotiation to New York, would ordinarily be presented to the drawee somewhere from Oetoher 12th to Oetober 1.th. Taking the average of these dates, a delay of about three days har oceurred when the correspondent elosed its doors. Now, while it is true that the court may sometimes determine the reasonableness or unreasonableness of delay in presentment of a negotiable instrument as a matter of law, the question is ordinarily one of fact. As between the drawer and payee in this ease, the question whether the delay was reasonable depends upon rirmmstances diselosed in evidence. If the bank knew that appellee desired to send the draft to Ortonville. to be there held for a few days for the completion of the land purehasc, and issued the paper to him for that purpose, then appellant ean claim no advantage from the fact that it was not forwarled to New York for payment on the same or following day, provided, of rourse, that such delay was reasonably neressary for the accomplishment of the known purpose for which it was obtained. Obviously this is a question for the jury to consider and pass upon, in riew of all the proved facts and the ordinary course and methorls of business. Bank drafts or bills of exchange differ from ordinary lank checks, in that the latter usually contemplate practically immerliate presentation for payment. This is especially true when the check is dlawn upon a bank in the town or eity where both drawer and payee reside. On the other hand, a bank draft, bill, or check upon a distant bank, user as a means of transmission of

- For the court's holding on thia proposition, see the extract from this case printed in note 8 , ante, p. 522 . - C. 
funds between different sections of the country, is more usually than otherwise negotiated, and passes through rarious hands, and serves the purpose of perhaps nany persons before final presentment. For instance, a resident of Iowa may send a New York draft to a creditor in San Francisco, and the latter may indorse it to his own creditor in Chicago, and the latter in turn indorse it to his creditor in New York, who indorses it to his local bank, which presents it to the drawe for payment. Sent directly from the place of its issuance, such draft would have been presenter within from two to four days of its date; but by the circuitous ronte we have described its transmission requires ten days or more. Yct no one, we think, would contend for the proposition that a delay in presentment thus occasioned would work a discharge of the drawer. Of course, if any person to whom the bill is indorsed fails to promptly negotiate and pass it along on its cource to final presentation, and loss follows, he alone must hear it, unless the delay has been oceasioned with the express or implied consent of the drawer. If a person, being about to set out upon an extended visit to a distant state, and wishing to carry his funds in bank drafts to be negotiated from time to time as he may need the money, applics to his banker, who issues the desired paper, knowing the purpose for and the manner in which it is to be used, we think it unquestionable that the risk of loss by the insolveney of the drawee is not shifted from the drawer to the payee simply because the latter does not put the bills in immediate course of collcetion.

So in the ease before us it is claimed by the appellee, and there is evidence tending to uphold his contention, that the appellant issued the draft to be sent by the former to Ortonville, knowing it was expected or liable to he there held temporarily for the completion of the transfer of the land which he was purchasing. The delay was not so great that we ean say it was manifestly beyond the contemplation of the parties. Such being our view of the merits of the case, we have to say that the appellant's motions for a directed verdict were eorrectly overruled, and the eause was properly submitted to the jury. As hearing upon the rase presenterl, see Story on Bills, $\$ \S 179-473$; 1 Daniel, Neg. Insts. (5th Eil.) 46(6-16!) : Wanicl, Neg. Insts. (5th Fil.) 159\%a : I/nntelius v. Charles, if Hll. 305.

Most of the anthorities citer to us hy the appellant have direct reference to the measures which the paye of a bill must take in order to eharge an indorser - rulus which are mot always opually applicahle to the drawer. Other authorities called to our attention are not inconsigtent with the conchusion rearherl by us. We do not attempt to determine the weight or preponderaner of the evidenee. "That was the provine of the jury alone. The fubling was adverse to the plaintiff, and we are not at liherty to set it asile.

The judgment of the District C'ourt is affirmed. 


\section{(b) Effect of delay upon indorser's liability.}

$\S 322$ S'TAR'T $v$. TUPPER.

81 Vermont, 19. - 1908.

JUDGMENT for plaintiff and defendant appeals.

Mussox, J. On the :2nd of August, 1906, the defendant, the payee of the check in suit, delivered it to the plaintiff, duly indorsed, in payment of a pre-existing indehtedness of less amount and received the difference in cash. 'The check was dated August twentieth, and was drawn on a bank in Melrose, Mass. 'The plaintiff held it six days before forwarding it for collection. It was presented and protested for want of funds September fourth. August twenty-fourth was the last day on which payment would have been made. The case states that the defendant is sued as indorser.

Most of the facts, including those above recited, were shown by an agreed statement. 'The evidence before the jury was with reference to what "the usual commercial way now in use" required of the bank through which the eheck was forwarded, and when the check would have been presented for payment if it had been received by the collecting bank on the twenty-third of August, and been forwarded in the way required. Several exceptions were taken to the admission and rejection of testimony. The defendant rested without offering evidence and moved for a verdict, and his motion was overruled on the ground that the defendant was not damaged by the plaintiff's neglect, inasmuch as the check would not have been paid if forwarded in due course. The plaintift then moved for a verdict on the ground indicated, and a verdict was ordered accordingly, to which the defendant excepted.

It is not necessary to consider the exceptions relating to the evidence. The agreed statement shows a failure to forward in due course, and this is decisive of the case presented. The considerations on which the holder of a check drawn without funds is permitted to excuse his neglect as against the drawer, are not applicable to an indorser. The drawer is presumed to know the insufficiency of the fund, while the indorser is entitled to rely on its sufficiency. The drawer is the one primarily liable, and prompt presentment and notice of nonpayment may enable the indorser to secure himself. The indorser's liability is impliedly conditioned on this being lone, and a failure therein will discharge him, even thougl presentment in due course would have been unavailing. In default of presentment and notice, an indorser can be charged only by affirmative proof that he knew when he passed the eheck that there were or wonld he no funds in the bank to meet it. Daniel Neg. Inst. 1587, 1596, 1646; Humphries 
v. Bicknell, Litt. 297; Carroll v. Sweet, 128 N. Y. 19; see Nash v. Harrington, 2 Aik. 9.7

Judgment reversed and cause remanded. ${ }^{8}$

135 Iows, 685. - 190\%.

WFarfr, J. On March \&. 1903, one C. F. Scholer, who was a de. positor in the Greenville Bank, doing a banking business at Greenville, Clay county, Iowa, made and delivered to one Claude Heathman his check on said bank pavable to the order of said Heathman for the sum of $\$ 50$ : and thereafter on March 12, 1903, said Scholer made and delivered to said Heathman another siimlar check on the same bank for the further sum of $\$ 50$. On or about the last-mentioned date Heathman indorsed and delivered both checks to the appellant. On Friday, March 13, 1903, near the close of business

I "The dispute in this ease is between the indorsec and the indorsers of a check. The following rules of the law merchant fixing the rights, duties, and liabilities of inlorsee and indorser each to the other... are well settled: The undertaking of the indorser of a check is that if not paid on presentation within a reasonable time, he will pay it. provided he is properly notified. Sucls reasonable time for precentation and demand for payment is admitted to br within the day following the indorsement. The indorsee, as between himself and thr indorser, undertakes to demand payment within the day following the indorsement, and, if payment is not made, to give due notice of dishonor. This is his sole duty. and he does anything else at his peril. 2 Danirl on Negotiable Instruments (5th Ed.), \& 1601: People ex rel. Poit Chester Savings Bank r. Cromirell, $102 \mathrm{~N}$. Y. 47. The fact that there are no funds in the account against which the chrck is drawn does not relieve the holder from presentation and notice of dishonor to the indorer, unless it appears that the indorser knew it. 2 Danirl on Negotiable Instruments (5th Fil.), \& I596; I Morse on Banks and Banking (4th Ed.). \$ 262, subd. 8. Nor are the righte of the indorese changed hecau-e he suffered no apparent damage hy reason of faihure to demand payment and give notice of dishonor to him within the reguired time. Mohark Bank v. Broderick, 13 Went. (N. Y.) 133: Tiedeman on ('ommereial Paper, \$ 442: Gough v. Stants. 13 Wend. (N. Y.) 54 ; First Vat. Bank of Wymore v. Miller, 37 Nob. 5nn." MeAlvay, C. J., in First Nat. Bank of Detroit v. Currie, 147 Mich. 72, 77. - C

A This case is reported in 15 L. X. S. 213. with the following note: "The ereneral rule that the failure to preant a check for payment within a reason. able tine releases the indoraer from liability thereon, even though presentment in due time would hase heen unavaling and be was not preindied by the failure to present in dur time. is diarusared in a note to the ease of Kirkpatrick v. Puryerar, 22 H. R. A. 78.5193 Tenn. 4091. The only case. besides the Start case, hearing on the prerixe question, dericled sinee the publication of the note just mentioned, is that of Trneress. $T$. M. Sinelair of Co., 122 IIl. App. 203. in which the anme rule ia approverl. Ser alon 2 Morse, Banks and Banking, 4th ed. ธุ 422: 2 Dan. Neg. Inst., 5th ed. § 1596." - C. 
hours, the appellant indorsed and delivered the cheeks to the appellee bink which was doing husiness at l'luser, in Pocalontas county,

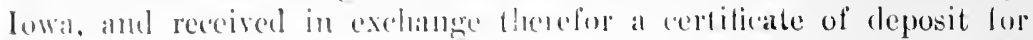
$\$ 100$ which was afferwarl paid. While the towns of Plover and Gremville are hut lim miles and they are on dillerent lines of rail-

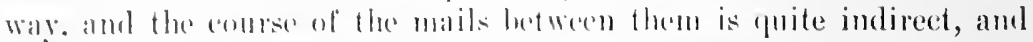
had the appelleo forwalded the ehecks by letter to the Greenville Bank on siaturay thry would probahly not have renched their destination until after hanking loms m Montay, March 16th. Instead of sending them direst to (imenville, the appellec, following its enstomary methon in such matters, sent the checks to its correspondent, the Ios Moines Savines bank at loes Moines. Iowa, by the first mail in that direction on Satumlay, Mareh 14th. On Monday, Mareh 16th, the Des Moines savings bank forwarled the cheeks to their correspomlent the ('jtizens' State Bank at Spencer, Clay county, Lowa, where they were recoivel on March 1\%th. On the same day the Citizens' State Bank tumer the rlecks over to the Citizens' National Bank of Sipencer, which was the local correspondent of the Greenville Bank. On the following lay, March 18th, the Citizens' National Bank forwarded them rlirect to the Greenville Bank. The laily mail from Spencer to Greenville does not leave mitil some time in the aftermoon, and if the cheeks reached Creenville on March 18th, as they doubtless dir, it was after banking hours, and were not received by the hank until the moruing of March 19th. Prior to this date, probahly alout Marely 10 th or $1 \%$ th. flye drawer harl stopped paynent on the checks claiming that they had been procured from him by framd, and acting mpon this motice the Grecnville Bani on March 19 th deelined to honor them, and raused them to be duly protested. 'Thercupon, the appellee instituted this action at law to reenver upon the appellant's indorsement of the cheeks. The appellant answered fenving liability upon sail indorsement berause of appellec's alleged negligence in presenting the checks for payment. Other defenses

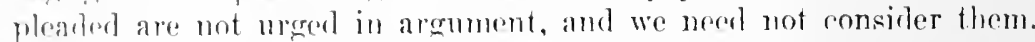
In ardition to these mattris it was also shown in evidence withont substantial dispmte, that the methoul aropted hy appollee and hy the several correfommlouts mentioned in forwarding the papere for presontation and demancl of paymont was in aceodance with the general costom frevaline amomg hanks in dealing with checks draw on nther hanks unt eloing business in the same rity or town, and castued be the reeriving bank. Tn evidenee was offered tombling to show that rither of the hanks, roroiving these reberks aftor their indorsement by appollant, failed to forwarl them on their way on the day of the rereipt or on the followiner lay, except possibly in the rase of the Des Unines Savings Bank, and the ray there intervening, if any, was sunday. At the close of the trestimony offered on the trial, the court suetained a motion to direct a verdict for the plaintiff for the amount 
of the checks with interest, and from the judgment entered on such directed verdict the defendant appeals.

The single question to be determined is whether this record presents a case in which a rerdiet for the defendant, if one had been returned, could properly be permitted to stand. C'ounsel's contention in support of the appellant's position is based upon two propositions.

1. It is said that in failing to forward the checks by the most direct route from Plover to (ireenville, and by electing to send them by a more eircuitous route through the hands of correspondent banks, appellee occasioned an unreasonable delay in the presentation of the checks to the drawee for paynent, and thereby discharged the appellant from liability as an indorser thereon. By the terms of the negotiable instrument statute a bank check, in the ordinary form, is classed as a bill of exchange payable on demand. Code Supp. 190: §3060-a185. ${ }^{9}$ By the same statute it is provicied that to charge the indorser of a bill of exchange payable on demand, presentation to the drawee and demand of payment slall be deemed sufficient if made within a reasonable time after its issue, or after the last negotiation of such bill. Code Supp. $190^{\circ}$, $\$ 3060-a 71^{1}$ It is also further provided that, in determining what is a "reasonable time" within the meaning of this act, regard must be had to the nature of the instrument, the usage of the trale or business, if any, with respect to such instruments, and the facts of the particular case. Code Supp. 1902, \$ 3060-a 193. ${ }^{2}$ Contrary to the requirement for notice to the indorser of the dishonor of a check or bill upon presentation for payment (Code Supp. 1902, §3060-a 103) ${ }^{3}$ the holder of the indorsed paper is not held to any fixed or invariable limit of time in which to make such presentment and demand. He is required to act with reasonable diligence and promptitude taking into consideration the nature of the instrument, the usages of the business world and the peculiar facts, if any, attenting the particular transaction in hand.

With this rule as our standard, we are clearly of the opinion that the record presents nothing to support a finding that the delay, if any, in presenting the checks for payment was cluargeable to negligence on part of the appellere. It was shown by the evidence without controversy - indeed, it is a matter of common knowledgethat, ly the system to which the handling of such business has heen reduced, the inmumerable cherks and libls recrived lyy the lanks soatterel all over the country flow in eronentrating currents to distributing bauks, whenee they go out to correspondent banks at or near the city or town where the drawee banks are locatel, for collection. 'T'o

- N. Y., \& 321.-C.

1 N. Y., \$ 131. - C.

2 N. Y., \& $4 .-\mathrm{C}$.

$3 \mathrm{~N}$, Y.. $\$ \$ 174-175 .-\mathrm{C}$.

NRGOT. INETHEY ENTB -47 
hold that the time hetween the jssue of a elieck upon a distant bank and its presentation for payment by this method is unreasonable, and serves to discharge the imforser, would not only tend to create disastrons confusion in this most important branch of business, but to a disregard of the statute which makes the usage in sueb business one of the stamlarls by which the reasonalbleness of the time of presentation for parment is to be determined. Again, as diselosed by the testimony, the transaction under consideration was not a simple matter of collecting checks deposited with the appellee for that purpose. 'The checks were negotiated by the appellant to the appellee who paid full ralue therefor. 'The apjellee indorsed the checks to the Des Moines Savings Bank, receiving eredit upon its deposit aceount with the latter for the full amount as for a deposit of so much cash. In other words, the checks were negotiated by the appellee to the Des Moines Savings Bank, and unler the statute already quoted (Code Supp. 1902 , $\$ 3060-a \% 1)$ reasonable time for presentation and demand is to he reckoned from the last negotiation of the paper. Checks are an almost universal substitute for money. They pass from hand to hand, hank to hank, and (ity to city, and, within reasonable limits, it may be said that no matter how long they remain ontstanding, so long as one negotiation promptly follows another and the eliecks are in fact in eirculation the statnte requires us to hold that the indorser is not legally prejuliced by the consequent delay in their presentation for payment. Indeed, while at common law it is generally held that when one receives a check parable at a distant bank reasonable diligence requires him to forward it for presentation not later than the next business day thereafter, yet it is equally well settled that this rule is not always one of imporative obligation, but is at times made to give way by reason of circumstances which sufficiently rebut any presumption or inference of negligence on part of the holder. Coal Co. v. Boxman. 69 Iowa, 152. And, among other circumstances having a bearing upon this question, the general course of husiness has always been rewognizod as important. Guelich r. Bank, 56 Iowa, 434; Freilorg v. Cody, 5. Vich. 10s; Bridgeport Bank v. Dyer, 19 Conn. 136. Thus, eren withont the statute it would be extremely doubtful whether a rerdict for the appellant upon the ground here contended for could he upheld: and with it, we think, the correctness of the ruling of the trial rourt thepon is not open to serious question.

3. Frror is assigned upon the ruling of the trial court refusing to permit the appellant to testify to his want of knowledge of the eustom of hanks with respect to the manner of transmitting checks for payment. To this exception we think it a sufficient answer that want of knowleder by one who negotiates and indorses a check, as to the usage of hanks relating to its presentation for payment, cannot prevent the application of the statute which makes such usacre a factor in 
determining whether due diligence has been shown. So, also, it may be said that the usage or custom here relied upon is not one of mere private or local character, but one of general observance in the banking business and as such will be presumed to be known by all persons dealing with such institutions. See 12 Cyc. p. 104t. Appellant knew that the checks were negotiable in character and as such were liable to pass from one indorser to another in their transmission to the bank of payment, and when he negotiated them he must be held to have done so with reference to the usual and ordinary manner in which such business is transacted, and to have consented to presentation, demand of payment being made in the manner which generally prevails among prudent, well-conducted banks. Had he negotiated them to a merchant or farmer or other individual who in turn negotiated them to the appellee bank, appellant being sued upon his indorsement would not he heard to deny knowledge of the usage of banks with respect to such business, and we camnot see that such want of knowledge would be of any more avail in a case like the present one where he indorses the paper direct to the bank. Wis contract, implied from his indorsement, was that if, upon presentation and demand within a reasonable time, the checks were dishonored, and due notice given thereof, he would make them good to his indorsec, and it can make no difference whether he did or did not understand what in law would be held a reasonable time for such presentment. Other questions argued are ruled by those already discussed, and we need not further consider them. Of course, we are not to be understood as holding that hanks are at likerty to arlopt any usage or manner of business they see fit, and escape all imputation of negligence for resulting losses to those with whom they may deal. It is reasonable to hold that checks must go forwarl for presentation with due regard to the interest of the drawers and indorsere, and if banks adopt unreasonahly cireuitous routes and mothods wherely loss results they should hear the burden, but, ordinarily, the natural caution which is engendered by self-interest will be sufficient to insure promptness and dispateh in the discharge of duties of this nature. Where, lowever, there is reasonable ground wpon which to base the charge of negligence, the case shomlal ino to the jury muler proper instructions.

In the instant ase we find nothing to support a fouding of this nature, and the jutgment of the District Court is affirmed.

\section{Supplemental opinion on rehearing.}

PЕR Cunum. In his petition for rehearing, the appellant insists that the opinion handerl down upon the original submission of this

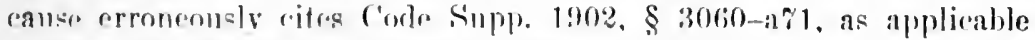
to the presentation for payment of bank checks, when in faret the rule there prescribed is intended to apply only to arafts or bills of ex- 
change ns distinguished from checks, and that the latter are governed solely by the provisions of Code Supp. 1902, $\$ 3060-a 186 . .^{4}$ The section first named provides that presentment of a bill of exchange will be sufticient if made within a reasomable time after the last negotiation thereof, white the section last named provides that a check must be presented within a reasonahle time after its issue. Whether the language of the last rited section of the statute has the effect to exclude bank checks from the eflect of the former it is not necessary for us to deride at this time, for, if we were to adopt the appellant's view in this respeed, it conk not work a reversal of the ease before us. Both sections allow a reasonable time for the presentation, and, where the check is drawn upon a lank located at a place distant from the place of its delivery to the payce or indorser, a presentment promptly mate by mail through other banks in the ordinary and usual course pursued in such business will be held as a matter of law to have been made within a reasonable time.

The petition for relsearing is therefore overruled.

\section{CARROLL $v$. SWEET.}

\section{New YoRK, 19. - 1891.}

Axdrews, J. The indorsement and transfer by the defendant to the plaintiff of the check of Woodrutf operated as provisional payment only of so much of the antecedent debt owing by the defendant to the plaintiff. There was no agreement that it should be taken in absolute satisfiaction of the debt, ancl, in the absence of such an agreement, the intendment of law is that it was conditional payment only. Hill $\therefore$. Beeve, 13 N. Y. 566 ; Bradford v. Fox, 38 N. Y. 289. The debt remained until discharged by payment of the eheck, or by such dealing with the check by the plaintiff as would, in judgment of law, convert what was originally a provisional payment into an absolute one. The check was dated August 22, 1887, and was drawn on the Asbury Park National Bank, and was on the same day indorsed and delivered by the defendant to the plaintitf at the place where the bank was located. The plaintiff, on accepting the check, assumed, as between himself and the defendant, an obligation to present the same to the bank for payment within the time prescribed by the law merchant, - that is to say, not later than the next day after its date, and, if refused, to protest the same, and give notice of non-payment. Smith v. Janes, 20 Wend. 192. It was not presented until the 31st of August, nine days after it was received by the plaintiff. The defendant was by such delay discharged from liability as indorser of

4 N. Y., § $322 .-$ C. 
the check, irrespective of any question of loss or injury. ${ }^{s}$ Presentment in due time, as fixed by the law merehart, was a condition upon performance of which the lialility of the defendant as indorser depended, and this delay was not excused although the drawer of the check had no funds, or was insolvent, or because presentment would have been unarailing as a means of procuring payment. Bank v. Broderick, 10 Wend. 30t: Gough v. staats, 13 Wend. 549. A different rule obtains as hetween the holder and drawer of a eheck. As between them presentment may be made at any time, and delay in presentment does not discharge the liability of the drawer, unless loss to him has resulted. Little $\mathbf{r}$. Bunk, 2 Hill, 425 . 'The action here is not upon the indorsement of the defendant, but upon the original indebtedness. If the discharge of the defendant's liability as indorser discharges also his liability as debtor for the original debt, the judgment must on that ground be reversed. ***

The court in this case directed a verdict for the plaintiff, and in this we think there was error. It cannot be doubted that if there was evidence tending to show that the delay in presenting the check to the Asbury Park Bank prevented its collection, or from which the jury might find that the whole or any part of the debt owing by the drawer of the check to the defendant, for which the check was given, was lost hy reason of the delay in the presentment, or by dealings between the plaintiff and the drawer, in respect to the cheek, without the assent of the defendant, the case should have been submitted to the jury. To the extent of the injury, the law would treat the omission to make dure presentment as tantamonnt to payment.

The facts most favorable to the defendant need to be stated. Woodruff, the maker of the chork, was, when the check was given, conlucting a hotel at Ashury Park, and the parties to the action were guests at his house. 'The defendant was indebted to the plaintiff for dentistry work, and the former, who resided in New York, had loaned money to Wondruff for which the eheek was given, and on the same day the defendant received the cheek he delivered it to the plaintiff on his delit. Woodruff had an account with the Aslury Park National Bank. On the day of the date of the check the lank charged to his account a demand note held by the bank against him for $\$ 500$, but, so far as appears, without any notice to Woodruff, and this rendered his bank account overdruwn. Woodruff was in embarrassed circumstances, lut was in the daily recoipt of alout $\$ 600$ from his business. He used part of the recripts for current expenses, withont depesiting them. and between the 22d and 31st of August he deposited about $\$ 900$ in the bank to the eredit of his account, and the inference is that it was applied in part to pay the $\$ 500$ note, and is

S. See Achi v. Bank of Franserille. 12.4 Wia. 73. at page 78, and extract fron First Nat. Bank v. Currie, 147 Mich. 72, in note 7, ante, p. 735. - C. 
part to pay current checks drawn ly Woodrutr. On the 22d of August, the day on which Woodrufl"s eheck to the defendant is dated, and after it hat been indorsed to the plaintifl hy the defendant, Woodruff, who hat been informed of the transfer, recuested the plantiti to accommodate him by holding the check a few days, stating as a reason that he was pressed in the payment of his alcounts, to which request the plaintill assented. He asked the plaintifl to lot him know when he wished to use the elleck, as he would then provide for it. Woodruff testified that he had money in his office sulficient to pay the elheck, and would have paid it at any moment, had payment been insisted upon; that he was in the rereipt of abont $\$ 600$ a day, and that he redeemed a number of other ehecks which went to protest at this time: that, two or three dars after the conversation of the $22 \mathrm{~d}$ of August, he spoke to the plaintitl again, and the plaintiff informed him that he had sent the check west. Woodruff said to him that he rearetted it very much, as he wished to make provision for the eheck. 'The cashier of the bank testified that there were no funds to meet the cheek, and that it would not have been paid if it had been presented any time after the 2:d of August. On August 31st, Woodruff, who was behind in his rent, was dispossessed from the hotel premises, and his business was elosed, and he then was and now is insolvent. It may be concerled that the only obligation upon the plaintiff, as between him and the defendant, was to present the cheek at the bank for payment witlin the time prescribed hy law, and, if payment was refused, to have the same protested, and notice of non-payment given to the defendant. If he had performed this duty, the defendant would have been apprised of the defanlt: and he would have had an opportunity to take such measures as he could to secure payment from Wondruff. One of the oljerts of requiring prompt notice to be given to indorsers and other parties secondarily liable on commercial paper, in rase of default, is that they may have an opportunity to secure themselves. Cherks are sunposed to be drawn arainst funds of the drawer, and prima farie, where it is shown that the drawer's account was not gond, the inferener of injury from non-presentment would he robutterl. Pult where as in this case, it is slown that the maker of the rhreck was solicitous that it should he paid: that he had the uneans of parment at command, and wonld hase provided for or waid the rbore if payment had been insisted upon: that the holder was apprised of the farts, and, for the arcommorlation of the makes, refrained from presenting the check, and presentation was delayed until open insolvency of the maker occurred, and he became, by the change of circumstances. mahle to provide for the check, - it cannot he said, we think, that there was no legal evidence of injury to he submitted to the jury. The plaintiff, instear of taking the usual

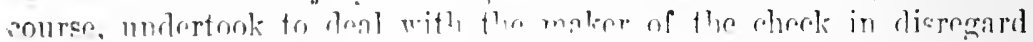
of his primary obligation to the defendant. It was for the jury to 
pass upon the circumstances, and to find whether the conduct of the plaintiff imposed a pecuniary injury upon the defendant. To the extent of such injury the law adjugges that the debt of the plaintiff has been paid. 'The judgment below should be reversed, and a new trial granted, with costs to abide the erent. All concur. ${ }^{\circ}$

\section{Certification of Check.}

\section{(a) Effect upon Drawer's Liability.}

$\S 324$

- MINO'T $v$. RUSS.

HEAD $v$. HORNBLOWER.

156 Massachesetts, 458. - 1892.

F1ELD, C. J. - The first case is an appeal from a judgment rendered by the Superior Court for the defendant, on his demurrer to the declaration. The defendant, on October :!), 1891, drew a check on the Maverick National Bank, payable to the order of the plaintiff, and, being informed by the plaintiff that the check must be certified by the bank before it would be receiver, the defendant on the same day presented the check to the bank for certification, and the bank certified it by writing on the face of the check the following: "Maverick National Bank. lay only through Clearing-House. J. W. Work, Cashier. A. C. J., Paying 'l'eller." After it was certified, the check was, on Saturday, Oct. 31, 1891, delivered by defendant to the plaintiffs, for a valuable consideration. 'T'he declaration alleges that the bank stopped payment on Monday morning, November 2, 1891, "before the commencement of business hours on that day," and that on that day payment was duly demanded of the bank, and notice of non-payment was duly given to the defendant.

The second case is an apumal from a julgment rendered for the defendants by the Superior ('ourt, on an algrend statement of farts. On Saturday, Oetober 31,1 s!l, the defemlants llew their check on the Maverick National Bank, pavable to the omler of the phantifs, and delivered it to then in payment of stordis bought by the defendants of the plaintiffs. The cherek was reerived too late to he deposited by the plaintiffs for colleretion in season to ber carriel to the clearing-lionse on that lay, but during hanking hours on that day the plaintiffs presented the chece to the Marerick National Bank

- See Manitoba Mortgage and Inrestment Company, Limitrd v. Wriss, 18 S. Dak. 459, reported in 5 A. \& F. Inn. ('as. 868, will mote entitlinl, "Dis. charge of debtor by creditor's negligence in presenting elueck of third person for payment." - C. 
for certification, and the bank rertified it by writing or stamping on its fale the following: "Maseriek National Bank. ('ertitied. Pay only through Clearing-House. C. C. Dometl, A. Cashier. Paying 'Teller."

At that time the defendants had on deposit sufficient funds to pay the check, and the bank on tertifieation charged to the defendants' aceount the amount of the check, and eredited it to a ledger account ealled rertified checks, in areordance with their uniform custom. After certitication, the plaintitls, on the same day, deposited the cheek in the Hamilton National Bank for collection. It is agreed that if the eheck had been presented for payment on Saturday, in banking hour's, it would have been paid: but the Maverick National Bank transacted no business after Saturday, and on Sunday the Comptroller of the Currency placed a national bank examiner in charge, and the bank was put into the hands of a receiver. 'The elearinghouse on November 2 refused to receive ehecks on the Maverick National Bank, and the eheck was on that day duly presented for payment, and due notice of non-payment was given to the defendants.

Each of the checks was in the ordinary form of check on a bank, and was payable on demand, and no presentment for acceptance or certification was necessary. In a sense, undoubtedly, a check is a species of bill of exchange, and in a sense also it is a distinct commercial instrument; but aecording to the general understanding of merchants, and according to our statutes, these instruments were checks, and not hills of exchange. "A check is an order to pay the holder a sum of money at the bank, on presentment of the check and demand of the money; no previous notice is necessary, no acceptance is required or expected, it has no days of grace. It is parable on presentment and not before." (Builard v. Randall, 1 (iray, 605, 606.) The duty of the bank was to pay these checks when they were presented for payment, if the drawers had sufficient funds on deposit. The bank owed no duty to the drawers to certify the checks, although it could certify them if it saw fit, at the request of either the drawers or the holders, and if it certified them it became bound directly to the holders, or to the persons who should herome the holders. In either case, the bank would charge to the aceount of the drawer the amount of the check, beeause by certifieation it had hecome absolutely liable to pay the cheek when presented. When a rheck payable to another person than the drawer is presented by the drawer to the bank for certification, the bank knows that it has not been negotiated, and that it is not presented for payment, but that the drawer wishes the obligation of the bank to pay it to the holder when it is negotiated, in addition to his own oblication. Put when the payee or holder of a rbeck presents it for certification, the bank know that this is done for the envenience or security of the holder. The holder could demand payment if he 
chose, and it is only because, instead of payment, the holder desires certitication, that the lank certifies the check instead of paying it. In one case the bank certifies the check for the use or convenience of the drawer, and in the other for the use or convenience of the holder. In the present cases the checks were seasonably presented to the bank for payment, and on the facts stated the defendants would be liable unless the certification discharged them from liability.

It is argued that the certification of a check, whereby the bank becomes absolutely liahle to pay it at any time on demand, discharges the drawer, because it is said that the check then becomes in effect a certificate of deposit: and it is also argued that the certification is in effect only an acceptance of a bill of exchange, and that if payment is duly demanded of the bank and refused, and notice of nonpayment duly given, the drawer is held. So far as the question lias been considered, it has been decided that the certification of a bank check is not, in all respects, like the making of a certificate of deposit, or the acceptance of a bill of exchange, but that it is a thing sui generis, and that the effect of it depends upon the person who, in his own behalf, or for his own benefit, induces the bank to certify the eheck. The weight of anthority is, that if the drawer in his own behalf, or for his own benefit, gets his check certified, and then delivers it to the payee, the drawer is not discharged; but that if the payce or holder, in his own hehalf or for his own henefit, gets it certified instead of getting it paid, then the drawer is discharged. (Born v. First National Bank, 123 Ind. 78; Rounds v. Smith. $42 \mathrm{Ill}$. 245; Brou'n v. Lectio, 13 Ill. 497: Andrevrs v. German National Bank, 9 Heisk. 211: First National Bank r. Leach, 52 X. Y. 350; Boyd v. Nasmith, 17 Ont. to ; Essex County Bank v. Bank of Montreal, 7 Piss. 193; First Iational Bank r. Whitman. 94 U. S. 343, 345; Metropolitan National Bank v. Jones. 27 X. F. Rep. 533: Continental National Bank v. Cormhauser, 37 Ill. App. 475: National

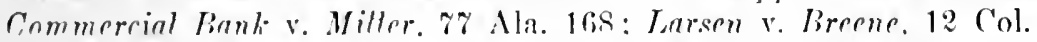
180: Mutuat Nationat Bamli v. Rolge. 28 Ta. An. 933: Morse on Banking, $\$ \$+11,415$.$) Ire are of opinion that this view of the law$ rests on sound reasons. If it he from that the existing methods of loing husiness make the nse of artifierl rhereks neeressary. the perkons

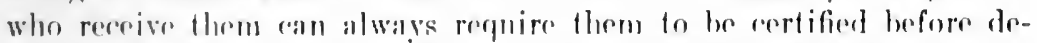
livery. If they reseive them Innerertified and then presont them to the bank for crertifieation insteal of paymont, fle certifieation should be considered as dischlarging the drawer.

It may also he said. that in the seromd ase the erertifiention amounter to an extersion of the time of payment at the replowet of the payees, without the consent of the drawers. Bufore the enrtifieation the drawers could have requested the payers to present the cherk for payment on Saturdave or could themselses haw drawn out the money and paid the check. After certification the amount 
of the check no longer stood to the credit of the irawers, and the

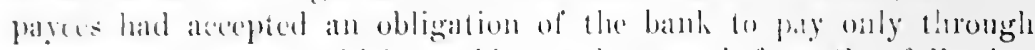
the cearing-house, which combl not happen hefore the following Momblay.

'The result is that in line lirst atse the judgment is reversed, and the demurer oremuled. and in the second case the judgment is aflirmed.

So ordered. ${ }^{7}$

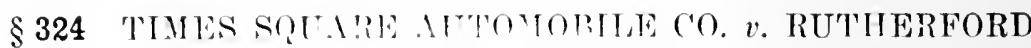 NATTONII BANK.}

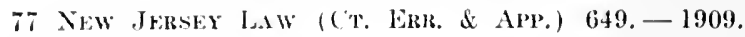

Gumare, ('. J. One P'urly, being desirous of purchasing a second-hame antomohile, employed Millarel Ashton, an auton.obile salesman, to assist him in making a proper selertion. Ashton took him to the salesrom of the 'Timus Simare Automohile Company, and, after looking ower its stork, Purly, with Asliton's approval, selected a car, the price of which was $\$(60)$, and gave his cheek on the Rutherford Natjonal Bank for the purchase price. The check was drawn to the order of Ashton, who indorsed it and delivered it to the manager of the automohile company. Immediately after receiving it, the autonobile company sent it by sperial messenger to the hanking house of the Rutherford National Bank with a request that it be certified. This repuest was complied with. Afterward, when the check was presented for payment, the bank lefused to honor it, upon the ground that it had received instructions from Purdy not to paly it. The automolife company threupun bromght suit against the bank on its contract o! centifiention. The defendant almited that it had certified the elextiand that it diil so at the reguest of the plaintiff, the holder theres, hut sought to justify its refusal to pay upon the ground that

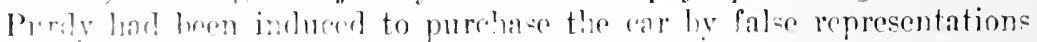
natri by the manaere of the platetiff as to it sondition and value. It was contenterl on helalf of the plaintiff that this defense was not opron to the dofombant. It was, however, armitted orer its objection. At the close of the rase plaintiff asked for a direction of a verdict in its favor. This renuest was rofused, the raso was sont to the iury, and a verdiet in favor of the defendant was rendered. The plaintiff now seeks a royersal of the judgment entered upon that verdiet, on the grouid that its request for a direction in its faror should have benn romplied with.

The effert of the certifiration of a cheek by the bank upon which

7 Ser 5 Am. \& Fne. Encye. L. (2) ed.) Pp. 1055-1056. - II, 
it is drawn depends upon whether it is done at the request of the drawer or of the holder. When a chech is presented by the drawer for certification, the bank knows that it has not yet been negotiated, and that the drawer wishes the obligation of the bank to pay it to the holder, when it is negotiated, in addition to his own obligation. A certification under such circumstances does not operate to discharge the drawer (Minot v. Russ, 156 Mass. 460, 5 Amer. \& Eng. Eney. of Law, 1056); and so long as the drawer remains undischarged, such a defense as that set up in the present case is open both to him and to the hank. But when the certification ly the bank is done at the request of the holder, the effect is radically different. The transaction, then, is virtually this: The bank says: "That check is good; we have the money of the drawer here ready to pay it: we will pay it now, if you will receive it." The holder says: "No, I will not take the money now; you may retain it for me until the check is presented for payment." The bank replies, "Very well, we will do so." First Nat. Bank of Jersey City v. Learh, 52 N. Y. 353. The result is to diseharge the rlrawer from any further liability on the check (Negotiable Instrument Act April 4, 1902, $\$ 188^{8}$ [P. L. p. 614]), and to substitute a new contract between the holder and the bank hy the terms of which the money called for by the check is transferred from the account of the drawer to the account of the holder. In contemplation of the law the obligation of the hask to the holder, when the certification is at his request, is the same as if the funds had been actually paid ont by the bank to him, by him redeposited to his own credit, and a certificute of deposit issued to him therefor. 5 Amer. \& Eng. Ency. of Law, 1055; Dan. on Neg. Inst., $\$ 1603$.

The defendant. in refusing parment of Purdy's check, apparently considered that its oldigation to the holder was no greater than if its certification had hwen made at Purdy's request. It failed to realize that its act operaterl as a payment of the check, so far as Purdy was roneerned, and trancforred the moneys which it ealled for to the arcount of the plaintitr. 'The cituation was the aame, so far as the defendant was roncerned, as if lurdy harl maid rash in the plantilf for the rar which he had purdaced. and the waintiff had then deposited the eash in the defordant's bank. Javing areepted the plaintiff's money, and issued to him a certifieate of depusit therofor, it

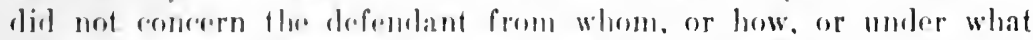

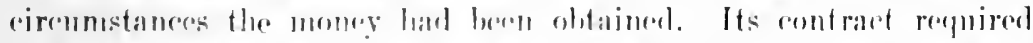
it to pay the amomit of the depmest to the plaintilf. or its order. and it rould not avoid its obligation fo do so by showing that the plaintiff had franciulently obtained the money whinh it had deposited with the defendant. 
'The defense interposed should have been overruled, and a verdiet directed for the phantill. 'T'he jublgment under review will be reversed.*

\section{(b) Effect upon indorser's liability.}

\section{\$ 324 EIRS'T NA'TONAL BANK OF DETROI'T' $v$. CURRIE,} E'I. Al.

\section{Mongax, 72. - 1907.}

Defendants were in partnership as brokers in Detroit. On Felruary i, 190:, they bought in their own name from a film of brokers in New York eity eertain bonds for Frank C. Andrews, one of their customers. In part payment of these bonds Andrews, on February 6 , gave them his ehe $k$ for $\$ 50,000$, drawn on the City Savings Bank, Detroit, payable to their order. They indorsed this check to the plaintiff bank and deposited it in the plaintiff bank to their credit. Ilaintiff sent the Andrews check to the City Savings Bank for ecrtifieation. It was returned certified, and plaintiff then wired $\$ 50,000$ to New York to the eredit of the defendants. The certified check was on February 7 presented by the plaintiff to the City Savings Bank for payment, and upon payment being refused it was protested and notice of dishonor duly given to defendants. Andrews' aecount at the C'ity Savings Bank, both when the check was eertified and when payment was demanded, was overdrawn more than $\$ 900,000$.

In an action against defondants for money had and received, a rerdict was directed for plaintiff for the amount of the eheck, with

* In Blake v. Hamilton IDime Sarings Bank Co., 79 Oh. St. 189, C. G. Blake \& C'o. drew a check on the Franklin Bank payable to the order of C. G. Blake. Blake hat the check certified by the liranklin Bank, and then indoresel the clieck to one Werbel in payment for a horse. Werbel indorsed the elieck and depreiter it in the Hamilton Dime Savings Bank Co.. and was given credit for it on the books of the hank. The Hamiltom Dime Savings Bank sent the cheek to a correspondent bank for collection, and it was protestel for non-prament for the reasers "Payment stopperd." 'The Hamilton Dime Savings Bank sued the Franklin Pank on the elierk and lilake was substituted as defendant. lilake answered that he had bern indued to purehase the horse and deliver the check by the false and fraululent representations of Werbel. In aflirming a jurlement for plaintiff the eourt held that (quoting the syllabus), "The object of certifying a check is to enslbe a holrler to use it as money. The drawer or indorser of a errtified ehere cannot, after its delivery, revoke it or stop payment upon it hy notice to the drawee not to pay, and a bank that has received a certified chrek for leposit, and has credited the depositor with the amount of it, is a bona fide holder and may enforce payment of it notwith. standing it may, before payment to the depositor, have received notice that the cherk was fraudulently ohtained by the depositor." Criticised in 22 Harv. Law Rer. 448 (April, 1903).-C. 
interest. Defendants appeal, contending that the court erred in directing such a verdict, for the following reasons:

" 1 . That the certification of the check for plaintiff at its request was equiralent to payment, and operated to release them as indorsers.

" 2 . 'That plaintiff, on presenting the check, elected to take certification, which is the obligation of the drawee bank to pay, and deferred formal presentation of the certified check for payment until the next day. Had it demanded payment instead of certification, or upon certification, as it should, the check would either have been paid or dishonored. If dishonored, the plaintiff would not have remitted [the $\$ 50,000$ to New York], and the bonds would not have been delivered, but remained in defendants' control. Whether paid or not, neither party would have lost anything. So that plaintiff's failure to demand payment at the time of certification caused the loss, and defendants cannot be held therefor."

MCAsraY, C. J. * * * The important question in the case at bar is whether certification of a check on presentation by the indorsee, though there are no funds, is equivalent to payment. As a general proposition we think it is, as to both the maker and indorser. 2 Daniel on Negotiable Instruments (5th ed.), § 1604, and cases cited. The rules of the law merchant are inflexible and arbitrary, and necessarily so. An indorser may always insist that the conditions requisite to make his undertaking enforceable shall be strictly complied with; namely, presentation for payment and notice of dishonor. As to the indorse the certifying bank is bound by estoppel where he has changed his position or parted with value on the strength of the certification. Brooklyn Trust Co. v. Toler, $65 \mathrm{Hun}$ (N. Y.), 187, 138 N. Y. 675, and cases cited.

In this ase plaintilf parted with no value before certification, but, relying upon the certification, transferred $\$ 50,000$ to New York. We find, then, that as between the plaintiff and the hank there was a new and enforceable contract reated by the rertification of the check. Ordinarily there would be no question but that such condition released the indorsers. In this case, however, it is claimed that, atthough the eheek had uot buen presented for payment, lut for certification, yet npon it as rertified payment was demanded, and the check was protested, and notice duly given within the time which the same would have been griven had the eheek been presented for payment instead of cortification, and because defendant indorsers have suffered no loss by reason of ereftification, and are in no different position than if surch payment had been demanded, therefore they are not released as indorsers. The elaim that un loss has oreurred to defendants, which we think is not supported hy the farts in the rase, can be eliminated, for the reason that the liability of the indorser is not predicaterd upon his loses. Sere rases ciferd, suprn. The ease relied upon by plaintiff to sustain its contention, and also by the 
cont in directing the rerdict, is Irving Lank v. Wetherald, 36 N. Y. iisi. Wo think the "ases ald distimgushahle. In that ease the note had hen discomted hy the indorsers, who received the proceeds at the tinc. It was, therefore, a compteted transaction between the indorsers and the indorsee. The indorsec, a bank, presented the note when due at the bank where it was payble and had it eertified. Isater in the day the certifying hank discovered that there were no fumbs 11) gay the note, and before 3 orelock r. M. notified the holding bank, whith refused to recognize the notice. The certifying bank then touk np the note. presented it at its own comnter, protested it, and notifed the indorsers. 'The cortifying bank suct the indorsers. The rase recognizing the well-established doctrine that a bank is estopped from denying its certification of a note as good where the presenting bank relies upon its acculacy and fails to protest the note for non-pirment and thus releases the inforscrs, holds that, where the mistake in certification is diseovered, and notuce siven to the presenting bank in time to make a re-presentation and charge the indorsers, the ertifying bank is discharged from further liability, and that the certifying bank in this rase took the note as a purchaser and acruired the rights of a holder and could maintain its action against the indorsers. The discounting bank received notive of the mistake before it in any way rhanged its position. It hat not parted with value or released the indorsers on the strength of the certification, otherwise the certifieation would have been binding.

In the case at har plaintilf parterl with value on the strenghth of the rertifieation. No enforeable contract was entered into between the parties to this suit hecause plaintilf never parted with value relving upon the indorsement. As between the certifying bank and the plaintiff there could be no revoution by the bank. There was no claim of mistake on the part of the certilying bank or any attempt to revoke its rertifiation. If the certification was in law a framl, it was the frand of Andrews and the roptifyiner bank, of which neither of the parties to this suit land knowledge. The presentment of the restifind rheck to the certifying bank, and its non-payment, was the repudiation by the hank of its independent contract of certifiration marle with the plaintilf. This cleck as it was when the indorsers partrel with it to the indorsee was never presented for payment. The certification was made without the knowledge or ronsent of the indorsers. Applying to this case the decision in the Wetherald case, so far as it has any hearing upon the questions here involved, it is authority for holding that the certifying bank rould not avoid liability on its cortification, for the reason that plaintiff had parted with value on the strength of it.

It was wrered in the trial court. and is urged in this court, that the certification of the check in the absence of funds did not operate 
to release the maker from his liability thereon, and therefore the indorsers can occupy no better position than the maker and are not released and upon this theory the trial court decided the case. No authorities are cited to us and we have been able to find none which support this proposition. As already stated, it is a general rule of law that where the holder of a check procures its certification by the bank upon which it is drawn, the drawer and all parties thereto are discharged. The relations of the different parties to a check and the nature of their contracts have already been sufficiently stated. The certification is an entirely new and different contract. By it the certifying bank becomes the primary debtor. The holder has released the maker and indorsers and voluntarily accepted the obligation of the certifying bank. It is not unlawful for one to draw checks upon an overdrawn account. Neither is it unlawful for the bank to pay such a check and to charge the amount thereof against the drawer. In such case, as in any other ease, the holder who obtains a certification has elected to accept the obligation of the bank instead of cash. So far as the drawer is concerned the check is paid because the holder by securing certification obtained what he desired as payment. The bank had been directed to pay cash, and when the holder obtained what he preferred to eash, it was none the less a payment. The rule which releases the maker and indorsers of a check upon certification procured by the holder, is not predicated upon the presence of funds in the hands of the certifying bank, but upon the principle that such certification operates as payment, discharging the maker whose contract has been fulfilled, and the indorser who was the guarantor of such fulfillment. If, in considering this proposition of law, the question of what relation may have been created between the bank and the maker in case of a certification in the absence of funds is eliminated as a factor, the corrertness of our reasoning is in our judgment conclusive. The insolveney of the certifying bank after the certification is a cireumstance which is likely to disturb our judgment of the legal question, because it oreasioned this suit. That fact is entirely immaterial to the question, the rights of the parties having been fixed before that insolvency was known, and they were utterly iznorant of its possibility. Our conclusion is, therefore, that the general rule applies to this case and discharges the drawer as well as the indorsers, notwithstanding the absence of funds.

Upon the undisputed facts in this ease the defendants were entitled, as a matter of law, to an instructed verdict in their favor. The court was in error in not granting their request to that effert.

The judgment is reversed and a new trial ordered. All coneur.

- This case is reported with notes on the foffect of erefification of check on the liability of Arawer or indoraer in 9 J. N. S. 698, 118 Am. St. Rep. 537, and in 11 A. \& F. Ann. Cas. 241.-C. 
4. DraweE not Ljable to Holder: A Check is not an AssignMENT of FunIS.

10 WaLLaCe (U.S.) 152. - 1869.

Is Enron to the Supreme Court of the District of Columbia, the case heing this: -

Millard, a captain in the military service of the United States, was in 1865 , on leaving the service, a creditor of the government for \$859, arrears of pay as captain. In settlement of this account the proper paymaster of the army drew and issued a check for that sum upon the National Bank of the Republic, a depositary of public money and finmeial agent of the United States, for the custody, transfer, and disbursement of the government funds, having funds for the payment of the check.

The bank, as testimony tended to show, had once paid the check on a forced indorsement of Millard's name. Ascertaining and exposing the forgery, and recovering possession of the eheck, Millard now presented the same, demanding payment to himself. This payment the bank refused to make. Thereupon he sued it, declaring on a special count on the transaction, and also on a general count for money had and received by the bank to his use.

On the trial the hank requested the court to charge, "that unless the jury were satisfied from the evidence that it accepted the check in faror of the plaintiff, or his assignees, or promised to pay the same to the plaintiff, or his assignees, he was not entitled to recover." But the court refused so to charge, and, verdict and judgment having gone against the bank, it brought the case here on error; the questions here argued and considered being: 1st. 'The general one,whether the holder of a bank check could sue the bank for refusing payment in the ahsence of proof that it was accepted by the bank or charged against the drawer. 2d. If not, whether the fact existing in this particular case, that the check was on a national bank (a public lepositary of the government funds) by an officer of the government, in favor of a pulblic creditor, varied the general rule.

Mr. J J cstice Davis delivered the opinion of the court.

The nnly question presented by the record which it is material to notice is this: Can the holder of a bank check sue the bank for refusing payment, in the ahsence of proof that it was accepted by the hank, or charged against the irawer?

It is no longer an open question in this court, since the decision in the cases of The Marine Bank v. The Fulton Bank (2 Wallace, 252), and of Thompson v. Riggs (5 Id. 663), that the relation of 
banker and customer, in their pecuniary dealings, is that of debtor and creditor. It is an important part of the business of banking to receive deposits, but when they are received, unless there are stipulations to the contrary, they belong to the bank, become part of its general funds, and can be loaned by it as other money. 'The banker is accountable for the deposits which he receires as a debtor, and he agrees to discharge these debts by honoring the checks which the depositors shall from time to time draw on him. The contract between the parties is purely a legal one, and has nothing of the nature of a trust in it. This subject was fully discussed by Lords Cottenham, Brougham, Lyndhurst, and Campbell, in the llouse of Lords, in the case of Foley v. Hill (2 Clark and Finnelly, :28), and they all concurred in the opinion that the relation between a banker and customer, who pays money into the bank, or to whose credit money is placed there, is the ordinary relation of debtor and creditor, and does not partake of a fiduciary character, and the great weight of American authority is to the same effect.

As checks on bankers are in constant use, and have been adopted by the commercial world generally as a substitute for other modes of payment, it is important, for the serurity of all parties concerned, that there should be no mistake about the status, which the holder of a check sustains towards the bank on which it is drawn. It is very elear that he ean sne the drawer if payment is refused, but can he also, in such a state of case, sue the bank? It is concederl that the depositor can bring assumpsit for the breach of the contract to honor his checks, and if the holder has a similar right, then the anomaly is presented of a right of action upon one promisc, for the same thing, existing in two distinct gersons, at the silme time. On principle, there can be no foundation for an action on the part of the holder, unless there is a privity of contrart between him and the bank. How can there bo such a privity when the hank owes no duty and is under no obligation to the holler? The holder takes the cheek on the credit of the drawer in the helief that he has funds to moet it, but in no sense can the hank be saicl to he connectol with the transaction. If it were trone that there was a privity of contal ract hetween the hanker and hrolder when thre rheck was gricen, the bank would be ohliged to pay the cherek, althomegh the drawer, lwefore it was presented, had comntromanderl it, and althomgh other wercks, drawa after it was iscurel, but hofore payment of it was domamled, had exhausterl the funds of thre drepositor. If surh a result should follow the giving of rherks, it is asy to soe that bankers would ho compelled to abandon altogrether the husiness of kerping deposit aceounts for their austomers. If. then, the hank diel not enntract with the holder of the eloek to pay it at the time it was grion. how can it be said that it owres nny duty to the holder until the check is 
presented and accepted? 'The right of the depositor, as was said by au eminent judge (Garliner, J., Chapman v. White, 2 Selden, 417 ), is a chose in action, and his check does not transfer the debt, or give a lien upon it to a third person without the assent of the lepositary. 'lhis is a well established principle of law, and is sustained by the English and American decisions. (Chapman v. White, 2 Selden, 412; Butterworth V. P'ech, 5 Bosworth, 311; Ballard v. Randall, 1 Gray, 605; Marter v. Auderson, 21 Wendell, 373; Dyliers v. Leather Mainfacturing Co., 11 Paige, 616; National Bank v. Eliol Bank, 5 American Law Register, r11; Parsons on Bills and Notes, edition of 1863. pp. 59, 60, 61, and notes; Parke, Baron, in argument in Bellamy v. Majoribanhs, 8 English Law and Equity, 522, 523; Wharton $v$. Walker, 4 Banwell \& Cresswell, 16:3; Warwick v. Rogers, 5 Manning \& Granger, 3rt; Byles on Bills, chapter "Check on a Banker;" Grant on Banking, London edition, 1856, 96.)

The few eases which assert a contrary doctrine, it would serve no useful purpose to review.

Testing the case at bar by these legal rules, it is apparent that the court below, after the plaintiff closed his case, shonld have instructed the jury, as requested by the defendant, that the plaintiff, on the evidence submitted by him, was not entitled to recover. The defendant did not accept the check for the plaintiff, nor promise him to pay it, but, on the contrary, refused to do so. If it were true, as the evidence tended to show, that the bank, before the check came to the plaintifl's hands, paid it on a forged indorsement of his signature, to a person not anthorized to receive the money, it does not follow that the bank promised the plaintiff to pay the money again to him, on the presentation of the check by him for payment.

It may be, if it could be shown that the bank had charged the check on its books against the drawer, and settled with him on that basis, that the plaintiff could recover on the count for money had and received, on the ground that the rule ex aquo et bono would be applicable, as this bank, having assented to the order and communicated its assent to the paymaster, would be considered as holding the money thus appropriated for the plaintiff's use, and therefore, under an implied promise to him to pay it on demand.

It is hardly necessary to say, that the check in question having been drawn on a public depositary, by an officer of the government, in favor of a public creditor, connot change the rights of the parties to this snit. The check was commercial paper, and subject to the laws which govern such paper, and it can make no difference whether the parties to it are private persons or public agents. (The United States v. Bank of Metropolis, 15 Peters, 37\%.)

As soon as the deposit was made to the credit of Lawler as paymaster, the bank was authorized to deal with it as its own, and 
Leame answerable to Lawler for the debt in the same manner that it would have been had the deposit been placed to his personal eredit. Judgment reversed and a venire de noco awarded. ${ }^{1}$

\section{§ 325 VAN BUSKIRK $v$. STATE BANK OF ROCKY FORD.}

35 Colorado, 142. - 1905.

Mr. Jestel: Camperi delivered the opinion of the court.

The parties are each doing a separate banking business in the sane town. A cheek drawn on the appellant by one of its depositors was ly the payee presenter for payment to the appellec. Appellee teleploned to appellant asking if the check was gool, and was informed that it was "goml," or "all right." This was the extent of the information givm, and there was no promise by appellant that it would arcept or pay the rluce unless the information given is, in law, that promise. Appellece then pain? the eheek upon the strength of the foregoing reply to its puestion, but otherwise would not have casherl it. $I$ few minutes theralter the drawer appeared before the drawee (appellant) and stopped payment, of which appellant immediately advised the approllee. Afterwards, and on the same day, when appellee presented the check, duly indorsed, to appellant for paymernt, the latter refused to pay it because it had been rirected by its depositor not to do so, although at the time the drawer had and still loas with appellanl sulfircient fumls for such payment.

'I'bereupus this artion was hrought ly appellee against appellant to recover the anoment of the rheek, npon the remond that appellant had promised to pay it. 'The trial court submitted the case to the

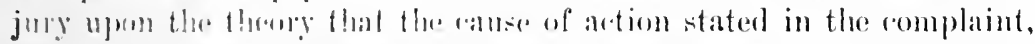

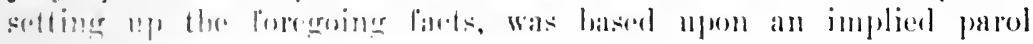

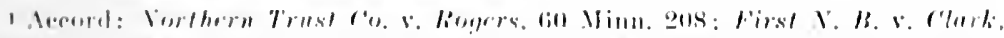

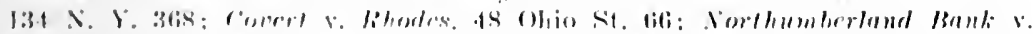

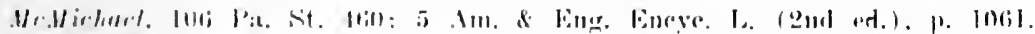

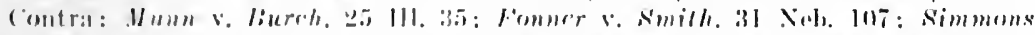

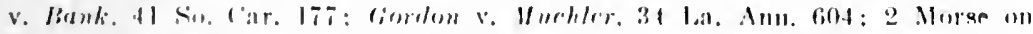

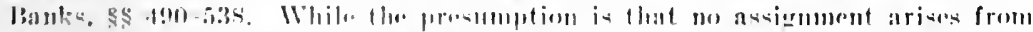

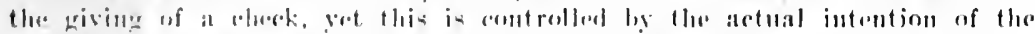

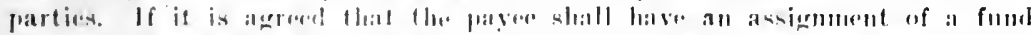

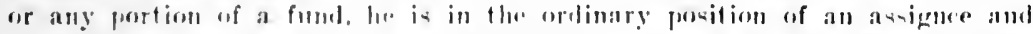

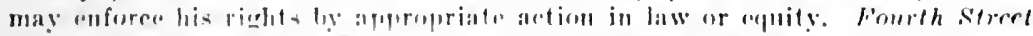

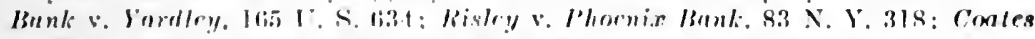

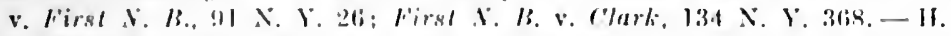

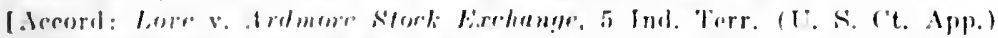

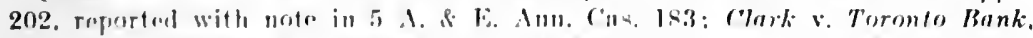

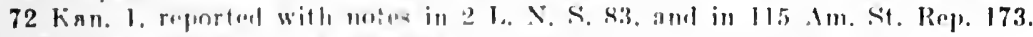

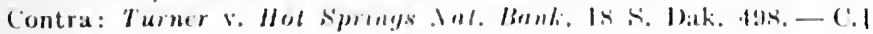


promise to pay. The verdiet and judgment were for the plaintiff, and the defendant appeals.

The two chief points relied upon by defendant below (appellant here) are (1) that under our Negotiable lustruments Law passed in 1897 (Session Laws $189 \%, p$. 210), an action will not lie in favor of the holder of a eheck arainst the drawee unless and until the same is accepted or certified by the drawee, which acceptance or certification must be in writing; and (2) that if a parol acceptance or promise to pay is binding, no such promise was established by the evidence.

1. 'The courts of England and America have often held that, at the common law, though many of the rules and principles applicable to bills of exchange apply to bank checks, the two kinds of instruments are not ilentical. liegardless of the common law rights of the parties under the facts of this case, we think there can be no doubt as to the correctuess of appellant's leading contention that, under our Negotiable Instruments Law, the drawee of a eheck is not liable to the holder unless and until he accepts or promises to pay the same, and such assent to his liability must be in writing. Section $126^{2}$ of our act defines a bill of exchange as " an unconditional order in writing addressed by one person to another, signed by the person giving it, requiring the person to whom it is addressed to pay on demand or at a fixed or determinable future time a sum certain in money to order or to bearer." Section $185^{3}$ reads: "A check is a bill of exchange drawn on a bank payable on demand. Except as herein otherwise provided, the provisions of this act applicable to a bill of exchange payable on demand apply to a check."

At the common law a bill of exchange payable on demand need not he presented for acceptance. Indeed, strictly speaking, there is no such thing as acceptance of a check in the ordinary sense of the term; yet by consent of the holder the drawee bank may enter into an engagement quite similar to that of acceptance by certifying the check to be good. instead of paying it. 2 Daniels on Negotiable Instruments (4th ed.), $\$ 1601$; see. 143 of our art." $A$ check is a speries of bill of exchange, viz, that particular kind of a bill which is drawn on a bank and payable on demand. Under our act it need not be presented for aeceptance unless it contains an express stipulation to that effect. Sec. 143 .

Before the passage of our Negotiable Instruments Law this court had ruled, in accordance with the weight of authority, that a right of action does not exist in favor of the holder of a eheck against the drawee bank where there has been by the latter no aceeptance

2 N. Y., § $210 .-\mathrm{C}$.

S. Y., § 321. - C.

1 N. Y., \& 240. -C. 
or promise to pay. Colo. Nat. Bank v. Boettcher, 5 Colo. 185 ; reaffirmed in Boettcher $v$. C'olo. Nat. Bank, 15 Colo. 16. Our statute has expressly so enacted. Sec. 189." 'The same cases at least tacitly recognized the doctrine that such acceptance or implied promise might, in the absence of a statute to the contrary, be proved by parol testinony, but this doctrine is abrogated by our statute as we proceed to show. According to this statute, though all bills of exchange are not checks, yet as a cheek is therein expressly said to be a bill of exchange drawn on a bank and payable on demand, every check is a bill, that is, it is a species of a bill. So that, though a check need not he presented for acceptance in order to render the parties thereto liable, still as the eheck itself does not operate as an assignment of any part of the fund to the eredit of the drawer with the bank, and the drawee bank is not liable to the holder, unless and until it accepts or certifies the check (sce. 189), and as (sec. 185) except as in the act otherwise provided all of its provisions applicable to a bill of exehange payable on demand apply to a check, and as no contrary provision for the acceptance of or promise to pay a eheck has been made, the provision applicable to a bill of exchange that acceptance or certification when made must be in writing applies also to a check. There being no pretense in this case that the pronise to pay or certification or acceptance of the check sued upon was in writing, the holder was not entitled to sue the bank upon it.

There are distinctions between an action on a bill or eheck as an accepted bill and onc foumded on a breach of promise to aceept. Boyre v. Eduards, I Peters, 111: IIomrietta. Nat. Lianli v. State Nat. Bank, 80 Tex. 6.8. Tut we do not consifler that such distinctions are important here. This action was based mpon a parol promise to pay the rherk. Aeceptance of a hill at common law and under our statute is morely the sirnification by the drawee of his assent to the order of the drawer. The logal moning of an aceeptance is that the acceptor engages to pay tho instrument acrording to the tenor of his acreptance. In ofler words. it is a promise to pay. Sossion Laws 1897, sers. 6\%, 1:3: 1 Janiuls on Nerentiablo Instriments (-1th ed.), $\$ 17 \%$. 'This atolion is one ly a holeler of a cherk against the drawer based upon a parol promice of tho lattre to pay, and it cannot be maintained.

2. It is well to olsorre that this is mot an ancion to recover money lost by the frand or wromgeloing of another, and if such were the cause of action plemberl the reviloner wombl mot support it. 'l'he only claim made by plantiff is that the information which the appellant gave in response to an inguiry was, in legal colforet, a promiso to pay the check when the same was presented for that purjose. There is no pretense Hat How information grion was false; it is conceded 
that the answer to plantill's inguiry on which the promise rests was true; hence there is present lere no element of an action ex delicto.

In thus disposing of the atse mpon the ground that a promise such as is here relied upon must be in writing, we are relieved of the neessity of considering whether the mere oral statement by the drawee bank that a cherk drawn upon it is "grool" ol "all right" gives rise to an action in lavor of one who parts with money upon the faith of it.

The jumbment should be reversed and the eause remanded, with instructions to the trial court to dismiss the action.

Reversed.

Chief Justee Gabbest and Mr. Justree S'teere concur.

\section{Furged or Raisen ('hecks: Rechrocal, Oblgations op Bank AND DVIPOSITOR.}

\section{$\$ 326^{\circ}$ CRIT'I'EN $v$. CIIEMICAL NA'IONAL BANK.}

171 New YoRк, 219.- 1902.

Appeas, from a jublement of the Appellate llivision of the Supreme Court in the first judicial department, alfirming a judgment in favor of plaintiff entered mpon the report of a referee.

Cullex, J. - The plaintilfs kept a large and arive account with the defendant, and this action is to recover an alleged balance of a deposit due to them from the hank. 'The plaintill's had in their employ a clerk named Davis. It was the dnty of Davis to fill up the checks which it might be necessary for the plaintifls to give in the course of business, to make corresponding entries in the stubs of the ahech book and present the checks so prepared to $\mathrm{Mr}$. Ciriten, one of thr platintifs, for signature, logedler with the bills in payment of which they were drawn. Alter signing a cherk critten would place

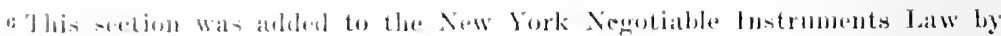

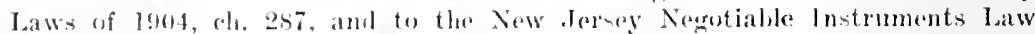
by I.aws of 1908 , clo. 215. Mr. ('rawforcl criticizes its incorporation into the

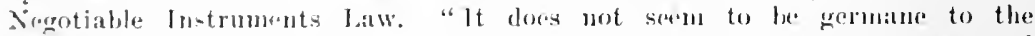
Siegotiable. In-trunents Jaw, and womlel more properly have been enacted as an amencluent to thro lianking law. If the statute is to be amonded by arling provisions outale of its proper scoper, it will soon lecome such a pipee of patchwork, that threre will be a lemand for its repeal." ('raw. Nog. Inst. Jaw, 3rd ed., p. I81. While Critten v. Themiral Sational Bank, reported hresein. was decided prior to the enactment of this statutory provision, nevorthelese tha principlos of law laid down in this case will doubtless be carrfully considrenel when the question as to what is the proper construetion of the statute cones before the New York courts. - C. 
it and the bill in an envelope addressed to the proper party, seal the envelope and put it in the mailing drawer. During the period from September, 1897, to October, 1s99, in twenty-four separate instances Davis abstracted one of the envelopes from the mailing drawer, opened it, obliterated by acids the name of the payee and the amount specified in the check, then made the eheck payable to cash and raised its amount, in the majority of cases, by the sum of $\$ 100$. He would draw the money on the eheck so altered from the defendant bank, pay the bill for which the cheek was drawn in cash and appropriate the excess. On one occasion Davis did not collect the altered check from the defendant, but deposited it to his own credit in another bank. When a check was presented to Critten for signature the number of dollars for which it was drawn would be cut in the check by a punching instrument. When Davis altered a check he would punch a new figure in front of those already appearing in the check. The checks so altered by Davis were charged to the account of the plaintiffs, which was balanced every two months and the vouchers returned to them from the hank. To Davis himself the plaintiffs, as a rule, intrusted the rerification of the bank balance. This work having in the absence of Davis been committed to another person, the forgeries were discovered and Davis was arrested and punished. It is the amount of these forged checks, over and above the sums for which they were originally drawn, that this action is brought to recover. The defendant pleaded payment and eharged negligence on plaintiff's part, both in the manner in which the ehecks were drawn and in the failure to discover the forgeries when the pass book was balanced and the vouchers surrendered. On the trial the alteration of the ehecks by Davis was estahlished heyond contradiction and the substantial issue litigated was that of the plaintiffs' negligence. The referee rendered a short decision in favor of the plaintiffs in which he states as the ground of his deeision that the plaintiffs were not negligent either (1) in signing the (dieeks as drawn by Davis, or (2) in failing to discover the forgeries at an earlier date than that at which they were made known to them.

The relation existing between a bank and a depositor being that of dehtor and creditor, the bank can justify a payment on the dopositor's account only upon the actual direction of the depositor. "The questions arising on such paper (chereks) between drawer and drawer, however, always relate to what the one has anthorizel the other to do. 'They are not questions of negligence or of liability of parties upon commercial paper, but are those of authority solely. * * Ther question of nogligenee amot arise unless the depositor has in drawing his eheek left hlanks unfilled, or by some attirmative act of negligence has facilitated the commission of a fraud by those into whose liands the cherk may rome." (r'runford v. West Side Bank, 100 N. Y. 50.) 'Therefore, when the fraudulent altera- 
tion of the checks was proved, the liability of the bank for their ambunt was mude ont and it was incumbent upon the defendant to estalutish athirmatively negligence on the plaintitls' part to relieve it from the conseyuences of its fault or misfortume in paying forged orders. Now, while the drawer of a check may be liable where he draws the instrument in such an incomplete state as to facilitate or invite frandulent alterations, * it is not the law that he is bound so to prepare the eheck that nohorly else can suecessfully tamper with it. (Socrété Gencralé v. Iletropolitan Bank, 27 L. T'. [N. S.] 819 ; Belknap v. National Bank of Norlh America, 100 Mass. 380.) In the present rase the linuchulent alturation of the checks was not merely in the perforation of the additional figure, but in the obliteration of the written name of the payee and the substitution therefor of the word " cash." Against this latter change of the instrument the plaintitls could not have been expected to guard, and without that alteration it woutd lave no way profited the criminal to raise the amount. Apart, however, from that consideration, the question was clearly one of fact to be determined largety by an inspection of the checks themselves. They are not produced before us, and we eannot say that the finding of the referee, that the plaintiff was guilty of no negligence in signing them in the condition in which they were presented for signature, was without sufficient evidence for its support.

We are now brought to the consideration of the finding of the referee that the plaintiffs were not guilty of negligence in failing to discover the forgeries after the returu of the checks and the balancing of the account in the pass book. Preliminarily we must determine what duty the depositor owes to his bank by way of examination and verification of his checks and account, for the learned counsel for the respondent asserts that no such duty in reality exists. 'This contention is principally based on the authority of Weisser's Adm'rs v. Denison $(10 \mathrm{~N}$. Y. 68). In that case a depositor sued his bank for the amount of certain checks to which his signature was forged by his elerk. His pass book was balanced and vouchers returned at intervals as in the present ease. At the trial he recovered a verdict for the full amount of the forgeries. On appeal the General Term of the Superior c'ourt ordered a reversal of the judgment unless the plaintitf would reduce his recovery to the anount paid on the forged checks prior to the time when the lank book was first balanced and vouchers returned. 'T'o this rerluction the plaintiff assented, and, on the defendant's appeal, the judgment as modified was affirmed by this court. In the opinions delivered by two distinguished judges the doctrine is asserted that the depositor owes no duty to the bank to

- But see National Exchange Bank v. Lester, 194 N. Y. 461, reported herein at p. 616. - C. 
examine his pass book or vouchers with the view to the detection of forgeries, but the decision itself is not authority for more than the proposition that the bank was not relieved from liability for forged ehecks which it had paid before the account was balanced by the failure of the depositor to subsequently discover the forgeries. As was said by Judge Johnson as to these ehecks, "Whatever loss the bank has sustained, it has suffered from its own negligence or want of skill in a matter as to which, in the first instance, it and it only was bound to exereise skill and diligence. To this loss no act of Weisser has contributed." The question again came hefore this court in the case of Frank v. Chemical National Bank of New York (84 N. Y. 209). That action was also brought to recover the amount of a series of checks forged by the depositor's elerk. A recovery by the plaintiffs was upheld, though not on the principle that the depositor owed no duty to his bank, but on the ground that he had discharged that duty. In the opinion there delivered, Judge Andrews said: "It does not seem to be unreasonable, in view of the course of business and the eustom of banks to surrender its vouchers on the periodical writing up of the accounts of depositors, to exact from the latter some attention to the account when it is made up or to hold that the negligent omission of all examination may. when injury has resulted to the bank, which it would not have suffered if such examination had been marle and the bank had received timely notice of objections, preclude the depositor from afterward questioning its correetness. But where forged checks have been paid and charged in the account and returned to the depositor, he is under no duty to the hank so to conduct the examination that it will necessarily lead to the disenvery of the fraud. If he examines the vouchers personally and is himself dereived by the skillful character of the forgery, his omission to disrover will not shift upon him the loss which in the first instance is the loss of the bank." In that case the depositor compared the returned rhecks with the stubs in the cheek book, but was deceived by the faret that the forger had abstracted the forged checks from the package. In the Supreme Court of the United States and in several of our sister states the rule is settled that the depositor owes his bank the luty of a reasonable verifieation of the returned checks. In L, ealher Manufacturers' Bank v. Morgan (117 U. S. 96) it was held that a depositor is homul personally or by his agent, and with due diligenee, to reamine the pass hook and vouchers, and to report to the hank without unreasonable delay any errors which may have leen discovered therein, and that if he fails to do so and the hank is therrby micler! to its prejudiec, he eannot afterwards dispute the eorrectness of the halanes shown in the pass hook. In Dana v. Natinnal Bank of the Republic (1.32 Mass. 156) the Supreme Court of Massachusctis said: "The mistake was in the payment of the money upon an altered check, believed to be genuine; 
it was not for the alvantage of the defendant, and its condition was changed by it. It was in the rourse of dealings between the parties in relation to which each owerl duties to the other. * * * The plaintiffs (depositors) owed to the defendant (bank) the duty of cxercising duc diligence to give it information that the payment was unanthorized; and this included not only due diligence in giving notice after knowledge of the forgery, but also due diligence in discovering it." In Myers v. Southwestern National Bank: (193 Penn. St. 1) it was held that the bank was entitled to have the vouchers which it surrendered with the pass book examined, and if rejected returned within a reasonable time, and that if this was not done because of the depositor's failure to perform his duty in that regard he should not be permitted to recover. 'The same rule of law obtains in Louisiana (De Fariet v. Bank of America, 23 La. Ann. 310), in Texas (Weinstein v. National Bank, 69 Tex. 38), and in Alabama (National Bank v. Allen, 100 Ala. 4\%6). The course of dealings between banks and their depositors is well known and is considered at length in the three cases first cited from other jurisdictions. The methods of depositors in drawing checks on their accounts have become much more uniform than at the time of the decision in Weisser v. Denison, supra. The practice of taking checks from check books and entering on the stubs left in the book the date, amount and name of the payee of the check issued has hecome general, not only with large commercial houses but with almost all classes of depositors in banks. The skill of the criminal has kept pace with the advance in honest arts and a forgery may be made so skillfully as to deceive not only the bank but the drawer of the check as to the genuineness of his own signature. But when a depositor has in his possession a record of the checks he has given, with dates, payees and amounts, a comparison of the returned checks with that record will necessarily expose forgeries or alterations. It is true that it will give no information as to the genuine character of the indorsements, and because the depositor has no greater knowledge on that subject than the bank, it owes the bank no duty in regard thereto. (Welsh v. German-American Bank, 7. N. Y. 424; Shipman V. Bank of the State of New York, 126 N. Y. 318.) It is also true that verification of the returned checks would not prevent a loss by the bank in the case of the payment of a single forced check and prohably not in many eases enable the hank to obtain a restitution of its lost money. It would, however, prevent the successful commission of continuous frauds by exposing the first forgeries. That this is a numerous class of frauds is apparent from the number of cases which we have rited, in all of which the forgery was not a single act, but a series of acts extending over a consirierable period of time, and the crime was committed by a clerk or emplovee of the depositor. Considering that the only certain test of the genuineness of the paid check may be the reoord marle by the 
depositor of the checks he has issued, it is not too much, in justice and fairness to the bank, to require of him, when he has such a record, to exercise reasonable care to verify the vouchers by that record.

While we hold that this duty rests upon the depositor, we are not disposed to aecept the doctrine asserted in some of the cases that by negligence in its discharge or by failure to discover and notify the hank, the depositor either adopts the ehecks as genuine and ratifies their payment or estops himself from asserting that they are forgeries. Such a doctrine would be in conflict not only with the opinions rendered in IVeisser v. Denison, supra, but against the decision there actually made. 'That authorify has stood for nearly fifty years and we would not feel justified in now overruling it. Nor, if the question were an open one in this state, would we deem the rule of estoppel or that of ratification a just one. If the depositor has by his negligence in failing to detect forgeries in his checks and give notice thereof caused loss to lis bank, either by enabling the forger to repeat his fraud or by depriving the bank of an opportunity to obtain restitution, he should be responsible for the damage caused by his defanlt, lnt beyond this his liahility should not extend. In the eases cited from the Supreme Court of the United States, from that of Massachuests and that of Pennsylvania, it is conecled that, if the bank has been gnilty of negligence in paying the forged whecks, then the doctrine of ratification and estoppel does not apply. It seems to us that the exerption is somewlat inconsistent with the principle on which the doctrine rests. Moreover, we see no reason why the bank shonlid he entitled to anything more than indemnity for the loss the depositor's negligence has raused it. In the present ase, a cheek altered by Javis from the smm of 420 to $\$ 622$ was paid by the defendant to thr colonial Bank, in which Davis hand deposited it. Against that bank the defemdant has ample recourse. If it were to be held that the plaintilfs were estopperd from denying the anemuine-

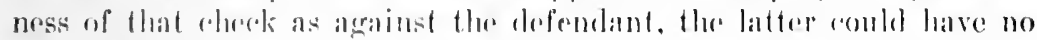
claim against the ('olonial bank, nor is it rear that the plantilfs

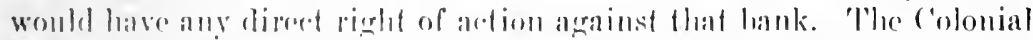

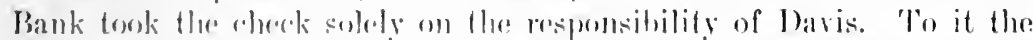

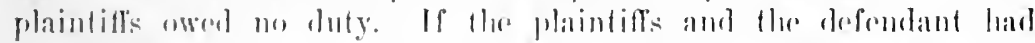

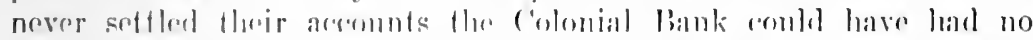
complaint against rither party for that monse. A rule which might operate to relieve that hank form the liability it assumed when it

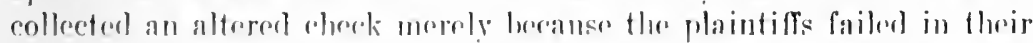

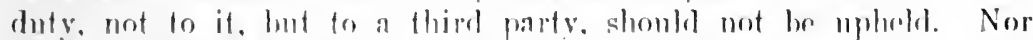
would it operate justly in a case in which the bank had paicl a single forgery unlese by the depositor's dofanlt and delay the hank had inst its opportunity to serenre restitution. 'l'his question is woll discussed by the Supreme Court of Alabina in the ase of National Bank v. 
Allen. supma, and we concur in the view expressed by that court that the liability of the depositor for neerlect of his duty to examine and verify his aldenut with the hams is limited to the damages sustained

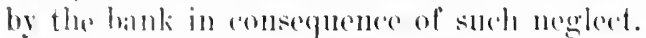

In the present ase Davis falsified the additions or totals at the foot of the pases of the check book. But with a few exceptions he did not alter the anounts expressed in the stubs. In no case did he change in the stubs the name of the payee of the check. It is clear, therefore, that at all times a comparison of the returned checks with the stubs in the check hooks would have exposed the alterations made in the checks. Of comrse, the knowledge of the forgeries that Davis possessed, from the fact that he himself was the forger, was in no respert to be attributed to the plaintills. But we see no reason why they were not chargeable with such information as a comparison of the checks with the check book would have imparted to an innocent party previously unaware of the forgeries. The plaintiffs' position may be no worse because they intrusted the examination to Davis instead of to a third person; but they can be no better off on that account. If they would have been wargeahle with the negligence or failure of another elerk in the rerification of the accounts, they must he equally so for the default of Davis, so far as the examination itself would have disclosed the facts. We think it plain, therefore, that the finding of the refere that the plaintiffs were not negligent in the examination of the pass book and vouchers is without evidence to sustain it. moses the plaintiffs discharged their duty to the defendant when they committed the examination to a proper clerk and were not responsible for the manner in which the clerk performed the task. From the language of the report of the learned referee it would seem as if this last were the theory on which his decision proceeded. We do not think it ran he sustained. If any duty rested on the plaintiffs we do not see why the orlinary rule of principal and agent or master and servant, that the principal or master is liable for the fault of his servant or agrent in the master's business, did not apply. 'This was so held in the case of Leather Manufacturers' Bank v. Morgan, supra, and nothing to the contrary is to be found in Frank v. Chemical National Bank of Neu Yorti, supra. There it is said: "The alleged duty, at most, only requires the depositor to use ordinary eare; and if this is exercised, whether by himself or his agents, the bank cannot justly complain, although the forgeries are not discovered until it is too late to retrieve its position or make reclamation from the forger." In that "ase. however. the question of the liability of the principal for the negligenee of his clerk dirl not arise, for the plaintiff mate the examination personally. There are execptions to the general rule of the liahility of the master for his employee. But this case does not fall within those excentions nor within the principle on which those exceptions are hased. 
These views would render it necessary to reverse the judgment appealed from except for another fiut now to be noted. The referee's report is in the form of a short decision and on appeal it is to be presumed that all facts warranted by the evidence and necessary to support the judgment have been found. (Amherst College r. Ritch, 151 N. Y. 282; Bartlett r. Goodrich, 153 N. Y. 421; Marden r. Dorthy, 160 N. Y. 39.) The sixth in sequence of these forgeries was a check of June 20 th, 1898, for $\$ 12.49$, altered to the sum of $\$ 112.49$, with the name of the payee erased and "Cash" written in the place thereof. The teller of the defendant, who paid the cheek and was a witness on its behalf, testified that the check showed on its face that the word "Cash" had been written in the place of the payee's name over an erasure; that the number of dollars was also written over an erasure; that he did not like the appearance of the eheck and that it was in such a mutilated condition when it was presented to him that, before paying it, he required Davis to indorse upon the check a receipt for its amount. That the defendant was grossly negligent in paying the eheck and has only itself to thank for that loss is apparent. But the effect of that negligence did not cease with the payment of the cheek. The referee might well have found that, had payment of the cheek been refused or had Davis been. required to obtain the indorsement or guaranty of the plaintiffs as to its correctness, the forgeries of Davis would have been exposed and their repetition would not have oceurred. That Davis was ahle to suecessfully continue from this time to his arrest a series of forgeries is as fairly attributable to the folly of the hank in paying to a clerk a check of his employers which had plainly been altered without making inquiry as to the reason or authority for the alteration, as it was to any earelessness of the plaintiffs in failing to detect the alteration when the checks were returned to them from the bank. Sinee we have held that the question in the case was not one of ratification or estoppel, but that the liability of the plaintitis to the bank was solely for the loss eaused by their negligence, it is a complete answer to the defendant's claim that its own negligenee contributerl to the loss. 'Thro learned counsel for the appellant coutends that the plaintiffs' anse of action is not based on negligence and that the plaintifis cinnot sue on contract and recover in tort. 'This raim is without force. 'The artion muquestionably was hrought on contract, hut it remains such. The platintits sue for a debt to which the defendant answers: Wr have paid the money, true, not arcording to vour clirestions, but in compliance with what we believerl to he your directions, and your negligent conduct in rour duty towards us fid us into that cror. 'To which the plaintits rejoin: Your own megligener contributed to the loss. All this may be true, yet the plaintiffs recover not in tort hut on contract, for the allegation of megligenere on the part of the defentant is nsord only to defeat its claim for relief on acrount of the plaintitfs' negligence. 
It follows that under the authority of Weisser v. Denison (supra) the defendant is not entitled to credit for the two elecels paid by it before the alceomt wats balanced and rouderes returned. For the third, fourth and fifth ehecks, anoming 10 w300, it is entitled to credit, unless it was guilty of merligence in their payment, a faet which is nother fomml by the referee nor establisher by the evirlenee. For the sixth eheek and the suberpuent ones it is not entitled to eredit berause of its negligence in paying the sixtle check.

'The judgment should be reversed and a new trial granted, costs to abile the event, monese the plaintiffs consent to deduct from their recovery the sum of $\$ 300$ with interest from November 15th, 18!9!, in which ease the judinment, as morlified, should be alfirmed, without costs of this appleal to cither party.

VAxx, J. (disenting). Whether the plaintilfs exereised reasonable eare in examining the cherks roturned as vonehers by the defendint was a question of fact, and, as they intrusterl the work to a competent agent and took other precautions, there was evidence to support the fonding in their favor, which, after affirmance by the Appellate Division, is comelusive here. (Amherst College v. Rilch, 151 N. Y. 28:.)

In my opinion the julgment below should neither be reversed nor modified, unless the court reaches the conclusion that the plaintiffs had constructive notice of what their agent discovered in examining the elecks. The rule which imputes to a principal knowledge aequired by his agent rests upon the presumption that the latter las diselosed all the material farts to the former. This presumption loes not extend to a fact which, if disclosed, would sulject the agrent to a prosecution for crime or defeat a scheme in which he was engaged to defraud his employer. (/lenry v. Allen, $151 \mathrm{X}$. Y. 1, ?; Benedict v. Arnour, 154 N. Y. 715, 7es : Bienenstol v. Ammidown, 155 N. Y. 47, 60: Pomeroy on Eq. Jur. \$ 675.) The dishonesty of the agent ehanges the situation. for the neressity of roncealing his dishonest acts, in order to presmit exposure and pmishment, destroys the presumption which would otherwise preval that he had marde the facts known to his principal. A presumption must be reasonable or it camnot exist, and it nould not be reasonalue to expert one engaged in exerating a frandulent projeret to make a diselosure which would not only defeal his purpose but would send him to prison. Knowledge is not imputable. When the agent is anding in hostility to his principal, or is engagerl in perpetsating or concealing a fratul.

In this rase thre agent rommitter the furtive acts and knew all about them long before le examinerl the souchers returnerl by the bank. He diseveref no fraud while making that examination, for

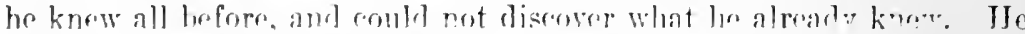
found ont nothing while arting as agent, but only while acting on 
his own account. He was still engaged in his scheme to defraud when he made the examination, and concealment was as necessary then as it had ever been. In concealing the fraud he did not act as agent, and he was engaged in concealing the fraud all the time after he began to carry on his system of forgery, and was so engaged when he examined the checks. In Frank v. Chemical Nat. Bank (84 X. Y. 209 ) the court said: "It was only because Goodheim was the criminal that the examination did not disclose to them the forgeries. He was not the plaintiffs' agent in issuing the forged paper, nor was he their agent in abstracting the false vouchers and falsifying the books, which was done in aid of his criminal purpose." If Goodheim, whose duty it was to examine the vouchers. discovered nothing imputable to the plaintiffs in that case, how could Daris, in examining the checks, make a discovery binding upon the plaintiffs in this case? Goodheim abstracted the false vouchers, so that the examination made by himself and the depositor would disclose no wrong, except by their absence, and Davis, whose duty it was to use the check punch, so used it as to leave sufficient space next to the dollar sign in which to subsequently cut a figure and thus raise the amount of the check. He also changed the footings at the bottom of the stub page of the check hook so as to prepare for the examination. If what Goodheim did was not binding on his principal, how can we say that what Davis did was binding on the plaintiffs? In neither case can the duties of the dishonest agent be so separated as to distinguish the fraud in concealing the forgery from the forgery itself, for each act was part of a single scheme. The forgery, the preparation for concealment and the constant concealment were suceessive steps in the same transaction. It cannot he held that what Davis would have discovered if he had not been the forger but somebody else, is imputable to the plaintiffs without also imputing to them linowledge of the space left to punch out another figure, as well as of the false fontings, for these arts were within the srope of his employment as much as the examination of the rouchers. In every case of suressful fraud by an agent, it is the nature of the duties intrusted to him that enables him to perpetrate the frand, and it is erroneons reasoning to say that if a part of those duties had heen intrusted to another clork, as he would have found out the facts. they must he impulod to the principal, beeause the latter in gond faith assigned such duties to the criminal.

Uncler the circomstanees, it cannot he presumed that Davis disclosed facts which an honest agent might have discovered in looking over the checks, but which the former knew before the checks ante to his hands for examination, withont subserting the reason upon which the rule of imputed knowledge is founded. Entertaining these views, I am compelled to dissent from those expressed in the prevailing 
opinion, so far as they are inconsistent with this memorandum, and (o) vete in faror of allirmanec.

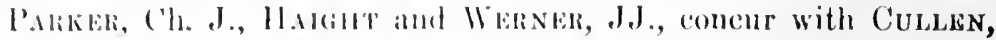

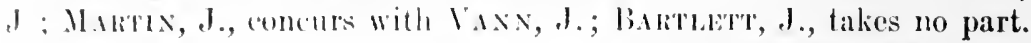
Judgment accordingly. ${ }^{7}$

F ser loug note to this ase in 2 (ol. Jaw kev. 4!o (November, 1902).

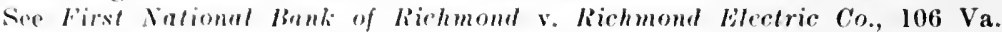
347. This ease is reported in 7 J. N. S. 744, wilh case note entitled, "Depositor's right to recover amount of forged or raised checks paid by bank as affected by the fate that he intrusted the examination of vouchers to the cmpleyee who was guilty of the original fraud." This note contains the following eareful and instructive analysis of the authorities:

"Assming that the depositor owes to the bank, and not merely to himself, the duty of verifying the account, and examining the vouchers returned by the bank, there are a number of difforent views. . . affecting the ultimate question whether the depositor is estoppel as against the bank by intrusting that duty to the dishonest employe. These views may he formulated as follows:

"(1) That, while the lepositor is not in the first instance chargeable with the disbonest employee's knowledge of his own fraud in raising or forging the check, yet, by intrusting the verifieation of the account and the examination of the vouchers to that employee, he becomes chargeable with the latter's antecelent knowledge. . . . [Citing, as in general support of this view, First Nat. Bank v, Richmond Fl. Co., 106 Va. 347, and First Nat. Bank v. Allen, 100 Ala. 476: as repudiating it, Kenneth Invest. Co. v. National Bank, 103 Mo. App. 613.1

"(2) That the effect of intrusting the verification of the account and the examination of the vouchers to the dishonest employee is the same as if no verification or examination had been made at all. . . [Citing August v. Fourth Nat. Bank, 15 N. Y. Supp. 139; and see view presented by the counsel for the bank in the case of Kenneth Invest. Co. v. Nat. Bank, supra, in his request to charge.]

"(3) That the duty resting upon the depositor to verify the account and examine the vouchers is not a personal one, fut may be delegated to a competent employee; and that the fraud, negligence or omission of such employee is not imputable to the depositor. In this view, the depositor is exonerated, if be las good reason to believe, and did helieve, that the employee in question was bonest and competent. . . Fiting as sustaining this viłw. Kenneth Inurst. Co. v. Nat. Bank, supra; Warhsmann v. Columbia Bnnk. 8 Mise. (N. Y.) 280; and Clark v. Nat. Shop of Leather Bank, 23 App. Div. 316 (obiter). atf'd in 164 N. Y. 504; and as at least impliedly supporting it, Frank v. Chem. Jat. Bank, S.t N. Y. 209.1

"(4) That the depositor who intrusts the verifieation of the account and the examination of the voucliers to the fraudulent employee, if in no worse, is at least in no better, position than if such duty had been intrusted to an honest and competent employee. This view assumes that the negligence or omission of such an employer would he imputable to the depositor;

In this view, it is apparent that the rights of the parties are made to turn upon the question whether an lonest and ermpetent employee, not having previous knowledge of the forgerice or other fraud, would, by the exercise of reasonable care, have discovered the same hy his examination of the vouchers. ,. [Citing, as sustaining this view, Critten v. Chemical Nat. Bank, 17] 


\section{$\S 326$ MCNEELY COMPANY $v$. BANK OF NORTH AMERICA.}

221 Pexisylvania, 58s. - 1908.

Actios by plaintiff against defendant bank to recover the amount of checks alleged to have been wrongfully paid by the bank. From an order dismissing exceptions to the report of the referee in favor of the defendant, plaintitf appeals.

Brows, J. McNeely Company, a corporation, was a depositor with the appellee, the Bank of North America, and had in its employ one Charles S. Reber, who between April 20, 1897, and Febrnary 24, 1903, forged the names of payees on 90 checks issued by it. *** The fact that Reber had forged some of the indorsenents was, as stated, discovered about Jannary 1, 19101 , and within two or three weeks thereafter it was known to the appellant that a very large number of the !o forgeries had heen conmitted; but no notice of this was given to the bank until nearly three months alterwards.

The duty of a depositor in a bank, upon discovering that it has paid: and charged to his aceomit either a check bearing his forged signature as drawer or his eheck on the forged indorsement of the payee, is to promptly notify it of the forgery. This notification is not only a duty, but it is what a depositor will instinctively do on discovering, upon the return of his bank look with canceled checks charged to his account, that there are among them some which he never signed or which were not paid to the payees named in them. 'This duty is not questioned by the learned comsel for the appellant. Their comtention is that, for the disegard of it, a depesitur is not to be harred from recovering from the hank what it may have paid on his forged signatures or on the forged indorsements of payees named in ehereks drawn by him, mless, by his faihure to prompity notify it of the forgeries, it has lost rights over anainst other parties, and the burben is upon it to prove such loss. Authorities aro not wanting to support

N. Y. 219, (the caso to which this is a netel: Mnun v. Vatiomal Bank, 1:32

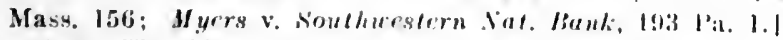

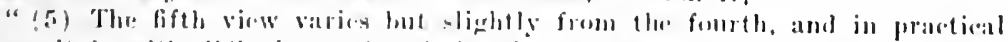

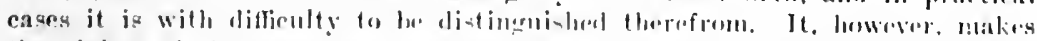

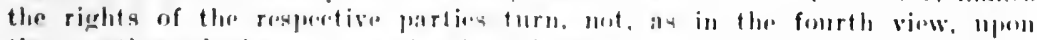
the question whether an axamination of the vollehere by all henest and com-

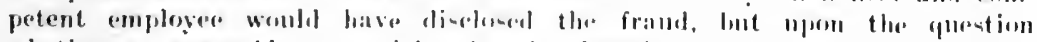

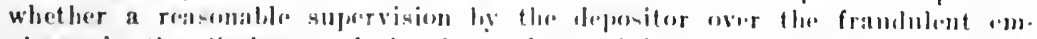

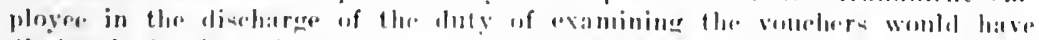
disclosed the forgeries. . . " fliting, as suntaining this view, lentler

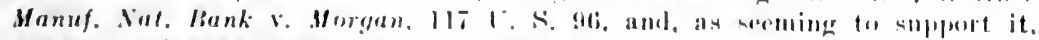

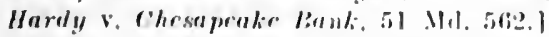

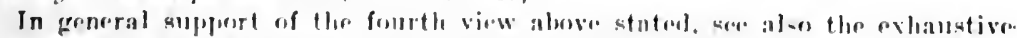

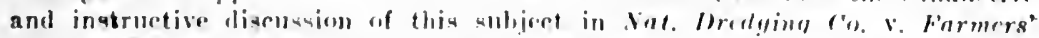

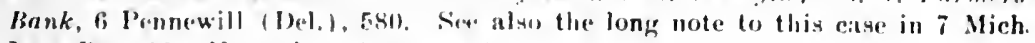

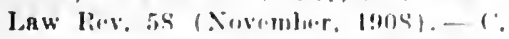


this, but the referee and court below did not follow them. Relying upon others, they ledel that the plaintiff, by reason of its failure to promptly notify the lank of its discovery of the forgeries, could not recover, even thomgh the bank had oflered no evidence that it could have protected itself and the plaintiff had not shown that it could not if prompt notice had been given.

The rolation between a bank and its depositor is a contractual one. Its molertaking with its depositor is to pay his checks, if he has sulficient funds with it for that purpose, and it assumes all the risk as against him of a mispayment in paying and charging to his account a cherk which he has not signed or one which he has signed bearing a forged indorsement of the payee. 'To his account it may not charge such a check. If it does, the depositor can recover from it the amount so charged. No payment by a bank on a forged signature of a depositor as drawer of a check or on a forged indorsement of his payee can affect him. His right is to get back from the bank whatever he lats deposited with it, less what has been properly paid out on his orders. 'The responsibility of the bank to the depositor is absolute, and it can retain no money deposited with it by him to reimburse it for any mispayment it has made out of such deposit; but it ean recover from a forger responsible for the mispayment, or from those who, by their indorsement of a cheek, have vouched for previous indorsements or the genuineness of the signature of the alleged drawer.

The right of a bank to recover from a forger, or from those to whom it may have paid a check bearing the forged signature of one of its depositors, or a forged indorsement, is its only remedy for the fraud practiced upon it by the forgery. The depositor's money is not affected by it, and, when he is the first to discover it, it is not reasonable that he should not be required to give prompt notice of it to the bank, if he intends to hold his depository liable for the mispayment, and this without regard to what may or may not result from a prompt effort to recover from the party or parties who may be liable to the bank for the mispayment. The depositor can gain nothing by withbolding knowledge of the forgery, but the bank, if kept in ignorance of it after his discovery of it, may lose everything. As soon as a bank learns that it has paid a check on a forged signature of a depositor, or on a forged indorsement on his check, it is its duty to promptly restore to the depositor's account what was improperly taken from it, and its right at the same time is to proceed agrainst those who wrongfully got the money. 'This right is to proeeed immediately, and to the promptness with which a bank is able to exercice it recovery is often due. When a depositor withholds from his bank his knowlerlge of the forgery, he withholds from it this right to proceed promptly for its own protection. It may or may not be able to recover from the forger by promptly proceeding against 
him, but its right is to try by so proceeding; and, when one of its depositors discovers that it has innoeently sustained a loss, he ought, not only in all good conscience, but as a legal duty, to notify it at once of its mistake; for by withholding from it what he has discovered he can, as just stated, gain nothing, but it may lose all. A forger may be insolvent or beyond the reach of civil or criminal process, but, by prompt procedings against hin, others may beeome interested in him and come to his assistance, who atter delay may not do so. 'This ineident to a bank's right to promptly proceed against a forger is not to be overlooked. Whenever a depositor knowingly withholds from it knowledge without which it cannot so proceed in an effort to protect itself, he ought to be regarded, when he comes to enforce alleged rights against it, as having withleld from it a substantial right, without regard to what might or might not have resulted from a prompt exercise of that right.

Other questions raised by the appellant need not be considered in view of the correct eonclusion of the court below that its delay in giving the appellee notice of the forgeries hars its right to recover.

The assignments of error are all overruled and the judgment is affirmed. ${ }^{9}$

8 In support of this position the court cites and disensses the following authorities: Rick v. Krlly and Rick v. Fisclier, 30 Pa. 527; Myrrs v. Southucstern Nat. Bank, 193 Pa. 1; United See. Life Ins. \& Trust Co. of Pa. v. Central Nat. Bank, 185 Pa. 586 ; and Leather. Manuf. Nat. Bank v. Morgan, 117 U. S. 96. - C.

9 This case is reported in 20 L. N. S. 79, with case note entitled, "Loss or prejuliee to bank resulting from negligent failure on part of lepositor or correspondent bank to give prompt notice of forgery, as a condition of its right to charge forgerd cliecks to latter's account." "The note says that "It seme to be the general rule, eontrary to that laid down in IfeVcely v. Bank of North Amerien, that before a baink is justified in chargingr the amount paid on forged paper against the aceount of a depositor or correspondent bank, hecause of negligence in discosering or reporting the forgery, it must show that, hreanse of sueh nugligenere it was prejudieed. or lost an opportunity to protect itsolf by action against the forger or other third party" : Citing Janin v. London 5 . S. F. Bank, 92 Cal. 14; Brixen v. Inseret Nat. Bank, 5 litah, 504; Third liat. Bank r. Mrrehants' Sat. Bank, i6 Hall. 475;

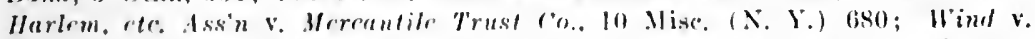

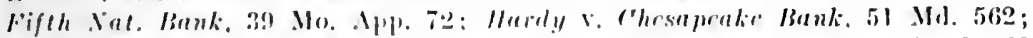
Murphy v. Ilet. Nat. Bank, I!l Mass. 159; Weinstcin v. Nat. Bank, 69 Tex. 38. - C. 


\section{Liability of Drawles to Drawer fol Wronglul Dishonor.}

\section{ATLAN'TIC NA'TIONAL BANK v. DAVIS.}

96 GноRян, $334 .-1895$.

Actron for damages for dishonoring plaintiff's eheck. The check whs for \$1:.ts. Plaintiff-had on deposit in defendant bank over s.300. By a mistake of a elerk payment was refused. Defendant on discovering the mistake wrote plaintiff explaining the matter and also wrote the holder or holder's forwarding bank explaining the frror and stating that plaintiff was one of defendant's best 'llstomers and had never drawn against his account without funds to his eredit. Verdict for plaintiff for $\$ 200$. Defendant appeals.

Luminin, Justice. - 1. 'The plaintill's (heck eame by due course of mail to the defendant bank, upon which it was drawn, and in which he had on deposit at the time suflicient funds with which to pay it. 'The eheck was returned unpaid. It seems clear from the evidence that this was done, not deliberately or maliciously, but in eonsequence of a mistake made by one of the employees of the bank. The paper was not protested nor wilfully dishonored. Still, so far as the plaintiff is concerned, we think what ocenred amounted to a refusal to pay his rheck. The consequences to him resulting from the inadvertence of the hank official were exactly the same as if there had been an express refusal to pay. We do not think a bank should be allowed to send out a paper with a badge of dishonor upon it, and then protect itself hy saying, in effect, that this was caused simply by its own carelessness.

2. It was not denierl that if the conduct of the bank amounted to a refusal to pay, it was liable in damages to the plaintiff; but the serious qunestion was, as to what should be the measure of such damagrs.

There was no proof of any actual or sperial damage, and the defendant therefore insisted that, at most, the damages awarded should be only nominal. We have given the subject some investiention, and as a result, we find ourselves mable to arecept this as a correct proposition of law. Tlle following authorities are pertinent, and throw much light unen the purestion:-

In 2 Adlison on ('ontract, \& 820 , the author, after stating the general rule that a banker is bound to bonor the cheress of his customers, if presented within banking hours and provided he has in hand suffecient funds for the purpose belongring to the customers, adds: "And if he refues, he is liahte to an action by the customer for substantial damages, without proof of actual damage; for it $i$ a a lizeredit

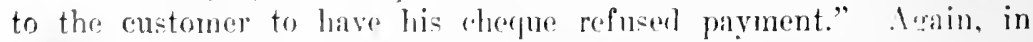
2 Morse on Banks, $\S 458$, after a statement of the general rute relat- 
ing the bank's duty in the premises, we find the following: "This duty and this right are so far substantial, that if the bank refuses, without sufficient justification, to pay the check of the customer, the customer has his action for damages against the bank. It has been said that if in such action the customer does not show that he has sufferen a tangible or measurable loss or injury from the refusal, he shall reeover only nominal damages. But the better authority seems to be, that even if such actual loss or injury is not shown, yet more than nominal damages shall be given. It can hardly he possible that a customer's check can he wrongfully refused payment without some impeachment of his credit, which must in fact be an actual injury, though he cannot from the nature of the case furnish independent distinet proof thereof."

Accordingly, it would seem that the plaintiff's recovery is not to be limited to merely nominal damages. We find authority for saying that in such a case he should be awarded "temperate" damages. Thus, in Birchall $r$. Third National Bank (19 Cen. Law J. 390 ), it was ruled that a bank is liable in temperate damages to a customer for a wrongful dishonor of his check, without proof of special damages. In the notes appended to an article on "Damages for Wrongful Dishonor of Chreks," following the report of the above eited case, will be found a large collection of anthorities, which may be of help to any one desiring to further pursue an investigation into this question. Another authority for the allowance of "temperate" damages to a customer for wrongful dishonor of his rheck, althnugh sperial damage is not slown. is Newmark on Special Bank Deposits, \$215: and the same rule is stated in $3 \mathrm{Am}$. and Eng. Ene. of Law, p. 226, under the title "Clieckis" (2d ed., rol. 5, pl. 1059-1060). In a note to the trext, Birchall's caser, supro, is rited.

3. In view of all the evidence disolosed by the resord, we think the verdict for $\$ 200$ remlered in the present case was "temperate," and therefore sustainable.

\section{Judgment affirmed.'}

1 Accord: Sichaffurr r. Ehrman, 139 III. 109, where a julgment for $\$ .150$

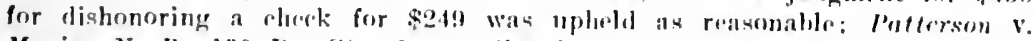
Marine N. B., 130 Pa. St. 4I9, verdiet for $\$ 300$ held reasonable. See also Bank of Commeree v, Gons, 39 Nob. 437. Where the depositor proecels as for a breach of contraet and not in tort it seeme that in the abserere of allegation and proof of sperial damages, he can recover ouly uominal daluages.

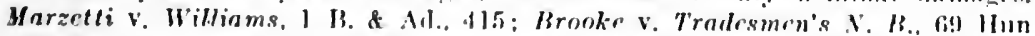
(N. Y.), 202; Burroughs v. Tradlesmen's N. B., 87 Hun (N. Y.), 6: ('itizens" N. B. v. Importers and Trallers' Bank, 119 N. Y. 195. - II.

[All the nuthorities agres that an action lies against a hank by a de. posjtor for the wrongful dishonor by the former of the latter's clierk, and that the depositor ly proving apecial loss is entitled to recover eompensatory damages. But where the depositor does not allege and prove apecial damages, the courts disagres as to whotler loe should be entitled to sulsatantial dam. 
ages or the confined to nominal damages only. On this point see lorick v. Palmetto Bank, it S. Cin. 1s5. reported with note in 7 A. \&. E. Ann. Cas. sls: Columbia Nat. Bank v. Machnight, 2!) App. Cns. Dist. of Col. 580, reported with note in $10 \mathrm{~A}$. \& $1 \%$. Ans. Cas. 897 ; and Third Nat. Bank of st.

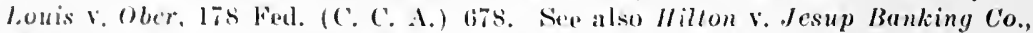
128 Ga. 30, reported in 10 A. \& E. Ann. ('is. 978, with note entitled "Admissibility in netion by depositor for damiages for wrongful dishonor of check, of evidence of lepositor's tinaneial stamding and eredit."

Some cases distinguish between an action brought by a merchant or trader, and one brought by a person who is not a merchint or trader. 'Thus, the court in Third Nat. Bank of St. Louis v. Ober, supra, said: "If the depositor is a merchant or trader, it will be presumed, without further proof, that substantial damages have been sustained. Schaffner v. E'hrman, 139 Ill. 109: James Co. v. Bank, 105 Tenn, 1; Svendsen v. Bank, 64 Minn. 40. This rule proceeds upon the fact. commonly recognized, that the eredit of a person engagel in such a calling is essential to the prosperity of his business, and the dishonoring of his checks is plainly caleulated to impair it and to infliet a most serious injury. In common opinion, substantial damage is the natural and probable eonsetnence of the act. and therefore a substantial recovery may be hal, withont pleading or proof of special damage. . . . On the other hand, if the depositor is not a merehant or trader, there is no such presumption of substantial injury, and his recovery should be a nominal one, unless he pleads and proves some special damage." But see Col. Nal. Bank v. Machnight, supra, where the court said: "Although in this case the plaintiff was a physician, and not a trader, we think the jury should not have been confined to nominal damages only."

Some confusion has also arisen because of the failure to distinguish between the cases (1) where the depositor proceeds as for a breach of eontract. and (2) where he proceeds in tort. For an excellent statement of the different considerations affecting the measure of damiges in these two classes of cases, see Daris v. Standard Yal. Bank, 50 App. Div. (N. Y.) 210.

In Callohan v. Bank of .1nderson, $69 \mathrm{~S}$. ('ar. 374. it was held by an evenly divided court that where a depositor has deposited with a bank funds suffcient to meet payment of a check drawn by him in favor of a third party, he has a riglit of action against the bank for its rofusal to pay such check in the absence of notice to him that the bank hals applied the funds so deposited in extinguishment of past dne elaims held against him. See this case reported in 2 A. \& E. Ann. Cas, 203, with note entitled, "Bank's lien or set-off against deposit for debt due it by depositor." - C.] 
PART II.

STATUTES 


\section{THE NEGOTIABLE INSTRUMENTS LAW.}

The Law has been enacted in the following states and territories:

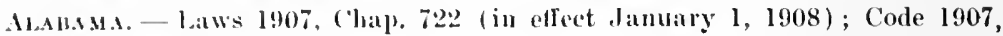
('hap). 115 , Sees. $4 ! 58-51+4 !$ ).

Arrzosa. - Rev. Sitat. 1!01, p. s52, title 4! of ('ivil Cote, Sees. 3304-3491 (in effect september 1, 1901): Laws 1905, ('hap. 23.

(onomon. - Laws 1897, (hap. tit (approved April 20, 1897); Rev. Stat. $1908,1 \%$. 1104-1126, Sees, $4464-4659$.

Coxxecticet. - laws Is!7, ('hap. 7. (approved Apr. 5, 1897); Genl. Stat. liev. 1902, p. 1028.

Distbict of (oI.IMBiA, - Jaws U. S. 1899 (in effect Apr. 3, 1899) ; Laws U. S. 1901; Laws U. S. 1902, Sees. 1304-1493.

Florim. - Laws 1897 , ('hap. 4524 (approved June 1, 1897) ; Genl. Stat. 1906 , p. 1147 ; Sees. 2394-3099.

Hawa11. - Laws 1907, det 89, p. 118 (approved Apr. 20, 1907).

losiro. - Laws 1903, p. 380 (in elreet Mar. 10, 1903).

ILL1xo1s. - Laws 1907, I. 403 (approved Jume 5, 1907).

Jows. - Laws 1902. Chap. 130 (approved Apr. J2, 1902); Laws 1906, Chap. 149: Code Supp. 1902, p. 352, Chap. 3-A, Sees. 3060-al-3060-a 198.

Kaxsas, - Laws 1905. (bap. 310 (in elfeet Jume 8, 1905); Genl. Stat. 1905 , p. 967, Chap. 70, Sees, 4533-4732.

Kextucky. - Laws 1904, Chap. 102 (approved Mareh 24, 1904).

Louisiana, - Laws 1904, Chap. 64 (approved June 29, 1904).

Marylaxd. - Laws 1898, Chap. 119 (approved Mareh 29, 1898).

MassachesetTs, - Laws 1898, Chap. 533 (in effect Jimuary 1, 1899); Laws 1899, Chap. 130; Rev. Laws 1902, p. 628, Chap. 73. Sees. 18-212; Laws 19]0, (hap. 4]\%.

Michicis. - Laws 1905, ('hap. 265 (approved Jume 16, 1905).

Missolri. - Jaws 1905, p. 243 (approved Apr. 10, 1905) ; Laws 1907, p. 366.

Montaxa. - Laws 1903, ('bap. 121 (in effeet Mareh 7, 1903).

Nrmmsка. - Jaws 1905, (hap. 83 (in effect August 1, 1905); Comp. Stat. 1907, chap. 41, Sees. 3558-a1-3558-al!s.

Novalu.- Laws 1907, (hap. 62 (in effect May 1, 1907).

NEW IlaMPSHRE. - Laws 1:109, ('hap. 123 (in effeet January 1, 1910).

New Jersey. - Laws 1!902, ('hap. 184 (approved April 4, 1902); Laws 1908, chap. 215.

New Mtexico. - Laws 1907, (hap. 83 (approved March 21, 1907).

New York. - laws 1s97, ('hap. (112; (in effect Oetoler 1, 1897); Laws 1898. (hap. 396: Jaws 1904. ('hap. 287; Cons. Laws, 1909, Chap. 43.

Nort n (Akolixs. - Laws 1899, ('hap. 733 (in effeet Mareh 8, 1899); Laws 1305, ('hap. 327; Laws 1907, Chap. 807; Revisal, 1905, p. 655, Chap. 54, Sees. 2151-2346.

NortI DAKoTA. - Laws 1899, ('hap. 113 (approved March 7, 1899); Civil Code, 1905, p. 1002, Chap. 90, Sces. 6303-6498. 
OHio. - Laws 1902, p. 162 (in effect January 1, 1903) ; Bates' Annot. Stat. (5th ed.), pp. 1800a-1807, Sces. 3171-317se.

OKLAHOMA.- Laws 1909, Chap. 24 (approved Mareh 20, 1909); Comp. Laws, 1909. Chap. 69, p. 1044, Sees. 4435-4624.

Orfiox. - Laws 1s99, p. 18 (approved February 16. 1899): Ballinger \& Cotton's Annot. Codes \& Stat., p. 1440, Sees. $4403-4594$.

Pennsylyajia. - Laws 1901, No. 162 (in effect September 2, 1901); Laws 1909, No. 169, p. 260.

RHode IsL.1xp. - Laws 1899, Chap. 674 (in effect July 1, 1899) ; Gen. Laws 1909, p. 648, Chip. 200.

Texressee. - Laws 1899, (hap. 94 (in effect May 16. 1899).

UrAu. - Laws 1899, Chap. 83 (in effeet July 1. 1899).

Virgixia. - Laws 1898, Chap. 866 (approved March 3, 1898); Laws 1906; Chap. 219: Code, 1904, (hap. 133a, See. 2841 a.

Washixgtox. - Laws 1899, ('hap. 149 (in effect Mareh 22. 1899): Remington \& Ballinger's Annot. Codes and Stat., Vol. 2. p. 120. Secs. 3392-3586.

West Vibginia, - laws 1907, Chap. 81 (in eflect January 1. 1908)

Wiscossix. - Laws 1899, Chap. 356 (in effect May 15, 1899): Laws 1901, Chap. 41; Laws 1905, Chap. 262; Laws 1907, Chap. 361.

Wroming. - Laws 1905, Chap. 43 (approved February 15, 1905); Comp. Stat. 1910, Chap. 210, Secs. 3159-3354. 


\section{EXPLANATORY NOTE.}

Tin text is that of the New York Negotiable Instruments Law. The material in the notes in brackets is taken from the notes of the draftsman of the act (.J. J. Crawford, Esq.), as they appeared in the draft printed by the Commissioners on Umformity of Laws. The reference, "Pages $x-x$ " is to the "Cases and Authorities" contained in Part I of this volume. The reference "Chalmers" is to ('halmers' Bills of Exchange Aet (5th ed.), London, 1896. The reference to "Daniel" is to Daniel on Negotiable Instruments. 


\section{THE NEGOTIABLE INSTRUMENTS LAW.}

Laws of New York, 1909, Chapter 43. ${ }^{1}$

AN ACT in relation to negotiable instruments, constituting chapter thirty-eight of the consolidated laws.

Decame a law February 17, 1909, with the approval of the Governor. Passed, three-fifths being present.

The People of the State of New York, represented in Senate and Assembly, do enact as follows:

\section{CHAPTER 38 OF THE CONSOLIDA'TED LAWS.}

\section{Negotiabie Instruments Law.}

ARTiCle I. SHORT TITLE; DEFINitions. (\$\$ 1, 2.)

II. Gexeral provisions. $(\$ \$ 3-7$.)

III. ForM Axp IxterpRetatiox. (\$§ 20-42.)

IV. CoNsideratiox. (\$\$ 50)-55.)

V. Negotiation. (\$\$ 60-80.)

VI. RIGHTS OF HOLDER. (\$\$ 90-98.)

VII. Liabilities of parTies. (\$\$ 110-119.)

VIJ. l'ResENTMEX Fol l'AYMENT. (\$S 130-148.)

JX. Notice of DIsItoxor. (\$\$ 160-189.)

X. DISCHARGE. (\$\$ 200-20ti.)

X1. Billas of l:xchaxik: FokM axd isterpretation. (\$\$ 210-215.)

XII. ACCEPTAXCE. (\$\$ 220-230.)

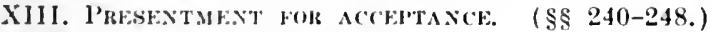

XIV. PHOTEST. (\$\$ 260-268.)

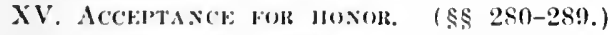

XVI. PAYMEXT FOR Hoxol. $(\$ \$ 300-306$.

XVJJ. liLLs Is St:TS. (\$\$ 310-315.)

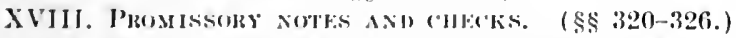

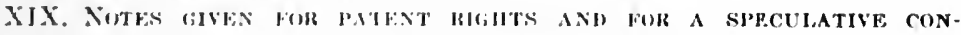
SHнRлTlo., (\$\$ 330-332.)

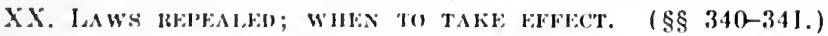

The uniform Nongtiable Instru. thus ebanging lhe original mumbering ments law was origillally anacted in of articles 24019 ; a fow additional Now York by L. 1s97, e. file. C"ertain arrors were eorrected, and a fow ver. errors, most of them manifest on the hal clunges made. The existing act, face of the act itself. were corrected lowever, is for all practical purposen by I. 1898, c. 336. When it was ill. the same as when it was originally on. corporated into the eomenlidated law4 aetod exerpt for the addition of $\$ 326$ in 1909. eretioms 3 to 7 wre male la J. 1904, c. $287 .-$ C. into a separate article, numberesl 2 


\section{AR'TICLE 1. \\ SIIOR'T TITLE: DEFINITIONS.}

Secriox 1. Short title.

2. Definitions.

\section{$\S 1$. Short title.}

'This chapter shall be known as the "Negotiable Instruments Law."

\section{$\S$ 2. Definitions.}

In this chapter, unless the context otherwise requires:

"Acceptance" means an aceptance completed by delivery or notification.

"Action" inehdes connter-elaim and set-off.

"Bank" includes any person or association of persons earrying on the busines of banking. whether incorporated or not.

"Parer" means the person in possession of a bill or note which is payahle to bearer.

"Bill" means bill of exchange, and "note" means negotiable promissoly note.

"Delivery" means transfer of possession, actual or constructive, from one person to another.

"Inolder" means the payce or indorsee of a bill or note, who is in possession of it, or the bearer thereof."

"Indorsement" means an indorsement completed by delivery.

"Instrument" means negotiable instrument.

"Issue" means the first delivery of the instrument, complete in form, to a person who takes it as a holder.

"Person" includes a body of persons, whether inconporated or not.

"Value" means valuable consideration.

"Written" includes printed, and "writing" includes print.

See Pills of Exchange Act, section 2.

\section{AR'TICLE II.}

\section{GENERAI, PROVISHONS.}

Sectior 3. Person primarily liable on instrument.

4. Reasonable time, what com-titutes.

5. Time, low computed when last day falls on holiday.

6. Application of chapter.

7. Law merchant: when governs. 


\section{$\S 3$. Person primarily liable on instrument.}

The person "primarily" liable on an instrument is the person whe by the terns of the instrument is absolutely required to pay the same. All other parties are "secondarily" liable.

\section{$\S$ 4. Reasonable time, what constitutes.}

In determining what is a "reasonable time" or an "unreasonable time" regard is to be had to the nature of the instrument, the usage of trade or business (if any) with respeet to such instruments, and the facts of the particular case.

See Bills of Exchange Act, sections 40, 45, 74, 86. See pages 484, 737.

\section{$\S 5$. Time, how computed; when last day falls on holiday.}

Where the day, or the last day, for doing any act herein required or permitted to be done falls on Sunday or on a holiday, the act may be done on the next succeeding secular or business day.

See $\S 145$. See N. Y. General Construction Law, $\$ \S 20,30$.

\section{§ 6. Application of chapter.}

The provisions of this ehapter do not apply to negotiable instruments made and detivered prior to Oetober first, eighteen hundred and ninety-seven.

\section{$\S 7$. Law merchant; when governs.}

In any case not provided for in this act the rules of the law merchant shall govern.

\section{ARTICIE III.}

\section{FORM AND INTERPRETATION.}

Secrios 20. Form of negotiable instrument.

21. Certainty as to sum; what constitutes.

22. When promise is unconditional.

23. Determinable future time; what constitutes.

24. Additional provisions not affecting negotiability.

25. Onissions; sral; partieular money.

26. When payable on demaud.

27. When payable to order.

28. When payahle to benrer.

29. 'Terms when suflicient.

30. Date; presumplion as to.

31. Anterlated and post-ilated.

32. When date may he inserted.

33. Blanks, when maty be fillorl.

34. Inecomplete inatrument not delivered.

35. Delivery; when eftectual: when presumed.

36. Construction where instrument is ambiguous.

37. Liability of person signing in trale: or assumed name.

38. Signature by agent; muthrority; lorw shown. 
39. Liability of person signing as agent.

40. Siguature by procuration; effeet of.

41. Effect of indorsement by infant or corporation.

42. lorged signature; effect of.

\section{$\S 20$. Form of negotiable instrument.}

An instrument to be negrotiable must conform to the following requirements :

1. It must be in writing ' and signed by the maker or drawer ${ }^{2}$

2. Must contain an unconditional ${ }^{3}$ promise $^{4}$ or order ${ }^{5}$ to pay a sum certain ${ }^{\circ}$ in money; ${ }^{7}$

3. Must be payable on demand ${ }^{8}$ or at a fixed or determinable future time: ${ }^{9}$

4. Must be payable to order ${ }^{10}$ or to bearer $;^{11}$ and

5 . Where the instrument is addressed to a drawee, he must he named or otherwise indicated therein with reasonable certainty.: 2

[Note. - See Bills of Exchange Act, sections 3, 4, 5, 6.] For definition of bill, note, check, see $\$ \$ 210,320,321$.

\section{$\S 21$. Certainty as to sum; what constitutes.}

The sum rayable is a sum certain ${ }^{13}$ within the meaning of this chapter, although it is to be paid:

1. With interest; ${ }^{14}$ or

2. By stated installments $;{ }^{15}$ or

3. By stated installments, with a provision that upon default in payment of any installment or of interest, the whole shall become due; ${ }^{16}$ or

4. With exchange, whether at a fixed rate or at the current rate: ${ }^{17}$ or

5. With costs of collection or an attorney's fee, in case payment shall not be made at maturity. ${ }^{18}$

[Note. - See Bills of Exchange Act, seetion 9.]

\section{$\S 22$. When promise is unconditional.}

An unqualified order or promise to pay is unconditional within the meaning of this chapter, though coupled with:

1 See \& 2. Pages 34-35.

2 Pages 35-37.

3 See \& 22 . Pages 46-61.

4 Pages 37-44.

S Pages 44-45.

- See \& 21. Pages 61-80.

7 Pages 81-89.

Soe \& 26. Pages 96-97.

- See § 23. Pages 97-106.
10 Sec \& 27. Pages 107-122.

1 See \& 28 . Pages 122-148.

12 See $\$ 210$. Pages 148-150.

13 Pages 61-64.

14 Pages 64-67.

15 Pages 67-72.

16 Pages 72-74.

17 Pages 74-78.

18 Pages 78-80, 
1. An indication of a particular fund out of which reimbursenent is to be made, or a particular account to be debited with the amount; ${ }^{19}$ or

2. A statement of the transaction which gives rise to the instrument. ${ }^{20}$

But an order or promise to pay out of a particular fund is not unconditional. ${ }^{21}$

[Note. - See Bills of Exchange Act, section 3, subdivision 3.]

\section{$\S$ 23. Determinable future time; what constitutes.}

An instrument is payable at a determinable future time, within the meaning of this chapter, which is expressed to be payable:

1. At a fixed period after date or sight; ${ }^{22}$ or

2. On or before a fixed or determinable future time specified therein ${ }^{23}$ or

3. On or at a fixed period after the occurrence of a specified event, which is certain to bappen, though the time of happening be uncertain. ${ }^{24}$

An instrument payable upon a contingency is not negotiable, and the happening of the event does not cure the defect. ${ }^{25}$

[Nore. - See Bills of Exchange Act, section 11.]

\section{$\S 24$. Additional provisions not affecting negotiability.}

An instrument which contains an order or promise to do any act in addition to the payment of noney is not negotiable. ${ }^{1}$ But the negotiable character of an instrument otherwise negotiable is not affected by a provision which:

1. Authorizes the sale of collateral securities in case the instrument be not paid at maturity $;{ }^{2}$ or

2. Authorizes a confession of judgment if the instrument be not paid at maturity; ${ }^{3}$ or

3. Waives the benefit of any law intended for the advantage or protection of the obligor ; ${ }^{4}$ or

4. Gives the holder an election to require something to be done in lieu of payment of money."

But nothing in this section shall validate any provision or stipulation otherwise illegal.

10 Pages 50-54.

20 Pagess 55-61.

21 Page 4!.

22 Page 17.

28 Pages $97-102$.

95.]
25. Pages 46-50, 103-106.

S Pages 90-91.

2 Pages 91-92.

- Page 93.

4 Page 94.

24 l'ages I02-103. [Byles on Bills, :Pages 94-96. 


\section{\$ 25. Omissions; seal; particular money.}

'The validity ant negotiable character of an instrument are not affected by the fart that:

1. It is not duted; ${ }^{\text {or }}$

$\therefore$ Does not specify the value given, or that any value has been given therefor: ${ }^{6}$ or

3. Does not specify the place where it is drawn or the place where it is payable: "or

4. Bears a seal; ; or

5. Designates a particular kind of current money in which payment is to be male. ${ }^{8}$

But nothing in this section shall alter or repeal any statute requiring in certain cases the nature of the consideration to be stated in the instrument.?

[Note. - Sce Bills of Exchange Act, section 3, suldivision (4).]

\section{$\S 26$. When payable on demand.}

An instrument is payable on demand:

1. Where it is expressel to be payable on demand, or at sight, ${ }^{10}$ or on presentation; or

2. In which no time for payment is expressed. ${ }^{10}$

Where an instrument is issued, accepted or indorsed when overdue, it is, as regards the person so issuing, accepting or indorsing it, payahle on demand."

[. Yote. - See Bills of Exchange Act, section 10.]

\section{$\S 27$. When payable to order.}

The instrument is payable to order where it is drawn payable to the order of a specified person or to him or his order. ${ }^{12}$ It may be drawn payable to the order of :

в Pages 158-159. See \$ 32 . “I'nder most of the contiuental cordes it is essential that a bill should be daterl." ('haimers, p. 13. And state a con-ideration. Il., p. 14. And in some it is neewssary that a bill should lo parable in a plaes different to that in which it is marle. "No distance is fixel by the eorles, "hut it has been deciderl that the place of payment must be so far rlistant from the place of icsue that thero may be a possible rate of exchange between the two." Ib., p. 15.

7 Pages 159-160. I'This is the rule in many states ly statute. See Daniel. § 33. Ser also Wreks v. Esler, 143 N. Y. 374.$]$

* Pages 81-89. [Danicl, \$ 56 et seg., and cases cited.] a See New York Neg. Inst. I., $\S \S 330-331$.

10 Page 96.

11 Page 97.

12 ['The Bills of Exchange Aet provides that "a bill is payable to oreler which is expressed to be so nayable or which is expressed to be payable to a particular person and does not contain words prohibiting transfer or indicating an intention that it should not be transferable." But this changes the law (Byles, 83; Smith v. Kendall, 6 T. R. 123; Manle v. Crawford, 14 IJun, 193; Daniel on Neg. Inst., section 105), and the change is not deemed arlvantageous. Frederick v. ('otton, 2 Shower, 8; Smith v. Meclure, '5 Fast, 476; Howard v. Palmer, f4 Me. 86; Daniel, \& 106.] 
1. A payee who is not maker, drawer or drawee; or

2. The drawer or maker ${ }^{13}$ or

3. 'The drawee ${ }^{14}$ or'

4. 'Two or more payees jointly ;'s or

5 . One or some of several payees $;^{16}$ or

6. The holder of an office for the tine being. ${ }^{17}$

Where the instrument is payable to order the payee must be named or otherwise indicated therein with reasonable certainty. ${ }^{18}$

| Nots. - Sise Bills of Exciange Aet, sections 5, 7. 8.1

\section{\$ 23. When payable to bearer.}

'l'he instrument is payable to bearer:

1. When it is expressed to be so payable $;^{19}$ or

2. When it is payable to a person named therein or bearer; ${ }^{19}$ or

3. When it is payable to the order of a fictitious or non-existing person, and such fact was known to the person making it so payable; ${ }^{20}$ or

4. When the name of the payee does not purport to be the name of any person; ${ }^{21}$ or

5. When the only or last indorsement is an indorsement in blank.:-"

[NoTk - See Bills of lixchange Act, sections 7, 8.]

\section{$\S 29$. Terms when sufficient.}

'The instrument need not follow the langnage of this chapter, but ?ny terms are sufficient which clearly indicate an intention to conform to the requirements hereof.

\section{30. Date, presumption as to.}

IV here the instrument or an acreptance or any indorsement thereon is dated, such date is deemed prima facie to be the true date of the making, drawing, arceptance or indorsement as the case may be. ${ }^{23}$

| Nork. - Sere litle of lixehangu Act, section 13.]

\section{$\S 31$. Ante-dated and post-dated.}

'The instrument is not invalid for the reason only that it is antedated or jost-dated, provided this is not done for an illegal or fraudulent purposs. T'le person to whom an instrument so dated is delivered arpuites the title thereto as of the date of delivery. 24

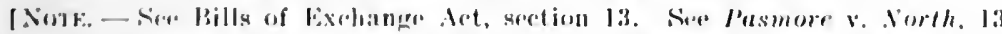

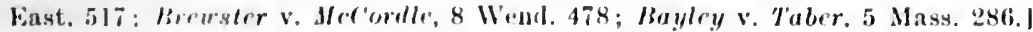

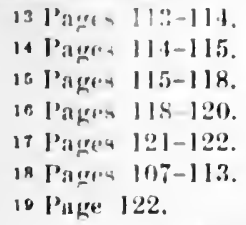

NHGOT, INATIUMENTH - 50 


\section{\$ 32. When date may be inserted.}

Where an instrument expressed to be payable at a fixed period after date is issued undated, or where the aleceptance of an instrument payable at a fixed period after sight is undated, any holder may insert therein the true date of issue or aeceptance, and the instrument shall be payable accordingly. ${ }^{25}$ The insertion of a wrong date does not aroid the instrument in the hands of a subsequent holder in due course; hut as to him, the date so inserted is to be regarded as the true date."

[Note. - See Bills of Exchange Act, section 12. See note, section 7.]

\section{$\S 33$. Blanks; when may be filled.}

Where the instrument is wanting in any material particular, the person in possession thereof has a prima facie anthority to complete it by filling up the blanks therein. ${ }^{2}$ And a signature on a blank praper delivered by the person making the signature in order that the paper may be converted into a negotiable instrument operates as a prima facie authority to fill it up as such for any amount. ${ }^{3}$ In order, however, that any such instrument, when completed, may be enforced against any person who becane a party thereto prior to its completion, it must be filled up strietly in accordance with the authority given and within a reasonable time. But if any such instrument, after completion, is negotiated to a holder in due course, it is valid and effectual for all purposes in his hands, and he may enforee it as if it hat been filled up strictly in accordance with the authority given and within a reasonable time. ${ }^{4}$

[Note. - See Bills of Exchange, section 20.] See $\$ 206$.

\section{$\S 34$. Incomplete instrument not delivered.}

Where an incomplete instrument has not been delivered it will not, if completed and negotiated, without authority, be a valid contract in the laands of any holder, as against any person whose signature was placed thereon hefore delicery.

1 Note. - Ser Daris Machine Co. v. Best, 105 N. Y. 59, 67; Sedguick v. If Kim, 53 X. Y. 307, 313; Baxendale v. Bennett, L. R. 3 Q. B. 525; Daniel, $\S \S 841,842 a$.]

\section{§ 35 Delivery; when effectual; when presumed.}

Fvery contract on a negotiahle instrument is incomplete and revocahle until delivery of the instrument for the purpose of giving effect thereto. As betwon immediate parties, and as regards a remote party other than a holler in lue course, the delivery, in order to be effectual, must be made either by or under the authority of the party

25. See $\$ 33$.

1 Pages 16i3-168.

Pages 163-168.
3 Pages 168-174.

4 Pages 174-192. 
making, drawing, accepting or indorsing, as the case may be; and in such case the delivery may be shown to have been conditional, or for a special purpose only, and not for the purpose of transferring the property in the instrument." But where the instrument is in the hands of a holder in due course, a valid delivery thereof by all parties prior to him so as to make them liable to him is conclusively presumed. And where the instrument is no longer in the possession of a party whose signature appears thereon, a valid and intentional delivery by him is presumed until the contrary is proved. ${ }^{\circ}$

[Note. - See Bills of Exchange Act, section 2].]

\section{$\S 36$. Construction where instrument is ambiguous.}

Where the language of the instrument is ambiguous, or there are omissions therein, the following rules of construetion apply:

1. Where the sum payable is expressed in words and also in figures and there is a discrepancy between the two, the sum denoted by the words is the sum payable; but if the words are ambiguous or uncertain, references may be had to the figures to fix the amount: ${ }^{7}$

2. Where the instrument prorides for the payment of interest, without specifying the date from which interest is to run, the interest runs from the date of the instrument, and if the instrument is undated, from the issue thereof $;{ }^{8}$

3. Where the instrument is not dated, it will be considered to be dated as of the time it was issued ${ }^{\circ}$

4. Where there is a conflict between the written and printed provisions of the instrument, the written provisions prevail: ${ }^{10}$

5. Where the instrument is so ambiguous that there is doubt whether it is a bill or note, the holder may treat it as either at his election; ${ }^{11}$

6. Where a signature is so placed upon the instrument that it is not clear in what capacity the person making the same intended to sign, he is to be deemed an indorser; ${ }^{12}$

7. Where an instrument containing the words "I promise to pay" is signed by two or more persons, they are deemed to be jointly and severally liable thereon. ${ }^{13}$

[Notr. - See Bills of Fxchange Aet, section 9.]

\section{§ 37. Liability of person signing in trade or assumed name.}

No person is liable on the instrument whose signature docs not appear thereon, except as herein otherwise expressly provided." But

- Pages 151-152.

- Pages 152-158. See 834.

TPages 192-194.

- Pagea 194-19.5.

- Page 195. ș 25, 30-32.

10 Pages 195-196.
11 Page lag.

12 Sre $\$ \$ 113.114$.

13 Pages 196-197. ISre Bills of Ex.

change Act, section 85.1

14 Pages 197-199. See $\$ 72$. 
one who signs in a trade or assumed name will be liable to the same extent as if he had signed in his own name.

f Note. - Sere Bills of lixchange Act, secetion 23.]

\section{§ 38. Signature by agent; authority; how shown.}

'The signature of any palty may be made by a duly authorized agent. No particular form of appointment is necessary for this purpose: and the anthority of the agent may be established as in other cases ot ageney.

\section{§ 39. Liability of person signing as agent.}

Where the instrument (ontains or a person adds to his signature words indicating that he signs for or on behalf of a principal, or in a representative aparily, he is not liable on the instrument if he was duly anthorized; ${ }^{15}$ "hut the mere addition of words describing him as an agent, or as filling a representative character, without disclosing his principal, does not exempt him lrom personal liability. ${ }^{6}$

[NoTE. - See Bills of Exchange Act, section 26; Byles on Bills, 36; Daniel, $\S \S \div 9 S-302$.

\section{$\S 40$. Signature by procuration; effect of.}

A signature by "procuration" operates as notice that the agent has hut a limited authority to sign, and the principal is bound only in case the agent in so signing acted within the actual limits of his authority. ${ }^{17}$

[Yote. - See Bills of Exchange Act, section 25; Byles on Bills, 33 ; Daniel, $\S 280$.

\section{§ 41. Effect of indorsement by infant or corporation.}

The indorsement or assignment of the instrument by a corporation or by an infant passes the property therein, notwithstanding that from want of rapacity the colporation or infant may incur no liability thereon. ${ }^{18}$

[Xote. - Sie Bills of Exchange Act, section 22.]

15 Page- 216-21!.

16 Pages $19 ! 1-216$.

17 l'ages $219-220$.

18 Pages 220-22l. Tlis section " is probably declaratory, but the law was not very clear." 'Chalmers, p. 60. "rapacity to incur liability must be distinguished from eapreity to transfer. * * An indorsement usually consists of two distinct eontracts, one exrcuted, the other excoutriy. It transfers the property in the lill, and it also involves a contingent liability on the part of the indorser." (Ib.) "liy this section, when a bill is payable to the order of an infant, his indorsement tranfers the property therein. * * In America it is not uncommon to get a bill made payable to the order of an infant clerk. IIis indorsement then operates as an inclorsement suns reonurs, though without discrediting the bill." (Ib., p. 63.) 


\section{$\S$ 42. Forged signature; effect of.}

Where a signature is forged or made without authority of the person whose signature it purports to be, it is wholly inoperative, and no right to retain the instrument, or to give a discharge therefor, or to enforce payment thereof against any party thereto, can be acquired through or under such signature, ${ }^{19}$ unless the party, against whom it is sought to enforce sneh right, is preeluded from setting up the forgery or want of authority. ${ }^{20}$

[NotE. - See Bills of Exclange Act, section 24.]

\section{ARTICLE IV.}

\section{CONSIDERATION.}

Section 50. Presumption of consideration.

51. What constitutes consideration.

52. What constitutes holder for value.

53. When lien on instrument constitutes holder for value.

54. Eflect of want of consideration.

55. Liability of accommodation party.

\section{$\S 50$. Presumption of consideration.}

Every negotiable instrument is deemed prima facie to have been issued for a valuable consideration; and every person whose signature appears thereon to have become a party thereto for value.21

[Notf. - See Bills of Exchange Act, section 30.]

\section{$\S 51$. What constitutes consideration.}

Value ${ }^{22}$ is any consideration sufficient to support a simple contract. An antecedent or pre-existing debt constitutes value; and is deemed such whether the instrument is payable on demand or at a future time. ${ }^{23}$

\section{$\S 52$. What constitutes holder for value.}

Where value has at any time been given for the instrument, the holder is deened a holder for value in respect to all parties who becane such prior to that time. ${ }^{24}$

[Note. - Sis Bills of Buchange Act, section 27, suludivision (2)].

\section{$\S 53$. When lien on instrument constitutes holder for value.}

Where the holder has a lien on the instrument, arising either from

19 Yagea 221-225.

20 Priges 225-233. "Mlie word" pre. cluded' was inserterl in eommitter. in lien of the word 'estoppres],' an Fing. lish technical torm, unknown to the Scotch law." Chalmers, J. 74.
21 l'ages 234-238.

22 See $\$ 2$.

23 l'ages $239-249$.

24 l'ages 249-251. A holder for value may or may not be a holder in due course. Sice $\$ 91$. 
contract or hy implication of law, he is deemed a holder for value to the extent of his lien. ${ }^{23}$

1 Nore - See Bills of Exchange Act, section 27.]

\section{$\S 54$. Effect of want of consideration.}

Absence or failure of consideration is matter of defense as against any person not a holder in due course; ${ }^{2}$ and partial failure of consideration is a defense pro lanto whether the failure is an ascertained and liquidated amomit or otherwise."

\section{§ 55. Liability of accommodation party.}

An accommodation party is one who has signed the instrument as maker, drawer, aceeptor or indorser, without receiving value therefor, ${ }^{3}$ and for the purpose of lending his name to some other person. Such a person is liahle on the instrument to a holder for value, notwithstanding such holder at the time of taking the instrument knew him to be only an accommodation party. ${ }^{4}$

[Nore. - See Bills of Exchange Act, section 28.]

\section{ARTICLE V.}

\section{NEGOTIATION.}

SEction 60. What constitutes negotiation.

61. Indorsement; how made.

62. Indorsement must be of entire instrument.

63. Kinds of indorsement.

64. Special indorsement; indorsement in blank.

65. Blank indorsement; how ehanged to special indorsement.

66. When indorsement restrietive.

67. Effect of restrictive indorsement; rights of indorsee.

68. Qualified indorsement.

69. Conditional indorsement.

70. Indorsement of instrument payable to bearer.

71. Indorsement where payable to two or more persons.

72. Efreet of instrument drawn or indorsed to a person as eashier.

73. Indorsement where name is wrongly designated or misspelled.

74. Indorsement in representative capacity.

75. Time of indorsement; presumption.

76. Place of indorsement; presumption.

25 Pages 252-253. Discount must be distinguished from pledge or deposit for security. A discounter or purchaser of the bill is a holder for full value. A pledgee is a trustee of the pledgor. If the pledgor could have sued on the instrument the pledgee may reeover the whole amount, aceounting to the pledgor for any surplus above the amount of the lien: otherwise he can recover only the amount of the lien. Chalmers, p. 86. 1 See $\$ 91$.

2 Pages 253-254. An immediate party stands in the same relation as one who is not a holder in due course. See Chalmers, p. 95.

3 Pages 257-258.

4 Pages 254-258. 
SEctros 7 . Continuation of negotiable character.

78. Striking out indorsement.

79. Transfer without indorsement; effect of.

80. When prior party may negotiate instrument.

\section{$\S 60$. What constitutes negotiation.}

An instrument is negotiated when it is transferred from one person to another in such manner as to constitute the transferee the holder thereof. ${ }^{5}$ If payable to bearer ${ }^{5}$ it is negotiated by delivery; ${ }^{8}$ if payable to order it is negotiated by the indorsement of the holder rompleted by delivery. ${ }^{7}$

[Note. - See Bills of Exchange Act, sections 31, subdivisions (1), (2) and (3).]

\section{$\S$ 61. Indorsement; how made.}

The indorsement must be written on the instrument itself or upon a paper attached thereto. ${ }^{8}$ 'The signature of the indorser, without additional words, is a sufficient indorsement."

\section{$\S 62$. Indorsement must be of entire instrument.}

The indorsement must be an inlorsement of the entire instrument. An indorsement, whieh purports to transfer to the indorsee a part only of the amount payable, or which purports to transfer the instrument to two or more indorsees severally, does not operate as a negotiation of the instrument." But where the instrument has been paid in part, it may be indorsed as to the residue.11

[NoTE. - Sce Bills of Exchange Act, section 32, subdivision (2); Daniel, 6 668.]

\section{$\S$ 63. Kinds of indorsement.}

An indorsement may be either special or in blank; and it may also be either restrictive or qualified, or conditional.

$\$ 2$.

"Page 259. Sae "holder" defined, of the rule would give rise to a ques

- Pages 260-261.

7 Pages 261-266 (including indorse. ment in form of assigmment and of guaranty).

"l'nges 26iti-267. frirosby v. Rimb. li; Wis. 6lb; Folyer v. Chase, 18 Piek. (i33; French v. Turuer, 15 Ind. 5:). 'The rule as commenuly staterl is, that where there is not room on the bill, the inJorsement may be on an allonge. But it is not mecesung that there slomblel Ise a physiens impossibility of writing the indorsement on the instrument it. solf; it may lese on an nllonge wherll. ever the necesuity or convenienee of the

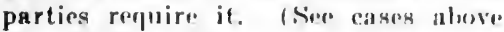
cited.) liesides, any such stutement tion of fact which might be determined vilrimsly. Soe Bills of Exehange Act, section 32. "Some of the foreign codses contain minute provisions to prewont frauds, $\therefore \%$, thut the first indorenent on the allonge must begin in the bill sund end on the allonge; otherwise "In allonge might be taken from one bill and stuck on to another." ('halmers, p. 107.

"Sine s\$s 63-6.4.

16) I'ilges 267-268.

" " $:$ the holder of a hill for $100 \mathrm{l}$., imclorses it, 'Pay 1), or order, 30 l.' 'This is invalid, muless (' also neknowl. mlge the receipt of $70 \mathrm{l}$. (Markins $\mathrm{v}$. ('arily. I Id. Ruym. 360.)" ('halmers, p. 107. 


\section{$\$ 64$. Special indorsement; indorsement in blank.}

A sperial indorsement specifies the person to whom, or to whose order the instrument is to he payalile; amel the imdorsement of such indorses is neressiry to the further negotiation of the instrument.12 An imborsement in bhank sperifies no imborsee, and an instrument so indorsad is payable to bearer, and may be negotiated by delivery. ${ }^{3}$

1 Nomt - See 13ills of Wishlinge Act, section 34.|

\section{\$ 65. Blank indorsement; how changed to special indorsement.}

'The hokder maly convert a blank indorsement into a speeial indorsement by wring over the signature of the indorser in blank any contrict consistent with the chatrater of the inclorsement. ${ }^{4}$

[Note. - See 13ills of Exchange Act, section 34; Daniel, $\$ 694$, and cases cited.]

\section{$\S 66$. When indorsement restrictive.}

An indorsenent is restrictive, which either:

1. Prohibits the further negotiation of the instrument; ${ }^{15}$ or

2. Constitutes the indorsee the agent of the indorser; ${ }^{10}$ or

3. Vests the title in the indorsee in trust for or to the use of some other person. ${ }^{17}$

But the mere absence of words implying power to negotiate does not make an indorsement restrictive. ${ }^{38}$

[Note. - Illustrations:

(1) Pay Bank of A. only. For deposit in Bank of A. only.

(2) Pay A. Cashier, or order, for collection.

(3) Pay A. for account of C'.

The language of the Bills of Exeluange Act, $(\$ 35)$, is: "It is a mere authority to deal with the bill as thoreby directed, and not a transfer of the ownership thereof." Tut this cannot apply to the indorsement mentionot in sublivision (3): for in sueh a ease the indorser means that the title shall pass. Thus, if the indorsement is "Pay A for use of $B$ " the title passes to $A$; but the inclorsement is restrictive to the extent that it gives uotice that the instrument cannot be urgotiated by $A$ for his own debt or for his own benefit. Hook v. Pratt, 78 N. Y. 371, 375.]

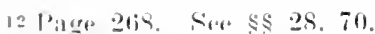

13 Pages 268-271. Srot \$ 28. pavalula to the order of Jolun Simith. He signs on the bark 'John Smith.' 'This act is interpreter by the law meschant as an inforsement in blank by Tohn Smith, and operates as if he had written: I. I heroly assign this bill to bearer. 2. I horolyy nurlortake that if this bill he dishonored, 1. on recoiv. ing due notice thereof. will indemenify the learer." flualumers. 1) 110. Siee § 116 .
14 Pages 268-271. "The holiter of a hill, inclorsed hy (' in blank, writes over C's signature the words. "Pay to the oriler of D)' 'The liolder who does this is not liable as an indorser, but tlie transaction operates as a special indorsement from $C$ to D. (Vincent v. Horlock, I ('amp. 442.)" Chalmers, p. 112.
1: Pages 271-274.
1) Pages 274-277.
17 Pages 277-280.
14 liges 272-274. 


\section{$\S 67$. Effect of restricting indorsement; rights of indorsee.}

A restrictive indorsement confers upon the indorsee the right:

1. To receive payment of the instrument;

2. To bring any action thereon that the indorser could bring;

3. To transfer his rights as such indorsee, where the form of the indorsement authorizes him to do so.

But all suhsequent indorsees aequire only the title of the first indorsee under the restrictive indorsement.

[Nотt. - See Bills of Exchange Act, section 35.]

Pages 280-284 See $\$ 77$.

\section{$\S$ 68. Qualified indorsement.}

Qualified indorsement constitutes the indorser a mere assignor of the title to the instrument. ${ }^{1 .}$ "It may be made by adding to the indorser's signature the words "without recourse" or any words of similar import Such an indorsement does not impair the negotiable character of the instrument. ${ }^{20}$

[NotE. - Sec Daniel. § 700.] Sce Bills of Exchange Act, section 16.

\section{$\S 69$. Conditional indorsement.}

Where an indorsement is conditional, a party required to pay the instrument may disregard the condition, and make payment to the indorsee or his transferee, whether the condition has been fulfilled or not. But any person to whom an instrument so indorsed is negotiated, will hold the simme, or the proceeds thereof, subject to the rights of the person indorsing conditionally.

| Notk. - The first sentence is the same as section 33 of the Bills of Exelange Act with a slight morlification. In his note to that section Judge Chalmers say's: "This seetion alters the law. It was formerly held that if a bill was indorsed conditionally, the aeceptor paid it at his peril if the eondition was not fultilled. This was hard on him. If he dishonored the bill he might be liable to damages, and yet it might be impossible for him to tind out if the condition had bern fulfilledl." See Daniel, $\$ \$ 697,698 a$. There appear to he no Auscrican eases upon the subject; and the only English ease is that of Robertson v. Kensington. 4 Taunt. 30.]

lage 287.

\section{$\S 70$. Indorsement of instrument payable to bearer.}

Where an instrument, payable to bearer, is indorsed specially. it may nevertheless he furtlier negotiated by delivery; but the person indorsing specially is liable as indorser to only such holders as make title through his indorsement. ${ }^{21}$

\section{$\S 71$. Indorsement where payable to two or more persons.}

Where an instrument is payalile to the order of two or more payees 
or indorsees who are not partners, all must indorse, unless the one indorsing hats antherity to indorse for the others. ${ }^{22}$

[Note. - Ser bills of Exchnuge Act, scetion 32, subdivision (3). 1)anicl. $\$ 701 a .1$

\section{$\S 72$. Effect of instrument drawn or indorsed to a person as cashier.}

Where an instrument is drawn or indorsed to a person as "cashier" or other fiscal ollicer of a hank or corporation, it is deemed prima facie to be payable to the bank or corporation of which he is such officer: and may be negotiated by either the indorsement of the bank or corporation, or the indorsenent of the officer. ${ }^{23}$

\section{$\S 73$. Indorsement where name is wrongly designated or misspelled.}

Where the name of a payee or indorsee is wrongly designated or misspelled, he may indorse the instrument as therein deseribed, adding, if he thinks fit, his proper signature. ${ }^{24}$

[NotE. - See Bills of Exehange Act, section 32, subdivision (4).]

\section{$\S 74$. Indorsement in representative capacity.}

Where any person is under obligation to indorse in a representative capacity, he may indorse in such terms as to negative personal liability.

[Notr. - Same as Bills of Exchange Act, section 31, subdivision (5).] $\S 68$; also $\S 39$.

\section{$\S 75$. Time of indorsement; presumption.}

Except where an indorsement bears date after the maturity of the instrument, every negotiation is deemed prima facie to have been effected before the instrument was overdue. ${ }^{25}$

[Yote. - See Bills of Exchange Act, section 36, subdivision (4). New Orleans, etc. v. Montgomery, 95 U. S. 1; Collins v. Gilbert, 94 U. S. 753 . See also numerous eases eited in Daniel, \& 328.$]$

\section{$\S 76$. Place of indorsement; presumption.}

Except where the contrary appears every indorsement is presumed prima facie to have been made at the place where the instrument is dated.'

[ For summary of rules governing conflict of laws, see Bills of Exchange Act, \$ 72.]

22 Page 298.

23 Pages 299-300. Sre \$ 37.

24 Pages 301-302. "A question sometimes arises as to how a bill payable (say) to 'Mrs. John Jones' should be indorsed. The proper form appears to he 'Ellen Jones, wife of John Jones,'
The form sometimes adopted, viz.,

'Mrs. John Jones,' is clearly irregular, though its invalidity has never been decided." Chalmers, p. 109. 2: Page 302. See $\$ 91$.

I Pages 302-305. 


\section{$\S$ 77. Continuation of negotiable character.}

An instrument negotiable in its origin continues to be negotiable until it has been restrictively indorsed 2 or discharged by payment ${ }^{3}$ or otherwise."

[NoтE. - See Bills of Fixchange Act, section 36.1

\section{$\S 78$. Striking out indorsement.}

The bolder may at any time strike out any indorsement which is not necessary to his title ${ }^{5}$ The indorser whose indorsement is struck out and all indorsers subsequent to him, are thereby relieved from liability on the instrument. ${ }^{6}$

\section{$\S 79$. Transfer without indorsement; effect of.}

Where the holder of an instrument payable to his order transfers it for value without indorsing it, the transfer vests in the transferee such title as the transferer had therein, and the transferce acquires, in addition, the right to have the indorsement of the transferer. But for the purpose of determining whether the transferee is a holder in due course, the negotiation takes effect as of the time when the indorsement is actually made. ${ }^{7}$

\section{$\S 80$. When prior party may negotiate instrument.}

Where an instrument is negotiated back to a prior party, ${ }^{8}$ such party may, subject to the provisions of this chapter, ${ }^{0}$ reissue and further negotiate the sanie. ${ }^{10}$ But lie is not entitled to enforce payment thereof against any intervening party to whom he was personally liable."

[Note. - See Bills of Exchange Act, section 37.]

\section{ARTICLE VI. \\ RIGHTS OF HOLDER.}

Section 90. Right of holder to sur: payment.

91. What constitutes a holder in due course.

92. When person not deemed holder in due course.

93. Notice ix.fore full amount paid.

94. When title defective.

95. What constitutes notice of defect.

96. Rights of holder in due course.

97. When subject to original defenses.

98. Who deemed holder in dur enurse.

2 See $\$ \$ 6 f-67$.

- See $\$ 200$.

4 Page 306.

3 Jages $306-307$.

- Serr 8116.

1 Pages 307-310. IThis is the same as Bills of Fixchange Act, sec. 31, subdivision (4). It establishos the equit. able rules as the rule at law. Daniel,

\$ 741.1

See $\$ 202$.

- Ser $\$ \$ 200-206$, as to discharger.

in Pages 310-313.

11 lages 310-313. This is a rule against circuity of action. 


\section{$\S 90$. Right of holder to sue; payment.}

The holder's of a menotiahlo instrument may sue thereon in his own name: ${ }^{13}$ and payment to him in due course discharges the instrument. ${ }^{14}$

(Nome. - Sce Bills of Fxchange Aet, section 38, subdivisions (1) and (3).]

\section{$\$ 91$. What constitutes a holder in due course.}

A holuer in due course is a lolder who has taken the instrument under the following conditions:

1. That it is complete and regular upon its face; ${ }^{15}$

2. 'That he became the holder of it before it was overdue, and without notice that it hat been previonsly dishonored, if such was the fact; ${ }^{16}$

3. 'That he took it in gool faith and for value; ${ }^{17}$

4. 'l'hat at the time it was negotiated to him he had no notice of any infirmity in the instrument or defect in the title of the person negotiating it. ${ }^{18}$

[Notr. - See Bills of bxehange Act, section 29, subdivions $(a)$ and $(b)$. ] "The act has substituted the trim 'holder in due course' for the cunbrous equivalent bona fide holder for value without notice." Chalmers, p. 90.

\section{$\S 92$. When person not deemed holder in due course.}

Where an instrument payable on demand is negotiated an unreasonable length of time after its issue, the holder is not deemed a holder in due course. ${ }^{19}$

[Note. - See Bills of Exchange Act, section 36, subdivision (3). Crim v. stockucather, 88 N. Y. 339 ; Herrick v. Woolierton, 41 N. Y. 581 ]

\section{$\S 93$. Notice before full amount paid.}

Where the transferee receives notice of any infirmity in the insirument or defect in the title of the person negotiating the same before he has paid the full amount agreed to be paid therefor, he will he deemed a holder in due course only to the extent of the amount theretofore paid by him. ${ }^{20}$

\section{$\S 94$. When title defective.}

The title of a person who negotiates an instrument is defective within the meaning of this chapter when he obtained the instrument, or

12 See $\$ 2$. "The Act deals only with tran-for Jy negotiation. that is, transfer accorling to the law merchant. It leaves untouched the rules of general law which regulate the transmission of bills by act of law, and their transfer as choses in action or ehattels according to the general law," (e. g., hy marriage, death, bankruptcy, sale on execution, etc.) Chalmers, p. 125.

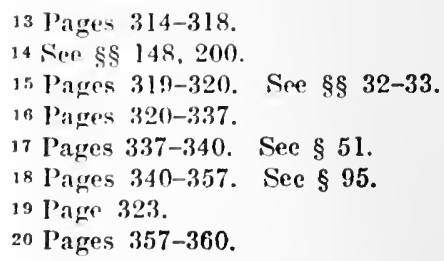


any signature thereto, by fraud, duress, or force and fear, or other unlawful means, or for an illegal consideration, or when he negotiates it in breach of faith, or under such circumstances as amount to a fraud. ${ }^{21}$

[Note. - See Bills of Exchange Act, scetion 29, subdivision (2).] "This list of defects in title may not be exhaustive. A person whose title is defective must be distinguished from a person who has no title at all, and who can give none; as for instance, a person making title through a forged indorsement. The words 'force and fear' were inserted in committee as the equivalent of the English technical term duress, which is unknown to Scotch law. (See Bell's Principles, 9th ed., § 12.)" Chalmers, p. 92.

\section{$\S$ 95. What constitutes notice of defeet.}

To constitute notice of an infirmity in the instrument or defeet in the title of the person negotiating the same, the person to whom it is negotiated must have had artual knowledge of the infirmity or defect, or knowledge of such facts that his action in taking the instrument amounted to bad faith.."2

\section{$\S 96$. Rights of holder in due course.}

A holder in due course holds the instrument free from any defect of title of prior parties and free from defenses available to prior parties among themselies, and may enforce payment of the instrument for the full amount thereof against all parties liable thereon. ${ }^{23}$

[Nowk. - See Bills of Exchange Act, section 38, subdivision (2).]

\section{§ 97. When subject to original defenses.}

In the hands of any holder other than a holder in due course, a negotiable instrument is subject to the same defenses as if it were non-negotiable. But a holder ${ }^{24}$ who derives his title through a holder in due conrse, and who is not himself a party to any frand or illegality affecting the instrument, has all the rights of such former holder in respect of all partios prior to the latter. ${ }^{25}$

\section{$\S$ 98. Who deemed holder in due course.}

Every holder is deemed prima facio to be a holder in due course; but when it is shown that the title of any person who has negotinted the instrmment was defective, the burden is on the holder to prove that he or some person under whom he clains acquired the title as a holiler in due course.' But the last mentioned mule does not apply

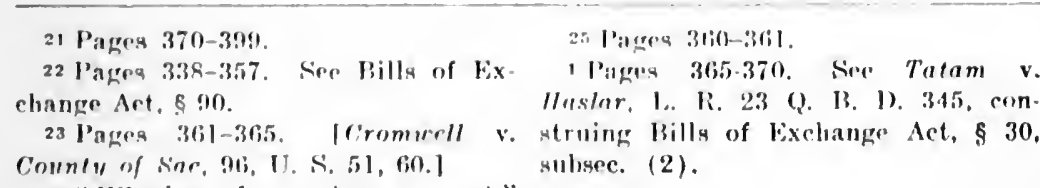

24 "Whether for value or not."

Bills of Exchange Act, \& 29, subaec.

(3), 
ill favor of a party who hecame hound on the instrument prior to the acquisition of such defective title.

1 Nutk: - This is similar to Bills of Exehange Act, section 30, subdivision (2): but the phrascology has been ehanged so as to better harmonize with the lamguage of section $55,\left(N^{*} . Y^{*} \$ 9.4\right)$, which is the same as Bills of Exchange Act, stetion 2!), sublivision (2). The lauguage of the liills of lixehange Aet is " subsejuent to the alleged fraud or illugality." But this is not quite cor. rect; for the holiler may be a holder in due course, though the fraud or illegality was in the transfor to him. The last sentence has no equivalent in the Bills of kxchange Act; but it is necessary to qualify the general statement. If $A$ issues his note to $B$, and $C$ grets possession of it and fraudulently negotiate. it to 1), the fraul of $C$ in nowise afferts $A$, and is no defense to him when sued on the instrument by $D .1$

\section{ARTICLE VII. \\ LIABILITIES OF PARTIES.}

Sectrox 110. Liability of maker.

11l. Liability of drawer.

112. Liability of aceeptor.

113. When person deemed indorser.

114. Liability of irregular indorser.

115. Warranty; where negotiation by delivery or by a qualifed indorsement.

116. I.jability of general indorser.

117. Liability of indorser where paper negotiable by delivery.

118. Order in which indorsers are liable.

119. Liability of agent or broker.

\section{§ 110. Liability of maker.}

The maker of a negotiable instrument by making it engages that he will pay it according to its tenor $;^{2}$ and admits the existence of the payee and his then capacity to indorse. ${ }^{3}$

[Xnt1.. - See Bills of Exehange Act, seetion 88.]

\section{$\S 111$. Liability of drawer.}

The drawer by drawing the instrument admits the existence of the payee and his then capacity to indorse; and engages that on due presentment the instrument will be accepted and paid, or both, aceording to its tenor, and that if it be dishonored, and the necessary proceedings on dishonor be duly taken, he will pay the amount thereof to the holder, or to any subsequent indorser who may be compelled to pay it."

2 Page 400. "The maker of a promiscory note is the prineipal debtor on the instrument. The maker is sometimes called the drawer, but the primary and absolute liability of the maker of a note must be distinguished from the speondary and conditional liability of the drawer of a bill of exchange. In general the maker of a note corresponds with the aceeptor of a bill of exchange, and the same rules apply to both." Chalmers, p. 270. See $\$ 130$.

3 Pages 401-403.

4 Pages 418-419. Bills of Exchange Act, \& 55. subsec. (1). The drawer's liability is similar to that of the in. dorser's. See $\S 116$. 
But the drawer may insert in the instrument an express stipulation negativing or limiting his own liability to the holder. ${ }^{5}$

\section{$\S 112$. Liability of acceptor.}

The acceptor by accepting ${ }^{6}$ the instrument engages that he will pay it according to the tenor of his acceptance ${ }^{i}$ and admits :

1. The existence of the drawer, the genuineness of his signature, and his capacity and authority to draw the instrument; ${ }^{8}$ and

2. The existence of the payee and his then capacity to indorse. ${ }^{9}$

[Note. - See Bills of Exchange Act, section 54. The Bills of Exchange Act contains the words, " but not the genumeness or validity of his indorsement." But as the section purports to specify what the acceptance admits, all other matters are nece-sarily excluded by implieation. To specify in some instances and not in others what is exclurled destroys the symmetry of the Act, and, besides, might give ri=e to doubts as to its construction.]

\section{$\S 113$. When person deemed indorser.}

A person placing his signature upon an instrument otherwise than as maker, drawer or acceptor is decmed to be an indorser, unless he clearly indicates by appropriate words his intention to be bound in some other capacity. ${ }^{10}$

[Note. - Section 56 of the Bills of Exchange Act provides: "Where a person signs a bill otherwise than as drawer or acceptor, he thereupon incurs the liabilities of an indorser to a holder in due eonrse." But this language is ton broad. There is no reason why one should not bind himself as guarantor or surety to a holder in due course if he clearly indicates such an intent. The language "otherwise than as maker," etc., would not meet the case of a signature so placed that there would be a question whether the person signing meant to hine himself as joint maker or otlerwi-e. Pint the point is corrected in section $17(K \mathrm{Y} . \$ 36)$, by the provision "that where a signature is so placed upon the instrument that it is not clear in what ealpacity the person making the same intendeg to sign, he will be deemed an indorser."]

\section{$\S 114$. Liability of irregular indorser.}

Where a person, not otherwise a narty to an instrument, places thereon his signature in blank before delivery, "oe is liable as indorser" in accordance with the following rules:

1. If the instrument is payable to the order of a third peraon, he is liable to the payee and all subsequent parties.

"ISee Jills of Exchange Art. sece tion 16.] Siee \$ 68 .

a As to acceptanees. ser

The acceptor is a primary party and aboolutely liable. Sies s 3 . No demand on him is necesuary to fix his liability. Siee $\$ 130$.

- Y'ages 403-418.

- Same as in $\$ 110$. "This section deals only with estoppels arising on the litl. There mas, of courap. Ix other eutoppols urising on evidenes. (Siee 8 42. ante.) If the amount of the bill be nitered, or if any other matriat alleration he made in it, the acerptor is not precluded ly this sec. tion from setting it up." Chalmera, p. 185.

11 |inges $4.18-4.5$ !.

II Pages 446-458. 
2. If the instrument is payable to the order of the maker or drawer, or is payable to hearer, he is liable to all parties subsequent to the maker or arawer.

?. If he signs for the ancommolition of the payee, he is liable to all parties subsequent to the payee.

dorts - This section is intended fo cover irregular indorsements. On this anbject the decisions are very conflieting. In some jurisdictions a person placing lois signature on the back of a note before the payee has indorsed is decened a joint maker; in other juriselictions loe is regarded as a guarantor: and in still others as an indorser; and those conts which hold him to be an indorser differ as to whether he is a lirst or secoml indorsey. The eases are too mumerous to be cited here. Nany of them will be found in Daniel on Negrotiable lustruments, sections 707.719 . The rule stated above is embolied in part in section 317 of the Civil cule of california, which reads: "One who indorses a negotiable instrument before it is delivered to the payee is liable to the payee thereon. as an indorser." This is also the effect (probably) of section 56 of the Bills of Fixchange Act. (See Chalmers on Bills. Notes and ('heques, section 5(i.) The ('alifornia rule is adopted beanse it is conducive to ecrtainty, and bealuse it appears to aecord more nearly with what must have heen the intention of the parties. When a plain man puts his signalure on the back of a negetiahle instrument le ordinarily understands that he is becoming liable as an indorser; and if he puts it there before the instrument is dediverd, he llwally does so for the purpose of gridug the maked or drawer credit with the payee or other person to whom it is negotiated. In many of the cases the reasoning is highly technieal. and the decisions are based upon considerations which, in all probahility, never entered the heads of the parties themselves. The California code makes no provision for a case where the instrument is drawn to the order of the maker or drawer. This is covered by subdivision 2, above. Subdivision 3 is added to provide for a case where, the paye being unable to enforee payment. thope might be a rucetion whether the indorser would be liable to a person claiming under the payee.

\section{ILLUSTRATIONS.}

Note made by A, payable to order of $B$, indorsed by $C$, and afterwards delivered to $B$. ( $C$ is liable as indorser to $B$.

Note ruade by $A$, payable to order of himself, indorsed by $B$, and afterwards delivered to $C^{\circ}$. P is liathe as indorser to $\mathrm{C}$.

Note made hy $A$. to order of $B$. indorsed by $C$ hefore $B$. hut for accommodation of $\mathrm{B}$, and diseounted by Bank of $\mathrm{X} . \mathrm{C}$ is liable as indorser to Bank of $\mathrm{X}$ and not to B.]

"1 rals. - Such an indorsement as is referred to by this section would in eontinental eountries he termed an 'aval,' which is eaid by Lord Blackburn to the an antiquated torm signifying 'underwriting.' $(5$ App. Cas. at p. 772.) According to Inthier (as cited hy Lord Blackburn, supra), an 'aval' might be either on the till itself or on a separate paper, and if such an 'aval' was given by anyone, his obligation to all subsequent bohlers of the bill was precisely the aame as that of the perarn to facilitate whoer trancfer the aval was given. and under whose signature it was written. English and Senteh law, as Jord Blackburn procesels to groint ust, de not go so far ats this. If a person, not the holder, indorse a bill. he is not a surety for the drawer or aeceptor to the drawer: 'such an indorsement creates no obligation to those who previously were partios to the bill. it is solely for the benefit of those who take subsequently. It is not a collateral engagement, but one on the bill, and it is for that reason and beeause the original hill has ineident to it the eapacity of an indorsement in the nature of an 'aval,' that such an indorsement requires no 
new stamp. (Steele v. McKinlay, 5 App. 754; see also, at p. 782, per Lord Watson. and his comments thereon, in Macdonald v. Whitfield, 8 App. Cas. 733, at p. 748.) " Chalmers, pp. 189-190.

\section{$\S 115$. Warranty where negotiation by delivery or by a qualified indorsement.}

Every person negotiating an instrument by delivery or by a qualified indorsement, warrants: ${ }^{12}$

1. That the instrument is genuine and in all respects what it purports to be;

2. That he has a good title to it;

3. 'That all prior parties had capacity to contract;

4. That he has no knowledge of any fact which would impair the validity of the instrument or reuder it valueless.

But when the negotiation is by delivery only, the warranty extends in favor of no holder other than the immediate transferee. The provisions of subdivision three of this sectiou do not apply to persons negotiating public or corporate securities, other than bills and notes.

[NoTE. - Where there is a latent defeet, as for example, usury, it is not covered by the implied warranty of a prorson negotiating the instrument without indorsemeni. In such cases scienter is necessary in order to render the transferer liable. (Littaucr v. (ioldman, 72 N. Y. 506.) Nor would he be liable if the maker of the note had beeome insolvent unless he knew such fact. (Bicknall v. Waterman, 5 R. I. 43; Fenn v. IIarrison, 3 T. R. 757; Fydell v. Clark, I Esp. 447.) The application of the rule of commercial paper to persons selling corporate honds, etc., wonld work great hardships and much public inconvinience. (Sce Otis v. Cullum, 92 U. S. 448.)]

See lills of Exchange Act, section 58, subsection (3). "There is some confusion in the cases owing to the distinetion between the warranty of gemuineness and the liability on the consideration having becn lost sight of. The warranty of geminenesis is an incident of the contract of sale, and it is immaterial whether the thing cold be a bill or any other personal chattel. The transferer is for this purpoe an ordinary vendor." Chalmers, p. 196.

\section{$\S 116$. Liability of general indorser.}

Every indorse ${ }^{13}$ who indorses without qualification, warrants to all subsequent hoklers in due course:

1. The matter and things mentioned in subdivisions one, two mol three of the next preceding section; and,

2. That the instrument is at the time of his indorsement valid and subsisting. ${ }^{4}$

And, in addition, he engages that on due fresentment, it shall be acceptret or paid, or hoth, as the case may le, areording to its tonor, and that if it bre distomored, nud the uecessalry proceedings on dishomor be duly taken, he will pay the amount thereof to the holder. or to any sulserefurent indorser who may be compelled to pay it. ${ }^{15}$

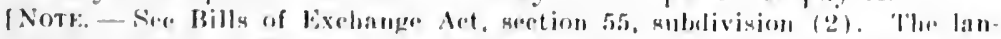
guage of the bills of Fxchange Act fixing the liabilities of the various parties

12 V'ages $419-437$.

13 Jag' 439-140).
14 Pagere 4:37-439.

is l'ages $442-445$.

NEOOT, INBTHUMKNTH - b1 
is uniformly, "is produded from denying, cte." But this is stating the effect of the principle nud not. the principle itself. Upon such a statement the question arises: Why is he precluded? 'The reason is that he has given implied warranties and admissions. 'lla more scintilie nefhed is to slate what these whranties and admissions are, and the other will follow by implication.]*

\section{$\S 117$. Liability of indorser where paper negotiable by delivery.}

Where a preson places his indorsement on an instrument negotiable by delivery he incurs all the liabilities of an indorser. ${ }^{16}$

[Notr. - See 1)aniel, \$ 663a, and cases there cited.]

\section{$\S 118.0$ rder in which indorsers are liable.}

As respects one another, indorsers are liable prima facie in the order in which they indorse; but evidence is admissible to show that as between or among themselves they lave agreed otherwise. ${ }^{17}$ Joint payees or joint indorsers who indorse are deemed to indorse jointly and severally. ${ }^{18}$

[Notr. - Evidence to show an agreement for a joint liability: See Easterly v. Barber, 66 N. Y. 433: Phillips v. Preston, 5 llow. (U. S.) 278; Wdelen v. White, 6 liush, 40s. Contra: Johnson v. Ramsay, 43 N. J. L. 279; Daniel, \$ 703. Evidence to show contract that one was to be prior inlorser: See slack v. Kirk, 77 Pa. St. 380; Reinhart v. Schall, 69 Md. 352; s'lagel v. Rust. 4 Gratt. 274; Daniel, $\$ 704$. As to joint payees indorsing: See Lane v. s'tacy, 8 Allen, 41 ; Daniel, \$ 704.]

\section{$\S 119$. Liability of an agent or broker.}

Where a broker or other agent negotiates an instrument without indorsement, he incurs all the liabilities prescribed by section one hundred and fifteen of this chapter, unless he discloses the name of his principal, and the fact that he is actung only as agent. ${ }^{19}$

1 Note. - Sce Meridan Nat. Bank v. Gallaudet, 120 N. Y. 298; Cabot Bank v. Morton, 4 Gray, 156; Worthington v. Coxles, 112 Mass. 30.]

\section{ARTICIE VIII.}

\section{PRESENTMENT FOR PAYMENT.}

Sectios 130. Effect of want of demand on principal debtor.

131. Presentment where instrument is not payable on demand.

132. What eonstitules a sufficient presentment.

133. Place of presentment.

134. Instrunent inust be exhibited.

135. Presentmont where instrument payahle at bank.

"The following provision in the original draft wa omitted in the final revis. ion: [But the provisions of this section do not apply to an indorser to whom the instrument has bwen indorsed restrictively as agent only. National Park Bank v. Seaboard National Bank, 114 N. Y. 28; United States v. American Exchange Nat. Bank, 70 Fed. Rep. 232.1 See pages 439-440.

16 Pager. 443.

17 Pages 459-465.
18 Pare 4 fifi.

19 Pages 441-442. 
Section 136. Presentment where principal debtor is dead.

13i. P'resentment to persons liable as partners.

138. Presentment to joint debtors.

139. When presentment not required to charge the drawer.

140. When presentment not required to charge the indorser.

141. When delay in making presentment is excused.

142. When presentment may be dispensed with.

143. When instrument dishonored by non-payment.

144. Liability of person secondarily liable, when instrument dishonored.

145. Time of maturity.

146. Time; how computed.

147. Rule where instrument payable at bank.

148. What coustitutes payment in due course.

\section{$\S$ 130. Effect of want of demand on principal debtor.}

Presentment for payment is not necessary in order to charge the person primarily liable on the instrument; ${ }^{20}$ but if the instrument is, by its terms, payable at a special place, and he is able and willing to pay it there at maturity and has funds there available for that purpose, such ability and willingness are equivalent to a tender of payment upon his part. But except as herein otherwise provided, presentment for payment is necessary in order to charge the drawer and indorsers. ${ }^{21}$

[Note. - See Bills of Exchange Act, section $52 ;$ Hills v. Place, $48 \mathrm{~N}$. Y. 520, 523; Parker v. Stroud, 98 N. Y. 379, 384; Cox v. National Bank, 100 U. S. 713 ; Wallace v. McConncll, 13 Peters, 136; Lozier v. Horan, 55 Iowa, 77; Insurance Company v. Wilson, 29 W. Va. 543.]

\section{$\S$ 131. Presentment where instrument is not payable on demand [and where payable on demand].}

Where the instrument is not payable on demand, presentment must be made on the day it falls due. $^{22}$ Where it is payable on demand, presentment must be made within a reasonable time ${ }^{23}$ after its issue, ${ }^{24}$ except that in the case of a bill of exchange, presentment for payment will be sufficient if made within a reasonable time after the last negotiation thereof. ${ }^{25}$

[Notr. - Sex Bills of Exchange Net, section 45, sublivision (2). All the authorities agrec that checks and bills of exchange payable: on dimand nust be presented promptly; but as to promissory motes drain so payable thire is much conflict. In Merritt v. Torld (23 N. Y. 28) the rule wus laid down by the Court of Appeals of New York that "a promissory note payable on demand, with interost, is a contiuning security: that an inulorser remuins liable until an actual demand, and that the holder is not chisgeable with neglect for omitting to make such demand within any particular time." The doctrine of this ease has been much criticisel. 'Thu rule of this ease was

20 J'ages $477-480$.

2) l'age 480 . See $6 \S 111,116$.

22 I'age 483.
23 Sim 6 4, ante.

24 I'nges 48.3-490.

25 l'ages 4!0-144. Sie $\$ \$ 241,322$ 
holel to be elanged ly this section of the Nogr. Inst. Law in com. Nat. Bk. v. Zimmerman, $155 \mathrm{~N}$. Y. 210 , reported herein at p. 483.1 In some States the time within whach promissory notes, pilyable on demand, must be presented, is lixed by statute. California Civil Cocle, seetion 3248; Connecticut Gen'l statutes. P. f05, section 1859; Minnesota Statutes (1891), reetion 2104.]

\section{$\S$ 132. What constitutes a sufficient presentment.}

Presentment for payment, to be sutheient, must be made:

1. By the holder, or by some person authorized to receive payment on his behalf ; ${ }^{\prime}$

2. At a reasonable hour on a business day; 2

3. At a proper place as berein defined; ${ }^{3}$

4. 'To the person primarily liable on the instrument, or if he is absent or inaceessible, to any person found at the place where the presentment is made."

\section{$\S$ 133. Place of presentment.}

Presentment for payment is made at the proper place:

1. Where a place of payment is specified in the instrument and it is there presented; ${ }^{5}$

2 . Where no place of payment is speeified, but the address of the person to make payment is given in the instrument and it is there presented; ${ }^{6}$

3. Where no place of payment is specified and no address is given and the instrument is presented at the usual place of business or residence of the person to make payment; ${ }^{7}$

4. In any other case if presented to the person to make payment wherever he can be found, or if presented at his last known place of business or residence. ${ }^{8}$

[NotE. - See Bills of Exchange Act, section 45, subdivision (4).]

\section{$\S 134$. Instrument must be exhibited.}

The instrument must be exhibited to the person from whom pay-

1 Pages 480-482. [See Bills of Exehange Act. cection 45, subdivision (2). Daniel. $\$ \$ 571-587.1$

2 Pages 494-495. [Salt Springs Nat. Bank v. Lurton, 58 N. Y. 430, 432 ; Farnsweorth v. Allen, 4 Gray, 453; Barclay v. Bailey. 2 Camp. 527; Wil. kins v. Jadis, 2 B. \& Ald. 188.]

3 See $\S 133$.

4 Pages 515-517. Ser §\$ 136-138. [The language of the Bills of Exehange Act is "or to some person authorized to pay or refuse payment on his behalf if with the exercise of reasmable diligenee such person eannot be found." But this rule appears to be more stringent than that of the law merchant. See Cromwell v. Hynson, 2 Camp. 596; Daniel, § 590.]

s Pages 508-512. "The place of payment may be specified either by the drawer, or by the aeeeptor for makerl." Chalmers, p. 145. See $\S 228$.

e lages 508-509.

7 Pages 512-515. [Gates v. Beecher, 60 N. Y. 518, 522; Daniel, $\S \S 635$, 636.]

8 Pages 512-515. 
ment is demanded, and when it is paid nust be delivered up to the party paying it. ${ }^{\circ}$

[Note. - See Musson v. Lake, 4 How. 262; F'reeman v. Boynton, 7 Mass. 483; Draper v. Clemens, 7 Mo. 52; Daniel, § 654.]

\section{$\S 135$. Presentment where instrument payable at bank.}

Where the instrument is payable at a bank, presentment for payment must be made during banking hours, unless the person to make payment has no funds there to meet it at any time during the day, in which case preaentment at any hour before the bank is closed on that day is sufficient. ${ }^{10}$

\section{$\S$ 136. Presentment where principal debtor is dead.}

Where the person primarily liable on the instrument is dead, and no place of payment is specified, presentment for payment must be made to his personal representative, if such there be, and if with the exercise of reasonable diligence, he can be found. ${ }^{11}$

[Note. - See Bills of Exchange Act, section 45, subdivision (7); Daniel, $\S 501$.$] This is declaratory. (Williams on Executors, 7th ed., p. 2003.)$ See $\$ 242$ (2) and 245 (1), for rule governing presentment for acceptance.

\section{$\S 137$. Presentment to persons liable as partners.}

Where the persons primarily liable ${ }^{12}$ on the instrument are liable as partners, and no place of payment is specified, presentment for payment may be made to any one of them, even though there has been a dissolution of the firm. ${ }^{13}$

[Note. - See Hubbard v. Mattheus, 54 N. Y. 43, 50; Fourth Nat. Bank v. Heuschuk, 52 Mo. 207; Crowley v. Barry, 4 Gill. 194; Cayuga Co. Bank v. Hunt, 2 Hill, 635; Daniel on Neg. Inst., sections 592-593.]

\section{$\S 138$. Presentment to joint debtors.}

Where there are several persons not partners, primarily liable on the instrument, and no place of payment is specified, presentment must be made to them all. ${ }^{14}$

(Note. - See Isills of Exchange Aet, section 45, subdivision (6). (Gates v. Beecher, 60 N. Y. 518,523 ; Union liank v. Willis, 8 Mete. 504; Arnold v. Dres. ser, 8 Allen, 435; Willis v. Green, 5 Hill, 232. In some cases this might be impracticable, but such ease's are covered by section 89 . (N. Y., § 142.) "This is probably declaratory (Union Bank v. Willis, 49 Mass. 504), but the point was not clear. Of course, if one pays, or in refusing payment, acts as the agent of the others, that is enough." (Chalmers. p. 14ti.

- Page 518. "In England, it is conceived that possasuion is frima farif evidence of ilentity, and that if the payer doubts tho identity of the per. son presenting, he must pay or refuge payment at his own risk." p. 203.
14 Pagers 495-504.

11 Pagers 516-517.

12 See \$2.

is Pagr 517.

14 Pages 5 17-518. 


\section{$\S 139$. When presentment not required to charge the drawer.}

Presentment for payment is not required in order to charge the drawer where he has no right to expect or require that the drawee or acceptor will pay the instrument. ${ }^{15}$

INote. - See Bills of kxehange Act, section 46 , subelivision (2) (c). Life Insurance Company v. Pendleton, 112 U. S. 696; Daniel, \$\$ 1074-1076.] See $\$ \$ 185-186$.

\section{$\S 140$. When presentment not required to charge the indorser.}

Presentment for payment is not required in order to charge an indorser where the instrument was made or accepted for his accommodation, and he has no reason to expect that the instrument will be paid if presented. ${ }^{16}$

[Notk. - See Bills of Exehange Act, section 46, subdivision (2) (d).] See $\S 186$.

\section{$\S 141$. When delay in making presentment is excused.}

Delay in making presentment for payment is excused when the delay is eaused by circumstances beyond the control of the holder and not imputable to his fault, misconduct or negligence. When the cause of delay ceases to operate, presentment must be made with reasonable diligence. ${ }^{17}$

[Note. - See Bills of Exchange Act. scetion 46, subdivision (1).] "The cases do not clearly distinguish betwcen excuses for non-presentment and excuses for delay in presentment, but when the question is one of reasonable diligence the distinction is an important one. (ef. Allen v. Edmumison, 2 Exch., at p. 724, notice of dishonor.) If presentment is delayed at the request of the drawer or indorser sought to be charged, the delay is presumably excused. (Lord Ward v. Oxford R'y Co.. 2 DeG. M. \& G. 750.)" Chalmers, p. 149. "Bill drawn in England, payable in Leghorn. At the time the bill matures Leghorn is besieged. The holder is not in Leghorn. This excuses delay. (Patience v. Townley, 2 Smith, 223.)" Ib., p. 148.

\section{$\S 142$. When presentment may be dispensed with.}

Presentment for payment is dispensed with:

1. Where after the exercise of reasonable diligence presentment as required by this chapter cannot be made; ${ }^{18}$

2. Where the drawee is a fictitious person; ${ }^{19}$

3. By waiver of presentment express or implied. ${ }^{20}$

[Notr. - Ses Pills of Exchange Act, section 46, subrivision (2).]

15 Pages 520-522.

16 Page 523.

17 Pages 518-520.

18 Pages 524-527. The Bills of Exchange Act adds: "The fact that the holder has reason to believe that the bill will, on presentment, be dishonored, does not dispense with the necessity for presentment." Chalmers (p. 150), says: "In some American States there is a tendency to dispense with the attempt to make presentment when sueh attempt would be futile. (Foster v, Julien, 24 N. Y. 28.) This tendeney is of doubtful expediency and finds no favor in England."

19 Page 575, note. This is declaratory. (Smith v. Bcllamy, 2 Stark. 223.) Chalmers, p. 150 . See $\$ 185$ (2).

2n On waiver, see $\$ \$ 180-182$. Pages 527-529. 


\section{§ 143. When instrument dishonored by non-payment.}

The instrument is dishonored by non-payment when:

1. It is duly presented for payment and payment is refused or eannot be obtained; or

2. P'resentment is excused and the instrument is overdue and unpaid.

[NotE. - See Bills of Exchange Act, section 47, subdivision (1).]

\section{$\S 144$. Liability of person secondarily liable, when instrument dis- honored.}

Subject to the provisions of this chapter, ${ }^{21}$ when the instrument is dishonored by non-payment, an immediate right of recourse to all parties secondarily liable 22 thereon, acerues to the holder. ${ }^{23}$

[Note. - See Bills of Exchange Act, section 47, subdivision (2).]

\section{$\S 145$. Time of maturity.}

Every negotiable instrument is payable at the time fixed therein without grace.* When the day of maturity falls upon Sunday, or a holiday, the instrument is payable on the next succeeding business day. ${ }^{24}$ Instruments falling due on Saturday are to be presented for payment on the next succeeding business day, except that instruments payable on demand may, at the option of the holder, he presented for payment before twelve o'clock noon on Saturday when that entire day is not a holiday. ${ }^{25}$

\section{$\S 146$. Time; how computed.}

Where the instrument is payable at a fixed period after date, after sight, or after the happening of a speeified event, the time of payment is determined by excluding the day from which the time is to begin to run, and by including the date of payment.

[Note. - Sue Bills of lixchange Act, section 14.] See New York General Construction Law, $\$ \$ 20,30$. ('ases, P. 504, note.

21 Soce $\S \S 280-289$.

22 See $\$ 3$.

23 Pages 442-445. "As a general rule the holdur's right of action againgt a lrawer or indorece dates from the time when notice of distionor is or ought to be received and not from the time when it is sent (Car. trique v. Bernabo, f; Q. H. 4981; alld in any case there is no right of action till the day after dishonor. The riglit of recoura muat he diatinguiahed from the right of action. ( kinnerly $v$. Thomas, 1894, 2 Q. H. 759.)" (.halm. ers, p. 152.
- Daye of erace are preserved by the Bills of Exchange Act, $\$$ 1.t: "lhreo days, ealled days of erace, are. in every case where the bill itsolf does not otherwise provide. alded to the time of payment as fixed by the bill, and the bill is due and pasabise on the last day of gruce." ('ases. pp. 234236. 501, note.

"t Where dnys of grace are allowed and the last diy of graer is a holiday, the instrument is due on the preceding day. Bille of Exchange: Act, $\$ 14$.

2:5 I'ages 50.4-50)8. 


\section{$\$ 147$. Rule where instrument payable at bank.}

Where the instrument is made payable at a bank it is equivalent to an order to the hank to pay the same for the account of the principal clebtor thereon.

INote. - Atha S'at. Bank v. Fourth Nat. Bank, 46 N. Y. 82; Commercial Bank v. Hughes, 17 Wend. 94; Commercial Nat. Bank v. Uenninger, 105 l'a. St. 4!6; Bedford Bank v. Acourn, 125 Ind. 582; Home Nat. Bank v. Newton, 8 13radwell, 563: Contrat: Grissom v. Commercial Bank, 87 Tenn. 350.]

\section{$\S 148$. What constitutes payment in due course.}

Payment is made in due course when it is made at or after the maturity of the instrument to the holder thereof in good faith and without notice that his title is defective.'

[Notk. - See Bills of Exchange Act, section 59.] See $\S 200$.

\section{ARTICLE IX.}

\section{NOTICE OF DISHONOR.}

Section 160. To whom notice of dishonor must be given.

161. By whom given.

162. Notice given by agent.

163. Eflect of notice given on behalf of holder.

164. Effect where notice is given by party entitled thereto.

165. When agent may give notice.

166. When notice sufficient.

167. Form of notice.

168. To whom notice may be given.

169. Notice where party is dcad.

170. Notice to partners.

171. Notice to persons jointly liable.

172. Notice to bankrupt.

173. Time within which notice must be given.

174. Where parties reside in same place.

175. Where parties reside in different places.

176. When sender deemed to have given due notice.

177. Deposit in post oflice, what constitutes.

178. Notice to antecedent party; time of.

179. Where notice must be sent.

180. Wajver of notice.

181. Whom affected by waiver.

182. Waiver of protest.

183. When notice dispensed with.

184. Delay in giving notice; how excused.

185. When notice need not be given to drawer.

186. When notice need not be given to indorser.

187. Notice of non-payment where acceptance refused.

188. Effect of omision to give notice of non-acceptance.

189. When protest need not be made; when must be made.

1 Cases, pp. 591-598. Sce $\$ 2$, as to "holder;" $\$ 95$, as to "good faith; " $\S 94$, as to defective title. 


\section{$\S 160$. To whom notice of dishonor must be given.}

Except as herein otherwise provided," when a negotiable instrument has been dishonored by non-aeceptance ${ }^{3}$ or non-payment, notice of dishonor must be given to the drawer and to each indorser, and any drawer or indorser to whom such notice is not given is diseharged. ${ }^{3}$

[Notr. - See Bills of Exchange Aet, seetion 48.]

NoтE. - A maker or acceptor is not entitled to presentment (\$130, ante) or notice. Want of notice of dishonor is no defense to a guarantor, unless he is actually injured for want of such notice. Brown v. Curtis, 2 N. Y. 225. ('ases, p. 467.

\section{$\S 161$. By whom given.}

The notice may be given hy or on behalf of the holder, or by or on behalf of any party to the instrument who might be compelled to pay it to the holder, and who, upon taking it up would have a right to reimbursement from the party to whom the notice is given. ${ }^{6}$

[Note. - See Bills of Exchange Aet, section 49, subdivision (1); Daniel, $\$ \$ 98 i-990$. The Bills of Exchange Aet uses only the words "holder" and "indorser." But the right extends to any person liable only as a surety, whether he is technically an indorser or not.]

\section{$\S 162$. Notice given by agent.}

Notice of dishonor may be given by an agent either in his own name or in the name of any party entitled to give notice, whether that party be his principal or not. ${ }^{7}$

[NotE. - See Bills of Exchange Act, section 49, subdivision (2); Daniel, $\S \S 991.992$, and cases citerl.।

\section{$\S 163$. Effect of notice given on behalf of holder.}

Where notice is given by or on hehalf of the holder, it enures for the benefit of all subsequent holders and all prior parties who have a right of recourse against the party to whom it is given. ${ }^{8}$

[Note. - See Bills of Exehange Act, seetion 49, subdivision (3); Daniel, § 990.]

2 See $\$ \S 180-186$.

3 See $\S 246$.

4 See $\S 143$.

- Cases, p. 530. "Where the drawer or indorser of a bill is discharged from his liability thereon by the omission to give him due notice of dishonor, he is also discharged from any liability on the consideration therefor. (Bridges v. Berry, 3 'Taunt. 130; l'recork v. Pursell, 14 C. B. N. S. 728.)" Chalmers, p. 153. For drawer's and indorser's contraet, see $\S 111$ and § 116.

- Pages 5.33-5.38.

т Cares, Pp. 535-536. "A bill in dorsed by (' is held by D. D's attorney gives notier of dishonor to the Jrawer, but by mistake gives it in ("s name instead of D's. The motice is sufficient, provided $C$ is liable to D. and has a right of recourse against the Irawer. (Marrison v. Rusror, Is M. \& W. 231.)" Clatmers, p. 155. "A party entitled to give notice may constilute the drawee or acesptor his agent for the purpose of giving notice of dishonor. (Kosher v. Kieran, 4 ('amp. 87, as modified hy Harrison v. Ruscoe, 15 .1. \& W., at $p$ 235.)" $I b$. s Pager 534-538. 


\section{$\$ 164$. Effect where notice is given by party entitled thereto.}

Hhere notice is riven hy or on behalf of a party entitled to give notice, it cmures for the benefit of the holder and all parties subseyuent to the party to whom notien is griven."

[Notk, - See Bills of lixchange Act, section 49, subdivision (4); Daniel, \$9!(1.) "In a Xow lork ease it was held that a notice duly sent by the holder did not enure for the benefit of a prior indorser when it did not reach the party to whom it was sent, but the diremmstanees of the ease were sonewhat special. (Bcale $\therefore$ I'arish, $20 \mathrm{~N}$. I. 407.) The Aet does not countenance this view." (halners, ph. 156-7. Chalmers citus Chapman v. Reane, 3 A. \& E. 193; Lysaght v. Bryant, 19 L. J. C. P. 160 ; Strecter v. Fort Bank, 34 N. 1. 413.

\section{$\S 165$. When agent may give notice.}

Where the instrument has been dishonored in the hands of an agent, he may either himself give notice to the parties liable thereon, or he may give notice to his prineipal. If he give notice to his principal, he must do so within the same time as if he were the holder, and the principal upon the receipt of such notice has himself the same time for giving notice as if the agent had been an independent holder. ${ }^{10}$

[NoTE. - See Bills of Exchange Act, seetion 49, subdivision (13).] "A bill payable in London is indorsed in blank by the holder, and deposited with a country banker for collection. 'Ihe country banker's London agrent presents it for payment and gives him due notice of its dishonor. The country banker on the day after the receipt of such notice gives notiee to lis anstomer, who in turn gives similar notice to his indorser. The indorser has received due notice. (Bray v. Haduen, 5 M. \& S. 68. See also Clode v. Bayley, 12 M. \& W. 51; Prince v. Oriental Bank, L. li. 3 App. Cas., at p. 332.)" Chalmers, p. 162.

\section{$\S 166$. When notice sufficient.}

A written notice need not be signed ${ }^{11}$ and an insufficient written notice may be supplenented and validated by verbal communication. ${ }^{2}$ A misdescription of the instrument does not vitiate the notice unless the party to whom the notice is given is in fact misled thereby. ${ }^{13}$

[Note. - See Bills of Exehange Aet, section 49, subdivision (7). Byles on Bills, 276; Daniel, $\$ \$ 979 \pi-950$. Subdivision (6) of reetion 49 of the Bills of

P l’ages $52,4-538$

in Page 5.38.

1I Put it must come from the right person. See $\S \S 161-162$. See $M a x$. cell v. Brain, 10 L. T. N. S. 301.

12 The sufficiency or insufticioney in such case is a question of fact. Houlditch v. Canty, 4 Bing. N. ('.411: Melvalfe v. Richarlson, II (. B. 10)11.

13 Pages 539-541. "A noties to the drawer which describes the hill as pay. ahle at the 's Bank, when in fact it was payable at the 'T Bank' (Brom. agr v. Vaughan, 16 L. I. Q. B. 10), or which doseribes a bill of exchange as a note (S'tockman v. I'arr, 11 M. \& W. s09; Bain v. Gregory, 14 L. 'I. N. S. 60l), or which transposes the names of the drawer and acceptor (Mellersh v. Rippen, 7 Exch. 578), or which describes the acceptor by a wrong name (Harpham v. Chill, I F. \& F. fi52). may be suflirient." ('halmers, 1. 159 
Exchange Act. which reads "Return of a dishonored bill to the drawer or an indorser is in point of law deemed a sufficient notice of dishonor" is omitted. In his note to that sub-section, Judge Chalmers says: "This subsection approves a common practice of collecting bankers which was previously of doubtful validity." No such practice prevails in this country.]

\section{$\S 167$. Form of notice.}

'l'he notice may be in writing or merely oral ${ }^{14}$ and may be given in any terms which sufficiently identify the instrument, and indicate that it has been dishonored by non-acceptance or non-payment. ${ }^{15}$ It may in all cases be given by delivering it personally or through the inails. ${ }^{10}$

\section{$\S 168$. To whom notice may be given.}

Notice of dishonor may be given either to the party himself or to his agent in that behalf. ${ }^{17}$

[Note. - See Bills of Exchange Act, section 49, subdivision (8). Fassin v. Hubbard, 55 N. Y. 465, 471; Lake Shore Nat. Bank v. Butler Colliery Co, 51 Hun, 63, 68.]

\section{$\S 169$. Notice where party is dead.}

When any party is lead, and his deatl is known to the party giving notice, the notice must be given to a personal representative, if there be one, and if with reasonable diligence, he can be found. ${ }^{\text {s }}$ If there

14 [See Bills of Exchange Act, section 49, subdivision (5); Cuyler v. Stcvens, 4 Wend. 566; Glusgow v. l'ratte, 8 Mo. 336; Byles on Bills, 271 ; Daniel, § 972.]

1s Cases, pp. 539-542. [1,y]es on Bills, 976: Daniol, ş 793-978. The statement that the holdrr looks for payment to the party to whom notice is sent is not necessary; for this is implied from the fact of giving notice. Bank of $U$. S. v. Carneal, 2 Peters, 543; Mills v. Bank, II Wheat. 431, 436; Nelson v. I'irst Nat. Bank (U.S. (ircuit Ct. App.), (i9) liedl. R(p). 798, 801.] "Notices of dishonor are now ronstrued very liberally. In 18.34 the House of Lorils, in solarter. Inlmer. I Bing. N. ('. 19, deeided that the notice must inform the lirlder, either in torms or hy neressary impliestion. that the hill had lowen presentorl and dishenoreds this ineonsenirent deciaion was frepuently regretted (see c. g. Fireraral v. Watson, I F. \& B., at p. 804), and was eventually got rid of by considering it merely a tinding on the particular fact.s. ( l'aul r. Jocl,
27 L. J. Ex., at p. 384.) Since 1841 (sec Furz v. Sharieond, 2 Q. B. 388, where the notice would now probably be sullicient), it does not appear that any written notice of dishonor has been liclel bad on the gromend of insulficirncy in form." Clalmers, p. 158.

10 Pages 542-546. See $\$ \$ 177,179$.

17 l'ages 546-547. "It is the duty of the irawer or indorser of a bill, if he be alsernt from his place of business or resideree, to see that there is some person there to receive notice on his behalf." Chalmers, p. l60, eiting Allen v. Erdmundson, 2 Exch., at 1. 723.

is Pilges 546-547. [See Bills of Exchanger Act, section 49, subdivision (9). The statement is based mpon the Ameriean derisions. Mrassachusetts Bank s. Olierer. 10 ('ush. 557: Mer rhants Bank v, Birch, 17 Juhns. 24. Sere also s'malley v. Wright, 40 N. I. l.aw, 471; Cooslnow \&. IVarren, 122 Ilass. 82; Bralls v. lerk, 12 Marh. 245: l'aynuga ('o. Bank v. Bennett, 5 Hill, 23fi; Mnspero v. Podesclaux, 22 La. Ann. 227.] 
be no personal representative, notice may be sent to the last residence ol last phate of business of the deceased."

\section{$\S 170$. Notice to partners.}

Where the parties to be notitied are partuers notice to any one partner is notice to the firm even thongh there has heen a dissolution."

\section{$\$ 171$. Notice to persons jointly liable.}

Notice to joint parties who are not partners must be given to each of them, unless one of then has athority to receive such notice for the others. $=1$

1 Nore. - Sec Bills of Exchange Aet, stetion 49, subdivision (11). The rule is hased upon the American decisions. Willis v. Gircen, 5 Hill, 232. See abo Daniel, s !99a, and eares cited.]

\section{$\S 172$. Notice to bankrupt.}

Where a party has been adjudged a bankrupt or an insolvent, or hats made an assignment for the benefit of creditors, notice may be given either to the party himself or to his trustee or assignee. ${ }^{22}$

[NoтE. - Sec Bills of Exelange Aet, section 4!), subdivision (10). Danie], § 1002; Callahan v. Kentucky Bank, 82 liy. 231; Contra: House v. Iinton Bank, 43 Ohio St. 346.1 "All that had been decided hefore the Act was that notice given to the bankrupt in ignorance that a trustee had been appointerl was suflicient." Chalmers, p. 160.

\section{$\S 173$. Time within which notice must be given.}

Notice may be given as soon as the instrument is dishoncred; ${ }^{23}$ and unless delay is excused as hereinafter provided, must be given within the times fixed by this chapter. ${ }^{24}$

\section{$\S 174$. Where parties reside in same place.}

Where the person giving and the person to receive notice reside in the same place, notice must be given within the following times:

1. If given at the place of husiness of the person to receive notice, it must be given before the close of business hours on the day following: ${ }^{25}$

19 Pages 540-547. frootmow $v$ Warren, 122 Ma=s. 82; Merchants' Bank v. Birch, 17 Johns. 25.]

20 Pages $547-548$. [See Coster $v$. Thomason, 19 Ala. T17: Storomb v. lizardi, 21 Ja. Ann. 355: IJubhard v. Mathers, 54 N. Y. 43, 50: Fourth Nat. Bank v. Henschuh, 52 Mo. 207.]

21 ['age's $547-548$.

22 Pages fig6-6,98.

23. Page 544. [Bank of Alerandria

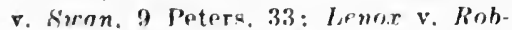
erts, 2 Wheat. 373 ; Ex parte Moline,
19 Ves. 2I6: Daniel, \$ 1036.] Bills of Exchange Act, section 49, subdivision (12).

24 [Bills of Exchange Act, section 49, subdivision (12). The phrase "must he given within a reasonable time thereafter," used in the Bills of Fxchange Act, is omitted; for the time is definitely fixed and this language has no force. 1

2: Pages 548-554, [See Daniel, $\$ \quad$ I038.] 
2. If giren at his residence, it must be given before the usual hours of rest on the day following; ${ }^{1}$

3 If sent by mail, it must he deposited in the post-office in time to reach him in usual course on the day following. ${ }^{2}$

\section{$\S 175$. Where parties reside in different places.}

Where the person giving and the person to receive notice reside in different places. the notice must be given within the following times:

1. If sent by mail, it must be deposited in the post-office in time to go by mail the day following the day of dishonor, or if there be no mail at a convenient hour on that day, by the next mail thereafter.*

2. If given otherwise than through the post-office, then within the time that notice would have been received in due course of mail, if it had heen deposited in the post-office within the time specified in the last subdivision. ${ }^{3}$

\section{$\S 176$. When sender deemed to have given due notice.}

Where notice of dishonor is duly addressed and deposited in the post-office, the sender is deemed to have given due notice, notwithstanding any miscarriage in the mails.

[Note. - See Bills of Excliange Act, section 49, subdivision (15); Byles on Bills. 27i.]

\section{$\S 177$. Deposit in post-office; what constitutes.}

Notice is deemed to have been deposited in the post-office when deposited in any branch post-office or in any letter box under the control of the post-office department."

1 Pages 548-554. ISee Phelps v. taining the notice was duly addressed Sitocking, 21 Nels. 444; Darbishire v. and posted. (Hackes v. Salter, 4 I'arker, 6 East, 8.]

2 ('asces. J. 55 fi. [This rule is that of the Bills of Exchange Act (\$ 49 , subsec. 12), and is in accordance with the practice in New lork ('ity. Some of the decisions deem serviee throngh the post-oflier insufficient, unless there is pronf that the notice was actually received in due time. (Sipe Danici, $\$ 1005$, and cases cited.) liut this rule wonla lo extremely inenwenient in large plapers.l Sep next seetirin.

- loges 558-560. IThis is substan. tially the sane as the lill of Fxchange Act, section 4!, sulsclivision (12) (b). It is sepporterl by numeroms Ameriesn

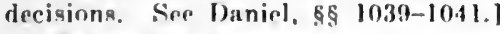

3 Pages 5fo-56).

- Pages 545-546. "It lies on the sender to prove that the letter con. Jing. 715; cf. Skilbeck v. Garbett, 7 Q. 3. 846.) The sufficiency of the direction on the letter is a question of reasonable diligence. If the drawer or indorser has a place of business, the notice sliould be ardressed to him there: if he has not, then it should be adlressed to him at his residence, and the party giving notice is hound to use reasounblo diligence to disenver such place of husinese or reaidener. Berridge v. Fitzgrrald, I. R. 4 Q. I3. 639.) When, however, the bill contains an aldress it seems that whch address is in any case sufficient to charge the party giving that adelress. (Burmester v. Barron, 17 Q. B. 828; ef. Hix parte. Baker, L. R. 4 (h. D. at p. 799.)" Chalmers, Jp. 155-6.

sPages 545-546. 


\section{$\$ 178$. Notice to antecedent party; time of.}

Where a party receise's notice of dishonor, he has, after the receipt of such notice, the same time for giving notice to antecedent parties that the holder has after the dishoner."

I.Yotr. - See Rills of lixelange Act, seetion 4!, subdivision (14); Daniel, $\$ 10.4:$ Byles on 1ills, 283.1

\section{$\S 179$. Where notice must be sent.}

Where a party hals added an address to his signature, notice of dishonor must be sent to that address; ${ }^{7}$ but if he has not given such address, then the notice must be sent as follows:

1. Either to the post-oflice nearest to his place of residence, or to the post-office where he is accustomed to receive his letters; ${ }^{8}$ or

2. If he live in one place and have his place of business in another, notice may be sent to either place; ${ }^{3}$ or

3. If he is sojourning in another place, notice may be sent to the place where he is so sojourning. ${ }^{10}$

But where the notice is actually received by the party within the time specified in this chapter, it will be suflicient, though not sent in accorlance with the requirements of this section.

\section{$\S 180$. Waiver of notice.}

Notice of dishonor may be wajed, either before the time of giving notice has arrivel, or after the omission to give due notice and the waiver may be express or implied."

[NotE. - See Bills of Exchange Aet, section 50, subdivision (2); Daniel, $\S \S 1147-1168$; Byles on Bills, 293.]

6 Pages 561-565. See § 165, note.

7 Pages 565-566. Note to $\S 176$.

8 Pages 566-571. [See Bank of $\mathrm{Co}$ lumbia v. Iawrener, 1 Peters, 578 ; National Bank v. Cade, 73 Mich. 449; Northwestern Coal Co. v. Bowman, 69 Iowa, 103.1

8 ['ages 566-57]. [Bank of U. S. v. Carnfal, 2 l'eters, 549; Williams v. Bank of U.S., 2 Peters, 96; Montgomcry Co. Bank v. Marsh, 7 N. Y. 481.] 10 Pages 571-573.

12 Pages 580-584. For waiver of presentment see $\S 142$. "Waiver of notice of dishonor in favor of the holder enures for the benefits of parties prior to such holder as well as subsequent holders. (Rabey v. Gilbert, 30 L. .T. Ex. 170.) Waiver of notice of dishonor by an indorser does not affect parties prior to such indorser. (Turner v. Leeeh, 4 B. \& Ald. 451.) An acknowledgment of liability must be made with full knowledge of the facts in order to operate as a waiver of notice of dishonor. (Goodall v. Dolley, 1 T. P. 712; ef. Pickin v. Graham, 1 Cr. \& M., at p. 72!.) Many of the cases fail to distinguish between admissions of liability, which are evidence of due notice having been received, and admissions of liability when due notice las not been given, and which therefore are evidence of waiver. The distinetion is important. (As to what is evidence of due notice, see Taylor v. Jones, 2 Camp. 105; Hicks v. Bcaufort, 4 Bing. N. C. 229 ; Brownell v. Bonney, I Q. B. 39; Curlewis v. Corfield, I Q. B. 814; Campbell v. Webster, 15 L. J. C. P. 4 ; Mills v. Gibson, 16 I. J. C. P. 249; 


\section{$\S 181$. Whom affected by waiver.}

Where the waiver is embodied in the instrument itself, it is binding upon all parties; ${ }^{12}$ but where it is written above the signature of an indorser, it binds him only. ${ }^{13}$

\section{$\S 182$. Waiver of protest.}

A waiver of protest, whether in the ease of a foreign bill of exchange or other negotiable instrument, is deemed to be a waiver not only of a formal protest, but also of presentment and notice of dishonor. ${ }^{14}$

\section{$\S 183$. When notice is dispensed with.}

Notice of dishonor is dispensed with when, after the exercise of reasonable diligence, it cannot be given to or does not reach the parties sought to be charged. ${ }^{15}$

[Notk. - See Bills of Exclainge Act, section 50, subdivision (2).]

\section{$\S 184$. Delay in giving notice; how excused.}

Delay in giving notice of dishonor is excused when the delay is caused by circumstances beyond the control of the holder and not imputable to his default, misconduct or negligence. When the cause of delay ceases to operate, notice must be given with reasonable diligence. $^{16}$

[Notr. - See Bills of Exchange Act, section 50; Daniel, $\$ \$ 1059-1146$. A more specific statement of what will axcuse delay is decmed impracticable. Any attempt to enumerate particular instimees would lead to confusion.l

Jackson v. Collins, I7 I. .I. Q. P. 142: Bartholomew v. Ilill. 5 J., T. N. S. T5ti. As to what is not, Bomeraile $v$. Iomer. 4 'Taunt. 93; Brailhwale $v$. Coleman. I N. \& M. 654; Brll v. Fronkis, 1 .1. \& f. 14ti; Holmes v. Sinimes, 34 \& K. 19.) In America it has bern held that a verbal waiver of notice may los re. verkel lwefore the time for giving notice

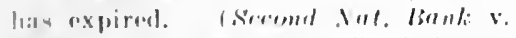
Uefiuire, 3.3 Oh. Sit. 295.) " ("latmers, lil. Ififi-7.

12 P'age 581 . ISier l'onl v. Inder. son, 116 Ind. 94: Hryant v. Merrhante' Jank, 8 Bush, 43.]

13 / Wooflman v. Thuratom, \& cush. 157 ; Farmers' linnk v. Firing, 78 liy. 26.4.1 "Sirel an indorsement. is somo" times spokern of as a facultatior in. dorament. It rolates anly to the ine dorsor'y liability and dare not otlere wise affect the negotiation of the bill. Such stipulations are resorted to when the payment of the hill is doubtful, and the drawer or inclorser wishes to save expense in ease of its return. In the Inifod states it las leerell leclal that an indorsement in the aluowe form dispenses with the neessity of notee to all subseguent indorsery (1)aniol, $\$$ log0: Jarshl'y v. Mrath, fi? Me. 90) : and in lirance a similar eomstrucfion has beren pilt an the plarases " herlour sons frais,' 'lirtour stoms protel, and 'sans remple de refour." (Noll.

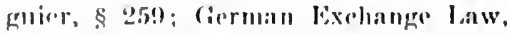
art. 42, seme ambignoms). It is dombtful wheller ther buglish Aet womlal hear smoly an intorpretation." f halmers. j. do.

'Tle alowe sertion fixes the law contrary to P'rrahley v. Ileath, supra.

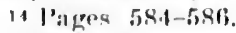

1." I'age 580 .

16 I'ages 573-574. 
$\$ 185$. When notice need not be given to drawer.

Sotice of dishomor is not requires to be griven to the drawer in either of the following eases:

1. Where the itrawer and drawee are the same person; ${ }^{17}$

$\because$ Where the drawee is a fictitions person or a person not having capacity to rontract; ${ }^{17}$

3. Where the drawer is the person to whom the instrument is presented for payment; ${ }^{17}$

4. Where the drawer has no right to expect or require that the drawee or acceptor will honor the instrument; ${ }^{18}$

5. Where the drawer has rountermanded payment. ${ }^{20}$

$\$ 186$. When notice need not be given to indorser.

Totice of dishomor is not required to be given to an indorser in either of the following eases:

1. Where the drawee is a fictitions person or a person not having eapacity to contract, and the indorser was aware of the fact at the time he indorsed the instrument; ${ }^{20}$

?. Where the indorser is the person to whom the instrument is presented for payment; ${ }^{21}$

3 . Where the instrument was made or accepted for his accommodation. ${ }^{22}$

[Notk: - See Bills of Exchange Act, section 50, subdivision (2) (d).]

\section{$\S 187$. Notice of non-payment where acceptance refused.}

Where due notice of dishonor by non-acceptance has been given, notice of a subsequent dishonor by non-payment is not necessary, unless in the meantime the instrument has been accepted. ${ }^{23}$

[NotE. - See Bills of Exchange Act, scetion 48, subdivision (2); Daniel, $\S 9.32$.

$\S 188$. Effect of omission to give notice of non-acceptance.

An omission to give notice of dishonor by non-acceptance does not prejudice the rights of a holder in due course subsequent to the omission. ${ }^{24}$

[Notf. - Sre Pills of Fxchange Act, spetion 48, subdivision (1).]

17 Pages 575-576n. [Sce Bills of Exchange Apt. certion 50. subdivision (2) (c) ; Daniel. \$\$ 128-129, 1088a.1 See "person" defined, $\S 2$.

is Pages 576-577. [life Insurance Company v. Prndleton, 112 U. S. 708; Daniel, $\leqq \leqq 1074,1076$. The language of the Bills of Exchange Act is "where the drawee or acceptor is as betwen himself and the drawer under no obligation to accept or pay the bill." But this is too narrow. It is not required that there should be any obligation to accept. See Idams v. Darby, 28 Mo. 162; Dickens v. Beal, 10 Peters, 572.] 19 [Sutcliffe v. McDoucll, 2 Nott. \& M'C. 251; Daniel, § 1081.]

20 See preceding section, note 17. 21 Pages 577-579. See preceding section, note 17.

22 Page 579.

23 Page 586.

24 Pages 587-589. 
$\S 189$. When protest need not be made; when must be made.

Where any negotiable instrument has been dishonored it may be protested for non-acceptance or non-payment, as the case may be; but protest is not required, except in the case of forejgn bills of exchange. ${ }^{25}$

[Note. - See Bills of Exchange Act, section 51, subdivision (1); Daniel, $\$ \$ 926,928$; Byles on Bills, 260. For the other provisions relative to protests see sections 152 and 160. (N. Y., $\$ \$ 260$ and 268.)]

Pages 589-590.

\section{ARTICLE $X$.}

\section{DISCHARGE.}

Secrios 200. Instrument; how discharged.

201. When persons secondarily liable on, discharged.

202. Right of party who discharges instrument.

203. Renunciation by holder.

204. Cancellation; unintentional; burden of proof.

205. Alteration of instrument; effect of.

206. What constitutes a material alteration.

$\oint$ 200. Instrument; how discharged.

A negotiable instrument is discharged:

1. By payment in due course by or on behalf of the principal debtor; '

2. By payment in due course by the party accommodated, where the instrument is made or accepted for accommodation; ${ }^{2}$

3. By the intentional cancellation thereof by the holder: ${ }^{3}$

4. By any other act which will discharge a simple rontract for the payment of money; ${ }^{4}$

5. When the principal debtor becomes the holder of the instrument at or after maturity in his own right."

[Note. - Sece Bills of Exchange Act, sections 59, 61, 63.]

$\S 201$. When persons secondarily liable on, discharged.

A person secondarily liable on the instrument is discharged:

1. By sny act which dischnrges the instrument: ${ }^{\circ}$

2. By the intentional cancellation of his signature by the holder ${ }^{7}$

3. By the discharge of a prior party; ${ }^{\mathrm{B}}$

1. By a valid tender of payment mude hy a prior party ;

28 Pages 58!-590.

I Pagres 59)1-597. Sep §̧ 148.

2 Pages $597-59,18$. Ser 855.

Pages 599-6018. Sep 804.

- Pager vios-fi26, 6i37.

- Pager 5:7-50). Sere \& 80.
- Sere preceling section.

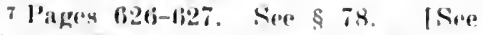
Bills of Fxchinge Act, section b3.]

B Pagres 627-624. [1)aniel, § 1307.]

? Page 629. 
5. By a release of the primeipal debtor, muless the holder's right of recourse anainst the party secondarily liahle is expressly reserved; 10

(i. By any angement hinding mpon the holder to extend the time of payment or to posflume the holder's right to enforce the instrument, muless the right of recourse against such party is explessly reserved. ${ }^{11}$

\section{$\S 202$. Right of party who discharges instrument.}

Whenever the instrument is paid by a party secondarily liable theroon, it is not lischarged: hut the party so paying it is remitted to his former rights as regards all prior parties, and he may strike ont his own and all subseyuent indorsements, and again negotiate the instrument, except:

1. Where it is payahle to the orter of a third person, and has been paid by the drawer: ${ }^{12}$ and

2. Where it was made or accepted for accommodation, and has been paid by the party ateommolated. ${ }^{13}$

[Note. - See Bills of Exchange Act, section 5!); Daniel, \$\$ 1235a-1241.] This seetion is. perhaps, not altogether elear. lixception (1) qualifies the last elause beginning "and he may strike out," ete., while exception (2) qualifies the whole of the preeding statement. If the instrument is paid by the party accommodated, it is discharged under the provisions of $\S 200$ (1). If paid ly a drawer of a bill payable to the order of a third person, the drawer (not being an accommolated party). may enforee payment against the acceptor but nay not re-issue the bill. If paid by an indorser, or by a drawer of a bill payable to drawer's order, the party paying (not being an accommodated party), min cuforce payment against prior parties or may strike out his own and subsequent indorsements, and re-issue the instrument.

\section{$\S 203$. Renunciation by holder.}

The holder may expressly renounce his rights against any party to the instrument, before, at or after its maturity. An absolute and unconditional roumediation of his rights against the principal debtor made at or after the maturity of the instrument, discharges the instrument. But a remuciation does not affect the rights of a holdor in due conrse withont notice. A renunciation must be in writing, unless the instrument is delivered up to the person primarily liable thereon. ${ }^{14}$

[Note. - Ses 13ills of Exchange Act, section 62; Byles on Bills, 190, 191; Daniel, $\$ \$ 541-545$. The Bills of Exchange Act repuires the renunciation to be "in writing, muless the bill is delivered to the aceptor." But this "ffected a chang" in the law.] "The words repuiring the renunciation to be in writing were adder in committee. They alter the English law, but bring it into aceordance with the Scotch law. At common law a eontract cannot

\footnotetext{
10 Pages 6.29-6331. [Daniel. \$ 13J0.]

12 Pares 6839-6.40.

1) Pages 63I-f338. [Daniel, §\$ 1326-

13 Pagres 640-641.

14 Pages 599-604.

See $\S 65$. 1388a.]
} 
be discharged by accord without satisfaction. The special rule as to bills and notes partially reproduced in this section seens to have been consciously imported into the law merchant from French law. (See Parke, B., in Foster v. Dauber, 4 kxeil., at p. 552.) This mode of discharge is known in France as remise roluntaire, and is recognized in countries where the civil law is followed. (See Nouguier, §§ 1043-1052.)" Chalmers, p. 212.

\section{$\S$ 204. Cancellation; unintentional; burden of proof.}

A cancellation made unintentionally, or under a mistake, or without the authority of the holder, is inoperative; but where an instrument or auy signature thereon appears to have been canceled the burden of jroof lies on the party who alleges that the cancellation was made mintentionally, or under a mistake or without authority. ${ }^{25}$

[Note. - See lialls of Exchange Act, section 63, subdivision (3).] Chalners cites: Raper v. Kirkbeek, 15 East, 17; Wilkinson v. Johnson, 3 B. \& C. 428; Nocell v. Rossi, 2 L. \& Al. 757; Castrique v. Imrie. L. R. 4 H. I. 435 ; Warriel: v. logers, 5 M. \& Gr. 340 and 373; Prinee v. Oriental Bank, L. R. 3 App. Cas. 325: Dominion Bank v. Anderson, 15 Sess. Cas. 408.

\section{$\S 205$. Alteration of instrument; effect of.}

Where a negotiable instrument is materially altered without the assent of all parties liable thereon, it is avoided, except as against a party who has himself made, authorized or assented to the alteration and subsequent indorsers. ${ }^{16}$ But when an instrument has been materially altered and is in the hands of a holder in due course, not a party to the alteration, he may enforce payment thereof according to its orjuinal tentr. ${ }^{17}$

[Notr:- Sie Bill of Exchinge Aet, section 64, subdivision (1): Daniel, $\S \$ 1393-1421 a$.

The Bill of lixchange Act eontains a provision that "where a bill has been materially altorol. but the alteration is not apparent, and the bill is in the hands of a holder in dure course, such holder may avail himself of the bill as

1: Pagros $6,0.5-6,0) 8,626-6,27$

16 l'ages 608-626.

17 Jages 15i, 1925, 726. "The proviso was intrulucell in anmulter to mitigate tho rigor of the commonlaw rule in favor of a loblelor in due

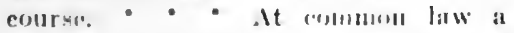
material aloration, ly wlommorever

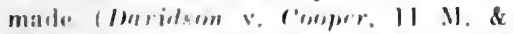
W. at p. 7!!!: afr'd I:3 M. \& W. 343), avoided and diachargerl the libll, except as against a party who mado or as. sental to the altorition. I//amolin v. Brurk, 9 9. li. 3omi.) Thuls where a bill was alterool by adlling a place of payment without the aceeptor's eron gent, aml was subsejuently iudorsod to a holder in due course, it was laid down that the holler could not sue the imborser on the bill, for the instru. mont ivas discharged. (Burchficld v. Hoore, 23 I. J. Q. I. 26I.) He could rnly sue on the considration. In America the rulo is not quitr so severe, and it is locld that an alteration by a stranger, or, as it is eallull, "an act of spoliution,' dores not avoirl n hill. (l'arsolls on lills, vol. II., 1. 57. : ef. U. S. v. Spuldin!, 2 Mısom, ds': Hinsmore ․ Huncan, 57 N. Y. 5.9.)" ('laalmera,

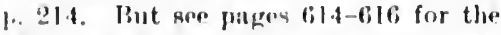
vifuet of $\$ 205$ upon the American rule. 
if it had not been altered, nul may anforce pilyment of it necording to its original tenor." But this effects a change in the luw.l This elange was subsequently alopted by the Commissioners on Uniformity of Laws, and is introduced in substunce above.

\section{$\S 206$. What constitutes a material alteration.}

Any alteration which changes:

1. 'The date; ${ }^{18}$

2. 'The sum payable, either for principal ${ }^{19}$ or interest; ${ }^{20}$

3. 'The time ${ }^{21}$ or place ${ }^{22}$ of payment;

4. The number or the relations of the parties; ${ }^{23}$

5 . The medium or currency in which payment is to be made; ${ }^{24}$

Or which adds a place of payment where no place of payment is specified, ${ }^{25}$ or any other change or addition which alters the effect of the instrmment in any respect, is a material alteration. ${ }^{1}$

[Note. - See Bills of Exchange Act, section 64.] lages 608-626.

is [See Wood v. Steele, 6 Wallace, 80; Crauford v. West Side Bank, 100 N. Y. 50, 56; Daniel, \$ 1376.] See $\$ 32$. 19 [See Daniel, § 1384.]

20 [Daniel, § 1385, and eases there cited.]

21 [Weyman v. Yeomans, 84 III. 403; Hiller v. Gilleland, 19 Pa. St. 119.]

22 [Tidmarsh v. Grover, l Maule \& S. 735 ; Bank of Ohio Valley v. Lockcood, 13 W. Va. 392.]

23 [Danie], §§ 138i-1390.]

24 [Angle v. Insurance Company, 92 U. S. 330; Church v. Houard, 17 Hun, 5; Darwin v. Rippey, 63 N. C. 318 ; Bagarth v. Brecdlove, 39 Tex. 561.l

25 [Whitesides v. Northern Bank, 10 Bush, 501.]

Distinguish authorized filling of blanks: \$ 33 .

"An alteration is material which in any way alters the operation of the bili and the liabilities of the parties, whether the ehange be prejudicial or beneficial (Fiardner v. Walsh, 5 E. \& B. 83 , at p. 89 ); and it may be that even this test is not wide enough. 'Any alteration,' says Jrett, I. .J., ' secms to me material wbich would alter the business effect of the instrument, if used for any business purpose.' (S'uffel v. Bank of Eingland, 9 Q. B. D. 555, at p. 568; see the test suggested by Cotton. I. J.. at p.). 574, 575.) 'The materiality of any alter- ation is a question of law. (Vance $v$. Lowther, 1 Ex. D. 176.)

"Subject to two exceptions the holder of a bill, which has been avoided by a material alteration, cannot sue on the consideration in respect of which it was negotiated to him. (Alderson v. Langlale, 3 B. \& Ad. (660.) Exception l. If the bill was negotiated to him after the alteration was made, and he was not privy to the alteration, he may sue on the consideration. (Burchiell v. Moore, 23 L. J. Q. B. 261 ; ef. Cundy v. Marriott, 1 B. \& Ad. 696.) Excrption 2. If the bill was altered while in his custody or under his control, he can still recover, provided (a) that he did not intend to commit a fraud by the alteration (l'arsone, vol. II., p. 572: Hunt v. Gray, 35 N. J. L. 227), and (b), that the party sued would not have liad any remedy over on the bill, if it had not been altered. (Athinson $\checkmark$ Hawdon, 2 A. \& E. 628; cf. Sutton v. Toomer, 7 B. \& C. 4lf; Alderson v. Langdale, 3 B. \& Ad. 660.)

"When a bill appears to have been altered, or there are marks of erasures on it, the party seeking to enforce the instrument is bound to give evidence to show that it is not avcided thereby. (Knight v. Clements, 8 A. \& F. 215: Clifford v. Parker, 2 M. \& Gr. 909.) " Chalmers, pp. 217-218. 


\section{ARTICLE XI.}

\section{BILLS OF EXCHANGE; FORM AND INTERPRETATION.}

SEction 210. Bill of exchange defined.

211. Bill not an assignment of funds in hands of drawee.

212. Bill addressed to more than one drawee.

213. Inland and foreign bills of exchange.

214. When bill may be treated as promissory note.

215. Referee in case of need.

\section{$\S 210$. Bill of exchange defined.}

A bill of exchange is an unconditional order in writing addressec by one person to another, signed by the person giving it, requiring the person to whom it is addressed to pay on demand or at a fixed or determinable future time a sum certain in money to order or to bearer.

[NotE. - See section 1 (N. Y. 20); Bills of Exchange Act, section 3.]

"A bill is sometimes called a draft, and an accepted bill is often referred to as 'an acceptance.' The person who gives the order is called the drawer. The person thereby ordered to pay is called the drawee, and if he signifies his assent to the order in duc form [see $\$ 220$ ], he is then called the acceptor. The person to whom the money is payable is called the payce or bearer. as the case may be. [See $\$ 2$.$] The foreign codes for the most part provide in$ terms that a bill may be drawn by one person for the account of another. The person for whose account the bill is drawn is spoken of in England as the 'third account.' For example, a merchant in America may direct his agent in England to draw on a correspondent in Paris for his (the principal's) account." Chalmers, p. 8.

\section{$\S 211$. Bill not an assignment of funds in hands of drawee.}

A bill of itself does not operate as an assignment of the funds in the hands of the drawee available for the payment thereof, and the drawee is not liable on the hill unless and until he accepts the same. ${ }^{2}$

[Note. - See Bille of Exchange Act, epetion 53.]

\section{$\S 212$. Bill addressed to more than one drawee.}

A bill may be addressed to two or more drawees jointly, whether they are partners or not; lut not to two or nore drawees in the alternative or in suecessions. ${ }^{3}$

[Notr. - See Bills of Exclange Act, seetion 6, sublivision (2).] See $\$ 229$ (5), and \& $242(1)$.

2 Pagi-4 644-646).

3 Pages 642-6i.43. "Theough a bill may not lese ndelresand to two drawias in succession, or in tler alternative, it may name a lrawer in case of neol [5 215]: hut hia atatua is wholly dif. ferent from that of an ordinary drawce. Alternative or successive drawess would give rise to diffienlty as to the recourar if the bill was dishonared. The dilliculty does not uriso in the case of a note, enowequently tha makors of a note may lo liable jointly, or jointly and ueverally, uepording to its temor, while the ureeptora of a bill (2ג) only be liable jointly. A note pay. 


\section{$\$$ 213. Inland and foreign bills of exchange.}

An inland bill of exchange is a bill which is, or on its face purports to be, both drawn and payable within this state. Any other bill is a foreign bill. Unless the contrary appears on the face of the bill, the bolder may treat it as an inland bill."

1 Nort. - Ses Bills of lixchange Act, section 4, subdivision (1); Buckner v. Finley, 2 Peters, 5s6; straubridge v. Robinson, 5 Gilman, 470.]

\section{$\S 214$. When bill may be treated as promissory note.}

IV here in a bill drawer and drawee are the same person, or where the drawee is a fictitions person, or a person not having capacity to contract, the holder may treat the instrument, at his option, either as a bill of exchange or a promissory note. ${ }^{5}$

|Note. - See Bills of Exehange Aet, section 5, subdivision (2).] See $\$ 30$ (5). "If both drawer and drawee are fictitious persons the bill might, perhaps, be treated as a note made by the first indorser." Chalmers, p. 18.

\section{$\S 215$. Referee in case of need.}

The drawer of a bill and any indorser may insert thereon the name of a person to whom the holder may resort in case of need, that is to say, in case the bill is dishonored by non-acceptance or non-payment. Such person is called the referee in case of need. It is the option of the holder to resort to the referee in case of need or not as he may see fit.

[Note. - See Bills of Exchange Aet, section 15; Daniel, §§ 111, 529.]

"The referee in case of need is sometimes ealled the drawee in ease of need, or simply the 'ease of need.' A bill must be protested or noted for protest before it can be presented to the ease of need. [See $\$ \$ 280,286$.$] The con-$ eluding words of the seetion settle the moot point, whether presentment to the ease of need is obligatory or optional." - C'halmers, p. 38.

Pages 643-645.

\section{ARTICIE XII.}

\section{ACCEPTANCE.}

Sectios 220. Aeceptaner, how made.

221. Holder antitled to aceeptance on face of bill.

222. Acceptanee by separate instrument.

223. Promice to accept; when equivalent to acceptance.

224. Time allowed drawee to acept.

225. Liability of drawee retaining or destroying bill.

226. Acceptance of inconplete bill.

227. Kinds of aeceptanec's.

228. What constitutes a general aceeptance.

229. Qualifiel acceptanee.

230. Rights of parties as to qualified aeceptance.

able in the alternative ly ome of two

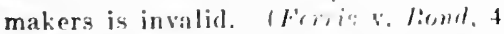
B. \& Ald. 679.) " Chalmers, p. 19.
4 Pages 646-647.

5 Page 647. 
220. Acceptance; how made.

The acceptance of a bill is the signification by the drawee of his assent to the order of the drawer. The acceptance must be in writing and signed by the drawee." It must not express that the drawee will perform his promise by any other means than the payment of money. ${ }^{7}$

\section{$\S 221$. Holder entitled to acceptance on face of bill.}

'The holder of a bill presenting the same for acceptance may require that the acceptance he written on the bill, and if such request is refused, may treat the bill as dishonored.

[Nort. - I N. Y. Rev. Stat., 768, section 9.] The English Act requires that the acceptance be written on the bill; the American Act leaves it optional with the holder to require it, or to waive it. This permits acceptances by telegraph. Giarretson v. North Atchinson Bank, 39 Fed. Rep. 113, 47 Fed. Rep. 867, 51 Fed. Rep. 16 .

\section{Acceptance by separate instrument.}

Where an acceptance is written on a paper other than the bill itself, it does not bind the acceptor except in favor of a person to whom it is shown and who, on the faith thereof, receives the bill lor value. ${ }^{8}$

[NoTE. - 1 N. Y. Rev. Stat. 768, section 7.]

\section{Promise to accept; when equivalent to acceptance.}

An unconditional promise in writing to aceept a bill before it is ilawn is deemed an actual acceptance in favor of every person who, upon the faith thereof, receives the hill for value.

[NoTk: - 1. N. Y. Rev. Stat. ifs, section 8.]

\section{$\S 224$. Time allowed drawee to accept.}

The drawee is allowed twenty-four hours after presentment in which to decide whether or not he will accept the bill; ${ }^{10}$ but the acceptance if given dates as of the day of presentation."

\section{$\S 225$. Liability of drawee retaining or destroying bill.}

Where a drawee to whom a bill is lelivered for acceptance destroys the same, or refuses within twenty-four hours after such delivery,

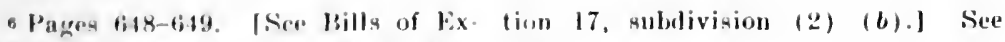

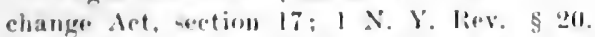

Stat., itis, ș fo. The Bills of lixphatuge

Act, following previous Fengliah stat. IItro $11 \& 2$ fororge JV., c. $78 ; 19 \& 20$ Victoria, c. is) requires that the ac-

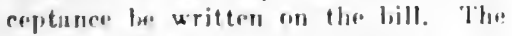
Ameriean atatutes do not perenralle re. quire this.l Ser next two rections.

7 [See Bills of Exchunge Aet, nec-

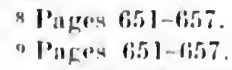

"1'There does not upwear to be nny direct anthority on this point; the rulc statol conforms to what is the common practice.] 
or within such other period as the holder may allow, to return the bill aceepted or non-incepted to the holder, he will be deemed to have aceepted the same."

[Notz. - 1 N. Y. Rev. Stat. 769, section 11; see Daniel, § 500.]

\section{§ 226. Acceptance of incomplete bill.}

A bill may be accepted before it has been signed by the drawer, or while otherwise incomplete. ${ }^{13}$ or when it is overdue, or after it has been dishonored by a previous refusal to accept, or by non-payment. ${ }^{14}$ But when a bill parable alter sight is dishonored by non-aceeptance and the drawee subsequently accepts it, the holder, in the absence of any different agreement, is entitled to have the bill accepted as of the date of the first presentment. ${ }^{15}$

[Note. - See Bills of Exchange Act, section 18; Daniel, $\$ \$ 490-495$.]

\section{$\S 227$. Kinds of acceptances.}

An acceptance is either general or qualified. A general acceptance assents without qualification to the order of the drawer. ${ }^{16} \mathrm{~A}$ qualified acceptance in express terms varies the effect of the bill as drawn. ${ }^{17}$

[Note. - See Bills of Exchange Act, section 19; Byles on Bills, 193; Daniel, $\S 509$ et seq.]

\section{$\S 228$. What constitutes a general acceptance.}

An acceptance to pay at a particular place is a general acceptance unless it expressly states that the bill is to be paid there only and not elsewhere. ${ }^{18}$

[Note. - See Bills of Exchange Act, seetion 19, subdivision (2); Wallace v. McConnell, 13 Peters, 136; Daniel, \$§ 519-520, 64]-643.]

12 Pages 658-665.

13 Pages 666-667. See $\S 33$.

14 Pages 667-668. Chalmers cites 1) utford v. Walcot, I Ld. Raym. 574; Wynnc v. Raikes, 5 East, 514.

15 "This subsection was added in committee. It accords with mercantile practice, and was intended to secure that, apart from special agreement, the holder should he put, as far as possible, in the samp position as if the bill had not been dishonored. Unless the contrary apporar by its terms, a bill of exchange is prima farif deemed to have been accepted brfore maturity and within a reasonable time after its issue, but there is no presumption as to the exact tine of acceptance. (Roberts v, Rethell, 12 C. B. 778.) " ('halmers, p. 45.

10 Pages 668-672. "An acceptance is, whencver possible, to be construed as general, not qualified; and a mere memorandum, such as a wrong due date, inconsistent with such construction, has ben rejected as being no part of the accrptance. (Fanshawe v. Peet, 26 L. J. Ex. 314; cf. Stone v. Metcalfe, 4 Camp. 217; Fitch v. Jones, 5 E. \& B., at p. 246; Decroix v. Heyer, 25 Q. B. D. 343.)" Chalmers, p. 46.

17 Spe $\$ 229$.

18 Pages 672-673. "This subsection reproduces the effect of the repealed 1 \& 2 Geo. 4, c. 78, which was passed to override tlie ease of Rowe v. Young, 2 Brod. \& Bing. 165; s. c. 2 Bligh. $H$. L. 391 , where it was held tlat an ordinary acceptanee payable at a banker's was a qualificd acceptance." Chal. mers, p. 48 . 


\section{§229. Qualified acceptance.}

An acceptance is qualified, which is:

1. Conditional, that is to say, which makes payment by the acceptor dependent on the fulfillment of a condition therein stated; ;" $^{\text {"1 }}$

2. Partial, that is to say, an acceptance to pay part only of the amount for which the bill is drawn; ${ }^{20}$

3. Local, that is to say, an acceptance to pay only at a particular place; ${ }^{21}$

4. Qualified as to time; ${ }^{22}$

5. The acceptance of some one or more of the drawees, but not of all. ${ }^{23}$

[Note. - See Bills of Exchange Act, section 19, subdivision (2); Byles on Bills, 193-194; Daniel, §§ 508-520.]

\section{$\S 230$. Rights of parties as to qualified acceptance.}

The holder may refuse to take a qualified acceptance, and if he does not obtain an unqualified acceptance, he may treat the bill as dishonored by non-acceptance. ${ }^{24}$ Where a qualified acceptance is taken, the drawer and indorsers are discharged from liability on the bill, unless they have expressly or impliedly authorized the holder to take a qualified aeceptance, or subsequently assent thereto. ${ }^{25}$ When the drawer or an indorser receives notice of a qualified acceptance, he must within a reasonable time express his dissent to the holder, or lie will he deemed to have assented thereto.'

[Note. - Sep Bills of Exchange Act, scetion 44; Byles on Bills, 192-193: Daniel, $\S \S 508,510$.

The Bills of Exchange Act provides that the provisions relative to the assent of the drawer and indorser fo not apply "to partial acceptance whereof due notice has been given," nud that "where a forcign bill has been acepted as to part, it nust to protested as to the balance." But there appears to be some loubt whether this correctly states the rule of the law merchant. See Daniel, 8511 ; Story on Bills, section 272.]

19 Pageg 673-674.

20 l'age 675.

21 Pages 675-676. Sce $\$ 228$.

22 Jage 676.

2a Page 67f. "Bill drawn on $B, X$ and $Y$. $B$ accepts, $X$ and $Y$ refuse to accept. This is a qualified accept. ance." Chalmers (p. 48), citing Mariua, No. In, New York Draft Code, \$ 1784; Nouguier. § 451.

24 Page 677. "Accorling to the continental coles, it seems that the holdor cannot rofuse a partial accept. ance. He can only protest as to the balance. (French Code, arts. 119120: Ferman Wxehange Iaw, arts. 2528.)" Chalmers, p. 140.

20 Pages 677-678.

1 "This subsection settles a loubtful point in favor of the holder. Ser subject diacusaed in Roure v. Foung, 2 Hligh. 391." Chalmers, p. 141. 


\section{AR'TICLE XIII. \\ PRESENTMLN'T FOR A'CEP'TANCE.}

Section 240. When presentment for acceptance must be made.

241. When failure to present releases drawer and indorser.

242. Presentment: how made.

243. On what days presentment may be made.

244. Presentment: where tine is insuflicient.

245. When presentment is exeused.

246. When dishonored by non-aceeptance.

247. Duty of holder where bill not accepted.

248. Rights of holder where bill not accepted.

\section{$\S 240$. When presentment for acceptance must be made.}

Presentment for acceptance must be made:

1. Where the bill is payable after sight, or in any other case where presentment for acceptance is necessary in oriler to fir the maturity of the instrument; ${ }^{2}$ or

2. Where the bill expressly stipulates that it shall be presented for acceptance; ${ }^{3}$ or

3. Where the bill is drawn payable elsewhere than at the residence or place of business of the drawee."

In no other case is presentment for acceptance necessary in order to render any party to the bill liable.

\section{$\S 241$. When failure to present releases drawer and indorser.}

Fxcept as herein otherwise provided, the holder of a bill which is required by the next preceding section to be presented for acceptance must either present it for acceptance or negotiate it within a reasonable time. ${ }^{6}$ If he fails to do so, the drawer and all indorsers are discharged. ${ }^{7}$

[NoTE. - See Bills of Exchange Act, seetion 40, subdivision (1); Wallace v. Agry. 4 Mason, 333; Daniel, $\$ \S 469-472$.

2 Pages 679-650. [Sere lills of EX- eeptance. An agent is bound to usf change Aet, section 39, subdivision due diligence in presenting for accept(1); Daniel, § 454.1

3 [See Bill of Exchange Act, section 39, subdivision (2).]

4 [/d.] Sire \& 244.

3 Pages 680-684. "Where presentment is optional, the object of presonting is (1), to obtain the acceptance of the drawee, and thereby secure his liability as a party to the bill; (2). to obtain an immediate right of recourse againat antecerlent parties in anee, ever when presentment is op. tional for the purposes of the Act, and he is liable to his principal for damagea resulting from his negligenee. (Pothier, No. 128; Nougnier, § 462 : Allen v. Suydam, 20 Wend. 321 ; Bank of Ian Diemen's Land v. Victoria Bank, J. R. 3 P. C. at p. 542.) " Chalmers, p. 132.

B See $\$ 4$.

7 Pages 681-684. 


\section{$\S$ 242. Presentment; how made.}

Presentment for acceptance must be made by or on behalf of the holder at a reasonable hour, ${ }^{8}$ on a business day, and before the bill is overdue, to the drawee or some person authorized to aceept or refuse acceptance on his behalf ${ }^{10}$ and

1. Where a bill is addressed to two or more drawees who are not partners, presentment must be made to them all, unless one has authority to accept or refuse acceptance for all, in which case presentment may be made to him only; "

2. Where the drawee is dead, presentment may be made to his personal representative; ${ }^{12}$

3. Where the drawee has been adjudged a hankrupt or an insolvent, or has made an assignment for the henetit of ereditors, presentment may be made to him or to his trustee or assignee. ${ }^{13}$ [Note. - See Bills of Exchange Act, section 41, subdivision (1).]

\section{$\S 243$. 0n what days presentment may be made.}

$A$ bill may be presented for acceptanee on any day on which negotiable instruments may be presented for payment under the provisions of sections one hundred and thirty-two and one hundred and forty-five of this chapter. When Saturday is not otherwise a holiday, presentment for acceptance may be made before twelve o'clock noon on that day.

\section{§ 244. Presentment where time is insufficient.}

Where the bolder of a bill drawn payable elsewhere than at the place of business or the residence of the drawee has not time with the exercise of reasonable diligence to present the hill for areeptance before presenting it for payment on the day that it falls due, the delay caused by presenting the bill for accoptanes before presenting it for payment is excosed and does not discharge the drawers and indorsers.

[Notr. - See Bills of Exchange Art, sortion 39. sublivicion (4).]

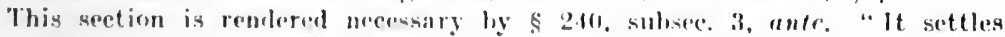
a moot point, and perhape alfers the law. Suppose a hill, payalle ome month after date, is drawn in Now York on a liverpool firm. hut payable al a london

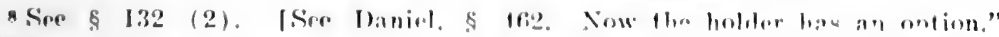
46.4a.1

See Ilato v. lirynolds, 27 N. Y. (Sire \& 245 (1]) Chalmors, [1. I3tin. 586, antr, 1) 680 .

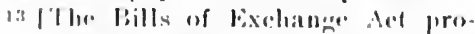
10 Pages 685-688. [Byles on Billa, agrement or lesage a presentement 182; Daniml, \$ 487.1

"IDaniel, \$488.] Ante, \$229 (5).

12 (Danicl, \$ 591.) "Before this "n. actment the law on this point was verve doubtful. Smith v. New fiouth Wales lhrough the past oflice ia mullicient." But prohably no such practice prevails in this cominty nor dome it nppear to hir: a pruetien that should be encour-
} Bank, B Moore, I'. ('. N. S., at PF. 4til, 
bank. It only reaches the Encrlish holder, or his agent, on the day that it matures. He must, nevertheless, present it for acceptance to the drawees in liverponl. The det provides that he shall not be prejulieed by so doing. Before the act the nsual practice was to protest the bill in Lonclon without any presentment to the drawees - an obvionsly inconvenient mode of procecding, for the holder's object is to get the bill paid, and not to run up expenses against the drawer and indorsers." Chalmers. p. 133.

\section{When presentment is excused.}

Presentment for acceptance is excused and a bill may be treated as lishonored by non-acceptance in either of the following cases:

1. Where the drawee is dead, ${ }^{14}$ or has absconded," ${ }^{15}$ or is a fictitious person or a person not having capacity to contract by bill : ${ }^{16}$

2. Where after the exercise of reasonable diligence, presentment cannot be made: ${ }^{17}$

3. Where although presentment has been irregular, acceptance has been refused on some other ground. ${ }^{18}$

\section{$\S 246$. When dishonored by non-acceptance.}

A bill is dishonored by non-acceptance:

1. When it is duly presented for acceptance, and such an acceftance as is prescribed by this chapter is refused or cannot be obtained; or

2. When presentment for acceptance is excused and the bill is not accepted.

[Notr. - See Bills of Exchange Act, section 43, subdivision (1).]

\section{$\S 247$. Duty of holder where bill not accepted.}

Where a bill is duly presented for acceptance and is not accepted within the prescribed time, the person presenting it must treat the bill as dishonored by non-acceptance or he loses the right of recourse against the drawer and indorsers. ${ }^{19}$

Note. - See Bills of Fxchange Act, section 42. The language of the Bills of Exchange Act is, "within the customary time," but the time herein is fixed hy scction 136. (N. Y., § 224.)] 'That is, due notice must be given to parties secondarily liable. Sec, however, $\$ 188$.

14 [See Bills of Fxchange Act, section 41, subdivision (2); Daniel, $\$ 1178.1$ Compare $\$ 242$, subsec 2 .

is [Daniel, § 1144. By the Bills of Exchange Act the bankruptcy of the drawee will excuse presentment for ae. ceptance. But this is not the rule of the Commercial Jaw. Daniel, §§11711172.1

is [See Danicl, \& 1111.]

17 [Daniel, \& 1059, et seq.] See § 142, subsec. 1 ; also \$ 183 .

18 "This is, perhaps, new law, and is important, having regard to the next subsection." Chalmers, p. 137n. The subsection referred to reads: "The fact that the holder has reason to helieve that the bill, on presentment, will be dishonored, does not excuse presentment." ' This provision does not appear in the American Act. But if the drawer has no right to expect acceptance, presentment for payment is excused. $\$ 139$.

19 Page 689. 


\section{$\S 248$. Rights of holder where bill not accepted.}

When a bill is dishonored by non-acceptance, an immediate right of recourse against the drawers and indorsers accrues to the holder, and no presentment for payment is necessary. ${ }^{20}$

[NotE. - See Bills of Exchange Act, section 43, subdivision (2).]

\section{ARTICLE XIV.}

\section{PROTEST.}

Secrion 260. In what cases protest necessary.

261. Protest: how made.

262. Protest: by whom made.

263. Protest; when to be made.

264. Protest: where made.

265. Protest both for non-acceptance and non-payment.

266. Protest lefore maturity where acceptor insolvent.

267. When protest dispensed with.

268. Protest where bill is lost or destroyed or wrongly detained.

\section{$\S 260$. In what cases protest necessary.}

Where a foreign bill, ${ }^{21}$ appearing on its face to be such is dishonored by non-acceptance, it must be duly protested for non-aceeptance, and where such a bill which has not previously been dishonored by nonacceptanee is dishonored by non-payment, it must be duly protested for non-payment. If it is not so protested, the drawer and indorsers are discharged. ${ }^{22}$ Where a bill does not appear on its face to be a foreign bill, protest thereof in case of dishonor is unnecessary. ${ }^{23}$

[Notr. - See Bills of Jixelange Act, section 51, subdivision (2).]

\section{$\S 261$. Protest; how made.}

'The protest must be annexed to the bill, or must contain a copy thereof, ${ }^{21}$ and must he under the hand and seal ${ }^{25}$ of the notary making it, and must specify:

20 lages tisti-60)0. "Tho immediate right of recourst arising on nou-ac. reptance is an exceptional right, und sreme preuliar fo linglion law and American law. (Whilehead v. Walkrr, g M. \& W.. al P. alf; Hatson v. Tur pley, 20 How. (1). ட..), at. [. 51!! : ef. Dunn v. O'herf', 5 M. \& S.. at p. 289.) Under the continental erolog the holder can only protest liee hill for non-ne. ceptance, and domand serurity from the drawer and indorsers. French Code, urte. 110, 120; Firman lixoliange Law, arts. 25.28.) The mfret of this conflint of laws dors not appeser to lave ben judieially eonsiderel." ('lislmers, p. 140.

21 Sies $\$ 213$.

22 Pagro 6!1. "The notice of dishonor is not barl beenuse it omits to slate that the bill has hem protested. (lis parte tournthal, I. R. 9 ('h. 591$.$) " ('halmers, p. 172.$

23 Pлge 000 .

24 Feer bills of Fochange Act, ace. (ion 51, subdivision (7); Daniel, $\$ \$ 1.14 .1$

25 rases, pl). 482, 590. IIn some of the Statre, is in Niw Yirk, the nas of a senl is not noessary where the cer- 
1. 'The time and place of presentment:

2 . 'l'he fare that presentment was made and the manner thereof :

3. 'The anse or reason for protesting the bill;

4. The demand mate and the answer griven, if any, or the fact that the drawee or aceeptor could not be found.'

\section{$\S 262$. Protest: by whom made.}

l'rotest may be made hy:

1. A notary public: 2 or

2. By any respertable resident of the place where the bill is dishomerel, in the presence of two or more rerlible witnesses. ${ }^{3}$

[Note. - See Todd s. Ieal's dtministrator, 49 Ala. 273; Daniel, \$\$ 934134-al; ( ivil cote of (ahfornia, 322ti.)

\section{§ 263. Protest: when to be made.}

When a hill is protested. such protest must be made on the day of its dishonor," unless lelay is escused as herein provided." When a bill has been doly notod." the protest may be subsequently extended as of the date of the noting. ${ }^{\text {t }}$

see pages $696-698$ s.

\section{$\S 264$. Protest; where made.}

A bill nust be protested at the place where it is dishonored, ${ }^{8}$ except that when a bill drawn payahle at the place of business or residence

tificate is to be used in the State: but a seal is probably desirable where the certificate is to be used in other juris. dictions.l

1 Pages 69]-695. [See Daniel, §§ 950-958. The Bills of Exchange Aet provides that protest must specify the person at whose request the bill is protested, hut this makes a change in the law. Daniel, \& 956.1

2 Pages $699-700$. "In England the notarial presentment of the bill to the drawee or acceptor is almost al. ways made by the notary's clerk. (Brooks' Notary, 4th ed., pp. 78 and 138.) In America the validity of a protest founded on such presentment has been douhted. (See I'arsons on Bills, p. 641.)" Chalmers, p. 175.

3 See Bills of Exchange Aet, section 94.

4 [See Bills of Exchange Act, spetion 51, subdivision (4); Drnnistoun v. Stevart, 19 How. 606: Jiyles on Bills, 257.] "Before the act it was not clear that a bill could not be lawfully noterl for protest on the lily after its dishonor: but the busines; members of the Select ('ommittee were manimons in thinking that noting on the day of dishonor should be made obligatory." Chalmers, p. 173.

S. See $\$ 267$.

" By 'noting' is meant the min. ute male by a notary public on a dishonered bill at the time of its dishonor. The formal notarial certificate. or protest, attesting the dishonor of the bill, is based upon the noting. The 'noting, con-ists of the notary'; ini tials, the date, the noting charges, and a mark referring to the notary's regiater written on the bill itself." Chalmers, p. 171.

7 Pages 694-695. [Bailey v. Dozier, 6 Ilow. 23: C'ayuga Co. Bank v. Munt, 2 Ilill, 635; Daniel, § 940; Byles on Jill:, 257.1

8 [Sice Danie], § 935; Byles on Bills, 217.1 
of some person other than the drawee, has been dishonored by nonacceptance, it must be protested for non-payment at the place where $i t$ is expressed to be payable, and no further presentment for payment to, or demand on, the drawee is necessary."

\section{$\$ 265$. Protest both for non-acceptance and non-payment.}

A bill which has been protested for non-acceptance may be subseIuently protested for non-payment.

[.'отE. - See Bills of Exchange Act, section 51, subdivision (3).] "Protest in such case might he necessary for the purpose of charging a foreign drawer $w$ indorser in his own country. An English act can only lay dewn the law for the United Kingdom. though by the comity of nations the duties of the holder would generally he regarded as regulated by the law of the place where they are to be performed . . Unter some continental codes no riglit of iction arises on non-acceptance; the holder enn demand security from anteredent parties, but he is bound to re-present the bill at maturity." Chalmers, 1. 172 .

\section{$\S 266$. Protest before maturity where acceptor insolvent.}

Where the acceptor has been adjudged a bankrupt or an insolvent or has made an assignment for the benefit of creditors, before the bill matures, the holder may cause the bill to be protested for better security against the llawer and indorsers.

[Note. - See Bills of Bxchange Art, section 51, suldivision (5); Daniel, \$530.] "Under some enntinental codes, when the acceptor fails during the currency of a bill, security can be demanded from the drawer and indorsers. (German Exchange Jaw, art. 29: Nethrrlands Code, arts. 177, 178.) English law provides no such remerly. and the ouly effect of such a protest in England is that the bill may he acceptenl for lomor. In France, if the arechtor fails, the bill may at one le treated as dishomored and protested for non-payment. (French Corle, art. 16i3): Nouguinr. \& 1275.)" Chalmers, p. 173.

\section{$\S 267$. When protest dispensed with.}

l'rolest is dispensed with ly any riremmstances which would dispense with notice of dishonor. ${ }^{0}$ Dedey in moting or protesting is excused

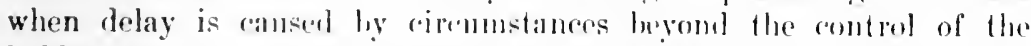
holder and not imputshle to his definlt, miscomeluet, or meglierence." When the canse of delay andse to oprate, the hill must be noted or

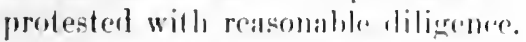

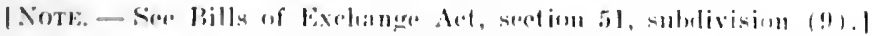

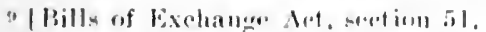
aublivision (1i): 2 and 3 IIjilliam 15 .

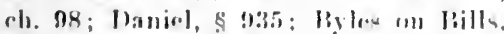
258.] "Silpposo a hill is drawn on $B$ in Liverpool. "paralibe at lloe $x$

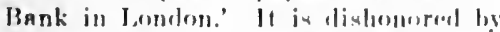
non-acepeptance. It is to lue protenterl for non pasment in Jondon withumt any further demand on $\mathrm{l}$. Orolinarily the protest recites the demand on the

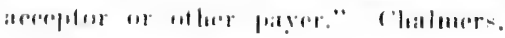
1. 17.1.

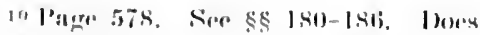
this inerrporate \$ liss? Sies rhal. mira, p. 17i;.

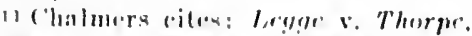

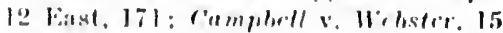
1., J. C. I'. 1: linllerehild v. Currie, 1 ?. I?., at p. 17. 


\section{$\$$ 268. Protest where bill is lost or destroyed or wrongly detained.}

Hhere a bill is lust or destroyen or is wrongly detained from the gerson entitled to holel it, protest may be made on a copy or writterl paticular's thereot.

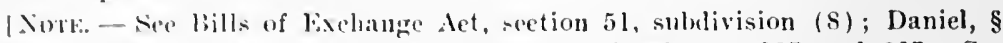
1.16.1.] "Pothier, No. 145: Brooks" Notary, 4th edt, pl. 137 and 2I7. See further as to lost bills, sections tia and 70 (Bills of Exchange Act). The particulars ean usually lo obtained from the bill book." Chalmers, p. 175n.

\section{ARTICLE XV.}

\section{ACCEPTANCE FOR HONOR.}

SEction 280 . When bill may be acepted for honor.

28l. Aceptanee for honor; how male.

282. When deemed to be an acceptance for honor of the drawer.

283. Liability of aceeptor for honor.

284. Agreement of acceptor for honor.

255. Naturity of bill payable after sight; aceepted for honor.

286. l'rotest of bill aecepted for honor or containing a reference in case of neel.

287. Presentment for payment to acceptor for honor; how made.

288. When delay in making presentment is exeused.

289. Dishonor of bill by acceptor for honor.

Note. - See pp. 701-706.

\section{$\S 280$. When bill may be accepted for honor.}

Where a bill of exchange has been protested for dishonor by nonacceptance or protested for better security and is not overdue, any person not being a party already liable thereon, may, with the consent of the holder, intervene and accept the bill supra protest for the honor of any party liable thereon or for the honor of the person for whose account the bill is dratrn. The aceptance for honor may be for part only of the sum for which the bill is drawn; and where there has been an acceptance for honor for one party, there may be a further aeceptance by a different person for the honor of another party.

[Xote. - Sep Bills of Exchange Act, section 65, subdivisions (1) and (2); Byles on Bills, 262-266. The Bills of Exelange Act makes no provision for different aceeptances supra protest; but this is authorized by the commercial law. Byles on Bills, 263.I "In the Unitel States, as in Fingland, the holder may refuse to allow acceptanee for honor (See Story, \$122), for he may wish to exereise his inmediate right of reeourse which arises on non-aceptance." Chalmers, p. 226.

\section{§ 281. Acceptance for honor; how made.}

An acceptance for honor supra protest must be in writing and indicate that it is an acceptance for honor, and must be signed by the acceptor for honor.

[Note. - See bills of Exchange Act, seetion 65, suldivision (3). The Bills of Exchange Act reguires the aeceptance for honor to be written on the bill, but see note to seetion 132 (N. Y., $\$ 220)$. ? 
$\S 282$. When deemed to be an acceptance for honor of the drawer.

Where an acceptance for honor does not expressly state for whose honor it is made, it is deemed to be an acceptance for the honor of the drawer.

[Note. - See Bills of Exchange Act, scetion 65, subdivision (4).

\section{$\S 283$. Liability of the acceptor for honor.}

The acceptor for honor is liable to the holder and to all parties to the bill subsequent to the party for whose honor he has accepted.

[Nоте.-See Bills of Exchange Act, section 66, subdivision (2).]

\section{$\S 284$. Agreement of acceptor for honor.}

The acceptor for honor by such acceptance engages that he will on due presentment pay the bill according to the terms of his acceptance, provided it shall not have heen paid by the drawee, and provided also, that it shall have been duly presented for payment and protested for non-payment and notice of dishonor given to him.

[Notk, - See Bills of Exchange Act, section 66, subulivision (1).]

\section{$\S 285$. Maturity of bill payable after sight; accepted for honor.}

Where a hill payalule after sight is accepted for honor, its maturity is calculated from the date of the noting for non-acceptance and not from the date of the aceeptance for honor.

[Note- - Sar Bills of Exchangr Act, section 65, subdivision (5).] "This section brings the law into accorlaner with mercantilo understanding, and gets rid of an inconvenient ruling to the reflect that maturity was to be ealculnted from the date of acceptinee for honor. (Williom v. Germuine, $7 \mathrm{~B}$. \& (. 468.)" ('halmers, p. 2.28.

\section{$\S 286$. Protest of bill accepted for honor or containing a reference in case of need.}

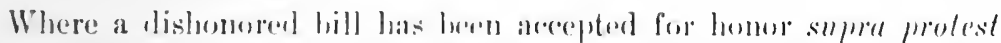

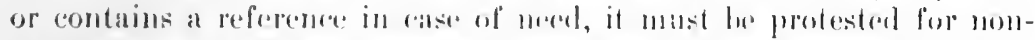
payment before it is presented for payment to the ancerper for honor or referee in rase of nempl.

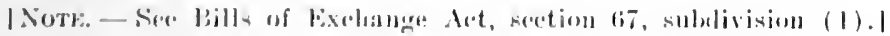

$\S 287$. Presentment for payment to acceptor for lionor; how made.

Presentment for payment to the aleenter lor homor must he made as follows:

1. If it is to low presented in the phane where the protest for non-payment was made, it must be presented not later than the dny following its maturity:

2. If it is to be presented in some other place than the place where it was protristod, then it must he forwaried within the time specified in section one londred and seventy-five.

[Notr. - Sier Bille of bixchange Aet, section 67, hubsec. (2). "I)oubts hav. ing ariwn as to the day whell hor hill should be again presented to the

КEOOT. INSTHUM RNTB- 
mereptur for homor. or refores in case of necd, for payment, the 6 and 7

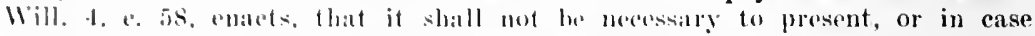

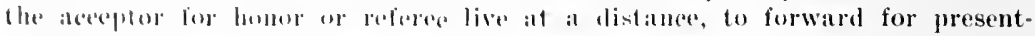
nent. till the day following that on which the bill becomes due." Byles on liills. "2tiis.l

\section{$\$ 288$. When delay in making presentment is excused.}

'The provisions of serelion one humbed and forty-one apply where there is delay in making presentulent to the acceptor for honor or inferee in ciscer wi need.

\section{Dishonor of bill by acceptor for honor.}

IIlen the hill is dishonored hy the aceeptor for honor it must be protested for nem-jayment hy him.

[Note. - Bills of Exchange Act, section (i7, subdivision (4).]

\section{ARTICLE XVI. \\ PAYMENT' FOR HONOR.}

SECTIOx 300. Who may make payment for honor.

301. Pilyment for houor; how made.

302. Declaration before payment for honor.

303. Preferenee of parties offering to pay for honor.

301. Elfret on subecquent parties where bill is paid for honor.

305. Where holler refuses to receive payment supra protest.

306. Rights of payer for honor.

Note. - Sec lp. 707-708.

\section{$\S 300$. Who may make payment for honor.}

Where a bill has been protested for non-payment, any person may intervene and pay it supra prolest for the honor of any person liable thereon or for the homor of the person for whose account it was drawn.

[Notk. - See Pills of Exehange Act, section 68, subdivision (1); Byles on lills, 267-269; Dinniel, § 1254.1

\section{§ 301. Payment for honor; how made.}

The proncut for honor supra protest in order to operate as such and not as a mere voluntary layment must be attested by a notarial ar of honor which may be apponded to the protest or form an extension to it.

[Xote. - Sin Bills of Exehange Aet, section 68, suldivision (3); Byles on bill-, 267; Haniol, \$ 1258.1

\section{$\S 302$. Declaration before payment for honor.}

The notarial art of honor must be founded on a declaration made by the payer for the honor or by his agent in that behalf declaring his intention to pay the hill for loonor and for whose honor he pays.

[Note. - See bills of Exchange Act, section 68, subdivision (4).] 


\section{$\S 303$. Preference of parties offering to pay for honor.}

Where two or more pessuns offer to pay a bill for the honor of hlllerent parties, the person whose payment will discharge most parties to the bill is to be given the preference.

[Note. - See Bills of Exchange Act, section 68, subdivision (2).]

\section{$\$ 304$ Effect on subsequent parties where bill is paid for honor.}

Where a bill has been paid for honor all parties subsequent to the party for whose honor it is paid are discharged, but the payer for honor is subrogated for, and succeeds to, both the rights and duties of the holder as regards the party for whose honor he pays and all parties liable to the latter.

[NoTE. - See Bislts of Exchange Act, section 68, subdivision (5); Daniel, $\S 1255$.

\section{$\S 305$. Where holder refuses to receive payment supra protest.}

Where the holder of a bill refuses to receive payment supra protest, he loses his right of recourse against any party who would have been discharged by such payment.

[Note. - See Bills of Exchange Aet, section *8, subdivision (7).]

\section{$\S 306$. Rights of payer for honor.}

'The payer for honor on paying to the holder the amount of the bill and the notarial expenses incidental to its dishonor, is entitled to receive both the bill itself and the protest.

[Note. - See Bills of Exchange Act, section 68, subdivision (6).]

\section{ARTIC'LE XVII.}

\section{BIIISS IN SLTS.}

Srction 310. Bill in sots constitutes one hill.

31). Rights of holders where dilferent parts are negotiated.

312. Liability of holder who indorses two or more parts of a set to ditrerent persons.

31.3. Areceptence of hills drawn in sots.

314. Payment by acereptor of bills drawn in sets.

315. Eifect of discharging onr of a set.

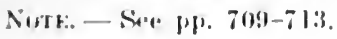

\section{$\S 310$. Bill in sets constitutes one bill.}

Where a bill is drawn in a set, anch part of the set being numhered and rontaining a roforence to the other parts, the whole of the parts constifutes une hill.

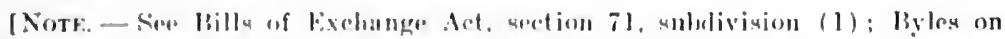

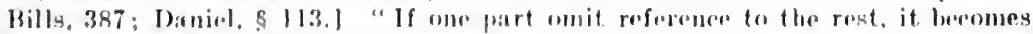
a urparate hill in the hande of $"$ bome fide holder. It has leon held that an agrement to deliver up an unacepted bill drawn in a set is an agrevent 
to deliver up all the parts in existence (Kearney r. West Cranada Co., 28 L. J. Ex. 16): nut also that a person who megotiates a bill of exehange drawn in a set, is bound to deliver np ntl the parts in his possession, but by negotiating one part he does not warmut that he hus the rest. (l'inard v. hlockman, 32 I. J. (1. B. S2.) In England the obligation to give a set is presumably a matter of bargain." Chalmers, p. 235.

\section{\$ 311. Rights of holders where different parts are negotiated.}

Where two or more parts of a set are negotiated to different holders in due course, the holder whose title first accrues is as between such holders the true owner of the bill. But nothing in this section affects the rights of a person who in lue course aceepts or pays the part first presented to him.

[ Nоте. - See Bills of Exchange Act, section 7], subdivision (3); Byles on Bills, 369.1

\section{$\S 312$. Liability of holder who indorses two or more parts of a set to different persons.}

Where the holder of a set indorses two or more parts to different persons he is liable on every such part, and every indorser subsequent tc him is liable on the part he has himself indorsed, as if such parts were separate bills.

[Хoте. - See Bills of Exchange Act, section 7], subdivision (2); Holds worth v. Hunter, 10 B. \& C. 449 ; Byles on Bills, 389.1

\section{$\S$ 313. Acceptance of bills drawn in sets.}

The acceptance may be written on any part, and it must be written on one part only. If the drawee accepts mcre than one part, and such accepted parts are negotiated to different holders in due course, he is liable on every such part as if it were a separate bill.

[NoTE, - See Bills of Exchange Act, scetion 7l, subdivision (4); Holdsworth v. Hunter, 10 B. \& $(\therefore 449$; Byles on Bills, 389.1

\section{$\S 314$. Payment by acceptor of bills drawn in sets.}

When the aeceptor of a bill drawn in a set pays it without requiring the part bearing his acceptance to be delivered up to him, and that part at maturity is outstanding in the hands of a holder in due course, he is liable to the holder thereon.

[Notk. - See Bills of Exebange Act, section 71, subdivision (5); Byles on Bills, 389.]

\section{$\S 315$. Effect of discharging one of a set.}

Except as herein otherwise provided, where any one part of a bill drawn in a set is discharged by payment or otherwise the whole bill is discharged.

[Notr. - See Bills of lixchange Aet, section 71, subdivision (6); Byles on Bills, 388.] 


\section{ARTICLE XVIII.}

\section{PROMISSORY NOTES AND CHECKS.}

Section 320. Promissory note defined.

321. Check defined.

322. Within what time a check must be presented.

323. Certification of check; effect of.

324. Effect where holder of check procures it to be certified.

325 . When clieck operates as an assignment.

326. Recovery of forged check.

\section{$\S 320$. Promissory note defined.}

A negotiable promissory note within the meaning of this chapter is an unconditional promise in writing made by one person to another signed by the naker es.gaging to pay on demand or at a fixed or determinable future time, a sum certain in money to order or to bearer. $^{12}$ Where a note is drawn to the maker's own order, it is not complete until indorsed by him. ${ }^{13}$

[NотE. - Sce Bills of Exchange Act, section 83.] "A bank note may be defined as a promiscory note issued ly a banker payable to beares on demand. But a bank note differs from an orlinary note in various important respects. Among others it may be reissued after payment. See further distinctions pointed out by Bramwell, B. (Lichfield Union v. Greenc, 26 L. J. Ex., at p. 142.)" Chalmers, p. 263.

\section{$\S$ 321. Check defined.}

A check is a bill of exchange drawn on a bank, ${ }^{14}$ payable on demand. ${ }^{16}$ Except as herein otherwise provided, the provisions of this chapter applicable to a bill of exchange payable on demand apply to a eheck. ${ }^{18}$

12 Pages $714-721$. Sie $\$ 20$, and

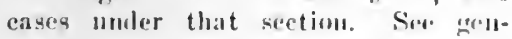
prally on form and interpretation, 5 ș $20-42$.

The English Aet includes notes payable "lo, or to the order of, a specified peruon or to lerisere," that is. it includes non-nogotiathle molos. So alson was the forner Niw lork statute. (Carnirright $\vee$ Giray. 127 X. Y. !2.) This section eloanges tlse Now York law and eorfines the operation of the Aet to negotiable notes.

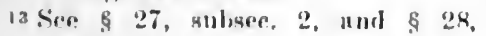
subace. 5. l'nge 715.

14 Pages 722-724. ISire Billa of Fix. changre Art, gertion 73: Bull v. Kas son. 123 U. S. 105; Mopkingon v. l'oseter, L. R. $18 \mathrm{Eq} .74 .1$ S.u. \$ุ 2, defin. ing "bank."
15 | Danial, \$1574.

18 "The Act is declaratory in so far as it defines a check ae a hill of exchangt. (.1\%lean v. Clydesdale Bank. 1. R. 9 Apr. (as. 95.) It is no part of the definition that a cleeck should he an inland bill, or that it should be Jrawn by a restomer upon his banker. - "Sere elecets pomparen with and distinguished from ordinary billy by Parke. P. (e Moure P. (', at p. 69), Firle, J., and Byles, .J. (8 r., B. N. S., "t tp. 380. 381, as molitioul he I. R. 19 Fi.. at p. 70, Jessel. M. R.). Palles, C. B. 110 Ir. R. ( . L.. at P. 490), and the Supreme court of the l'nited Stateq. (10 Wallacre at p. B47.) All rlierku are hillu of rechanger. hit all bille of exchange aro not checks; throfore, an antlwority to draw checks 


\section{$\$ 322$. Within what time a check must be presented.}

A check must be presented for payment within a reasonable time after its issue or the drawer will be discharged from liability thereon to the extent of the loss earsed by the delay. ${ }^{17}$

1Note. - See smith v. fones, 2 Bush, 103; Cork v. Bacon, 45 Wi3. 192: Bull v. Kasson, 123 1. S. 105; 1aniel, \$\$ 1586-1600.] See Bills of Exchange Act. section $i 4$. For effect of delay upon indorser's liability, see pages 734-743.

\section{$\S 323$. Certification of check; effect of.}

Where a check is certified by the bank on which it is drawn the certification is equivalent to an acceptance. ${ }^{18}$

\section{$\S 324$. Effect where the holder of check proeures it to be certified.}

Where the holder of a check procures it to be accepted or certified the drawer ${ }^{19}$ and all indorsers ${ }^{20}$ are discharged from liability thereon.

\section{$\S 325$. When check operates as an assignment.}

A rheck of itself does not operate as an assignment of any part of the funds to the eredit of the drawer with the bank, and the bank is not liable to the boliler, unless and until it accepts or certifies the check. $^{21}$

[Note. - See Bank v. Millarl, 10 Wall. 152; Bank v. Schuler, 120 U. S. 511 ; Bank v. Whitman, 94 U. S. 343,344 ; St. L. \& S. F. R'y Co. v. Johnson. 133 U. S. 566; Attorney-fieneral v. C'ontinental life Insuranee lo., $7 \mathrm{l}$ N. Y. 325,330 ; First Nat. Bank of Union Mills v. Clark, 134 N. Y. 365; O'Connor v. Hechanies' Bank, 124 N. Y. 324; Covert v. Rhodes, 48 Ohio St. 66; l'ickle v. Peoples' Nat Bank, 88 'Tenn. 380; Borteher v. Colorado Nat. Bank, 15 Colo. 16; llopkinson v. Foster, L. R. 18 Eq. 74; Contra: Fonner v. Smith, 31 Neb. 107 ; Munn v. Bureh, 25 Ill. 35; Bankv. Patton, 109 111. 470, 485.] See § 211.

\section{$\S 326$. Recovery of forged eheck.}

No bank shall be liable to a depositor for the payment by it of a forged or raised eheck, unless within one year after the return to

does not necessarily include an authority to draw bills. Forster v. Mack: reth, L. R. 2 Ex. li3.). Apart from statute, the distinctions between checks and ordinary bills of exchange arise from the relationship of banker and eustomer subsisting between the drawer and drawee of a cheek. A check is intended for prompt presentment, while a note payable on demand is deemed to be a continuing seeurity. (Brooks v. Mitehell, 9 M. \& W., at p. 18; Chartered Bank v. Diekson, I. R. 3 C. P., at p. 579.) " Chalmers, pp. 245-246.

17 Pages 725-733. Sre "rrasonable time," defined in $\$ 4$. Independent of statute a check must be prisented or forwarded for presentuent on the day after it is received. Chalmers, p. 248. The draft of the Ameriean Aet origi. nally contained the following: "The death of the drawer does not operate as a revocation of the authority of the hank to pay a elieck, if the clicek is presented for payment within ten days from the date thereof: "but this was struek out of the final draft. [This was taken from the statutes of Massachusetts (Pub. St. Supp. 1888, ch. 210.) There seems to be some doubt as to the common-law rule. Bee Daniel, § 1618b.]

18 Pages 743-751.

19 Pages 743-748.

20 Pages 748-751.

21 lages 752-758. 
the depositor of the voucher of such payment, such depositor shall notify the bank that the eheek so paid was forged or raised.

Added by Law's of 1904, ch. 287. See note 6, ante, p. 758. See also pages 758-771.

\section{ARTICLE XIX. ${ }^{22}$}

\section{NOTES GIVFN FOR PATENT RIGHTS AND FOR A SPECULATIVE} CONSIDERATION.

SEction 330. Negotiable instruments given for patent rights.

331. Negotiable instruments given for a speculative consideration.

332. How negotiable bonds are made non-negotiable.

\section{$\S$ i30. Negotiable instruments given for patent rights.}

A promissory note or other negotiable instrument, the consideration of which consists wholly or partly of the right to make, use or sell any invention claimed or represented by the vendor at the time of sale to be patented, must contain the words "given for a patent right" prominently and legilly written or printed on the face of such note or instrument above the signature thereto; and such note or instrument in the hands of any purehaser or holder is subject to the same defenses as in the hanits of the original holder; but this section does not apply to a negotiable instrument given solely for the purchase price or the use of a patented article.

It is a mislemeanor, to take, sell, or transfer such an instrunent, knowing the consideration to be as above describel, unless the words "given for a patent right" appear on the instrument above thr signature. N. Y. Penal Law, \$ 1520 (originally Laws of N. Y. 1897, c. 613). See note 1, ante, pp. 384-385.

\$331. Negotiable instruments given for a speculative consideration.

If the consideration of a promissory note or other negotiable instrument consists in whole or in part of the purchase price of any farm product, at a price greator by at least four times than the fair market value of the same produet at the time, in the locality, or of the membership and rights in an association, company or combination to prouluce or sell any farm product at a fictitious rate, or of a contract or bond to purchase or soll ally farm prochuct at a price greater by four times than the market value of the same produrt at the time in the lomality, the words, "given for a spereulative considerntion," or other words elearly showing the muture of the consideration, must be prominently and logihly written or printerl on the face of surb note or instrument, abowe the signature thereof: and such note or instrument, in the lands of any purchaser or holder, is subjeret to the same defenses as in the hands of the original owner or holder.

22 Not a part of the Nogotiable: Instrum nts law in umst stales. See note 1 , ante, pp. $384-385$. 
It is a miademeanor to take, sell or transfer such an instrument, knowing the consideration to be ns abose deseribed, unless the words "given for a speculative consideration," or other words elearly showing the nature of the consideration, appear on the instrument above the signature. N. Y. l'enal

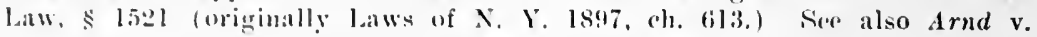
sjoblom, 131 W'is. lit2, ante, p. 383, and note 1, ante, p[1. 384-385.

\section{$\S 332$. How negotiable bonds are made non-negotiable.}

'The owner or holder of any erporate or municipal bond or obligation (except such as are designated to cilculate as money, payable to bearer), heretofore or herealiter issued in and payable in this state, but not registered in prrsuance of any state law, may make such bond or obligation, or the interest coupon accompanying the same, non-negotiable, by subscribing his mame to a statement indorsed thereon, that such bond, obligation or coupon is his property; and thereon the prineipal sum therein mentioned is payable only to such owner or holder, or his legal representatives or assigns, mless such bond, ohligation or compon he transferred by indorsement in hlank, or payable to bearer, or to order, with the addition of the assignor's place of residence.

\section{ARTICLE XX. ${ }^{23}$}

LAWS REPEALED; WHEN TO TAKE EFFECT.

Section 340. Laws repealed.

341. When to take effect.

\section{$\S 340$. Laws repealed.}

Of the laws emumerated in the schedule hereto annexed, that portion specified in the last column is hereby repealcd.

\section{$\S 341$. When to take effect.}

This chapter shall take effect immediately. ${ }^{24}$

Schedule of Laws Repealed.

Revised Statutes. Sections. Subject matter.

R. S., pt. II, ch. 4, tit. II...... All..... Bills and notes.

Laws of Chapter. Sections. Subject matter.

$1788 \ldots . . .33 \ldots$ All.... Promissory notes to be negotiable.

$1794 \ldots 48 \ldots$ All.... Promissory notes to be negotiable same as bills of exchange.

23 This particular schedule of repeals applies, of course, only to New York state.

24 The Negotiable Instruments Law was originally enaeted in New York by Laws of 1897 , ch. 612 , which took fffect October 1, 1887. 
Laws of Chapter. Sections. Subject matter.

$1501 \ldots$ 44... All... Promissory notes to be negotiable same as bills of exchange.

$1819 \ldots$... $34 \ldots$ All.... Regulating recovery of damages upon certain bills of exchange.

1523... 216... All... Notice of protest in New York eity regulated in certain cases.

1826.... 17... All... Notice of protest in New York city further regulated.

1828... 20... 15, para. Adding $\S 22$ to R. S., pt. 2 , ch. 4, 30 (2nd title 2 .

meet.).

1828... 21... 1, paras. Repealing Laws 1801, 1819, 1823, 51, 2\%2, 1826 , above. $393,460$.

1835.... 141. . All... Notice of protest: how given.

$1857 \ldots . .416 \ldots$ All.... Commercial paper.

$1865 \ldots$... $309 \ldots$ All.... Protest of foreign hills, etc.

$1880 \ldots$ 4... 438... Negrotiability of corporate bonds; how limited.

1871... 84.... All... Negotiable bonds; how made nonnegotiable.

18.3.... 595.... All.... Negotiable bonds; how made negotiable.

1877... 65... All... Negotiable instruments given for pitent righlits.

$188 \% \ldots \quad 461 \ldots$ Ell .... Ellect of holidays upon payment of commercial paper.

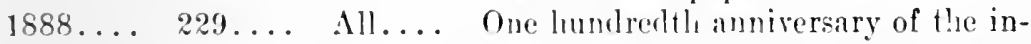
angruration of fieorge llashington.

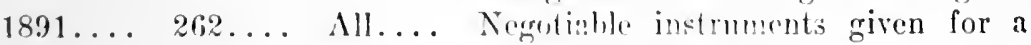
speremlative purpose.

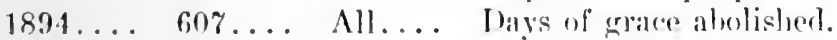

$1897 \ldots$... $612 \ldots$.... The Necotiahle Instruments Iaw as originally enacted in New York. ${ }^{25}$

$1897 \ldots .613 \ldots \ldots$ … $3 \ldots$

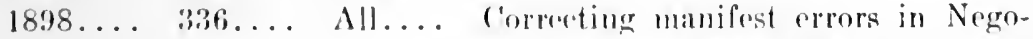
tiable lustrmuents Iaw as originally cuacted.2s

1904.... 287... All... Allling $\$$ :3:ti. Soce note $i$, ante, p. $i 58$.

25 Sec note 1, antr, p. 779. 



\section{ENGLISH}

\section{BILLS OF EXCHANGE ACT, 1882}

45 AND 46 VICT. CH. 61.

As Amended by 6 Edw. 7, Ch. 17, 1906. 



\title{
BILLS OF EXCHANGE ACT, 1882.
}

\author{
45 AND 46 VICT., СH. 6I.
}

\section{An act to codify the law relating to bills of exchange, cheques, and promissory notes.}

[18th August, 1882.]

Be it enacted by the Queen's Most Excellent Majesty, by and with the advice and consent of the Lords Spiritual and Temporal, and Conmons, in this present Parliament assembled, and by the authority of the same, as follows:

\section{PART I.}

\section{Short title.}

\section{Preliminary.}

This act may be cited as the Bills of Exchange Act. 1882.

\section{Interpretation of terms.}

In this act, unless the context otherwise requires -

"Acceptance" means an acceptance completed by delivery or notification.

"Action" includes counter-claim and set-off.

"Banker" includes a body of persous, whether incorporated or not, who carry on the business of banking.

"Bankrupt" includes any person whose estate is vested in a trustee or assignee, under the law for the time being in force relating to bankruptcy.

"Bearer" means the person in possession of a bill or note which is payable to bearer.

"Bill" means bill of exchange, and " note" means promissory note.

"Delivery" means transfer of possession, actual or constructive, from one person to another.

"Holder" means the payee or endorsee of a bill or note who is in possee. fion of it, or the bearur thereof.

"Indorsement" means an indorsement completed by delivery.

"Isaue" means the first delivery of a bill or note, completed in form, to a person who takes it as a holder.

"Person" includes a bouly of persons, whether incorporated or not.

"Value" means valuable consilleration.

"Written " includes printed, and "writing" includes print. 
PART 11.

Bhls of Hichange.

Form and Interpretation.

\section{Blll of exchange deflned.}

(1) A bill of exchange is an unconditional order in writing, addressed by one person to another, signed by the person giving it, requiring the person to whom it is athressed to pay on demand or at a fixed or determinable future time. a sum certain in money to or to the order of a specitied person, or to bearer.

(2) In instrument which does not comply with these anditions, or which orders any act to be clone in addition to the payment of money, is not a bill of exchange.

(3) An order to pay out of a particular fund is not unconditional within the meaning of this section; but an unqualified order to pay, coupled with $(a)$ an indication of a particular fund out of which the drawee is to re-imburse him. self or a particular account to be debited with the amount, or $(b)$ a statement of the transaction which gives rise to the bill, is unconditional.

(4) A bill is not invalid by reason -

(a) That it is not dated;

(b) That it does not specify the value given. or that any value has been given therefor;

(c) That it does not specify the place where it is drawn or the place where it is payable.

\section{Inland and foreign bills.}

(1) An inland bill is a bill which is, or on the face of it purports to be-(a) both drawn and payable within the British Islands, or (b) drawn within the British Islands upon some person resident therein. Any other bill is a foreign bill.

For the purposes of this act " British Islands" mean any part of the United Kingdom of Great Britain and Ireland, the Islands of Man, Guernsey, Jersey, Alderney, and Sark, and the islands adjacent to any of them being part of the dominions of Her Majesty.

(₹) Unless the contrary appear on the face of the bill the holder may treat it as an inland bill.

\section{Effect where different parties to bill are the same person.}

(1) A bill may be drawn payable to, or to the order of, the drawer; or it may be drawn payable to, or to the orler of, the drawee.

(2) Where in a bill drawer and lrawee are the same person, or where the drawee is a fictitious person or a person not having capacity to contract, the holder may treat the instrument, at his option, either as a bill of exchange or as a promissory note.

\section{Address to drawee.}

(1) The drawee must be named or otherwise indicated in a bill with reasonable certainty.

(2) A bill may be addressed to two or more drawees whether they are partners or not, but an orler addressed to two drawees in the alternative, or two or more drawees in succession, is not a bill of exchange. 


\section{Certainty required as to payee.}

(1) Where a bill is not payable to bearer, the payee must be named or otherwise indicated therein with reasonable certainty.

(2) A bill may be made payable to two or more payees jointly, or it may be made payable in the alternative to one of two, or one or some of sereral payees. A bill mas also be made payable to the holder of an office for the time being.

(3) Where the payee is a fictitious or non-existing person, the bill may be treated as payable to bearer.

\section{What bills are negotiable.}

(1) When a bill contains words prohibiting transfer, or indicating an intention that it should not be transferable, it is ralid as between the parties thereto, but is not negotiable.

(2) A negotiable bill may be payable either to order or to bearer.

(3) A bill is payable to bearer which is expressed to be so payable, or on which the only or last indorsement is an indorsement in blank.

(4) A bill is payable to order which is expressed to be so payable, or which is expressed to be payable to a particular person, and does not contain words prohibiting transfer or indicating an intention that it should not be transferable.

(5) Where a bill, either originally or by indorsement, is expressed to be payable to the order of a specified person, and not to him or his order, it is nevertheless payable to him or lis order at his option.

8. Sum payable.

(1) The sum payable by a bill is a sum certain within the meaning of this act, although it is required to be paid -

(a) With interest.

(b) By stated installments.

(c) By stated installments, with a provision that upon default in pay. ment of any installment the whole shall becone duc.

(d) According to an indicated rate of exchange, or accorling to a rate of exchange to be ascertained as directed by the bill.

(2) Where the sum payable is expressed in words and also in figures, and there is a discrepancy between the two, the sum lenoted by the words is the amount payable.

(3) Where a bill is expresserl to he payable with interest, unless the instrument otherwise provicles, interest runs from the date of the bill, and if the bill is undated from the issuse thereof.

10. BIIl payable on demand.

(1) A bill is payable om lemand -

(a) Which is expressed to be payable on demand, or at sight, or on presentition : or

(b) In which no time for paymont is expressol.

(2) Where a bill is aceepted or indorsed when it is overdue, it shall, as regards the accuptor who so arecopts, or any indorser who so indorses it, be deemed a bill payable on demand.

\section{Blll payable at a future time.}

$A$ bill is payable at a determinable foture time within the meaning of this act which is expressed to the payable- 
(1) At a fixed period after date or sight.

(2) On or at a fixed period after the accurrence of a specified event which is certain to happen, though the time of happening may be uncertain.

An instrument expressed to be payable on a contingeney is not a bill, and the happening of the erent does not cure the defect.

\section{Omission of date in bill payable after date.}

Where a bill expressel to he payable at a fixed period after date is issued unclated, or where the acceptance of a bill payable at a fixed period aftersight is undated, any holder may insert therein the true date of issue or acceptance, and the bill shall be payable aecordingly.

provilel that (1) where the holder in good faith and by mistake inserts a wrong date, and (2) in every case where a wrong date is inserted, if the bill subsequently comes into the hands of a holder in due course, the bill shall not be avoided thereby, but shall operate and be payable as if the date so inserted had been the true date.

\section{Ante-dating and post-dating.}

(1) Where a bill or an acceptance or any indorsement on a bill is dated, the dite shall, unless the contrary be proved, be deemed to be the true date of the drawing, acceptance or indorsement, as the case may be.

(2) A bill is not invilid by reason only that it is ante-dated or post-dated, or that it bears date on a Sunday.

\section{Computation of time of payment.}

Where a bill is not payable on demand, the day on which it falls due is determined as follows:

(1) Three days, called days of grace, are, in every case where the bill itself does not otherwise provide, added to the time of nayment as fixed by the bill, and the bill is due and payable on the last day of grace :

Provided that -

(a) When the last day of grace falls on Sunday, Christmas Day, Good Friday, or a day appointed by Royal proclamation as a public fast or thanksgiving day, the bill is, except in the case hereinafter provided for, due and payable on the preceding business day;

(b) When the last day of grace is a bank holiday (other than Christmas day or Good Friday) under the Bank Holidays Act, 1871,* and acts amending or extending it, or when the last day of grace is a Sunday and the second day of grace is a bank holiday, the bill is due and payable on the succeeding business day.

(2) Where a bill is payable at a fixed period after date, after sight, or after the happening of a specified event, the time of payment is determined by excluding the day from which the time is to begin to run and by including the day of payment.

(3) Where a bill is payable at a fixed period after sight, the time begins to run from the date of the acceptance if the bill be accepted, and from the date of noting or protest if the bill be noted or protested for non-acceptance or for non-delivery.

(4) The term "month" in a bill means calendar month. 


\section{Case of need.}

The drawer of a bill and any indorser may insert therein the name of a person to whom the lolder may resort in case of need, that is to say, in case the bill is dishonored by.non-acceptance or non-payment. Such person is called the referee in case of need. It is in the option of the holder to resort to the referee in case of need or not as he may think fit.

\section{Optional stipulations by drawer or indorser.}

The drawer of a bill, and any indorser, may insert therein an express stipulation -

(1) Negativing or limiting his own liability to the holder;

(2) Waiving as regards himself some or all of the holder's duties.

\section{Deflnition and requisites of acceptance.}

(1) The acceptance of a bill is the signification by the drawee of his assent to the order of the drawer.

(2) An acceptance is invalid unless it complies with following conditions, namely :

(a) It must be written on the bill and be signed by the drawee. The mere signature of the drawee without additional words is sufficient.

(b) It must not express that the drawee will perform his promise by any other means than the payment of money.

\section{Time for acceptance.}

A bill may be accepted -

(1) Before it has been signed by the drawer, or while otherwise incomplete:

(2) When it is overdue, or after it has been dishonored by a previous ref usal to aceept, or hy non-payment :

(i) When a bill payablc after sight is dishonored by non-acceptance, and the Irawee sulsequently accepts it, the holder, in the absence of any different greemnt, is entitled to have the bill accepted as of the date of first presentm. nt to the drawee for aceptance.

\section{Gencral and qualifled acceptances.}

(1) An acceptance is eitler (a) general or (b) qualified.

(2) A gemeral aceeptance assents without qualification to the order of the drawer. $A$ yualified acceptance in express terms varies the effect of the bill as drawn.

In particular an aceeptance is qualified which is -

(a) Comlitionul, that is to saly, which makes payment by the acceptor Iependent on the fulfillment of a condition therein stated :

(b) Partial, that is (o) Haty. an acceptance to paty part only of the anomat for which the bill is drawn:

(c) Iox:al, that is to say, an acceptance to pay only at a particular aprerifienl plisce:

An areeptance to pay at a particular place is a general aceptance. moless it expressly states that the bill is to be paid there only and not olsewhrere:

(d) Qualifion as to time:

(e) The acceptance of sonte one or more of the drawees, lut not of all NRGOT. INSTRUMENTB - 64 


\section{Inchoate instruments.}

(1) Where a simple signature on a blank stamped paper is delivered by the signer in order that it my be enverted into a bill, it operates as a prima facie authority to till it up as a complete bill for any amount the stamp will cover, using the signature for that of the drawer, or the acceptor, or an indorser: and, in like manner, when a bill is wanting in any material particular, the person in possession of it has a prima facie authority to fill up the omission in any way he thinks fit.

(2) In order thist any such instrument when completed may be enforceable against any person who became a party thereto prior to its completion, it must be filled up within a reasonable time, and strictly in accordance with the authority given.

Reasonable time for this purpose is a question of fact.

Provided that if any such instrument after completion is negotiated to a holder in due course, it shall be valid and effeetual for all purposes in his hands, and he may enforce it as if it had been filled up within a reasonable time and strictly in accordance with the authority given.

\section{Delivery.}

(1) Every contract on a bill, whether it be the drawer's, the acceptor's, or an indorser's, is incomplete and revocable, until delivery of the instrument in order to give effect thereto.

Provided that where an acceptance is written on a bill, and the drawee gives notice to or according to the directions of the person entitled to the bill that he has accepted it, the acceptance then becomes complete and irrevocable.

(2) As between immediate parties, and as regards a remote party other than a holder in due course, the delivery -

(a) In order to be effectual must be made either by or under the authority of the party drawing, accepting, or indorsing, as the case may be:

(b) May be slown to have been conditional or for a special purpose only, and not for the purpose of transferring the property in the bill.

But if the bill be in the hands of a holder in due course a valid delivery of the bill by all parties prior to him so as to make them liable to him is conclusively presumed.

(3) Where a bill is no longer in the possession of a party who has signed it as drawer, acceptor, or indorser, a valid and unconditional delivery by him is presumed until the contrary is proved.

\section{Capacity and Authority of Parties.}

\section{Capacity of parties.}

(1) Capacity to incur liability as a party to a bill is co-extensive with capacity to contract.

Provided that nothing in this section shall enable a corporation to make itself liable as drawer, acceptor, or indorser of a bill unless it is competent to it so to do under the law for the time being in force relating to corporations.

(2) Where a bill is drawn or indorserl by an infant. minor, or corporation having no capacity or power to incur liability on a bill, the drawing or indorse- 
ment entitles the holder to receive payment of the bill, and to enforce it against any other party thereto.

\section{Signature essential to liability.}

No person is liable as drawer, indorser, or acceptor of a bill who has not signed it as such :

Provided that -

(1) Where a person signs a bill in a trade or assumed name, he is liable thereon as if he had signed it in his own name:

(2) The signature of the name of a firm is equivalent to the signature by the person so signing of the names of all persons liable as partners in that firm.

\section{Forged or unauthorized signature.}

Subject to the provisions of this Act, where a signature on a bill is forged or placed thereon without the authority of the person whose signature it purports to be, the forged or unauthorized signature is wholly inoperative, and no right to retain the bill, or to give a discharge therefor, or to enforce payment thereof against any party thereto, can be acquired through or under that signature, unless the party against whom it is sought to retain or enforce payment of the bill is precluded from setting up the forgery or want of anthority.

Provided that nothing in this section shall effect the ratification of an unauthorized signature not amounting to a forgery.

\section{Procuration signatures.}

A signature by procuration operates as notice that the agent has but a limited authority to sign, and the principal is only bound by such signature if the agent in 60 signing was acting within the actual limits of his authority.

\section{Person signing as agent or in representative eapacity.}

(1) Where a person signs a bill as drawer, indorser, or acceptor, and adds words to his signature indicating that he sigus for or on behalf of a principal, or in a representative character, he is not personally liable thereon; but the mere adilition to his signature of words describing him as an agent, or as fill. ing a representative character, does not exempt him from personal liability.

(2) In determining whether a signature on a bill is that of the principal or that of the agent by whose hand it is written, the construction most favorable to the validity of the instrument shall be allopted.

\section{The Consideration for a Bill.}

\section{Value and holder for value.}

(1) Valuable consideration for a bill may be constituted by, -

(a) Any consideration sufficient to support a simple contract;

(b) An antecolent alobt or liability. Such a dobt or liability is deemed valualul considuration whether the bill is payable on demand or at a future time.

(2) Where value hats at any time been given for a bill tho holdur is dremed to be a holuor for value as regards the acceptor and all parties to the bill who becaine parties prinr to sllch time.

(3) Where the holder of a bill has a lien on it arising either from contract or hv implication of law, he is deemed to be a holder for value to the extent of the sum for which he has a lien. 


\section{Accommodation bill or party.}

(1) In accommodation party 10 a bill is a person who has signed a bill as drawer, acceptor, or inclorser, without receiving value therefor, and for the purpose of lenling his name to some other person.

(2) An aecommodation party is liable on the bill to a holder for value; and it is immaterial whether, when such holder took the bill, he knew such party to be an accommodation party or not.

\section{Holder in due course.}

(1) A holder in clue course is a holder who has taken a bill, complete and regular on the face of it, under the following conditions; namely.

(1) That he became the holder of it before it was overdue, and without notice that it had been previously dishonored, if such was the fact:

(b) That he took the bill in good faith and for value, and that at the time the bill was negotiated to him he had no notice of any defect in the title of the person who negotiated it.

(2) In particular the title of a person who negotiates a bill is defective within the meaning of this Act when he obtained the bill, or the acceptance thereof, by fraud, duress, or force and fear, or other unlawful means, or for an illegal consideration, or when he negotiates it in breach of faith, or under such circumstances as amount to a fraud.

(3) A holder (whether for value or not), who derives his title to a bill through a holder in due course, and who is not himself a party to any fraud or illegality affecting it, has all the rights of that holder in due course as regards the acceptor and all parties to the bill prior to that holder.

\section{Presumption of value and good faith.}

(1) Every party whose signature appears on a bill is prima facie deemed to have become a party thereto for value.

(2) Every holder of a bill is prima facio deemed to be a holder in due course; but if in an action on a bill it is admitted or proved that the accep. tance, issue, or subsequent negotiation of the bill, is affected with fraud, duress, or force and fear, or illegality, the burden of proof is shifted, unless and until the holder proves that, subsequent to the alleged fraud or illegality, value has in good faith been given for the bill.

\section{Negotiation of Bills.}

\section{Negotiation of bill.}

(1) A bill is negotiated when it is transferred from one person to another in such a manner as to constitute the transferee the holder of the bill.

(2) A bill parable to bearer is negotiated by delivery.

(3) A bill payable to order is negotiated by the indorsement of the holder completed by delivery.

(4) Where the holder of a bill payable to his order transfers it for value without indorsing it, the transfer gives the transferee such title as the trans. feror had in the bill, anc the transferee in addition acquires the right to have the indorsement of the transferor.

(5) Where any person is under obligation to indorse a bill in a representative capacity, he may indorse the bill in such terıns as to negative personal liability. 


\section{Requisites of a valid indorsement.}

An indorsement in order to operate as a negotiation must comply with the following conditions, namely, -

(1) It must be written on the bill itself and be signed by the indorser. The simple signature of the indorser on the bill, without additional words, is sufticient.

An indorsement written on an allonge, or on a "copy" of a bill issued or negotiated in a country where "copies" are recognized, is deemed to be written on the bill itself.

(2) It must be an indorsement of the entire bill. A partial indorsement, that is to say, an indorsement which purports to transfer to the indorsee a part only of the amount payable, or which purports to transfer the bill to two or more indorsees severally, does not operate as a negotiation of the bill.

(3) Where a bill is payable to the order of two or more payees or indorsees who are not partners all must indorse, unless the one indorsing has authority to indorse for the others.

(4) Where, in a bill payable to order, the payee or indorsee is wrongly designated, or his name is misspelt, he may indorse the bill as therein described adding. if he thinks fit, his proper signature.

(5) Where there are two or more indorsements on a bill, each indorsement is deemed to have been made in the order in which it appears on the bill, until the contrary is proved.

(b) An indorsement may be made in blank or special. It may also contain terms making it restrictire.

\section{Conditional indorsement.}

Where a bill purports to be indorsed conditionally, the condition may be disregarcled by the payer, and payment to the indorsee is valid whether the condition has been fulfilled or not.

\section{Indorsement in blank and special indorsement.}

(1) An indorsement in blank specifies no indorsee, and a bill so indorsed becomeg payable to bearer.

(2) A special indorsement specifies the person to whom, or to whose order, the bill is to be payable.

(3) The provisions of this Act relating to a payee apply with the necessary modifications to an indorsee under as special indorsenent.

(4) When a bill has been indorsed in blank, any holder may convert the blank indorsement into a sperial indorsement by writing above the indorser's signature a direction to pay the bill to or to tho order of himself or some other person.

\section{Restrlctive indorsement.}

(1) An inforsement is restrictive which prohibits the further negotiation of the bill, or which oxpresses that it is anere anthority to deal with the bill us therehy directed, and not a transfer of theownerslnip theraof, ns, for eximple. if a bill twe indorsed " P'aly D. only," or "Pay D. for the account of X.," or "Pay D. or order for colluetion."

(2) A restrietive indorsenent gives the indorser the right to receivo payment of the bill and to sue any party thereto that his indorser could have 
sued, but gives him no power to transfor his rights as indorsee unless it expressly authorize him to do so.

(3) Where a restrictive indorsement authorizes further transfer, all subsequent indorsees take the bill with the same rights and subject to the same liabilities as the first indorsee under the restrictive indorsement.

36. Negotiation of overdue or dishonoured bill.

(1) Where a bill is negotiahle in its origin it continues to be negotiable until it has been $(a)$ restrictively iudorsed or (b) discharged by payment or otherwise.

$(2)$ Where an overdue bill is negotiated, it can only be negotiated subject to any defeet of title affecting it at its maturity, and thenceforward no person who takes it can acquire or give a better title than that which the person from whom he took it had.

(3) A bill payable on demand is deemed to be overdue within the meaning and for the purposes of this section, when it appears on the fice of it to have been in circulation for an unreasonable length of time. What is an unreasonable length of time for this purpose is a question of fact.

(4) Except where an indorsement bears date after the maturity of the bill, every negotiation is prima facie deemed to have been effected before the bill was overdue.

(5) Where a bill which is not overdue has been dishonoured any person who takes it with notice of the dishonour takes it subject to any defect of title attaching thereto at the time of dishonour, but nothing in this sub-section shall affect the rights of a holder in due course.

\section{Negotiation of bill to party already liable thereon.}

Where a bill is negotiated back to the drawer, or to a prior indorser, or to the acceptor, such party may, subject to the provisions of this Act, re-issue and further negotiate the bill, but he is not entitled to enforce payment of the bill against any intervening party to whom he was previously liable.

\section{Rights of the holder.}

The rights and powers of the holder of a bill are as follows:

(1) He may sue on the bill in his own name:

(2) Where he is a holder in due course, he holds the bill free from any defect of title of prior parties, as well as from mere personal defences available to prior parties among themselves, and may enforce payment against all parties liable on the bill:

(3) Where his title is defective $(a)$ if he negotiates the bill to a holder in due conrse, that holder obtains a good and complete title to the bill, and $(b)$ if he obtains payment of the bill the person who pays him in due course gets a valid discharge for the bill.

\section{General Duties of the Holder.}

\section{When presentment for acceptance is necessary.}

(1) Where a bill is payable after sight, presentment for acceptance is necessary in order to fix the maturity of the instrument.

(2) Where a bill expressly stipulates that it slall be presented for acceptsnce, or where a bill is drawn payahle elsewhere than at the residence or place of business of the drawee, it must be presented for acceptance before it can be presented for payment. 
(3) In no other case is presentment for acceptance necessary in order to render liable any party to the bill.

(4) Where the holder of a bill, drawn payable elsewhere than at the place of business or residence of the drawee, has not time, with the exercise of reasonable diligence, to present the bill for acceptance before presenting it for payment on the day that it falls due, the delay caused by presenting the bill for acceptance before presenting it for payment is excused, and does not discharge the drawer and indorsers.

\section{Time for presenting bill payable after sight.}

(1) Subject to the provisions of this Aet, when a bill payable after sight is negotiated, the holder must either present it for acceptance or negotiate it within a reasonable time.

(2) If he do not do so, the drawer and all indorsers prior to that holder are discharged.

(3) In determining what is a reasonable time within the meaning of this section, regard shall be had to the nature of the bill, the usage of trade with respect to similar bills, and the facts of the particular case.

\section{Rules as to presentment for acceptance, and excuses for non-pre- sentment.}

(1) A bill is duly presented for acceptance which is presented in accordance with the following rules:

(a) The presentment must be made by or on behalf of the holder to the drawee, or to some person authorized to accept or refuse acceptance on his behalf, at a reasonable hour on a businees day and before the bill is overdue :

(b) Where a bill is addressed to two or more drawees, who are not partners, presentment must be made to them all, unless one has authority to accept for all, then presentment may be made to him only :

(c) Where the drawee is dead, presentment may be made to his personal representative :

(d) Where the drawee is bankrupt, presentment may be made to him or his trustee:

(e) Where authorized by agreement or usage, a presentment through the: post office is sufficient.

(2) Presentment in accordance with these rules is excused, and a bill may be treated as dishonoured by non-acceptance-

(a) Where the drawee is dead or bankrupt, or is a fictitions person or a person not having ealpacity to contract by bill:

(b) Where, after the exercise of reasonable diligence, such prenentment cannot be effected :

(c) Where, althomgh the presentment has heen irregular, acreptinnoe has been refused on some other ground.

(3) The fact that the holice has reason to beliove that the bill, on presentment, will in dishonoured does not excuse presentment.

42. Non-acceptance.

(1) When a bill is duly presented for acceptance and is not accepted within 
the customary time, the person presenting it must treat it as dishonoured by non-acceptance. If he do not, the hoider shall lose his right of recourse agrinst the drawer and indorsers.

\section{Dishonour by non-acceptance and its consequences.}

(1) A bill is dishonoured by non-aceeptance-

(a) When it is duly presented for acceptance, and such an acceptance as is prescribed by this act is refused or cannot be obtained; or

(b) When presentment for acceptance is excused and the bill is not accepted.

(2) Suliject to the provisions of this Act, when a bill is dishonoured by non acceptance, an inmediate right of recourse against the drawer and indorsers accrues to the holder, and no presentment for payment is necessary.

\section{Dutles as to qualifled acceptances.}

(1) The holler of a bill may refuse to take a quahified acceptance, and if he does not obtain an unqualified acceptance may treat the bill as dishonoured by non-acceptance.

(2) Where a qualified acceptance is taken, and the drawer or an indorser has not expressly or impliedly authorized the holder to take a qualified acceptance, or does not subsequently assent thereto, such drawer or indorser is discharged from his liability on the bill.

The provisions of this sub-section do not apply to a partial acceptance, whereof due notice has been given. Where a foreign bill has been accepted as to part, it nust be protested as to the balance.

(3) When the drawer or indorser of a bill receives notice of a qualified acceptance, and does not within a reasonable time express his dissent to the holder, he shall be deemed to have assented thereto.

\section{Rules as to presentment for payment.}

Subject to the provisions of this Act, a bill must be duly presented for payment. If it be not so presented the drawer and endorsers shall bo discharged.

A bill is duly presented for payment which is presented in accordance with the following rules:-

(I) Where the bill is not payable on demand, presentment must be made on the day it falls clue.

(2) Where the bill is payable on demand, then, subject to the provisions of this Act, presentment must be made within a reasonable time after its issue in order to render the drawer liable, and within a reasonable time after its indorsement, in order to render the indorser liable.

In determining what is a reasonable time, regard shall be had to the nature of the bill, the usage of trade with regard to similar bills, and the facts of the particular case.

(3) Presentment must be made by the holder or by some person authorized to receive payment on his behalf at a reasonable hour on a business day, at the proper place as hereinafter defined, either to the person designated hy the hill as payer, or to some person authorized to pay or refuse payment on his behalf if with the exercise of reasonable diligence such person can there be found. 
(4) $\Lambda$ bill is presented at the proper place :-

(a) Where a place of payment is specified in the bill and the bill is there presented.

(b) Where no place of payment is specified, but the address of the drawee or acceptor is given in the bill, and the bill is there pre. sented.

(c) Where no place of payment is specified and no address given, and the bill is presented at the drawee's or acceptor's place of business if known, and if not. at his ordinary residence if known.

(d) In any other case if presented to the drawee or acceptor wherever he can be found, or if presented at bis last known place of business or residence.

(5) Where a bill is presented at the proper place, and after the exercise of reasonable diligence no verson authorized to pay or refuse paynent can be found there, no further presentment to the drawee or acceptor is required.

(6) Where a bill is drawn upon, or accepted by, two or more persons who are not partners, and no place of payment is specified, presentment must be made to them all.

(i) Where the drawee or acceptor of a bill is dead, and no place of payment is specified, presentment must be made to a personal representative, if such there be, and with the exercise of reasonable diligence he can be found.

(8) Where authorized by agreement or usage a presentment through the post-office is sufficient.

\section{Excuses for delay or non-presentment for payment.}

(1) Delay in making presentment for payment is excused when the delay is caused by circumstances beyond the control of the holder, and not imputable to his default, misconduct, or negligence. When the cause of delay ceases to operate presentment inust be made with reasonable diligence.

(2) Presentment for parment is dispensed with, -

(a) Where, after the exercise of reasonable diligence, presentments as required by this Act, cannot be effected.

The fact that the holder has reason to believe that the bill will, on presentment, be dishonoured, does not dispense with the necessity for presentment.

(b) Where the drawee is a fictitious person.

(c) As regards the lrawer where the drawee or acceptor is not bound, as between himself and tho drawer, to accept or pay the bill, and the drawer has no reason to believe that the bill would be paid if presented.

(d) As regarls an inclorser, where the bill was accepted or male for the accommodation of that indorser, and he has no reason to expect that the bill would be paisl if presented.

(e) By waiver of presentment, express or implied.

\section{Dishonour by non-payment.}

(1) A bill is dishonoured by non-payment (a) when it is duly presented for payment nnd payment is refused or cannot be obtaiued, or (b) when presentment is excuserl and the bill is overdue aud unpaid.

(2) Subject to the provisions of this $\Lambda$ ct, when a bill is dishonoured by non. 
payment, an immediate right of recourse against the drawer and indorsers accrues to the holder.

\section{Notice of dishonour and effect of non-notice.}

Subject to the provisions of this Act, when a bill has been dishonoured by non-aceeptince or by non-payment notice of dishonour must be given to the drawer and each indorser, and any drawer or indorser to whom such notico is not given is discharged;

Provided that -

(1) Where a bill is dishonoured by uon-acceptance, and notice of dishonour is not given, the rights of a lolder in due course subsequent to the omission, shall not be prejudiced by the omission.

(2) Where a bill is dishonoured by non-acceptance, and due notice of dishonor is given, it shall not he necessary to give notice of a subsequent dishonour by non-payment unless the bill shall in the meantime have been accepted.

\section{Rules as to notice of dishonour.}

Notice of dishonour in order to be valid and effectual must be given in accordance with the following rules:-

(1) The notice must be given by or on behalf of the holder, or by or on behalf of an indorser who, at the time of giving it, is himself liable on the bill.

(2) Notice of dishonour may be given by an agent either in his own name, or in the name of any party entitled to glve notice whether that party be his principal or not.

(3) Where the notice is given by or on behalf of the holder, it enures for the benefit of all subsequent holders and all prior indorsers who have a right of recourse against the party to whom it is given.

(4) Where notice is given by or on behalf of an indorser entitled to give notice as hereinbefore provided, it enures for the benefit of the holder and all indorsers subsequent to the party to whom notice is given.

(5) The notice may be given in writing or by personal communication, and may be given in any terms which sufficiently identify the bill, and intimate that the bill has been dishonoured by non-acceptance or non-payment.

(6) The return of a dishonoured bill to the drawer or an indorser is, in point of form, deened a sufficient notice of dishonour.

(7) A written notice need not be signed, and an insufficient written notice may he supplemented and validated by verbal communication. A misdescription of the hill shall not vitiate the notice unless the party to whom the notice is given is in fact misled thereby.

(8) Where notice of dishonour is required to be given to any person, it may be given either to the party himself, or to his agent in that behalf.

(9) Where the drawer or indorser is dead, and the party giving notice knows it, the notice must be given to a personal representative, if such there be, and with the exercise of reasonable diligence he can be found.

(10) Where the drawer or indorser is bankrupt, notice may be given either to the party himself or to the trustee.

(11) Where there are two or more drawers or indorsers who are not partners notice must be given to each of them, unless one of them has authority to receive such notice for the others. 
(12) The notice may be giren as soon as the bill is dishonoured, and must be given within a reasonable time thereafter.

In the absence of special circumstances notice is not deemed to have been given within a reasonable time, unless -

(a) Where the person giving and the person to receive notice reside in the same place, the notice is given or sent off in time to reach the latter on the day after the dishonour of the bill.

(b) Where the person giving and the person to receive notice reside in different places, the notice is sent off on the day after the dishonour of the bill, if there be a post at a convenient hour on that day, and if there be no such post on that day then by the next post thereafter.

(13) Where a bill when dishonoured is in the hands of an agent, he may either himself give notice to the parties liable on the bill, or he may give notice to his principal. If he give notice to his principal, he must do so within the same time as if he were the holder, and the principal upon receipt of such notice has himself the same time for giving notice as if the agent had been an independent holder.

(14) Where a party to a bill receives due notice of dishonour, he has after the receipt of such notice the same period of time for giving notice to antecedent parties that the holder has after the dishonour.

(15) Where a notice of dishonour is duly addressed and posted, the sender is deemed to have giren due notice of dishonour, notwithstanding any miscarriage by the post-office.

\section{Excuses for non-notice and delay.}

(1) Delay in giving notice of dishonour is excused where the delay is caused by circumstances beyond the control of the party giving notice, and not imputable to his defanlt, misconduct, or negligence. When the cause of delay ceases to operate the notice must be given with reasonable diligence.

(2) Notice of dishonour is dispensed with -

(a) When, after the exercise of reasonable diligence, notice as required by this act cannot he given to or does not reach the drawer or indorser sought to be charged :

(b) By waiver, express or implied. Notice of dishonour may be waived before the time of giving notice has arrived, or after the omission to grive duo notice :

(c) As regards the irawer in the following cases, namely, (1) where drawer and drawee are the same person, (2) where the drawee is a fictitious person or a person not having capacity to contract, (3) where the Irawer is the person to whom the hill is presented for payment, (4) where the drawoe or acceptor is as between himself and the drawor under no obligation to acerpt or pay the bill, (5) where the dratver bay countermanded paymont :

(d) As regards the indorser in the following cases, namely, (1) where the drawes is a fictitions person or a person not having eapacity to contract and the indorsier was aware of the fact at the time he indorsed the bill, (2) where the indorser is the prorson to whom the bill is presented for parment, (3) where the bill was accepted or made for his accommodation. 


\section{Noting or protest of bill.}

(1) Where an inland bill has been dishonoured it may, if the holder think fit, be noted for non-acceptance or non-payment, as the caso may be; but it shall not be necessary to noto or protest any such bill in order to preserve the recourso against the drawer or indorser.

(2) Where a foreign bill, appearing on the face of it to be such, has been dishonoured hy non-acceptance it must be duly protested for non-acceptance, and where such a bill, which has not been previously dishonoured by nonscceptance, is dishonoured by non-payment it must be duly protested for nonpayment. If it be not so protested the drawer and indorsers are discharged. Where a bill does not appear on the face of it to be a foreign bill, protest thereof in case of dishonour is unnecessary.

(3) A bill which has been protested for non-acceptance may be subsequently protested for non-payment.

(4) Subject to the provisions of this Act. when a bill is noted or protested, it must be noted on the day of its dishonour. When a bill has been duly noted, the protest may be subsequently extended as of the date of the noting.

(5) Where the accejtor of a bill becomes bankrupt or insolvent or suspends payment before it matures, the holder may cause tho bill to be protested for better security against the drawer and indorsers.

(6) A bill must be protested at the place where it is dishonoured :

Provided that -

(a) When a bill is presented through the post-office, and returned by post dishonoured. it may be protested at the place to which it is returned and on the day of its return if received during business hours, and if not received during business hours, then not later than the next business day :

(b) When a bill drawn payable at the place of business or residence of some person other than the drawee, has been dishonoured by nonacceptance, it must be protested for non-payment at the place where it is expressed to be payable, and no further presentment for payment to, or demand on, the drawee is necessary.

(7) A protest must contain a copy of the bill, and must be signed by the notary making it, and must specif $y-$

(a) The person at whose request the bill is protested :

(b) The place and date of protest, the cause or reason for protesting the bill, the demand made, and the answer given, if any, or the fact that the drawee or acceptor could not be found.

(8) Where a bill is lost or destroyed, or is wrongly detained from the person entitled to hold it, protest may be made on a copy or written particulars thereof.

(9) Protest is dispensed with by any circumstance which would dispense with notice of dishonour. Delay in noting or protesting is excused when the delay is caused by circumstances beyond the control of the holder, and not imputable to his default, misconduct, or negligence. When the cause of delay ceases to operate the bill must be noted or protested with reasonable diligence.

\section{Duties of holder as regards drawee or acceptor.}

(1) When a bill is accepted generally presentment for payment is not neces. sary in order to render the acceptor liable. 
(2) When by the terms of a qualified acceptance presentment for payment is required, the acceptor, in the absence of an express stipulation to that effect, is not discharged by the omission to present the bill for payment on the day that it matures.

(3) In order to render the acceptor of a bill liable it is not necessary to protest it, or that notice of dishonour should be given to him.

(4) Where the holder of a bill presents it for payment, he shall exhibit the bill to the person from whom he demands payment, and when a bill is paid the holder shall forthwith deliver it up to the party paying it.

\section{Liabilities of Parties.}

\section{Funds in hands of drawee.}

(1) A bill, of itself, does not operate as an assignment of funds in the hands of the drawee available for the payment thereof, and the drawee of a bill who does not accept as required by this Act is not liable on the instrument. This sub-section sliall not extend to Scotland.

(2) In Scotland, where the drawee of a bill has in his hands funds a vailable for the payment thereof, the bill operates as an assignment of the sum for which it is drawn in favor of the holder, from the time when the bill is presented to the drawee.

\section{Liabllity of acceptor.}

The acceptor of a bill, by accepting it -

(1) Engages that he will paty it according to the tenor of his acceptance:

(2) Is precluded from denying to a holder in due course :

(a) The existence of the drawer, the genuineness of his signature, and his capacity and authority to draw the bill;

(b) In the case of a bill payable to drawer's order, the then capacity of the drawer to indorse, but not the genuineness or validity of his indorsement ;

(c) In the case of a bill payable to the order of a third person, the existence of the payee and his then capacity to indorse, but not the genuiness or valiclity of his indorsement.

\section{Labllity of drawer or indorser.}

(1) Tho clrawer of a bill by drawing it -

(a) Engiges that on duo presentment it shall he accepted and paid accorling to its tenor, and that if it he dishonoured he will compensate the holder or any indorser who is compelled to pay it, provided that the requisite proceedings on dishonour be iuly taken;

(b) Is precludeal from denying to a holder in dus course tho existence of the patyen and his then caplacity to indorse.

(2) The indorser of a bill by molorwing it -

(a) Engages that on due presentment it shall bo accoptenl and paid according to its toung, and that if it be dishouomred he will com. perisate the loblder or a subsecpuent indorser who is compelled to pay it, providisl that the requisite prosedinge on dishomour be duly takm :

(b) Is precluded from denying to a lolder in due course the genuine 
ness and regularity in all respects of the drawer's signature and all previous indorsements;

(c) Is precluded from denying to his immediate or a subsequent indorsee that the bill was at the time of his intorsement a valid and subsisting bill, and that he had then a good title thereto.

\section{Stranger signing bill liable as indorser.}

Where as person signs a bill otherwise than as drawer or acceptor, he thereby incurs the liabilities of an indorser to a holder in due course.

\section{Measure of damages against parties to dishonoured bill.}

Where a bill is dishonoured, the meisure of damages, which shall be deomed to be liquidated damages, shall be as follows:

(1) The holder may recover from any party liable on the bill, and the drawer who has been compelled to pay the bill may recover from the acceptor, and an indorser who has been compelled to pay the bill may recover from the acceptor or from the drawer, or from a prior indorser -

(a) The amount of the bill:

(b) Interest thereon from the time of presentment for payment if the bill is payable on demand, and from the maturity of the bill in any other case :

(c) The expenses of noting, or, when protest is necessary, and the protest has been extended, the expenses of protest.

(2) In the case of a bill which has been dishonoured abroad, in lieu of the above damages, the holder may recover from the drawer or an indorser, and the drawer or an indorser who has been compelled to pay the bill may recover from any party liable to him, the amount of the re-exchange with interest thereon until the time of payment.

(3) Where by this Act interest may be recovered as damages, such interest may, if justice require it, be withheld wholly or in part, and where a bill is expressed to be payable with interest at a given rate, interest as damages may or may not be given at the same rate as interest proper.

\section{Transferor by delivery and transferee.}

(1) Where the holder of a bill payable to bearer negotiates it by delivery without indorsing it, he is called a "transferor by delivery."

(2) A transferor by delivery is not liable on the instrument.

(3) A transferor by delivery who negotiates a bill thoreby warrants to his immediate transferee being a holder for value that the bill is what it purports to be, that he has a right to transfer it, and that at the time of transfer he is not aware of any fact which renders it valueless.

\section{Discharge of Bill.}

\section{Payment in due course.}

(1) A bill is discharged by payment in due course by or on behalf of the drawee or acceptor.

"Payment in due course" means payment marle at or after the maturity of the bill to the holder thereof in good faith and without notice that his title to the bill is defective.

(2) Subject to the provisions hereinafter contained, when a bill is paid by the drawer or an indorser it is not discharged; but 
(a) Where a bill payable to, or to the order of, a third party is paid by drawer, the drawer may enforce payment thereof against the acceptor, but may not re-issue the bill :

(b) Where a bill is paid by an indorser, or where a bill payable to drawer's order is paid by the drawer, the party paying it is remitted to his former rights as regards the acceptor or antece dent parties, and he may, if he thinks fit, strike out his own and subsequent indorsements, and again negotiate the bill.

(3) Where an accommodation bill is paid in due course by the party accon!modated the bill is discharged.

\section{Banker paying demand draft whereon indorsement is forged.}

Where a bill payable to order on demand is drawn on a banker, and the banker on whom it is drawn pays the bill in good faith and in the ordinary course of business, it is not incumbent on the banker to show that the indorsement of the payee or any subsequent indorsement was made by or under the authority of the person whose indorsement it purports to be, and the banker is deemed to have paid the bill in due course, although such indorsement has been forged or made without authority.

\section{Acceptor the holder at maturity.}

When the acceptor of a bill is or becomes the holder of it at or after its maturity, in his own right, the bill is discharged.

\section{Express waiver.}

(1) When the holder of a bill at or after its maturity absolutely and unconditionally renounces his rights against the acceptor the bill is discharged.

The renunciation must be in writing, unless the bill is delivered up to the acceptor.

12) The liabilities of any party to a bill may in like manner be renounced by the holder before, at, or after its maturity; but nothing in this sectien shall affect the rights of a holder in due course without notice of the renunciation.

\section{Cancellation.}

(1) Where a bill is intentionally cancelled by the holder or his agent, and the cancellation is apparent thereon, the bill is discharged.

(2) In like manner any party liable on a bill may be discharged by the intentional cancellation of his signature lyy the holder or his agent. In such case any indorser who would have had a -ight of recourse against the party whose signature is cancelled, is ilso discharged.

(3) A cancellation made unintentionally, or under a mistake, or without the authority of the lolder. is inoperative; but where a bill or any signature thereon appears to have beon cancelled the burden of proof lies on the party who alleges that the cancellation was mado unintentionally, or under a mistake, or without authority.

\section{Alteration of blll.}

(1) Where a bill or acceptance is materially altered without the aseent of all parties liable on the bill, the bill is avoided except as against a party who 
has himself made, authorised, or assentel to the alteration, and subsequent intorsers.

Provided that.

Where a bill lias been materially altered, but the alteration is not apparent, and the bill is in the hand of a holder in due conrse, such holder may avail himself of the bill as if hat not been altered, and may enforce payment of it according to its original tenor.

(2) In particular the following alterations are miterial, namely, any alteration of the date, the sum payable, the time of payment, the place of payment, and, where a bill has been accepted generally, the addition of a place of payment without the acceptor's assent.

\section{Accetance and Payment for Honour.}

\section{Acceptance for honour supra protest.}

(1) Where a bill of exchange has been protested for dishonour by nonacceptance, or protested for better security, and is not overdue, any person, not heing a party alrearly liable thereon, may, with the consent of the holder, intervene and accept the bill supra protest for the honour of any party liable thereou, or for the honour of the person for whose account the bill is drawn.

(2) A bill may be accepted for honour for part only of the sum for which it is drawn.

(3) An acceptance for honour supra protest in order to be valid must -

(a) Be written on the bill, and inclicate that it is an acceptance for honour:

(b) Be signed by the acceptor for honour.

(4) Where an acceptance for honour does not expressly state for whose honour it is made, it is deemed to be an acceptance for the honour of the drawer.

(5) Where a bill payable after sight is accepted for honour, its maturity is calculated from the date of the noting for non-acceptance, and not from the date of the acceptance for honour.

\section{Liability of acceptor for honour.}

(1) The acceptor for honour of a bill by accepting it engages that he will, on due presentment, pay the bill accorling to the tenor of his acceptance, if it is not paid by the drawee, provided it has been luly presented for payment, and protesterl for non-payment, and that he receives notice of these facts.

(2) The acceptor for honour is liable to the holder and to all parties to the bill subsequent to the party for whose honour he has accepted.

\section{Presentment to acceptor for honour.}

(1) Where a dishonoured bill has been accapted for honour supra protest, or contains a reference in case of need, it must be protested for non-payment before it is presented for payment to the acceptor for honour, or referee in case of need.

(2) Where the address of the acceptor for honour is in the same place where the bill is protested for non-payment, the bill must be presented to him not later than the day following its maturity : and where the arldress of the acceptor for honour is in onme place other than the place where it was protested for non-payment. the bill must he forwarded not later than the day following its maturity for presentment to him.

(3) Delay in presentment or non-presentment is excused by any circum- 
stance which would excuse delay in presentrment for payment or non-pre. sentment for payment.

(1) When a bill of exchange is dishonoured by the acceptor for honour it must be protested for non-payment by him.

68. Payment for honour supra protest.

(1) Where a bill has been protested for non-parment, any person may intervene and pay it supra protest for the honour of any party liable thereon, or for the honour of the person for whose account the bill is drawn.

(2) Where two or more persons offer to pay a bill for the honour of different parties, the person whose payment will discharge most parties to the bill shall have the preference.

(3) Payment for honour supra protest, in order to operate as such and not as a mere voluntary payment, must be attested by a notarial act of honour which may be appended to the protest or form an extension of it.

(4) The notarial act of honour must be founded on a declaration made by the payer for honour, or his agent in that behalf, declaring his intention to pay the bill for honour, and for whose honour he pays.

(5) Where a bill has been paid for honour, all parties subsequent to the party for whose honour it is paid are discharged, but the payer for honour is subrogated for, and succeeds to both the rights and duties of, the holder as regards the party for whose honour he pays, and all parties liable to that party.

(6) The payer for honour, on paying to the holder the amount of the bill and the notarial expenses incidental to its dishonour, is entitled to receive both the bill itself and the protest. If the holder do not on demand deliver them up. he shall be liable to the payer for honour in damages.

(7) Where the holder of a bill refuses to receive payment supra protest be shall lose his right of recourse against any party who would have been discharged by such payment.

\section{Lost Instruments.}

\section{Holder's right to duplicate of lost bill.}

Where a bill has been lost before it is overdue, the person who was the holder of it may apply to the drawer to give him another bill of the same tenor, giving security to the drawer if required to indemnify him against all persons whatever in case the bill alleged to have been lost shall be found again.

If the drawer on request as aforesaid refuses to give such duplicate bill, he may be compelled to do so.

\section{Action on lost bill.}

In any action or proceeding upon a bill, the court or a judge may order that the loss of the instrument slaall not be set up. providerl an indennity he given to the satisfaction of the court or julge against the clains of any other person upon the instrument in question.

Bill in a Set.

71. Rules as to sets.

(1) Where a hill is drawn in a set, each part of the set being numbered, and containing a reference to the other parts. the whole of the parts constitute one bill.

TEOOT. INETRUXZNT -68 
(2) Where the holder of a set indorses two or more parts to different persons, he is liable on every such part, and every indorser subsequent to him is fiable on the part he has himself indorsed as if the said parts were separate bills.

(3) Where two or more parts of a set are negotiated to different holders in due course, the holder whose title first accrues is as between sueh holders deemed the true owner of the bill; but nothing in this subusection shall affect the riglits of a person who in due course necepts or pays the part first presented to him.

(4) The acceptance may be written on any part, and it must be written on one part only.

If the drawee accepts more than one part, and such accepted parts gets into the hands of different holders in due course, he is liable on every such part as if it were a separate bill.

(5) When the acceptor of a bill drawn in a set pays it without requiring the part bearing his acceptance to be delivered up to him, and that part at maturity is outstanding in the hands of a holder in due course, he is liable to the holder thereof.

(6) Subject to the preceding rules, where any one part of a bill drawn in a set is discharged by payment or otherwise, the whole bill is discharged.

\section{Conflict of Laws.}

\section{Rules where laws conflict.}

Where a bill drawn in one country is negotiated, accepted, or payable in another, the rights, duties, and liabilities of the parties thereto are determined as follows :-

(1) The validity of a bill as regards requisites in form is determined bo the law of the place of issue, and the validity as regards requisites in form of the supervening contracts, such as acceptance, or indorsement, or acceptarce supra protest, is determined by the law of the place where such contract was made.

Provided that -

(a) Where a bill is issued out of the United Kingdom it is not invalid by reason only that it is not stamped in accordance with the law of the place of issue :

(b) Where a bill, issued out of the United Kingdom, conforms, as regards requisites in form, to the law of the United Kingdom, it may, for the purpose of enforcing payment thereof, be treated as valid as between all persons who negotiate, hold, or become parties to it in the United Kingdom.

(2) Subject to the provisions of this Aet, the interpretation of the drawing, indorsement, acceptance, or acceptance supra Irotest of a bill, is determined by the law of the place where such contract is made.

Provided that where an inland bill is indorsed in a foreign country the indorsement shall as regards the payer be interpreted according to the law of the Uniterl Kingdom.

(3) The duties of the holder with respect to presentment for acceptance or payment and the necessity for or sufficiency of a protest or notice of dishonour, or otherwise, are determined by the law of the place where the act is done or the bill is dishonoured.

(4) Where a bill is drawn out of but payable in the United Kingdom and the 
sum payable is not expressed in the currency of the United Kingdom, the amount shall, in the absence of some express stipulation, be caleulated according to the rate of exchange for sight drafts at the place of payment on the day the bill is payable.

(5) Where a bill is drawn in one country and is payable in another, the due date thereof is determined according to the law of the place where it is payable.

\section{PART III.}

\section{Cheques on a Banker.}

73. Cheque defined.

A cheque is a bill of exchange drawn on a banker payable on demand.

Except as otherwise provided in this Part, the provisions of this Act appli. cable to a bill of exchange payable on demand apply to a cheque.

\section{Presentment of cheque for payment.}

Subject to the provisions of this Act -

(1) Where a cheque is not presented for payment within a reasonable time of its issue, and the drawer or the person on whose account it is drawn had the right at the time of such presentment as between him and the banker to have the cheque paid and suffers actual damage through the delay, he is discharged to the extent of such damage, that is to say, to the extent to which such drawer or person is a crellitor of such banker to a larger amount than he would have been had such cheque been paid.

(2) In determining what is a reasonable time regard shall be had to the nature of the instrument, the usage of trade and of bankers, and the facts of the particular case.

(3) The holder of such cheque as to which such drawer or person is dis. charged shall be a creditor, in lieu of such drawer or person, of such banker to the extent of such discharge, and entitled to recover the amount from him.

\section{Revocation of banker's authority,}

The duty and authority of a banker to pay a cheque drawn on him by his custoner are determinerl by -

(1) Countermand of pisyment :

(2) Notice of customer's death.

\section{Crossed Cheques.}

\section{General and special crossings deflned.}

(1) Where a cheque bears across its face an aldition of - (a) the words " and company" or any abbreviation thereof between two jarallel transverse lines, either with or without the worls " not negotiahle;" or (b) two parallol transverme lines simply, either with or without the words " not negotiable, - " that addition constitutes a crossing, and the cheque is crossed generally.

(2) Where a cheque bears across its face an addition of the nume of a banker, rither with or without the words " not negotiahle," that arddition constitutes a crossing. and the chepue is crossed specially and to that banker.

77. Crossing by drawer or after Issue.

(1) A cherue may be crossed generally or specially by the ilrawer. 
(2) Where a cheque is uncrossed, the holder may cross it generally or specially.

(3) Where a cheque is crosied generally the holder may cross it specially.

(4) Where a cheque is crossed generally or specially, the holder may add the words " not negotiable."

(5) Where a cheque is crossed specially, the banker to whom it is crossed may anain cross it specially to another banker for collection.

(6) Where an uncrossed eheque, or a cheque crossed generally, is sent to a banker for collection, he may cross it specially to himself.

\section{Crossing a material part of check.}

$A$ crossing anthorized by this Act is a material part of the cneque; it shall not be lawful for any person to obliterate or, except as authorized by this Act, to add to or alter the crossing.

\section{Duties of banker as to crossed cheques.}

(1) Where a cheque is crossed specially to more than one banker except when crossed to an agent for collection being a banker, the banker on whom it is drawn shall refuse payment thereof.

(2) Where the banker on whom a cheque is drawn which is so crossed nevertheless pays the same, or pays a cheque crossed generally otherwise than to a banker, or if crossed specially otherwise than to the banker to whom it is crossed, or his agent for collection being a banker, he is liable to the true owner of the cheque for any loss he may sustain owing to the cheque having been so paid.

Provided that where a cheque is presented for payment which does not at the time of presentment appear to be crossed, or to have had a crossing wbich has been obliterated, or to have been added to or altered otherwise than as authorised by this Act, the banker paying the cheque in good faith and without negligence shall not be responsible or incur any liability, nor shall the payment be questioned by reason of the cheque having been crossed, or of the crossing having been obliterated or having been added to or altered otherwise than as authorised by this Act, and of payment having been made otherwise than to a banker or to the banker to whom the eheque is or was crossed, or to his agent for collection being a banker, as the case may be.

\section{Protection to banker and drawer where cheque is crossed.}

Where the banker, on whom a erossed cheque is drawn, in good faith and without negligence pays it, if crossed generally, to a banker, and if crossed specially, to the banker to whom it is crossed, or his agent for collection being a banker, the banker paying the cheque, and, if the cheque has come into the hands of the payee, the rlrawer, shall respectively be entitled to the same rights and be placerl in the same position as if payment of the cheque had been made to the true owner thereof.

\section{Effect of crossing on holder.}

Where a person takes a crossed cheque which bears on it the words " not negotiable," he shall not have and shall not be capable of giving a better title to the cheque than that which the person from whom he took it had.

\section{Protection to collecting banker. [Amended 1906. See post, p. 873.]}

Where a banker in good faith and without negligence receives payment for a customer of a cheque crossed generally or specially to hinself, and the 
customer bas no title or a defective title thereto, the banker shall not incur any liability to the true owner of the cheque by reason only of having received such payment.

PART IV.

\section{Promissory Notes.}

\section{Promissory note deflned.}

(1) A promissory note is an unconditional promise in writing made by one person to another signed by the maker, engaging to pay, on demand or at a fixed or determinable future time, a sum certain in money, to, or to the order of, a specified person or to bearer.

(2) An instrument in the form of a note payable to maker's order is not a note within the meaning of this section unless and until it is indorsed by the maker.

(3) A note is not invalid by reason only that it contains also a pledge of collateral security with authority to sell or dispose thereof.

(4) A note which is, or on the face of it purports to be, both made and payable within the British Islands is an inland note. Any other note is a foreign note.

\section{Delivery necessary.}

A promissory note is inchoate and incomplete until delivery thereof to the payee or bearer.

\section{Joint and several notes.}

(1) A promissory note may be made by two or more makers, an they may be liable thereon jointly, or jointly and severally according to its tenor.

(2) Where a note runs "I promise to pay" and is signed by two or more persons it is deemed to be their joint and several note.

\section{Note payable on demand.}

(1) Where a note payable on demand has been indorsed, it must be presented for payment within a reasonable time of the indorsement. If it be not so presented the indorser is discharged.

(2) In determining what is a reasonable time, regard shall be had to the nature of the instrument, the usage of trade and the facts of the particular case.

(3) Where a note payable on demand is negotiated, it is not deemed to be overduc, for the purpose of affecting the holder with clefects of title of which he had no notice, by reason that it appears that a reasonable time for presenting it for payment has elapsed since its issue.

\section{Presentment of note for payment.}

(1) Where a promissory note is in the boly 'of it made payable at a particular place, it must be presented for payment at that place in order to render the maker liable. In any other case, presentment for payment is not necessary in order to render the maker liable.

(2) Presentment for payment is necessary in order to render the indorser of note liable.

(3) Whrre a note is in the body of it made payable at a particular place, 
presentment at that place is necessary in order to render an indorser liable; but when a place of payment is indicated by way of memorandum only, presentment at that plice is sufficient to rencler the indorser liable, but a presentment to the makcr elsewhere, if sufticient in other respects, shall also suthice.

\section{Llability of maker.}

The maker of a promissory note by making it -

(1) Engages that he will pay it according to its tenor;

(2) Is precluded from denying to a holder in due course the existence of the payee and his then capacity to indorse.

\section{Application of Part II to notes.}

(1) Subject to the provisions in this Part, and except as by this section provided, the provisions of this Act relating to bills of exchange apply, with the necessary modifications, to promissory notes.

(2) In applying those provisions the naker of a note shall be deemed to correspond with the acceptor of a bill, and the first indorser of a note shall be deemed to correspond with the drawer of an accepted bill payable to drawer's order.

(3) The following provisions as to bills do not apply to notes; namely, provisions relating to -

(a) Presentment for acceptance;

(b) Acceptance;

(c) Acceptance supra protest ;

(d) Bills in a set.

(4) Where a foreign note is dishonoured, protest thereof is unnecessary.

\section{PART V.}

\section{SUPPLEMENTARY.}

\section{Good faith.}

A thing is deemed to be done in good faith, within the meaning of this Act, where it is in fact done honestly, whether it is done negligently or not.

\section{Signature.}

(1) Where, by this Act, any instrument or writing is required to be signed by any person, it is not necessary that he slould sign it with his own hand, but it is sufficient if his signature is written thereon by some other person by or under his authority.

(2) In the case of a corporation, where by this Act any instrument or writing is required to be signed, it is sufficient if the instrument or writing be sealed with the corporate seal.

But nothing in this section shall be construed as requiring the bill or note of a corporation to be under seal.

\section{Computation of time.}

Where, by this Act, the time limited for doing any act or thing is less than three lays, in reckoning time, non-business days are excluded.

"Non-business days" for the purposes of this Act mean-

(a) Sunday, Good Friday, Christmas Day : 
(b) A bank holiday under the Bank Holidays Act, 1871, or acts amending it :

(c) A day appointed by Royal proclamation as a public fast or thanksgiving day.

Any other day is a business day.

\section{When noting equivalent to protest.}

For the purposes of this Act, where a bill or note is required to be protested within a specified time or before some further proceeding is taken, it is sufficient that the bill has been noted for protest before the expiration of the specified time or the taking of the proceeding ; and the formal protest may be extended at any time thereafter as of the date of the noting.

\section{Protest when notary not accessible.}

Where a dishonoured bill or note is authorized or required to be protested, and the services of a notary cannot be obtained at the place where the bill is dishonoured, any householder or substantial resident of the place may, in the presence of two witnesses, give a certificate, signed by them, attesting the dishonour of the bill, and the certificate shall in all respects operate as if it were a formal protest of the bill.

The form given in Schedule 1 to this Act may be used with necessary modifications, and if used shall be sufficient.

\section{Dividend warrants may be crossed.}

The provisions of this Act as to crossed cheques shall apply to a warrant for payment of dividend.

\section{Repeal.}

The enactments wentioned in the second schedule to this Act are hereby repealed as from the commencement of this Act to the extent in that schedule mentioned.

Provided that such repeal shall not affect anything done or suffered, or any right, title, or interest acquired or accrued before the commencement of this Act, or any legal proceeding or remedy in respect of any such thing, right, title, or interest.

\section{Savings.}

(1) The rules in bankruptey relating to bills of exchange, promissory notes, and cheques, whall continue to apply thereto notwithstanding anything in this Act containerl.

(2) The rules of common law including the law merchant, sive in so far as they are inconsistent with the expresy provisions of this Act, shall continue to apply to hills of exchange, promissory notes, and cheques.

(3) Nothing in this set or in any repeal effecter thereby shall affect -

(a) The provisions of the. Stamp Act, 1870,* or acts amending it, or any law or enactment for the time lesing in force relating to the revenum:

(b) The frovisions of the Companies Act, 1462, $\nmid$ or acts amending it, or any act rolating to joint stock banks or companies : 
(c) The provisions of any act relating to or confirming the privileges of the Bank of Eingland or the Bank of Ireland respectively :

(d) The validity of any usage relating to dividend warrants, or the indorsements thereof.

\section{Saving of summary dillgence in Scotland.}

Nothing in this Act or in any repeal effected thereby shall extend or restrict, or in any way alter or affect the law and practice in Scotland in regard to summary diligence.

\section{Construction with other acts, etc.}

Where any act or document refers to any enactment repealed by this $\Lambda$ ct, the act or document shall be construed, and shall operate, as if it referred to the corresponding provisions of this Act.

\section{Parol evidence in judicial proceedings in Scotland.}

In any judicial proceeding in Scotland, any fact relating to a bill of exchange, bank cheque, or promissory note, which is relevant to any question of liability thereon, may he proved by parol evidence: Provided that this enactuent shall not in any way affect the existing law and practice whereby the party who is, according to the tenor of any bill of exchange, bank cheque, or promissory note, debtor to the holder in the amount thereof, may bo required, as a condition of obtaining a sist of diligence, or suspension of a charge, or threatened charge, to make such consignation, or to find such caution as the court or judge before whom the cause is depending may require.

This section shall not apply to any case where the bill of exchange, bank cheque, or promissory note has undergone the sesennial prescription.

\section{First Schedule.* (Sec. 94.)}

Form of protest which may be used when the services of a notary cannot be obtained.

Know all men that I, A. B. (householder), of in the county of , in the United Kingdom, at the request of C. D., there being no notary public available, did on the day of 188 at demand payment (or acceptance) of the bill of exchange hereunder written, from E. F., to which demand he made answer (state answer, if any). Wherefore, I now in the presence of G. H. and J. K. do protest the said bill of exchange.

$$
\text { (Signed) }
$$

A. B.

G. H. K. Witnesses.

N. B. - The bill itself should be annexed, or a copy of the bill and all that is written thereon should be underwritten.

- The other schedules are purely local Iu laterest, and are therefore omitted.-ED. 


\title{
BILLS OF EXCHANGE (CROSSED CHEQUES) ACT, 1906. ${ }^{1}$
}

\author{
6 Evw. 7, e. 17.
}

AN ACT to amend section eighty-two of the Bills of Exchange Act, 1882 .

th August, 1906.

SEc. 1. A banker receives payment of a crossed cheque for a customer within the meaning of section eighty-two of the Bills of Exchange Act, 1882, notwithstanding that he eredits his customer's account with the amount of the cheque before receiving payment thereof.

SEc. 2. This act may be cited as the Bills of Exchange (Crossed Cheques) Act, 1906, and this act and the Bills of Exchange Act, 1882, may be cited together as the Bills of Exchange Acts, 1882 and 1906.

1 "Note. - This act was passed to get rill of the decision in Capital and Counties Bank v. Gordon. A. C. (1S93), 240, H. L., where it was held that if a bank received a crossed cheque from a customer, and at once credited his account with the amount, the bank became holders for value of the cheque, and in receiving payment thereof, received it on their own account, and not merely as agents for collection on behalf of their customer. They therefore did not come within the protection given by section 82 of the act of 1882 to collecting bankers. . ." Chalmers, A Digest of the Law of Bills of Exchange, etc., 7 th ed., p. $400 .-\mathrm{C}$. 



\section{N D E X.}

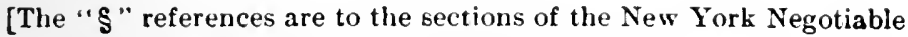 Instrument Law ; other references are to pages.]}

Acceptance: (See NON-ACCEPTANCE.) definition ind effect, 40:-41s, \& $2, \quad 112$. form and effect, 648-668, 88 2:20-225. writing and signature, $645-649, \$ 220$. parol, 64? 6 , 6it8.

unly by driwee, 649-65\%, \& 200 .

delivery necessary, 051 .

promise to accept, 654-65i, \& 203 .

by refusal to return bill, fi46, 658-6655, $8:-205$

of incomplete or dishonored bill, 666-668, 8 .2.ti.

time allowel for, fifo-fofs, $\$ 224$.

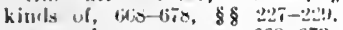

Eeneral acceptanee, forig-6irs, \$ $\$ 228$.

qualified acceptance, tin-6its, \& 229.

ronlitional, 673-674, § 229.

partial, 675, \& 229 .

local, 675-6i-6, \& 229 .

qualitierl as tis time, tito, \& 229.

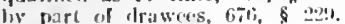

cffert of qualified acceptince, $677-678$, 830 .

of bills in a set, $709-710$, \& 313 .

\section{Acreptance for lionor:}

nlich alluwed, Fu), \& 280 .

partiog to, 7(1), \& eso.

fir what amount. 2or).

1. rmal repuisitu, 7 ( 1,881 .

protest for mon-acceptinnce, 701, \$280. writing and signature, \& 201.

intorpretation,

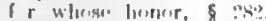

reffece on inalurity of lill, \& 285.

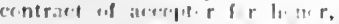

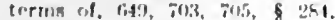

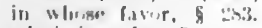

arlminsions ly, ire.

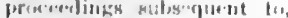

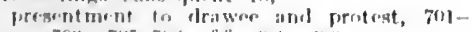

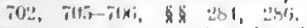

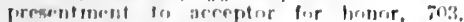
in)-imi, $28 \%$.

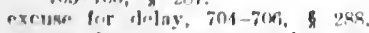

protent fer nun faymers by accepter for hronor, 289 .

\section{Acrepulor:}

menteleration, 250-251.

lialility if. I1? \& 192.

armientons if, 40? 418 , 112

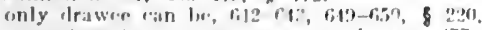

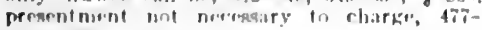
Anil?.

\section{Acceutor for liouror:}

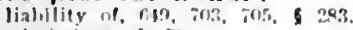

athimising ril, ins.

who may her, san?

\section{Accommotation Paper:}

atermmotation party"

eorpuration as, 256 .

terfined, $255,25 \%-258, \$ 55$.

liahility to holder, $254-258,55$.

nulice when maker is, 254, 5-9, \& 156 .

order of liability of $45.4-465$.

aceomumionated party.

nut entitled to presentmont, \$ 140

not entitled to nutice, 579, \$ $\$$ si.

payment by, 507-508, 640-6it], $\$ \$ 200-202$.

tratusfer by, after maturity, $325-335$.

rolloise of, $(: 31 \mathrm{n}$.

consideration for, 243-244.

imount recoverabli, in, 36i] -362

payment of stpria protest, inst.

\section{Action on Negotiable Paper:}

inefinest, \& 2.

transfer fir purpose in, 3lfin.

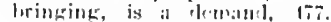

hy restrictive indorsec, 280-284, \$ 67.

lectween inclorsirs, $45 \%-16 \%$.

upun instrument payalule to hearer, afo.

after lishonue fir noin-itceptance, tion, als

on bills in it set, $713 \mathrm{n}$.

against abett sizning without autlurity, ?I:-21!"

mpon wirrmintes in s:11., 418-4t:.

111. il guiarinty, 171-17.1.

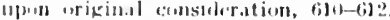

in rewerer money pitist on furged palper, 403J1:

\section{Idational Mre:}

provision fir. rentors iustrument non-

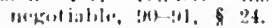

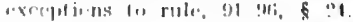

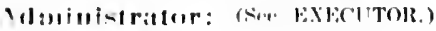

Mamisanolls:

ly maker, f(1) - |lk, \$110.

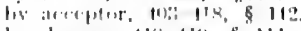

li. drawer, $118-110$, \& 111.

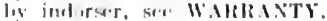

\section{Ifrill:}

Ag

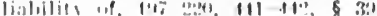

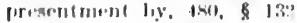

promentmont lis, enti:

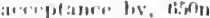

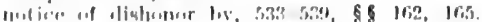

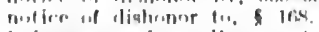

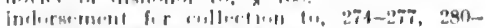
and $13 \%-110$, b f fif, fis.

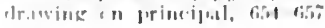

Mlumge:

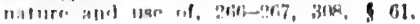




\section{Necratlon:}

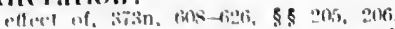

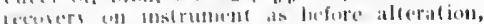
157. 1ill, 185, 726, \& 2015

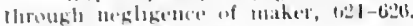

of inlorser, tilci-tiol.

materlal, tilun, \$

hurelete if prove, tilon.

intereme, b11-6.14.

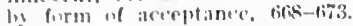

\section{Meruative litrlies:}

polves, whether allowed, 118-130

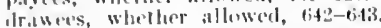
mikers, whether allowel, 643n.

\section{Imhinuly:}

of linkuage in instrument, $122-197, \S 36$. of signalures to inslruments, $197-220,8$

\section{Ambiermoms Instrumenl:}

conseruction of, $148-150,192-197, \& 36$.

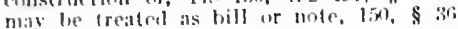

\section{Imollint}

must be certain, $61-80, \$ \& 20-2]$

renverahle, $25 \%-251,391-394,594-597, \$ \S 53$, (m)

\section{Interealent Delnt:}

is accommodation paper, 243-244.

\section{Iasignee: (See B.INKR!PT.)}

\section{Assimment :}

ind rscument by, 2til-363.

qualified indorsement is, 284, \$ 67.

Cransfer without inclersement, $307-310, \$ 79$ of guarmties, 4i]-1it.

of funds, bill is not, 64t-64ti, \& 211 . rleeck is not, $752-7.59,8325$.

for benetit of ireditors, protest for beffer security, \& 2fif.

Menruey's Fecs:

pruvision for, flors not render sum unerrtain, $78-80, \$ 21$.

\section{Band I'ath:}

equivalent to knowlerlge, $337-390$. \& 9.5 undervalue as evidence of, $33 i-340$.

Bank: (son cllle(kS.)

definition of, \$2.

casluin as payee or indorsee, 2len, $290-390$, 872.

bill or nute payable al, nregentment of, 19:- $404,524-527, \$ 135$. is an oruer on \& 14 . not by mere netiee, 51?-51? notire of tisliener. $537-538,561-565$. certifieate of denesit, 13.

savings bank order by, $46-48$. ilratt by, $725 \mathrm{n}$.

\section{Bank lionk:}

crinelition of retura of : is.

\section{Bank Nutes:}

history of og

whother current money, 81-95.

whothor demand nocessary, 4\%8n.

\section{Bankrupt :}

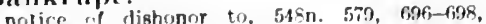
8172

prementment for armentance to, \& 242

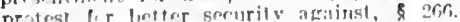
dischares ol, does not discharge instrument, $628 n$.

\section{Banter:}

le finell, 120, \&"

bill or note payblble to, 123-118, 260-261, $8 \% 20,0$.

instrmunt indorsed in blank payable to, \$ 11.

indersoment of instrument payable to, 288ait. \$ in

\section{liofler fincllity:}

prolest for, \& 20 tit.

\section{lsills of Hxchaune:}

histury, 2.13 .

form, $158-15 \%, 6142, \$ 210$

generial recpujsites, sece Folis of NEGo. TIAIBLE INSTKUMIENTS.

drawee, 148-150, 642-1443, \&\& 20, 212.

referee in rase of need, $5.13-644, \& 215$.

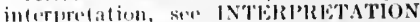

bill not an assigument of funds, 644-646, \& 211.

inland and foreign bills, fiff-647, \& 213.

distinguislied frum cliceck, $722-724, \$ 321$

\section{IBills of Jxrballue Act:}

text of, 845-873.

uritin of, 3-8.

constructiul of, 5, 126, 396-397.

\section{liills in a Sel:}

when treated as one bill, $709,710-713,8310$ negutiation of purts to different persons, $709-510, \$ 311$

rights of holiler, \& 311.

liability of indersers, \& 312 . aereptanie of, $709-710, \S 313$. payment uf, 710, \$314.

lischarere of \& :315.

enpies elistinguisherl, 710-711.

Blank Indursement: (See INDORSEMENT.)

instrument pityable to hearer, $14 .-148, \$ 28$ letiution and effect, 268-271, \& 16.5 .

converted inte special, $268-270, \& 65$

\section{I3links:}

when blatuls nay loe filled, 107-111, lais192, 319-3ำ, \& \& 32'-34

distinguisherl from spiles, biti-fig4. as notien of inferts. 319-320. \$ 91

Bona-fide Hollar: (see IIOLDFR in DTE (OOTRSE.)

\section{IBondis:}

when negntialile, 31-33, 419-431.

luw make noll negotialle, \& 332 jmblir ret rerpirite, \$ 115.

\section{broker: (See AGENT.)}

Burden of procif:

when on holdar to prove he is holder in dur rolurse, sitis-370, $374-375, \& 98$

to sluw mistike in rancellation, fizT, \$204. in sliow alerralios, fion.

to show that instrument was transferred when nverilur, 399

\section{Cancellation:}

intentional, $37 \%, 599, \$ 200,204$

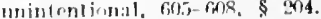

burrton of prinf, fiet, \& 204

\section{camacity of loarties:}

to ivul ren, ono, ont है

armissions of, 40]-418, \& $110-112$

werrinty of, 434, \& $\$ 1150116$.

inraparity as a refense, $372,475$.

drawee, $555, \$ \delta 214,245$. 
Cashier:

indorsement, when payable to, $216 \mathrm{n}, 290$ 300,82 .

\section{Certainty :}

of sum payable, $61-80$, if $20,21$.

of promise, $46-61,8520,22$.

of time, $96-106, \quad 23$

of parties,

drawee, $148-150,20$.

payee, $107-113,27$.

\section{Certificate of Deposit :}

negotiability of, $43-44 \mathrm{n}$.

demand necessary, 477n.

distinguished from deposit slip, 43n-14n.

diatinguished from saving bank order, 1648.

\section{Certificate of Protest:}

form and contents, 691-698, 261 .

correction of, 508-509.

as to presentment for acceptance, 685, 694695.

a. evidence of notice of dishonor, $589-590$.

Certification of Check:

effect upon drawer's liability, 743-748, 324. effect upon indorser's liability, 748-751, 324 .

\section{Checks:}

defined, 321.

distinguished from bills, 722-725.

presentment for payment,

effect of delay upon drawer's liability, 725734, f 322 .

upon indorser' liability, 734-743.

Certification: (See CERTIFICATION OF CHECK.)

liability of drawee.

to holder, $752-758,325$.

to drawer lor wrongful dishonor, 772-774.

\section{Codes:}

American, 9-13, 7t9-841.

Continental, 13-15.

English, 3-9, 845-873.

mentruction of, 5, 12,396, 451.

\section{Collateral Security:}

athorizing sale of, does not render instru ment non-negotiable, 91-92, 24 .

inatrument issued as, is contingent, 105-106. instrument tranaferred, as for antecedent debt, 239-249, 51 .

failure to sell, 633-634.

Collection:

biil or note payable with costs of, 78-80, 21.

indormement for, 274-277, 280-284, sf 6o fi of check, time allowerl, $725-751$.

Conditional: (Sre UNCONDITIONAL.)

ordern or promines, 4t-61, if $20,22$.

delivery, 151-152, 35 .

indoraement, 287,69

acreptance, Bis-674, I 229.

\section{Conkideratlon:}

nerenity of, 23 ;n.

presumpticin rif, 234-239, 716,-72n, I $\mathrm{kn}$.

adequacy of, $23: \mathrm{m}, 337-340$.

what conatitutes, 51 .

payment of preseinting rlebt, 240

coliateral nerurity for precexinting debt. $238-24$ ?

in accommontation papre, 24,3-244, 20 effert of want or fallure of, 253-254, f 54 . need not be aperified. 159, 169 , 25 . tor aeceptor'n promine, 25n-251.

by precerding holder, 243-251, 52 .
Consideration - Continued.

action upon original, $610 \mathrm{n}, 611-614$.

statement of, docs not render conditional, $55-61,822$.

in restrictive indorsement, 27\%-280.

in transfer in trust, 277-280.

patent right as, $384 n-385 n, f 330$. speculative, f 331.

\section{Construction :}

of ambiguous instruments, 16]-220, s 36 .

of codifying statutes, $5,12,396,451$.

\section{Constructive Notice:}

from form of paper, 345-357.

\section{Contingency :}

instrument payable on, not negotiable, 46. $49,103-106$, if 22,24 .

what is not, $50-61$.

\section{Contribution:}

among sureties, 461-162.

\section{Copy of Bill:}

use in protest of, 691-695, 261 .

negotiating copy, 710 .

\section{Corporation :}

as accommodation indorser, 256 .

indorsement by, 221, 41 .

payee a fiscal officer of, 72

seal of, on corporate paper, 160 n.

paper of, diverted by officer, 346-354.

signature by officers of, 199-216.

paper of, indorsed by directors, 577-579.

Costs:

provision for costs of collection does not render sum uncertain, $78-80$, f 21 .

of prior suit, whether recoverable by surety. 364

\section{Coverture:}

28 a defense, 372 .

transfer after, $628 \mathrm{n}$

note signed by married women, 434

\section{Currency :}

whether treated as money, 83n.

\section{Current Funds:}

whether treated as money, $82-83$

\section{Current Money:}

particular kinsl may be specified, 85-89, I 5 . what constituten, $82-89$.

('ustom:

is origin of law merchant, 23-24, 30-31.

\section{Date:}

non-essential, $158-159,195,25$

nrnaumpting ot to, $195,8 \delta 30,36$.

mistake in, 101-302.

ante-dateil and pustodated instruments, 101168,31 .

when date may be inserted, 163-168, 32

change of, a material alteration, 200 .

(1)1 ur before flxed, 97-98.

alteration of, 206 .

if acceptance, 226

print-daterl cherk, $724 \mathrm{n}$

1)ay: (Sor TIME.)

I)en[h: (Ser FXXCUTOR.)

of party primarily liahle, 357n, 510-\$17. sion, 694-685, I 136 .

if drawer or Indorier, 640-549. If 169-170.

of irawee liefire acreptaner, 245

inatrunient payabie at or affer, $102-106$, $234-235,710-720$. 


\section{Defanit :}

in payment of installment, 72-74, 21

\section{Defernse's:}

absulute, $37^{2} \mathrm{n}, 372-374$

conditional or personal, $373 n, 373-374, \& \& 54$, $93-94.97$

burden of proof, see BURINEN OF PROOF,

defenses to negotiable instrunents,

alterition, $373 \mathrm{n}, \mathrm{tak}-6 \% 2 \mathrm{2}, 205$.

cancellation, 37311, 590-(0) \& \&200, 20.4.

discharge in bankruptey, 373 .

diversiun by agent, $239-243,346-352$.

duress, $370-375$.

failure of consideration, 253-254, 268, 419. forgers, $168,201-233,403-418,441,8 \& 33$, 4..

fraud, $373 \mathrm{n}, 357-359,360-361,476$

fraud as to nature of contract, 387-399.

carnishment, 373 .

infancy, 220 .

illegality, 36s-370, 371, 373n, 432.

non-demand or notice, 477-480.

parol agreement, 270-271.

payment, $373 n, 591-592,639-641, \$ 7$, 200

set-off, $373 \mathrm{n}, 320-324,475$.

want of consideration, 373n, 337-338.

want of delivery, 373n, 152-153.

want of delivery as a negotiable instrument, $38 i-399$.

want of title in holder, 314-318.

defenses to guaranty, $474-476$.

Delay: (See DiLlGeNCE.)

in making presentment, 97, 518-520, 725743, \& 322

in giving notice, $573-574,8184$.

in proceeding against principal, $633-634$.

in making presentment for acceptance, 681$685,821$.

in making protest, \& 267 .

\section{Dellvery:}

defined, \& 2

when presumed, $154-158, \$ 35$.

of incomplete instrument, 386-387, \& 34 .

egsential, 151-152, 265n, \& 35 .

conditiona1, 151-152.

want of, as rlefense, 152-158, 387-399.

negotiation by, $342, \& 60$.

warranty in necotiation by, 419-437, \& 115 . after acceptance, $65 \%$.

indorsement of paper negotiable by, 4.3. s 117.

upon payment. \& 134 . 306 .

of notice of dishonor. 542-546, \& 167 .

obtained by trick, 387-399.

Demand: (See PRESENTMENT FOR PAY MENT.)

\section{Demand Bill or Note:}

when when overdue, $323-324,82$.

when presentment for payment must be made, 483-494, \& 131.

\section{Deposit :}

indorsement for, 282-284

\section{Deposit Sllp:}

distinguished from certificate of deposit, $43 n-44 n$.

Diligence: (See DELAY.)

in making presentment, 483-501, 704-706, \& 142 .

in riving notice, 548-565, 589, \& $183,184$.

in pregenting check, $725-743,8322$

in making protest, 267 .
Disclinrge of Instrument:

payment and relfinsfer, 591-599, \$\$ $80,200$.

payment in lue course, 591-592, 200.

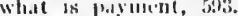

payment hy intorser, 59.4-597.

payment by party necommodated, 640-641, \& 202 .

payment or purchase, 59i-598.

cancellation or renunciation, see CANCEL LATION, RENINCIATION.

alteration, see ALTERATION.

by operation of law, 628n.

of bills in a set, \& 315 .

Discliarac of Surety:

what effects, $474-476,605-608,629-638$, $\$ 201$.

extension of tine, does it discharge?, 63I. (i33, $634-6 i 38, \$ \& 200-201$.

rescrvation of riglits against, 629-633, \& 201.

ly quilified acceptance, $67 i-678,8230$.

by payment for honor, 707, \$304.

by non-presentment for acceptance, 681, 8241

by failure of holder to take nccessary steps, \& 247 .

by non-protest, \& 260 .

by payment for honor, \& 304

by non-presentment of check, 748-752, \& 322 .

Dishonor: (Sce PRESENTMENT; NOTICE; PROTEST.)

by non-payment, $\$ \& 143,289$.

by non-acceptance, $\$ \S 221,246$.

notice after, \& 160 .

protest after, \&\& 189, 260 .

acceptance after, $667-668, \& 226$.

action for wrongful dishonor, 772-774.

Drawee: (Sce ACCEPTANCE.)

must be certain, 148-151, \& 20 .

in case of nced, 643-644, \& 215 .

liability of, 644-64f, 752-758, 772-774 $\$ \$ 211,3: 25$.

joint drawces, 642-643, \& 212 .

alternative or successive, 642-643, 212

only drawee can accept, $649-650$, \& 220 .

fictitious, excuse of steps, 575n, $\$$ \& 142, 185, 186.

may he also payee, $114-115, \& 27$.

may he also drawer, 113-114, \& 27 .

Trawee in Case of Need: (See REFFREE IN CASE OF NEED.)

Drawer: (See FORM; PRESENTMENT; NOTICE; PROTEST.)

contract of, 118, \& 111 .

arlmissions of, $418-419$, \& 111

when not entitled to presentment, $520-522$, $\$ 139$.

when not entitled to notice, 575-577, 580585,8185 .

discharge of drawer, \&\& $160,230,241,260$ 392

payment by, $639-6,40,8202$

may he payee, \& 27 .

may be drawee, 150 .

\section{I) Bill:}

whether a negotiable instrument, 37-40, 42.

I)uress :

as a defense, $370-375$, 94 .

\section{Election :}

of holder to require something in lieu of money, 94-96, \& 24 .

\section{Escrow :}

delivery in, $151 \mathrm{n}$. 
Estate: (See EXECUTOR.)

instrument payable to an, 111-113.

Hxcliange:

provision for, does nat render sum uncertain, 74-77, 21 .

note payable in, not negotiable, $81-82$.

recovery of re-exchange, $364 n$.

Excuse of Steps: (See DILIGENCE.)

\section{Fxecutor :}

presentment for payment to, 516-517, 694695,8136 .

notice of dishonor to, 54i-548, \& 169 .

transfer of instrument to maker as, $628 \mathrm{n}$.

presentment for acceptance to, \& 24 ?.

instrument payable to, 111-113.

\section{Exemptions :}

wajver of, does not render instrument nonnegotiable, 94, \& 24.

Extinguishment: (See DISCHARGE.)

Fallure of Consideration: (See CONSIDF:RATION, )

effect of, 253-254, 54.

ss a delenge, $253-254,268,419$.

\section{Fictitious Parties:}

payee, instrument payable to bearer, 123144. 28.

drawee, notice excused, 575n, \& \& 142, 185, 186.

bill may be treated as note, 214

presentment excused, $575 \mathrm{n}, \$ 142,245$.

\section{Figures :}

discrepancy hetween words and, 192-194 36 .

\section{Finder:}

of instrument, right of action, 314.

\section{Foreign Bllls:}

defined, $646-647,213$

require protest, $482,555,691 \mathrm{n}, 8 / 189,260$.

\section{Forelgn Money:}

whether treated as money, 88-69.

\section{Fingery:}

of signatures generally, 221-233, 42 .

if Iraker's sicnature, in3-\$1s.

by filling blank, 168-190, 6]6-624.

of indsrment. 433-434, 438

of renewal note, fors ring.

ratification of, $222-203$.

an a drifrnse, Jf, $221-233,403-118,441$, $1333,42$.

warranty against, 438, 116.

rorne of Negotlable Instruments: writing and miknature, 34-37, 20.

promine or oriler, 3i-fil, 20 .

uncrinditional, 4f-6i, 22.

cortainty,

rif $11 \mathrm{~m}, 61-\mathrm{kn}$. 21

if time, oro-ler, is 23,26

of payer, $107-113,2 \%$.

of drawere, 14x-15s, \& 20

payahle in mency, si- 10,20

no alditional aet in-sim, of 24

payable to eiriser rir licarer, lifi-147, is 30 , 27, 28 .

delivery, 151-158, 35

non-marntials, 158-ien, 25.

\section{Fraud:}

as a Jeefrnwe, $373 \mathrm{n}, 25 \pi-36 n, 350-35,1,470$

an to nature if montrart, 347-3m.

by seller, 4.3? - 13\%, 113.

\section{Fund :}

particular fund designated for reimbursement, 54-55), \& 20 .

bill not an assignment of, $644-646,5211$.

check not an assignment of, $75:-75$, o $3: 25$ current funds, whether money, s'- $84,25$. acceptance "when in funds," 6ith.

want of lunds in hands of drawee, effect, $520-5: 2,560-577,8$ \& 139,185

\section{General Acceptance:}

form and effect of, $665-673$, \& $827,228$.

to pay at a particular place, $672-673,8228$

\section{Gift :}

of donee's obligation, 599-6i04, \& 203

Good Fatth: (See NoTICE; HOLDER IN DUE COURSE.)

\section{Grace, Days of:}

abolished, 145 .

when last day of, a holiulay, 183.

non-negotiable bills have, $715-716$.

sight bill entitled to, $679-680$.

\section{Guaranty: (Sre WARRANTY.)}

transfer by indorsing, 26,3-265.

writing above blank indorsement, 269-270.

contract of guarantor, $46 \vec{i}-4 \vec{i}$.

whether transferable, 471-4i4.

lefenses to, $+74-4 i 6$.

indorser of non-negotiable note undertakes, ז20-721.

whether accommodation contract is s continuing, 328-:335.

whether irregular indorsement a, 4t7n, raln whether acceptance by a stranger a, $650 \mathrm{n}$.

\section{IIolder:}

defined, \& 2

when dieemed halder for value, 249-253, 319$360, \quad 8 \% 52,91$.

may convert blank indorsement into special, $268-209, \quad$ \& 65.

under special indersement of instrument payable to bearer, $285-297$, 870 .

of instrument transterred without indorse ment, 307-310, 79

may strike out indorsement, $306-307,58 \%$ 202.

may sue in his own name, $314-318,90$.

title of in action, $314-318$.

rutitled to lenelit of warrinty, 115

principal diblur as, $507-549$, है

dischlarge of intrument by, 5ol-60\%, \& 200

discharge of party ly, fo6-bi39, $80 t$.

ronunciation of rights $\mathrm{by}, 5 \mathrm{~m}-\mathrm{in} 8,203$.

may reluse oral acceptance, \& 221.

may refuse qualified acceptance, 677, 230

"ption to resort to referee in case of need. 215.

conaent to acreptance for henor, 280

refusal to recrive payment for honor, 3n5. Hreturing certifleation of rlseck, 743-751. 324 .

Jutic of, fis? \& 24

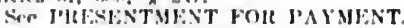

NOTICE OF litSIFONOL.

IITFEFXTMINT FOH ACCEPTANCE. PUOTY:ST.

richen of, upm dishonor, fom, \& 249

duty to recolve payment for honor, 305

in. action agairiat laak on rherk, 752-788, 1325.

IIolder in Due Course: (Sme DE rFins.s.)

remulaitem to constitute.

instrument complete and recular, 319. (1) 
llolder in louc Conrse-continued. unstrument mol werdue, $320-337,80$.

tahen in gent fath and for value, 3at-340,

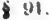

taken withont notice of intirmity, 340-357, 891 .

holder deriving tille from, seto, \& 97 . may" recower full atmotmt, 3ti1-36t, \& 96.

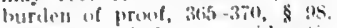

nutsere to, before consilleration pait, 357 अ(i) \& 83

of instrument wrongfully tilled up, 163-191.

of instrument tramsterred without indorse ment, $307-310,89$

of altered instrument, (ill, \$ 205.

of instrunient transferred after dishonor for non-aceeptatice, 587-58:!, \& 188.

of part of bilis in a set, 311 .

intillei to warratities, $419-442$, \& 115 .

\section{Holder for Vaine:}

what constitutes, 249-253, 337-340, \& 52 .

may enfure akitinst aceomnodation party, $254-255, \$ 55$.

anount recoverable by, $361-364, \S 96$,

\section{Holiday:}

time, how eomputed, 5 \& 5,145 .

bill or note due on, 4\&3̈n, 504-508, \& 145

presentment for acceptance on, 504-508, \& \& $145,243$.

\section{Howr:}

Whether reasonahle for presentment, 494-495. of scrvice of notice of dishonor, 552-553, \& 174 .

of closing of mails, 556-558, \& 175.

for prisentment for acceptance, 842

\section{Hushand and Wife: (See Cover- TURE.)}

\section{Illegality:}

as a defense, $375-370,371,373 \mathrm{n}, 432$ warranty against, 432-433, \& 115 .

\section{Impossibility :}

as exeuse for steps, 524-527, 573-574.

Incomplete Instrument:

want of delivery of, a tlefense, $386-387$, \& 34 . as notice of defects, $319, \S 91$. acceptance of, $666-668, \$ 226$.

\section{Indorsee :}

carnint be two or more severally, 62 sperial, must indorse to transfer, 268,864 under restrictive indorsement, $271-284, \$ \$ 66$, 67.

under conditional indorsement, $28 i, 69$ if two or more, all must indorse, 298,81 eashier, payabie to bank, 299-301, 72 . name misspelled, 301-302, \& 73 . in trust, $277-280, \& 66$

\section{Indorsement:}

defined, $\$ 6$.

form required, 34-35, 37, 266-268, \&\& 61-62. minst be of whole instrument, 267-268, $\$ 62$ kinds of, $26,8-28,3,863$.

special, 268, \& 64

hlank, $144,268-271,8528,64$.

restrictive, $271-281,866$

qualified. 284-287, 68.

conditional, 287, \& 69.

of inslrument payable to hearer, 288-298, 170.

of insrument pavable to two or more perans, 208, \& 71.

of instrument payable to cashier, 299-301, 72.

where name misspelled, 301-302, 73. in representative capacity, 74 .
Iudorsement - Continued.

presumption as to time of, 302 , 75 .

presimpition as to place of, 302-306, o 7h.

strikllite onte, 306-307, \& 78

irausfer by, 2til-2titi, 80.

tritusfer witlient, $307-310$, 79.

ly infint or corporation, $220-221,811$.

of uverilue instrument, 97, 272, 320-337.

warranty from, 419-140, 115 .

forked, $221-233,8+2$.

tilling up blank, $268-270$, 65

\section{Indorser :}

who deemed indorser, 458-459, f113.

liability of general, 442-445, 116 .

warrinties of, 419-440, 115

for what ambunt liable, $363,896$.

irregular, 446-458, \& 114 .

order of liability, 459-465, 8118

when not entitled to notice of dishonor, 577 $586,8186$.

payment hy, 594-597.

of instrument payable to bearer, 288-298, 50 .

of parts of bills in set, 709,312

of a eheek, 748-752.

discharge of,

by striking out indorsement, 306, 78 .

by failure to take steps, \&8 130, 160, 241. 260.

by taking qualified acceptance, 677,230

by certification of check, 748-752, 324 .

action against on day of maturity, 443-145.

\section{Indorser Withont Recourse: (See} WITHOUT RECOURSE.)

\section{Infant :}

indorsement by, 220,418-419, 8 11, 111.

defense of infancy, 372 .

\section{Inland BIll:}

defined, 646-647, § 213.

protest of, $482,585,691 \mathrm{n}, \quad 189$.

\section{Installments :}

do not render sum uncertain, 67-72, 21 . nor provision that upon default in one, all shall be due, $72-73$, \& 21 .

\section{Interest}

does not render sum payable uncertain, 64$67, \& 21$.

runs from what time, $39 n, 194-195,36$

overdue as dishonoring paper, 335-337.

alteration in, 8206 .

demand note payable with, 483-488.

\section{Interpretation :}

date, 161-163, \& 30

hlanks, $163-192,8 \& 32-33$.

ambiguous language, 192-197, 36

ambiguous signatures, $197-220$, \& $37-39$.

codifying statutes, 5, 12, 126-127, 396-397, 451.

\section{Inurement :}

doctrine of, as to notice, 581-535.

I. O. U. :

whether a negotiable inatrument, 37-40, 12.

\section{Irregular Indorser :}

liability of, 446-458, 114.

\section{Joint Parties:}

acceptors or makers.

presumption, 196, 36.

presentment to, 517, 138.

payees,

in instrument, 115-118, \& 27 .

indorsement by, 298, $817,118$.

drawers, notice to, 171 
Jolnt Parties - Contiaued.

indorsers,

presumption, $466, \mathbf{f} 118$.

contribution among, $461-462$.

right to securitien, 466.

notice to, 171 .

drawees,

bill addressed to, 642-644, 212.

presentment to, $687-688$, 242 .

retransfer to one of the, $599 \mathrm{n}$.

discharge of one, 631n.

Judgment :

suthorizing confession of, does not render instrument non-negotiable, 93, 24

in tavor of principal debtor, discharges surety, 628n.

Laches: (See DELAY.)

Law Merchant:

when governs, \& 7 .

history of, 15-23.

\section{Llability of Parties: (See PARTIES.)}

Lien:

on instrument constitute holder for value, 252, \& 53 .

\section{Lost Instrument :}

liability on, $400,532 \mathrm{n}$.

protest of, 268 .

right of tinder, 314.

\section{Malls: (See POST-OFFICE.)}

\section{Maker:}

liability of, $400,110$.

admissions by, 401,110 .

note to maker's own order, 213, 715, \& 27 , 320.

signature of, $35-36$.

negligence in signing, 391-399.

jolint and several, 196.

presentment not necessary to charge, 477 480.

\section{Marriage: (See Coverture.)}

Maturity: (See GRACE; HOLIDAY.)

day of, 183, 145.

time of, for demand notes, 322-324, 483-494.

action againat indorser on day of, 143-145.

protent before day of, when proper, 266 .

Money:

instrument must be payable in, $81-89$, I 20 , 220.

what constltutes current, $82-90$.

election in lieu of, 94-06, 24.

promine in addition to payment of, 90-96. I 24 .

toreign, 88-89.

-pecifying current does not affect negotiabil. ity, 82, i 25 .

steration in kind of, 206.

Negllgence:

is not bad tasth, but only evidence of it, $340-35 f^{2}, 95$

in vikning instrument, 301-300.

in leaving spaces, Bib-624.

Negotiable Instruments:

hiotory of, 21-31.

corfification of, $3-15$

kinds of, 24-23.

She BILIS OF FXCHANOR.

PROYIRSORY NOTE.S.

CIIECKS.

BกNกร.
Negotlable Instruments - Continued. form of (see FORM OF NEGOTIABLE IN. STRUMENTS).

continuation of negotiable character, 272$274, \& 77$.

defenses to (see DEFENSES).

paper payable in trust is, 35t-357.

Negotiable Instruments Law:

history of, 9-13.

list of states which have enacted, 776 .

text of, $779-841$.

Negotiation: (See INDORSEMENT; DELIVERY.)

defined, 25, 259, 60 .

by delivery, 260,860 .

by indorsement and delivery, 261-266, 6 may delay presentment, $190-494,735,740$, \& 131 .

of overdue instrument, 272-274, 320-337.

of guaranties, 471-474.

Non-Acceptance: (See ACCEPTANCE.) effect of, $689,690,824$.

notice of, necessary, $530-533, \& 160$.

effect of subsequent presentment for payment, 530n, 587-589, \& 247 .

\section{Non-Negotiable Notes:}

what are, 145-148,715-721, \& \& 20, 320.

have grace, 715-716.

as to presumptive consideration, 716-720.

liability of indorser of, $265 \mathrm{n}, 530 \mathrm{n}, 720-721$.

any instrument in hands of holder not in due course is like, \& 97 .

Non-Payment :

notice of, when necessary, 530, 160.

\section{Notarial Act of Honor:}

necessary to payment tor honor, 707, $\$ 301-$ 302.

Notary: (See PROTEST.)

when presentment by, necessary, 482, 685, $691 \mathrm{n}, 88189,260$

protest by, $691-700, \$ 260-263,267-268$.

whether he must act in person, 481, 698-700. signature and sesl, 181-482, 261 .

tees of, $363,589 \mathrm{n}$.

Notlce: (See IIOLDER IN DUE COURSE.)

of defect or defense, 340-357, s 95 .

trom face of paper, $345-357$.

hefore tull amount paid, 357-360, 93.

not from indorsement without recourse, 285287, 68 .

overdue paper, $320-337$.

overdue interest as, $335-337$.

not because payable in trust, 354-357.

Notice of Isthonor:

necestary to chirge drawer or indoraer, 530 5.33, 1fo.

what constituting sufficient notice.

ty whom given, 533-538, 161.

form of, 539-512, 107

mode of nervice, 542-546, 167.

to whom civen, $6013-518$, of $188-172$

within what time, 548-505, if 173-176.

at what place, $5055-673,179$.

when delay excuaed, 573-575, 184

when notice dispensed with.

a to drawer, 675-677, I 185 .

as is indoraer, $577-$ sen, $18 \%$

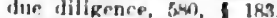

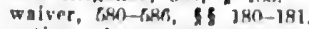

notice of non.payment when acceptance refusard, LSB, I 187 .

prome nit noticr. 590-500, 18 ?

nurcenaive noticre, SM-CAS, 178. 
Noting:

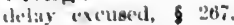

subsidguent entension of protest, $696-698$, $8 \div 63$.

()nice:

lohder of, as payed, 121, § 27.

Orier:

bill must contain, 44-45, \& 20 .

uncunditional, $4(i-t), 820,22$

no allitionst ate. 90, \& 24 .

Lill must be payable to, or bearer, 145-14s, $8820,27-38$.

" Oriler or bearer ":

nut necessity by law merchant, 158-159.

not necessiry by bills of exchange act 827 (note), 66in.

necesary by negotiable instruments law, $145-145, \& \& 20,27-28$.

\section{Overalue Bill or Note:}

is payible on demind, $97,272-274,826$.

continues negotiable, $272-274,877$.

indursement of, $97,272-274$.

iransferee not holder in due course, 320-337, 891

overdue interest, $335-337$.

when demand notc is overdue, 322-324, 483494.

acceptance of, \& 226 .

presentment for acceptance before, $680, \S 242$ accommodation paper, 328-335.

Parol: (See WrITINA.)

acceptance by, film

varying indorsement by, $27 \mathrm{ln}$.

\section{Particular Fund:}

indication of, 50-54, \& 22

order or promise to pay out of, 49,822 .

\section{Parties:}

primarily liable,

defined, \& 3 .

maker, 4 in \& \& 110 .

acceptor, 403, \& 112.

discharge of, 591-626, \& 200 .

secondarily liable,

defined, 3

drawer, $418, \& 111$.

indorser, 44.) \& 116

irregular indorger, 416, \& 114 .

discharge of, $6: 6, \delta 201$.

murantor. 466.

acceptor for honor, 701-706, \& $880-289$

drawee, 149, \& 20,

payer, $106,-148,8 \& 20,27-28$.

joint and several (see JOINT PARTIES)

sccommorlation (see ACCoMMOHATION PARTY).

alteration in, 6(18-6) 10,8206

to aetirn must appear on bill, 197-199, 837.

\section{Partners:}

signatures liy, $6.50 \mathrm{n}$

accommodation papet by. 345-34f,

presentment for ronymerit to, 654-69.5, \& 137 .

notice of dishroner to, 547-548, 575, \& 170 .

authority to make alterations, b08-610.

authrity to accept, f,87-fi,88.

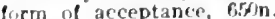

indersement hy, 20, \& 71.

\section{Patent Rights:}

nequtiable instrument given for, $384,385 n$, \&. 330 .

Pavee:

win may be, 113-12], \& 27.

must be certain, $10 \pi-113, \& 27$. l'ayere - Conflumed.

hitutus, 10:3-14t, 28.

(wo or nure, 115-lis, 27

oble ut some of several, 118-121, 27.

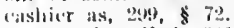

name misspelleel, 3i1, \$ 73.

adnuissions as to, 401, 103, 419, \& 110-112.

whether holder in due course, 174-190, 396.

\section{Payment:}

to comelitional indorste, 287, 69.

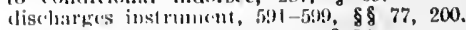

holder may anforec, 314-319, \&90.

nerotiable instrument as, 741.

of forged bill, J03-418.

in due comrse, $591-590,8148$

by indorser lives not discharge maker, 594$5 ! 17$.

by party seconclarily liable, 639-641, \& 202. by accommodated party, 640-641, \& 202 . of bills in a set, $\$ 314$

after notice of lefect, $357-360, \& 93$.

of bills under forgerl indorsenient, 433, 441, $403-418,221-233$

renmal note as, 503

\section{Payment for Honor:}

when proper, $707, \$ 300$.

by whom, 707, \$300.

for whom, $707, \$ 300$

formal requisites,

prior dishonor ancl protest, 707, \& 300 .

notarial act of honor, $707, \$ \$ 301-302$.

declaration of intention, \& 302 .

effect of,

discharge of parties subsequent, 708n, 8304 .

liability of prior parties, 707, \& 304 .

effect of refusil to receive, \& 305

does not apply to notes, 708 .

Payment Supra Protest: (See PAY. MENT FOR HONOR.)

\section{Peneil:}

necessary writing may be in, 34-35, 37.

Personal Representative: (See EX. ECITOR.)

\section{Place:}

of drawing or payment need not be specified, $158-159,825$.

of indorsement, presumption, 302-306, \& 76 . of presentment.

for payment, 508-516, \& 133

for acceptance, fi85n.

to acreptor for honn, \& 287 .

of aceptance, $478 \mathrm{n}, 675-676$, \& \& 228,240

of serving notice, $565, \$ 179$.

of payment, \& 240 .

a)terition in, \& $20 f$.

\section{Post-Office}

notice of dishonor through, 543-546, 556n, $554-561,565,566-573,8 \S 167,174-177$, 179.

Jelays caused by, 518-520, 176 .

interruption of mails by war, $573-574$.

Pre-exlsting I)ebt: (See ANTECEDENT [DERT.)

Presentmont for Acceptance: (See ACCEPTANCE.)

when necessary, 679-685, \& 240.

within what time, $680-684,8241$.

what is sufficient, fi85-f88, \& 242.

when delay excuserl, \& 244.

when presentment excuserl, 688-689, \& 245 .

duty of holder where bill not accepted, 689 , 5. 247 .

effect of disbonor, $689-690$, \& 248 . 
Presentment for Payment:

necessity of

not to charge acceptor or maker, 4ii-480.

not after dishonor for non-acceptance. s 245 .

to charge Jrawer or indurser, 450.

tu charge accepler for howor, 703, 705, 8245 .

what constifutty sutlicient,

hy wism, 4so-48\%, \& 132.

at what time, ts:3-5is, \$ 132

at what placts, 5 s-51ti, of 133 .

to whom, 5 tic-5is, \& $13:$

when maker de.id, sit-5]\%, \$ 136 .

when makers joint, in -51 s \& 138

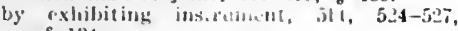
134.

to acceptur for lonor, s : 3

when delay excouml, 515-5:0, \& 141

when presintment excusid,

no right to expect it, $530-5: 4, \$ \$ 130,140$

when impessilife, 5:4-5\%7, 14 .

when waiverl, $527-5 \%$, s is?.

of checks, it5-it3, \& 322 .

\section{l'resmumffuns: (see BURDI:N of} PROOF.)

of consideration in negotiable instrument, $234-239,850$.

of consideration in non-negotiable instrument, $716-720$.

of value for every signature, \&5t).

of place of indorsement, $300-300, \& 76$.

of time of indursenient, $3 t^{2}, 85$.

that holder is looldt.r in due course, 365 $375,591-592, \& 98$

of order of indurser's liability, 450-166, \& 118

that partics indorse jointly and severally 466, \& 118

frum deposit of notice of dishonor in mail, 5it-545, \& 170

frimary Party: (See P.ARTIES.)

l'uitelpal: (See AGENT.)

\section{loncuration:}

พistolure by, 219-2:20, \&40.

l'Po:ulse: (See FORM.)

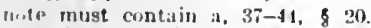

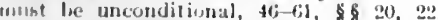

moust not be of act adlotitional tis payment of moncey, $90-94 \%$,

- pay ont of particular fuml, 4!-5.1, 20

(1) areent, when an areveptance, $654-652$ 8203.

l'romingory Noto:

urevin and histury, $25-28,711$

deofinition of, 3 3on.

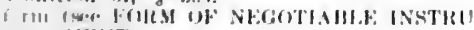
MIENT)

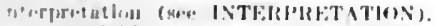

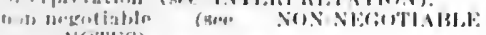
(rites)

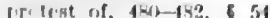

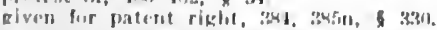

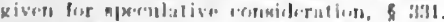

Imbligurila ingtrument may be treaterl as $113,150,833$

\section{I'roberst:}

whon proper, \& ian

netom anil inlaml lilla, 14!.

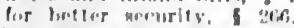

when nen

firrion bille riel o arri.

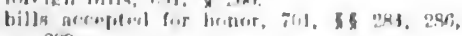
sis?

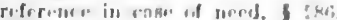

before payment fir heinor, sis, six).
Protest - Continued

what constituted sufticient

form and contents, 691-698, 261.

by whom, 698-i00, $26^{\circ}$.

on what das, \& 203

at what place, \& 264

mule of naking.

noting, $694^{\circ}-649, \& 263$.

certicite of, $695-605,261$.

lust bill, 8 as.

when excused, 5is-579, 267.

as jruef uf notice of dishonor, 548-554, 582 390.

fo's reasonable for, $363-364,549 n$

Waiver ul, 584-585, 181 .

Purchase for Value without Notice: (See HOLDER IN DUE COLRSE.)

Purchase of Instrument: (See TRANSFER.)

tistinguished from loan, $361 \mathrm{n}$.

distinguished from payment, 597-598.

Qualified Acceptance:

definition and effect, $673-678,688 \mathrm{n}$, is 229 230.

\section{Qualified Indorsement:}

definition and effect, 284-287, 68

\section{littification:}

if forgery, 221-223.

of usathorized alteration, $610 \mathrm{n}$.

Rirasonable Time: (See TIME.)

lu, determined, 483-494, 654n, 735-740, 4 .

lirferee in Case of Need:

itefinct, (13) \& 215 .

protest before presentment to, 286 .

excuse lor delay in presentment to, 8288.

Re-issue: (See RFTransfrer.)

l,y prior party, 276-277, 310-313, 639-640, 80.

Release: (See DISCHARGE.)

of principal, 591-626, \& 200 .

of kurety, (gee DISCHARGE OF SURETY).

liemovil from state:

ifferet upwin presentment, 513-515.

iffect upon notice, 571-573.

\section{Rourwal Note:}

Whet her payment of former note, 593, 605-008.

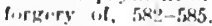

promisw to make, rentlers instrument fon. lingent, lowin.

\section{Rronntinton:}

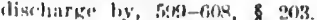

writinge or iolisery neenasy, 601-604, 208.

lixisfriellor Imilorsement:

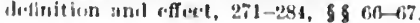

\section{lioteminfier:}

(1) prinr party, effect of, 276-277, 310-313,

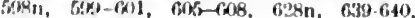
60.

sinte of Negotlable Instrumbut: (Sim NFC,OTIATION; TKANSFEIR: IVARIRANTY.)

\section{Solurilay:}

malurity if inatrument ron, 304-an, 146

promeniunt for arceptancr on, 243.

S.11:

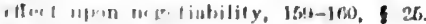

of nutury, \& 261 . 
Secondary larty: (See PARTIES; DIs. CHAKGE: OF SURETY.)

Security: (he COLLATERAL SECULITit:S.)

protest for better, 266 .

Seller of Negotiable Instrument: warrantles by, 419-14:, \& 115 . agent's li.tbility as, t1t-143, \$ 119. payment distingoished from sale, 59;-608.

Set, IBills in n: (Siee BLLLS IN A SET.)

Set-on:

48 a detense, 373n, 320-324, 175.

SIght 13111s:

presentment for acceptance, $679-680$, \& \& 23 , 240.

have grace, 679-650.

\section{Signature:}

only thuse liable whose signatures appear, $197-201,205-207,37$.

by maker or drawer, 35-36, 20 .

by acceptor, $648-649,220$.

by indurser, $37,260, \$ 61$.

by agent, 197-220, 37-40.

fictitious, \& 37 .

irregular, 446-458, \& 15, 113, 114.

ambiguous, $197-220$, \& \& $36-39$.

forged, 221-233, \$ 42.

presumption as to value for, \&50.

joint, 196,836 .

distinguislıed from subseription, 36n.

on blank paper, $168-169,83$.

on ineomplete instrument, 163-192.

lacking on instrument, 319

obtained by trick, 387-399.

\section{Spaces :}

unauthorized filling in, 616-624.

distinguished trom blanks, 616-624.

Special Indorsement:

definition and effect, 268, 64 .

written above blank indorsement, 268-271, 65

of instrument payable to bearer, 288-297, \&70.

Statement of Transaetion:

does not render bill or note conditional, $55-$ 61, \& 22.

Statute of Frauds:

irregular indorsement, $447 \mathrm{n}$.

guaranties, $469-470$.

delense to instrument, $628 \mathrm{n}$.

Stolen Instrument: (See LOST IN.
STRUMFNT.)

Sum Certain: (See CERTaINTY.)

Sunday: (See HOLIDAY.)

Surety: (See DISCHARGE OF SURETY; GUARANTOR.)

contribution among sureties, 461-462.

right to securities, 466 .

delenses available $t n, 474-476,0,29-6,38$

reservation of rights against, 629-631, 201.

\section{Tender of rayment:}

by principal discharges surety, 629, 201.

what amounts to, $478-480, \$ 130$.

\section{Time :}

how computed, $483 \mathrm{n}, 8$ \& $5,146$.

resonable, hrow determined, 483-494, e84n, $735-740,84$

certainty of, gfi-106, f 23.
Timo - Continued.

of indorsenent, presumption, 302,76 .

for making prescentment, 483-548, if 131, 136.

of inaturity, 96-102, 483n, i 145 .

forgiving notice of dishonor, 548-565, fs $173-175$.

allowed drawee to accept, $660-666,524$

aceptance qualifled as to, 676, \& 229 .

(or presentulent for acceptance, 680-684.

for thaking prutest, 263.

for presenting elieck, 725-743, 322 .

given to principal, is surety disclarged(331-633, 634-638, 85 200-201.

given to principal discharges guarantor, $638 \mathrm{n}$ when indorsement subsequent to transfer takes effect, $307-310,879$.

presentment, when time insuffleient tor, 244

'TitJe: (See HOLDER IN DUE COURSE.)

when defective, 94.

warranty, 433, 115

of indorsee under restrictive indorsement, $274-276,280-284,867$.

of inclorsee under infant's indorsement, 220, 841.

of transferce without indorsement, 307-310 879.

of holder of instrument payable to bearer and restrictively indorsed, 288-291.

of holder in action, 314-318.

of holder to guarnty, $471-474$.

Trausfer: (See NEGOTIATION; HOLDER IN DUUE COURSE.)

what constitutes, 259 .

by delivery, 260, $\$ 60$.

by indorsement, 261,60 .

without indorsement, $307-310,79$.

retransfer, $310-313,880$.

for purpose of suit, $316 \mathrm{n}$.

in trust, $277-280$, \& 66 .

warranties, 419-442, \& 115 .

when overdue, $320-337$, 91 .

of overdue accommodation paper, 328-335.

Trust :

indorsement in, $277-280, \$ 66$.

under conditional indorsement, 287, 69 .

instrument payable in, 354-357.

holder may recover in trust for indorser, 594-597.

\section{Cucertainty: (See CERTAINTY.)}

\section{Inconditional Promlse or Order:} (See FORM.)

necessary to negotiability, $46, \$ 20,22$

when order or promise is uneonditonal, $46-61, \& \& 20,22$

\section{Usury:}

purchase of business paper is not, $361 \mathrm{n}$

taking interest in advance is not, 567 .

as a defense, $372,378-383$.

warranty arainst, 427-431, 437-439.

Value: (See HOLDFR FOR VALUE.)

defined, $8 \& 2,51$.

need not be specified, 158-159, 25.

holder for, $249-253,337-340,52,01$. antecedent debt as, 239-249, of 51 .

\section{Virtual Acceptance:}

form of, 654-657, 5223

effect, $65 \mathrm{in}$.

\section{Waiver:}

of benefit of Jaw, 94. 24 .

of presentment for payment, 527-529, 14.

of notice of dishonor, 580-586, 180 .

of protest, 584-585, is $182,267$. 
Warranty of Seller:

where transfer by delivery, 419-442, 115.

where transfers by indorsement, $437-410$ 5116.

by agent who transfers, 441-142, 119.

by agent who signs tor principal, 216-217.

Without Recourse:

indorsement qualified by, 272-274, 284-287, 568.

wuranties where so translerred, 119-442, f 115.

\section{Writing:}

defined, 2

necessity of, in negotiable inatrument, 34-35, 50.

necessity of, in case of renunciation, 601-604, 5203 .

holder may require acceptance in. $648-049$, 5220 .

acceptance by separate, 651-654. 222.

necessity of, in acceptance tor honor. 281. promise to accept must be in, 654-657, 223 . condict with print, 195-196, 36 . 








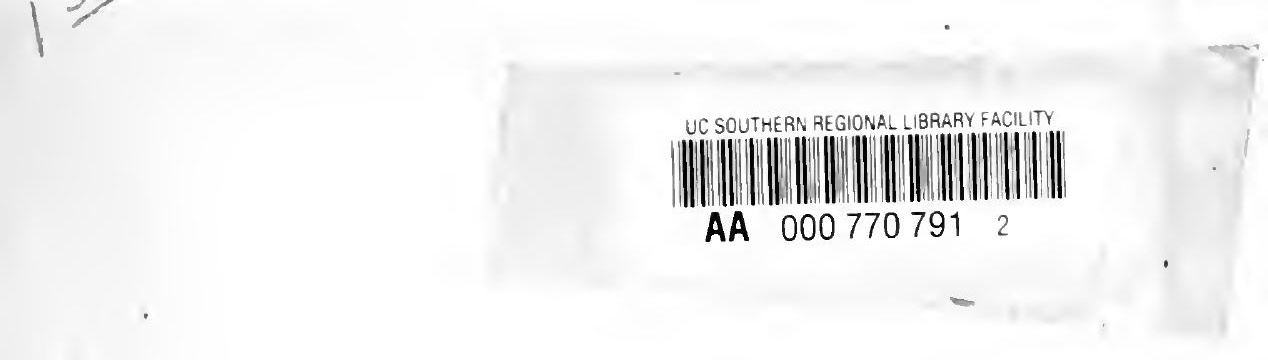




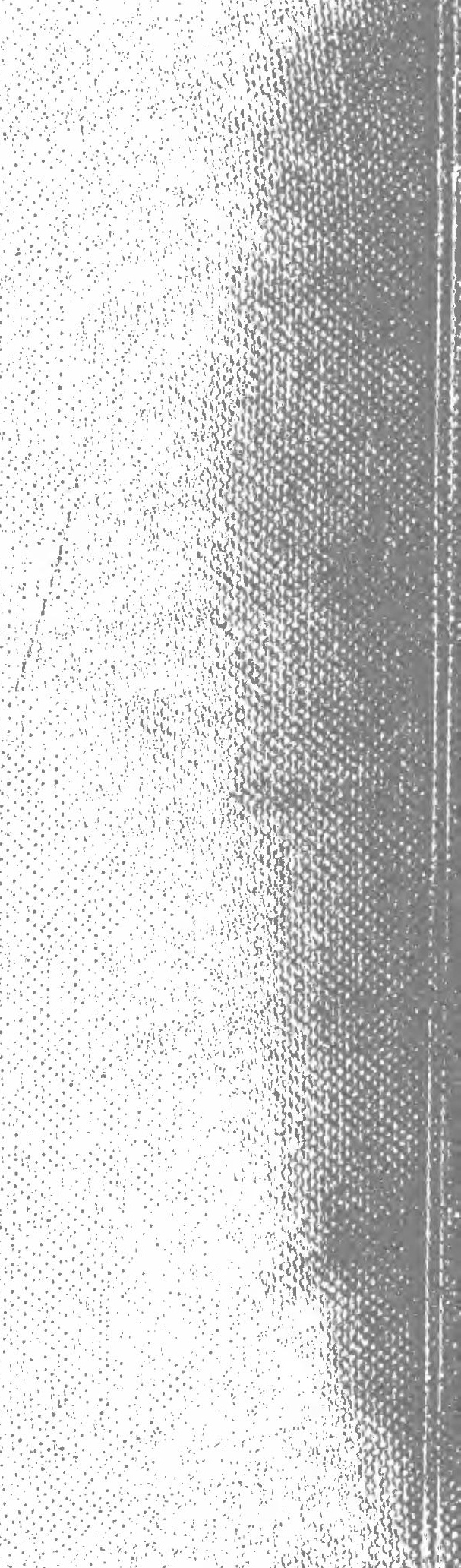

